\title{
Parlementair onderzoek : een studie van het onderzoeksrecht in Nederland, het Verenigd Koninkrijk en de Verenigde Staten
}

Citation for published version (APA):

Loeffen, S. (2013). Parlementair onderzoek : een studie van het onderzoeksrecht in Nederland, het Verenigd Koninkrijk en de Verenigde Staten. [, Maastricht University]. Sdu Uitgevers. https://doi.org/10.26481/dis.20130628sl

Document status and date:

Published: 01/01/2013

DOI:

10.26481/dis.20130628sl

Document Version:

Publisher's PDF, also known as Version of record

Please check the document version of this publication:

- A submitted manuscript is the version of the article upon submission and before peer-review. There can be important differences between the submitted version and the official published version of record. People interested in the research are advised to contact the author for the final version of the publication, or visit the DOI to the publisher's website.

- The final author version and the galley proof are versions of the publication after peer review.

- The final published version features the final layout of the paper including the volume, issue and page numbers.

Link to publication

\footnotetext{
General rights rights.

- You may freely distribute the URL identifying the publication in the public portal. please follow below link for the End User Agreement:

www.umlib.nl/taverne-license

Take down policy

If you believe that this document breaches copyright please contact us at:

repository@maastrichtuniversity.nl

providing details and we will investigate your claim.
}

Copyright and moral rights for the publications made accessible in the public portal are retained by the authors and/or other copyright owners and it is a condition of accessing publications that users recognise and abide by the legal requirements associated with these

- Users may download and print one copy of any publication from the public portal for the purpose of private study or research.

- You may not further distribute the material or use it for any profit-making activity or commercial gain

If the publication is distributed under the terms of Article 25fa of the Dutch Copyright Act, indicated by the "Taverne" license above, 
PARLEMENTAIR ONDERZOEK 

PARLEMENTAIR ONDERZOEK

Een studie van het onderzoeksrecht in Nederland, het Verenigd Koninkrijk en de Verenigde Staten

\section{PROEFSCHRIFT}

ter verkrijging van de graad van doctor aan de Universiteit Maastricht, op gezag van de Rector Magnificus, Prof. dr. L.L.G. Soete,

volgens het besluit van het College van Decanen, in het openbaar te verdedigen op vrijdag 28 juni 2013 om 12.00 uur

door

Sandor Carl Loeffen 


\section{Promotores:}

Prof. mr. L.F.M. Verhey (Universiteit Leiden)

Prof. mr. A.W. Heringa

\section{Beoordelingscommissie:}

Prof. dr. M.L.H.K. Claes (voorzitter)

Prof. dr. J.Th.J. van den Berg

Prof. mr. E.C.M. Jurgens (Vrije Universiteit)

Prof. mr. H.R.B.M. Kummeling (Universiteit Utrecht)

Mr. dr. W. van der Woude

(C) 2013 S.C. Loeffen/Sdu Uitgevers bv, Den Haag

\section{Ontwerp omslag: Villa Y, Den Haag}

ISBN: 9789012391115

NUR: 823

Behoudens de in of krachtens de Auteurswet gestelde uitzonderingen, mag niets uit deze uitgave worden verveelvoudigd, opgeslagen in een geautomatiseerd gegevensbestand of openbaar gemaakt in enige vorm of op enige wijze, hetzij elektronisch, mechanisch, door fotokopieën, opnamen of enige andere manier, zonder voorafgaande schriftelijke toestemming van de auteur.

All rights reserved. No part of this publication may be reproduced, stored in a retrieval system, or transmitted in any form or by any means, electronic, mechanical, photocopying, recording or otherwise, without the author's prior consent. 


\section{Voorwoord}

Aan het einde van een omvangrijk project als het schrijven van een proefschrift past een woord van dank aan iedereen die daaraan op de een of andere wijze een bijdrage heeft geleverd. Dat geldt in de eerste plaats voor mijn promotores Luc Verhey en Aalt Willem Heringa. Zij brachten mij op het onderwerp, waren steeds bereid mijn stukken kritisch en met interesse te lezen en zorgden bovendien voor de nodige aanmoediging tijdens de rit. Ook gaven zij mij de ruimte het onderzoek deels in het buitenland te verrichten; de maanden in Londen en Washington heb ik als een enorme verrijking ervaren. De leden van de beoordelingscommissie dank ik voor hun bereidheid het manuscript te lezen. Met hun deskundig commentaar heb ik getracht mijn voordeel te doen. In het kader van het onderzoek heb ik verder vele gesprekken mogen voeren met (voormalige) leden, medewerkers en andere kenners van de parlementen die in dit boek centraal staan. Dit was niet alleen bijzonder nuttig, maar zorgde er ook voor dat het studiemateriaal tot leven kwam. Ik ben iedereen die in de loop van de tijd bereid was mij te woord te staan of anderszins te helpen dan ook zeer erkentelijk.

Hoewel schrijven aan een proefschrift een grotendeels individuele bezigheid is, had ik het geluk dat ik dit in een aangename omgeving mocht doen. Met de collega's aan de Maastrichtse juridische faculteit was het prettig werken. Ik bewaar ook goede herinneringen aan de vele lunchgesprekken in de Tribunal, de Preuf, de mensa of aan het Vrijthof over het vak, de stad, de universiteit, de politiek, buitenlandse reizen en wat ons verder bezighield. Mijn nieuwe collega's van de afdeling Staats- en bestuursrecht aan de Vrije Universiteit, die mij in de allerlaatste fase van het proefschrift gastvrij ontvingen, zorgden ervoor dat ik mij daar direct thuisvoelde. Familie en vrienden, die vaak hebben moeten horen dat het bijna af was, bedank ik voor hun steun en warme belangstelling door de jaren heen. Tot slot, Roel van den Oever. Samen waagden we de sprong naar Maastricht. De talloze gesprekken die we aan de keukentafel over onze proefschriften voerden waren inspirerend, stimulerend, opbeurend en bij tijd en wijle confronterend. Bovenal was jij degene die in alles steeds weer de menselijke maat bracht, waar ik die nog wel eens uit het oog verloor.

Amsterdam, februari 2013. 



\section{Inhoudsopgave}

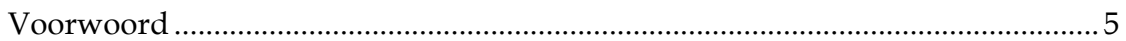

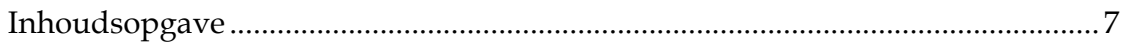

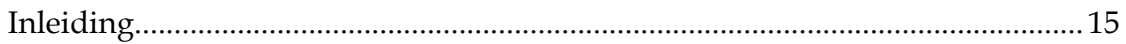

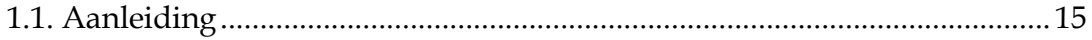

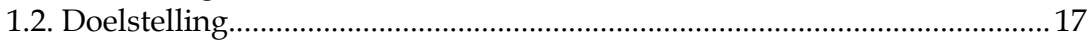

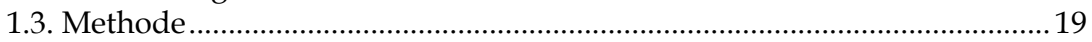

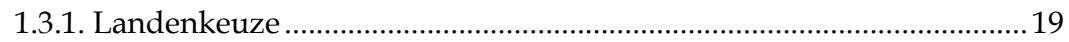

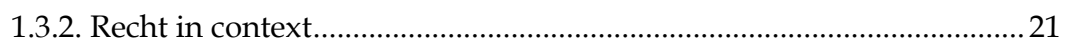

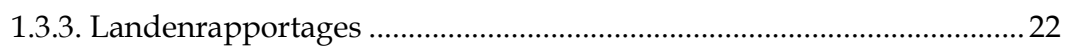

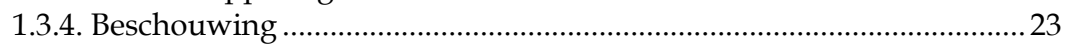

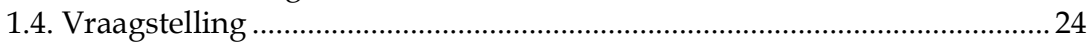

Deel I. Parlementair onderzoek in Nederland ......................................................2 27

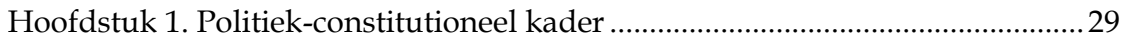

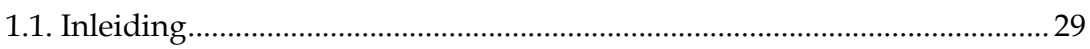

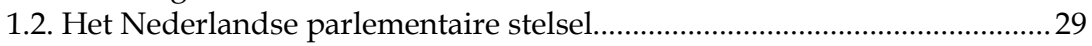

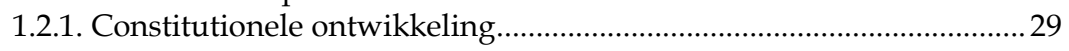

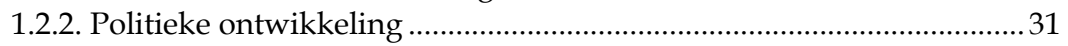

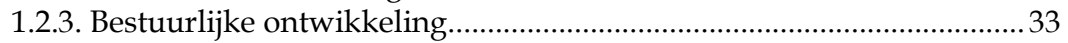

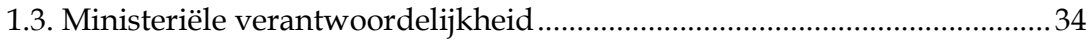

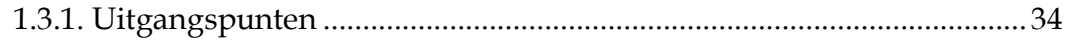

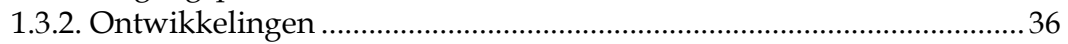

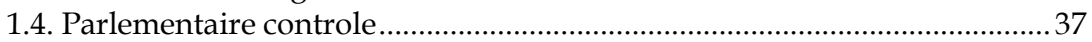

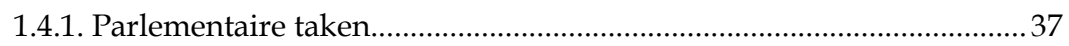

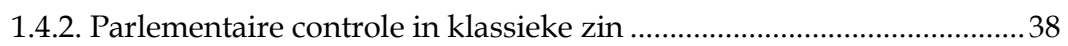

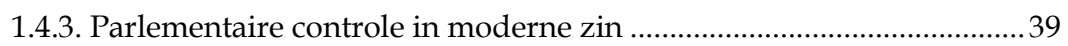

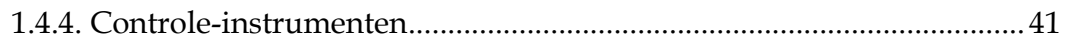

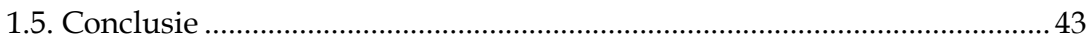

Hoofdstuk 2. Onderzoeksrecht en onderzoeksbevoegdheden.............................. 45

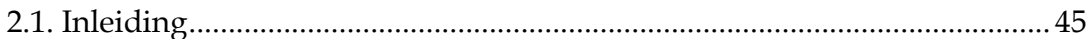

2.2. Betekenis en reikwijdte onderzoeksrecht ................................................... 45

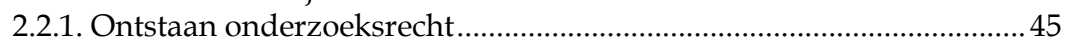

2.2.2. Vroege onderzoekspraktijk ................................................................. 51

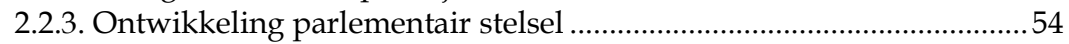

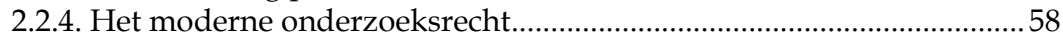

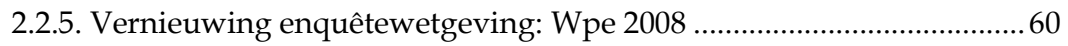


2.2.6. Geen beperkingen bij regulier parlementair onderzoek? ....................62 62

2.3. Onderzoeksbevoegdheden bij parlementaire enquêtes ............................... 64

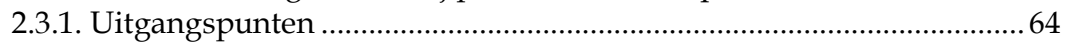

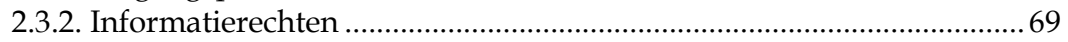

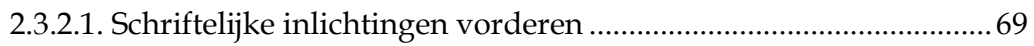

2.3.2.2. Mondelinge inlichtingen vorderen................................................. 70

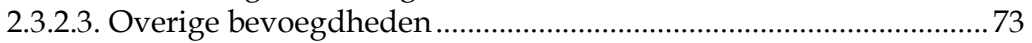

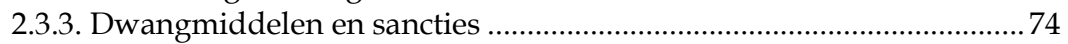

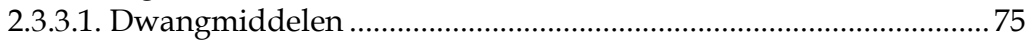

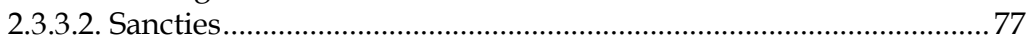

2.3.4. Rechtsbescherming, verschoning en bewijsuitsluiting ..........................78

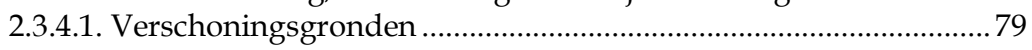

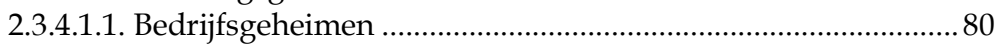

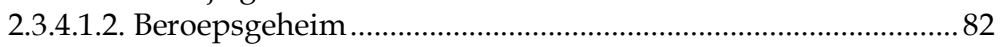

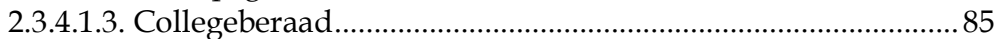

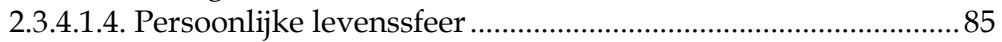

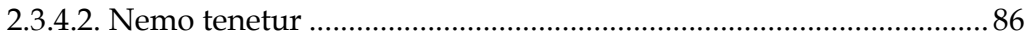

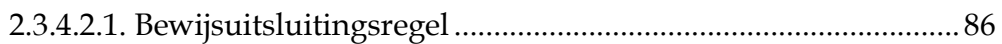

2.3.4.2.2. Geen zwijgrecht of immuniteitsregeling ................................. 90

2.4. Onderzoeksbevoegdheden bij regulier parlementair onderzoek............... 91

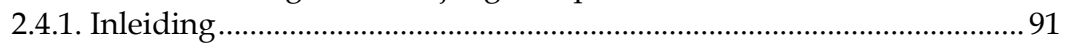

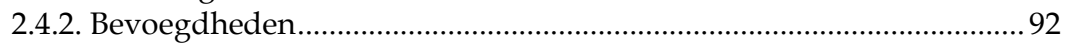

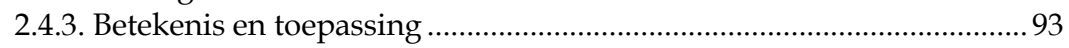

2.5. De positie van bewindspersonen en ambtenaren ......................................96

2.5.1. Ministers en staatssecretarissen ................................................................96

2.5.1.1. Inlichtingenplicht en verantwoordingsplicht ................................97

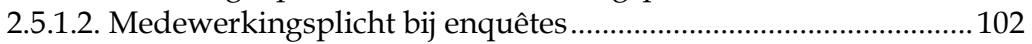

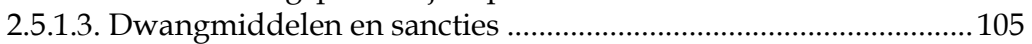

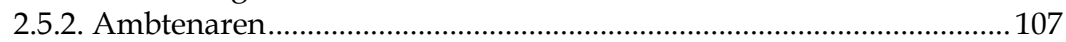

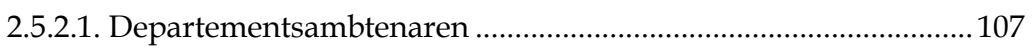

2.5.2.2. Adviescolleges en zelfstandige bestuursorganen.......................... 110

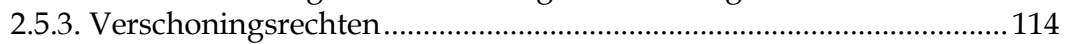

2.5.3.1. Regulier parlementair onderzoek ................................................. 114

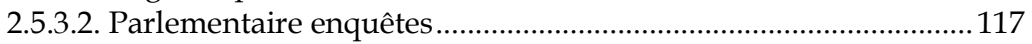

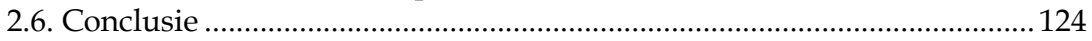

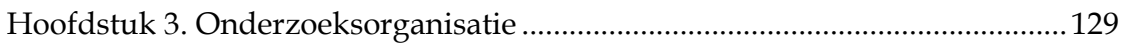

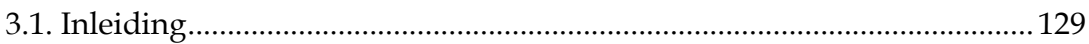

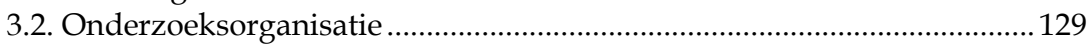

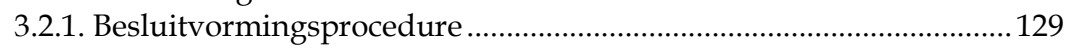

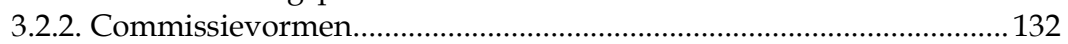

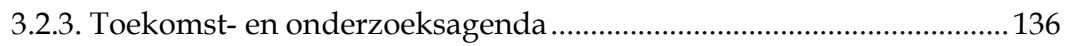

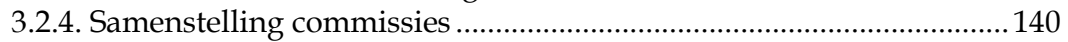

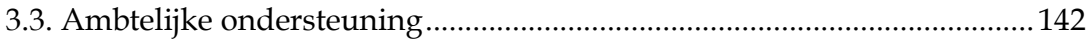

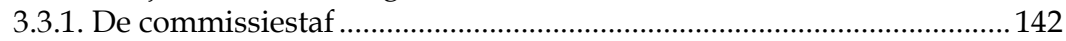

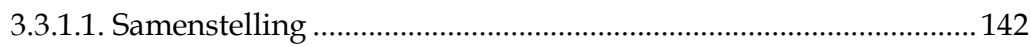


3.3.1.2. Functies en taakverdeling.......................................................... 143

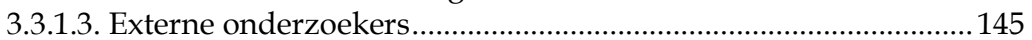

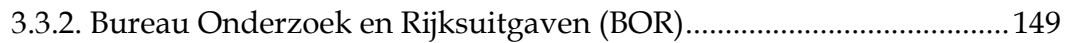

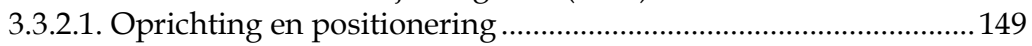

3.3.2.2. Organisatie en taken........................................................................ 150

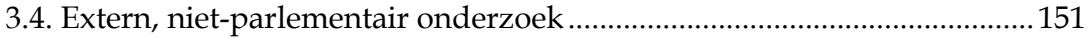

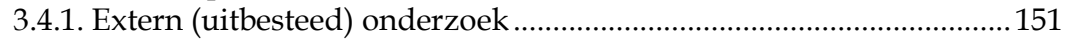

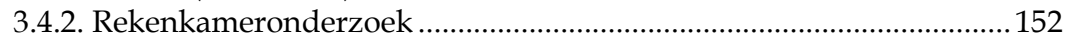

3.5. Parlementair onderzoek in de Eerste Kamer ................................................ 153

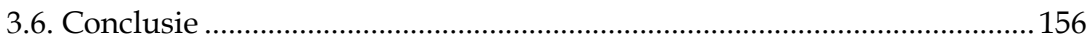

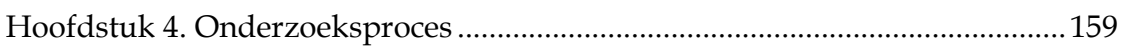

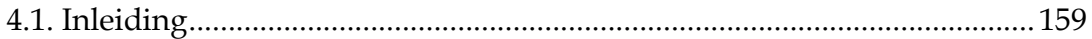

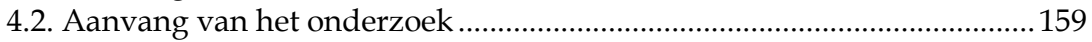

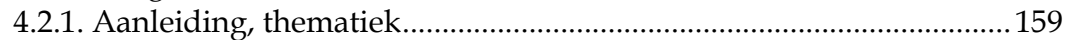

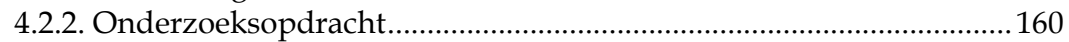

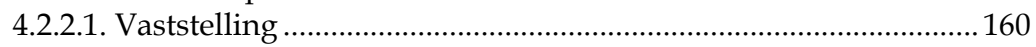

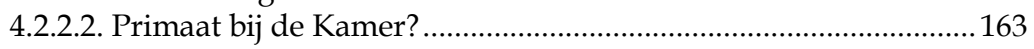

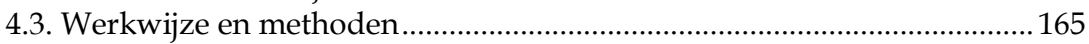

4.4. Vooronderzoek: documentenanalyse en interviews..................................167

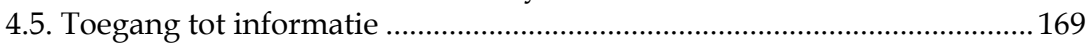

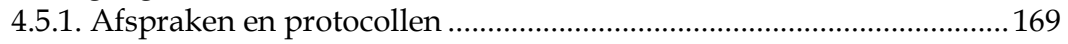

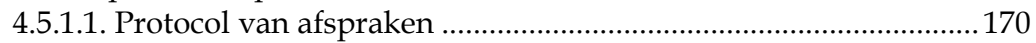

4.5.1.2. Zelfstandige bestuursorganen; markttoezichthouders ................174

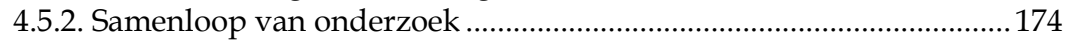

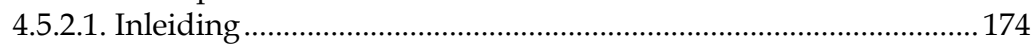

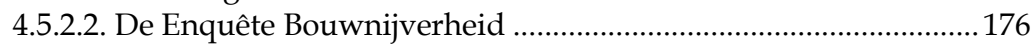

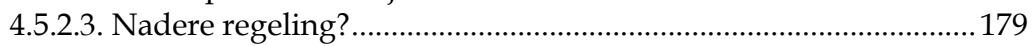

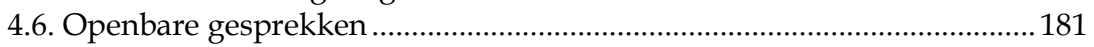

4.6.1. Procedure, rol voorzitter.................................................................... 181

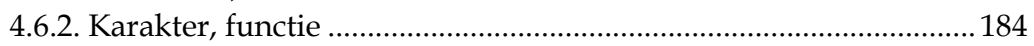

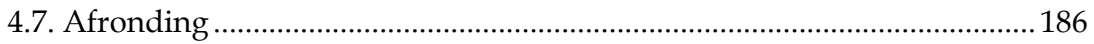

4.7.1. Totstandkoming, inhoud en publicatie eindrapport........................... 186

4.7.2. Openbaarheid, vertrouwelijkheid en archivering ............................... 190

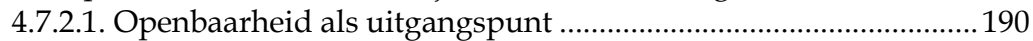

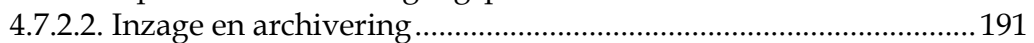

4.7.3. Behandeling eindrapport, implementatie en evaluatie ......................196

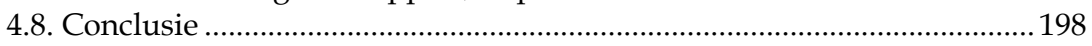

Deel II. Parlementair onderzoek in het Verenigd Koninkrijk ............................ 201

Hoofdstuk 1. Politiek-constitutioneel kader .......................................................... 203

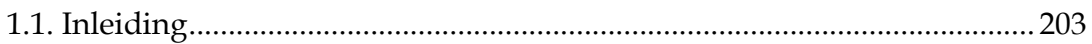

1.2. Het Britse parlementaire stelsel ................................................................ 203

1.3. Beginselen van verantwoordelijkheid en controle .................................... 206

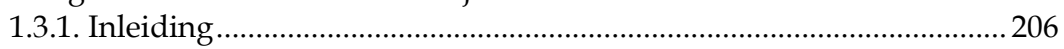

1.3.2. Ministeriële verantwoordelijkheid ..................................................... 207 


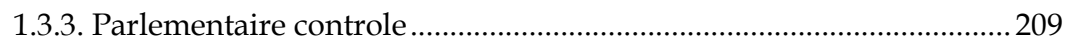

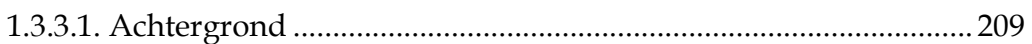

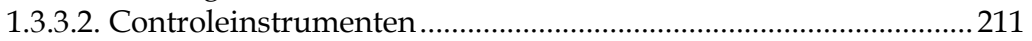

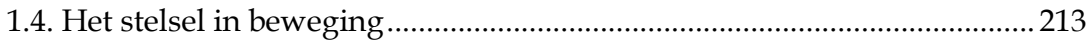

1.4.1. Ministeriële verantwoordelijkheid in ontwikkeling?........................213

1.4.1.1. Groei ambtelijke dienst ..................................................................... 213

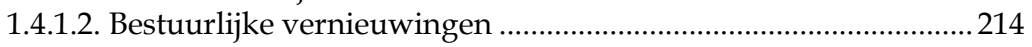

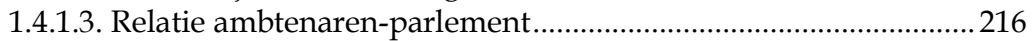

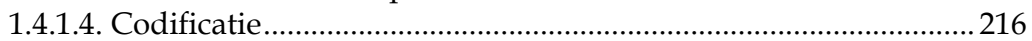

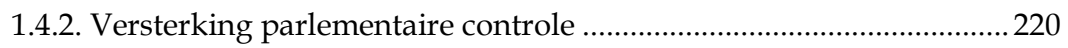

1.4.3. Andere verantwoordings- en controlemechanismen.........................223

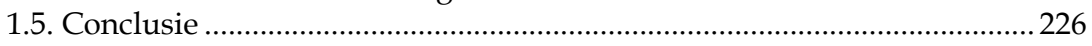

Hoofdstuk 2. Onderzoeksrecht en onderzoeksbevoegdheden.............................229

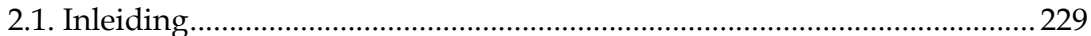

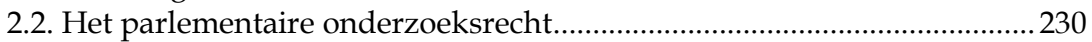

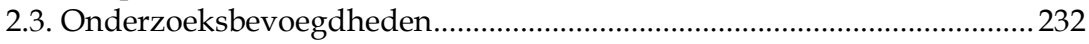

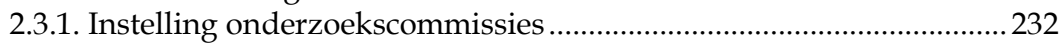

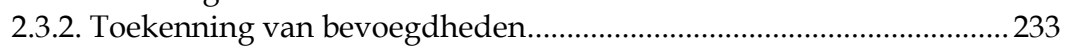

2.3.3. To send for persons, papers and records (PPR) ................................. 234

2.3.3.1. Het oproepen van getuigen ........................................................... 234

2.3.3.2. Het horen van getuigen ................................................................ 236

2.3.3.3. Het opvragen van documenten ................................................... 238

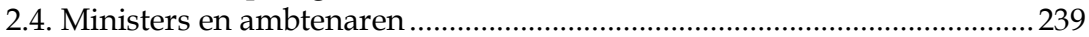

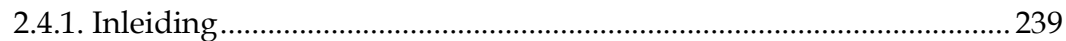

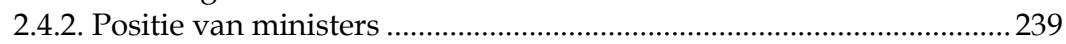

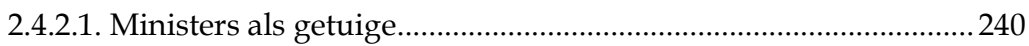

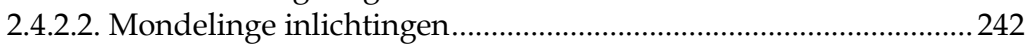

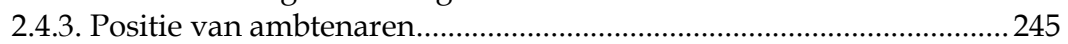

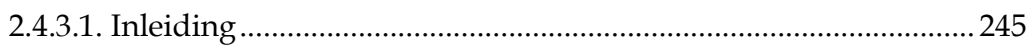

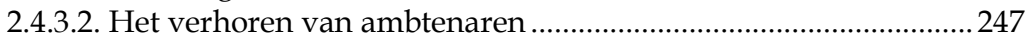

2.4.3.3. Welke ambtenaar verschijnt namens de minister?....................... 250

2.4.3.4. Onderzoek naar ambtelijk handelen ............................................. 252

2.4.4. Departementale stukken en schriftelijke inlichtingen .........................255

2.4.5. Verzelfstandigde publieke diensten: NDPBs en agencies ..................257

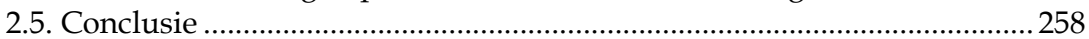

Hoofdstuk 3. Onderzoeksorganisatie .............................................................. 263

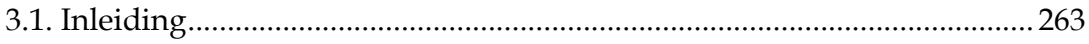

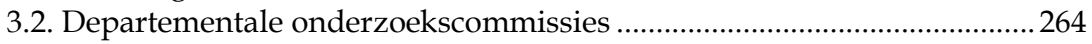

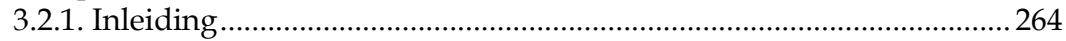

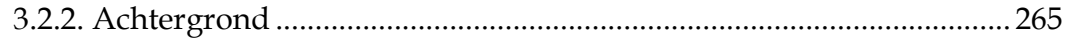

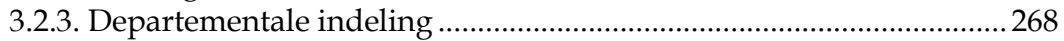

3.2.4. Samenstelling en benoeming............................................................ 270

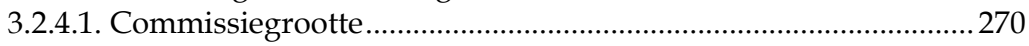

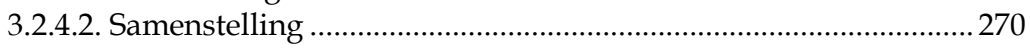


3.2.4.3. De rol van de commissievoorzitter................................................ 274

3.2.4.4. Het instellen van subcommissies.................................................... 275

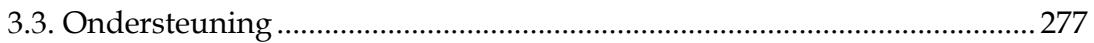

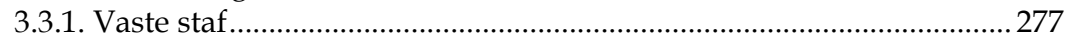

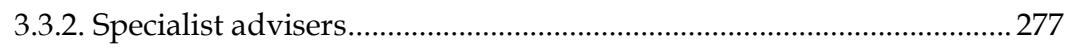

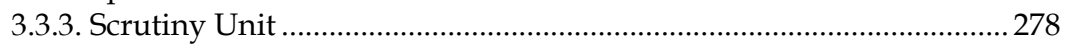

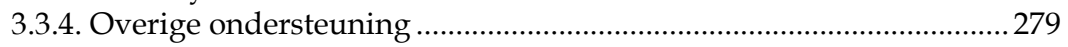

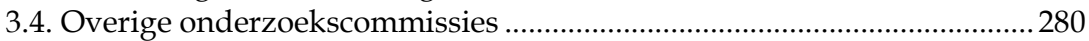

3.4.1. Thematische onderzoekscommissies ('cross-cutting committees') ...280

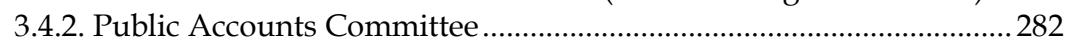

3.4.2.1. De commissie .................................................................................... 282

3.4.2.2. Samenwerking met Comptroller \& Auditor General ...................282

3.4.2.3. Bijzondere positie van Accounting Officers ....................................2 283

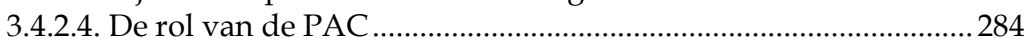

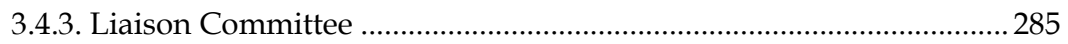

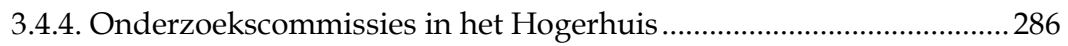

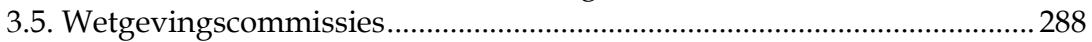

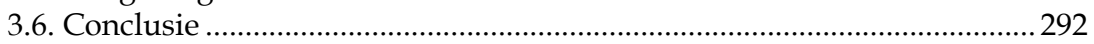

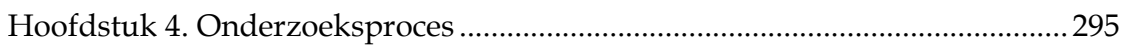

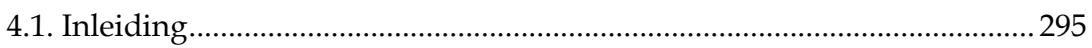

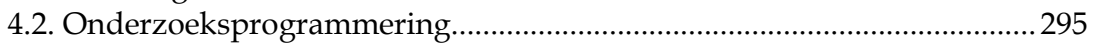

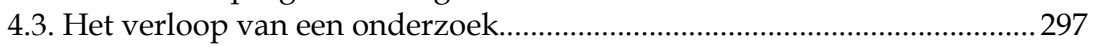

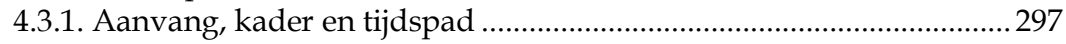

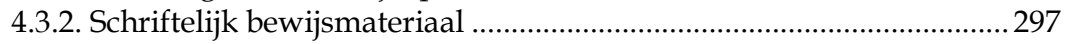

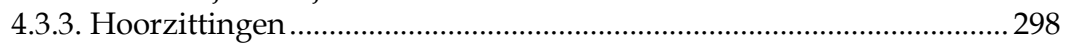

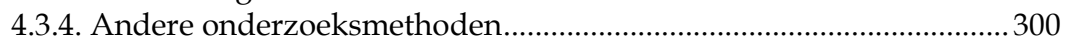

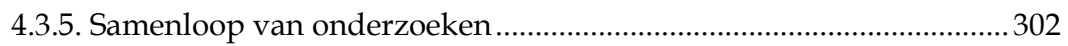

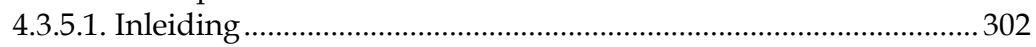

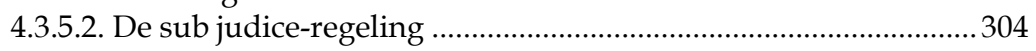

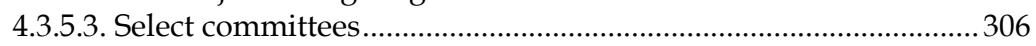

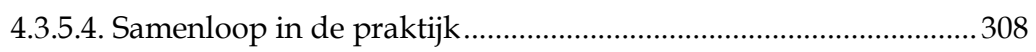

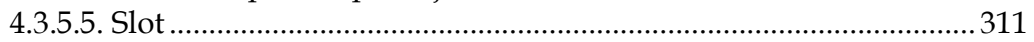

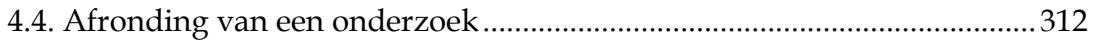

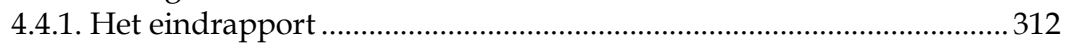

4.4.1.1. Rapportagebevoegdheid ........................................................... 312

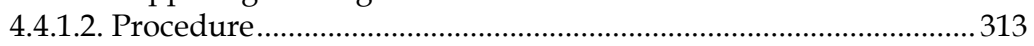

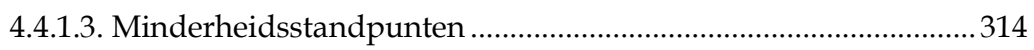

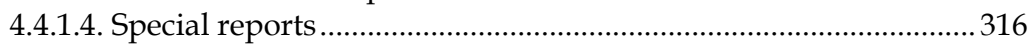

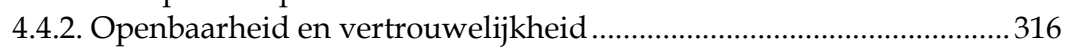

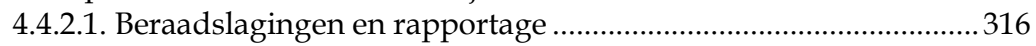

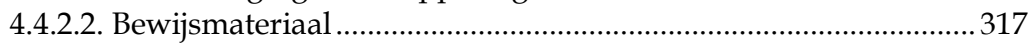

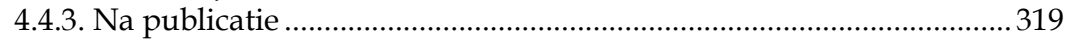

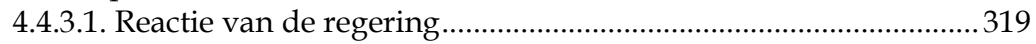

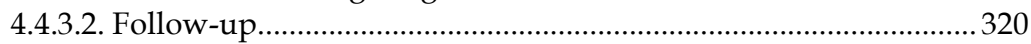

4.4.3.3. Parlementaire behandeling.......................................................... 321 


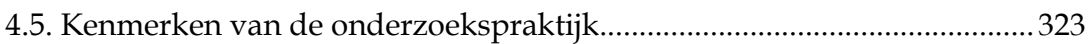

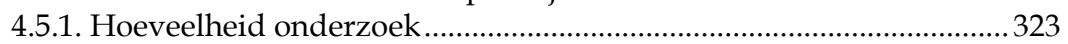

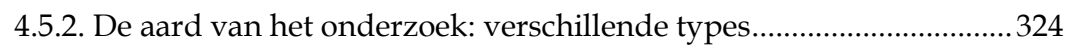

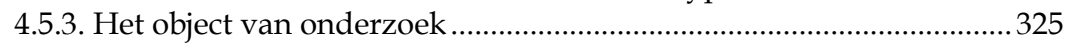

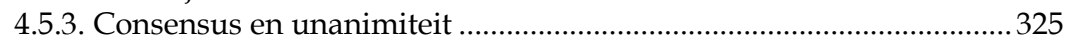

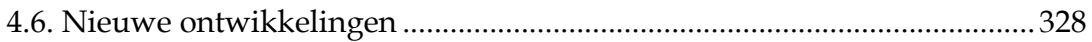

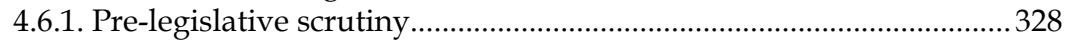

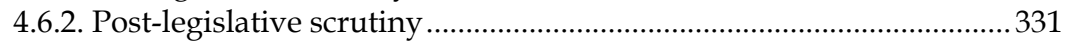

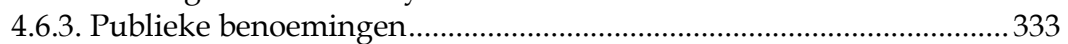

4.7. Slotbeschouwing: dertig jaar departmental select committees .................337

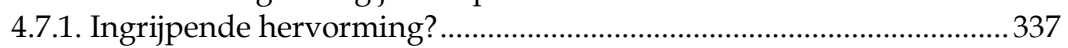

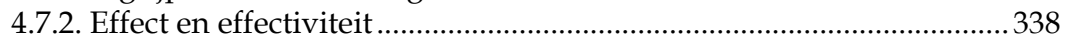

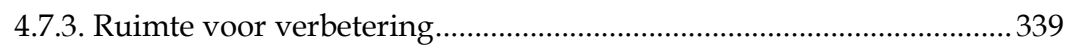

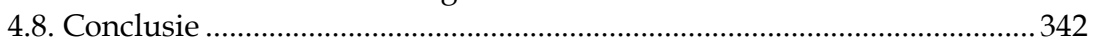

Deel III. Parlementair onderzoek in de Verenigde Staten..................................345

Hoofdstuk 1. Politiek-constitutioneel kader ........................................................... 347

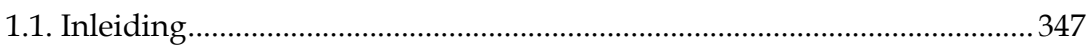

1.2. Het Congres en de wetgevende macht ..................................................... 347

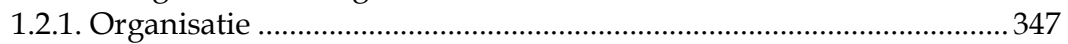

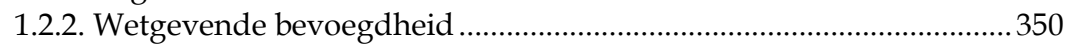

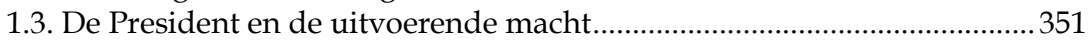

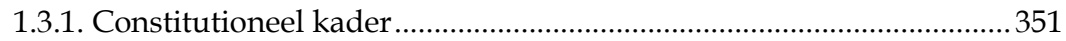

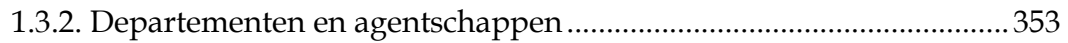

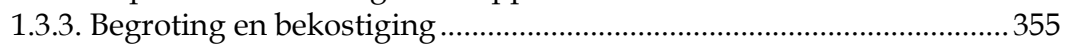

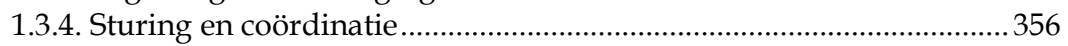

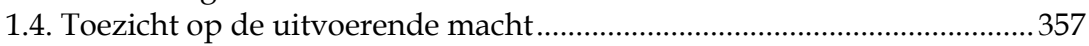

1.4.1. Oversight: toezicht door het Congres …............................................ 357

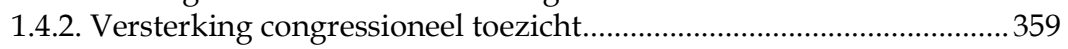

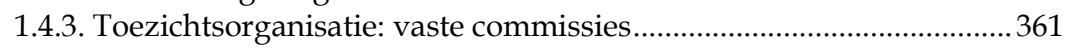

1.4.4. Toezichtsinstrumentarium: het onderzoeksrecht...............................362

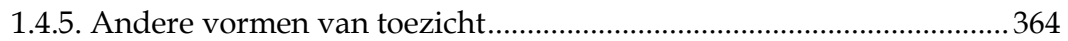

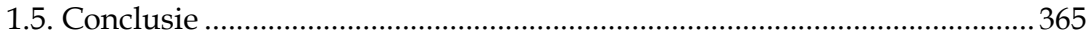

Hoofdstuk 2. Onderzoeksrecht en onderzoeksbevoegdheden.............................367

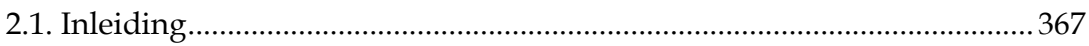

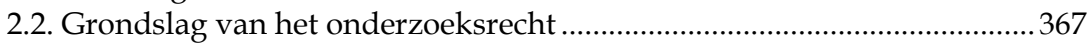

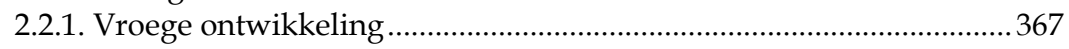

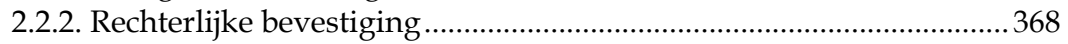

2.2.2.1. Restrictief begin: Kilbourn v. Thompson (1881) ........................... 368

2.2.2.2. Principiële erkenning: McGrain v. Daugherty (1927) .................. 371

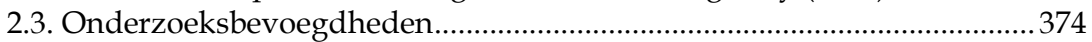

2.3.1. Getuigen verhoren en documenten opvragen ('subpoena power') ..374

2.3.2. Dwangmiddelen en sancties ('Contempt of Congress') ......................378

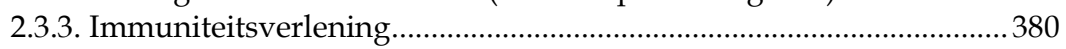

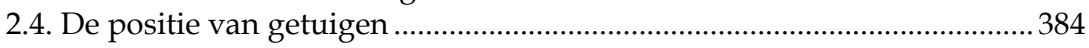


2.4.1. Inleiding: de 'Red Scare', HUAC en McCarthy ....................................384

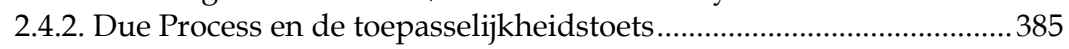

2.4.3. Het non-incriminatierecht ....................................................................... 389

2.5. Tussenconclusie, mede in vergelijkend perspectief ...................................392

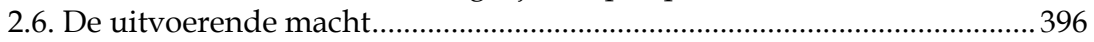

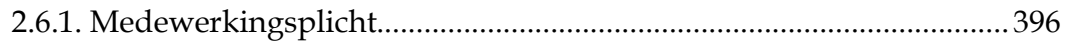

2.6.2. De ontwikkeling van het 'executive privilege' ....................................397

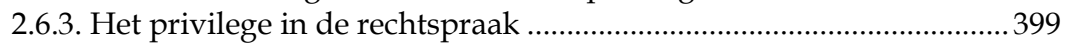

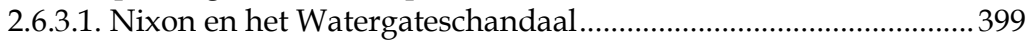

2.6.3.2. Reagan en het Environmental Protection Agency......................... 403

2.6.3.3. George W. Bush en het ontslag van federale aanklagers.............. 405

2.6.4. Slot: informatieconflicten in de praktijk ..............................................407

Hoofdstuk 3. Onderzoeksorganisatie ................................................................... 411

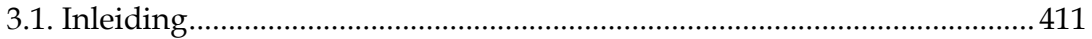

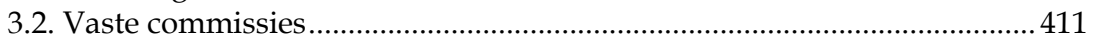

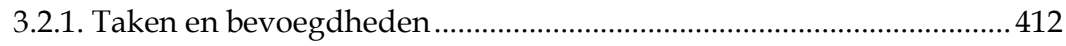

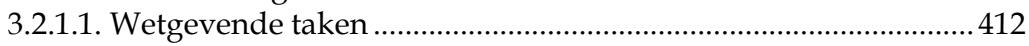

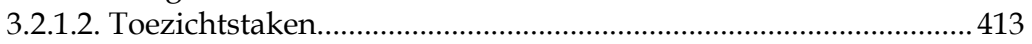

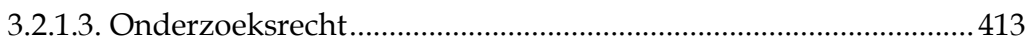

3.2.1.4. House Oversight and Government Reform Committee................414

3.2.1.5. Senate Permanent Subcommittee on Investigations ......................415

3.2.2. Samenstelling, omvang, verhoudingen .................................................. 416

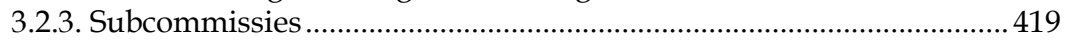

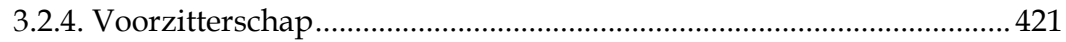

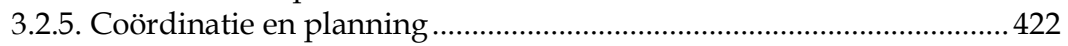

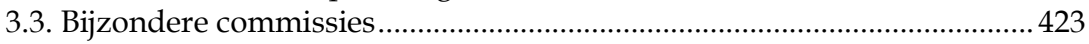

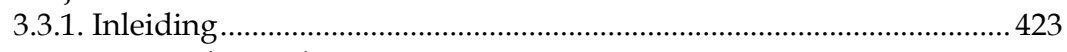

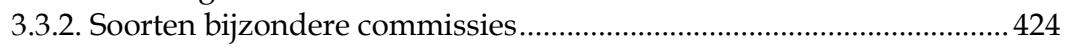

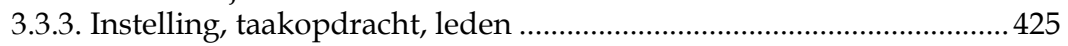

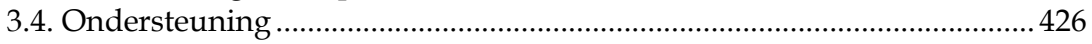

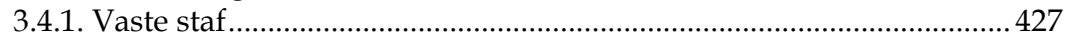

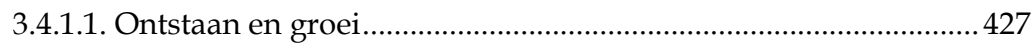

3.4.1.2. Samenstelling, taken en middelen................................................. 429

3.4.1.3. Partijpolitieke achtergrond en aansturing ......................................430

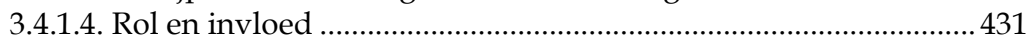

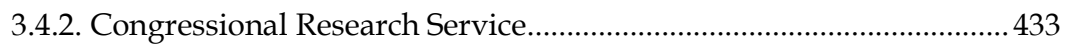

3.4.3. Government Accountability Office …................................................. 434

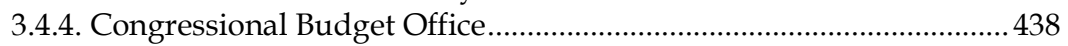

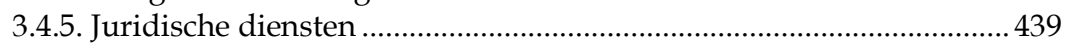

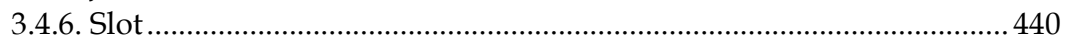

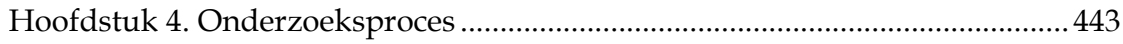

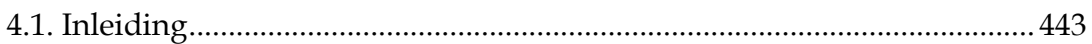

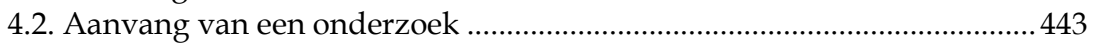

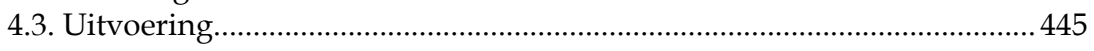




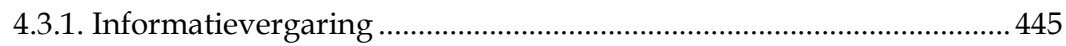

4.3.2. Beperkingen: samenloop van onderzoeken ........................................446

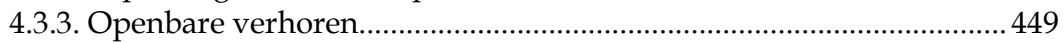

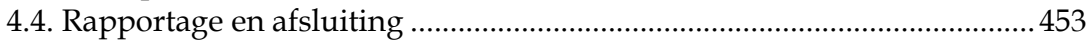

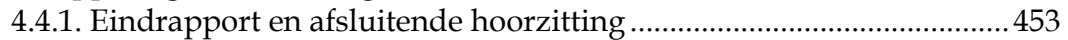

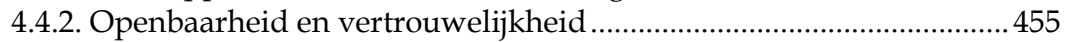

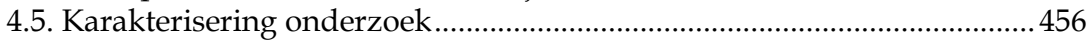

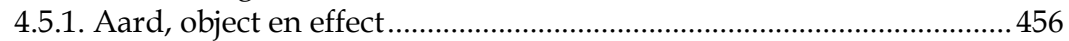

4.5.2. Kwantiteit en kwaliteit.......................................................................... 458

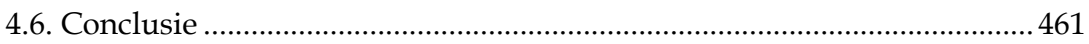

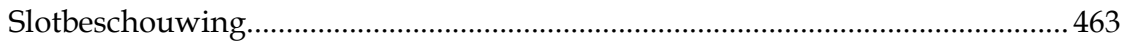

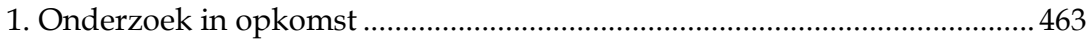

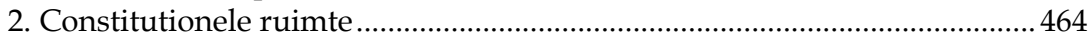

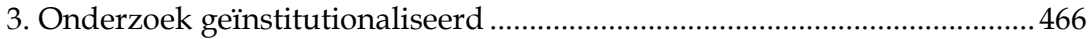

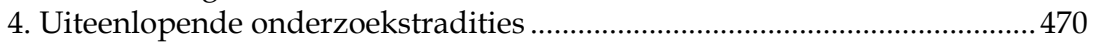

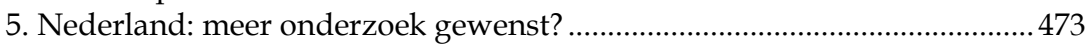

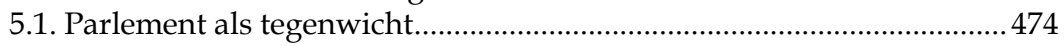

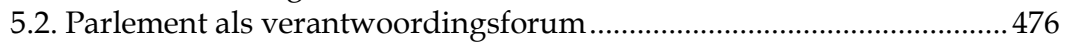

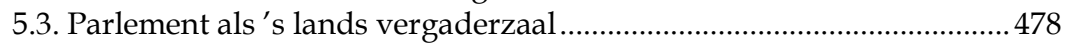

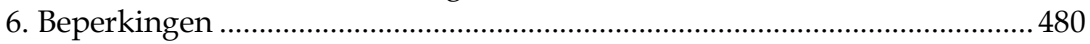

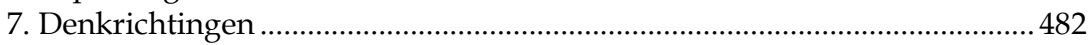

7.1. Eerste denkrichting: verbetering coördinatie......................................... 482

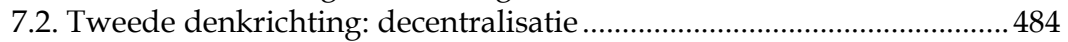

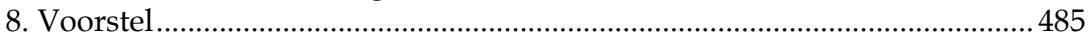

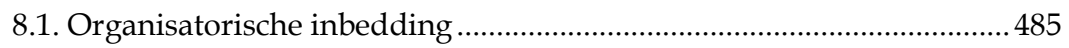

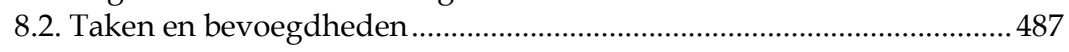

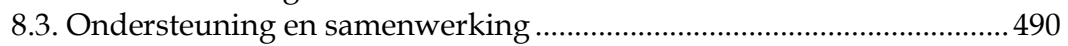

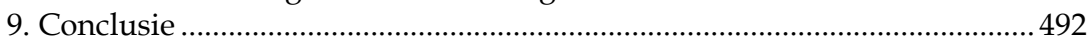

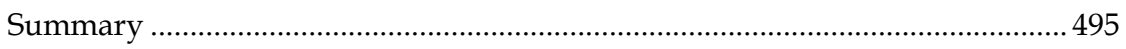

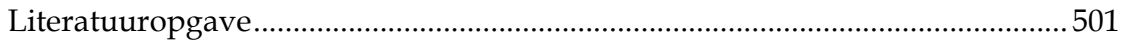

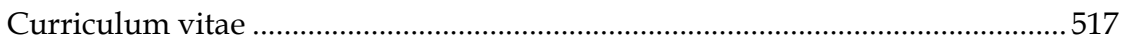




\section{Inleiding}

\subsection{Aanleiding}

Parlementair onderzoek in Nederland heeft zich de afgelopen decennia sterk ontwikkeld. Het parlementaire recht van onderzoek werd reeds in 1848 grondwettelijk verankerd, maar verkeerde het gedurende een groot deel van de twintigste eeuw in onbruik. Eind jaren 70 kwam hier verandering in. Een wetswijziging moest het enquêterecht weer bij de tijd brengen en een voorstel tot grondwetswijziging zou er zelfs voor moeten zorgen dat een parlementaire minderheid tot het houden van een enquête zou kunnen besluiten. De grondwetswijziging kwam er niet, ${ }^{1}$ maar dat heeft de Tweede Kamer er niet van weerhouden om het onderzoeksinstrument vanaf die tijd steeds vaker in te zetten. Parlementair onderzoek - soms uitgevoerd door enquêtecommissies, maar veel vaker door onderzoekscommissies zonder enquêtebevoegdheden - is inmiddels een vertrouwd verschijnsel geworden en lijkt niet meer weg te denken uit de parlementaire werkwijze.

Over die werkwijze en, meer in algemene zin, het functioneren van het parlement bestaat al enige tijd discussie. Vanuit verschillende hoeken klinkt kritiek op de wijze waarop het parlement zijn kerntaken verricht. ${ }^{2}$ Zo stelt de Raad van State in zijn jaarverslag over 2005 dat de Staten-Generaal in hun rol als mede-wetgever en controleur beperkt worden "door hun afhankelijkheid van wat de regering aanlevert, de coalitie vraagt en de media eisen." 3 Om zijn functioneren te verbeteren en de binding met het bestuur en de media losser te maken, zo stelt de Raad, dient het parlement minder afhankelijk te zijn van de informatievoorziening van de regering en meer aandacht te besteden aan de controle op de effecten van beleid. Parlementair onderzoek, gericht op beleidsevaluatie ex post, kan daaraan bijdragen. ${ }^{4}$ Het versterken van de onderzoeksfunctie van het parlement wordt ook gezien als een manier om de balans tussen regering en parlement te verbeteren. Jurgens schrijft hierover, onder verwijzing naar een Kamervoorzitter die de zelfstandigheid van het parlement ten opzichte van de regering hoog in het vaandel had staan:

\footnotetext{
"Eigen, gericht onderzoek is bij uitstek het middel waarmee een parlement zijn staatsrechtelijke en politieke zelfstandigheid laat zien. Vergroten wij de omvang daarvan in de Kamer, voegt de senaat er zich dan ook voor het eerst bij (...) dan wordt het parlement opnieuw wat Anne Vondeling zo graag wilde: EEN LEEUW." 5
}

\footnotetext{
${ }^{1}$ Het voorstel werd uiteindelijk in tweede lezing verworpen door de Eerste Kamer. Zie ook hierna, Deel I, par. 2.2.4.

2 Bovend'Eert \& Kummeling 2010, p. 27.

${ }^{3}$ Jaarverslag Raad van State 2005, p. 39.

${ }^{4}$ Jaarverslag Raad van State 2005, p. 40.

${ }^{5}$ Jurgens 2004, p. 224.
} 
De kritiek op het functioneren van het parlement vormde ook voor de Tweede Kamer zelf de afgelopen decennia verschillende malen aanleiding om haar eigen organisatie en werkwijze tegen het licht te houden. ${ }^{6}$ De meest recente evaluatie vond plaats in de periode 2007-2009. Naar aanleiding van de motie-Schinkelshoek c.s., waarin werd geconstateerd dat de positie, reputatie en werkwijze van het parlement al enige tijd onderwerp van publiek debat zijn, ${ }^{7}$ verrichtte de Kamer een zogenaamde zelfreflectie. ${ }^{8}$ Hieruit kwam onder meer naar voren dat de Kamer volgens velen toe was aan een herijking: het accent lag teveel op fracties en individuele leden en te weinig op het instituut waar het fundamentele, beslissende debat wordt gevoerd en besluiten worden genomen. ${ }^{9}$ Ook de parlementaire informatiepositie werd als problematisch ervaren. De Kamer, zo werd geconcludeerd, is voor haar informatievoorziening (te) sterk afhankelijk van de regering, ontvangt soms niet altijd de benodigde informatie en heeft op andere momenten juist moeite om de overvloed aan informatie te 'schiften'. Verder werd een toenemend incidentalisme in de Kamer gesignaleerd. In het huidige mediatijdperk is het voor Kamerleden van belang zichzelf voortdurend zichtbaar te profileren, met als gevolg een sterke groei van het aantal Kamervragen en spoeddebatten. ${ }^{10}$ In de concrete voorstellen die naar aanleiding van deze zelfreflectie werden gedaan, vormde het doen van meer parlementair onderzoek een belangrijk onderdeel. ${ }^{11}$

Parlementair onderzoek heeft de laatste tijd ook om andere redenen de nodige aandacht gekregen. De moderne onderzoekspraktijk, zoals die de afgelopen decennia is ontstaan, blijkt een aantal knelpunten te kennen. Bij verschillende onderzoeken, met name enquêtes, bestond bijvoorbeeld discussie over de positie van getuigen en de samenloop tussen parlementair en strafrechtelijk onderzoek. Mede daarom is de

\footnotetext{
${ }^{6}$ De bijzondere Kamercommissies die hiertoe werden ingesteld werden bekend onder de naam van hun voorzitters, die destijds tevens Kamervoorzitter waren, te weten Dolman (1985/86), Deetman (1990/93) en Weisglas (2003). Zie ook Van Schagen 1994, p. 1 en Bovend'Eert \& Kummeling 2010, p. 27-28.

${ }^{7}$ Kamerstukken II 2006/07, 30 996, nr. 9.

8 Een daartoe ingestelde stuurgroep onder leiding van Kamervoorzitter Verbeet voerde in dit kader een reeks gesprekken met Kamerleden, ambtelijke medewerkers, externe betrokkenen en deskundigen. Het proces werd afgesloten met een conferentie in maart 2009 en een rapport getiteld 'Vertrouwen en zelfvertrouwen'.

${ }^{9}$ Rapport parlementaire zelfreflectie 2009, p. 9.

10 Rapport parlementaire zelfreflectie 2009, p. 30 e.v. Het stellen van mondelinge vragen en het houden van spoeddebatten wordt, zo blijkt uit het meest recente parlementsonderzoek, door veel Kamerleden - met name aan coalitiezijde - als weinig effectief beschouwd. Het vertrouwen in het onderzoeksinstrument blijkt daarentegen aan alle zijden onverminderd hoog, ondanks het feit dat het 'nieuwe' er inmiddels wel vanaf is en er ook knelpunten worden geconstateerd. Parlementaire onderzoeken (enquêtes) zouden bovendien niet slechts aangewezen zijn bij falend overheidsbeleid, maar ook betrekking kunnen hebben op maatschappelijke problemen. Zie Andeweg \& Thomassen 2007, p. 53-59. Het najagen van de waan van de dag, waardoor de werkelijke maatschappelijke vraagstukken onvoldoende aan bod komen, leidt bij veel Kamerleden tot ergernis; ruim eenderde van de Kamerleden beschouwt dit als een gebrek in de parlementaire werkwijze. Idem, p. 102-103.

${ }^{11}$ Zo werd voorgesteld te gaan werken met een zogenaamde Toekomst- en onderzoeksagenda. In het gebruik van andere parlementaire instrumenten, zoals het vragenrecht, zouden Kamerleden juist selectiever moeten zijn. Zie Rapport parlementaire zelfreflectie 2009, p. 47 e.v.
} 
wetgeving rondom het onderzoeksrecht, die grotendeels stamde uit het midden van de negentiende eeuw, recentelijk herzien. In mei 2008 trad de vernieuwde Wet op de parlementaire enquête (Wpe 2008) in werking, die was voorbereid door een speciale Kamercommissie. ${ }^{12}$ De nieuwe wet beoogt de bevoegdheden van enquêtecommissies op bepaalde punten te versterken en tegelijkertijd de rechten en plichten van getuigen te verhelderen. Bij deze gelegenheid werd ook de interne regelgeving omtrent andere vormen van (parlementair) onderzoek vernieuwd. ${ }^{13}$

\subsection{Doelstelling}

Parlementair onderzoek heeft de afgelopen decennia, zo kan uit het voorgaande worden afgeleid, sterk aan betekenis gewonnen en is nog steeds in ontwikkeling. Het onderzoeksinstrument speelt bovendien een prominente rol in de lopende discussie over de parlementaire werkwijze. Die discussie, die ook in andere westerse landen wordt gevoerd, is van groot belang gezien de rol die de volksvertegenwoordiging speelt in het waarborgen van de democratische legitimiteit van het overheidsbestuur. In het Nederlandse staatsbestel vervult het parlement, als enig direct door de kiezer gelegitimeerd orgaan, een democratische sleutelpositie. Binnen dat stelsel vormen de beginselen van machtenscheiding en 'checks and balances' belangrijke uitgangspunten. Hieruit volgt onder meer dat het parlement met een zekere zelfstandigheid en onafhankelijkheid moet kunnen opereren en tegelijkertijd dat de volksvertegenwoordiging beschikt over mogelijkheden om controle uit te oefenen op regering. ${ }^{14}$ Wanneer betwijfeld wordt of het parlement in voldoende mate in staat is om zijn sleutelrol in de praktijk waar te maken, dan raakt dat het hart van de Nederlandse democratie. Vanuit staatsrechtelijk oogpunt is nadere overdenking van de parlementaire werkwijze daarom gewenst.

Tegen deze achtergrond beoogt dit proefschrift een bijdrage te leveren aan de gedachtevorming door het parlementaire onderzoeksrecht centraal te stellen en aan een grondige studie te onderwerpen. Daarbij wordt het onderzoeksrecht niet alleen in Nederland, maar ook in twee buitenlandse stelsels op vergelijkbare wijze nader bestudeerd en in kaart gebracht. Zoals hierna nog zal worden toegelicht, is gekozen voor het Britse parlement en het Amerikaanse Congres. Aan de hand van de drie landenstudies wordt tot slot bezien in hoeverre een vergelijking van de ervaringen in deze stelsels kan leiden tot aanbevelingen ten aanzien van het Nederlandse onderzoeksrecht en de wijze waarop het parlement dat recht toepast.

Uiteraard is het niet de eerste keer dat het parlementaire onderzoeksrecht nader wordt bestudeerd. Het proefschrift van Boon, dat in 1982 verscheen, is een van de eerste rechtswetenschappelijke werken op dit gebied in Nederland. ${ }^{15}$ De publicatie van dit proefschrift ging vooraf aan de eerste moderne parlementaire enquête in Nederland, die in 1983 plaatsvond. Enkele jaren later verscheen in de Groningse reeks

\footnotetext{
12 Stb. 2008, 148.

${ }^{13}$ Belangrijkste resultaat daarvan is de Regeling parlementair en extern onderzoek 2008.

14 Zie ook Bovend'Eert \& Kummeling 2010, p. 10 e.v.

${ }^{15}$ Het allereerste proefschrift op dit terrein dateert echter van 1860 . Verder verscheen in 1978 een preadvies over het enquêterecht. Zie Karsten 1860 en Kappeyne van de Coppello 1978.
} 
over parlementsrecht een monografie over het enquêterecht van Dölle. ${ }^{16}$ Vervolgens verschenen zo nu en dan artikelen over (aspecten van) het onderzoeksrecht, veelal bij gelegenheid van de aanvang of de afronding van een parlementaire enquête. ${ }^{17}$ De eerste overzichtsstudie van de moderne parlementaire onderzoekspraktijk in Nederland verscheen in 2002 van de hand van Muller en Coenen. Zij benaderen het thema voornamelijk vanuit bestuurskundig-organisatorisch oogpunt en beperken zich niet tot de parlementaire enquête, maar behandelen verschillende vormen van onderzoek. ${ }^{18}$ Juridische literatuur die de afgelopen jaren is verschenen, richt zich wederom hoofdzakelijk op het enquêterecht. ${ }^{19}$ Daarnaast wordt het onderwerp in de Nederlandse staatsrechtelijke literatuur steeds vaker vanuit vergelijkend perspectief benaderd. Boon vergeleek dertig jaar geleden het nog net niet ontwaakte Nederlandse enquêterecht al met het Duitse en het Amerikaanse. Meer recente studies richtten zich op het onderzoeksrecht in verschillende Europese stelsels. ${ }^{20}$ In de voorbereiding van de nieuwe Wet op de parlementaire enquête speelde rechtsvergelijking eveneens een rol: in opdracht van de Tweede Kamer verscheen een drietal rapporten omtrent het enquêterecht in Duitsland, het Verenigd Koninkrijk en Frankrijk. ${ }^{21}$

Dat de rechtswetenschappelijke studie van het parlementaire onderzoeksinstrument in Nederland zich tot nu toe, mede in vergelijkende zin, vooral toespitst op het enquêterecht of onderdelen daarvan is misschien niet onbegrijpelijk - bij het enquêterecht krijgen de parlementaire werkzaamheden immers een bijzondere juridische dimensie, waarbij de positie van individuele burgers in het geding kan zijn maar tegelijkertijd moet worden vastgesteld dat de enquête in de praktijk een tamelijk uitzonderlijk verschijnsel is gebleven. In de afgelopen dertig jaar hebben negen enquêtes plaatsgevonden. Veel belangrijker, althans in kwantitatieve zin, is het 'gewone' parlementaire onderzoek, verricht door tijdelijke commissies die niet over enquêtebevoegdheden beschikken. De Kamer heeft sinds de opleving van het onderzoeksrecht ruim dertig van dergelijke onderzoeken van verschillende omvang uitgevoerd en het is vooral dit type onderzoek dat de laatste jaren de meeste groei heeft doorgemaakt. 22

In dit proefschrift wordt het onderzoeksrecht daarom in brede zin bestudeerd. Niet alleen de enquête, maar ook andere vormen van onderzoek komen aan bod. In de analyse wordt ingegaan op juridische vraagstukken, zoals de plaats van het onderzoeksrecht in het constitutionele stelsel, de betekenis van onderzoeksbevoegdheden en de recente vernieuwingen die op dit vlak hebben plaatsgevonden, maar ook op verschillende politieke, procedurele en organisatorische aspecten die van belang zijn voor een goed begrip van de betekenis en werking van het onderzoeksrecht in de praktijk. Daarbij zal tevens aandacht worden besteed aan een aantal specifieke knel-

\footnotetext{
${ }^{16}$ Dölle 1985.

17 Zie bijvoorbeeld Naeyé \& Schalken 1996 en Van Dijk 1999.

18 Muller \& Coenen 2002.

19 Zie o.a. Pedroli 2002, Lubberdink 2003 en Drexhage 2009.

${ }^{20}$ Zie bijvoorbeeld over België: Van Damme \& Meersschaut 2003.

21 Zie Kummeling, Kortmann \& Verhey 2006.

${ }^{22}$ Mede als gevolg van de eerder genoemde Toekomst- en onderzoeksagenda, die de Kamer in 2009 invoerde. Zie Kamerstukken II 2009/10, 32 224, nr. 1.
} 
punten die in de loop der tijd in de bestaande Nederlandse onderzoekspraktijk naar voren zijn gekomen.

\subsection{Methode}

In de hierboven geformuleerde doelstelling is gekozen voor een vergelijkende benadering. Rechtsvergelijking kan worden omschreven als het systematisch vergelijken van twee of meer rechtsstelsels of onderdelen van rechtsstelsels. ${ }^{23}$ Er bestaat geen geijkte methode voor het beoefenen van het vergelijkende recht. Voor de wijze waarop een rechtsvergelijkend onderzoek moet worden uitgevoerd bestaan verschillende methodologische invalshoeken. ${ }^{24}$ De bruikbaarheid daarvan hangt mede af van de doelen of motieven die aan het onderzoek ten grondslag liggen. ${ }^{25} \mathrm{Bij}$ elk vergelijkend onderzoek dient daarom een aantal keuzes te worden gemaakt. De methodologische uitgangspunten die de basis vormen van de onderhavige studie, worden hieronder nader uiteengezet.

\subsubsection{Landenkeuze}

Het maken van een brede analyse zoals hier beoogd noopt tot een beperking van het aantal stelsels dat kan worden betrokken in de vergelijking. Voor deze studie is daarom naast Nederland gekozen voor twee buitenlandse stelsels: het Verenigd Koninkrijk en de Verenigde Staten.

Er zijn verschillende redenen om het Britse en het Amerikaanse stelsel te betrekken bij de vergelijking. De belangrijkste is dat zowel het Britse parlement als het Amerikaanse Congres, in vergelijking met veel andere westerse parlementen, een bijzonder rijke onderzoekstraditie kennen. De drie stelsels hebben verder een aantal algemene overeenkomsten. Nederland, het Verenigd Koninkrijk en de Verenigde Staten kunnen worden gekenschetst als westerse, liberale democratieën gevestigd op verlichte ideeën over onder meer representatie, staatsinrichting, machtsverdeling en -beteugeling. ${ }^{26}$ De omvang en betekenis van het uitvoerende regeringsapparaat op centraal niveau is groot, wat samenhangt met de groei van overheidstaken in de twintigste eeuw. In staatsrechtelijke zin is het parlement in alle genoemde stelsels belast met een algemene controletaak ten aanzien van de uitvoerende macht. Het parlement beschikt hiertoe onder meer over een algemeen onderzoeksrecht. Belangrijk is bovendien dat het onderzoeksrecht in alle drie de stelsels in handen is van een parlementaire meerderheid. De stelsels beschikken daarmee in de kern over een aantal belangrijke gemeenschappelijke kenmerken. Daarbij komt dat het Britse parle-

\footnotetext{
${ }^{23}$ Koekkoek 2001, p. 177.

24 Zie bijvoorbeeld Reitz 1998, p. 618. De klassieke benadering is die van de zogenaamde functionele methode, waarbij het werk van Zweigert en Kötz als standaardwerk fungeert. Zie Zweigert \& Kötz 1998. Andere benaderingen zijn onder meer de conceptuele of institutionele methode en de integrale methoden, waaronder de modelmatige methode van Koopmans en de structureel-empirische methode van Koekkoek en Niekerk worden begrepen. Zie over deze methoden van rechtsvergelijking verder: Oderkerk 1999.

${ }^{25}$ Zie onder meer Dannemann 2006, p. 401-406.

${ }^{26}$ Zie ook Janse de Jonge 1993, p. 8-9.
} 
ment, vaak beschouwd als 'moeder aller parlementen', een voorbeeld is geweest in de vormgeving van zowel het Nederlandse parlement als het Amerikaanse Congres. Omgekeerd vormde het Amerikaanse Congres een inspiratiebron voor het Britse parlement bij de introductie van het stelsel van vaste onderzoekscommissies in het Lagerhuis.

Tegelijkertijd moet worden onderkend dat er ook aanmerkelijke verschillen tussen de stelsels bestaan. De meest in het oog springende constitutionele verschillen liggen op het vlak van de verhouding tussen regering en parlement. Op dat punt kunnen de Nederlandse en Britse stelsels in constitutionele zin worden gekwalificeerd als parlementaire stelsels, met als belangrijkste kenmerk dat de regering afhankelijk is van het vertrouwen van een parlementaire meerderheid en ministers een verantwoordingsplicht hebben jegens het parlement. Het Amerikaanse Congres vormt daarentegen een van pijlers in een presidentieel stelsel, gekenmerkt door gescheiden, elkaar in evenwicht houdende machten, waarbij vertrouwensregel en ministeriële verantwoordelijkheid ontbreken. Ook in politieke, historische en culturele zin zijn er verschillen tussen de drie stelsels, bijvoorbeeld als het gaat om de betekenis van politieke partijen voor de verhouding tussen regering en parlement. In die zin kunnen de Britse en Amerikaanse stelsels worden gezien als tegenpolen met fundamenteel verschillende regeerstelsels. Opmerkelijk is echter, dat het parlementaire onderzoeksinstrument, ondanks de genoemde verschillen, in zowel de Verenigde Staten als het Verenigd Koninkrijk blijkt te kunnen floreren, zij het op geheel eigen wijze. In beide stelsels werd in de loop der tijd, zoals in Nederland, een debat gevoerd over de positie van het parlement en de mate waarin het in staat is zijn constitutionele kerntaken, in het bijzonder zijn controlerende taak, te vervullen. Naar aanleiding daarvan heeft in zowel het Amerikaanse Congres als het Britse parlement een aanzienlijke intensivering van de onderzoeksfunctie plaatsgevonden.

Tegen deze achtergrond heeft eerder staatsrechtelijk onderzoek naar het Amerikaanse Congres respectievelijk het Britse parlement reeds laten zien dat deze stelsels interessante aanknopingspunten kunnen bieden voor de onderzoeksfunctie van het Nederlandse parlement. Boon schreef in 1982 met het oog op het Nederlandse enquêterecht al in vergelijkende zin over de sterke onderzoeksbevoegdheden van het Amerikaanse Congres. ${ }^{27}$ Onderdelen van het Amerikaanse stelsel, zoals de regeling rondom het verlenen van strafrechtelijke immuniteit aan getuigen, spelen ook nu nog een rol in de Nederlandse discussie over het parlementaire enquêterecht. ${ }^{28}$ Dat maakt een nadere studie van dit stelsel zoals dat thans fungeert reeds de moeite waard. Ook ten aanzien van de parlementaire werkwijze in bredere zin kan een vergelijking met de Verenigde Staten aanknopingspunten bieden. Dat het Amerikaanse stelsel in constitutioneel opzicht sterk verschilt van het Nederlandse, met name door de afwezigheid van een vertrouwensrelatie tussen regering en parlement en het ontbreken van een beginsel van ministeriële verantwoordelijkheid, hoeft daaraan niet in de weg te staan. Heringa maakte in het licht van de discussie over de effectiviteit van

\footnotetext{
${ }^{27}$ Boon 1982, p. 17 e.v.

${ }^{28}$ Zie bijvoorbeeld Doorenbos in De WPE onder de loep 2004, p. 60 en de memorie van toelichting bij het wetsvoorstel inzake de vernieuwing van de Wet op de Parlementaire Enquête, Kamerstukken II 2005/06, 30415 , nr. 6, p. 56.
} 
parlementaire controle op dit punt eerder een vergelijking tussen het Amerikaanse Congres en het Nederlandse parlement. Wat het Congres laat zien, zo stelt Heringa, is dat het ontbreken van ministeriële verantwoordelijkheid als constitutioneel aanknopingspunt de ontwikkeling van een intensieve congressionele controle- en onderzoekspraktijk geenszins heeft verhinderd. In de discussie over de parlementaire controletaak zou daarom verder moeten worden gedacht dan de ingang van de ministeriële verantwoordelijkheid, die paradoxaal genoeg in Nederland eerder belemmerend dan activerend lijkt te werken. Met name waar het zelfstandige informatievergaring en expertisevorming betreft zou het Nederlandse parlement, ondanks de constitutionele verschillen tussen beide stelsels, veel kunnen leren van het Amerikaanse Congres. ${ }^{29}$

Ten aanzien van het Britse parlement maakte Verhey, eveneens in het licht van de parlementaire controlefunctie, een schets van het stelsel van permanente onderzoekscommissies in het Lagerhuis. In zowel Nederland als het Verenigd Koninkrijk speelt het beginsel van ministeriële verantwoordelijkheid een centrale rol, maar belangrijk verschil is dat het Lagerhuis in het sterk monistische Britse stelsel een veel zwakkere positie inneemt ten opzichte van de regering dan de Nederlandse Tweede Kamer. Juist daarom is het volgens Verhey opmerkelijk dat het Britse parlement in staat is gebleken om ingrijpende organisatorische hervormingen door te voeren in de vorm van het stelsel van select committees, dat heeft geleid tot meer structuur en continuilteit in de parlementaire controle. Hoewel Verhey geen aanleiding ziet voor het overnemen van een dergelijk commissiestelsel in Nederland, kan de Tweede Kamer met name op organisatorisch vlak wel degelijk lering trekken uit de Britse ervaringen. ${ }^{30}$

In dit proefschrift wordt voortgebouwd op de eerdere vergelijkende verkenningen van de parlementaire onderzoeksfunctie in het Britse parlement en het Amerikaanse Congres. Uitgangspunt is dat een diepgravende analyse en vergelijking van onderling sterk verschillende stelsels en tradities juist vanwege de diversiteit aan onderzoeksmodaliteiten interessante nieuwe gezichtspunten zou kunnen opleveren. Bovendien kan een dergelijke integrale studie bijdragen aan een beter begrip van de aard en functie van parlementair onderzoek in deze stelsels en de mate waarin verschillen tussen de onderzoekstradities verband houden met de bredere politiekconstitutionele context.

\subsubsection{Recht in context}

Het onderzoeksobject dat in deze studie centraal staat is, als gezegd, parlementair onderzoek. Voor een goed begrip is het van belang deze term nader te definiëren. In dit boek wordt onder parlementair onderzoek verstaan: een onderzoek dat wordt uitgevoerd door een commissie, ingesteld door het parlement of een van zijn kamers en bestaande uit parlementsleden, aan de hand van een door de kamer vastgesteld onderzoekskader en toegekende onderzoeksbevoegdheden, waarbij na afloop de onderzoeksresultaten worden gerapporteerd aan de kamer.

\footnotetext{
${ }^{29}$ Heringa 2001, p. 159 e.v.

${ }^{30}$ Verhey 2001b, p. 320 e.v. Zie ook Verhey 2006, p. 63 e.v.
} 
Met deze definitie is getracht het onderzoeksobject zoveel mogelijk in algemene, niet stelselgebonden termen uit te drukken. Het gebruik van nationaalrechtelijke terminologie, dogmatiek of systematiek zou het zicht op relevante aspecten namelijk onnodig kunnen vertroebelen. Het begrip 'parlementaire enquête', dat in de Nederlandse wetgeving en literatuur wordt gehanteerd, heeft bijvoorbeeld andere juridische connotaties dan het begrip 'parliamentary inquiry' in de Britse context. Bovendien wordt met de gegeven definitie beoogd te voorkomen dat slechts juridische aspecten in het onderzoek worden betrokken en daarmee een onvolledig beeld ontstaat. Het is immers denkbaar - zeker met dit onderwerp - dat een bevoegdheid, procedure of mechanisme in het ene stelsel is vervat in rechtsregels, terwijl een equivalent verschijnsel in een ander stelsel met name door partijverhoudingen en politieke spelregels wordt bepaald. ${ }^{31}$

Voor een goed begrip van het onderzoeksobject is een open blik belangrijk. In de landenstudies die de basis vormen van dit proefschrift, wordt daarom niet alleen aandacht besteed aan het onderzoeksobject als zodanig maar ook aan de context waarin dit zich bevindt. ${ }^{32}$ In de landenstudies wordt getracht inzicht te verschaffen in de werking van het politiek-constitutionele stelsel als geheel. Om een goed beeld te krijgen is echter méér nodig. Aangezien het onderzoeksobject slechts ten dele beheerst wordt door rechtsregels, wordt ook nadrukkelijk aandacht besteed aan de historische, politieke en culturele aspecten die van invloed zijn op de werking van het parlementaire onderzoeksrecht. ${ }^{33}$ Gekozen is aldus voor wat kan worden genoemd een contextuele benadering van het recht.

\subsubsection{Landenrapportages}

De resultaten van de landenstudies worden neergelegd in afzonderlijke landenrapporten. Het opstellen van landenrapporten is een beproefde onderzoeksmethode in het vergelijkende recht. ${ }^{34}$ De landenrapporten dienen in de eerste plaats als basis voor de vergelijkende beschouwing. De rapportages zijn daarom voornamelijk gericht op het inventariseren en illustreren van de relevante rechtsregels, bevoegdheden, procedures en werkwijzen met betrekking tot parlementair onderzoek in het betreffende stelsel. De landenrapporten fungeren daarom ook als zelfstandige studies van (aspecten van) buitenlands recht. ${ }^{35}$

\footnotetext{
${ }^{31}$ Het betrekken van niet-juridische equivalenten in de studie is een belangrijk kenmerk van de functionele methode van rechtsvergelijking. Zie Zweigert \& Kötz 1998, p. 34-35 en Reitz 1998, p. 621.

32 Reitz 1998, p. 621.

${ }^{33}$ Hoewel van een juridisch comparatist geen systematische kennis van álle relevante 'buitenrechtelij$\mathrm{ke}^{\prime}$ kenmerken van een rechtsstelsel kan worden verwacht, zou in elk geval moeten worden getracht om zoveel mogelijk relevante bronnen te raadplegen en te betrekken in het onderzoek. Zie Zweigert \& Kötz 1998, p. 38. Vgl. ook Koopmans 2003, p. 6, die wijst op de waarde van (publiekrechtelijke) rechtsvergelijking als middel om een beter begrip te krijgen van de sociale en culturele factoren die het recht beïnvloeden en de verhouding tussen recht en politiek.

34 Zweigert \& Kötz 1998, p. 43.

${ }^{35}$ Mede om die reden wordt hier niet gekozen voor een thematische opzet, die ook wel gebruikelijk is bij rechtsvergelijkend onderzoek. Zie bijvoorbeeld Reitz 1998, p. 634. In die opzet wordt gewerkt met themahoofdstukken, waarbinnen de gekozen rechtsstelsels ten aanzien van de betreffende thema's direct met elkaar worden vergeleken. Een thematische organisatie bergt het risico in zich dat het zicht
} 
De landenrapporten dienen ook, als gezegd, inzicht te verschaffen in de relevante politieke, historische of culturele context waar die van belang is voor een goed begrip van de parlementaire onderzoeksfunctie. Dit betekent dat tevens gebruik zal worden gemaakt van relevante literatuur uit andere academische disciplines en zal worden nagegaan op welke wijze het onderzoeksthema en de verschillende deelthema's door juristen en andere onderzoekers in het betreffende rechtsstelsel zelf worden benaderd. ${ }^{36}$ Ook van belang is de vraag in hoeverre er sprake is van een 'heersende leer' met betrekking tot een vraagstuk en welke verschillen er zijn tussen recht ('law on the books') en praktijk ('law in action'). ${ }^{37}$ Voor een beter begrip zijn daarom, naast literatuurstudie, werkbezoeken aan de betrokken parlementen gebracht en informele gesprekken gevoerd met academici, parlementsleden, stafleden en andere (praktijk)deskundigen.

\subsubsection{Beschouwing}

Na de landenrapporten volgt de vergelijkende slotbeschouwing, waarin op basis van de landenstudies wordt gezocht naar concrete aanknopingspunten voor verdere ontwikkeling van parlementair onderzoek in Nederland. Deze benadering sluit aan bij een stroming in het vergelijkend staatsrecht, door Hirschl de comparative reference benadering genoemd, gericht op het verkrijgen van inzicht in andere rechtsstelsels met de bedoeling oplossingen te vinden voor problemen of vraagstukken in het eigen stelsel. Deze stroming gaat uit van de veronderstelling dat "whereas most relatively open, rule-of-law polities face essentially the same set of constitutional challenges, they may adopt quite different means or approaches for dealing with these challenges." 38

Uiteraard moet daarbij wel in ogenschouw genomen worden, dat parlementaire bevoegdheden, procedures en organisatievormen in buitenlandse stelsels functioneren in een specifieke constitutionele en politieke context, die aanzienlijk kan verschillen van het eigen stelsel. Hoewel dit aspect een voortdurend punt van aandacht zal zijn in de vergelijkende analyse, is er tegelijkertijd reden tot enige relativering. Zo mag worden aangenomen dat het Nederlandse politiek-constitutionele bestel, zoals zich dat in de afgelopen honderdvijftig jaar heeft ontwikkeld, voldoende robuust en veerkrachtig is om vernieuwingen te kunnen incorporeren. Of, zoals de Amerikaanse staatsrechtbeoefenaar Tushnet stelt: "[e]verything we know about the doctrines and institutions of law tells us that doctrines and institutions can accommodate much more change than we might think. We have discovered that we can tinker with a

op de bredere context vertroebeld raakt. Landenrapportages bieden daarentegen meer mogelijkheden om de opgedane kennis met betrekking tot de afzonderlijke stelsels weer te geven en inzicht te verschaffen in de karakteristieke systematiek van het recht en de historische en politieke eigenheid van het stelsel.

${ }^{36}$ Reitz spreekt in dit verband over onderzoek vanuit een intern perspectief, waarbij met het oog op de vergelijkende analyse moet worden uitgegaan van de vraag: "How does the foreign lawyer appear to think about this question and how does that compare to the way we think about it in our legal system?" Zie Reitz 1998, p. 628

37 Zie Reitz 1998, p. 629-631.

${ }^{38}$ Zie Hirschl 2005, p. 127. 


\section{PARLEMENTAIR ONDERZOEK}

wide range of doctrines and institutions without transforming in the short run what we regard as constitutional fundamentals." 39

Een vergelijkende beschouwing gericht op het zoeken naar aanknopingspunten in buitenlandse stelsels kan dus zinvol en verantwoord zijn, mits relevante contextuele aspecten zorgvuldig in de analyse worden betrokken. Daarbij hoort ook dat enige terughoudendheid in acht wordt genomen als het gaat om de vraag op welke wijze een (variant van een) buitenlandse figuur zal functioneren in de Nederlandse context. Niet altijd kan immers worden voorzien welke dynamiek een hervorming teweeg zal brengen, vooral niet in een politiek instituut als het parlement. Om die reden, maar ook omwille van de praktische toepasbaarheid en politieke haalbaarheid, wordt in de analyse gezocht naar mogelijkheden van kleinschalige hervormingen die bij voorkeur geen systeem- of grondwetswijziging behoeven. ${ }^{40}$

\subsection{Vraagstelling}

Uit de hierboven geformuleerde doelstellingen en methoden kan nu een vraagstelling worden gedestilleerd, aan de hand waarvan het onderzoek zal worden gestructureerd en uitgevoerd. Deze vraagstelling valt uiteen in twee hoofdvragen, die elk afzonderlijk nog verder worden uitgesplitst in deelvragen.

1. Hoe is parlementair onderzoek geregeld in Nederland, het Verenigd Koninkrijk en de Verenigde Staten, zowel in recht als praktijk?

a. In welk politiek-constitutioneel kader moet de parlementaire onderzoeksfunctie worden geplaatst? In hoeverre is het parlement belast met controle van de regering? Welke andere constitutionele taken of bevoegdheden zijn van belang voor de werking van parlementair onderzoek?

b. In hoeverre beschikt het parlement over een recht van onderzoek? Wat is de reikwijdte van dit onderzoekrecht? Over welke concrete onderzoeksbevoegdheden beschikt het parlement? En hoe is bij de uitoefening van het onderzoeksrecht de verhouding met de uitvoerende macht geregeld?

c. Hoe is parlementair onderzoek georganiseerd? Hoe ziet het commissiestelsel eruit? Hoe worden onderzoekscommissies samengesteld? In hoeverre worden onderzoekscommissies ambtelijk of anderszins ondersteund?

d. Hoe ziet de onderzoekspraktijk eruit? Wat is de aard en functie van parlementaire onderzoeken? Welke werkwijze hanteren commissies en hoe verloopt een onderzoek in procesmatige zin?

2. Wat zijn de belangrijkste overeenkomsten en verschillen tussen de onderzochte stelsels ten aanzien van het onderzoeksinstrument, zowel in recht als in praktijk? Kan het Nederlandse parlement op dit terrein leren van het Britse parlement en het Amerikaanse Congres? En welke aanbevelingen kunnen op basis van het vergelijkende onderzoek worden gedaan?

\footnotetext{
39 Tushnet 2008, p. 14.

${ }^{40} \mathrm{Zie}$ over deze bescheiden vorm van constitutionalisme, die overigens niet per definitie slechts bescheiden effecten sorteert: Vermeule 2007.
} 
Het onderzoek is als volgt opgebouwd. In het tweede, derde en vierde deel wordt verslag gedaan van de drie landenstudies. In elk deel worden de deelvragen bij de eerste onderzoeksvraag in vier hoofdstukken behandeld. De landenrapporten geven aldus een overzicht van parlementair onderzoek in recht en praktijk in elk van de drie landen afzonderlijk. ${ }^{41}$ In de slotbeschouwing wordt aan de hand hiervan bezien op welke wijze buitenlandse ervaringen aanknopingspunten kunnen bieden voor de onderzoeksfunctie van het Nederlandse parlement.

${ }^{41}$ Het onderzoek is afgesloten op 1 oktober 2012. Ontwikkelingen die nadien hebben plaatsgevonden, konden slechts incidenteel worden meegenomen. 

Deel I.

Parlementair onderzoek in Nederland 



\section{Hoofdstuk 1. Politiek-constitutioneel kader}

\subsection{Inleiding}

In dit hoofdstuk wordt het politiek-constitutionele kader geschetst, waarbinnen parlementair onderzoek in Nederland zich afspeelt. Allereerst wordt een overzicht gegeven van de wezenskenmerken van het Nederlandse parlementaire stelsel. Daarna wordt ingegaan op de constitutionele verhouding tussen regering en parlement, die in belangrijke mate wordt bepaald door de politieke ministeriële verantwoordelijkheid en de vertrouwensregel. Tot slot wordt bezien wat de betekenis van de parlementaire controletaak is en op welke wijze hieraan uitvoering wordt gegeven.

\subsection{Het Nederlandse parlementaire stelsel}

\subsubsection{Constitutionele ontwikkeling}

Het parlementaire stelsel in Nederland heeft zich geleidelijk ontwikkeld, waarbij de macht van de Koning sinds de Grondwet van 1815 steeds verder is ingeperkt door onder andere invoering van de strafrechtelijke ministeriële verantwoordelijkheid in 1840, de politieke ministeriële verantwoordelijkheid in 1848 en het ontstaan van de vertrouwensregel in de tweede helft van de negentiende eeuw. Een radicale omwenteling, waarbij de monarch de macht resoluut werd afgenomen om deze vervolgens aan het soevereine volk toe te kennen, zoals bijvoorbeeld in Frankrijk of België heeft plaatsgevonden, is in Nederland uitgebleven. ${ }^{1}$

Het is tegen deze achtergrond dat het Nederlandse parlement zich geleidelijk heeft ontwikkeld tot een volwaardige volksvertegenwoordiging. Dit begon vrij traag. Onder het bewind van Koning Willem I kwam aan de Staten-Generaal een bescheiden rol toe, evenals voor de ministers overigens. De Koning drukte een sterk persoonlijk stempel op het regeringsbeleid. ${ }^{2}$ De Grondwet gaf het parlement weliswaar medewetgevende bevoegdheid, maar het recht van amendement ontbrak en het budgetrecht was zwak ontwikkeld. ${ }^{3}$ Bovendien had de Koning een ruime zelfstandi-

\footnotetext{
${ }^{1}$ Het beginsel van volkssoevereiniteit is daarom nooit in de Nederlandse Grondwet terechtgekomen. Zie Bovend'Eert \& Kummeling 2010, p. 9. Zie over de rol van het begrip volkssoevereiniteit in het staatsrecht van andere Europese landen: Van den Driessche 2005.

2 Bovend'Eert \& Kummeling 2010, p. 408. Zie ook Van Schagen 1994, p. 12.

${ }^{3}$ Bovend'Eert \& Kummeling 2010, p. 409.
} 


\section{NEDERLAND}

ge regelgevende bevoegdheid: hij rekende alle bevoegdheden die de Grondwet niet onomwonden aan een ander ambt toeschreef tot zijn koninklijk prerogatief. ${ }^{4}$

De plaats van het parlement in het Nederlands staatsbestel begon vanaf 1840 langzaam te veranderen. In dat jaar werd de Grondwet herzien, met name ingegeven door grote ontevredenheid vanuit de Tweede Kamer omtrent de besteding van middelen door de regering. ${ }^{5}$ De begroting werd daarom voortaan tweejaarlijks vastgesteld, maar veel belangrijker was dat alle koninklijke besluiten voortaan door zowel de Koning als een minister diende te worden ondertekend (contraseign), zodat de minister strafrechtelijk verantwoordelijk zou kunnen worden gehouden indien het besluit de wet of Grondwet overtrad. ${ }^{6}$ Deze wijzigingen brachten verandering in de verhouding tussen regering en parlement. Mede onder druk van revolutionaire bewegingen elders in Europa die monarchale regeringen tot hervormingen dwongen, mondde deze ontwikkeling uit in de Grondwetswijziging van 1848, waarbij onomwonden in de Grondwet werd vastgelegd dat de ministers volledig politiek verantwoordelijk zijn en dat de Koning onschendbaar is (thans artikel $42 \mathrm{Gw}$ ). ${ }^{7}$

De verankering van de politieke ministeriële verantwoordelijkheid in de Grondwet van 1848 betekende overigens niet dat daarmee het parlementaire stelsel in Nederland gevestigd was. ${ }^{8}$ De centrale rol die het parlement in een parlementair stelsel speelt wordt niet alleen bepaald door de verantwoordingsplicht van ministers tegenover de Staten-Generaal, maar vooral ook door de vertrouwensregel die in de tweede helft van de negentiende eeuw geleidelijk ontstond. ${ }^{9}$ Tegen het einde van de negentiende eeuw kon gesproken worden van een staatsrechtelijke regel, inhoudende dat ministers moeten opstappen als blijkt dat zij niet langer het vertrouwen genieten van een meerderheid in de Tweede Kamer. Hiermee was de ultieme macht van het parlement gevestigd.

De ontwikkeling van het Nederlandse parlementaire stelsel vertoont aldus een geleidelijke verschuiving van de macht van de Koning via de ministers naar het parlement. Inzake de positie van ministers heeft het parlement middels de vertrouwensregel uiteindelijk het laatste woord. Daarmee beschikt het parlement over een belangrijke politieke machtspositie. Tegelijkertijd moet echter worden vastgesteld dat regering en parlement over eigen grondwettelijke taken en bevoegdheden beschikken, die zij vaak slechts in samenwerking kunnen uitoefenen. Te denken valt aan de totstandkoming van wetgeving en de begroting. In de staatsrechtelijke literatuur

\footnotetext{
${ }^{4}$ Daarbij werd de Koning door het parlement een handje geholpen door de invoering van de zogenaamde Blanketwet, die de zelfstandige macht van de Koning verder versterkte. Zie hierover Van Schagen 1994, p. 11-12.

${ }^{5}$ Elzinga \& Warmelink 1993, p. 17.

${ }^{6}$ Bovend'Eert \& Kummeling 2010, p. 409. Zie ook Elzinga 1994c, p. 65-66.

7 Van der Pot/Elzinga \& De Lange 2006, p. 144-145.

8 Bovend'Eert \& Kummeling 2010, p. 410.

${ }^{9}$ Een aantal bekende politieke incidenten luidden deze ontwikkeling in. Zie hierover o.a.: Elzinga \& Warmelink 1993, p. 19-20.
} 
wordt de verhouding tussen regering en parlement daarom wel als gelijkwaardig en nevengeschikt bestempeld. ${ }^{10}$

Het constitutionele kader, zoals zich dat in de negentiende eeuw ontwikkelde, is niet de enige factor die bepalend is voor de positie van het parlement in het staatsbestel. Ook politiek-bestuurlijke ontwikkelingen die zich sindsdien hebben voorgedaan, hebben mede vorm gegeven aan het Nederlandse parlementaire stelsel zoals dat thans vigeert.

\subsubsection{Politieke ontwikkeling}

Had de Koning begin negentiende eeuw nog een sterk politiek overwicht, met de invoering van de ministeriele verantwoordelijkheid verschoof het zwaartepunt binnen de regering naar de ministers. Sinds het ontstaan van de vertrouwensregel was duidelijk dat ministers niet konden aanblijven zonder het vertrouwen van een meerderheid in de Tweede Kamer. Hoe bestendig deze nieuwe staatsrechtelijke werkelijkheid zou zijn en welke rol deze in de politieke praktijk zou gaan spelen, moest echter nog blijken. ${ }^{11}$ Een aantal ontwikkelingen op politiek, maatschappelijk en bestuurlijk terrein is hierop van grote invloed geweest.

Van belang is allereerst de opkomst van politieke partijen aan het einde van de negentiende eeuw. Op partijvorming berustte binnen het parlement lange tijd een taboe. Ten tijde van de grondwetsherziening van 1848 waren de meeste politici ervan overtuigd dat politieke partijen een vrij functioneren van de volksvertegenwoordiging in de weg zouden staan. Er waren wel ideologische verbanden binnen de Tweede Kamer, de zogenaamde 'kamerclubs', maar van structureel gezamenlijk optreden in de Kamer was geen sprake. Dit veranderde tegen het einde van de negentiende eeuw. Er ontstonden protestantse, liberale, socialistische en katholieke politieke partijen en de samenwerking binnen de kamerclubs werd hechter. ${ }^{12}$ Met de uitbreiding van het kiesrecht in 1887 leidden verkiezingen tot linkse (liberale) of rechtse (confessionele) meerderheden in de Tweede Kamer. Het werd steeds vanzelfsprekender dat op basis van de verkiezingsuitslag een kabinet zou worden gevormd dat kon steunen op de Kamermeerderheid. ${ }^{13}$

De rol van politieke partijen en de daaraan gelieerde Kamerfracties nam verder toe met de invoering van het algemene (mannen-)kiesrecht en de hervorming van het kiesstelsel in 1917. Het nieuwe stelsel van evenredige vertegenwoordiging noopte tot landelijke lijstvorming en het voeren van een centrale partijorganisatie en -campagne met een aansprekende lijsttrekker. Van linkse of rechtse meerderheidsblokken was geen sprake meer; na verkiezingen volgden voortaan (moeizame) coalitiebesprekingen tussen verschillende partijen. ${ }^{14} \mathrm{Op}$ alle fronten werden politieke partijen dominant. Kamerleden werden voor hun verkiezing afhankelijk van hun partij. Het

\footnotetext{
10 Zie, bijvoorbeeld, Elzinga \& Warmelink 1993, p. 15 en Bovend'Eert \& Kummeling 2010, p. 15, waar wordt geconcludeerd dat "het parlement tezamen met de regering dé centrale plaats inneemt in het Nederlandse staatsbestel."

11 Elzinga \& Warmelink 1993, p. 20.

12 Elzinga \& Warmelink 1993, p. 20.

13 Van der Pot/Elzinga \& De Lange 2006, p. 150, 635

14 Van der Pot/Elzinga \& De Lange 2006, p. 636-637.
} 


\section{NEDERLAND}

overheidsoptreden werd in deze periode steeds verder geparlementariseerd: duidelijk werd dat partijen en fracties een belangrijke stem hadden in de vorming van het regeringsbeleid. ${ }^{15}$ Zowel de samenstelling van het parlement als van het kabinet werden partijaangelegenheden.

Het parlementaire stelsel ontwikkelde zich op deze manier van een kiezersdemocratie naar een partijendemocratie. ${ }^{16}$ De band tussen kabinet en parlementaire coalitiefracties werd in de loop van de twintigste eeuw steeds sterker. ${ }^{17}$ Duidelijk werd dat het uitgangspunt dat ministers en kabinet dienen te beschikken over het politieke vertrouwen van een Kamermeerderheid en bij afwezigheid daarvan dienen te wijken, ook in de politieke praktijk geworteld was geraakt. De vertrouwensregel werd aldus een regel van ongeschreven staatsrecht. ${ }^{18}$

$\mathrm{Na}$ de Tweede Wereldoorlog kreeg het proces van kabinetsformatie een vaste vorm. Voortaan regeerden kabinetten op basis van een regeerakkoord tussen de coalitiefracties. ${ }^{19} \mathrm{Er}$ is een verschil waarneembaar tussen de formele verhouding tussen regering en parlement, die kan worden beschreven met termen als nevenschikking en dualisme, en de praktische invulling hiervan, die sterk afhankelijk is van partijpolitieke verhoudingen, zoals Elzinga en Warmelink constateren: "Het Nederlandse parlementaire stelsel is derhalve een mix geworden van formele (grond)wettelijke en feitelijke (partij)politieke elementen." 20

Dat het Nederlandse parlementaire stelsel sinds de invoering van het algemeen kiesrecht niet wezenlijk is veranderd en zich zonder al te grote schokbewegingen heeft kunnen ontwikkelen, hangt in belangrijke mate samen met de verzuiling die de Nederlandse samenleving tot in de jaren 60 van de twintigste eeuw kenmerkte. De belangrijkste levensbeschouwelijke en politieke stromingen waren op bijna alle maatschappelijke terreinen afzonderlijk georganiseerd. Door de grote verbondenheid van kiezers met hun eigen zuil leidden verkiezingen zelden tot bijzondere zetelschommelingen in de Tweede Kamer. De leiders van de verschillende zuilen voerden bovendien een zogenaamde pacificatiepolitiek, die onder andere bestond uit een "pragmatische verdraagzaamheid" ten opzichte van de andere zuilen. ${ }^{21}$ Het politieke klimaat in Nederland werd daarom lange tijd gekarakteriseerd door een grote mate van stabiliteit.

Het politieke klimaat veranderde tegen het einde van de jaren '60 van de twintigste eeuw. De traditionele zuilen begonnen scheuren te vertonen en er ontstond maatschappelijke weerstand tegen de pacificatiepolitiek van de grote partijen, die

\footnotetext{
15 Elzinga \& Warmelink 1993, p. 22.

${ }^{16}$ Elzinga \& Warmelink 1993, p. 23-24.

${ }^{17}$ In de periode tussen de wereldoorlogen was dit overigens nog niet vanzelfsprekend. De economische crisis in de jaren 30 noopten echter tot ingrijpende maatregelen, waardoor kabinetten ook zonder vastomlijnde steun van een Kamermeerderheid konden regeren. Zie verder Van der Pot/Elzinga \& De Lange 2006, p. 636-637.

18 Zie ook Elzinga \& Warmelink 1993, p. 23.

${ }^{19}$ Van der Pot/Elzinga \& De Lange 2006, p. 637-638.

${ }^{20}$ Elzinga \& Warmelink 1993, p. 24. Zie ook: Van den Berg 2007, p. 27 e.v., die zich gelet op de politieke realiteit sterk afzet tegen het evenwichtsdenken en de idealisering van dualisme in literatuur en media.

${ }^{21}$ Van Schagen 1994, p. 18-19.
} 
geassocieerd werden met regentenmentaliteit en achterkamertjespolitiek. De roep om meer openheid en democratisering nam toe, verkiezingsuitslagen werden grilliger en er verschenen protestpartijen in de Tweede Kamer. ${ }^{22}$

Deze ontwikkeling zette zich de afgelopen decennia voort. De grote middenpartijen verloren steeds meer van hun vaste aanhang, waardoor het moeilijker werd om stabiele coalities te vormen die op de steun van een Kamermeerderheid konden rekenen. Het verloop van Kamerleden werd groter. Bovendien werden Kamerleden, meer dan voorheen, vooral professionals die het Kamerlidmaatschap als een tijdelijke halte in hun carrière beschouwen. ${ }^{23}$ Met de opkomst van Pim Fortuyn aan het begin van de eenentwintigste eeuw zijn rechts-populistische bewegingen in de Kamer - en hun afkeer van traditionele politieke mores - een belangrijker stempel gaan drukken op de dagelijkse parlementaire praktijk.

\subsubsection{Bestuurlijke ontwikkeling}

Ook om andere redenen veranderde de feitelijke positie van de Tweede Kamer en haar leden in deze periode. Ten eerste heeft de opbouw van de verzorgingsstaat vooral in de naoorlogse periode geleid tot een enorme groei van het bestuurlijke apparaat. Het beheer en de sturing van de omvangrijke en complexe beleidsprogramma's noopte tot verregaande delegatie van regelgevende bevoegdheid door de formele wetgever aan de regering. Het zwaartepunt van besluitvorming kwam bij de departementale voorfase te liggen. Het belang van de formele wet en de daaraan verbonden parlementaire bevoegdheden als het recht van amendement namen af.

In de Tweede Kamer verschoof een groot deel van de aandacht daarom van het formele wetgevingsproces naar beleidsbeïnvloeding. ${ }^{24}$ Aan de hand van beleidsnota's van regeringszijde voert de Kamer veelvuldig overleg met de verantwoordelijke ministers om zodoende in een vroeg stadium invloed te kunnen uitoefenen op de vorming van het regeringsbeleid. ${ }^{25}$ Ook dit heeft ertoe geleid dat de band tussen regering en parlement, of in elk geval tussen de regeringsgezinde coalitiefracties in de Tweede Kamer, hechter is geworden. ${ }^{26}$

Hieraan gerelateerd is het fenomeen van 'verkokering': op elk afzonderlijk beleidsterrein vormden departementsambtenaren, maatschappelijke groeperingen en fractiespecialisten in het parlement een steeds hechter geheel. Het gebrek aan afstemming met andere 'beleidskokers' was weinig bevorderlijk voor de samenhang in het overheidsbeleid. ${ }^{27}$ De verschuiving van parlementaire werkzaamheden naar commissies, die veelal de departementale (sub)structuren volgden, droeg hier evenmin aan bij. ${ }^{28}$ Met de toegenomen complexiteit van de overheidstaak en het proces van verkokering werd het Kamerlidmaatschap professioneler en intensiever. Kamer-

\footnotetext{
22 Van Schagen 1994, p. 21.

23 Van den Berg 2007, p. 18.

${ }^{24}$ Zie Van Schagen 1994, p. 19-20.

25 Van Schagen 1994, p. 26. Zie ook Van den Berg 2007, p. 29 e.v.

${ }^{26}$ Van Schagen 1994, p. 26.

27 Van Schagen 1994, p. 22. Zie hierover bijvoorbeeld ook de nota van de Commissie-Vraagpunten van de Tweede Kamer, Kamerstukken II 1990/91, 21 427, nr. 3, p. 7.

${ }^{28}$ Bovend'Eert \& Kummeling 2010, p. 187.
} 


\section{NEDERLAND}

leden kregen hierdoor steeds vaker het verwijt onvoldoende zicht te hebben op wat zich buiten Den Haag afspeelde. ${ }^{29}$

Een tweede belangrijke ontwikkeling die de positie van de Tweede Kamer heeft veranderd is de toegenomen internationalisering. ${ }^{30}$ Met name de Europese samenwerking heeft in de tweede helft van de twintigste eeuw een grote vlucht genomen. Op steeds meer beleidsterreinen vindt besluitvorming op Europees niveau plaats. De invloed van het Nederlandse parlement op dergelijke besluitvorming is niet erg groot. ${ }^{31}$ Dit komt enerzijds omdat de (formele) mogelijkheden voor beïnvloeding tamelijk beperkt zijn, anderzijds omdat Kamerleden zich van oudsher weinig leken te interesseren voor Europese zaken. Daarbij werd vaak gedacht dat het wel aan het Europees Parlement kon worden overgelaten om zich met Europese wetgeving en beleidscontrole bezig te houden. De laatste jaren lijkt hierin enige verandering te komen en wordt van het nationale parlement meer betrokkenheid verwacht ten aanzien van 'Europa'. 32

\subsection{Ministeriële verantwoordelijkheid}

\subsubsection{Uitgangspunten}

Zoals hierboven reeds naar voren is gekomen, is het beginsel van de ministeriële verantwoordelijkheid een kenmerkend onderdeel van het Nederlandse parlementaire stelsel. Zeer geleidelijk verschoof in de 19e eeuw de macht binnen de regering van de Koning naar de ministers, die vervolgens op hun beurt verantwoording schuldig werden aan het parlement.

Het Nederlandse staatsrecht kent verschillende vormen van ministeriële verantwoordelijkheid. De belangrijkste vorm is thans de politieke verantwoordelijkheid. In de huidige Grondwet is de politieke ministeriële verantwoordelijkheid neergelegd in artikel 42, tweede lid, waarin is bepaald dat de Koning onschendbaar is en de ministers verantwoordelijk zijn. Uit de tekst van de bepaling kan worden afgeleid wat de oorspronkelijke functie van de politieke ministeriële verantwoordelijkheid was, toen deze in 1848 in de Grondwet werd vastgelegd. De verantwoordelijkheid had met name betrekking op de relatie tussen de Koning en de ministers. Niet alleen strafrechtelijk, maar in alle politieke opzichten waren het vanaf dat moment de ministers die de verantwoordelijkheid voor het handelen van de regering op zich namen.

Toen in de loop van de negentiende eeuw duidelijk werd dat de Koning geen politieke rol van betekenis meer zou spelen in het Nederlandse staatsbestel, veranderde de betekenis van deze bepaling. Thans wordt aangenomen dat de politieke ministeriële verantwoordelijkheid zich in hoofdzaak uitstrekt over drie gebieden: het

${ }^{29}$ Van Schagen 1994, p. 23-24.

30 Zie ook Van Schagen 1994, p. 24-25.

31 Zie verder Van der Pot/Elzinga \& De Lange 2006, p. 732.

32 Van der Pot/Elzinga \& De Lange 2006, p. 732-733. Het Verdrag van Lissabon bevat specifieke bepalingen die de positie van nationale parlementen in Europese besluitvorming moet versterken, in het bijzonder op het terrein van de naleving van het Europese subsidiariteitsbeginsel ('Early Warning System'). Zie hierover uitvoerig: Kiiver 2012. 
handelen van de Koning, het handelen van de minister zelf en het handelen van de aan hem ondergeschikte ambtelijke dienst. ${ }^{33}$ Naast de individuele ministeriele verantwoordelijkheid kent het Nederlandse staatsrecht ook een collectieve vorm van ministeriële verantwoordelijkheid. Deze vloeit voort uit de collegiale besluitvorming in de ministerraad. ${ }^{34}$

De ministeriële verantwoordelijkheid brengt met zich mee dat ministers een verantwoordingsplicht hebben ten opzichte van het parlement. ${ }^{35}$ Hieruit volgt ook het belang van de ministeriële verantwoordelijkheid in het Nederlandse staatsrecht: het parlement wordt langs deze weg in staat gesteld de bestuursdienst integraal te controleren. De ministeriële verantwoordelijkheid vervult aldus een belangrijke scharnierfunctie tussen het ongekozen openbaar bestuur en het gekozen parlement. ${ }^{36}$

Bij het bepalen van de omvang van de ministeriële verantwoordelijkheid ('waarvoor is de minister precies verantwoordelijk?') wordt in het Nederlandse staatsrecht doorgaans uitgegaan van het adagium: 'geen verantwoordelijkheid zonder bevoegdheid'. Dit houdt in dat de minister slechts verantwoordelijk is ten aanzien van zaken die hij formeel kan beïnvloeden. ${ }^{37}$ Het betreft een onvoorwaardelijke vorm van verantwoordelijkheid, waarbij de vraag of de minister persoonlijk betrokken was, daadwerkelijk invloed heeft uitgeoefend of een verwijt treft, niet van belang is. In Nederland gaat het daarbij in eerste instantie om het handelen van departementsambtenaren, waaraan de minister ingevolge artikel $44 \mathrm{Gw}$ leiding geeft. ${ }^{38}$ Het

\footnotetext{
${ }^{33}$ Over de betekenis en reikwijdte van de politieke ministeriële verantwoordelijkheid in Nederland is de afgelopen jaren een grote hoeveelheid literatuur verschenen. Met name het rapport van de Commissie-Scheltema, dat in 1993 verscheen, is van groot belang geweest voor de gedachtevorming op dit punt. Zie Steekhoudend ministerschap 1993. Zie verder o.a.: Kortmann 2008, p. 321 e.v.; Broeksteeg 2004, p. 20; Bovend'Eert 2002, p. 35 e.v.; Van den Driessche 2005, p. 190 e.v. en de verschillende bijdragen in Broeksteeg, Van den Berg \& Verhey 2006.

34 Steekhoudend ministerschap 1993, p. 10. Zie over de verhouding tussen individuele en collectieve verantwoordelijkheid o.a. Van den Berg 1995, p. 223, waarin wordt gesteld dat de collectieve verantwoordelijkheid in de praktijk veel belangrijker is dan de individuele.

35 Steekhoudend ministerschap 1993, p. 8.

36 Steekhoudend ministerschap 1993, p. 8. Zie ook Verhey 2001a, p. 8.

37 Steekhoudend ministerschap 1993, p. 7. Er zijn echter ook andere opvattingen. Visser stelt dat ministeriële verantwoordelijkheid verder gaat dan louter formele bevoegdheden en tevens feitelijk handelen omvat, namelijk wanneer voor een goede uitoefening van het ministerschap kan worden verwacht dat een minister "zich inzet om iets te bereiken door te overleggen, overtuigen, bezoeken of activeren." Zie Visser 2008, p. 287. Zijlstra heeft betoogd dat ministers ook verantwoordelijkheid dragen voor het voldoende behartigen van de publieke taak (de zogenaamde 'ex-anteverantwoordelijkheid' of 'stelselverantwoordelijkheid'). Zie bijvoorbeeld Zijlstra \& Wilkeshuis 2006, p. 12 e.v. Volgens Van Angeren kan vanuit democratisch perspectief geen bestuur worden uitgeoefend zonder dat daaraan een verantwoordingsplicht is gekoppeld; de minister is dus volledig verantwoordelijk en dientengevolge is hij ook volledig bevoegd. In deze visie volgt de bevoegdheid dus uit de verantwoordelijkheid, in plaats van andersom. Zie Van Angeren 1996. Anderen achten deze gevolgtrekking bedenkelijk: het gevaar ontstaat dat ministers zich allerlei bevoegdheden gaan toe-eigenen op basis van hun algemene bestuurstaak. Zie o.a. Kortmann 1996.

38 Ingevolge artikel 44, tweede lid, Grondwet staat de minister aan het hoofd van een ministerie, al zijn er ook zogenaamde ministers zonder portefeuille. Zij beschikken wel over ministeriële taken en bevoegdheden, maar hebben niet de leiding over een ministerie en beschikken ook niet over een eigen begroting. Zie hierover nader Van der Pot/Elzinga \& De Lange 2006, p. 517-518.
} 


\section{NEDERLAND}

handelen van deze ambtenaren kan staatsrechtelijk dus aan de minister worden toegerekend. ${ }^{39}$

\subsubsection{Ontwikkelingen}

De opbouw van de verzorgingsstaat en de daarmee gepaard gaande groei van het bestuurlijk apparaat heeft de afgelopen decennia geleid tot vragen over de bestuurbaarheid en efficiency van de ambtelijke dienst. Ook het hierboven geschetste staatsrechtelijke kader stond ter discussie. Zo concludeerde een bijzondere Kamercommissie in 1990 dat "de ministeriële verantwoordelijkheid, tenminste gedeeltelijk, een fictie is geworden, omdat de minister niet meer op alles goed kan toezien wat er op het ministerie in zijn naam gebeurt." 40

Om de greep op het ambtelijke apparaat te vergroten zijn in de jaren 80 en 90 van de twintigste eeuw verschillende vernieuwingen doorgevoerd. Zo werden binnen de ambtelijke organisatie allerlei nieuwe managementtechnieken geïntroduceerd, veelal overgenomen uit het bedrijfsleven. ${ }^{41}$ Ook werden sommige ambtelijke diensten geprivatiseerd. De in staatsrechtelijk opzicht meest besproken vernieuwing was het beleid om ambtelijke diensten te verzelfstandigen. Door organisatieonderdelen los te maken uit de departementale structuur en op afstand te plaatsen van de politieke leiding, zo was de gedachte, zou de minister zich kunnen concentreren op de hoofdlijnen van het beleid, terwijl de ambtelijke dienst zich volledig kan richten op een goede en efficiënte uitvoering. ${ }^{42}$

De afgelopen decennia heeft dit 'op afstand plaatsen' op grote schaal plaatsgevonden door voormalige departementale diensten bij wet onder te brengen in zogenaamde zelfstandige bestuursorganen (zbo's). Deze organen vallen niet binnen de hiërarchische structuur van de ministeries; de minister heeft slechts zeggenschap ten aanzien van een zbo voor zover dit in de instellingswet is geregeld. Bekende voorbeelden zijn overheidstaken waarbij grote hoeveelheden beschikkingen veelal routinematig moeten worden afgegeven, zoals studiefinanciering of kinderbijslag. ${ }^{43}$ Het gevolg is dat een groot deel van de overheidstaken op rijksniveau inmiddels binnen zbo's zijn ondergebracht.

De opkomst van zbo's en de daarachter schuilgaande gedachte dat bepaalde overheidsdiensten beter zouden functioneren wanneer deze op grote(re) afstand van de politieke leiding op het ministerie zouden worden geplaatst, staat op gespannen voet met de staatsrechtelijke scharnierfunctie van de ministeriële verantwoordelijk-

\footnotetext{
${ }^{39}$ Warmelink 1994, p. 105.

${ }^{40}$ Zie de nota van de bijzonder commissie Vraagpunten, Kamerstukken II 1990/91, 21 427, nr. 3, p. 13.

${ }^{41}$ Te denken valt aan vormen van zelfbeheer en contractmanagement. Zie hierover Steekhoudend ministerschap 1993, p. 47-48.

42 't Hart \& Wille 2002, p. 233 e.v. Zie voorts over de veranderende betekenis van de ministeriële verantwoordelijkheid en de opkomst van zelfstandige bestuursorganen o.a.: Scheltema 1974, Scheltema 2000 en Zijlstra 2009.

${ }^{43}$ Overigens kunnen er ook andere redenen zijn voor verzelfstandiging, bijvoorbeeld omdat onafhankelijke oordeelsvorming gewenst is. Een bekend voorbeeld is de Kiesraad. De laatste jaren zijn daar de marktautoriteiten bijgekomen. Als gevolg van de financiële crisis speelt echter ook daar inmiddels de discussie over de vraag of het parlement voldoende controle kan uitoefenen.
} 
heid. Beperking van de ministeriële verantwoordelijkheid betekent immers in constitutionele zin eveneens een beperking van de mogelijkheid voor het parlement om via de ministeriële verantwoordingsplicht - toezicht te houden op het ambtelijk apparaat. De commissie-Scheltema spreekt daarom van een "leemte in de staatsrechtelijke benadering, voor zover deze ervan uitgaat dat met behulp van de verantwoordingsplicht van de minister een volledige controle op het openbaar bestuur kan worden uitgeoefend." 44 Het instellen van zbo's gebeurde bovendien tamelijk ongecoördineerd. De instellingsmotieven, organisatiewijze en de mate van ministeriële zeggenschap lopen daarom sterk uiteen. ${ }^{45}$

Inmiddels is duidelijk dat de verwachting, dat ministers zich door verzelfstandiging van uitvoeringsorganisaties kunnen concentreren op de hoofdpunten van beleid, niet is uitgekomen. Kamerleden verlangen nog steeds tekst en uitleg van ministers, wanneer zich binnen zbo's die binnen hun werkterrein actief zijn, problemen voordoen, los van de vraag of de minister ten aanzien van het betreffende probleem over zeggenschap beschikt en aldus formeel verantwoordelijk kan worden gehouden. ${ }^{46}$ Daarnaast is niet duidelijk of de beoogde efficiencywinst bij verzelfstandigde organisaties ook daadwerkelijk is behaald.

Van het aanvankelijke politieke enthousiasme over verzelfstandiging van ambtelijke diensten is daarom niet veel meer over. ${ }^{47}$ Sinds 2006 geldt het uitgangspunt, vastgelegd in een kaderwet, dat verzelfstandiging alleen nog onder specifieke voorwaarden mogelijk is. ${ }^{48}$ Niettemin lijken zelfstandige bestuursorganen een permanente plek in het bestuurlijke landschap te hebben verworven. Niet alleen vanwege de grote organisatorische kosten die terugkeer van zbo's binnen de departementale organisatie met zich mee zouden brengen, maar ook omdat nieuwe overheidstaken, zoals op het gebied van het markttoezicht, zich niet goed verhouden met politieke sturing vanuit het departement. Ook het EU-recht stelt op dat punt eisen. ${ }^{49}$ Het blijft daarom de vraag of het parlement in staatsrechtelijke zin afdoende controle kan uitoefenen op het bestuurlijke apparaat.

\subsection{Parlementaire controle}

\subsubsection{Parlementaire taken}

De bevoegdheden waarover het parlement thans beschikt, zijn in de loop van de negentiende eeuw ontstaan. ${ }^{50}$ Uit het geheel aan parlementaire bevoegdheden, zoals

\footnotetext{
44 Steekhoudend ministerschap 1993, p. 11.

45 Zo concludeerde de Rekenkamer reeds in 1995 in haar jaarverslag. Zie Kamerstukken II 1994/95, 24 130, nr. 3. Zie verder't Hart \& Wille 2002, p. 239. Zie ook Verhey 2001a, p. 14-15.

46 't Hart \& Wille 2002, p. 240. Zie ook het rapport van de werkgroep Verzelfstandigde Organisaties op Rijksniveau (commissie-Kohnstamm): Een herkenbare staat 2004.

47 Zie nader: 't Hart \& Wille 2002, p. 239-243.

48 Zie art. 3 Kaderwet zelfstandige bestuursorganen.

${ }^{49}$ Zie bijvoorbeeld Verhey \& Verheij 2005, p. 321.

${ }^{50}$ Zie ook hierboven, par. 1.2.1.
} 


\section{NEDERLAND}

die in de Grondwet zijn neergelegd, worden in de staatsrechtelijke literatuur meestal twee kerntaken afgeleid: de medewetgevende taak en de controlerende taak. ${ }^{51}$

\subsubsection{Parlementaire controle in klassieke zin}

De belangrijkste constitutionele grondslag voor de parlementaire controletaak vormt, zoals hierboven reeds bleek, de bepaling inzake de ministeriële verantwoordelijkheid (art. 42, tweede lid, Grondwet). Verantwoording afleggen, zo stelt de CommissieScheltema, betekent dat ministers "aanspreekbaar en aansprakelijk zijn, (bevredigend) rekenschap afleggen, rechtvaardigen en verdedigen." 52 Dit vereist in de eerste plaats dat informatie wordt verstrekt aan de Kamers, maar dat is niet voldoende. Verantwoording afleggen betekent echter tevens "het uitleggen, motiveren en verdedigen van het gevoerde beleid," zo stelt de Commissie-Scheltema. ${ }^{53}$ Het verantwoordingsproces stelt het parlement dus niet alleen in staat inzicht te verkrijgen in het regeringshandelen, maar ook om een oordeel te vormen over het gevoerde beleid. Zo beschouwd stelt de ministeriële verantwoordingsplicht het parlement in staat om het regeringsbeleid en -handelen achteraf te controleren.

Uit de verantwoordingsplicht vloeit dus in eerste instantie een inlichtingenplicht voort. Deze is, tegelijkertijd met de ministeriële verantwoordelijkheid, opgenomen in de Grondwet. De inlichtingenplicht is, zo stelde de minister van Binnenlandse Zaken en Koninkrijksrelaties in 2002 in een notitie aan de Tweede Kamer, "het middel bij uitstek om die verantwoordelijkheid te laten functioneren." 54 Thans is deze inlichtingenplicht terug te vinden in artikel $68 \mathrm{Gw}$, waarin is bepaald dat de minister inlichtingen moet verschaffen aan "de kamers elk afzonderlijk en in verenigde vergadering" op ieder moment en ten aanzien van elk onderwerp, mondeling of schriftelijk, wanneer "een of meer leden" dat verlangen. Verantwoording afleggen betekent in de praktijk dan ook vaak het geven van antwoord op vragen van een of meerdere Kamerleden. ${ }^{55}$ Hoewel de tekst van deze bepaling suggereert dat inlichtingen slechts "op verzoek" verschaft dienen te worden, wordt aangenomen dat ministers tevens op eigen initiatief informatie moeten verstrekken aan het parlement. 56

Uit de tekst van artikel 68 blijkt overigens niet dat de gevraagde inlichtingen slechts betrekking kunnen hebben op zaken waarvoor de betreffende minister verantwoordelijkheid draagt. In de literatuur wordt hierover verschillend gedacht.

\footnotetext{
51 Bovend'Eert \& Kummeling 2010, p. 195.

52 Steekhoudend ministerschap 1993, p. 8.

53 Steekhoudend ministerschap 1993, p. 8.

54 Kamerstukken II 2001-02, 28 362, nr. 2, p. 1.

55 Hoewel in de parlementaire praktijk reeds lange tijd vaststaat dat kamerleden individueel (dus zonder steun van de meerderheid van de Kamer) het recht hebben om inlichtingen van een minister te vragen, is dit pas bij de Grondwetherziening van 1987 als zodanig uitdrukkelijk in de Grondwet vastgelegd. Zie voor een beschrijving van de ontwikkeling van het parlementair inlichtingenrecht: Visscher 1994, p. $238-242$.

56 Zie Kamerstukken II 2001-02, 28 362, nr. 2, p. 3. Zie ook Visscher 1994, p. 242 en Bovend'Eert \& Kummeling 2010, p. 268-269, die betogen dat de ministeriële plicht om uit eigener beweging inlichtingen te verschaffen moet worden teruggevoerd op art. $42 \mathrm{Gw}$ en niet zo zeer op de vertrouwensregel, zoals in de notitie over de reikwijdte van artikel 68 wordt gesteld.
} 
Sommige auteurs stellen dat de inlichtingenplicht niet verder reikt dan de verantwoordingsplicht, terwijl anderen verdedigen dat de minister ook over zaken, waarvoor hij geen verantwoordelijkheid draagt, inlichtingen zal moeten verschaffen indien de Kamers daarom vragen. ${ }^{57}$ Uit de bepaling blijkt in elk geval dat de inlichtingenplicht niet onbegrensd is. De minister mag weigeren om bepaalde inlichtingen te verstrekken op grond van het 'belang van de staat', zoals artikel 68 aangeeft. Ook de betekenis en reikwijdte van deze verschoningsgrond kan echter niet met exactheid worden vastgesteld. Wel kan uit de grondwetsgeschiedenis en de staatsrechtelijke praktijk een aantal situaties worden onderscheiden, waarin het belang van de staat ertoe zou kunnen leiden dat ministers weigeren om inlichtingen te verschaffen, dan wel om deze slechts vertrouwelijk aan de Kamer te verstrekken. ${ }^{58}$

\subsubsection{Parlementaire controle in moderne zin}

Het traditionele beeld van de parlementaire kerntaken, waarbij een onderscheid wordt gemaakt tussen medewetgeving en controle, lijkt om verschillende redenen niet meer aan te sluiten bij de moderne praktijk. De betekenis van de wet is in de loop der tijd veranderd. $\mathrm{Zij}$ fungeert thans vooral als beleidsinstrument, dat ten dienste staat van het regeringsbeleid. Om die reden is het juridische onderscheid tussen het wetgevingsproces en de controlerende werkzaamheden in het parlement in de praktijk niet al te scherp meer. Bovend'Eert en Kummeling stellen daarom dat de parlementaire betrokkenheid bij wetgeving vaak ook een controlerende activiteit is. ${ }^{59}$ Daarnaast is het belang van de formele wet als zodanig verder afgenomen en werkt de openbare dienst steeds meer op grond van gedelegeerde, bestuurlijke regelgeving. Het gevolg hiervan is dat de parlementaire aandacht voor een belangrijk deel naar een eerder stadium is verschoven, in een poging om enige vorm van zeggenschap te behouden. ${ }^{60}$

Hierboven werd al geconstateerd dat de regering beleidvoorstellen daarom vaak in een vroeg stadium aan de Tweede Kamer voorlegt, omdat in de Kamer het idee leeft dat alleen dan nog enige invloed kan worden uitgeoefend op de vaststelling van het beleid. Tijdens de wetgevingsfase, waarin het parlement theoretisch een belangrijke rol vervult, zou de mogelijkheid om invloed uit te oefenen sterk teruggedrongen zijn door de toegenomen complexiteit van wetgeving. Via de controlefunctie, meer specifiek het inlichtingenrecht, en het begrotingsrecht tracht de Kamer haar verloren positie te herwinnen. Deze moderne vorm van parlementaire controle strekt zich inmiddels uit over het gehele regeringsoptreden, zelfs op beleidsterreinen waar geen wetgeving wordt beoogd. ${ }^{61}$ Tuurenhout noemt dit 'prospectieve' parlementaire controle, gericht op beleid in wording, als tegenhanger van 'retrospectieve' controle

\footnotetext{
57 Zie hierover nader par. 2.5.1.1.

58 Zie nader par. 2.5.3.

${ }^{59}$ Bovend'Eert \& Kummeling 2010, p. 195.

${ }^{60}$ Elzinga \& Warmelink 1993, p. 34.

61 Zie bijvoorbeeld Heringa e.a. 2012, p. 161-162.
} 


\section{NEDERLAND}

(ofwel de traditionele controle 'achteraf'). ${ }^{62}$ Elzinga maakt een enigszins vergelijkbaar onderscheid tussen structurele en incidentele controle. ${ }^{63}$

Met het oog op deze vervlechting van wetgevende en controlerende activiteiten heeft Van Schagen de parlementaire kerntaken op een andere wijze geclassificeerd. Hij spreekt van betrokkenheid bij de totstandkoming van regelgeving, het houden van toezicht op de uitvoering, en werkzaamheden in het kader van de vaststelling van en controle op de begroting. ${ }^{64}$ Toch lijkt ook deze, meer genuanceerde, weergave van de parlementaire kernwerkzaamheden niet afdoende om de moderne praktijk te beschrijven. Er is een grijs tussengebied aan parlementaire activiteiten ontstaan dat zich moeilijk laat plaatsen. Van den Berg stelt hieromtrent: “Tussen normerende en kaderstellende interventie enerzijds en controle en verantwoording anderzijds is een juridisch vormloos geheel ontstaan van brieven, notities, beleidsnota's en zogenaamde PKB's ... waarmee het grootste deel van de tijdsbesteding van Kamerleden heengaat." 65 Effect hiervan is volgens Van den Berg dat het parlement zich veel bezighoudt met beïnvloeding van beleidsvorming vooraf en daarmee feitelijk is gaan meeregeren. ${ }^{66}$

Parlementaire controle heeft, samenvattend, in de loop der tijd een andere betekenis gekregen. Controle in klassieke zin, waarbij een sterk verband wordt gelegd met het afleggen van verantwoording door ministers, is in hoge mate een 'reactieve' bezigheid. In de moderne praktijk is het parlement - met name de Tweede Kamer juist veel meer bezig met controle van de regering in de Angelsaksische zin van het woord (control, "beheersen"), wat veel verder gaat dan alleen reactieve controle. ${ }^{67}$ Wellicht daardoor staat het uitoefenen van controlerende activiteiten in de klassieke zin onder druk: de intensieve aandacht voor beleidsbeïnvloeding vooraf lijkt het systematisch nagaan van de uitkomsten of effecten van beleid achteraf in de weg te zitten. ${ }^{68}$ In de discussie over het functioneren van het parlement, zoals die de afgelopen jaren zowel binnen als buiten het Binnenhof is gevoerd, speelt dit laatste dan ook een belangrijke rol. Terugkerende klacht, zo bleek ook recentelijk nog tijdens de uitgebreide parlementaire zelfreflectie, is dat controle teveel in het teken zou staan van incidenten en 'de waan van de dag', zoals die in de media naar voren komt, wat leidt tot een stroom aan schriftelijke vragen, commissievergaderingen, spoeddebatten en moties. 69

\footnotetext{
62 Tuurenhout 1992, p. 28.

${ }^{63}$ Elzinga 1994b, p. 32-34.

${ }^{64}$ Zie Van Schagen 1994, p. 68-70. Zie voor nog andere categoriseringen o.a. Elzinga \& Warmelink 1993, p. 25 e.v., waar onderscheid wordt gemaakt tussen vrijwillige en verplichte samenwerking van regering en parlement. Zie verder Kortmann 2008, p. 246-248, die spreekt over samenwerkingsbevoegdheden en zelfstandige bevoegdheden.

65 Van den Berg 2007, p. 30.

${ }^{66}$ Van den Berg 2007, p. 30.

${ }^{67}$ Zie Elzinga \& Warmelink 1993, p. 34.

68 Zie verder Van den Berg 2007, p. 32.

${ }^{69}$ Rapport parlementaire zelfreflectie 2009, p. 34 e.v. en Van den Berg 2009, p. 130. Zie verder ook Verhey 2001a, p. 31 en Bovend'Eert 2007, p. 91-93.
} 


\subsubsection{Controle-instrumenten}

Het parlement beschikt over verschillende controle-instrumenten, die hun grondslag vinden in de Grondwet en nader zijn uitgewerkt in de Reglementen van Orde van de Kamers. Parlementaire controle in klassieke zin, zo bleek hierboven, vloeit voornamelijk voort uit de ministeriële verantwoordelijkheid en de inlichtingenplicht van art. $68 \mathrm{Gw}$. Het recht op inlichtingen is terug te vinden in een aantal parlementaire instrumenten. Hiertoe behoren in elk geval de mogelijkheid van interpellatie, dat aan de Kamer als geheel toekomt en het individuele vragenrecht. De Tweede Kamer heeft deze parlementaire rechten uitgewerkt in haar Reglement van Orde. ${ }^{70}$ De Eerste Kamer heeft dit eveneens gedaan, met uitzondering van het mondelinge vragenrecht. ${ }^{71}$ Het vragenrecht stelt Kamerleden in staat om rechtstreeks en gericht informatie te krijgen over regeringsbeleid en -standpunten: schriftelijke vragen zijn geschikt om gedetailleerde of technische informatie te verkrijgen, terwijl mondelinge vragen zich met name lenen voor onderwerpen die in de publieke belangstelling staan. ${ }^{72}$ De hoeveelheid vragen is gedurende de afgelopen decennia aanzienlijk toegenomen: van minder dan honderd in 1915 naar tussen 1400 en 1700 vragen aan het einde van de twintigste eeuw. Daarna nam het aantal weer sterk toe, met in 2007 zelfs ruim 2600 vragen. De meeste zijn afkomstig van de oppositiefracties. Het aantal mondelinge vragen ligt de laatste jaren rond de honderd. ${ }^{73}$

In het verlengde van het vragenrecht ligt het interpellatierecht. Ook deze vorm van inlichtingen vragen is uitgewerkt in de reglementen van orde van beide Kamers. ${ }^{74}$ Het betreft hier de mogelijkheid om buiten de agenda van de Kamer een onderwerp aan de orde te stellen en de betrokken minister verantwoording te laten afleggen. Het houden van een interpellatie is met name geschikt wanneer het gaat om actuele, spoedeisende zaken. Een belangrijk verschil met het vragenrecht is dat het recht van interpellatie niet toekomt aan de individuele Kamerleden, maar aan de Kamers als geheel. Een verzoek tot het houden van een interpellatie van een Kamerlid dient te worden gesteund door tenminste dertig leden om te worden ingewilligd door de Kamer als geheel. In de praktijk worden interpellaties, ook als ze van kleine oppositiefracties afkomstig zijn, nauwelijks geweigerd. ${ }^{75}$ Tijdens het interpellatiedebat krijgen de interpellant en de andere aanwezige leden de gelegenheid om de gewenste inlichtingen van de betrokken minister te vragen. Het aantal interpellaties wisselt sterk en ligt de laatste jaren tussen de 5 en 13 per jaar. Dit zou te maken kunnen hebben met de schommelingen in de kracht van de oppositie, maar ook het toegenomen contact tussen ministers en Kamerleden in de commissies, wat de noodzaak voor interpelleren verminderd heeft. ${ }^{76}$ Daarnaast lijkt de interpellatie in de praktijk te zijn voorbijgestreefd door het zogenaamde spoeddebat, dat is bedoeld voor spoedeisende, actuele zaken waarover de Kamer wil debatteren met de minister

70 Zie artt. 133-139 RvOTK.

71 Zie artt. 139-140 RvOEK.

72 Bovend'Eert \& Kummeling 2010, p. 323.

73 Bovend'Eert \& Kummeling 2010, p. 323.

74 Zie art. 133 RvOTK en art. 139 RvOEK.

75 Bovend'Eert \& Kummeling 2010, p. 319.

76 Bovend'Eert \& Kummeling 2010, p. 319-320. 
en eveneens kan worden aangevraagd met steun van tenminste dertig leden. ${ }^{77}$ Door het grote aantal spoeddebatten ${ }^{78}$ is de korte termijn waarop dit type debat zou moeten plaatsvinden in de praktijk vaak nauwelijks meer haalbaar. ${ }^{79}$

Het vragenrecht en het interpellatierecht, alsmede het spoeddebat, spelen een specifieke rol in het verantwoordingsproces. Ze bieden de mogelijkheid voor individuele Kamerleden om direct inlichtingen te krijgen van bewindspersonen, waardoor inzicht kan worden verkregen in het functioneren van de uitvoerende macht. Bovendien kunnen Kamerleden via het stellen van gerichte vragen ervoor zorgen dat de "lawine aan informatie" van regeringszijde enigszins te sturen is. ${ }^{80}$ Ook het politieke element van het inlichtingenrecht moet niet worden onderschat: het stellen van vragen of het houden van een interpellatie maakt het politieke bedrijf zichtbaar en kan de regering de nodige prikkels geven om zo goed mogelijk te functioneren. De regering wordt uitgedaagd om haar beleid uit te leggen en te verdedigen. Beide controlemiddelen zijn bij uitstek geschikt om minderheden binnen het parlement in staat te stellen om het regeringshandelen aan de kaak te stellen.

Wanneer parlementaire controle in de moderne betekenis wordt bezien, waarbij het niet slechts gaat om controle achteraf maar ook om controle (of beleidsbeïnvloeding) vooraf, dan kunnen ook andere procedures worden aangemerkt als instrumenten van controle. In de praktijk komt vooral het vrijwel permanente overleg in het kader van de vaste commissies in beeld. Reeds voordat een wetsprocedure aanvangt, hebben de vaste commissies van de Tweede Kamer, die veelal langs departementale lijnen zijn ingedeeld, vaak al uitvoerig met 'hun' vakministers van gedachten gewisseld. Ook wanneer geen wetgevingsprocedure aan de orde is, vindt in dit verband veelvuldig overleg plaats tussen regering en Kamer. Formele aanknopingspunten voor deze vormen van overleg zijn vaak niet zozeer de wetgevende bevoegdheden van het parlement, maar vooral de ministeriële verantwoordelijkheid, de inlichtingenplicht en het begrotingsrecht. Inlichtingen verkrijgt een vaste commissie in de eerste plaats middels de beleidsnota's die de regering ter bespreking aan de commissie voorlegt om zodoende de gevoelens in het parlement omtrent de kabinetsplannen te toetsen. ${ }^{81}$ Daarnaast is volop gelegenheid tijdens de behandeling van wets- en begrotingsvoorstellen om met de minister van gedachten te wisselen over de regeringsvoorstellen, waaraan vaak een uitvoerige memorie van toelichting is toegevoegd. Het Reglement van Orde voorziet hiertoe in het wetgevingsoverleg, het begrotingsoverleg, het nota-overleg en het algemeen overleg. ${ }^{82}$ Deze overlegvormen, die vooral bedoeld zijn om in een vroeg stadium een vorm van zeggenschap of in-

\footnotetext{
77 Art. 54a RvOTK. Zie verder Bovend'Eert \& Kummeling 2010, p. 320.

${ }^{78}$ In 2008 waren het er bijvoorbeeld 65. Zie Bovend'Eert \& Kummeling 2010, p. 320.

79 Bovendien blijken niet alle aanvragen even spoedeisend. Mede om die reden is de naam onlangs veranderd in 'dertigledendebat'. Zie Kamerstukken II 2010/11, 32 743, nr. 1.

80 Visscher 1994, p. 256.

${ }^{81}$ De bijzondere Kamercommissie die onderzoek deed naar de werkwijze van de Kamer (commissieDolman) achtte de nota dan ook een potentieel waardevol instrument voor zowel het versterken van de parlementaire positie in het wetgevingsproces als voor de parlementaire controle "door het confronteren van beleidsvoornemens met de feitelijke praktijk." Kamerstukken II 1985/86, 19 336, nrs. 1 en 2, p. 8.

82 Zie art. 28 RvOTK.
} 
spraak te verkrijgen in de vorming van het regeringsbeleid, is daarom in de parlementaire praktijk minstens zo belangrijk als het vragen- en interpellatierecht.

Het parlementaire onderzoeksrecht fungeert eveneens als controlemiddel. Sinds 1848 beschikt de Tweede Kamer over het recht van onderzoek (enquêterecht, thans artikel $70 \mathrm{Gw}$ ), dat in de Wet op de parlementaire enquête is uitgewerkt. Sinds 1887 is dit enquêterecht ook voor de Eerste Kamer beschikbaar, al heeft deze Kamer hiervan nog nooit gebruik gemaakt. In de Tweede Kamer is de afgelopen decennia naast het enquêteonderzoek ook een 'gewone' vorm van onderzoek ontstaan, die voortvloeit uit de inlichtingenplicht van art. $68 \mathrm{Gw} .{ }^{83}$ Parlementaire onderzoeken bevatten vaak elementen van zowel klassieke als moderne parlementaire controle. Zo kan een onderzoek naar de uitvoering van een bepaald onderdeel van het regeringsbeleid worden aangemerkt als een klassieke vorm van controle, terwijl het doen van aanbevelingen of een toekomstgericht onderzoek weer meer een moderne vorm van controle is. De betekenis van het onderzoeksrecht in de parlementaire praktijk komt hierna nog uitvoeriger aan de orde.

\subsection{Conclusie}

De ontwikkeling van het Nederlandse parlementaire stelsel was een geleidelijk proces, dat zich voor een belangrijk deel tussen het midden van de negentiende eeuw en het begin van de twintigste eeuw afspeelde. Dit begon met de invoering van de strafrechtelijke en politieke ministeriële verantwoordelijkheid in de periode 1840-1848, waardoor de macht verschoof van de Koning naar de ministers. Met het ontstaan van de vertrouwensrelatie tussen de ministers en het parlement veranderde de machtsbalans wederom; tegen het einde van de negentiende eeuw drukte de Tweede Kamer een belangrijk stempel op de totstandkoming van wetgeving en beleid. De ontwikkeling van het partijenstelsel, versterkt door de invoering van het algemeen kiesrecht en het stelsel van evenredige vertegenwoordiging, zorgde voor een steeds hechtere politieke band tussen kabinet en de meerderheidsfracties in de Kamer - een band die sinds de Tweede Wereldoorlog bezegeld wordt door een intensief proces van kabinetsformatie en het sluiten van regeerakkoorden.

Het aldus ontstane parlementaire stelsel kenmerkte zich lange tijd door een hoge mate van stabiliteit en continuïteit. Lange tijd vloeide deze stabiliteit voort uit de typisch Nederlandse verzuilde samenleving. Toen de verzuiling in de jaren zestig van de twintigste eeuw ten einde kwam, zorgde het evenzeer op consensus gerichte 'poldermodel' nog lange tijd voor een zekere mate van politieke stabiliteit en continuïteit. Met de opbouw van de verzorgingsstaat, die na de Tweede Wereldoorlog plaatsvond, kreeg het openbaar bestuur op allerlei maatschappelijke terreinen een steeds grotere verantwoordelijkheid. De volksvertegenwoordiging raakte daardoor verder op de achtergrond. Later, in de jaren tachtig en negentig, nam de rol van het parlement nog verder af door de grootschalige verzelfstandiging van overheidsdiensten.

Mede onder druk van nieuwe protestpartijen groeide vanaf de jaren zestig de roep om democratisering en effectieve parlementaire controle op het openbaar be-

83 Zie nader: art. 18 RvOTK. 
stuur. Klassieke instrumenten op het gebied van wetgeving en controle leken niet langer effectieve middelen om invloed uit te oefenen op de vorming van beleid. Het belang van de formele wet nam af ten gunste van lagere vormen van regelgeving, waardoor de regering een steeds groter stempel kon drukken op het overheidsbeleid. Ook de controletaak van het parlement veranderde van karakter. Van oudsher kon de Kamer, via de band van de ministeriële verantwoordings- en inlichtingenplicht, achteraf controle uitoefenen op de uitoefening van het overheidsbeleid. Kamerleden besteden tegenwoordig echter een groot gedeelte van hun tijd aan allerlei nieuwe vormen van overleg tussen ministers en Kamer, waar aan de hand van beleidsnota's werd getracht tijdig invloed uit te oefenen op de beleidsvorming. Zo is het beeld ontstaan van een parlement dat vooral probeert 'mee te regeren'.

De toegenomen aandacht voor beleidsbeïnvloeding vooraf, die sterk lijkt op de Angelsaksische vorm van parlementaire controle, lijkt ten koste te zijn gegaan van de traditionele controle achteraf. Die klassieke controle is niet zelden sterk incidentgericht, zoals de veelheid aan Kamervragen en spoeddebatten laat zien. Tegelijkertijd vormde de roep om versterking van de parlementaire controletaak, die sinds de jaren zestig voortdurend klinkt, ook de basis voor de herontdekking van een oud parlementair instrument: het parlementaire onderzoek. Het reeds in 1848 grondwettelijk erkend parlementaire onderzoeksrecht heeft zich vanaf de jaren tachtig kunnen ontwikkelen tot een gevestigd instrument voor diepgravende en systematische parlementaire controle, maar blijkt zich eveneens goed te lenen voor effectieve parlementaire beleidsbeïnvloeding.

Tegen deze achtergrond wordt in het volgende hoofdstuk nader ingegaan op de historische ontwikkeling en de hedendaagse betekenis van het parlementaire onderzoeksrecht. 


\section{Hoofdstuk 2. Onderzoeksrecht en onderzoeksbevoegdheden}

\subsection{Inleiding}

Het parlementaire recht van onderzoek ('enquête'), zoals verankerd in artikel $70 \mathrm{Gw}$, is uitgewerkt in een wet die uitzonderlijke bevoegdheden toekent aan een daarvoor ingestelde parlementaire commissie. Deze enquêtecommissie kan burgers dwingen om te verschijnen en te antwoorden op vragen en kan inzage vorderen in schriftelijke stukken, waarbij eventueel dwangmiddelen of strafrechtelijke sancties kunnen worden ingezet. Dit maakt het 'enquêterecht' (deze term zal hierna worden aangehouden wanneer over dit wettelijke onderzoeksrecht wordt gesproken) tot een zwaar en ingrijpend instrument.

Naast het parlementaire enquêterecht beschikt het parlement ook over de mogelijkheid om onderzoek te doen zonder daarbij gebruik te maken van deze enquêtebevoegdheden. In de praktijk wordt deze vorm van parlementair onderzoek veel vaker toegepast dan de enquêtevorm; om die reden wordt in het navolgende de term reguliere parlementaire onderzoeken gebruikt wanneer gedoeld wordt op parlementaire onderzoeken (of onderzoekscommissies) zonder enquêtebevoegdheden.

Voordat de onderzoeksbevoegdheden die het parlement ter beschikking heeft, besproken kunnen worden, dient eerst de vraag te worden beantwoord waarover een parlementair onderzoek eigenlijk wel en niet mag gaan. Wat is, met andere woorden, de omvang (reikwijdte) van het onderzoeksrecht? De uitvoerige discussie die hierover op verschillende momenten gedurende de afgelopen anderhalve eeuw is gevoerd, wordt uiteengezet in de volgende paragraaf.

\subsection{Betekenis en reikwijdte onderzoeksrecht}

\subsubsection{Ontstaan onderzoeksrecht}

Het recht van enquête is sinds 1848 een grondwettelijk vastgelegde bevoegdheid van de Tweede Kamer. Thans is het "recht van onderzoek (enquête)", zoals de grondwetgever het heeft omschreven, terug te vinden in artikel $70 \mathrm{Gw}$. Ook voor 1848 was er overigens al sprake van onderzoeken door het Nederlandse parlement, dan wel diens voorgangers. Zo verrichtten de Staten van Holland in 1651 onderzoek naar de aanval die stadhouder Willem II een jaar daarvoor uitvoerde op de stad Amsterdam. ${ }^{1}$ En in 1845 voerde de Tweede Kamer een onderzoek uit naar de gebrekkige

\footnotetext{
1 Boon 1982, p. 116.
} 
toestand van wetgeving en bestuur in Suriname op verzoek van een aantal Amsterdamse kooplieden. ${ }^{2}$

In de aanloop naar de Grondwetsherziening van 1848 bestond bij veel TweedeKamerleden behoefte aan een grondwettelijk verankerd onderzoeksrecht. ${ }^{3}$ Een van de redenen die tijdens de mondelinge beraadslagingen werd genoemd, is de nuttige functie die een enquête zou kunnen vervullen bij de beoordeling van onteigeningszaken. ${ }^{4}$ De regering voegde naar aanleiding van deze wens vanuit de Kamer daarom een bepaling toe aan haar grondwetsontwerp, luidende: "De Tweede Kamer heeft het regt van onderzoek (enquête), te regelen door de wet." De bepaling werd vervolgens zonder veel discussie opgenomen in de nieuwe Grondwet. ${ }^{5}$

De Grondwet van 1848 droeg de wetgever dus op om het parlementaire enquêterecht uit te werken in een wettelijke regeling. De regering kwam aan deze eis tegemoet door in 1849 een voorstel voor een enquêtewet bij de Kamer in te dienen. ${ }^{6}$ Dit voorstel werd echter zeer slecht ontvangen in de Commissie van Rapporteurs ${ }^{7}$ : men vond het regeringsvoorstel ondoordacht, slecht voorbereid en onvoldoende gemotiveerd. Omdat het enquêterecht nieuw was in de Nederlandse grondwet, had de commissie gewild dat de regering een rechtsvergelijkend onderzoek had gedaan naar het karakter en de werking van het enquêterecht in andere constitutionele staten. ${ }^{8}$ Aan het einde van het zittingsjaar 1849 kwam het voorstel te vervallen, omdat in die tijd de zogenaamde 'sluiting is stuiting'-regel nog gehanteerd werd. ${ }^{9}$ Op 18 april 1850 werd daarom door de regering een nieuw wetsvoorstel aangeboden. ${ }^{10}$ In de memorie van toelichting bij dit wetsvoorstel besteedde de minister van Justitie aanmerkelijk meer aandacht aan de betekenis van het parlementaire enquêterecht. De Grondwet zelf geeft hierover geen uitsluitsel, zo begint de regering, omdat slechts wordt erkend dat de Tweede Kamer een enquêterecht bezit. De regering stelde echter op grond van de parlementaire geschiedenis vast dat bij zowel regering als parlement "geene weifeling of verschil van gevoelen over de beteekenis dier woorden heeft bestaan, zoodat veilig kan worden aangenomen, dat men bij stilzwijgende

\footnotetext{
2 Boon 1982, p. 118. Zie ook Kappeyne van de Coppello 1978, p. 60 en Van der Pot/Elzinga \& De Lange 2006, p. 783.

${ }^{3}$ Uit het voorlopig verslag bij de ontwerp-grondwet wordt hierover opgemerkt: "Eene regtstreeksche toekenning van het regt van enquête, zoo niet aan beide Kamers, dan toch aan de Tweede, wordt door velen wenschelijk geacht. De bepaling daaromtrent zou òf bij het tegenwoordige artikel òf bij art. 29 kunnen worden gevoegd." Handelingen II 1847/48, p. 480.

${ }^{4}$ Kappeyne van de Coppello 1978, p. 60.

5 Tijdens de behandeling van de Enquêtewet, waarmee uitvoering werd gegeven aan deze grondwetsbepaling, stelde Groen van Prinsterer, niet bepaald een voorstander van het enquêterecht, daarom dat het recht "op zonderlinge wijze in de Grondwet gebragt [is], zonder genoegzaam overleg". Hij beschuldigde de meerderheid van de Kamer, die aandrong op een enquêtebepaling, er zelfs van weinig besef te hebben van de betekenis van deze "anomalie" in onze Grondwet. Handelingen II 1849/50, zitting van 13 juli, p. 5-6.

${ }^{6}$ Handelingen II 1849, p. 277.

7 Rapporteurs hielden zich, binnen het destijds vigerende stelsel van afdelingen, bezig met het voorbereidende onderzoek van een wetsvoorstel. Zie hierover nader: Van Schagen 1994, p. 33-35.

${ }^{8}$ Bijlage Handelingen II 1849, p. 179-181.

${ }^{9}$ Boon 1982, p. 119-120.

${ }^{10}$ Bijlage Handelingen II 1849/50, p. 231-232.
} 
overeenkomst dat regt van onderzoek heeft op het oog gehad, dat elders door wetgevende vergaderingen wordt uitgeoefend." 11

Bij het vormgeven van de Nederlandse enquêtewet liet de regering zich in belangrijke mate inspireren door de enquêtepraktijk in andere landen. Zo werd allereerst gekeken naar Engeland, "waar het bedoelde regt van onderzoek het langst heeft bestaan en het meest in practijk is gebragt". De beide kamers bleken daar een onbeperkt enquêterecht te bezitten, "dat in het alvermogen van het Engelsch parlement geworteld is". Een enquête kon op elk onderwerp betrekking hebben, "doch is door de gewoonte tot de zoodanige beperkt, die voor dusdanig onderzoek vatbaar schijnen." Parlementaire enquêtes bleken in Engeland meestal door de regering te worden geïnitieerd, vaak ter voorbereiding van nieuwe wetgeving. Iedereen die zich in Engeland bevindt kon zo nodig met behulp van parlementaire dwangmiddelen als gijzeling worden gedwongen om te getuigen, tenzij het gaat om leden van het Hogerhuis, die alleen na machtiging van dat Huis gegijzeld kunnen worden. De commissies bestonden uit leden van verschillende partijen en over het lidmaatschap wordt gewoonlijk achter de schermen onderhandeld. Getuigen en deskundigen konden door alle leden van de commissie ondervraagd worden, wat bevorderde dat de zaken van verschillende zijden belicht worden. Alleen een enquêtecommissie uit het Hogerhuis kon een verklaring onder ede afdwingen, omdat die kamer in bepaalde gevallen rechtsmacht uitoefent. De enquêtecommissie sloot een onderzoek af met een verslag, dat gewoonlijk beperkt was tot een weergave van "het licht door de getuigen verspreid" en zelden conclusies bevatte. ${ }^{12}$

De regering besteedde vervolgens aandacht aan de parlementaire praktijk in Frankrijk en België, waar men, zo vermoedde de regering, het enquêterecht vanuit Engeland had overgenomen. ${ }^{13}$ In het bijzonder hoopte de regering te kunnen achterhalen of het enquêterecht in deze landen wijzigingen had ondergaan of op een andere wijze is geregeld "ten gevolge der afwijkende instellingen dier rijken". De parlementaire onderzoeksfunctie bleek in Frankrijk een grotendeels ongeschreven parlementair recht te zijn, dat als vanzelfsprekend voortvloeide uit het recht van het parlement om de nodige inlichtingen te verzamelen alvorens wetten te maken of (andere) beslissingen te nemen die tot haar werkkring behoren. ${ }^{14}$ Het enquêterecht functioneerde op vergelijkbare wijze als in Groot-Brittannië: zelfs ministers konden na machtiging van de kamer door de enquêtecommissie worden gedwongen om te getuigen. In België was het enquêterecht grondwettelijk erkend en kende ook daar geen specifieke beperkingen. Echter, in het algemeen werd in België aangenomen dat het enquêterecht begrensd werd door de "grondwettigen werkkring der Kamers" en dat een nadere wettelijke regeling noodzakelijk was om op grond van het enquêterecht verplichtingen voor autoriteiten en anderen te scheppen. Een voorstel daartoe in 1831 bleek echter op constitutionele bezwaren te stuiten, omdat "het de verschillende staatsmagten ondereen mengde, en dus van geen zuiver beginsel uitging." 15

\footnotetext{
11 Bijlage Handelingen II 1849/50, p. 233.

12 Bijlage Handelingen II 1849/50, p. 233.

${ }^{13}$ Bijlage Handelingen II 1849/50, p. 233.

14 Bijlage Handelingen II 1849/50, p. 233.

${ }^{15}$ Bijlage Handelingen II 1849/50, p. 234.
} 
In geen van de drie onderzochte stelsels bleek de omvang van het enquêterecht dus uitdrukkelijk te zijn vastgelegd. De regering vond het daarom niet nodig om de grenzen van het Nederlandse enquêterecht in algemene zin vast te leggen. Het enquêterecht, zo concludeerde de regering, werd uit de aard der zaak begrensd door de omvang van de parlementaire taken:

\begin{abstract}
"Het Gouvernement (...) is van oordeel, dat, hoe onbeperkt ook het regt van enquête zij toegekend, de toekenning aan de Tweede Kamer eene eigendommelijke beperking van dit regt binnen den grondwettigen werkkring van dat staatsligchaam medebrengt, die bij ieder voorstel tot het instellen eener enquête den toetssteen ter beslissing moet opleveren, en die men vruchteloos trachten zoude door algemeene regelen meer bruikbaar te maken." 16
\end{abstract}

Het wetsvoorstel zelf bevatte veel elementen die ontleend waren aan de Britse, Franse en Belgische praktijk. De Tweede Kamer kon op basis van dit voorstel besluiten dat een speciaal daartoe ingestelde parlementaire commissie een onderzoek (enquête) uitvoert. Alle ingezetenen, inclusief ambtenaren, waren in beginsel verplicht medewerking te verlenen aan een parlementaire enquête vanaf het moment dat deze is bekendgemaakt. Zo nodig konden getuigen of deskundigen hiertoe gedwongen worden. De regering heeft daarnaast getracht om rekening te houden met het beginsel van de machtenscheiding en de gevreesde vermenging van staatmachten, waarop het Belgische wetsvoorstel indertijd stukliep. Daarom werden de toepassing van dwangmiddelen en strafsancties opgedragen aan de rechterlijke macht en niet aan de enquêtecommissie of de Kamer zelf. ${ }^{17}$ Bovendien meende de regering, in de geest van de Grondwet, dat ministers niet zouden kunnen worden gedwongen om voor een enquêtecommissie te verschijnen. $\mathrm{Zij}$ waren immers in het normale verkeer tussen regering en parlement gehouden om de nodige inlichtingen te verschaffen, voor zover dit niet in strijd is met het belang van de staat. De omvang van deze verplichting, die in artikel 89 van Grondwet is vastgelegd, kon niet bij wet worden uitgebreid en daarom wordt "ten overvloede" voor ministers een uitzondering gemaakt op de algemene opkomstplicht, zo stelde de regering. ${ }^{18}$ Voor ambtenaren gold in het verlengde hiervan dat zij zelfstandig of op bevel van hun meerdere met een beroep op het belang van de staat kunnen weigeren, wanneer de commissie hen verzoekt bepaalde stukken te overleggen. ${ }^{19}$ Tenslotte stelde de regering dat het vanzelf sprak, dat een enquêtecommissie ophoudt te bestaan op het moment dat de Kamer ontbonden wordt. In het wetsvoorstel werd dit nadrukkelijk vastgelegd. De regering zag haar ontbindingsbevoegdheid als een middel om een parlementair onderzoek dat de grenzen van het enquêterecht zou overschrijden, te kunnen afbreken. ${ }^{20}$

Tijdens de behandeling in beide Kamers kwam de vraag wat de grenzen van het enquêterecht zijn op twee plaatsen aan de orde. In de Commissie van Rapporteurs

\footnotetext{
16 Bijlage Handelingen II 1849/50, p. 234. De regering sloot hiermee aan bij de Commissie van Rapporteurs die zich in het verslag naar aanleiding van het eerdere (vervallen) wetsvoorstel eveneens op het standpunt gesteld dat een nadere regeling op dit punt onwenselijk was.

${ }_{17}$ Bijlage Handelingen II 1849/50, p. 234 (t.a.v. art. 8).

18 Bijlage Handelingen II 1849/50, p. 234 (t.a.v. art. 3, tweede lid).

19 Bijlage Handelingen II 1849/50, p. 234 (t.a.v. art. 19).

${ }^{20}$ Bijlage Handelingen II 1849/50, p. 234 (art. 27)
} 
uitten sommige leden de wens om een heldere definitie van het enquêterecht op te nemen in de wet, om te voorkomen dat de enquête zou worden misbruikt door de kamermeerderheid en zou verworden tot een geducht wapen tegen de regering. De grote meerderheid zag echter geen bezwaren tegen het ontbreken van een dergelijke omschrijving - dit zou wegens de veelheid aan mogelijke onderwerpen ondoenlijk zijn - en bovendien, zo vond deze meerderheid, getuigde het van een "verkeerd denkbeeld" dat de enquête zou worden ingezet als wapen tegen de regering. ${ }^{21}$ Tijdens de plenaire behandeling kwam de betekenis van het enquêterecht wederom aan de orde. Ook hier wezen enkele leden op de mogelijke gevaren van de kennelijke onbegrensdheid van het enquêterecht in handen van het parlement. Toch bleek men het grotendeels met elkaar eens te zijn over de onmogelijkheid om het begrip in de wet te definiëren of af te bakenen. Hierbij zal ook de vrees dat een definitie waarschijnlijk alleen maar zou leiden tot het inperken van het enquêterecht hebben meegespeeld. ${ }^{22}$ Bij de behandeling in de Eerste Kamer stelde minister van Justitie Nedermeyer van Rosenthal daarom: “De attributen dier Tweede Kamer zijn in de Grondwet geschreven en die attributen moeten bij ieder voorstel tot het instellen eener enquête den eenigen toetssteen uitmaken. Men moet zich dan afvragen behoort het onderwerp tot de bevoegdheid der Tweede Kamer? En het antwoord daarop, met het oog op de Grondwet gegeven, is een oneindig veiliger toetssteen dan eene gewaagde definitie." 23 Het voorstel tot het houden van een enquête zou bovendien tijdens een openbare vergadering worden behandeld en dan kon worden bezien of de Kamer zich wellicht zou begeven "op het gebied der administrative of op dat der regterlijke magt, en er alzoo eene vermenging van staatsmagten uit zou voortvloeijen." 24

Een tweede onderwerp van debat was de uitzondering op de algemene opkomstplicht die voor ministers werd gemaakt. In artikel 3 van het wetsvoorstel werd bepaald dat de "hoofden der ministeriële departementen" alleen konden worden ondervraagd "op de wijze bij art. 89 der Grondwet voorgeschreven." Dit stuitte op onbegrip bij de Commissie van Rapporteurs en tijdens de plenaire behandeling ontstond over dit punt een discussie tussen de minister en de Kamer, maar ook tussen de leden van de Kamer onderling. Het Kamerlid Van Dam van Isselt betoogde dat het onbegrijpelijk is waarom voor ministers een uitzondering wordt gemaakt die niet voor gewone burgers geldt. ${ }^{25}$ Anderen stelden echter dat het niet nodig is om een minister voor een enquêtecommissie te ondervragen, omdat de Grondwet met artikel 89 reeds een inlichtingenplicht bevatte. ${ }^{26}$ In zijn reactie op deze kritiek legde ook de minister van Justitie een verband tussen het interpellatierecht en het enquêterecht. Uit het stelsel van de Grondwet blijkt, zo verklaart de minister, dat het verkeer tussen regering en Kamer volledig beheerst werd door artikel 89, de bepaling die de ministers verplicht om inlichtingen te verschaffen aan de beide Kamers. Hij voegde

${ }^{21}$ Bijlage Handelingen II 1849/50, p. 313.

22 Dölle 1985, p. 33.

${ }^{23}$ Handelingen I 1849/50, p. 229.

24 Handelingen I 1849/50, p. 229.

${ }^{25}$ Handelingen II 1849/50, zitting van 13 juli, p. 2. Zie ook Kappeyne van de Coppello 1978, p. 68.

${ }^{26}$ Zie de bijdragen van de leden Fokker, Costerus en Wichers: Handelingen II 1849/50, zitting van 13 juli, p. 11-12. 
daaraan toe: "De Grondwet, die beide deze regten zoo naauw aaneensluit, dat zij als het ware van elkander schijnen af te hangen, kan niet bedoeld hebben dat een Minister bovendien voor eene commissie van enquête zou verschijnen." 27 De kritiek op de uitzonderingspositie van ministers bleek overigens voor de meerderheid van de Kamer niet overtuigend te zijn: een amendement strekkende tot het schrappen van deze uitzondering werd met 41 tegen 9 stemmen verworpen. Met slechts enkele kleine aanpassingen werd het wetsvoorstel in beide Kamers aangenomen en op 5 augustus 1850 in het Staatsblad gepubliceerd. ${ }^{28}$ In 1852 nam de Kamer de uitoefening van het enquêterecht op in haar Reglement van Orde. ${ }^{29}$

De regering nam aan, zoals hierboven bleek, dat het enquêterecht even ver reikt als de bevoegdheden van de Kamer. ${ }^{30}$ De Kamers leken zich hierin in meerderheid te kunnen vinden. Maar wat betekent dit? Wat is de omvang van de bevoegdheid van de Kamer en daarmee van het enquêterecht, ofwel, waarover kan de Kamer een enquête houden? Ondanks de weerzin aan de kant van de regering om een eenduidige definitie van de omvang van het enquêterecht vast te leggen, kunnen uit de wetsgeschiedenis toch enige aanwijzingen worden afgeleid omtrent het standpunt van de regering.

Ten eerste kan gewezen worden op de vergelijking met het Britse enquêterecht, dat als voorbeeld diende. Uit de analyse van de regering bleek dat de parlementaire enquête in Groot-Brittannië, doorgaans op regeringsinitiatief, destijds voornamelijk werd toegepast ter voorbereiding van wetgeving. Verder bestonden de parlementaire werkzaamheden in die tijd voornamelijk uit wetgevingsactiviteiten. Een opmerking van minister Nedermeyer in het plenaire debat in de Tweede Kamer laat dat goed zien. Het enquêterecht, zo stelde hij, dient "om zelf te verzamelen zoodanige bouwstoffen, als licht kunnen spreiden, zoowel over een wetsontwerp dat in behandeling is, als over iedere andere zaak, die tot de attributen der Tweede Kamer behoort." 31 Voor wat betreft de overige 'attributen' en taken die aan de Kamer toekwamen, lijkt aannemelijk dat de regering in die tijd een veel beperkter beeld van de omvang van die parlementaire 'werkkring' had dan thans het geval zou zijn. Het overheidsapparaat was nog klein, de verzorgingsstaat nog ver weg, de Koning oefende veel bevoegdheden zelfstandig uit. Tegen deze achtergrond is het goed denkbaar dat de regering, toen zij stelde dat de vastlegging van een enquêterecht voor de Tweede Kamer 'eene eigendommelijke beperking van dit regt binnen den grondwettigen werkkring van dat staatsligchaam meebrengt', een instrument voor ogen had dat met name in het wetgevingsproces een rol zou vervullen - en dan nog vooral in bijzondere gevallen, waarin aanvullende informatie nodig was die alleen onder dwang van derden kon worden verkregen. ${ }^{32}$

\footnotetext{
${ }_{27}$ Handelingen II 1849/50, zitting van 13 juli, p. 13.

${ }^{28}$ Wet van 5 augustus 1850, Stb. 1850, 45.

${ }^{29}$ Kappeyne van de Coppello 1978, p. 60.

${ }^{30}$ Handelingen I 1849/50, p. 229.

${ }^{31}$ Handelingen II 1849/50, zitting van 13 juli, p. 7.

32 Tijdens de mondelinge behandeling van het wetsvoorstel zei de minister: "Ik kan niet gelooven, dat men moet aannemen, dat in het instellen van een enquête in het algemeen een bewijs van afkeuring der staatkunde van het Gouvernement gelegen zoude zijn, maar nog veel minder dat eene commissie van onderzoek van het standpunt van een inquisitoriaal onderzoek tegen een der Ministers behoort
} 
De gedachte dat het enquêterecht ook voor controledoeleinden zou kunnen worden ingezet, lijkt hier nog ver weg. De uitzondering op de algemene medewerkingsplicht die in het wetsvoorstel voor ministers werd gemaakt, stond daaraan in de weg. De minister gaf tijdens de mondelinge behandeling aan, dat de ondervraging van ministers slechts door middel van het inlichtingen- en interpellatierecht van art. $89 \mathrm{Gw}$ kon plaatsvinden. Bovendien konden ambtenaren, als gezegd, met een beroep op het staatsbelang door de enquêtecommissie gevraagde inzage in schriftelijke stukken weigeren. Deze elementen van de Enquêtewet, waartegen een grote meerderheid van de Kamer kennelijk geen bezwaren had, versterken de indruk dat de minister en de Kamer het enquêterecht niet zagen als een middel om het functioneren van ministers en ambtenaren te onderzoeken met het doel om politieke verantwoordelijkheden vast te stellen.

\subsubsection{Vroege onderzoekspraktijk}

De regering, zo kan uit deze aanwijzingen worden opgemaakt, had dus een naar huidige maatstaven beperkt enquêterecht voor ogen. Toen het voorstel werd behandeld in het parlement had de overgrote meerderheid geen bezwaren van constitutionele aard. Toch was op dat moment al wel duidelijk geworden dat binnen de Tweede Kamer verschillend gedacht werd over de omvang van het grondwettelijke enquêterecht.

In 1852 werd het eerste enquêtevoorstel bij de Kamer ingediend en ook aangenomen. Het ging om een voorstel om onderzoek te doen naar mogelijke verbetering van de wet op de accijns op zout. ${ }^{33}$ Hier speelde de bevoegdheidskwestie nog geen rol. Het werd in de Kamer stevig bediscussieerd, maar de discussie ging vooral over de vraag of een enquête op dat moment nog wel nodig was, aangezien de Kamer slechts enige maanden eerder een nieuwe wet inzake de zoutaccijns had aangenomen. ${ }^{34}$ Het tweede enquêtevoorstel dat werd ingediend, het voorstel-Wintgens over de toestand van de zeevisserijen, werd om vergelijkbare redenen sterk bekritiseerd. Het zou niet nodig zijn om een onderzoek met deze strekking te doen, zo werd in de Kamer gezegd, omdat de feiten reeds voldoende helder waren. Evenals bij de zoutaccijnsenquête kreeg de indiener van het zeevisserij-voorstel het verwijt dat de enquête vooral ten doel zou hebben de politieke keuzes die de meerderheid van de Kamer even daarvoor had gemaakt, via een parlementair onderzoek wederom ter discussie te stellen. ${ }^{35}$ De minister van Binnenlandse Zaken, Thorbecke, suggereerde

uit te gaan. Naar mijne wijze van zien, zal, wanneer het regt van onderzoek aan het doel beantwoordt, de uitoefening van dat regt in den regel van evenveel nut zijn voor de Regering als voor de wetgevende magt, om, waar het belangrijke zaken geldt, inlichtingen te verkrijgen." Handelingen II 1849/50, zitting van 13 juli, p. 8 .

33 Handelingen II 1851/52, p. 674.

${ }^{34}$ Handelingen II 1852/53, p. 98-104.

35 Het Kamerlid Gevers Deijnoot herinnerde de Kamer aan het visserijbeleid dat tijdens de jongste begrotingsbehandeling is uitgezet en goedgekeurd en roept tijdens de plenaire behandeling van het enquêtevoorstel uit: "En nu vraag ik, Mijne Heeren, wanneer deze kamer zich onlangs zoo bepaald heeft uitgelaten, of het toestaan dat een onderzoek plaats grijpe naar de middelen van herstel [van de 
dat de regering het voorgestelde onderzoek zelf wel zou verrichten, zodat de Kamer kan beschikken over voldoende informatie. Met de toezegging van de minister dat dit onderzoek er zou komen en dat tevens gewerkt zou worden aan een nieuw wetsvoorstel terzake van de zeevisserij, trok de indiener het enquêtevoorstel aan het einde van het Kamerdebat in. 36

Bij de behandeling van het enquêtevoorstel inzake drankmisbruik ${ }^{37}$ (het voorstel-Rochussen) werd voor de eerste keer een uitvoerig debat gevoerd over de omvang van de bevoegdheid van de Kamer tot het houden van een enquête. Het Kamerlid Bosscha opende de discussie met de stelling dat het enquêterecht van de Kamer "onbegrensd is en zich mag uitstrekken over alle onderwerpen." Door het enquêterecht in de Grondwet te plaatsen direct na het inlichtingen- en interpellatierecht, heeft men in zijn ogen willen uitdrukken dat het parlementair onderzoek niet beperkt behoeft te zijn tot wetgevingsactiviteiten. Een discussie over de bevoegdheid van de Kamer om een enquête te houden, is dus eigenlijk geheel overbodig, zo concludeert Bosscha, want het enquêterecht is onbegrensd. Het Kamerlid Van Hoëvell meende dat Bosscha te ver ging en hield het erop dat "de Kamer alleen eene enquête mag houden over zulke onderwerpen, welke van hare bevoegdheid zijn." 38 Wat hij vervolgens onder de bevoegdheden van de Kamer verstond, maakte hij evenwel niet duidelijk.

Andere leden waren van mening dat het enquêterecht veel beperkter moest worden opgevat. Van Reppard en De Kempenaer hielden, met een beroep op de grondwetsgeschiedenis, vast aan het idee dat het enquêterecht slechts in het kader van de wetgevingstaak van de Kamer kan worden uitgeoefend. De Kempenaer stoorde zich bovendien aan de suggestie dat de bevoegdheden van de Tweede Kamer inzake het enquêterecht kunnen worden bepaald door middel van een vergelijking met het Engelse enquêterecht: de almachtige positie van het parlement in het Britse constitutionele stelsel verschilt te zeer van de positie van de Tweede Kamer, waarvan de bevoegdheden in de Grondwet juist zijn afgebakend. ${ }^{39}$

Het Kamerlid Van Nispen van Sevenaer was dan weer voorstander van een ruime interpretatie van het enquêterecht. Hij wees de aanhangers van de enge visie erop, dat bij de invoering van het enquêterecht reeds gerefereerd werd aan het parlementaire onderzoek inzake de bestuursperikelen in Suriname in 1845. De oude Grondwet droeg het bestuur der koloniën op aan de Koning, dus het betreffende parlementair onderzoek had onmiskenbaar betrekking op het optreden van de regering en niet op wetgeving. De Kamer, aldus Van Nispen, had bij de grondwetsherziening dus wel degelijk een enquêterecht met "eene veel wijdere strekking" op het oog. ${ }^{40}$ Ook Groen van Prinsterer constateerde dat van een tot de wetgevingsfunctie beperkte opvatting van het enquêterecht geen sprake kon zijn. Het enquêterecht was, overigens tot zijn spijt, "zonder eenige beperking aan de Tweede Kamer verleend"

Nederlandse zeevisserij], niet in strijd zou zijn met de meening, bij dat hoofdstuk der Staatsbegrooting geuit?" Handelingen II 1852/53, p. 115.

${ }^{36}$ Handelingen II 1852/53, p. 121.

${ }^{37}$ Handelingen II 1854/55, p. 831.

${ }^{38}$ Handelingen II 1855/56, p. 579.

${ }^{39}$ Handelingen II 1855/56, p. 570.

${ }^{40}$ Handelingen II 1855/56, p. 571. 
en slechts beperkt door bevoegdheden die uit de werkkring der Kamer voortvloeien. "Maar," zo concludeerde hij vervolgens, "ook om deze bevoegdheid te bepalen, om dien werkkring te omschrijven, hebben wij, bij het subjective der beschouwing, geen regel, dan die aan onze bedachtzaamheid, aan onze eigene wijsheid, en, gelijk men te regt heeft herinnerd, als ultimum remedium, aan de wijsheid der kiezers ontleend wordt." 41

Het debat eindigde, nadat Rochussen nog (tevergeefs) had aangegeven dat hij zijn voorstel zou intrekken als de minister zou toezeggen om zelf met een onderzoek en een wetsvoorstel te komen, met de verwerping van het voorstel met 34 tegen 23 stemmen. ${ }^{42}$ De meerderheid zag geen noodzaak om een parlementair onderzoek in te stellen naar deze kwestie, omdat deze voldoende duidelijk was, en gaf de voorkeur aan het samenstellen van een commissie die terzake de mogelijkheid van een wetsvoorstel moest verkennen. ${ }^{43}$

De discussie over de bevoegdheid van de Kamer werd voortgezet bij de volgende gelegenheid, die zich eind 1855 aandiende. Het betrof het zogenaamde 'muntplaatjesschandaal'. De aanbesteding van een opdracht tot het produceren van koperen munten voor Nederlands-Indië werd door de minister van Koloniën gegund aan een aannemer die-in tegenstelling tot de overige inschrijvers - niet over de benodigde productiefaciliteiten bleek te beschikken. Nadat deze aannemer de opdracht gegund was en hij besloten had de koperplaatjes dan maar door een Brits bedrijf te laten vervaardigen, kreeg hij van de minister van Financiën ook nog vrijstelling van de verschuldigde invoerrechten en bovendien werd hij in staat gesteld om zonder vergoeding gebruik te maken van de faciliteiten van 's Rijks Munt. De ontstane publieke ophef en verdachtmakingen leidden tot een voorstel voor een parlementaire enquête naar deze zaak, maar bij de behandeling daarvan werd het de Kamer kennelijk te heet onder de voeten: met een motie van orde werd het voorstel vrij snel van tafel geveegd. ${ }^{44}$ Nadat een ander Kamerlid het afgevoerde voorstel met exact dezelfde onderzoeksvragen opnieuw indiende, leek een grondige behandeling van het voorstel onoverkomelijk. De Commissie van Rapporteurs was verdeeld, maar reageerde in meerderheid negatief op het voorstel. Tijdens de mondelinge behandeling ontstond een fel debat, waarin voor een belangrijk deel wederom de bevoegdheid van de Kamer centraal stond. Tegenstanders, waaronder de minister van Justitie, stelden dat het voorstel een rechtstreekse aanval op enkele ministers was en om die reden ongeoorloofd. De voorstanders ervan betoogden daarentegen stellig dat het enquêterecht niet beperkt kon worden tot de wetgevingsfunctie van het parlement. Tegen het einde van het debat, dat twee dagen in beslag nam, legde Thorbecke, inmiddels weer Kamerlid en een groot voorstander van een ruime opvatting van het enquêterecht, de omvang van het enquêterecht nog eens bondig uit:

\footnotetext{
${ }^{41}$ Handelingen II 1855/56, p. 572.

42 Handelingen II 1855/56, p. 587.

43 Zie het voorstel-Van Hoëvell om "een commissie van vijf leden uit [de Kamer] te benoemen, ten einde te onderzoeken, of, en in welken zin, een voorstel zal worden gedaan omtrent de middelen tot bestrijding of uitroeijing van het misbruik van sterken drank", dat met 37 tegen 16 stemmen werd aangenomen. Handelingen II 1855/56, p. 589-594.

${ }^{44}$ Handelingen II 1855/56, p. 386.
} 


\section{NEDERLAND}

“Wanneer komt over het algemeen eene enquête te pas?

Men heeft gezegd, Mijnheer de Voorzitter, de Kamer is niet bevoegd. Maar wie heeft de grenzen, waarbinnen die bevoegdheid besloten is, aangewezen? Mij dunkt één punt zal niet kunnen worden tegengesproken, zelfs niet door den Minister van Justitie. Eene enquête is geoorloofd, kan zelfs pligt zijn ten aanzien van alle aangelegenheden van wetgeving en bestuur, waarmede de Tweede Kamer in aanraking komt. Het regt van enquête omvat dus alle belangen, die onder het bereik van wetgeving en bestuur zijn. Het is derhalve even onbeperkt, als de deelneming van de Tweede Kamer aan de aangelegenheden van wetgeving en bestuur en van alle zaken, die onder het bereik van wetgeving en bestuur zijn, onbeperkt te noemen. Het is alzoo in zeker opzigt onbeperkt." 45

Thorbecke vervolgt:

"Wanneer komt nu enquête te pas? Mij dunkt, wanneer de inlichtingen, die men van het Gouvernement verkregen heeft of verkrijgen kan, zijn uitgeput en wanneer de Kamer anders inlichtingen behoeft. Dit is nu hier het geval." 46

Het was de eerste keer dat zo duidelijk werd uitgesproken wat andere voorstanders van een ruime uitleg waarschijnlijk al langer meenden: de Kamer mag ook onderzoek doen naar bestuurlijke handelingen van de regering. Of de meerderheid van de Kamer er ook zo over dacht, kan niet uit het verloop van het debat worden afgeleid. Hoewel de indiener uit het beperkte aantal tegenstanders dat, overigens in felle bewoordingen, tijdens de mondelinge behandeling het woord had gevoerd meende te kunnen afleiden dat zijn voorstel een goede kans maakte, werd het voorstel uiteindelijk met 37 tegen 17 stemmen afgewezen. ${ }^{47}$

\subsubsection{Ontwikkeling parlementair stelsel}

Bij de enquêtevoorstellen inzake drankmisbruik en het muntplaatjesschandaal speelde de bevoegdheidsvraag, zo bleek hierboven, een grote rol in het parlementaire debat. Beide voorstellen werden uiteindelijk verworpen. In hoeverre constitutionele overwegingen daarbij een rol speelden, is moeilijk te zeggen. Boon is van mening dat de toon van de debatten laat zien dat het toch vooral politieke motieven waren die voor velen doorslaggevend waren. ${ }^{48}$

$\mathrm{Na}$ het muntplaatjesvoorstel begon de ruime opvatting van het enquêterecht steeds meer terrein te winnen. Slechts twee maanden na de afwijzing van het muntplaatjesonderzoek werd het volgende enquêtevoorstel behandeld. ${ }^{49}$ Het had betrekking op de uitvoering van een door de regering verleende concessie voor een aantal waterstaatswerken en het heffen van tol op het Zwolse Diep. ${ }^{50}$ In de Commissie van Rapporteurs werden door enkele leden nog constitutionele bezwaren ingebracht. De Kamer zou zich volgens de commissie op het terrein van de uitvoerende macht be-

${ }^{45}$ Handelingen II 1855/56, p. 541.

${ }^{46}$ Handelingen II 1855/56, p. 541.

${ }^{47}$ Handelingen II 1855/56, p. 547.

48 Boon 1982, p. 134.

${ }^{49}$ Handelingen II $1855 / 56$, p. 828.

${ }^{50}$ Handelingen II 1855/1856, p. 404. 
geven door het houden van een parlementair onderzoek naar concessies en tolheffing; in plaats daarvan zou de Kamer gebruik moeten maken van het inlichtingenrecht van artikel $89 \mathrm{Gw} .{ }^{51}$ De indiener van het voorstel verzekerde echter stellig dat het slechts zou gaan om de uitvoering van de concessie, waarmee de bevoegdheidsvraag in elk geval voor een Kamermeerderheid afdoende beantwoord was. ${ }^{52}$ Het voorstel werd vervolgens zonder veel discussie aangenomen met 29 tegen 19 stemmen.

Vanaf de Enquête Zwolse Diep (1856) raakte de bevoegdheidskwestie steeds verder op de achtergrond. De ontwikkelingen rondom het parlementaire enquêterecht lijken hier sterk te worden beïnvloed door de veranderende positie van het parlement vanaf de jaren 60 van de negentiende eeuw. In deze periode ontstond de overtuiging dat een kabinet of minister zonder het vertrouwen van een Kamermeerderheid niet langer kon aanblijven. De gedachte dat al het overheidsoptreden op de een of andere manier parlementair gelegitimeerd zou moeten zijn, kwam steeds vaker naar voren. Bij de grondwetswijziging van 1887 werd de versterking van het parlement ten opzichte van de regering als het ware bezegeld. De zelfstandige regelgevende bevoegdheid van de regering werd toen sterk ingeperkt. ${ }^{53}$ Bij dezelfde gelegenheid werd het enquêterecht ook toegekend aan de Eerste Kamer en aan de Verenigde Vergadering.

Ook de verhoudingen binnen het parlement begonnen te veranderen. In deze tijd ontstonden enkele zogenaamde 'kamerclubs', waarin door Kamerleden op politieke en pragmatische gronden werd samengewerkt. De kamerclubs, de voorlopers van de fracties, kregen aan het einde van de negentiende eeuw een steeds grotere invloed op de kabinetsvorming. De positie van het parlement was nu zo sterk geworden, dat duidelijk was dat een kabinet niet kon regeren zonder de instemming van een Kamermeerderheid. ${ }^{54}$ De invoering van het stelsel van evenredige vertegenwoordiging in 1917 versterkte de band tussen kamerfractie en partij. Het parlement werd steeds meer het domein van politieke partijen. Dit had gevolgen voor de werking van het parlement. "Het gebruik en de invulling van de parlementaire bevoegdheden," constateren Elzinga en Warmelink dan ook met betrekking tot deze ontwikkeling, "werd steeds sterker bepaald door de politieke verhoudingen en partij-politieke overwegingen." 55

De centrale positie van de regering binnen het staatsbestel was niet langer onbetwist en zeker niet onaantastbaar. In deze context werd het onderzoeksrecht steeds meer een vanzelfsprekendheid. Bij de behandeling van het enquêtevoorstel Maas en Zuid-Willemsvaart (1858/59) en het voorstel omtrent de noodzaak van een zeemacht (1861/62) werden nog wel constitutionele bezwaren geuit door enkele Kamerleden; de voorstellen werden echter aanvaard, al was het in beide gevallen met een kleine meerderheid, en uitgevoerd. De regering zelf stelde zich bij de behandeling van deze

\footnotetext{
51 Handelingen II 1855/1856, p. 493.

52 Bijlagen Handelingen II 1855/1856, p. 630 ("Er wordt geen onderzoek gedaan naar de bevoegdheid der Regering, wel naar de wijze, waarop in dit geval van die bevoegdheid is gebruik gemaakt; en dit, naar het oordeel van den ondergetekeende, met alle regt.")

53 Elzinga \& Warmelink 1993, p. 22.

54 Elzinga \& Warmelink 1993, p. 22-23.

55 Elzinga \& Warmelink 1993, p. 24.
} 


\section{NEDERLAND}

enquêtevoorstellen opvallend genoeg niet afkeurend op. ${ }^{56}$ De overige enquêtes in de negentiende eeuw vonden plaats in een periode waarin het parlement zijn hoogtijdagen vierde. In deze belle époque van het Nederlandse parlement functioneerden Kamerleden in grote mate zelfstandig. Velen namen een bijzonder actieve houding aan ten opzichte van de regering. De reikwijdte van het onderzoeksrecht stond bij de besluitvorming over deze enquêtes niet meer ter discussie. ${ }^{57}$ De onderwerpen, zo constateert Boon, hadden evenwel zeker niet meer alleen betrekking op wetgeving. ${ }^{58}$

De vraag die zich nu aandient is, wat de parlementaire praktijk in de negentiende eeuw heeft betekend voor de grenzen van het enquêterecht. Boon concludeert dat "in de loop van de jaren zestig van de vorige eeuw onomstotelijk is komen vast te staan, dat het parlementair enquêterecht niet is beperkt tot onderwerpen van wetgeving of andere, in de Grondwet expliciet genoemde, parlementaire rechten." 59 Dölle gaat minder ver en ziet eerder een verschuiving in de interpretatie van het enquêterecht, waarbij een ruime uitleg dominant is geworden. In de loop van de tijd lijkt een consensus te zijn ontstaan, zo stelt hij, waarbij de politieke enquête naast de wetgevingsenquête in beginsel geoorloofd is, zelfs als het gaat om enquêtes in de sfeer van verdachtmakingen en schandalen in of buiten het parlement. Deze consensus werd mogelijk tegen de achtergrond van de ontwikkeling van het parlementaire stelsel, waarin het parlement een sterkere rol ging vervullen en meer taken en bevoegdheden kreeg. Parlementaire controle ten aanzien van het regeringsoptreden via activering van de ministeriële verantwoordelijkheid, zo werd duidelijk, was een van de taken ('attributen') van het parlement. 60

Nadat de enquête naar de toestand in de fabrieken in 1887 werd afgerond, werden nauwelijks nog enquêtevoorstellen ingediend. De ontwikkeling van het parlementaire stelsel aan het einde van de negentiende eeuw kan eveneens verantwoordelijk worden gehouden voor de neergang van het enquêterecht. Het ontstaan van het partijenstelsel rond de eeuwwisseling en de gevolgen hiervan voor de zelfstandigheid van Kamerleden en de verhouding tussen regering en parlement, lijkt hiervoor de belangrijkste reden. Het ontstaan van de 'partijendemocratie' had de verhouding tussen regering en parlement veranderd; het was nu vooral de oppositie die de regering kritisch volgde, terwijl de coalitiefracties steeds meer de taak op zich namen om de regering in bescherming te nemen. Het voorstellen van een enquête kon door de regering worden opgevat als een motie van wantrouwen, dus de coalitiefracties, die veelal een kamermeerderheid vormden, probeerden het gebruik van dit instrument te voorkomen. Dit vormde een sterke politieke hindernis voor het vinden van een kamermeerderheid. ${ }^{61}$

\footnotetext{
${ }^{56}$ De enquête naar de mogelijkheid van een zeemacht werd overigens door de regering 'uitgelokt'. Zie verder Boon 1982, p. 134.

57 Boon 1982, p. 134-135. Het betreft de Enquêtes Nederlandse koopvaardijvloot (1873/74), Besmettelijke ziekte onder het rundvee (1875/76), Nederlandse spoorwegen (1880/81) en Kinderarbeid en toestand fabrieken en werkplaatsen (1886).

58 Boon 1982, p. 135.

59 Boon 1982, p. 135.

${ }^{60}$ Dölle 1985, p. 22-24.

61 Zie Dölle 1985, p. 63. Zie ook Visscher 1978, p. 233 en Engels 1987, p. 27.
} 
De parlementaire enquête raakte zo voor lange tijd in onbruik. Oud concludeerde in 1967 dat "het recht van enquête weinig praktische betekenis meer heeft." 62 De enige uitzondering vormt de zogenaamde oorlogsenquête, waartoe in 1947 werd besloten. Dit onderzoek was bedoeld om de regering in Londen de gelegenheid te geven om achteraf verantwoording af te leggen aan het parlement, dat gedurende de oorlog niet bijeen kon komen, over haar beleid gedurende de bezettingsjaren. ${ }^{63}$ Dat dit in de vorm van een enquête gebeurde, kan worden gezien als een procedurele noodgreep. Afgezien van deze uitzonderlijke enquête, zou het bijna een eeuw duren voordat er weer een enquête zou plaatsvinden.

Naast de hierboven geschetste politieke belemmeringen, kwamen in debatten ook meer substantiële bezwaren tegen het gebruik van het enquêteinstrument naar voren. Tegenstanders beschouwden de enquête - wellicht indachtig de kostbare en langdurige oorlogsenquête - vaak als een paardenmiddel, dat een te zware belasting zou vormen voor de Kamer en voor vertraging zou zorgen. ${ }^{64} \mathrm{Bij}$ de behandeling van het voorstel-Aarden c.s. voor een enquête naar de concentratie van economische macht door fusies in 1969 werd door sommige leden bovendien betwijfeld of de oude Enquêtewet nog wel voldeed op het punt van de bescherming van derden. Zo werd gevreesd dat de openbaarheid van het onderzoek tot ernstige schade aan de belangen van ondernemingen zou leiden. Verder merkten verschillende leden op dat de wet niet uitsloot dat de Kamer na afloop van het onderzoek zou besluiten gegevens openbaar te maken, terwijl de enquêtecommissie aan de verstrekker had toegezegd dat deze vertrouwelijk zouden worden behandelen. ${ }^{65}$

Dat het gedurende lange tijd onmogelijk bleek om een kamermeerderheid te bewegen een parlementaire enquête te houden, betekende overigens niet dat de Kamer in deze periode in het geheel geen behoefte had aan het zelfstandig verrichten van onderzoek. Zo nu en dan bleken parlementaire onderzoeken waarbij geen enquêtebevoegdheden werden verleend, wel voldoende politieke steun te behalen. Zo werd in 1938 een bijzondere commissie ingesteld naar aanleiding van het optreden van de marechaussee in Oss. ${ }^{66}$ Andere voorbeelden zijn het onderzoek in 1958 naar het defensieaankoopbeleid als gevolg van de zogenaamde 'helmenaffaire' 67 en het onderzoek naar aanleiding van het kwestieuze ontslag van een ambtenaar van defensie in $1962 .{ }^{68}$ Geheel ontdaan van enige politieke gevoeligheid waren dergelijke onderzoeken niet, zo kan uit de onderwerpskeuze van de genoemde voorbeelden al wel worden afgeleid. Toch werden deze lichtere vormen van onderzoek, waarbij commissies geen wettelijke dwangmiddelen ter beschikking hadden, kennelijk niet ge-

\footnotetext{
62 Zie Oud 1967, p. 681.

63 Dölle 1985, p. 62.

64 Zie Dölle 1985, p. 63 en Engels 1987, p. 27.

${ }^{65}$ Kamerstukken II 1968/69, 9995, nr. 4, p. 7-8 en Kamerstukken II 1968/69, 9995, nr. 5, p. 8. Het voorstel werd met grote meerderheid afgewezen: alle regeringspartijen stemden tegen. Zie voor mogelijke andere verklaringen voor het in onbruik raken van de enquête ook: Visscher 1978, p. 231-233 en Kappeyne van de Coppello 1986, p. 79-80.

66 Zie voor het rapport: Bijlage Handelingen II 1938-1939, p. 61-82.

${ }^{67}$ Kamerstukken II 1958/59, 5450, nr. 1.

${ }^{68}$ Kamerstukken II 1962/63, 6624, nr. 3.
} 


\section{NEDERLAND}

zien als een te grote bedreiging voor de coalitieverhoudingen. ${ }^{69}$ Wanneer er ten aanzien van een bepaald feit of voorval een sterke behoefte aan nader onderzoek ontstond - hetzij veroorzaakt door de natuurlijke profileringsdrang van kamerleden, zoals Boon suggereert, hetzij door druk van buitenaf, zoals door Dölle wordt vermoed 70 - dan konden 'gewone' parlementaire commissies incidenteel dus een aanvaardbaar alternatief zijn voor een als te riskant, zwaar of onevenwichtig bestempelde enquête.

\subsubsection{Het moderne onderzoeksrecht}

Een kentering in de grote sluimering, zoals de lange periode zonder enquêtes wel wordt genoemd, ${ }^{71}$ doet zich voor in de jaren 60 en 70 van de twintigste eeuw. Tegen de achtergrond van een sterk groeiend overheidsapparaat, de toegenomen complexiteit van de samenleving en onvrede over het gebrek aan invloed van de volksvertegenwoordiging op de vorming van het overheidsbeleid, ontstond binnen het parlement steeds meer behoefte aan versterking van de controlerende functie. Bovendien zorgde de ontzuiling ervoor dat politieke partijen meer oog dienden te houden voor de effecten van overheidsbeleid op kiezers, die steeds minder trouw werden. Het gezag van de overheid, met name van de niet-gekozen organen, was niet langer vanzelfsprekend. 72

Het opkomende parlementaire activisme ${ }^{73}$ in deze periode bracht ook een opleving in de interesse voor het instrument van de parlementaire enquête, zowel in de pers als in de wetenschap en de politiek. Dit leidde in 1977 tot de aanvaarding van een initiatiefwetsvoorstel-De Vries c.s. tot wijziging van de Enquêtewet, die bij deze gelegenheid werd omgedoopt tot de Wet op de Parlementaire Enquête (WPE). ${ }^{74}$ Bedoeling van de initiatiefnemers was om het onderzoeksinstrument eenvoudiger toepasbaar te maken door de eisen voor het indienen van een enquêtevoorstel te versoepelen. Zo werd onder meer het zogenaamde 'nauwkeurigheidsvereiste' geschrapt. ${ }^{75}$ Verder diende de positie van getuigen te worden verbeterd. Zij kregen, met instemming van de commissievoorzitter, het recht zich tijdens een enquêteverhoor te laten bijstaan. Ook werd in de wet een regeling opgenomen omtrent openbaarheid en vertrouwelijkheid, waarover bij het enkele jaren daarvoor afgewezen enquêtevoorstel-Aarden c.s. discussie was ontstaan. Voortaan was het uitgangspunt dat verhoren in het openbaar zouden plaatsvinden, al kon de commissie om gewich-

\footnotetext{
${ }^{69}$ Soms werd een enquêtevoorstel uitdrukkelijk afgewezen, waarna het instellen van een bijzondere commissie of een andere 'lichtere' commissievorm wel op een meerderheid kon rekenen. Dit was bijvoorbeeld in de zaak-Oss het geval. Wat mogelijk ook meespeelde, zo stelt Boon, is dat bij dergelijke 'quasi-enquêtes' - anders dan bij formele enquêtes - destijds niet de gewoonte bestond om alle vergaarde stukken en gespreksverslagen openbaar te maken, waardoor de publicitaire gevolgen beter in de hand te houden waren. Zie Boon 1982, p. 200-201.

70 Boon 1982, p. 200 en Dölle 1985, p. 65.

${ }^{71}$ Dölle 1985, p. 62.

72 Dölle 1985, p. 65-68.

${ }^{73}$ Dölle 1985, p. 28.

${ }^{74}$ Zie over de voorgeschiedenis van deze wetswijziging: Jurgens 1975, p. 103 e.v.

75 Zie ook hierna, par. 3.2.2.
} 
tige redenen, zowel ter bescherming van het onderzoeksbelang als van de belangen van derden, daarvan afwijken. De verslagen van besloten zittingen zouden vervolgens geheim blijven. ${ }^{76} \mathrm{Bij}$ amendement waren bovendien enkele bepalingen aan het voorstel toegevoegd. Van groot belang was het schrappen van de uitzondering op de opkomst- en antwoordplicht voor ministers. Veel discussie werd er niet aan gewijd, maar zoals Dölle betoogt, gaat het hier om een aanmerkelijke verandering in het enquêterecht die laat zien dat het denken over de plaats van het parlement ten opzichte van de regering was veranderd. ${ }^{77}$ Daarnaast werd de inzage- en afgifteplicht van schriftelijke stukken uitgebreid. 78

Enige jaren daarna, tijdens de voorbereiding van de Grondwetsherziening van 1983, stond het onderzoeksrecht opnieuw in de parlementaire belangstelling. In het oorspronkelijke regeringsvoorstel voor een nieuwe Grondwet werd het enquêterecht in nagenoeg ongewijzigde vorm overgenomen. Om de drempel voor het instellen van een parlementaire enquête te verlagen, diende het Kamerlid Faber bij de behandeling van het grondwetsvoorstel daarom een amendement in. Het voorgestelde enquête-artikel zou de Kamer verplichten een parlementaire enquête in te stellen wanneer een minderheid van eenvijfde van de leden dat zou wensen. De regering en de Raad van State waarschuwden dat een dergelijke aanpassing het enquêterecht, zoals in Duitsland, tot een politiek strijdmiddel van de oppositie zou maken. ${ }^{79}$ In het parlement leefde bij velen inderdaad de overtuiging dat het enquêterecht niet alleen een wapen van het parlement tegen de regering zou kunnen zijn, maar vooral ook een middel om de oppositionele minderheid ten opzichte van de regering en de regeringspartijen te versterken. ${ }^{80}$ In eerste lezing werd het voorstel aangenomen in beide Kamers. Vervolgens nam de Tweede Kamer het voorstel ${ }^{81}$ in tweede lezing opnieuw aan. De Eerste Kamer gooide uiteindelijk roet in het eten: het minderheidsrecht werd nipt verworpen met 36 tegen 35 stemmen. 82

Dat het enquêterecht een meerderheidsrecht is, veranderde uiteindelijk dus niet, maar de debatten rondom de grondwetsherziening lieten wel zien dat er inmiddels een brede consensus was ontstaan over de omvang van het enquêterecht. Niet alleen was duidelijk dat de omvang van het enquêterecht werd bepaald door de omvang van de bevoegdheden van de Kamer, maar ook dat de interpretatie daarvan vooral bij de Kamer zelf ligt. ${ }^{83}$ Het inzetten van het parlementaire onderzoeksinstrument kon eind jaren 70 steeds vaker op steun rekenen. Zo werden in de periode in korte tijd meerdere bijzondere commissies voor onderzoek door de Kamer ingesteld. Ook

\footnotetext{
${ }^{76}$ Kamerstukken II 1975/76, 13 837, nrs. 1-3.

77 Dölle 1985, p. 77-79.

78 Bovend'Eert \& Kummeling 2010, p. 380.

${ }^{79}$ Van der Pot/Elzinga \& De Lange 2006, p. 785.

${ }^{80}$ Dölle 1985, p. 84-85.

${ }^{81}$ Zie Kamerstukken II 1981/82, 16 915, nr. 2.

82 Dölle 1985, p. 89.

${ }^{83}$ Dölle 1985, p. 27.
} 


\section{NEDERLAND}

werden enkele tijdelijke subcommissies voor onderzoek gevormd door vaste commissies. ${ }^{84}$

Uiteindelijk brak in 1983 het moment aan dat een enquêtevoorstel op een meerderheid in de Tweede Kamer mocht rekenen. De RSV-enquête, waarbij onderzoek gedaan werd naar de rol die de regering had gespeeld bij de instandhouding en ondergang van het RSV-scheepsbouwconcern en de financiële middelen die daarmee gemoeid waren, was bij uitstek een politieke enquête. Binnen de Kamer was het enthousiasme voor het voorstel aanvankelijk overigens niet groot. De publieke opinie liet echter een sterke voorkeur voor een enquête zien en daarbij kwam dat de meerderheid - gezien de grote steun die bij de grondwetsherziening voor het minderheidsrecht nog werd verleend - nu in zekere zin de daad bij het woord zou moeten voegen. 85

De eerste 'moderne' parlementaire enquête bleek toonaangevend te zijn voor de enquêtes die sindsdien met enige regelmaat hebben plaatsgevonden. Er brak een nieuwe bloeiperiode aan voor parlementair onderzoek, die echter een geheel ander karakter zou hebben dan de eerste bloeiperiode tijdens de negentiende eeuw. De parlementaire enquête in Nederland was vanaf nu voornamelijk een politieke enquête, die werd ingezet als instrument bij de uitoefening van de parlementaire controletaak. Aan pure wetgevingsenquêtes leek weinig behoefte meer, al is de scheidslijn tussen beide vormen van enquêtes niet heel duidelijk te trekken: een politieke enquête kan uiteraard ook aanleiding zijn voor wetsherziening. Een hernieuwd initiatief vanuit de Tweede Kamer om, naar aanleiding van het succes van het RSVonderzoek, van het enquêterecht een minderheidsrecht te maken, deze keer toe te kennen aan een derde van de Kamer, sneuvelde in 1985 wederom in de Eerste Kamer. ${ }^{86}$ Het herboren enquêterecht bleef daarmee een meerderheidsrecht.

\subsubsection{Vernieuwing enquêtewetgeving: Wpe 2008}

Bijna drie decennia na het eerste, moderne parlementaire onderzoek is de functie van het onderzoeksrecht in de parlementaire praktijk nauwelijks nog voorwerp van discussie. Het belang van eigenstandig, diepgravend onderzoek verricht door parlementariërs wordt zowel binnen als buiten het parlement breed onderschreven. De laatste jaren concentreerde de discussie over het onderzoeksrecht zich voornamelijk op de uitvoeringspraktijk, waarbij de positie van getuigen en de samenloop met bijvoorbeeld strafrechtelijke onderzoeken veel aandacht kreeg. Dit bleek ook bij de behandeling van het wetsvoorstel voor een nieuwe enquêtewet, die de oude wet op een aantal punten moest moderniseren. Het wetsvoorstel, ingediend in 2006, was voorbereid door een tijdelijke commissie bestaande uit Tweede Kamerleden. ${ }^{87}$ De Wet op de

\footnotetext{
84 Voorbeelden zijn de bijzondere commissies inzake de Arabische olieboycot (1976) en de affaireAantjes (1978) en de subcommissies steunverlening bedrijven (1978) en godsdienstige sekten (1980). Zie ook Engels 1987, p. 30-31.

${ }^{85}$ Dölle 1985, p. 91-92.

86 Van der Pot/Elzinga \& De Lange 2006, p. 786.

87 Zie nader: Kamerstukken II 2005/06, nr. 6, p. 3-4. Belangrijkste, door de Kamer geformuleerde knelpunten waren: de regeling rondom de openbaarheid en vertrouwelijkheid van stukken, de positie van getuigen en de samenloop met ander onderzoek.
} 
parlementaire enquête 2008 (hierna: Wpe 2008) trad uiteindelijk op 9 mei 2008 in werking. ${ }^{8} 8$

Tijdens de behandeling van het wetsvoorstel ontspon zich, opvallend genoeg, een uitvoerige discussie over de reikwijdte van het enquêterecht. Aanleiding was de stelling van de initiatiefnemers van het wetvoorstel dat de oude wet geen beperkingen oplegde ten aanzien van de onderwerpen waarop een enquête betrekking kan hebben en dat een enquête "derhalve op alles betrekking [kan] hebben wat de Kamer wil onderzoeken." Het is, zo voegden zij er aan toe, dus aan de Kamer om te bepalen of en waarover een enquête zou moeten gaan. ${ }^{89}$

De Raad van State zag wel degelijk grenzen aan het enquêterecht en stelde in haar advies: "Een enquête zal verband moeten houden met de medewetgevende of de controlerende taak van de kamer, maar het ligt voor de hand dat de kamer zich van die beperking ook bewust is. Binnen die grenzen is het alleen aan de kamer om te beslissen over de wijsheid en de wenselijkheid van het instellen van een enquête." 90

In de Eerste Kamer bestonden vooral bij de CDA-fractie sterke bezwaren tegen de zienswijze van de initiatiefnemers. Het lid Dölle (CDA) diende daarom een motie in, waarin de Kamer werd gevraagd te bevestigen dat "steeds de overwegende opvatting in de constitutionele theorie en de constitutionele praktijk is geweest dat deze omvang van het enquêterecht wordt begrensd door de omvang van de parlementaire bevoegdheden" en "dat dit betekende dat enquêtes betrekking dienden te hebben op onderwerpen die voorwerp kunnen zijn van wetgeving in formele zin (wetgevingsenquêtes) en/of onderwerpen ten aanzien waarvan de ministeriele verantwoordelijkheid kan worden geactiveerd (politieke enquêtes)" ${ }^{91}$

$\mathrm{Na}$ een uitvoerig debat pasten de initiatiefnemers hun standpunt uiteindelijk aan door zich achter de opvatting van de Raad van State te scharen. Volgens de initiatiefnemers was de motie-Dölle hiermee overbodig geworden. ${ }^{92}$ Niettemin werd de motie door een Kamermeerderheid, bestaande uit de coalitiepartijen en de SGP, aangenomen. De overige fracties stemden tegen omdat zij de motie overbodig achtten, dan wel omdat zij vreesden dat het enquêterecht hierdoor juist verder beperkt zou worden dan tot dan toe het geval was. ${ }^{93}$

Die vrees is misschien wat overdreven. ${ }^{94}$ Zoals hierboven bleek, overheerst al vanaf het begin van de parlementaire geschiedenis rondom het enquêterecht de opvatting dat de reikwijdte van het enquêterecht wordt bepaald door de omvang van de bevoegdheden van het parlement. Deze bevoegdheden hebben voor het grootste deel betrekking op wetgeving en controle, waarbij het accent in de loop der tijd

\footnotetext{
88 Stb. 2008, 148.

${ }^{89}$ Kamerstukken II 2005-06, 30 415, nr. 3, p. 9. Idem nr. 6, p. 9. Hiermee sloten de initiatiefnemers zich in wezen aan bij de visie van Boon. Zie Boon 1982, p. 135 en hierboven, par. 2.2.4.

${ }^{90}$ Kamerstukken II 2005-06, 30 415, nr. 4, p. 2-3. Ook in de staatsrechtelijke literatuur wordt aansluiting gezocht bij de parlementaire wetgevings- en controletaken. Zie bijvoorbeeld Bovend'Eert \& Kummeling 2010, p. 377 en Van der Pot/Elzinga \& De Lange 2006, p. 783.

${ }^{91}$ Kamerstukken I 2007-2008, 30 415, nr. H.

92 Handelingen I 2008-09, nr. 17, p. 730.

93 Zie de bijdragen in Handelingen I 2008-09, nr. 19, p. 812-816.

${ }_{94}$ Zie bijvoorbeeld de bijdrage van het lid Engels (D66), Handelingen I 2008-09, nr. 19, p. 814.
} 
steeds meer op de laatste is gaan liggen. Het moderne enquêterecht heeft dan ook vooral het karakter van een controlemiddel. In die zin geeft de formulering die de Raad van State koos de constitutionele praktijk het beste weer. ${ }^{95}$ In de motie wordt in plaats van 'controle' gesproken over 'het activeren van ministeriële verantwoordelijkheid'. Of hier nu zoveel licht tussen zit, zoals in het debat in de Eerste Kamer wel werd gesuggereerd, betwijfel ik. Eerder is er sprake van twee zijden van dezelfde medaille: de ministeriële verantwoordelijkheid vormt het aanknopingspunt voor parlementaire controle van het regeringsoptreden. De indiener van de motie bevestigde dit overigens met zoveel woorden aan het einde van het debat. ${ }^{96}$ Van een beperking lijkt mij dan ook geen sprake.

Ook voor de praktijk maakt het waarschijnlijk weinig uit. Het aantal terreinen waarop de moderne overheid ingrijpt is zo groot, dat bijna elk onderwerp wel op de een of andere manier in verband te brengen is met een wetgevende taak of, via de ministeriële verantwoordelijkheid, met de controlerende bevoegdheden van het parlement. Bovendien is het de Kamer zelf die beoordeelt of een onderwerp zich leent voor een enquête. Er zullen zich in de praktijk dan ook weinig gevallen voordoen waarin het parlement niet op enigerlei wijze bevoegd zou zijn op grond van zijn taken c.q. bevoegdheden. ${ }^{97}$ Helemaal onbegrensd is het daarmee echter niet. Er zijn andere, uit het staatsrecht voortvloeiende grenzen die in acht zullen moeten worden genomen. Voor het parlement geldt wat voor elk overheidsorgaan geldt, namelijk dat het rekening zal moeten houden met constitutionele beginselen als de machtenscheiding of de grondrechten. ${ }^{98}$ Overigens zal ook hierdoor in de praktijk niet snel tot volledige onbevoegdheid moeten worden geconcludeerd; het komt feitelijk aan op een zorgvuldige formulering van de onderzoeksopdracht. Wat in elk geval problematisch lijkt, is een voorbeeld dat Dölle noemde, namelijk een enquête met betrekking tot een individueel rechterlijk vonnis. ${ }^{99} \mathrm{Om}$ die reden was het oorspronkelijke standpunt van de initiatiefnemers dus wat te kort door de bocht. 100

\subsubsection{Geen beperkingen bij regulier parlementair onderzoek?}

In het kielzog van de hernieuwde belangstelling voor de enquête heeft de Tweede Kamer ontstond ook steeds meer ruimte voor parlementaire onderzoeken die niet de

\footnotetext{
95 Ook Dölle erkent dit in zijn monografie. Zie Dölle 1985, p. 29.

${ }^{96}$ Handelingen I 2008-09, nr. 19, p. 816. ("Deze opvatting [van de Raad van State] is net als die van de meeste mensen die over dit onderwerp hebben geschreven, dezelfde als in mijn motie is verwoord.") Opvallend is echter, dat Dölle in zijn monografie wel een (klein) onderscheid lijkt te maken tussen de controlerende taak en het activeren van ministeriële verantwoordelijkheid. Zie Dölle 1985, p. 29.

${ }_{97} \mathrm{Bij}$ mijn weten is dit, sinds de ruime opvatting van het onderzoeksrecht is aanvaard, nog nooit aan de orde geweest.

98 Zie ook Kortmann 2008, p. 249-250. Achteraf gezien, zo concludeert Drexhage, was het daarom wellicht verstandig geweest als de wet "zelf de belangrijkste desiderata noemt waarop de kamers acht hebben te slaan bij hun beslissing om al of niet een enquête in te stellen." Zie Drexhage 2009, p. 9.

${ }^{9}$ Handelingen I 2008-09, nr. 17, p. 727. Vgl. ook Kortmann 2008, p. 250, noot 413, waar wordt gesteld dat een enquête "op het terrein van de rechtspraak" geoorloofd is, mits "de functionele rechterlijke onafhankelijkheid niet wordt aangetast."

100 Of, in de woorden van mede-initiatiefnemer Depla, "iets te ruig". Handelingen I 2008-09, nr. 17, p. 731.
} 
status hebben van enquête in de zin van de Wet op de parlementaire enquête. Het betreft onderzoeken die in de praktijk sterk lijken op enquêtes, maar zijn ingesteld op grond van het Reglement van Orde van de Tweede Kamer. Deze commissies beschikken daarom niet over de wettelijke onderzoeksbevoegdheden die voortvloeien uit de enquêtewet. Getuigen kunnen bijvoorbeeld niet worden gedwongen om medewerking te verlenen. Dit reguliere parlementaire onderzoek - soms ook wel quasienquêtes genoemd ${ }^{101}$ - heeft zich sindsdien ontwikkeld tot de meest gebruikte onderzoeksvorm. De parlementaire enquête wordt veelal gezien als een zwaar en ingrijpend middel, dat daarom vooral fungeert ultimum remedium voor gevallen waarin een regulier parlementair onderzoek onvoldoende zou opleveren.

De discussie die in de afgelopen 150 jaar is gevoerd over de reikwijdte van het parlementaire recht van onderzoek, had uitsluitend betrekking op de omvang van het enquêterecht. De vraag is welke grenzen gelden bij het reguliere onderzoek door het parlement. Voor zover hiervoor in de literatuur en in de parlementaire geschiedenis aandacht is, domineert de opvatting dat onderzoek zonder speciale bevoegdheden niet aan constitutionele grenzen gebonden is. Immers, zo is de gedachte, het simpelweg doen van onderzoek komt een ieder - en dus ook het parlement - van nature toe. In het debat over de nieuwe enquêtewet in de Eerste Kamer stelde Dölle bijvoorbeeld dat "het parlement, net als media en wetenschap, de vrijheid heeft een onderzoek in te stellen naar ieder gewenst onderwerp, ook als de materie buiten de beïnvloedingssfeer van het parlement ligt." 102

Mij lijkt deze benadering - vanuit theoretische oogpunt - niet consequent, wanneer tegelijkertijd ten aanzien van de omvang van het enquêterecht het uitgangspunt wordt gehanteerd dat voor het parlement geldt wat ook voor andere staatsorganen geldt, namelijk dat haar beweegruimte inherent beperkingen kent op basis van constitutionele uitgangspunten als de machtenscheiding. Dat bij regulier parlementair onderzoek geen bijzondere (dwang)bevoegdheden aan de orde zijn, doet daar niets aan af. 103 De vraag wat de reikwijdte van het onderzoeksrecht is, is daarmee eveneens relevant wanneer de Kamer besluit tot het doen van een regulier parlementair onderzoek. Een grondslag voor dergelijk onderzoek is te vinden in het enquêterecht van artikel $70 \mathrm{Gw}$. Echter, ook de ministeriële verantwoordelijkheid van artikel 42 $\mathrm{Gw}$, de inlichtingenplicht van artikel $68 \mathrm{Gw}$ en de wetgevende bevoegdheden van

\footnotetext{
101 Zie bijvoorbeeld Kortmann 2008, p. 252.

102 Zie Handelingen I 2008-09, nr. 17, p. 703. Zie ook Dölle 1985, p. 11-13, waar in dit verband het onderscheid tussen het droit d'enquirir (een natuurlijk recht op informatie) en het droit d'enquête wordt gemaakt.

103 Dölle stelt in zijn monografie ten aanzien van het 'natuurlijke recht' om informatie in te winnen de retorische vraag: "Wie zal de Kamer, maar ook een fractie of een individueel Kamerlid in ernst het recht willen ontzeggen om een onderzoek naar een bepaalde aangelegenheid in te stellen." Dölle 1985, p. 13. Ik zie hier vanuit staatsrechtelijk oogpunt echter een wezenlijk verschil tussen de Kamer als instituut en het individuele Kamerlid als persoon: de eerste is immers een overheidsorgaan dat slechts bevoegd is tot handelen indien daartoe een uitdrukkelijke bevoegdheidsgrondslag bestaat. Het instellen van een commissie die, toegerust met een onderzoeksopdracht en gebruik makend van parlementaire faciliteiten zoals een onderzoeksbudget, als zodanig naar buiten treedt, kan als 'handelen' worden gezien.
} 


\section{NEDERLAND}

art. 81 e.v. Gw kunnen als basis dienen. ${ }^{104}$ Hieruit volgt mijns inziens dat een regulier parlementair onderzoek, net als een parlementaire enquête, steeds verband zal moeten houden met de uitoefening van de parlementaire taken, waarvan wetgeving en controle de belangrijkste zijn. En ook hier geldt dat het parlement, hoe ruim deze kaders in de praktijk ook zijn, als staatsorgaan rekening zal moeten houden met constitutionele beginselen als machtenscheiding en grondrechten.

\subsection{Onderzoeksbevoegdheden bij parlementaire enquêtes}

Hierboven is duidelijk geworden wat de omvang van het onderzoeksrecht van het Nederlandse parlement is. In het navolgende worden de bevoegdheden in kaart gebracht, die het parlement op grond van wetgeving en Kamerreglementen ter beschikking staan bij de uitoefening van het onderzoeksrecht. In deze paragraaf wordt ingegaan op de onderzoeksbevoegdheden bij een parlementaire enquête. In paragraaf 2.4 staat het reguliere parlementaire onderzoek centraal. De positie van ministers en ambtenaren bij parlementaire enquêtes en reguliere onderzoeken komt afzonderlijk aan bod in paragraaf 2.5.

\subsubsection{Uitgangspunten}

Een enquêtecommissie, die als zodanig is ingesteld bij besluit van de Tweede Kamer, Eerste Kamer of verenigde vergadering, beschikt vanaf de dag na de bekendmaking van het besluit in de Staatscourant over de bevoegdheden die door de Wpe 2008 worden verleend. ${ }^{105}$ Het verstrijken van de zittingsduur of de ontbinding van de Kamer heeft hierop geen invloed. ${ }^{106}$ De commissie kan haar bevoegdheden uitoefenen tot de dag waarop de Kamer de enquête beëindigt. ${ }^{107}$ Dit gebeurt gewoonlijk nadat de commissie haar eindrapport heeft aangeboden en aan de Kamer verantwoording heeft afgelegd, maar de Kamer kan ook voortijdig een enquête beëindigen. 108 De commissie oefent haar bevoegdheden zelfstandig uit. Dat betekent, dat de Kamer niet bevoegd wordt geacht om direct in te grijpen of om de commissie bindende aanwijzingen te geven. ${ }^{109}$ Wel kan de Kamer tussentijds, al dan niet op voorstel van de commissie, besluiten de omschrijving van het onderwerp van de enquête te wijzigen. 110

\footnotetext{
104 Zie in vergelijkbare zin ook Bovend'Eert \& Kummeling 2010, p. 376, waar wordt gesteld dat het doen van 'gewoon' onderzoek, anders dan het houden van een enquête, ook met behulp van de reguliere bevoegdheden van het parlement mogelijk is. Zie met betrekking tot art. $68 \mathrm{Gw}$ ook hierna, par. 2.5.1.

105 Art. 2, eerste lid, Wpe 2008. Zie over de besluitvormingsprocedure in de Tweede Kamer ook art. 4 RPE. Meer over deze procedure in par. 4.2.

106 Art. 4, derde lid, Wpe 2008. Een Kamerontbinding kan wel invloed hebben op de samenstelling van de commissie. Zie nader art. 36 Wpe 2008. Zie ook Kamerstukken II 2005/06, 30 415, nr. 6, p. 11.

107 Art. 4, eerste lid, Wpe 2008.

108 Zie art. 34 Wpe 2008.

${ }^{109}$ Vgl. Munneke 2006, p. 284-285.

110 Art. 2, derde lid, Wpe 2008.
} 
Grenzen aan de uitoefening van enquêtebevoegdheden. De vraag waarover de Kamer een enquête kan houden, is hiervoor reeds uitvoerig aan de orde geweest. ${ }^{111}$ Een andere vraag is, in hoeverre de enquêtecommissie bij de uitoefening van haar bevoegdheden begrensd wordt. Twee algemene beperkingen kunnen uit de wet worden afgeleid. Allereerst kan de commissie haar bevoegdheden slechts uitoefenen wanneer dit past binnen de omschrijving van het onderwerp van de enquête. Deze omschrijving wordt bij de instelling van de enquête door de Kamer vastgesteld. ${ }^{112}$ Treedt de commissie daarbuiten, zo volgt hieruit, dan zijn derden niet verplicht tot medewerking. Een "zo helder mogelijke" omschrijving van het onderwerp is daarom volgens de initiatiefnemers van de Wpe 2008 van groot belang. ${ }^{113}$ Tegelijkertijd is het zo dat de commissie een ruime beoordelingsruimte heeft als het gaat om de vraag of de uitoefening van bevoegdheden in een concreet geval binnen dit kader valt.114 De rechter kan daarom slechts marginaal toetsen aan de onderzoeksopdracht. "Alleen indien er evident sprake van is dat daarbuiten wordt gehandeld," zo stellen de initiatiefnemers, kan de rechter een verzoek om dwangmiddelen tegen een weigerachtige persoon in te zetten, afwijzen. 115

Daarnaast geldt sinds de wetsherziening van 2008 het algemene uitgangspunt dat de commissie haar wettelijke bevoegdheden slechts kan uitoefenen voor zover dat naar het redelijk oordeel van de commissie voor de vervulling van haar taak noodzakelijk is. ${ }^{116}$ Dit zogenaamde evenredigheidsbeginsel bestond ook al onder de oude wet, zij het alleen ten aanzien van de bevoegdheid om schriftelijke bescheiden op te vragen. In de nieuwe wet is het evenredigheidsbeginsel dus van toepassing verklaard op alle bevoegdheden. Het evenredigheidsbeginsel houdt tevens in, zo voegen de initiatiefnemers toe, "dat de enquêtecommissie van haar bevoegdheden op de voor derden minst belastende wijze gebruik dient te maken en niet naar willekeur handelt." 117 Met de zinsnede "naar het redelijk oordeel van de commissie" heeft de bepaling een subjectief karakter gekregen. Hiervoor is gekozen, zo stellen de initiatiefnemers, omdat het in de praktijk niet altijd goed mogelijk is om nauwkeurig te bepalen wat een redelijke bevoegdheidsuitoefening is. Ook hier heeft de commissie dus een ruime beoordelingsmarge en kan de rechter slechts marginaal toetsen. Volgens de indieners past dit laatste bij "de verhouding tussen volksvertegenwoordiging en rechter." 118

111 Zie par. 2.2.

112 Art. 2, derde lid, Wpe 2008.

113 Kamerstukken I 2006/07, 30 415, nr. F, p. 3.

114 Kamerstukken II 2005/06, 30 415, nr. 6, p. 14.

115 Kamerstukken II 2005/06, 30 415, nr. 6, p. 14. Over de inzet van dwangmiddelen en de rol van de rechter, zie nader: par. 2.3.3.

116 Art. 4, tweede lid, Wpe 2008.

117 Kamerstukken II 2005/06, 30 415, nr. 6, p. 14. Aldus verankert art. 4, tweede lid, de beginselen van proportionaliteit en subsidiariteit. Zie Kamerstukken II 2005/06, 30 415, nr. 10, p. 5.

118 Kamerstukken II 2005/06, 30 415, nr. 6, p. 14-15. In de Eerste Kamer stelde de CDA-fractie zich aanvankelijk op het standpunt dat mocht worden aangenomen dat de commissie ook onder de oude wet bij alle bevoegdheden geacht werd niet onredelijk te handelen. Verschil met de huidige wet, zo stelden zij, was echter dat het evenredigheidsbeginsel bij alle overige bevoegdheden dus niet was gesubjectiveerd. Vanuit het perspectief van de getuige is het evenredigheidsbeginsel in de nieuwe wet ten aanzien van de overige bevoegdheden dus verzwakt. De initiatiefnemers bestreden deze visie. Zie 
Het begrip 'waarheidsvinding'. In de literatuur is voorts nog een derde algemene beperking geformuleerd. Deze zou voortvloeien uit het doel of de functie van het enquête-instrument. Evenals de reikwijdte van het enquêterecht is ook de functie van de enquête niet (grond)wettelijk vastgelegd. Volgens de initiatiefnemers van de Wpe 2008 is de enquête "controle-instrument en een instrument voor waarheidsvinding", maar kan ook dienen als "wegbereider" voor toekomstige wetgeving of om "misstanden aan de kaak stellen". Het gaat vooral om "waarheidsvinding en het trekken van lessen voor de toekomst." Het belang van waarheidsvinding staat daarbij, onafhankelijk van de enquêteopdracht, telkens voorop. "Het gaat dus bij elke enquête om het vinden van de waarheid over feiten en gebeurtenissen." 119 Munneke legt eveneens de nadruk op waarheidsvinding. Hij definieert de enquête als een instrument gericht op "het vaststellen van feiten ten dienste van het parlement." Voor de enquêtecommissie, zo stelt hij, is dit "een normatief gegeven." Veel verder kan de enquêtecommissie volgens Munneke niet gaan:

\footnotetext{
“Die waarheidsvinding is 'voorbereidend' van aard: het is aan de kamer om (eventueel) consequenties te verbinden aan de door de commissie aan het licht gebrachte feiten. De enquêtecommissie dient zich van die rolverdeling bewust te zijn en ervoor te waken niet zelf de rol van de kamer over te nemen. Het is dus niet de commissie die consequenties aan de vastgestelde feiten verbindt." 120
}

Terwijl de initiatiefnemers het doel en de functie van de enquête vooral in beschrijvende zin aanhalen, ziet Munneke hierin dus een normatief kader dat op zichzelf beperkingen met zich meebrengt voor de wijze waarop de enquêtecommissie haar bevoegdheden uitoefent. Munneke stelt in dit verband dat het niet zo kan zijn dat een parlementaire enquête het karakter van een strafrechtelijk onderzoek aanneemt. ${ }^{121}$ Ook de initiatiefnemers zijn op dit punt duidelijk. ${ }^{122}$ De normatieve grondslag voor deze beperking ligt mijn inziens echter veeleer in de machtenscheidingsgedachte dan in een functieomschrijving van het enquêteinstrument.

In andere gevallen is dit normatieve kader nog minder bruikbaar. Zo betoogt Munneke dat een enquêtecommissie niet op de stoel van de Kamer moet gaan zitten door bijvoorbeeld ministers ter verantwoording te roepen, in plaats van louter na te gaan hoe ver hun verantwoordelijkheid reikt. Dit zou niet passen bij het op feitenonderzoek en waarheidsvinding gerichte enquête-instrument. ${ }^{123}$ De vraag is echter,

Kamerstukken I 2006/07, 30 415, nr. C, p. 9 en nr. F, p. 4. Tijdens de mondelinge behandeling stelde Van der Staaij, namens de initiatiefnemers, dat het om een 'gewone' marginale toetsing gaat, vergelijkbaar met de marginale toetsing van de bestuursrechter wanneer een bestuursorgaan beleids- of beoordelingsvrijheid heeft. De reikwijdte van de rechterlijke toetsing moet op een lijn worden gesteld met de toetsing in het kader van art. 3:4 Algemene wet bestuursrecht. De bezwaren van de CDA-fractie werden met deze toelichting, zo leek het althans, weggenomen. Zie verder Handelingen I 2007/08, 17, p. 719-720.

119 Kamerstukken II 2005/06, 30 415, nr. 6, p. 7.

${ }^{120}$ Munneke 2006, p. 280.

121 Munneke 2006, p. 280.

122 Kamerstukken II 2005/06, 30 415, nr. 6, p. 7.

${ }^{123}$ Munneke 2006, p. 286-287. 
waarom een enquêtecommissie niet zou kunnen fungeren als een forum waar ministers verantwoording kunnen afleggen in de zin van art. 42, tweede lid, Gw. Ik zie hier geen bezwaren, althans niet van constitutionele aard, die de leden van een enquêtecommissie zou beletten om bij het verhoor van een minister bijvoorbeeld te vragen om een nadere toelichting of verdediging van bepaalde beleids- of uitvoeringshandelingen. Bovendien leent het eindrapport van een enquêtecommissie zich uitstekend voor het verbinden van consequenties aan de vastgestelde feiten, althans in de zin van het beoordelen van de wijze waarop een minister verantwoording heeft afgelegd. Dit lijkt mij een aanvaardbare vorm van 'werkverdeling' tussen commissie en Kamer, waarmee een bijdrage kan worden geleverd aan de uitvoering van de parlementaire controletaak. Voorwaarde is wel, dat de commissie hiervoor een heldere machtiging heeft verkregen van de Kamer. ${ }^{124}$ De bewegingsruimte voor de enquêtecommissie wordt hier dus vooral bepaald door de enquêteopdracht. In combinatie met het evenredigheidsbeginsel is dat dan ook het beste aanknopingspunt voor het bepalen van de 'bewegingsruimte' van enquêtecommissies. Het gebruik van het begrip 'waarheidsvinding' als een normatieve begrenzing lijkt mij minder geschikt, maar ook in meer descriptieve zin ${ }^{125}$, biedt het weinig toegevoegde waarde. Zoals Drexhage, maar ook Muller, terecht stellen, valt bij het benadrukken van het concept waarheidsvinding nog wel wat kanttekeningen te plaatsen. Drexhage wijst op de toegenomen openbaarheid, de media-aandacht, de grote maatschappelijke druk, de beperkte tijd die beschikbaar is, de ongevraagde informatie van buitenaf, achterdocht en krampachtigheid bij getuigen, het risico van 'groepsdenken' en andere methodologische fouten bij de onervaren parlementaire onderzoekers als factoren die de waarheidsvinding kunnen bemoeilijken. Wellicht belangrijker nog, "een parlementair onderzoek is geen rechtszaak, geen historisch-wetenschappelijk onderzoek en meestal ook geen beleidsonderzoek, maar een stap in een politiek verantwoordingsproces." 126 Wanneer waarheidsvinding vervolgens moet leiden tot het "trekken van lessen voor de toekomst', zoals vaak het geval is bij parlementaire onderzoeken, dan gaat het er vooral om van de gevonden feiten, die onvermijdelijk onvolledig en verwarrend zullen zijn, "een verhaal (...) te maken waarin het gebeurde kan worden toegerekend aan personen en kan gaan 'gelden' als uitkomst van menselijk handelen". De conclusie dat de zaken nu eenmaal zo gelopen zijn, is immers vaak weinig bevredigend. ${ }^{127}$ Parlementaire onderzoeken hebben dan ook vaak een symbolische, rituele of reinigende functie ${ }^{128}$, waarbij het soms eerder gaat om het vinden van een waarheid dan om de waarheid. ${ }^{129}$ In de besluitvorming rondom enquêtes lijkt het

\footnotetext{
124 Zie over de verhouding tussen ministers en enquêtecommissies verder: par. 2.5.1.

125 Ook de initiatiefnemers zien in het begrip waarheidsvinding kennelijk geen zelfstandige beperking voor de uitoefening van bevoegdheden, zo kan uit de memorie van toelichting worden afgeleid. Zie Kamerstukken II 2005/06, 30 415, nr. 6, p. 13.

126 Drexhage 2009, p. 6.

127 Drexhage 2009, p. 6.

128 Zie over de symbolische en rituele functie van parlementair onderzoek nader: Muller \& Coenen 2002, p. 148-149.

${ }^{129}$ Muller 2002, p. 49. Zie ook Drexhage 2009, p. 6. Zie voor een eveneens kritische reactie op het gebruik van het begrip 'waarheidsvinding' in de memorie van toelichting: Kummeling 2007. Vanuit
} 
begrip waarheidsvinding ook vooral een retorische functie te vervullen ('de onderste steen...'), bedoeld om de gewichtigheid van het instrument en de ernst van de situatie te onderstrepen. Gelet op de genoemde kanttekeningen lijkt mij zelfs het louter retorisch gebruik van het begrip af te raden: de hoge verwachtingen die de term 'waarheid' oproept, kunnen immers gemakkelijk tot teleurstellingen leiden en daarmee het publieke vertrouwen in het parlement en in het enquêterecht beschadigen. Het rituele effect van een onderzoek wordt daarmee weer teniet gedaan. ${ }^{130}$

Algemene medewerkingsplicht. Aan de bevoegdheden, die de commissie op grond van de wet zijn toegekend, is een algemene medewerkingsplicht gekoppeld. Deze medewerkingsplicht, neergelegd in art. 14 Wpe 2008, geldt voor elke Nederlander, elke ingezetene van Nederland en verder iedereen die in Nederland verblijf houdt. Voorts zijn ook rechtspersonen die in Nederland gevestigd zijn en rechtspersonen die hun bedrijfsactiviteiten geheel of gedeeltelijk in Nederland uitoefenen, onderworpen aan de medewerkingsplicht. ${ }^{131}$ Uit de bepaling volgt, dat de verplichting niet geldt voor buitenlanders die zich niet in Nederland bevinden. De initiatiefnemers stelden dat een dergelijke verplichting voor hen moeilijk afdwingbaar zou zijn. ${ }^{132}$

De algemene verplichting van art. 14 houdt in dat genoemde (rechts)personen de commissie binnen de door haar gestelde termijn alle medewerking dienen te verlenen die deze vordert bij de uitoefening van haar wettelijke bevoegdheden. Deze hebben, kortweg, betrekking op het vorderen van schriftelijke inlichtingen, inzage in documenten, het verhoren van getuigen en deskundigen en het betreden van plaatsen. ${ }^{133} \mathrm{Bij}$ niet-medewerking kan de commissie de rechter verzoeken om dwangmiddelen in te zetten. Bovendien is niet-medewerking strafbaar. ${ }^{134}$ De medewerkingsplicht geldt zelfs indien betrokkene een geheimhoudingsplicht heeft, zo blijkt uit art. 15.

De medewerkingsplicht geldt niet, wanneer de commissie een van de algemene beperkingen die hierboven zijn besproken overschrijdt. Daarnaast kent de wet een

meer filosofisch perspectief kan overigens ernstig worden betwijfeld of 'de waarheid' überhaupt te vinden is.

130 Zie ook Muller 2002, p. 44.

131 Deze algemene medewerkingsplicht vormt een uitbreiding van het oude art. 3 WPE, waarin in vergelijkbare termen een opkomstplicht voor verhoor was geformuleerd. De opkomstplicht voor Nederlanders in het buitenland stamt uit 1948, toen de eerste enquête die geen strikt binnenlands karakter had werd gehouden (de oorlogsenquête). Zie ook Boon 1982, p. 122 en Dölle 1985, p. 50. In tegenstelling tot de opkomstplicht in de oude wet geldt de algemene medewerkingsplicht nu ook voor buitenlandse rechtspersonen die in Nederland werkzaam zijn. Kamerstukken II 2005/06, 30 415, nr. 6, p. 27.

132 Kamerstukken II 2005/06, 30 415, nr. 6, p. 28. De Enquêtecommissie-De Wit, die naar aanleiding van de (mondiale) crisis onderzoek deed naar het financiële stelsel, had in totaal 21 buitenlanders opgeroepen die zich niet in Nederland bevonden. De meesten gaven, ondanks aandringen van de commissie, geen gehoor aan deze oproep. De commissie raadde de Kamer daarom aan om te zoeken naar mogelijkheden om de bereidheid van buitenlanders om medewerking te verlenen in de toekomst te verbeteren, bijvoorbeeld door bilaterale afspraken te maken met buurlanden. Ook ten aanzien van de "politieke spelers op het niveau van de Europese Unie" bestaat behoefte aan inlichtingen, gelet op het toegenomen belang van Europese regelgeving. Kamerstukken II 2011/12, 31 980, nr. 61, p. 569, 576-577.

133 Zie verder hierna, par. 2.3.2.

134 Zie verder hierna, par. 2.3.3. 
aantal specifieke verschoningsrechten voor personen van wie medewerking wordt gevorderd, vastgelegd in de artikelen 19 tot en met 24 . Hierover later meer. ${ }^{135}$

\subsubsection{Informatierechten}

\subsubsection{Schriftelijke inlichtingen vorderen}

Art. 6 Wpe 2008 verschaft de enquêtecommissie de bevoegdheid om inzage in, afschrift van of kennisneming op andere wijze van documenten te vorderen. De commissie kan daarbij zelf aangeven op welke wijze de kennisneming dient te worden verleend, zo is bepaald in het tweede lid.

De bevoegdheid tot het opvragen van schriftelijke stukken was oorspronkelijk van beperkte omvang. In de Enquêtewet van 1850 bevatte art. 3 een algemene plicht om gevolg te geven aan "vorderingen" van de enquêtecommissie; in art. 20 en 21 werd vervolgens een verplichting opgenomen tot het verlenen van inzage in schriftelijke stukken die van belang zouden kunnen zijn voor het onderzoek, maar deze bepaling was slechts gericht tot ministers en ambtenaren. Een algemene plicht tot het verlenen van toegang tot schriftelijke stukken indien de enquêtecommissie daarom vraagt, is het resultaat van de wetswijziging van 1977. Bij de behandeling van het initiatiefvoorstel-De Vries c.s. drongen leden van de PvdA en de PPR aan op een bepaling die deze verplichting zou verruimen. De initiatiefnemers waren het daarmee eens ${ }^{136}$ en voegden het art. 14a in, houdende dat de commissie "te allen tijde" inzage kan vorderen en afschrift kan nemen "van alle bescheiden, waarover getuigen of deskundigen beschikken waarvan naar haar redelijk oordeel inzage of afschrift voor de vervulling van haar taak nodig is." Deze nieuwe bevoegdheid voor de enquêtecommissie kwam vervolgens zonder discussie in de herziene wet terecht. ${ }^{137}$

Bij de wijziging van de WPE naar aanleiding van het initiatiefvoorstel-De Kwaadsteniet c.s., dat in 1991 kracht van wet kreeg, werd de bevoegdheid tot het vorderen van toegang tot schriftelijke stukken verder verruimd. ${ }^{138}$ Art. 14a stelde de commissie in staat om alleen documenten op te vragen bij personen die zouden worden opgeroepen voor een (openbaar) verhoor. De RSV-enquêtecommissie, die in haar rapport veel aandacht besteedde aan de enquêteprocedure en werkwijze, gaf op het punt van informatieverzameling aan dat deze bepaling een belemmerende werking had. De commissie wilde namelijk voorafgaand aan de openbare verhoren een nietopenbaar dossieronderzoek doen. Sommige getuigen bleken huiverig om aan de vordering van de gevraagde gegevens voor dit vooronderzoek gehoor te geven, omdat ze vreesden daarmee hun recht te verspelen om zich later met een beroep op een verschoningsgrond te kunnen verzetten tegen openbaarmaking van die gegevens. ${ }^{139}$ Bij de wetswijziging van 1991 werd art. 14a wegens deze verwarring geschrapt. Art. 3 , eerste lid, werd vervolgens opnieuw geformuleerd, waardoor alle personen op wie

\footnotetext{
135 Zie par. 2.3.4.

136 Kamerstukken II 1976/77, 13 837, nr. 6, p. 6.

137 Dölle 1985, p. 82.

138 Wet van 1 juli 1991 tot wijziging van de Wet op de Parlementaire Enquête en in verband daarmee opnemen van een bepaling in het Wetboek van Strafrecht, Stb. 1991, 415.

139 Kamerstukken II 1986/87, 19 816, nr. 3, p. 2-3.
} 


\section{NEDERLAND}

reeds de verplichting rustte om te verschijnen voor een enquêtecommissie, tevens te allen tijde verplicht zou worden om de commissie inzage te geven, afschrift te laten nemen of het anderszins laten kennisnemen van "alle bescheiden waarover zij beschikken en waarvan naar het redelijk oordeel van de commissie inzage, afschrift of kennisneming anderszins voor de vervulling van haar taak nodig is." 140 De koppeling met het verhoor werd dus losgelaten. ${ }^{141}$

In de Wpe 2008 is de omvang van deze bevoegdheid niet veranderd. ${ }^{142} \mathrm{Wel}$ is het begrip 'bescheiden' in art. 6 vervangen door de techniekonafhankelijke term 'documenten'. De toevoeging in het tweede lid dat de commissie bevoegd is om te bepalen op welke wijze kennisneming zal worden verleend, kan worden gezien als een verduidelijking van een bevoegdheid die voorheen impliciet uit de wet kon worden afgeleid.

Een belangrijke vernieuwing is de bevoegdheid, neergelegd in art. 5 Wpe 2008, om schriftelijke inlichtingen te vorderen. Voorheen konden enquêtecommissies slechts bestaande schriftelijke bescheiden opvragen. Wanneer de commissie behoefte had aan een toelichting of een verklaring van de verstrekker van de stukken, dan kon dat alleen middels een mondeling verhoor worden afgedwongen. Nu kan dit ook op schriftelijke wijze. Te denken valt aan "een document waarin feiten of documenten in onderling verband worden gebracht." 143 Op deze manier kan informatie op een toegankelijkere en meer gestructureerde wijze worden aangeboden, zo verwachten de initiatiefnemers, wat de voortgang van het onderzoek ten goede kan komen. Bovendien, voegen zij daaraan toe, kunnen informatieverstrekkers zich op deze manier, anders dan bij een verhoor, niet gemakkelijk aan hun verplichting onttrekken door te stellen dat zij de informatie niet paraat hebben. ${ }^{144}$

\subsubsection{Mondelinge inlichtingen vorderen}

Het openbare verhoor is een van de meest zichtbare onderdelen van een parlementaire enquête. De initiatiefnemers van de nieuwe Wpe noemden het zelfs het 'hart' van de enquête. ${ }^{145}$ De bevoegdheden inzake het verhoor zijn geregeld in de artt. 9 tot en met $13 \mathrm{~W}$ pe 2008. De commissie kan personen als getuige of deskundige horen, zo bepaalt art. 9. Daarbij geldt een quorum van drie commissieleden, zo bepaalt het tweede lid. ${ }^{146}$ In art. 10 is bepaald dat getuigen of deskundigen worden opgeroepen middels een aangetekende brief van de commissievoorzitter. De oproeping kan eventueel ook per deurwaardersexploot plaatsvinden. ${ }^{147}$ In de oproep dient, naast het

\footnotetext{
140 Stb. 1991, 415, p. 1-3.

141 Zie ook Lubberdink 2003, p. 16-18.

142 De medewerkingsplicht (art. 14) en het evenredigheidsbeginsel (art. 4, tweede lid), die in de nieuwe wet voor alle bevoegdheden van de commissie gelden, waren in de oude wet opgenomen in de inzagebepaling (art. 3 oud) en brengen op dit punt dus geen verandering. Zie ook Kamerstukken II 2005/06, 30415 , nr. 6, p. 19.

143 Kamerstukken II 2005/06, 30 415, nr. 6, p. 16.

144 Kamerstukken II 2005/06, 30 415, nr. 6, p. 16-17.

145 Kamerstukken II 2005/06, 30 415, nr. 6, p. 20.

146 Zie over de wijze waarop getuigen en deskundigen worden gehoord ook hierna, par. 4.6.

147 Art. 10, eerste lid, Wpe 2008. Onder de oude WPE vonden formele oproepen via dagvaarding plaats.
} 
tijdstip en de plaats van het verhoor, melding te worden gemaakt van de feiten waaromtrent informatie wordt verlangd en van de gevolgen, verbonden aan het niet verschijnen op het verhoor. ${ }^{148}$ Tussen de ontvangst van de oproep en het verhoor zit in beginsel minimaal acht dagen, al kan de commissie besluiten in het belang van de enquête of met instemming van de betrokkene het verhoor eerder te doen plaatsvinden. ${ }^{149}$ Er bestaat geen 'recht' om verhoord te worden. ${ }^{150}$

In de praktijk wordt meestal vrijwillig gehoor gegeven aan een oproep, maar het gebruik van een formele vordering blijkt zo nu en dan noodzakelijk te zijn. Zo heeft de Enquêtecommissie Bouwnijverheid vijf van de vijfenzestig getuigen die verhoord zijn op deze manier moeten dwingen om te verschijnen. ${ }^{151}$

De medewerkingsplicht van art. 14 brengt ten aanzien van de bevoegdheid om personen te verhoren met zich mee, dat op getuigen en deskundigen zowel een plicht tot verschijnen als een plicht tot antwoorden rust. Dat was ook onder de oude wet al zo. ${ }^{152}$ De uitbreiding van het evenredigheidsbeginsel ${ }^{153}$ in de nieuwe wet brengt op dit punt met zich mee, dat de commissie thans alleen bevoegd is getuigen op te roepen en te ondervragen voor zover dit naar haar redelijk oordeel noodzakelijk is voor de vervulling van haar taak. ${ }^{154}$ De commissie kan, zo is in artikel 8 vastgelegd, een besloten voorgesprek houden met personen die zij mogelijk als getuige of deskundige zal horen. Het verlenen van medewerking aan een voorgesprek is niet verplicht. ${ }^{155}$

Enquêteverhoren vinden in beginsel plaats in de openbaarheid, zo blijkt uit art. 11, eerste lid. Deze openbaarheid kan, indien de commissie dat wenselijk acht, op twee manieren worden beperkt. Ten eerste kan, al dan niet op verzoek van de getuige of deskundige, worden besloten dat om gewichtige redenen geen beeld- of geluidsregistraties door derden kunnen worden gemaakt van de openbare zitting. Dit betekent dat radio- en televisieopnamen kunnen worden geweerd, als de commissie daartoe aanleiding ziet. De schrijvende pers blijft in dit geval echter welkom en het verslag, dat van het verhoor wordt gemaakt, wordt openbaar. ${ }^{156}$ De tweede optie, neergelegd in art. 12, is om een verhoor, al dan niet op verzoek, om gewichtige redenen geheel of gedeeltelijk in een besloten zitting af te nemen. Van een dergelijk besloten verhoor wordt een vertrouwelijk verslag opgemaakt en de commissieleden dienen geheimhouding te bewaren omtrent hetgeen hen tijdens de besloten zitting ter ore is gekomen. ${ }^{157}$

\footnotetext{
148 Art. 10, derde lid, Wpe 2008.

149 Art. 10, tweede en vierde lid, Wpe 2008.

150 Kamerstukken II 2005/06, 30 415, nr. 6, p. 20. Bij de wetswijziging in 1991 werd benadrukt dat een te verhoren getuige ook niet het recht heeft om ongevraagd informatie te verstrekken of verklaringen af te leggen. Kamerstukken II 1988/89, 19 816, nr. 10, p. 13.

151 Kamerstukken II 2002/03, 28 244, nrs. 5-6, p. 38.

152 Boon 1982, p. 122. Zie ook Dölle 1985, p. 35-37.

153 Art. 4, tweede lid, Wpe 2008. Zie ook hierboven, par. 2.3.1.

154 Dölle ging er reeds onder de oude wet al vanuit, dat getuigen geen antwoordplicht hadden wanneer de vragen geen verband hielden met de enquêteopdracht. Zie Dölle 1985, p. 37.

155 Zie hierover ook hierna, par. 4.4.

156 Art. 11, tweede en derde lid, Wpe 2008.

157 Art. 12, tweede en derde lid, Wpe 2008. De openbaarheid en vertrouwelijkheid van onderzoeksstukken komt nog uitvoeriger aan de orde in par. 4.7.2.
} 
De oude wet regelde niets over radio- en televisieopnamen, maar enquêtecommissies hadden de gewoonte om in het belang van openheid (en om geen onderscheid te maken met de schrijvende pers) dergelijke opnamen in beginsel toe te staan. ${ }^{158}$ Dit aspect van de moderne enquêtepraktijk heeft in de literatuur tot kritiek geleid. Met name het rechtstreeks op televisie uitzenden van verhoren, zo luidde de kritiek, kan bijzonder ingrijpend zijn, vooral voor getuigen die niet gewend zijn aan media-aandacht. 159 De Raad van State onderkende in zijn advies over het wetsvoorstel-Wpe het belang van openbaarheid bij enquêtes, die anders dan een strafproces bij uitstek een "publieke zaak" vormen, maar vond tevens dat te weinig tegemoet werd gekomen aan de risico's die radio- en televisieopnamen voor getuigen met zich meebrengen, met name op het vlak van reputatieschade. De Raad adviseerde daarom het begrip 'gewichtige redenen' nader uit te werken. Verder wees de Raad erop, dat getuigen die bezwaren hebben tegen beeld- en geluidsregistratie volgens het wetsvoorstel weliswaar geen beroep bij de bestuursrechter toekomt, maar dat de burgerlijke rechter als restrechter wel degelijk kan oordelen over klachten van getuigen over inbreuken op hun persoonlijke levenssfeer. ${ }^{160}$ De initiatiefnemers erkenden dit laatste, maar zagen verder geen aanleiding om het wetsvoorstel op dit punt te wijzigen. ${ }^{161}$

De commissievoorzitter is bevoegd om een getuige voorafgaand aan een verhoor de eed of belofte te doen afleggen. Deze bevoegdheid bestaat al sinds 1850, maar het gebruik ervan is sinds de heropleving van de enquête gebruikelijk geworden. ${ }^{162}$ Gezien deze praktijk, maar ook met het oog op de waarheidsvinding die bij de initiatiefnemers van de nieuwe wet voorop staat, is er in de Wpe 2008 voor gekozen om in art. 13, eerste lid, als uitgangspunt te nemen dat een getuigenverhoor onder ede wordt afgenomen, tenzij de commissie uitdrukkelijk anders besluit. ${ }^{163}$ Bij deskundigen wordt, anders dan onder de oude wet, ook de eed of belofte afgenomen. Hiervan kan niet worden afgezien, omdat, zo redeneerden de initiatiefnemers, van hen te allen tijde mag worden verwacht dat zij hun taak onpartijdig en naar beste weten zullen verrichten. ${ }^{164}$

\footnotetext{
158 Wanneer getuigen daartegen bezwaren uitten, kon worden besloten om radio- of televisieopnamen niet toe te staan. In 1990 werd een motie aanvaard, waarin werd erkend dat de commissie de bevoegdheid heeft om af te wegen of er al dan niet voldoende gewichtige redenen zijn om aan het verzoek van een getuige te voldoen. Zie Kamerstukken II 1989/90, 19 816, nr. 24. Tot een wetswijziging leidde dit toen niet. Zie verder Kamerstukken II 2005/06, 30 415, nr. 6, p. 21.

159 Zie Boon 1982, p. 217-218, die verwijst naar de Amerikaanse en Duitse praktijk. Zie ook Dölle 1985, p. 110-112 en Jurgens 2004, p. 223. Zie verder Drexhage 2009, p. 11.

160 Kamerstukken II 2005/06, 30 415, nr. 4, p. 7. Zie over rechtsbescherming bij parlementaire enquêtes ook hierna, par. 2.3.4.1.

161 Kamerstukken II 2005/06, 30 415, nr. 6, p. 22.

162 De RSV-commissie lijkt hierbij de toon te hebben gezet. Door alle verhoren onder ede af te nemen, zo redeneerde deze enquêtecommissie, kan voorkomen worden dat de indruk ontstaat dat sommige getuigen minder betrouwbaar zijn dan anderen. Kamerstukken II 1984/85, 17 817, nr. 17, p. 17.

${ }^{163}$ Een reden om niet de eed of belofte af te nemen zou kunnen zijn, dat de getuige een gebrekkige geestesgesteldheid heeft en daardoor de betekenis ervan onvoldoende zou begrijpen. Kamerstukken II 2005/06, 30415 , nr. 6, p. 23.

164 Art. 13, tweede lid, Wpe 2008. Zie ook Kamerstukken II 2005/06, 30 415, nr. 6, p. $23,77$.
} 
De opkomst- en antwoordplichten gelden niet voor de andere gesprekken die een enquêtecommissie met getuigen of deskundigen voert. Sinds de RSV-enquête bestaat de praktijk dat commissies voorgesprekken houden met potentiële getuigen ter voorbereiding op een mogelijk openbare verhoor. ${ }^{165}$ Hoewel het gaat om een bevoegdheid die geen verplichtingen voor de betrokken gesprekspartners met zich meebrengt, hebben de initiatiefnemers op dit punt gemeend hierover een bepaling in de wet op te moeten nemen om de levende onduidelijkheid over de status van het voorgesprek en de positie van de getuige weg te nemen. ${ }^{166}$ In art. 8 Wpe 2008 is aldus geregeld dat de commissie een besloten voorgesprek kan houden met personen die zij mogelijk als getuige of deskundige zal horen. Het verlenen van medewerking hieraan is niet verplicht. ${ }^{167}$ Bovendien bewaren de commissieleden geheimhouding omtrent hetgeen hen ter kennis is gekomen en blijft het gespreksverslag vertrouwelijk. ${ }^{168}$ De commissie mag de getuige in een later openbaar verhoor dus niet confronteren met hetgeen gezegd is in een voorgesprek. ${ }^{169}$ Wel mag de commissie, zo stellen de initiatiefnemers, de verkregen informatie gebruiken als achtergrond voor haar conclusies, zolang dit gebeurt in een vorm die niet tot een persoon te herleiden is. ${ }^{170}$ Hoe ver de commissie daarin kan gaan, is uiteindelijk ter beoordeling van de commissie zelf: het commissierapport valt onder de parlementaire immuniteit van art. 71 $\mathrm{Gw}$, waardoor een eventueel beroep van een benadeelde bij de (civiele) rechter geen kans van slagen heeft. ${ }^{171}$

\subsubsection{Overige bevoegdheden}

Met de vernieuwing van de enquêtewet in 2008 kreeg de enquêtecommissie de bevoegdheid om elke plaats in Nederland te betreden zonder toestemming van de rechthebbende. Deze is neergelegd in art. 7 Wpe 2008. Voor het betreden van woningen zonder toestemming van de rechthebbende moet de commissie wel eerst een machtiging van de rechter verkrijgen. ${ }^{172}$ In de toelichting op deze nieuwe bevoegdheid wordt echter benadrukt dat het slechts gaat om het recht om plaatsen te betreden (waaronder overigens ook ministeries moeten worden verstaan), niet de bevoegdheid om vervolgens huiszoeking te doen en documenten in te zien. ${ }^{173}$ De

\footnotetext{
165 Sinds 1977 bepaalde de wet namelijk dat verhoren in beginsel in het openbaar dienden plaats te vinden. Hierdoor gingen enquêtecommissies een scheiding aanbrengen tussen het vooronderzoek, waarin schriftelijke stukken werden onderzocht en vertrouwelijke voorgesprekken werden gevoerd, en een openbare fase, waarin de verhoren plaatsvonden. Zie Drexhage 2009, p. 10.

166 Kamerstukken II 2005/06, 30 415, nr. 6, p. 23-24.

167 Art. 8, tweede lid, Wpe 2008. Het informeren van de betrokkene hierover is, anders dan bij het verhoor, niet wettelijk geregeld. Het wordt aan de Kamer overgelaten om op dit punt, maar ook ten aanzien van alle andere bevoegdheden van de enquêtecommissie, helder informatiemateriaal te vervaardigen met betrekking tot de positie van personen die met een enquêtecommissie in aanraking komen. Zie Kamerstukken II 2005/06, 30 415, nr. 6, p. 26 en nr. 10, p. 9.

168 Art. 8, derde en vierde lid, Wpe 2008. Meer hierover in par. 4.7.2.

169 Zie het advies van de Raad van State, Kamerstukken II 2005/06, 30 415, nr. 4, p. 15.

170 Kamerstukken II 2005/06, 30 415, nr. 6, p. 26.

171 Zie ook Kamerstukken II 2005/06, 30 415, nr. 6, p. 36-37. Zie over de betekenis van de immuniteitsregeling van art. $71 \mathrm{Gw}$ in het kader van parlementaire onderzoeken verder: par. 2.5.1.3 en 3.3.1.3.

172 Art. 7, tweede lid, Wpe 2008.

173 Kamerstukken II 2005/06, 30 415, nr. 3, p. 17.
} 


\section{NEDERLAND}

Raad van State reageert kritisch op deze vernieuwing: het betreden van woningen raakt aan het grondwettelijke huisrecht (art. $12 \mathrm{Gw}$ ) en daarmee moet niet lichtvaardig worden omgesprongen; het betreden van woningen en andere plaatsen acht de Raad in het algemeen niet nodig. Geadviseerd werd deze bevoegdheid te schrappen uit het wetsvoorstel. 174

In hun reactie wordt dit advies door de indieners niet opgevolgd, al wordt in verband met de beperkingssystematiek van het eveneens op het betreden in woningen betrekking hebbende art. 8 EVRM in de toelichting op het voorstel wel meer aandacht besteed aan de beweegredenen en noodzakelijkheid van deze beperking op het huisrecht. ${ }^{175}$ Ook in de Eerste Kamer was kritiek, wat leidde tot een motie waarin werd opgeroepen de binnentredingsregeling in de Wpe of anderszins nader te regelen. ${ }^{176}$

\subsubsection{Dwangmiddelen en sancties}

Bij de uitoefening van hun onderzoeksbevoegdheden beschikken enquêtecommissies over verschillende wettelijke dwangmiddelen en sancties. De eerste enquêtewet, die in 1850 in werking trad, voorzag hier reeds in. De toenmalige regering liet zich op dit punt inspireren door de Britse enquêtecommissies, die als zeer machtig werden beschouwd. ${ }^{177}$ Aangezien het Nederlandse parlement, anders dan het Britse, geen eigen rechtsmacht bezit, moesten hiertoe wettelijke voorzieningen worden getroffen. De wet van 1850 kende twee dwangmiddelen in het geval van getuigen die onvoldoende medewerking verleenden, te weten het bevel tot medebrenging ${ }^{178}$ en de gijzeling ${ }^{179}$. Tevens was het mogelijk personen die weigerden medewerking te verlenen strafrechtelijk te vervolgen. ${ }^{180}$ Typerend voor de Nederlandse enquêtewet - in vergelijking met de Britse situatie - is dat het parlement niet zelf kon beslissen over de toepassing van dwangmiddelen en sancties: dit werd opgedragen aan de rechter. ${ }^{181}$

De wettelijke dwangmiddelen en sancties zijn in de loop der tijd slechts incidenteel toegepast. Dit wil niet zeggen dat de waarde ervan beperkt is. Verwacht mag worden dat van het bestaan van dwang- en sanctiemogelijkheden enige preventieve werking uitgaat. Ook de indieners van het recente initiatiefwetsvoorstel benadrukken dit preventieve effect. ${ }^{182}$ In de nieuwe Wpe zijn de bestaande dwangmiddelen en sancties in gemoderniseerde vorm gehandhaafd.

Waar de dwangmiddelen vooral bedoeld zijn om weigerachtige (rechts)personen aan te sporen om alsnog medewerking te verlenen, hebben de wet-

\footnotetext{
174 Kamerstukken II 2005/06, 30 415, nr. 4, p. 8.

175 Kamerstukken II 2005/06, 30 415, nr. 4, p. 8-9.

176 Kamerstukken I 2007/08, 30 415, J.

177 Een Britse enquêtecommissie kon, zo vermeldde de regering, "een ieder voor zich roepen; geen rang of stand bevrijdt den Engelschman van te verschijnen en te getuigen; hij kan door inhechtenisneming en gevangenis daartoe gedwongen worden." Handelingen II 1849/50, p. 233.

178 Art. 13 WPE (oud).

${ }^{179}$ Art. 17 WPE (oud).

180 Art. 10 WPE (oud).

181 Zie ook Kamerstukken II 2005/06, nr. 6, p. 47-48.

182 Kamerstukken II 2005/06, nr. 3, p. 44.
} 
telijke sancties die kunnen worden opgelegd vooral een bestraffend karakter. ${ }^{183}$ Enquêtecommissies kunnen naar eigen inzicht bepalen welke instrumenten zij op welk moment willen aanwenden. ${ }^{184}$

\subsubsection{Dwangmiddelen}

De dwangmiddelen zijn neergelegd in hoofdstuk 5 van de wet. Ingevolge art. 25 kan de voorzieningenrechter bij de rechtbank te Den Haag op verzoek van de commissie "een persoon die weigert haar medewerking te verlenen bij de uitoefening van de haar bij deze wet verleende bevoegdheden bevelen deze medewerking alsnog te verlenen." Het toepassen van dwangmiddelen is dus opgedragen aan de burgerlijke rechter. ${ }^{185}$ Deze zal moet oordelen of de uitoefening van bevoegdheden door de commissie in het concrete geval gerechtvaardigd is. Uitgangspunt is dat de rechter het verzoek van de commissie toewijst, tenzij het verzoek onwettig is, een verschoningsgrond van toepassing is, of sprake is van strijd met het evenredigheidsbeginsel. ${ }^{186}$ Daarbij gaat de wet uit van een omgekeerde bewijslast: de verweerder zal moeten aantonen dat het verzoek van de enquêtecommissie ongerechtvaardigd is. ${ }^{187}$

Indien de rechter besluit een bevel tot medewerking uit te vaardigen, biedt de wet twee middelen om de tenuitvoerlegging daarvan te ondersteunen. Zoals ook onder de oude wet, bestaat de mogelijkheid om de ondersteuning van de "openbare macht" in te roepen. Het inzetten van de sterke arm is echter niet langer beperkt tot personen die weigeren te verschijnen voor verhoor, maar ook bij niet-medewerking aan het verlenen van inzage in documenten of het verschaffen van toegang tot plaatsen. ${ }^{188}$

Nieuw is daarnaast dat aan het bevel tot medewerking ook een dwangsom kan worden verbonden. ${ }^{189}$ Het opnemen van een dwangsomregeling werd al langere tijd in de literatuur bepleit. ${ }^{190}$ De initiatiefnemers van de wet onderschreven de opvatting

\footnotetext{
183 Kamerstukken II 2005/06, nr. 6, p. 46.

184 Van een rangorde is dus geen sprake, al ligt het volgens de initiatiefnemers "voor de hand, dat doorgaans eerst de dwangmiddelen worden ingezet en dan pas de mogelijkheden van strafrechtelijke vervolging worden bezien." Kamerstukken II 2005/06, nr. 6, p. 47.

185 Zie Kamerstukken II 2005/06, nr. 6, p. 48. Met enkele uitzonderingen zijn op de toetsing van dwangmiddelen het reguliere burgerlijke procesrecht en de daarbij horende beroepsmogelijkheden van toepassing. Zo is de enquêtecommissie niet verplicht om gebruik te maken van een procureur en is het rechterlijke bevel uitvoerbaar bij voorbaat. Verder dient de rechter uiterlijk binnen zeven dagen te beslissen, tenzij de commissie om een onverwijlde uitspraak heeft gevraagd. Zie nader: Kamerstukken II 2005/06, nr. 6, p. 81.

186 Zie art. 25, vijfde lid, Wpe 2008. De rechter kan uiteraard ook steeds toetsen aan hogere normen, zoals de grondwettelijke en verdragsrechtelijke grondrechten. Zie ook par. 2.3.4.

187 Aldus de indieners in Kamerstukken II 2005/06, nr. 6, p. 81. De Raad van State adviseerde in haar advies deze omkering ten aanzien van de wetmatigheidstoetsing ongedaan te maken. De indieners wezen dit af met een beroep op het bijzondere karakter van de parlementaire enquête. Zie Kamerstukken II 2005/06, nr. 4, p. 13-14.

188 Zie art. 27 Wpe 2008. Het bevel tot medebrenging in art. 13 WPE (oud) had slechts betrekking op getuigen die weigerden te verschijnen voor verhoor. Zie verder Kamerstukken II 2005/06, nr. 6, p. 49. 189 Zie art. 26 Wpe 2008.

190 Zo pleitte Boon in 1982 al voor verbetering van het instrumentarium door invoering van de dwangsom, die desnoods de gijzeling zou kunnen vervangen. De dwangsom had in het burgerlijk procesrecht reeds bewezen veel effectiever te zijn dan de gijzeling, zo stelde hij. Zie Boon 1982, p. 207.
} 
dat de dwangsom een nuttige, meer eigentijdse aanvulling op de bestaande dwangmiddelen kan zijn. Bovendien, zo voegden zij toe, zal de toepassing van dit dwangmiddel in tegenstelling tot de bestaande mogelijkheden minder ingrijpen in de persoonlijke levenssfeer van de betrokkene. ${ }^{191}$

Hoewel de oude wet de mogelijkheid van het opleggen van een dwangsom niet kende, bleek deze in de praktijk overigens al wel te zijn ontstaan. In 2002 vorderde de Enquêtecommissie Bouwnijverheid op grond van art. 3, eerste lid, WPE (oud) inzage in documenten die in bezit waren van het accountantskantoor Deloitte \& Touche. Dit weigerde de gevraagde stukken te leveren, omdat daarmee een vertrouwelijkheidsafspraak zou worden geschonden. De commissie, die deze mening niet deelde, besloot vervolgens niet de strafrechtelijke weg in te slaan, waarbij de commissie proces-verbaal zou opmaken van de weigering en deze zou overdragen aan de officier van justitie die dan zou moeten beslissen of tot vervolging zou worden overgegaan. Deze procedure, zo schreef de commissie in haar eindrapport, zou immers niet garanderen dat de stukken op korte termijn beschikbaar zouden komen. ${ }^{192}$ In plaats hiervan koos men daarom voor een civiel kort geding om de documenten boven tafel te krijgen. De president van de rechtbank wees de vordering echter af. In hoger beroep werd de commissie wel in het gelijk gesteld. Ten aanzien van de ontvankelijkheid oordeelde het Amsterdamse Hof, dat in de WPE niets was geregeld over dwangmiddelen die de enquêtecommissie kon inzetten om de inzageplicht af te dwingen. Uit de wetsgeschiedenis kon verder niet worden afgeleid "dat de WPE exclusief is bedoeld en dat in het bijzonder de privaatrechtelijke weg is uitgesloten", zo stelde het hof. ${ }^{193}$ Aangezien aan Deloitte ook geen beroep op een verschoningsgrond toekwam, werd het kantoor bevolen om de stukken binnen 24 uur ter beschikking te stellen op straffe van een dwangsom van vijfhonderdduizend euro per dag. ${ }^{194}$

De Deloitte-zaak liet zien dat de dwangmiddelen in de oude enquêtewet in de praktijk onvoldoende soelaas boden, met name ten aanzien van het verkrijgen van inzage in documenten. ${ }^{195}$ Een mogelijke verklaring hiervoor is dat de algemene inzageplicht pas later is toegevoegd aan de wet en dat de oorspronkelijke dwangmiddelen hierop niet zijn aangepast. In de nieuwe Wpe is dit verholpen en is de oplossing die de Bouwnijverheidscommissie hiervoor bedacht, een dwangsom via de civiele kort-gedingrechter, in feite gecodificeerd.

In art. 28 is tenslotte geregeld dat de getuige of deskundige die voor de commissie is verschenen maar weigert een verklaring af te leggen, op bevel van de voorzie-

\footnotetext{
Tijdens het symposium over de modernisering van de WPE pleitte Kummeling eveneens voor de invoering van "minder middeleeuwse dwangmiddelen", zoals de dwangsom. Zie De WPE onder de loep 2004, p. 15. Bij dezelfde gelegenheid haalde Daalder eveneens de mogelijkheid van de dwangsom aan. Het probleem met het bestaande instrumentarium is, zo constateerde hij, dat het een enquêtecommissie geen enkele mogelijkheid biedt "om snel op tafel te krijgen wat ze wil." De WPE onder de loep 2004, p. 28.

${ }^{191}$ Kamerstukken II 2005/06, nr. 6, p. 48.

192 Kamerstukken II 2002/03, 28 244, nr. 6, p. 44.

${ }^{193}$ Hof Amsterdam 12 augustus 2002, NJ 2003, 305, r.o. 4.12.

194 Hof Amsterdam 12 augustus 2002, NJ 2003, 305, r.o. 4.31-37. Zie ook Kamerstukken II 2002/03, 28

244 , nr. 6, p. 44-45.

195 Zie ook Drexhage 2009, p. 12.
} 
ningenrechter in gijzeling kan worden gesteld tot hij aan zijn verplichting heeft voldaan. Dit was ook onder de oude wet al mogelijk. De regeling houdt in, dat de enquêtecommissie bij de voorzieningenrechter in Den Haag kan verzoeken om een bevel tot gijzeling van een getuige (of deskundige) die is verschenen maar zonder grond weigert een verklaring af te leggen. ${ }^{196}$ De rechter toetst daarbij of de getuige een wettelijke verschoningsgrond toekomt en of er sprake is van strijd met het evenredigheidsbeginsel. ${ }^{197}$ De rechter dient uiterlijk binnen drie dagen een beslissing te nemen; tot die tijd kan de commissie de getuige zelf in bewaring houden, indien nodig met hulp van de sterke arm. ${ }^{198}$ De gijzeling wordt beëindigd zodra de getuige aan zijn verplichtingen heeft voldaan, maar duurt in elk geval niet langer dan dertig dagen. ${ }^{199}$

Het dwangmiddel gijzeling - meer nog dan de medebrenging, zeer ingrijpend van aard - is tot op heden nog nooit in de praktijk toegepast. Wel werd soms serieus rekening gehouden met het toepassen van dit dwangmiddel. De Enquêtecommissie Bouwnijverheid achtte het bij aanvang niet uitgesloten dat tot gijzeling zou moeten worden overgegaan bij weigerachtige getuigen en besloot daarom zelfs de nodige voorbereidingen te treffen. De commissie had met de hoofdofficier van justitie een "oriënterend gesprek" en sprak met de president van de rechtbank over de "logistieke aspecten." Gelukkig, zo schreef de commissie in haar eindrapport, bleek de toepassing van dit dwangmiddel uiteindelijk niet nodig te zijn. Alle getuigen werkten, soms na aandringen, in voldoende mate mee. ${ }^{200}$ Wat de waarde van dit dwangmiddel in de toekomst zal zijn, nu de dwangsom wellicht veel effectiever zal blijken, moet, zoals de Raad van State in haar advies opmerkte, worden afgewacht. ${ }^{201}$

\subsubsection{Sancties}

De sancties op het niet verlenen van medewerking aan een parlementaire enquête zijn geregeld in het Wetboek van Strafrecht. Met de inwerkingtreding van de nieuwe Wpe werden deze bepalingen waar nodig aangepast. Ingevolge artikel $192 \mathrm{Sr}$ kan een weigerachtige getuige gestraft worden met een gevangenisstraf van maximaal

196 Art. 28, eerste lid, Wpe 2008.

197 Evenals bij de toetsing onder art. 25 geldt hier een omgekeerde bewijslast. Zie nader: Kamerstukken II 2005/06, nr. 6, p. 82-84.

198 Art. 28, derde en vierde lid, Wpe 2008. Omdat de rechter binnen korte termijn (drie dagen) dient te beslissen over het verzoek van de commissie, vonden de initiatiefnemers het niet nodig om, gelet op het recht op toegang tot de rechter zoals dat onder meer voortvloeit uit art. 5 EVRM en art. $15 \mathrm{Gw}$, ten aanzien van de bewaring door de commissie een (aparte) rechtsgang te creëren. Kamerstukken II 2005/06, nr. 6, p. 83.

199 Art. 28, achtste lid, Wpe 2008. De termijn van dertig dagen sluit aan bij het strafprocesrecht. Onder de oude wet gold een maximale duur van een half jaar. Dit vonden de initiatiefnemers, gelet op de gemaakte inbreuk op de persoonlijke vrijheid en levenssfeer, niet langer proportioneel. Zie Kamerstukken II 2005/06, nr. 10, p. 16.

${ }^{200}$ Kamerstukken II 2002/03, 28 244, nr. 6, p. 40.

201 Zie ook het advies van de Raad van State, Kamerstukken II 2005/06, nr. 4, p. 9, die stelt dat de gijzeling in de nieuwe wet wellicht niet veel meer zou zijn dan een "symbool van de macht die een enquêtecommissie over personen kan uitoefenen." De initiatiefnemers hechtten niettemin aan de handhaving van dit dwangmiddel vanwege de preventieve werking en in geval van personen met ruime financiële armslag waarbij een dwangsom weinig indruk zou maken. Kamerstukken II 2005/06, nr. 6, p. 50. 


\section{NEDERLAND}

zes maanden of een geldboete van de derde categorie. Voorts kan het niet voldoen aan het verschaffen van inzage in documenten op grond van 192a Sr worden bestraft met een gevangenisstraf van maximaal vier maanden of een geldboete van de tweede categorie. ${ }^{202}$

Met de herziening van de Wpe werden hieraan nog twee bepalingen toegevoegd: artikel 192b, dat het niet-voldoen aan een vordering tot het geven van schriftelijke inlichtingen sanctioneert, en artikel 192c, dat niet-medewerking aan het betreden van een plaats strafbaar stelt. Hiermee werden ook de nieuwe bevoegdheden van de enquêtecommissie van corresponderende strafbepalingen voorzien. Tenslotte is het afleggen van een valse verklaring voor een enquêtecommissie, alsmede het omkopen van een getuige om een valse verklaring af te leggen, strafbaar op grond van art. $207 \mathrm{Sr} .{ }^{203}$

De vervolging van weigerachtige personen wordt sinds de nieuwe wet in werking is getreden, volledig beheerst door het Wetboek van Strafvordering. De oude wet kende op dit punt nog een bijzondere regeling, maar dit werd niet langer nodig bevonden. Vervolging van weigerachtige personen gebeurt dus volgens het reguliere strafprocesrecht en vindt plaats bij de strafrechter. In de oude wet werd hiervoor nog de burgerlijke rechter aangewezen. ${ }^{204}$

Anders dan het bevel tot medebrenging en de gijzeling is strafrechtelijke vervolging in de praktijk wel degelijk door enquêtecommissies toegepast, al blijft het beperkt tot incidenten. Naar aanleiding van de RSV-enquête is strafrechtelijke vervolging ingesteld tegen een bestuurslid van RSV omdat hij weigerde bepaalde vragen van de commissie te beantwoorden. De betreffende persoon werd vervolgens niet veroordeeld, omdat de rechter concludeerde dat hij zich terecht had beroepen op een verschoningsgrond.205 Naar aanleiding van de Enquête Opsporingsmethoden zijn twee getuigen in verband met hun getuigenverklaringen veroordeeld wegens meineed. 206

\subsubsection{Rechtsbescherming, verschoning en bewijsuitsluiting}

De algemene medewerkingsplicht, die in art. 14 Wpe 2008 is neergelegd, geldt in beginsel ook in het geval de betrokkene een wettelijke geheimhoudingsplicht heeft, zo blijkt uit art. 15.207 De oude wet kende deze bepaling niet. De initiatiefnemers van

202 Ten aanzien van deze bepalingen is in art. 192a Sr, in lijn met het nieuwe art. 6 Wpe, de terminologie aangepast: waar de oude wet sprak over 'inzage in of het nemen van afschrift van bescheiden', wordt nu gesproken over 'inzage in of het nemen van afschrift van of het anderszins kennisnemen van documenten'.

203 Zie nader: Kamerstukken II 2005/06, nr. 6, p. 50-51.

204 Aangezien er geen grond was om voor de berechting van deze strafbare feiten de burgerlijke rechter aan te wijzen, moest dat volgens de initiatiefnemers van de wet als een archaïsme worden gezien. Zie Kamerstukken II 2005/06, nr. 3, p. 48.

${ }^{205}$ HR 9 december 1986, NJ 1987, 621 m.nt. 't Hart.

${ }^{206}$ HR 8 juli 2003, NJ 2003, 711 m.nt. Knigge. Zie over de vervolging wegens meineed ook hierna, par. 2.3.4.2.1.

${ }^{207}$ Voor ondergeschikten geldt een bijzondere regeling (art. 15, tweede lid). Verder brengt de reguliere hiërarchie van normen met zich mee, dat de doorbreking van art. 15 geen effect heeft op internationale geheimhoudingsplichten. Zie verder Kamerstukken II 2005/06, 30 415, nr. 6, p. 32-33. 
de nieuwe Wpe hebben hiermee willen benadrukken "dat het belang van informatievergaring door de enquêtecommissie in algemene zin zwaarder dient te wegen dan het belang van vertrouwelijkheid dat met een wettelijke geheimhoudingsverplichting wordt gediend." 208 Veel wettelijke geheimhoudingsbepalingen zijn overigens relatief geformuleerd: zij gelden niet, indien elders een wettelijke plicht tot medewerking bestaat. Met Drexhage kan echter, meer in het algemeen, de vraag worden gesteld, hoe deze bepaling zich verhoudt tot algemene juridische uitgangspunten als de lex specialis- en lex posterior-regels. Daarover geeft de wet geen duidelijkheid, waardoor getuigen die hierdoor met conflicterende geheimhoudings- en medewerkingsplichten worden geconfronteerd in een lastige positie kunnen worden gebracht. ${ }^{209}$ Mij lijkt dat de Wpe 2008, een gewone wet, binnen de geldende normenhiërarchie in elk geval niet per definitie voorrang zal hebben op nieuwere, bijzondere wetten waarin geheimhoudingsplichten worden opgelegd. Dat brengt met zich mee, dat een getuige die te maken heeft met conflicterende geheimhoudings- en medewerkingsverplichtingen zich, ondanks art. 15 Wpe 2008, steeds zal moeten afvragen welke verplichting voorrang heeft.

In het verkeer met de enquêtecommissie kan een ieder zich laten bijstaan, zo is bepaald in art. 17. Dit kan niet alleen in geval van formele bevoegdheidsuitoefening, maar ook bijvoorbeeld bij vrijwillige medewerking aan een voorgesprek. Onder de oude wet was het recht op bijstand nog beperkt tot het openbare verhoor. Wel kan de enquêtecommissie "om gewichtige redenen" besluiten dat iemand zich tijdens een voorgesprek of een verhoor niet mag laten bijstaan, blijkt uit het tweede lid. ${ }^{210}$

\subsubsection{Verschoningsgronden}

In een aantal in de wet omschreven gevallen is een betrokkene niet verplicht om medewerking te verlenen. ${ }^{211}$ Hierbij gaat het om de verschoningsgronden die zijn opgenomen in hoofdstuk 4, paragraaf 2 van de wet. Deze verschoningsgronden kunnen, anders dan onder de oude wet, worden ingeroepen bij alle vormen van medewerking die de commissie vordert. 212 Alle bepalingen zijn geformuleerd als verschoningsrechten, waarmee bedoeld wordt dat betrokkenen niet verplicht zijn om een beroep op de verschoningsgrond te doen. Bovendien is het de enquêtecommissie ook niet verboden om naar bepaalde informatie te vragen; de verantwoordelijkheid ligt bij de informatieverstrekker. ${ }^{213}$

De wet voorziet niet in de mogelijkheid om vooraf de toepassing van bevoegdheden, zoals een oproep voor verhoor of het vorderen van inzage in documenten,

\footnotetext{
208 Zelfs in het geval van een absolute geheimhoudingsplicht zorgt art. 15 Wpe 2008 er volgens de initiatiefnemers voor, dat personen toch medewerking moeten verlenen aan een vordering van een enquêtecommissie; uiteraard betekent dit tevens dat het om deze reden overtreden van een wettelijke geheimhoudingsplicht niet strafbaar zal zijn op grond van art. 272 Sr. Kamerstukken II 2005/06, 30 415, nr. 6, p. 31-33.

209 Drexhage 2009, p. 15.

210 Zie verder: Kamerstukken II 2005/06, 30 415, nr. 6, p. 34-35.

211 Zie ook Drexhage 2009, p. 14.

212 Kamerstukken II 2005/06, 30 415, nr. 6, p. 37.

213 Onder de oude wet gold bijvoorbeeld nog wel een verbod om te vragen naar opvattingen die binnen de ministerraad werden geuit. Zie verder Kamerstukken II 2005/06, 30 415, nr. 6, p. 37-38.
} 
door de enquêtecommissie te laten toetsen door de rechter. Volgens de initiatiefnemers zou zulks "tot een ongewenste juridisering van de enquêteprocedure" leiden. Zij wijzen erop dat, vanuit het oogpunt van de machtenscheiding, tegen besluiten van de Kamer meestal ook geen beroep bij de (bestuurs)rechter openstaat. Daar staat tegenover dat de commissie haar dwangmiddelen alleen kan inzetten met behulp van de rechter. Voor de weigerachtige getuige of betrokkene ontstaat op dat moment, dus achteraf, de mogelijkheid van rechterlijke toetsing. ${ }^{214}$ In de bestaande praktijk, voegen de indieners eraan toe, lijkt dit systeem niet op problemen te stuiten. ${ }^{215}$ De indieners erkenden overigens dat, bij gebrek aan een specifieke rechtsgang, de burgerlijke rechter ook in het geval van een parlementaire enquête te allen tijde kan worden benaderd in zijn rol als restrechter. De voorzieningenrechter zou bijvoorbeeld een verbod kunnen uitvaardigen om een bevoegdheid in een bepaald geval uit te oefenen, al moet volgens hen worden aangenomen dat de burgerlijke rechter zich terughoudend zal opstellen. ${ }^{216}$

Wat betreft de wettelijke verschoningsgronden kan een onderscheid worden gemaakt tussen algemene verschoningsgronden, die in beginsel voor iedereen gelden, en enkele bijzondere verschoningsgronden die zijn gericht op ministers en ambtenaren. Hieronder worden de algemene verschoningsgronden besproken; de bijzondere komen aan de orde in paragraaf 2.3.5.

\subsection{Bedrijfsgeheimen}

De enquêtewet kent al sinds 1850 een verschoningsgrond terzake van bedrijfsgeheimen. Tot 1991 ging het om een absoluut geformuleerde verschoningsgrond, op grond waarvan iemand geen geheimen aan de commissie behoefde te openbaren wanneer zulks schade zou toebrengen aan de uitoefening van diens beroep of bedrijf. Bij de RSV-enquête, de eerste enquête na de heropleving van het enquêterecht, bleek de rechter niet geneigd om bij de toepassing van deze verschoningsgrond een afweging van belangen te maken tussen de enquêtecommissie en de betrokkene. In de zaak

${ }^{214}$ Hierbij dient de rechter te toetsen aan de criteria genoemd in art. 25 Wpe 2008. Zie nader: hierboven, par. 2.3.3.1.

${ }^{215}$ Kamerstukken II 2005/06, 30 415, nr. 6, p. 35-36. Zie ook Kamerstukken II 2005/06, 30 415, nr. 10 , p. 16. In de literatuur is niettemin verschillende malen gepleit voor het opstellen van een bestuursrechtelijke rechtsgang in het enquêterecht. Zie Lubberdink 2003, p. 33 en de bijdrage van Daalder in De WPE onder de loep 2004, p. 28-29, die het gebrek aan een bestuursrechtelijke bezwaar- en beroepsprocedure beide als "niet meer van deze tijd" typeren. Drexhage acht het beroep op de machtenscheiding in dit geval niet erg sterk, omdat de Kamer tijdens een parlementaire enquête anders dan gewoonlijk direct kan ingrijpen in individuele rechtsposities. Zij stelt dat "het beginsel van checks and balances juist een sterk argument oplevert om wel te voorzien in rechtsbescherming vooraf, nu het om zeer ingrijpende bevoegdheden gaat." Drexhage 2009, p. 13.

${ }^{216}$ Kamerstukken II 2005/06, 30 415, nr. 6, p. 36. Bij de burgerlijke rechter zou een beroep kunnen worden gedaan op de verschoningsrechten, maar naar analogie met de toetsing achteraf op grond van art. 25 Wpe 2008, zijn ook andere weigeringsgronden denkbaar. Te denken valt aan het reeds genoemde evenredigheidvereiste, de beperkingen die voortvloeien uit de omschrijving van het onderwerp van de enquête, alsmede eventuele strijdigheid met hogere normen zoals verdrags- of grondwettelijke bepalingen. Gezien de grote beleids- en beoordelingsvrijheid die de commissie in veel gevallen heeft, bijvoorbeeld door de subjectieve formulering van het evenredigheidsbeginsel, mag inderdaad verwacht worden dat de toetsing in de praktijk vaak marginaal zal zijn. Zie ook Drexhage 2009, p. 14 en het advies van de Raad van State, Kamerstukken II 2005/06, nr. 4, p. 7. 
van een getuige die door de commissie was opgeroepen en werd vervolgd wegens zijn weigering om bepaalde bedrijfsgevoelige informatie rondom de betaling van 'commissies' aan tussenpersonen te verstrekken, oordeelde de Hoge Raad uiteindelijk dat de enquêtecommissie niet behoefde te worden ingelicht omtrent feiten en omstandigheden die "waarschijnlijk schade zou kunnen berokkenen" aan een bedrijf en dat "een afweging [...], achteraf, door de strafrechter, tot een zodanige onzekerheid omtrent de reikwijdte van het verschoningsrecht [zou] leiden dat dit daardoor op onaanvaardbare wijze zou worden aangetast." 217

De bepaling werd bij de wetswijziging in 1991 aangepast. ${ }^{218}$ Met de nieuwe bepaling wilden de toenmalige initiatiefnemers benadrukken dat bij het beoordelen van een beroep op deze verschoningsgrond een belangenafweging moet worden gemaakt. Bovendien zou de bepaling ook voor (oud-)werknemers gaan gelden. ${ }^{219}$ Alleen wanneer openbaarmaking van beroeps- of bedrijfsgeheimen op een onevenredige wijze schade zou toebrengen aan de private belanghebbende, waarbij de schade aan het belang van de derde dus niet in verhouding staat tot het belang dat de enquêtecommissie heeft bij openbaarmaking, zou de derde zich met succes kunnen beroepen op deze verschoningsgrond. Het enkele feit dat door medewerking te verlenen aan een parlementaire enquête bepaalde beroeps- of bedrijfsgeheimen zullen worden prijsgegeven waardoor (mogelijk) schade ontstaat, werd dus onvoldoende om met succes een beroep te kunnen doen op deze verschoningsgrond. Gevolg hiervan was, dat het in concrete gevallen onduidelijk zou zijn of een beroep op de verschoningsgrond zou slagen, omdat de belangen van de commissie steeds moeten worden meegewogen. Daar komt bij dat bij die afweging de belangen van de commissie voorop zouden moeten staan, zo stelden de toenmalige indieners, en dus niet die van de betrokkene. ${ }^{220}$ De rechter zou voortaan in het geval van een conflict achteraf moeten bepalen hoe de belangenafweging bij een beroep op deze verschoningsgrond zou moet uitvallen. 221

Met de nieuwe Wpe 2008 is hierin geen wezenlijke verandering gekomen. Wel maakt de betreffende bepaling (art. 22) nu duidelijk dat ook vertrouwelijke bedrijfgegevens van derden, die iemand bijvoorbeeld om contractuele redenen of wegens een keuring in handen heeft, onder de verschoningsgrond vallen.222 Over de onduidelijkheid over de belangenafweging in concrete gevallen, die de relatieve verschoningsgrond met zich meebrengt, zeggen de initiatiefnemers dat de praktijk hierin zijn

${ }^{217}$ HR 9 december 1986, NJ 1987, 632, r.o. 5.2-5.3 (m.nt. 't Hart).

218 Kamerstukken II 1986/87, 19 816, nr. 3, p. 4-5. Zie ook Boon 1982, p. 174-176 en 219-212; Enquêtecommissie-RSV, Kamerstukken II 1984/85, 17 817, nr. 17, p. 18; Dölle 1985, p. 37, 136-138, 145-149.

219 Zie Kamerstukken II 1986/87, 19 816, nr. 3, p. 5. Ter verduidelijking werd, mede op verzoek van de PvdA-fractie, daarom de term "onevenredige schade" in het nieuwe art. 18 opgenomen. Kamerstukken II 1988/89, 19 816, nr. 10, p. 12-13. Overigens werd in de nieuwe tekst tevens (in bevestigende zin) een einde gemaakt aan de bestaande onduidelijkheid over de vraag of het verschoningsrecht ook voor (oud-)werknemers zou gelden. De tekst biedt werkgevers echter niet de mogelijkheid om hun werknemers te bevelen om bedrijfsgeheimen niet te openbaren, zoals werd voorgesteld.

${ }^{220}$ Handelingen II 1989/90, 92, p. 5182.

${ }^{221}$ Zo meenden ook de indieners van de wijzigingswet. Zie Kamerstukken II 1988/89, 19 816, nr. 10, p. 14.

222 Zie Kamerstukken II 2005/06, 30 415, nr. 6, p. 44. Zie voor kritiek op de oude bepaling hieromtrent: Daalder in De WPE onder de loep 2004, p. 26. 
weg zal moeten vinden en dat de rechter uiteindelijk zal moeten oordelen indien de commissie besluit tegen een weigerachtige betrokkene dwangmiddelen in te zetten of aangifte te doen. ${ }^{223}$

\subsection{Beroepsgeheim}

De wetgever heeft erkend dat het belang van bepaalde beroepsbeoefenaars om informatie geheim te houden zwaarder weegt dan het onderzoeksbelang van de enquêtecommissie. Het gaat daarbij om beroepen met een vertrouwensfunctie. De beroepsmatige verschoningsgrond is te vinden in art. 24 Wpe 2008. Inhoudelijk stamt de bepaling, afgezien van enige tekstuele aanpassingen, nog grotendeels uit 1850. De huidige bepaling stelt dat iemand niet verplicht is informatie aan de commissie te verstrekken "voor zover hij uit hoofde van zijn ambt of beroep tot geheimhouding verplicht is en het informatie betreft die aan hem in die hoedanigheid is toevertrouwd." Ook hier geldt evenwel, dat de betreffende beroepsbeoefenaar niet verplicht is om gebruik te maken van dit verschoningsrecht.

De tekst van art. 24 komt sterk overeen met bepalingen in het strafrecht en civiele recht waarin een vergelijkbare professionele verschoningsgrond is neergelegd.224 De wetgever heeft bij de invoering van de enquêtewet in 1850 niet beoogd om voor het enquêterecht een afwijkende verschoningsgrond te introduceren. ${ }^{225}$ Bovendien gaat de rechter er sinds het zogenaamde Notaris-Maasarrest uit 1985 van uit dat de professionele verschoningsgrond in zowel het strafproces als het burgerlijke proces voortkomt uit een algemeen rechtsbeginsel.226 De betekenis van het algemene professionele verschoningsrecht wordt dus bepaald door dit algemene rechtsbeginsel. De Hoge Raad legt in dit arrest eveneens uit wat het object van het professionele verschoningsrecht is: het gaat bij dit verschoningsrecht niet om het individuele belang van de vertrouwenspersoon, maar om het zwaarwegende maatschappelijke belang om in vertrouwelijkheid advies of bijstand te kunnen verkrijgen. Hiermee is tevens het onderscheid met de verschoningsgrond van art. 22 duidelijk; daarbij gaat het immers wel om individuele belangen en mogelijke schade als gevolg van medewer-

\footnotetext{
${ }^{223}$ Kamerstukken II 2005/06, 30 415, nr. 6, p. 45.

224 Zie art. 218 Sv en art. 165, tweede lid onder b, Rv.

${ }^{225}$ In de memorie van toelichting verwijst de regering voor deze verschoningsgrond naar de strafrechtelijke versie: "De bepaling van art. 189 [oud] van het Wetboek van Strafvordering is hier als beginsel vooropgesteld; de billijkheid daarvan kan niet worden betwist." Bijl. Handelingen II 1849/50, p. 235. Zie voorts Boon 1982, p. 176-177. Dölle wijst er overigens terecht op dat met deze verwijzing niet gezegd is dat de wetgever destijds van mening was dat het belang van informatieverwerving in het strafproces gelijk te stellen is aan het belang van de informatieverwerving door het parlement; traditioneel is het strafproces (mede) gericht op waarheidsvinding, terwijl de parlementaire enquête daar (anders dan nu het geval is) destijds veel minder op gericht was. De regering heeft met deze zinsnede waarschijnlijk, zo stelt Dölle, slechts willen benadrukken dat vertrouwensrelaties die in het strafproces worden beschermd ook bij een parlementaire enquête bescherming verdienen. Dölle 1985, p. 149.

226 De Hoge Raad overweegt in dit arrest: "De grondslag van dit verschoningsrecht moet worden gezocht in een in Nederland geldend algemeen rechtsbeginsel dat meebrengt dat bij zodanige vertrouwenspersonen het maatschappelijk belang dat de waarheid in rechte aan het licht komt, moet wijken voor het maatschappelijk belang dat een ieder zich vrijelijk en zonder vrees voor openbaarmaking van het besprokene om bijstand en advies tot hen moet kunnen wenden." Zie HR 1 maart 1985, NJ 1986, 173, r.o. 3.1. Zie ook Fernhout 2004, p. 121 e.v.
} 
king aan de enquête. Om die reden is de professionele verschoningsgrond in absolute termen geformuleerd. Met de invoering van de Wpe 2008 is hierin geen verandering gebracht. ${ }^{227}$

Uit de omvangrijke jurisprudentie die ten aanzien van de straf- en civielrechtelijke professionele verschoningsgronden is ontwikkeld, kan worden afgeleid dat in ieder geval vier professionele 'vertrouwenspersonen' een beroep kunnen doen op professionele verschoning: de advocaat, de arts, de geestelijke en de notaris. ${ }^{228}$ Voor andere personen geldt dat per beroep of functie afzonderlijk moet worden vastgesteld of deze tot de kring van verschoningsgerechtigden behoort. Hierbij lijkt de rechter in veel gevallen andere hulpverleners die feitelijk hetzelfde werk doen als de 'klassieke vier' het verschoningsrecht eveneens toe te kennen. Fernhout spreekt daarom van vier "beroepssferen" of "beroepskringen" waarop het professionele verschoningsrecht van toepassing kan zijn: de juridische hulpverlening, de (para)medische hulpverlening, de geestelijk-maatschappelijke hulpverlening en het notariaat. ${ }^{229}$ Vast staat dat registeraccountants, belastingadviseurs, wetswinkeliers, deurwaarders, gezinsvoogden, maatschappelijk werkers, ouderlingen en sekteleiders in ieder geval niet behoren tot de kring van professioneel verschoningsgerechtigden. ${ }^{230}$ Daarentegen staat sinds het Goodwinarrest van het Europese Hof voor de Rechten van de Mens uit 1996 vast dat journalisten op grond van art. 10 EVRM hun bronnen in veel gevallen geheim mogen houden. ${ }^{231}$

Of deze lijn in de straf- en civielrechtelijke rechtspraak moest worden doorgetrokken naar het enquêterecht, bleef lang onduidelijk. ${ }^{232}$ Hierin kwam verandering met de eerder genoemde Deloitte-zaak, waarin het accountantskantoor weigerde de enquêtecommissie Bouwnijverheid inzage te verlenen in een vertrouwelijk onderzoeksdossier. Tot op heden is dit het enige geval waarin de toepassing van het professionele verschoningsrecht bij een parlementaire enquête tot een rechterlijke uitspraak heeft geleid.233 Ook deze zaak betreft een beroepsgroep waarvan onzeker was of deze tot de kring van verschoningsgerechtigden behoorde. Deloitte beriep zich op de professionele verschoningsgrond van art. 19 WPE (oud) met de stelling dat haar medewerkers in de functie van 'forensisch accountant' behoren tot de beroepen die door die bepaling werden bestreken. Het beroep van forensisch accoun-

${ }^{227}$ Zie Kamerstukken II 2005/06, 30 415, nr. 6, p. 43.

228 Zie nader Fernhout 2004, p. 182 e.v.

${ }^{229}$ Fernhout 2004, p. 182-183.

${ }^{230}$ Fernhout 2004, p. 193.

231 EHRM 27 maart 1996, NJ 1996, 577 (Goodwin). Zie ook HR 10 mei 1996, NJ 1996, 578. Zie verder Fernhout 2004, p. 240-242.

232 Voor Dölle, schrijvend in 1985, is deze gelijkstelling tussen het professionele verschoningsrecht in het strafrecht en het enquêterecht nog allerminst vanzelfsprekend. Hij bepleit daarom dat de wetgever, wanneer die instemt met deze gelijkstelling, dit bevestigt door bijvoorbeeld de tekst van art. 19 WPE (oud) identiek te maken aan art. 218 Sv of door simpelweg naar die strafrechtelijke bepaling te verwijzen. Dölle bespreekt overigens ook nog andere varianten voor modernisering van het 19eeeuwse verschoningsregime. Dölle 1985, p. 136-162, 175.

${ }^{233}$ Wat niet wil zeggen dat de toepassing van deze verschoningsgrond niet tot conflicten heeft geleid. Een van de potentiële getuigen in de RSV-enquête beriep zich op art. 19 met een beroep op het bankgeheim. Dat beroep werd door de commissie simpelweg niet aanvaard. Kamerstukken II 1984/85, 17 817, nr. 17, p. 19. 
tant moet volgens Deloitte worden onderscheiden van de registeraccountant. Forensische accountants voeren geen controlerende taken uit, zoals de andere registeraccountants, maar doen forensisch onderzoek. Het onderzoek door KPMG-accountants inzake de uitgaven van de leden van $B$ en $W$ van Rotterdam was een voorbeeld van forensisch accountantsonderzoek. Bij dit type accountantswerk was het gebruikelijk om aan informanten vertrouwelijkheid toe te zeggen, aldus Deloitte. ${ }^{234}$

Het hof stelde in haar arrest allereerst vast dat tot de kring van "functionele geheimhouders" waarop art. 19 WPE (oud) doelt in ieder geval de geestelijke, de geneeskundige, de advocaat en de notaris behoren. ${ }^{235}$ Ook was duidelijk dat de registeraccountant hier niet toe behoorde, voegde het hof toe. Niet duidelijk was echter of het door Deloitte geïllustreerde beroep van forensisch accountant tot de groep van functionele geheimhouders kan worden gerekend. Het hof oordeelde dat voor de beantwoording van de vraag of aan (de forensisch accountants van) Deloitte een professioneel verschoningsrecht toekomt, doorslaggevend was "of de belangen van de verschillende categorieën van belanghebbenden bij de functies die de forensische accountant vervult, naar behoren kunnen worden gediend zonder verschoningsrecht tegenover de enquêtecommissie; en of de geheimhoudplicht van de forensische accountant zwaarder moet wegen dan het aanzienlijke maatschappelijke belang dat de waarheid in het onderzoek van de enquêtecommissie aan het licht komt, in gevallen waarin dat mede afhankelijk is van de getuigenis van de forensische accountant." 236 Uit deze formulering blijkt dat de rechter aansluiting zocht bij het genoemde NotarisMaasarrest. ${ }^{237}$ In haar uitspraak beantwoorde het hof vervolgens de eerste vraag bevestigend (het forensisch werk van registeraccountants wordt niet "in relevante ma$t^{\prime \prime}$ belemmerd als informanten niet op geheimhouding kunnen rekenen) en de tweede vraag ontkennend (het belang van de forensisch registeraccountant weegt dus niet zwaarder dan het belang van de parlementaire enquêtecommissie). ${ }^{238}$ Hieruit volgde dat er onvoldoende reden is om de forensische accountant als geheimhouder in de zin van art. 19 WPE (oud) aan te merken, waardoor het beroep van Deloitte op het professionele verschoningsrecht faalde.

Voor de beantwoording van de vraag welke beroepen onder de bescherming van de professionele verschoningsgrond vallen, moet dus worden aangesloten bij de jurisprudentie hieromtrent in het straf- en civiele procesrecht. Met de invoering van de Wpe 2008 is hierin geen verandering gekomen. 239

\footnotetext{
${ }^{234}$ Hof Amsterdam 12 augustus 2002, NJ 2003, 305, r.o. 4.24.

235 Deze beroepen vormen een beperkte groep die "van oudsher" als functionele geheimhouders worden aangemerkt. Hof Amsterdam 12 augustus 2002, NJ 2003, 305, r.o. 4.26.

${ }^{236}$ Hof Amsterdam 12 augustus 2002, NJ 2003, 305, r.o. 4.28.

237 Vgl. r.o. 3.1 van HR 1 maart 1995, NJ 1986, 173.

${ }^{238}$ Hof Amsterdam 12 augustus 2002, NJ 2003, 305, r.o. 4.29.

${ }^{239}$ Het in de wet opsommen van beroepsgroepen zou ertoe kunnen leiden dat bepaalde beroepen onterecht niet vermeld zouden worden, zo stelden de initiatiefnemers. In de memorie van toelichting worden, naast de arts, geestelijke, notaris en advocaat ook de apotheker, vroedvrouw en verpleegkundige genoemd. In elk geval niet verschoningsgerechtigd zijn de politieambtenaar, de registeraccountant en de belastingadviseur. Verder zouden ook ambtenaren een beroep op deze verschoningsgrond kunnen doen, wanneer zij bijvoorbeeld de functie van vertrouwenspersoon integriteit vervullen of werkzaam zijn bij een klokkeluidersmeldpunt. Kamerstukken II 2005/06, 30 415, nr. 6 , p. 43-44. Verder wordt onder verwijzing naar het Goodwinarrest erkend dat een verzoek aan een
} 


\subsection{Collegeberaad}

Op grond van art. 21 Wpe 2008 is niemand verplicht om informatie te verstrekken over de beraadslagingen in een vergadering van een college waarvoor een wettelijke geheimhoudingsplicht geldt. Het gaat daarbij met name om het geheim van de gerechtelijke raadkamer en van een besloten gemeenteraads- of statenvergadering. Ook een besloten vergadering van het college van B en $W$ of van gedeputeerde staten, waarbij de leden geheimhouding is opgelegd, valt hieronder. ${ }^{240}$ Met uitzondering van de gerechtelijke raadkamer en de Afdeling bestuursrechtspraak van de Raad van State, kan het betreffende college op verzoek van de enquêtecommissie echter ontheffing verlenen van deze geheimhoudingsplicht. ${ }^{241}$

\subsection{Persoonlijke levenssfeer}

Sinds de inwerkingtreding van de Wpe 2008 kent de wet ook een verschoningsrecht wegens de persoonlijke levenssfeer. Op grond van art. 23 is iemand niet verplicht om informatie te verstrekken "voor zover deze informatie de persoonlijke levenssfeer betreft en het belang van de informatieverkrijging door de commissie niet opweegt tegen het belang van de vertrouwelijkheid van deze informatie." Met deze bepaling wordt erkend dat bij moderne parlementaire enquêtes soms privacygevoelige onderwerpen aan bod kunnen komen. ${ }^{242}$ Bovendien hebben de initiatiefnemers door het opnemen van deze bepaling getracht tegemoet te komen aan de eisen van art. 10 Gw en art. 8 EVRM wanneer een overheidsorgaan, waartoe ook de enquêtecommissie moet worden gerekend, een inbreuk maakt op het grondrecht op privacy. In deze bepaling is, evenals bij het verschoningsrecht inzake bedrijfsgeheimen, gekozen voor een relatieve formulering: de belangen van het individu moeten worden afgewogen tegen het algemene belang van "waarheidsvinding", dat de enquêtecommissie nastreeft. 243 Het verschoningsrecht kan tevens worden ingeroepen wanneer de gevraagde informatie betrekking heeft op de privacy van anderen. ${ }^{244}$ Van een familiaal verschoningsrecht is echter geen sprake. ${ }^{245}$

journalist om bronnen prijs te geven in beginsel in strijd is met art. 10 EVRM. Een dergelijk bevel zou alleen bij "zwaarwegende eisen van algemeen belang" gerechtvaardigd zijn. De precieze betekenis van dit verschoningsrecht is echter niet in algemene zin vast te stellen en moet uit de zich ontwikkelende jurisprudentie hieromtrent worden afgeleid. Zie verder Kamerstukken I 2006/07, nr. F, p. 8.

240 Kamerstukken I 2006/07, 30 415, nr. C, p. 23.

241 Zie art. 21, tweede en derde lid, Wpe 2008. Zie verder Kamerstukken II 2005/06, 30 415, nr. 6, p. 43.

${ }^{242}$ In de memorie van toelichting passen de initiatiefnemers de beperkingssystematiek van art. $10 \mathrm{Gw}$ en art. 8 EVRM uitdrukkelijk toe. Kamerstukken II 2005/06, 30 415, nr. 6, p. 45.

243 Kamerstukken II 2005/06, 30 415, nr. 6, p. 45-46.

244 Kamerstukken I 2006/07, 30 415, nr. C, p. 24.

245 Volgens de initiatiefnemers gaat het bij de belangenafweging om "de aard van de informatie en de context waaronder deze is verkregen (...). Het kan dus zijn dat privacygegevens van een buurman die op vertrouwelijke wijze aan de getuige zijn verstrekt, niet verstrekt behoeven te worden, terwijl bepaalde gegevens van de partner of gezinsleden wel verstrekt behoren te worden." Overigens gaan zij ervan uit, dat de commissie in de praktijk doorgaans de gewenste gegevens bij de betreffende persoon zelf zal opvragen in plaats van bij iemand aan wie de gegevens zijn toevertrouwd. Kamerstukken I 2006/07, 30 415, nr. F, p. 7-8. Vgl. ook Drexhage 2009, p. 15. 


\section{NEDERLAND}

De initiatiefnemers verwachtten overigens niet, dat een beroep op privacy veel zal voorkomen. Als dat wel het geval is, dan zal "van geval tot geval" moeten worden bekeken of een dergelijk beroep terecht is. Als voorbeeld noemden de initiatiefnemers het bordeelbezoek, dat tijdens de bouwnijverheidsenquête aan de orde kwam. Hier zou een beroep op art. 23 gerechtvaardigd zijn. Dit zou echter anders worden, wanneer het bordeelbezoek "niet uitsluitend een privé-aangelegenheid is, maar als functie het verkrijgen of verlenen van gunsten of tegenprestaties heeft voor een doel dat in de enquête mede wordt onderzocht". ${ }^{246}$ Ook in het verleden verrichte strafrechtelijke handelingen kunnen volgens de indieners "onder omstandigheden" in de persoonlijke levenssfeer liggen.247

\subsubsection{Nemo tenetur}

\subsection{Bewijsuitsluitingsregel}

Personen die tot medewerking verplicht zijn, lopen het risico dat zij zichzelf daardoor gedwongen blootstellen aan strafrechtelijke vervolging of andere vormen van sanctionering. Al bij het eerste ontwerp voor een enquêtewet leefde binnen de Kamer de wens om een bepaling op te nemen waardoor "niemand voor hetgeen hij aan de commissie van onderzoek openbaart, vervolgd kan worden." 248 Sinds 1850 kent de enquêtewet daarom een zogenaamde bewijsuitsluitingsregel, waardoor getuigenverklaringen die op vordering van de commissie zijn afgelegd, niet als bewijs in rechte kunnen dienen. ${ }^{249}$ Uitzondering daarop is een vervolging wegens meineed, gepleegd door een getuige die onder ede een verklaring heeft afgelegd voor een enquêtecommissie. 250 Veel parlementaire discussie leverde deze bepaling destijds niet op. ${ }^{251}$ Dit hangt wellicht samen met de destijds nog gehuldigde opvatting dat parlementaire enquêtes zich vooral leenden voor wetgevingsvraagstukken. De eerste parlementaire enquêtes, die in de negentiende eeuw plaatsvonden, sloten daarbij aan. Na de opleving van de parlementaire enquête in de jaren 70 veranderde dit: vanaf die tijd zou het enquêterecht vooral worden ingezet om wantoestanden, affaires en schandalen waarbij de overheid op een of andere manier betrokken was, te onderzoeken. De kans dat ten aanzien van een onderwerp of gebeurtenis zowel een parlementaire enquête als een strafrechtelijk onderzoek (of een andere, op sanctionering gerichte procedure) zou plaatsvinden, nam hierdoor sterk toe. Ook in de praktijk was dit niet langer ondenkbaar, zoals bijvoorbeeld bleek bij de Enquête Opsporingsmethoden en de Enquête Bouwnijverheid. ${ }^{252}$

Kenmerkend voor de regeling zoals die sinds 1850 in de wet is opgenomen is, dat deze slechts in beperkte mate bescherming biedt aan getuigen en andere betrokkenen tegen gerechtelijke procedures naar aanleiding van hun medewerking aan een

\footnotetext{
${ }^{246}$ Kamerstukken II 2005/06, 30 415, nr. 10, p. 14-15.

247 Kamerstukken I 2006/07, 30 415, nr. C, p. 24.

248 Bijlage Handelingen II 1849, p. 181.

249 Art. 24 WPE (oud).

250 Art. 25 WPE (oud).

${ }^{251}$ De bepaling werd bij de behandeling van het wetsvoorstel van 1850 zonder verder debat in beide Kamers aangenomen. Handelingen II 1849/50, zitting van 13 juli, p. 14 en Handelingen I 1849/50, p. 231. 252 Zie ook Munneke 2006, p. 321.
} 
parlementaire enquête. De bepaling beperkt immers slechts de bewijsmogelijkheden; de getuige is geenszins immuun voor strafvervolging. Wanneer het openbaar ministerie langs andere weg voldoende bewijs weet te verzamelen omtrent een getuige of anderen over wie tijdens een enquête belastende informatie naar buiten is gekomen, dan staat de wet een veroordeling of een andere vorm van sanctionering niet in de weg. ${ }^{253}$ Dit kan de getuige voor een lastige afweging plaatsen: voldoe ik aan de wettelijke plicht tot medewerking aan een enquête en verstrek ik de gevraagde - wellicht belastende - informatie, zwijg ik en neem ik het risico op vervolging wegens nietmedewerking, of vertel ik niet de waarheid, waardoor ik gestraft kan worden wegens meineed?

In de literatuur staat de bewijsuitsluitingsregel daarom al geruime tijd ter discussie. In 1982 pleit Boon reeds voor de invoering van een familiaal verschoningsrecht, op grond waarvan getuigen het recht zouden krijgen om vragen van een enquêtecommissie onbeantwoord te laten wanneer zij vreesden zichzelf of hun familieleden te belasten. ${ }^{254}$ Doorenbos stelt dat de bestaande regeling er niet alleen toe kan leiden, dat opsporingsambtenaren op basis van de getuigenis gericht onderzoek gaan doen naar een getuige, maar ook dat medegetuigen of -verdachten gebruik maken van de mogelijkheid om hun verhaal aan te passen aan de in het openbaar afgelegde getuigenverklaringen van anderen, zodat de enquêteverklaring indirect toch nog kan meewegen in het bewijs. Bovendien zou, als een getuige naar aanleiding van een enquêteverhoor wordt vervolgd, de rechterlijke oordeelsvorming worden beïnvloed door hetgeen tijdens een enquêteverhoor gezegd is. ${ }^{255}$ Jurgens pleit voor een zwijgrecht naar Amerikaans model, maar dan met name wanneer 'gewone burgers' worden verhoord. ${ }^{256}$ Dölle kiest tenslotte voor een beperktere oplossing, namelijk het recht op een besloten verhoor. ${ }^{257}$

Uit de enquêtepraktijk kwam de vraag op of de huidige regeling nog wel in overeenstemming is met het nemo tenetur-beginsel, op grond waarvan niemand kan worden gedwongen om medewerking te verlenen aan diens eigen veroordeling. Op dit punt is enige jurisprudentie ontstaan. Het ging om een casus die voortvloeide uit de Enquête Opsporingsmethoden uit 1996. De politiefunctionarissen Langendoen en Van Vondel van de criminele inlichtingendienst Kennemerland werden door de Enquêtecommissie Opsporingsmethoden verhoord omtrent hun kennis van of betrokkenheid bij een omstreden opsporingsmethode, waarbij door de betrokken politiediensten grote hoeveelheden drugs op de Nederlandse markt werden gebracht teneinde een beter inzicht te krijgen in de georganiseerde drugcriminaliteit (de zogenaamde Delta-methode). De verklaringen die Langendoen en Van Vondel onder ede aflegden omtrent vermeende onrechtmatige betalingen aan criminelen bleken niet overeen te stemmen met verklaringen die een (kennelijk betrouwbare) informant tijdens een besloten gesprek met de enquêtecommissie had afgelegd. De enquête-

\footnotetext{
253 Zie ook Boon 1982, p. 222.

254 Boon 1982, p. 223-224.

${ }^{255}$ Doorenbos 2003, p. 57-58. Zie ook diens bijdrage in De WPE onder de loep 2004, p. 60. Zie voor kritiek op dit standpunt: Lubberdink 2003, p. 29.

256 Jurgens 2004, p. 223.

${ }^{257}$ Dölle 1985, p. 160. Zie verder Drexhage 2009, p. 15-16.
} 
commissie vermoedde dat de twee meineed pleegden en deed daarom op de dag van de presentatie van het eindrapport op grond van art. 25 WPE (oud) aangifte van meineed bij het openbaar ministerie.

De twee rechercheurs werden zowel in eerste aanleg als in hoger beroep veroordeeld. De Hoge Raad verwierp het cassatieberoep, omdat de parlementaire enquête niet kan worden gezien als een strafrechtelijke vervolging en daarom buiten het bereik van art. 6 EVRM valt. ${ }^{258}$ Eén van de rechercheurs, Van Vondel, diende vervolgens een klacht in bij het Europese Hof voor de Rechten van de Mens. Het Straatsburgse hof bekeek allereerst of de betreffende enquête kon worden beschouwd als een vorm van strafrechtelijke vervolging, waardoor de vereisten van art. 6 in beeld zouden komen. $\mathrm{Na}$ een gedetailleerde analyse van de achtergrond en werkwijze van de commissie-Van Traa concludeerde het Hof:

\begin{abstract}
"As to the question whether these proceedings entailed a determination of a 'criminal charge', the Court has found no reason for holding that the inquiry conducted by the PEC in any way amounted to a disguised form of criminal proceedings directed against the applicant. It concerned a broad inquiry into controversial methods of criminal investigation used in cases concerning organised crime and, moreover, Article 24 of the Parliamentary Inquiries Act explicitly prohibits the use in evidence in criminal proceedings of statements made before the PEC. This is not altered by the fact that subsequent criminal proceedings were brought against the applicant, as this is irrelevant to the question whether the proceedings before the PEC, as such, determined a criminal charge (...). The Court therefore finds that the proceedings before the PEC also fall outside of the scope of Article 6 under its criminal head (...)." 259
\end{abstract}

Het Hof oordeelde dat deze parlementaire enquête dusdanig algemeen van karakter was ('it concerned a broad inquiry...') dat deze niet kon worden gekwalificeerd als een strafrechtelijke procedure ('criminal charge') in de zin van art. 6 EVRM. Niet alleen op formele, maar ook op materiële, feitelijke gronden kon in de onderhavige zaak dus niet gesproken worden van een strafrechtelijke procedure. De bepaling van art. 24 WPE versterkte deze conclusie, zo voegde het Hof toe, omdat deze bepaling het gebruik van enquêtegetuigenissen in een strafrechtelijke procedure juist expliciet uitsluit.

Vervolgens ging het Hof in op de relatie tussen de parlementaire enquêteprocedure en het verbod van gedwongen zelf-incriminatie. In art. 6, zo stelde klager, ligt volgens vaste rechtspraak van het Hof besloten dat een verdachte het recht heeft te zwijgen en niet verplicht kan worden om medewerking te verlenen aan zijn eigen veroordeling (ook wel nemo tenetur genoemd). Het Hof bevestigde dit, maar voegde daaraan toe dat hieruit niet volgt dat elke maatregel die burgers aanzet om informatie aan autoriteiten te verstrekken daarom onrechtmatig is. Sterker nog, een parlementaire enquêtecommissie kan haast niet zonder de bijzondere bevoegdheid om burgers te dwingen om informatie te verstrekken, merkte het Hof op. Art. 24 bood voldoende bescherming:

"Noting the prohibition set out in Article 24 of the Parliamentary Inquiries Act, the Court cannot find that, to the extent that the applicant's evidence before the PEC would have been of a self-

\footnotetext{
${ }^{258}$ HR 8 juli 2003, NJ 2003/711, m.nt. Knigge.

${ }^{259}$ EHRM 23 maart 2006, EHRC 2006/80, m.nt. Loeffen (Van Vondel/Nederland), par. 1.
} 
incriminating nature or would have incriminated others, such disclosure would have exposed him or any other person to a risk of criminal prosecution on the basis of such evidence." 260

In deze meineedzaak was overigens helemaal geen gedwongen zelf-incriminatie aan de orde, benadrukte het Hof tenslotte:

"This was not an example of forced self-incrimination before the PEC about an offence which he had previously committed; it was the offence itself. It may be that the applicant lied in order to prevent uncovering conduct which, in his perception, might possibly be criminal and lead to a prosecution. However, the right to silence and not to incriminate oneself cannot be interpreted as giving a general immunity to actions motivated by the desire to evade investigation." 261

De zienswijze van klager werd hier aldus door het hof resoluut van de hand gewezen. Met name de suggestie dat het plegen van meineed geoorloofd zou zijn wanneer een getuige vreest zichzelf tijdens een enquêteverhoor te belasten, kon op weinig sympathie rekenen. De strafrechtelijke vervolging en veroordeling voor meineed als gevolg van de valse verklaring die tijdens een getuigenverhoor onder dwang was afgelegd, kon aldus volgens het Hof de toets van art. 6 doorstaan en de klacht werd niet-ontvankelijk verklaard. 262

Het Europese Hof heeft met deze uitspraak een tweetal signalen afgegeven betreffende de verhouding tussen enquêteonderzoek en strafrechtelijk onderzoek. Op grond van deze uitspraak kan worden geconcludeerd dat de Nederlandse enquêtewetgeving, waarbij getuigen een spreekplicht hebben en slechts in beperkte mate bescherming genieten tegen strafrechtelijke vervolging naar aanleiding van hun getuigenverklaring, op zichzelf voldoet aan de eisen van het Verdrag. Tegelijkertijd is hiermee niet gezegd dat parlementaire enquêtecommissies nooit met de verplichtingen van art. 6 te maken zouden kunnen krijgen. Het Hof gaat in zijn uitspraak nergens zover te stellen dat een parlementaire enquête altijd buiten het bereik van art. 6 valt. Het Hof betrekt nadrukkelijk de feitelijke gang van zaken tijdens de Enquête Opsporingsmethoden in haar redenering.

Door deze casuïstische benadering blijft er bij toekomstige enquêtes ruimte voor een andere rechterlijke afweging. Wanneer een getuige meent dat een enquêtecommissie wegens het karakter en de inhoud van de vraagstelling dan wel op grond van haar onderzoeksopdracht teveel op de stoel van het openbaar ministerie gaat zitten, dan is een klacht op grond van art. 6 niet geheel kansloos. Bij een vervolging wegens het niet voldoen aan een vordering van een enquêtecommissie, zou de rechter dan naar het voorbeeld van het Europese Hof een specifieke analyse van de achtergrond en werkwijze van de betreffende enquêtecommissie moeten maken.

\footnotetext{
260 EHRM 23 maart 2006, par. 1.

261 EHRM 23 maart 2006, par. 1.

262 Een tweede klacht in deze zaak, die betrekking had op telefoontaps, werd door het Hof wel in behandeling genomen. Ten aanzien van die klacht oordeelde het Hof uiteindelijk dat er sprake was van een schending van art. 8 EVRM. Zie EHRM 25 oktober 2007, nr. 38258/03 (Van Vondel/Nederland).
} 


\subsection{Geen zwijgrecht of immuniteitsregeling}

In de Wpe 2008 is de bewijsuitsluitingsregel op enkele punten aangepast aan de moderne praktijk. Het nieuwe art. 30 geldt niet alleen voor mondelinge verklaringen, maar ook voor documenten die op vordering van de enquêtecommissie zijn verstrekt. Hoewel reeds onder het oude art. 24 kon worden aangenomen dat het begrip 'verklaringen' ruim zou moeten worden opgevat en dus ook schriftelijke stukken zou moeten omvatten, wordt in de nieuwe bepaling aan de onzekerheid op dit punt een einde gemaakt. ${ }^{263}$ Verder bevestigt art. 30 dat de bewijsuitsluitingsregel niet alleen geldt voor strafrechtelijke procedures, maar ook voor civielrechtelijke, bestuursrechtelijke of tuchtrechtelijke procedures. Ook kunnen op verklaringen of documenten die zijn afgelegd respectievelijk verstrekt op vordering van een enquêtecommissie geen disciplinaire maatregelen, bestuurlijke sancties of bestuurlijke maatregelen worden gebaseerd. De bewijsuitsluitingsregel geldt niet, zo volgt uit art. 32, in het geval van vervolging wegens meineed, omkoping van een getuige of deskundige, of bij vervolging wegens het niet verlenen van medewerking aan een vordering van een enquêtecommissie. Deze uitzondering bestond in vergelijkbare zin ook al onder de oude wet en is bedoeld om het afleggen van valse verklaringen voor een enquêtecommissie te voorkomen. ${ }^{264}$ Nieuw in de Wpe 2008 is tenslotte de bepaling, neergelegd in art. 31, dat de enquêtecommissie geen informatie verstrekt aan andere personen of organen ten behoeve van één van de in art. 30 genoemde procedures, zelfs niet indien daartoe een wettelijke plicht zou bestaan. Deze beperking geldt echter niet in het geval van een meineed- of omkopingszaak op grond van art. 31, zelfs niet ten aanzien van de vertrouwelijke verslagen van voorgesprekken. ${ }^{265}$

De initiatiefnemers gingen in hun toelichting ook in op de invoering van een verschoningsrecht voor personen die vrezen zichzelf of anderen daarmee bloot te stellen aan strafrechtelijke vervolging. In de literatuur is, als gezegd, door verschillende auteurs gepleit voor een dergelijk zwijgrecht. De initiatiefnemers wilden dat pad echter niet op. De gemoderniseerde artikelen 30 en 31 zouden voldoende bescherming bieden, ook al is die bescherming niet volledig. De enquêtecommissie dient juist en zo volledig mogelijk te worden geïnformeerd, stellen zij, en een dergelijk verschoningsrecht zou "het belang van informatievergaring door de enquêtecommissie in feite ondergeschikt maken aan het strafproces." 266 De initiatiefnemers wezen erop dat de enquêtecommissie kan kiezen voor een besloten verhoor, wanneer het gevaar van zelfincriminatie aannemelijk is. Bovendien brengt het evenredigheidsbeginsel met zich mee, zo voegden zij daaraan toe, dat wanneer een verklaring

\footnotetext{
263 Zie Lubberdink 2003, p. 27-28. De indieners waren het met Lubberdink eens. Zie Kamerstukken II 2005/06, 30415 , nr. 6, p. 54.

264 Zie art. 25 WPE (oud).

265 De Raad van State adviseerde de bepaling aan te passen, in die zin dat enquetecommissies geen informatie uit voorgesprekken zouden mogen verstrekken aan het openbaar ministerie. De initiatiefnemers wezen dit af en verwezen naar de Van Vondel- en Langendoenzaak, waarin verslagen van voorgesprekken als bewijsmateriaal werden gebruikt. Zie Kamerstukken II 2005/06, 30 415, nr. 4, p. 15.

266 Kamerstukken II 2005/06, 30 415, nr. 6, p. 55-56. Hierbij wordt verwezen naar het standpunt van de initiatiefnemers bij de wetswijziging van 1991, die op grond van de ervaringen tot dan toe eveneens geen reden zagen om het toenmalige art. 24 aan te passen. Zie Kamerstukken II 1988/90, 19 816, nr. 10, p. 6-7. Zie ook Lubberdink 2003, p. 29-30.
} 
belastend zou kunnen zijn, de enquêtecommissie "onder omstandigheden [kan] overwegen geen vragen over dit onderwerp te stellen." 267 Het is dus een verantwoordelijkheid van de commissie om de positie van getuigen steeds in het oog te houden. Dat de bestaande regeling in de praktijk wel degelijk functioneert, zo stelden de initiatiefnemers op vragen vanuit de Eerste Kamer, bleek wel uit de wijze waarop de rechter zich opstelde in de bouwfraudezaken: bewijsmateriaal werd buiten toepassing gelaten, omdat de politie alleen door de enquêteverhoren te volgen op de hoogte had kunnen komen van het bestaan van het materiaal. ${ }^{268}$

Een andere vorm van getuigenbescherming die in de literatuur wel wordt bepleit ${ }^{269}$, het verlenen van strafrechtelijke immuniteit zoals die in de Verenigde Staten bestaat, werd eveneens afgewezen door de initiatiefnemers. Zij vreesden dat getuigen hierdoor zouden gaan "leeglopen" voor een enquêtecommissie in ruil voor immuniteit, wat tot "onaanvaardbare uitkomsten" zou leiden. 270

In de Tweede Kamer toonde alleen de regering zich een voorstander van de invoering van een (familiaal) verschoningsrecht wegens zelfincriminatie. ${ }^{271}$ In de Eerste Kamer bleken verschillende fracties voorstander te zijn van een dergelijk verschoningsrecht. Met een kleine meerderheid werd zelfs een motie aangenomen, waarin in overweging werd gegeven om een "een verschoningsrecht op nonincriminatie (zwijgrecht)" op te nemen in de nieuwe wet. ${ }^{272}$ De regering drong, hoewel zij het wetsvoorstel bekrachtigde, in een brief aan de Kamervoorzitters aan op een "ruimhartige uitvoering" van deze motie en liet hierin uitdrukkelijk de mogelijkheid open om zelf een wetsvoorstel in te dienen. ${ }^{273}$ De Tweede Kamer besloot evenwel op advies van de initiatiefnemers en haar Presidium eerst ervaring te willen opdoen met de nieuwe wet alvorens te beslissen over verdere aanpassingen. ${ }^{274}$

\subsection{Onderzoeksbevoegdheden bij regulier parlementair onderzoek}

\subsubsection{Inleiding}

Hierboven bleek dat het parlementaire enquêterecht een kleurrijke geschiedenis kent en in de loop der tijd vele, vaak constitutioneel geïnspireerde debatten heeft opgeleverd. De andere vormen van onderzoek die binnen het parlement worden verricht, waar geen enquêtebevoegdheden aan te pas komen, hebben in vergelijking veel minder aandacht gekregen. Niettemin maakt de Tweede Kamer veelvuldig gebruik

\footnotetext{
267 Kamerstukken II 2005/06, 30 415, nr. 6, p. 56.

268 Kamerstukken I 2006/07, 30 415, nr. C, p. 27.

269 Doorenbos in De WPE onder de loep 2004, p. 59-60. Zie ook Drexhage 2009, p. 16.

${ }_{270}$ Kamerstukken II 2005/06, 30 415, nr. 6, p. 56. Zie ook de vragen van de D66-fractie in de Eerste Kamer, Kamerstukken I 2006/07, 30 415, nr. C, p. 27.

${ }^{271}$ Handelingen II 2006/07, nr. 13, p. 866. Als alternatief werd een recht op een besloten verhoor genoemd.

272 Motie-Rehwinkel c.s., Kamerstukken I 2006/07, 30 415, nr. J.

273 Kamerstukken II 2007/08, 30 415, nr. 17.

${ }^{274}$ Kamerstukken II 2007/08, 30 415, nr. 18 en Handelingen II 2007/08, 94, p. 6664. Zie voor een kritische noot bij de discussies over een zwijgrecht tijdens de behandeling van de nieuwe Wpe: Drexhage 2009, p. 16. Meer hierover en over de figuur van de strafrechtelijke immuniteit in par. 2.6 en in Deel III.
} 


\section{NEDERLAND}

van niet-wettelijk geregelde vormen van parlementair onderzoek. Het gaat dan voornamelijk om parlementaire commissies die op grond van het Reglement van Orde van de Tweede Kamer (RvOTK) worden ingesteld met een specifieke, onderzoeksgerichte opdracht. Dergelijke onderzoekscommissies komen al geruime tijd voor, zo bleek hierboven reeds, zij het vrij incidenteel. 275 Parallel aan de opleving van het enquêterecht in de jaren 70 en 80 kwam ook deze vorm van parlementair onderzoek steeds vaker voor. Sinds 1983 hebben meer dan dertig parlementaire onderzoeken plaatsgevonden die door een onderzoekscommissie, niet zijnde een enquêtecommissie, zijn uitgevoerd. Van oudsher werd hiervoor veelal de figuur van de bijzondere commissie gehanteerd. Met de herziening van het commissiestelsel in 1994 verdween deze commissievorm. ${ }^{276}$ Sindsdien wordt voor parlementaire onderzoeken waarbij geen enquêtebevoegdheden worden verleend veelal uitgevoerd door zogenaamde tijdelijke commissies. Af en toe hebben ook informele werkgroepen of subcommissies die werden ingesteld door bestaande (vaste) parlementaire commissies zich beziggehouden met onderzoek. In 2008 besloot de Kamer echter dat parlementair onderzoek voortaan slechts in de vorm van een enquêtecommissie of een tijdelijke commissie kan worden uitgevoerd. ${ }^{277}$

Het aantal parlementaire onderzoeken dat de Tweede Kamer heeft uitgevoerd is inmiddels veel groter dan het aantal parlementaire enquêtes. Terwijl elk jaar een of meerdere 'gewone' parlementaire onderzoeken, ook wel quasi-enquêtes genoemd 278 , door de Tweede Kamer worden ingesteld, vinden enquêtes slechts incidenteel plaats. In het navolgende wordt daarom de term 'regulier parlementair onderzoek' gebruikt wanneer wordt gedoeld op parlementaire onderzoeken die geen enquêtestatus hebben. Het betreft overigens een onderzoeksvorm die in de Tweede Kamer tot ontwikkeling is gekomen. Waar in het navolgende gesproken wordt over het 'parlement' of de 'Kamer', wordt daarom gedoeld op de Tweede Kamer. De Eerste Kamer heeft onlangs voor het eerst in haar bestaan een vergelijkbare onderzoekscommissie ingesteld. ${ }^{279}$ Een enquête heeft in de senaat tot op heden niet plaatsgevonden.

\subsubsection{Bevoegdheden}

Het reguliere parlementaire onderzoek wordt, zo is in art. 142 RvOTK bepaald, uitgevoerd door zogenaamde tijdelijke commissies. Deze commissievorm is neergelegd in art. 18 RvOTK. De Kamer kan een tijdelijke commissie instellen "voor specifieke onderwerpen". Deze commissievorm is bij uitstek geschikt voor het instellen van commissies met een onderzoeksopdracht. Het instellingsbesluit moet in ieder geval een nauwkeurige omschrijving van het onderwerp waarover de commissie de Kamer dient te rapporteren bevatten, alsmede de termijn waarvoor de commissie wordt

\footnotetext{
275 Zie par. 2.3.3.

276 Zie Van Schagen 1994, p. 79.

277 Zie Kamerstukken II 2007/08, nr. 31 019, nr. 6, p. 6. Hierover meer hierna, par. 3.2.2.

278 Kortmann 2008, p. 252.

${ }^{279}$ Het gaat om een parlementair onderzoek naar de privatisering en verzelfstandiging van overheidsdiensten (commissie-Kuiper). Zie Handelingen I 2011/12, 2, p. 3. Meer over parlementair onderzoek in de Eerste Kamer en de procedurele inbedding hiervan in par. 3.5.
} 
ingesteld, zo blijkt uit het tweede lid. ${ }^{280}$ Sinds kort kent de Kamer een Regeling parlementair en extern onderzoek (RPE), die kan worden gezien als een bijlage van het Reglement van Orde. ${ }^{281}$ Hierin zijn nadere bepalingen opgenomen ten aanzien van het reguliere parlementaire onderzoek, enquêteonderzoek en extern uitgevoerd onderzoek. ${ }^{282}$

Tijdelijke commissies beschikken over dezelfde bevoegdheden als alle andere commissies die op grond van het Reglement zijn ingesteld. Deze bevoegdheden staan (niet-limitatief) opgesomd in art. 27 RvOTK. Het betreft "in ieder geval": (a) de bevoegdheid om zich tot een minister te wenden ter verkrijging van alle stukken waarvan zij de kennisneming nodig acht, (b) mondeling of schriftelijk in overleg te treden met een minister, (c) rondetafelgesprekken te beleggen of (d) hoorzittingen te houden, (e) werkbezoeken af te leggen, (f) zich te laten voorlichten door adviescolleges en $(\mathrm{g})$ externe deskundigen in te schakelen. ${ }^{283}$ De bevoegdheid onder (a) om zich tot de minister te wenden om kennis te nemen van schriftelijke documenten is ook neergelegd in de RPE. ${ }^{284}$ De commissie kan deze bevoegdheden zelfstandig uitoefenen: verlof van de Kamer of het presidium is niet nodig. De Kamer stelt, na advies van het Presidium, het onderzoeksbudget van de commissie vast. Dit gebeurt aan de hand van het onderzoeksvoorstel, waarin een indicatie van de kosten dient te worden opgenomen. 285

\subsubsection{Betekenis en toepassing}

Belangrijk verschil tussen de bevoegdheden van tijdelijke commissies op grond van het Reglement van Orde en de bevoegdheden waarover enquêtecommissies beschikken op grond van de Wet op de parlementaire enquête, is dat reglementaire bevoegdheden in beginsel slechts de Kamer zelf kunnen binden. Aangezien het een interne regeling betreft, is het uitgangspunt dat slechts de Kamer zelf, haar leden en haar organen rechten of plichten kunnen ontlenen aan het Reglement van Orde. Tijdelijke commissies kunnen dus, anders dan enquêtecommissies, geen medewerking

\footnotetext{
${ }^{280}$ Deze termijn kan op verzoek van de commissie door de Kamer worden verlengd. Zie art. 18, derde lid, RvOTK.

281 Zie art. 140 RvOTK.

${ }^{282}$ Zie voor de bepalingen en de toelichting daarop: Kamerstukken II 2007/08, 31 019, nr. 6 en Handelingen II 2007/08, nr. 105, p. 753-7531. De RPE vervangt het in 2001 ingevoerde 'Draaiboek onderzoek', dat aan herziening toe was naar aanleiding van de vernieuwing van de Wet op de parlementaire enquête. De nieuwe regeling wordt in de Kamerstukken afgekort tot 'RPE', een aanduiding die ook hier zal worden gebruikt.

283 Zie de overeenkomstige secties (a) tot en met (g) van art. 27 RvOTK. De laatste bevoegdheid die in deze bepaling is genoemd, de Kamer voorstellen een groot project aan te wijzen (h), is voor een tijdelijke commissie met een onderzoekstaak minder van belang. Zie ook art. 9, tweede lid, RPE, waarin, anders dan art. 27 suggereert, er vanuit gegaan wordt dat de bevoegdheden van tijdelijke commissies hier wel limitatief zijn opgesomd.

${ }^{284}$ In de toelichting op art. 12, eerste lid, RPE wordt gesteld dat tijdelijke commissies hiertoe een beroep kunnen doen op de inlichtingenplicht van art. 68 Gw. Zie Kamerstukken II 2007/08, 31 019, nr. 6, p. 13.

285 Zie art. 10 RvOTK jo. artt. 4, 6 en 7 RPE.
} 
van derden afdwingen. Ten aanzien van ministers en staatssecretarissen, zo zal hierna nog blijken, ligt dit anders. 286

Dat een tijdelijke commissie niet de bevoegdheid heeft om derden te verplichten om medewerking te verlenen, betekent niet dat een regulier parlementair onderzoek geen effect kan hebben op de positie en belangen van derden. Evenals enquêtes blijken reguliere parlementaire onderzoeken vaak betrekking te hebben op maatschappelijk gevoelige thema's. Voorbeelden zijn de parlementaire onderzoeken naar de besluitvorming rondom infrastructuurprojecten, de tekortkomingen van het tbsstelsel of, recentelijk, de financiële crisis. Evenals de openbare verhoren van enquêtecommissies krijgen de hoorzittingen van parlementaire onderzoekscommissies veel media-aandacht. Getuigen, deskundigen, ministers, ambtenaren en andere betrokkenen wordt tijdens deze hoorzittingen gevraagd naar hun ervaringen of standpunten met betrekking tot het onderzoeksonderwerp. Hoewel deelname aan deze hoorzittingen plaatsvindt op basis van vrijwilligheid, althans voor anderen dan bewindspersonen ${ }^{287}$, kan een verzoek van de onderzoekscommissie om te verschijnen mede door de indringende wijze waarop de pers omgaat met parlementaire onderzoeken een ingrijpende gebeurtenis zijn. Burgers die niet dagelijks met de Haagse politieke praktijk in aanraking komen, kunnen onder sterke politieke en maatschappelijke druk komen te staan, waardoor zij door hun optreden - of weigering daartoe - in hun belangen kunnen worden aangetast. Bovendien, zo bleek in de praktijk, is voor buitenstaanders niet altijd duidelijk welke rechten en plichten zij hebben ten opzichte van een tijdelijke commissie. Het verschil tussen een regulier parlementair onderzoek en een enquêteonderzoek is niet altijd goed zichtbaar.

Het besluit in 2004 om de Wet op de Parlementaire Enquête te moderniseren werd mede daarom door de Kamer aangegrepen om ook het "andere parlementaire onderzoek beter te formaliseren." 288 Volgens het Presidium was de "maatschappelijke impact" van beide onderzoeksvormen "op veel punten vergelijkbaar." De commissie die de opdracht kreeg om een wetsvoorstel voor te bereiden, werd verzocht een regeling te ontwerpen voor zowel de parlementaire enquête als het parlementaire onderzoek. Hierin moest ook aandacht worden besteed aan een aantal andere knelpunten rondom het reguliere parlementaire onderzoek, namelijk de toegang en archivering van vertrouwelijke informatie en de positie van externe onderzoeksbureaus. 289

\footnotetext{
${ }^{286}$ In de literatuur is wel betoogd dat het Reglement van Orde van de Tweede Kamer "externe werking" zou hebben, aangezien het ook voor anderen rechten en plichten zou scheppen "waar men zich naar behoort te gedragen". Zie Hagelstein 1991, p. 77-78. Ook in de Kamer zelf is wel eens voorgesteld om het Reglement externe werking toe te kennen. Vanuit staatsrechtelijk oogpunt is dit echter moeilijk verdedigbaar: het zou immers impliceren dat de Kamer, zelfstandig, over een (wetgevende) bevoegdheid beschikt die zij niet heeft. Zie ook: Bovend'Eert \& Kummeling 2010, p. 19-20. In art. 10 RPE wordt bevestigd dat tijdelijke commissies geen medewerking van derden kunnen afdwingen. De bijzondere positie van ministers en ambtenaren komt aan de orde in par. 2.5 .

${ }^{287}$ Zie hierna, par. 2.5.

288 Kamerstukken II 2003/04, 29547, nr. 1, p. 3.

${ }^{289}$ Kamerstukken II 2003/04, 29 547, nr. 1, p. 3. Over de toegang tot vertrouwelijke stukken en de positie van externe onderzoekers: zie par. 4.4 .
} 
De commissie kwam zelf echter tot de conclusie dat een wettelijke regeling voor het reguliere parlementaire onderzoek niet wenselijk was en presenteerde in december 2005 een wetsvoorstel dat slechts de enquête regelde. Belangrijkste reden daarvoor was dat een wettelijke regeling alleen nodig is "indien op burgers rechtens afdwingbare verplichtingen kunnen worden neergelegd." 290 De Raad van State steunde deze afweging. "Een wettelijke regeling van andere onderzoeken dan de enquête zou die onderzoeken een onnodig zwaar gewicht geven," merkte de Raad op. ${ }^{291}$ In plaats daarvan zou een verbeterde regeling van het parlementair onderzoek in het Reglement kunnen volstaan. Daarin diende volgens de Raad de genoemde knelpunten wel uitdrukkelijk te worden geregeld en uitgewerkt, in het bijzonder de positie van getuigen. Voor hen, zo voegt de Raad toe, "is het nauwelijks relevant dat zij formeel niet tot medewerking verplicht zijn: een verzoek om in het openbaar voor een onderzoekscommissie te verschijnen kan in de praktijk niet goed worden genegeerd." 292

Dat laatste wordt door de initiatiefnemers bestreden: zij menen dat in de praktijk wel degelijk verschil bestaat tussen een oproep om te verschijnen voor een (reguliere) onderzoekscommissie en een oproep van een enquêtecommissie. ${ }^{293}$ Gelet op de eerder aangehaalde publieke druk om medewerking te verlenen bij een onderzoek naar een maatschappelijk gevoelig thema, kunnen bij de praktische betekenis van dit formele onderscheid wel vraagtekens worden gezet. De hoorzittingen die parlementaire onderzoekscommissies houden, kunnen door de thematiek, de toonzetting en de media-aandacht gemakkelijk het karakter krijgen van een openbaar verhoor door een parlementaire enquêtecommissie. Dit wordt misschien nog wel versterkt door de ingebruikname van de nieuwe 'Enquêtezaal' in het Kamergebouw, waar opmerkelijk genoeg ook de hoorzittingen van onderzoekscommissies plaatsvinden. Het verschil is voor de buitenstaander nauwelijks zichtbaar. Het opnemen van een regeling voor het reguliere parlementaire onderzoek in de wet verandert hier op zichzelf echter weinig aan. Op dit punt hebben personen die betrokken raken bij parlementaire onderzoeken waarschijnlijk meer baat bij overzichtelijke informatievoorziening over hun rechten en plichten. Een informatiebrochure, die standaard aan 'buitenstaanders' wordt toegestuurd, lijkt het meest aangewezen. ${ }^{294}$ Bovendien ligt het voor de hand om ook in de beeldvorming een duidelijker onderscheid tussen de twee onderzoeksvormen te maken, bijvoorbeeld door de Enquêtezaal te reserveren voor parlementaire enquêtes en bij de reguliere onderzoeken gebruik te maken van de gewone commissiezalen.

Tijdens de parlementaire behandeling kreeg het standpunt van de initiatiefnemers dat er een scherp onderscheid tussen enquêtes en reguliere onderzoeken moet worden gemaakt, veel steun. Wel riep de Tweede Kamer het Presidium op om snel met een voorstel te komen voor een heldere regeling van het reguliere parlementaire

\footnotetext{
290 Kamerstukken II 2005/06, 30 415, nr. 3, p. 8.

${ }^{291}$ Kamerstukken II 2005/06, 30 415, nr. 4, p. 6.

292 Kamerstukken II 2005/06, 30 415, nr. 4, p. 6.

${ }^{293}$ Kamerstukken II 2005/06, 30 415, nr. 4, p. 6-7.

${ }^{294}$ Naar aanleiding van de vernieuwing van de Wpe is gestart met de ontwikkeling van "voorlichtingsmateriaal voor leden en burgers". Zie Kamerstukken II 2006/07, 30 415, nr. 16.
} 


\section{NEDERLAND}

onderzoek in het Reglement van Orde. ${ }^{295}$ In feite werd hiermee gekozen voor bestendiging en explicitering van de bestaande onderzoeksstructuur. ${ }^{296}$ Er leek weinig behoefte te bestaan aan "vernieuwende vormen van onderzoek", zoals door de PvdA-fractie in de Eerste Kamer opgeworpen, waarbij bijvoorbeeld flexibel zou kunnen worden omgegaan met de toekenning van enquêtebevoegdheden. 297

\subsection{De positie van bewindspersonen en ambtenaren}

Parlementair onderzoek in Nederland is sinds de opleving in de jaren 80 uitgegroeid tot een instrument dat voornamelijk wordt ingezet in het kader van de parlementaire controletaak. ${ }^{298}$ Bij veel parlementaire onderzoeken staat de uitvoerende macht dan ook centraal. Het functioneren van ministers, staatssecretarissen en ambtenaren is soms direct voorwerp van onderzoek. Bovendien spelen zij een sleutelrol als het gaat om het verschaffen van informatie over beleidsvorming en -uitvoering.

In het licht van de in hoofdstuk 1 besproken relatie tussen regering en parlement wordt in deze paragraaf bezien welke positie bewindspersonen en ambtenaren innemen ten opzichte van een parlementaire onderzoekscommissie. In hoeverre zijn ministers, staatssecretarissen en ambtenaren verplicht om medewerking te verlenen aan een parlementair onderzoek? Is hun positie anders dan in het normale verkeer tussen regering en parlement? Wat is het verschil tussen ministers en staatssecretarissen enerzijds en ambtenaren anderzijds? Wat is de positie van de ambtenaren die werkzaam zijn op departementen of bij andere overheidsorganisaties bij enquêtes en reguliere onderzoeken? En maakt het uit of het gaat om een parlementaire enquête of een regulier parlementair onderzoek?

\subsubsection{Ministers en staatssecretarissen}

De Grondwet vormt het fundament voor het verkeer tussen regering en parlement. De positie van ministers en staatssecretarissen ten opzichte van een parlementaire onderzoekscommissie wordt dan ook in de eerste plaats bepaald door de toepasselijke grondwetsbepalingen. In dit verband staan drie bepalingen centraal: de ministeriële verantwoordingsplicht (art. 42, tweede lid), de ministeriële inlichtingenplicht (art. 68) en het enquêterecht (art. 70). Daarnaast bevatten de Wet op de parlementaire enquête 2008 en het Reglement van Orde van de Tweede Kamer bepalingen die betrekking hebben op ministers. Hieronder wordt nagegaan welke verplichtingen deze bepalingen, mede in onderling verband, met zich meebrengen voor ministers in het kader van een parlementair onderzoek.

\footnotetext{
295 Zie Kamerstukken II 2007/07, 30 415, nr. 13.

296 Zie Kamerstukken II 2005/06, 30 415, nr. 10, p. 2. Zie ook Drexhage 2009, p. 7.

297 Zie Kamerstukken I 2006/07, 30 415, nr. B, p. 8-9 en nr. E, p. 4-6. Gewezen werd op ervaringen in het Verenigd Koninkrijk en de Verenigde Staten. Volgens de initiatiefnemers biedt de nieuwe wet in elk geval niet minder flexibiliteit dan de oude wet. Zie Kamerstukken I 2006/07, 30 415, nr. F, p. 11-12. Zie ook de vraag van Tweede-Kamerlid Boelhouwer (PvdA) over de mogelijkheid van 'mini-enquêtes'. Handelingen II 2006/07, nr. 13, p. 830.

298 Zie hierboven, par. 2.2.4.
} 


\subsubsection{Inlichtingenplicht en verantwoordingsplicht}

Art. $68 \mathrm{Gw}$ vormt het belangrijkste aanknopingspunt voor de informatieverstrekking door de regering aan het parlement. ${ }^{299}$ Hierin is bepaald dat ministers en staatssecretarissen de Kamers afzonderlijk en de verenigde vergadering schriftelijk de door een of meerdere leden verlangde inlichtingen geven, waarvan de verstrekking niet in strijd is met het belang van de staat. ${ }^{300}$ Deze ministeriële inlichtingenplicht werd ingevoerd bij de grondwetsherziening van 1848. Met de ministeriële plicht om inlichtingen te verschaffen correspondeert een parlementair recht om inlichtingen te verzoeken en te ontvangen. ${ }^{301}$ De bevoegdheid om de regering te ondervragen over een onderwerp dat niet op de parlementaire agenda staat, heeft zich in de praktijk ontwikkeld tot een recht dat aan individuele Kamerleden toekomt. ${ }^{302}$ Uiteindelijk zijn de woorden "de door een of meer leden verlangde inlichtingen" in 1987 in de Grondwet gekomen. ${ }^{303}$ Hoewel op grond van het huidige art. 68 dus gesproken kan worden van een individueel vragenrecht, worden de inlichtingen nog altijd verstrekt aan de Kamer als geheel.

Aangenomen wordt dat het recht om inlichtingen aan ministers of staatssecretarissen te vragen niet alleen geldt voor individuele Kamerleden, maar ook toekomt aan parlementaire commissies. ${ }^{304}$ Dit ligt ook voor de hand: wanneer Kamerleden individueel het recht hebben om ministers en staatssecretarissen om inlichtingen te verzoeken, dan hebben zij dat recht ook als zij deel uitmaken van een parlementaire commissie. Deze zienswijze sluit aan bij de parlementaire praktijk. Aangezien veel van de parlementaire werkzaamheden, zoals de behandeling van wetsvoorstellen of regeringsnota's, tegenwoordig grotendeels in commissieverband plaatsvinden ${ }^{305}$, is het gebruikelijk geworden dat ministers ook bij commissievergaderingen verschijnen of schriftelijk reageren op hetgeen in een commissie naar voren wordt gebracht. Hieruit kan worden afgeleid, dat bewindspersonen de grondwettelijke plicht hebben om medewerking te verlenen aan een parlementair onderzoek, in die zin dat zij gehouden zijn inlichtingen te verschaffen, waarom door de commissie wordt gevraagd. 306

299 Zie over deze bepaling o.a. Van der Pot/Elzinga \& De Lange 2006, p. 777-782; Kortmann 2008, p. 317-321; Broeksteeg 2004, p. 14-17; Bovend'Eert \& Kummeling 2010, p. 265-279; Bovend'Eert 2002, p. 85-92; Koekkoek 2000, p. 370-373; Van Schagen 1994, p. 236-244; en uitvoerig: Munneke 2006, p. 51163.

$300 \mathrm{Op}$ het belang van de staat als verschoningsgrond wordt nader ingegaan in par. 2.5.3. Hier staat de inlichtingenplicht als zodanig centraal.

${ }^{301}$ In het navolgende worden de termen (ministeriële) inlichtingenplicht en (parlementair) inlichtingenrecht dan ook afwisselend gebruikt.

302 Zie Munneke 2006, p. 69. Zie ook Van Schagen 1994, p. 238-242.

303 Zie Munneke 2006, p. 69-70. Dat het individuele vragenrecht niet reeds in 1983 werd gecodificeerd, had te maken met de verwerping door de Eerste Kamer van het amendement-Faber, waarin naast dit vragenrecht ook de 'minderheidsenquête' werd geregeld. Dat laatste ging de senaat te ver en daarom werd ook de vastlegging van het individuele vragenrecht verworpen. Dit is door de regering gecorrigeerd bij de grondwetsherziening van 1987. Zie Kortmann 1987, p. 225-228.

304 Zie ook Bovend'Eert 2002, p. 91.

305 Zie ook Van Schagen 1994, p. 73.

${ }^{306}$ De uitzonderingen op deze verplichting komen hierna nog aan de orde. 
Ministers en staatssecretarissen, zo stelt art. 68, geven de kamers "mondeling of schriftelijk de door een of meer leden verlangde inlichtingen". Betekent deze zinsnede nu dat de betreffende bewindspersoon de keuze heeft om, afhankelijk van zijn voorkeur, de informatie mondeling dan wel schriftelijk te verstrekken? Hiervan lijkt geen sprake te zijn: het parlement heeft niet alleen het recht om inlichtingen te vragen, maar kan daarbij tevens aangeven op welke wijze die inlichtingen dienen te worden verstrekt. Wanneer de commissie meent onvoldoende te worden ingelicht door de minister, dan is het aan de kamer om de minister te verzoeken alsnog over de brug te komen. Hoewel de Grondwet niet voorziet in een methode om de inlichtingenplicht feitelijk af te dwingen, kan de kamer wel te allen tijde politieke middelen inzetten om de gewenste inlichtingen boven tafel te krijgen. In het uiterste geval kan dat resulteren in het verlies van vertrouwen. 307

Hieruit volgt, dat ministers en staatssecretarissen ook ten opzichte van een parlementaire (onderzoeks)commissie verplicht zijn om inlichtingen te verschaffen op de wijze die de commissie aangeeft. Daarbij kan het gaan om het verschaffen van mondelinge inlichtingen, schriftelijke inlichtingen of het verlenen van inzage in documenten waarover de betreffende bewindspersonen beschikken. De Tweede Kamer zelf gaat er eveneens vanuit dat haar commissies bevoegd zijn de minister te verzoeken om bepaalde documenten te verstrekken, zo blijkt uit art. 27 RvOTK, waar het informatierecht van kamercommissies nader is gespecificeerd. Voor een goede vervulling van haar taken, zo wordt hier gesteld, is een commissie onder meer bevoegd "zich tot een minister te wenden ter verkrijging van alle stukken waarvan zij de kennisneming nodig acht" en "mondeling of schriftelijk in overleg te treden met een minister". ${ }^{308}$ Wel kan worden aangenomen, dat een tijdelijke commissie in haar vraagstelling beperkt wordt door de reikwijdte van de onderwerpsbeschrijving die de Kamer bij haar instelling heeft vastgesteld. 309

In de literatuur is discussie over de exacte reikwijdte van de inlichtingenplicht van art. $68 \mathrm{Gw}$. Zo bestaat allereerst verschil van mening over het vermeende verband tussen de inlichtingenplicht en de ministeriële verantwoordelijkheid. Door sommigen wordt betoogd dat de omvang van de grondwettelijke inlichtingenplicht van een minister gelijk is aan de omvang van de eveneens grondwettelijke ministeriele verantwoordelijkheid. Zo ziet Kortmann een duidelijk verband tussen art. 42, waarin de politieke ministeriële verantwoordelijkheid is vastgelegd, en art. 68. De inlichtingenplicht maakt duidelijk aan wie de minister verantwoording moet afleggen en werkt die verantwoordingsplicht nader uit. ${ }^{310}$ De inlichtingenplicht strekt zich, zo volgt uit deze redenering, slechts uit over die aangelegenheden waarvoor de minister ook verantwoordelijkheid draagt. Worden inlichtingen gevraagd over zaken die niet onder de verantwoordelijkheid van de minister vallen, dan is de minister dus niet verplicht om de gevraagde inlichtingen aan de kamer te verstrekken. ${ }^{311}$

${ }^{307}$ Zo meent ook de minister van Binnenlandse Zaken in zijn notitie over de reikwijdte van art. 68 Gw. Zie Kamerstukken II 2001/02, 28 362, nr. 2, p. 3-4. Zie ook Bovend'Eert \& Kummeling 2010, p. 274.

308 Zie art. 27, sub a en b, RvOTK.

${ }^{309}$ Zie art. 18, tweede lid, RvOTK.

310 Kortmann 2008, p. 317-318.

311 Zie voorts Munneke 2006, p. 76-77. 
Verschillende auteurs bestrijden deze beperkte visie op de reikwijdte van de grondwettelijke inlichtingenplicht. Zo wijst Broeksteeg er bij wijze van voorbeeld op dat de minister van Justitie niet verantwoordelijk is voor de inhoud van rechterlijke uitspraken, maar dat een kamerlid een minister wel kan vragen om een reactie op een rechterlijke uitspraak en de mate waarin de minister bereid is zijn beleid op die uitspraak aan te passen. Het geven van inlichtingen en het afleggen van verantwoording moeten daarom worden onderscheiden: ook wanneer een vraag betrekking heeft op een onderwerp dat niet tot de portefeuille van een minister behoort, dient hij volgens Broeksteeg toch informatie te verstrekken. ${ }^{312}$ Ook Munneke gaat uit van een ruimere opvatting. In zijn dissertatie gaat hij in op het historische verband tussen de grondwettelijke verantwoordingsplicht en de inlichtingenplicht van art. 68. De aanleiding voor het opnemen van een expliciete inlichtingenplicht in de nieuwe Grondwet van 1848 was de opstelling van de Koning in de periode daaraan voorafgaand. Koning Willem I had zijn ministers geregeld verboden om het parlement inlichtingen te verschaffen omtrent allerlei zaken die met regelgeving te maken hadden en daarom ontstond de wens om bij de grondwetsherziening een specifieke bepaling op te nemen die het informatierecht van het parlement ten opzichte van de regering zou waarborgen. ${ }^{313}$ Hoewel de politieke ministeriële verantwoordelijkheid en de inlichtingenplicht beide in 1848 werden ingevoerd, is de conclusie dat de tweede louter een uitwerking is van de eerste om historische redenen dus niet juist. De ministeriële verantwoordelijkheid moet dan ook niet als een begrenzing van de inlichtingenplicht worden beschouwd. Aangenomen mag worden, zoals Munneke stelt, dat de inlichtingenplicht meebrengt dat informatie "van welke aard en waarover ook" op verzoek dient te worden verschaft, ook wanneer het verstrekken daarvan niet kan worden opgevat als het afleggen van verantwoording. 314

Ook de regering lijkt deze ruime opvatting van de inlichtingenplicht te steunen, zo kan uit de kabinetsnotitie die de minister van Binnenlandse Zaken en Koninkrijksrelaties in 2002 omtrent dit onderwerp naar de kamer stuurde, worden opgemaakt. De inlichtingenplicht, zo stelt de minister, "vloeit voort uit de verantwoordingsplicht die in het parlementaire stelsel ligt opgesloten", maar "[u]itsluitend het belang van de staat kan aan het verstrekken van inlichtingen in de weg staan." 315 De Grondwet vereist dus dat alle inlichtingen, van welke aard ook, waarom door een of meerdere kamerleden wordt gevraagd, worden verstrekt, tenzij zulks in strijd is met het belang van de staat.

In de kabinetsnotitie en de literatuur worden, naast het belang van de staat, nog wel andere beperkingen genoemd. Munneke wijst op de functie van het parlementaire inlichtingenrecht, namelijk het mogelijk maken van een goede parlementaire taakvervulling. Het ligt daarom voor de hand, dat ministers niet verplicht zijn om inlichtingen te verschaffen die geheel niet bijdragen aan de verwezenlijking van de

\footnotetext{
312 Broeksteeg 2004, p. 16.

313 Zie voor een uitgebreide weergave van deze geschiedenis: Munneke 2006, p. 52-65. Zie ook Van Schagen 1994, p. 238-239.

314 Munneke 2006, p. 83.

315 Kamerstukken II 2001/02, 28 362, nr. 2, p. 1-3.
} 
parlementaire taken, waarvan wetgeving en controle de belangrijkste zijn. ${ }^{316}$ Verder wordt algemeen aangenomen dat een minister niet gehouden is inlichtingen te verstrekken wanneer daarbij 'natuurlijke belemmeringen' bestaan. ${ }^{317}$ Hiervan is sprake wanneer het verzamelen of het verstrekken van informatie onevenredig veel moeite zou kosten of wanneer de gevraagde gegevens simpelweg niet voorhanden zijn. Het komt ook voor dat bewindspersonen weigeren om gegevens te verstrekken die wel voorhanden zijn, maar waarvan zij het verstrekken om politieke of andere redenen niet wenselijk achten, zonder dat daarbij direct een beroep op het belang van de staat wordt gedaan. Dit wordt wel een 'aanvankelijke weigering' genoemd. Van een uitzondering op de inlichtingenplicht kan in zo'n geval geen sprake zijn: het gaat immers om politieke onwenselijkheid en niet om feitelijke onmogelijkheid om informatie te verstrekken. De minister zal in debat met de vragensteller moeten motiveren waarom de inlichtingen geheel of gedeeltelijk geweigerd worden, waarna de kamer desnoods haar politieke middelen kan inzetten om de minister onder druk te zetten, zodat deze alsnog over de brug zal komen. ${ }^{318}$ De aanvankelijke weigering wordt in de praktijk breed geaccepteerd. ${ }^{319}$

Wettelijke geheimhoudingsverplichtingen doen in het algemeen niet af aan de inlichtingenplicht van ministers ten opzichte van het parlement. De grondwettelijke inlichtingenplicht is van een hogere orde en doorgaans zien wettelijke verplichtingen niet op de bijzondere inlichtingenrelatie tussen regering en parlement. Uitgangspunt is daarom, dat wettelijke geheimhoudingsverplichtingen niet zijn bedoeld om de grondwettelijke inlichtingenplicht te beperken. Alleen wanneer een geheimhoudingsplicht uitdrukkelijk de bijzondere relatie tussen regering en parlement betreft, kan een weigering op die grond in materiële zin als staatsbelang worden aangemerkt. Dit is in de praktijk zeer uitzonderlijk. ${ }^{320}$ Anders ligt het bij geheimhoudingsplichten die van een hogere orde zijn, zoals verplichtingen op grond van rechtstreeks werkend Europees recht. Soms gaat het daarbij om dusdanig strenge geheimhoudingsnormen, dat deze nationale grondwettelijke inlichtingenplichten te boven kunnen gaan. ${ }^{321}$ Niettemin zouden tegenstrijdige verplichtingen, zo stelt Munneke,

\footnotetext{
${ }^{316}$ Munneke noemt inlichtingen omtrent zaken die louter privékwesties betreffen, bijvoorbeeld van de minister of een kamerlid, en dus niets met het openbaar belang van doen hebben, als voorbeeld van inlichtingen die buiten de reikwijdte van art. $68 \mathrm{Gw}$ vallen. Munneke 2006, p. 84.

317 Zie Kamerstukken II 2001/02, 28 362, nr. 2, p. 4-6. Zie ook Bovend'Eert \& Kummeling 2010, p. 271272 en Kortmann 2008, p. 318-319.

${ }^{318}$ Geconstateerd moet worden dat een kamerlid, dat op grond van art. 68 een individueel vragenrecht bezit, in het geval van een aanvankelijke weigering betrekkelijk machteloos is. Wanneer de vragensteller in een debat de minister niet kan overtuigen van de noodzaak om de inlichtingen te verstrekken, dan is hij aangewezen op de steun van de kamer die de minister met behulp van politieke middelen zou kunnen dwingen. Zie verder Munneke 2006, p. 90-91. Van Schagen stelt dat de waarde van het individuele inlichtingenrecht echter niet moeten worden onderschat, al was het maar vanwege het belang dat aan het juist informeren van de kamer (en daarmee ook van een individueel kamerlid) wordt gehecht. Zie Van Schagen 1994, p. 242.

319 Van der Pot/Elzinga \& De Lange 2006, p. 780. Zie verder Munneke 2006, p. 89-90.

320 Zie hierover nader: Munneke 2006, p. 148-150.

${ }^{321}$ Munneke 2006, p. 151. Dit speelde in het bijzonder bij de Enquête Financieel Stelsel. Zie hierover hierna, par. 2.5.3.2.
} 
zoveel mogelijk met elkaar verenigd dienen te worden, bijvoorbeeld door na te gaan in hoeverre vertrouwelijke verstrekking van gegevens mogelijk is. 322

Zoals gezegd heeft de kamer, indien een minister weigert - al dan niet met een expliciet beroep op het belang van de staat - om de door een of meer leden verlangde inlichtingen te verstrekken, de mogelijkheid om zijn politieke middelen in te zetten teneinde de minister van gedachten te doen veranderen. De ultieme sanctie daarbij is het opzeggen van het vertrouwen in de minister. Indien de minister niet uit eigen beweging opstapt, is hiervoor uiteraard wel een Kamermeerderheid nodig. Vastgesteld moet worden, dat de kamer een minister uiteindelijk niet kan dwingen om de gevraagde inlichtingen daadwerkelijk te verschaffen. ${ }^{323}$ Buiten deze algemene c.q. tijdelijke beperkingen aan de inlichtingenplicht, kan een minister op grond van art. $68 \mathrm{Gw}$ uiteindelijk alleen volharden in zijn weigering om bepaalde inlichtingen te verstrekken met een beroep op het belang van de staat. Daarbij is van belang dat art. $68 \mathrm{Gw}$ niet dwingend voorschrijft, dat inlichtingen aan het parlement altijd in openbaarheid worden verstrekt; vertrouwelijke inzage of kennisgeving is mogelijk, indien het belang van de staat zich tegen openbaarheid verzet.

Met het uitgangspunt dat ministers verplicht zijn om inlichtingen te verschaffen aan de Kamer, wordt in de praktijk tamelijk flexibel omgegaan. Ministers weigeren soms aanvankelijk om inlichtingen te verstrekken zonder dat daarbij de praktische onuitvoerbaarheid of strijd met het staatsbelang wordt aangehaald. Uiteindelijk is het aan de Kamer om te bepalen of een minister in dergelijke gevallen al dan niet terecht weigert en blijft weigeren om de door een of meerdere Kamerleden gevraagde inlichtingen te verstrekken. ${ }^{324}$ Deze op politieke opportuniteit gebaseerde werkwijze bestond overigens al voor de invoering van het individuele vragenrecht in 1987; bij de behandeling van het wijzigingsvoorstel is niet uitdrukkelijk bedoeld deze praktijk af te schaffen. ${ }^{325} \mathrm{Er}$ is slechts gepoogd de bestaande gewoonte om ook vragen van parlementaire minderheden toe te staan, te codificeren. Deze pragmatische praktijk past bij de Nederlandse verhouding tussen regering en parlement. Aan de ene kant vormt het huidige art. 68 een erkenning van de rechten van parlementaire minderheden, omdat individuele Kamerleden geen verlof van de Kamer meer nodig hebben om inlichtingen aan bewindspersonen te vragen. Aan de andere kant bevestigt de praktijk dat het Nederlandse parlementaire stelsel uitgaat van een regering die steunt op een parlementaire meerderheid en waarbij de relatie tussen regering en parlement niet alleen door grondwettelijke bepalingen maar ook door politieke verhoudingen wordt bepaald.

\footnotetext{
${ }^{322}$ Munneke 2006, p. 153.

323 Zie ook Kortmann 2008, p. 319-320; Van der Pot/Elzinga \& De Lange 2006, p. 780-781. Het is overigens nog nooit voorgekomen dat een minister wegens het uitsluitend weigeren van verstrekken van inlichtingen aan de kamer heeft moeten opstappen. (Anders ligt het bij het verstrekken van onjuiste inlichtingen.) Kennelijk is de dreiging van een vertrouwensbreuk voldoende, of weet men middels politiek overleg tot overeenstemming te komen.

324 Zie ook de genoemde kabinetsnotitie over art. 68, waar de regering aangeeft dat het uiteindelijk de kamermeerderheid is die besluit of met het antwoord van de minister genoegen genomen wordt. Kamerstukken II 2001/02, 28 362, nr. 2, p. 3.

${ }^{325}$ Zie Kortmann 1987, p. 227-228.
} 


\section{NEDERLAND}

Resumerend kan, aan de hand van bovenstaande bespreking van de grondwettelijke inlichtingenplicht, het volgende worden gesteld over de constitutionele positie van ministers in het kader van een parlementair onderzoek. Ministers zijn in beginsel op grond van art. 68 verplicht om alle inlichtingen te verstrekken waarom een parlementaire onderzoekscommissie vraagt. De wijze waarop deze inlichtingen dienen te worden verschaft, wordt bepaald door de commissie. Het kan gaan om het verstrekken van mondelinge inlichtingen, schriftelijke inlichtingen of het verlenen van inzage in documenten. De commissie kan de minister vragen om middels het verstrekken van inlichtingen verantwoording af te leggen, maar de minister is ook buiten zijn verantwoordingsplicht verplicht om de inlichtingen te verstrekken waarom de commissie verzoekt. Dit geldt in het algemeen niet voor informatie die op geen enkele wijze verband houdt met de parlementaire takuitoefening, of indien er natuurlijke belemmeringen bestaan. In het kader van een parlementair onderzoek komt daarbij, dat het moet gaan om inlichtingen die verband houden met de onderzoeksopdracht die de Kamer voor de onderzoekscommissie heeft vastgesteld. In het reguliere verkeer tussen regering en parlement is voorts aanvaard, dat ministers op politieke gronden aanvankelijk weigeren om bepaalde informatie te verstrekken. Aangenomen kan worden, dat dit ook geldt in de relatie tussen minister en parlementaire onderzoekscommissie. Het is vervolgens aan de Kamer om te bepalen of de gebruikelijke politieke middelen moeten worden ingezet om de minister te bewegen alsnog de gevraagde inlichtingen te verstrekken, waarbij het opzeggen van vertrouwen als ultieme sanctie kan worden gezien. Volhardt een minister in zijn weigering om bepaalde inlichtingen te verschaffen, dan kan dat op grond van art. $68 \mathrm{Gw}$ alleen met een beroep op het belang van de staat. Hierop wordt nader ingegaan in paragraaf 2.5.3.

\subsubsection{Medewerkingsplicht bij enquêtes}

De algemene medewerkingsplicht bij enquêtes, die is neergelegd in art. 14 Wpe 2008, geldt eveneens voor ministers en staatssecretarissen. De wet kent ministers geen bijzondere status toe. Hieruit kan worden afgeleid, dat bewindspersonen geen vragen onbeantwoord kunnen laten of verzoeken naast zich neer kunnen leggen die geen betrekking hebben op hun functie. ${ }^{326}$ Ministers hebben het recht zich, zoals ieder ander, gedurende het gehele enquêteonderzoek te laten bijstaan. ${ }^{327}$ In verband met de ministeriële verantwoordelijkheid geldt voor gewezen ministers en staatssecretarissen, dat zij slechts door tussenkomst van de minister-president medewerking kunnen verlenen aan een verzoek om schriftelijke inlichtingen of documenten wan-

\footnotetext{
${ }^{326}$ Vgl. Munneke 2006, p. 282-283.

327 Art. 17, eerste lid, Wpe 2008. Wel kan de commissie besluiten "om gewichtige redenen" dat iemand zich tijdens een voorgesprek of verhoor niet mag laten bijstaan. Het is de vraag of dit geen strijd oplevert met art. 69, derde lid, Gw, waarin is vastgelegd dat bewindspersonen zich tijdens parlementaire vergaderingen kunnen doen bijstaan. Zie Drexhage 2009, p. 13, noot 106. Deze kwestie lijkt mij echter vergelijkbaar met de vraag of de parlementaire immuniteit van art. 71 van toepassing is tijdens een verhoor. Zie hierna, par. 2.5.1.4.
} 
neer deze betrekking hebben op hun ambtsperiode. ${ }^{328}$ Van belang is verder, dat de wet een aantal bijzondere verschoningsrechten kent voor (gewezen) bewindspersonen, waaronder het belang van de staat. ${ }^{329}$

De ministeriële verplichting om medewerking te verlenen aan een parlementaire enquête was lang niet vanzelfsprekend. Ten tijde van de grondwettelijke verankering van het enquêterecht leefde bij velen de opvatting dat het enquêterecht moet worden onderscheiden van het gewone inlichtingenrecht. ${ }^{330}$ Terwijl het inlichtingenrecht gericht is op ministers, zo was de gedachte, is het enquêterecht in eerste instantie bedoeld om inlichtingen te verkrijgen van derden. Het biedt het parlement de mogelijkheid om informatie van anderen, waaronder ook ambtenaren moeten worden gerekend, te krijgen en zo nodig af te dwingen. Het belangrijkste instrument dat enquêtecommissies in 1850 in de Enquêtewet kregen toebedeeld, was dan ook de mogelijkheid om getuigen te verplichten om te verschijnen voor verhoor. Ministers werden van deze verplichting uitdrukkelijk uitgezonderd. Een minister kon daarmee alleen worden ondervraagd door de kamer zelf, op grond van de reguliere inlichtingenplicht. De wet stelde destijds ten aanzien van de algemene getuigplicht voor personen die zich "binnen het Rijk" bevonden, dat "de hoofden der ministeriële departementen" alleen konden worden ondervraagd "op de wijze bij art. 89 der Grondwet voorgeschreven". ${ }^{331}$ Hier werd gedoeld op de interpellatie, waarvan Thorbecke in 1856 zei: "Een interpellatie is een enquête op ministers en een enquête is een interpellatie op alle andere ingezetenen." 332 Wel kende de Enquêtewet de verplichting voor zowel ministers als ambtenaren om de enquêtecommissie inzage te verlenen in voor handen zijnde stukken, tenzij naar hun oordeel het belang van de staat zich daartegen zou kunnen verzetten. 333

De positie van ministers in het kader van de parlementaire enquête veranderde na de Tweede Wereldoorlog. Omdat het parlement tijdens de bezettingsjaren 19401945 ontbonden was, werd de enquête gezien als een alternatief instrument waarmee de leden van de regering in Londen verantwoording konden afleggen omtrent het gevoerde regeringsbeleid. De uitzonderingsclausule in de wet werd daarom in 1948 aangevuld met de woorden "behoudens voor zover de verlangde inlichtingen betrekking hebben op een periode gedurende welke de Staten-Generaal ten gevolge van een ingetreden noodtoestand niet of niet normaal gefunctioneerd hebben" 334 . Hiermee ontstond dus een opening in de wettelijke barrière. De opvatting dat het enquêterecht, buiten deze bijzondere situatie, niet gebruikt kan worden om inlichtin-

\footnotetext{
328 Zie art. 16, eerste lid, Wpe 2008. Deze bepaling is tijdens de behandeling in de Tweede Kamer ingevoegd naar aanleiding van vragen van de VVD-fractie. Zie nader: Kamerstukken II 2005/06, 30 415, nr.

10, p. 11 en Kamerstukken II 2005/06, 30 415, nr. 11.

${ }^{329}$ Hierover meer in par. 2.5.3.

330 Zie hierboven, par. 2.2.1.

331 Art. 3 Enquêtewet 1850.

332 Zie Dölle 1985, p. 35.

333 Zie art. 20 Enquêtewet 1850 ("Het hoofd van het departement van algemeen bestuur bij hetwelk, of onder wiens ondergeschikte ambtenaren, stukken voorhanden zijn, welker inzage door de commissie, als met het onderwerp des onderzoeks in verband staande, schriftelijk verlangd wordt, bewilligt die inzage, tenzij hij oordeelen mogt dat zij met het belang en de zekerheid van het Rijk, de kolonien en bezittingen van het Rijk in andere werelddeelen in strijd zoude kunnen zijn.")

${ }^{334}$ Dölle 1985, p. 50.
} 
gen van de regering te verkrijgen, verloor in de naoorlogse periode steeds meer aan overtuigingskracht. Uiteindelijk werd in 1977, toen de enquêtewet ook op andere punten werd gewijzigd, de uitzondering op de getuigplicht voor ministers geschrapt. De indieners van het wijzigingsvoorstel meenden, overigens pas na opmerkingen vanuit de Kamer op een eerder wetsontwerp, dat de betreffende uitzondering niet langer nodig was. ${ }^{335}$ Deze wetswijziging legde de basis voor de transformatie van het enquêterecht tot controle-instrument in de jaren 80 .

Gevolg hiervan is dat de medewerkingsplicht van ministers in het kader van een parlementaire enquête wat betreft haar omvang sterk is gaan lijken op de inlichtingenplicht die ministers op grond van art. $68 \mathrm{Gw}$ ten opzichte van reguliere parlementaire onderzoekscommissies hebben. In beide gevallen zijn ministers in beginsel verplicht om in een verklaring de gevraagde inlichtingen te verschaffen en om de commissie te laten kennisnemen van schriftelijke stukken. Verschil is nog wel, dat enquêtecommissies, in tegenstelling tot individuele Kamerleden, in de uitoefening van hun bevoegdheden beperkt worden door de grenzen van hun onderzoeksopdracht. ${ }^{336}$ De juridische betekenis van deze begrenzing is overigens beperkt: het inzetten van dwangmiddelen uit de Wpe tegen een weigerachtige minister is uitgesloten, zoals hierna nog zal blijken. Een rechterlijk oordeel naar aanleiding van een weigering om een vraag op deze grond te beantwoorden, dat toch al terughoudend zou zijn in verband met het subjectief geformuleerde evenredigheidsbeginsel, valt in het geval een conflict tussen bewindspersonen en enquêtecommissies niet te verwachten. In dergelijke conflicten, zo laat ook de praktijk zien, komt het aan op een politieke oplossing.

Betekent dit nu ook, dat voor het verkrijgen van inlichtingen van bewindspersonen het enquêterecht en het inlichtingenrecht in feite inwisselbaar zijn geworden? Dat lijkt mij toch weer wat te sterk uitgedrukt. Gelet op de bijzondere verhouding tussen regering en parlement en het specifiek daarvoor bedoelde instrument van art. $68 \mathrm{Gw}$, alsmede het zware karakter van het enquêterecht, ligt het voor de hand dat de kamers zich steeds in eerste instantie van hun inlichtingenrecht bedienen. Veel sterker kan het niet worden gesteld: het blijft aan de kamer om te bepalen of en wanneer zij het enquêtemiddel inzet. ${ }^{337}$ In de literatuur wordt verder betoogd dat de bijzondere verhouding eveneens met zich meebrengt, dat niet van bewindspersonen kan worden verlangd dat zij ten overstaan van een enquêtecommissie verantwoording afleggen in de zin van art. 42 , tweede lid, Gw. De verantwoordingsplicht, zo is de gedachte, geldt jegens de gehele Kamer en niet slechts ten opzichte van een parlementaire enquêtecommissie. Wel zou de commissie vragen kunnen stellen die er op gericht zijn vast te stellen wat de reikwijdte van de ministeriële verantwoordelijkheid

\footnotetext{
335 Kamerstukken II 1976/77, 13 837, nr. 6, p. 6-7.

${ }^{336}$ Het vertalen van de beschrijving van de onderzoeksopdracht naar concrete grenzen met betrekking tot de vraagstelling zal echter niet altijd eenvoudig zijn. Zie Munneke 2006, p. 286. Zie verder hierboven, par. 2.3.1.

${ }^{337}$ Dölle stelt in dit verband echter dat uit de aard van het parlementaire stelsel kan worden afgeleid dat een minister pas door een enquêtecommissie zou moeten worden opgeroepen als pogingen om de gewenste informatie via de normale weg te verkrijgen, zijn gestrand. Zie Dölle 1985, p. 128. Deze opvatting lijkt mij te strict en, hoe het ook zij, in elk geval niet in overeenstemming met de sindsdien ontstane enquêtepraktijk.
} 
is. ${ }^{338}$ Hierboven is reeds aangegeven, dat deze zienswijze te beperkend is. Niet valt in te zien, waarom de Kamer een enquêtecommissie niet zou kunnen opdragen om feitenonderzoek bijvoorbeeld te combineren met een verantwoordingsproces. ${ }^{339}$

Samengevat komt het bovenstaande er op neer, dat de verplichting voor ministers en staatssecretarissen om medewerking te verlenen aan parlementaire onderzoeken niet verschilt van de normale verplichtingen die bewindspersonen jegens de Kamer hebben op grond van art. $68 \mathrm{Gw}$. Daarbij maakt het in wezen niet uit of het om een enquêtecommissie gaat of om een tijdelijke commissie in het kader van een regulier parlementair onderzoek. ${ }^{340}$ De positie van bewindspersonen bij enquêtes en reguliere onderzoeken verschilt wel op andere punten. Daarop wordt hieronder ingegaan.

\subsubsection{Dwangmiddelen en sancties}

Een bijkomend gevolg van de wetswijziging van 1977 was, dat de wettelijke dwangmiddelen en sancties voortaan ook ingezet konden worden tegen onwillige bewindspersonen. Ook kreeg de enquêtecommissie hiermee de bevoegdheid om een minister of staatssecretaris onder ede te verhoren. ${ }^{341}$ Indien het vermoeden bestond dat een bewindspersoon een valse verklaring had afgelegd, zou deze zelfs kunnen worden vervolgd op grond van meineed.

Bovenstaande machtsmiddelen hebben in de moderne enquêtepraktijk ten opzichte van ministers en staatssecretarissen weinig reële betekenis gehad. Mogelijk hebben de initiatiefnemers destijds deze consequenties van het opheffen van de uitzondering voor ministers op de getuigplicht niet voorzien. De initiatiefnemers van de Wpe 2008 corrigeerden dit in elk geval door het inzetten van dwangmiddelen en het opleggen van sancties jegens bewindspersonen expliciet uit te sluiten. ${ }^{342} \mathrm{Na}$ kritiek van de Raad van State op het eerste wetsontwerp dat zij aan de Kamer stuurden, waarin de inzet van dwangmiddelen en sancties uitdrukkelijk werd opengelaten, concludeerden de indieners "bij nader inzien" dat zulks niet paste bij de staatsrechtelijke verhouding tussen regering en parlement. Indien een bewindspersoon onvoldoende medewerking zou verlenen aan een enquêteonderzoek, zo stelden zij, "kunnen uitsluitend politieke conclusies worden getrokken." Op deze manier werd bovendien voorkomen, dat de rechter - als "derde" - uiteindelijk zou moeten oordelen over een conflict tussen regering en parlement over medewerking aan een enquêteonderzoek. ${ }^{343}$ Ook Kamerleden, op wie in beginsel eveneens een algemene medewerkingsplicht rust, werden bij deze gelegenheid om dezelfde redenen uit-

\footnotetext{
338 Zie Munneke 2006, p. 285-289.

339 Zie nader: par. 2.3.1.

${ }^{340} \mathrm{Bij}$ de behandeling van de vernieuwde enquêtewet bevestigden de initiatiefnemers dit beeld door te stellen dat "er in de relatie tot het kabinet in beginsel geen verschil bestaat tussen een parlementaire enquête en ander parlementair onderzoek." Zie Kamerstukken II 2005/06, 30 415, nr. 10, p. 2.

$341 \mathrm{Al}$ mag worden aangenomen dat de verplichting om de waarheid te spreken evenzeer geldt in andere gevallen waarbij een minister inlichtingen aan de Kamer verstrekt.

342 Zie art. 29 Wpe 2008 en art. 192d Sr.

343 Zie het advies van de Raad van State, Kamerstukken II 2005/06, 30 415, nr. 4, p. 5 en de toelichting ten aanzien van het hierna nog te bespreken ministeriële verschoningsrecht inzake het belang van de staat, Kamerstukken II 2005/06, 30 415, nr. 6, p. 40.
} 


\section{NEDERLAND}

drukkelijk uitgezonderd van de inzet van dwangmiddelen en sancties. ${ }^{344}$ De nieuwe wet bevestigt verder dat een enquêtecommissie de mogelijkheid heeft om schriftelijke inlichtingen van bewindspersonen te vorderen. In de oude wet kwam dit niet expliciet naar voren. ${ }^{345}$

De mogelijkheid van het afnemen van een verhoor onder ede is in de nieuwe Wpe wel gehandhaafd. In de praktijk was de gewoonte ontstaan om ministers en staatssecretarissen, evenals andere getuigen, altijd onder ede te verhoren. De indieners waren van mening dat het "een zeer vreemde indruk" zou wekken als op dit punt een verschil zou worden gemaakt tussen bewindspersonen enerzijds en alle andere getuigen anderzijds. Wel stelden zij, in navolging van de Raad van State, dat bewindspersonen (en Kamerleden) in het geval zij een valse verklaring onder ede zouden afleggen, niet kunnen worden vervolgd wegens meineed op grond van de parlementaire immuniteitsregeling van art. $71 \mathrm{Gw} .{ }^{346}$

Dit laatste komt mij niet juist voor. De immuniteit voor strafvervolging, zoals die in art. $71 \mathrm{Gw}$ is vastgelegd, geldt alleen voor "leden van de Staten-Generaal, de ministers, de staatssecretarissen en andere personen die deelnemen aan de beraadslaging". In de literatuur wordt er vanuit gegaan, dat personen die worden gehoord door een Kamercommissie geen aanspraak maken op de bescherming van art. 71.347 Dit lijkt mij terecht, immers, gehoord worden door een commissie is iets wezenlijk anders dan 'deelnemen aan beraadslagingen'. In die zin verschilt de positie van bewindspersonen niet van die van elke andere persoon die wordt gehoord. Art. 71 is daarom niet van toepassing in het geval van een bewindspersoon die wordt gehoord door een (reguliere) parlementaire onderzoekscommissie. 348 Ook bij enquêtes is een beroep op art. $71 \mathrm{Gw}$ daarom niet mogelijk, al geldt op grond van art. 30 Wpe 2008 voor een minister of staatssecretaris, zoals voor elke getuige, dat verklaringen op vordering van de commissie afgelegd in rechte niet als bewijsmateriaal kunnen worden gebruikt. ${ }^{349}$ Veroordeling op grond van art. 32 Wpe 2008 wegens het afleggen van een valse verklaring onder ede lijkt mij echter, anders dan de initiatiefnemers en de Raad van State aannemen, in elk geval formeel niet uitgesloten. Of een vervolging van ministers of staatssecretarissen wegens meineed praktisch erg waarschijnlijk is, kan echter betwijfeld worden. Er zijn immers ook politieke middelen om een minister die de waarheid geweld aandoet, te bestraffen.

\footnotetext{
344 Zie eveneens art. 29 Wpe 2008 en art. 192d Sr. Kamerstukken II 2005/06, 30 415, nr. 6, p. 28, 48.

345 Daarmee is niet gezegd dat enquêtecommissies onder de oude wet die mogelijkheid niet zouden hebben. De commissie zou dan immers minder mogelijkheden hebben om inlichtingen te vragen dan een willekeurig Kamerlid op basis van art. 68. Zie verder Kamerstukken II 2005/06, 30 415, nr. 6, p. 1617. Doel van de nieuwe bepaling is overigens om ook "derden" te verplichten om schriftelijk inlichtingen te verschaffen; de indieners gaan er, zo lijkt het, dus vanuit dat ministers en ambtenaren deze plicht reeds hadden.

346 Zie Kamerstukken II 2005/06, 30 415, nr. 4, p. 5-6 en nr. 6, p. 23.

347 Zie bijvoorbeeld Bovend'Eert \& Kummeling 2010, p. 144-145.

${ }^{348}$ Vgl. ook Drexhage 2009, p. 13, noot 103.

${ }^{349}$ Art. 30 Wpe 2008.
} 


\subsubsection{Ambtenaren}

\subsubsection{Departementsambtenaren}

In het dagelijkse verkeer tussen regering en parlement blijven ambtenaren doorgaans buiten beeld. Het stelsel van ministeriële verantwoordelijkheid, zoals dat voortvloeit uit art. 42, tweede lid Gw en art. 44, eerste lid, Gw, brengt mee dat ministers niet alleen verantwoordelijkheid dragen voor hun eigen handelen, maar ook voor dat van de aan hen ondergeschikte ambtenaren. ${ }^{350}$ Deze ondergeschikte rijksambtenaren zijn voornamelijk werkzaam op de departementen en de daartoe behorende rijksdiensten. Kort gezegd betekent dit dat de kamer zich bij de controle op departementsambtenaren dient te richten tot de verantwoordelijke minister. Deze ambtenaren zijn zelf geen verantwoording schuldig aan het parlement.

Buiten het verantwoordingsproces zijn contacten tussen ambtenaren en de Kamers slechts in beperkte mate mogelijk. Ambtenaren dienen zich daarbij te houden aan de voorschriften, die zijn vastgelegd in de Aanwijzingen externe contacten rijksambtenaren 1998. Deze regeling is vastgesteld door de minister-president na overleg met de ministerraad. ${ }^{351}$ Hieruit blijkt dat een minister van geval tot geval kan beslissen om schriftelijke of mondelinge contacten met ambtenaren op verzoek van de Kamers toe te staan. De minister bepaalt zelf of hij met een dergelijk verzoek instemt en met welke ambtenaar contact kan worden gelegd. Bovendien is in de Aanwijzingen vastgelegd dat de contacten zoveel mogelijk in aanwezigheid van de minister plaatsvinden. Ambtenaren dienen zich in alle gevallen te beperken tot het verstrekken van mededelingen van feitelijke aard. Openbare rapporten of documenten worden op verzoek direct toegezonden aan het parlement, maar wanneer het gaat om andere schriftelijke inlichtingen dan wel een rapport of document dat naar het oordeel van de ambtenaar niet openbaar is, wordt het verzoek doorgeleid aan de minister. Dit geldt ook in het geval van mondelinge contacten. De minister kan altijd een verzoek vanuit de kamer weigeren. Tenslotte kunnen ambtenaren zelf alleen op aanwijzing van de betrokken minister in contact treden met een Kamerlid. ${ }^{352}$

De regeling beoogt, gelet op het beginsel van de ministeriële verantwoordelijkheid, alle contacten tussen ambtenaren en kamer(leden) via de minister te laten verlopen. "In het algemeen", zo wordt in de toelichting gesteld, "vinden geen rechtstreekse contacten plaats tussen de beide kamers der Staten-Generaal en ambtenaren." 353 Directe contacten tussen ambtenaren en parlement moeten dus als uitzonderlijk worden beschouwd. ${ }^{354}$

\footnotetext{
350 Zie verder o.a. Van der Pot/Elzinga \& De Lange 2006, p. 515-516; Bovend'Eert \& Kummeling 2010, p. 266-267. Andere vormen van ministeriële verantwoordelijkheid, zoals de verantwoordelijkheid voor de Koning en de strafrechtelijke en civielrechtelijke ministeriële verantwoordelijkheid, blijven hier buiten beschouwing. De bijzondere positie van ambtenaren werkzaam op niet hiërarchisch ondergeschikte diensten, zoals zelfstandige bestuursorganen (zbo's), komt hierna nog aan de orde.

351 Stcrt. 1998, nr. 104, p. 8.

352 Zie Aanwijzingen 3 tot en met 7, Stcrt. 1998, nr. 104, p. 8.

353 Zie toelichting bij Aanwijzing 1, Stcrt. 1998, nr .104, p. 8.

354 Deze restrictieve regeling (ook wel de 'Oekaze Kok' genoemd) is totstandgekomen in 1998, na een aantal incidenten waarbij ambtenaren zich in de media kritisch uitlieten over het regeringsbeleid. Zie
} 
Wat betekent dit nu voor de positie van departementsambtenaren bij parlementaire onderzoeken? Bij regulier parlementair onderzoek geldt de normale verhouding tussen ministers, ambtenaren en Kamer, zoals die voortvloeit uit de artt. 42 en 68 Gw en de Aanwijzingen externe contacten. Dit betekent dat ambtenaren geen zelfstandige rol spelen, maar uitsluitend met goedvinden van de verantwoordelijke minister medewerking verlenen aan een parlementaire onderzoekscommissie. Voor zover ambtenaren medewerking verlenen, doen zij dit in naam van de minister. Het Reglement van Orde van de Tweede Kamer sluit hierbij aan. Wil een commissie een rijksambtenaar horen, dan dient zij zich tot de verantwoordelijke minister te richten. 355 Op grond van de Aanwijzingen dient de ambtenaar zich te beperken tot het verstrekken van feitelijke informatie. Voor het verkrijgen van inzage in departementale stukken zal de commissie zich rechtstreeks moeten richten tot de minister. ${ }^{356}$

Bij parlementaire enquêtes ligt dit anders. In de systematiek van de wet vallen ambtenaren, evenals ministers, in beginsel gewoon onder de algemene medewerkingsplicht. ${ }^{357}$ De getuigplicht van art. 9 Wpe 2008 is van toepassing, zij het dat ambtenaren bij enquêtes een zelfstandig beroep kunnen doen op het belang van de staat. ${ }^{358}$ Het ligt anders ten aanzien van het verstrekken van schriftelijke inlichtingen en documenten. Voor zover deze schriftelijke inlichtingen of documenten betrekking hebben op "de periode van zijn ambtsvervulling", verleent een ambtenaar die ten behoeve van een minister werkt alleen medewerking "door tussenkomst van" de minister. ${ }^{359}$ Dit betekent, kort gezegd, dat departementale stukken alleen door ministers kunnen worden verstrekt en niet door ambtenaren. ${ }^{360}$ Ook bij voormalige amb-

ook Bovend'Eert \& Kummeling 2010, p. 292; Verhey 2001a, p. 4, 28-29; en uitvoerig: Enthoven 2011, p. 371-468.

355 Zie art. 29, tweede lid, RvOTK.

356 Zie art. 27, sub a, RvOTK. Zie ook art. 12, eerste lid, Regeling onderzoek.

357 Dit volgt uit de algemene medewerkingsplicht van art. 14 Wpe 2008. Voorheen kende de wet een aparte bepaling inzake de medewerkingsplicht van ambtenaren. Zie art. 3, derde lid, WPE (oud). Het bestaan van deze bepaling kan worden teruggevoerd op de Enquêtewet van 1850. De eerste volzin van het toenmalige art. 3 luidde: "Van het tijdstip der eerste bekendmaking af, zijn alle ingezetenen en andere binnen het grondgebied des rijks verblijf houdende personen verpligt aan de oproepingen tot verhoor te voldoen door de commissie uitgevaardigd, en alle openbare ambtenaren gehouden om, in overeenstemming met de bepalingen dezer wet, gevolg te geven aan de vorderingen der commissie van onderzoek, die deze tot uitvoering van haren last noodig oordeelt." Stb. 1850, 45. Op ambtenaren rustte een ruimere verplichting om medewerking te verlenen dan op gewone burgers; de laatsten konden slechts worden opgeroepen voor verhoor, terwijl ambtenaren, zo blijkt uit art. 21, met toestemming van hun minister ook schriftelijke stukken ter beschikking moesten stellen. Sinds de inzageplicht ook op gewone burgers rust, biedt de bepaling over ambtenaren weinig toegevoegde waarde meer. Die mening waren ook de initiatiefnemers van de nieuwe wet toegedaan. Zie Kamerstukken II 2005/06, 30415 , nr. 6, p. 30.

358 Zie hierna, par. 2.5.3.

359 Zie art. 16, tweede lid, Wpe 2008.

360 Met de woorden "door tussenkomst van de minister" hebben de indieners, zo bevestigen zij na vragen van de Raad van State, dus bedoeld duidelijk te maken dat het de minister is die deze documenten verstrekt. Ambtenaren die aan een minister ondergeschikt zijn, hebben dus geen zelfstandige verantwoordelijkheid om schriftelijke stukken te verstrekken of - met een beroep op het staatsbelang - verstrekking te weigeren. Kamerstukken II 2005/06, 30 415, nr. 4, p. 11-12. Bij de Enquête Financieel Stelsel bleek dit toch anders te werken. Zo kwam het voor, dat ambtenaren naar aanleiding van een besloten voorgesprek of na een openbaar verhoor toezeggingen deden over het beschikbaar stellen 
tenaren geldt dat, indien zij nog departementale stukken voorhanden hebben, de commissie deze uitsluitend via de minister kan opvragen. ${ }^{361}$ De medewerkingsplicht van ambtenaren beperkt zich daarmee feitelijk tot een getuigplicht. ${ }^{362}$

De enquêtecommissie behoeft niet, zoals reguliere parlementaire onderzoekscommissies, eerst toestemming te vragen aan de verantwoordelijke minister om in contact te treden met een ambtenaar. Ook kan de minister niet aanwijzen welke ambtenaar gehoord mag worden. Bij het verhoren van ambtenaren zijn enquêtecommissies niet gehouden om zich tot vragen van feitelijke aard te beperken; wanneer dit in het belang van het onderzoek is, kan ambtenaren ook om persoonlijke opvattingen of oordelen over bijvoorbeeld gevoerd beleid worden gevraagd. De mogelijkheid om ambtenaren zelfstandig te verhoren biedt de enquêtecommissie de gelegenheid om de personen die achter de schermen betrokken zijn bij de ontwikkeling en uitvoering van beleid te ondervragen over aangelegenheden die voor het onderzoek van belang zijn.

Echter, ook de relatie tussen minister en ambtenaar zelf kan voorwerp van onderzoek zijn. Zo stelde de Raad van State dat via een parlementaire enquête "eventuele verschillen tussen minister en ambtenaren in het openbaar kunnen worden blootgelegd." 363 Volgens de Raad kan de zelfstandige rol van ambtenaren bij een enquête daarom leiden tot een 'doorkruising' van de ministeriële verantwoordelijkheid. De initiatiefnemers vonden deze conclusie te ver gaan: ambtenaren zijn immers niet zelf verantwoordelijk voor de inlichtingen die zij aan een enquêtecommissie verstrekken. Voor zover deze verklaring betrekking heeft op hun ambtsvervulling, zo stellen de initiatiefnemers, wordt deze aan de minister toegerekend. ${ }^{364}$

Dit laatste lijkt mij strict genomen niet helemaal juist. Eerder is namelijk gesteld, dat het uitgangspunt is dat de omvang van de ministeriële verantwoordelijkheid in

van nadere, schriftelijke informatie. Deze informatie werd vervolgens veelal rechtstreek door de betrokken ambtenaar aan de commissie verstrekt. Dit gebeurde ook door voormalige ministers, die volgens de wet uitsluitend door tussenkomst van de minister-president documenten kunnen verstrekken. De commissie loste dit op, door de betrokken minister c.q. de minister-president mede te delen dat de betreffende informatie officieel gevorderd werd, waardoor de betreffende bewindspersoon de mogelijkheid kreeg om tussenbeide te komen. Deze werkwijze heeft in de praktijk geen problemen opgeleverd, concludeert de commissie, al wordt "door alle betrokkenen (...) geconstateerd dat artikel 16 onvoldoende duidelijkheid biedt in de hierboven beschreven gevallen." Zie Kamerstukken II 2011/12, 31 980, nr. 61, p. 575.

361 Zie wederom art. 16, tweede lid, Wpe 2008. De Raad van State adviseerde om ten aanzien van gewezen ambtenaren niets te regelen, aangezien zij niet langer onder de ministeriële verantwoordelijkheid vallen. De initiatiefnemers dachten hier anders over en wezen erop, dat voormalige ambtenaren wellicht nog departementale stukken op hun thuiscomputer hebben staan. Wanneer het stukken betreft die door de minister in het belang van de staat niet zouden worden verstrekt, dan zou de enquêtecommissie deze stukken dus via een omweg alsnog kunnen verkrijgen. Dat werd als ongewenst beschouwd. Zie verder Kamerstukken II 2005/06, 30 415, nr 4, p. 12.

362 Naast de bevoegdheid om ambtenaren onder ede te verhoren kan de commissie ook het recht op binnentreden (art. 7 Wpe 2008) toepassen ten aanzien van departementale ambtenaren. De wet laat toe dat de enquêtecommissie ministeries betreedt. Deze bevoegdheid omvat overigens niet het doorzoeken en kennisnemen van documenten. Zie Kamerstukken II 2005/06, 30 415, nr. 6, p. 17. Zie verder: hierboven, par. 2.3.2.3.

363 Kamerstukken II 2005/06, 30 415, nr. 4, p. 4.

364 Zie Kamerstukken II 2005/06, 30 415, nr. 4, p. 4 en Kamerstukken II 2005/06, 30 415, nr. 6, p. 30. 


\section{NEDERLAND}

Nederland wordt bepaald aan de hand van het adagium 'geen verantwoordelijkheid zonder bevoegdheid'. ${ }^{365}$ De algemene getuigplicht van art. 14 Wpe 2008 brengt met zich mee, dat de zeggenschap van de minister met betrekking tot het handelen van zijn ambtenaren wordt beperkt zodra de commissie departementsambtenaren op grond van art. 9 Wpe 2008 oproept voor verhoor. In het vigerende stelsel van de ministeriële verantwoordelijkheid betekent dit, dat de verklaring die een ambtenaar op vordering van de commissie aflegt niet aan de minister kan worden toegerekend. Wel stellen de initiatiefnemers terecht, dat een enquêteverhoor niets afdoet aan de verantwoordelijkheid van de minister voor het ambtelijk handelen waarover de ambtenaar een verklaring aflegt. Niettemin lijkt het mij verstandig om een onderscheid te maken tussen de verklaring enerzijds en het 'onderliggende' handelen anderzijds. De minister kan slechts ter verantwoording worden geroepen ten aanzien van het laatste. Dit staat los van het verhoor. De eventuele persoonlijke interpretaties of oordelen die een ambtenaar daarover tijdens een enquêteverhoor verstrekt, kunnen daarmee niet onder de ministeriële verantwoordelijkheid worden gebracht.

Het voorgaande leidt tot de conclusie, dat departementsambtenaren tijdens een enquêteverhoor uitsluitend op persoonlijke titel spreken. Ministers kunnen slechts door de Kamer ter verantwoording worden geroepen ten aanzien van het onderliggende departementale optreden, dat bij het verhoor naar voren komt. Dit heeft belangrijke consequenties. Waar de politiek-ambtelijke verhoudingen in het normale verkeer gekenmerkt worden door een hoge mate van vertrouwelijkheid, kan de bijzondere positie die ambtenaren innemen tijdens een parlementaire enquête ervoor zorgen dat deze verhoudingen onder druk komen te staan. ${ }^{366}$

\subsubsection{Adviescolleges en zelfstandige bestuursorganen}

Naast departementsambtenaren nemen ook personen die werkzaam zijn bij overheidsorganisaties die niet of niet geheel ondergeschikt zijn aan een minister een bijzondere plaats in bij parlementair onderzoek. Aan de ene kant betreft het organen die wegens hun taken onafhankelijk zijn van regering en parlement. Hierbij kan gedacht worden aan adviescolleges zoals de Raad voor het openbaar bestuur (Rob) en de Gezondheidsraad. Aan de andere kant is er een grote groep zogenaamde zelfstandige bestuursorganen. Hiertoe behoren enerzijds toezichthoudende organen, zoals de Nederlandse Mededingingsautoriteit (NMa), anderzijds ook grote 'beschikkingenfabrieken' zoals het Uitvoeringsorgaan Werknemersverzekeringen en de Sociale Verzekeringsbank. Kenmerkend is dat ten aanzien van deze adviescolleges en zelfstandige bestuursorganen geen of slechts beperkte ministeriële verantwoordelijkheid bestaat. De omvang van de ministeriële zeggenschap (en daarmee van de ministeriële verantwoordelijkheid) hangt af van regelingen hieromtrent in de instellingswet van het betreffende orgaan. In vergelijking met departementale ambtenaren, die geheel ondergeschikt zijn aan de verantwoordelijke minister, nemen zij daarom een bijzondere positie in. 367

\footnotetext{
365 Zie par. 1.3.1.

${ }^{366}$ Meer hierover in par. 2.5.3.

${ }^{367} \mathrm{Zie}$ over de verzelfstandiging van overheidsorganisaties ook: hierboven, par. 1.3.2.
} 
Regulier parlementair onderzoek. Bij regulier parlementair onderzoek gelden, zoals hierboven reeds bleek, dezelfde staatsrechtelijke normen als in het dagelijkse verkeer tussen regering en parlement. Terwijl de positie van departementsambtenaren ten opzichte van een parlementaire onderzoekscommissie helder is, omdat deze wordt bepaald aan de hand van de ministeriële verantwoordelijkheid, kan dit niet worden gezegd ten aanzien van personen werkzaam bij adviesraden en zelfstandige bestuursorganen. De klassieke ministeriële verantwoordelijkheid geldt niet of niet volledig. Bovendien zijn de Aanwijzingen inzake externe contacten op deze groep niet van toepassing.

Op grond van de Kaderwet adviescolleges kunnen de Kamers adviescolleges die zijn ingesteld om de regering te adviseren omtrent wetgeving en beleid, schriftelijk om advies vragen. Het adviescollege behandelt de adviesaanvraag vervolgens op de wijze, voorgeschreven door de wet. ${ }^{368}$ Kort gezegd houdt dit in, dat het adviescollege de aanvraag zelfstandig en onafhankelijk van de aanvrager behandelt. De selectie van de leden van deze adviescolleges vindt plaats op basis van deskundigheid. Benoeming gebeurt bij koninklijk besluit voor de duur van vier jaar. Deze periode kan tweemaal worden verlengd. Ministers beschikken niet over een aanwijzingsbevoegdheid ten aanzien van deze personen. $\mathrm{Zij}$ kunnen bovendien alleen worden ontslagen op zwaarwegende gronden. ${ }^{369}$ De ministeriële verantwoordelijkheid voor deze personen is hierdoor zeer beperkt. In hoeverre deze adviescolleges en hun leden ook buiten de wettelijke adviseringsprocedure medewerking kunnen verlenen aan een parlementair onderzoek, bijvoorbeeld door het afleggen van een verklaring tijdens een hoorzitting, wordt uit de wet niet duidelijk. Hierbij geldt, dat de functie en positie van het adviescollege nader wordt bepaald in zijn eigen instellingswet.

In de praktijk zouden de leden of medewerkers van adviescolleges vooral een bijdrage aan parlementair onderzoek kunnen leveren in hun rol als deskundigen. 370 Gezien hun positie als zelfstandige en onafhankelijke adviseur van zowel regering als parlement, is er weinig op tegen wanneer een lid of medewerker bijvoorbeeld als deskundige zouden worden gehoord of wanneer een college zou worden benaderd om op zelfstandige en onafhankelijke wijze een (deel)onderzoek uit te voeren. Een verplichting om medewerking te verlenen hebben zij echter niet.

Ook ten aanzien van zelfstandige bestuursorganen is niet helemaal duidelijk in hoeverre en op welke wijze hun bestuurders en medewerkers medewerking kunnen verlenen aan parlementair onderzoek. Ook zbo's zouden door parlementaire onderzoekscommissies kunnen worden benaderd met het oog op hun specifieke deskundigheid, maar daarnaast is onderzoek naar het functioneren van zbo's, gelet op hun voorname rol in het openbaar bestuur en de budgetten waarmee zij werken, in de praktijk ook goed denkbaar. De ministeriële verantwoordelijkheid voor het handelen van zbo's, hun bestuurders en medewerkers is beperkt. De precieze omvang daarvan wordt bepaald door de bevoegdheden die de minister ten aanzien van een zbo heeft op grond van de instellingswet en, indien van toepassing, de Kaderwet zelfstandige

\footnotetext{
368 Art. 17 e.v. Kaderwet adviescolleges.

369 Zie artt. 11-13 Kaderwet adviescolleges.

370 Parlementair onderzoek naar het functioneren van adviescolleges zelf is uiteraard ook denkbaar, maar minder waarschijnlijk.
} 
bestuursorganen. Ten aanzien van de ministeriële bevoegdheden en daarmee van de mate waarin ministers formeel invloed kunnen uitoefenen op beleid en besluitvorming binnen een zbo, zijn de verschillen groot. Soms zijn deze bevoegdheden grotendeels beperkt tot het benoemen en ontslaan van bestuurders, in andere gevallen beschikt de minister tevens over bijvoorbeeld budgettaire of aanwijzingsbevoegdheden. Het parlement staat op afstand en kan ministers alleen ter verantwoording roepen ten aanzien van de beperkte bevoegdheden die zij hebben. Een rechtstreekse verantwoordingsrelatie tussen zbo's en het parlement ontbreekt.

Wanneer een parlementaire onderzoekscommissie informatie wil met betrekking tot het handelen van zbo's, dan kan zij twee wegen bewandelen. De directe weg is om bij de bestuurders of medewerkers van het zbo zelf aan te kloppen. De normale verantwoordingsrelatie tussen ministers en ambtenaren geldt immers niet. Tenzij de instellingswet een regeling bevat omtrent contacten met het parlement, mag worden aangenomen dat het een zbo vrij staat om - met inachtneming van eventuele geheimhoudingsplichten of andere wettelijke beperkingen - medewerking te verlenen aan een parlementair onderzoek. Verplicht zijn zij hiertoe echter niet. ${ }^{371}$ Het bestuur van een zbo zal in de praktijk afwegen in hoeverre en op welke wijze medewerking aan een parlementair onderzoek kan worden verleend, bijvoorbeeld gelet op de taak en positie van het zbo, de aard van de gevraagde inlichtingen en eventuele conflicterende verplichtingen of belangen.

De commissie zou, indien het zbo zou weigeren, ook bij de meest betrokken minister kunnen aankloppen. Gegevens die eventueel bij de minister of diens ministerie aanwezig zijn zullen moeten worden verstrekt, zo volgt uit art. $68 \mathrm{Gw}$. Een andere ingang wordt verschaft door de Kaderwet zelfstandige bestuursorganen. Ministers hebben ten behoeve van de uitoefening van hun taak op grond van art. 20 van deze wet een algemeen inlichtingen- en inzagerecht ten aanzien van zbo's waarop deze wet van toepassing is. ${ }^{372}$ De commissie zou de betrokken minister(s) kunnen aansporen om gebruik te maken van dit inlichtingenrecht dan wel het zbo op die grond ervan te overtuigen om alsnog medewerking te verlenen. De wet geeft het zbo echter wel de bevoegdheid om bij het verstrekken van inlichtingen aan de minister aan te geven, welke gegevens een vertrouwelijk karakter hebben. Deze vertrouwelijkheid kan voortvloeien uit de aard van de gegevens, dan wel uit afspraken die met de verstrekker van de gegevens hieromtrent zijn gemaakt. De minister dient omtrent die gegevens geheimhouding te bewaren. Het is niet duidelijk of hieruit moet worden afgeleid dat de minister in dat geval ook jegens het parlement een geheimhoudingsplicht bezit. ${ }^{373}$ Indien dit in de praktijk zo zou moeten worden geïnterpreteerd, dan kan de verstrekking van inlichtingen aan een parlementaire onderzoekscommissie langs deze weg, als het erop aankomt, dus uiteindelijk altijd verhinderd worden door

\footnotetext{
371 Zie ook Verhey \& Verheij 2005, p. 239-240.

372 Deze inlichtingenplicht, zo blijkt uit de memorie van toelichting, is bedoeld om de minister in staat te stellen om verantwoording af te leggen aan het parlement omtrent de uitoefening van de bevoegdheden die hij heeft ten aanzien van het zbo. Zie Kamerstukken II 2000/01, 27 426, nr. 3, p. 16, 26. Voor zbo's die niet onder de werking van de kaderwet vallen, moet worden teruggevallen op de instellingswet om te bepalen in hoeverre de betrokken minister over een inlichtingenrecht beschikt.

${ }^{373}$ De tekst van de bepaling noch de parlementaire geschiedenis geven hieromtrent duidelijkheid. Zie Verhey \& Verheij 2005, p. 229.
} 
het zbo. Andere wettelijke geheimhoudingsplichten van ministers en zelfstandige bestuursorganen worden door het algemene ministeriële inlichtingenrecht overigens niet opgeheven. ${ }^{374}$ Met name bij financiële toezichthouders spelen bijzondere geheimhoudingsplichten, soms voortvloeiend uit het Europese recht, die verstrekking van informatie aan een parlementaire onderzoekscommissie zouden kunnen verhinderen. ${ }^{375}$ De Tijdelijke commissie onderzoek financieel stelsel (Tcofs), die in 2009 onderzoek deed naar de oorzaken van de financiële crisis en aanbevelingen deed voor een verbeterde werking van het financiële stelsel, werd hiermee geconfronteerd toen zij een groot aantal interne, veelal vertrouwelijke stukken opvroeg bij de minister van Financiën en de president van De Nederlandsche Bank. Hier ging het om de geheimhoudingsplicht op grond van artikel 1:89 Wet op het financieel toezicht. De commissie heeft in samenspraak met het ministerie, DNB en de Autoriteit Financiële Markten "gezocht naar de grenzen van de geheimhoudingsplicht, zodat op prudente wijze recht kon worden gedaan aan de betrokken belangen." Naar eigen zeggen zijn haar informatieverzoeken accuraat behandeld. ${ }^{376}$

Parlementaire enquêtes. Bij parlementaire enquêtes geldt, dat ook de leden, bestuurders en ambtenaren van adviescolleges en zelfstandige bestuursorganen onder de algemene medewerkingsplicht van art. 14 Wpe 2008 vallen. De uitzondering op de algemene medewerkingsplicht die voor departementsambtenaren geldt, namelijk dat schriftelijke inlichtingen of documenten uitsluitend door de minister worden verstrekt, geldt niet voor deze groep personen. De leden, bestuurders en ambtenaren van adviescolleges en zelfstandige bestuursorganen kunnen op dit punt dus zelfstandig voldoen aan vorderingen van de enquêtecommissie. 377 Tot 2008 was dit anders. In art. 22 WPE (oud) was geregeld dat de regeling voor de inzage in schriftelijke bescheiden waarover de aan de minister ondergeschikte ambtenaren beschikken (art. 21 , eerste lid), eveneens van toepassing is op "de leden van staatscolleges of andere ambtenaren, wier werkkring hen niet rechtstreeks onder enig ministerie rangschikt". 378

Juist omdat deze organen niet onder de (volledige) ministeriële verantwoordelijkheid vallen, zagen de initiatiefnemers van de nieuwe wet geen aanleiding om het verstrekken van informatie nog langer via de meest betrokken minister te laten lopen. ${ }^{379}$ De reeds bestaande mogelijkheid om medewerking te weigeren met een beroep op het belang van de staat, bleef wel ongewijzigd. De indieners achtten het ongewenst dat een enquêtecommissie bepaalde informatie niet van een minister of

\footnotetext{
374 Kamerstukken II 2000/01, 27 426, nr. 3, p. 26.

375 Zie uitvoerig: Verhey \& Verheij 2005, p. 239-244.

376 De gemaakte afspraken over de informatieverschaffing en de wijze waarop de commissie met vertrouwelijke gegevens zal omgaan zijn, zoals in Nederland gebruikelijk, vastgelegd in informatieprotocollen. Zie Kamerstukken II 2009/10, 31 980, nrs. 3-4, p. 31-32. Het gebruik van protocollen komt nog uitvoerig aan de orde in Deel I, par. 4.5.

377 De Hoge Colleges van Staat, de Nationale ombudsman, alle adviescolleges, alle toezichthouders en alle zelfstandige bestuursorganen op centraal niveau, door de indieners "overige tot de staat behorende organen" genoemd, kunnen rechtstreeks inlichtingen en documenten leveren wanneer de enquêtecommissie daarom verzoekt. Kamerstukken II 2005/06, 30 415, nr. 6, p. 31.

378 De oude bepaling stamde, op enkele taalkundige wijzigingen na, nog geheel uit 1850 .

379 Kamerstukken II 2005/06, nr. 6, p. 31. Tijdens de parlementaire behandeling werd aan deze vernieuwing geen nadere aandacht besteed.
} 


\section{NEDERLAND}

diens ambtenaren kan krijgen, maar wel bij een ander overheidsorgaan. Het is, zo voegden zij daaraan toe, immers niet onwaarschijnlijk dat een zelfstandig bestuursorgaan of een adviescollege beschikt over informatie die afkomstig is van ministeries. ${ }^{380}$ Artikel 19, eerste lid, Wpe 2008 bepaalt daarom kortweg dat ambtenaren "werkzaam of werkzaam geweest ten behoeve van een tot de staat behorend orgaan" niet verplicht zijn "informatie aan de commissie te verstrekken, voor zover deze verstrekking in strijd met het belang van de staat is". 381

Sinds de inwerkingtreding van de Wpe 2008 is de positie van adviescolleges en zelfstandige bestuursorganen bij enquêtes dus veranderd. Voortaan hebben hun leden, bestuurders en ambtenaren bij enquêtes niet alleen een getuigplicht, maar ook een verplichting tot het rechtstreeks verlenen van inzage in schriftelijke informatie waarover zij beschikken. In de nieuwe wet is er uitdrukkelijk voor gekozen dat wettelijke geheimhoudingsplichten niet gelden tijdens een parlementaire enquête. Er is geen equivalent van art. $20 \mathrm{Kzbo}$, waarbij het zbo de vertrouwelijke omgang met de verstrekte inlichtingen zou kunnen afdwingen; wel zou een beroep op een van de wettelijke verschoningsgronden kunnen worden gedaan. ${ }^{382} \mathrm{Al}$ met al kan worden gesteld dat enquêtecommissies, althans op papier, veel directer toegang krijgen tot zelfstandige bestuursorganen. Bezien zal moeten worden hoe dit in de praktijk uitpakt. 383

\subsubsection{Verschoningsrechten}

Uit het bovenstaande kan worden afgeleid, dat ministers en staatssecretarissen op grond van de inlichtingenplicht van art. $68 \mathrm{Gw}$ in beginsel verplicht zijn om medewerking te verlenen aan een parlementair onderzoek. In het geval van een parlementaire enquête geldt die verplichting ook voor departementsambtenaren en personen werkzaam bij adviescolleges en zelfstandige bestuursorganen.

De bijzondere positie die de regering inneemt in het staatsbestel brengt echter met zich mee, dat het verschaffen van inlichtingen aan een Kamer (of aan een van haar commissies) in sommige gevallen niet - of slechts in beperkte mate - gerechtvaardigd zal zijn. Zowel de Grondwet als de Wet op de parlementaire enquête voorzien daarom in een bijzondere verschoningsgrond voor de regering: het belang van de staat. Bij parlementaire enquêtes is daarnaast het geheim van de ministerraad als verschoningsgrond in de wet opgenomen.

\subsubsection{Regulier parlementair onderzoek}

Bij regulier parlementair onderzoek geldt, dat ministers, zo volgt uit art. $68 \mathrm{Gw}$, alleen verplicht zijn om mondelinge of schriftelijke inlichtingen te verstrekken voor

\footnotetext{
380 Kamerstukken II 2005/06, 30 415, nr. 6, p. 31.

381 Zie hierover verder: par. 2.5.3.

382 Tegelijkertijd spelen ook bij enquêtes de bijzondere geheimhoudingsplichten die bepaalde zbo's, met name financiële toezichthouders, deels op grond van Europeesrechtelijke voorschriften in acht dienen te nemen. Zie hierover nader: par. 4.4.2.

${ }^{383}$ Zie ook hierna, par. 2.5.3.2.
} 
zover dat niet in strijd is met het belang van de staat. Een beroep op het belang van de staat is de enige grondwettelijke manier om de weigering tegenover de kamer te kunnen volhouden en te legitimeren. ${ }^{384}$ Het is daarom van belang om vast te stellen wat onder het begrip 'belang van de staat' moet worden verstaan. Hierover kan betrekkelijk weinig met zekerheid worden gezegd. Een blik op de grondwetsgeschiedenis levert niet veel aanknopingspunten op. Bij de invoering van de inlichtingenplicht in 1848 heeft de regering bewust getracht met de introductie van een vrij onbepaald begrip een bepaalde bewegingsruimte voor zichzelf te creëren. De door Thorbecke voorgestelde formulering waarbij slechts in het geval van het verklaren van oorlog en het sluiten van vrede een beroep op het staatsbelang (destijds nog rijksbelang genoemd) geoorloofd was, werd niet gevolgd. ${ }^{385}$

In het bestaan van onduidelijkheid over de exacte betekenis van de uitzonderingsgrond in art. 68 schuilt uiteraard een gevaar. Wanneer een beroep op het staatsbelang mogelijk is op elk moment dat een minister om wat voor reden dan ook geneigd is te weigeren het parlement te informeren, dan verliest het begrip elk onderscheidend vermogen. ${ }^{386}$ In de loop der tijd is dan ook van verschillende kanten getracht om het begrip 'belang van de staat' nader te definiëren. 387 Overzichtelijk in dit verband is een kabinetsnotitie uit 2002 over de reikwijdte van art. 68 Gw. De minister van Binnenlandse Zaken en Koninkrijksrelaties gaat in die notitie in op de vraag in welke gevallen het verstrekken van inlichtingen met een beroep op het staatsbelang mag worden geweigerd, dan wel uitsluitend in vertrouwelijke vorm zou kunnen gebeuren. Hierin worden zes categorieën van belangen geïdentificeerd, die onder omstandigheden zo zwaar kunnen wegen dat een weigering om inlichtingen hieromtrent te verstrekken aan de kamer met een beroep op het staatsbelang gerechtvaardigd zou zijn. Het betreft: de eenheid van de Kroon, de veiligheid van de staat, vertrouwelijk verstrekte bedrijfsinformatie, de bescherming van de persoonlijke levenssfeer, persoonlijke beleidsopvattingen in stukken voor intern beraad en gegevens omtrent lopende strafzaken. 388

De genoemde categorieën zijn afgeleid van de Wet openbaarheid van bestuur (Wob). In deze wet is een soortgelijke opsomming van gevallen te vinden, waarin het bestuur geen informatie behoeft te verstrekken aan de verzoekende burger. ${ }^{389}$ Hoewel het te ver voert om hier op elk van deze categorieën nader in te gaan, is het goed om enkele algemene kanttekeningen te plaatsen bij deze opsomming. Allereerst geeft deze opsomming slechts beperkte duidelijkheid: zoals de regering ook al aangeeft,

\footnotetext{
${ }^{384}$ Hoewel een weigering aanvankelijk ook zonder een expliciet beroep op deze uitzonderingsgrond mogelijk is, zoals hierboven reeds bleek. Zie par. 2.5.1.1.

385 Munneke 2006, p. 59-66, 111-112.

386 Munneke 2006, p. 112.

387 Zie o.a. Van der Pot/Elzinga \& De Lange 2006, p. 780.

388 Kamerstukken II 2001/02, 28 362, nr. 2, p. 8-10.

389 Zie art. 10, eerste en tweede lid, Wob. De vergelijking met de Wob gaat overigens niet helemaal op gezien het wezenlijke verschil tussen de relatie overheid-burger en regering-parlement. Zie over de verhouding tussen het belang van de staat in art. 68 en de weigeringsgronden in de Wob ook Munneke 2006, p. 144-148. Zie voorts Van Schagen 1994, p. 243-244 en Van der Pot/Elzinga \& De Lange 2006, p. 780 .
} 
kunnen de genoemde belangen een beroep op het staatsbelang rechtvaardigen. ${ }^{390}$ Hierdoor bestaat nog steeds een bepaalde marge en is in het concrete geval een afweging tussen het specifieke (staats)belang en het belang van een goed geïnformeerd parlement noodzakelijk. Bovendien worden in de literatuur naast de genoemde categorieën nog andere belangen als (mogelijk) staatsbelang genoemd. Zo kan bijvoorbeeld ook het beschermen van de homogeniteit van de ministerraad als een staatsbelang worden gezien. ${ }^{391}$

Wat in elk geval duidelijk is, is dat het geheel niet verstrekken van inlichtingen slechts in zeer uitzonderlijke gevallen aanvaardbaar wordt geacht. ${ }^{392}$ Een absolute weigering om inlichtingen te verstrekken aan het parlement kan namelijk in veel gevallen worden voorkomen, wanneer de verstrekking in vertrouwelijkheid kan plaatsvinden. De regering benadrukt in haar nota dat vertrouwelijke verstrekking van informatie mogelijk is, maar alleen wanneer verstrekking in openbaarheid in strijd met het belang van de staat zou zijn. ${ }^{393}$ Te denken valt aan vertrouwelijke bedrijfsgegevens of zaken die de privacy van burgers raken. Vanuit democratisch oogpunt heeft openbare verstrekking wellicht de voorkeur, maar art. 68 vereist dit niet. Wanneer een minister de gevraagde inlichtingen (mondeling of schriftelijk) in vertrouwelijkheid verstrekt, is strikt genomen een beroep op het staatsbelang niet nodig. 394

Vertrouwelijke verstrekking van inlichtingen komt in de parlementaire praktijk regelmatig voor. Bekend voorbeeld is de vaste commissie voor inlichtingen- en veiligheidsdiensten, die veel informatie van ministers onder beding van geheimhouding ontvangt. Ook bij parlementair onderzoek gebeurt dit. Het is daarbij bovendien gebruik geworden om voorafgaand aan het onderzoek afspraken te maken met de verantwoordelijke ministers over de wijze waarop inlichtingen worden verstrekt. Hiervoor is in 2002 een standaardprotocol vastgesteld door de voorzitter van de Tweede Kamer en de minister van Binnenlandse Zaken en Koninkrijksrelaties. Daarnaast maken commissies zelf eigen afspraken met de betrokken bewindspersonen. ${ }^{395}$ Een absolute weigering om inlichtingen te verschaffen met een expliciet beroep op het belang van de staat is, mede daarom, in de onderzoekspraktijk nog niet voorgekomen. De commissie heeft er belang bij om goede afspraken te maken de betrokken ministers, aangezien zij in het geval van een definitieve weigering niet over juridische middelen beschikt om de gewenste inlichtingen alsnog boven tafel te krijgen. Alleen politiek overleg en andere informele wegen kunnen in geval van een conflict uitkomst bieden.

Voor departementsambtenaren geldt, dat zij in het kader van een regulier parlementair onderzoek alleen met toestemming van hun minister inlichtingen aan een

\footnotetext{
390 Kamerstukken II 2001/02, 28 362, nr. 2, p. 6.

${ }^{391}$ Munneke 2006, p. 122-123.

392 Zie Kamerstukken II 2001/02, 28 362, nr. 2, p. 12. Zie ook de brief van de commissie voor de vernieuwing van de Wet op de Parlementaire Enquête aan de Tweede Kamer, waarin de visie die de regering in 2002 verwoordde lijkt te worden onderschreven. Kamerstukken II 2005/06, 29 283, nr. 36, p. 4.

393 Kamerstukken II 2001/02, 28 362, nr. 2, p. 3.

${ }^{394}$ Munneke 2006, p. 106-107, 143.

395 Stcrt. 2002, 37. Hierover meer in par. 4.5.1.
} 
parlementaire onderzoekscommissie verstrekken. Hierdoor is het uiteindelijk altijd de minister die bepaalt of het belang van de staat in het geding is. Personen werkzaam bij adviescolleges en bij zelfstandige bestuursorganen kunnen, zoals hierboven bleek, in beginsel zelfstandig medewerking verlenen aan een parlementair onderzoek. Aangezien op hen geen medewerkingsverplichting rust, zullen zij hierin een eigen afweging moeten maken. De belangen waarmee ministers rekenen moeten houden, zullen ook voor deze overheidsorganisaties zwaar wegen. Indien het zbo weigert om de gevraagde gegevens te verstrekken en de commissie de gegevens indirect, dus via de minister, wil opvragen, dan geldt de verschoningsgrond van het staatsbelang overeenkomstig art. $68 \mathrm{Gw}$ onverkort. De inlichtingen komen strikt genomen immers van de minister. Los daarvan kan het zo zijn, dat een adviescollege of zelfstandig bestuursorgaan eigen wettelijke geheimhoudingsverplichtingen heeft die het verstrekken van inlichtingen aan een parlementaire onderzoekscommissie in bepaalde gevallen zou kunnen verhinderen.

\subsubsection{Parlementaire enquêtes}

Medewerkingsplicht en geheimhoudingsplichten. Bij parlementaire enquêtes hebben niet alleen ministers en staatssecretarissen, maar ook ambtenaren een verplichting om gehoor te geven aan verzoeken van enquêtecommissies om het verstrekken van inlichtingen en documenten. Dit volgt uit de algemene medewerkingsplicht van art. 14 Wpe 2008. Eveneens op ministers en ambtenaren van toepassing is art. 15, waarin uitdrukkelijk is bepaald dat geheimhoudingsverplichtingen niet boven de medewerkingsplicht gaan, zelfs indien zij wettelijk zijn opgelegd, tenzij een beroep kan worden gedaan op een van verschoningsrechten in de Wpe. ${ }^{396}$ Hierboven bleek echter al, dat de meeste wettelijke geheimhoudingsplichten ook in het normale verkeer tussen bewindspersonen en parlement geen obstakel vormen voor het (vertrouwelijk) verschaffen van inlichtingen. ${ }^{397}$

Moeilijker ligt het, wanneer het geheimhoudingsplichten betreft die voortvloeien uit internationale rechtsnormen. Ministers en bestuurders van zelfstandige bestuursorganen, met name markttoezichthouders, hebben hier veelvuldig mee te maken. Volgens de initiatiefnemers heeft art. 15 Wpe "uit de aard der zaak" geen betrekking op "internationale geheimhoudingsverplichtingen". Deze gaan volgens hen voor op de medewerkingsplicht en kunnen een grondslag vormen voor een beroep op het belang van de staat. ${ }^{398}$ Hoewel dit vanuit de gebruikelijke hiërarchie van normen bezien op het eerste gezicht vanzelf spreekt, is dit toch wat kort door de bocht. Hierboven werd al aangegeven, dat met name bij Europeesrechtelijke normen de verhouding ten opzichte van nationale constitutionele normen niet altijd eenduidig is. ${ }^{399}$ Recentelijk speelde dit bij aanvang van de parlementaire enquête inzake het financieel stelsel (commissie-De Wit), die onder meer betrekking had op de omvangrijke overheidssteun tijdens de bankencrisis van 2008. De commissie wilde alle rele-

\footnotetext{
396 Art. 15 Wpe 2008. Zie hierover ook hierboven, par. 2.3.4 en hierna, par. 4.4.2.

${ }^{397}$ Zie hierboven, par. 2.5.1.1.

398 Kamerstukken II 2005/06, nr. 6, p. 33.

${ }^{399}$ Zie hierboven, par. 2.5.1.1 en nader: Munneke 2006, p. 151-153.
} 
vante informatie ten aanzien van het onderwerp van haar onderzoek kunnen inzien, inclusief vertrouwelijke toezichtsinformatie die bij het kabinet en bij de toezichthouders rustte. ${ }^{400}$ De minister van Financiën verzocht daarop de Raad van State om nader in te gaan op de spanning die kon worden geconstateerd tussen enerzijds de mogelijke verstrekking van vertrouwelijke toezichtsinformatie door de minister, De Nederlandsche Bank en de Autoriteit Financiële Markten aan de parlementaire enquêtecommissie en anderzijds de geheimhoudingsverplichtingen op grond van art. 1:89 e.v. Wet op het financieel toezicht (Wft). Deze geheimhoudingsplichten vloeien voort uit Europese richtlijnen. ${ }^{401}$ Meer concreet vroeg de minister of de mogelijkheid bestaat om de commissie onder strikte geheimhouding inzage te verlenen in toezichtvertrouwelijke informatie. Daarbij suggereerde de minister om de betreffende documenten in een afgesloten ruimte op het ministerie van Financiën voor de commissieleden ter inzage te leggen, waarbij de commissie absolute geheimhouding zou bewaren en de informatie op geen enkele wijze zou verveelvoudigen of herleidbaar in haar rapport zou opnemen. ${ }^{402}$

De Raad kwam tot de conclusie dat de Europese richtlijnen, waarop het nationaalrechtelijke geheimhoudingsregime is gebaseerd, weliswaar niet expliciet in het verschaffen van inlichtingen aan nationale parlementen voorzien, maar dat op grond van raadsnotulen bij de totstandkoming van deze geheimhoudingsbepalingen en latere uitlatingen van de Europese Commissie niet zonder meer kon worden gesteld dat de richtlijnen in de weg staan aan de rechten van parlementaire onderzoekscommissies in de lidstaten om overeenkomstig de nationale constituties informatie te verkrijgen. ${ }^{403}$ Een eenduidige juridische basis voor het verstrekken van toezichtvertrouwelijke informatie aan een parlementaire enquêtecommissie kon echter niet worden gegeven, aldus de Raad. Tegelijkertijd zou het niet verstrekken van informatie ertoe leiden dat deze "bijzondere enquêtecommissie" ondergeschikt zou worden gemaakt aan de Europese financiële toezichtwetgeving. De Raad adviseerde daarom om een middenweg te kiezen die zoveel mogelijk aan beide zwaarwegende belangen tegemoet zou komen. Uitgangspunt zou moeten zijn, dat toezichtvertrouwelijke informatie aan de commissie zou worden verstrekt onder strikte geheimhouding. De Wpe biedt daartoe mogelijkheden, zo concludeerde zij. Hoewel de Raad de modaliteiten die de minister schetste als "een goede aanzet" ziet, spreekt hij zich niet uit over de exacte vorm waarin deze informatievoorziening zou moeten plaatsvinden. Hierover zouden betrokkenen concrete afspraken moeten maken. ${ }^{404}$

\footnotetext{
400 Zie Kamerstukken II 2010/11, 31 980, nr. 38, p. 9.

${ }^{401}$ Het betrof een zogenaamde voorlichtingsaanvraag aan de Afdeling advisering van de Raad van State krachtens art. 21a, eerste lid, Wet op de Raad van State.

402 Zie de brief van de minister van Financiën van 21 februari 2011, Stcrt. 2011, nr. 5695, p. 1-2.

403 De Raad achtte daarbij bovendien van belang, dat bij de totstandkoming van deze richtlijnen geen rekening was gehouden met de omvangrijke interventies in de financiële sector en dat meer in het algemeen bij de recente verdragsherzieningen een sterkere rol is weggelegd voor zowel het Europese parlement als de nationale parlementen. Verder bleek ook in andere lidstaten dat de richtlijnen (vertrouwelijke) informatieverstrekking aan het parlement niet leken te verhinderen. Zie Stcrt. 2011, nr. 5695, p. 4-7.

404 Stcrt. 2011, nr. 5695, p. 8.
} 
Het bovenstaande laat zien, dat geheimhoudingsplichten op grond van het internationale of Europese recht (of het daarvan afgeleide nationale recht) niet in alle gevallen de medewerkingsplicht van ministers en bestuurders van zbo's bij een parlementaire enquête overstijgen. Of dit zo is, is mede afhankelijk van de wijze waarop met deze normen is beoogd de nationale constitutionele verhoudingen te beïnvloeden. Onduidelijkheid hierover leidt, zo bleek in deze casus, tot de noodzaak om onderling afspraken te maken waarbij een afweging wordt gemaakt tussen verschillende belangen. In dit geval was daarbij van belang, dat het hier gaat om een enquête naar een uitzonderlijk ingrijpende vorm van overheidsoptreden waarbij destijds geen of nauwelijks parlementaire controle mogelijk was. 405

Belang van de staat. De Wpe erkent, evenals art. $68 \mathrm{Gw}$, het belang van de staat als een grond voor verschoning. Art. 19, eerste lid, Wpe 2008 bepaalt dat minister en staatssecretarissen, gewezen bewindspersonen, alsook de leden, bestuurders en ambtenaren van 'tot de staat behorende organen' niet verplicht zijn om informatie aan de commissie te verstrekken, voor zover deze verstrekking in strijd is met het belang van de staat. Ook personen werkzaam bij adviescolleges en zelfstandige bestuursorganen kunnen zich dus rechtstreeks op het staatsbelang beroepen. Hiervoor is gekozen omdat deze personen vaak over informatie beschikken die van betrokken ministeries afkomstig is. ${ }^{406}$ Wel kan de commissie in het geval van staatssecretarissen en leden, bestuurders en ambtenaren van staatsorganen aan de minister 'wie het aangaat' vragen om een beroep op het staatsbelang te bevestigen. Bij voormalige ministers en staatssecretarissen kan een bevestiging van de minister-president worden gevraagd. ${ }^{407}$

Bij de herziening van de enquêtewet in 2008 is de formulering van het verschoningsrecht 'belang van de staat' aangepast aan art. $68 \mathrm{Gw}$. Hiermee hebben de indieners willen bevestigen dat de betekenis van de verschoningsgrond ook in de nieuwe enquêtewet niet afwijkt van de grondwettelijke regeling. De regeringnotitie uit 2002 over de reikwijdte van art. 68 wordt door hen bovendien als beoordelingskader aangemerkt. 408 Onder de oude wet was hierover nog discussie mogelijk. Zo stelt art. 68 $\mathrm{Gw}$ dat de minister inlichtingen kan weigeren wanneer dat in strijd met het belang van de staat "is". Het oude art. 20, tweede lid, WPE sprak ten aanzien van ambtenaren daarentegen over "wordt geoordeeld te zijn". In art. 21, eerste lid, WPE (oud) werd eveneens gesproken over het oordeel van de minister. Of hiermee werkelijk een van art. $68 \mathrm{Gw}$ afwijkende invulling is beoogd, kan overigens worden betwijfeld. Het parlement bezit op grond van art. $68 \mathrm{Gw}$ reeds een zeer omvangrijk recht op informatie van ministers en staatssecretarissen. De WPE is niet bedoeld om daaraan iets toe te voegen of af te doen. Wanneer dat wel het geval zou zijn geweest, dan zou moeten worden geconstateerd dat de leden van een parlementaire enquêtecommissie als individueel Kamerlid een sterker recht op informatie bezitten dan als commissie-

405 Uiteindelijk is een informatieprotocol tot stand gekomen. Zie de brief van de enquêtecommissie over de voortgang van haar onderzoek, Kamerstukken II 2011/12, 31 980, nr. 53. Zie ook hierna, par. 4.7.2.

406 Kamerstukken II 2005/06, nr. 6, p. 31.

407 Zie art. 19, tweede en derde lid, Wpe 2008. Onder de oude wet kon niet de commissie, maar de Kamer om bevestiging vragen.

408 Zie Kamerstukken II 2005/06, 30 415, nr. 6, p. 38-39. 


\section{NEDERLAND}

lid. De parlementaire enquête is bedoeld om het parlement de mogelijkheid te geven informatie van derden te verkrijgen en af te dwingen, naast de reeds bestaande informatierechten ten opzichte van de regering. Het valt moeilijk in te zien waarom ministers tegenover een enquêtecommissie over een sterker verschoningsrecht zouden moeten beschikken dan tegenover de Kamer als geheel. ${ }^{409} \mathrm{Bij}$ de wetsherziening van 2008 is de vermoedelijk overeenkomstige betekenis van de bepalingen in Grondwet en enquêtewet in feite bevestigd.

Evenals bij het reguliere parlementaire onderzoek, beschikt een enquêtecommissie niet over wettelijke middelen om een minister die zich beroept op dit verschoningsrecht, of die de gegrondheid bevestigt van een beroep hierop door andere verschoningsgerechtigden ${ }^{410}$, te dwingen om alsnog de gevraagde inlichtingen of documenten te verschaffen. Het is, zo stellen de initiatiefnemers, "de primaire verantwoordelijkheid van de minister om te beoordelen of de verstrekking van inlichtingen in strijd is met het belang van de staat." 411 Derden, onder wie de rechter, spelen bij conflicten in deze verhouding geen rol. ${ }^{412}$ De dwangmiddelen en sancties die bij enquêtes kunnen worden ingezet tegen weigerachtige personen zijn uitdrukkelijk niet op ministers van toepassing. ${ }^{413}$ De commissie zal in overleg met de minister moeten proberen om tot een oplossing te komen. Om conflicten te voorkomen, hebben enquêtecommissies, meer nog dan reguliere onderzoekscommissies, daarom de gewoonte om op voorhand specifieke afspraken met de betrokken ministers te maken over de wijze waarop inlichtingen worden verstrekt en de rol van departementsambtenaren en zelfstandige bestuursorganen daarbij. ${ }^{414}$

Ook ten aanzien van ambtenaren, die in beginsel een zelfstandige medewerkingsplicht hebben, ontkomt de enquêtecommissie er in de praktijk niet altijd aan om de verantwoordelijke minister erbij te betrekken. Immers, wanneer een ambtenaar zelfstandig een beroep doet op het staatsbelang, dan kan alleen de minister dit bevestigen en daarmee handhaven. De minister en de ambtenaar hebben hier, zo kan uit art. 19, eerste lid, Wpe 2008 worden afgeleid, ieder een verantwoordelijkheid. Dit roept nog wel de vraag op, hoe ministers zich dienen op te stellen ten opzichte van ambtenaren die worden opgeroepen door een enquêtecommissie. Brengt genoemde bepaling nu met zich mee, dat ministers - met het oog op hun verantwoordelijkheid voor de bescherming van staatsbelangen - hun ambtenaren voorafgaand aan een voorgesprek of verhoor kunnen vragen naar de informatie die zij voornemens zijn aan de commissie te verschaffen? Zo ja, zijn ambtenaren dan verplicht om hun ministers daarover in te lichten? En kunnen ministers hun ambtenaren vervolgens opdra-

\footnotetext{
409 Zie ook: Munneke 2006, p. 299-300.

410 In het geval van een voormalig minister of een (voormalig) staatssecretaris of ambtenaar die zich op dit verschoningsrecht beroept. Zie art. 19, tweede en derde lid, Wpe 2008.

${ }^{411}$ Kamerstukken II 2005/06, 30 415, nr. 6, p. 40.

412 Zie Kamerstukken II 2005/06, 30 415, nr. 6, p. 40.

413 Zie hierboven, par. 2.3.3.

414 Bij de Enquête Opsporingsmethoden hield de commissie wel nadrukkelijk rekening met de mogelijkheid van een beroep op het staatsbelang. Ter voorbereiding vroeg zij daarom twee deskundigen om de betekenis van deze verschoningsgrond in de context van de enquête nader toe te lichten. Zie over deze adviezen: Munneke 2006, p. 301-304. Zie verder: par. 4.2.3.
} 
gen om bepaalde informatie met een beroep op het staatsbelang niet aan de commissie te verstrekken?

De wet noch de memorie van toelichting geven antwoord op deze vragen. Waar het hier in essentie om gaat, is de vraag in hoeverre een parlementaire enquête de reguliere, hiërarchische politiek-ambtelijke gezagsrelatie doorbreekt. Die gezagsrelatie vloeit voort uit de politieke ministeriële verantwoordelijkheid en de ministeriële leiding over het departement, zoals neergelegd in art. 42, tweede lid, respectievelijk art. 44, eerste lid, Grondwet. De verhouding tussen minister en ambtenaar heeft dus een grondwettelijke status. Het enquêterecht heeft ex art. 70 Grondwet echter eveneens die status. Bovendien is vanaf het eerste uur duidelijk, dat de (grond)wetgever met de codificatie van het enquêterecht heeft bedoeld om de reguliere verhouding in geval van een enquête te doorbreken. De Enquêtewet van 1850 bevatte immers al een getuigplicht voor ambtenaren. Ook het zelfstandige verschoningsrecht voor ambtenaren in verband met het belang van de staat, inclusief de eventueel daarop volgende bevestiging door de minister, is reeds in die wet terug te vinden. ${ }^{415}$ Uit de zelfstandige medewerkingsplicht die ambtenaren op grond van de Wpe hebben, vloeit verder voort, zo bleek hierboven reeds, dat de minister geen verantwoordelijkheid draagt voor de verklaring die een ambtenaar tegenover een enquêtecommissie aflegt. ${ }^{416}$ Dat laatste kan mijns inziens ook gesteld worden ten aanzien van een zelfstandig beroep op het staatsbelang. Het systeem van de wet geeft ambtenaren een eigenstandige positie in de context van een parlementaire enquête, waarmee de reguliere verhoudingen wordt doorbroken. Zij spreken op persoonlijke titel en dienen zelfstandig af te wegen in hoeverre in concrete gevallen een beroep op het belang van de staat aangewezen is en de gevraagde inlichtingen niet (onvoorwaardelijk) kunnen worden verstrekt. De minister komt in deze systematiek op de tweede plaats en komt pas in beeld als een beroep op het staatsbelang reeds is gedaan. Een en ander brengt met zich mee, dat ministers hun ambtenaren niet vooraf 'op het matje kunnen roepen' of instructies kunnen geven wanneer zij worden gehoord door een enquêtecommissie - niet alleen als het gaat om inlichtingen waarbij een beroep op het staatsbelang aan de orde zou kunnen zijn, maar om alle inlichtingen die een ambtenaar verstrekt. Een ambtenaar kan in een dergelijk geval dus met recht weigeren om met de minister in overleg te treden. Dit wil overigens niet zeggen, dat een ambtenaar ook moet weigeren. Zoals bij elke andere getuige berust ook op ambtenaren geen geheimhoudingsplicht ten aanzien van hetgeen zij tijdens een voorgesprek aan de commissie hebben medegedeeld; die geheimhouding geldt alleen voor de commissie zelf. ${ }^{417}$ Het is aan ambtenaren om te bepalen in hoeverre zij het, om wat voor reden dan ook, wenselijk achten om met een bewindspersoon in overleg te treden. ${ }^{418}$

415 Zie artt. 4 jo. 20 Enquêtewet 1850. Zie ook hierboven, par. 2.2.1.

${ }^{416}$ Zie par. 2.5.2.1.

417 Zie art. 8, derde lid, Wpe 2008.

418 De Enquêtecommissie-De Wit heeft in haar eindrapport voorgesteld de geheimhoudingsplicht van art. 8 uit te breiden tot personen met wie een voorgesprek is gevoerd. Aangezien zulks op gespannen voet zou staan met verplichtingen van ondergeschikten aan hun werkgevers, zou die verplichting niet moeten gelden voor de werkkring van deze personen. Ook wordt erkend dat ambtenaren informatie, welke tijdens een besloten voorgesprek is gewisseld, moeten kunnen delen met hun bewindspersonen. Zie Kamerstukken II 2011/12, 31 980, nr. 61, p. 574. Dit voorstel en de gemaakte uitzondering lijken 
Ten aanzien van adviescolleges en zelfstandige bestuursorganen is het, zo bleek hierboven ${ }^{419}$, meer dan voorheen mogelijk dat tussen enquêtecommissies en deze organen een directe verhouding ontstaat. Een enquête naar het functioneren van een zbo zou vrijwel geheel zonder bemoeienis van de betrokken minister kunnen plaatsvinden. Het is echter de vraag of dit verstandig is. Formeel is het zo dat de enquêtecommissie bij een weigering om mondelinge of schriftelijke inlichtingen te verschaffen haar dwangmiddelen en sancties in stelling kan brengen tegen de bestuurders van de adviescolleges of zelfstandige bestuursorganen. Of dit binnen de Nederlandse verhoudingen veel praktijkwaarde heeft, is echter de vraag. ${ }^{420}$ In theorie zou een zbo bovendien in eerste instantie deze pas kunnen afsnijden door een beroep te doen op het belang van de staat. Op grond van art. 19, tweede lid, Wpe 2008 kan de enquêtecommissie vervolgens de meest betrokken minister om een bevestiging van dit beroep vragen. Indien die bevestiging wordt gegeven, dan verschuift in feite de verantwoordelijkheid voor het beroep op het staatsbelang naar de minister. ${ }^{421}$ De inzet van dwangmiddelen en sancties tegen bewindspersonen is, zoals hierboven al duidelijk werd, wettelijk uitgesloten. Mocht de minister echter weigeren te bevestigen en daarmee in feite aangeven dat het zbo zich ten onrechte op deze verschoningsgrond heeft beroepen, dan stellen de bestuurders van het zbo, indien zij blijven volharden in hun weigering, zich alsnog bloot aan dwangmiddelen of sanctionering.

Overigens wordt ook van de enquêtecommissie zelf verwacht, dat zij bij de uitoefening van haar taken het belang van de staat in ogenschouw neemt. Zo kan de commissie, indien een minister of ambtenaar aarzelt om bepaalde inlichtingen te verstrekken omwille van het staatsbelang, er voor kiezen om niet te volharden in haar verzoek of om over te gaan tot vertrouwelijke kennisname. ${ }^{422}$ Kamerleden die om medewerking worden verzocht, komt echter geen beroep op het staatbelang toe. 423

Geheim van de ministerraad. Naast het belang van de staat als verschoningsrecht kent de Wet op de parlementaire enquête een tweede uitzondering op de medewer-

mij zinvol, mits duidelijk is dat de bevoegdheid voor ambtenaren om informatie uit een voorgesprek met bewindspersonen te delen niet tevens een verplichting daartoe behelst. Tegen de achtergrond van de zelfstandige medewerkingsplicht mag een ambtenaar niet (achteraf) worden tegengeworpen, al dan niet in combinatie met disciplinaire sancties, dat hij zijn bewindspersoon onvoldoende inzicht heeft gegeven in hetgeen hij met een enquêtecommissie heeft besproken. Dit zou hem namelijk in een onmogelijke positie plaatsen.

419 Zie par. 2.5.2.2.

${ }^{420}$ Zie hierover ook de bijdrage van Kummeling in De WPE onder de loep 2004, p. 15.

${ }^{421}$ Dit lijkt mij een logische constructie, aangezien de invulling van de betekenis van het staatsbelang als verschoningsgrond in het Nederlandse constitutionele bestel uiteindelijk aan de minister wordt gelaten. Als dat bij zbo's anders zou zijn en de enquêtecommissie dwangmiddelen of sancties zou willen inzetten tegen de betreffende zbo-bestuurders, dan zou het zelfs zo kunnen zijn dat uiteindelijk de rechter hierover zal moeten oordelen. Dat zou een doorbreking van het bestaande stelsel zijn.

422 Zie de antwoorden van de initiatiefnemers op vragen vanuit de Eerste Kamer, Kamerstukken I 2006/07, 30 415, nr. C, p. 20.

${ }^{423}$ Kamerstukken I 2006/07, 30 415, nr. C, p. 20 en Kamerstukken I 2006/07, 30 415, nr. F, p. 6. De initiatiefnemers vinden dat niet passen in de relatie tussen Kamerleden onderling en achten het "ongewenst indien er informatie binnen de Kamer aanwezig is, die niet gebruikt kan worden door de enquêtecommissie." 
kingsplicht voor bewindspersonen en ambtenaren. In art. 20, eerste lid, is bepaald dat (voormalige) ministers en staatssecretarissen of (voormalige) ambtenaren die ten behoeve van een bewindspersoon werkzaam zijn (geweest), niet verplicht zijn informatie te verstrekken over de beraadslagingen in een vergadering van de ministerraad. Wel kan de commissie van (voormalige) bewindspersonen vorderen dat zij inlichtingen verschaffen omtrent de beslissingen die zij genomen hebben in de ministerraad en de gronden waarop zij berusten, zo blijkt uit het tweede lid, tenzij het belang van de staat daaraan in de weg zou staan. Wanneer het daarbij gaat om schriftelijke informatie, dan dient de vordering te zijn gericht aan de ministerpresident. Ambtenaren zijn niet verplicht om informatie over de beslissingen van de ministerraad en de gronden waarop deze berusten, te geven. Hiervoor moet de commissie dus bij de bewindspersonen zelf zijn, zo kan uit het tweede lid worden afgeleid.

Met deze bepaling is beoogd de homogeniteit van de ministerraad te beschermen. Art. 45, derde lid, Gw schrijft voor dat de ministerraad beraadslaagt en besluit over het algemeen regeringsbeleid; bovendien heeft de raad als taak om de eenheid van dat beleid te bevorderen. Op grond van deze bepaling berust op ministers de plicht om naar buiten toe als eenheid op te treden. Meningsverschillen dienen binnenskamers te worden beslecht. Meer specifiek komt het homogeniteitsbeginsel tot uitdrukking in het Reglement van Orde van de Ministerraad (RvOMR). Ministers mogen niet handelen tegen een besluit van de ministerraad (art. 12 RvOMR) en ten aanzien van hetgeen besproken wordt of geschiedt tijdens vergaderingen van de ministerraad geldt een geheimhoudingsplicht, zo bepaalt art. 26 RvOMR.424

Hoewel inhoudelijk geen aanmerkelijke wijzigingen zijn beoogd, wijkt de formulering van het huidige art. 20 Wpe 2008 in procedurele zin wel af van de oude regeling. Zo wordt, anders dan voorheen, niet van de enquêtecommissie geëist dat ontheffing van de ministerraad wordt gevraagd wanneer een minister ondervraagd wordt over de beraadslagingen tijdens een ministerraadvergadering. De enquêtecommissie mag bovendien ongehinderd vragen stellen ten aanzien van hetgeen is besproken en voorgevallen in de ministerraad; de verantwoordelijkheid voor het waarborgen van de homogeniteit en de vertrouwelijkheid van de ministerraad ligt ten volle bij de minister die wordt ondervraagd. Omdat er geen sprake meer is van een ondervragingsverbod voor de enquêtecommissie, zal een minister bij elke vraag moeten inschatten of deze betrekking heeft op de beslissingen van de ministerraad en de gronden waarop deze rusten of dat de vraag betrekking heeft op de beraadslagingen. Alleen in het eerste geval is hij verplicht om te antwoorden. ${ }^{425}$

Hoewel de wet hieromtrent niets bepaalt, staat het de ministerraad vrij om een minister geheel of gedeeltelijk ontheffing te verlenen van de geheimhoudingsplicht. Dat geldt ook voor het verstrekken van de notulen of andere, nadere informatie over de beraadslagingen in de ministerraad. ${ }^{426}$ Bij de Enquête Financieel Stelsel verschafte

\footnotetext{
424 Zie Kortmann 2008, p. 163.

425 Kamerstukken II 2005/06, 30 415, nr. 6, p. 42.

$426 \mathrm{Op}$ dat laatste punt bepaalde de oude wet nog, dat de minister alleen een door de ministerpresident ondertekend uittreksel van de ministerraadnotulen kon verstrekken, tenzij de raad anders zou besluiten. De initiatiefnemers vonden het niet langer nodig om ten aanzien van de vrijwillige
} 


\section{NEDERLAND}

het kabinet onder beding van vertrouwelijkheid geobjectiveerde samenvattingen van relevante passages van ministerraden. Ook kreeg de commissie inzage in ministerraadsnotulen, maar daarbij werd aangegeven dat dit moest worden opgevat als een uitzondering "zonder precedentwerking naar de toekomst". Bovendien werd, tot onvrede van de commissie, alleen de voorzitter, de onder-voorzitter en de griffier inzage verleend. 427

Overige verschoningsrechten. Wat betreft de reguliere verschoningsrechten in de Wpe 2008 geldt, dat ook ministers en ambtenaren zich hierop in voorkomende gevallen kunnen beroepen. Daarbij gaat het voornamelijk om het geheime collegeberaad (art. 21), vertrouwelijke bedrijfsgegevens (art. 22) en de persoonlijke levenssfeer (art. 23). Het beroepsgeheim kan van toepassing zijn wanneer een ambtenaar bijvoorbeeld een vertrouwensfunctie vervult. ${ }^{428}$ Ten aanzien van vertrouwelijke bedrijfsgegevens en informatie die de persoonlijke levenssfeer betreft, kan echter ook sprake zijn van strijdigheid met het belang van de staat (art. 19). Zo is het goed denkbaar dat een ambtenaar vanuit zijn functie toegang heeft tot gevoelige bedrijfsgegevens, bijvoorbeeld in het kader van een aanbestedingsprocedure of vergunningverlening. In dat geval zijn dus meerdere verschoningsgronden aanwendbaar. Waarschijnlijk ligt een beroep op het staatsbelang meer voor de hand, aangezien het in art. 19 om een absoluut verschoningsrecht gaat en in de artt. 22 en 23 om een relatief verschoningsrecht.

\subsection{Conclusie}

Het parlementaire onderzoeksrecht, zoals dat in 1848 in de Grondwet met de toevoeging 'enquête' maar zonder nadere omschrijving werd opgenomen en in 1850 werd uitgewerkt in de Enquêtewet (later: Wet op de Parlementaire Enquête), heeft in de loop der tijd een sterke ontwikkeling doorgemaakt. De reikwijdte van het onderzoeksrecht is lange tijd voorwerp van discussie geweest. Na een tamelijk restrictief begin, waarbij de gedachte overheerste dat de parlementaire enquête uitsluitend kan worden ingezet ten behoeve van het wetgevingsproces, kreeg een ruimere interpretatie van het onderzoeksrecht - tegen de achtergrond van de groeiende macht van het parlement - in de loop van de negentiende eeuw meer aanhang. Na verloop van tijd werd niet meer betwijfeld dat enquêtes in het kader van de parlementaire controletaak (zogenaamde 'politieke enquêtes'), gericht op het activeren van de ministeriële verantwoordelijkheid, grondwettelijk aanvaarbaar waren. De ontwikkeling van het parlementaire stelsel, die het onderzoeksrecht een impuls gaf, zorgde er tegen het einde van de negentiende eeuw opmerkelijk genoeg ook voor dat de parlementaire enquête voor langere tijd van het toneel verdween. Met de opkomst van het partijenstelsel rond de eeuwwisseling en de hechtere (maar fragiele) band tussen kabinet en coalitiefracties, werden enquêtes gezien als politiek risicovol. Parlementaire onder-

verstrekking van informatie over de beraadslagingen in de ministerraad iets te regelen. Kamerstukken II 2005/06, 30 415, nr. 6, p. 42.

427 Kamerstukken II 2011/12, 31980 , nr. 61, p. 575.

${ }^{428}$ De normale ambtseed kan dus niet onder het beroepsgeheim worden geschaard. Zie verder par. 2.3.4.1.2. 
zoeken zonder de status van enquête konden bij tijd en wijle nog wel op voldoende steun rekenen.

De 'grote sluimering' die hierdoor ontstond duurde tot de jaren 70 van de twintigste eeuw, toen een hernieuwd parlementair activisme zorgde voor een heropleving van het enquêterecht. Na een wetswijziging in 1977, waardoor ook bewindspersonen konden worden verhoord, is de enquête vrijwel geheel in het teken van de parlementaire controletaak komen te staan. De hernieuwde parlementaire interesse voor het enquêterecht zorgde ook voor een sterke toename van het aantal tijdelijke onderzoekscommissies zonder enquêtebevoegdheden. Die variant is voor de praktijk inmiddels veel belangrijker en kan daarom 'regulier parlementair onderzoek' worden genoemd. De enquête geldt nog steeds als een bijzonderheid: een zwaar middel, dat vaak wordt gezien als ultimum remedium.

$\mathrm{Na}$ drie decennia van modern parlementair onderzoek werd de Wet op de Parlementaire Enquête, die inhoudelijk nog grotendeels uit 1850 stamde, in 2008 geheel herzien. Bij de parlementaire behandeling van het initiatiefwetsvoorstel ontstond opnieuw discussie over de reikwijdte van het enquêterecht. Die discussie lijkt te zijn veroorzaakt door de nogal ferme stelling van de initiatiefnemers in de memorie van toelichting dat een enquête over alles kan gaan wat de Kamer wil onderzoeken. Dit leidde tot kritiek van de Raad van State en de aanvaarding van een motie in de Eerste Kamer, waarin werd uitgesproken dat het enquêterecht wordt begrensd door de omvang van de parlementaire bevoegdheden. Dit lijkt mij een juiste stelling. Een groot materieel verschil met de aanvankelijke (overigens later bijgestelde) opvatting van de initiatiefnemers is er niet - de bevoegdheden van het parlement, met name op het gebied van wetgeving en controle, zijn immers bijzonder ruim - maar met deze motie wordt wel bevestigd dat het enquêterecht niet helemaal onbegrensd is. Deze stelling kan mijns inziens overeenkomstig van toepassing worden verklaard op het reguliere parlementaire onderzoek, aangezien ook daarvoor geldt dat de toepassing van parlementaire instrumenten altijd verband moet houden met de constitutionele taken of functies die de Kamer zijn toebedeeld.

In de toepassing van haar wettelijke bevoegdheden is de enquêtecommissie gebonden aan de onderzoeksopdracht die de kamer haar heeft verleend. Daarnaast kent de wet een evenredigheidsbeginsel, op grond waarvan de commissie haar bevoegdheden alleen kan uitoefenen voor zover dat naar haar redelijk oordeel noodzakelijk is voor de vervulling van haar taak. De subjectieve formulering zorgt ervoor, dat de rechter slechts marginaal kan toetsen of de bevoegdheidsuitoefening ten aanzien van een individuele medewerkingsplichtige rechtmatig is. Dat een parlementaire enquête voorts gericht dient te zijn op waarheidsvinding, een gedachte die in de literatuur en de parlementaire geschiedenis leeft, volgt mijns inziens niet uit enig constitutioneel of wettelijk voorschrift. Ook in meer descriptieve zin is het gebruik van de term waarheidsvinding als het (ultieme) doel van parlementair onderzoek af te raden: hierdoor kunnen verwachtingen worden gewekt die moeilijk waar te maken zijn.

Kenmerkend voor parlementaire enquêtes is de algemene medewerkingsplicht voor derden in combinatie met de verregaande bevoegdheden van de enquêtecommissie. De nieuwe wet, die in 2008 tot stand kwam, heeft een aanzienlijke verheldering, systematisering en modernisering van deze bevoegdheden gebracht. Zo bestaat 
nu de mogelijkheid om schriftelijke inlichtingen te vorderen en niet slechts, zoals onder de oude wet, reeds bestaande documenten. Daarmee kan de commissie efficienter informatie vergaren. Een andere nieuwe bevoegdheid, die om plaatsen te betreden, lijkt gezien de aard van het enquêterecht minder nodig. De nieuwe wet heeft ook het arsenaal aan dwangmiddelen en sancties gemoderniseerd, met de dwangsom als belangrijkste vernieuwing. De positie van getuigen, die onder de oude wet tot veel discussie leidde, is eveneens verbeterd, bijvoorbeeld wat betreft hun verschoningsrechten. Juridisch niet helemaal helder is echter de regeling rondom conflicterende wettelijke geheimhoudingsplichten, ondanks de stellige formulering van art. 15 Wpe 2008. Verder is de langlopende discussie over de bewijsuitsluitingsregel en het gebrek aan een (familiaal) verschoningsrecht op non-incriminatie nog niet geheel voorbij, nadat de Eerste Kamer bij de aanvaarding van het wetsvoorstel een motie aannam. In deze discussie wordt vaak de vergelijking gemaakt met de Verenigde Staten, waarbij tevens de daar bestaande strafrechtelijke immuniteitsregeling wordt betrokken. Ook op een ander omstreden element van de moderne enquêtepraktijk, het (rechtstreeks) uitzenden van verhoren op radio en televisie, heeft de nieuwe wet geen verandering gebracht. Op deze punten wordt teruggekeerd in Deel III. 429

Ook de regeling rondom regulier parlementair onderzoek, waarbij geen wettelijke enquêtebevoegdheden worden verleend, is in 2008 herzien. Het opnemen van deze vorm van onderzoek in de wet, waarop de Kamer bij de beslissing om de WPE te herzien had aangedrongen, vonden de initiatiefnemers terecht niet nodig. Derden krijgen immers geen wettelijke verplichtingen opgelegd. Wel dient de kamer, gezien de grote media-aandacht en de publieke druk die kan ontstaan, personen die betrokken raken bij een regulier parlementair onderzoek goed voor te lichten over hun rechten en plichten. Ook is het aan te bevelen om in de onderzoekspraktijk een duidelijker onderscheid te maken, bijvoorbeeld door de Enquêtezaal in de Tweede Kamer alleen voor enquêtes te gebruiken.

Gelet op de constitutionele verhoudingen zoals die in hoofdstuk 1 zijn geschetst, nemen ministers, staatssecretarissen en ambtenaren een bijzondere positie in tijdens parlementaire onderzoeken. Voor bewindspersonen geldt echter, dat hun verplichting om medewerking te verlenen aan parlementaire onderzoeken niet verschilt van de normale verplichtingen die bewindspersonen jegens de Kamer hebben op grond van art. $68 \mathrm{Gw}$. Daarbij maakt het in wezen ook niet uit of het nu om een enquêtecommissie gaat of om een tijdelijke commissie in het kader van een regulier parlementair onderzoek. Bij enquêtes is het wel gebruikelijk dat ministers en staatssecretarissen onder ede worden verhoord. In hun rol als getuige tijdens een enquêteverhoor kunnen zij geen aanspraak maken op parlementaire immuniteit. Dit betekent, althans in theorie, dat zij, wanneer zij een valse verklaring zouden afleggen, strafbaar zijn wegens meineed.

Voor ambtenaren geldt dat bij regulier parlementair onderzoek de normale verhouding tussen ministers, ambtenaren en Kamer, zoals die voortvloeit uit de artt. 42 en $68 \mathrm{Gw}$ en de Aanwijzingen externe contacten, van toepassing is. Dit betekent dat ambtenaren geen zelfstandige rol spelen, maar uitsluitend met goedvinden en in

${ }^{429}$ Zie Deel III, par. 2.5. 
naam van de verantwoordelijke minister medewerking verlenen aan een parlementaire onderzoek. Dit geldt niet voor personen werkzaam bij adviescolleges en zelfstandige bestuurorganen: zij kunnen zelfstandig medewerking verlenen aan parlementaire onderzoeken, al zijn zij daartoe niet verplicht. Bij enquêtes ligt dit anders: departementsambtenaren hebben al sinds de codificatie van het enquêterecht een medewerkingsplicht, waardoor de reguliere verhouding tussen minister en ambtenaar, die wordt beheersd door de grondwettelijke ministeriële verantwoordelijkheid, wordt doorbroken. Ministers zijn dan ook niet verantwoordelijk voor de verklaring die hun ambtenaren afleggen. De zelfstandige positie van ambtenaren bij enquêtes brengt ook met zich mee, dat ambtenaren, evenals bewindspersonen, het verschoningsrecht van het belang van de staat is toegekend. Wanneer een ambtenaar zich verschoont wegens het belang van de staat, dan kan de minister om een bevestiging worden gevraagd. Beiden hebben hier dus een verantwoordelijkheid. Dit betekent echter niet, dat ministers hun ambtenaren na een oproep van een enquêtecommissie 'op het matje kunnen roepen' of instructies kunnen geven ten aanzien van hetgeen zij al dan niet willen gaan verklaren tijdens een voorgesprek of hoorzitting, zo kan uit de zelfstandige rol van de ambtenaar tijdens een enquête worden afgeleid. Aan verzoeken om schriftelijke inlichtingen verlenen departementsambtenaren, anders dan personen werkzaam bij adviescolleges en zelfstandige bestuursorganen, overigens niet zelfstandig medewerking. 
NEDERLAND 


\section{Hoofdstuk 3. Onderzoeksorganisatie}

\subsection{Inleiding}

Parlementair onderzoek wordt in Nederland bijna altijd uitgevoerd door een tijdelijke parlementaire commissie, die ad hoc voor dat doel wordt ingesteld. In de Tweede Kamer wordt voor parlementair onderzoek hoofdzakelijk gebruik gemaakt van twee commissievormen: de enquêtecommissie, die de beschikking heeft over wettelijke enquêtebevoegdheden, en de zogenaamde tijdelijke commissie, zonder enquêtebevoegdheden. Er zijn in het verleden echter ook onderzoeken uitgevoerd binnen de vaste commissies, waarbij gebruik gemaakt werd van subcommissies of (informele) werkgroepen. Tot voor kort hield alleen de Tweede Kamer zich bezig met parlementair onderzoek. In september 2011 besloot de Eerste Kamer echter voor het eerst in haar geschiedenis een onderzoekscommissie in te stellen. ${ }^{1}$

In dit hoofdstuk staat de totstandkoming en samenstelling van parlementaire onderzoekscommissies centraal. Hieronder worden allereerst de commissievormen in de Tweede Kamer besproken. Ook de besluitvorming rondom het instellen van onderzoekscommissies in de Tweede Kamer komt daarbij aan bod. Verder wordt kort ingegaan op de onderzoeksstructuren binnen de Eerste Kamer. Vervolgens komt de personele samenstelling van parlementaire onderzoekscommissies aan de orde. Daarbij wordt tevens ingegaan op de interne verhoudingen binnen deze commissies. Tot slot wordt bezien over welke ambtelijke en inhoudelijke ondersteuning de onderzoekscommissies beschikken.

\subsection{Onderzoeksorganisatie}

\subsubsection{Besluitvormingsprocedure}

Met de toename van het aantal parlementaire onderzoeken in de loop van de jaren 80 en 90 van de twintigste eeuw ontstond binnen de Tweede Kamer behoefte aan eenduidige procedures rondom de totstandkoming, samenstelling en werkwijze van parlementaire onderzoekscommissies. In 1996 constateerde de Enquêtecommissie Opsporingsmethoden in haar eindrapport dat "te vaak het wiel opnieuw moet worden uitgevonden" wanneer de Kamer een parlementair onderzoek wil uitvoeren. De commissie deed daarom de aanbeveling een draaiboek vast te stellen, waarin de opgedane ervaringen van de afgelopen decennia omtrent de organisatie van (omvangrijke) parlementaire onderzoeken konden worden vastgelegd. ${ }^{2}$ In 1998 besloot de

\footnotetext{
${ }^{1}$ Handelingen I 2011/12, nr. 1, p. 5-6.

2 Inzake opsporing 1996, p. 480.
} 


\section{NEDERLAND}

Kamer daarom een onderzoeksdraaiboek vast te stellen. ${ }^{3}$ Hierin werden niet alleen richtlijnen gegeven omtrent parlementair onderzoek, maar ook ten aanzien van de besluitvorming rondom extern uitgevoerd onderzoek.

De nieuwe enquêtewet, die in 2008 in werking trad, maakte het noodzakelijk om de bestaande procedurevoorschriften aan te passen. Het Reglement van Orde van de Tweede Kamer werd daartoe gewijzigd. Veel voorschriften omtrent de enquête werden geschrapt; volstaan kon worden met de bepalingen in de nieuwe wet. Tegelijkertijd werd het onderzoeksdraaiboek omgedoopt tot de Regeling parlementair en extern onderzoek (RPE), die kan worden gezien als bijlage bij het Reglement van Orde. 4

De oorspronkelijke wens van de Kamer om het reguliere parlementaire onderzoek net als de enquête bij wet te regelen en te komen tot een 'Wet op het parlementaire onderzoek', werd door de initiatiefnemers "na rijp beraad" afgewezen. Aangezien derden bij regulier parlementair onderzoek alleen op basis van vrijwilligheid medewerking verlenen, zo meenden zij, is een wettelijke regeling niet nodig. ${ }^{5}$ Wel is bij deze gelegenheid getracht de besluitvorming rondom parlementaire enquêtes en reguliere parlementaire onderzoeken te moderniseren en vereenvoudigen. ${ }^{6}$

De RPE spreekt van een parlementair onderzoek wanneer de Kamer verantwoordelijkheid draagt voor de uitvoering van het onderzoek. ${ }^{7}$ Meer specifiek wordt parlementair onderzoek gedefinieerd als:

\footnotetext{
"een activiteit op basis van een besluit door de Kamer, op voorstel van één of meer leden tot vaststelling van een vraagstelling/onderzoeksopdracht, waarbij beantwoording van die vraag dan wel uitvoering van het onderzoek niet aan de regering wordt gevraagd en waarbij de Kamer verantwoordelijkheid draagt voor de uitkomsten van het onderzoek." 8
}

Wanneer de Kamer opdracht geeft of verzoekt tot een onderzoek, maar geen verantwoordelijkheid draagt voor de uitkomsten ervan, dan wordt gesproken van een extern onderzoek. Daarbij kan gedacht worden aan onderzoek door universitaire of private onderzoeksinstituten, maar ook door instellingen met een wettelijke taak zoals het Rijkinstituut voor Volksgezondheid en Milieu of het Sociaal-Cultureel Planbureau. Een aparte status heeft het zogenaamde verzoekonderzoek door de Algemene Rekenkamer. ${ }^{9}$

\footnotetext{
${ }^{3}$ Het Draaiboek Onderzoek is sindsdien enkele malen aangepast. De laatste versie is te vinden in: Kamerstukken II 2001/02, 28 336, nr. 8.

${ }^{4}$ De Kamer stemde op 3 juli 2008 in met het voorstel van het Presidium voor een Regeling parlementair en extern onderzoek. Handelingen II 3 juli 2008, TK 105, p. 7531-7532. Zie voor tekst en toelichting: Kamerstukken II 2007/08, 31 019, nr. 6. In latere Kamerstukken wordt naar deze regeling verwezen middels de afkorting RPE, die hier wordt overgenomen.

${ }^{5}$ Kamerstukken II 2005/06, 30 415, nr. 6, p. 8. Ook de Raad van State steunde deze keuze, mits de door de Kamer gesignaleerde knelpunten in het reguliere onderzoek - waaronder de onduidelijkheid over de positie van getuigen - afdoende zouden worden aangepakt. Idem, nr. 4, p. 6.

${ }^{6}$ Kamerstukken II 2006.07, 31 019, nr. 2, p. 1.

${ }^{7}$ Art. 2 RPE.

${ }^{8}$ Kamerstukken II 2006/07, 31 019, nr. 6, p. 5.

${ }_{9}^{9}$ Art. 3 RPE en Kamerstukken II 2006/07, 31 019, nr. 3, p. 6-8.
} 
Bij parlementair onderzoek wordt de uitvoering in handen gelegd van een door de Kamer in te stellen enquêtecommissie of een tijdelijke commissie (zonder enquêtebevoegdheden). ${ }^{10}$ De besluitvormingsprocedure is geregeld in art. 4 e.v. RPE. Hieruit blijkt, dat de besluitvorming omtrent het houden van een parlementair onderzoek langs twee wegen kan verlopen. De eerste is dat een of meer leden of een (bestaande) commissie een onderzoeksvoorstel opstellen. Hierbij kunnen de leden assistentie krijgen van het parlementaire onderzoeksbureau (BOR). ${ }^{11}$ Het voorstel dient aan een aantal voorwaarden te voldoen. Zo moet het de aanleiding en een 'vastomlijnde onderzoeksvraag' die is opgesplitst in deelvragen bevatten. Ook moet een indicatie gegeven worden van de kosten, tijdsduur en benodigde (ambtelijke) ondersteuning. Verder moet in het voorstel een onderbouwde keuze worden gemaakt voor het in te zetten onderzoeksinstrument: een enquêtecommissie, een tijdelijke commissie zonder enquêtebevoegdheden of een extern onderzoek in opdracht of op verzoek van de Kamer. ${ }^{12}$ Het voorstel wordt aan het Presidium gezonden, die het met advies voorlegt aan de Kamer. De Kamer besluit vervolgens over het voorstel. ${ }^{13}$ De tweede weg is die van de zogenaamde 'onderzoeksmotie'. Dit is een motie waarin de Kamer wordt opgeroepen een onderzoek in te stellen, waarbij de nadere uitwerking ontbreekt. Het Presidium kan een dergelijke motie voorleggen aan de meest betrokken (vaste) commissie(s) ter nadere invulling, waarna het voorstel aan de Kamer wordt voorgelegd. ${ }^{14}$

De huidige besluitvormingsprocedure is sterk vereenvoudigd ten opzichte van de oude procedure. In het onderzoeksdraaiboek werd nog uitgegaan van een voorfase, waarin moest worden bezien of een parlementair onderzoek nuttig en noodzakelijk was. Het proces begon met een zogenaamde probleemsignalering: wanneer één of meer leden een informatiebehoefte signaleerden waarin een parlementair (of ander) onderzoek zou kunnen voorzien, wordt door dit lid (deze leden) een zogenaamd "onderzoekskader" opgesteld. Het onderzoekskader werd vervolgens aan de meest betrokken commissie toegestuurd, waarna de griffier van die commissie in overleg trad met het Onderzoeks- en Verificatiebureau (OVB, thans BOR) en de Dienst Informatievoorziening (DIV) van de Kamer, die een advies aan de commissie opstelden. Pas daarna kon worden begonnen met het opstellen van een daadwerkelijk onderzoeksvoorstel. ${ }^{15}$ In het verleden werd soms een 'voorwerkgroep' ingesteld, die de noodzaak van een parlementair onderzoek moest onderzoeken. ${ }^{16}$ Daarbij viel op dat dergelijke werkgroepen bijna altijd adviseren om een parlementair onderzoek

\footnotetext{
${ }^{10}$ Art. 2 RPE.

${ }^{11}$ In de toelichting op de RPE wordt geadviseerd om in een zo vroeg mogelijk stadium contact op te nemen met het BOR. Kamerstukken II 2007/08, 31 019, nr. 6, p. 9-10. Zie nader: hierna, par. 3.3.2.

12 Art. 4, eerste en tweede lid, RPE.

13 Artt. 6 en 7 RPE.

14 Art. 4, derde lid, RPE. Zie ook Kamerstukken II 2006/07, 31 019, nr. 6, p. 9, 12.

15 Zie artt. 1.1.-2.6. Draaiboek 2001, Kamerstukken II 2001/02, 28 336, nr, 8, p. 1-2.

${ }^{16}$ Zie bijvoorbeeld de Werkgroep vooronderzoek opsporingsmethoden, ingesteld door de vaste commissie voor Justitie, die de opmaat vormde voor de Parlementaire Enquête Opsporingsmethoden. Zie verder Kamerstukken II 1995/96, 24 072, nr. 12, p. 7.
} 


\section{NEDERLAND}

te houden. ${ }^{17}$ Ook werden wel tijdelijke commissies ingesteld, die de noodzaak van een parlementaire enquête moesten onderzoeken. ${ }^{18}$

Het idee van een verplichte voorfase, waarin nut en noodzaak van een parlementair onderzoek moest worden verkend, is inmiddels verlaten. Het wordt nu aan de Kamer overgelaten om te bepalen, op welke wijze een parlementair onderzoek wordt ingeleid. De drempel tot het initiëren van een parlementair onderzoek is hiermee (in elk geval procedureel) verlaagd. ${ }^{19}$ Wel benadrukte het Presidium in de toelichting op de RPE het belang van zorgvuldig geformuleerde en onderbouwde onderzoeksvoorstellen. Onderzoeksvoorstellen die in een commissie zijn voorbereid genieten daarom de voorkeur boven onderzoeksmoties. ${ }^{20}$

\subsubsection{Commissievormen}

Sinds de wijziging van het Reglement van Orde in 2008 heeft de Kamer, indien zij besluit tot het houden van een parlementair onderzoek, de keuze uit twee commissievormen: de enquêtecommissie en de tijdelijke commissie zonder enquêtebevoegdheden. ${ }^{21}$

Enquêtecommissies. De Wet op de parlementaire enquête 2008 stelt in artikel 2 dat de Kamer de mogelijkheid heeft om op voorstel van één of meerdere leden een parlementaire enquête in te stellen. Hiermee wordt uitvoering gegeven aan art. $70 \mathrm{Gw}$, waarin de bevoegdheid van het parlement om een enquête te houden is verankerd. De wet geeft enkele procedurevoorschriften, die de Kamer in acht moet nemen wanneer zij besluit tot het houden van een enquête. De Kamer dient de uitvoering van de enquête op te dragen aan een 'commissie van de Kamer'. ${ }^{22}$ Het enquêterecht kan op grond van de wet dus niet worden uitgeoefend door afzonderlijke Kamerleden, het Presidium of de Kamer als geheel. De wet regelt niet uit hoeveel leden een enquêtecommissie dient te bestaan. Wel is bepaald dat tenminste drie leden aanwezig moeten zijn bij het horen van een getuige of deskundige. ${ }^{23}$ Gelet op het belang van openbare hoorzittingen voor de enquêtepraktijk, betekent dit feitelijk dat drie leden het minimum is. ${ }^{24}$ Het besluit tot het houden van een enquêteonderzoek dient een omschrijving te bevatten van het onderwerp waarop de enquête betrekking zal heb-

\footnotetext{
${ }_{17}$ De voorwerkgroep bleek vaak onder grote politieke druk te staan om tot een dergelijke conclusie te komen. Muller \& Coenen 2002, p. 49.

${ }^{18}$ Een voorbeeld is de Tijdelijke commissie onderzoek bouwfraude, die tot de conclusie kwam dat, gelet op de aard van de vermoedens van onregelmatigheden in de bouwnijverheid, een parlementaire enquête bij uitstek geschikt was om diepgravend onderzoek te doen naar de bouwsector en onder ede alle informatie boven tafel te krijgen. Kamerstukken II 2002/03, 28 244, nrs. 5-6, p. 22-23.

${ }^{19} \mathrm{Zie}$ ook art. 142 RvOTK (oud), dat ten aanzien van een enquêtevoorstel gedaan door één of meerdere leden bepaalde dat eerst een voorbereidend onderzoek diende plaats te vinden door een hiertoe in te stellen tijdelijke commissie als bedoeld in art. 18 RvOTK.

${ }^{20}$ Kamerstukken II 2006/07, 31 019, nr. 6, p. 9.

${ }^{21}$ Art. 141 jo. art. 142 RvOTK. Zie ook art. 2 RPE.

22 Art. 2, tweede lid, Wpe 2008.

${ }^{23}$ Zie art. 9, tweede lid, Wpe 2008. Vgl. art. 1, vijfde lid, WPE (oud), waarin dit quorum vereist werd bij de uitoefening van alle bevoegdheden van de commissie.

${ }^{24}$ Zie ook Kamerstukken II 2005/06, 30 415, nr. 6, p. 10. Meer over de personele samenstelling in par. 3.2.4.
} 
ben. De Kamer kan deze omschrijving gedurende het onderzoek, al dan niet op voorstel van de commissie, wijzigen. ${ }^{25}$ Het besluit tot het instellen van een enquêteonderzoek, het onderzoeksvoorstel en de commissiesamenstelling worden door de Kamervoorzitter gepubliceerd in de Staatscourant. ${ }^{26}$

Het Reglement van Orde kent sinds 2008 geen nadere voorschriften meer omtrent de enquête. Voorheen werd hier bijvoorbeeld nog bepaald, dat een voorstel schriftelijk bij de Kamer diende te worden ingediend, dat het zo mogelijk reeds de namen van de te horen getuigen en deskundigen diende te bevatten, dat bij een voorstel afkomstig van één of meer leden een vooronderzoek nodig was en dat een enquête altijd aan een termijn gebonden dient te zijn. ${ }^{27}$ Hiermee is de besluitvorming rondom een enquêteonderzoek vereenvoudigd.

Tijdelijke commissies. De Kamer kan ook besluiten een parlementair onderzoek te houden waarbij geen bijzondere enquêtebevoegdheden aan de onderzoekscommissie worden verleend. Dit kan om verschillende redenen aantrekkelijker zijn dan een enquêtecommissie. Het onderzoeksthema is bijvoorbeeld weinig omstreden, waardoor het onwaarschijnlijk is dat eventuele getuigen of deskundigen zullen weigeren hun medewerking te verlenen. Soms is de medewerking van derden überhaupt niet of nauwelijks nodig, waardoor enquêtebevoegdheden niet noodzakelijk worden geacht. Bovendien heeft onderzoek door tijdelijke commissies in de praktijk een minder zwaarwichtig imago dan enquêtes, die vaak als paardenmiddel worden beschouwd. Parlementaire enquêtes zijn daarom bijna per definitie beladen en kunnen de verhoudingen binnen de regeringscoalitie onder druk zetten. Een tijdelijke commissie zonder enquêtebevoegdheden is in die zin vaak minder gevoelig. Waarom in het ene geval voor een enquête wordt gekozen en in het andere geval voor een tijdelijke commissie, is mede daarom moeilijk op inhoudelijke gronden te verklaren. ${ }^{28}$

Een tijdelijke commissie zonder enquêtebevoegdheden kan dus politiek gezien aantrekkelijker zijn dan een enquêtecommissie. Het Reglement van Orde biedt hiertoe mogelijkheden. Het huidige commissiestelsel stamt grotendeels uit 1994, toen het Reglement van Orde van de Tweede Kamer geheel werd herzien. ${ }^{29}$ Het parlementaire werk had zich in toenemende mate verplaatst van de plenaire zittingen naar de commissies. Het stelsel van allerhande commissies dat in de loop van de tijd was ontstaan had volgens critici geleid tot verkokering en versnippering. ${ }^{30}$ De Commissie

\footnotetext{
${ }^{25}$ Art. 2, derde lid, Wpe 2008. Tot 1977 bepaalde de wet, dat een besluit tot het houden van een enquête een "nauwkeurige omschrijving" van de enquêteopdracht diende te bevatten. Bij de wetswijziging in dat jaar werd dit zogenaamde nauwkeurigheidsvereiste geschrapt. De toenmalige initiatiefnemers waren van mening "dat de Kamer geen aansporing behoeft om zo nauwkeurig mogelijk haar besluiten te formuleren." Zie Kamerstukken II 1975/76, 13 837, nrs. 1-3, p. 8. Zie nader hierna, par. 4.2.2.

${ }^{26}$ Art. 2, vijfde lid, Wpe 2008.

27 Zie artt. 140-144 RvOTK (oud).

${ }^{28}$ Om dezelfde reden wordt soms voor een parlementair onderzoek gekozen en in andere gevallen juist voor bestuurlijk onderzoek of het instellen van een externe commissie, zoals na de cafébrand in Volendam of de vuurwerkramp in Enschede. Zie ook Lubberdink 2003, p. 12-13.

${ }^{29}$ Regeling van 22 juni 1993, inwerkingtreding 17 mei 1994, Kamerstukken II 22 590. Zie art. 15 RvOTK. De Kamer kan ingevolge deze bepaling slechts die commissies instellen waarin het Reglement voorziet.

${ }^{30}$ Zie bijvoorbeeld de commissie-Dolman, Kamerstukken II 1985/86, 19 336, nrs. 1-2, p. 19, die kritiek uitoefende op de werkwijze van de Kamer en in het bijzondere het versnipperde commissiewerk.
} 


\section{NEDERLAND}

voor de Werkwijze, die het nieuwe commissiestelsel bij de Kamer introduceerde, beoogde een heldere driedeling: het stelsel zou bestaan uit commissies die elk de zaken van één ministerie zouden behandelen, commissies die een bepaald beleidsterrein integraal zouden behandelen en commissies die voor een bepaalde tijd met een bepaalde opdracht zouden worden ingesteld. ${ }^{31} \mathrm{Na}$ enige wijzigingen heeft dit geresulteerd in het commissiestelsel dat is neergelegd in hoofdstuk VII van het Reglement. Later is hieraan nog de zogenaamde themacommissie toegevoegd, waardoor het stelsel thans in hoofdzaak uit vier soorten commissies bestaat: de vaste commissies, de algemene commissies, de themacommissies en de tijdelijke commissies. ${ }^{32}$ Alleen de vaste commissies en de overige commissies worden direct door het Reglement ingesteld; de andere commissies worden bij afzonderlijk besluit van de Kamer, dat bij gewone meerderheid wordt genomen, in het leven geroepen. Het Reglement stelt geen limiet aan het aantal algemene, tijdelijke of thematische commissies.

De tijdelijke commissie is een van de nieuwe commissievormen die in 1994 werden ingevoerd. Het Reglement laat het doel van de commissie in het midden: art. 18 RvOTK bepaalt slechts dat de Kamer een tijdelijke commissie kan instellen "voor specifieke onderwerpen". De Kamer krijgt hier dus een grote vrijheid. De Commissie voor de Werkwijze had verschillende functies voor de tijdelijke commissie in gedachten, zoals uit de behandeling van haar voorstel blijkt. ${ }^{33}$ Sinds 1994 heeft de Kamer tijdelijke commissies echter hoofdzakelijk ingesteld om parlementaire onderzoeken uit te voeren. Hoewel het Reglement dus ten aanzien van het doel van een tijdelijke commissie geen beperkingen stelt, heeft de Commissie voor de Werkwijze wel getracht met enkele procedurele voorwaarden te voorkomen dat een wildgroei aan tijdelijke commissies zou ontstaan. ${ }^{34}$ Een belangrijk kenmerk van de tijdelijke commissie is namelijk dat deze wordt ingesteld met een duidelijke opdracht en een plicht tot rapporteren aan de Kamer: het tweede lid van art. 18 bepaalt dat het besluit tot het instellen van een tijdelijke commissie, dat bij gewone meerderheid wordt genomen, een nauwkeurige omschrijving dient te bevatten van het onderwerp waarover de commissie de Kamer dient te rapporteren. Het instellingsbesluit dient tevens de termijn waarvoor de commissie wordt ingesteld te bevatten. ${ }^{35}$ Het doen van medede-

\footnotetext{
${ }^{31}$ Kamerstukken II 1991/92, 22 590, nr. 3, p. 1-3. Zie ook Van Schagen 1994, p. 78-80.

32 Zie artt. 16-18 RvOTK. Daarnaast kent het Reglement een aantal specifieke commissies (de 'Overige commissies'), zoals de Commissie voor de Verzoekschriften en de Commissie voor de Werkwijze. Zie artt. 19-24 RvOTK.

${ }^{33}$ De Commissie voor de Werkwijze, die het voorstel indiende, had voor tijdelijke commissies bijvoorbeeld de taak om een vraagpuntennota uit te brengen of een bepaald wetsvoorstel te behandelen in gedachte. De taken van een tijdelijke commissie zijn in ieder geval niet noodzakelijkerwijs beperkt tot onderzoeksactiviteiten, zo merkt de Commissie nog op. Zie Kamerstukken II 1992/93, 22 590, nr. 5, p. 15-16.

34 Van Schagen 1994, p. 83.

35 Art. 18, tweede lid, RvOTK. De termijn kan, evenals bij enquêtecommissies, door de Kamer worden verlengd. Art. 18, derde lid, RvOTK. De tijdelijke commissie verschilt van de algemene commissie (art. 17 RvOTK). De laatste moet zich juist richten op een algemeen onderwerp en is niet verplicht te rapporteren aan de Kamer. Zie ook Van Schagen 1994, p. 83.
} 
ling in de Staatscourant van de instelling van een tijdelijke (onderzoeks)commissie is sinds 2008 niet meer voorgeschreven. ${ }^{36}$

Vaste commissies. Tot voor kort kon een parlementair onderzoek ook worden uitgevoerd door een bestaande commissie. ${ }^{37}$ In de praktijk bleken de vaste commissies, die zich hoofdzakelijk bezig houden met de voorbereidende behandeling van wetsvoorstellen en overleg met ministers over het regeringsbeleid, hiervan af en toe gebruik te maken. Op grond van art. 27 RvOTK beschikken zij over dezelfde onderzoeksbevoegdheden als tijdelijke commissies. Hoewel verlof vragen van de Kamer voor het houden van een onderzoek daarom strikt genomen niet nodig was, werd er in het onderzoeksdraaiboek wel vanuit gegaan dat een onderzoeksvoorstel werd voorgelegd aan het Presidium, die het met advies ter goedkeuring zou doorleiden naar de Kamer. ${ }^{38}$ Bovendien speelde mee, dat het Presidium verantwoordelijk is voor het beheer van de begroting van de Kamer. Over de toekenning van een onderzoeksbudget aan een (werkgroep van een) commissie besliste de Kamer op voordracht van het Presidium. ${ }^{39}$ Het uitvoeren van een onderzoek is nauwelijks denkbaar zonder een budget waaruit eventuele tijdelijke medewerkers, externe deskundigen en werkbezoeken kunnen worden betaald. ${ }^{40}$

De vaste commissies konden ook besluiten om een werkgroep uit hun midden in te stellen, waaraan de uitvoering van het onderzoek werd opgedragen. Gezien de doorgaans grote omvang van de vaste commissies (20 à 30 leden) had het samenstellen van een werkgroep in de praktijk de voorkeur. Het Reglement van Orde voorziet niet in een regeling met betrekking tot de instelling van werkgroepen door bestaande commissies. Tot 1994 bevatte het Reglement nog wel een bepaling omtrent subcommissies. Aangenomen werd dat deze subcommissies konden beschikken over alle bevoegdheden die ook aan gewone commissies toekwamen. Volgens de Commissie voor de Werkwijze, die de herziening van 1994 voorbereidde, zouden deze subcommissies echter te gemakkelijk een eigen leven kunnen gaan leiden zonder dat de Kamer invloed kon uitoefenen op de instelling ervan. ${ }^{41}$ Voortaan konden alleen nog op informele wijze subcommissies of werkgroepen worden ingesteld. Deze zouden geen commissiebevoegdheden, zoals het houden van hoorzittingen, meer kunnen uitoefenen. ${ }^{42}$

Informele subcommissies of werkgroepen kunnen aldus niet worden voorzien van onderzoeksbevoegdheden, faciliteiten, ondersteuning of een eigen (onderzoeks)budget. In de praktijk moeten zij worden gezien als informele samenwerkingsver-

\footnotetext{
${ }^{36}$ De Voorzitter zorgde voorheen voor publicatie van het besluit tot het instellen van een onderzoek en van de samenstelling van de commissie in de Staatscourant. Zie Draaiboek 2001, art. 5.1 onder g, Kamerstukken II 2001/02, 28 336, nr, 8, p. 4.

37 Zie art. 5.1. Draaiboek 2001, Kamerstukken II 2001/02, 28 336, nr, 8, p. 3.

38 Zie artt. 4.1.-4.2. Draaiboek 2001, Kamerstukken II 2001/02, 28 336, nr. 6, p. 3.

${ }^{39}$ Zie art. 9 jo. 10, tweede lid, RvOTK en art. 4.4 Draaiboek 2001, Kamerstukken II 2001/02, 28 336, nr. 6, p. 3 .

${ }^{40}$ Hieronder wordt duidelijk dat ook het Draaiboek Onderzoek nadere regels stelt ten aanzien van bestaande commissies die onderzoek willen doen.

41 Kamerstukken II 1992/93, 22 590, nr. 5, p. 18. Van de mogelijkheid van subcommissies werd overigens weinig gebruik gemaakt en voor zover ze werden ingesteld, hadden ze allen een tijdelijk karakter en dienden ze vaak als onderzoekscommissie. Zie Van Schagen 1994, p. 85.

42 Kamerstukken II 1992/93, 22 590, nr. 5, p. 18.
} 


\section{NEDERLAND}

banden, die onderzoekswerkzaamheden verrichten in naam van de commissies waaruit zij voortkomen. De betrokkenheid van de Kamer is beperkt. Een recent praktijkvoorbeeld leert dat het instellen van een werkgroep, inclusief de benoeming van de leden en de voorzitter daarvan, aan de betreffende commissies wordt overgelaten. Bij het parlementair onderzoek inzake de NATO Response Force, dat een gezamenlijk initiatief van twee vaste commissies was, werd aan de Kamer voorgesteld "de vaste commissies voor Buitenlandse Zaken en Defensie zelf het onderzoek te laten verrichten". ${ }^{43}$ Het onderzoeksvoorstel was opgesteld, overeenkomstig het toenmalige onderzoeksdraaiboek, door een werkgroep bestaande uit leden van de vaste commissies. Nadat de Kamer overeenkomstig het voorstel besloten had, ${ }^{44}$ droegen de commissies de uitvoering van het onderzoek op aan dezelfde werkgroep die het onderzoeksvoorstel had opgesteld. ${ }^{45}$

Zoals gezegd bepaalt het Reglement van Orde sinds 2008 dat de uitvoering van parlementair onderzoek in handen wordt gelegd van een door de Kamer in te stellen enquêtecommissie of een tijdelijke commissie (zonder enquêtebevoegdheden). ${ }^{46}$ Onderzoek door vaste commissies is daarmee uitgesloten. In de toelichting op de nieuwe regeling wijst het Presidium het gebruik van vaste Kamercommissies of werkgroepen daaruit ook uitdrukkelijk af. Een vaste commissie zou namelijk het risico lopen ook het eigen optreden in een zaak te moeten beoordelen. Bovendien geldt voor een werkgroep uit een vaste commissie dat deze niet kan beschikken over formele commissiebevoegdheden. ${ }^{47}$

\subsubsection{Toekomst- en onderzoeksagenda}

De besluitvorming rondom parlementair onderzoek in Nederland, zo is hierboven duidelijk geworden, heeft een sterk incidenteel karakter. Onderzoeksvoorstellen vloeien veelal voort uit de actualiteit. Een onderzoek komt er vervolgens alleen, wanneer de voorstanders ervan voldoende parlementaire steun weten te verzamelen.

Veel voorstellen, met name wanneer deze van oppositiezijde komen, halen het wegens gebrek aan politieke steun niet. Tegelijkertijd wordt het onderzoeksinstrument als zodanig binnen de Tweede Kamer veelal als waardevol gezien, zo bleek recentelijk bijvoorbeeld nog bij de parlementaire zelfreflectie. ${ }^{48}$ Naar aanleiding van deze zelfreflectie zijn initiatieven ontplooid in de richting van een meer structurele inzet van het onderzoeksinstrument. De Kamer steunde het voorstel van de stuurgroep zelfreflectie om te experimenteren met een toekomst- en onderzoeksagenda. Het kan daarbij gaan om zogenaamde uitvoeringsonderzoeken 'ex post' of om toekomstverkenningen. Een uitvoeringsonderzoek 'ex post' wordt omschreven als "een onderzoek naar de uitvoeringspraktijk van bestaande regelgeving" met "het karakter van een beleidsevaluatie". Onder 'toekomstonderzoek' wordt verstaan: "een onder-

\footnotetext{
${ }^{43}$ Kamerstukken II 2004/05, 30 162, nr. 1, p. 1-2.

${ }^{44}$ Handelingen II 2004/05, p. 5677.

45 Zie het eindrapport van de werkgroep: Kamerstukken II 2005/06, 30 162, nrs. 2-3, p. 9.

${ }^{46}$ Art. 2 RPE.

47 Zie Kamerstukken II 2006/07, 31 019, nr. 3, p. 6, 8.

${ }^{48}$ Zie Rapport parlementaire zelfreflectie 2009, p. 271, 282.
} 
zoek naar ontwikkelingen die zich op een bepaald beleidsterrein kunnen afspelen". Deze vormen van onderzoek moeten volgens het Presidium worden onderscheiden van uitvoeringsonderzoeken 'ex ante', zoals uitvoeringstoetsen op aanhangige wetsvoorstellen, en parlementaire onderzoeken naar aanleiding van actuele ontwikkelingen. 49

De vaststelling van de toekomst- en onderzoeksagenda vindt plaats in het najaar, aan het begin van het nieuwe financiële jaar. De periode rondom Prinsjesdag is, zo stelt het Presidium, een goed moment om vooruit te kijken en stil te staan bij uitvoeringsvraagstukken. ${ }^{50}$ De procedure is als volgt. Vóór 1 oktober kunnen de fracties onderwerpen aandragen bij de vaste commissies. De commissies kunnen vervolgens elk één voorstel indienen bij de Commissie voor de Rijksuitgaven. Ook eventuele moties voor een onderzoek die tijdens de Algemene Beschouwingen worden aangenomen, worden meegenomen. De commissie selecteert ten hoogste drie voorstellen, die aan de Kamer worden voorgelegd. ${ }^{51}$ De voorstellen worden marginaal getoetst aan de hand van een aantal criteria, te weten: maatschappelijke en politieke relevantie, de mate van urgentie, de meerwaarde van een parlementair onderzoek ten opzichte van ander (afgerond of lopend) onderzoek door bijvoorbeeld de Rekenkamer, alsmede de uitvoerbaarheid (binnen een jaar). De Kamer beslist in december of de geselecteerde voorstellen in beginsel zullen worden gehonoreerd. De drie vaste commissies die het betreft, krijgen vervolgens tot 1 maart de tijd om een uitgewerkt voorstel aan de Kamer voor te leggen overeenkomstig de RPE, waarna de Kamer definitief besluit of de voorstellen kunnen worden uitgevoerd. 52

Vanwege capaciteits- en budgettaire beperkingen kunnen jaarlijks maximaal drie van deze toekomst- en 'ex post' uitvoeringsonderzoeken worden uitgevoerd, zo besloot het Presidium mede naar aanleiding van de parlementaire behandeling van het zelfreflectierapport. ${ }^{3}$ In totaal wordt voor de onderzoeksagenda een budget van $€ 1,5$ mln per jaar beschikbaar gesteld. 54

Uit overzichten van de Commissie voor de Rijksuitgaven blijkt dat voor de onderzoeksagenda 2010 door de fracties in totaal 15 voorstellen werden ingediend bij de vaste commissies, waarvan er uiteindelijk 8 aan de Commissie voor de Rijksuitgaven werden voorgelegd. Voor het jaar 2011 werden 27 voorstellen ingediend, waar-

\footnotetext{
${ }^{49}$ De laatste categorie kan uit haar aard moeilijk in een onderzoeksagenda worden opgenomen. In het stimuleren van ex-anteonderzoeken, zoals de stuurgroep voorstelde, zag het Presidium weinig: deze zouden ook in het reguliere wetgevingstraject kunnen plaatsvinden, bijvoorbeeld in de vorm van uitgebreide hoorzittingen, of worden overgelaten aan onafhankelijke externe instanties. Zie verder Kamerstukken II 2009/10, 31 845, nr. 9, p. 1-2.

${ }^{50}$ Kamerstukken II 2009/10, 31 845, nr. 9, p. 2.

51 De commissie heeft reeds ervaring op dit terrein, aangezien zij tevens onderzoeksvoorstellen ten aanzien van grote projecten of verzoekonderzoeken van de Algemene Rekenkamer begeleidt. Het Presidium gaf in overweging om deze commissie om te dopen tot de Commissie voor Rijksuitgaven en Onderzoeken, maar dat is niet gebeurd. Kamerstukken II 2009/10, 31 845, nr. 9, p. 3.

52 Zie verder Kamerstukken II 2009/10, 31 845, nr. 9, p. 2-3. Zie ook art. 4-7 RPE, Kamerstukken II 2007/08, 31 019, nr. 6, p. 2. Bij de eerste ronde heeft de Commissie voor de Rijksuitgaven de criteria nader geoperationaliseerd. Zie Kamerstukken II 2009/10, 32 224, nr. 1, p. 4.

${ }^{53}$ Kamerstukken II 2009/10, 31 845, nr. 9, p. 1.

54 Kamerstukken II 2009/10, 31 845, nr. 9, p. 3-4.
} 


\section{NEDERLAND}

van er 12 werden voorgelegd. ${ }^{55}$ De overgrote meerderheid van de ingediende voorstellen kon worden getypeerd als uitvoeringsonderzoek ex post. Een aantal vaste commissies ontving meerdere voorstellen. Met name Verkeer en Waterstaat en Justitie bleken populair. Waar in het eerste jaar slechts vier fracties voorstellen indienden, bleek in het tweede jaar elke fractie behalve de SGP een voorstel in te hebben gediend. Verreweg de meeste voorstellen kwamen van de SP. Enkele voorstellen werden bij meerdere commissies ingediend, al werden die slechts door één commissie behandeld. Ook werden enkele voorstellen uit het eerste jaar ook in het tweede jaar ingediend. Tot nu toe bleken er binnen de vaste commissies geen problemen te zijn bij het selecteren van één voorstel dat kon worden voorgelegd aan de Commissie voor de Rijksuitgaven. ${ }^{56}$ Voor 2010 werden onderzoeken gehonoreerd op het gebied van de jeugdzorg, doeltreffendheid van inburgering en 'integraal indiceren'. ${ }^{57}$ Voor 2011 ging het om onderhoud en innovatie van het Nederlandse spoorsysteem, lessen uit recente arbeidsmigratie en de economische dimensie van verduurzaming van de voedselproductie. ${ }^{58}$

$\mathrm{Na}$ de eerste ronde verrichtte de Commissie voor de Rijksuitgaven ook een procesevaluatie, waaruit enkele aanbevelingen kwamen die bij de tweede ronde nog eens onder de aandacht werden gebracht. Benadrukt werd, dat de commissie "veronderstelt dat bij de commissies die aan zet zijn voldoende draagvlak bestaat om het door de Kamer geselecteerde onderzoek of verkenning ook daadwerkelijk in uitvoering te nemen." 59 Dit was kennelijk niet vanzelfsprekend, zo bleek ook uit het feit dat de commissie voor VWS het door haar ingediende voorstel over integraal indiceren uiteindelijk niet ter hand heeft genomen. Daarnaast werd erop gewezen, dat tijdelijke commissies het meest logische 'vehiculum' zijn voor het uitvoeren van de toekomsten onderzoeksagenda. ${ }^{60}$ Tijdens de eerste ronde bleken twee van de drie onderzoeken namelijk, in afwijking van het Reglement van Orde zoals dat in 2008 werd gewijzigd, door een 'werkgroep' c.q. een 'klankbordgroep' te zijn uitgevoerd. ${ }^{61}$ Hoewel hiermee "vooralsnog goede ervaringen" werden opgedaan met deze "in 2010 bewust gekozen" afwijkende vormen, blijft de tijdelijke commissie de voorkeur houden gelet op de beschikbare onderzoeksbevoegdheden en de toe te kennen onderzoeksbudgetten. De betreffende vaste commissies dachten daar dus kennelijk anders over. ${ }^{62}$ In

\footnotetext{
55 Zie Kamerstukken II 2010/2011, 32 224, nr. 1, p. 1; Kamerstukken II 2011/12, 32 224, nr. 2, p. 1; Kamerstukken II 2010/11, 32 224, nr. 3, p. 5-6.

${ }^{56}$ Zie Kamerstukken II 2010/11, 32 224, nr. 3, p. 5-6.

57 Kamerstukken II 2010/11, 32 224, nr. 1, p. 1.

58 Kamerstukken II 2010/11, 32 224, nr. 2, p. 1.

${ }^{59}$ Kamerstukken II 2010/11, 32 224, nr. 2, p. 1

${ }^{60}$ Kamerstukken II 2010/11, 32 224, nr. 2, p. 1-2. Het Presidium benadrukte dit reeds in zijn voorstel voor de onderzoeksagenda. Zie Kamerstukken II 2009/10, 31 845, nr. 9, p. 4, noot 1.

${ }^{61}$ Het betreft de Werkgroep toekomstverkenning jeugdzorg, onderdeel van de algemene commissie voor Jeugd en Gezin (Kamerstuk 32 296) en de klankbordgroep Inburgering, onderdeel van de algemene commissie voor Wonen, Wijken en Integratie (Kamerstuk 32 321). In het laatste geval werd voor deze vorm gekozen, omdat het inhoudelijke onderzoek geheel werd uitbesteed.

62 Zie Kamerstukken II 2009/10, 32 321, nr. 1, p. 2-3 (Onderzoek naar de effecten van inburgering op participatie in het kader van de Onderzoeks- en toekomstagenda 2010).
} 
2011 werd voor twee onderzoeken een tijdelijke commissie ingesteld. 63 Voor het derde onderzoek werd wederom voor een klankbordgroep binnen een vaste commissie gekozen, waarbij een groot deel van het onderzoek werd uitbesteed aan een externe instantie. ${ }^{64}$

Het groeiend aantal voorstellen dat de eerste jaren werd ingediend en voorgelegd lijkt erop te wijzen dat binnen de Kamer voldoende animo bestaat voor deze nieuwe onderzoeksplanning, naast de (inmiddels traditionele) mogelijkheid van ad hoc geïnitieerde reguliere onderzoeken of enquêtes. Bij de meest recente onderzoeksagenda's bleek deze stijgende lijn echter niet te worden voortgezet. Voor de onderzoeksagenda van 2012 werden uiteindelijk slechts vier voorstellen aan de Commissie voor de Rijksuitgaven voorgelegd. ${ }^{65}$ Een verklaring voor deze daling kon bij de tussentijdse evaluatie die eind dat jaar plaatsvond, nog niet worden gegeven. ${ }^{66}$ Voor 2013 werd in afwijking van de hierboven geschetste procedure besloten geen indienronde te houden, omdat deze dan zou moeten plaatsvinden in de periode waarin verkiezingen zouden worden gehouden en de nieuwe vaste commissies zouden worden geconstitueerd. Bovendien, zo berichtte de Commissie voor de Rijksuitgaven aan de Kamer, zou een aantal onderzoeken uit 2012 een langere doorlooptijd hebben en was inmiddels een parlementaire enquête in voorbereiding. Een nieuwe onderzoeksagenda zou daardoor in het voorjaar zorgen voor een te grote belasting van zowel de leden als het ambtelijk personeel van de Kamer. Besloten werd de procedure eenmalig aan te passen en de onderzoeken van 2012 tevens van toepassing te laten zijn voor de onderzoeksagenda van 2013.67

De tot op heden uitgevoerde onderzoeken vertonen verder aanzienlijke verschillen met betrekking tot de onderzoeksvorm, inzet van onderzoeksinstrumenten, omvang en intensiteit. 68 Ook de betrokkenheid van Kamerleden wisselt sterk: in sommige gevallen wordt het eigenlijke onderzoek zelfs geheel uitbesteed. Opvallend is een passage in het eindrapport van de werkgroep 'Toekomstverkenning Jeugdzorg', waarin de nieuwe werkwijze als volgt wordt getypeerd:

"Het heeft niet de 'zwaarte' van een parlementair onderzoek of parlementaire enquête. Het is
een nieuw, lichter parlementair instrument. Het is echter zwaarder dan het instrument van een
reeks hoorzittingen of rondetafelgesprekken; vaak toegepaste en overigens prima instrumenten
voor de Kamer om zich voor te bereiden op wetgeving of controle op de beleidsuitvoering door

\footnotetext{
${ }^{63}$ Het betreft de parlementaire onderzoeken Lessen uit de recente arbeidsmigratie (Kamerstuk 32 680) en Onderzoek en innovatie spoor (Kamerstuk 32 707).

64 Zie Parlementair onderzoek Economische dimensie verduurzaming voedselproductie, Kamerstukken II 2010/11, 32 708, nr. 1.

${ }^{65}$ Het ging om voorstellen van vijf commissies, waarbij één voorstel door twee commissies gezamenlijk werd voorgelegd. De voorstellen waren afkomstig van vijf verschillende fracties. Kamerstukken II 2011/12, 32 224, nr. 4, p. 1 en Kamerstukken II 2011/12, 32 224, nr. 5, p. 3.

${ }^{66}$ Kamerstukken II 2011/12, 32 224, nr. 5, p. 5. Hoewel hieruit natuurlijk een afnemende interesse bij fracties zou kunnen worden afgeleid, al dan niet tijdelijk van aard, zou de daling bijvoorbeeld ook het gevolg kunnen zijn van een intensievere informele afstemming tussen fracties voorafgaand aan de indiening van voorstellen bij de vaste commissies.

${ }^{67}$ Kamerstukken II 2011/12, 32 224, nr. 6, p. 1-4 en Handelingen II 2011/12, 5 juli 2012, TK 105, p. 126.

68 Zo bracht de Werkgroep 'Toekomstverkenning Jeugdzorg' een rapport uit van 20 pagina's, terwijl dat van de tijdelijke commissie onderzoek Lessen uit recente arbeidsmigratie 117 pagina's bedraagt.
} 


\section{NEDERLAND}

het kabinet. Deze toekomstverkenning is een nieuw op zichzelf staand instrument van de Kamer." 69

De verdere ontwikkeling van deze nieuwe tussenvorm van parlementair onderzoek zal uiteraard moeten worden afgewacht. Een meer fundamentele evaluatie van de Toekomst- en onderzoeksagenda wordt verwacht na afronding van de onderzoeken voor 2012, waarbij getoetst zal worden aan het doel om de controlerende taak van de Kamer te versterken. ${ }^{70}$

\subsubsection{Samenstelling commissies}

Nadat de besluitvorming omtrent het houden van een parlementair onderzoek is afgerond, kan worden overgegaan tot de samenstelling van de onderzoekscommissie. De Wpe 2008 bepaalt dat de Kamer, nadat besloten is tot een enquête, de leden van de enquêtecommissie benoemt uit haar midden. Ook kan zij leden, al dan niet op hun verzoek, van hun lidmaatschap ontslaan. ${ }^{71}$ Het lidmaatschap eindigt in elk geval wanneer een commissielid het Kamerlidmaatschap verliest. Dit geldt niet, wanneer het lidmaatschap (na verkiezingen) terstond opnieuw aanvangt. Een andere grond voor verlies van lidmaatschap is wanneer het lid zelf als getuige of deskundige door de commissie wordt gehoord. ${ }^{72}$

Voor zowel enquête- als tijdelijke commissies geldt, dat de reguliere regeling voor de benoeming van commissieleden uit het Reglement van Orde, zoals neergelegd in art. 25, van toepassing is. ${ }^{73}$ Hier blijkt dat de samenstelling een bevoegdheid is die voornamelijk bij de Kamervoorzitter berust. Deze benoemt de leden van de commissies, inclusief hun plaatsvervangers, en kan ontheffing van het lidmaatschap verlenen. ${ }^{74}$ Slechts waar het gaat om het aantal leden van een commissie, heeft de Kamer de mogelijkheid om de beslissing van de Voorzitter naast zich neer te leggen en anders te besluiten. ${ }^{75}$

Naast het benoemen van de leden zal ook moeten worden bepaald wie het voorzitterschap van de commissie zal bekleden. Ook hiervoor geldt, dat de reguliere procedure voor de benoeming van commissievoorzitters wordt gevolgd. ${ }^{76}$ Art. 26

${ }^{69}$ Kamerstukken II 2009/10, 32 296, nr. 8, p. 1.

70 Zie de besluitenlijst procedurevergadering Commissie voor de Rijksuitgaven, <http:/ / www.tweedekamer.nl/images/besluitenlijst\%20pv\%20RU\%20d.d.\%2016\%20juni\%202011_tc m118-221978.pdf>.

${ }^{71}$ Zie art. 2, eerste en vierde lid, Wpe 2008.

${ }^{72}$ Art. 36 Wpe 2008. Een suggestie van de CDA-fractie in de Eerste Kamer om commissieleden, nadat zij hun Kamerlidmaatschap zijn verloren, vanwege hun opgebouwde ervaring en expertise toch toe te staan om lid te blijven van een enquêtecommissie, werd door de initiatiefnemers afgewezen. De verregaande, wettelijke bevoegdheden maken dit ongewenst, zo stelden de initiatiefnemers. Kamerstukken I 2006/07, 30415 , F, p. 5.

${ }^{73} \mathrm{Zie}$ art. 8 RPE.

74 Zie art. 25, tweede en derde lid, RvOTK.

75 Zie art. 25, eerste lid, RvOTK. De omvang van commissies is niet in het Reglement vastgelegd, omdat rekening moet kunnen worden gehouden met de grootte van de fracties in de Kamer en de verhouding tussen regerings- en oppositiefracties. Zie Bovend'Eert \& Kummeling 2010, p. 184.

${ }^{76}$ Zie art. 8 RPE. Vgl. ook Kamerstukken II 2005/06, 30 415, nr. 6, p. 11. In het Draaiboek 2001 werd nog voorgeschreven, dat de verkiezing van de voorzitter geschiedt bij geheime en schriftelijke stemming. 
van het Reglement van Orde bepaalt, dat tijdens de eerste vergadering van een nieuw ingestelde commissie, welke onder leiding van de Kamervoorzitter plaatsvindt, door de leden uit hun midden een commissievoorzitter wordt gekozen. De commissievoorzitter wordt door de commissie benoemd. 77

In de praktijk is de selectie van de commissieleden vooral het werk van de fracties in de Kamer. ${ }^{78}$ Het aantal leden van onderzoekscommissies varieert; vaak hebben commissies zeven à acht leden, maar de Paspoortcommissie had bijvoorbeeld slechts vier leden. Vergeleken met de vaste commissies zijn onderzoekscommissies dus vrij klein. Over de invulling van de commissiezetels onderhandelen de fracties. ${ }^{79}$ De toewijzing van het commissievoorzitterschap speelt in deze onderhandelingen een belangrijke rol, aangezien deze in de praktijk een belangrijk stempel drukt op de koers van het onderzoek. ${ }^{80}$ Ook in publicitair opzicht kan het binnenhalen van een commissievoorzitterschap aantrekkelijk zijn voor een fractie. Deze functie is dan ook gewild. Het selectieproces van commissieleden en -voorzitter wordt daarom beheerst door partijpolitieke afspraken en compromissen. Het verloop van deze onderhandelingen is uiteraard mede afhankelijk van het karakter van het parlementaire onderzoek dat verricht gaat worden. Bij een onderzoek dat gepaard gaat met veel publiciteit en politieke gevoeligheid heeft de samenstelling van de commissie en de vervulling van het voorzitterschap meer voeten in de aarde dan bij een minder gevoelig onderzoek. 81

Over de partijpolitieke verhoudingen en de verhouding tussen coalitie- en oppositiepartijen binnen onderzoekscommissies bestaan geen voorschriften. Bij de samenstelling van de vaste commissies wordt in de praktijk wel gestreefd naar een afspiegeling van de partijpolitieke verhoudingen in de Kamer. ${ }^{82}$ Bij onderzoekscommissies is dit niet het geval. Het is gebruikelijk dat alle fracties één lid leveren, waarbij de kleinste fracties vanwege de beperkte omvang van onderzoekscommissies en de benodigde tijdsinvestering slechts incidenteel een eigen kandidaat naar voren schuiven. ${ }^{83}$ De Kamer c.q. de Kamervoorzitter nemen pas een besluit over de samenstelling nadat de fracties hierover onderling overeenstemming hebben bereikt. ${ }^{84}$

\footnotetext{
77 Art. 26, eerste lid, RvOTK. De commissie benoemt eveneens een ondervoorzitter.

${ }^{78}$ In het oude Draaiboek werd nog uitdrukkelijk bepaald dat het de Kamerfracties zijn die de leden van enquêtecommissies en tijdelijke (onderzoeks)commissies voordragen, waarna de Voorzitter de kandidaten benoemt. Zie Draaiboek 2001, art. 5.1 onder b en c, Kamerstukken II 2001/02, 28 336, nr. 6, p. 3 .

${ }^{79}$ Muller \& Coenen 2002, p. 42.

80 Zie over de rol van de voorzitter van een onderzoekscommissie nader: Muller \& Coenen 2002, p. 6264.

${ }^{81} \mathrm{Bij}$ de aanvang van de RSV-enquête bestond bijvoorbeeld veel discussie over het voorzitterschap. Uiteindelijk werd besloten weliswaar een CDA-voorzitter te benoemen, maar tevens een presidium in te stellen waarin, naast de voorzitter, twee ondervoorzitters van PvdA- en VVD-huize zitting hadden. De commissie werd vervolgens gesplitst in twee subcommissies, die elk onder leiding van een ondervoorzitter stonden. Zie Dölle 1985, p. 98. Zie ook Muller \& Coenen 2002, p. 42-43.

82 Bovend'Eert \& Kummeling 2010, p. 184-185.

${ }^{83}$ Aanvankelijk, tot begin jaren 90, kwam het nog wel eens voor dat een grote fractie meer dan één lid leverde. Zo waren PvdA, CDA en VVD in de RSV-commissie vertegenwoordigd met twee leden, terwijl D66, SGP en CPN elk één lid leverden. Bovendien werd destijds nog gewerkt met plaatsvervangende leden, waarmee ook andere fracties vertegenwoordigd waren. Het benoemen van meerdere
} 
De positie van commissievoorzitter werd aanvankelijk min of meer bij toerbeurt vervuld door een van de drie traditionele middenpartijen (CDA, PvdA en VVD), later bleken ook fracties zoals D66, GroenLinks en de SP in aanmerking te komen om een voorzitterskandidaat naar voren te schuiven. ${ }^{85}$ De vraag of de kandidaat tot een coalitie- of oppositiefractie behoort, is daarbij niet doorslaggevend. Veeleer lijkt van belang of de persoon in kwestie een zekere statuur heeft bereikt en voldoende vertrouwen geniet bij andere fracties.

\subsection{Ambtelijke ondersteuning}

\subsubsection{De commissiestaf}

\subsubsection{Samenstelling}

Een parlementaire onderzoekscommissie kan nauwelijks functioneren zonder de hulp van ambtelijke stafmedewerkers. De wettelijke en reglementaire voorschriften voorzien niet in veel ondersteuning. In het Reglement van Orde is slechts bepaald dat de commissies die de Kamer op grond van het Reglement instelt, worden bijgestaan door de Griffier van de Kamer of door een plaatsvervangende griffier, alsmede door een of meer andere ambtenaren van de Kamer die door de Griffier zijn aangewezen. ${ }^{86}$ De nadere invulling van de commissiestaf gebeurt op ad hoc basis. Het onderzoeksvoorstel, dat door de initiërende leden of commissies wordt opgesteld, dient in elk geval een indicatie te bevatten van de benodigde (ambtelijke) ondersteuning. ${ }^{87}$

In de praktijk varieert de samenstelling van de staf. Een vastomlijnde selectieprocedure ontbreekt. ${ }^{88}$ Uitgangspunt is dat wanneer de Kamer een enquêtecommissie of tijdelijke commissie instelt, de Griffier van de Tweede Kamer een commissiegriffier aanwijst. Verder kan, desgewenst, zowel in de opstartfase als in de daadwerkelijke uitvoering van het onderzoek ondersteuning worden gekregen vanuit het onderzoeksbureau en andere diensten binnen de Kamer. ${ }^{89}$ Vaak bestaat de staf deels uit reguliere medewerkers van de Kamer en deels uit een beperkt aantal tijdelijk ingehuurde externe medewerkers. De omvang en samenstelling van de staf is mede afhankelijk van het toegewezen onderzoeksbudget. De praktijk vertoont grote verschillen op dit punt: terwijl de subcommissie Visquoteringsregelingen slechts kon beschikken over een griffier en dus het onderzoek grotendeels zelf moest

leden per fractie werd later ongebruikelijk; de gestage afkalving van de drie grote fracties speelde hier ongetwijfeld een rol.

${ }^{84}$ Zie ook: Muller \& Coenen 2002, p. 42 en Bovend'Eert \& Kummeling 2010, p. 184-185. In de toelichting bij de eerste versie van het Draaiboek werd nog aangegeven dat in het overleg van de fractiesecretarissen wordt bepaald welke fractie de voorzitter mag leveren en dat in dit overleg afspraken worden gemaakt over de aanwijzing van voorzitters voor de verschillende vormen van onderzoekscommissies. Zie ook: Muller \& Coenen 2002, p. 42 en Kamerstukken II 1997/98, 25 861, nr. 2, p. 7. In latere versies van het Draaiboek en in de RPE is het 'fractiesecretarissenoverleg' niet meer terug te vinden.

${ }^{85}$ Zie ook Bovend'Eert \& Kummeling 2010, p. 185.

${ }^{86}$ Art. 15, tweede lid, RvOTK.

${ }^{87}$ Art. 4, tweede lid, RPE.

${ }^{88}$ Zie ook Muller \& Coenen 2002, p. 66.

${ }^{89}$ Kamerstukken II 2007/08, 31 019, nr. 6, p. 10. 
verrichten, beschikte de enquêtecommissie Opsporingsmethoden over een staf van maar liefst vijfentwintig wetenschappers en praktijkdeskundigen. ${ }^{90}$ De staf blijkt wegens de aanwezige expertise en de hoeveelheid tijd die zij in vergelijking met de commissieleden ter beschikking hebben vaak een groot stempel te kunnen drukken op het verloop van het onderzoek. ${ }^{91}$

Hoewel de huidige regelingen hieromtrent niets regelen, mag worden aangenomen dat de stafleden altijd onder politieke verantwoordelijkheid van de onderzoekscommissie werken. ${ }^{92}$ Ook zijn zij niet persoonlijk aansprakelijk voor de uitkomsten van het onderzoek, omdat zij hun werkzaamheden altijd in naam van de commissie uitvoeren.

\subsubsection{Functies en taakverdeling}

De belangrijkste stafleden en hun taken worden hieronder besproken. Het betreft achtereenvolgens de griffier, de onderzoekscoördinator, de onderzoekers en de overige stafleden.

Aan het hoofd van de ambtelijke ondersteuning van de commissie staat de griffier. Deze vormt de schakel tussen de commissie en haar staf. ${ }^{93}$ Op grond van het Reglement van Orde wordt deze functie uitgeoefend door de Griffier van de Kamer of een door de Griffier aangewezen plaatsvervangend griffier. ${ }^{94}$ De commissiegriffier werkt gewoonlijk op basis van een mandaatbesluit van de Griffier van de Kamer, die eindverantwoordelijk is voor alle inhoudelijke en organisatorische activiteiten van de ondersteuning van de onderzoekscommissie. De commissiegriffier is, indien van toepassing, tevens belast met het beheer van het toegekende budget van de commissie. ${ }^{95}$ In de praktijk wordt doorgaans een van de plaatsvervangend griffiers van de Kamer aangesteld als griffier van de onderzoekscommissie. De selectie van de griffier van de onderzoekscommissie vindt plaats door de Griffier van de Kamer, al is de (beoogd) voorzitter van de onderzoekscommissie soms ook betrokken bij het selectieproces. De griffier heeft in eerste instantie de taak om de staf organisatorisch en administratief aan te sturen, maar kan daarnaast, afhankelijk van de persoon, ook een meer inhoudelijke rol bij het onderzoek vervullen. ${ }^{96}$

\footnotetext{
${ }^{90}$ Muller \& Coenen 2002, p. 67-68.

${ }^{91}$ Muller \& Coenen 2002, p. 65.

92 Voorheen werd dit uitdrukkelijk vermeld in het onderzoeksdraaiboek. Zie Draaiboek 2001, art. 5.2 onder a.

${ }_{93}$ Muller \& Coenen 2002, p. 66. Een uitzondering vormt de werkgroep NATO Response Force. Deze werkgroep had geen griffier, maar kon beschikken over een staf van drie onderzoeksmedewerkers die voor enkele dagen per week aan het onderzoek werkten. Kamerstukken II 2005/06, 30 162, nrs. 2-3, p. 11.

94 Art. 15, tweede lid, RvOTK.

${ }_{95}$ Het betreft een mandaatsconstructie zoals die in het oude onderzoeksdraaiboek is opgenomen. Zie Draaiboek 2001, art. 5.2 onder a. Aangenomen mag worden dat dit nog steeds de gebruikelijke werkwijze is, al is hieromtrent in de huidige regelingen niets meer vastgelegd.

${ }^{96}$ Muller \& Coenen 2002, p. 66. Voorheen was ook de Directeur Constitutioneel Proces, waaronder de diensten commissieondersteuning vielen, vaak betrokken bij de selectie, maar deze positie bestaat sinds de wijziging van de hoofdstructuur van het ambtelijk apparaat van de Kamer van 1 januari 2005 niet meer. Zie Besluit Mandaat, Volmacht en Machtiging directeuren ambtelijke organisatie Tweede Kamer der Staten-Generaal 2006, Stcrt., 2006, 71, p. 31.
} 
Met name wanneer het om grootschalige parlementaire onderzoeken gaat, wordt aan de ambtelijke staf nog een aantal onderzoekers toegevoegd, die veelal van buiten de Kamer worden aangetrokken. Een onderzoekscoördinator - ook wel secretaris, inhoudelijk coördinator of rapporteur genoemd - krijgt vaak de taak om het onderzoek inhoudelijk te coördineren. De onderzoekscoördinator wordt aangesteld op grond van voornamelijk inhoudelijke en managementkwaliteiten en onderhoudt nauwe contacten met de voorzitter van de onderzoekscommissie. ${ }^{97}$ De taken die aan deze functionaris worden toebedeeld verschillen per onderzoek. De onderzoekscoordinator is doorgaans in eerste instantie belast met het toezicht op de voortgang en de inhoudelijke afstemming tussen de deelonderzoeken of externe onderzoeken, maar kan door de commissie ook expliciet opgedragen worden de openbare verhoren of hoorzittingen voor te bereiden, de uitvoering van het onderzoek te faseren en te structureren of het feitelijke schrijven van het (concept-)eindrapport op zich te nemen. ${ }^{98}$ Ook de herkomst en achtergrond van de onderzoekscoördinator verschilt. Soms is deze afkomstig uit de vaste staf van de Kamer, maar met name bij grote en inhoudelijk gecompliceerde parlementaire onderzoeken wordt ook wel gekozen voor bijvoorbeeld een hoogleraar met inhoudelijke deskundigheid en ervaring met onderzoeksmanagement. ${ }^{99}$

De overige onderzoekers die bij grotere parlementaire onderzoeken worden toegevoegd aan de staf, beschikken veelal over een specifieke deskundigheid in verband met het onderzoeksonderwerp of een onderdeel daarvan. Zij werken, zoals alle andere stafleden, onder verantwoordelijkheid en op gezag van de onderzoekscommissie. Wanneer niet voldoende expertise binnen het ambtelijk apparaat van de Kamer aanwezig is, worden onderzoekers van buiten de Kamer tijdelijk aangetrokken. Deze onderzoekers worden voor de tijd dat zij werken aan het onderzoek benoemd tot ambtenaar van de Kamer. 100

Tenslotte bestaat de staf doorgaans uit een aantal secretariële medewerkers en documentalisten. Zij richten zich met name op de administratieve ondersteuning van het commissiewerk respectievelijk het verzamelen, ordenen en eventueel analyseren van informatie ten behoeve van de commissie en de onderzoekers. ${ }^{101}$ Deze medewerkers worden over het algemeen vanuit de Kamerorganisatie gerecruteerd.

\footnotetext{
97 Muller \& Coenen 2002, p. 66.

98 Zie voor variërende taakomschrijvingen: Tijdelijke commissie Integratiebeleid, Kamerstukken II 2003/04, 28 689, nrs. 8-9, p. 12; Enquêtecommissie Srebrenica, Kamerstukken II 2002/03, 28 506, nr. 4, p. 41-42; Enquêtecommissie Bouwnijverheid, Kamerstukken II 2002/03, 28 244, nrs. 5-6, p. 25; Enquetecommissie Vliegramp Bijlmermeer, Kamerstukken II 1998/99, 26 241, nr. 10, p. 6. Zie ook Muller \& Coenen 2002, p. 66-67.

99 De Tijdelijke commissie Infrastructuurprojecten stelde bijvoorbeeld een Delftse hoogleraar met expertise op het gebied van infrastructuurbeleid aan. Tijdelijke commissie Infrastructuurprojecten, Kamerstukken II 2004/05, 29 283, nrs. 5-6, p. 130.

100 Zie bijvoorbeeld de Enquetecommissie Srebrenica, zie Kamerstukken II 2002/03, 28 506, nr. 4 en de Enquêtecommissie Bouwnijverheid, Kamerstukken II 2002/03, 28 244, nrs. 5-6, p. 25.

101 Muller \& Coenen 2002, p. 66.
} 


\subsubsection{Externe onderzoekers}

Bijna alle parlementaire onderzoekscommissies krijgen, als gezegd, bij hun onderzoek in meer of mindere mate hulp van extern ingehuurde onderzoekers. De figuur van externe onderzoeker werd voor de eerste maal gebruikt bij de RSV-enquête, die, zoals vaker, een voorbeeld bleek te zijn voor latere onderzoekscommissies. ${ }^{102}$ De RSV-commissie kreeg van de Kamer "een door haar te bepalen aantal onder haar verantwoordelijkheid werkende externe deskundige onderzoekers." 103

Wanneer het gaat om onderzoekers, die tijdelijk in dienst van de Kamer treden en in naam van de commissie hun werkzaamheden verrichten, is er feitelijk geen verschil met medewerkers die vanuit de Kamerorganisatie aan de commissiestaf worden toegevoegd. In de praktijk maken onderzoekscommissies echter ook gebruik van externe onderzoekers, die op eigen naam een bijdrage leveren aan het onderzoek. Met name bij grootschalige onderzoeken is dit het geval. Er zijn verschillende redenen denkbaar waarom onderzoekscommissies delen van het onderzoek uitbesteden. Zo kunnen externe onderzoekers een specifieke meerwaarde voor het onderzoek bieden. De Enquêtecommissie Vliegramp Bijlmermeer liet bijvoorbeeld grote delen van het onderzoek uitvoeren door interne stafmedewerkers, maar wegens het ontbreken van voldoende specialistische kennis werd besloten om twee onderzoeken extern uit te besteden. ${ }^{104}$ Het is ook denkbaar dat de Kamer zelf om praktische redenen of omwille van politieke en wetenschappelijke onafhankelijkheid bij voorbaat besluit dat het onderzoek geheel of gedeeltelijk moet worden uitbesteed. Daarbij wordt een deel van het onderzoek uitbesteed aan bijvoorbeeld een universiteit of een particulier onderzoeksbureau. Zij voeren het (deel)onderzoek zelfstandig uit en leveren uiteindelijk een onderzoeksrapport aan de commissie, die het vervolgens als bijlage bij het eigen eindrapport voegt. Een voorbeeld is de uitbesteding door de Tijdelijke Commissie Onderzoek Integratiebeleid van delen van het onderzoek aan het Verwey-Jonker Instituut en het bureau QA+. De commissie schreef op basis van de rapporten van het extern uitgevoerde onderzoek een eigen eindrapport; hieraan werden de deelrapporten van de externe bureaus als bijlage toegevoegd. 105

De juridische status van externe onderzoekers die een bijdrage leveren aan een parlementair onderzoek was in het verleden niet altijd duidelijk. Bij de Enquête Opsporingsmethoden, waarin een groot deel van het onderzoek werd uitbesteed, leidde dit achteraf tot problemen. Het onderzoek van een externe onderzoeksgroep werd uitgevoerd "onder verantwoordelijkheid van de commissie". Om aan deze verantwoordelijkheid invulling te geven werd een begeleidingsgroep ingesteld, bestaande uit een aantal commissieleden, de inhoudelijk secretaris en twee stafleden. "Deze begeleidingsgroep heeft vele intensieve vergaderingen met de onderzoeksgroep-

\footnotetext{
102 Zie Enquêtecommissie RSV, Kamerstukken II 17 817, nr. 17, p. 9.

103 Kamerstukken II 17 817, nr. 17, p. 10.

104 Zie Kamerstukken II 1998/99, 26 241, nr. 10, p. 20. De rapporten van de externe onderzoeksbureaus zijn als appendices bij het eindrapport van de commissie gevoegd.

105 Bruggen bouwen, eindrapport Tijdelijke Commissie Onderzoek Integratiebeleid, Kamerstukken II 2003/04, 28 689, nrs. 8-9, p. 15-26. Zie ook: Rapport bronnenonderzoek Verwey-Jonker Instituut, Kamerstukken II 2003/04, 28 689, nr. 11; Rapport aanvullend bronnenonderzoek Verwey-Jonker Instituut, Kamerstukken II 2003/04, 28 689, nr. 12; Rapport aanvullend bronnenonderzoek QA+, Kamerstukken II 2003/04, 28 689, nr. 13.
} 
Fijnaut gehouden over de voortgang van het onderzoek."106 De rapporten van de onderzoeksgroep werden als bijlagen bij het eindrapport van de commissie gevoegd.107 In haar eindrapport merkt de commissie ten aanzien van het externe onderzoek op:

\begin{abstract}
"Hoewel het onderzoek namens de commissie werd uitgevoerd, zijn de bevindingen van de onderzoeksgroep-Fijnaut te beschouwen als een onafhankelijk wetenschappelijk oordeel over de aard en omvang van de georganiseerde criminaliteit. In haar eindrapport geeft de commissie haar oordeel over deze bevindingen." 108
\end{abstract}

De deelrapportage die de onderzoeker had verzorgd, bevatte een casus waarin werd beschreven welke rol een niet bij name genoemde advocaat speelde bij de witwaspraktijken van een criminele organisatie. Toen de naam van de betreffende advocaat, die meende ten onrechte in een kwaad daglicht te zijn gesteld in het rapport, in de pers werd achterhaald, vorderde hij schadevergoeding van de onderzoeker.

In de civiele procedure die volgde, beriep de onderzoeker zich met name op art. $71 \mathrm{Gw}$. De leden van de parlementaire onderzoekscommissie zelf kunnen niet in rechte worden vervolgd of aangesproken met betrekking tot hetgeen zijn mondeling of schriftelijk naar buiten hebben gebracht. Het beginsel van parlementaire immuniteit, vastgelegd in art. $71 \mathrm{Gw}$, beschermt hen tegen dergelijke acties. Art. 71 beschermt ook "andere personen die deelnemen aan de beraadslaging". De vraag was echter, in hoeverre externe onderzoekers beschermd worden door deze immuniteitsregeling.

Het beroep op de parlementaire immuniteit werd zowel in eerste aanleg als in hoger beroep en uiteindelijk tevens in cassatie verworpen. Het arrest van de Hoge Raad is van belang, omdat hierin meer duidelijkheid wordt gegeven omtrent de positie van externe onderzoekers die medewerking verlenen aan een parlementair onderzoek. ${ }^{109}$ De Hoge Raad verwerpt het beroep van de onderzoeker op art. 71, zo blijkt uit de onderstaande passage:

\footnotetext{
"Uit de omstandigheid dat het PEC-rapport met alle bijlagen behoort tot de stukken waarop de parlementaire immuniteit betrekking heeft, volgt (...) niet dat de opsteller van enig stuk dat als bijlage bij het PEC-rapport is opgenomen, zoals X., moet worden aangemerkt als een (andere) persoon die deelneemt aan de beraadslaging in de Tweede Kamer of aan de beraadslaging in de PEC. Immers, onder "beraadslaging" in art. 71 dient te worden verstaan het "parlementaire debat", dat wil zeggen de schriftelijke of de mondelinge uitwisseling van gedachten en standpunten in een vergadering van een Kamer of een Kamercommissie. Het verlenen van bijstand aan de PEC brengt niet de bevoegdheid mee van de leden van de onderzoeksgroep (...) om zelf deel te nemen aan het parlementaire debat." 110
}

\footnotetext{
106 Kamerstukken II 1995/96, 24 072, nr. 12, p. 29.

107 Zie Kamerstukken II 1995/96, 24 072, nrs. 16-20. In deze kamerstukken zijn het "Eindrapport onderzoeksgroep Fijnaut" en de door deze onderzoekers verrichten deelonderzoeken 1 tot en met 4 opgenomen.

108 Kamerstukken II 1995/96, 24 072, nr. 12, p. 30.

109 HR 28 juni 2002, NJ 2002, 577 en JB 2002/266 m.nt. L.F.M. Verhey. Zie over dit arrest ook Kummeling 2005, p. 60 e.v. en Lubberdink 2003, p. 35-37.

110 Zie r.o. 4.2 .
} 
Hoe moet de omstandigheid dat de betrokken onderzoeker werkte 'onder verantwoordelijkheid van de enquêtecommissie' nu worden beoordeeld? Hieraan moet volgens de HR weinig waarde worden gehecht. ${ }^{111}$ Ook diens stelling dat hij bescherming zou genieten op basis van een 'afgeleide' immuniteit, werd afgewezen, omdat art. $71 \mathrm{Gw}$ geen ruimte laat voor een dergelijke ruime interpretatie. Een erkenning hiervan zou een uitbreiding van de parlementaire immuniteit betekenen, maar dat zou de rechtsvormende taak van de rechter te boven gaan.112

De Hoge Raad verschafte tevens een aantal modaliteiten waaronder externe onderzoekers aansprakelijkheid kunnen vermijden. Zo zou een deskundige door een Kamercommissie kunnen worden ingeschakeld "zonder op eigen naam naar buiten te treden". Op deze manier kan civiel- en strafrechtelijke aansprakelijkheid worden vermeden. Verder zou de deskundige als zodanig kunnen worden verhoord door de enquêtecommissie, waardoor hij bescherming geniet onder de bewijsuitsluitingsregel. ${ }^{113}$ Wanneer toch wordt verlangd dat een persoon onder eigen naam bijstand verleent aan de Kamer dan zou nog kunnen worden overwogen, aldus de HR, om het reglement van orde aan te passen, "zodat Kamerleden zich tijdens de beraadslaging kunnen laten bijstaan door een persoon die onder eigen naam deelneemt aan de beraadslaging" - waardoor de immuniteitsregeling zich ook over deze persoon zou uitstrekken - of om af te spreken dat de Staat de ingeschakelde deskundige schadeloos stelt, indien hij door een derde wordt aangesproken." 114

Bij de herziening van de Wet op de Parlementaire Enquête kwam de immuniteitskwestie nadrukkelijk aan bod. De initiatiefnemers kwamen tot de conclusie dat er geen aanleiding was om een regeling te treffen omtrent de positie van externe deskundigen. Het arrest van de Hoge Raad is duidelijk, zo stelden zij, en de lijn die daarin werd gevolgd kon worden gehandhaafd. Dit betekent, dat wanneer externe onderzoekers op eigen naam een bijdrage leveren aan een parlementaire enquête, zij het risico lopen om door eventuele benadeelden strafrechtelijk of civielrechtelijk aansprakelijk te worden gesteld voor beweringen in het rapport. Bezwaarlijk achten zij dit allerminst: "externe deskundigen moeten immers instaan voor hun wetenschap." Dergelijke aansprakelijkheid kan worden uitgesloten, wanneer de onderzoekers op naam van de commissie werken. ${ }^{115}$ Niet uitgesloten is echter dat, zoals in het geval van de Enquête Opsporingsmethoden ${ }^{116}$, andere afspraken worden gemaakt, bijvoorbeeld wanneer het uitbesteden van (deel)onderzoek juist moet zorgen voor een wetenschappelijk of neutraal element in het parlementaire onderzoek. Zowel de commissie als de betrokken onderzoekers zullen dus nadrukkelijk moeten afspreken, onder wiens naam een (deel)onderzoek zal worden uitgevoerd en gepubliceerd. ${ }^{117}$

\footnotetext{
111 Zie r.o. 4.2. Zie in vergelijkbare zin: r.o. 2.17-2.18 (conlid A-G Langemeijer).

112 NJ 2002, 577, r.o. 4.4 .

113 Art. 24 WPE (oud). Zie NJ 2002, 577, r.o. 4.5. De bewijsuitsluitingsregel van art. 24 WPE (oud), thans art. 30 Wpe 2008, biedt echter slechts beperkte bescherming, zoals hierboven reeds bleek. Zie par. 2.3.4.2.1. Zie ook Kummeling 2005, p. 63-64.

114 NJ 2002, 577, r.o. 4.5 .

115 Kamerstukken II 2005/06, 30 415, nr. 6, p. 65-66.

116 Zie ook Muller \& Coenen 2002, p. 61-62.

117 Overigens wordt door parlementaire onderzoekscommissie, naast externe onderzoekers, ook wel gebruik gemaakt van zogenaamde externe adviseurs en klankbordgroepen. Deze adviseurs zijn niet
} 
De betekenis die de Hoge Raad aan art. $71 \mathrm{Gw}$ toekende in het kader van de parlementaire enquête, kan ook worden toegepast op het reguliere parlementaire onderzoek. Het gaat immers om een parlementaire immuniteitsregeling. Ook daar kunnen externe onderzoekers een rol spelen. In de toelichting op de RPE wordt kort ingegaan op de positie van externe onderzoekers. Erkend wordt dat tijdelijke commissies en enquêtecommissies "in de regel onderzoekswerkzaamheden uitbesteden". Anders dan bij extern onderzoek als bedoeld in art. 3 RPE geldt hierbij echter, dat de enquêtecommissie of tijdelijke commissie "verantwoordelijk (is) voor de totstandkoming en de inhoud van het onderzoek, inclusief de delen die zij door anderen hebben laten opstellen." 118 Wat in dit verband precies onder verantwoordelijkheid moet worden verstaan, wordt niet nader omschreven. Mij lijkt dat civiel- of strafrechtelijke aansprakelijkheid van de externe onderzoekers niet is uitgesloten wanneer zij op eigen naam een bijdrage leveren aan het onderzoek. ${ }^{119}$ Het in eigen naam verrichten van deelonderzoek wordt in elk geval niet uitdrukkelijk uitgesloten.

Afsluitend kan worden geconcludeerd, dat de positie van externe onderzoekers met het arrest van de Hoge Raad voldoende duidelijk is. Bij de recente herziening van de wet- en regelgeving rondom parlementair onderzoek is hierbij aangesloten. Mijns inziens vertoont het geldende recht op dit punt een evenwichtig beeld. De meest voor de hand liggende benadering is, dat bij het aantrekken van externe onderzoekers wordt bepaald of zij anoniem dan wel op eigen naam zullen werken. ${ }^{120}$ Afhankelijk daarvan kan de aansprakelijkheidsvraag worden beantwoord. Welke optie het meest opportuun is, zal afhangen van het type onderzoek dat aan de externe onderzoeker wordt uitbesteed. Wanneer het uitbestede onderzoek een sterk wetenschappelijk karakter heeft en in hoge mate onafhankelijk van de onderzoekscommissie wordt uitgevoerd, bijvoorbeeld omdat is afgesproken dat de onderzoeksvragen door de onderzoekers zelfstandig kunnen worden uitgewerkt of bijgesteld, dan ligt het voor de hand dat dit op eigen naam gebeurt en de onderzoeker (of diens werkgever) eventuele aansprakelijkheid voor onzorgvuldigheden aanvaardt. Zulks heeft de voorkeur, omdat wetenschappelijk onderzoek in beginsel openbaar en controleerbaar dient te zijn. In een dergelijk geval valt immers moeilijk in te zien, waarom daar andere normen zouden moeten gelden dan in het reguliere academische verkeer. Het verlenen van anonieme medewerking door wetenschappers lijkt mij daarom in het algemeen ongewenst. ${ }^{121}$ Aan een verbreding van de im-

\footnotetext{
betrokken bij het onderzoek maar reflecteren bijvoorbeeld vanuit hun specifieke deskundigheid op de aanpak of uitvoering van het onderzoek. De Werkgroep NATO Response Force vroeg bijvoorbeeld, naar aanleiding van een aantal gesprekken, nader schriftelijk advies aan twee staatsrechtdeskundigen. Hun adviezen zijn als bijlage bij het eindrapport gevoegd. Zie Kamerstukken II 2005/06, 30 162, nrs. 2-3, p. 12. Ook hier lijkt mij, dat de aansprakelijkheid voor deze adviezen, aangezien ze op eigen naam zijn uitgebracht, bij de betreffende deskundigen ligt.

118 Zie de toelichting op de RPE, Kamerstukken II 2007/08, 31 019, nr. 6, p. 6.

119 Zo ook Kummeling over vergelijkbare bewoordingen in het oude onderzoeksdraaiboek. Zie Kummeling 2005, p. 63.

${ }^{120}$ Het verhoren van deskundigen komt, zoals ook Kummeling stelt, wat gekunsteld over en biedt bovendien geen absolute immuniteit.

121 Zie ook Kummeling 2005, p. 62-63.
} 
muniteitsregeling via een wijziging van het reglement van orde, zoals de HR suggereerde ${ }^{122}$, is dan ook geen behoefte. ${ }^{123}$

\subsubsection{Bureau Onderzoek en Rijksuitgaven (BOR)}

\subsubsection{Oprichting en positionering}

In 2001 constateerde het Presidium dat binnen de Kamer behoefte bestond aan het structureren van haar onderzoeksactiviteiten, met name daar waar niet gekozen wordt voor de modaliteit van de parlementaire enquête. ${ }^{124}$ Daarom werd een begin gemaakt met het opzetten van een eigen onderzoeksbureau dat de Kamer hierbij zou moeten helpen. In een bijlage bij de Raming voor 2002 gaf het Presidium een toelichting op de functie en de positie van deze nieuwe dienst, genaamd het Onderzoeksen Verificatiebureau (OVB). Er leek hoofdzakelijk een rol te zijn weggelegd in de voorbereiding en begeleiding bij de uitbesteding van onderzoek. Ook zou het bureau zich gaan bezighouden met de verificatie van onderzoek dat is verricht door derden, bijvoorbeeld door departementen. Bij parlementair onderzoek zou de rol van het bureau beperkt zijn tot advisering en begeleiding waar nodig. Het was bijvoorbeeld niet de bedoeling, dat medewerkers van het OVB deel uit zouden gaan maken van de staf van onderzoekscommissies. ${ }^{125}$

Om zijn adviesfunctie goed te kunnen uitvoeren, moest het OVB onafhankelijk van de verschillende Kamercommissies kunnen opereren. Het bureau diende direct verantwoording af te leggen aan de Kamer, via het Presidium. ${ }^{126}$ In eerste instantie werd naast het OVB ook nog een andere functionaris aangesteld: de bijzondere presidiumadviseur. Deze had de taak om het Presidium te adviseren over voorstellen voor onderzoek die afkomstig zijn van leden van de (vaste) commissies. ${ }^{127}$ Evenals het hoofd OVB werd ook de bijzondere adviseur benoemd door het Presidium. ${ }^{128}$ De bijzondere presidiumadviseur stond geheel buiten de politieke en ambtelijke organisatie van de Kamer, zo bleek uit het organogram van de Kamer. ${ }^{129}$

Bij de wijziging van de structuur van de ambtelijke organisatie van de Kamer in 2005 werd het onderzoeksbureau samen met onder andere de diensten commissieondersteuning (DCO's) hiërarchisch rechtstreeks geplaatst onder de Griffier, het ambtelijke hoofd van de Kamer. ${ }^{130}$ Benoeming en ontslag van het hoofd van het OVB, alsmede van de overige medewerkers, behoorde voortaan tot de exclusieve bevoegdheid van de Griffier. ${ }^{131}$ De directe verantwoordingsrelatie met de Kamer en

\footnotetext{
122 NJ 2002, 577, r.o. 4.5 .

${ }^{123}$ In de literatuur gaan juist stemmen op die in een tegengestelde richting wijzen, namelijk die van een beperking van de parlementaire immuniteit ten aanzien van onderzoeksrapporten. Zie bijvoorbeeld de noot van Verhey bij HR 28 juni 2002, JB 2002/266 en Lubberdink 2003, p. 36-37.

124 Kamerstukken II 2000/01, 27 677, nr. 6, p. 24.

${ }^{125}$ Kamerstukken II 2000/01, 27 677, nr. 6, p. 24 en Kamerstukken II 2000/01, 27 677, nr. 11, p. 18.

126 Kamerstukken II 2000/01, 27 677, nr. 6, p. 24-25.

127 Handelingen II 2001/02, p. 5205.

128 Art. 13, derde lid, RvOTK (oud).

129 Zie het organogram bij de Raming voor 2003. Kamerstukken II 2001/02, 28 336, nr. 3, p. 20.

130 Zie art. 1, Besluit Mandaat, Volmacht en Machtiging directeuren ambtelijke organisatie Tweede Kamer der Staten-Generaal 2006, Stcrt., 2006, 71, p. 31.

131 Zie art. 13, vijfde lid, RvOTK.
} 


\section{NEDERLAND}

het Presidium werd hiermee dus verlaten. De bijzondere presidiumadviseur verdween eveneens.

In 2008 werd besloten tot een fusie van het OVB met de commissiestaf van de Commissie voor de Rijksuitgaven. Hiermee werd tegemoet gekomen aan "de politieke wens tot het creëren van een herkenbare en krachtige organisatie-eenheid binnen de Tweede Kamer ter ondersteuning van de controlerende taak." 132 Het nieuwe Bureau Onderzoek en Rijksuitgaven (BOR) heeft dezelfde positie binnen de Kamerorganisatie $^{133}$ als het oude onderzoeksbureau en ressorteert dus direct onder de Griffier.

Uit een zelfevaluatie die het BOR in 2009 uitvoerde, waarin zowel Kamerleden als ambtenaren werkzaam voor de Kamer werden ondervraagd, speelde de positionering van het bureau nauwelijks. Onder Kamerleden werd hierover niets opgemerkt. De meeste (adjunct)griffiers binnen de Kamer onderschreven het beeld van een onafhankelijk opererend bureau. Op het niveau van de diensthoofden werd de positie van het bureau op verschillende manieren beoordeeld. Sommigen zagen het als neutraal en zelfstandig, terwijl anderen benadrukten dat samenwerking tussen de ambtelijke diensten van belang was. Enkelen stelden dat het bureau juist op afstand van de Griffier zou moeten worden geplaatst, of zelfs geheel los van de Kamerorganisatie. ${ }^{134}$ Dit laatste kwam overigens ook bij de start van het onderzoeksbureau in 2001 nog ter sprake, bijvoorbeeld door het bureau een wettelijke basis te geven. ${ }^{135}$ Zover is het uiteindelijk nooit gekomen. In 2009 werd geconcludeerd, dat de gekozen positionering binnen de Kamerorganisatie, namelijk rechtstreeks onder de Griffier, voldoet. 136

\subsubsection{Organisatie en taken}

Bij de start telde het OVB twee medewerkers. ${ }^{137}$ In de jaren daarna groeide dit naar vijf fulltime posities. Sinds de fusie bestaat de formatie van het BOR uit ongeveer 12 fte. In 2009 bestond de staf uit een bureauhoofd, acht medewerkers, twee analisten en een managementassistent. ${ }^{138}$ Hierin zijn dus ook de voormalige stafmedewerkers van de Commissie voor de Rijksuitgaven opgenomen. De medewerkers zijn vooral generalisten, die inzetbaar zijn op verschillende terreinen. Er wordt gewerkt in vier clusters, die ieder de werkterreinen van drie of vier vaste commissies bestrijken. ${ }^{139}$

Het BOR verricht verschillende soorten activiteiten. Zo houdt het bureau zich bezig met advisering en ondersteuning tijdens de begrotingsbehandeling, bij parlementair onderzoek en grote projecten, en wordt inhoudelijke ondersteuning geboden aan de Commissie voor de Rijksuitgaven. Andere taken zijn het doen van onderzoek naar de werkwijze van de Kamer en, meer in het algemeen, het verbreden en verdie-

\footnotetext{
132 Zie BOR-evaluatie 2009.

${ }^{133}$ Zie Wijziging mandaatsbesluiten Tweede Kamer, Stcrt. 2009, nr. 121, p. 8.

134 BOR-evaluatie 2009, par. 4.4.6.

135 Kamerstukken II 2000/01, 27 677, nr. 11, p. 18-19.

136 BOR-evaluatie 2009, par. 4.5 .

137 Kamerstukken II 2000/01, 27 677, nr. 10, p. 20-21.

138 Stand medio 2009, waarbij de formatieruimte nog niet volledig was ingevuld. BOR-evaluatie 2009, par. 4.2.

${ }^{139}$ BOR-evaluatie 2009, par. 4.2 .
} 
pen van kennis over onderzoek en rijksuitgaven. ${ }^{140}$ Het BOR richt zich primair op inhoudelijke ondersteuning van de vaste commissies, zo wordt gesteld in de eerder genoemde zelfevaluatie. In 2008 werden maar liefst $85 \%$ van de notities voor de vaste commissies geschreven. De overige notities waren gericht aan individuele leden, de Kamer als geheel, of aan "specifieke (onderzoeks)werkgroepen". ${ }^{141}$ Notities en rapporten van het BOR zijn bedoeld voor intern gebruik door de leden van de Kamer. In beginsel zijn ze daarom niet openbaar, tenzij de geadresseerde (meestal een commissie) zelf besluit tot openbaarmaking. ${ }^{142}$

Wanneer de Kamer het initiatief neemt tot eigen of uitbesteed onderzoek, dan is het BOR daar in de praktijk altijd bij betrokken. Vanuit haar adviserende functie is het BOR vooral actief in de voorbereidende fase van de besluitvorming rondom parlementair onderzoek. Voorheen werd in het onderzoeksdraaiboek een adviesaanvraag bij het BOR voorgeschreven. Thans wordt Kamerleden die een onderzoeksvoorstel voorbereiden dringend aangeraden om zich hierbij door het bureau te laten ondersteunen. ${ }^{143}$ In de praktijk is het BOR echter ook na aanvang van een parlementair onderzoek intensief betrokken. De laatste jaren maken medewerkers van het BOR nagenoeg altijd deel uit van de staf van een onderzoekscommissie. ${ }^{144}$

Wat dit laatste betreft, kan gesteld worden dat de rol van het onderzoeksbureau bij parlementair onderzoek in de loop der jaren is gegroeid. Niettemin is de omvang van het bureau beperkt. De activiteiten van het bureau worden, zo blijkt uit de zelfevaluatie, door zowel Kamerleden als ambtenaren als kwalitatief hoogwaardig en zinvol beoordeeld. Ook uit de parlementaire zelfreflectie kwam een dergelijk beeld naar voren. ${ }^{145}$ Wel lijkt er, naast de reguliere vormen van inhoudelijke en processuele ondersteuning die het bureau biedt, behoefte aan meer mogelijkheden om het BOR ook voor actuele vraagstukken te kunnen inzetten. Veel ruimte voor verdere groei lijkt er binnen de huidige formatie echter niet te zijn. ${ }^{146}$

\subsection{Extern, niet-parlementair onderzoek}

\subsubsection{Extern (uitbesteed) onderzoek}

Naast parlementair onderzoek, dat per definitie wordt uitgevoerd door een Kamercommissie, maakt de Tweede Kamer ook veelvuldig gebruik van de mogelijkheid om

\footnotetext{
140 BOR-evaluatie 2009, par. 2.2.1.

141 BOR-evaluatie 2009, par. 2.2.2.

142 Enthoven 2011, p. 324.

143 Zie Draaiboek 2001, artt. 2.3, 3.2 en 4.2 en Kamerstukken II 2007/08, 31 019, nr. 6, p. 9-10. Dit past in het streven naar vereenvoudiging van de voorbereidende fase van parlementair onderzoek.

144 Zie bijvoorbeeld Enquêtecommissie Srebrenica, Kamerstukken II 2002/03, 28 506, nr. 4, p. 41; Tijdelijke commissie Integratiebeleid, Kamerstukken II 2003/04, 28 689, nrs. 8-9, p. 11; Tijdelijke commissie Zorguitgaven, Kamerstukken II 2003/04, 28 852, nrs. 2-3, p. 5; Werkgroep Onderzoek NATO Response Force, Kamerstukken II 2005/06, 30 162, nrs. 2-3, p. 11. Zie ook Enthoven 2011, p. 324.

145 Rapport parlementaire zelfevaluatie 2009, p. 117.

146 BOR-evaluatie 2009, par. 4.5.
} 
onderzoeksopdrachten uit te besteden aan externe onderzoeksinstellingen. ${ }^{147}$ Er kan zelfs gesproken worden van een stijgend aantal uitbestedingen. ${ }^{148}$ Extern onderzoek, zoals dit in de Kamer wordt genoemd, lijkt vooral te worden gezien als een instrument om specifieke, technische kennis te vergaren. Bovendien wordt dit als een minder zware vorm van onderzoek gezien dan parlementair onderzoek. ${ }^{149}$ Bij 'extern onderzoek' gaat het volgens de RPE om “[v]ormen van onderzoek in opdracht van, of op verzoek van, de Kamer door derden, waarbij de Kamer geen verantwoordelijkheid draagt voor de uitkomsten." Het onderscheid met parlementair onderzoek ligt dus in het feit, dat de Kamer het onderzoek niet zelf uitvoert en ook niet verantwoordelijk is voor de uitkomsten ervan. ${ }^{150}$ Extern onderzoek kan worden uitgevoerd in opdracht van de Kamer of op verzoek van de Kamer. Bij onderzoek in opdracht, veelal uitgevoerd door gespecialiseerde onderzoeksbureaus in de private sector, kan de Kamer zich gedurende het onderzoek actiever opstellen - bijvoorbeeld door middel van een klankbordgroep - dan bij onderzoek op verzoek, dat veelal wordt overgelaten aan universiteiten of (semi-)publieke onderzoeksinstituten zoals het $\mathrm{CPB}$, het SCP of het RIVM. ${ }^{151}$

De RPE voorziet ook voor extern onderzoek in een besluitvormingsprocedure die grotendeels overeenkomt met die voor parlementair onderzoek.152 De Griffier treedt op als de dagelijkse begeleiding van de uitvoerder; in de praktijk gebeurt dit door het onderzoeksbureau van de Kamer. Er kan daarnaast een klankbordgroep worden ingesteld van Kamerleden uit de meest betrokken commissie(s). ${ }^{153}$ Bij extern onderzoek gelden geen bijzondere onderzoeksbevoegdheden inzake toegang tot informatie. Wel kunnen, evenals bij parlementair onderzoek, hierover afspraken worden gemaakt met de betrokken ministers, die zo nodig worden neergelegd in een protocol. ${ }^{154}$

\subsubsection{Rekenkameronderzoek}

Ook onderzoek door de Algemene Rekenkamer dat op verzoek van de Kamer wordt uitgevoerd, wordt in de RPE aangemerkt als extern onderzoek, zij het met een bijzonder karakter. De Algemene Rekenkamer verricht op grond van de Comptabiliteitswet onderzoek naar het financiële beheer dat door ministers wordt gevoerd. $\mathrm{Zij}$ onderzoekt niet alleen de rechtmatigheid van het gevoerde beheer, maar ook de doel-

\footnotetext{
147 Muller \& Coenen 2002, p. 31-32.

148 Gemiddeld vinden twee à drie uitbestedingen plaats per jaar. Voorbeelden zijn onderzoeken naar de veiling van UMTS-telefoonfrequenties, klimaatverandering en de toekomst van woningcorporaties. Zie Kamerstukken II 2007/08, 31 019, nr. 8, p. 3.

149 Zie de toelichting op de RPE, Kamerstukken II 2007/08, 31 019, nr. 6, p. 7.

150 Kamerstukken II 2007/08, 31 019, nr. 6, p. 5.

151 Kamerstukken II 2007/08, 31 019, nr. 6, p. 7. Ten aanzien van instanties die zijn opgericht om de regering te adviseren en vallen onder de Kaderwet adviescolleges, bepaalt art. 17 dat de Kamers rechtstreeks om advies kunnen vragen. Zie nader: Bovend'Eert \& Kummeling 2010, p. 404-406.

152 Art. 4 RPE.

153 Art. 11 RPE. Zie ook Kamerstukken II 2007/08, 31 019, nr. 6, p. 7-8.

154 Art. 12, tweede lid, jo. 13, tweede lid, RPE.
} 
treffendheid en de doelmatigheid van het gevoerde (rijks)beleid alsmede de doelmatigheid van het gevoerde beheer. ${ }^{155}$

Op grond van art. 90 Comptabiliteitswet kan de Rekenkamer een onderzoek instellen indien een van beide Kamers der Staten-Generaal daarom verzoekt. Verplicht daartoe is zij overigens niet. Bovendien bepaalt de Rekenkamer zelf hoe zij een onderzoek waarom een van de Kamers heeft verzocht, invult en uitvoert. Bij de uitoefening van haar werkzaamheden beschikt de Rekenkamer over bijzondere informatierechten en onderzoeksbevoegdheden. 156 Juist om deze bijzondere bevoegdheden, maar ook vanwege de specifieke (financiële) expertise die de Algemene Rekenkamer in huis heeft, kan het voor de Kamer opportuun zijn om de Rekenkamer een bepaald onderzoek te laten verrichten, zo wordt in de toelichting op de RPE gesteld. ${ }^{157}$ Voorbeelden zijn onderzoeken die de Rekenkamer op verzoek van de Tweede Kamer verrichtte naar het paspoortproject (dat later uitmondde in een parlementaire enquête) en de kosten van de studiefinanciering. ${ }^{158}$ Meer recentelijk deed de Rekenkamer op verzoek van de Kamer onderzoek naar de besteding van spoorbudgetten door ProRail. Om dit specifieke, financieel-inhoudelijke onderzoek werd verzocht in het kader van het parlementaire onderzoek naar onderhoud en innovatie op het spoor. ${ }^{159}$

\subsection{Parlementair onderzoek in de Eerste Kamer}

Sinds 1887 beschikt de Eerste Kamer over het grondwettelijke recht van enquête. ${ }^{160}$ Tot op heden heeft zij hier echter nog nooit gebruik van gemaakt. Eenmaal, in 1981, werd een voorstel gedaan voor een enquête. Het voorstel werd echter verworpen; de regeringsgezinde fracties stemden tegen. In 2000 werd door de CDA-fractie, destijds een oppositiepartij, voorgesteld een enquête te houden over de wachtlijsten in de zorg; tot een formeel voorstel is het echter nooit gekomen, omdat het voorstel al in een procedurevergadering van de betrokken commissie sneuvelde.

De ontwikkeling van de onderzoeksfunctie die vanaf begin jaren 80 in de Tweede Kamer heeft plaatsgevonden, is dus aan de Eerste Kamer voorbij gegaan. Hiervoor kunnen twee verklaringen worden gegeven. In de Eerste Kamer, meer nog dan in de Tweede Kamer, vormt de tijdsinvestering die een parlementair onderzoek met zich meebrengt een belangrijk obstakel. Senatoren zijn immers deeltijdparlementariers; bovendien bedraagt het aantal Kamerleden slechts de helft van het aantal in de Tweede Kamer. Daarnaast stelt de Eerste Kamer zich in vergelijking met de Tweede

\footnotetext{
155 Zie artt. 82, tweede lid jo. art. 85 Comptabiliteitswet. Zie ook Van der Pot/Elzinga \& De Lange 2006, p. 804 en Bovend'Eert \& Kummeling 2010, p. 339-340.

156 Zie bijvoorbeeld art. 87, eerste en tweede lid, Comptabiliteitswet (bevoegdheid om administratie rijksdiensten te onderzoeken, inlichtingenplicht ministers). Zie ook art. 91 Comptabiliteitswet.

157 Kamerstukken II 2007/08, 31 019, nr. 6, p. 8.

158 Zie voor meer voorbeelden: Bovend'Eert \& Kummeling 2010, p. 340.

159 Zie de brief van de president van de Rekenkamer aan de voorzitter van de Tweede Kamer, Kamerstukken II 2010/11, 32 707, nr. 4, waarin werd ingestemd met het verzoek om onderzoek te doen. Wel werd aangegeven dat de voorgelegde onderzoeksvragen en aandachtspunten gezien het tijdsbestek enigszins zouden worden toegespitst.

160 Zie hierboven, par. 2.2.3.
} 


\section{NEDERLAND}

Kamer doorgaans bescheiden op. De senaat beschikt in vergelijking over minder bevoegdheden, waarvan het ontbreken van een amendementsrecht het bekendste is, en de Grondwet voorziet niet in een conflictregeling tussen beide kamers. De staatsrechtelijke ongelijkheid tussen de kamers heeft er (mede) voor gezorgd dat het politieke primaat bij de Tweede Kamer ligt. ${ }^{161}$ De senaat beperkt zich daarom veelal tot juridische en constitutionele toetsing (heroverweging) van wetsvoorstellen. Van haar controlebevoegdheden maakt zij slechts spaarzaam gebruik. In het geval van enquêtes bestaat bovendien de vrees dat de uitkomsten ervan politieke consequenties kunnen hebben voor bewindslieden. In zowel praktisch, politiek als staatrechtelijk opzicht geldt voor de Eerste Kamer daarom een hogere drempel om tot een parlementair onderzoek te besluiten.

Dat het onderzoeksrecht in de Eerste Kamer niet de plaats heeft verworven die het in de Tweede Kamer heeft, is daarom weinig verwonderlijk. Toch is er zo nu en dan discussie over de vraag of de Eerste Kamer niet vaker gebruik zou moeten maken van haar onderzoeksrecht. Zo wordt in de literatuur wel gesteld dat de Eerste Kamer juist vanwege haar meer onafhankelijke positie ten opzichte van de regering bij uitstek geschikt is voor het houden van enquêtes. Bovend'Eert en Kummeling zien daar om bovengenoemde redenen echter weinig in. ${ }^{162}$ Jurgens ziet juist wel een rol voor de senaat als het gaat om parlementair onderzoek, maar dan met name in het evalueren van de uitvoering van wetgeving. ${ }^{163}$

De voorstanders van parlementair onderzoek door de Eerste Kamer hebben inmiddels gehoor gevonden. De laatste jaren werden in het kader van de behandeling van wetsvoorstellen al zo nu en dan op kleine schaal onderzoeksactiviteiten ontplooid.164 In 2011 bleek een Kamermeerderheid bereid een voorstel van het lid Schuurman (ChristenUnie) voor een volwaardig parlementair onderzoek, gericht op de privatisering en verzelfstandiging van overheidsdiensten, te steunen. Hoewel het er in eerste instantie op leek dat middels een motie werd besloten tot een enquête, werd in hetzelfde debat door de indiener toegezegd dat er ruimte zou zijn om een definitieve beslissing hierover uit te stellen tot het moment dat een voorbereidingscommissie de mogelijkheden van een parlementair onderzoek rondom dit thema had verkend. De nieuwe Kamer, die na de verkiezingen van mei 2011 zou aantreden, zou het definitieve besluit nemen. ${ }^{165}$ De voorbereidingscommissie kwam tot de conclusie dat het zware onderzoeksinstrumentarium behorende bij een enquête gelet op de vraagstelling en de opzet van het onderzoek waarschijnlijk niet nodig zou zijn. Zij stelde voor een (tijdelijke) bijzondere commissie in te stellen op grond van art. 34,

161 In de Grondwet is dit het sterkst zichtbaar in de redactie van artikel 51, waar is bepaald dat de Staten-Generaal bestaat uit de Tweede Kamer en de Eerste Kamer. Zie verder Bovend'Eert \& Kummeling 2010, p. 37 e.v.

162 Bovend'Eert \& Kummeling 2010, p. 387.

163 Jurgens 2004, p. 224.

164 Zo organiseerde de vaste commissie voor VWS in het kader van het wetsvoorstel omtrent het electronisch patientendossier een expertmeeting, waarin externe deskundigen werden gehoord. Het Rathenau Instituut verrichtte in dat kader op verzoek van de Kamer een voorbereidend onderzoek. Zie Kamerstukken I 2009/10, 31 466, E.

165 Handelingen I 2010/11, 15 maart 2011, nr. 20, p. 46. Zie ook Kamerstukken I 2010/11, 29 maart 2011, nr. 22, p. 1. 
tweede lid, RvOEK, die het onderzoek zou moeten gaan uitvoeren. ${ }^{166}$ In september 2011 stemde de Kamer in met het parlementair onderzoek zoals voorgesteld in het rapport van de voorbereidingscommissie. ${ }^{167}$

De discussie over het voorstel-Schuurman ging niet alleen over de inhoud van het voorstel, maar ook om de vraag welke rol de Eerste Kamer zou moeten spelen ten aanzien van het parlementaire onderzoeksrecht. De indiener, die in het onderzoeksrecht een middel zag om de rol van de Eerste Kamer in het staatsbestel te versterken, benadrukte dat de senaat op dit terrein hooguit een aanvullende functie zou moeten vervullen. In de enquêtepraktijk in de Tweede Kamer gaat het volgens Schuurmans vaak om onderwerpen die "politiek geladen" of "politiek (zeer) actueel" aanvoelen. In de Eerste Kamer moet het eerder gaan om onderzoek "dat in het verlengde ligt van de toenemende nadruk die de Eerste Kamer legt op de kwaliteit en zorgvuldigheid van wetgeving en op de uitvoerbaarheid en maatschappelijke effecten van wetgeving, op de gevolgen voor burger en samenleving en op de rechtmatigheid en doelmatigheid van het optreden van de overheid" en om "langdurige kwesties die de Tweede Kamer laat liggen." 168 De voorbereidingscommissie sloot zich hier in haar rapport bij aan en stelde dat "een door de Eerste Kamer in te stellen parlementair onderzoek in zijn vraagstelling en werkwijze dient aan te sluiten bij de specifieke rol van de Eerste Kamer in het Nederlandse staatsbestel", waarbij de nadruk ligt op de "kwaliteit van de wetgeving, de maatschappelijke betekenis van het overheidsoptreden en de uitvoerbaarheid van wet- en regelgeving." 169 In de debatten over het voorstel ontving deze opvatting van verschillende kanten steun. Het lid Engels (D66) stelde echter dat er staatsrechtelijk geen reden is voor bijzondere terughoudendheid, waarbij hij erop wees dat de senaat beschikt over dezelfde controlebevoegdheden als de Tweede Kamer. ${ }^{170}$ Dat laatste moge zo zijn, maar zoals hierboven reeds betoogd, zijn er wel degelijk belangrijkste staatsrechtelijke verschillen die ervoor zorgen dat de positie van de Eerste Kamer een wezenlijk andere is dan die van de Tweede Kamer. Een bescheidener opstelling lijkt mij daarom constitutioneel aangewezen. Mijns inziens ligt het dan ook voor de hand dat de Eerste Kamer, nu het erop lijkt dat zij serieus werk wil maken van het ontwikkelen van een onderzoeksfunctie, in de toepassing van het onderzoeksrecht zoekt naar manieren waarop zij de bestaande

\footnotetext{
166 Kamerstukken I 2010/11, XC, C, p. 17.

167 Handelingen I 2010/11, nr. 1, p. 1-4-5. Alleen de CDA- en PVV-fracties stemden tegen. De VVDfractie had geen behoefte aan het onderzoek, maar stemde uiteindelijk toch in. Op 4 oktober 2011 werden de leden van de Parlementaire Onderzoekscommissie Privatisering / Verzelfstandiging Overheidsdiensten benoemd. Zij bestaat uit zeven leden en zeven plaatsvervangende leden, waarmee alle fracties zijn vertegenwoordigd. Dat laatste is overigens op grond van art. 36, tweede lid, RvOEK vereist. Voorzitter is R. Kuiper (ChristenUnie).

168 Kamerstukken I 2010/11, XC, A, p. 2.

${ }^{169}$ Het onderhavige onderzoek zou daarom, met het oog op verbetering van de politieke besluitvorming, inzicht moeten bieden in de parlementaire beraadslaging omtrent privatiserings- en verzelfstandigingsoperaties en de effecten van deze operaties op de verhouding tussen overheid en burger. Daarbij zou men zich om pragmatische redenen moeten beperken tot een aantal casus. Kamerstukken I 2010/11, XC, C, p. 7, 10.

170 Zie Handelingen I 2010/11, 15 maart 2011, nr. 20, p. 25-26.
} 
praktijk in de Tweede Kamer vanuit haar rol als chambre de réflection kan complementeren. ${ }^{171}$

Een andere vraag die het besluit tot het houden van een parlementair onderzoek oproept, is op welke wijze dit onderzoek moet worden uitgevoerd. Het Reglement van Orde van de Eerste Kamer bevat alleen bepalingen omtrent de parlementaire enquête. ${ }^{172}$ De voorbereidingscommissie stelde daarom, als gezegd, voor om een bijzondere commissie op grond van art. 34, tweede lid, RvOEK in te stellen. Die kan volgens de voorbereidingscommissie in elk geval beschikken over de reguliere onderzoeksbevoegdheden waarover ook de vaste commissies in de Eerste Kamer beschikken: het voeren van overleg met ministers, het tijdens een vergadering horen van personen "van wier oordeel zij kennis wenst te nemen", personen of instellingen vragen om schriftelijk commentaar, of het houden van hoorzittingen. ${ }^{173}$ De betreffende bepalingen zijn echter toegespitst op de behandeling van naar de Kamer gezonden 'voorstellen' (vgl. art. 32 RvOEK); voor het doen van onderzoek los van een concreet wetsvoorstel lijken ze dus niet direct bedoeld. Een probleem lijkt mij dit overigens niet; de bepalingen bevatten geen verplichtingen ten aanzien van derden en kunnen gezien worden als bevoegdheden die een ieder - dus ook de Eerste Kamer - toekomen. De voorbereidingscommissie suggereerde verder dat de onderzoekscommissie zich in haar werkwijze zou kunnen richten naar de relevante bepalingen en regelingen in de Tweede Kamer. ${ }^{174}$ Ook zou zij een voorbeeld kunnen nemen aan de Tijdelijke Commissie Onderzoek Financieel Stelsel in de Tweede Kamer, die een vergelijkbare taak had. ${ }^{175}$ Hoewel gesproken kan worden van een procedureel tekort, zo erkent ook de voorbereidingscommissie in haar aanbevelingen, blijkt het ontbreken van een gedetailleerde regeling in het $\mathrm{RvO}$ de instelling en uitvoering van een (regulier) parlementair onderzoek in de Eerste Kamer niet te verhinderen.

\subsection{Conclusie}

Parlementair onderzoek in Nederland wordt vrijwel altijd verricht door tijdelijke commissies, ingesteld door de Tweede Kamer. Soms krijgen deze commissies de status van enquêtecommissie. De samenstelling is een bevoegdheid van de Kamervoorzitter, maar het selectieproces wordt beheerst door politieke onderhandelingen tussen de Kamerfracties. Onderzoekscommissies vormen geen afspiegeling van de partijpolitieke krachtsverhoudingen; in het Nederlandse meerpartijenstelsel is

\footnotetext{
171 Of uit de genoemde uitgangspunten een bestendige praktijk voortvloeit, zal uiteraard moeten worden bezien. Het type onderzoek dat hier wordt voorgestaan, valt wellicht samen met de beleids- en uitvoeringsevaluaties die ook centraal staan in de nieuwe Toekomst- en onderzoeksagenda van de Tweede Kamer. Zie hierboven, par. 3.2.3. De commissie-Kuiper, die het privatiseringsonderzoek heeft verricht, typeert haar onderzoek in haar eindrapport als 'wetgevingsonderzoek'. Zie Kamerstukken I 2012/13, C, B, p. 3.

172 Zie artt. 128-138 RvOEK.

173 Zie art. 34, tweede lid jo. art. 51-53 RvOEK. Voor het houden van hoorzittingen is toestemming van de Kamervoorzitter nodig.

${ }^{174}$ In het bijzonder werden genoemd: art. 18 RvOTK, waarin de taakomschrijving van tijdelijke commissies is opgenomen, art. 142 RvOTK, alsmede de RPE. Kamerstukken I 2010/11, XC, C, p. 17.

175 Kamerstukken I 2010/11, XC, C, p. 17. De commissie beveelt de Kamer aan om het Reglement te herzien en aan te vullen met betrekking tot parlementair onderzoek. Idem, p. 19.
} 
veeleer sprake van een soort vertegenwoordigingsmodel. Alle fracties kunnen een kandidaat naar voren schuiven, waarbij de kleinste fracties, gezien de tijdsinvestering en de beperkte ruimte binnen een onderzoekscommissie, slechts af en toe een commissielid kunnen leveren. De invulling van het voorzitterschap lijkt te rouleren tussen de grotere fracties, waarbij ook de politieke 'aanvaardbaarheid' van de kandidaten die door de fracties naar voren geschoven worden, een rol speelt.

Vanuit de moderne onderzoekspraktijk, zoals die sinds 1983 tot ontwikkeling is gekomen, is een min of meer gestandaardiseerde besluitvormingsprocedure ontstaan rondom het instellen van een parlementair onderzoek. Deze procedure werd vastgelegd in een onderzoeksdraaiboek. Onderdeel hiervan was een tamelijk zware voorfase, waarin de nadruk lag op het bepalen van de noodzaak en toegevoegde waarde van een onderzoek. Deze voorfase mondde uit in een zorgvuldig geformuleerd en omlijnd onderzoeksvoorstel, waarover de Kamer vervolgens besliste. Na de herziening van het Reglement van Orde in 2008, waarbij de Regeling Parlementair en Extern Onderzoek (RPE) werd ingevoerd die het onderzoeksdraaiboek verving, is de voorfase vereenvoudigd. Hiermee is de drempel om een onderzoek te starten in procedurele zin enigszins verlaagd. Een uitgewerkt onderzoeksvoorstel vormt echter nog steeds de basis van de besluitvorming; zorgvuldigheid en kwaliteit blijven daarmee belangrijke ijkpunten. Onderzoek door vaste commissies, die in het verleden hiertoe nog wel eens een onderzoekswerkgroep uit hun midden samenstelden, behoort bovendien niet meer tot de mogelijkheden. De Kamer benadrukt hiermee het bestaande uitgangspunt, waarbij parlementair onderzoek wordt opgedragen aan tijdelijke (enquête)commissies. Hiermee wordt in feite ook het traditionele beeld van parlementair onderzoek in Nederland bevestigd: het gaat om ad hoc onderzoeken, veelal gericht op incidenten, die onder druk van een gecentraliseerd besluitvormingsproces en de vereiste uitwerking van onderzoeksvoorstellen vaak een tamelijk zwaar en intensief karakter hebben.

Het incidentele karakter van parlementair onderzoek in Nederland brengt voorts met zich mee, dat de ambtelijke ondersteuning die onderzoekscommissies krijgen eveneens een voornamelijk tijdelijk karakter heeft. Wanneer besloten wordt tot een parlementair onderzoek dan worden, afhankelijk van de omvang en benodigde expertise, tijdelijke onderzoeksmedewerkers aangetrokken die veelal van buiten de Kamerorganisatie komen. De Tweede Kamer zelf heeft slechts een kleine vaste onderzoeksstaf, ondergebracht in het Bureau Onderzoek en Rijksuitgaven. Dit bureau houdt zich buiten parlementair onderzoek vooral bezig met het begeleiden van extern uitgevoerd onderzoek in opdracht of op verzoek van de Tweede Kamer. Dit externe onderzoek, uitbesteed aan universiteiten of onderzoeksbureau dan wel in de vorm van verzoekonderzoek door de Algemene Rekenkamer, heeft zich in het kielzog van de opkomst van parlementair onderzoek ontwikkeld tot een belangrijk onderdeel van de parlementaire onderzoeksfunctie in Nederland.

Hoewel de organisatie van parlementair onderzoek in de afgelopen decennia dus min of meer vaste vormen heeft gekregen, is de onderzoeksfunctie nog steeds in beweging. De herziening van de enquêtewet en de discussies over de toekomst van het parlement, zoals de Parlementaire Zelfreflectie, hebben geleid tot initiatieven om de onderzoeksfunctie verder te ontwikkelen. Sinds de invoering van de Toekomsten onderzoeksagenda in 2009 heeft de Kamer een procedure in handen waarmee 
jaarlijks op gecoördineerde wijze lichtere vormen van onderzoek kunnen worden gepland, die vooral in de sfeer van beleidsevaluaties en toekomstverkenningen liggen. Dit programma dient ter aanvulling op de bestaande praktijk van ad hoc, op actuele gebeurtenissen gerichte, grotere onderzoeken. De fracties kunnen jaarlijks voorstellen indienen, waarna de Kamer op advies van de Commissie voor de Rijksuitgaven maximaal drie voorstellen honoreert. Een andere bijzondere ontwikkeling is dat de Eerste Kamer onlangs voor de eerste keer in haar bestaan besloten heeft een parlementair onderzoek te houden. 


\section{Hoofdstuk 4. Onderzoeksproces}

\subsection{Inleiding}

In dit hoofdstuk staat het onderzoeksproces centraal. Bezien wordt, hoe een parlementair onderzoek verloopt en welke stadia in dit proces zijn te onderscheiden. Tussendoor wordt nadere aandacht besteed aan enkele bijzondere aspecten. Zo wordt ingegaan op de samenloopproblematiek: de situatie waarbij parlementair onderzoek betrekking heeft op feiten of personen die tevens voorwerp zijn van bijvoorbeeld een strafrechtelijke vervolging of bestuursrechtelijke sanctieprocedure. Verder wordt stilgestaan bij de regeling rondom de openbaarheid en vertrouwelijkheid van onderzoeksinformatie, die door parlementaire onderzoekscommissies wordt vergaard.

\subsection{Aanvang van het onderzoek}

\subsubsection{Aanleiding, thematiek}

In de Nederlandse parlementaire onderzoekstraditie, zoals die met name sinds de jaren 80 tot ontwikkeling is gekomen, vormen incidenten vaak de aanleiding om een onderzoek in te stellen. Het eerste moderne parlementaire onderzoek, de RSVenquête, was op dit punt een voorbeeld. Het belang van incidenten in de Nederlandse onderzoekstraditie kan op verschillende manieren worden verklaard. Enerzijds speelt de politieke context waarin een onderzoeksvoorstel ontstaat een belangrijke rol. Een concreet voorval is een aantrekkelijk aanknopingspunt voor parlementaire initiatieven. Daarnaast kan ook het ontbreken van een permanente onderzoeksstructuur meespelen: om een parlementair onderzoek van de grond te krijgen, moet een Kamermeerderheid bereid gevonden worden om een onderzoekscommissie in te stellen. Dit versterkt de noodzaak om aan te sluiten bij voorvallen die veel politieke aandacht genieten. Verder wordt parlementair onderzoek vaak gezien als een instrument om in concrete gevallen in een informatiebehoefte te voorzien, wanneer de regering daarin tekortschiet. ${ }^{1}$

Het aantal parlementaire onderzoeken dat werd ingesteld, is de loop der tijd toegenomen. Met name in de jaren 90 is een sterke stijging waarneembaar. Hoewel op zichzelf staande incidenten nog steeds een belangrijke aanleiding vormen, was in 14 van de 31 naoorlogse parlementaire onderzoeken het leervermogen van departe-

\footnotetext{
${ }^{1}$ Muller \& Coenen 2002, p. 24. Muller en Coenen kunnen zich daarom ook niet vinden in de gedachte dat parlementair onderzoek alleen wenselijk is als andere vormen van onderzoek ontoereikend zouden zijn, zoals de commissie-Klimaatverandering in haar rapport stelde. De vraag of parlementair onderzoek wenselijk is, is volgens hen in de eerste plaats een politieke beslissing en hangt niet af van inhoudelijke noodzaak.
} 


\section{NEDERLAND}

menten de directe aanleiding voor het onderzoek. ${ }^{2}$ Verder gebruikt de Kamer haar onderzoeksinstrument steeds vaker voor bredere studies naar (toekomstige) maatschappelijke vraagstukken. Voorbeelden zijn parlementaire onderzoeken naar het klimaatbeleid, integratie en onderwijsvernieuwingen. Het bredere, beleidsanalytische onderzoek heeft samen met onderzoek gericht op toekomstige ontwikkelingen onlangs een belangrijke impuls gekregen door de invoering van de zogenaamde toekomst- en onderzoeksagenda in de Tweede Kamer. ${ }^{3}$

De onderzoeksthema's en -doelstellingen waarmee parlementaire onderzoekscommissies zich bezighouden, zijn zeer verschillend van aard. Er lijkt weinig lijn te ontwaren in de gekozen thema's. Het is vooral een politieke afweging die bepalend is voor de vraag waarop parlementair onderzoek is gericht. ${ }^{4}$ Een analyse van Muller en Coenen van de concluderende hoofdstukken van parlementaire onderzoeksrapporten laat echter toch een zeker patroon zien. In alle parlementaire onderzoeken is aandacht voor de omvang en reikwijdte van de politieke en bestuurlijke verantwoordelijkheid van bewindspersonen. Vaak wordt getracht na te gaan of bewindspersonen feitelijk op te hoogte waren van bepaalde gebeurtenissen, in hoeverre het gaat om ministerieel of ambtelijk handelen, welke beïnvloedingsmogelijkheden er waren en in hoeverre de betrokken bewindspersonen verwijten kunnen worden gemaakt. ${ }^{5}$ Het ambtelijk handelen zelf is eveneens een terugkerend thema, waarbij onder meer wordt nagegaan in hoeverre ambtenaren de betrokken bewindspersonen voldoende hebben geïnformeerd en de mate van vrijheid die ambtenaren hebben gehad om een eigen afweging te maken. ${ }^{6}$ Andere veel voorkomende thema's zijn het gebrek aan adequate en heldere normering, gebrekkige financiële controle van overheidsdiensten, falende parlementaire controle, organisatorische knelpunten (bureaucratie etc.), problemen in de coördinatie tussen overheidsdiensten, de scheiding tussen beleid en uitvoering, de verhouding tussen de publieke en private sector en de heersende bestuurscultuur in Nederland. ${ }^{7}$

\subsubsection{Onderzoeksopdracht}

\subsubsection{Vaststelling}

Onderzoekscommissies zijn gebonden aan hun onderzoeksopdracht, dat wil zeggen aan het onderzoeksonderwerp zoals neergelegd in een of meerdere onderzoeksvragen en aangevuld met bepalingen omtrent de organisatie en tijdsduur van het onderzoek. De vaststelling van de onderzoeksopdracht is dus een bevoegdheid van de Kamer, niet van de onderzoekscommissie zelf. De RPE bevestigt dit. De Kamer draagt verantwoordelijkheid voor een parlementair onderzoek en besluit uiteindelijk over het onderzoeksvoorstel, zoals dat door een of meer leden of door een (vaste) commissie is opgesteld. 8

\footnotetext{
2 Zie het rapport van de Algemene Rekenkamer, Leren van parlementair onderzoek 2007, p. 32-33.

${ }^{3}$ Zie hierboven, par. 3.2.3.

${ }^{4}$ Muller \& Coenen 2002, p. 129.

${ }^{5}$ Muller \& Coenen 2002, p. 131-133.

${ }^{6}$ Muller \& Coenen 2002, p. 134-135.

${ }^{7}$ Muller \& Coenen 2002, p. 135-141. Zie ook Leren van parlementair onderzoek 2007, p. 31.

${ }^{8}$ Art. 2 jo. 4, 7 RPE.
} 
De Wet op de parlementaire enquête 2008 schrijft voor dat het besluit tot het houden van een enquêteonderzoek tevens een omschrijving bevat van het onderwerp waarop het onderzoek betrekking zal hebben. ${ }^{9}$ Oorspronkelijk bepaalde de wet dat het onderwerp "nauwkeurig" diende te worden omschreven, maar deze eis is bij de wetswijziging van 1977 geschrapt. De gedachte daarbij was, dat de nauwkeurigheidseis weinig toegevoegde waarde had, omdat de Kamer uiteindelijk alleen zelf kan oordelen over de nauwkeurigheid van de onderzoeksopdracht. ${ }^{10}$ Ook bij een tijdelijke commissie is het de Kamer die de onderzoeksopdracht vaststelt. Het Reglement van Orde stelt dat het instellingsbesluit van een tijdelijke commissie onder meer een "nauwkeurige omschrijving van het onderwerp waarover de commissie de Kamer dient te rapporteren" moet bevatten. ${ }^{11}$ Hier geldt de nauwkeurigheidseis dus nog wel, al kan evenals bij de enquête worden afgevraagd of dit begrip nu zoveel sturende werking heeft. 12

De onderzoeksopdracht wordt in het onderzoeksvoorstel vaak ingeleid met een beschrijving van het onderzoeksonderwerp en het doel van het onderzoek. Het belangrijkste element van de onderzoeksopdracht is echter de onderzoeksvraag: wat dient de commissie in kaart te brengen? Het is niet verwonderlijk dat de formulering van een onderzoeksvraag politieke gevoeligheid met zich meebrengt. In de besluitvorming rondom parlementair onderzoek wordt het vaststellen van de onderzoeksvraag dan ook beheerst door politieke onderhandelingen. De precieze formulering van deze vraag gaat vaak gepaard met intensief overleg tussen de verschillende partijen om tot overeenstemming kunnen komen. ${ }^{13}$

De RPE geeft een aantal criteria waaraan een onderzoeksvoorstel moet voldoen. Het dient in ieder geval een vastomlijnde onderzoeksvraag en een opsplitsing daar-

\footnotetext{
${ }^{9}$ Art. 2, derde lid, Wpe 2008.

${ }^{10}$ Kamerstukken II 1976/77, 13 837, nr. 6, p. 4.

11 Art. 18, tweede lid onder a, RvOTK. Waarom hier nog wel een nauwkeurigheidseis wordt gesteld, is niet duidelijk.

12 Zie Kappeyne van de Coppello 1978, p. 82-83. Zie ook Dölle 1985, p. 119-120, waar wordt gesteld dat het nauwkeurigheidsvereiste wel degelijk een betekenis kan hebben. De Kamer beoordeelt weliswaar zelf de nauwkeurigheid van een onderzoeksopdracht, maar kan de eis van nauwkeurigheid en de normativiteit van dit woord in ieder geval niet negeren. Bovendien zou een rechter een enquêtecommissie die haar opdracht te ruim interpreteert wellicht eerder een halt toeroepen, indien het komt tot een confrontatie tussen commissie en getuige. Tenslotte zal het een enquêtecommissie sneller dwingen terug te keren naar de Kamer wanneer zij het onderzoek een andere wending wil geven, wat een versterking van het primaat van de Kamer ten aanzien van het enquêterecht zou betekenen. Vgl. ook Daalder 2008, p. 327, die vanuit het bestuursrechtelijke specialiteitsbeginsel betoogt dat de omschrijving van het onderzoeksonderwerp zodanig moet zijn dat een rechter, die moet oordelen over de inzet van dwangmiddelen, "kan beoordelen of de uitoefening van een bevoegdheid in een concreet geval toelaatbaar is."

${ }^{13}$ Muller \& Coenen 2002, p. 47-48. Een goed voorbeeld is de RSV-enquête. Deze enquêtecommissie doet in haar eindrapport uitvoerig verslag van de totstandkoming van de enquête en de afwegingen die daaraan ten grondslag lagen. Bij de fracties van CDA en VVD bestond veel huivering voor een parlementaire enquête. Uiteindelijk heeft een kleine groep van fractievertegenwoordigers (de 'staatsrechtgeleerden') een compromis kunnen sluiten tussen de verschillende fractiestandpunten. Zo werd in de enquêteopdracht vastgelegd dat de enquêtecommissie gebruik moest maken van zogenaamde 'externe deskundige onderzoekers', een tot dan toe onbekende constructie. Kamerstukken II 1984/85, 17 817, nr. 17, p. 7-12. Zie ook Dölle 1985, p. 92-96.
} 
van in deelvragen te bevatten. ${ }^{14}$ Uit de bevoegdheid van de Kamer om de onderzoeksopdracht vast te stellen mag worden afgeleid, dat de Kamer, al dan niet op verzoek van de onderzoekscommissie, gedurende het onderzoek de onderzoeksopdracht nog kan aanpassen. In art. 2, derde lid, Wpe 2008 wordt dit bevestigd ten aanzien van de parlementaire enquête. Aangenomen kan worden, dat dit ook geldt bij het andere parlementaire onderzoek. Dit gebeurde bijvoorbeeld bij de Werkgroep NATO Response Force, die haar onderzoek naar "de procedure van parlementaire betrokkenheid bij besluiten tot uitzending van Nederlandse militairen" na een motie van de fractievoorzitters van PvdA en VVD tijdens het Kamerdebat over de uitzending van militairen naar Afghanistan moest verbreden met een onderzoek naar de aard en reikwijdte van art. $100 \mathrm{Gw} .{ }^{15}$

Wat onder een 'vastomlijnde onderzoeksvraag', die in art. 4 RPE wordt verlangd, moet worden verstaan, is natuurlijk voor verschillende uitleg vatbaar. In de praktijk blijkt dat de onderzoeksopdracht vaak slechts op hoofdlijnen richting geeft aan het onderzoek. ${ }^{16}$ De onderzoeksopdracht die in het vastgestelde onderzoeksvoorstel is opgenomen, is dan niet altijd direct uitvoerbaar. De onderzoekscommissie zal in dat geval haar opdracht nader moeten uitwerken. De RSV-enquêtecommissie deelde de Kamervoorzitter direct bij aanvang van het onderzoek mede, dat zij haar opdracht ruim zou interpreteren en zich, om volledig antwoord te kunnen geven op de gestelde vragen, niet strikt zou kunnen beperken tot de factoren die werden genoemd in de onderzoeksopdracht. ${ }^{17}$ De Tijdelijke commissie Infrastructuurprojecten werd in het onderzoeksvoorstel expliciet de ruimte gegeven om de vastgestelde onderzoeksvragen nader te specificeren en te operationaliseren. ${ }^{18}$ De Enquêtecommissie Vliegramp Bijlmermeer diende de vragen die geformuleerd waren door de voorbereidende werkgroep slechts "als leidraad" te gebruiken bij haar onderzoek. Naar aanleiding van een aantal oriënterende gesprekken besloot deze commissie vervolgens haar doelstellingen te verscherpen en de onderzoeksvragen nader uit te werken en aan te vullen. Nieuwe inzichten die gedurende het onderzoek werden opgedaan, leidden hier voorts tot het toevoegen van nieuwe vragen. ${ }^{19}$

Het komt ook voor dat de onderzoeksopdracht onvoldoende duidelijk is. Een voorbeeld hiervan is de Enquête Srebrenica. Het voorstel tot het houden van een

\footnotetext{
${ }^{14}$ Art. 4, tweede lid onder b, RPE.

${ }^{15}$ Zie Kamerstukken II 2005/06, 30 162, nrs. 2-3, p. 9-10.

16 Muller \& Coenen 2002, p. 49.

17 Zie Kamerstukken II 1984/85, 17 817, nr. 5. Zie ook Dölle 1985, p. 95-96.

18 "Het is aan de in te stellen tijdelijke commissie (...) om te bepalen op welke wijze deze te werk wil gaan bij het beantwoorden van deze vragen en welke (delen van) projecten als casus worden onderzocht." Kamerstukken II 2003/04, 29 283, nr. 1, p. 4.

${ }^{19}$ Kamerstukken II 1998/99, 26 241, nr. 10, p. 15. De commissie schrijft met betrekking tot haar doelstellingen: "De primaire doelen van het onderzoek, zoals dat door de Tweede Kamer is vastgesteld, zijn waarheidsvinding en het trekken van lessen voor de toekomst. Bij de vliegramp speelt een belangrijke rol dat in de loop van de jaren allerhande verhalen en theorieën zijn ontstaan met betrekking tot (onderdelen van) de ramp. Dit is aanleiding om voor het eindrapport doelstellingen te formuleren met betrekking tot de kwaliteit. De Commissie is van oordeel dat er geen twijfel mag ontstaan over de juistheid van de bevindingen. Tevens dient het rapport de samenhang tussen allerlei aspecten van de ramp in kaart te brengen. Tenslotte moet het een compleet beeld geven van alles wat een directe relatie heeft met de ramp en wat ter discussie staat."
} 
enquête kwam van een tijdelijke commissie, die de opdracht had te rapporteren over mogelijke onderwerpen voor een parlementair onderzoek naar het Srebrenica-drama. In haar rapport aan de Kamer legde deze commissie een aantal onderzoeksonderwerpen voor die in een enquête aan bod zouden moeten komen. ${ }^{20}$ In het debat over dit rapport kwamen vanuit de Kamer opmerkingen over de voorstellen van de commissie. De voorzitter van de tijdelijke commissie suggereerde tijdens het debat dat het rapport samen met de uitkomsten van het debat als basis voor de enquêtecommissie kunnen dienen. De Kamer ging hier stilzwijgend mee akkoord, zo constateerde de enquêtecommissie later in haar eindrapport. ${ }^{21}$ De enquêtecommissie besloot daarom bij aanvang van haar werkzaamheden op grond van de "annotaties" vanuit de Kamer de gegeven onderzoeksonderwerpen te herformuleren. Hiervan werd de Kamer tussentijds op de hoogte gesteld. ${ }^{22}$ Vervolgens werkte de commissie deze onderwerpen zelfstandig uit tot een groot aantal specifieke vragen per onderzoeksonderwerp en een algemene vraag met "hulpvragen". ${ }^{23}$

\subsubsection{Primaat bij de Kamer?}

Het uitgangspunt dat de Kamer in beginsel het laatste woord heeft over het onderzoeksonderwerp en de formulering van de onderzoeksvragen, behoeft gezien de praktijk dus enige nuancering. Een onderzoekscommissie blijkt de ruimte te krijgen (of zich toe te eigenen) om zelfstandig het onderwerp en de vraagstelling nader uit te werken of bij te stellen. Onderzoekscommissies krijgen dus een bepaalde mate van vrijheid bij het interpreteren van hun opdracht. ${ }^{24}$ Vanuit praktisch oogpunt is dit overigens begrijpelijk. De indieners van een onderzoeksvoorstel kunnen voorafgaand aan het onderzoek nu eenmaal niet alle aspecten van het onderzoek overzien. Voortschrijdend inzicht kan tot aanpassing of specificatie van onderzoeksvragen of tot wijzigingen in de richting van het onderzoek nopen. Dit geldt zeker voor de tijdsduur: er blijken maar weinig onderzoeken te zijn, die binnen de vooraf gestelde termijn zijn afgerond. ${ }^{25}$

In het voormalige onderzoeksdraaiboek was nog bepaald dat de onderzoekscommissie - op voorstel van haar voorzitter en griffier en met medewerking van het onderzoeksbureau - zo spoedig mogelijk na haar instelling of na de vaststelling van de onderzoeksopdracht, een gedetailleerd 'plan van aanpak' diende vast te stellen. ${ }^{26}$

\footnotetext{
${ }^{20}$ Het betreft de Tijdelijke commissie Aanvullende onderwerpen NIOD-rapport. Zie Kamerstukken II 2001/02, 28341, nr. 2.

${ }^{21}$ Kamerstukken II 2002/03, 28 506, nrs. 2-3, p. 9.

${ }^{22}$ Kamerstukken II 2002/03, 28 506, nr. 1.

${ }^{23}$ Kamerstukken II 2002/03, 28 506, nrs. 2-3, p. 9-14 Het proces van herziening en uitwerking van de onderzoeksopdracht is door de commissie vrij uitvoerig beschreven in haar plan van aanpak, dat als bijlage bij het eindrapport is gevoegd. Zie Kamerstukken II 2002/03, 28 506, nr. 4, p. 30-38.

${ }^{24}$ Muller \& Coenen 2002, p. 49. Een recent voorbeeld is het onderzoek naar de zorguitgaven, waarbij de tijdelijke commissie meende dat het "niet opportuun" was om een metastudie van de eerder uitgevoerde onderzoeken in de zorg te houden, terwijl de commissie hiertoe expliciet de opdracht had gekregen. Zie het eindrapport van de commissie: Kamerstukken II 2003/04, 28 852, nrs. 2-3, p. 7.

${ }^{25}$ Muller \& Coenen 2002, p. 50.

${ }^{26}$ In dit plan van aanpak diende onder andere aandacht te worden besteed aan de uitvoering van de onderzoeksopdracht, de eerste planning van de uit de voeren taken, de taakverdeling, de taak en rol
} 
Bij recente parlementaire onderzoeken blijkt inderdaad een plan van aanpak, ook wel onderzoeksopzet of draaiboek genoemd, te zijn gemaakt. Opvallend genoeg vereiste het draaiboek niet, dat de Kamer in de gelegenheid wordt gesteld om het plan van aanpak te beoordelen en haar goedkeuring te verlenen. In welke mate de Kamer betrokken wordt bij dit plan van aanpak, verschilt daarom in de praktijk aanzienlijk. Zo legde de tijdelijke commissie Infrastructuurprojecten haar plan vertrouwelijk aan de Kamer voor en maakte slechts een samenvatting ervan openbaar. ${ }^{27} \mathrm{Bij}$ de Enquête Vliegramp Bijlmermeer werd een plan van aanpak opgesteld door de staf, dat vervolgens met enkele aanpassingen door de commissie zelf werd vastgesteld. ${ }^{28}$ De enquêtecommissie Srebrenica stelde een gedetailleerd plan van aanpak op, dat uiteindelijk als bijlage bij het eindrapport werd gepubliceerd. ${ }^{29}$ De enquêtecommissie Bouwnijverheid stelde de Kamer, omdat hierover voorafgaand een toezegging was gedaan, tussentijds op de hoogte van de onderzoeksopzet die zij had uitgewerkt. De opzet werd bovendien in de kamerstukken opgenomen. ${ }^{30}$

In de huidige onderzoeksregeling is over een gedetailleerd plan van aanpak, opvallend genoeg, niets meer terug te vinden. Kennelijk wordt thans aan de commissie overgelaten, in hoeverre een nadere uitwerking gewenst is en of deze aan de Kamer moet worden voorgelegd. Helemaal vrij kan de commissie hier echter niet in zijn binnen de bestaande systematiek. Wanneer een onderzoekscommissie haar onderzoeksopdracht zodanig zou bewerken dat de richting van het onderzoek substantieel verandert, dan lijkt mij dat de Kamer daarover eerst een bevestigende uitspraak zal moeten doen alvorens de commissie de uitvoering van het onderzoek ter hand kan nemen. Dit volgt uit het nog steeds gehanteerde uitgangspunt dat de Kamer het primaat heeft bij de uitoefening van haar onderzoeksrecht. De gang naar de Kamer is in elk geval noodzakelijk, wanneer een nadere uitwerking van de onderzoeksopdracht ingrijpende gevolgen zou hebben voor de kosten van het onderzoek. Het is immers de Kamer die daarover beslist. Ook wanneer het onderzoek een aanzienlijk langere tijdsduur zou krijgen, is voorafgaande toestemming van de Kamer noodzakelijk. De vaststelling van de tijdsduur blijkt in de praktijk een belangrijk middel te zijn voor de Kamer om het onderzoek vooraf te sturen, omdat hierin mede wordt bepaald welke

van de voorzitter, de nadere invulling van de wenselijke (externe) ondersteuning, de noodzaak van een informatieprotocol en de vertrouwelijkheid van informatie. Zie Draaiboek 2001, art. 5.2 onder b.

${ }_{27}$ Kamerstukken II 2003/04, 29 283, nr. 3. De Kamer stelde het plan van aanpak vervolgens vast.

${ }^{28}$ Kamerstukken II 1998/99, 26 241, nr. 10, p. 9. Niet duidelijk is of de Kamer van dit plan van aanpak op de hoogte is gesteld. Het eindrapport bevat, zo lijkt het, slechts een samenvatting van het plan van aanpak.

${ }^{29}$ Kamerstukken II 2002/03, 28 506, nr. 4, p. 29-47. Ook hier is niet duidelijk of het plan van aanpak voorafgaand al dan niet vertrouwelijk is voorgelegd aan de Kamer.

${ }^{30}$ Kamerstukken II 2001/02, 28 244, nrs. 1-3. De commissie merkte overigens in haar eindrapport op dat een enquêtecommissie, "binnen de ruime grenzen die de WPE daaraan stelt en binnen de afgesproken doorlooptijd van de enquête, in hoge mate haar eigen organisatie [kan] inrichten en haar werkwijze [kan] bepalen." Hieronder moet volgens deze commissie kennelijk ook het ontwerpen van een onderzoeksopzet, het aantrekken van een staf en het maken van afspraken over tussentijdse terugkoppeling van de voortgang aan de Tweede Kamer worden begrepen. Kamerstukken II 2003/04, 28 244, nrs. 5-6, p. 24. 
diepgang het onderzoek zou moeten hebben. ${ }^{31}$ Dit laatste raakt de kern van het onderzoek en de vaststelling hiervan moet dus bij de Kamer liggen.

\subsection{Werkwijze en methoden}

Een parlementair onderzoek verloopt in Nederland volgens een tamelijk vast stramien. In grote lijnen kan een onderscheid worden gemaakt tussen drie fases: het vooronderzoek, de openbare gesprekken (hoorzittingen) en de rapportage. De eerste moderne parlementaire enquête was hierin toonaangevend. De RSVenquêtecommissie kreeg de opdracht onderzoek te doen naar het beleid van opeenvolgende kabinetten ten aanzien van het RSV-concern en met name naar de besteding van overheidsmiddelen en de controle daarop. ${ }^{32}$ Het betrof een zeer complexe affaire, die veel voorwerk vergde: duizenden dossiers moesten worden doorgelicht en de commissie hield vele zogenaamde 'informele gesprekken' met betrokkenen, voordat kon worden begonnen met de openbare verhoren. In deze fase werd ook veelvuldig gebruik gemaakt van de medewerking van externe onderzoekers. ${ }^{33}$ De ontstane tweedeling tussen het vooronderzoek en het openbare gedeelte is mede het gevolg van de wetswijziging van 1977, waarbij in de wet werd vastgelegd dat verhoren in beginsel in het openbaar dienden plaats te vinden. ${ }^{34}$

De laatste fase, waarin aan de Kamer wordt gerapporteerd over de bevindingen, vormt een verplicht onderdeel van elk parlementair onderzoek. ${ }^{35}$ Het houden van openbare gesprekken, de tweede fase, is niet verplicht, al hebben alle onderzoekscommissies tot op heden gebruik gemaakt van dit instrument, dat in belangrijke mate fungeert als een publiek venster op het onderzoek. ${ }^{36}$

Het is de eerste fase, het vooronderzoek, waarin - in beslotenheid - het grootste deel van het feitelijke onderzoekswerk plaatsvindt. Over de wijze waarop dit dient te gebeuren, is nauwelijks iets geregeld. Tegelijkertijd zijn juist de vormgeving en gebruikte methodiek in belangrijke mate bepalend voor de uitkomsten van het onderzoek. ${ }^{37}$ De enquêtewet bevat van oudsher regels omtrent bevoegdheden, maar geen voorschriften omtrent de wijze waarop het onderzoek moet worden aangepakt. Commissies beschikken op dit punt dan ook over veel vrijheid, zo constateerde Dölle na afloop van de RSV-enquête in 1985.38 Ook de RSV-commissie zelf dacht daar zo over: "Een groot voordeel is - zo hebben wij het althans ervaren - dat een enquête-

\footnotetext{
${ }^{31}$ Zie Muller \& Coenen 2002, p. 50-51. Vgl. art. 4, tweede lid, onder c en d, RPE, waarin is bepaald dat een onderzoeksvoorstel een indicatie van tijdsduur en het benodigde budget moet bevatten.

32 Dölle 1985, p. 94. Zie ook Kamerstukken II 1984/85, 17 817, nr 17, p. 9-10.

33 Dölle 1985, p. 96.

34 Zie art. 18a WPE (oud) en Drexhage 2009, p. 10.

35 Zie art. 18, tweede lid onder a, RvOTK (tijdelijke commissies) en art. 33 Wpe 2008 (enquêtecommissies). Onder de oude enquêtewet werd overigens nog niet expliciet verlangd van de commissie dat zij de resultaten van haar onderzoek zou vastleggen in een openbaar rapport. De wet bepaalde slechts dat de Kamer na beëindiging van het onderzoek kan beschikken over de "processen-verbaal en de overige bescheiden van het onderzoek", mits het geen vertrouwelijke stukken betreft. Zie art. 29a WPE (oud).

${ }^{36}$ Meer hierover in par. 4.6.

37 Zie ook Muller \& Coenen 2002, p. 47.

${ }^{38}$ Dölle 1985, p. 103.
} 


\section{NEDERLAND}

commissie binnen de grenzen van de Wet en van de begroting die de Kamer heeft toegestaan, tot op grote hoogte haar eigen werkwijze kan bepalen, teneinde het onderzoek zo grondig en tegelijk zo vlot mogelijk te laten verlopen." ${ }^{39}$ In de Wet op de parlementaire enquête 2008 is hieraan weinig veranderd. Nieuw is alleen een bepaling ${ }^{40}$ omtrent de rechten en plichten van personen die worden gevraagd voor een besloten voorgesprek, dat in de moderne onderzoekspraktijk onderdeel is gaan uitmaken van het vooronderzoek. Ook bij het reguliere parlementaire onderzoek bestaan geen specifieke voorschriften omtrent de werkwijze. ${ }^{41}$

De afgelopen decennia is een min of meer vaste werkwijze ontstaan die door veel onderzoekscommissies wordt gehanteerd, mede omdat nieuwe onderzoekscommissies vaak naar hun voorgangers kijken. ${ }^{42}$ Zowel wat betreft de toegepaste onderzoeksmethoden als de fasering van het onderzoek zijn daarom patronen zichtbaar. Veelal beperken commissies zich tot twee onderzoeksmethoden: documentenanalyse en interviews. ${ }^{43}$ Het lijkt erop, dat enquêtecommissies en tijdelijke commissies zich vooral richten op de bevoegdheden die hen expliciet op grond van de Wet op de parlementaire enquête respectievelijk het Reglement van Orde zijn toebedeeld. Muller en Coenen constateren dan ook een zekere vanzelfsprekendheid bij het kiezen voor deze methoden. ${ }^{44}$ Er zijn echter verschillende andere onderzoeksmethoden denkbaar, die volgens hen eveneens toepasbaar zijn. Gedacht kan worden aan literatuuranalyse, casusonderzoek en werkbezoeken - methoden die incidenteel wel worden toegepast door onderzoekscommissies - maar ook aan enquêtes (vragenlijsten), experimenten, simulaties of participerende observatie. 45

Het ontbreken van nadere voorschriften of richtlijnen betekent uiteraard niet, dat de Kamer haar onderzoekscommissies hierin volledig vrij moet laten. In het onderzoeksvoorstel kunnen hieromtrent nadere aanwijzingen worden opgenomen. Het oude onderzoeksdraaiboek gaf hiertoe een aanzet, omdat in het onderzoeksvoorstel dat aan de Kamer ter goedkeuring werd voorgelegd een "algemene keuze voor de wijze waarop deze [onderzoeks-]vraag zal worden beantwoord" diende te worden gemaakt. ${ }^{46} \mathrm{Bij}$ de Enquête Srebrenica werd bijvoorbeeld door de voorbereidende tijdelijke commissie aangegeven dat de enquête als aanvulling op de twee bestaande Srebrenica-rapporten zou moeten dienen. Het was dus uitdrukkelijk niet de bedoeling, dat de commissie het reeds gedane onderzoek nog eens dunnetjes over zou doen. ${ }^{47}$

\footnotetext{
${ }^{39}$ Kamerstukken II 1984/85, 17 817, nr. 17, p. 14.

${ }^{40}$ Art. 8 Wpe 2008.

${ }^{41}$ Vgl. art. 18 RvOTK.

42 Muller \& Coenen 2002, p. 47.

${ }^{43}$ Muller \& Coenen 2002, p. 52.

${ }^{44}$ Muller \& Coenen 2002, p. 51-52.

${ }^{45}$ Muller \& Coenen 2002, p. 52-54.

${ }^{46}$ Draaiboek 2001, art. 3.3 onder b.

47 Uit het Kamerdebat volgde eveneens dat de enquêtecommissie deze eerdere rapportages als uitgangspunt voor haar eigen onderzoek zou moeten nemen en dat aanvullend feitenonderzoek dus niet nodig was, zo concludeerde de enquêtecommissie in haar plan van aanpak. Tegen deze achtergrond koos de commissie voor de onderzoeksmethoden documentenanalyse, interviews en openbare verhoren. Zie Kamerstukken II 2002/03, 28 506, nr. 4, p. 38.
} 


\subsection{Vooronderzoek: documentenanalyse en interviews}

Het vooronderzoek is, zo bleek hierboven, niet in wettelijke of reglementaire voorschriften uitgewerkt. De meeste onderzoekscommissies besteden veel tijd aan het vooronderzoek, waarin zij voornamelijk schriftelijke stukken verzamelen en analyseren en (besloten) gesprekken of interviews houden met betrokkenen en deskundigen. De openbare gesprekken dienen dan vaak ter verificatie van de bevindingen uit het vooronderzoek.

Het vooronderzoek bestaat veelal uit een combinatie van documentenanalyse, informele interviews en formelere voorgesprekken. De intensiteit, diepgang en tijdsduur van dit vooronderzoek is afhankelijk van de omvang van het parlementaire onderzoek waartoe de Kamer heeft besloten. Met name bij omvangrijke onderzoeken, zoals enquêtes, is het zaak om op een efficiënte manier de vaak grote hoeveelheid informatie die verkregen wordt van overheidsdiensten, private ondernemingen, de media of andere bronnen te ordenen en te waarderen. Verschillende onderzoekscommissies blijken daartoe vaak een eigen, systematische wijze van informatieverwerking te ontwikkelen. ${ }^{48}$ De hoeveelheid informatie is soms zelfs zo groot, dat de commissie zich genoodzaakt ziet een verlenging van de onderzoekstermijn aan te vragen bij de Kamer. ${ }^{49}$

De afgifte van de gewenste informatie blijkt soms tot problemen te leiden: overheidsdiensten of andere informatiebezitters werken, zelfs indien hiertoe wettelijke verplichtingen bestaan, niet altijd ruimhartig mee aan het ter beschikking stellen van materialen of staan alleen vertrouwelijke inzage toe. Dit kan tot vertraging van het vooronderzoek leiden. ${ }^{50}$ In de praktijk maken commissies daarom vooral afspraken met grote informatieleveranciers, doorgaans ministeries of andere overheidsdiensten, over de wijze waarop inlichtingen worden verstrekt. ${ }^{51}$

Onderzoekscommissies met een omvangrijke onderzoeksopdracht pakken het vooronderzoek vaak thematisch aan. Ook een indeling in chronologische tijdvakken komt voor. Op die manier wordt getracht de hoeveelheid informatie het hoofd te bieden en tevens het onderzoek gaandeweg nader af te bakenen. ${ }^{52}$ De commissie formuleert op grond van het uitgewerkte onderzoeksvoorstel, vaak na enig oriënterend onderzoek, een aantal onderzoeksthema's of -gebieden. De commissieleden, staf en eventuele externe onderzoekers worden vervolgens verdeeld in teams. ${ }^{53}$ De

\footnotetext{
${ }^{48}$ Muller \& Coenen 2002, p. 52.

${ }^{49}$ De Enquêtecommissie Bouwnijverheid trof bijvoorbeeld tijdens het onderzoek een grote hoeveelheid aanvullend feitenmateriaal aan, dat nader moest worden onderzocht en uiteindelijk leidde tot extra gesprekken en verhoren. Zie Kamerstukken II 2002/03, 28 244, nrs. 5-6, p. 41-42.

50 Wederom kan de Enquêtecommissie Bouwnijverheid hier als voorbeeld dienen: het accountantskantoor Deloitte \& Touche weigerde bepaalde stukken ter beschikking te stellen, waarna de commissie een kort geding bij de burgerlijke rechter instelde. De vordering werd in eerste instantie afgewezen. In hoger beroep (via een zogenaamd turbo spoedappèl) werd de commissie uiteindelijk wel in het gelijk gesteld, waardoor volgens de commissie voorkomen werd dat de voortgang en volledigheid van het onderzoek in gevaar kwam. Zie Kamerstukken II 2002/03, 28 244, nrs. 5-6, p. 43-45.

51 Meer hierover in par. 4.5.

52 Muller \& Coenen 2002, p. 60.

${ }^{53}$ Een goed voorbeeld is de RSV-enquêtecommissie, die werkte met een aantal tijdvakken en op grond van het toenmalige art. 40 van het Reglement van Orde zichzelf opdeelde in twee thematisch sub-
} 


\section{NEDERLAND}

onderzoeksteams richten zich elk op een eigen onderzoeksgedeelte en komen veelal met afzonderlijke deelrapportages, die door de commissie uiteindelijk worden samengevoegd in of verwerkt tot één eindrapport. Teneinde de eenheid en de koers van het onderzoek te bewaken, vindt doorgaans tussentijds overleg plaats tussen de verschillende teams. ${ }^{54}$

De besloten gesprekken die tijdens het vooronderzoek worden gevoerd dienen twee doelen. Ten eerste kunnen de bevindingen die de commissie op grond van de documentenanalyse heeft gedaan in interviews met betrokkenen of deskundigen worden geverifieerd. Bovendien kunnen onduidelijkheden worden opgehelderd, ontbrekende gegevens worden aangevuld en kan de commissie op nieuwe sporen worden gezet. Een tweede reden waarom besloten gesprekken worden gehouden is het kunnen selecteren van getuigen en deskundigen die later in het openbaar verhoord of gehoord zullen worden. ${ }^{55}$ Het gesprek heeft dan het karakter van een voorgesprek, waarin de betreffende getuige of deskundige wordt voorbereid op het openbare gesprek dat in de volgende fase van het onderzoek zal plaatsvinden. ${ }^{56}$ Veelal volgt een voorgesprek op een of meerdere interviews met dezelfde persoon, omdat vaak tijdens een interview pas kan worden bepaald of het nuttig of noodzakelijk is om iemand in het openbaar te horen. De lijst met bevindingen, die vaak naar aanleiding van de documentenanalyse en interviews wordt opgesteld, kan tijdens de voorgesprekken gericht worden getoetst en gespecificeerd. ${ }^{57}$ Het aantal interviews en voorgesprekken dat een onderzoekscommissie houdt, is uiteraard afhankelijk van de onderzoeksopdracht en de afwegingen die de commissie zelf maakt. ${ }^{58}$

Interviews, ook wel "informele oriënterende gesprekken" 59 genoemd, worden veelal afgenomen door stafleden. Een gespreksverslag, als dat er al is, beperkt zich vaak tot enkele aantekeningen. De voorgesprekken hebben een formeler karakter dan de interviews. Een voorgesprek wordt gevoerd door commissieleden. Hiervan wordt een stenografisch verslag gemaakt, dat ter goedkeuring aan de ondervraagde wordt voorgelegd. In de praktijk bleek verschillende malen, met name bij enquêtes, dat voor personen die werden uitgenodigd voor een voorgesprek niet altijd duidelijk was, in hoeverre zij verplicht waren om hieraan medewerking te verlenen. Bovendien was niet duidelijk wat de commissie met de verkregen informatie uit een voor-

commissies: de subcommissie-Overheid en de subcommissie-RSV, elk onder leiding van een van de twee vice-voorzitters van de commissie. Kamerstukken II 1984/85, 17 817, nr. 17, p. 23-24. Zie ook Dölle 1985, p. 100. De Enquête Bouwnijverheid kende vijf deelprojecten met eigen projectleiders en vier à vijf toegevoegde onderzoekers. De commissieleden maakten overigens geen deel uit van deze onderzoeksteams. Kamerstukken II 2002/03, 28 244, nrs. 5-6, p. 24-26.

${ }^{54}$ Zie bijvoorbeeld Enquêtecommissie Bouwnijverheid, Kamerstukken II 2002/03, 28 244, nrs. 5-6, p. 32.

${ }^{55}$ Muller \& Coenen 2002, p. 80.

56 Zie bijvoorbeeld Enquêtecommissie Srebrenica, Kamerstukken II 2002/03, 28 506, nrs. 2-3, p. 16.

57 Muller \& Coenen 2002, p. 80-82. De afweging om iemand al dan niet in het openbaar te horen, wordt overigens niet altijd enkel op inhoudelijke gronden gemaakt. Sommige betrokkenen moeten bijvoorbeeld vanwege hun positie in elk geval in het openbaar gehoord worden, al zal hun bijdrage wellicht niet direct veel toevoegen aan het onderzoek. Muller \& Coenen 2002, p. 80-81.

${ }^{58}$ Muller \& Coenen 2002, p. 80-82.

59 Zie Enquête Bouwnijverheid, Kamerstukken II 2002/03, 28 244, nrs. 5-6, p. 37. 
gesprek kan doen. ${ }^{60}$ In de nieuwe wet is er daarom voor gekozen om de bestaande praktijk op dit punt te codificeren. Art. 8 Wpe 2008 bepaalt dat niemand verplicht is om medewerking te verlenen aan een voorgesprek, dat de leden geheimhouding bewaren omtrent hetgeen hen tijdens het gesprek ter kennis is gekomen, en dat het ondertekende gespreksverslag vertrouwelijk blijft. ${ }^{61}$ Dit laatste betekent overigens slechts, dat de commissie informatie niet in herleidbare vorm mag gebruiken, bijvoorbeeld tijdens een hoorzitting of in haar rapport. Het staat de commissie volgens de initiatiefnemers wel vrij om de informatie in niet-herleidbare vorm "als achtergrond te gebruiken voor haar conclusies". ${ }^{62}$ Ook na afloop van de enquête heeft niemand inzage in de vertrouwelijke verslagen van voorgesprekken. ${ }^{63}$ Voor personen die gehoord zijn in een voorgesprek geldt thans geen geheimhoudingsplicht. De Enquêtecommissie-De Wit heeft voorgesteld hierin verandering te brengen, waarbij wel een uitzondering zou moeten worden gemaakt voor de werkkring van betrokkenen. ${ }^{64}$

\subsection{Toegang tot informatie}

\subsubsection{Afspraken en protocollen}

Parlementair onderzoek heeft doorgaans betrekking op, kort gezegd, het functioneren van de overheid. ${ }^{65}$ Het kan daarbij gaan om beleidsvorming en -uitvoering in brede zin, maar ook om het meer specifieke optreden van individuele bewindspersonen en concrete prestaties van het ambtelijke apparaat. Zowel bij enquêtes als bij reguliere onderzoeken is een adequate verschaffing van informatie door de uitvoerende macht van groot belang voor het parlement.

In de praktijk verloopt de verschaffing van informatie meestal zonder grote problemen. In veel gevallen zijn de betrokken bewindspersonen en ambtelijke diensten voldoende bereid om de gevraagde medewerking te verlenen. De toon werd gezet bij de eerste moderne parlementaire enquête in 1983. Het meest betrokken mi-

${ }^{60}$ Zie de bijdrage van Kummeling in De WPE onder de loep 2004, p. 14. Zie ook Kamerstukken II 2005/06, 30415 , nr. 6, p. 23.

61 Zie art. 8, tweede, derde en vierde lid, Wpe 2008. Zie ook Kamerstukken II 2005/06, 30 415, nr. 6, p. 23-24. Bij interviews worden in de praktijk geen afspraken of garanties met betrekking tot vertrouwelijkheid gegeven, al zijn geen gevallen bekend waarin wordt geciteerd uit of verwezen naar hetgeen naar voren kwam tijdens een interview. Muller \& Coenen 2002, p. 80. Aan een weigering om het verslag te ondertekenen zijn overigens geen juridische consequenties verbonden. Zie Kamerstukken I 2006/07, 30 415, C, p. 17.

62 Kamerstukken II 2005/06, 30 415, nr. 6, p. 26. Het verslag van een voorgesprek kan echter wel worden overhandigd aan het openbaar ministerie in een meineed- of omkopingszaak, als bedoeld in art. 32 Wpe 2008. De Raad van State had kritiek op deze uitzondering, aangezien dit betekent dat een getuige tijdens een verhoor niet kan worden geconfronteerd met een vermoeden van meineed, maar de commissie wel achteraf aangifte kan doen. Dit is volgens de Raad niet in het belang van de getuige, noch van de commissie die bezig is met waarheidsvinding. Het advies om de uitzondering te schrappen werd niet gevolgd, omdat een meinedige verklaring de enquête volgens de initiatiefnemers "in de kern" raakt. Zie Kamerstukken II 2005/06, nr. 4, p. 15.

${ }^{63}$ Zie art. 40, tweede lid onder e, Wpe 2008. Meer hierover in par. 4.4.2.

${ }^{64}$ Kamerstukken II 2011/12, 31 980, nr. 61, p. 574. Zie ook hierboven, par. 2.5.3.2.

${ }^{65}$ Zie ook hierboven, par. 4.2.1. 
nisterie (Economische Zaken) leverde zonder problemen "karrevrachten" aan schriftelijk materiaal, zo is in het eindrapport van de RSV-enquêtecommissie te lezen. ${ }^{66}$ Een welwillende houding van regeringszijde is echter niet vanzelfsprekend. Weigerachtigheid van de betrokken bewindspersonen kan verschillende oorzaken hebben. Ministers stellen zich soms op het standpunt dat inzage in bepaalde gegevens niet relevant is voor het onderzoek. In andere gevallen hebben de bezwaren te maken met de gevoeligheid van de informatie. ${ }^{67}$ De betekenis van het 'belang van de staat' zorgt bij dergelijke conflicten vaak voor discussie. ${ }^{68}$ Ook het verzoek om bepaalde, met naam genoemde ambtenaren te kunnen horen, kan bij de minister op bezwaren stuiten.

Conflicten over de verstrekking van informatie vormen een risico voor zowel de onderzoekscommissie als de regering. De commissie kan erdoor gehinderd worden in haar onderzoekstaak. Bovendien kan bij veelvuldige weigeringen van ministers om bepaalde informatie te verstrekken de indruk ontstaan dat de commissie te afhankelijk is van de regering. Dit kan schadelijk zijn voor de geloofwaardigheid van de commissie. ${ }^{69}$ Wanneer de Kamer zich bij een conflict met de regering echter achter de commissie schaart, kan een weigering uitlopen op een politieke crisis waarbij de positie van ministers op het spel komt te staan.

\subsubsection{Protocol van afspraken}

Om conflicten te voorkomen, is in de praktijk de gewoonte ontstaan om op voorhand afspraken te maken over de informatievoorziening tussen de onderzoekscommissie en de meest betrokken bewindspersonen. Voordeel van dergelijke afspraken, doorgaans vastgelegd in een zogenaamd 'informatieprotocol', is dat niet bij elk informatieverzoek opnieuw overleg moet plaatsvinden tussen minister en commissie. ${ }^{70}$ Meestal worden deze protocollen openbaar gemaakt, bijvoorbeeld in de vorm van een bijlage bij het eindrapport. ${ }^{71}$ In deze informatieprotocollen worden afspraken

\footnotetext{
${ }^{66}$ De informatievoorziening door Sociale Zaken vond de commissie daarentegen soms wat laat en schaars, al wilde men daarmee niet suggereren dat het betreffende ministerie onvoldoende medewerking verleende. Kamerstukken II 1984/85, 17 817, nr. 17, p. 36.

${ }^{67}$ Muller \& Coenen 2002, p. 57.

68 Zo weigerden de betrokken ministers in eerste instantie om de Enquêtecommissie Opsporingsmethoden inzage te geven in criminele inlichtingenregisters. De veiligheid van informanten zou er door in gevaar kunnen komen. Uiteindelijk kon een compromis worden bereikt en verplichtte de enquêtecommissie zich om de (soms geanonimiseerde) informatie vertrouwelijk te behandelen. De voorzitter van de commissie kon te allen tijde kennisnemen van de niet-geanonimiseerde versies. Zie Kamerstukken II 1995/96, 24 072, nr. 12, p. 23-27. Zie ook Muller \& Coenen 2002, p. 58.

${ }^{69}$ Muller \& Coenen 2002, p. 59.

${ }^{70}$ De Enquêtecommissie Srebrenica noemde het informatieprotocol daarom de "smeerolie" tussen de regering en de enquêtecommissie. Kamerstukken II 2002/03, 28 506, nrs. 2-3, p. 20.

71 Zie bijvoorbeeld: Enquête Opsporingsmethoden, Kamerstukken II 1994/95, 24 072, nr. 3; Enquête Bouwnijverheid, Kamerstukken II 2001/02, 28 244, nr. 3, p. 8-12; Enquête Srebrenica, Kamerstukken II 2002/03, 28 506, nr.4, Appendix B. De Tijdelijke commissie Infrastructuurprojecten maakt wel melding van een informatieprotocol, maar heeft dit als zodanig niet openbaar gemaakt. Kamerstukken II 2004/05, 29 283, nrs. 5-6, p. 131. Bij sommige (kleinere) onderzoeken of bij onderzoeken waarbij weinige informatie van overheidswege nodig is, is niet altijd sprake van een formeel protocol. De Enquêtecommissie Vliegramp Bijlmermeer had slechts behoefte aan een aantal zeer specifieke documenten die bij verschillende ministeries en toezichthoudende diensten aanwezig waren. In het eindrapport
} 
gemaakt over zaken als inzageprocedures, contactpersonen, het oprichten van een secretariaat bij een ministerie ten behoeve van informatievoorziening aan de commissie, maar ook over het vertrouwelijk verstrekken van documenten of de wijze waarop ambtenaren medewerking verlenen aan een enquête of onderzoek. Sinds de Enquête Opsporingsmethoden bestaat de gewoonte, dat de commissievoorzitter het recht krijgt om te controleren of het beroep van een minister op een verschoningsgrond, zoals het belang van de staat, terecht is. ${ }^{72}$ Ook is de gewoonte ontstaan, dat bewindspersonen de mogelijkheid krijgen om voorinzage in het eindrapport te krijgen, zodat een controle op onjuistheden, vertrouwelijke aspecten en het belang van de staat kan plaatsvinden. ${ }^{73}$

Begin 2002 kwamen de voorzitter van de Tweede Kamer en de minister van Binnenlandse Zaken en Koninkrijksrelaties een standaardprotocol overeen, gebaseerd op de opgedane ervaringen met informatieuitwisseling tussen Kamer, ministers en ambtenaren. Dit Protocol van afspraken over onderzoeken Tweede Kamer ${ }^{74}$ zou moeten gaan gelden voor alle toekomstige parlementaire onderzoeken, inclusief enquêtes. ${ }^{75}$ Het protocol bevat een aantal procedurele richtlijnen of werkafspraken. Zo draagt het protocol de betrokken partijen op om contactpersonen op ambtelijk niveau aan te wijzen en afspraken te maken over de achivering van informatie na afloop van het onderzoek. Ook is vastgelegd dat de betrokken bewindspersonen altijd de gelegenheid krijgen om het eindrapport vóór publicatie te controleren op bovengenoemde punten. ${ }^{76}$ Eventuele geschillen dienen in overleg te worden opgelost. ${ }^{77}$

Het protocol bevat echter meer dan alleen procedurele richtlijnen. In art. C.1 en C.2 is bepaald dat de kamer alle informatie die de minister als vertrouwelijk aanduidt, ook als vertrouwelijk dient te behandelen. De minister bepaalt dus, welke stukken vertrouwelijk zijn en welke niet. Dit is opmerkelijk. Zoals eerder besproken, zijn ministers op grond van art. $68 \mathrm{Gw}$ verplicht om de Kamers alle inlichtingen te verstrekken die door een of meerdere leden worden gevraagd. Dit is slechts anders, wanneer het belang van de staat in het geding is. ${ }^{78}$ In dat geval zou vertrouwelijke verstrekking kunnen worden overwogen en in het uiterste geval kan verstrekking worden geweigerd. In het protocol lijkt het alsof de minister om wat voor reden dan

\footnotetext{
wordt slechts gemeld dat het ministerie van V\&W als coördinerend ministerie werd aangewezen "voor wat betreft het verzamelen van en toegankelijk maken van de relevante documenten ten behoeve van de Commissie." Kamerstukken II 1998/99, 26 241, nr. 10, p. 11.

72 Zie de bijdrage van Kummeling in De WPE onder de loep 2004, p. 14. In informatieprotocollen wordt hieromtrent gewoonlijk slechts afgesproken, dat er overleg plaatsvindt - eerst op ambtelijk niveau, daarna eventueel tussen commissievoorzitter en de betrokken minister - indien de commissie van mening is dat ten onrechte een beroep op een verschoningsgrond zoals het belang van de staat wordt gedaan en informatie om die reden slechts vertrouwelijk, in bewerkte vorm of geheel niet wordt verstrekt. Zie bijvoorbeeld Kamerstukken II 2002/03, 28 244, nrs. 5-6, p. 364-365 (Enquête Bouwnijverheid) en Kamerstukken II 2011/12, 31 980, nr. 61, p. 689 (Enquête Financieel Stelsel).

${ }^{73}$ Kamerstukken II 2005/06, 30 415, nr. 6, p. 66-67.

74 Protocol van afspraken over onderzoeken Tweede Kamer waarbij inlichtingen van ministers en staatssecretarissen worden gevraagd, Stcrt. 2002/37, p. 10 (hierna: Protocol 2002).

75 Vgl. Stcrt. 2002/37, p. 10, art. A.1-A.2. Zie ook Muller \& Coenen 2002, p. 39.

76 Art. E.1 Protocol 2002.

77 Art. E.2 Protocol 2002.

${ }^{78} \mathrm{Zie}$ hierboven, par. 2.5.1.1.
} 


\section{NEDERLAND}

ook, dus los van een beroep op het belang van de staat, wordt toegestaan om informatie alleen op vertrouwelijke basis te verstrekken. Onduidelijk is waarom de kamer de minister hier bij voorbaat zoveel ruimte aan de regering heeft gegeven.

In art. $\mathrm{D}$ is voorts bepaald, dat de onderzoekscommissie aan de minister dient te laten weten over welke onderwerpen zij mondelinge informatie van ambtenaren wenst. De minister beslist of en in hoeverre aan een verzoek om bepaalde ambtenaren te horen, gelet op de Aanwijzingen externe contacten van rijksambtenaren, tegemoet kan worden gekomen. De minister bepaalt tevens op welke manier het verstrekken van mondelinge informatie door ambtenaren gebeurt. Ambtenaren zijn daarbij gebonden aan de reeds genoemde Aanwijzingen en hun wettelijke geheimhoudingsplicht. ${ }^{79}$ Bovendien moeten ambtenaren zich bij het verstrekken van mondelinge inlichtingen beperken tot inlichtingen van feitelijke aard en dienen zij zich te onthouden van het uitdragen van persoonlijke beleidsopvattingen. Ook deze afspraken zijn opvallend. In de Wet op de parlementaire enquête is immers geregeld, dat een enquêtecommissie zonder ministeriële toestemming ambtenaren mag verhoren; pas wanneer het belang van de staat in het geding is en de ambtenaar daar (zelfstandig) een beroep op doet, komt de minister aan bod. ${ }^{80}$ Ook de verplichting voor ambtenaren om zich te beperken tot het geven van feitelijke informatie en in geen geval persoonlijke beleidsopvattingen te uiten, volgt niet uit de wet. Zelfs in geval van een gewoon parlementair onderzoek, waarbij de minister wel formeel zeggenschap heeft over de mate van medewerking door (departements)ambtenaren, valt niet in te zien waarom een ambtenaar niet - met toestemming van zijn minister - méér dan uitsluitend feitelijke informatie kan geven. Ook hier kan dus worden geconcludeerd, dat de kamer zich zonder duidelijke noodzaak bij voorbaat al aan banden heeft gelegd.

In de literatuur is het standaardprotocol dan ook kritisch ontvangen. Peters stelt dat de Tweede Kamer meer tijd had moeten besteden aan de onderhandelingen met de regering over het standaardprotocol of desnoods zelf een protocol had moeten vaststellen. ${ }^{81}$ Ook Muller en Coenen zijn van oordeel dat de Tweede Kamer haar vrijheden bij het inrichten van parlementair onderzoek teveel heeft ingeperkt met als gevolg een te grote invloed van de regering op bijvoorbeeld de samenstelling van de staf van een onderzoekscommissie, het (ver)horen van ambtenaren en het gebruik van vertrouwelijke stukken. Het protocol, zo concluderen zij, gaat teveel uit van "parallelle belangen tussen de parlementaire onderzoekscommissie en het kabinet" en dat is een verkeerde veronderstelling. ${ }^{82}$ Ook uit de praktijk kwam kritiek, zij het indirect. Zo verzette de Tijdelijke commissie Infrastructuurprojecten zich tegen het standpunt van de minister-president, dat "een departement eenzijdig kan bepalen dat belangrijke informatie die een parlementaire onderzoekscommissie nodig acht

\footnotetext{
79 Verwezen wordt naar art. 125a, derde lid, Ambtenarenwet en art. 2:5 Awb. Zie art. D.2 Protocol 2002.

${ }^{80}$ Zie hierboven, par. 2.5.2.1. en 2.5.3.2.

${ }^{81}$ Zie de bijdrage van Peters in De WPE onder de loep 2004, p. 51.

82 Muller \& Coenen 2002, p. 40-41. Zie ook de bijdrage van Muller in De WPE onder de loep 2004, p. 7273 en de discussie, p. 83.
} 
voor haar onderzoek(-srapport) vertrouwelijk behandeld dient te worden indien naar haar mening de grond daartoe ontbreekt." 83

De vraag is waarom de Kamer zich, tegen de achtergrond van eerder genoemde (grond)wettelijke bepalingen, in een dergelijk restrictief kader heeft laten plaatsen. Mogelijk is dit een consequentie die inherent is aan het maken van algemene afspraken, dus los van een concrete onderzoekscontext, over gevoelige aangelegenheden als het omgaan met vertrouwelijke informatie en de medewerking van ambtenaren. ${ }^{84}$ Waar de balans tussen het belang van de onderzoekscommissie en de belangen van de regering in een concreet geval moet worden gevonden, hangt echter af van allerlei factoren. Zo spelen de ernst van het onderzoeksonderwerp en de gevoeligheid van de informatie die de commissie wil inzien een rol, maar ook de politieke statuur van de commissie en de onderhandelingsvaardigheden van haar voorzitter. Dergelijke afwegingen zijn moeilijk in algemene regels te vatten. Of bepaalde informatie bijvoorbeeld onder voorwaarde van vertrouwelijkheid zal worden verstrekt, lijkt mij iets waarover in concreto afspraken zouden moeten worden gemaakt, waarbij rekening wordt gehouden met het belang van de staat en, wanneer de onderhandelende partijen dat wensen, andere (politieke) gevoeligheden.

Vanuit het perspectief van de Kamer is het dus verstandiger om op ad hoc basis afspraken te maken met de betrokken bewindspersonen, waarbij rekening kan worden gehouden met de specifieke onderzoeksopdracht. ${ }^{5}$ Dit blijkt ook de bestaande praktijk te zijn, ondanks het algemene karakter van het standaardprotocol uit 2002. In de RPE is bepaald, dat enquêtecommissies en tijdelijke commissies afspraken kunnen maken over informatie-uitwisseling met de minister. ${ }^{86}$ In antwoord op vragen vanuit de CDA-fractie stelde de Kamervoorzitter, dat veel enquêtecommissies en tijdelijke commissies "maatwerkafspraken" maken in aanvulling op het algemene protocol van 2002. ${ }^{87}$ Over de inhoud daarvan bevat de RPE geen nadere voorschriften. Ook de nieuwe enquêtewet laat dit over aan de betrokken partijen. De initiatiefnemers benadrukken de "noodzaak om per enquêteonderzoek op maat afspraken te maken". 88 Binnen dit kader bestaat hiervoor overigens voldoende ruimte. Het stan-

\footnotetext{
${ }^{83}$ Kamerstukken II 2004/05, 29 283, nrs. 5-6, p. 131-132. Deze commissie kwam zelf een informatieprotocol met de regering overeen, zo schrijft zij in het eindrapport, overigens zonder het standaardprotocol daarbij te noemen.

${ }^{84} \mathrm{Vgl}$. ook de bijdrage van Kummeling in De WPE onder de loep 2004, p. 14, die juist stelt dat een aantal kernpunten van de informatieverstrekking een wettelijke basis zouden moeten krijgen, omdat bewindspersonen thans "makkelijk in de verleiding komen om de noodzaak van informatieverschaffing aan een parlementaire enquêtecommissie te betwijfelen." De initiatiefnemers van de nieuwe enquêtewet zagen hierin echter geen heil. Kamerstukken II 2005/06, 30 415, nr. 6, p. 66. Zie ook Lubberdink 2003, p. 24-25.

85 Ook gedurende het onderzoek zal het wellicht nodig zijn om overleg te voeren over specifieke verzoeken om inzage in (vertrouwelijke) informatie. Een voorbeeld is de gang van zaken rondom het geheime deel van het rapport-Wieringa, waarbij tijdens de Enquêtecommissie Opsporingsmethoden zelfs de minister-president betrokken raakte. Zie voor een verslag van deze onderhandelingen het eindrapport van de commissie: Kamerstukken II 1995/96, 24 072, nr. 12, p. 40-41. Zie verder Muller \& Coenen, p. 56, 96-97.

${ }^{86}$ Zie art. 13, eerste lid, RPE.

${ }^{87}$ Kamerstukken II 2007/08, 31 019, nr. 8, p. 4-5

88 Kamerstukken II 2005/06, 30 415, nr. 6, p. 66. Uit een door hen uitgevoerde analyse van recente informatieprotocollen, blijkt ook dat deze "steeds toegespitst [zijn] op de dan geldende specifieke situa-
} 
daardprotocol is een afspraak tussen de toenmalige Kamervoorzitter en minister, die de Kamer als zodanig niet kan binden. Aangezien de Kamer formeel slechts gebonden kan worden door (grond)wettelijke bepalingen of haar eigen reglement van orde, kunnen de afspraken in het protocol niet als juridisch bindend worden beschouwd. 89

\subsubsection{Zelfstandige bestuursorganen; markttoezichthouders}

Het protocol van afspraken, dat in 2002 tot stand kwam, heeft niet direct betrekking op ambtenaren werkzaam bij verzelfstandigde diensten (zbo's). Zowel bij reguliere parlementaire onderzoeken als bij enquêtes geven de toepasselijke (grond)wettelijk kaders de mogelijkheid, zo bleek hierboven, dat zbo's weigeren om bepaalde inlichtingen te verschaffen. ${ }^{90}$ Ook hier speelt daarom de noodzaak om, in het belang van een voortvarend en effectief onderzoeksproces, afspraken te maken met de betrokken instanties. Bij markttoezicht speelt bovendien mee, dat ook uit het internationale of Europese recht (of het daarvan afgeleide nationale recht) geheimhoudingsplichten kunnen voortvloeien die in bepaalde gevallen de medewerkingsplicht van ministers en bestuurders van zbo's bij een parlementaire enquête overstijgen. ${ }^{91}$

Dit laatste speelde een belangrijke rol bij aanvang van de Enquête Financieel Stelsel, waarbij de commissie inzage wilde in bepaalde (marktgevoelige) toezichtsinformatie berustend bij het kabinet en de financiële markttoezichthouders DNB en AFM. Dit was overigens de eerste keer, dat een onderzoekscommissie in belangrijke mate aangewezen was op de medewerking van een zelfstandig bestuursorgaan. Uit een voorlichting door de Raad van State bleek dat de verhouding tussen Europese normen en nationale constitutionele verhoudingen in dit geval niet eenduidig was. ${ }^{92}$ Uiteindelijk is na veelvuldig overleg tussen kabinet, de toezichthouders en de enquêtecommissie een informatieprotocol tot stand gekomen, waarbij het uitgangspunt is dat medewerking wordt verleend aan het beschikbaar stellen van de benodigde informatie. Bovendien werden met beide toezichthouders nadere afspraken gemaakt over de inzage in passages die in verstrekte documenten zijn weggelakt. ${ }^{93}$

\subsubsection{Samenloop van onderzoek}

\subsubsection{Inleiding}

Parlementair onderzoek heeft soms betrekking op onderwerpen, die tevens voorwerp zijn van ander onderzoek. Daarbij moet vooral gedacht worden aan strafrechte-

tie". Tegelijkertijd gaven de initiatiefnemers, opmerkelijk genoeg, in overweging om op een aantal punten tot een modelprotocol te komen. Kamerstukken II 2005/06, 30 415, nr. 6, p. 66-67. Mogelijk werd het reeds bestaande standaardprotocol hier over het hoofd gezien.

${ }^{89}$ Zie ook Kamerstukken II 2007/08, 31 019, nr. 8, p. 5, waarin wordt bevestigd dat het protocol een "onderlinge afspraak" is, waarvan de "juridische zeggingskracht" beperkt is.

${ }^{90}$ Zie nader hierboven, par. 2.5.2.2.

91 Zie hierboven, par. 2.5.3.2.

92 Zie hierboven, par. 2.5.3.2.

${ }^{93}$ De protocollen en nadere afspraken met het kabinet, de AFM en DNB zijn als bijlage bij het eindrapport van de enquêtecommissie gepubliceerd. Zie Kamerstukken II 2011/12, 31 980, nr. 61, p. 688 e.v. Zie hierover ook hierna, par. 4.7.2.2. 
lijk onderzoek, maar ook aan bestuursrechtelijke of tuchtrechtelijke sanctieprocedures, die betrekking hebben op hetzelfde feitencomplex als een parlementair onderzoek. De uitwisseling van informatie kan bij een dergelijke samenloop van onderzoeken in verschillende opzichten problematisch zijn. Zo zou de politie kunnen worden gehinderd in haar opsporingsonderzoek, wanneer bepaalde informatie via bijvoorbeeld een openbare hoorzitting van een parlementaire onderzoekscommissie te vroeg naar buiten komt. Bij enquêtes is van belang, dat de bewijsuitsluitingsregel ${ }^{94}$ van art. 30 Wpe 2008 de bewijsvoering van het openbaar ministerie zou kunnen belemmeren. De officier van justitie zal voor de rechter namelijk moeten kunnen aantonen, dat het bewijs niet voortvloeit uit verklaringen die door verdachte of anderen op vordering van een enquêtecommissie zijn afgelegd. Bovendien zou een parlementair onderzoek gevolgen kunnen hebben voor de onbevangenheid van de rechter, wanneer deze bijvoorbeeld over feiten zal moeten oordelen die uitvoerig in een hoorzitting of rapport van een onderzoekscommissie aan de orde zijn gekomen. ${ }^{95}$

De problematiek van samenlopende onderzoeken speelde reeds vóór de heropleving van het parlementaire onderzoeksrecht in 1983. Aanvankelijk stelde dat de Kamer zich meestal terughoudend op; feiten die ook strafrechtelijke aandacht hadden, werden veelal buiten het onderzoek gelaten, of het strafproces werd voorrang verleend. ${ }^{96}$ Deze terughoudendheid verdwijnt daarna naar de achtergrond. Verschillende commissies, die met mogelijke samenloop te maken krijgen, benadrukken vooral de verschillen tussen parlementair onderzoek en strafrechtelijk onderzoek. Zo stelt de Enquêtecommissie Paspoortproject, die onderzoek moest doen naar de feiten en verantwoordelijkheden rondom de invoering van een nieuw paspoort, dat de waarheidsvinding bij een enquête niet gericht is op rechtsgevolgen, maar betrekking heeft op de grote lijnen en daarom een veel globaler karakter heeft dan waarheidsvinding bij een gerechtelijk onderzoek. ${ }^{97}$

In paragraaf 2.5 bleek reeds, dat zowel bij enquêtes als bij reguliere parlementaire onderzoeken het uitgangspunt is dat overheidsdiensten - op eigen naam dan wel via de verantwoordelijke minister - in beginsel verplicht zijn om de door de commissie gevraagde inlichtingen te verstrekken. Het openbaar ministerie is hiërarchisch volledig ondergeschikt aan de minister van Veiligheid en Justitie. Dit blijkt onder meer uit de bepaling, dat de minister van Justitie aan de leden van het OM algemene en bijzondere aanwijzingen kan geven betreffende de uitoefening van hun taken en

\footnotetext{
${ }^{94}$ Zie nader, par. 2.3.4.2.1.

95 Boon 1982, p. 142-143.

${ }_{96}$ Zo aanvaardde de Kamer in de zaak-Oss, die in 1938 door een bijzondere Kamercommissie werd onderzocht, het verzoek van de minister om uitstel bij het verschaffen van inlichtingen omtrent het gedrag van enkele marechaussees tot na de uitspraak van de Centrale Raad van Beroep. Bij de Enquête Regeringsbeleid 1940-1945 werd vanuit de Kamer opgemerkt dat de enquêtecommissie zich niet bezig zou moeten houden met het optreden van oud-premier De Geer, zolang het strafproces tegen hem nog niet was afgerond. En in 1981 legde de bijzondere Kamercommissie die onderzoek deed naar de zaak-Kahn zich meerdere malen neer bij de weigering van de minister van Justitie om inzage te geven in het voorbereidende strafdossier dat rondom de kerngeleerde was aangelegd. Anders liep het bij het onafhankelijke onderzoek naar de affaire-Menten (1978), al was dit geen parlementair onderzoek. Wel betreurde de commissie achteraf de ontstane vermenging. Zie nader: Boon 1982, p. 143-150. 97 Kamerstukken II 1987/88, 20 599, nr. 7, p. 26-27. Zie verder Lubberdink 2003, p. 20-22. Vgl. ook Boon 1982, p. 142.
} 


\section{NEDERLAND}

bevoegdheden. ${ }^{98}$ Dit betekent dat de minister bevoegd is, om officieren van justitie concrete aanwijzingen te geven indien een parlementaire onderzoekscommissie bijvoorbeeld zou verzoeken om inzage te krijgen in een strafdossier. Het verstrekken van inlichtingen aan een parlementaire enquêtecommissie kan daarom door de minister of door het openbaar ministerie zelf worden geweigerd wegens 'strijd met het belang van de staat'. Dit begrip moet bovendien ruim worden geïnterpreteerd. ${ }^{99}$ Het publieke belang van een effectieve strafrechtelijke handhaving kan daarom eveneens worden gezien als een belang van de staat in de zin van art. 19 Wpe 2008. ${ }^{100}$ Hetzelfde kan gezegd worden over gewone parlementaire onderzoeken en het 'belang van de staat' in art. $68 \mathrm{Gw}$. Er is daarom ruimte voor ministers en ambtenaren om te weigeren informatie te verstrekken, wanneer de verstrekking ervan een lopend of toekomstig strafrechtelijk of bestuursrechtelijk onderzoek zou hinderen of beschadigen.

Ook bij verwachte samenloop is het daarom gebruikelijk, dat commissies in overleg met de verantwoordelijke ministers en de betrokken instanties tot procedureafspraken komen, die veelal in protocollen worden vastgelegd. Hierbij wordt getracht zoveel mogelijk recht te doen aan de belangen en doelstellingen van de verschillende onderzoekende instanties. ${ }^{101}$ Zo worden afspraken gemaakt over de verstrekking van informatie over bijvoorbeeld lopende strafzaken, maar ook over de wijze waarop wordt omgegaan met getuigen die tevens verdachte zijn of anderszins een rol spelen bij andere onderzoeken. De onderzoeksvragen die in deze verschillende onderzoeken gesteld worden, komen soms zeer dicht bij elkaar, zo bleek bijvoorbeeld bij de Enquête Bouwnijverheid. De bouwfraude-affaire, waarop deze enquête betrekking had, leidde tot verschillende onderzoeken die parallel aan elkaar liepen. Het ging daarbij niet slechts om strafrechtelijke procedures, maar ook om kartelonderzoek door de Nederlandse Mededingingsautoriteit (NMa), die destijds overigens nog niet verzelfstandigd was en nog onderdeel was van de departementale hiërarchie, zij het binnen een wat afwijkend wettelijk regime.102 Een zorgvuldige afstemming tussen de betrokken instanties werd daarom noodzakelijk geacht. Om een beeld te geven van de wijze waarop dit is aangepakt, wordt de gang van zaken bij deze enquête hieronder nader belicht. 103

\subsubsection{De Enquête Bouwnijuerheid}

De problematiek van samenlopende onderzoeken speelde een hoofdrol in de aanloop naar de Enquête Bouwnijverheid, die in 2002 plaatsvond. De Kamer wenste een parlementaire enquête naar de vermeende grootschalige fraude in de bouwwereld, terwijl ook het openbaar ministerie onderzoek wilde doen naar mogelijke strafbare

\footnotetext{
98 Art. 127 Wet RO. Zie ook Munneke 2006, p. 178.

${ }^{99}$ Zie hierboven, par. 2.5.3.

100 Voorheen art. 21 WPE. Zie Lubberdink 2003, p. 22 en Munneke 2006, p. 139-140, 298-304.

101 Samenloop met strafrechtelijk of bestuursrechtelijk onderzoek was onder meer aan de orde bij de Enquêtes Bouwsubsidies, Vliegramp Bijlmermeer en Bouwnijverheid en bij de onderzoekscommissies inzake Bosio en Vie d'Or. Zie Kamerstukken II 2005/06, 30 415, nr. 6, p. 52. Zie ook Muller \& Coenen 2002, p. 43-45.

102 Zie Verhey \& Verheij 2005, p. 148.

${ }^{103}$ Zie over de samenloopproblematiek bij deze enquête ook uitvoerig: Lubberdink 2003, p. 22 e.v.
} 
feiten. Bovendien startte de NMa een groot onderzoek naar mededingingsvervalsing in deze sector.

De parlementaire enquête moest vooral de "structuurkenmerken" van de bouwsector in kaart brengen en inzicht geven in de mate waarin deze structuur samenhangt met de vermeende onregelmatigheden en welke rol de verschillende actoren daarbij gespeeld hebben. Om beter inzicht te krijgen in deze structuurkenmerken, moesten in ieder geval twee "majeure zaken", de Schipholtunnelzaak en de Bosboekhouding, waarmee de systematische fraude in de bouwsector aan het licht werd gebracht, nader onderzocht worden. Bij die laatste zaak zou een probleem kunnen ontstaan, omdat het OM en de NMa juist ieder (mede op verzoek van de Kamer) een eigen onderzoek naar deze schaduwboekhouding waren gestart. De tijdelijke commissie, die de enquête voorbereidde, stelde daarom dat de enquêtecommissie goede afspraken over informatie-uitwisseling diende te maken met deze instanties en dat zorgvuldige afstemming diende plaats te vinden. ${ }^{104}$

De minister van Justitie werd gevraagd om een reactie op de voorstellen van de tijdelijke commissie. In zijn brief raadde hij het onderzoeken van de Bosboekhouding en eventuele andere zaken die reeds voorwerp waren van lopend strafrechtelijk onderzoek ten zeerste af. ${ }^{105}$ De minister benadrukte dat het voor een strafrechtelijk onderzoek van groot belang is dat het openbaar ministerie de volledige regie kan voeren over het horen van getuigen en verdachten, teneinde de kwaliteit van hun verklaringen te kunnen waarborgen. Het $\mathrm{OM}$ moet kunnen voorkomen dat verdachten kunnen communiceren over de af te leggen verklaringen en bovendien zijn verklaringen die reeds meerdere malen zijn afgelegd minder betrouwbaar. De bewijsuitsluitingsregel van art. $24 \mathrm{WPE}^{106}$, zo stelde de minister, zorgt ervoor dat het enquêteverhoor van getuigen voor het OM "geen bruikbare informatie oplevert maar wel een ernstig bewijsprobleem over de redenen van wetenschap". Mocht de Kamer desondanks besluiten om de enquêtecommissie parallel aan het OM onderzoek te laten doen naar hetzelfde feitencomplex, dan zou in onderlinge afspraken moeten worden vastgelegd dat het $\mathrm{OM}$ de regie over het horen van getuigen en verdachten zou behouden. "Afspraken die hier niet in voorzien brengen een aan zekerheid grenzende waarschijnlijkheid met zich met dat het Openbaar Ministerie bepaalde strafzaken prijs zal moeten geven ten behoeve van het parlementaire onderzoek", voegde de minister daar aan toe. ${ }^{107}$ De minister opperde in dit verband om de betrokken officieren van justitie uitsluitend via vertrouwelijke voorgesprekken te horen, wanneer de enquêtecommissie informatie over lopende strafzaken zou willen krijgen.

De tijdelijke commissie bleef echter bij haar standpunt. Hoewel goede afspraken en afstemming noodzakelijk zijn, benadrukte zij in reactie op de brief van de minister dat een enquêtecommissie autonome onderzoeksbevoegdheden heeft en dat de enquête een eigen functie vervult: het scheppen van een totaalbeeld. Daarmee zou het parlement de afzonderlijke onderzoeken van kabinet, OM en NMa overstijgen. ${ }^{108}$

\footnotetext{
104 Kamerstukken II 2001/02, 28 093, nrs. 22-23, p. 36-37.

105 Kamerstukken II 2001/02, 28 093, nrs. 24, p. 2-6.

106 Thans geregeld in art. 30 Wpe 2008.

107 Kamerstukken II 2001/02, 28 093, nrs. 24, p. 5.

108 Kamerstukken II 2001/02, 28 093, nrs. 24, p. 1.
} 


\section{NEDERLAND}

Hoewel de VVD-fractie tijdens het debat over het rapport van de tijdelijke commissie nog bedenkingen uitte over de samenloop van de verschillende onderzoeken, steunde een Kamermeerderheid de tijdelijke commissie in haar oordeel dat het uiteindelijk aan de enquêtecommissie was om te bepalen hoe de regie over de verhoren moet worden gevoerd. Alle fracties benadrukten evenwel dat de enquêtecommissie goede afspraken met het OM en de NMa diende te maken. ${ }^{109}$

Naar aanleiding van het debat over de aanbevelingen van de tijdelijke commissie werd de Enquêtecommissie Bouwnijverheid uiteindelijk op 5 februari 2002 met algemene stemmen door de Kamer ingesteld. ${ }^{110}$ Enkele maanden later bereikte de enquêtecommissie, zoals gebruikelijk bij enquêtes, overeenstemming met een aantal ministers over de verstrekking van informatie. ${ }^{111}$ Met de ministers van Justitie en Economische Zaken werden aanvullende afspraken gemaakt over de afstemming tussen het enquêteonderzoek en de lopende onderzoeken van het OM en de NMa. Deze afspraken met de ministers van Justitie en Economische Zaken komen grotendeels overeen. Samengevat komt het erop neer dat:

- de commissie in beginsel op verzoek inzage in of afschrift van lopende onderzoeksdossiers krijgt;

- de commissie vooraf overleg voert met ministers over de planning van gesprekken c.q. verhoren; indien het personen betreft die betrokken zijn bij lopende onderzoeken, vindt overleg plaats over het tijdstip waarop de minste schade voor lopend onderzoek ontstaat;

- het in het openbaar verhoren van medewerkers van het OM en de NMa over lopende zaken alleen plaats vindt na overleg met de betreffende ministers;

- getuigen, verdachten en anderen die onderdeel zijn van een lopend justitieel of bestuurlijk onderzoek tijdens verhoor niet rechtstreeks worden geconfronteerd met gegevens uit lopende onderzoeken;

- de commissie door medewerkers van OM en NMa vertrouwelijk wordt geïnformeerd over de voortgang van onderzoeken; indien er strijd zou zijn met het staatsbelang kunnen vragen onbeantwoord blijven; van de minister kan vervolgens een bevestiging van het beroep op het staatsbelang worden verlangd;

- indien het verstrekken van onbewerkte gegevens strijdig zou zijn met het staatsbelang, de (vice-)commissievoorzitter onder geheimhouding inzage kan krijgen om de juistheid van de weggelaten delen te beoordelen; de minister kan om bevestiging van het beroep op het belang van de staat worden gevraagd;

\footnotetext{
109 Handelingen II 2001/02, p. 3243-3264. Zie ook NRC Handelsblad 31 januari 2002, p. 3.

${ }_{110}$ Handelingen II 2001/02, p. 3339. Het betreft de aanvaarding van de motie-Van Oven c.s., Kamerstukken II 2001/02, 28 093, nr. 25, waarin de aanbevelingen van de tijdelijke commissie om een enquêteonderzoek in te stellen naar de "structuurkenmerken in de bouwnijverheid, de mate waarin deze samenhangen met de gesignaleerde onregelmatigheden in deze sector en naar de opstelling en handelswijze van de verschillende actoren in het geheel" werden opgevolgd.

111 Kamerstukken II 2001/02, 28 244, nr. 3, p. 4-7. Het ministerie van VROM trad op als coördinerend ministerie. Op de algemene afspraken over informatievoorziening door ministeries wordt hier niet nader ingegaan. Zie hiervoor par. 4.5.1.
} 
- in het enquêterapport zoveel mogelijk wordt vermeden dat schade aan lopende zaken wordt toegebracht; zogenaamde operationele informatie over lopende zaken wordt niet in de rapportage opgenomen. ${ }^{112}$

De gemaakte afspraken benadrukken enerzijds het recht van de enquêtecommissie om op verzoek volledige inzage in lopende onderzoeken te krijgen, terwijl anderzijds rekening wordt gehouden met het belang van effectief strafrechtelijk of bestuursrechtelijk optreden door de betreffende autoriteiten. Er ligt een sterke nadruk op overleg tussen de commissie en de betrokken ministers, teneinde schade aan lopende onderzoeken zoveel mogelijk te voorkomen. ${ }^{113}$ Niettemin beslist de enquêtecommissie uiteindelijk zelf welke getuigen zij oproept voor verhoor en op welk moment dat gebeurt. ${ }^{114}$ Voorts blijkt uit deze afspraken dat slechts in uitzonderlijke situaties, waarin het belang van de staat op het spel staat, het inzien van bepaalde stukken door of namens de minister kan worden geweigerd of beperkt. Er is niet voor gekozen om het begrip 'belang van de staat' in deze concrete situatie nader te omschrijven en te specificeren. Daar staat tegenover, dat de (vice-)voorzitter van de enquêtecommissie bij een beroep op het staatsbelang de mogelijkheid krijgt om onder geheimhouding van de betreffende stukken kennis te nemen.

\subsubsection{Nadere regeling?}

De wijze waarop in bovengenoemde enquête is omgegaan met de samenloop van onderzoeken en de bijbehorende belangen, heeft succesvol uitgepakt. De commissie ontving veel lof voor haar werk; het enquêterapport biedt inzicht in de aard, omvang en systematiek van de fraude bij de aanbesteding van grote overheidsprojecten. Tegelijkertijd zijn slechts enkele bouwondernemers veroordeeld voor hun betrokkenheid bij de bouwfraude en in totaal is van de geschatte fraude van 15 miljard euro slechts 400 miljoen in de vorm van NMa-boetes teruggevloeid naar de staat. ${ }^{115}$ Dit lijkt vooral te maken te hebben met afwegingen die de betrokken instanties zelf hebben gemaakt. Het openbaar ministerie heeft er wegens capaciteitsgebrek voor gekozen niet alle fraudegevallen te onderzoeken en zich te beperken tot de hoofdrolspelers. De NMa heeft een clementieregeling gehanteerd, waarbij bouwon-

112 Zie Kamerstukken II 2001/02, 28 244, nr. 3, p. 8-12. Zie ook Lubberdink 2003, p. 23-24. Voorts is afgesproken dat voor reeds afgeronde strafrechtelijke of bestuursrechtelijke onderzoeken door OM resp. NMa geldt dat de commissie volledige inzage krijgt in de dossiers, tenzij het staatsbelang zich daartegen verzet. In dat laatste geval is inzage door de (vice-)voorzitter van de enquêtecommissie op voorwaarde van geheimhouding wel mogelijk.

${ }^{113}$ De commissie omschrijft de afspraken als volgt: "Als uitgangspunt van deze afspraken geldt dat de enquêtecommissie binnen de kaders van de Wet op de Parlementaire Enquête (WPE) maximale vrijheid heeft haar onderzoek in te richten, maar dat de commissie bij het gebruik van deze vrijheid in voorkomende gevallen het belang meeweegt van reeds lopende strafrechtelijke en bestuursrechtelijke procedures." Kamerstukken II 2001/02, 28 224, nr. 3, p. 2.

114 De voorzitter van de enquêtecommissie liet aan de vooravond van de openbare verhoren weten hoe wat hem betreft de rangorde tussen de enquêtecommissie en het openbaar ministerie is: de commissie kan iedereen kan die zij wil op elk moment oproepen voor verhoor. Het openbaar ministerie dient op andere wijze haar informatie te verzamelen als een enquêteverhoor, gelet op art. 24 WPE, het strafrechtelijk onderzoek in de wielen zou rijden. Algemeen Dagblad 20 augustus 2002, p. 18.

115 Zo bleek in een Zembla-uitzending in november 2006 over de resultaten van de aanpak van de bouwfraude, vijf jaar na de bewuste uitzending waarin de Bosboekhouding openbaar werd gemaakt. 


\section{NEDERLAND}

dernemers korting zouden krijgen op hun boete wanneer zij vrijwillig medewerking zouden verlenen aan het NMa-onderzoek. Hiermee hoopte de NMa haar onderzoek te versoepelen. In dit geval van samenloop is, zo kan worden geconcludeerd, door de betrokken instanties in feite voorrang gegeven aan het belang van het verkrijgen van inzicht in de structuur en omvang van de bouwfraude, dat via een enquête beter kon worden bereikt dan via individueel strafrechtelijk of bestuursrechtelijk onderzoek. ${ }^{116}$ Er zijn geen aanwijzingen dat het enquêteonderzoek schade heeft toegebracht aan de lopende strafrechtelijke of bestuursrechtelijke onderzoeken.

Lubberdink opperde naar aanleiding van deze enquête om vanuit het oogpunt van rechtszekerheid de samenloopregeling, die bij de Enquête Bouwnijverheid werd getroffen, wellicht in de wet op te nemen. ${ }^{117}$ Anderen riepen juist op tot terughoudendheid van de kant van het parlement, wanneer sprake is van mogelijke samenloop. Daarbij wordt vooral gewezen op de risico's voor de positie van getuigen, mogelijke belemmering van straf- of bestuursrechtelijk onderzoek, en het gevaar dat het parlementaire onderzoek de rechter zou kunnen beïnvloeden. Door sommigen werd gepleit voor het Franse stelsel, waarin samenloop met strafrechtelijk onderzoek bij wet is uitgesloten. ${ }^{118}$

Gezien de discussie kreeg de commissie die de vernieuwing van de Wet op de Parlementaire Enquête voorbereidde de opdracht van de Kamer om "in het wetsvoorstel in ieder geval in te gaan op (...) de samenloop met ander, al dan niet justitieel, onderzoek." 119 Deze commissie kwam tot de conclusie, dat een nadere wettelijke regeling omtrent samenloop niet wenselijk was. $\mathrm{Zij}$ stelde, dat het alleen aan de Kamer was om te bepalen of een parlementaire enquête wenselijk was, niet aan de wetgever. Hoewel de Kamer er voor zou kunnen kiezen om geen onderzoek te doen naar feiten die ook voorwerp van een strafrechtelijk onderzoek zijn (of zijn geweest), achtten de initiatiefnemers het op zichzelf - onder verwijzing naar de "andersoortige functie" van het strafproces - niet bezwaarlijk indien beide soorten onderzoek naast elkaar zouden lopen. Ook waren de initiatiefnemers geen gevallen bekend, waarin samenloop van onderzoeken belemmerend werkte of tot bewijsproblemen had geleid. ${ }^{120}$ Tegelijkertijd mocht van zowel de Kamer als de enquêtecommissie worden verwacht, dat zij zorgvuldig omgaan met "andere belangen van de staat." In de praktijk dienen daarom afspraken te worden gemaakt om afstemmingsproblemen te voorkomen. Het samenloopprotocol dat bij de Bouwnijverheidsenquête is gebruikt, werd daarbij als voorbeeld aangehaald. ${ }^{121}$

De vraag of een parlementaire enquête opportuun is, ten aanzien van zowel onderwerp als tijdsplanning, blijft dus aan de Kamer. Ook bij het reguliere parlementai-

\footnotetext{
116 Zie ook Buruma 2002, p. 708.

117 Lubberdink 2003, p. 25. Wel tekende hij daarbij aan dat rechtszekerheid moeilijk te bereiken is, aangezien de meeste onduidelijkheid wordt veroorzaakt door het begrip 'belang van de staat', dat moeilijk in algemene termen kan worden geduid.

118 Doorenbos in De WPE onder de loep 2004, p. 57-64. In die zin ook Glazener 2002, p. 710.

119 Kamerstukken II 2003/04, 29 547, nr. 1, p. 1.

120 Kamerstukken II 2005/06, 30 415, nr. 6, p. 52.

${ }^{121}$ Het 'Franse stelsel' werd om deze redenen uitdrukkelijk afgewezen. Kamerstukken II 2005/06, 30 415, nr. 6, p. 52-53.
} 
re onderzoek is dit zo gebleven. ${ }^{122}$ Er leek ook niet direct een dringende noodzaak om op dit punt een andere weg in te slaan. Parlementair en strafrechtelijk of bestuursrechtelijk onderzoek zijn tot op heden niet onverenigbaar gebleken. Bovendien is niet in te zien, waarom een parlementair onderzoek per definitie ondergeschikt zou moeten worden gemaakt aan het strafproces. Soms is het algemeen belang beter gediend met een tijdig, openbaar, breed opgezet parlementair onderzoek dan met een reeks individuele strafzaken. De bouwfraudeaffaire is daar een voorbeeld van. Het maken van ad hoc afspraken blijkt vooralsnog een effectieve manier om in concrete situatie een juiste balans te vinden tussen de verschillende belangen, waarbij tegelijkertijd rekening kan worden gehouden met de positie van getuigen c.q. verdachten. ${ }^{123}$ Van de Kamer mag verwacht worden, dat daarbij rekening wordt gehouden met andere onderzoeksbelangen.

Ook de initiatiefnemers verwachtten gezien de ervaringen in de recente praktijk niet, dat conflictsituaties zich snel zullen voordoen. In voorkomende gevallen rekenen de initiatiefnemers erop dat langs politieke weg een oplossing wordt bereikt. Voor een (wettelijke) conflictregeling voelden de initiatiefnemers in elk geval weinig: dit zou niet binnen de staatsrechtelijke verhoudingen tussen kabinet en Kamer passen. ${ }^{124}$

\subsection{Openbare gesprekken}

\subsubsection{Procedure, rol voorzitter}

Nadat het vooronderzoek is afgerond, volgt het openbare gedeelte van het onderzoek. ${ }^{125}$ Alle parlementaire onderzoekscommissies maken in meer of mindere mate gebruik van de mogelijkheid om in het openbaar personen te ondervragen, bijvoorbeeld wegens hun politieke, ambtelijke, bedrijfsmatige of persoonlijke betrokkenheid, hun feitenkennis, beroepsmatige ervaring of hun wetenschappelijke deskundigheid met betrekking tot het onderzoeksonderwerp of een deelaspect daarvan.

In hoofdstuk 2 is reeds uitvoerig ingegaan op de bevoegdheden van onderzoekscommissies om personen te (ver)horen. Voor tijdelijke commissies, die voor het reguliere parlementaire onderzoek worden ingesteld, geldt, kort gezegd, dat zij krachtens art. 27 RvOTK net als alle andere Kamercommissies bevoegd zijn om mondeling overleg te voeren, hoorzittingen te houden of rondetafelgesprekken te

\footnotetext{
122 Kamerstukken II 2006/07, 31 019, nr. 3, p. 10.

123 Een wettelijke regeling waarin afspraken omtrent samenloop zouden worden vastgelegd, kent waarschijnlijk dezelfde nadelen als het algemene informatieprotocol tussen regering en Kamer, dat hierboven aan de orde was. Zie par. 4.5.1.

124 Kamerstukken I 2006/07, 30 415, C, p. 25.

125 De Enquête Vliegramp Bijlmermeer vormde een uitzondering op deze praktijk. Hier was het feitenonderzoek nog niet afgerond op het moment dat de openbare verhoren begonnen. Deze samenloop van verschillende onderzoeksfasen kwam de voorbereiding ervan niet ten goede, zo erkende de commissie. Zie Kamerstukken II 1998/99, 26 241, nr. 10, p. 16. Zie ook Rouvoet 1999, p. 21-22 en Muller \& Coenen 2002, p. 82.
} 


\section{NEDERLAND}

beleggen met ministers, ambtenaren en andere personen. ${ }^{126}$ Medewerking van rijksambtenaren vindt plaats door tussenkomst van de minister, derden kunnen alleen op vrijwillige basis worden uitgenodigd voor een openbaar gesprek. ${ }^{127}$ De Wet op de parlementaire enquête 2008 bevat verschillende bepalingen omtrent het horen van getuigen en deskundigen. Deze hebben vooral betrekking op de bevoegdheden van de enquêtecommissie om personen te dwingen om medewerking te verlenen en op de rechten van getuigen en deskundigen. ${ }^{128}$

Zowel het Reglement van Orde als de Wet op de parlementaire enquête laten het grotendeels aan de commissie over, om te bepalen hoe zij een hoorzitting vormgeven. Tijdelijke commissies hebben sinds de reglementswijziging van 2004 op dit vlak veel vrijheid gekregen. Hoorzittingen kunnen openbaar of besloten zijn, met open aanmelding of op uitnodiging, of in de vorm van een rondetafelgesprek. ${ }^{129} \mathrm{Bij}$ dat laatste is sprake van 'tweerichtingsverkeer'. Ook kunnen werkbezoeken worden afgelegd, waarbij ter plaatse tevens een hoorzitting kan worden gehouden. ${ }^{130}$ Een hoorzitting van een tijdelijke commissie kan, zo mag worden aangenomen, worden aangemerkt als een commissievergadering als bedoeld in de artt. 33-37 RvOTK. Hieruit volgt, dat de commissie besluit over het tijdstip, het onderwerp, de openbaarheid van de zitting en de personen die worden uitgenodigd om gehoord te worden. De commissievoorzitter beschikt tijdens vergaderingen - en dus ook tijdens hoorzittingen - over dezelfde reglementaire ordebevoegdheden als de Kamervoorzitter. Zo kan de voorzitter beslissen wie van de leden het woord krijgt en vragen kan stellen. Ook kan hij een lid dat afwijkt van het onderwerp van de hoorzitting tot de orde roepen of vermanen om eventuele beledigende of anderszins verstorende bewoordingen terug te nemen. Geeft een lid aan dergelijke verzoeken geen gehoor, dan kan de voorzitter hem het woord ontnemen. In het uiterste geval kan een lid zelfs worden uitgesloten van verdere deelname aan de vergadering. ${ }^{131}$

De Wet op de parlementaire enquête bevat veel minder bepalingen van procedurele aard. De wet bepaalt slechts, dat het ondervragen van getuigen en deskundigen gebeurt door de enquêtecommissie in aanwezigheid van tenminste drie leden. ${ }^{132}$ Het Reglement van Orde bevat sinds 2008 in het geheel geen nadere voorschriften omtrent de enquête meer. Hiertoe werd besloten, zo blijkt uit de toelichting op de reglementswijziging, omdat alle relevante voorschriften inzake de enquête in de nieuwe wet zouden worden opgenomen. Bovendien beoogde het Reglement bepalingen met externe werking te bevatten en dat was ongewenst. Het Reglement kon

\footnotetext{
${ }^{126}$ Van hoorzittingen dient mededeling te worden gedaan aan de Kamer en op internet. Zie art. 29 RvOTK.

127 Zie par. 2.4.2.

128 Zie over deze bevoegdheden hierboven, par. 2.3.2.2.

${ }^{129}$ Kamerstukken II 2003/04, 29 264, nr. 5, p. 1.

${ }^{130}$ Bovend'Eert \& Kummeling 2010, p. 493-494.

131 Zie art. 35 jo. 58-60 RvOTK. Een eventuele uitsluiting geldt daarbij slechts voor één dag en betreft alleen openbare vergaderingen van de commissie.

132 Art. 9, eerste en tweede lid, Wpe 2008.
} 
op dit punt daarom verregaand worden vereenvoudigd. ${ }^{133}$ Tot de vernieuwing in 2008 bepaalde het Reglement van Orde nog, dat het ondervragen van getuigen en deskundigen gebeurt door de voorzitter van de enquêtecommissie, tenzij deze het woord aan een van de andere commissieleden geeft. ${ }^{134}$ De commissievoorzitter kon op grond hiervan dus de regie voeren tijdens de ondervragingen. Of de voorzitter sinds de reglementswijziging gebruik kan maken van de reguliere ordebevoegdheden, 135 zoals die onder andere voor voorzitters van tijdelijke commissies gelden, kan niet met zekerheid worden gezegd. De enquêtecommissie wordt namelijk niet genoemd in hoofdstuk VII van het Reglement, waarin de commissiebevoegdheden zijn geregeld. Zij wordt alleen nog genoemd in hoofdstuk XII, waar zij in art. 141 wordt gekenmerkt als een "commissie uit de Kamer". Indien de bepalingen inzake commissies niet zouden gelden voor enquêtecommissies, dan blijft slechts art. 9 Wpe 2008 over, waarin is bepaald dat personen worden gehoord door de commissie in aanwezigheid van tenminste drie leden. ${ }^{136}$ Dat zou een aanmerkelijke verzwakking van de positie van de voorzitter betekenen. Het lijkt mij onwaarschijnlijk dat de Kamer dit bij de recente reglementswijziging heeft willen bewerkstelligen. ${ }^{137}$ Voor alle duidelijkheid zou het echter beter zijn, om de enquêtecommissie toe te voegen aan de lijst met commissievormen in hoofdstuk VII.

Afgezien van deze ogenschijnlijke onvolkomenheid in de systematiek van het Reglement, kan de vraag gesteld worden of de reguliere ordebevoegdheden van de voorzitter afdoende zijn. Een onderzoekscommissie is in haar werkwijze nauwelijks vergelijkbaar met een gewone (vaste) commissie, waarin de voorzitter slechts een 'technische' taak heeft. De voorzitter van een onderzoekscommissie speelt doorgaans zowel procedureel als inhoudelijk een leidende rol. Dit doet hij in de praktijk grotendeels langs informele weg. ${ }^{138}$ Dit is begrijpelijk, gezien het belang van consensus en samenwerking dat in de Nederlandse traditie als essentieel voor het functioneren

\footnotetext{
133 Kamerstukken II 2006/07, 31 019, nr. 5, p. 2. Verder werd het ondervragen van een getuige door medewerkers van de commissie niet wenselijk geacht; ook daarom kon art. 145 RvOTK (oud) verdwijnen. Kamerstukken II 2006/07, 31 019, nr. 2, p. 3.

134 Zie art. 145 RvOTK (oud). De processen-verbaal van de verhoren dienden te worden ondertekend door de aanwezige commissieleden en de griffier. Zie art. 147 RvOTK (oud).

135 Zie artt. 26, 35 jo. 58-60 RvOTK.

${ }^{136}$ In de (summiere) toelichting op het voorstel tot reglementswijziging werd ten aanzien van het schrappen van de bepaling over de commissievoorzitter (art. 145 RvOTK) ook naar deze bepaling verwezen. Niet helemaal duidelijk is, wat hiermee werd bedoeld, maar het lijkt erop dat de oude bepaling eenvoudigweg als een doublure werd gezien. Zie Kamerstukken II 2006/07, 31 019, nr. 2, p. 3. De toelichting op een latere versie van het voorstel, waarin in het geheel niet meer naar deze bepaling wordt verwezen, lijkt dit vermoeden te bevestigen. Zie Kamerstukken II 2006/07, 31 019, nr. 5, p. 2-3. Ook de Enquêtecommissie Financieel Stelsel stelt in haar eindrapport vraagtekens bij het ontbreken van een nadere, interne procedureregels voor enquêtecommissies in het Reglement van Orde. Kamerstukken II 2011/12, 31 980, nr. 61, p. 577.

137 Aannemelijker is, dat in het belang van vereenvoudiging iets te rigoureus te werk is gegaan.

138 Zo probeerde de voorzitter van de Enquêtecommissie Bouwsubsidies tijdens de hoorzittingen via briefjes de andere commissieleden in te seinen. Er worden overigens wel procedureafspraken gemaakt of protocollen opgesteld rondom de verhoren, mede ter ondersteuning van de voorzitter, maar die hebben vooral betrekking op 'onverwachte' gebeurtenissen als weigerachtige getuigen, een beroep op het staatsbelang of onrust op de publieke tribune. Zie Muller \& Coenen 2002, p. 85-86. Zie over de rol van de voorzitter ook hierboven, par. 3.2.4.
} 
van een onderzoekscommissie wordt gezien. Om die reden is het eveneens verdedigbaar dat de belangrijkste onderzoeksbevoegdheden formeel bij de commissie als geheel zijn gelegd. Het verdelen van de verhoren over de commissieleden en het maken van afspraken over de vraagstelling hoort daarbij, zo laat de praktijk zien. 139 Tijdens een hoorzitting spelen naast het belang van collegiale samenwerking echter ook andere belangen een rol. Gezien de grote politieke en maatschappelijke druk die een hoorzitting met zich mee kan brengen, met name bij enquêtes gecombineerd met ingrijpende bevoegdheden, zou de voorzitter mijns inziens veel nadrukkelijker de verantwoordelijkheid moeten krijgen om een zorgvuldig verloop van de ondervragingen te waarborgen. Zo zou de voorzitter er voor moeten waken, dat de uitoefening van commissiebevoegdheden altijd gericht blijft op de onderzoeksopdracht, dat de rechten van getuigen worden beschermd en dat hetgeen in vertrouwelijkheid tijdens voorgesprekken is medegedeeld niet tijdens een openbaar verhoor door commissieleden wordt prijsgegeven. ${ }^{140}$ Dat vereist een actieve houding van de voorzitter, maar ook adequate procedurele middelen om te kunnen ingrijpen, in het bijzonder wanneer, mede onder druk van de televisiecamera's, de gemoederen tijdens een ondervraging oplopen.

\subsubsection{Karakter, functie}

In de praktijk blijkt de medewerking van derden aan deze openbare gesprekken, zowel bij enquêtes als bij reguliere onderzoeken, slechts bij uitzondering problemen op te leveren. Er blijkt veelal vrijwillig, al dan niet na enig aandringen van commissiezijde, gehoor te worden gegeven aan een uitnodiging tot het verschijnen voor een onderzoekscommissie. ${ }^{141}$ Incidenteel ziet een enquêtecommissie zich genoodzaakt haar wettelijke bevoegdheden in te zetten (of daarmee te moeten dreigen) om medewerking aan een verhoor af te dwingen. ${ }^{142}$ Vooral bij enquêtes - die veelal over politiek of maatschappelijk gevoelige onderwerpen gaan - blijken sommige getuigen huiverig te zijn om in het openbaar en onder ede te worden verhoord, niet in de laatste plaats omdat deze verhoren vaak rechtstreeks op televisie worden uitgezonden. In sommige gevallen besluit een commissie dan om het verhoor in beslotenheid af te

\footnotetext{
${ }^{139} \mathrm{Al}$ neemt de voorzitter ook hierbij vaak de leiding, bijvoorbeeld bij het 'doorvragen' over een bepaald onderwerp, aangezien hij vaak over de meeste inhoudelijke expertise beschikt. De verdeling van de verhoren over de commissieleden heeft binnen verschillende commissies geleid tot conflicten, omdat leden meenden onvoldoende ruimte te krijgen. Bij de Enquête Financieel Stelsel leidde dit zelfs tot het vertrek van een commissielid. Zie ook: Muller \& Coenen 2002, p. 84-85.

140 Kritiek op het verloop van parlementaire onderzoeken is vaak gericht op incidenten in die sfeer. Zie bijvoorbeeld Van Dijk 1999, p. 13, en Rouvoet 1999, p. 23, met betrekking tot de Enquête Vliegramp Bijlmermeer. Zie ook hierboven, par. 2.3.1. Ook bij reguliere parlementaire onderzoeken zou dit kunnen spelen, al zal dit gezien de beperkte bevoegdheden van tijdelijke commissies waarschijnlijk minder snel tot problemen leiden.

${ }^{141}$ Zo verliep bij de Tijdelijke commissie Infrastructuurprojecten de medewerking "in enkele gevallen niet rimpelloos", maar uiteindelijk "zijn alle genodigden ook daadwerkelijk voor de commissie verschenen." Kamerstukken II 2004/05, 29 283, nrs. 5-6, p. 135.

142 De Enquêtecommissie Bouwnijverheid bijvoorbeeld riep vijf getuigen op per dagvaarding - in plaats van de gebruikelijke uitnodiging per aangetekende brief - om te waarborgen dat zij zouden verschijnen. Uiteindelijk zijn alle getuigen verschenen. Zie Kamerstukken II 2002/03, 28 244, nrs. 5-6, p. 38,40 .
} 
nemen of om andere maatregelen te nemen die de privacy van de betreffende persoon moeten beschermen. ${ }^{143}$

Het houden van openbare gesprekken in het kader van een parlementair onderzoek kan meerdere doelen dienen. In het eindrapport van de Enquêtecommissie Srebrenica worden de belangrijkste onderzoeksdoelen treffend opgesomd: het ophelderen van eventuele (nog resterende) onduidelijkheden uit het vooronderzoek, het bevestigen van de eerste bevindingen, waarheidsvinding en het informeren van het publiek omtrent de onderzochte gebeurtenissen. ${ }^{144}$ De openbare gesprekken zijn overigens niet louter gericht op het onderzoek zelf. Muller en Coenen merken op dat de openbare gesprekken tevens de gelegenheid zijn waarbij commissieleden, na een periode van politieke onzichtbaarheid wegens de vaak tijdrovende onderzoekswerkzaamheden, zichzelf politiek kunnen profileren. Daarnaast is dit niet alleen het moment om het publiek te informeren, maar ook om verantwoording af te leggen over de werkzaamheden van de commissie. De commissie kan, meer nog dan bij de rapportage, tijdens de verhoren laten zien hoe zij tot dan toe met het onderzoek is omgegaan. ${ }^{145}$

Aan de voorbereiding van de openbare gesprekken wordt veel aandacht besteed. Allereerst moet naar aanleiding van de resultaten van het vooronderzoek een definitieve lijst met te horen personen worden gemaakt. Het is gebruikelijk geworden dat per getuige of deskundige een dossier wordt samengesteld, waarin alle relevante gegevens met betrekking tot de persoon worden gebundeld. ${ }^{146} \mathrm{Bij}$ de samenstelling van de lijst moet tevens bepaald worden wat de volgorde is waarin de betreffende personen worden gehoord. De volledige lijst wordt vaak vooraf bekendgemaakt, maar soms kiest een onderzoekscommissie ervoor om de lijst gefaseerd openbaar te maken. ${ }^{147} \mathrm{Op}$ die manier kan de commissie tussentijds de wijzigingen aanbrengen die zij nodig acht, waarmee voorkomen wordt dat veranderingen in de lijst met personen of de volgorde van de verhoren vragen oproepen bij de betreffende getuigen of het publiek. In de gekozen volgorde van de gesprekken is volgens Muller en Coenen een patroon zichtbaar. Eerst worden voornamelijk personen opge-

${ }^{143}$ Art. 18a WPE bepaalt dat een openbaar verhoor de regel is, maar dat de commissie om gewichtige reden kan besluiten om een verhoor in beslotenheid af te nemen. Het verslag van een dergelijk verhoor moet vertrouwelijk behandeld worden. De Enquetecommissie Vliegramp Bijlmermeer nam één besloten verhoor af, omdat de betreffende getuige namen van mensen die de verhalen over 'witte pakken' konden bevestigen niet in het openbaar wilde prijsgeven. Kamerstukken II 1998/99, 26 241, nr. 10, p. 23. De Enquêtecommissie Opsporingsmethoden wilde geen besloten verhoren houden, omdat de resultaten daarvan niet in een openbare rapportage konden worden gebruikt en deze verhoren dus weinig meerwaarde zouden hebben. In plaats daarvan werden andere veiligheidsmaatregelen getroffen. Zo verschenen sommige getuigen in vermomming voor de commissie. Zie Inzake Opsporing, p. 20. Zie verder Muller \& Coenen 2002, p. 88-90.

144 Kamerstukken II 2002/03, 28 506, nr. 4, p. 46. Het openbare gesprek kan voorts bruikbare citaten voor het eindrapport opleveren. Zie Tijdelijke commissie Besluitvorming uitzendingen, Kamerstukken II 1999/2000, 26 454, nr. 9, p. 12.

145 Muller \& Coenen 2002, p. 74-75.

146 Vaak is tijdens het voorgesprek reeds een begin gemaakt met dit dossier, waarin onder andere verslagen van interviews en vragenlijsten zijn opgenomen. Zie Muller \& Coenen 2002, p. 81, 84. Onderzoekscommissies noemen dit dossier ook wel gespreksnotitie, verhoorset of documentatiemap.

${ }^{147}$ Muller \& Coenen 2002, p. 82-83. 
roepen die de feiten rondom het onderzoeksonderwerp kunnen verhelderen. Als de feiten eenmaal genoegzaam duidelijk zijn, volgt een serie verhoren die meer duidelijkheid geven over politieke en ambtelijke verantwoordelijkheden die aan de orde kunnen zijn. ${ }^{148}$

De grondige voorbereiding van de openbare gesprekken leidt ertoe dat deze gesprekken doorgaans weinig nieuwe informatie opleveren. ${ }^{149}$ De meeste gesprekken zijn dan ook gericht op het bevestigen van de kennis die reeds tijdens het vooronderzoek is opgedaan of het onderbouwen van het oordeel dat de commissie reeds gevormd heeft. De staf van de onderzoekscommissie stelt gewoonlijk een vragenlijst op, waarbij aangesloten wordt bij de doelstellingen van de hoorzitting. ${ }^{150}$ Het gesprek is vaak niet meer dan een herhaling van een eerder gevoerd voorgesprek. ${ }^{151}$ Hoewel het verhoor daarom wellicht weinig verrassend overkomt, hoeft dit voor het onderzoek als zodanig niet problematisch te zijn. Het echte onderzoekswerk is tegen de tijd dat aan de openbare gesprekken wordt begonnen, immers al grotendeels afgerond.

\subsection{Afronding}

In deze paragraaf staat de afsluitende fase van een parlementair onderzoek centraal. Hieronder wordt allereerst ingegaan op de rapportage. Het eindrapport vormt het verslag van het onderzoek, waarin de parlementaire onderzoekscommissie haar bevindingen presenteert. In paragraaf 4.7.2. wordt vervolgens stil gestaan bij aspecten van openbaarheid en vertrouwelijkheid, die bij de opmaak van de rapportage een belangrijke rol spelen. Daarna wordt kort ingegaan op de politieke afwikkeling (de debatten) die plaatsvinden nadat het eindrapport is gepresenteerd.

\subsubsection{Totstandkoming, inhoud en publicatie eindrapport}

Een parlementair onderzoek wordt afgesloten met een eindrapport. Parlementaire onderzoekscommissies zijn hiertoe verplicht. Wanneer de onderzoekscommissie de vorm van een tijdelijke commissie heeft, bestaat op grond van art. 18, tweede lid onder a, RvOTK een verplichting om te rapporteren omtrent het onderwerp waarvoor

\footnotetext{
${ }^{148}$ Dit "algemene" patroon, dat vooral bij de Enquête Opsporingsmethoden zichtbaar was, kent overigens vele afwijkingen, voegen zij daaraan toe. Muller \& Coenen 2002, p. 83. Het patroon lijkt dan ook vooral toepasbaar op parlementaire enquêtes, die meer dan andere parlementaire onderzoeken, gericht zijn op het kunnen vaststellen van politieke (of ambtelijke) verantwoordelijkheid.

${ }_{149}$ De Enquêtecommissie Opsporingsmethoden stelt in haar eindrapport echter dat zij door de openbare gesprekken wel degelijk veel nieuwe informatie verkreeg. Zie Kamerstukken II 1995/96, 24 072, nr. 12, p. 40. Zie ook Muller \& Coenen 2002, p. 96-97. Een mogelijke reden hiervan zou kunnen zijn dat de commissie in haar vooronderzoek niet kon beschikken over delen van een geheim rapport (het rapport-Wierenga) waaruit deze informatie had kunnen blijken. Het rapport was in handen was van de ministers van Justitie en Binnenlandse Zaken en werd later met succes alsnog door de commissie opgeëist.

150 Zie bijvoorbeeld Tijdelijke commissie Besluitvorming uitzendingen, Kamerstukken II 1999/2000, 26 454, nr. 9, p. 18.

151 Muller \& Coenen 2002, p. 87.
} 
de commissie is ingesteld. ${ }^{152}$ Voor enquêtecommissies geldt dat zij op grond van art. 33 Wpe 2008 verplicht zijn om na afloop van het onderzoek aan de Kamer een openbaar verslag uit te brengen. ${ }^{153}$ Rapporten worden aangeboden aan de Kamervoorzitter, waarna het in handen van de meest betrokken (vaste) commissie wordt gesteld. ${ }^{154}$ Mocht voor een andere commissievorm worden gekozen, zoals een werkgroep uit een vaste commissie, dan bestaat slechts een rapportageverplichting wanneer dat uitdrukkelijk wordt verlangd. In de praktijk worden alle parlementaire onderzoeken afgesloten met een onderzoekrapport.

In het eindrapport doet de onderzoekscommissie verslag van het onderzoek dat zij heeft verricht. De relevante feiten die bij de documentenanalyse en tijdens de mondelinge gesprekken, verhoren of hoorzittingen naar voren zijn gekomen, worden op een geordende wijze samengebracht. De commissie maakt in haar onderzoeksverslag duidelijk hoe zij haar bevindingen beoordeelt, welke waarde zij aan bepaalde gegevens hecht en in welke context de feiten volgens haar moeten worden bezien. ${ }^{155}$ Soms komt een onderzoekscommissie - al dan niet op verzoek van de Kamer - ook met tussentijdse rapportages, waarin een beeld wordt geschetst van het onderzoeksplan, organisatorische aangelegenheden, de voortgang van het onderzoek, etc. ${ }^{156}$

Onderzoeksrapporten zijn in de moderne Nederlandse praktijk zeer omvangrijk. Kon een parlementaire enquêtecommissie in 1855 nog volstaan met een rapport van zes pagina's, 157 vanaf de RSV-enquête is het gebruik geworden om de kamer en het publiek uitgebreider te informeren over het verloop van het onderzoek en de resultaten van de werkzaamheden. Afhankelijk van de aard en de omvang van het onderzochte onderwerp, varieert de omvang van relatief beknopt (honderd à tweehonderd pagina's ${ }^{158}$ ) tot zeer omvangrijk (honderden pagina's ${ }^{159}$ ). Onderzoekscommissies trachten in hun eindrapport een omvattend beeld te scheppen van het onderzoek en de resultaten hiervan. ${ }^{160}$ De initiatiefnemers van de nieuwe enquêtewet waren van mening, dat vaker zou kunnen worden volstaan met een rapportage

152 De bepaling sluit overigens niet uit dat mondeling verslag wordt uitgebracht aan de kamer, al ligt een dergelijke manier van rapporteren niet erg voor de hand.

${ }^{153}$ De oude Wet op de Parlementaire Enquête bevatte geen verplichting voor enquêtecommissies om verslag uit te brengen aan de Kamer. De initiatiefnemers vonden dit echter zo belangrijk, dat vermelding ervan in de wet nodig werd geacht. Zie Kamerstukken II 2005/06, 30 415, nr. 6, p. 58.

${ }_{154}$ Art. 15, eerste en tweede lid, RPE. Zie over het vervolg hierna, par. 4.4.3.

155 Muller \& Coenen 2002, p. 95.

156 Zie bijvoorbeeld de (beknopte) tussenrapporten van de Enquêtecommissie Bouwnijverheid, Kamerstukken II 2001/02, 28 244, nr. 1 en 3.

157 Verslag der Commissie belast met het houden der enquête omtrent de uitvoering van de concessie tot landaanwinning en verdieping van het vaarwater op het Zwolsche Diep, Handelingen II 1856/57, p. 103-108. Het verslag bevat een opsomming van de resultaten van de enquête, waaraan toegevoegd enkele bijlagen met onder andere de verslagen van de dertien verhoren.

158 Zie bijvoorbeeld het eindrapport van de Tijdelijke Commissie Onderzoek TBS, Kamerstukken II 2005/06, 30 250, nrs. 4-5.

159 Een voorbeeld is het eindrapport van de Enquêtecommissie Opsporingsmethoden, dat bijna vijfhonderd pagina's telt. Zie Kamerstukken II 1995/96, 24 073, nr. 11.

160 Zie bijvoorbeeld de Enquêtecommissie Opsporingsmethoden, die stelt: "Het eindrapport wil een omvattend beeld geven van de onderwerpen die de enquêtecommissie heeft onderzocht. De bevindingen, beoordelingen en voorstellen tot normering van de kant van de commissie worden daarin verwerkt." Kamerstukken II 1995/96, 24 072, nr. 12, p. 43. 
op kernpunten. ${ }^{161}$ Aan deze oproep werd direct gehoor gegeven. De Werkgroep Toekomstverkenning jeugdzorg, die voortvloeide uit de Toekomst- en Onderzoeksagenda 2010 van de Tweede Kamer, volstond met een rapport van 13 pagina's. ${ }^{162}$

Nog omvangrijker dan het eindrapport zelf zijn overigens de bijlagen die veelal bij het rapport worden gevoegd. Het is gebruik geworden dat onderzoekscommissies veel van de belangrijkste documenten die een rol hebben gespeeld tijdens het onderzoek als bijlage toevoegen, zodat de kamer en het publiek kunnen beoordelen waarop het verrichte onderzoek is gebaseerd. ${ }^{163}$ Veel voorkomende bijlagen zijn de verslagen van verhoren of hoorzittingen, de belangrijkste correspondentie van de commissie en deelrapporten van eventuele externe onderzoekers die bij het onderzoek betrokken zijn geweest. Ook hier is verschil in omvang te zien, variërend van enkele honderden pagina's ${ }^{164}$ tot zelfs duizenden pagina's. ${ }^{165}$

Cruciaal onderdeel van het eindrapport is de afsluitende paragraaf met de conclusies en aanbevelingen. De conclusies geven in ieder geval een samenvatting van de belangrijkste onderzoeksresultaten en bevindingen. Ze bevatten vaak een beoordeling van het beleid, maar kunnen ook betrekking hebben op het functioneren van bewindspersonen, ambtenaren en andere betrokkenen. ${ }^{166}$ Welk soort conclusies de commissie trekt, hangt van verschillende factoren af. Allereerst is het onderwerp van het onderzoek van invloed. Bij enquêtes, zoals het onderzoek naar het paspoortproject of de RSV-affaire, ligt het meer voor de hand dat de commissie het optreden van ministers of ambtenaren beoordeelt dan bij een parlementair onderzoek naar klimaatverandering of het integratiebeleid van de afgelopen 30 jaar. Ten tweede komt bij dit onderdeel van het eindrapport de politieke dimensie van parlementair onderzoek nadrukkelijk naar voren. Het geven van een oordeel over het door een minister gevoerde beleid, zijn persoonlijke optreden of dat van zijn ambtenaren, kan grote politieke consequenties hebben. Ministers kunnen zich onder druk van de stevige bewoordingen waarmee de commissie zijn functioneren in haar rapport omschrijft, gedwongen voelen om op te stappen. De mate waarin een onderzoekscommissie 'harde' conclusies trekt omtrent het functioneren van bewindspersonen, is vooral

${ }^{161}$ Kamerstukken II 2005/06, 30 415, nr. 6, p. 58.

162 Zie Kamerstukken II 2009/10, 32 296, nr. 8.

163 Zie ook Muller \& Coenen 2002, p. 103-104.

$164 \mathrm{Bij}$ het reeds genoemde TBS-onderzoek werd zo'n vierhonderd pagina's aan bijlagen toegevoegd, bestaande uit een beschrijving van het Nederlandse TBS-stelsel, een rapport van de Raad voor Maatschappelijke Ontwikkeling en de verslagen van de openbare gesprekken. Kamerstukken II 2005/06, 30 250 , nr. 6.

165 Zie bijvoorbeeld de Enquêtecommissie Bouwnijverheid, Kamerstukken II 2002/2003, 28 244, nrs. 7A12. De bijlagen bevatten de verslagen van de verhoren (7A-B) en vijf deelrapporten (8-12). In totaal beslaan de bijlagen zo'n 3.000 pagina's. Een ander voorbeeld is de Enquête Opsporingsmethoden. Kamerstukken II 1995/96, 24 072, nrs. 12-20. Hier is onder andere bijgevoegd een verslag van de procedures en werkwijze van de commissie, de verhoren, een uitvoerige beschrijving van alle soorten opsporingsmethoden die de commissie heeft onderzocht en het eindrapport inclusief deelrapporten van de externe onderzoeksgroep-Fijnaut, die in opdracht van de commissie een aantal casestudies omtrent georganiseerde criminaliteit heeft uitgevoerd.

166 Muller \& Coenen 2002, p. 98. 
afhankelijk van de politieke overeenstemming die hierover binnen de commissie kon worden bereikt. 167

Naast conclusies bevatten de rapporten van parlementaire onderzoekscommissies doorgaans ook aanbevelingen. ${ }^{168}$ Deze aanbevelingen zijn meestal gericht aan ministeries of 'de overheid', maar ook wel aan de Tweede Kamer, de rechterlijke macht of de samenleving. ${ }^{169}$ Soms wordt een compleet wetsvoorstel of een nieuwe organisatiestructuur uitgewerkt, zoals het geval was bij de Enquête Opsporingsmethoden. Naast 'harde' maatregelen, zoals veranderingen op het gebied van regelgeving of organisatie, worden doorgaans ook minder concrete aanbevelingen gedaan, bijvoorbeeld op het gebied van gedragsverandering of het vergroten van het leervermogen. ${ }^{170}$ De gekozen formulering is mede afhankelijk van de reactie die de commissie van de regering verwacht: meent men dat de regering meer specifieke aanwijzingen nodig heeft, dan worden de aanbevelingen concreter dan wanneer dat niet nodig wordt geacht. 171

Gezien de mogelijke politieke consequenties voor bewindspersonen of coalitieverhoudingen is het niet verwonderlijk dat binnen de commissie grote meningsverschillen kunnen ontstaan wanneer de conclusies en aanbevelingen moeten worden geformuleerd. Het gebruik van kwalificaties als 'onverantwoord' of 'onaanvaardbaar' kan ertoe leiden dat de positie van de betreffende bewindspersoon politiek niet langer houdbaar is. Na een periode van doorgaans vrij harmonieuze samenwerking tussen de commissieleden, kunnen in deze fase scherpe tegenstellingen ontstaan. Allerlei politieke processen kunnen op gang komen: overleg met de eigen fractie, het in bescherming nemen van de eigen bewindspersonen, het lekken van conclusies om de publieke opinie te beïnvloeden, verdeeldheid binnen de commissie en het uitbrengen van een minderheidsstandpunt. ${ }^{172}$ Soms is het bereiken van overeenstemming over de te kiezen formulering zo moeilijk gebleken, dat conclusies uiteindelijk in zeer onduidelijke bewoordingen in het eindrapport terecht komen. Het gevolg van dergelijk "diffuus taalgebruik", zoals Muller en Coenen het noemen, is dat niet altijd duidelijk wordt wat de commissie bedoelt. ${ }^{173}$ Dit zorgt niet alleen voor verwarring in de kamer en in de media, maar het kan tevens consequenties hebben voor de overtuigingskracht van het rapport.

\footnotetext{
167 Zie ook Muller \& Coenen 2002, p. 98-99.

168 Slechts vier onderzoeksrapporten uit de periode 1945-2007 bevatten geen aanbevelingen, zo blijkt uit onderzoek van de Algemene Rekenkamer. Zie Leren van parlementair onderzoek 2007, p. 34.

169 Leren van parlementair onderzoek 2007, p. 34.

170 Leren van parlementair onderzoek 2007, p. 10, 35.

171 Muller \& Coenen 2002, p. 99, 141-144.

172 Muller \& Coenen 2002, p. 98-99. Een voorbeeld van een minderheidsstandpunt is te vinden in het eindrapport van de RSV-enquêtecommissie, waar VVD-commissielid Korthals zich uiteindelijk niet kon vinden in de kwalificatie van het functioneren van VVD-minister Van Aardenne. Kamerstukken II 1984/85, 17 817, nr. 16, p. 469. Zie ook Muller \& Coenen 2002, p. 100. Minderheidsstandpunten zijn in Nederland overigens uitzonderlijk.

173 Muller \& Coenen 2002, p. 101.
} 


\subsubsection{Openbaarheid, vertrouwelijkheid en archivering}

\subsubsection{Openbaarheid als uitgangspunt}

Het parlement vergadert en besluit in beginsel in het openbaar. De Grondwet gaat er van uit dat parlementaire vergaderingen in openbaarheid plaatsvinden. Alleen bij wijze van uitzondering wordt vergaderd achter gesloten deuren. ${ }^{174}$ Ook commissievergaderingen zijn in beginsel openbaar, zo blijkt uit het Reglement van Orde van de Tweede Kamer, tenzij de Kamer of de commissie anders besluit. ${ }^{175}$ Commissieleden dienen in dit laatste geval geheimhouding te bewaren omtrent de gedachtewisseling tijdens een besloten vergadering en ten aanzien van in vertrouwelijkheid verstrekte stukken. ${ }^{176}$

Ook bij parlementair onderzoek speelt openbaarheid een belangrijke rol.177 Dit ligt voor de hand: het creëren van openheid van zaken omtrent het onderzochte onderwerp is immers vaak een van de expliciete of impliciete doelen van het parlementaire onderzoek. ${ }^{178}$ Het onderzoeksproces speelt zich echter voor een belangrijk deel achter gesloten deuren af. Commissieleden en hun stafmedewerkers zijn in die periode bezig met literatuuronderzoek en houden besloten interviews en voorgesprekken met getuigen, deskundigen of anderen. ${ }^{179}$ Deze fase is van groot belang: al eerder is vastgesteld dat het gedeelte van het onderzoek dat achter de schermen plaatsvindt, dat wil zeggen de documentenstudie en de besloten interviews en voorgesprekken, voor een groot deel de koers en uitkomst van het onderzoek bepalen.

De beslotenheid maakt plaats voor openheid op het moment dat de openbare hoorzittingen aanvangen. Hierbij geldt het wettelijke uitgangspunt, dat verhoren in het openbaar plaatsvinden; slechts om 'gewichtige redenen' kan de commissie besluiten om geen beeld- of geluidsregistratie toe te laten of om te kiezen voor een besloten verhoor. ${ }^{180}$

Uiteindelijk wordt ook het eerdere deel van het onderzoek inzichtelijk bij de publicatie van het eindrapport, eventueel voorafgegaan door een of meer tussenrapportages. Hierin doet de commissie verslag van haar werkwijze en legt zij aan de Kamer verantwoording af over de gekozen richting en de gemaakte afwegingen en beslissingen. Bovendien bevat het rapport de gegevens en documentatie op basis waarvan de commissie haar onderzoek heeft gedaan. Hierdoor wordt het onderzoek voor zowel collega-Kamerleden als het bredere publiek controleerbaar. In feite zorgt

\footnotetext{
174 Art. 66 Gw.

175 Art. 37, tweede en derde lid, RvOTK.

176 Art. 38, eerste lid, RvOTK. Op schending van de vertrouwelijkheid staan sancties. De kamer kan besluiten een commissielid voor ten hoogste een maand uit te sluiten van deelname aan commissievergaderingen of van toezending van vertrouwelijke stukken.

177 Zo benadrukken ook de initiatiefnemers van de nieuwe enquêtewet. Zie Kamerstukken II 2005/06, 30415 , nr. 6, p. 58.

178 Zo moest de Enquête Vliegramp Bijlmermeer onder meer inzicht geven in "het optreden en de rol van de diverse instanties en overheidsinstellingen na de ramp en bij de verdere afwikkeling ervan" (Kamerstukken II 1998/99, 26 241, nr. 10, p. 4) en kreeg de Enquêtecommissie Bouwnijverheid de opdracht om "de rol van de overheid in haar hoedanigheid van toezichthouder, vergunningverlener en wet- en regelgever" te onderzoeken (Kamerstukken II 2001/02, 28 244, nr. 1, p. 3).

179 Zie hierboven, par. 4.4 .

180 Art. 11, eerste en tweede lid, en art. 12, eerste lid, Wpe 2008. Zie ook hierboven, par. 2.3.2.2.
} 
deze openbaarheid 'achteraf' dus voor een hoge mate van transparantie. Onderzoekscommissies zijn zich bewust van dit belang, getuige de grote omvang van de bijlagen bij de rapportages. Het publiceren van onderzoeksmateriaal draagt bovendien bij aan de kracht van de conclusies en aanbevelingen in het rapport. ${ }^{181}$

\subsubsection{Inzage en archivering}

Enquêtes. Bij de modernisering van de enquêtewet is uitgebreid aandacht besteed aan de openbaarheid en vertrouwelijkheid van documenten die door de enquêtecommissie zijn verzameld. De indieners hebben daarbij getracht de ontstane praktijk vast te leggen in de wet.

De dag na de publicatie van het eindrapport krijgen alle overige Kamerleden op grond van art. 38 het recht om de documenten die op vordering aan de commissie zijn overlegd, in te zien. De commissie kan wel besluiten dat bepaalde documenten vertrouwelijk behandeld dienen te worden door de Kamerleden. ${ }^{182}$ Kamerleden kunnen de dag na de presentatie van het rapport ook de vertrouwelijke verslagen van besloten verhoren inzien, zo bepaalt de wet. Zij dienen wel altijd geheimhouding te bewaren omtrent de inhoud ervan. ${ }^{183}$ Over verslagen van voorgesprekken regelt art. 38 niets, waaruit moet worden afgeleid dat deze niet voor Kamerleden ter inzage komen. ${ }^{184}$

De nieuwe wet schrijft dus voor dat alle op vordering overlegde documenten na afloop van het onderzoek ter inzage aan de overige Kamerleden moeten worden gelegd. Het werk van de enquêtecommissie, zo oordeelden de initiatiefnemers, moest "uit de aard der zaak gecontroleerd kunnen worden door de gehele Kamer." 185 Onder de oude wet was dit niet geheel duidelijk. Er leek daarom wel enige ruimte te bestaan om bepaalde overlegde stukken niet ter inzage te geven, zo stelt Drexhage. Zij voorspelt dat deze strakke regeling ertoe zal leiden dat informatiebezitters in de toekomst wellicht minder geneigd zullen zijn om vertrouwelijke stukken aan de commissie te overleggen, maar alleen inzage zullen geven of slechts zullen toelichten in een voorgesprek. Een afspraak, zoals bijvoorbeeld bij de Enquête Srebrenica, dat bepaalde stukken na afloop van de enquête zullen worden geretourneerd en dus niet in het archief zullen worden opgenomen, is volgens Drexhage onder de huidige wet niet meer mogelijk. ${ }^{186}$ Wanneer de wettekst echter strikt wordt opgevat, lijkt er mijns inziens toch wel ruimte te zijn. Art. 38 heeft immers uitsluitend betrekking op documenten die 'op vordering' van de commissie zijn 'overlegd'. Als bijvoorbeeld in een voorgesprek met de betreffende informant zou worden afgesproken dat bepaalde stukken op vrijwillige basis worden verstrekt, dan ontstaat geen inzagerecht voor

\footnotetext{
181 Zie over de wijze waarop commissies hiermee omgaan nader Muller \& Coenen 2002, p. 96-98.

182 Zie art. 38, tweede lid, jo. art. 40 Wpe 2008.

183 Zie art. 38, derde lid, Wpe 2008. Van de inzagemogelijkheid voor Kamerleden wordt in de praktijk nauwelijks gebruik gemaakt. Muller \& Coenen 2002, p. 98.

184 Zie ook Kamerstukken II 2005/06, 30 415, nr. 6, p. 88, en Drexhage 2009, p. 18.

185 Kamerstukken II 2005/06, 30 415, nr. 6, p. 59.

186 Ook het kabinet wees hierop tijdens de behandeling van het wetsvoorstel. De initiatiefnemers aanvaardden dit risico. Zie Handelingen II 2005/06, nr. 13, p. 869, 875. Zie ook Drexhage 2009, p. 18.
} 
andere Kamerleden en kan alsnog tot retournering of vernietiging worden overgegaan. ${ }^{187}$

Derden kunnen de dag na presentatie van het rapport op grond van art. 39 inzage krijgen in de stukken die onder de commissie berusten, tenzij de commissie beperkingen heeft gesteld aan de openbaarheid. 188 Art. 40 Wpe 2008 bevat de regeling inzake het stellen van beperkingen aan inzage. In een bepaald aantal gevallen is de commissie verplicht om beperkingen te stellen aan openbaarmaking, namelijk wanneer zulks de eenheid van de Kroon of de veiligheid van de staat in gevaar zou kunnen brengen, het vertrouwelijke bedrijfsgegevens betreft die in vertrouwen aan de overheid zijn verstrekt, het privacygevoelige persoonsinformatie betreft of wanneer het gaat om het verslag van een voorgesprek of besloten verhoor. In andere gevallen kan de commissie beperkingen stellen. Het gaat daarbij om gevallen waarin het belang van openbaarmaking niet opweegt tegen een aantal andere belangen, te weten internationale betrekkingen; economische belangen van de staat; opsporing en vervolging van strafbare feiten; inspectie, controle en toezicht door bestuursorganen; de eerbiediging van de persoonlijke levenssfeer; en het voorkomen van onevenredige bevoordeling van personen of bedrijven. Voorts bepaalt art. 40 dat ook documenten die zijn opgesteld ten behoeve van intern beraad van de commissie, vertrouwelijk kunnen blijven.

De gronden waarop de commissie kan besluiten om bepaalde documenten niet openbaar te maken, zijn ten opzichte van de oude wet verruimd. Voorheen bepaalde de wet slechts dat schriftelijke bescheiden "om gewichtige redenen" als vertrouwelijk konden worden aangemerkt ter bescherming van personen die tot medewerking verplicht waren, dan wel in verband met de bescherming van bedrijfsgeheimen. ${ }^{189}$ De indieners achtten dat te beperkt. In de nieuwe wet is aangesloten bij de maatstaven die ook in de Wet openbaarheid van bestuur (Wob) worden gehanteerd ten aanzien van de openbaarmaking van documenten door overheidsorganen. Hiermee is tevens beoogd te voorkomen dat documenten van ministeries en andere overheids-

187 Zie ook Kamerstukken II 2005/06, 30 415, nr. 4, p. 14-15, waarin de initiatiefnemers ook dit onderscheid tussen gevorderde en vrijwillig verstrekte informatie maken. De vraag is echter, evenals bij vertrouwelijke stukken die wel onderdeel uitmaken van het enquêtearchief, welke waarde de inlichtingen die op deze wijze zijn verkregen zullen hebben voor het onderzoek indien de commissie er tijdens hoorzittingen of in haar rapport niet naar kan verwijzen. Omdat het dan om vrijwillige verstrekking gaat, kan de verstrekker immers nadere eisen stellen ten aanzien van de mate van geheimhouding gedurende het onderzoek en in de rapportage.

188 Zie art. 39, eerste lid, Wpe 2008. Het betreft in elk geval de stukken die op vordering van de commissie zijn overlegd, aangezien die ingevolge art. 38 per definitie onderdeel uitmaken van het enquêtearchief, maar ook eventuele andere stukken die nog onder de commissie dan wel de Kamer berusten, kunnen nu door een ieder ingezien worden tenzij er beperkingen zijn gesteld. Tijdens het onderzoek vrijwillig verstrekte documenten kunnen overigens later alsnog worden bestempeld als noodzakelijk voor het onderzoek en als zodanig worden opgenomen in het archief, zo stelden de initiatiefnemers in reactie op vragen hieromtrent van de Raad van State. Zie Kamerstukken II 2005/06, 30415 , nr. 4, p. 15.

189 Zie art. 18b WPE (oud). Dit betekende dat Kamerleden alleen vertrouwelijke inzage konden krijgen, terwijl derden in het geheel geen inzage zouden hebben. 
organen die op grond van art. 10 Wob niet openbaar kunnen worden gemaakt, wel via een enquêtecommissie ter inzage van derden zouden kunnen komen. 190

$\mathrm{Na}$ afloop van het onderzoek, dat wil zeggen nadat de Kamer heeft besloten de enquête te beëindigen, gaat het archief van de commissie van rechtswege over op de Kamer. ${ }^{191}$ De Kamer is in beginsel gebonden aan het oordeel van de commissie omtrent de vertrouwelijkheid van bepaalde documenten, ook nadat de commissie is opgehouden te bestaan, al heeft zij op grond van art. 39, tweede lid, wel de bevoegdheid om ten aanzien van een specifiek document of ten behoeve van een individuele verzoeker met een bijzonder belang de vertrouwelijkheid op te heffen of buiten toepassing te laten. ${ }^{192}$ Het betreft een nieuwe bepaling. De initiatiefnemers gaan ervan uit, dat de Kamer deze bevoegdheid uiterst terughoudend zal toepassen en zich in het algemeen zal richten naar de gronden die in art. 40 zijn genoemd. Bovendien, zo merken de indieners op, zou het "onwenselijk zijn als afspraken die de enquêtecommissie met bijvoorbeeld het kabinet heeft gemaakt over vertrouwelijkheid van documenten, door de Kamer wordt geschonden." 193 Niettemin bleek bij het eerste onderzoek onder de nieuwe wet, de Enquête Financieel Stelsel, dat alleen al het bestaan van "de mogelijkheid voor de Kamer om door de commissie gestelde beperkingen aan de openbaarheid van documenten op te heffen, een belangrijk argument vormde voor de autoriteiten om de commissie slechts inzage te verlenen in toezichtvertrouwelijke informatie, in plaats van deze aan de commissie te verstrekken." 194 Het is daarom de vraag of de wetgever er verstandig aan heeft gedaan om met deze bepaling, die kennelijk de nodige argwaan wekt, de deur als het ware op een kier te zetten. De Enquêtecommissie Financieel Stelsel maakte zich in het bijzonder zorgen over de mogelijkheid dat de Kamer verslagen van besloten voorgesprekken zou openbaarmaken. Strict genomen laat de wet dit toe, maar de commissie betwijfelde of de wetgever dit ook zo bedoeld had. ${ }^{195}$ Gezien de functie van het voorgesprek lijkt een verduidelijking in de wet op dit punt inderdaad aangewezen. Zowel de commissie als de Kamer zijn immers gebaat bij een zo groot mogelijke openheid aan de kant van hun gesprekspartners en het voorgesprek, zo volgt ook uit art. 8, is juist bedoeld om die openheid te bevorderen. De kans, hoe klein ook, dat de beslotenheid van dat gesprek op een later moment wordt doorbroken, kan het vertrouwen ernstig beschadigen.

De nieuwe wet bepaalt overigens uitdrukkelijk, dat de enquêtecommissie gedurende haar werkzaamheden niemand inzage hoeft te verlenen in de documenten die

\footnotetext{
190 Zie verder Kamerstukken II 2005/06, 30 415, nr. 6, p. 60-61. Na twintig jaar wordt het materiaal overgebracht naar het Nationaal Archief. De Kamer dient op dat moment te beslissen of de gestelde beperkingen aan de openbaarheid van bepaalde documenten moet worden gehandhaafd of dat het materiaal openbaar wordt. De Archiefwet 1995 is tevens van toepassing op de Eerste en Tweede Kamer. Zie hierover uitvoerig: Kamerstukken II 2005/06, 30 415, nr. 6, p. 62-64.

191 Zie art. 35 Wpe 2008.

192 Zie art. 39, tweede lid, Wpe 2008.

193 Kamerstukken II 2005/06, 30 415, nr. 6, p. 62.

194 Kamerstukken II 2011/12, 31980 , nr. 61, p. 576.

195 Kamerstukken II 2011/12, 31 980, nr. 61, p. 576.
} 
onder de commissie berusten. ${ }^{196}$ De initiatiefnemers achten het van belang dat leden van een enquêtecommissie "hun werk ongestoord en in stilte moeten kunnen verrichten." Bovendien bestaat het gevaar dat de voorpublicatie van een document los van zijn context "een geheel eigen leven" gaat leiden. ${ }^{197}$ Ook heeft niemand recht op voorinzage van het eindrapport, hoewel het in de praktijk voorkomt "dat bewindspersonen vooraf inzage krijgen in passages van het concepteindrapport", zo erkennen de indieners. Een wettelijk recht op voorinzage voor bewindspersonen of andere personen die hebben meegewerkt aan het onderzoeken achtten zij echter onwenselijk. ${ }^{198}$ Het bestaande 'Protocol van afspraken over onderzoeken Tweede Kamer' uit 2002 verleent bewindspersonen echter in alle gevallen een recht op voorinzage. Art. E.1 bepaalt dat betrokken ministers en staatssecretarissen de gelegenheid krijgen om het concepteindrapport in te zien, teneinde het te kunnen beoordelen op feitelijke onjuistheden, aspecten van vertrouwelijkheid en het belang van de staat. ${ }^{199}$ Dit is op zichzelf niet onredelijk, maar zoals reeds eerder betoogd, lijkt mij deze standaardafspraak niet in lijn met het in de wet geformuleerde uitgangspunt dat de enquêtecommissie uiteindelijk zelf moet kunnen bepalen in hoeverre en om welke redenen zij voorinzage aan bewindspersonen wil verlenen.

Reguliere onderzoeken. Sinds 2008 is ook voor het reguliere parlementaire onderzoek een inzageregeling getroffen ten aanzien van het verzamelde onderzoeksmateriaal. Deze lijkt sterk op die bij enquêtes, zij het in vereenvoudigde vorm. Tijdelijke commissies hoeven tot de publicatie van het eindrapport geen inzage te verlenen in de onder de commissie berustende documenten. ${ }^{200} \mathrm{Na}$ aanbieding van het rapport gaan alle documenten van rechtswege over op de Kamer. ${ }^{201}$ Alles wordt vervolgens in beginsel openbaar, dat wil zeggen, een ieder kan om inzage verzoeken. ${ }^{202}$ De commissie kan echter aangeven welke documenten vertrouwelijk moeten blijven. Derden krijgen geen inzage in vertrouwelijke documenten. ${ }^{203}$

Aanvullende afspraken. In de informatieprotocollen, die gewoonlijk tussen regering en onderzoekscommissie worden afgesloten, worden meestal ook specifieke afspraken gemaakt over de wijze waarop de commissie in haar eindrapport omgaat met vertrouwelijke informatie. Veelal krijgen bewindspersonen het recht om het conceptrapport voor publicatie in te zien en te controleren op feitelijke onjuistheden of eventuele schending van afspraken omtrent vertrouwelijkheid. Zo kreeg de minister van Justitie bij de Enquête Bouwnijverheid een "adviesrecht met betrekking tot correctie van feiten". Verder werd in het informatieprotocol vastgelegd dat informatie

196 Zie art. 37 Wpe 2008. Zie nader: Kamerstukken II 2005/06, 30 415, nr. 6, p. 59. Onder de oude wet (art. 18b WPE) bestond hierover nog enige onduidelijkheid. Overigens heeft de commissie wel de mogelijkheid om tussentijds inzage te verlenen. Zie art. 37, tweede lid, Wpe 2008. Hierover nader: Kamerstukken II 2005/06, 30 415, nr. 6, p. 60.

197 Zie Kamerstukken II 2005/06, 30 415, nr. 6, p. 58-59.

198 Kamerstukken II 2005/06, 30 415, nr. 6, p. 58. Zie ook Kamerstukken II 2005/06, 30 415, C, p. 28.

199 Stcrt. 2002/37, p. 10.

200 Art. 18, eerste lid, RPE.

201 Art. 17, eerste lid, RPE.

202 Kamerstukken II 2007/08, 31 019, nr. 6, p. 11.

${ }^{203}$ Art. 18, tweede lid, RPE. Op schending van de vertrouwelijkheid door (voormalige) commissieleden of andere Kamerleden kunnen sancties worden gesteld. Zie artt. 147 jo. 145 RvOTK. Zie ook Kamerstukken II 2007/08, 31 019, nr. 8, p. 5. 
die de minister als vertrouwelijk had bestempeld, vertrouwelijk diende te blijven. "In het eindrapport inclusief de daarbij behorende bijlagen van de parlementaire enquêtecommissie wordt rekening gehouden met deze vertrouwelijkheid," zo werd daar aan toegevoegd. ${ }^{204}$ Ook gedurende het onderzoek kan op grond van nieuwe inzichten en ontwikkelingen worden onderhandeld over inzage in en openbaarheid van bepaalde documenten. Verder kan het zo zijn dat een minister slechts kan worden overtuigd om de commissie inzage te verlenen, wanneer wordt afgesproken dat de betreffende informatie niet via het eindrapport in de openbaarheid zal komen. ${ }^{205}$

Bij de Enquête Financieel Stelsel speelde het risico van openbaarmaking van gevoelige toezichtsinformatie een belangrijke rol bij het maken van afspraken. De commissie verzocht de minister van Financiën, DNB en AFM om kennisname van geheime toezichtsinformatie, die mede ten grondslag lag aan de omvangrijke steunmaatregelen die de overheid trof ten tijde van de bankencrisis eind 2008. Het betrof gegevens waarop strikte, op Europese richtlijnen gebaseerde wettelijke geheimhoudingsregels ${ }^{206}$ van toepassing waren. De minister verzocht de Afdeling advisering van de Raad van State om voorlichting. Hierin stelde de Raad dat een balans moest worden gevonden tussen het belang van effectieve parlementaire controle enerzijds en het belang van Europese geheimhoudingsplichten ten aanzien van financiële instellingen anderzijds. De wet, zo werd geconcludeerd, biedt de ruimte om de commissie onder strikte geheimhouding inzage te geven in de gevraagde toezichtsdocumenten. Dit zou volgende de Raad echter alleen kunnen wanneer deze documenten niet zouden worden "verveelvoudigd of anderszins herleidbaar in documenten" zouden worden opgeslagen, omdat anders het risico van openbaarmaking na afloop van de enquête zou ontstaan op grond van art. 39. Bovendien zou moeten worden afgesproken dat de commissie de verkregen informatie alleen "in zodanige vorm gebruikt dat deze niet herleidbaar is tot specifieke instellingen of personen". Het voorstel van de minister, waarin commissieleden in een afgesloten ruimte op het ministerie onder strikte geheimhouding inzage konden krijgen, werd door de Raad gezien als een "goede aanzet" voor nadere afspraken, maar merkte tevens op dat een dergelijke werkwijze op gespannen voet zou staan met de onderzoeksopdracht van de commissie "waarin informatie over individuele financiële ondernemingen een belangrijke plaats inneemt." 207

Naar aanleiding van deze voorlichting besloten kabinet, DNB en AFM om enkel vertrouwelijke inzage te geven in toezichtsvertrouwelijke documenten, waarvoor

\footnotetext{
204 Zie de 'Werkafspraken tussen de parlementaire enquêtecommissie bouwnijverheid en de staatssecretaris van VROM', Kamerstukken II 2001/02, 28 244, nr. 3, p. 6-8. Soortgelijke afspraken werden gemaakt met de ministers van Justitie en Economische Zaken ten aanzien van lopende of afgehandelde strafzaken en NMa-zaken.

205 Dit speelde bijvoorbeeld tijdens de Enquête Opsporingsmethoden, waar uiteindelijk na intensief overleg tussen de betrokken ministers en de enquêtecommissie werd afgesproken dat de commissie de gewenste inzage in het geheime rapport-Wieringa zou krijgen, maar hieruit niet zou mogen citeren dan na overleg met de ministers van Justitie en Binnenlandse Zaken. Kamerstukken II 1995/96, 24 072, nr. 12, p. 40-41. De toestemming werd later overigens probleemloos verstrekt. Zie ook Muller \& Coenen 2002, p. 96-97.

206 Art. 1:89 e.v. Wet financieel toezicht.

207 Stcrt. 2011, nr. 5695, p. 7-8.
} 
speciale 'datarooms' werden ingericht, die alleen toegankelijk waren voor commissieleden en staf. Hoewel de commissie van oordeel bleef dat de betreffende informatie wel degelijk had kunnen worden verstrekt, en dus niet louter ter inzage behoefde te worden gegeven, stemde zij hiermee in om verdere vertraging van het onderzoek te voorkomen. ${ }^{208}$ De afspraken werden vastgelegd in verschillende informatieprotocollen. ${ }^{209}$ Het gevolg van deze afspraken is, dat de commissie een belangrijk deel van de onderzoeksgegevens slechts heeft kunnen inzien. Van de gegevens die wel zijn verstrekt, kon het meeste niet openbaargemaakt worden. De commissie concludeert in haar eindrapport dat "het feit dat slechts een klein deel van de door de commissie in haar onderzoek gebruikte informatie in de openbaarheid kan komen te weinig recht doet aan het gewicht van het instrument van de parlementaire enquête, waarbij openbare informatieverschaffing en verantwoording essentieel zijn." 210

\subsubsection{Behandeling eindrapport, implementatie en evaluatie}

Zowel bij enquêtes als bij reguliere parlementaire onderzoeken wordt van onderzoekscommissies verwacht dat zij na presentatie van het eindrapport verantwoording afleggen aan de Kamer over hun werkzaamheden. Daarna wordt het onderzoek formeel beëindigd en wordt de enquêtecommissie respectievelijk de tijdelijke commissie opgeheven. ${ }^{211}$ In de nieuwe enquêtewet is er uitdrukkelijk voor gekozen om de beëindiging van de enquête niet per definitie te laten samenvallen met de aanbieding van het rapport. Op die manier kan de commissie haar bevoegdheden nadien nog gebruiken om aanvullend onderzoek te doen, mocht de Kamer daar behoefte aan hebben. ${ }^{212}$

$\mathrm{Na}$ aanbieding aan de Kamervoorzitter wordt het rapport in handen gesteld van de meest betrokken (vaste) commissie(s), die zal beslissen hoe het rapport verder zal worden behandeld. 213 Veelal krijgen Kamerleden na aanbieding van het rapport de gelegenheid om schriftelijke vragen te stellen aan de commissie of aan de regering.

\footnotetext{
208 Kamerstukken II 2011/12, 31 980, nr. 61, p. 567.

209 De protocollen en nadere afspraken omtrent de vertrouwelijke inzage van toezichtsgevoelige informatie zijn als bijlage opgenomen in het eindrapport. In de nadere afspraken met het kabinet is geregeld dat de commissieleden en hun staf in een speciaal daartoe ingerichte besloten ruimte op het ministerie van Financiën onder stricte geheimhouding kunnen kennisnemen van weggelakte, toezichtsvertrouwelijke passages in door het kabinet verstrekte documenten. De betreffende informatie kon alleen voor de oordeelsvorming worden gebruikt en mocht niet herleidbaar tot een specifieke instelling of persoon in het eindrapport worden verwerkt. Verveelvoudiging van documenten en het gebruik van mobiele telefoons in de ruimte was niet toegestaan, persoonlijke aantekeningen dienden na afloop van het onderzoek te worden vernietigd. Toegangpassen dienden na het verlaten van de ruimte steeds te worden ingeleverd. Vergelijkbare afspraken werden gemaakt met de AFM en DNB, die een gezamenlijke dataroom hadden ingericht in het gebouw van de Nederlandse Mededingingsautoriteit. Zie Kamerstukken II 2011/12, 31 980, nr. 61, p. 688 e.v.

${ }^{210}$ Kamerstukken II 2011/12, 31 980, nr. 61, p. 573.

211 Art. 34, eerste lid, Wpe 2008 en art. 16 RPE.

212 Dit volgt uit art. 4, eerste lid, Wpe 2008. Zie ook Kamerstukken II 2005/06, 30 415, nr. 6, p. 56-57. Van de beëindiging van een enquête wordt mededeling gedaan in de Staatscourant. Zie art. 34, derde lid, Wpe 2008.

${ }^{213}$ Art. 15, tweede lid, RPE. Vgl. ook art. 7.2 jo. 7.3 Draaiboek 2001.
} 
Ook de betrokken commissie als geheel kan vragen stellen. ${ }^{214}$ De onderzoekscommissie krijgt vervolgens enkele dagen of weken de tijd om de vragen te beantwoorden. Daarna vindt een debat plaats tussen de Kamer en de onderzoekscommissie. Aan het einde van het debat wordt doorgaans een motie aangenomen, waarin de Kamer aangeeft voldoende grondslag te zien voor een debat met de regering. ${ }^{215}$ Het debat met de regering wordt vervolgens gevoerd door de fractiewoordvoerders; de (voormalige) commissieleden keren terug in hun fractie. ${ }^{216}$ In het debat met de regering komen de inhoudelijke aspecten van het onderzoeksrapport naar voren, maar kunnen ook de politieke consequenties van het rapport een belangrijke rol spelen. Vaak eindigt het debat met een aantal moties ten aanzien van de bevindingen en beslispunten die de commissie heeft geformuleerd. Hieruit kan dan worden afgeleid in hoeverre de Kamer de inhoud van het rapport van de commissie onderschrijft. De regering komt vervolgens vaak met een plan van aanpak. ${ }^{217}$

$\mathrm{Na}$ het debat met de regering is de behandeling van het parlementaire onderzoek feitelijk ten einde. Vervolgens komt het aan op de uitvoering van de aanbevelingen en de toezeggingen hieromtrent van de zijde van de regering. Doorgaans houdt de regering de kamer door middel van voortgangsrapportages op de hoogte. Verbeterpunten worden door de regering en de betrokken departementen of andere overheidsinstanties in behandeling genomen, bijvoorbeeld door het instellen van een ambtelijke werkgroep. ${ }^{218}$ Parlementaire onderzoeken leiden uiteindelijk zelden direct tot het vertrek van bewindspersonen. ${ }^{219}$

Opvallend is, dat een structurele monitoring van de opvolging van de aanbevelingen uit de onderzoeksrapporten door de Kamer zelf vaak ontbreekt. Veelal blijft het parlement op afstand ${ }^{220}$ en laat het zich vooral door de regering informeren over de voortgang. Voornaamste uitzondering hierop is de evaluatie die naar aanleiding van de Enquête Opsporingsmethoden heeft plaatsgevonden door de Tijdelijke Commissie Uitvoering aanbevelingen enquêtecommissie opsporingsmethoden (commissie-Kalsbeek). 221 Het onderzoek van deze commissie was erop gericht te achterhalen in hoeverre de definitieve lijst van beslispunten die door de Tweede Kamer en de regering naar aanleiding van het enquêteonderzoek was opgesteld, "had bijgedragen aan de bestrijding van de crisis in de opsporing". 222 In de literatuur wordt er wel voor gepleit om vaker op dergelijke wijze na te gaan wat de effecten

214 Zie bijvoorbeeld Kamerstukken II 2011/12, 32 680, nr. 10.

215 Zie wederom bijvoorbeeld Kamerstukken II 2011/12, 32 680, nr. 13. Zie verder Muller \& Coenen 2002, p. 106-107.

${ }^{216}$ Muller pleit ervoor om ook tussen de commissie en de regering een rechtstreeks debat te houden. Pas daarna zou de Kamer een eigen oordeel moeten vellen. Zie de bijdrage van Muller in De WPE onder de loep 2004, p. 74.

${ }^{217}$ Muller \& Coenen 2002, p. 108-109.

${ }^{218}$ Zo stelden de ministeries van Buitenlandse Zaken en Defensie naar aanleiding van het rapport van de Tijdelijke commissie Besluitvorming uitzendingen een gezamenlijke werkgroep in die moest nagaan welke aanbevelingen nadere implementatie behoefden. Zie Kamerstukken II 2007/08, 31 235, nrs. $1-2$, p. 50 .

${ }^{219}$ Muller \& Coenen 2002, p. 109.

${ }^{220}$ Muller \& Coenen 2002, p. 109-110.

${ }^{221}$ Het eindrapport is te vinden in Kamerstukken II 1998/99, 26 269, nr. 5.

${ }^{222}$ Kamerstukken II 1998/99, 26 269, nr. 5, p. 8. 
van parlementair onderzoek zijn. ${ }^{223}$ Uit een analyse van de Algemene Rekenkamer blijkt, dat een nauwgezette evaluatie van groot belang is voor de mate waarin departementen en andere overheidsdiensten daadwerkelijk en structureel lering trekken uit parlementaire onderzoeken. ${ }^{224} \mathrm{Bij}$ de invoering van de RPE werd dan ook door het Presidium aanbevolen om bij de implementatie een aantal momenten aan te wijzen waarop wordt geëvalueerd of de voorgenomen verbeteringen zijn ingezet. Deze evaluatie zou in elk geval één à anderhalf jaar na verschijning van het rapport moeten plaatsvinden. 225

\subsection{Conclusie}

Parlementair onderzoek verloopt in Nederland veelal volgens een vast patroon. De RSV-enquête is wat betreft de werkwijze van parlementaire onderzoekscommissies toonaangevend gebleken. Het besluit tot het houden van een enquête of een regulier onderzoek ligt bij de plenaire vergadering. Die stelt ook de onderzoeksopdracht vast, al blijken commissies in de praktijk enige ruimte te krijgen om de onderzoeksvragen nader in te vullen. Substantiële wijziging van de onderzoeksopdracht kan niet zonder toestemming van de Kamer. De vastgestelde tijdslimiet en de hoogte van het toegekende budget stellen op zichzelf beperkingen aan de beweegruimte van de commissie.

Een parlementair onderzoek verloopt vervolgens meestal in drie fases: het vooronderzoek, de openbare gesprekken (hoorzittingen) en de rapportage. Na afloop van een onderzoek is in een enkel geval een evaluatieonderzoek gedaan, maar in veel gevallen is de 'follow-up' beperkt. Tijdens het vooronderzoek staat het verzamelen en analyseren van informatie centraal. Onderzoekscommissies zijn daarbij sterk afhankelijk van de medewerking van informatieverstrekkers, waarbij de regering vaak de belangrijkste is. Enquêtecommissies beschikken daarbij weliswaar over verregaande wettelijke informatierechten, maar de verschoningsgrond van het belang van de staat en het risico van vertraging van het onderzoek maken dat zij, net als reguliere onderzoekscommissies, er in de praktijk niet aan ontkomen om afspraken te maken over de verstrekking van informatie. Hierbij geldt een standaardprotocol uit 2002, op basis waarvan aan het begin van het onderzoek specifieke afspraken worden gemaakt met het kabinet en eventuele andere instanties. Aangezien de Wpe noch het Reglement van Orde iets regelen omtrent de eventuele samenloop van parlementair en strafrechtelijk of bestuursrechtelijk onderzoek, is het gebruikelijk dat ook daaromtrent afspraken worden gemaakt met de verantwoordelijke ministers en de betrokken instanties, teneinde te voorkomen dat samenlopende onderzoeken elkaar onnodige schade berokkenen. De vraag of de samenloop van onderzoeken nadere

\footnotetext{
${ }^{223}$ Muller \& Coenen 2002, p. 184-185. Zie ook Muller in De WPE onder de loep 2004, p. 74-75.

224 In haar rapport, waarin wordt onderzocht welke uitwerking de uitkomsten van drie parlementaire onderzoeken hadden op ministeries, concludeerde de Rekenkamer dat aanbevelingen en verbetermaatregelen "beter beklijven als de implementatie gevolgd wordt door een evaluatie. In zo'n evaluatie moet niet alleen worden bekeken of de aanbevelingen zijn opgevolgd, maar ook wat de effectiviteit van de ingezette verbetermaatregelen is. Als aan deze voorwaarden is voldaan, wordt duurzaam leren van parlementair onderzoek bevorderd." Leren van parlementair onderzoek 2007, p. 10.

${ }^{225}$ Kamerstukken II 2007/08, 31 019, nr. 6, p. 11-12.
} 
(wettelijke) regeling verdient, zoals in de literatuur wel bepleit met het oog op de bescherming van getuigen, is bij de recente herziening van de enquêtewet ontkennend beantwoord. Een dringende noodzaak was er ook niet. In de navolgende delen zal worden bezien hoe in andere stelsels met deze problematiek wordt omgegaan.

Wanneer inlichtingen in vertrouwelijke vorm worden verstrekt of uitsluitend ter inzage worden gegeven, kan de commissie deze informatie niet in herleidbare vorm gebruiken in haar eindrapport. Dit kan het werk van de commissie bemoeilijken, zeker wanneer het blootleggen van een omvangrijk, vaak controversieel feitencomplex ('waarheidsvinding') deel uitmaakt van de door de Kamer vastgestelde onderzoeksopdracht. Met een dergelijke doelstelling lijkt het verstandig om al in de besluitvorming over het al dan niet instellen van een (enquête)onderzoek uitvoerig aandacht te besteden aan eventuele belemmeringen in de vergaring van inlichtingen; zo mogelijk zou een en ander reeds op dat moment - als het politieke momentum het grootst is - met de betreffende informatieverstrekkers, zoals het kabinet, moeten worden afgestemd. Dat zulk overleg niet altijd in het voordeel van de commissie (en de Kamer) uitpakt, zoals bij de recente Enquête Financieel Stelsel het geval bleek, toont de beperkingen van het parlementaire onderzoeksinstrument wanneer het wordt ingezet voor grootschalig, origineel feitenonderzoek.

Soms is een hoge mate van vertrouwelijkheid juist wel in het belang van de commissie. Zo kan absolute vertrouwelijkheid, zoals tijdens een voorgesprek, bijdragen aan de bereidwilligheid van informatiebezitters om openheid van zaken te geven en op die manier het onderzoek verder te helpen. Om die reden voorziet de Wpe in de mogelijkheid voor de commissie om ook na afloop van het onderzoek, wanneer haar archief overgaat op de Kamer, nog beperkingen te stellen aan de openbaarheid van documenten. Helemaal sluitend is de wettelijke regeling echter niet, want de Kamer kan besluiten deze beperkingen incidenteel weer op te heffen. Bij het eerste onderzoek onder de nieuwe wet, de Enquête Financieel Stelsel, bleek dat het bestaan van die mogelijkheid tot huiverigheid bij informatieverstrekkers leidde. Het is daarom de vraag of de wetgever er verstandig aan heeft gedaan om de deur als het ware op een kier te zetten. Verder is de wet thans niet duidelijk over de vraag of ook de verslagen van besloten voorgesprekken langs deze weg openbaar zouden kunnen worden.

De openbare gesprekken dienen om de kennis die tijdens het vooronderzoek is opgedaan, in het openbaar te doen bevestigen, maar ook om het publiek te informeren over het werk van de commissie en niet in de laatste plaats als het moment waarop commissieleden zich (politiek) kunnen profileren. Het is grotendeels aan de commissies zelf om te bepalen hoe zij een hoorzitting vormgeven. De Wpe is hieromtrent zeer summier en voor zover het Reglement van Orde bepalingen bevat, bijvoorbeeld ten aanzien van de ordehandhaving door de voorzitter, gelden deze opmerkelijk genoeg alleen voor reguliere onderzoekscommissies en niet voor enquêtecommissies. Dit laatste lijkt een onvolkomenheid in de herziening van de verschillende wettelijke en reglementaire regelingen rondom de enquête in 2008. Los daarvan is het de vraag of, in het bijzonder ter bescherming van getuigen, de positie van voorzitter van een enquêtecommissie niet (verder) versterkt zou moeten worden. In de volgende delen wordt hierop in vergelijkende zin nader ingegaan. 
$\mathrm{Na}$ afronding van het onderzoek presenteert de commissie haar bevindingen in een eindrapport, dat wordt aangeboden aan de Kamervoorzitter. Vervolgens debateert de Kamer met de commissie over het rapport, waarna doorgaans een motie wordt aangenomen waarin de Kamer aangeeft voldoende grondslag te zien voor een debat met de regering. Na dat debat is het onderzoek feitelijk ten einde. Het opvolgen van de aanbevelingen die de commissie heeft gedaan en die door de Kamer zijn ondersteund, vindt op een enkele uitzondering na niet systematisch plaats. Veelal neemt de Kamer genoegen met een periodieke voortgangsrapportage van de betrokken ministers, terwijl een systematische follow-up vaak als cruciaal wordt gezien voor de effectiviteit van een parlementair onderzoek. Bij de invoering van de RPE werd afgesproken dat parlementaire onderzoeken voortaan standaard dienen te worden geëvalueerd. Hoe de Kamer dat in de praktijk zal aanpakken, moet worden afgewacht. 


\section{Deel II.}

Parlementair onderzoek in het Verenigd Koninkrijk 



\section{Hoofdstuk 1. Politiek-constitutioneel kader}

\subsection{Inleiding}

In het eerste hoofdstuk wordt het politiek-constitutionele kader waarbinnen parlementair onderzoek in het Verenigd Koninkrijk zich afspeelt geschetst. Daarbij wordt eerst ingegaan op de historische ontwikkeling van het Britse parlementaire stelsel, waarna de betekenis van de constitutionele beginselen van ministeriële verantwoordelijkheid en parlementaire controle worden besproken. Vervolgens wordt ingegaan op de ontwikkelingen die deze kenmerkende onderdelen van het Britse stelsel in de loop van de twintigste eeuw hebben doorgemaakt.

\subsection{Het Britse parlementaire stelsel}

De geschiedenis van het Britse parlement als instituut gaat terug tot 1265 , toen de Engelse koning Henri III een persoonlijk adviescollege oprichtte, bestaande uit de feodale adel en vertegenwoordigers van steden en gewesten. Al vroeg ontstond een scheiding tussen een adelijk Hogerhuis (House of Lords) en een Lagerhuis (House of Commons) bestaande uit niet-adelijke leden. De invloed van dit parlement - dat slechts incidenteel bijeengeroepen werd - was beperkt. De koning behield het recht om wetgeving op te schorten en te regeren middels koninklijke prerogatieven, waarvan de omvang onbepaald was. Met name koning James II, de laatste in de Stuartdynastie, maakte hiervan veelvuldig gebruik. De toenemende onvrede hierover binnen de politieke elite leidde in 1688 tot de 'Glorious Revolution'. James vluchtte naar het buitenland, waarna de troon werd aangeboden aan het Nederlandse koningspaar William en Mary, zij het onder een aantal voorwaarden gesteld door het parlement. In deze voorwaarden, neergelegd in de Engelse Bill of Rights, werd het wetgevende gezag van het parlement erkend en de koninklijke prerogatieven sterk ingeperkt. ${ }^{1}$

Van een parlementair stelsel kon in die periode echter nog niet gesproken worden. Het bestuur, inclusief de uitvoering van wetgeving, behoorden nog steeds toe aan de kroon (Crown), waarmee destijds nog werd gedoeld op de koning persoonlijk. In de loop van de achttiende eeuw verschoof de uitoefening van deze koninklijke bevoegdheden echter grotendeels naar het Cabinet, bestaande uit de Prime Minister en de belangrijkste ministers. De koninklijke macht kreeg meer en meer een symbolisch karakter. Na 1832 kwam vast te staan dat het Cabinet steeds het vertrouwen nodig had van een meerderheid in de House of Commons. Halverwege de negentiende eeuw kwam de ministeriële verantwoordelijkheid tot ontwikkeling. Dit an-

1 Zie nader Bradley \& Ewing 2007, p. 51-54. Zie ook Turpin \& Tomkins 2007, p. 376, 571-573 en Norton 2005, p. 16-19. 
kerpunt binnen het Britse staatsrecht behelst in de eerste plaats een collectieve verantwoordelijkheid van de leden van het Cabinet voor de besluiten die in het Cabinet werden genomen. Deze collectieve verantwoordelijkheid stelde het Cabinet in staat om een vuist te maken ten opzichte van de monarch. Bagehot kon in 1867 met zekerheid stellen dat de Koning voor wat betreft zijn constitutionele bevoegdheid om zijn ministers te benoemen, aan het hoofd stond van wat hij de constitutie in ceremoniële zin (de 'dignified constitution') noemde. De Prime Minister was de leider van het Cabinet en oefende daarmee de werkelijke regeermacht uit; hij stond aan het hoofd van het 'doelmatige' gedeelte van de constitutie ('efficient constitution'). ${ }^{2}$

Ook ontstond in deze periode een individuele vorm van ministeriële verantwoordelijkheid. Het was de tijd dat het centrale ambtelijke apparaat een grote groei doormaakte, onder andere door de invoering van allerlei vormen van sociale wetgeving. Vrij snel ontstond binnen het parlement de overtuiging dat de nieuwe overheidsdiensten die deze wetgeving moesten gaan uitvoeren onder leiding van een minister moesten worden geplaatst die lid was van het parlement en daar ook ter verantwoording kon worden geroepen. Sinds die tijd kent het Verenigd Koninkrijk een permanente, anonieme ambtelijke dienst die ondergeschikt is aan ministers. ${ }^{3}$

Het parlementaire stelsel kreeg in de loop van de negentiende en twintigste eeuw verder vorm door de geleidelijke invoering van het algemeen kiesrecht voor de House of Commons. De eerste uitbreiding vond plaats in 1832, maar omdat deze beperkt was konden parlementsleden nog voldoende kiezers trekken zonder de hulp van partijorganisaties. Er was sprake van een kortstondige 'golden age' voor het Lagerhuis, waarin parlementariërs tamelijk onafhankelijk opereerden en regeringen veelvuldig werden weggestuurd of overstemd. ${ }^{4}$ Duidelijk werd, dat deze kamer het politieke primaat bezat ten opzichte van de ongekozen House of Lords. Naarmate het kiesrecht verder werd uitgebreid en het aantal kiezers dat moest worden bereikt groter werd, werden kandidaten steeds afhankelijker van een sterk ontwikkeld partijapparaat. Rond de eeuwwisseling waren strak georganiseerde en gedisciplineerde politieke partijen de dominante krachten in de House of Commons geworden. Bovendien kon een van de partijen, mede als gevolg van het kiesstelsel, doorgaans een absolute meerderheid verwerven. De wetgevende macht verschoof daarmee feitelijk naar het Cabinet, waarbinnen de Prime Minister, tevens politiek leider van de meerderheidspartij, een leidende rol kon gaan spelen. Hierdoor werd de regering in de eerste helft van de twintigste eeuw op allerlei manieren dominant in het parlementaire proces. Zo kwam de wetsbehandeling in het parlement vrijwel geheel in het teken te staan van een zo efficiënt mogelijke uitvoering van de politieke agenda van de meerderheidspartij. In het Lagerhuis lag de nadruk op het politieke debat in de plenaire zaal (Chamber) en op de wetgevingscommissies (standing committees), waarin de partijmanagers (whips) de dienst uitmaakten; het gebruik van onder-

\footnotetext{
2 Bagehot 1867, p. 11.

${ }^{3} \mathrm{Bij}$ de hervorming van de ambtelijke dienst in 1854 werd dit uitgangspunt bevestigd. Zie Bradley \& Ewing 2007, p. 109-110.

4 Norton 2005, p. 19-20.
} 
zoekscommissies (select committees), wat eerder incidenteel wel voorkwam, nam juist sterk af. 5

$\mathrm{Na}$ de Tweede Wereldoorlog veranderde dit. De dominantie van de regering had ertoe geleid dat het zijn van Lagerhuislid voornamelijk een bijbaan was. Het parlement functioneerde tamelijk amateuristisch. Vanaf de jaren 50 van de twintigste eeuw begon dit te veranderen. Het aantal carrièrepolitici nam sterk toe. Parlementsleden waren steeds hoger opgeleid, zagen hun werk als een voltijdsbaan en maakten, mede vanuit carrièreperspectief, meer en meer gebruik van parlementaire instrumenten als het debat en het vragenrecht. Ook eisten zij betere faciliteiten: vanaf de jaren 60 werden daarom de kantoorvoorzieningen verbeterd en kregen de leden een eigen budget voor secretariële ondersteuning en onderzoeksmedewerkers. Ook de bibliotheek van het Lagerhuis werd uitgebreid. ${ }^{6}$

In deze periode begon het klassieke tweepartijensysteem en de daaruit voortvloeiende almacht van de regering te veranderen. De samenleving veranderde en de klasseverschillen die voorheen de politieke scheidslijn vormde tussen de twee grote partijen, de Conservatives en Labour, waren niet langer allesbepalend in de Britse politiek. Een derde partij, de Liberal Democrats, won steeds meer terrein. ${ }^{7}$ Ook het stemgedrag van backbenchers - de grote groep parlementsleden die geen bijzondere functie, zoals een (schaduw)ministerspost, uitoefenen - was vanaf de jaren 70 geen automatisme meer. Het aantal 'backbench rebellions', waarbij een groep backbenchers zich in bepaalde kwesties tegen het beleid van de partijleiding keerden, nam sindsdien toe. Zelfs met een absolute meerderheid in het parlement zag de regering zich steeds vaker genoodzaakt om overleg te voeren met andere partijen teneinde haar beleidsdoelen te kunnen verwezenlijken. ${ }^{8}$ Webb stelt daarom dat "since 1970, the UK has moved some way from its traditional status as a classic exemplar of majoritarian democracy towards its polar antithesis as a model, that of consensus democracy." 9

Wellicht de belangrijkste institutionele hervorming die samenhangt met de veranderende verhoudingen binnen het Lagerhuis, is de invoering van een stelsel van permanente onderzoekscommissies (departmental select committees) in 1979. Deze hervorming gaf backbenchers de mogelijkheid om middels het onderzoeksinstrument parlementaire controle uit te oefenen en de ministeriële verantwoordelijkheid te activeren. Het nieuwe commissiestelsel, zo stelt Norton, betekende "a major departure from the chamber-orientated House that had been dominant since the advent of party government." 10

\footnotetext{
${ }^{5}$ Norton 2005, p. 20-21.

${ }^{6}$ Norton 2005 , p. 22-25.

${ }^{7}$ Webb 2000, p. 8-9.

${ }^{8}$ Tot voor kort beperkte de samenwerking tussen partijen zich altijd tot vormen van consultatie of het maken afspraken omtrent specifieke beleidspunten. Webb 2000, p. 11. In 2010 leidde een 'hung Parliament' echter voor het eerst in de Britse geschiedenis tot een formele coalitieregering, waarbij beide partijen - de Conservatives als de Liberal Democrats - ministers leverden en de leider van de kleinste partij de post van Deputy Prime Minister ging bekleden.

${ }_{9}^{9}$ Webb 2000, p. 1, waarbij gedoeld wordt op het onderscheid van Lijphart tussen meerderheids- en consensusmodellen in democratische stelsels.

${ }^{10}$ Norton 2005, p. 28.
} 


\subsection{Beginselen van verantwoordelijkheid en controle}

\subsubsection{Inleiding}

De staatsrechtelijke wortels van parlementair onderzoek in het Britse parlement, waarop in de navolgende hoofdstukken nader zal worden ingegaan, zijn niet eenvoudig bloot te leggen. Het Britse staatsrecht wordt, zoals bekend, gekenmerkt door de afwezigheid van een geschreven grondwet. Dat wil uiteraard niet zeggen dat het Verenigd Koninkrijk geen constitutionele orde kent. Het geheel aan constitutionele regels moet in de eerste plaats worden opgemaakt uit een samenstel van fundamentele wet- en regelgeving en vaste jurisprudentie ('common law'). Daarnaast vormen 'conventions' een belangrijke bron van constitutioneel recht. Conventions reguleren belangrijke aspecten van het politieke stelsel, zoals de verhouding tussen staatsinstellingen en de uitoefening van taken en bevoegdheden door ambtsdragers zoals het staatshoofd, ministers, parlementsleden, rechters en ambtenaren. Conventions zijn, kort gezegd, gewoonten en praktijken die de status van constitutionele regel hebben bereikt, omdat ze door degenen die het betreft worden ervaren als verplichtingen (of rechten). Het verschil met wettelijke en jurisprudentiële regels is, dat conventions niet door de rechter worden gehandhaafd, maar door politieke instellingen zoals het Lagerhuis. ${ }^{11}$ Voorbeelden zijn de reeds genoemde conventie dat ministers lid dienen te zijn van een van de huizen van het parlement en dat de regering steeds het vertrouwen van een meerderheid in het Lagerhuis nodig heeft. ${ }^{12}$

De Britse constitutionele orde, zoals het samenstel van constitutionele rechtsregels kan worden genoemd, is het resultaat van honderden jaren staatsrechtelijke ontwikkeling. Van een vastomlijnde staatsrechtelijke doctrine, die aan deze orde ten grondslag lag, is daarom geen sprake. Wel kan een aantal fundamentele beginselen worden aangewezen, die de ontwikkeling van het constitutionele recht door de jaren heen hebben beïnvloed. ${ }^{13}$ De beginselen van parlementaire soevereiniteit en de rechtsstaat ('rule of law'), wellicht de meest karakteristieke elementen uit het Britse staatsrecht, hebben de oudste papieren. Later hebben ook de beginselen van machtenscheiding, democratie en politieke verantwoordelijkheid ('responsible and accountable government') in het Verenigd Koninkrijk een centrale plaats verworven. ${ }^{14}$

Het voert te ver om hier op al deze kernbegrippen van het Britse staatsrecht nader in te gaan. Op deze plaats is vooral de betekenis van het beginsel van 'responsible and accountable government' van belang. In haar meest essentiële betekenis houdt dit in, dat " $[w]$ ithin a democracy, those who govern must be accountable, or responsible, to those whom they govern." 15 Aan dit beginsel kan volgens Turpin en Tomkins een aantal betekenissen worden toegekend, die betrekking hebben op de

\footnotetext{
11 Turpin \& Tomkins 2007, p. 157.

12 Zie nader over de betekenis, het ontstaan en de toepassing van 'conventions' in het Britse staatsrecht: Bradley \& Ewing 2007, p. 20-31 en Turpin \& Tomkins 2007, p. 156-179.

13 Turpin \& Tomkins 2007, p. 33-34.

14 Zie uitvoerig: Bradley \& Ewing 2007, p. 7, 51-122 en Turpin \& Tomkins 2007, p. 34-137.

15 Bradley \& Ewing 2007, p. 107.
} 
relatie tussen regering en parlement. Zo kan begrip worden gelezen als een beginsel op grond waarvan van de regering mag worden verwacht dat zij 'responsive' (ontvankelijk, gevoelig) is voor behoeften of opvattingen uit de samenleving. Hieruit volgt tevens, dat het volk, al dan niet via een vertegenwoordigend orgaan, een zekere mate van a priori 'control' (in de zin van zeggenschap of invloed) moet hebben op de regering. ${ }^{16}$ In enge zin kan het beginsel van 'responsible and accountable government' vooral worden gezien als een verantwoordingsplicht voor de regering. In deze betekenis wordt vaak de term 'accountability' gebruikt. De regering wordt geacht haar handelen a posteriori toe te lichten, uit te leggen en te verdedigen (verantwoording af te leggen), maar ook om fouten of misstanden te corrigeren (verantwoordelijkheid te nemen). ${ }^{17}$

Zo beschouwd geeft het beginsel van 'responsible and accountable government' invulling aan de relatie tussen parlement en regering. Het parlement, zo kan hieruit worden afgeleid, heeft de taak om de regering te controleren, zowel vooraf als achteraf. Op de regering berust tegelijkertijd de verplichting om verantwoording af te leggen aan het parlement. De wijze waarop deze twee zijden van hetzelfde beginsel in het Britse staatsrecht zijn uitgewerkt wordt hieronder nader uiteengezet.

\subsubsection{Ministeriële verantwoordelijkheid}

Uit het beginsel van 'responsible and accountable government' kan, zoals gezegd, zowel een controletaak voor het parlement als een verantwoordingsplicht ('accountability') voor de regering worden afgeleid. In deze paragraaf staat de verantwoordingsplicht centraal. Is de betekenis en uitwerking van de parlementaire controletaak in het Britse staatsrecht vrij helder te noemen, hetzelfde kan moeilijk beweerd worden met betrekking tot de verantwoordingsplicht. Deze is omgeven door een grote mate van staatsrechtelijke schimmigheid. ${ }^{18}$ Centraal staat de doctrine van ministeriële verantwoordelijkheid ('ministerial responsibility'). Deze doctrine, tot ontwikkeling gekomen in conventies, geldt in de literatuur als het concrete aanknopingspunt voor parlementaire controle. Zoals Turpin en Tomkins het formuleren: "it is through the mechanisms of ministerial responsibility that Parliament persists in its effort to 'watch and control' the government." 19

In essentie komt de doctrine op het volgende neer. De politieke ministeriële verantwoordelijkheid is in het Verenigd Koninkrijk, zo bleek eerder al, tot ontwikkeling gekomen in de 19e eeuw. In deze eeuw verschoof de regeermacht definitief van de Koning naar de ministers. Onderdeel hiervan was het ontstaan van een conventie inzake de collectieve ministeriële verantwoordelijkheid van het Cabinet. Lord Salis-

\footnotetext{
16 Turpin \& Tomkins 2007, p. 565-566.

17 Turpin \& Tomkins 2007, p. 566. Zie ook Bradley \& Ewing 2007, p. 107, die het beginsel slechts in enge zin beschrijven.

${ }^{18}$ Niet in de laatste plaats omdat termen als 'responsibility' en 'accountability' soms synoniem lijken te zijn en elders van elkaar worden onderscheiden, waarbij bovendien niet altijd sprake is van consistentie. Aangezien dit niet de plaats om de uitvoerige literatuur die over dit onderwerp is verschenen te bespreken, wordt volstaan met enkele hoofdlijnen.

19 Turpin \& Tomkins 2007, p. 134.
} 


\title{
VERENIGD KONINKRIJK
}

bury omschreef de betekenis van de collectieve ministeriële verantwoordelijkheid ('collective ministerial responsibility') in 1878 als volgt:

\begin{abstract}
"For all that passes in Cabinet every member of it who does not resign is absolutely and irretrievably responsible and has no right afterwards to say that he agreed in one case to a compromise, while in another he was persuaded by his colleagues... It is only on the principle that absolute responsibility is undertaken by every member of the Cabinet, who, after a decision is arrived at, remains a member of it, that the joint responsibility of Ministers to Parliament can be upheld and one of the most essential principles of parliamentary responsibility established." 20
\end{abstract}

Cabinet ministers zijn dus, zolang ze in functie zijn, ten volle gebonden aan besluiten die in het Cabinet genomen zijn. Dit betekent dat ze gehouden zijn deze besluiten te steunen en te verdedigen. ${ }^{21}$ Thans geldt de collectieve verantwoordelijkheid voor alle leden van de regering, dus ook voor ministers die niet behoren tot het Cabinet. De collectieve verantwoordelijkheid vervult hiermee een rol als een instrument om de eenheid van het regeringsoptreden te bewaken. Dat instrument is in handen van de Prime Minister, die bepaalt in hoeverre de eenheid van het regeringsoptreden in concrete situaties moet worden gehandhaafd.22 Dit betekent, zoals Bradley en Ewing stellen, dat "[t]he consequences of collective responsibility are thus in part what the Prime Minister of the day chooses to make them." 23 Voor het parlement is vooral van belang dat de conventie van collectieve verantwoordelijkheid ervoor zorgt dat het mogelijk wordt vast te stellen wat het beleid van de regering als geheel is. Elke minister kan bovendien afzonderlijk worden aangesproken op het gehele regeringsbeleid. ${ }^{24}$

In het verlengde van de collectieve verantwoordelijkheid is een conventie met betrekking tot de individuele ministeriële verantwoordelijkheid ('individual ministerial responsibility') tot ontwikkeling gekomen. Deze individuele verantwoordelijkheid reikt verder dan alleen het uitleggen en verdedigen van het algemene regeringsbeleid. De individuele ministeriële verantwoordelijkheid houdt volgens Tomkins in, dat ministers persoonlijk verantwoording dienen af te leggen aan het parlement omtrent hun ministeriële handelingen en beleid, hun persoonlijk handelen, en het handelen van het aan hen ondergeschikte ambtelijke apparaat. ${ }^{25}$ De individuele verantwoordelijkheid heeft daarom een verbindende functie: op basis van de individuele ministeriële verantwoordelijkheid is een minister die aan het hoofd staat van een departement voor het parlement het exclusieve aanspreekpunt voor het handelen van de aan hem ondergeschikte ambtelijke dienst. Ambtenaren zijn dus niet zelfstandig verantwoording schuldig aan het parlement. Voor het parlement vormt de individuele ministeriële verantwoordelijkheid daarmee het aanknopings-

\footnotetext{
${ }^{20}$ Geciteerd in Bradley \& Ewing 2007, p. 110.

21 Zie ook Turpin \& Tomkins 2007, p. 376 ("The convention of collective ministerial responsibility obliges ministers to support the politics and decisions of the government to which they belong...").

22 Tomkins 2008, p. 249-250.

23 Bradley \& Ewing 2007, p. 113-114. Sinds 1992 is de collectieve ministeriële verantwoordelijkheid gecodificeerd in de Ministerial Code, de richtlijnen voor ministers opgesteld door de Prime Minister. Zie de artt. 2.1 en 2.3 van de meest recente herziening van de Ministerial Code (3 juli 2007).

24 Tomkins 2008, p. 249-250.

25 Tomkins 2008, p. 251-252.
} 
punt waarmee het optreden van ministers en het openbaar bestuur kan worden gecontroleerd ('scrutinized').

\subsubsection{Parlementaire controle}

\subsubsection{Achtergrond}

Het idee dat het parlement de taak heeft om de regering te controleren is nergens expliciet vastgelegd. Dat het parlement die taak heeft, is echter niet omstreden. John Stuart Mill, de negentiende-eeuwse Britse politieke denker, beschouwde de controletaak als de hoofdfunctie van het parlement. Hij schreef in een tijd dat het parlement zijn 'golden age' beleefde. ${ }^{26}$ Het parlement moest echter niet willen regeren; hiervoor is een vertegenwoordigend orgaan ongeschikt. In een klassiek geworden passage stelt Mill daarom: "the proper office of a representative assembly is to watch and control the government: to throw the light of publicity on its acts: to compel a full exposition and justification of all of them which any one considers questionable; to censure them if found condemnable, and ... to expel them from office..." 27

Volgens Bradley en Ewing is de stelling van Mill nog steeds relevant. De positie van het parlement is de afgelopen anderhalve eeuw echter onder druk komen te staan, bijvoorbeeld door de ontwikkeling van het partijenstelsel en de groei van de uitvoerende macht. Het belang van effectieve parlementaire controle over de regering is daarmee volgens Bradley en Ewing niet verminderd. Wel betekent dit, dat het parlement adequate middelen en instrumenten nodig heeft om haar controletaak te kunnen waarmaken. Daarnaast vereist dit politieke wil bij parlementariërs die geen lid zijn van de regering om ministers kritisch te volgen. ${ }^{28}$

Ook Blackburn en Kennon lijken in hun standaardwerk over de functies en werking van het parlement voort te bouwen op de stelling van Mill. Volgens hen is het parlement in de eerste plaats als een debatforum. Het parlement is enerzijds een forum waar verschillende partijen en actoren de gelegenheid hebben om met elkaar in debat te gaan over de onderwerpen van hun keuze. Anderzijds stelt het parlement de regering in staat om zijn werk te doen. Daaruit volgt volgens hen dat "[i]f these forums can be said to have a principal function, it is that of exercising constant scrutiny over those who have the powers of government and debating all matters brought before them from whatever source, and, through the operation of the government's majority in the Commons, of enabling members of the government to fulfill their constitutional role." 29 Middels het parlementaire debat kan het parlement dus voortdurend controle ('scrutiny') uitoefenen op het werk van de regering. Hoewel de regering doorgaans een meerderheid in het Lagerhuis heeft, is de regering volgens Blackburn en Kennon verplicht het parlement de gelegenheid te geven deze controlefunctie te vervullen:

\footnotetext{
${ }^{26}$ Zie hierboven, par. 1.2.

${ }^{27}$ Mill 1861, p. 282.

${ }^{28}$ Bradley \& Ewing 2007, p. 192-193.

${ }^{29}$ Blackburn \& Kennon 2003, p. 6-7.
} 


\section{VERENIGD KONINKRIJK}

"ministers can obtain the parliamentary legitimation they require for their business only if they also allow opportunities and procedures for debate or other forms of scrutiny on both the business they must initiate and on matters brought forward by others. This is the meaning of the phrase 'parliamentary government': not government by Parliament, but government through Parliament. The government may govern, but Parliament is the forum for the public debate and criticism of those acts of government." 30

Dat het parlement de mogelijkheid moet hebben om met de regering in debat te gaan of op andere wijze de wetgevende of uitvoerende activiteiten van de regering te controleren of te onderzoeken, vloeit dus voort uit de aard van het parlementaire systeem ('parliamentary government').

Vervolgens stellen Blackburn en Kennon dat, om van een effectief parlementair debat (in brede zin) te kunnen spreken, het parlementaire systeem aan twee voorwaarden moet voldoen:

"Effective debate, in its broad sense, requires two things. First, there must be adequate opportunities for debate to be initiated by the various participants. Second, there must be appropriate procedures and techniques for looking critically at different kinds of business; in particular there must be methods for obtaining the information necessary for effective and influential debate or scrutiny." 31

Effectieve controle ('scrutiny') van het werk van de regering is dus alleen mogelijk als het parlement zowel de gelegenheid als de instrumenten heeft om de nodige informatie boven tafel te krijgen. De groeiende complexiteit van het overheidsoptreden geeft aan hoe belangrijk dit is:

“...if Parliament is to match the decision-taking processes of government (which includes detailed study of the relevant information) with anything like effective scrutiny, then the House must be able to inform itself. It would clearly be wrong for Members to be limited, in the supply of information, to that which ministers choose to make public without request, plus whatever they may learn from the press and other outside sources. Parliamentary procedures must therefore be available to enable the House as a whole, committee, or individual Members to obtain further information." 32

In normatieve zin komt uit de Britse literatuur dus een duidelijk beeld naar voren omtrent de betekenis van de parlementaire controletaak. Deze kan kortweg worden omschreven als 'a duty to watch and control the government' en vereist de nodige middelen en instrumenten. Omstreden lijkt dit uitgangspunt, als gezegd, niet. De staatsrechtelijke discussie over dit onderwerp spitst zich eerder toe op de mate waarin het parlement in staat blijkt om deze controletaak uit te oefenen, zoals hierna nog zal blijken. ${ }^{33}$

\footnotetext{
${ }^{30}$ Blackburn \& Kennon 2003, p. 11.

${ }^{31}$ Blackburn \& Kennon 2003, p. 11.

32 Blackburn \& Kennon 2003, p. 16-17.

${ }^{33}$ Zie par. 1.4 .
} 


\subsubsection{Controleinstrumenten}

Het beginsel van 'responsible and accountable government' komt in het Britse staatsrecht op verschillende wijzen tot uitdrukking. Zo zijn er periodieke verkiezingen voor de House of Commons, beschikt het parlement over wetgevende en budgettaire bevoegdheden en wordt voor het overige een zekere mate van parlementaire invloed op het openbaar bestuur gewaarborgd via de vertrouwensregel. De invloed van het parlement op het bestuur is echter maar gedeeltelijk af te leiden uit de constitutionele rechten en bevoegdheden die het parlement toekomen; de politieke context, gekenmerkt door een sterke dominantie van het partijenstelsel en de overheersende rol van de regering, heeft ervoor gezorgd dat de betekenis van bovengenoemde beinvloedingsmogelijkheden in de praktijk beperkt is. ${ }^{34}$ Exemplarisch is de wetsbehandeling in de House of Commons. De regering bepaalt de wetgevingsagenda en om deze agenda efficiënt te kunnen doorvoeren vindt de voorbereidende behandeling veelal plaats in zogenaamde 'standing committtees' die, anders dan de naam doet vermoeden, slechts een tijdelijk karakter hebben en na behandeling van het voorgelegde wetsvoorstel weer worden ontbonden. Bovendien wordt de samenstelling van deze commissies volledig bepaald door de partijmanagers ('whips'); het partijpolitieke debat voert in deze commissies de boventoon, waardoor van een zorgvuldige behandeling vaak weinig terechtkomt. ${ }^{35}$

Het gebrek aan invloed op wetgevend en budgettair terrein heeft in de loop van de twintigste eeuw geleid tot een groeiende interesse bij Lagerhuisleden voor controle in de enge zin: het uitoefenen van controle op het regeringshandelen en de uitvoering van wetgeving en beleid a posteriori. Hiertoe beschikt de House of Commons over drie instrumenten. ${ }^{36}$ Daarvan heeft het debatrecht waarschijnlijk de oudste papieren. Debatten vinden doorgaans plaats in de plenaire zaal ('Chamber') en kunnen allerlei onderwerpen hebben. Het kan gaan om wetsvoorstellen, beleidsvoornemens van de regering of de uitvoeringspraktijk, maar bijvoorbeeld ook, wanneer het initiatief vanuit de backbenches komt, om specifieke onderwerpen die vooral van belang zijn voor een bepaald kiesdistrict. Wanneer het initiatief van de regering of de oppositie komt, dan staan de partijpolitieke verschillen vaak centraal. Er is dagelijks ruimte op de parlementaire agenda om een debat op aanvraag van een individueel lid te houden (zogenaamde 'adjournment debates'). Ministers zijn verplicht om aanwezig te zijn en te reageren, maar bijdragen van leden aan dergelijke debatten moeten wel verband houden met zaken waarvoor de betreffende minister(s) een zekere verantwoordelijkheid dragen. ${ }^{37}$ Als controleinstrument, zo stellen Turpin en Tomkins, is

\footnotetext{
${ }^{34}$ Zie hierboven, par. 1.2.

35 Zie nader: Blackburn \& Kennon 2003, p. 385 e.v. Aanhoudende kritiek op deze werkwijze heeft onlangs echter geleid tot enkele hervormingen. Meer hierover in hoofdstuk 3.

${ }^{36}$ Overigens kunnen deze instrumenten eveneens worden gezien als mogelijkheden tot het uitoefenen van controle a priori. Immers, de wetenschap dat het parlement achteraf (kritisch) controle uitoefent op het regeringshandelen kan ministers ertoe aanzetten om te anticiperen op de opvattingen en behoeften van parlementsleden. Met betrekking tot het derde instrument, de inzet van 'select committees', wordt hierop in de volgende hoofdstukken nog nader ingegaan.

37 Zie nader Blackburn \& Kennon 2003, p. 377. Om meer ruimte te scheppen voor dergelijke debatten is sinds 2000 een tweede debatruimte in gebruik, Westminster Hall, waarin met name debatten aangevraagd door backbenchers worden gehouden. Zie ook Bradley \& Ewing 2007, p. 217.
} 
het debatrecht het effectiefst wanneer het gaat om nog niet definitieve beleidsvoorstellen die door de regering aan het Huis worden voorgelegd, bijvoorbeeld in de vorm van een 'Green Paper', zodat het debat kan fungeren als "a test of parliamentary and public opinion." Een erg sterk controleinstrument is het echter niet, zo voegen zij daaraan toe. Debatten hebben zelden direct invloed op het regeringsbeleid of op de stemverhoudingen in het parlement, maar "they are an essential part of the continuous parliamentary scrutiny of government, compelling it to explain and defend its policies and decisions." 38

Ten tweede bestaat de mogelijkheid van het stellen van mondelinge en schriftelijke vragen. Er is een dagelijks vragenuur, waarop ministers bij toerbeurt verschijnen om mondelinge vragen te beantwoorden. Daarnaast is er wekelijks een vragenuur met de Prime Minister. Schriftelijke vragen kunnen op ieder moment worden gesteld aan alle ministers. ${ }^{39}$ In de literatuur wordt het vragenrecht vooral gezien als een instrument waarmee individuele Lagerhuisleden de ministeriële verantwoordelijkheid kunnen activeren. Zo wordt in Erskine May, het meest gezaghebbende handboek op het gebied van parlementaire procedure, gesteld dat vragen aan ministers gericht moeten zijn op "the public affairs with which they are officially connected, to proceedings pending in Parliament, or to matters of administration for which they are responsible." Vragen die hiermee onvoldoende verband houden, zo blijkt in de praktijk, kunnen door de Speaker buiten de orde worden verklaard. ${ }^{40}$

Het derde en meest recentelijk tot ontwikkeling gekomen handvat van parlementaire controle in de House of Commons is het stelsel van 'departmental select committees': permanente onderzoekscommissies bestaande uit backbenchers van alle partijen, die elk een departement monitoren. Hoewel de figuur van de select committee door de eeuwen heen al op incidentele basis werd ingezet voor onderzoeksdoeleinden, dateert het huidige stelsel van vaste select committees van 1979. De invoering van deze permanente onderzoekscommissies vormt een uitvloeisel van de toenemende onvrede in de tweede helft van de twintigste eeuw over het functioneren van het parlement, dat door de ontwikkeling van een overheersend partijenstelsel, een sterk groeiend overheidsapparaat en de toenemende complexiteit van beleidsvorming, steeds minder in staat werd geacht de regering effectief te controleren. ${ }^{41}$ In de jaren 60 , een periode waarin veel aandacht was voor institutionele hervormingen, won het idee dat invoering van een systeem van gespecialiseerde onderzoekscommissies tot een versterking van het parlement kon leiden, steeds meer

\footnotetext{
38 Turpin \& Tomkins 2011, p. 610. Over enkele recente vernieuwingen, bedoeld om debatten aantrekkelijker te maken, zie Turpin \& Tomkins 2011, p. 611.

${ }^{39}$ In 2008-09 werden ruim 4.000 mondelinge vragen ingediend, waarvan er zo'n 1.300 ook daadwerkelijk mondeling werden beantwoord. De rest werd schriftelijk afgedaan. Daarnaast werden ruim 56.000 schriftelijke vragen gesteld. Voor het vragenuur met de Prime Minister bestaat de mogelijkheid om, nadat de ingediende vraag is gesteld, een aanvullende vraag ('supplementary question') te stellen die niet vooraf is ingediend. Zie verder Turpin \& Tomkins 2011, p. 614-615.

${ }^{40}$ Erskine May 2004, p. 344. Er zijn ook nog andere redenen waarom vragen niet behoeven te worden beantwoord. De parlementaire jurisprudentie hieromtrent komt nog uitvoeriger aan de orde bij de bespreking van de ondervraging van ministers door onderzoekscommissies. Zie par. 2.4.2.

${ }^{41}$ Zie hierboven, par. 1.2.
} 
terrein. ${ }^{42}$ Bijkomend voordeel van dergelijke commissies zou zijn, dat de vele backbenchers, die weinig omhanden hadden, hierin een nuttige tijdsbesteding zouden kunnen vinden. De invoering van een stelsel van onderzoekscommissies had het voordeel dat geen fundamentele wijzigingen hoefden te worden aangebracht in het bestaande politiek-staatsrechtelijke systeem: de centrale positie van de regering op wetgevend en beleidsmatig terrein kon onaangeroerd blijven. ${ }^{43}$ De commissies kregen de taak "to examine the expenditure, administration and policy of the principle government departments ... and associated public bodies" en beschikken daartoe over een aantal onderzoeksbevoegdheden. ${ }^{4}$

De in 1979 ingevoerde departementale onderzoekscommissies zijn inmiddels niet meer weg te denken uit het Britse parlement; zelfs de House of Lords heeft inmiddels een beperkt aantal vaste onderzoekscommissies ingesteld die zich met controle bezighouden. De onderzoekscommissies, klein van omvang en samengesteld op basis van de relatieve partijsterkte, hebben zich de afgelopen decennia dan ook ontwikkeld tot een van de centrale pijlers onder de parlementaire controlefunctie. Het stelsel heeft, zo wordt veelal aangenomen, gezorgd voor een zekere verdieping en verzakelijking van de parlementaire controle. Het blijkt samenwerking over partijgrenzen heen te stimuleren en vormt daarmee een atypisch element in het van oudsher 'adversariale' Britse parlement. Tegelijkertijd wordt al lange tijd erkend dat het stelsel - waarschijnlijk mede daarom - ook beperkingen kent. Turpin en Tomkins stellen dan ook dat "select committees are Parliament's best method for enforcing the accountability of goverment, and in this they have had some success, although their achievement has been partial and uneven." 45

\subsection{Het stelsel in beweging}

\subsubsection{Ministeriële verantwoordelijkheid in ontwikkeling?}

\subsubsection{Groei ambtelijke dienst}

De hierboven beschreven doctrine van ministeriële verantwoordelijkheid is ontstaan in de negentiende eeuw, in een tijd dat het parlement zijn gouden eeuw beleefde. Sindsdien is er veel veranderd. Enerzijds heeft de uitbreiding van het kiesrecht en de opkomst van het partijenstelsel de verhouding tussen regering en parlement sterk veranderd. In feite, zo stelt Woodhouse, een expert op het gebied van ministeriële verantwoordelijkheid, erfden de politieke actoren van de twintigste eeuw een doctrine uit een vervlogen politieke realiteit. ${ }^{46}$ Een andere belangrijke ontwikkeling die zich in de twintigste eeuw voltrok is de veranderende verhouding tussen ministers en departementen: de ambtelijke dienst groeide snel en was bovendien onderhevig aan ingrijpende organisatorische hervormingen. ${ }^{47}$

\footnotetext{
42 Baines 1989, p. 14. Zie ook Johnson 1988, p. 162.

43 Zie verder Baines 1989, p. 14-15.

${ }^{44}$ Zie House of Commons Standing Order No. 152 van 25 juni 1979 (laatstelijk gewijzigd: 30 juni 2010), lid 1.

45 Turpin \& Tomkins 2011, p. 626.

46 Woodhouse 2004, p. 282.

${ }^{47}$ Woodhouse 2004, p. 283-286.
} 
Dit leidde ertoe, dat in de loop van de twintigste eeuw steeds op steeds meer terreinen een zekere spanning ontstond tussen de constitutionele doctrine en de politiek-bestuurlijke praktijk. De discussies over de betekenis van de ministeriële verantwoordelijkheid die hieruit voortvloeiden, brachten vaak meer verwarring dan helderheid. Zo werd in negentiende-eeuwse literatuur nog aangenomen, dat een minister op grond van de ministeriële verantwoordelijkheid verplicht was om af te treden indien op het departement grote fouten werden gemaakt. Het idee, dat door sommigen werd aangehangen, dat ministers conventioneel verplicht waren om af te treden indien hun ambtenaren fouten maken, verhield zich echter slecht met de bestuurlijke realiteit, waarin ministers door de sterke groei van het ambtelijk apparaat steeds minder persoonlijk betrokken konden zijn bij de feitelijke gang van zaken op hun departement. Op basis van praktijkvoorbeelden lijkt daarom slechts sprake van een verplichting tot aftreden, wanneer de minister direct betrokken is geweest bij de geconstateerde departementale misstanden of wanneer sprake is van falend optreden van de minister persoonlijk. Of de minister in voorkomende gevallen ook daadwerkelijk aftreedt, is vooral een politieke kwestie. Bepalend is niet zozeer de constitutionele doctrine, maar de politieke realiteit waarin vooral de steun van de Prime Minister en van de eigen partij belangrijke factoren zijn. 48

\subsubsection{Bestuurlijke vernieuwingen}

De relatie tussen ministers en de ambtelijke dienst veranderde niet alleen door de sterke groei van het bestuurlijke apparaat, waardoor de invloed van ministers over de dagelijkse gang van zaken afnam. Ingrijpende bestuurlijke veranderingen droegen hier eveneens aan bij. Zo werden in de loop der tijd talloze zelfstandige overheidsdiensten opgericht, die geen deel uitmaken van de departementale structuur. Deze Non-Departmental Public Bodies (NDPBs, ook wel 'quangos' genoemd) functioneren "to a greater or lesser extent at arm's length from Ministers" en verrichten uiteenlopende taken; soms gaat het om adviserende of inspectietaken waarbij een zekere politieke onafhankelijkheid gewenst is, maar er zijn ook grote uitvoerende organen ('executive NDPBs'), "typically established in statute and carrying out executive, administrative, regulatory and/or commercial functions." 49 In de jaren 80 en 90 werden ook binnen de departementale organisatie grote hervormingen ingezet. Terwijl het aantal NDPBs weer enigszins werd teruggedrongen, 50 werden in het kader van het zogenaamde 'Next Steps'-programma binnen de departementen talloze 'executive agencies' gecreëerd. De hoofden van deze agencies werden verantwoordelijk voor de uitvoering van beleid en kregen daartoe een grote mate van beheersmatige en financiele zelfstandigheid. De taken en doelstellingen van deze agencies wordt vastgesteld door de minister; deze worden, vaak vergezeld van prestatieafspraken, vastgelegd in een 'framework document'. Met deze hervorming is getracht een

\footnotetext{
${ }^{48}$ Zie uitvoerig: Woodhouse 2004, p. 294-310 en Turpin \& Tomkins 2011, p. 576-586.

49 Cabinet Office, 'Public Bodies 2009', < http://www.civilservice.gov.uk/wpcontent/uploads/2011/09/PublicBodies2009_tcm6-35808.pdf>, p. 5. In 2009 kende de Britse centrale overheid in totaal 766 NDPBs, waarvan 192 organisaties tot de categorie 'executive' werden gerekend. Voorbeelden daarvan zijn de Environment Agency en de Homes and Communities Agency.

50 Turpin \& Tomkins 2011, p. 435-436.
} 
organisatorische scheiding aan te brengen: de minister blijft verantwoordelijk voor 'policy', daarbij geholpen door departementale beleidsafdelingen, terwijl de uitvoering van beleid met een grote mate van autonomie wordt overgelaten aan executive agencies binnen het departement. 51

Wat betekenen deze veranderingen voor de doctrine van ministeriële verantwoordelijkheid? In de literatuur wordt aangenomen, dat de ministeriële verantwoordelijkheid ten aanzien van NDPBs beperkt is tot de uitoefening van de wettelijke bevoegdheden die ministers nog hebben, zoals benoeming en ontslag van bestuurders, alsmede voor het beleid, effectiviteit en efficiency van de dienst ('poli$\mathrm{cy}^{\prime}$ ) in algemene zin. Ten aanzien van beheers- en uitvoeringsactiviteiten ('administration') is de minister niet of hooguit indirect verantwoordelijk. ${ }^{52} \mathrm{Bij}$ 'Next Steps agencies' is de ministeriële verantwoordelijkheid formeel niet beperkt, maar de organisatorische scheiding tussen beleid en uitvoering heeft ertoe geleid dat ministers in de praktijk vragen van parlementsleden over uitvoeringskwesties doorsturen naar de 'chief executives' van de betreffende agencies, die vervolgens de beantwoording op zich nemen. In hoeverre ministers feitelijk betrokken zijn in dit proces, bijvoorbeeld door vormen van inzage of goedkeuring, verschilt van agency tot agency. ${ }^{53}$

Bovengenoemde hervormingen bevestigen een bredere ontwikkeling in het denken over de betekenis van ministeriële verantwoordelijkheid gedurende de jaren 80 en 90, waarbij ministers zich steeds vaker uitsluitend verantwoordelijk achtten voor beleidsmatige beslissingen en niet voor operationele zaken, zelfs wanneer dit niet geformaliseerd was in de vorm van een 'executive agency'. Hierop bestond kritiek, zowel binnen als buiten het parlement. Immers, of dit onderscheid geformaliseerd was of niet, het bleek in de praktijk vaak erg moeilijk om vast te stellen waar de grens ligt en in hoeverre uitvoeringsgebreken te wijten zijn aan beleidsmatige of operationele beslissingen. De houding van ministers bleek in de praktijk vaak ambivalent. Aan de ene kant leek er, getuige het (deels geformaliseerde) onderscheid tussen beleid en uitvoering, behoefte aan een duidelijke scheiding van ministeriële en ambtelijke taken en verantwoordelijkheden. Aan de andere kant leek het onderscheid ministers de ruimte te geven om zich in voorkomende gevallen aan hun verantwoordelijkheid te onttrekken en op die manier de (politieke) schuldvraag af te schuiven op ambtenaren, dan wel om zich intensief te bemoeien met politieke gevoelige uitvoeringszaken. Het maken van een onderscheid tussen beleid en uitvoering, zo concludeert Woodhouse, "enabled the lines of responsibility to be blurred and allowed the minister to disclaim responsibility for serious departmental fault on the grounds that the fault was administrative, even if he knew, or should have known, what was happening." 54

\footnotetext{
51 Turpin \& Tomkins 2011, p. 432-433.

52 Turpin \& Tomkins 2011, p. 437. Zie ook Woodhouse 2004, p. 284.

53 Woodhouse 2004, p. 285.

54 Woodhouse 2004, p. 312-313. Een ander onderscheid, dat tussen 'accountability' en 'responsibility', dat in de jaren 90 steeds vaker gemaakt werd, had eenzelfde effect. Zie hierover ook: Woodhouse 2004, p. 313-316.
} 


\section{VERENIGD KONINKRIJK}

\subsubsection{Relatie ambtenaren-parlement}

Het samenspel van bestuurlijke hervormingen en de wijze waarop ministers hiermee omgingen hebben de politiek-ambtelijke verhoudingen de afgelopen decennia daarom aanzienlijk veranderd. Het klassieke beeld van de ambtenaar die in de schaduw van de verantwoordelijke minister opereert, was niet langer vanzelfsprekend: het optreden van ambtenaren, met name dat van 'chief executives', belandde gemakkelijker onder politieke schijnwerpers. Ook de relatie tussen ambtenaren en het parlement veranderde. Van oudsher vormde ministers de schakel tussen parlement en ambtelijke dienst; maar de komst van de 'select committees', die ten opzichte van de plenaire zaal een veel minder partijpolitiek geladen karakter bleken te hebben, bood parlementsleden de mogelijkheid om in het belang van een commissieonderzoek direct in contact te treden met ambtenaren.

Sindsdien verschijnen ambtenaren veelvuldig als getuige tijdens hoorzittingen, waar zij inlichtingen verschaffen omtrent aspecten van het regeringsbeleid. Ambtelijke richtlijnen bepalen echter, dat zij uitsluitend in naam en op aanwijzing van de verantwoordelijke minister medewerking kunnen verlenen aan onderzoeken door parlementaire commissies. Meer directe contacten tussen parlement en ambtelijke dienst hebben dus niet geleid tot aanpassing van de constitutionele doctrine. ${ }^{55}$ Tegelijkertijd laat de praktijk zien, dat diezelfde doctrine ook niet (langer) aan dergelijke contacten in de weg staat.

\subsubsection{Codificatie}

De doctrine van ministeriële verantwoordelijkheid, zo bleek hierboven, verloor in de loop van de twintigste eeuw veel van haar reële betekenis. Enerzijds waren politiekbestuurlijke verhoudingen onderhevig aan ingrijpende veranderingen, anderzijds werd de doctrine vertroebeld door weinig verhelderende discussies tussen ministers en parlement over de betekenis en reikwijdte van de conventie.

Tegen die achtergrond ontstond in de jaren 90 binnen het parlement behoefte aan meer houvast, met name ten aanzien van de vraag in hoeverre ministers op grond van de doctrine verplicht zijn om inlichtingen te verstrekken aan het parlement. De directe aanleiding was het rapport van de commissie-Scott, die in 1996 rapporteerde over de vermeende betrokkenheid van ministers en ambtenaren bij grootscheepse illegale wapenhandel met Irak gedurende de wapenboycot in de jaren '80. De commissie constateerde dat ministers tijdens deze affaire talloze malen verzuimd hadden om het parlement adequaat te informeren over het regeringbeleid inzake wapenexport naar Irak. Bovendien bleken antwoorden op parlementaire vragen verschillende malen misleidend. Hoewel niet duidelijk werd of ministers het parlement met opzet misleid hadden, concludeerde Scott dat bij gebrek aan volledige openheid van zaken het parlement werd belemmerd in zijn taak om de regering te controleren, waardoor het democratische proces werd ondermijnd. ${ }^{56}$

\footnotetext{
55 Zie ook: Woodhouse 2004, p. 328-329. Op de positie van ambtenaren in het kader van onderzoeken door 'select committees' wordt nader ingegaan in hoofdstuk 2.

56 Inquiry into Exports of Defence and Dual-Use Goods to Iraq and Related Prosecutions (Scott Report), HC 115 (1995-96), p. 1800-1801. Zie hierover ook Turpin \& Tomkins 2007, p. 135-136, 572 en Bradley \& Ewing 2007, p. 118.
} 
Voortbouwend op het Scott-rapport deed de Public Service Committee in de House of Commons vervolgens onderzoek naar de betekenis van de ministeriële verantwoordelijkheid. De commissie constateerde dat de bestaande onduidelijkheid over de betekenis van ministeriële verantwoordelijkheid, verwarring over termen als 'responsibility' en 'accountability', de focus op het aftreden van ministers en het vaststellen van blaam en verwijtbaarheid niet bevorderlijk was voor een effectieve parlementaire controle op de uitvoerende macht. De enige leidraad voor ministers die op dat moment bestond was de handleiding van de Prime Minister (Questions of Procedure for Ministers, de latere Ministerial Code), die niet bepaald uitblonk in helderheid. 57 De Public Service Committee achtte het vooral onaanvaardbaar dat voorschriften omtrent de verplichtingen van ministers jegens het parlement eenzijdig werden opgesteld door de Prime Minister en stelde voor om in beide huizen een parlementaire resolutie aan te nemen waarin de verplichtingen van ministers jegens het parlement op grond van hun verantwoordelijkheid in duidelijke bewoordingen zouden worden uiteengezet. 58

Beide huizen van het parlement volgden deze aanbeveling op. In maart 1997 namen zij ieder afzonderlijk een (nagenoeg identieke) resolutie aan inzake de relatie tussen ministers en het parlement. De resolutie aangenomen in het Lagerhuis ('Ministerial Accountability') luidt:

"That, in the opinion of this House, the following principles should govern the conduct of Ministers of the Crown in relation to Parliament:

(1) Ministers have a duty to Parliament to account, and be held to account, for the policies, decisions and actions of their Departments and Next Steps Agencies;

(2) It is of paramount importance that Ministers give accurate and truthful information to Parliament, correcting any inadvertent error at the earliest opportunity. Ministers who knowingly mislead Parliament will be expected to offer their resignation to the Prime Minister;

(3) Ministers should be as open as possible with Parliament, refusing to provide information only when disclosure would not be in the public interest, which should be decided in accordance with relevant statute and the Government's Code of Practice on Access to Government Information (Second Edition, January 1997);

(4) Similarly, Ministers should require civil servants who give evidence before Parliamentary Committees on their behalf and under their directions to be as helpful as possible in providing accurate, truthful and full information in accordance with the duties and responsibilities of civil servants as set out in the Civil Service Code (January 1996)." 59

Ministers hebben, zo blijkt uit deze resolutie, de onvoorwaardelijke plicht verantwoording af te leggen aan het parlement en accurate en juiste informatie te verschaf-

\footnotetext{
57 Zo werd in dit reglement gesteld dat ministers "will wish to be as open as possible to Parliament and the public", waarmee de suggestie werd gewekt dat openheid slechts een streven was in plaats van een constitutionele verplichting. Sir Burke Trend, Cabinet Secretary in de jaren '60, omschreef de $Q P M$ in eerste instantie als niet meer dan een aantal tips voor beginners, een etiquetteboek voor ministers. Zie verder Public Service Committee, Ministerial Accountability and Responsibility (1996), HC 313-I (1995-96), p. xxi en Riddell 2000, p. 79-80.

58 Public Service Committee, Ministerial Accountability and Responsibility (1996), HC 313-I (1995-96), p. xxviii-xxx. Het rapport bevat een ontwerpresolutie, die als basis diende voor de uiteindelijke resoluties die door beide huizen zijn aangenomen. Meer hierover in paragraaf 2.3.

${ }^{5}$ HC Deb vol 292, cols 1046-7, 19 maart 1997. De resolutie in het Hogerhuis is inhoudelijk identiek. Zie HL Deb vol 579, cols 1055-62, 20 maart 1997.
} 


\section{VERENIGD KONINKRIJK}

fen. Verder moeten ministers zo open mogelijk zijn tegenover het parlement; een weigering om informatie te verschaffen is alleen toegestaan wanneer het verstrekken ervan niet 'in the public interest' is. Ambtenaren die een getuigenis voor een parlementaire commissie afleggen dienen het parlement eveneens op een accurate, juiste en volledige wijze te informeren. Ook is duidelijk dat ministers onverkort aanspreekbaar ('accountable') zijn voor de intern-verzelfstandigde onderdelen van hun departement (de 'Next Steps agencies'). Met deze resoluties werd de ongeschreven conventie van individuele ministeriële verantwoordelijkheid in belangrijke mate gecodificeerd. De conventie kan hierdoor niet langer door de regering naar believen worden aangepast. ${ }^{60}$ In 1997 is ook de Ministerial Code, waarin onder meer de verplichtingen van ministers ten opzichte van het parlement zijn neergelegd, in overeenstemming gebracht met de parlementaire resoluties. ${ }^{61}$

Sindsdien kan dus worden gesteld dat er sprake is van een zekere mate van overeenstemming tussen parlement en regering over de betekenis van het beginsel van ministeriële verantwoordelijkheid voor hun onderlinge verhouding. ${ }^{62}$ Weir en Beetham beschouwen de resoluties als "significant, at least in symbolic way, for it shifts the locus of the duty of openness from the PM (and his rule-book) to Parliament." 63 Zij wijzen er echter ook op dat de regering zich sterk heeft bemoeid met de tekst van de resolutie; de ontwerpresolutie zoals die door de Public Service Committee was opgesteld is op een aantal punten sterk afgezwakt. ${ }^{64}$ Zo werd aan de bepaling over ambtenaren die voor parlementaire commissies verschijnen toegevoegd dat hun optreden altijd namens de minister en met inachtneming van zijn aanwijzingen plaatsvindt. De Public Service Committee had juist aanbevolen bepaalde ambtenaren zelf verantwoording te laten afleggen aan parlementaire commissies, met name wanneer aan hen uitvoerende taken zijn gedelegeerd zoals het geval is bij chief executives van verzelfstandigde executive agencies. ${ }^{65}$ De regering vreesde echter een aantasting van het niet-politieke karakter van de Britse ambtelijke dienst. 66

De gebezigde terminologie biedt veel bewegingsruimte aan ministers. Te denken valt aan de bepaling dat ministers 'as open as possible' moeten zijn, een voorschrift dat veel aan de persoonlijk beoordeling van de betreffende ministers overlaat. ${ }^{67}$ Door het gebruik van vage termen als 'accurate', 'truthful' en 'the public interest' geeft de resolutie de regering de gelegenheid om de betekenis en reikwijdte van de ministeriele verantwoordelijkheid in concrete situaties naar eigen inzicht en in haar eigen (politieke) voordeel in te vullen. Vooral wanneer het gaat om politiek

\footnotetext{
60 Turpin \& Tomkins 2007, p. 572.

61 Zie de meest recente versie, Ministerial Code 2007, § 1.2, b t/m e. De in de derde subparagraaf genoede Government's Code of Practice on Access to Government Information is inmiddels vervangen door de Freedom of Information Act 2000.

62 Zie ook Bradley \& Ewing 2007, p. 120, die benadrukken dat de parlementaire resoluties en het ministerieel reglement, hoewel ze geen kracht van wet hebben, een "statement of principle" vormen met "great authority on the relationship between government and Parliament."

${ }^{63}$ Weir \& Beetham 1999, p. 350.

${ }^{64}$ Zie Public Service Committee, Ministerial Accountability and Responsibility, HC 313-I (1995-96), p. xix.

65 Public Service Committee, Ministerial Accountability and Responsibility, HC 313-I (1995-96), p. liii.

66 Public Service Committee, Government Response, HC 67 (1996-97), p. v.

${ }^{67}$ Weir \& Beetham 1999, p. 350.
} 
gevoelige en mogelijk schadelijke onderwerpen, zoals de 'Arms-to-Iraq' affaire68, werkt dit in het nadeel van het parlement - althans van degenen die zich binnen het parlement bezig houden met parlementaire controle zoals de leden van select committees. Het voorstel van de Public Service Committee dat "The House recognises that Ministers may need, upon occasions, to withhold information, but believes they should do so only exceptionally" is niet terug in de uiteindelijke resolutie. Daarin is bepaald dat ministers mogen weigeren om informatie aan het parlement te verstrekken, wanneer dat niet in "the public interest" is. Hoewel niet duidelijk is wat de Public Service Committee bedoelde met 'only exceptionally', is ook het begrip 'public interest' niet nader gedefinieerd. Het voorstel van de commissie om, in lijn met de Code of Practice, de Ombudsman de bevoegdheid te geven te oordelen over klachten van parlementariërs over het niet verstrekken van informatie door de regering, werd overigens eveneens door de regering verworpen. 69

Het codificeren van het beginsel van ministerial accountability in twee parlementaire resoluties en in het ministerieel reglement is, ondanks hun tekortkomingen, een belangrijke ontwikkeling geweest in de discussie over de vraag welke verplichtingen ministers hebben jegens het parlement. Met de resoluties wordt bevestigd dat de ministeriële verantwoordelijkheid eerst en vooral meebrengt dat ministers een verantwoordingsplicht hebben ten opzichte van het parlement. De vraag of ministers in voorkomende gevallen moeten aftreden, blijft een politieke afweging waarbij de Prime Minister een sleutelrol speelt. Het maken van een onderscheid tussen 'policy' en 'administration' of tussen 'responsibility' en 'accountability' kan in elk geval niet langer worden aangewend als excuus om het parlement geen inlichtingen te verstrekken. Ook de erkenning van de rol van ambtenaren in het verantwoordingsproces via hun bijdrage aan onderzoeken van 'select committees' kan worden gezien als winst.

Duidelijk is echter tevens, dat een formele aanpassing van de doctrine van ministeriële verantwoordelijkheid aan de moderne verhoudingen tussen ministers, ambtenaren en parlement voor de regering destijds een brug te ver was. De spanningen die daaruit voortvloeien, gecombineerd met de bewegings- en interpretatieruimte die de resoluties bieden, maken toekomstige discussies over de ministeriële verantwoordelijkheid onvermijdelijk. ${ }^{70}$ In de jaren na de vaststelling van de resoluties verschoof de aandacht echter naar het functioneren van het parlement zelf.

\footnotetext{
${ }^{68}$ Zie het eerder genoemde rapport van de commissie-Scott.

${ }^{69}$ Zie Public Service Committee, Ministerial Accountability and Responsibility (1996), HC 313-I (1995-96), p. xxxi e.v. Zie verder Weir \& Beetham 1999, p. 351.

${ }^{70}$ In elk geval lijkt de verzelfstandiging van ambtelijke diensten over zijn hoogtepunt heen. De huidige coalitieregering heeft zelfs een ambitieus 'terugkeerprogramma' opgesteld, op grond waarvan een groot aantal NDPBs zal worden opgeheven en taken zullen worden overgeheveld naar de departementen. Doel hiervan is het verbeteren van de publieke verantwoording en het besparen van kosten. De Public Administration Select Committee, die de plannen onderzocht, reageerde sceptisch. Zie hierover nader: Turpin \& Tomkins 2011, p. 436-437.
} 


\subsubsection{Versterking parlementaire controle}

In 1997 trad, na een lange periode van conservatieve regeringen, een nieuwe regering aan onder leiding van Labourleider Tony Blair. De Labourregering was verkozen op basis van een ambitieus verkiezingsprogramma, waarin veel aandacht werd geschonken aan staatsrechtelijke vernieuwingen. Zo werden voorstellen gedaan op het gebied van decentralisatie ('devolution'), het kiesstelsel en het Hogerhuis. De nieuwe regering wekte in dit kader dan ook hoge verwachtingen. Enkele jaren later bleek echter in de verhouding tussen regering en parlement weinig veranderd te zijn; de regering kon rekenen op een overweldigende meerderheid in het Lagerhuis en bleek uiteindelijk weinig geïnteresseerd te zijn in versterking van de controlerende functie van het parlement. De kritiek richt zich enerzijds op de regering, die niet geneigd bleek om zijn dominante positie prijs te geven en mee te werken aan versterking van de parlementaire controlefunctie. Anderzijds richt de kritiek zich op het Lagerhuis zelf, waar te weinig werk gemaakt zou worden van effectieve controle van de uitvoerende macht. ${ }^{71}$ Onder druk van deze kritiek kwam het functioneren van de House of Commons daarom aan het einde van de eerste termijn van de regering-Blair opnieuw op de agenda.

In deze periode (2000-2001) verscheen een tweetal invloedrijke rapporten over versterking van de controlerende functie van het parlement. Het eerste is het rapport Strengthening Parliament van een commissie ingesteld door de toenmalige leider van de Conservatieve oppositie. De commissie onder leiding van Lord Norton had de taak "[t]o examine the cause of the decline in the effectiveness of Parliament in holding the executive to account, and to make proposals for strengthening democratic control over the Government". De commissie stelt dat het Britse staatsrechtelijke model (het 'Westminster model') niet fundamenteel zou moeten worden herzien, maar constateert wel dat het systeem onder druk staat en dat de verhouding tussen regering en parlement onvoldoende in balans is. Het parlement schiet met name tekort, zo concludeert de commissie, in zijn rol als controleur van de regering ("calling government to account"). ${ }^{72}$ De commissie doet een groot aantal voorstellen om de geconstateerde onbalans te corrigeren. Veel voorstellen hebben betrekking op de parlementaire onderzoekscommissies (departmental select committees), die verder zouden moeten worden versterkt. Daarnaast dient de oppositie meer financiële middelen te krijgen; dienen backbenchers van beide partijen een budget te krijgen; en dient er een alternatief carrièrepad te worden gecreëerd voor parlementsleden die zich willen toeleggen op controle van in plaats van deelname aan de regering. Ook stelt de commissie-Norton dat de controlerende activiteiten van het Hogerhuis verder moeten worden ontwikkeld en dat het parlement structureel meer aandacht moet besteden aan belasting- en begrotingszaken. Tegelijkertijd dient de regering aan ban-

\footnotetext{
${ }^{71}$ Het traditionele beeld van het 'elective dictatorship' leek door de regering-Blair en zijn trouwe Labour-fractie te worden bevestigd. Het eerder genoemde onderzoek van Philip Cowley uit 2002 en 2005 wijst overigens in een andere richting, namelijk die van een steeds groter wordende groep backbenchers die bereid zijn actief en op eigenzinnige wijze de eigen regering te bekritiseren en te controleren. Zie o.a. Cowley 2005. Zie ook Turpin \& Tomkins 2007, p. 130-131.

72 Norton Commission 2000, p. 59.
} 
den te worden gelegd: zo zou het aantal ministers moeten worden beperkt en moet de regering verplicht worden om belangrijke aankondigingen in het parlement te doen in plaats van eerst aan de media. ${ }^{73}$

Het tweede rapport, The Challenge for Parliament: Making Government Accountable verscheen kort daarna en is afkomstig van een commissie van parlementariërs en wetenschappers, ingesteld door de Hansard Society. De commissie was gevraagd te onderzoeken "how Parliament carries out its role as scrutineer of the words and actions of the Executive and assess whether the structure and processes are in need of change." 74 De commissie onderzocht de verschillende manieren waarop de beide huizen van het parlement de regering controleren ("pursue accountability"), bijvoorbeeld via debatten, het vragenrecht en parlementaire onderzoeken (select committee inquiries), maar keek ook naar de niet-parlementaire wegen waarlangs de regering wordt gecontroleerd, zoals rechterlijke toetsing. De bevindingen van de Hansard Society-commissie over het functioneren van het parlement - "the principle means for holding Government to account between general elections on behalf of the public" - liegen er niet om:

\footnotetext{
"Serious gaps and weaknesses in the working of accountability were found. Scrutiny of Government by MPs and peers is neither systematic nor rigorous. The quality of information provided to Parliament is variable. Parliamentary inquiries have a poor record in locating responsibility for failures by the Executive, ensuring that the Government acts upon them and in following up recommendations for improvement. A survey of MPs' views carried out especially for the Commission showed that Members themselves are sceptical about Parliament's ability to hold the Government to account." 75
}

Deze tekortkomingen moeten dringend worden aangepakt, zo betoogt de commissie. Het parlement dient te worden hervormd. De commissie betoogt: "Parliament should be at the apex of a system of accountability - drawing more effectively on the investigations of outside regulators and commissions, enhancing the status of select committees and clarifying the role of Parliament and its politicians." Verder dienen de controleactiviteiten van het Lagerhuis en het Hogerhuis beter op elkaar te worden afgestemd en is het van groot belang dat het parlement "reflect and articulate issues of public concern." 76

Om deze doelstellingen, gericht op het verbeteren van parlementaire controle van de uitvoerende macht, te bereiken, bevat het rapport zeven 'principles' voorzien van een reeks gedetailleerde aanbevelingen. Zo moet het parlement de spin in het web (the "apex") van onafhankelijke toezichthouders en commissies die controle uitoefenen op de uitvoering van publieke diensten worden, waarbij de verhouding tussen het parlement en deze externe instanties wordt geformaliseerd en de controle gesystematiseerd (1). Parlementariërs moeten een actieve controlerende houding aannemen; het parlement moet daartoe een "culture of scrutiny" ontwikkelen die de

\footnotetext{
${ }^{73}$ Zie voor een overzicht van alle aanbevelingen: Norton Commission 2000, p. 61-64. De specifieke voorstellen uit het rapport van de commissie-Norton, met name ten aanzien van de select committees, komen uitvoeriger aan de orde in de volgende paragrafen.

${ }^{74}$ Hansard Society Commission 2001, p. vii.

${ }^{75}$ Hansard Society Commission 2001, p. x.

${ }^{76}$ Hansard Society Commission 2001, p. x.
} 
verschillende rollen die politici moeten vervullen (partijloyaliteit vs. parlementaire controle) beter in balans doet komen (2). Het commissiestelsel van het Lagerhuis is het "principle vehicle for promoting this culture of scrutiny and improving parliamentary effectiveness" en moet verder worden uitgebouwd en ontwikkeld; zo zouden de functies van de select committees nader moeten worden gedefinieerd, zouden nieuwe onderzoeksmethoden moeten worden toegepast (subcommissies, rapporteurs), zou het salaris van commissievoorzitters moeten worden verhoogd en zouden de ambtelijke ondersteuning en financiële middelen van commissies moeten worden versterkt (3). Verder moeten debatten in de plenaire zaal (Chamber) aantrekkelijker worden (4), moet financiële controle van de regering systematischer en grondiger worden aangepakt (5) en moeten de controleactiviteiten in het Hogerhuis verder worden uitgebouwd en gecoördineerd (6). Tenslotte stelt de commissie dat het parlement op zijn sterkst is wanneer de publieke opinie wordt gearticuleerd en gemobiliseerd; beide huizen moeten daarom hun communicatie met het publiek verbeteren (7). .77

Beide rapporten hebben in belangrijke mate bijgedragen aan de vorming van een parlementaire hervormingsagenda. ${ }^{78}$ Ook binnen het parlement zijn in deze periode veel voorstellen totstandgekomen die de positie van met name het Lagerhuis zouden kunnen versterken. Zo bracht de Liaison Committee, de commissie waarin alle voorzitters van de departmental select committees verenigd zijn, in maart 2000 een rapport uit getiteld Shifting the Balance: Select Committees and the Executive met een grote hoeveelheid aanbevelingen ter versterking van het stelsel van onderzoekscommissies in het Lagerhuis. ${ }^{79}$ De Public Administration Select Committee (PASC) is eveneens zeer actief op het terrein van staatsrechtelijke en bestuurlijke hervormingen. 80

De talloze concrete voorstellen ter verbetering en versterking van de controlerende functie van het parlement (met name het Lagerhuis), voornamelijk afkomstig van staatsrechtbeoefenaren, denktanks en hervormingsgezinde backbenchers, leidden niet direct tot ingrijpende parlementaire hervormingen. Hiervoor zijn twee, min of meer voor de hand liggende oorzaken aan te wijzen. De eerste is de opstelling van de regering. Deze heeft, zoals gezegd, ondanks de hoge verwachtingen, sinds 1997 betrekkelijk weinig initiatieven genomen om tot implementatie van hervormingen op dit terrein te komen. Bij het aantreden van de regering-Blair waren de verwachtingen hooggespannen, niet in de laatste plaats omdat de nieuwe regering een speciale par-

\footnotetext{
77 Zie verder Hansard Society Commission 2001, p. x-xi. Een lijst met de 47 aanbevelingen op basis van de genoemde principles is vinden op p. 107-113. Het rapport van de Hansard Society Commission komt uitvoeriger aan de orde in de volgende paragrafen.

78 Zie bijv. Beetham e.a. 2002, p. 135.

${ }^{79}$ Liaison Committee, Shifting the Balance: Select Committees and the Executive, HC 300 (1999-2000). Een jaar later publiceerde de commissie een vervolgrapport getiteld Shifting the Balance: Unfinished Business, HC 321 (2000-01).

${ }^{80}$ Zie bijv. Ministerial Accountability and Parliamentary Questions, HC 820 (1997-98); Quangos, HC 209-I (1998-99); Taming the Prerogative: Strengthening Ministerial Accountability to Parliament, HC 422 (2003-04); Government by Inquiry, HC 51-I (2004-05); The Ministerial Code: the case for independent investigation, HC 1457 (2005-06); Politics and Administration: Ministers and Civil Servants, HC 122-I (2006-07).
} 
lementaire commissie in het leven riep om het Lagerhuis te moderniseren. Deze Modernisation Committee staat van begin af aan onder leiding van de Leader of the House of Commons, die zowel voorzitter van de Labourfractie in het Lagerhuis als lid van het Cabinet is. De resultaten van deze commissie op hervormings- en versterkingsvlak zijn zeer beperkt gebleken. De commissie wist te bewerkstelligen dat er een extra vergaderzaal werd gecreëerd (Westminster Hall) waar meer tijd en ruimte is om bijvoorbeeld rapporten van select committees met de verantwoordelijke ministers te bespreken. Ook werden de werk- en vergadertijden van het Lagerhuis aangepast aan de hedendaagse eisen.

In 2002 wist de commissie, destijds onder leiding van de ambitieuze Robin Cook, tevens een bescheiden pakket aan maatregelen ter versterking van de select committees door het Lagerhuis te loodsen. ${ }^{81}$ Een van de meest ingrijpende voorstellen van Cook, het hervormen van de selectieprocedure voor leden van select committees waarbij de selectie zou uit de handen van de party whips genomen worden en aan een nieuwe nominatiecommissie bestaande uit parlementaire senioren zou worden overgelaten (waarvan gehoopt werd dat deze zich minder zou laten leiden door het regeringsbelang), werd echter na een effectieve actie van de regeringswhips door een meerderheid verworpen. ${ }^{82}$ De invloed van de whips op de nominatie van de leden van select committees is een belangrijk punt van kritiek, omdat hierdoor niet altijd de meest geschikte (en wellicht meest kritische) parlementariërs worden geselecteerd.

Pas in 2010, toen de Labourregering van Gordon Brown op zijn eind liep en het parlement gebukt ging onder een omvangrijk declaratieschandaal, bleek er weer ruimte voor verdere hervormingen. Een hervormingscommissie onder leiding van de vooraanstaande Labour-backbencher Tony Wright kwam met verregaande voorstellen. Twee van deze voorstellen werden uiteindelijk door regering en parlement aanvaard: een rechtstreekse, geheime verkiezing van de leden en voorzitters van select committees, alsmede maatregelen ter vermindering van de invloed van de regering op de parlementaire agenda. ${ }^{83}$

\subsubsection{Andere verantwoordings- en controlemechanismen}

In het voorgaande werd, vanuit de beginselen van 'responsible and accountable government', ingegaan op de betekenis en toepassing van de ministeriële verantwoordingsplicht en de parlementaire controletaak. Buiten het genoemde parlementaire verantwoordings- en controleproces is het Britse openbaar bestuur onderworpen aan verschillende andere vormen van verantwoording en controle. Deze mechanismen vervullen soms functies die in de parlementaire context ontbreken, zoals individuele rechtsbescherming. Andere zijn juist bedoeld om het parle-

\footnotetext{
81 Sindsdien krijgen commissievoorzitters een extra toelage op hun parlementaire vergoeding. Ook werd de ambtelijke en specialistische ondersteuning van commissies verder uitgebreid en werd een lijst met 'principle objectives of select committees' opgesteld. Zie verder Modernisation Committee, Select Committees, HC 224-I (2001-02).

82 Zie Beetham e.a. 2002, p. 138.

${ }^{83}$ House of Commons Reform Committee, Rebuilding the House, HC 1117 (2008-09). Zie ook Russell 2011. Meer over de selectie van commissieleden in hoofdstuk 3.
} 
mentaire proces te versterken en zijn daarom uitdrukkelijk met het parlement verweven. ${ }^{84} \mathrm{Om}$ enig inzicht te verschaffen in de context waarin het parlement zijn controlefunctie vervult, worden de belangrijkste andere mechanismen hieronder kort geschetst.

Rechterlijke controle. Met de groei van de overheidsbemoeienis in de loop van de twintigste eeuw nam ook het belang van individuele rechtsbescherming toe. De belanghebbende burger heeft, indien de wet daarin voorziet, de mogelijkheid om een overheidsbeslissing op inhoudelijke gronden bij de rechter aan te vechten ('appeal'). De burger maakt daarnaast steeds vaker gebruik van 'judicial review': een inherente rechtsgang in het Engelse en Schotse bestuursrecht die erop gericht is om na te gaan of overheidsinstanties op een zorgvuldige, faire wijze hebben gehandeld en er geen sprake is van misbruik of overschrijding van bevoegdheden. Deze rechterlijke procedure wordt niet alleen gezien als een instrument voor individuele rechtsbescherming, ook als een middel om de kwaliteit van het openbaar bestuur in algemene zin te bevorderen. ${ }^{85}$

Parlementaire ombudsman. Naast rechterlijke controle kent het Verenigd Koninkrijk sinds 1967 een ombudsman op het niveau van de centrale overheid. Deze Parliamentary Commissioner for Administration, zoals het instituut heet, behandelt klachten van burgers over wanbestuur ('maladministration') binnen de departementen en andere centrale overheidsinstellingen. Burgers kunnen de ombudsman echter niet rechtstreeks benaderen: klachten kunnen alleen via een parlementslid worden ingediend. Deze (niet onomstreden) brugfunctie hangt samen met het oorspronkelijke doel van het instituut: het verbeteren van de controlerende functie van het parlement. De ombudsman wordt benoemd voor een eenmalige termijn van maximaal zeven jaar en kan slechts worden ontslagen op vordering van beide huizen van het parlement. Het werk van de ombudsman wordt gemonitord door de Public Administration Select Committee, die aan de hand van rapporten en jaarverslagen bredere tendensen in het functioneren van het openbaar bestuur kan signaleren. Daarnaast gebruikt de commissie haar onderzoeksinstrumenten en politieke invloed om ministers aan te spreken op eventuele departementale nalatigheid in het opvolgen van de rapporten van de ombudsman. ${ }^{86}$

Financiële controle. Op het gebied van financiële controle is een belangrijke rol weggelegd voor de National Audit Office, die onder leiding staat van de Comptroller and Auditor General (C\&AG). De NAO controleert de rekeningen ('auditing') van de departementen, executive agencies en andere publieke diensten. Daarnaast doet de NAO onderzoek naar de effectiviteit en efficiëntie van overheidsuitgaven. De resultaten van deze studies worden gerapporteerd aan de Public Accounts Committee (PAC), een bijzondere, in 1861 opgerichte commissie van de House of Commons. Het voorzitterschap van deze commissies is volgens conventie altijd een lid van de oppositie. Deze commissie behandelt de rapporten en houdt hoorzittingen met de betrokken ambtenaren en ministers over de bevindingen. ${ }^{87}$

\footnotetext{
${ }^{84}$ Sommige van deze mechanismen komen daarom verderop nog opnieuw aan de orde.

85 Zie nader: Turpin \& Tomkins 2011. p. 666.

86 Turpin \& Tomkins 2011, p. 627-628. Hierover meer in par. 4.3.1.

87 Zie hierover nader: par. 4.3.2.
} 
Openbare onderzoeken. Een bijzondere figuur die hier nog vermelding verdient is die van het zogenaamde openbare onderzoek ('public inquiry'). Een 'public inquiry' kan door de regering worden ingesteld wanneer er sprake is van maatschappelijke onrust ('public concern') en een breed gevoelde behoefte aan onafhankelijk onderzoek naar ingrijpende gebeurtenissen of schandalen. Vaak gaat het om een grootschalige feitenanalyse bedoeld om te achterhalen wat er gebeurd is, wie verantwoordelijk is en welke lessen kunnen worden geleerd voor de toekomst. ${ }^{88} \mathrm{Fa}$ lend overheidsoptreden (of het vermoeden daarvan) en het handelen van ministers en ambtenaren spelen daarbij vaak een rol. Deze onderzoeken worden uitgevoerd door een ad hoc ingestelde commissie, soms onder voorzitterschap van een (oud)rechter. Voorbeelden zijn het Scarman-onderzoek naar de rellen in de Londense wijk Brixton van 1981, de Saville-commissie die de gebeurtenissen op 'Bloody Sunday' onderzocht en het in 2011 ingestelde onderzoek geleid door rechter Leveson naar aanleiding van een omvangrijk afluisterschandaal in de Britse pers.

Openbare onderzoeken van dit type ontstonden in de jaren 20 van de vorige eeuw. Voordien was het gebruikelijk dat voor dergelijke onderzoeken naar grote misstanden een tijdelijke parlementaire 'select committee' of een staatscommissie ('royal commission') werd ingesteld. Hierin kwam verandering in 1913, toen een onderzoek naar corruptie binnen de liberale regering bij de aanleg van een telegraafnetwerk. De parlementaire commissie, bestaande uit zowel liberale en conservatieve leden, kon het niet eens worden. De meerderheid concludeerde dat de verdachte ministers niets te verwijten viel, terwijl de conservatieve leden in een minderheidsrapport wel degelijk onoirbaar handelen constateerden. Over de uitkomst van het onderzoek werd vervolgens in het Lagerhuis langs partijlijnen gestemd en de ministers konden aanblijven. ${ }^{89}$ Onvrede over deze gang van zaken leidde in 1921 tot wetgeving, op grond waarvan het parlement, middels resoluties in beide kamers, kon besluiten tot de instelling van een 'tribunal of inquiry' met dezelfde rechten en bevoegdheden als een rechtbank, bijvoorbeeld ten aanzien van het verhoren van getuigen en het verzamelen van bewijsmateriaal. ${ }^{90}$

Hoewel de figuur van de 'tribunal of inquiry' sindsdien verschillende malen is toegepast, bleken ministers de afgelopen decennia, wanneer bij een groot incident of schandaal de roep om een onafhankelijk onderzoek niet te weerstaan was, steeds vaker de voorkeur te geven aan buitenwettelijke onderzoekscommissies die zij geheel naar eigen smaak konden vormgeven. Het onderzoek van Lord Hutton naar de dood van Dr. Kelly in 2003 is daar een voorbeeld van. Dergelijke commissies konden uiteraard geen gebruik maken van speciale onderzoeksbevoegdheden. De wildgroei aan onderzoekscommissies leidde in 2005 tot een wetsherziening, bedoeld om op dit vlak weer enige structuur aan te brengen. ${ }^{91} \mathrm{Bij}$ die gelegenheid is de betrokkenheid van het parlement echter verder beperkt: voortaan is het besluit tot een (wettelijk) openbaar onderzoek volledig in handen van ministers. Het parlement behoeft nog

\footnotetext{
88 Bradley \& Ewing 2007, p. 710-711.

${ }^{89}$ Bradley \& Ewing 2007, p. 711-712.

90 Zie de Tribunals of Inquiry (Evidence) Act 1921.

91 Daarnaast was er behoefte aan strictere kaders nadat de Saville Inquiry naar de gebeurtenissen op Bloody Sunday zich gedurende twaalf jaar had voortgesleept en vele miljoenen had gekost.
} 
slechts op de hoogte te worden gesteld. ${ }^{92}$ Een uitgewerkt voorstel van de Public Administration Select Committee om ook een door het parlement ("the great forum of the nation") geïnitieerd onafhankelijk onderzoek mogelijk te maken in de vorm van een 'parliamentary commission of inquiry' 93 , bestaande uit een combinatie van parlementaire en niet-parlementaire leden en voorzien van afdwingbare onderzoeksbevoegdheden, is tot op heden niet opgevolgd. ${ }^{94}$

\subsection{Conclusie}

Bij het bepalen van de constitutionele verhouding tussen regering en parlement in het Verenigd Koninkrijk moet, bij afwezigheid van een geschreven grondwettelijke tekst, voornamelijk worden teruggevallen op de ongeschreven beginselen van het Britse staatsrecht, in het bijzonder de grondslagen van het Britse parlementaire stelsel en de vertegenwoordigende democratie. In de Britse staatsrechtelijke literatuur wordt de verhouding tussen regering en parlement vaak beschreven aan de hand van het beginsel van 'responsible and accountable government'. Onder het begrip 'responsible and accountable government' kan enerzijds worden verstaan dat regeerders zich middels periodieke verkiezingen dienen te onderwerpen en verantwoording dienen af te leggen aan de geregeerden en tussentijds aan hun vertegenwoordigers in het parlement. Anderzijds vereist dit dat het parlement de regeerders voortdurend ter verantwoording roept en uitleg verlangt over het gevoerde beleid en de genomen beslissingen.

De ministeriële plicht om het parlement inlichtingen en uitleg te geven over het regeringsbeleid en de uitvoering daarvan is in de loop der tijd steeds verder verankerd in de Britse staatsrechtelijke doctrine. In de negentiende eeuw kwam eerst de collectieve ministeriële verantwoordelijkheid tot ontwikkeling, op grond waarvan de regering als eenheid naar buiten dient te treden en ministers verantwoordelijk zijn voor het algemene regeringsbeleid. In het verlengde hiervan is de conventie van de individuele ministeriële verantwoordelijkheid ontstaan. De kern van deze conventie is dat ministers verantwoording dienen af te leggen voor hun persoonlijk handelen, het handelen als minister en het handelen van het aan hen ondergeschikte ambtelijke apparaat. Na een jarenlange discussie over de precieze betekenis en omvang van de ministeriële verantwoordingsplicht, bereikten regering en parlement vlak voor het aantreden van de Labourregering in 1997 overeenstemming over een gezamenlijke beschrijving van de individuele ministeriële verantwoordelijkheid, die werd gecodificeerd middels parlementaire resoluties in beide Huizen en opgenomen in de Ministerial Code. Deze beschrijving bevat een algemene plicht voor ministers om verantwoording af te leggen over het beleid, de besluiten en de handelingen van hun departementen en bijbehorende 'next steps agencies'. Zij zijn verplicht om accurate

\footnotetext{
92 Zie Inquiries Act 2005, art. 6.

93 Public Administration Select Committee, Parliamentary Commissions of Inquiry, HC 473 (2007-08).

${ }^{94}$ In juli 2012 is weliswaar een Parliamentary Commission on Banking Standards ingesteld, maar het lijkt erop dat het hier feitelijk gaat om een 'joint select committee' aangezien de leden afkomstig zijn uit de beide kamers en de toegekende bevoegdheden vergelijkbaar zijn met die van de reguliere select committees. Zie nader: Gay 2012.
} 
en waarheidsgetrouwe informatie te verschaffen aan het parlement en dienen zo open mogelijk te zijn. Wel kunnen zij inlichtingen weigeren wanneer openbaarmaking van informatie niet in het openbaar belang zou zijn.

Uit de ministeriële verantwoordingsplicht kan worden afgeleid dat het parlement de constitutionele taak heeft de regering - en meer in het algemeen de uitvoerende macht - voortdurend te controleren. De parlementaire controletaak vloeit als het ware voort uit de aard van het Britse parlementaire stelsel. Het controleren van de regering kan zelfs worden gezien als de voornaamste functie van het parlement, zoals de Britse politiek filosoof John Stuart Mill reeds in 1861 stelde: "Instead of the function of governing, for which it is radically unfit, the proper office of a representative assembly is to watch and control the government" ${ }^{95}$ Deze stelling beschrijft in essentie de nog steeds geldende constitutionele verhouding tussen regering en parlement in het Verenigd Koninkrijk, al is de verwezenlijking van de parlementaire controlefunctie in de tussentijd sterk onder druk komen te staan door de ontwikkeling van het partijenstelsel en de sterke groei van de uitvoerende macht. In de loop der tijd zijn, mede daarom, ook andere verantwoordings- en controlemechanismen ontstaan, zoals de functie van de parlementaire ombudsman en de figuur van het openbare onderzoek. Toch is in 1979 een belangrijke stap gezet in versterking van de parlementaire controlefunctie met de invoering van het stelsel van permanente onderzoekscommissies ('departmental select committees') in het Lagerhuis. Het stelsel van permanente onderzoekscommissies wordt over het algemeen als een succesvol controle-instrument gezien. De commissies hebben de afgelopen decennia een stevige plaats binnen het parlement weten te bemachtigen.

Aan het begin van de 21e eeuw, wellicht mede in het licht van de geringe vernieuwingen die de regering-Blair bleek te willen realiseren, werden van verschillende kanten nieuwe voorstellen gedaan om de positie en functie van het parlement als de voornaamste constitutionele controleur van de regering te versterken. Het verder versterken van de vaste parlementaire onderzoekscommissies vormde in deze discussie een belangrijk onderdeel. In 2010 bleek er uiteindelijk voldoende politieke wil in het parlement te zijn om de selectie van commissieleden, een jarenlang discussiepunt, voortaan middels een geheime stemming te laten verlopen en daarmee uit handen van de partijmanagers ('whips') te nemen.

Het Britse stelsel van permanente onderzoekscommissies, zoals dat de afgelopen decennia tot ontwikkeling is gekomen, is dus nog steeds in ontwikkeling. In de volgende hoofdstukken worden de commissies, hun bevoegdheden, organisatie en werkwijze nader bezien.

95 Mill 1861, p. 282. 
VERENIGD KONINKRIJK 


\section{Hoofdstuk 2. Onderzoeksrecht en onderzoeksbevoegdheden}

\subsection{Inleiding}

Parlementair onderzoek vindt in het Britse parlement, zoals ook elders gebruikelijk is, in commissieverband plaats. Zowel het Lagerhuis als het Hogerhuis kennen vaste onderzoekscommissies, de 'select committees'. Select committees, zo stellen Blackburn en Kennon, "fulful a function which the House itself could not possibly undertake - they can hear evidence from outsiders, deliberate informally and draw up conclusions." 1 Select committees moeten worden onderscheiden van de voornaamste andere commissievorm in het Lagerhuis, de zogenaamde 'public bill committees' (voorheen 'standing committees'). ${ }^{2}$ Ook het Hogerhuis kent verschillende andere soorten commissies, voornamelijk ten behoeve van de behandeling van wetsvoorstellen. ${ }^{3}$

Select committees kunnen worden ingezet voor verschillende onderzoekstaken. De onderzoeksactiviteiten van de meeste select committees zijn erop gericht het regeringsbeleid en de uitvoering daarvan te controleren. Bekendste voorbeelden daarvan zijn de departmental select committees, die ieder een bepaald ministerie en daaraan gerelateerde overheidsorganen controleren. Er zijn echter ook select committees die tot taak hebben om bepaalde procedurele of organisatorische aangelegenheden van het Huis te onderzoeken. Incidenteel worden select committees ingesteld voor de behandeling van (concept-)wetsvoorstellen. ${ }^{4}$ Meer over de verschillende functies, de samenstelling en de werkwijze van select committees volgt in het derde hoofdstuk.

In dit hoofdstuk staan de onderzoeksbevoegdheden van select committees centraal. Daarbij wordt de nadruk gelegd op de select committees in het Lagerhuis. De situatie in het Hogerhuis komt slechts aan de orde, wanneer deze afwijkt van die in het Lagerhuis. ${ }^{5}$ Alvorens de bevoegdheden van commissies in kaart te brengen, wordt kort ingegaan op de herkomst van het parlementaire onderzoeksrecht.

\footnotetext{
1 Blackburn \& Kennon 2003, p. 398.

2 Daarnaast kent het Lagerhuis nog 'Committees of the Whole House' en de 'private bill committees', die hier verder buiten beschouwing blijven. Zie Blackburn \& Kennon 2003, p. 384, 398.

${ }^{3}$ Zie voor een overzicht: Rodgers \& Walters 2006, p. 234-237.

${ }^{4}$ Zie verder Blackburn \& Kennon 2003, p. 398.

${ }^{5}$ Zie ook Erskine May 2004, p. 722 e.v.
} 


\subsection{Het parlementaire onderzoeksrecht}

De Britse staatsrechtelijke doctrine biedt geen concreet constitutioneel aanknopingspunt waarop de bestaande parlementaire onderzoekspraktijk is gestoeld. Een parlementair recht van onderzoek is als zodanig in het staatsrecht niet te vinden. Een expliciete erkenning ervan is dan ook zeldzaam. ${ }^{6}$ In het meest gezaghebbende handboek op het gebied van het parlementaire staatsrecht, Erskine May, wordt het onderzoeksrecht - anders dan bijvoorbeeld het vragenrecht en het debatrecht - niet afzonderlijk behandeld. Alleen het bestaan van specifieke onderzoeksbevoegdheden wordt op verschillende plaatsen beschreven. ${ }^{7}$ Het lijkt erop dat het parlementaire onderzoeksrecht als een vanzelfsprekendheid wordt gezien.

Ook ten aanzien van de herkomst van de wel veelvuldig aangehaalde parlementaire onderzoeksbevoegdheden, vervat in de "power to send for persons, papers and records", bestaat echter onduidelijkheid. Een mogelijke grondslag kan gevonden worden in de middeleeuwse rol van het Engelse parlement als rechtsprekende instantie ('High Court of Parliament'). Als rechterlijke instantie moest het parlement kunnen beschikken over de nodige informatie. Weigerachtigheid of obstructie door derden kon gestraft worden op basis van 'contempt'. ${ }^{8}$

Helemaal sluitend is deze historische verklaring voor het bestaan van PPRbevoegdheden en de daaraan gekoppelde strafrechtelijke contempt-bevoegdheid echter niet. Dat het Hogerhuis, althans tot voor kort, (mede) kan worden gezien als een rechtsprekende instantie, wordt niet betwijfeld. ${ }^{9}$ Anders ligt dit bij het Lagerhuis, waar de rechtsprekende functie historisch minder goed verklaarbaar is. Niettemin heeft het Lagerhuis deze strafrechtelijke bevoegdheden tot in de zeventiende eeuw wel uitgeoefend. ${ }^{10}$ Woodhouse meent daarom dat er sprake is van een "medieval misconception", op grond waarvan het Lagerhuis zich de bevoegdheid "to send for persons, papers and records' (PPR) en de (mede) daaruit voortvloeiende strafrechtelijke jurisdictie als het ware heeft kunnen toe-eigenen.

Naast de historische inconsistentie zijn ook de taak en de positie van het parlement in de loop der tijd veranderd. De functie van rechtspraak is naar de achtergrond verdwenen en met name het Lagerhuis heeft zich sterk ontwikkeld als wetgevende kamer. Woodhouse stelt daarom dat het veel aannemelijker is dat de PPR-rechten aan het parlement moeten worden toegeschreven omdat deze bevoegdheden nu eenmaal horen bij "the fundamental right of Parliament to information, not

\footnotetext{
${ }^{6}$ Zo schrijft de Joint Committee on Parliamentary Privilege in 1999 in haar rapport: "The right to institute inquiries and require the attendance of witnesses and production of documents ('to send for persons, papers, and records') is part of the law and custom of Parliament." Joint Committee on Parliamentary Privilege, First Report, HL 43-I (1998-99), § 234. Op dat laatste element, het recht om getuigen op te roepen, wordt vervolgens wel nader ingegaan, op het eerste echter niet.

7 Zie bijv. Erskine May 2004, p. 74 ('Power to summon witnesses'), 149 e.v. ('Obstructing witnesses and others'), 739 e.v. ('Select Committees in the House of Commons').

${ }^{8}$ Woodhouse 1994, p. 178. Zie ook Erskine May 2004, p. 92.

${ }^{9}$ Erskine May gaat er zelfs vanuit dat select committees in het Hogerhuis automatisch over de PPRbevoegdheden beschikken, dus zonder dat deze eerst moeten worden gedelegeerd door het Huis. Erskine May 2004, p. 722.

${ }^{10}$ Erskine May 2004, p. 92.
} 
in any judicial capacity but in its scrutinizing role as a legislature."11 Ook verschillende parlementaire commissies, waaronder de Procedure Committee die in 1977 het nieuwe stelsel van vaste select committees ontwierp, gaan uit van het idee van een fundamenteel parlementair recht op informatie als grondslag voor de bestaande onderzoeksbevoegdheden. ${ }^{12}$

Hoe het ook zij, dát zowel het Hogerhuis als het Lagerhuis kunnen beschikken over een aantal klassieke onderzoeksbevoegdheden wordt in de doctrine noch in de praktijk betwist. Het Britse parlement maakte al sinds de late middeleeuwen zo nu en dan gebruik van tijdelijke onderzoekscommissies ('select committees'). Dergelijke commissies werden ingesteld voor allerlei kwesties, bijvoorbeeld om een einde te maken aan godsdienstige disputen, om onderzoek te doen naar vermeende malversaties van parlementsleden, of om de militaire mislukkingen tijdens de Krimoorlog in kaart te brengen. ${ }^{13}$ De discussie spitst zich veeleer toe op de beperkingen die aan de uitoefening van parlementaire onderzoeksbevoegdheden door select committees kleven. Sommige beperkingen lijken algemeen geaccepteerd. Zo kunnen commissies alleen over onderzoeksbevoegdheden beschikken wanneer en voor zover het Huis deze bevoegdheden aan hen delegeert en kunnen strafrechtelijke bevoegdheden ('contempt') alleen door het Huis zelf worden uitgeoefend. ${ }^{14}$ Minstens zo belangrijk zijn voorts de beperkingen die gelden bij het verkrijgen van mondelinge en schriftelijke inlichtingen van ministers en ambtenaren, die veelal verband houden met de conventies rondom de ministeriële verantwoordelijkheid. De betekenis van deze conventie leidt in de praktijk zo nu en dan tot spanningen tussen parlementaire commissies en ministers. Parlementaire commissies zien in de ministeriële verantwoordelijkheid eerst en vooral een verplichting om adequaat en ruimhartig verantwoording af te leggen aan het parlement (en haar commissies), terwijl ministers de ministeriële verantwoordelijkheid in voorkomende gevallen juist gebruiken als een argument om medewerking te weigeren, bijvoorbeeld om het verstrekken van bepaalde departementale inlichtingen te weigeren of om ambtenaren te verbieden als getuige te verschijnen. ${ }^{15}$

Daar komt nog bij, dat de politieke context waarbinnen het parlement zijn formele bevoegdheden uitoefent sinds hun ontstaan sterk veranderd is. Door verschillende procedurele hervormingen aan het begin van de twintigste eeuw heeft de regering de touwtjes in het Lagerhuis stevig in handen gekregen, vaak ten koste van de rechten van individuele parlementsleden. De PPR-bevoegdheden die aan parlementaire commissies worden toegekend, zo kan worden geconcludeerd, zijn in de moderne praktijk dus onderhevig aan zowel conventionele, procedurele als aan politieke factoren die de bruikbaarheid van deze onderzoeksbevoegdheden sterk beper-

\footnotetext{
11 Woodhouse 1994, p. 179.

12 Zie Select Committee on Procedure, First Report, HC 588 (1977-78), p. lxxxviii. Zie verder Woodhouse 1994, p. 177-178.

${ }^{13}$ Rodgers \& Walters 2006, p. 345-346.

14 Select Committee on Procedure, First Report, HC 588 (1977-78), p. lxxxviii-lxxxix.

15 Woodhouse spreekt dan ook van een fundamenteel verschil van inzicht, dat in de praktijk voor de nodige spanningen kan zorgen. Zie Woodhouse 1994, p. 177-178. Zie ook Woodhouse 2004, p. 286-287. Zie verder hierna, par. 2.4.
} 
ken. ${ }^{16}$ De betekenis ervan voor de onderzoekspraktijk moet daarom - zeker in relatie tot de regering - worden gerelativeerd. Informele werkwijzen spelen een belangrijke rol. 17

In het navolgende worden de onderzoeksbevoegdheden waarover parlementaire onderzoekscommissies in het Lagerhuis beschikken, hun beperkingen en praktische betekenis, nader in kaart gebracht. De bijzondere positie die ministers en ambtenaren daarbij innemen, komt aan de orde in een afzonderlijke paragraaf.

\subsection{Onderzoeksbevoegdheden}

\subsubsection{Instelling onderzoekscommissies}

Select committees kunnen op verschillende manieren worden ingesteld. Het Lagerhuis kan door middel van een 'order' besluiten een select committee op te richten. ${ }^{18}$ In het betreffende besluit, de 'order of reference', wordt tevens vastgelegd welke taak of opdracht de commissie krijgt en hoeveel leden de commissie zal tellen. ${ }^{19}$ Wanneer select committees een meer permanent karakter hebben, zoals de departmental select committees, worden de betreffende instellingsbesluiten opgenomen in de Standing Orders van het Huis. ${ }^{20}$ Daarin is doorgaans vastgelegd dat de leden van de betreffende commissie benoemd worden voor de duur van de parlementaire zittingstermijn, dus totdat het parlement wordt ontbonden, tenzij het Huis anders heeft bepaald. ${ }^{21}$ Select committees die middels een standing order zijn opgericht, worden automatisch ontbonden op het moment dat het Lagerhuis wordt ontbonden. ${ }^{22} \mathrm{Zo}$ lang de standing orders niet worden aangepast, is het nieuwe parlement wel gehou-

\footnotetext{
16 Zie ook Woodhouse 1994, p. 180.

17 Zo stellen Turpin en Tomkins in hun handboek dat het parlement "relies less on its formal powers (eg, to enforce the production of papers or punish for contempt) than on the conventional responsibility owed to it by ministers, and the practices and procedures that have crystallised about this convention." Turpin \& Tomkins 2011, p. 591.

${ }^{18}$ Een 'order' is een besluit van het Huis dat "directs its committees, its Members, its officers, the order of its own proceedings and the acts of all persons whom they concern". Dit in tegenstelling tot 'resolutions', waarmee "the House declares its own opinions and purposes." Beide soorten besluiten komen tot stand wanneer het debat over de motie waarin het besluit wordt voorgesteld is afgerond en de motie, zo nodig met stemming ('division'), wordt aangenomen. Zie verder Erskine May 2004, p. 382, 418 en Rodgers \& Walters 2006, p. 288.

${ }^{19}$ Dit kan ook op een later tijdstip nog gebeuren op basis van een motie die de commissievoorzitter indient bij het Huis. Zie Woodhouse 1994, p. 180.

${ }^{20}$ Rodgers \& Walters 2006, p. 357. Zie bijvoorbeeld Standing Order No. 152 van 25 juni 1979 (laatstelijk gewijzigd: 30 juni 2010) betreffende de instelling van select committees "to examine the expenditure, administration and policy of the principle government departments". Deze select committees, anders dan select committees die bij incidentele order worden ingesteld, blijven bestaan totdat het Huis besluit de standing orders, door Erskine May omschreven als "expressly permanent rules", te wijzigen. Zie Erskine May 2004, p. 5-6.

${ }^{21}$ Zie bijvoorbeeld Standing Order No. 152, lid 5: “Unless the House otherwise orders, each Member nominated to the committee shall continue to be a member of it for the remainder of the Parliament." 22 Erskine May 2004, p. 775.
} 
den om de betreffende select committees opnieuw in te stellen. ${ }^{23}$ Voor select committees die op ad hoc basis zijn opgericht, geldt dat het moment van opheffing bepaald wordt in de betreffende order, doorgaans wanneer de commissie haar taak heeft vervuld.

Van belang is verder dat het Huis invloed kan uitoefenen op select committees middels het geven van instructies. Een instructie, die op elk moment tot aan de publicatie van het eindrapport kan worden gegeven, kan bijvoorbeeld betrekking hebben op het verlengen of beperken van de onderzoekstermijn, maar ook op het beperken van de reikwijdte van een onderzoek of de bevoegdheden die aan de commissie zijn gedelegeerd. ${ }^{24}$

De formele mogelijkheden die het Huis heeft om, als delegans, in te grijpen in het werk van de select committees, worden in de praktijk nauwelijks gebruikt. Bij veel select committees - in ieder geval die commissies die in de standing orders zijn geregeld - is de opdracht aan de commissie zeer ruim geformuleerd. Zo hebben de departmental select committees de opdracht "to examine the expenditure, administration and policy of the principle government departments" ${ }^{25}$ Dit geeft de select committees een grote mate van vrijheid in de keuze van onderzoeksonderwerpen. ${ }^{26}$

\subsubsection{Toekenning van bevoegdheden}

De (standing) order of reference bepaalt tevens over welke bevoegdheden de commissie beschikt. De bevoegdheden van commissies in het Lagerhuis zijn namelijk, inherent aan hun positie, van beperkte omvang: een select committee beschikt slechts over bevoegdheden voor zover deze middels delegatie door het Huis zijn toegekend. ${ }^{27}$ Select committees zijn ondergeschikt ('subordinate') aan het Huis en kunnen daarom nooit over méér bevoegdheden beschikken dan de bevoegdheden welke het Huis zelf toekomen. ${ }^{28}$ Hieruit volgt tevens dat de toegekende bevoegdheden slechts kunnen worden uitgeoefend in relatie tot de taak of het doel van de commissie (kortweg de 'terms of reference' genoemd), zoals vastgelegd in het instellingsbesluit. Een commissie die haar bevoegdheden buiten haar taakomschrijving toepast, zo stelt Woodhouse, handelt daarmee ultra vires. ${ }^{29}$ Welke consequenties verbonden zijn aan het onrechtmatig uitoefenen van bevoegdheden, is overigens niet duidelijk. Er zijn geen voorbeelden bekend van commissies die om deze reden door het Huis, middels een instructie of anderszins, werden beperkt in hun bevoegdheden. Een verklaring

\footnotetext{
${ }^{23}$ Het Hogerhuis kent een aantal zogenaamde 'sessional committees'. Het instellingsbesluit van die commissies blijft in stand van sessie tot sessie (d.w.z. van jaar op jaar), tot het moment dat het Huis een nieuw instellingsbesluit ('order of appointment') neemt. In de praktijk betekent dit dat dergelijke commissies permanent ingesteld zijn. Zie House of Lords Standing Order No. 64 van 10 november 1975 (laatstelijk gewijzigd: 15 mei 2012). Zie verder Erskine May 2004, p. 718.

${ }^{24}$ Erskine May 2004, p. 744-745.

${ }^{25}$ Zie Standing Order No. 152 van 25 juni 1979 (laatstelijk gewijzigd: 30 juni 2010), lid 1.

${ }^{26}$ Meer over de instelling en samenstelling van de belangrijkste onderzoekscommissies, de 'departmental select committees' en enkele bijzondere ('cross-cutting') commissies, in hoofdstuk 3.

${ }^{27}$ Erskine May 2004, p. 743. Bij select committees in het Hogerhuis ligt dit anders. Zie hierna.

${ }^{28}$ Rodgers \& Walters 2006, p. 357. Zie ook Blackburn \& Kennon 2003, p. 398.

${ }^{29}$ Woodhouse 1994, p. 180.
} 


\title{
VERENIGD KONINKRIJK
}

hiervoor zou kunnen worden gevonden in de grote mate van vrijheid die select committees, nadat ze zijn ingesteld, genieten. Blackburn en Kennon beschrijven deze vrijheid als volgt:

\begin{abstract}
"A select committee having been thus appointed and nominated is now free to use the powers given [to] (sic) it by the House as it thinks fit. For example, it interprets its own order of reference; it chooses its own subjects for inquiry within the scope of that order; it determines the days and times of its own sittings; it summons evidence of its own choosing; and it prepares and agrees its own reports and special reports. Subject to the rules and practices of the House it also, in effect, regulates its own proceedings, and there is no appeal to the Speaker on a decision of a committee of its chairman." 30
\end{abstract}

\subsubsection{To send for persons, papers and records (PPR)}

Een belangrijke bevoegdheid die aan de meeste select committees wordt toegekend, is de eerder genoemde 'power to send for persons, papers and records'. ${ }^{31}$ Alle departemental select committees ${ }^{32}$, maar ook de meeste andere vaste select committees als de Public Accounts Committee ${ }^{33}$, de Environmental Audit Committee ${ }^{34}$ en de Public Administration Select Committee ${ }^{35}$ beschikken over deze bevoegdheden. ${ }^{36}$ 'PPR' (Persons, Papers, Records), zoals het kortweg wel wordt aangeduid, kan worden gezien als de instrumentele basis van waaruit parlementaire onderzoekscommissies werken. Of, in de typering van Blackburn en Kennon: "It encapsulates the essential power to obtain information by requiring the attendance of individuals and the production of documents." 37

\subsubsection{Het oproepen van getuigen}

De eerste bevoegdheid die voortvloeit uit de 'power to send for persons, papers and records' is de mogelijkheid om personen op te roepen voor verhoor. In beginsel kan elke Britse burger die zich in het Verenigd Koninkrijk bevindt op grond hiervan worden verplicht om te verschijnen voor een select committee. Naar analogie met gerechtelijke procedures lijken ook buitenlanders die zich in het Verenigd Koninkrijk bevinden aan deze plicht te zijn onderworpen, aangezien zij zich binnen de parlementaire rechtsmacht bevinden. 38

\footnotetext{
${ }^{30}$ Blackburn \& Kennon 2003, p. 579.

31 Verder krijgen de commissies doorgaans bepaalde bevoegdheden die betrekking hebben op hun eigen organisatie en werkwijze.

32 Standing Order No. 152 van 25 juni 1979 (laatstelijk gewijzigd: 30 juni 2010), lid 4, sub a.

33 Standing Order No. 148 van 3 april 1862 (laatstelijk gewijzigd: 5 juli 2001), lid 1.

${ }^{34}$ Standing Order No. 152A van 10 november 1997 (laatstelijk gewijzigd: 25 november 2008), lid 4, sub a.

35 Standing Order No. 146 van 25 juni 1979 (laatstelijk gewijzigd: 25 november 2008), lid 2, sub a.

36 Momenteel beschikt alleen de Joint Select Committee on Statutory Instruments over minder bevoegdheden op dit terrein. Zie (House of Commons) Standing Order No. 151 van 30 maart 1983 (laatstelijk gewijzigd: 4 juli 2007), lid 6-7.

${ }^{37}$ Blackburn \& Kennon 2003, p. 626. Zij spreken van 'core powers'.

$38 \mathrm{Om}$ die reden kunnen personen die zich in het buitenland bevinden niet worden verplicht om te verschijnen, al blijken ze wel op vrijwillige basis te kunnen worden uitgenodigd. Zie verder Erskine May 2004, p. 764.
} 
Bij weigering kan de commissie een getuige formeel sommeren te verschijnen. In dat geval wordt een 'order' uitgevaardigd die is ondertekend door de voorzitter van de commissie. Wanneer een getuige, daartoe te zijn gesommeerd, nog immer weigert te verschijnen, is er sprake van 'contempt of Parliament'. De commissie kan dit rapporteren aan het Huis. ${ }^{39}$ De strafrechtelijke jurisdictie van het parlement is echter niet gedelegeerd aan commissies, waardoor alleen het Huis kan besluiten een weigerachtige getuige wegens 'contempt' te veroordelen. Het Lagerhuis kan in het uiterste geval een onwillige getuige laten gevangennemen. Een besluit tot gevangenneming, in een dergelijk geval te beschouwen als een gijzeling bedoeld als dwangmiddel, kan worden opgelegd voor de duur van de parlementaire zittingstermijn. ${ }^{40}$ Indien het gaat om een lichtere zaak, dan kan ook een reprimande of een vermaning worden uitgesproken. ${ }^{41}$

Select committees verhoren jaarlijks tientallen getuigen. In de praktijk blijkt het vrijwel nooit nodig om getuigen formeel te sommeren te verschijnen. De meeste getuigen verschijnen vrijwillig. Doorgaans volstaat daarom een uitnodiging per brief. ${ }^{42}$ Slechts in uitzonderlijke gevallen maken commissies gebruik van hun bevoegdheid om getuigen middels een 'order' te sommeren te verschijnen. ${ }^{43}$ Sinds 1945 is zes maal een dergelijk bevel uitgevaardigd door een select committee; de laatste keer dat dit gebeurde was in 1992, toen de gebroeders Maxwell weigerden te verschijnen voor de Social Security Committee. Daarna leek het instrument in vergetelheid te zijn geraakt. Tot voor kort, want in 2011 gebruikte de Culture, Media and Sport Committee het instrument om Rupert en James Murdoch te dwingen te verschijnen om te getuigen omtrent het afluisterschandaal in de Britse pers, waarbij een van hun kranten betrokken was. ${ }^{44}$ In alle gevallen verschenen de getuigen na te zijn gesommeerd. ${ }^{45}$

Hoewel de opkomstplicht, zoals doorgaans in de (standing) orders vastgelegd, in algemene zin is geformuleerd, moet deze plicht ten aanzien van een aantal categorieën personen worden genuanceerd. Allereerst kunnen leden van het Huis niet worden gesommeerd door een select committee om te verschijnen als getuige. Een dergelijke 'order' kan alleen door het Huis zelf worden uitgevaardigd. ${ }^{46}$ Dit geldt

\footnotetext{
${ }^{39}$ Erskine May 2004, p. 758.

${ }^{40}$ Het Hogerhuis, dat van oudsher een rechterlijke functie vervult, kan een gevangenisstraf voor een bepaalde duur uitspreken en boetes opleggen. Het Lagerhuis beschikt niet over deze mogelijkheden. Wel zijn er in het verleden voorstellen gedaan om zulks bij wet te regelen. Zie voor nadere details: Erskine May 2004, p. 157-161.

41 Erskine May 2004, p. 161-163.

42 Blackburn \& Kennon 2003, p. 626.

${ }^{43}$ Erskine May 2004, p. 758.

${ }^{44}$ Leden van de commissie speculeerden vervolgens in de media over de mogelijke consequenties van het negeren van het bevel, zoals een stemming in het Huis om de Murdochs gevangen te zetten "in a cell under Big Ben." Zie 'Phone hacking: both Murdochs agree to face MPs following jail threat', The Guardian, 14 juli 2011.

45 Alleen de gebroeders Maxwell weigerden vervolgens om op alle vragen antwoord te geven. Zie Leopold 1992, p. 543.

${ }^{46}$ Een Commons-resolutie uit 1688 bepaalt dat "if any Member of the House refuse, upon being sent to, to come to give evidence or information as a witness to a committee, the committee ought to acquaint the House therewith, and not summon such Member to attend the committee." Zie Erskine May 2004, p. 759. Zie ook Woodhouse 1994, p. 182.
} 
ook voor leden van het Hogerhuis: zij verschijnen slechts voor een Commonscommissie op vrijwillige basis. ${ }^{47}$ Een select committee die collega's uit het Lagerhuis of het Hogerhuis zouden dwingen te verschijnen, zo stelt Woodhouse, handelt in strijd met de 'privileges of Parliament'. ${ }^{48}$ De positie van ministers ligt gecompliceerder in verband met de conventie van ministeriële verantwoordelijkheid. Ook voor ambtenaren brengt die conventie beperkingen met zich mee. In paragraaf 2.4. wordt uitvoeriger ingegaan op de positie van ministers en ambtenaren.

\subsubsection{Het horen van getuigen}

Een getuige die wordt gehoord door een select committee is verplicht antwoord te geven op alle vragen die door commissieleden worden gesteld. ${ }^{49}$ Een weigering om tijdens een hoorzitting van een select committee een vraag te beantwoorden kan worden opgevat als contempt. 50

De positie van de getuige is opvallend weinig ontwikkeld in het parlementaire (gewoonte)recht. Zo blijkt uit precedenten dat getuigen in het parlement geen beroep kunnen doen op voor de hand liggende verschoningsrechten die wel tot ontwikkeling zijn gekomen in het gerechtelijke proces. Zo heeft een getuige niet het recht om het beantwoorden van bepaalde vragen te weigeren wegens een geheimhoudingsplicht, omdat het vertrouwelijke informatie betreft (bijvoorbeeld tussen advocaat en cliënt), of wanneer hij vreest dat beantwoording kan leiden tot civiele procedures of zelf-incriminatie. ${ }^{51}$ Indien een getuige niet wenst te antwoorden en het betreffende commissie(lid) blijft aandringen op de beantwoording, dan kan uiteindelijk alleen een beroep worden gedaan op de commissievoorzitter, die bevoegd is te beslissen dat de vraag onbeantwoord kan blijven of in een besloten verhoor zal worden beantwoord. 52

Wel is het zo, dat al hetgeen door getuigen, mondeling dan wel schriftelijk, aan een parlementaire commissie is overlegd, valt onder het 'parliamentary privilege'. Dit betekent dat getuigen niet in rechte kunnen worden aangesproken of vervolgd op basis van de verklaringen die zij hebben afgelegd of stukken die zij hebben verstrekt. 53

Bovendien is de bevoegdheid van de commissie om vragen te stellen niet onbegrensd. De vraagstelling dient te passen binnen het onderzoekskader dat het Huis in

\footnotetext{
${ }^{47}$ House of Lords Standing Order No. 25 van 26 juli 1983 bepaalt: “Any Lord requested by a Committee appointed by the Commons to attend as a witness before it or before any Sub-Committee appointed by it shall have the leave of this House to attend, if his Lordship thinks fit." Een vergelijkbare bepaling voor het Lagerhuis is op genomen in House of Commons Standing Order No. 138 van 30 maart 1983.

${ }^{48}$ Over de betekenis van 'parliamentary privilege' zie ook hierna, par. 4.3.5.

${ }^{49}$ Wederom moet voor ministers en ambtenaren een uitzondering worden gemaakt. Zie paragraaf 2.4.

${ }^{50}$ Zo werd bevestigd in een resolutie van het Lagerhuis uit 1947. Zie Erskine May 2004, p. 130, 761. Zie ook Leopold 1992, p. 543-544.

51 Zie Erskine May 2004, p. 762.

52 Erskine May 2004, p. 762. Een besloten verhoor betekent overigens niet per definitie dat het verslag van het verhoor vertrouwelijk blijft; hierover beslist de commissie zelf. Zie verder hoofdstuk 4 .

${ }^{53}$ Leopold 1992, p. 549. Het instigeren van een gerechtelijke procedure tegen een getuige op grond van diens mondelinge of schriftelijke verklaringen wordt zelfs gezien als een vorm van 'contempt of Parliament'. Zie Erskine May 2004, p. 151-152.
} 
de (standing) order of reference heeft gesteld, al biedt dit kader bij de permanente select committees vaak zoveel ruimte aan de commissie dat dit doorgaans nauwelijks een rol speelt. De voorzitter van de commissie kan een individueel commissielid dat zich in zijn vraagstelling toch buiten dit kader begeeft of dreigt te begeven, tot de orde roepen. Wanneer hierover of over andere zaken tijdens de hoorzitting onenigheid zou ontstaan tussen de leden van de commissie, dan kan de voorzitter besluiten de getuige(n) en de overige aanwezigen te verzoeken de zaal te verlaten, waarna de commissie de kwestie onderling zal bespreken. ${ }^{54}$

Een select committee is voorts, evenals het Huis, te allen tijde gebonden aan de parlementaire regels omtrent sub judice: zaken die onder de rechter zijn kunnen geen voorwerp van debat in het parlement zijn. ${ }^{55}$ Blackburn en Kennon gaan er daarnaast van uit dat commissies niet bevoegd zijn vragen te stellen die "unfair" zijn ten opzichte van de betreffende getuige, of vragen te stellen die ertoe zouden leiden dat "classified information" openbaar zou worden. Wat moet worden beschouwd als een (on)redelijke vraag, zal in de praktijk echter moeilijk te bepalen zijn. In alle gevallen geldt dat de commissieleden in voorkomende gevallen onderling tot overeenstemming zal moeten komen over de aanvaardbaarheid van bepaalde vragen. 56 Het Huis blijkt via de order of reference of middels een instructie een commissie te kunnen opdragen om bepaalde getuigen in de gelegenheid de stellen hun zienswijze naar voren te brengen. ${ }^{57}$

Er bestaat geen rechtsgang voor getuigen die menen op een onrechtmatige wijze te zijn ondervraagd door een select committee. Het werkt eerder andersom: wanneer een getuige weigert een bepaalde vraag te beantwoorden, kan de commissie formeel niets anders dan de zaak voorleggen aan het Huis. Het Huis kan vervolgens de betreffende getuige verplichten te antwoorden, op straffe van een veroordeling wegens contempt. Dit is een zware en tijdrovende procedure, die, zoals eerder gesteld, in de praktijk niet (meer) wordt toegepast. Dit betekent dat de getuige, ondanks het bestaan van een formele antwoordplicht, feitelijk een sterke positie heeft. Ook hier geldt echter dat select committees, zoals Rodgers en Walters uitleggen, evenals bij het oproepen van getuigen, andere manieren hebben om medewerking af te dwingen:

\footnotetext{
"A select committee's strongest weapon is publicity rather than the use of formal powers. A recalcitrant witness looks as though he or she has something to hide; the trick is for the committee to make not giving evidence more embarrassing or awkward than acceding to the committee's request." 58
}

Hoewel hoorzittingen van select committees doorgaans voor het publiek toegankelijk zijn (en soms zelfs rechtstreeks op televisie of via internet worden uitgezonden), kan de commissie, als gezegd, besluiten een hoorzitting geheel of gedeeltelijk achter ge-

\footnotetext{
${ }^{54}$ Erskine May 2004, p. 762. Zie ook Blackburn \& Kennon 2003, p. 628.

${ }^{55}$ Meer over de sub judice-regels in relatie tot select committees in hoofdstuk 4.

56 Blackburn \& Kennon 2003, p. 628.

57 Zie ook Erskine May 2004, p. 744-745.

${ }^{58}$ Rodgers \& Walters 2006, p. 358.
} 
sloten deuren te doen plaatsvinden. ${ }^{59}$ Commissies blijken in de praktijk incidenteel hiertoe bereid, bijvoorbeeld wanneer het gaat om privacy- of bedrijfsgevoelige kwesties. 60

Tenslotte moet nog vermeld worden dat select committees bij het horen van getuigen de mogelijkheid hebben de eed af te nemen. De Parliamentary Witnesses Oaths Act 1871 geeft het Lagerhuis en haar commissies deze bevoegdheid. ${ }^{61}$ De eed (of belofte) kan voorafgaand aan de hoorzitting worden afgenomen door de commissievoorzitter of door de clerk, zo is in de standing orders geregeld. ${ }^{62}$ Het onder ede afleggen van een valse verklaring tijdens een parlementaire hoorzitting is strafbaar onder de Perjury Act 1911.63 Deze wet treedt niet in de plaats van de traditionele parlementaire contempt-regel: het afleggen van een valse verklaring kan te allen tijde, dus ook als de eed niet is afgenomen, worden gestraft als een vorm van contempt. ${ }^{64}$ Het is overigens ongebruikelijk voor select committees om getuigen onder ede te horen. ${ }^{65}$ Dit is opmerkelijk, gezien de mogelijkheden die het strafrecht biedt om betrekkelijk eenvoudig de moeizame contempt-procedures te omzeilen. ${ }^{66}$

\subsubsection{Het opvragen van documenten}

Tenslotte hebben select committees met de bevoegdheid 'to send for persons, papers and records' de mogelijkheid documenten op te vragen. Evenals bij mondelinge vragen, dienen verzoeken om schriftelijke informatie gerelateerd te zijn aan het onderzoek dat de select committee uitvoert. ${ }^{67}$ In het algemeen kan gesteld worden dat de positie van getuigen waar het gaat om de verschaffing van documenten aan select committees niet verschilt van hun positie tijdens een verhoor. ${ }^{68}$ Dat betekent bijvoorbeeld dat het leveren van documenten niet kan worden geweigerd, omdat de bezitter de betreffende gegevens onder strikte geheimhouding heeft verkregen. ${ }^{69}$ Een weigering om de gevraagde documenten ter beschikking te stellen aan een commissie kan worden gerapporteerd aan het Huis, die de weigerachtige kan verplichten de documenten te leveren op straffe van veroordeling wegens contempt. Het uitvaardigen

\footnotetext{
${ }^{59}$ De commissie kan hiertoe bijvoorbeeld besluiten wanneer een getuige bezwaar heeft gemaakt tegen de openbaarheid van de hoorzitting om een van de voornoemde redenen. Standing Order No. 125 van 16 juli 1971 (laatstelijk gewijzigd 26 oktober 2004) geeft select committees de bevoegdheid "to admit the public during the examination of witnesses". Bij een hoorzitting achter gesloten deuren maakt de commissie formeel gezien dus geen gebruik van deze bevoegdheid. Zie verder Erskine May 2004, p. 762.

${ }^{60}$ Rodgers \& Walters 2006, p. 365. Ook bij gevoelige departementale informatie, die bijvoorbeeld betrekking heeft op de nationale veiligheid of defensie, worden wel verhoren achter gesloten deuren gehouden. Zie hierover nader par. 2.4.

61 Zie Parliamentary Witnesses Oaths Act 1871 c. 83 , art. 1.

62 Zie Standing Order No. 132 van 20 febr. 1872 (gewijzigd: 1 aug. 1963).

63 Zie Perjury Act 1911, art. 2.

64 Erskine May 2004, p. 763.

${ }^{65}$ Niettemin noemt Erskine May enkele recente voorbeelden. Zie Erskine May 2004, p. 763.

${ }^{66} \mathrm{Bij}$ een verdenking van overtreding van de Perjury Act kan de zaak immers direct worden overgedragen aan politie en openbaar ministerie. Zie verder Rodgers \& Walters 2006, p. 427, die wijzen op de nuttige (morele) werking die de eedaflegging kan hebben op getuigen.

${ }^{67}$ Erskine May 2004, p. 757.

68 Blackburn \& Kennon 2003, p. 628.

${ }^{69}$ Erskine May 2004, p. 762.
} 
van een bevel om stukken te overleggen is in de praktijk zeldzaam; uit de recente geschiedenis zijn slechts enkele voorbeelden bekend van private organisaties die door een commissie werden gesommeerd om documenten te overleggen. Doorgaans worden stukken opgevraagd door middel van een informeel verzoek per brief. ${ }^{70}$ Ook hier geldt dat ministers en ambtenaren wegens hun bijzondere constitutionele positie niet zonder meer kunnen worden gehouden aan de algemene verplichting om op verzoek van een select committee inzage te verlenen in schriftelijke stukken. ${ }^{71}$

Het opvragen van documenten is in de praktijk een belangrijk onderdeel van het onderzoek van select committees. Veelal wordt eerst schriftelijke informatie ('written evidence') verzameld, op basis waarvan wordt bepaald welke personen als getuige zullen worden uitgenodigd. Commissies ontvangen in de praktijk ook zonder daartoe formeel te verzoeken grote hoeveelheden schriftelijk materiaal van privépersonen en -organisaties, die vaak graag hun medewerking verlenen in de hoop het onderzoek van de commissie te kunnen beïnvloeden. Commissies kunnen echter besluiten om ongevraagd toegezonden stukken niet als bewijsmateriaal te aanvaarden. ${ }^{72}$

\subsection{Ministers en ambtenaren}

\subsubsection{Inleiding}

In deze paragraaf wordt nader ingegaan op de verhouding tussen parlementaire onderzoekscommissies en de uitvoerende macht. In het bijzonder wordt ingegaan op de positie van ministers (2.4.2.), de positie van departementsambtenaren (2.4.3.), het verkrijgen van inzage in departementale stukken (2.4.4.) en de bijzondere positie van verzelfstandigde publieke diensten (2.4.5.).

\subsubsection{Positie van ministers}

Onderzoekscommissies zijn niet bevoegd, zoals hierboven al werd aangestipt, om leden van het parlement te sommeren om te verschijnen. $\mathrm{Zij}$ genieten een zekere bescherming op grond van hun parlementaire privileges. Alleen het Huis is op grond van conventies bevoegd een bevel tot verschijnen te geven. De onderzoekscommissies van het Lagerhuis, of beter gezegd hun leden, kunnen in geval van weigerachtigheid een voorstel hieromtrent voorleggen aan de plenaire vergadering. ${ }^{73}$

De bijzondere positie die parlementsleden in dit verband innemen, geldt evenzeer voor ministers. Zij zijn volgens conventie gedurende hun ambtsperiode immers altijd lid van een van beide huizen van het parlement. ${ }^{74}$ Ook ex-ministers die lid van

\footnotetext{
${ }^{70}$ Erskine May 2004, p. 758.

${ }^{71}$ Meer hierover in paragraaf 2.4.4.

72 Erskine May 2004, p. 757. Meer over de onderzoekspraktijk in hoofdstuk 4.

${ }^{73}$ Zie hierboven, par. 2.3.3.1. Zie ook Woodhouse 1994, p. 182.

${ }^{74}$ In het geval van ministers zou het Huis dit middels een verzoek aan de Kroon ('address to the Crown') moeten doen, aangezien het 'Her Majesty's ministers' betreft. In de praktijk is dit overigens nog nooit gebeurd. De enige select committee die wel ministers (en andere parlementsleden) kan
} 
het Lagerhuis zijn, kunnen wegens dat lidmaatschap niet door een commissie worden verplicht om te verschijnen. Voormalige ministers die tot lid van het Hogerhuis zijn benoemd - iets wat niet ongebruikelijk is - genieten bovendien extra bescherming ten opzichte van onderzoekscommissies in het Lagerhuis, aangezien leden van het Hogerhuis nooit tegen hun wil kunnen worden verplicht om als getuige in het andere huis te verschijnen. ${ }^{75}$

\subsubsection{Ministers als getuige}

Ministers verschijnen in de praktijk veelvuldig voor onderzoekscommissies. Zo werd tussen 1992 en 1997 in totaal 405 maal een minister door onderzoekscommissies gehoord. ${ }^{76} \mathrm{Bij}$ het onderzoek dat de departementale onderzoekscommissies doen ligt het voor de hand dat ministers in de gelegenheid worden gesteld om een verklaring af te leggen in het kader van de onderzoeken die de commissies doen naar het werk van hun ministeries. Het is gebruikelijk dat ministers tenminste eenmaal per jaar verantwoording afleggen voor de select committee die hun ministerie controleert. ${ }^{77}$ Dit gebeurt doorgaans op schriftelijke uitnodiging, dus zonder een formele oproep. Uit deze praktijk zou kunnen worden afgeleid dat ministers dus eigenlijk op vrijwillige basis verschijnen, maar dat lijkt toch niet het geval. De ministeriële verantwoordingsplicht maakt dat ministers, ondanks hun privileges als parlementsleden, niet zomaar kunnen weigeren om te verschijnen voor een select committee. In dat verband stelt Woodhouse, mede gelet op de vele precedenten sinds 1979 die duiden op een grote bereidwilligheid van ministers om te verschijnen, dat inmiddels een conventie tot ontwikkeling is gekomen, op grond waarvan ministers en andere leden, in het bijzonder ex-ministers die na hun ambtsperiode Lagerhuislid zijn gebleven, een uitnodiging van een select committee dienen te aanvaarden. ${ }^{78}$ De functie van deze conventie is "to facilitate the work of the committees and to prevent Parliament having to be called upon to use its formal powers." 79 Het grote belang van de ministeriële verantwoordingsplicht, in combinatie met de bevoegdheid van het Lagerhuis om haar (ministeriële) leden te dwingen om voor een commissie te verschijnen, vormen de grondslag van deze conventie.

De gevallen waarin ministers of voormalige ministers desondanks weigeren om gehoor te geven aan een uitnodiging, zijn zeldzaam. In 1979, vlak na de invoering van het nieuwe stelsel van departmentale select committees, weigerde de Attorney General om te verschijnen voor een subcommissie van de Home Affairs Committee. De commissie legde zich hierbij neer. In 1989 werd de voormalige minister Edwina Currie uitgenodigd te verschijnen voor de Agriculture Select Committee om te getuigen over zaken waarvoor zij als minister verantwoordelijkheid droeg. Currie was na haar aftreden lid gebleven van het Lagerhuis. Na aanvankelijk te hebben geweigerd, bleek de voormalige minister uiteindelijk toch bereid te verschijnen nadat de com-

oproepen, is de Standards and Privileges Committee. Zie Standing Order No. 149 van 6 november 1995 (laatstelijk gewijzigd: 12 maart 2012), lid 6.

75 Zie par. 2.3.3.

76 Blackburn \& Kennon 2003, p. 592.

77 Meer over de werkwijze van select committees in het volgende hoofdstuk.

78 Woodhouse 1994, p. 182.

${ }^{79}$ Woodhouse 1994, p. 182. 
missie had gedreigd de kwestie aan het Huis voor te leggen. ${ }^{80}$ Tenslotte weigerde in 1994 de voormalige Prime Minister Thatcher - inmiddels als Baroness Thatcher lid van het Hogerhuis - nog om te verschijnen voor de Foreign Affairs Committee.

Tijdens een onderzoek in 2002 met betrekking tot de Londense metro bleek geen enkele minister op het ministerie van Financiën bereid te zijn te verschijnen voor een subcommissie van de Transport Committee, die onderzoek deed naar de mogelijk excessieve invloed die Financiën heeft uitgeoefend bij de reorganisatie van het publieke metrobedrijf. Deze commissie rapporteerde dat "Treasury Ministers have treated this Committee with disdain" en stelde het Huis voor een minister van Financiën dan maar te sommeren te verschijnen. ${ }^{81}$ Deze aanbeveling werd niet overgenomen. Namens de regering antwoordde Robin Cook, destijds Leader of the House, op vragen in de Chamber dat ministers van de Treasury bereid zijn te verschijnen voor elke select committee wanneer zaken worden onderzocht die binnen de 'remit' van de Treasury valt, zoals belastinggerelateerde kwesties, maar dat het beginsel van ministerial accountability meebrengt dat een minister niet kan worden geacht te verschijnen voor een select committee wanneer hij geen verantwoordelijkheid draagt voor de zaken die worden onderzocht. ${ }^{82}$

Prime Ministers verschenen tot voor kort overigens in het geheel niet voor onderzoekscommissies. In 2000 stelde de Liaison Committee, de commissie bestaande uit de voorzitters van onderzoekscommissies, de Prime Minister echter voor om (als 'Chief Executive') jaarlijks te verschijnen voor de Liaison Committee naar aanleiding van het jaarverslag dat de regering publiceert. Met een verwijzing naar de conventie op grond waarvan niet de Prime Minister, maar de vakministers verantwoording afleggen aan het parlement voor zaken waarvoor zij in eerste instantie verantwoordelijk zijn, wees de toenmalige Prime Minister Blair dit voorstel af. ${ }^{83}$ In 2002 bleek Blair echter van standpunt veranderd te zijn en kondigde hij aan voortaan elk half jaar voor de Liaison Committee te zullen verschijnen om vragen over uiteenlopende onderwerpen te beantwoorden. ${ }^{84}$ Deze gewoonte is door zijn opvolgers Brown en Cameron overgenomen.

Hoewel ministers in de praktijk doorgaans bereid zijn te verschijnen voor een select committee, en zelfs gesproken kan worden van een conventionele verplichting om te verschijnen, illustreren de voorbeelden die hierboven beschreven zijn dat onderzoekscommissies in geval van weigerachtigheid feitelijk een zwakke positie innemen. Over formele dwangmiddelen beschikken de commissies niet. Wanneer overleg achter de schermen niets oplevert, blijken onderzoekscommissies - al dan niet onder protest - doorgaans te berusten in de houding van de betreffende ministers, wetende dat een verzoek om een verschijningsbevel in de plenaire vergadering

\footnotetext{
${ }^{80}$ Zie Woodhouse 1994, p. 183-184.

81 Transport, Local Government and the Regions Committee, The Attendance of a Minister from HM Treasury before the Transport, Local Government and The Regions Committee, HC 771 (2001-02), § 8. Zie ook Turpin \& Tomkins 2007, p. 617.

82 HC Deb (2001-02) 383, c 704. Zie ook Erskine May 2004, p. 759-760.

${ }^{83}$ Liaison Committee, Shifting the Balance. Unfinished Business, HC 312 (2000-01), § 145.

${ }^{84}$ Zie Turpin \& Tomkins 2007, p. 617, die opmerken dat hieruit blijkt dat de mate waarin ministers verantwoording afleggen aan het parlement soms afhankelijk lijkt van een eenzijdige beslissing van de Prime Minister. Zie ook Blackburn \& Kennon 2003, p. 626-627.
} 


\section{VERENIGD KONINKRIJK}

weinig kans zal maken gezien het overwicht van de regering. Bij de instelling van de select committees in 1979 wist de toenmalige Leader of the House, Norman St. John Stevas, te verhinderen dat de commissies formele bevoegdheden zouden krijgen om de medewerking van ministers en hun departementen af te dwingen, zoals wel werd voorgesteld in het ontwerp-commissiestelsel van de Procedure Committee, met de belofte dat de regering alles in het werk zou stellen om de commissies de door hen gewenste informatie te verschaffen, desnoods op vertrouwelijke basis. ${ }^{85}$

Bij gebrek aan formele dwangmiddelen zijn onderzoekscommissies daarom aangewezen op andere middelen om een weigerachtige minister ervan te overtuigen te verschijnen. Het belangrijkste middel daartoe is de publiciteit. Ministers willen voorkomen dat zij teveel politieke schade oplopen door niet te verschijnen. Omgekeerd geldt echter ook voor onderzoekscommissies het risico van prestigeverlies wanneer getuigen, in het bijzonder ministers, niet kunnen worden gehoord omdat zij simpelweg weigeren te verschijnen. Politieke verhoudingen bepalen dus in grote mate - waarschijnlijk veel meer dan de formele bevoegdheden - de wijze waarop onderzoekscommissies en ministers met elkaar omgaan. ${ }^{86}$ Dit verklaart eveneens waarom zo weinig ministers weigeren om te getuigen, ondanks de relatief zwakke formele positie van onderzoekscommissies. Een confrontatie lijkt door beide kanten zoveel mogelijk te worden vermeden.

\subsubsection{Mondelinge inlichtingen}

Parlementsleden kunnen, wanneer zij verschijnen voor een select committee, op grond van hun parlementaire privileges niet verplicht worden om vragen die commissieleden stellen te beantwoorden. ${ }^{87}$ Dit impliceert dat ministers, die immers lid zijn van het parlement, eveneens vragen onbeantwoord kunnen laten wanneer zij voor een commissie verschijnen. Ook hier geldt echter, dat de positie van ministers wezenlijk verschilt van die van andere parlementsleden. Ministers hebben een constitutionele plicht om verantwoording af te leggen aan het parlement over het gevoerde beleid en de uitvoering daarvan, zoals bevestigd in de parlementaire resoluties inzake 'ministerial accountability' uit 1997.88 Aangenomen kan worden dat deze verplichting eveneens ten opzichte van onderzoekscommissies geldt, aangezien deze commissies onderdeel uitmaken van het Huis. Ministers kunnen zich daarom niet zonder meer beroepen op hun parlementaire privileges wanneer zij, om wat voor reden dan ook, geen (volledig) antwoord willen geven op vragen van onderzoekscommissies, voor zover die vragen betrekking hebben op hun ministeriële verantwoordelijkheid.

Hoe de rechten van ministers op grond van hun parlementaire privileges enerzijds en hun verplichtingen op grond van de ministeriële verantwoordelijkheid anderzijds moeten worden afgewogen, wordt uit de literatuur niet goed duidelijk. ${ }^{89} \mathrm{De}$ kwestie is echter voornamelijk theoretisch van aard, want in de praktijk spelen de

\footnotetext{
85 Zie Baines 1989, p. 31.

${ }^{86}$ Zie ook Rodgers \& Walters 2006, p. 358-359.

${ }^{87} \mathrm{Zie}$ hierboven, par. 2.3.3.1.

88 Zie hiervoor, par. 1.4.1.4.

${ }^{89} \mathrm{Vgl}$. Woodhouse 1994, p. 185-186.
} 
parlementaire privileges van ministers nauwelijks een rol. De nadruk ligt op de ministeriële verantwoordingsplicht. Zo is in de parlementaire resoluties omtrent de ministeriële verantwoordelijkheid bepaald dat "Ministers have a duty to Parliament to account" en "Ministers should be as open as possible with Parliament". 90

Tegelijkertijd biedt deze verantwoordingsplicht voor ministers ook de ruimte om bepaalde informatie aan het parlement of aan onderzoekscommissies te onthouden. In dezelfde parlementaire resoluties van 1997 is vastgelegd dat ministers kunnen weigeren om informatie te verstrekken wanneer dat niet in het openbaar belang ('public interest') zou zijn. Woodhouse spreekt dan ook van een paradoxale situatie "in which the conventional mechanism through which ministers account to Parliament also acts to restrict that accountability as exercised before committees." 91

In welke gevallen kan een minister nu weigeren om inlichtingen te verstrekken? De term 'public interest' wordt in de genoemde parlementaire resolutie niet gedefinieerd. Wel wordt aangegeven dat de vraag of sprake is van strijd met het openbaar belang "should be decided in accordance with relevant statute and the Government's Code of Practice on Access to Government Information..." 92 Deze Code of Practice werd in 2000 vervangen door de Freedom of Information Act (FOI Act). De FOI Act geeft burgers het recht om overheidsinformatie in te zien, mits de betreffende informatie niet onder een van de wettelijke uitzonderingsgronden valt. Voorbeelden van uitzonderingsgronden in de FOI Act zijn de nationale veiligheid, defensiebelangen, internationale betrekkingen, privacygevoelige informatie en handelsbelangen. ${ }^{93}$

Uitgangspunt is dus, dat ministers het verstrekken van inlichtingen aan het parlement in elk geval kunnen weigeren indien zij dezelfde informatie eveneens zouden kunnen (of moeten) weigeren wanneer een burger een verzoek daartoe zou indienen onder de genoemde wet. Een nadere toelichting op de betekenis van de 'public interest'-criterium in de resolutie geeft de parlementaire geschiedenis niet. Het is echter niet uit te sluiten dat er nog andere weigeringsgronden zijn waarop ministers zich kunnen beroepen tijdens een verhoor voor een select committee. Hierbij zou kunnen worden aangesloten bij de parlementaire 'jurisprudentie' omtrent het individuele vragenrecht. In de parlementaire resoluties wordt ten aanzien van de positie van ministers immers geen onderscheid gemaakt tussen individuele parlementsleden en commissies; de ministeriële verantwoordingsplicht is in beide gevallen leidend. ${ }^{94}$

Erskine May geeft een overzicht van de parlementaire praktijk ten aanzien van het vragenrecht. Uitgangspunt is, dat parlementaire vragen aan ministers gericht moeten zijn op "the public affairs with which they are officially connected, to proceedings pending in Parliament, or to matters of administration for which they are responsible." 95 Verderop wordt kortweg gesteld dat vragen aan ministers "must re-

\footnotetext{
90 Zie HC Deb vol 292, cols 1046-47, 19 maart 1997.

${ }^{91}$ Woodhouse 1994, p. 186.

92 Zie art. 3 van de Commons-resolutie, HC Deb vol 292, cols 1046-47, 19 maart 1997.

${ }^{93}$ Zie art. 21 e.v. Freedom of Information Act 2000.

94 Ook de ambtelijke richtlijnen omtrent het verstrekken van departementale stukken aan select committees, die hieronder nader aan de orde komen, eveneens aan op de terminologie die wordt gebruikt in de parlementaire jurisprudentie over het vragenrecht. Zie verder par. 2.4.4.

95 Erskine May 2004, p. 344.
} 
late to matters for which those Ministers are officially responsible." 96 Vragen die betrekking hebben op zaken waarvoor de minister niet of niet volledig bevoegd is, kunnen daarom door de voorzitter buiten de orde worden verklaard. Dit geldt bijvoorbeeld voor vragen waarmee bevestiging werd gezocht van bepaalde berichten in de pers. Ook vragen die betrekking hebben op de portefeuille van een andere minister kunnen worden afgekeurd. Hetzelfde geldt voor vragen omtrent het handelen van lagere overheden, geprivatiseerde staatsbedrijven en verzelfstandigde overheidsorganisaties (NDPBs). Voor die laatste categorie geldt, dat ministers alleen vragen kunnen worden gesteld ten aanzien van de (beperkte) bevoegdheden zij nog bezitten ten aanzien van deze organisaties. ${ }^{97}$ Vragen met betrekking tot de gang van zaken bij een 'executive agency' worden meestal door de minister doorgestuurd aan het hoofd van de dienst (de 'chief executive'), dat vervolgens schriftelijk reageert. Mocht een parlementslid niet tevreden zijn met het antwoord, dan kan de minister alsnog worden benaderd. ${ }^{98}$

Er zijn ook andere gevallen waarin ministers gewoonlijk weigeren te antwoorden. Hierbij gaat het bijvoorbeeld inlichtingen omtrent vertrouwelijk (intern) overleg, maar ook om diplomatiek verkeer en zaken die onder de rechter zijn (sub judice) of wanneer het verschaffen van inlichtingen te kostbaar of omslachtig is. Er bestaat geen formele mogelijkheid om ministers te dwingen om antwoord te geven op vragen; de vragensteller kan de weigering aan de orde stellen in een debat of trachten op andere wijze politieke druk uit te oefenen. ${ }^{99}$

Bovenstaande beperkingen, zo kan worden aangenomen, gelden waarschijnlijk dus ook wanneer ministers worden verhoord door select committees. Evenals in het geval van een weigering om (fysiek) te verschijnen, zoals hiervoor besproken, staan de commissies in het geval van een weigering om vragen te beantwoorden - ook wanneer een dergelijke weigering niet terug te voeren zou zijn op de beginselen van ministeriële verantwoordelijkheid - in formele zin dus relatief zwak en komt het vooral aan op de politieke en retorische overtuigingskracht van de commissie. De situatie verschilt echter op één belangrijk punt: select committees beschikken over de mogelijkheid om een verhoor in beslotenheid af te nemen. Het verslag van een besloten verhoor kan, indien de commissie daartoe besluit, geheim blijven. ${ }^{100}$ Dit maakt het mogelijk om verstrekte departementale inlichtingen vertrouwelijk te behandelen. In veel gevallen zal op die manier kunnen worden voorkomen dat het 'public interest' in gevaar komt, waardoor een belangrijke grondslag onder het niet-verstrekken van inlichtingen komt te vervallen. In de praktijk maken commissies, mede om die reden, ook wel gebruik van de mogelijkheid van een besloten verhoor. ${ }^{101}$

\footnotetext{
96 Erskine May 2004, p. 348.

97 Zie voor een uitvoerig overzicht van gevallen waarin vragen ontoelaatbaar werden beoordeeld: Erskine May 2004, p. 348-350.

98 Turpin \& Tomkins 2011, p. 612. Zie over de bijzondere positie van NDPBs en agencies verder: par. 2.4.5.

${ }^{99}$ Daarnaast bestaat de mogelijkheid om de vraag, zoals iedere burger dat kan, rechtstreeks aan het betreffende departement te stellen met een beroep op de Freedom of Information Act. Zie Turpin \& Tomkins 2011, p. 613.

100 Zie hierboven, par. 2.3.3.2. en hierna, hoofdstuk 4.

101 Zie Rodgers \& Walters 2006, p. 365.
} 


\subsubsection{Positie van ambtenaren}

\subsubsection{Inleiding}

Ambtenaren nemen in het Britse parlementaire stelsel een bijzondere positie in. In het licht van de doctrine van de ministeriële verantwoordelijkheid, zoals die in de loop van de negentiende eeuw in de vorm van conventies tot ontwikkeling kwam, beschikken zij niet over een eigen verantwoordingsplicht ten opzichte van het parlement en zijn het de ministers die verantwoording afleggen voor het handelen van de aan hen ondergeschikte ambtelijke dienst.

De parlementaire resoluties omtrent de ministeriële verantwoordelijkheid bevestigen dat het de minister is die verantwoording schuldig is aan het parlement voor "the policies, decisions and actions of their Departments and Next Steps Agencies." 102 Tegelijkertijd wordt ambtenaren wel degelijk een actieve rol toegekend in het parlementaire verantwoordingsproces. Zo bepaalt artikel 4 van de resolutie:

“...Ministers should require civil servants who give evidence before Parliamentary Committees on their behalf and under their directions to be as helpful as possible in providing accurate, truthful and full information in accordance with the duties and responsibilities of civil servants as set out in the Civil Service Code..." 103

Hoewel de staatsrechtelijke positie van ambtenaren kort gezegd dus nog steeds wordt gekenmerkt door onzelfstandigheid en ondergeschiktheid, zoals ook wordt bevestigd in de Civil Service Code104, staat dit kennelijk geenszins in de weg aan een actieve ambtelijke bijdrage aan het verschaffen van inlichtingen aan parlementaire onderzoekscommissies. Zij doen dit echter altijd in naam van hun ministers ("on their behalf"). De bepaling is ook niet gericht aan ambtenaren, maar aan ministers ("Ministers should require civil servants..."), waarmee andermaal wordt bevestigd dat ambtelijke medewerking aan parlementaire onderzoeken nog altijd geschiedt onder verantwoordelijkheid van de minister. 105

De bepalingen over de rol van ambtenaren in het politieke verantwoordingsproces in de parlementaire resoluties van 1997 kunnen worden gezien als een bevestiging van een ontstane praktijk. Al sinds de jaren '70 hanteert de regering richtlijnen ten behoeve van de ambtenaren die verschijnen voor parlementaire commissies van vergelijkbare strekking. Deze richtlijnen, getiteld 'Departmental Evidence and Response to Select Committees', staan in de praktijk bekend als de Osmotherly Rules, genoemd naar de oorspronkelijke opsteller ervan. Sinds 1978 zijn de aanwijzingen

\footnotetext{
102 Zie HC Deb vol 292, cols 1046-7, 19 maart 1997.

103 Zie HC Deb vol 292, cols 1046-7, 19 maart 1997.

104 Zie thans artt. 2, 14 Civil Service Code 2010. De Civil Service Code is een gedragscode voor ambtenaren, vastgesteld door de Minister for the Civil Service, die sinds de Constitutional Reform and Governance Act 2010 een wettelijke grondslag heeft. De wet stelt onder meer dat de Code tenminste dient te bepalen dat ambtenaren "carry out their duties for the assistance of the administration as it is duly constituted for the time being" (art. 5) en dat zij hun taken uitvoeren "with integrity and honesty, and ... with objectivity and impartiality" (art. 7).

105 Zie ook Woodhouse 2004, p. 290.
} 
openbaar. 106 De meest recente editie dateert van 2005.107 De Osmotherly Rules bevatten tal van gedragsregels voor ambtenaren die verschijnen voor select committees. De Rules gelden als bindende aanwijzingen voor ambtenaren. ${ }^{108}$ Begrijpelijkerwijs heeft het parlement deze aanwijzigingen als zodanig nooit formeel als bindend of maatgevend aanvaard.

Bij de vaststelling van de parlementaire resoluties omtrent de ministeriële verantwoordelijkheid stelde de Public Service Committee, die in haar rapport Ministerial Accountability and Responsibility met een ontwerpresolutie kwam, dat "as witnesses before a Committee, civil servants are themselves bound by the obligation not to obstruct or impede Members or Officers of the House in the performance of their duty." 109 Op ambtenaren, zo suggereert de tekst van de conceptresolutie, berust dezelfde verplichting als op elke andere getuige, namelijk om het parlement en haar commissies niet te hinderen in hun werkzaamheden. De commissie zag met andere woorden geen reden om ambtenaren anders te behandelen dan andere getuigen. ${ }^{110}$

Het voorstel van de Public Service Committee kon op weinig sympathie rekenen bij de regering. In zijn reactie op het commissierapport stelt de regering dat, hoewel veel waarde gehecht moet worden aan de verplichting van ministers en ambtenaren om het parlement zo volledig en accuraat mogelijk te informeren, de woordkeuze van de conceptresolutie "unacceptable" is: "it has the effect of weakening the line of accountability from civil servants to Ministers and from Ministers to Parliament." 111 De regering voegde daaraan toe:

\footnotetext{
"When civil servants give evidence to Select Committees they are doing so, not in a personal capacity, but as representatives of their Ministers. This does not mean, of course, that officials may not be called upon to give a full account of government policies, or the justification, objectives and effects of those policies, but their purpose in doing so is to contribute to the central process of Ministerial accountability, not to offer personal views or judgements on matters that may be of political controversy. To ask civil servants to do so would undermine their professional political impartiality." 112
}

\footnotetext{
106 Nadat de Procedure Committee het document had opgevraagd. Zie Public Service Committee, Ministerial Accountability and Responsibility, HC 313-I (1995-96), § 80, p. xxxvii.

107 Zie Osmotherly Rules 2005. Voor een overzicht van de belangrijkste wijzigingen door de jaren heen: Gay 2005.

108 Zie Osmotherly Rules 2005, § 42. De voorschriften voor ambtenaren zoals in de Rules vastgelegd gelden in relatie tot de onderzoekscommissies in beide Huizen van het parlement, al gelden voor een aantal specifieke commissies andere of aanvullende regelingen. Het betreft de Public Accounts Committee, de Europese commissies in beide Huizen en enkele select committees die zich met wetgevingsvraagstukken bezighouden (zoals de Joint Committee on Statutory Instruments). Zie Osmotherly Rules 2005, § 4-7.

${ }_{109}$ Public Service Committee 1996, Ministerial Accountability and Responsibility, HC 313-I (1995-96), § 82, p. xxxviii.

${ }^{110}$ Hierbij lijkt de commissie te zijn geïnspireerd door het eerder genoemde openbaar onderzoek van Sir Richard Scott. Scott had bij zijn onderzoek de toezegging gekregen van de Prime Minister dat hij elke individuele ambtenaar op persoonlijke titel zou kunnen ondervragen. Zie Public Service Committee 1996, Ministerial Accountability and Responsibility, HC 313-I (1995-96), § 83, p. xxxviii-xxxvix.

111 Public Service Committee, Government Response, HC 67 (1996-97), p. ix.

112 Public Service Committee, Government Response, HC 67 (1996-97), p. ix.
} 
Waar de Public Service Committee benadrukt dat ambtenaren, zoals elke andere getuige, een verplichting hebben om het parlement en haar commissies niet te hinderen in de uitoefening van hun taken, wijst de regering op de hechte constitutionele band tussen ministers en ambtenaren die voortvloeit uit de ministeriële verantwoordelijkheid. Ambtenaren kunnen, zo betoogt de regering, uitsluitend als getuige voor een parlementaire commissie optreden in de rol van vertegenwoordiger van de minister; hun verklaringen leggen zij af namens de minister en met inachtneming van eventuele ministeriële aanwijzingen.

Om ervoor te zorgen dat de resolutie nog kon worden aanvaard voordat het parlement in de aanloop naar de verkiezingen van 1997 zou worden ontbonden, accepteerden de critici (waaronder niet in de laatste plaats de leden van de Public Service Committee) uiteindelijk schoorvoetend het voorstel van de regering. ${ }^{113}$ Sindsdien lijkt het parlement erin te berusten dat ambtenaren uitsluitend in de rol van vertegenwoordiger van de verantwoordelijke minister kunnen optreden. Het uitgangspunt in de Rules, namelijk dat ambtenaren alleen namens hun minister medewerking verlenen aan parlementaire commissies, is in feite gecodificeerd in de genoemde parlementaire resoluties van 1997.

In de praktijk geven de uitgangspunten van de Osmotherly Rules nauwelijks aanleiding tot conflicten tussen regering en parlementaire commissies; integendeel, samen met de genoemde resoluties kunnen zij worden gezien als een geheel van "informal conventions which normally enable committees to carry out their work without major hindrance." 114 In de dagelijkse onderzoekspraktijk blijken de voorschriften bovendien niet al te strikt te worden uitgelegd en vormen zij geen onaanvaardbare belemmering in het werk van onderzoekscommissies, zoals de Procedure Committee in 1990 al constateerde in haar rapport over het functioneren van het commissiestelsel. ${ }^{115}$

\subsubsection{Het verhoren van ambtenaren}

Ambtenaren verschijnen in het Verenigd Koninkrijk veelvuldig voor parlementaire onderzoekscommissies. Vooral de departementale onderzoekscommissies, die de taak hebben "to examine the expenditure, administration and policy of the principle government departments" en "associated public bodies"116, hebben de gewoonte om bij hun onderzoeken medewerking te vragen van ambtenaren van de relevante ministeries of andere publieke diensten.

Doorgaans verschijnen ambtenaren naar aanleiding van een informele, schriftelijke uitnodiging voor een hoorzitting; een formele oproep op basis van de PPRbevoegdheden blijft dus meestal achterwege. Daarnaast nemen ambtenaren, al dan

\footnotetext{
113 Niet onbelangrijk is dat de regering-Major rekenen op de steun van de leiding van de Labouroppositie, die naar het zich liet aanzien de nieuwe regering zou vormen na de verkiezingen. Zie verder Weir \& Beetham 1999, p. 351. Zie ook Riddell 2000, p. 79 e.v.

114 Liaison Committee Note 2004.

115 Bovendien bestaat volgens deze Commissie het gevaar dat "a wholesale review at Parliament's behest could simply result in a new set of guidelines which, whilst superficially less restrictive, would then be applied rigorously and to the letter." Zie Procedure Committee, The Working of the Select Committee System, HC 19-I (1989-90), § 157, p. xxxix.

${ }^{116}$ House of Commons Standing Order No. 152 van 25 juni 1979 (laatstelijk gewijzigd: 30 juni 2010).
} 
niet vergezeld door hun minister, op verzoek deel aan informele briefings met onderzoekscommissies. ${ }^{117}$ Over het algemeen, zo blijkt uit onderzoek door de Public Service Committee, zijn onderzoekscommissies tevreden over de wijze waarop ministeries medewerking verlenen aan onderzoeken. ${ }^{118}$

Uitgangspunt bij het verhoren van ambtenaren is, als gezegd, dat zij tijdens hoorzittingen van parlementaire onderzoekscommissies uitsluitend optreden in naam van hun verantwoordelijke ministers. In die rol wordt van hen verlangd dat zij ruimhartig medewerking verlenen aan een verhoor. In $\S 9$ van de Osmotherly Rules is dit als volgt verwoord:

\begin{abstract}
"Select Committees have a crucial role in ensuring the full and proper accountability of the Executive to Parliament. Ministers have emphasised that, when officials represent them before Select Committees, they should be as forthcoming and helpful as the can in providing information relevant to Committee inquiries. In giving evidence to Select Committees, officials should take care to ensure that no information is withheld which would not be exempted if a parallel request were made under the Freedom of Information Act."
\end{abstract}

Ambtenaren, zo kan hieruit worden afgeleid, hebben in hun functie als vertegenwoordiger van hun minister de uitdrukkelijke taak om de ministeriële verantwoordingsplicht mede ten uitvoer te leggen. Zij dienen de commissie dan ook zo behulpzaam mogelijk te zijn en in ieder geval geen informatie achter te houden die ook via een beroep op de Freedom of Information Act zou kunnen worden verkregen.

Wat het betekent om parlementaire commissies behulpzaam te zijn, wordt uitgewerkt in de hoofdstukken 3 en 4 van de Rules. In $\S 40$ wordt wederom benadrukt dat ambtenaren "who give evidence to Select Committees do so on behalf of their Ministers and under their directions." Immers, zo wordt uitgelegd in $\S 41$, "it is the Minister, not the civil servant, who is accountable to Parliament for the evidence given to the Committee." Voor het optreden van ambtenaren voor parlementaire commissies betekent dit het volgende. Van ambtenaren mag allereerst worden verwacht dat zij namens de minister het regeringsbeleid mondeling toelichten en uitleggen ("to give a full account of Government policies"). Naast het beantwoorden van vragen over het regeringsbeleid is het in beginsel niet uitgesloten dat ambtenaren ingaan op vragen betreffende hun eigen handelen ("their own actions") of hun herinneringen aan specifieke gebeurtenissen ("recollections of particular events"), mits dit past bij het uitgangspunt dat ambtenaren slechts voor onderzoekscommissies verschijnen "to contribute to the central process of Ministerial accountability." Het is echter uitdrukkelijk niet de bedoeling dat ambtenaren ingaan op vragen over hun persoonlijke opvattingen ten aanzien van politiek gevoelige zaken $(\S 41)$.

Het voorgaande betekent meer in het bijzonder, dat ambtenaren zich bij hun optreden voor onderzoekscommissies zoveel mogelijk dienen te beperken tot "questi-

117 Zie ook Osmotherly Rules 2005, § 31, 34.

118 Het ministerie van Financiën blijkt zo nu en dan minder coöperatief te zijn als het gaat om select committees die andere departementen controleren, maar onderzoek willen doen naar zaken die financiële zaken betreffen waarbij Financiën betrokken zou zijn. Zie Public Service Committee 1996, Ministerial Accountability and Responsibility, HC 313-I (1995-96), § 81, p. xxxviii. 
ons of fact and explanation relating to government policies and actions." Zij worden geacht het regeringsbeleid actief uit te leggen, toe te lichten en zelfs te verdedigen: "They should be ready to explain what those policies are; the justification and objectives of those policies as the Government sees them; the extent to which those objectives have been met; and also to explain how administrative factors may have affected both the choice of policy measures and the manner of their implementation." Wel moet hun optreden voor onderzoekscommissies steeds verenigbaar blijven met het beginsel van ambtelijke neutraliteit. Ambtenaren "should as far as possible avoid being drawn into discussion of the merits of alternative policies where this is politically contentious." Mochten commissies daar toch op aansturen, dan dienen ambtenaren aan te geven "that the questioning should be referred to Ministers" (§ 55). In het uiterste geval betekent dit dus, dat een ambtenaar geacht wordt vragen van een commissie inhoudelijk onbeantwoord te laten.

Voorzichtigheid is eveneens geboden wanneer er redenen zijn om informatie in het geheel niet te verstrekken of wanneer het gaat om informatie die op het departement als vertrouwelijk wordt aangemerkt. Wanneer de commissie tijdens een verhoor om gevoelige informatie vraagt, dient de ambtenaar de commissie erop te wijzen dat de informatie alleen op vertrouwelijke basis kan worden verstrekt, te weten tijdens een besloten verhoor of in de vorm van een vertrouwelijk memorandum $(\S 88) .119$

Ambtenaren met specifieke expertise, zoals economen of statistici in overheidsdienst, bevinden zich in een bijzondere positie. Hen zou namelijk kunnen worden gevraagd om hun vakkundige opvattingen ten aanzien van "professional or technical issues underlying government policies or decisions." Hun positie is vooral precair wanneer die opvattingen zouden afwijken van het officiële regeringsstandpunt dat zij geacht worden te verdedigen, maar wellicht tijdens interne advisering hebben bekritiseerd. De Osmotherly Rules zijn hierover duidelijk: "It is not generally open to such witnesses to describe or comment upon the advice which they have given to Departments, or would give if asked. They should not therefore go beyond explaining the reasoning which, in the Government's judgement, supports its policy." Ook zij zouden, indien een commissie blijft aandringen op een professioneel antwoord, moeten verwijzen naar de minister (\$56).

De positie van voormalige ambtenaren ligt anders. Personen die niet langer in ambtelijke dienst zijn, vallen immers niet langer onder de ministeriële verantwoordelijkheid. De minister draagt voor hun getuigeverklaringen dus geen verantwoordelijkheid. De regering is echter geen voorstander van het oproepen van voormalige ambtenaren wanneer het gaat om het regeringsbeleid: "retired officials cannot be said to represent the Minister and hence cannot contribute directly to his or her accountability to the House. It is primarily for these reasons, as well as for obvious practical points of having access to up to date information and thinking, that Minis-

119 Meer over het al dan niet verstrekken van vertrouwelijke of gevoelige gegevens hierboven, par. 2.4.4. 
ters would expect evidence on Government matters to be given by themselves or by serving officials who report to them." 120

\subsubsection{Welke ambtenaar verschijnt namens de minister?}

Hoewel ambtenaren verschijnen, zoals gezegd, veelvuldig en doorgaans zonder problemen voor parlementaire onderzoekscommissies verschijnen, leidt een verzoek tot het horen van ambtenaren incidenteel toch tot frictie tussen ministers en commissies. Een hardnekkig discussiepunt betreft de vraag of onderzoekscommissies zelf kunnen bepalen welke ambtenaren zij als getuige willen horen, of dat zij deze persoonskeuze aan de verantwoordelijke minister moeten overlaten.

De laatste optie ligt, wanneer het uitgangspunt wordt aanvaard dat ambtenaren uitsluitend als vertegenwoordiger van de verantwoordelijke minister optreden, het meest voor de hand. ${ }^{121}$ De Osmotherly Rules gaan hiervan dan ook uit: "The line of ministerial accountability means that it is for Ministers to decide which official or officials should represent them." (§ 43) Mocht een select committee aangeven dat zij een bepaalde ambtenaar wil horen, dan geldt weliswaar dat "the presumption should be that Ministers will agree to meet such a request", maar de uiteindelijke beslissing is aan de minister ( $(44)$. Bovendien behoudt de minister het recht om een alternatieve ambtenaar bij de commissie aan te bevelen. In het uiterste geval kan de minister voorstellen om, in plaats van zijn ambtenaren, zelf te verschijnen voor de commissie. De regering erkent in $\S 47$ overigens dat onderzoekscommissies formeel de bevoegdheid hebben om ambtenaren ook tegen de zin van de verantwoordelijke minister te sommeren om te verschijnen, al wordt daaraan fijntjes toegevoegd dat de bepalingen in de Osmotherly Rules te allen tijde van kracht zijn en dat de minister bevoegd is om de betreffende ambtenaren de nodige instructies te geven. Ingevolge de eerder genoemde $\S 41$ en 55 kan dit bijvoorbeeld inhouden, dat deze ambtenaren bepaalde politiek-gevoelige vragen onbeantwoord moeten laten.

In het verleden heeft deze houding enkele malen tot conflicten geleid tussen select committees en de regering, waarvan het bekendste voorbeeld de zogenaamde Westland-affaire is. In deze affaire, die tot het vertrek van twee ministers leidde en een grote politieke crisis veroorzaakte binnen de toenmalige regering-Thatcher, bestond verschil van mening tussen de minister van Defensie enerzijds en de minister van Handel en Industrie anderzijds over de wijze waarop de Westlandhelicopterfabriek van de ondergang zou moeten worden gered. Naar aanleiding van deze crisis startte de Defence Select Committee een onderzoek naar de reddingspoging. Ontevreden met de verklaringen afgelegd door de minister van Handel en Industrie, verzocht de commissie vijf specifieke ambtenaren van het ministerie van

\footnotetext{
120 Osmotherly Rules 2005, § 48. De regering blijkt ook in de praktijk bereid om verzoeken van commissies om ex-ambtenaren te horen af te wijzen, zo ondervond de Trade and Industry Committee in 1992. Zie Bradley \& Ewing 2007, p. 288.

121 Woodhouse spreekt echter van twee conflicterende standpunten, waarbij enerzijds kan worden betoogd dat commissies zich kunnen beroepen op hun PPR-bevoegdheden, die onbegrensd zijn en daarom ook op ambtenaren van toepassing zijn, en anderzijds kan worden gesteld dat de ministeriële verantwoordelijkheid met zich meebrengt dat ambtenaren geen "constitutional personality" hebben. Hoewel het tweede standpunt, dat de regering sinds lange tijd huldigt, in de praktijk domineert, betekent dit niet dat dit daarmee staatsrechtelijk het juiste is. Zie verder Woodhouse 1994, p. 202 e.v.
} 
Handel en Industrie om te verschijnen. Dit verzoek werd geweigerd door het ministerie en door de Cabinet Office. Hoewel de commissie zich in reactie op de weigering nog wel met stelligheid beriep op haar bevoegdheid 'to send for persons, papers and records', zag zij er uiteindelijk van af om deze bevoegdheid kracht bij te zetten en de kwestie voor te leggen aan het Huis. In plaats daarvan koos de commissie voor een pragmatische oplossing. Gezien de hevige weerstand van regeringszijde, zo overwoog de commissie, zouden de betreffende ambtenaren waarschijnlijk onder strikte aanwijzingen staan om niet te antwoorden op bepaalde vragen. Dit zou het onderzoek niet verder helpen en de betreffende ambtenaren bovendien in een ongemakkelijke en oneerlijke positie plaatsen. In plaats van de betreffende ambtenaren ververscheen de Cabinet Secretary, die een intern departementaal onderzoek naar de kwestie had geleid. ${ }^{122}$

Het standpunt van de regering is sindsdien niet wezenlijk veranderd. In 1990 bleek de toenmalige Cabinet Secretary, Sir Robin Butler, namens de regering bereid om te bevestigen dat onderzoekscommissies het recht hebben om ambtenaren op te roepen (zoals ook in de Osmotherly Rules erkend) en dat ambtenaren tevens een 'duty to attend' hebben. ${ }^{123}$ Naar aanleiding van het rapport van de Public Service Committee uit 1996 zegde de regering toe in beginsel mee te werken aan een verzoek van een select committee om een individuele, met naam genoemde ambtenaar te horen (zie $\S$ 44), maar dit zou niets afdoen aan het andere uitgangspunt dat een ambtenaar te allen tijde namens en op aanwijzing van zijn minister optreedt en dat de minister desnoods kan besluiten om zelf als getuige kan verschijnen. ${ }^{124}$

Na de Westland-affaire hebben zich nog verschillende incidenten rondom het verschijnen van ambtenaren voorgedaan. Enkele jaren geleden was dit nog het geval bij de Foreign Affairs Committee, die geen toestemming kreeg om medewerkers van de inlichtingendienst te horen in haar onderzoek naar de besluitvorming rond de inval in Irak. ${ }^{125}$

Onderzoekscommissies kunnen bij weigerachtigheid van de kant van de regering trachten een beroep te doen op het Huis, maar zoals bij andere conflicten met de regering zal het verkrijgen van een meerderheid politiek gezien weinig realistisch zijn. Al zou een commissie willen betogen dat ambtenaren uiteindelijk verplicht zijn om te verschijnen wanneer een parlementaire commissie op grond van haar PPRbevoegdheden daarom verzoekt, de Westland-affaire heeft duidelijk gemaakt dat

\footnotetext{
122 Zie verder Blackburn \& Kennon 2003, p. 627 en Woodhouse 1994, p. 204-205.

123 Woodhouse 1994, p. 206. Zie ook Rodgers \& Walters 2006, p. 359.

124 Zie Public Service Committee 1996, Ministerial Accountability and Responsibility, HC 313-I (1995-96), § 83, p. xxxviii-xxxvix en, voor de reactie van de regering, Public Service Committee, Government Response, HC 67 (1996-97), p. ix. Zie ook Liaison Committee Note 2004, § 8. Deze toezegging is vastgelegd in de Osmotherly Rules (zie § 44) en geldt eveneens voor politieke adviseurs van ministers die in ambtelijke dienst zijn (de zogenaamde 'special advisers').

${ }^{125}$ De Foreign Affairs Committee stelde naar aanleiding van dit incident voor de positie van ambtenaren en opnieuw ter discussie te stellen. Foreign Affairs Committee, Implications for the Work of the House and its Committees of the Government's Lack of Co-operation with the Foreign Affairs Committee's Inquiry into The Decision to go to War in Iraq, HC 440 (2003-04), § 13-14. Zie ook Rodgers \& Walters 2006, p. 359.
} 
formele bevoegdheden op dit punt worden overvleugeld door de politieke noodzaak om tot overeenstemming te komen met de regering. ${ }^{126}$

In dergelijke gevallen zijn parlementaire commissies daarom feitelijk aangewezen op vormen van politieke beïnvloeding wanneer zij zich niet willen neerleggen bij het regeringsstandpunt. De meest voor de hand liggende methoden zijn het aanspreken van partijlijnen of het uitoefenen van publicitaire druk. Dat laatste brengt, wanneer het gaat om het oproepen en verhoren van specifieke ambtenaren, overigens wel het risico met zich mee dat ambtenaren worden blootgesteld aan (negatieve) beeldvorming in de media zonder dat zij uiteindelijk de gelegenheid krijgen om zich in het openbaar te verdedigen. Ook wanneer wel wordt ingestemd met een verzoek van een commissie, bestaan er risico's. Berucht voorbeeld is het verhoor van Dr. David Kelly. Deze wapeninspecteur in dienst van het Britse ministerie van Defensie werd in 2003 opgeroepen door de Foreign Affairs Committee naar aanleiding van geruchten dat de Britse regering de aanwezigheid van massavernietigingswapens in Irak in de aanloop naar de Amerikaans-Britse invasie schromelijk had overdreven. De ondervraging richtte zich niet alleen op het regeringsbeleid, maar ook op Kelly's eigen betrokkenheid en zijn contacten met journalisten. ${ }^{127}$

\subsubsection{Onderzoek naar ambtelijk handelen}

In de parlementaire resoluties omtrent de ministeriële verantwoordelijkheid, zo bleek hierboven, wordt van ministers verwacht dat zij hun ambtenaren opdragen om ruimhartig medewerking te verlenen aan parlementaire onderzoeken. ${ }^{128}$ Een punt van discussie is, of dit betekent dat ambtenaren ook medewerking dienen te verlenen aan parlementaire onderzoeken die niet het regeringsbeleid of de uitvoering daarvan als zodanig, maar het optreden ('conduct') van individuele ambtenaren betreffen. De regering trekt op dit punt een duidelijke grens.

De eerder genoemde Westland-affaire geldt ook hier als exemplarisch. Directe aanleiding voor het oproepen van de vijf ambtenaren van het ministerie van Handel en Industrie was de verklaring die minister Brittan had afgelegd. De minister had tegenover de Defence Committee verklaard dat zijn ambtenaren met zijn goedkeuring betrokken waren bij het lekken van een vertrouwelijke brief. Hoewel hij aangaf de volledige verantwoordelijkheid op zich te nemen voor dit incident, weigerde hij vervolgens uit te leggen wat er precies gebeurd was. Hierdoor ontstond twijfel over de juistheid van de verklaring van de minister dat de ambtenaren op zijn instructie hadden gehandeld. De indruk bestond dat de betrokken ambtenaren de brief buiten medeweten van de minister hadden gelekt. De minister weigerde de vijf ambtenaren

\footnotetext{
126 Zie ook Woodhouse 1994, p. 205.

127 Twee dagen na het verhoor beroofde de wapenexpert zich van het leven. In het openbare onderzoek (zie ook hierboven, par. 1.4.3.) onder leiding van Lord Hutton naar de omstandigheden van deze dramatische gebeurtenis werd geconcludeerd dat een eventuele weigering van de minister van Defensie om Kelly, die als lagere ambtenaar niet gewend was om met grote mediadruk om te gaan, te laten getuigen waarschijnlijk tot grote politieke ophef zou hebben geleid. Report of the Inquiry into the Circumstances Surrounding the Death of Dr David Kelly C.M.G. by Lord Hutton, HC 247 (2003-04), § 430. Zie ook Bradley \& Ewing 2007, p. 288-289.

128 Zie art. 4, HC Deb vol 292, cols 1046-7, 19 maart 1997.
} 
toestemming te geven om als getuige voor de Defence Committee te verschijnen en beschuldigde de commissie ervan als een disciplinair tribunaal te willen optreden. ${ }^{129}$

In de Osmotherly Rules, die naar aanleiding van de Westland-affaire zijn aangescherpt, komt de terughoudendheid op dit punt duidelijk naar voren. ${ }^{130}$ Aangezien het uitgangspunt is dat ambtenaren de taak hebben als getuige voor een select committee om namens de minister het regeringsbeleid toe te lichten, is het volgens de regering ongepast om het persoonlijk functioneren van ambtenaren ter discussie te stellen. Van ambtenaren wordt dan ook verwacht dat zij zich in hun optreden voor select committees niet laten betrekken in "what would amount to disciplinary investigations which are for Departments to undertake" (§41). Van een dergelijk disciplinaire onderzoek is volgens de regering sprake wanneer ambtenaren in een positie worden gebracht, waarbij zij kunnen worden blootgesteld aan kritiek of verwijten ten aanzien van hun persoonlijk handelen:

\footnotetext{
"Occasionally questions from a Select Committee may appear to be directed to the conduct of individual officials, not just in the sense of establishing the facts about what occurred in making decisions or implementing Government policies, but with the implication of allocating individual criticism or blame." (\$73)
}

Wanneer het handelen van ambtenaren ter discussie komt te staan, dan is het aan de minister om een formeel onderzoek in te stellen volgens de procedures die daartoe binnen het departement zijn opgesteld. Na afloop informeert de minister de select committee over de uitkomsten van het onderzoek. Inlichtingen over eventuele ambtelijke misstappen dienen niet door de betreffende ambtenaren te worden verstrekt, maar door de minister of, namens hem, een 'senior official' $(\$ 74,77)$.

De regering sluit dus uit dat ambtenaren wiens persoonlijk handelen ter discussie zou staan, kunnen verschijnen voor een select committee. Verder verstrekt de regering in beginsel geen details van disciplinaire of arbeidsrechtelijke procedures die tot personen herleidbaar zijn. Dergelijke procedures zijn "a matter of confidence and trust" en het openbaarmaken van gegevens kan leiden tot reputatieschade zonder dat daar de nodige waarborgen tegenover staan. Mocht een select committee dergelijke gegevens toch nodig hebben voor haar onderzoek, dan dienen afspraken te worden gemaakt over vertrouwelijkheid (\$75). Indien een commissie gedurende een onderzoek op ambtelijke misstappen stuit, "the Committee should be asked not to pursue their own investigation into the conduct of the person concerned, but to take up the matter with the Minister." (§ 76)

De regering voert voor zijn bezwaren tegen het onderzoeken van persoonlijk handelen van ambtenaren twee motieven aan. Allereerst staat de conventie van de ministeriële verantwoordelijkheid eraan in de weg dat parlementaire commissies zich met het functioneren van individuele ambtenaren bezighouden. Dat is immers de taak van de verantwoordelijke ministers. Het zijn ministers die vervolgens verantwoording afleggen aan het parlement (of aan haar commissies) omtrent hun even-

\footnotetext{
${ }^{129}$ Woodhouse 1994, p. 207-209.

130 Turpin \& Tomkins 2012, p. 622.
} 
tuele disciplinaire optreden. ${ }^{131}$ Een tweede motief, zo wordt in de Osmotherly Rules gesteld, is het beschermen van de rechtspositie van ambtenaren. Onderzoek naar vermeende tuchtrechtelijke overtredingen kan het beste plaatsvinden op basis van departementale procedures, "designed and agreed for the purpose, and with appropriate safeguards for the individual." (\$74) 132

Ondanks de bezwaren blijkt een parlementair onderzoek naar specifiek ambtelijk falen in de praktijk toch niet helemaal uitgesloten. In 2001/02 deed een bijzondere commissie in de House of Lords onderzoek naar een helicoptercrash uit 1994. Eerder had de House of Commons Defence Committee een kleinschalig onderzoek gedaan, waarbij de verantwoordelijke minister en enkele ambtenaren werden gehoord. In haar rapport beperkte die commissie zich tot meer algemene, beleidsmatige vragen en liet zij de omstandigheden van de crash als zodanig buiten beschouwing. ${ }^{133}$ De Lords-commissie, ingesteld met een kleine meerderheid door het Huis na een negatief advies van de eigen Liaison Committee, kreeg de opdracht de bevindingen van een intern onderzoek door de luchtmacht tegen het licht te houden. In dat interne onderzoek werd geconcludeerd dat de piloten nalatig waren. De Lordscommissie kwam uiteindelijk tot een ander oordeel en stelde dat de resultaten van het interne onderzoek niet tot de conclusie van nalatigheid kon leiden. ${ }^{134}$ Opmerkelijk is, dat de regering zich niet verzette tegen de instelling van de commissie. Sterker nog, tijdens het debat over de motie waarmee de commissie werd ingesteld verklaarde de verantwoordelijke minister dat "the Air Marshals will then be able to explain properly in their own words to the Select Committee why they reached the conclusions that they did, something they have not been able to do properly before" ${ }^{\prime \prime} 135$

Wellicht zag de regering het parlementaire onderzoek als een kans om haar eigen, interne onderzoek te kunnen verdedigen. Het parlementaire onderzoek vond overigens plaats nadat het interne (disciplinaire) onderzoek was afgerond. Bovendien deed de Lords-commissie het eigenlijke feitenonderzoek niet over, maar beperkte zij zich tot een analyse van de gegevens die uit eerder onderzoek naar voren waren gekomen, mede aan de hand van de verklaringen van getuigen die werden gehoord. ${ }^{136}$ In bijzondere omstandigheden, zoals die van een geruchtmakend militair

\footnotetext{
${ }^{131}$ Select committees, zo wordt in de Rules gesteld, "have agreed that it is not their task to act as disciplinary tribunals." Waar deze 'overeenstemming' op is gebaseerd wordt niet duidelijk. Zie Osmotherly Rules 2005, § 76 .

132 Woodhouse betwijfelt of het rechtsbeschermingsmotief bij het opstellen van de richtlijnen omtrent ambtelijk optreden werkelijk zo zwaar woog voor de regering: "Ministers may not answer the questions, and the protection of the conduct of individual civil servants from committee scrutiny may also mean that certain facts are protected. The failure of the government to address these issues may lead to the conclusion that a secondary objective of the guide-lines was to impose a further restriction on the ability of select committees to secure information, particularly information that may be potentially embarrassing to the government." Zie Woodhouse 1994, p. 213.

${ }^{133}$ House of Commons Defence Committee, Lessons of the Chinook crash on the Mull of Kintyre, HC 611 (1997-98).

${ }^{134}$ House of Lords Select Committee on the Chinook ZD 576 Crash, Report of 31 January 2002, HL 25 (iii) $(2001 / 02)$, \& 174.

${ }^{135}$ HL 25 (iii) (2001/02), § 34.

${ }^{136}$ Zie verder HL 25 (iii) (2001/02).
} 
ongeluk, blijkt er dus toch ruimte te zijn voor een parlementair (vervolg)onderzoek naar ambtelijk falen zonder dat de regering ingevolge de Osmotherly Rules een politieke blokkade opwerpt. ${ }^{137}$

\subsubsection{Departementale stukken en schriftelijke inlichtingen}

Het opvragen van schriftelijke stukken valt in beginsel onder de bevoegdheid to send for persons, papers and records', waarover parlementaire onderzoekscommissies gewoonlijk beschikken. Het opvragen van departementale stukken is echter onderhevig aan formele beperkingen. Op basis van oude conventies is een commissie niet gerechtigd tot het uitvaardigen van een formeel verzoek om stukken die in beheer zijn van een Secretary of State. Aangezien bijna alle departementen worden geleid door een Secretary of State, betekent dit dus dat de PPR-bevoegdheid niet inzetbaar is om departementale stukken te verkrijgen; een verzoek daartoe zou via het Huis moeten verlopen. ${ }^{138}$

Tegelijkertijd wordt op grond van de ministeriële verantwoordelijkheid, zoals verwoord in de parlementaire resoluties van 1997, van ministers verlangd dat zij zo open mogelijk zijn in het verstrekken van informatie. Ook dienen zij ambtenaren op te dragen om select committees behulpzaam te zijn. In de praktijk wordt de soep daarom minder heet gegeten en wordt doorgaans medewerking verleend aan (informele) verzoeken van select committees om departementale stukken ter beschikking te stellen of schriftelijke inlichtingen te verschaffen. ${ }^{139}$

De Osmotherly Rules laten het in beginsel aan departementsambtenaren zelf over om verzoeken van select committees om schriftelijke inlichtingen of departementale stukken af te handelen. Overleg met de verantwoordelijke minister is doorgaans alleen nodig "if there is any doubt among officials on the detail of the policy to be explained to the Committee, or on what information should be disclosed." (\$59) Overleg is in ieder geval aangewezen, zo wordt daaraan toegevoegd, wanneer overwogen wordt om bepaalde inlichtingen niet te verstrekken. Er zijn immers gevallen waarin informatieverzoeken van parlementaire commissies niet behoeven te worden gehonoreerd. In de Rules wordt hieromtrent gesteld dat "any withholding of information should be in accordance with the law" en dat "care should be taken to ensure that no information is withheld which would not be exempted if a parallel request were made under the FOI Act" ( $\$ 53$ ). Het achterhouden van informatie, zo voegt de regering nog toe, kan op basis van "long-standing conventions" gerechtvaardigd zijn "on grounds of public policy". (§ 67)

Met de verwijzing in de Rules naar de Freedom of Information Act als richtsnoer wordt aangesloten bij bewoordingen van gelijke strekking in de parlementaire reso-

${ }^{137}$ Ook de regering erkent dit in de Osmotherly Rules, onder verwijzing naar het Chinook-onderzoek, al typeerde zij dit geval wel als "wholly exceptional" (§ 78).

${ }^{138}$ Strict genomen gaat het erom dat commissies geen bevel tot afgifte kunnen geven ten aanzien van stukken waarom, wanneer het Huis deze zelf zou opvragen, alleen kan worden verzocht middels een 'Address to the Crown'. Een dergelijk 'Address' is nodig in het geval van stukken die in beheer zijn van een Secretary of State. Zie nader: Erskine May 2004, p. 757.

${ }^{139} \mathrm{Vgl}$. art. 4 van de parlementaire resoluties en de Osmotherly Rules 2005, §9, 40. Zie verder hierboven, par. 2.4.3.2. 
luties van 1997, waar is omschreven wanneer een minister mag weigeren om informatie te verstrekken aan het parlement. ${ }^{140}$ Een verzoek van een parlementaire onderzoekscommissie om inzage in departementale stukken moet eveneens worden beoordeeld aan de hand van de weigeringsgronden uit de Freedom of Information Act. Ook hierbij is echter verdedigbaar dat er andere gronden voor weigering kunnen zijn, voortvloeiend uit de afspraken, neergelegd in ambtelijke richtlijnen, omtrent de beantwoording van parlementaire vragen. Te denken valt aan de disproportionele kosten die met het verstrekken van bepaalde inlichtingen kunnen zijn gemoeid. 141

Zoals ook bij het verhoren van ministers al werd opgemerkt, kunnen parlementaire onderzoekscommissies toch niet helemaal op één lijn gesteld worden met individuele parlementsleden die gebruik maken van hun vragenrecht. Bij commissies zijn er meer mogelijkheden voor het verstrekken van inlichtingen op vertrouwelijke basis, omdat de risico's kleiner zijn. Het aantal personen dat toegang tot de informatie krijgt is immers vele malen kleiner dan wanneer de inlichtingen aan het gehele Huis worden verstrekt en bovendien kunnen allerlei praktische arrangementen worden bedacht waarmee de vertrouwelijkheid beter kan worden gewaarborgd. De Osmotherly Rules bevatten ten aanzien van departementale inlichtingen dan ook een uitvoerige regeling omtrent vertrouwelijke verstrekking. Departementen dienen altijd te bezien of gegevens die niet kunnen worden openbaargemaakt, wel op vertrouwelijke basis zouden kunnen worden verstrekt aan de commissie die om de gegevens heeft verzocht (\$68). Informatie die als gevoelig ('sensitive') wordt gezien kan alleen worden verstrekt als de parlementaire commissie toezegt deze vertrouwelijk te behandelen, dan wel alleen te publiceren met de nodige 'sidelining' (het wegstrepen van gevoelige passages) (\$85-86). Strict geheime ('classified') informatie dient, indien een verzoek daartoe redelijk is en relevant voor het werk van de betreffende commissie, in beginsel eveneens te worden verstrekt. Hierover zijn afspraken gemaakt met de Liaison Committee, zo wordt in de Rules gemeld. Dergelijke informatie dient op een beveiligde plaats in de Committee Office te worden bewaard, waar het ter inzage ligt voor de commissieleden. Informatie met het predicaat 'Top Secret' kan alleen worden verstrekt na de persoonlijke goedkeuring van de verantwoordelijke minister. (\$92) ${ }^{142}$

Wanneer een commissie het oneens zou zijn met een weigering om bepaalde inlichtingen te verstrekken dan rest haar procedureel gezien, als gezegd, slechts de mogelijkheid om de kwestie in de plenaire vergadering van het Huis aan de orde te

\footnotetext{
140 Zie daarover par. 2.4.2.2.

141 Zie thans Guidance to Officials on Drafting Answers to Parliamentary Questions 2010, < http://www.cabinetoffice.gov.uk/sites/default/files/resources/drafting-pq-responses.pdf> (laatst geraadpleegd: 26 november 2012), § 7. Het is overigens niet de bedoeling, zo blijkt uit deze richtlijnen, dat expliciet wordt gerefereerd aan de bepalingen in de Freedom of Information Act. Volgens de regering zouden de termijnen die staan voor het beantwoorden van parlementaire vragen geen uitvoerige beoordeling van 'the public interest' toelaten. Zie verder Turpin \& Tomkins 2011, p. 612-613.

142 Zie verder § 71-79 van de Osmotherly Rules voor aanwijzingen ten aanzien van kwesties die onder de rechter (sub judice) zijn, stukken betreffende een vorige regering en inlichtingen omtrent het gedrag van individuele ambtenaren. De meeste aanwijzingen gelden zowel voor het verstrekken van mondelinge als schriftelijke inlichtingen.
} 
stellen. Kort na de invoering van het stelsel van departementale onderzoekscommissies zegde de toenmalige Leader of the House toe dat in dergelijke gevallen tijd zou worden vrijgemaakt op de parlementaire agenda. ${ }^{143}$ In de Osmotherly Rules wordt deze procedure vermeld in $\S 30$. In 1998 kwam een conflict tussen de Foreign Affairs Committee en de regering over de verstrekking van telegrammen die het ministerie van Buitenlandse Zaken had ontvangen over de schending van een wapenembargo op deze manier in de plenaire vergadering, echter niet op voorstel van de commissie zelf (die achter de schermen nog in onderhandeling was met de regering) maar via een motie van de oppositie. De motie werd verworpen, toen de regering toezegde een vertrouwelijke samenvatting te verstrekken van een aantal telegrammen. ${ }^{144}$

Wanneer vertrouwelijke inzage echter niet als een oplossing wordt gezien en de regering zou volharden in een weigering om bepaalde inlichtingen te verstrekken, dan staan commissies uiteindelijk tamelijk machteloos. Het afdwingen van het verstrekken van departementale inlichtingen is immers bijzonder moeilijk, aangezien een meerderheid in het Huis bereid zal moeten worden gevonden om een motie te steunen. In dergelijke gevallen lopen select committees dus op tegen de politieke grenzen van hun mogelijkheden. In de praktijk gebruiken commissies, wanneer dit nodig zou zijn, dan ook vooral informele manieren om ministers ervan te overtuigen om medewerking te verlenen.

\subsubsection{Verzelfstandigde publieke diensten: NDPBs en agencies}

De departemental select committees, zo blijkt uit Standing Order 152, hebben niet alleen de taak de 'expenditure, policy and administration' van de voornaamste departementen te monitoren, maar ook die van 'associated public bodies'. Bij de instelling van de commissies in 1979 was deze toevoeging vooral bedoeld om de Britse staatsbedrijven, die voorheen door een aparte select committee werden gemonitord, onder te brengen bij de nieuwe commissies. Naast staatsbedrijven bleken commissies zich ook bezig te gaan houden met het monitoren van organisaties die behoren tot de grote en diverse groep zelfstandige overheidsorganen, de zogenaamde 'Nondepartmental Public Bodies' (NDPBs). ${ }^{145}$ NDPBs zijn er in soorten en maten. Doorgaans zijn zij ingesteld op grond van de wet en afhankelijk van hun werkterrein en taken in meer of mindere mate gelieerd aan ('sponsored by') de departementen die inhoudelijk het meest betrokken zijn. Hiertoe behoren allerlei adviescolleges, tribunalen en commissies. Zij zijn veelal ingesteld om onafhankelijke expertise te bundelen of om een grotere afstand tot de politiek te creëren. Een deel van deze organen verricht adviserende of rechterlijke taken, terwijl andere NDPBs juist als uitvoerende ambtelijke diensten worden getypeerd. ${ }^{146}$ NDBPs maken geen deel uit van de depar-

\footnotetext{
143 Turpin \& Tomkins 2011, p. 623-624. Deze procedure is eveneens de aangewezen weg wanneer een conflict zou ontstaan over het verstrekken van mondelinge inlichtingen, bijvoorbeeld bij een weigering om bepaalde ambtenaren te laten getuigen. Zie hierboven, par. 2.4.3.3.

144 Turpin \& Tomkins 2011, p. 623-624.

145 Zie onder meer Procedure Committee, The Working of the Select Committee System, HC 19-I (1989-90), §37-39. Zie ook hierboven, par. 1.4.1.2.

146 Zie uitvoeriger: Bradley \& Ewing 2007, p. 304 e.v.
} 
tementale organisatie en worden geleid door bestuursraden. ${ }^{147}$ Hun taken, bevoegdheden, financierings- en organisatiewijze zijn zeer verschillend. ${ }^{148}$ Ministers zijn slechts verantwoordelijk voor zover zij formele bevoegdheden hebben; daarbij kan gedacht worden aan het benoemen en ontslaan van bestuurders. Door het werk van NDPBs te onderzoeken en hun bestuurders te horen, vullen de select committees tot op zekere hoogte een leemte in het stelsel van ministeriële verantwoordelijkheid die is ontstaan door de groei van het aantal verzelfstandigde organen. ${ }^{149}$

In de Osmotherly Rules wordt er vanuit gegaan dat NDPB-bestuurders in eigen naam medewerking verlenen aan parlementaire onderzoekscommissies. Wanneer de leden van deze NDPB-besturen dus als getuige verschijnen voor parlementaire onderzoekscommissies, dan spreken zij niet namens een minister. Ook het verstrekken van schriftelijke inlichtingen gebeurt op eigen naam. Wel wordt NDPB-bestuurders en -medewerkers aangeraden de Rules als hulpmiddel te gebruiken in het verkeer met de commissies. (\$ 2) Zo zouden zij de commissies bijvoorbeeld, evenals de departementen, behulpzaam moeten zijn en geen informatie achter moeten houden die op grond van de Freedom of Information Act zou moeten worden verstrekt. (§ 51)

Hoewel het aantal NDPBs in de jaren negentig enigszins werd teruggedrongen, werden tegelijkertijd in het kader van het zogenaamde 'Next Steps'-beleid van de regering-Thatcher talloze ambtelijke diensten binnen departementen verregaand verzelfstandigd. Deze diensten zijn omgevormd tot zogenaamde 'executive agencies', met aan het hoofd een 'chief executive'. ${ }^{150}$ Uit een inventarisatie in 2001 blijkt dat ongeveer in eenderde van de onderzoeksrapporten van select committees aandacht wordt besteed aan het functioneren van NDPBs en 'executive agencies'. $151 \mathrm{Op}$ executive agencies, die weliswaar verzelfstandigd zijn maar nog steeds onderdeel uitmaken van de departementen, zijn de Rules wel onverkort van toepassing, zo blijkt uit $\S 1$. Wanneer een select committee inlichtingen verlangt met betrekking tot zaken die tot het werkterrein van een executive agency behoren, dan is het uitgangspunt in de Osmotherly Rules dat de "Ministers will, normally, wish to nominate the Chief Executive as being the official best placed to represent them." Aan deze "chief executives' zijn, als gezegd, verregaande beheersmatige bevoegdheden toegekend, al geldt de ministeriële verantwoordelijkheid nog steeds onverkort. Daarom wordt tevens benadrukt dat "like other officials they give evidence on behalf of the Minister to whom they are accountable and are subject to that Minister's instruction." (§ 50)

\subsection{Conclusie}

Een precieze grondslag van het parlementaire recht van onderzoek blijkt in het Britse staatsrecht en de doctrine moeilijk te kunnen worden vastgesteld. Wellicht wreekt zich hier het ontbreken van een geschreven grondwet, waarin het onderzoeksrecht -

\footnotetext{
147 Zie over de benoeming van bestuurders en de nieuwe rol van parlementaire onderzoekscommissies daarbij hierna, par. 4.6.3.

148 Zie verder o.a.: Turpin \& Tomkins 2011, p. 434 e.v.

149 Tot op zekere hoogte, want door de beperkte middelen kunnen commissies onmogelijk alle NDPBs de nodige aandacht geven. Zie hierover ook Verhey \& Verheij 2005, p. 241-242.

150 Zie o.a. Turpin \& Tomkins 2011, p. 432 e.v.

151 Zie Hansard Society Commision 2001, p. 161-162.
} 
zoals elders - onomstotelijk zou kunnen worden erkend. Het meest aannemelijke aanknopingspunt voor het bestaan van een parlementair onderzoeksrecht is de taak en functie van het parlement in het Britse staatsbestel. Om haar wetgevende en controlerende taken goed te kunnen uitoefenen, zo kan worden geredeneerd, dient zij de mogelijkheid te hebben om informatie op te vragen en te analyseren. Ook de ministeriële verantwoordingsplicht kan worden gezien als een aanknopingspunt, al vloeien daaruit tegelijkertijd beperkingen voort. Dát het parlement een onderzoeksrecht heeft, wordt in elk geval niet betwist, al is het maar omdat het parlement al eeuwen lang over verregaande onderzoeksbevoegdheden beschikt.

Parlementair onderzoek vindt in het Britse parlement uitsluitend in commissieverband plaats. Zowel het Lagerhuis als het Hogerhuis kunnen hiertoe onderzoekscommissies ('select committees') instellen middels een daartoe strekkend meerderheidsbesluit. In dit besluit, de zogenaamde 'order of reference', kunnen onderzoeksbevoegdheden aan onderzoekscommissies worden gedelegeerd. Voorts worden hierin de onderzoeksopdracht, de instellingsduur en het aantal leden van de commissie vastgelegd. Het Huis kan de uitvoering van de opdracht en de inzet van bevoegdheden door de onderzoekscommissie vanuit haar positie als delegans beinvloeden via instructies, al blijkt deze mogelijkheid in de praktijk niet toegepast te worden.

Met betrekking tot de permanente onderzoekscommissies in beide Huizen geldt dat de onderzoeksopdracht, zoals vastgelegd in de Standing Orders, zeer ruim is geformuleerd. Zo hebben de departementaal-geörienteerde onderzoekscommissies in het Lagerhuis de opdracht 'to monitor the expenditure, administration and policy' van de betreffende ministeries; deze relatieve onbepaaldheid verschaft de commissies in wezen de mogelijkheid een eigen, tamelijk autonoom onderzoeksbeleid te voeren en dit beleid aan te passen wanneer actuele ontwikkelingen daartoe aanleiding geven.

De meest kenmerkende onderzoeksbevoegdheden die parlementaire onderzoekscommissies doorgaans krijgen toebedeeld hebben betrekking op het verzamelen van mondeling en schriftelijk bewijsmateriaal. Deze informatierechten, in de Britse doctrine de bevoegdheid 'to send for persons, papers and records' (PPR) genoemd, is in theorie zeer sterk: kort gezegd geldt dat een ieder die zich in het Verenigd Koninkrijk bevindt verplicht is om commissies medewerking te verlenen door op verzoek van een commissie te verschijnen als getuige of schriftelijke stukken te verschaffen. Het niet voldoen aan een parlementair verzoek om informatie te verschaffen als getuige, kan worden opgevat als minachting ('contempt of Parliament') en is strafbaar.

Conflicten tussen commissie en getuigen over verzoeken om medewerking zijn in de praktijk zeldzaam. Slechts in een handvol gevallen hebben commissies een formele oproep ('order') doen uitgaan. Veelal verlenen getuigen na een schriftelijke uitnodiging medewerking op vrijwillige basis. Hoewel ook de onderwerpskeuze hierbij een rol zal spelen (waarover later meer), lijken commissies conflicten over medewerking van derden zoveel mogelijk te willen vermijden omdat zij niet beschikken over effectieve dwangmiddelen of sanctiemogelijkheden. Commissies zijn hiervoor aangewezen op het Huis, dat slechts bij meerderheidsstemming kan beslui- 
ten tot het inzetten van de parlementaire dwangmiddelen of sancties tegen een weigerachtige getuige wegens 'contempt of Parliament'.

Wanneer het gaat om de medewerking van ministers en ambtenaren, liggen de verhoudingen gecompliceerder. Ministers zijn volgens conventie altijd lid van het parlement. Dit beperkt de mogelijkheid om ministers als getuige op te roepen; parlementsleden kunnen niet gesommeerd worden te verschijnen voor een parlementaire commissie. Daartoe is een besluit van het betreffende Huis noodzakelijk. Ministers bezitten echter ook een verantwoordingsplicht jegens het parlement en daarom kan gesteld worden dat praktijk dat ministers een schriftelijke uitnodiging van een commissie om te verschijnen steeds aanvaarden, inmiddels de status van een constitutionele conventie te hebben verkregen. Tegelijkertijd ontbreekt het de commissies aan formele mogelijkheden om weigerachtige ministers te dwingen te verschijnen, wat betekent dat in geval van weigerachtigheid de commissies in de praktijk op andere manieren zullen moeten proberen ministers op andere gedachten te brengen, bijvoorbeeld middels onderhandelingen via de politieke kanalen of door de publiciteit te zoeken. Eenmaal verschenen kunnen ministers op grond van hun privileges als parlementslid niet verplicht worden om vragen van de commissie te beantwoorden. Ook hier geldt echter dat de ministeriële verantwoordelijkheid, zoals verwoord in de parlementaire resoluties van 1997, met zich meebrengt dat ministers een constitutionele plicht hebben om het parlement, inclusief haar commissies, zo goed mogelijk te informeren. Tegelijkertijd geeft de ministeriële verantwoordelijkheid ministers de mogelijkheid om bepaalde inlichtingen niet te verstrekken ter bescherming van 'the public interest'.

Ambtenaren kunnen bovendien, zo heeft het parlement aanvaard, uitsluitend in naam van hun ministers - en daarmee dus ook alleen met ministeriële toestemming medewerking verlenen aan een parlementair onderzoek. In de parlementaire resoluties van 1997 is overeenkomstig de wens van de toenmalige regering vastgelegd dat ambtenaren uitsluitend namens de minister verschijnen en op diens aanwijzingen dienen te handelen in het verkeer met parlementaire commissies. Het is dan ook de minister die bepaalt welke ambtenaar namens hem verschijnt, zo blijkt uit de interne richtlijnen voor ambtenaren die de regering heeft opgesteld (de Osmotherly Rules). Enkele incidenten in het verleden hebben laten zien dat onderzoekscommissies hun formele bevoegdheden jegens individuele ambtenaren moeilijk gestand kunnen doen en met name bij politiek gevoelige zaken niet veel meer kunnen doen dan in overleg te treden met de betrokken ministers om tot overeenstemming te komen. De ambtelijke richtlijnen laten nadrukkelijk de mogelijkheid open dat ministers zelf verschijnen voor parlementaire commissies, wanneer zij bezwaren hebben tegen het horen van (specifieke) ambtenaren. Het verstrekken van departementale stukken kan op grond van oude conventies in het geheel niet door commissies worden afgedwongen.

Deze formeel zwakke positie staat in de praktijk echter niet in de weg aan een doorgaans constructieve samenwerking tussen parlementaire onderzoekscommissies, ministers en departementen. Ambtenaren verschijnen veelvuldig als getuige tijdens hoorzittingen. Ministers verschijnen veelvuldig voor parlementaire onderzoekscommissies, in het bijzonder de op hun departement gerichte onderzoekscommissies in het Lagerhuis. Dit gebeurt meestal op vrijwillige basis; ministers zien een dergelijk optreden vaak als een gelegenheid om hun beleid uit te leggen en te verde- 
digen. Ondanks de ambtelijke richtlijnen omtrent het verlenen van medewerking aan parlementaire onderzoeken blijken ambtenaren, hoewel te allen tijde in naam van de minister handelend, in de praktijk over de ruimte te beschikken om in hoge mate zelfstandig verzoeken van commissies om inlichtingen af te handelen. Ministers behouden zich echter te allen tijde het recht voor om in te grijpen, bijvoorbeeld door verzoeken om bepaalde ambtenaren te horen af te wijzen. De richtlijnen laten er geen twijfel over bestaan dat er geen licht mag ontstaan tussen ministers en hun ondergeschikte ambtenaren: hun bijdrage dient uitsluitend ter ondersteuning van de ministeriële verantwoordingsplicht. Een duidelijke grens wordt dan ook getrokken wanneer parlementaire commissies onderzoek willen doen naar ambtelijk falen; slechts in een uitzonderlijk geval werkt de regering daaraan mee. 
VERENIGD KONINKRIJK 


\section{Hoofdstuk 3. Onderzoeksorganisatie}

\subsection{Inleiding}

Het Britse parlement kent een grote verscheidenheid aan commissievormen. In het Lagerhuis wordt onder meer gebruik gemaakt van zogenaamde 'public bill committees', 'committees of the whole House', 'grand committees', 'second reading committees', 'committees in report stage' en 'select committees'. Erskine May maakt op basis van de procedurele kenmerken van deze commissievormen onderscheid tussen twee categorieën. Enerzijds de commissies "which proceed by debate" en anderzijds de select committees, "which proceed by taking evidence, deliberation and report".${ }^{1}$ De meeste commissies zouden in deze verdeling aan de hand van hun werkwijze kunnen worden omschreven als fora vergelijkbaar met de plenaire vergadering (Chamber). Omdat select committees werken op basis van bewijsvergaring, overleg en verslaglegging kunnen zij worden beschouwd als onderzoekscommissies.

Het onderscheid tussen debatcommissies enerzijds en onderzoekscommissies anderzijds is door recente hervormingen minder scherp geworden. De wetgevingscommissies, voorheen 'standing committees', zijn hervormd en worden thans public bill committtees genoemd. Hoewel de werkwijze niet fundamenteel is veranderd, beschikken deze public bill committees in tegenstelling tot hun voorgangers over een aantal onderzoeksbevoegdheden. Van zuivere debatcommissies, op de manier waarop Erskine May dit bedoelde, kan met betrekking tot de wetgevingscommissies - in ieder geval vanuit procedureel oogpunt - inmiddels niet meer worden gesproken. Het is echter nog te vroeg om te kunnen stellen dat de wetgevingscommissies ook in de praktijk meer zijn gaan lijken op de reeds bestaande onderzoekscommissies.

Het Lagerhuis kent diverse soorten onderzoekscommissies. ${ }^{2}$ De belangrijkste zijn de negentien departemental select committees, die elk kort gezegd de taak hebben om de werkzaamheden van een ministerie te monitoren. Naast deze 'departementale onderzoekscommissies' zijn er vijf zogenaamde 'cross-cutting committees': Environmental Audit, European Scrutiny, Liaison, Public Accounts en Public Administration. Daarnaast zijn er verschillende onderzoekscommissies die zich met wetgevingszaken bezighouden: Consolidation, Human Rights, Regulatory Reform, Statutory Instruments en Tax Law Rewrite Bills. Verder zijn er nog enkele 'huishoudelijke' commissies, zoals Procedure, Standards and Privileges, Administration en Finance and Services. Bovengenoemde commissies hebben allen een permanente status, in die zin dat hun bestaan is vastgelegd in de Standing Orders. Daarnaast maakt het Huis zo nu en dan gebruik van ad hoc onderzoekscommissies, de laatste

\footnotetext{
${ }^{1}$ Erskine May 2004, p. 794.

${ }^{2}$ Indeling ontleend aan Rodgers \& Walters 2006, p. 347-356.
} 
jaren vooral ter behandeling van conceptwetsvoorstellen. Het Hogerhuis maakt eveneens gebruik van (permanente en tijdelijke) onderzoekscommissies, zij het op beperktere schaal. Leden van het Hogerhuis spelen verder een rol in een aantal gezamenlijke onderzoekscommissies van beide Huizen.

Hieronder zal de organisatie en werkwijze van de belangrijkste onderzoekscommissies worden besproken. De meeste aandacht is daarbij voor de departementale onderzoekscommissies, die het leeuwendeel van het parlementaire onderzoek in het Lagerhuis voor hun rekening nemen. Vervolgens wordt aandacht besteed aan een aantal overige onderzoekscommissies met een bijzondere functie, al komt hun organisatie en werkwijze op veel punten overeen met die van de departementale commissies. Verder komen ook de onderzoekscommissies in het Hogerhuis en gezamenlijke commissies aan de orde. Tenslotte worden de wetgevingscommissies, die sinds 2006 over onderzoeksbevoegdheden beschikken, op hoofdlijnen besproken.

\subsection{Departementale onderzoekscommissies}

\subsubsection{Inleiding}

Het Lagerhuis kent sinds 1979 een aantal vaste onderzoekscommissies, die de taak hebben to examine the expenditure, administration and policy of the principle government departments ... and associated public bodies' ${ }^{3}$ Voor alle grote ministeries is een aparte commissie ingesteld. Op dit moment kent het Lagerhuis negentien van deze departementaal-georiënteerde onderzoekscommissies, die in de Britse literatuur 'departemental select committees' worden genoemd. ${ }^{4}$ De werkzaamheden van deze 'departementale onderzoekscommissies' hebben betrekking op het onderzoeken van de bestedingen, de uitvoeringspraktijk en het beleid ('to examine the expenditure, administration and policy') van het departement dat zij schaduwen. In de literatuur wordt in plaats van het begrip 'to examine' (onderzoeken) vaak het meer omvattende begrip 'to monitor' (controleren, volgen, in beeld brengen) gebruikt om het werk van de departementale onderzoekscommissies te omschrijven. De activiteiten van deze commissies zijn veelzijdig. Niet alleen biedt de formele onderzoeksopdracht hiertoe veel ruimte, ook zijn de departementale onderzoekscommissies de laatste jaren steeds meer aanvullende taken op zich gaan nemen. De achtergrond, organisatie, werkwijze en het onderzoek van deze commissies worden hieronder nader belicht.

\footnotetext{
${ }^{3}$ Zie House of Commons Standing Order No. 152 van 25 juni 1979 (laatstelijk gewijzigd: 30 juni 2010), lid 1.

${ }^{4}$ Zie House of Commons Standing Order No. 152 van 25 juni 1979 (laatstelijk gewijzigd: 30 juni 2010), lid 2. Voor enkele minder voorname ministeries, zoals de Office of the Leader of the House of Commons, bestaat geen departmental select committee. Dit geldt ook voor de Cabinet Office, al wordt dit departement in de praktijk 'gevolgd' door de Public Administration Select Committee. Zie hierover par. 3.4.1.
} 


\subsubsection{Achtergrond}

De invoering van een stelsel van vaste, departementaal-georiënteerde onderzoekscommissies kan worden gezien als een uitvloeisel van de groeiende onvrede in de tweede helft van de twintigste eeuw over het functioneren van het parlement, dat door de ontwikkeling van een overheersend partijenstelsel, een sterk groeiend overheidsapparaat en de toenemende complexiteit van beleidsvorming, steeds minder in staat werd geacht de regering effectief te controleren. In de jaren '60, een periode waarin veel aandacht was voor institutionele hervormingen, won het idee dat versterking van het parlement (uitsluitend) kon worden bereikt door invoering van een systeem van gespecialiseerde onderzoekscommissies steeds meer terrein. ${ }^{5}$ Een dergelijk stelsel zou de positie van het Lagerhuis kunnen versterken en tegelijkertijd de vele backbenchers een zekere functie kunnen verschaffen, zo was de gedachte. Bovendien had de invoering van een stelsel van onderzoekscommissies het voordeel dat geen fundamentele wijzigingen worden aangebracht in het bestaande politiekstaatsrechtelijke systeem: de centrale positie van de regering inzake beleidsbepaling zou onaangetast blijven. ${ }^{6}$

Vanaf de jaren '60 zijn verschillende experimenten gedaan met gespecialiseerde onderzoekscommissies. De figuur van 'select committee', dat hiervoor werd gebruikt, bestond overigens al veel langer en werd voornamelijk op ad hoc basis ingezet voor parlementair onderzoek omtrent specifieke onderwerpen of gebeurtenissen. ${ }^{7} \mathrm{De}$ eerste stappen richting meer systematisering werden gezet in 1965, op het terrein van begrotingscontrole. De reeds bestaande Estimates Committee (begrotingscommissie) werd hervormd en verdeeld in subcommissies, inclusief vijf gespecialiseerde subcommissies voor brede beleidsterreinen als technologische en wetenschappelijke zaken, economische zaken en sociale zaken. Een verdere hervorming vond plaats na de verkiezingen van 1966 op initiatief van de nieuwe Leader of the House, Richard Crossman, die ervan overtuigd was dat verdere hervorming van het commissiestelsel nodig was en bovendien alleen succesvol kon zijn als onderzoekscommissies zich niet uitsluitend met financiële verantwoording bezig zouden mogen houden, maar ook met beleidszaken. ${ }^{8}$ Tussen 1966 en 1970 werden in totaal zes nieuwe gespecialiseerde onderzoekscommissies ingevoerd, de zogenaamde Crossman committees. Deze commissies verschilden onderling sterk, zowel wat betreft (politieke) totstandkoming en werkwijze als prestaties, waardoor het systeem al snel als onsamenhangend werd ervaren. ${ }^{9}$ Bovendien ontstond een zekere mate van overlap met de nog steeds bestaande begrotingssubcommissies. Nog problematischer was de weinig constructieve houding van ministers en ambtenaren en een voortdurende discussie over de vraag of de Crossman committees zich naast financiële controle ook met be-

\footnotetext{
${ }^{5}$ Baines 1989, p. 14. Zie ook Johnson 1988, p. 162.

${ }^{6}$ Zie verder Baines 1989, p. 14-15.

7 Zie voor voorbeelden: Rodgers \& Walters 2006, p. 345-346.

${ }^{8}$ Baines 1989, p. 19-20.

${ }_{9}^{9}$ Baines 1989, p. 19-20. Zie ook Johnson 1988, p. 162, die de totstandkoming en vormgeving van onderzoekscommissies door de regering in deze periode beschrijft als " the opportunistic response ... to the mood in favour of reform."
} 
leidsvraagstukken mochten bezighouden. ${ }^{10}$ Ondanks de problemen, leek er echter geen weg terug: veel backbenchers waren inmiddels overtuigd van het nut van de commissies. ${ }^{11}$

De roep om een meer gestructureerd en systematisch commissiestelsel leidde in 1970 onder de nieuwe (Conservatieve) regering tot een verdere hervorming met het oog op een betere afstemming van het werk van de begrotingscommissie (vanaf nu Expenditure Committee genaamd) en de gespecialiseerde commissies. ${ }^{12}$ Belangrijk is voorts dat vanaf 1974 de leden van de commissies benoemd werden voor de gehele parlementsperiode, in plaats van per parlementair jaar. De gewenste structuur en samenhang bleef echter uit, terwijl de hoeveelheid commissieonderzoek sinds 1966 wel sterk was toegenomen. Waarschijnlijk mede gezien de voortdurende onvrede over het functioneren van het commissiestelsel, kondigde de Leader of the House in 1975 een algehele evaluatie van het functioneren van het parlement aan. In 1976 werd een Procedure Committee ingesteld met de opdracht "to consider the practice and procedure of the House in relation to public business and to make recommendations for the more effective performance of its functions." 13

De commissie rapporteerde in juli 1978 en constateerde dat de balans tussen regering en parlement "now weighted in favour of the Government to a degree which arouses widespread anxiety and is inimical to the proper working of our parliamentary democracy." 14 Desondanks benadrukte de Procedure Committee dat zij geen voorstander was van fundamentele staatrechtelijke hervormingen: "We believe that a new balance must be struck, not by changes of a fundamental or revolutionary character in the formal powers of the institutions concerned, but by changes in practice of an evolutionary kind, following naturally from present practice." 15 De oplossing werd gezocht in een hervorming van het stelsel van select committees, het centrale thema in het rapport van de commissie. ${ }^{16}$ De commissie kwam, ondanks haar terughoudende insteek, met verregaande voorstellen ter versterking van het commissiestelsel. Hiertoe zouden bijna alle bestaande onderzoekscommissies worden afgeschaft en vervangen door een nieuw stelsel, gerelateerd aan de afzonderlijke beleidsterreinen die onder de verantwoordelijkheid van de belangrijkste ministeries

\footnotetext{
10 Baines 1989, p. 20-21.

11 Baines 1989, p. 22.

12 Baines 1989, p. 23. Zie ook Johnson 1988, p. 162-163.

${ }_{13}$ Procedure Committee, First Report, HC 588 (1977-78), § 1.1., p. vii. Zie ook Baines 1989, p. 23-26.

14 Procedure Committee, First Report, HC 588 (1977-78), § 1.5., p. viii. Zie ook Maer \& Sandford 2004, p. 9.

15 Procedure Committee, First Report, HC 588 (1977-78), § 1.6., p. viii. Zie ook Baines 1989, p. 27.

${ }_{16}$ Een aantal leden van de Procedure Committee was uitgesproken voorstander van versterking van het commissiestelsel, wat de nadruk op dit onderwerp kan verklaren. Een andere verklaring zou kunnen worden gevonden, zoals Johnson betoogt, in de partijpolitieke verhoudingen in de late jaren 70. Geen van de partijen had een meerderheid in het Lagerhuis en er leek brede politieke steun te zijn voor versterking van het parlement ten opzichte van de regering. Wellicht richtte de commissie zich daarom liever op voorstellen omtrent de (relatief populaire) onderzoekscommissies in plaats van andere, meer controversiële zaken als het functioneren van het (door de regering gedomineerde) wetgevingsproces. Zie Johnson 1988, p. 163-165.
} 
vielen. ${ }^{17}$ Het stelsel zou moeten bestaan uit twaalf commissies met een permanent karakter, waarvan de instelling zou worden geregeld in één Standing Order. Elke commissie zou ongeveer tien leden moeten hebben, die zouden worden benoemd voor de duur van een parlementaire zittingstermijn. Hun onderzoeksopdracht zou "permissive rather than mandatory" moeten zijn en betrekking moeten hebben op alle aspecten van bestedingen, uitvoeringspraktijk en beleid van de afzonderlijke ministeries en de daaraan gerelateerde staatsbedrijven en publieke diensten. ${ }^{18}$ De commissie deed voorts uitvoerige aanbevelingen ten aanzien van de organisatie en bevoegdheden van select committees, mede gelet op de problemen die de Crossman committees ondervonden, bijvoorbeeld ten aanzien van commissieondersteuning en de medewerking van ministers en ambtenaren. Commissieleden zouden niet langer moeten worden genomineerd door de partijmanagers, maar door een Committee of Selection. Tenslotte zou het werk van de nieuwe commissies moeten worden gecoördineerd door een Liaison Committee. ${ }^{19}$

In het debat over het rapport van de Procedure Committee werd duidelijk dat een hervorming en uitbreiding van het stelsel van onderzoekscommissies in het parlement vrijwel unanieme steun genoot. De toenmalige Leader of the House, Michael Foot, was als vertegenwoordiger van de regering echter terughoudend. De val van de Labourregering in het voorjaar van 1979 en de daarop volgende verkiezingen brachten de hervorming van het stelsel echter in een stroomversnelling. De nieuwe Conservatieve regering onder leiding van Margaret Thatcher had de invoering van het stelsel, zoals ontworpen door de Procedure Committee, in haar verkiezingsmanifest opgenomen. ${ }^{20}$ Het voorstel werd door de nieuwe Leader of the House, Norman St John-Stevas, grotendeels overgenomen en met voortvarendheid voorgelegd aan het Huis in juni 1979. Dit gold uitdrukkelijk niet voor veel van de aanbevelingen ten aanzien van de bevoegdheden van de select committees. Zo werden de bevoegdheden van commissies met betrekking tot het verhoren van ministers en de toegang tot vertrouwelijke departementale informatie niet versterkt. In plaats daarvan zegde St. John-Stevas in het debat over het nieuwe stelsel toe dat "all ministers would do everything in their power to cooperate with the new system of committees and make it a success" en dat "the Government would make available to select committees as much information as possible, including where necessary confidential information on the understanding that committees would treat it in accordance with the conventions governing such matters." 21

Wisselende ervaringen met tijdelijke commissies, een ambivalente houding van regeringszijde en een groeiend besef onder backbenchers dat onderzoekscommissies een waardevolle bijdrage leveren aan de parlementaire taakuitoefening leidde uit-

\footnotetext{
17 Enkele bestaande commissies, waaronder de Public Accounts Committee, zouden vanwege hun bijzondere taken kunnen blijven bestaan. Procedure Committee, First Report, HC 588 (1977-78), § 5.21. e.v., p. liv e.v.

18 Procedure Committee, First Report, HC 588 (1977-78), § 5.48 e.v., p. lxiv .e.v. Zie ook Baines 1989, p. 28.

${ }_{19}$ Procedure Committee, First Report, HC 588 (1977-78), hoofdstukken 6 en 7, p. lxvii e.v. Zie ook Baines 1989, p. 28-29.

${ }^{20}$ Baines 1989, p. 29-30.

${ }^{21}$ Zie ook Baines 1989, p. 31. Zie ook hierboven, hoofdstuk 2.
} 
eindelijk dus tot een 'gerationaliseerd' systeem van departementaal-georiënteerde commissies met een 'permissieve' in plaats van 'verplichtende' taakopdracht. Deze poging tot systematisering van het parlementaire onderzoek vond zijn basis in een tijd van politieke instabiliteit en hervormingszin, maar werd uiteindelijk ingevoerd toen de steun voor onderzoekscommissies vrijwel universeel leek te zijn geworden. Belangrijke factoren die hierbij een rol lijken te hebben gespeeld is dat ministers inmiddels minder afkerig tegenover een intensivering van de parlementaire controlefunctie stonden en er gedurende zeer korte tijd het politieke momentum bestond voor een ingrijpende parlementaire hervorming. ${ }^{22}$

Het stelsel is nog steeds in beweging. Zo werden enkele hervormingen doorgevoerd naar aanleiding van aanbevelingen van de Modernisation Committee, een bijzondere commissie onder voorzitterschap van de Leader of the House ingesteld door de Labourregering die tussen 1997 en 2008 met (beperkte) voorstellen kwam voor hervorming van de werkwijze van het Lagerhuis. ${ }^{23}$ Het declaratieschandaal in 2009 leidde tot de instelling van wederom een bijzondere commissie, de House of Commons Reform Committee, deze keer niet onder leiding van een prominent regeringslid maar van een invloedrijke backbencher, Tony Wright. Deze commissie kwam onder meer met voorstellen ter versterking van het stelsel van select committees, met name op het gebied van de benoeming van commissieleden. ${ }^{24}$

\subsubsection{Departementale indeling}

Het stelsel van departmental select committees dat in 1979 werd ingevoerd bestond aanvankelijk uit twaalf departementaal-georiënteerde commissies, aangevuld met twee commissies voor Welsh Affairs en Scottish Affairs. ${ }^{25}$

Kern van het commissiestelsel is dat het is vormgegeven langs de lijnen van de departementale indeling. Het is dan ook gebruikelijk dat het stelsel wordt aangepast, wanneer de departementale organisatie (in het Britse discours vaak de 'machinery of government' genoemd) verandert, bijvoorbeeld wanneer departementen worden gesplitst, samengevoegd of voorzien van een nieuwe naam. Het herstructureren van select committees naar aanleiding van departementale herindelingen gebeurt middels amendering van de betreffende Standing Order, waarvoor een meerderheidsbe-

\footnotetext{
${ }^{22}$ De invoering vond plaats in de eerste maanden van het premierschap van Thatcher, die zich op dat moment met andere zaken bezighield en het voorstel, zo wordt vermoed, zou hebben afgewezen als het op een later tijdstip was voorgelegd. Zie Rodgers \& Walters 2006, p. 346-347. Enigszins ironisch is, zo betoogt Johnson, dat deze ingrijpende parlementaire hervorming plaatsvond aan het begin van een periode waarin de traditioneel dominante positie van de regering (wellicht meer dan ooit) werd hersteld. Zie Johnson 1988, p. 165. Zie voor een overzicht van de recente politicologische literatuur omtrent de voorwaarden voor het slagen van institutionele hervormingen in de context van het Britse politieke stelsel ook: Russell 2011, p. 612-633.

${ }^{23}$ Het ging met name om het verhogen van het salaris van commissievoorzitters en het versterken van de ambtelijke ondersteuning. Zie Modernisation Committee, Select Committees, HC 224-I (2001-02).

${ }^{24}$ House of Commons Reform Committee, Rebuilding the House, HC 1117 (2008-09). De aanbevelingen van deze hervormingscommissie komen hieronder nog nader aan de orde. Meer over de achtergrond van deze commissie: Russell 2011, p. 615 e.v.

${ }^{25}$ Baines 1989, p. 30-31. De twee regionale commissies zijn eigenlijk ook departementaal-georiënteerd, omdat zij formeel gericht zijn op het werk van de Welsh Office respectievelijk de Scottish Office.
} 
sluit in de plenaire vergadering nodig is. Dit gebeurt op initiatief van de Leader of the House. Sinds de laatste herziening (juli 2010) voorziet de Standing Order in negentien departmental select committees, bijna allemaal gerelateerd aan één ministerie. ${ }^{26}$

Een belangrijk ministerie dat lange tijd door geen enkele select committee werd gevolgd, was de Lord Chancellor's Department, dat zich onder meer bezighield met de gerechtelijke bedrijfsvoering en de benoeming van rechters. Politieke controle over dergelijke aangelegenheden werd bij de hervorming van 1979 als ongewenst beschouwd. Dit veranderde in 1992, toen dit departement grotendeels onder de hoede van de Home Affairs Committee werd gebracht. ${ }^{27}$ In 2007 werd het departement samengevoegd met delen van de Home Office en is sindsdien genaamd Ministry of Justice. Het werkterrein van de huidige Justice Committee betreft het gehele ministerie, inclusief de rechterlijke organisatie en het openbaar ministerie, maar met uitzondering van de vervolging en beoordeling in individuele zaken, benoemingen en de adviezen van de Law Officers aan ministers. 28

De organisatie van de departementen is een taak die bij wet is opgedragen aan de regering. ${ }^{29}$ De regering kan op elk moment besluiten tot een departementale herindeling en naar aanleiding daarvan een voorstel indienen tot aanpassing van de commissiestructuur. Wanneer dit gebeurt tijdens een parlementaire zittingsperiode leidt dit soms tot onvrede bij commissieleden, vooral wanneer de vrees bestaat dat bepaalde beleidsaspecten door de veranderde structuur binnen de commissies minder aandacht zullen krijgen dan voorheen. In 1997, toen de ministeries van Transport en Milieu werden samengevoegd, werd aan dergelijke bezwaren tegemoetgekomen door het aantal leden van de nieuwe departmental select committee te vergroten en daaruit twee subcommissies voor Transport respectievelijk Milieu in te stellen. ${ }^{30}$

\footnotetext{
${ }^{26}$ Zie House of Commons Standing Order No. 152 van 25 juni 1979 (laatstelijk gewijzigd: 30 juni 2010). De negentien commissies zijn: Business, Innovation and Skills; Communities and Local Government; Culture, Media and Sport; Defence; Energy and Climate Change; Environment, Food and Rural Affairs; Foreign Affairs; Health; Home Affairs; Education; International Development; Justice; Northern Ireland Affairs; Scottish Affairs; Transport; Science and Technology; Treasury; Welsh Affairs; en Work and Pensions. Alle commissies monitoren een departement met (vrijwel) dezelfde benaming. Alleen de Science and Technology Committee monitort slechts een deel van een department, namelijk het Government Office for Science (GO-Science), onderdeel van het Department for Business, Innovation and Skills. Omdat GO-Science de taak heeft om het overheidsbeleid en -besluitvorming in brede zin aansluit bij wetenschappelijke standaarden, heeft ook de commissie een departementsoverstijgend werkterrein op het gebied van wetenschappelijke en technologische ontwikkelingen. In 2007 besloot premier Brown de voorganger van GO-Science, het Office for Science and Technology, op te heffen, waarna ook de select committee werd opgeheven. In 2009, bij een nieuwe departementale herindeling, werd de commissie echter heropgericht.

27 Blackburn \& Kennon 2003, p. 572.

${ }^{28}$ Zie House of Commons Standing Order No. 152 van 25 juni 1979 (laatstelijk gewijzigd: 30 juni 2010), lid 2. Met de Law Officers wordt (voor Engeland en Wales) gedoeld op de Attorney General en de Sollicitor General, die enerzijds lid zijn van de regering zijn anderzijds aan het hoofd van het openbaar ministerie staan. Zie hierover verder o.a. Bradley \& Ewing 2007, p. 407-408.

${ }^{29}$ Zie de Ministers of the Crown Act 1975 c. 26, art. 1. Zie ook Bradley \& Ewing 2007, p. 279.

${ }^{30}$ Hetzelfde gebeurde dat jaar bij de samenvoeging van de ministeries van Onderwijs en Werkgelegenheid. Zie Blackburn \& Kennon 2003, p. 572. De afschaffing van de Science and Technology Committee in 2007 leidde eveneens tot onvrede. De vrees bestond dat dit departementsoverstijgende
} 


\subsubsection{Samenstelling en benoeming}

\subsubsection{Commissiegrootte}

Bij inwerkingtreding van het nieuwe stelsel in 1979 bestonden de meeste commissies uit 11 leden. Enkele commissies telden slechts 9 leden; alleen de Scottish Affairs Committee was groter en had 13 leden. Vergeleken met het stelsel van vóór 1979 was de gemiddelde commissiegrootte iets toegenomen. ${ }^{31}$ Niettemin kunnen de departementale onderzoekscommissies, gerelateerd aan het totaal aantal leden van het Lagerhuis, nog steeds relatief klein genoemd worden. Na de stelselhervorming waren in totaal 148 parlementariërs lid van een van de veertien departementale commissies, ten opzichte van 97 onder het oude stelsel. ${ }^{32}$ De gemiddelde grootte van de commissies werd verder verhoogd naar aanleiding van een rapport van de Modernisation Committee in 2002 die constateerde dat veel meer parlementariërs het lidmaatschap van een select committee ambieerden dan kon worden geaccommodeerd. De commissie adviseerde de standaardomvang te vergroten tot 15 leden, waardoor in totaal zo'n 50 extra leden actief zouden kunnen zijn in select committees. Hierdoor zouden commissies tevens beter in staat zijn om hun taken uit te oefenen, bijvoorbeeld door het instellen van subcommissies. ${ }^{33}$ Deze aanbeveling werd uiteindelijk deels door de regering overgenomen. In 2005 bestonden acht commissies uit 14 leden, één commissie uit 13 leden en negen commissies uit 11 leden. ${ }^{34}$

Onlangs is het aantal leden weer naar beneden gebracht, op advies van de commissies zelf. Volgens de Liaison Committee, die op dit punt de aanbevelingen van de House of Commons Reform Committee volgde, was de betrokkenheid van leden in de commissies niet optimaal en werkte het grotere aantal leden niet bevorderend voor de zo gewenste samenwerking tussen commissieleden. Ook het aantal parlementsleden dat een commissielidmaatschap ambieerde bleek niet te zijn toegenomen, waardoor een groot aantal commissieleden in meerdere commissies actief moeten zijn. Sinds 2010 bestaan de meeste commissies daarom weer uit 11 leden. ${ }^{35}$

\subsubsection{Samenstelling}

Het lidmaatschap van de departementale onderzoekscommissies staat formeel open voor alle leden van het Huis. In de praktijk komen in beginsel alleen backbenchers,

beleidsterrein onvoldoende aandacht zou krijgen. In 2009 werd de commissie, zoals gezegd, heringevoerd.

31 Vóór 1979 bestonden de meeste commissies (dat wil zeggen, subcommissies van de Expenditure Committee en enkele gespecialiseerde commissies) uit 9 leden. Zie voor verdere analyse ook Lock 1989, p. 320-321.

32 Een toename van 50 procent. Lock 1989, p. 320-321.

${ }^{33}$ Zie Modernisation Committee, Select Committees, HC 224-I (2001-02), § 44-50. Het gevaar dat het vergroten van commissies de effectiviteit ervan nadelig zouden kunnen beïnvloeden, werd destijds door de commissie gerelativeerd. Zie over de commissiegrootte ook Blackburn \& Kennon 2003, p. 573574 .

${ }^{34}$ Zie HC Deb 13 juli 2005, col. 840 e.v.

35 Zie House of Commons Standing Order No. 152 van 25 juni 1979 (laatstelijk gewijzigd: 30 juni 2010). Zie verder Liaison Committee, Rebuilding the House. Select Committee Issues, HC 272 (2009-10), § 18. Zie ook House of Commons Reform Committee, Rebuilding the House, HC 1117 (2008-09), § 54-55. 
zowel van regerings- als oppositiezijde, in aanmerking voor het lidmaatschap. ${ }^{36}$ Dit wordt gezien als een van de belangrijkste redenen waarom de departementale onderzoekscommissies in staat blijken om een zekere afstand te bewaren tot de dagelijkse partijpolitieke strijd tussen regering en oppositie. ${ }^{37}$

Het selectiesysteem voor de departementale onderzoekscommissies, zoals dat in 1979 werd ingevoerd, stond al lange tijd ter discussie. Hoewel de selectie van leden formeel een taak is van een Committee of Selection, bleek dit namelijk feitelijk in handen te zijn van de partijmanagers ('whips') van de verschillende partijen in het Huis. Na parlementaire verkiezingen kregen alle backbenchers bij de twee grote partijen de kans zich te kandideren voor een zetel in een select committee. Het aantal zetels dat een partij kon vullen was afhankelijk van de relatieve grootte van de partij in het Huis. ${ }^{38}$ Vervolgens bepaalden de partijmanagers in overleg welke kandidaten zouden worden voorgedragen om de toegewezen zetels in te vullen. De Committee of Selection, bestaande uit negen leden (waarvan overigens zeven whips) ${ }^{39}$, speelde in het selectieproces eigenlijk geen rol. Ook de verdeling van de voorzittersposities onder de partijen en zelfs de invulling daarvan - formeel werd de voorzitter tijdens de eerste vergadering door de nieuwbenoemde leden gekozen - was veelal onderdeel van partijpolitieke onderhandelingen tussen de partijmanagers. ${ }^{40}$

In een rapport uit 2001 over de verhouding tussen select committees en de regering, was de Liaison Committee (de commissie bestaande uit de voorzitters van de select committees) kritisch over het functioneren van de selectiecommissie. ${ }^{41}$ In 1979 was de gedachte dat als de nieuwe departementale commissies "independent monitors of Government" zouden moeten zijn, het selecteren van de commissieleden niet aan de regering of de partijen zou moeten worden overgelaten. In de praktijk, zo

\footnotetext{
${ }^{36}$ Dit geldt overigens ook voor alle andere select committees, zie hierna. De enige uitzondering hierop betreft het voorzitterschap van de (tijdelijke) Modernisation Committee, dat door de Leader of the House werd vervuld. Zie Rodgers \& Walters 2006, p. 359. Een gebrek aan backbenchers aan oppositiezijde na de verkiezingen van 2001 leidde er toe dat sommige commissieleden die benoemd werden tot schaduwminister of woordvoerder toch lid bleven van de select committee. Zie Blackburn \& Kennon 2003, p. 576-577.

37 Zie o.a. Blackburn \& Kennon 2003, p. 571.

${ }^{38} \mathrm{Na}$ de verkiezingen van 2005 bezette de Labourpartij bijvoorbeeld 55\% van de zetels in het Huis; dit betekent dat select committees van 11 leden in totaal 6 Labourleden hebben. De Conservatieven beschikten over $31 \%$ van de kamerzetels tegenover 3 zetels per commissie. De overige oppositiepartijen leverden meestal twee leden per commissie; de meeste hiervan kwamen toe aan de Liberal Democrats ( $10 \%$ van de kamerzetels), de rest is verdeeld over de overige (regionale) partijen. Bij het bepalen van de verdeelsleutel wordt eveneens bezien of het commissiestelsel als geheel een evenwichtige afspiegeling van de partijverhoudingen in het Huis is. Zie Blackburn \& Kennon 2003, p. 575.

${ }^{39}$ Rodgers \& Walters 2006, p. 355.

${ }^{40}$ In 1979 werden de voorzitterszetels van de veertien departementale commissies gelijkelijk verdeeld tussen de regerende Conservatieve Partij en Labour. Vanaf 1983 heeft de regering de meerderheid van de commissies in handen. Dit is zo gebleven na de wisseling van regeringspartij in 1997. Zie Rodgers \& Walters 2006, p. 360. Tijdens de eerste vergadering van de commissie werd door de commissieleden, op aanwijzing van hun whips, in de meeste gevallen de persoon gekozen die in het informele onderhandelingsproces als voorzitter uit de bus is gekomen. Een enkele keer blijken commissieleden de aanwijzingen van hun whips niet op te volgen, zoals in 2001 bij de International Development Committee het geval was. Zie Blackburn \& Kennon 2003, p. 581-582.

${ }^{41}$ Liaison Committee, Shifting the Balance. Select Committees and the Executive, HC 300 (1999-2000), § 10-23.
} 
constateerde de Liaison Committee, draagt de selectiecommissie de kandidaten voor op basis van lijstjes die door de partijmanagers worden opgesteld. Deze praktijk had tot gevolg dat de voordracht van uiteindelijke kandidaten lang op zich kan laten wachten, waardoor de waardevolle tijd aan het begin van een parlementaire termijn verloren gaat. ${ }^{42}$ Vertraging ontstaat eveneens bij tussentijdse vacatures in commissies - soms wel drie vacatures binnen één commissie - terwijl zich volop kandidaten melden. En tenslotte blijkt, zo stelde de commissie, dat bepaalde leden buiten de commissies zijn gehouden of zelfs uit commissies zijn verwijderd "on account of their views". ${ }^{43}$ Dit laatste is waarschijnlijk nog het meest problematisch, vooral wanneer dit gebeurt aan de zijde van de regeringspartij.

De Liaison Committee stelde daarom voor de selectieprocedure te veranderen. Voortaan zou de selectie gebeuren door de Liaison Committee, die zou worden omgedoopt tot Select Committee Panel. Aangezien dit panel direct na verkiezingen nog geen leden zou hebben (aangezien er nog geen voorzitters van select committees zijn), zou in eerste instantie een drietal ervaren, gerespecteerde senioren in het Huis moeten worden benoemd die onafhankelijk te werk zouden gaan. Alle backbenchers zouden zich individueel en rechtstreeks bij het panel kunnen aanmelden. Ook de whips zouden kandidaten kunnen aandragen. Het panel zou binnen afzienbare tijd een selectie moeten maken en aan het Huis moeten voorleggen. Gedurende de parlementaire termijn zou het panel een lijst met kandidaten moeten aanhouden, die kan worden gebruikt bij eventuele vacatures. Deze procedure zou bijdragen aan een transparant en eerlijk selectieproces. ${ }^{44}$

Het voorstel van de Liaison Committee werd door de regering afgewezen. Een opmerkelijke gebeurtenis bij de benoeming van nieuwe commissieleden na de verkiezingen van 2001 deed de houding van de regering echter veranderen. Toen de motie met daarin de lijst met kandidaten werd voorgelegd, bleken twee populaire voormalige commissievoorzitters niet te zijn genomineerd door de Committee of Selection. Vermoed werd dat dit te maken had met de onafhankelijke opstelling van deze twee Labourleden in de voorgaande parlementsperiode. ${ }^{45}$ Onvrede binnen de Labourfractie deed de nieuwe Leader of the House Robin Cook uiteindelijk besluiten een vrije stemming te houden in het Huis, waarna de twee voormalige commissievoorzitters met grote meerderheden werden herbenoemd tot leden van hun oude commissies. 46 De Modernisation Committee (onder voorzitterschap van de Leader of the House) kwam naar aanleiding van dit incident met een hervormingsvoorstel. Voorstellen om de leden direct te laten verkiezen door het Huis werden afgewezen;

\footnotetext{
${ }^{42} \mathrm{Al}$ direct bij de invoering van het nieuwe stelsel in 1979 deed zich een aanzienlijke vertraging voor. De commissies werden ingesteld in juni, maar de leden werden pas benoemd in november omdat voorzitter van de selectiecommissie een brede consultatie had aangekondigd. De taak bleek moeilijker dan gedacht, zo verklaarde hij later. Uiteindelijk duurde het tot januari 1980 voordat de commissies aan het werk konden, omdat de benoeming van de voorzitters op zich liet wachten. Zie Baines 1989, p. 31.

${ }^{43}$ HC 300 (1999-2000), § 10-13.

${ }^{44}$ HC 300 (1999-2000), § 14-20. Deze aanbeveling werd onderschreven door de Norton Commission uit de Conservatieve Partij. Zie Norton Commission 2000, p. 29.

${ }^{45}$ Rodgers \& Walters 2006, p. 360.

${ }^{46}$ Zie over deze affaire nader: Cowley 2005, p. 79-83.
} 
dit zou de gewenste balans en diversiteit binnen commissies niet ten goede komen en bovendien werd het als onwenselijk beschouwd dat leden van de regeringspartij zouden meebeslissen over de commissieleden van oppositiezijde. Het voorstel waar de commissie mee kwam leek sterk op het voorstel van de Liaison Committee. De selectie van kandidaten zou uit de handen van de whips worden genomen en aan een Committee of Nomination worden opgedragen, bestaande uit een aantal ervaren leden en onder voorzitterschap van de neutrale Deputy Speaker van het Huis. ${ }^{47}$ Opmerkelijk genoeg werd dit voorstel bij stemming in het Huis (met een kleine meerderheid) verworpen. ${ }^{48}$ Naar aanleiding van het incident in 2001 wordt de kandidatenlijst aan Labourzijde voortaan wel ter goedkeuring voorgelegd aan de voltallige Labourfractie, waarin de backbenchers een meerderheid vormen. ${ }^{49}$

Het leek er lang op dat benoeming van de leden van select committees, een discussiepunt van het eerste uur, te gevoelig was om wezenlijke veranderingen door kunnen te voeren. Het idee van een directe, geheime verkiezing van commissieleden onder alle leden van het Huis won echter steeds meer terrein. In 2007 omarmde een democratiseringswerkgroep binnen de Conservatieve Partij dit idee, waardoor het uiteindelijk werd verheven tot partijstandpunt. ${ }^{50}$

Tegen die achtergrond kwam de House of Commons Reform Committee, die werd ingesteld op voorstel van de toenmalige premier Brown naar aanleiding van het omvangrijke declaratieschandaal, eind 2009 met een verregaand hervormingsvoorstel, dat uiteindelijk wel de eindstreep haalde. ${ }^{51}$ Het nieuwe benoemingsstelsel, dat nog net voor de verkiezingen van 2010 in de Standing Orders werd vastgelegd, ziet er als volgt uit. De voorzitters van de belangrijkste select committees, waaronder de negentien departemental select committees, worden geselecteerd op basis van een geheime stemming onder alle leden van het Huis. ${ }^{52} \mathrm{Na}$ de kamerbrede voorzittersverkiezingen volgen verkiezingen voor de overige leden van de commissies. Anders dan bij de voorzittersposities vindt de verkiezing van de overige leden plaats binnen de eigen partijgeledingen. ${ }^{53}$ De wijze waarop de partijen binnen hun geledingen commissieleden verkiezen, wordt aan henzelf overgelaten. Wel dienen zij de wijze van verkiezing voor te leggen aan de Speaker, die op basis van onafhankelijk advies moet bepalen of de procedure 'voldoet'. 54 Van ministers wordt verwacht dat zij zich

\footnotetext{
47 Zie Modernisation Committee, HC 224 (2001-02), § 7-23.

48 Volgens sommigen het gevolg van een monsterverbond van de whips aan beide zijden van het Huis. Rodgers \& Walters 2006, p. 360. Zie ook Blackburn \& Kennon 2003, p. 576.

49 Zie o.a. de verklaring van Robin Cook in het debat over de hervorming van de selectiecommissie, HC Deb 14 mei 2002, col. 651.

${ }^{50}$ Russell 2011, p. 616.

${ }^{51}$ House of Commons Reform Committee, Rebuilding the House, HC 1117 (2008-09), hoofdstuk 3.

52 Zie House of Commons Standing Order No. 122B van 4 maart 2010 (laatstelijk gewijzigd: 7 juni 2010).

${ }^{53}$ Zie HC 1117 (2008-09), § 87 e.v. De betreffende Standing Order regelt hieromtrent daarom niets. Zie House of Commons Standing Order No. 121 van 25 juni 1852 (laatstelijk gewijzigd: 12 maart 2012).

54 Ook moeten de kiesregels openbaar worden gemaakt. Partijen zouden intern bijvoorbeeld regels kunnen stellen die regionale spreiding of andere vormen van diversiteit bevorderen. Verder wordt het door de commissie als vanzelfsprekend beschouwd dat leden in niet meer dan één commissie worden benoemd, maar laat het aan de partijen over om hieromtrent eigen voorzieningen te treffen. Zie HC 1117 (2008-09), § 88-89.
} 


\section{VERENIGD KONINKRIJK}

vrijwillig van stemming onthouden met betrekking tot de commissie die hun eigen ministerie monitort.

Wat niet veranderd is, is dat de verdeling van de commissievoorzitterschappen over de partijen - dus: welke partij mag welke commissie gaan leiden - nog steeds gebeurt in overleg tussen de partijmanagers. Verdere democratisering op dit punt bleek binnen de Reform Committee niet haalbaar, maar werd ook als praktisch moeilijk uitvoerbaar gezien. ${ }^{55}$ Wel bepaalt de Speaker het aantal voorzitterschappen en commissiezetels dat elke partij naar evenredigheid krijgt toebedeeld en moet het Huis voortaan uitdrukkelijk instemmen met de uitkomst van het overleg tussen de partijmanagers. Het overleg over de verdeling van de voorzitterschappen is bovendien aan een tijdslimiet gebonden. ${ }^{56}$

Bij de start van de parlementaire zittingstermijn in 2010 werden 24 commissievoorzitters gekozen. In de meeste gevallen konden de leden kiezen uit meerdere kandidaten. Voor de Public Account Committee waren zelfs zes Labourkandidaten. Van de 650 leden brachten 590 hun stem uit. Vervolgens hielden de partijen interne verkiezingen voor de overige commissieleden. Opvallend was dat in vergelijking met het oude stelsel nieuwe parlementsleden het bijzonder goed deden in de partijverkiezingen. In de Business, Innovation and Skills Committee gingen 9 van de 11 commissiezetels naar leden die voor het eerst in het parlement zaten. ${ }^{57}$ Russell, die als specialist adviser betrokken was bij de Reform Committee, betitelt deze verkiezingen dan ook als "a new outbreak of democracy inside the House of Commons". Hoewel het nog te vroeg is om de werkelijke betekenis van deze hervormingen te kunnen beoordelen, kan volgens haar in elk geval worden geconstateerd dat de verkiezing heeft bijgedragen aan een grotere legitimiteit van de commissies: zowel hun voorzitters als de overige leden ontlenen hun positie niet langer aan de partijmanagers, maar aan een verkiezing door het gehele Huis respectievelijk de hele fractie. ${ }^{5}$

\subsubsection{De rol van de commissievoorzitter}

De voorzitter speelt een spilfunctie binnen de commissie. Het voorzitterschap van een departmental select committee is alles behalve een neutrale (technische) positie: de voorzitter neemt ten volle deel aan het werk van de commissie en is vaak zelfs haar drijvende kracht. De departementale onderzoekscommissies werken in beginsel op basis van collegiale besluitvorming, maar het is veelal de voorzitter die daarbij het voortouw neemt, zoals bij het bepalen van de onderzoekslijnen en het selecteren van

\footnotetext{
55 Russell 2011, p. 620.

${ }^{56}$ De Speaker maakt de proportionele verdeling van het aantal voorzitterschappen en overige zetels over de partijen direct na de parlementaire verkiezingen bekend. Vervolgens dienen de partijmanagers in beginsel uiterlijk een week na aanvang van een parlementaire zittingstermijn de onderlinge verdeling van de verschillende commissievoorzitterschappen bekend te maken. Zie House of Commons Standing Order No. 122B van 4 maart 2010 (laatstelijk gewijzigd: 7 juni 2010), lid 2-4. Zie ook HC 1117 (2008-09), § 83, 90.

${ }^{57}$ Russell 2011, p. 627.

58 Russell 2011, p. 627-628. Zij ziet tevens grotere kansen voor verdere hervormingen in de toekomst, aangezien de nieuwbakken parlementsleden na deze verkiezing (en daarnaast met de instelling van een Backbench Business Committee) eraan gewend raken dat zij veel meer controle en zeggenschap hebben over hun institutie en zich daarmee minder gelegen zullen laten liggen aan de partijmanagers. Russell 2011, p. 631.
} 
getuigen. Bovendien zijn de meeste commissierapporten opgesteld door (of namens) de voorzitter. ${ }^{59}$ De stijl van leidinggeven verschilt van persoon tot persoon. De leidinggevende kwaliteiten van de voorzitters zijn van groot belang voor het functioneren van de departementale commissies, zo stellen Rodgers en Walters:

\footnotetext{
"Whichever style they adopt, the role of a good chairman is crucial in keeping the committee together: giving all its members a chance, promoting consensus, foreseeing political problems, establishing good - but not cosy - relationships with ministers in the relevant department, and providing leadership when the going gets tough." 60
}

De commissievoorzitters worden gezien als een belangrijke factor in het succes van de permanente (departementale) onderzoekscommissies. In 1999 constateerde de Liaison Committee in haar rapport Shifting the Balance van 1999 dat de positie van de commissievoorzitter versterking behoefde. Te vaak bleken commissievoorzitters (overigens evenals gewone commissieleden) bereid hun functie op te geven voor een vacante ministeriële functie of een rol als opposition frontbencher (woordvoerder). De commissie stelde daarom voor de commissievoorzitters een toelage toe te kennen bovenop hun normale parlementaire vergoeding. Op deze manier zou het voorzitterschap van een onderzoekscommissie een alternatief carrièrepad kunnen worden binnen het parlement. ${ }^{61}$ De Modernisation Committee nam deze aanbeveling in 2002 over, maar stelde tegelijkertijd voor een maximale termijn te verbinden aan het voorzitterschap van een commissie, zodat er voldoende kansen zijn voor nieuwe kandidaten. ${ }^{62}$ De salarisverhoging werd in 2003 doorgevoerd.63 Tevens geldt een maximum van twee herbenoemingen of een aaneengesloten voorzitterschap van acht jaar. ${ }^{64}$ De nieuwe benoemingswijze op basis van een kamerbrede, geheime stemming kan ertoe leiden dat de spilfunctie die de voorzitter vervult, maar ook diens publieke profiel wegens campagneactiviteiten en de extra publiciteit die de verkiezingen met zich meebrengen, 65 in de toekomst verder zal worden versterkt.

\subsubsection{Het instellen van subcommissies}

Select committees kunnen beschikken over de mogelijkheid om subcommissies in te stellen. De bevoegdheid om subcommissies in te stellen dient, evenals andere bevoegdheden, uitdrukkelijk door het Huis aan de commissie te worden gedelegeerd.

\footnotetext{
${ }^{59}$ Rodgers \& Walters 2006, p. 361.

${ }^{60}$ Rodgers \& Walters 2006, p. 361.

${ }^{61}$ HC 300 (1999-2000), § 29-34. Ook buiten het parlement werden dergelijke voorstellen gedaan. Zie de Norton Commission 2000, p. 36, en de Hansard Society Commission 2001, p. 22.

62 HC 224 (2000-01), § 40-43.

${ }^{63}$ HC Deb 30 October 2003, col. 448. Thans is de toelage $£ 14.582$ bovenop de normale vergoeding van $£ 65.738$ (exclusief onkostenvergoedingen). Dit is echter nog steeds substantieel minder dan de extra vergoeding die de meeste ministers ontvangen: tussen $£ 30.000$ en $£ 78.000$. Zie UK Parliament, About Parliament: MPs Pay and Allowances, <http://www.parliament.uk/about/how/members/ pay_mps.cfm> (laatst geraadpleegd: 28 november 2012).

${ }^{64}$ House of Commons Standing Order No. 122A van 14 mei 2002 (gewijzigd: 13 juli 2005).

65 Zo deed de winnende Labourkandidaat voor de Public Accounts Committee, Margaret Hodge, in de aanloop naar de voorzittersverkiezingen in de media toezeggingen over een onderzoek dat zij zou gaan initiëren indien zij verkozen zou worden. Zie P. Curtis, 'Select committee elections: Margaret Hodge offers Labour spending inquiry', The Guardian, 8 juni 2010.
} 
Bovendien kan een select committee haar eigen bevoegdheden, zoals de PPRbevoegdheden, slechts subdelegeren aan een subcommissie indien het Huis dat expliciet mogelijk heeft gemaakt in de (standing) order.

In het verleden beschikten slechts enkele select committees over de bevoegdheid om subcommissies in te stellen. Sinds 2001 zijn alle departmental select committees, de Public Administration Select Committee en de Environmental Audit Committee hiertoe bevoegd. ${ }^{66}$ Sommige select committees kunnen slechts één subcommissie instellen, andere zijn daarin vrij. Veelal wordt in de (standing) order aangegeven wat het minimale en maximale aantal leden van een subcommissie moet zijn en wat het quorum is. Soms wordt het aan de select committee overgelaten om te bepalen met welk doel een subcommissie wordt benoemd, zoals in het geval van de departmental select committees. ${ }^{67}$ In andere gevallen, zoals bij de Committee on Standards and Privileges, is in de standing orders in algemene zin gesteld dat de commissie bevoegd is "to refer to such sub-committees any of the matters referred to the committee." 68 In weer andere gevallen wordt in de (standing) order aangegeven dat een select committee de mogelijkheid heeft om subcommissies in te stellen voor het verzamelen van bewijs of het werk van de select committee te verdelen. ${ }^{69}$

De bevoegdheden van sub-committees komen vaak overeen met de bevoegdheden van de voltallige select committee, al kunnen sub-committees doorgaans niet zelfstandig rapporteren aan het Huis. Zij rapporteren slechts aan de voltallige select committee, die een eventueel concept-rapport van de sub-committee kan overnemen, aanpassen en publiceren. Niet altijd blijken de leden van select committees overigens bereid om in te stemmen met het (op basis van verzameld bewijs opgestelde) concept-rapport van een subcommissie waarbij zij zelf niet betrokken waren. ${ }^{70} \mathrm{Sub}$ committees zijn doorgaans wel bevoegd het bewijsmateriaal dat zij hebben verzameld ('minutes of evidence'), al dan niet door tussenkomst van de select committee, integraal aan het Huis te rapporteren. ${ }^{71}$

Voor zover het geen overdracht van bevoegdheden betreft, regelen select committees in beginsel zelf de werkwijze van hun subcommissies. Zo kunnen select committees middels een 'order' zelf de leden en voorzitter van hun subcommissie(s) benoemen. ${ }^{72}$ In de praktijk blijken select committees ook informele subcommissies in te stellen, bijvoorbeeld ten behoeve van overleg over bepaalde onderzoeken of het schrijven van concept-rapporten. Voor zover zij niet zijn ingesteld op grond van een bevoegdheid daartoe in de betreffende (standing) order, gaat het hierbij feitelijk om

${ }^{66}$ Zie bijvoorbeeld Standing Order No. 152 van 25 juni 1979 (laatstelijk gewijzigd: 30 juni 2010), lid 3 jo. lid 4. Zie verder Blackburn \& Kennon 2003, p. 578 en Erskine May 2004, p. 767.

67 Zie Standing Order No. 152 van 25 juni 1979 (laatstelijk gewijzigd: 30 juni 2010), lid 3 jo. lid 4, waarin geen nadere omschrijving van de taken of functies de sub-committee van een departmental select committee is opgenomen.

68 Zie Standing Order No. 149 van 6 november 1995 (laatstelijk gewijzigd: 12 maart 2012), lid 4.

${ }^{69}$ Erskine May 2004, p. 767.

${ }^{70}$ Wanneer subcommissies echter de bevoegdheid zouden krijgen om zelfstandig te rapporteren aan het Huis, dan zou een subcommissie in feite een volwaardige commissie zijn. Zie Blackburn \& Kennon 2003, p. 579.

71 Zie bijvoorbeeld Standing Order No. 152 van 25 juni 1979 (laatstelijk gewijzigd: 30 juni 2010), lid 3 jo. lid 4. Zie ook Blackburn \& Kennon 2003, p. 579.

72 Erskine May 2004, p. 768. Zie ook Blackburn \& Kennon 2003, p. 578-579. 
niet meer dan een groep commissieleden. Deze groep treedt dan ook niet als zodanig naar buiten. ${ }^{73}$

\subsection{Ondersteuning}

\subsubsection{Vaste staf}

De departementale onderzoekscommissies beschikken over een relatief kleine vaste staf, doorgaans bestaande uit vijf à zes medewerkers. De commissiestaf staat onder leiding van een Clerk. De Clerk is de belangrijkste ambtelijke adviseur van de commissie, treedt op als griffier en werkt nauw samen met de commissievoorzitter. De Clerk geeft daarnaast leiding aan de staf en is veelal verantwoordelijk voor de ambtelijke ondersteuning van commissieonderzoeken. De meeste commissies kennen tevens een Second Clerk, die een deel van de commissieonderzoeken begeleidt en als griffier optreedt bij eventuele subcommissies. Alle clerks zijn in vaste dienst van het Lagerhuis en hebben de status van Officer of the House. Hun ambtelijke positie brengt met zich mee, dat zij zich neutraal opstellen en kunnen werken voor elke commissie(voorzitter) onafhankelijk van partijpolitieke samenstelling. ${ }^{74}$ Hiernaast beschikken alle commissies over een of meerdere committee specialists. Dit zijn inhoudelijke specialisten, die worden aangesteld op tijdelijke basis. De commissiespecialisten verrichten inhoudelijk onderzoek en verzorgen briefings voor de commissie. Tenslotte bestaat de vaste staf uit een of meerdere committee assistants en secretaries, die de administratieve ondersteuning van de commissie verzorgen: het opmaken van commissierapporten, het uitnodigen van getuigen en het organiseren van hoorzittingen en werkbezoeken. ${ }^{75}$

De staf is organisatorisch ondergebracht in de Committee Office, onderdeel van de Department of the Clerk of the House. De stafleden worden niet door de commissie zelf aangetrokken maar door de Committee Office, al is de commissievoorzitter doorgaans wel betrokken bij de opvulling van vacatures voor committee specialists. ${ }^{76}$ De Committee Office bestaat uit ongeveer 160 stafleden, die de ongeveer dertig (departementale en andere) onderzoekscommissies van het Lagerhuis ondersteunen.

\subsubsection{Specialist advisers}

Naast de vaste staf kan een onderzoekscommissie gebruik maken van zogenaamde specialist advisers. Dit zijn externe deskundigen, veelal ervaren academici, die worden ingeschakeld ten behoeve van individuele onderzoeken, "to supply information which is not readily available or to elucidate matters of complexity within the committee's order of reference" 77 . Deze specialist advisers ondersteunen het onder-

${ }^{73}$ Zie verder Erskine May 2004, p. 768.

74 Of, zoals Blackburn en Kennon schrijven: "Clerks work with a designated committee whatever the changes in the party in power, in members or in chairmen." Blackburn \& Kennon 2003, p. 594.

75 Zie verder: Rodgers \& Walters 2006, p. 361-362.

76 Blackburn \& Kennon 2003, p. 594-595.

77 House of Commons Standing Order No. 152 van 25 juni 1979 (laatstelijk gewijzigd: 30 juni 2010), lid $4 \mathrm{sub} b$. 


\section{VERENIGD KONINKRIJK}

zoekswerk van de commissie en werken in opdracht van de Clerk. Zij zijn slechts op parttime basis in dienst en worden per dag betaald, waardoor het systeem een hoge mate van flexibiliteit kent. De mate waarin specialist advisers worden ingezet verschilt van commissie tot commissie: van een incidenteel aangestelde specialist adviser ten behoeve van een technisch of anderszins complex onderzoek tot een min of meer vaste groep van zo'n tien tot vijftien specialist advisers tegelijkertijd. Gemiddeld zijn zo'n 150 specialist advisers verbonden aan de verschillende (departementale en overige) onderzoekscommissies. ${ }^{78}$

\subsubsection{Scrutiny Unit}

In 2002 werd, op aanbeveling van de Modernisation Committee, besloten tot een bescheiden uitbreiding van de ambtelijke ondersteuning van departementale onderzoekscommissies middels de oprichting van een centraal onderzoeksbureau binnen de Committee Office, de Scrutiny Unit. ${ }^{79} \mathrm{Bij}$ dit bureau zijn ongeveer zeventien onderzoekers werkzaam, bestaande uit economen, juristen, accountants en statistici. Deze zijn veelal op tijdelijke basis gedetacheerd door ministeries of de National Audit Office (NAO). Daarnaast kent de Unit een hoofd en adjunct-hoofd, enkele clerks en een aantal administratieve medewerkers, allen in dienst van de Committee Office. De onderzoekers zijn voornamelijk gespecialiseerd op twee terreinen: financiële analyse en wetgeving. Select committees kunnen de Unit inschakelen voor specialistisch onderzoek, zoals het analyseren van departementale begrotingen of jaarverslagen of ontwerpwetsvoorstellen die aan onderzoekscommissies worden voorgelegd. De Scrutiny Unit wordt echter ook voor andere onderzoekswerkzaamheden van select committees ingezet, bijvoorbeeld wanneer een commissie kampt met vacatures in haar eigen staf. 80

Het initiatief voor dit onderzoeksbureau kwam van de Liaison Committee. In haar rapport over het functioneren van het stelsel van onderzoekscommissies uit 1999 stelde de commissie dat het werk van de commissies alleen verder zou kunnen worden uitgebouwd, bijvoorbeeld op terreinen als financiële controle en wetgeving, wanneer daar een zekere uitbreiding van de ambtelijke ondersteuning tegenover zou staan. Van belang was wel dat dit op een evenwichtige wijze zou gebeuren:

\footnotetext{
"The credibility of the system depends upon Members being fully involved in the work of the committees, being prepared to put in the necessary preparation and study as well as taking part in the committee's programme. Addition staff resources may improve the quality of a committee's work, but should not be the means of increasing a committee's output at the cost of Member involvement." 81
}

\footnotetext{
78 Rodgers \& Walters 2006, p. 362.

${ }^{79}$ HC Deb 14 mei 2002, col. 715. Zie ook House of Commons Modernisation Committee, First Report: Select Committees, HC 224-I (2001-02), § 27-30. Zie verder Blackburn \& Kennon 2003, p. 595.

${ }^{80}$ Rodgers \& Walters 2006, p. 362. Zie ook Liaison Committee, The Work of Committees in 2007, HC 427 (2007-08), Appendix 3 (The work of the Scrutiny Unit in 2007).

${ }^{81}$ HC 300 (1999-2000), §9.
} 
Juist omdat de onderzoekswerkzaamheden op terreinen als financiën en wetgeving niet in gelijke mate over het jaar verdeeld is en niet alle commissies evenveel behoefte aan specialistische ondersteuning nodig zullen hebben, was de oprichting van een centraal onderzoeksbureau waarvan alle commissies gebruik kunnen maken de meest efficiënte manier om meer deskundige ondersteuning te creëren. Dit bureau zou klein moeten beginnen; verdere groei zou moeten afhangen van de mate waarin het bureau wordt ingezet door de commissies. ${ }^{82}$ Een evaluatie door de NAO in 2007, vijf jaar na oprichting, leidde tot de conclusie dat de Unit in haar korte bestaan zowel de kwantiteit als de kwaliteit van het financieel commissieonderzoek had verhoogd en daarnaast een instrumentele rol speelde in het analyseren van ontwerpwetsvoorstellen door select committees. 83

\subsubsection{Overige ondersteuning}

Naast bovengenoemde vormen van ondersteuning maken onderzoekscommissies gebruik van verschillende interne diensten, waaronder het House of Commons Department of Information Services (voorheen de House of Commons Library). Sinds enkele jaren worden onderzoekers van de bibliotheek zo nu en dan op tijdelijke basis toegevoegd aan de vaste staf van commissies ten behoeve van specifieke onderzoeken. ${ }^{84}$

Een andere belangrijke bron van ondersteuning is de National Audit Office. Naast de formele band met de Public Accounts Committee (zie hierna) levert de NAO ook ondersteuning aan andere onderzoekscommissies in de vorm van detachering van medewerkers. In 2007 maakten elf select committees gebruik van de diensten van de NAO. Sinds enige tijd vervaardigt de NAO schriftelijke briefings over de prestaties van ministeries, "to assist committees in navigating and interpreting the substantial amounts of information available on the performance of specific departments and to identify areas that committees may wish to explore" .85

Tenslotte beschikt de Liaison Committee over een klein budget dat kan worden gebruikt om externe onderzoekers in opdracht van select committees onderzoekswerkzaamheden te laten verrichten (uitbesteed onderzoek). Select committees kunnen hiertoe aanvragen indienen bij de Liaison Committee. Dit jaarlijkse budget wordt, opmerkelijk genoeg, vaak niet geheel uitgeput. Commissies lijken meer te vertrouwen op hun eigen vaste staf, de diensten van de Scrutiny Unit en van hun specialist advisers. ${ }^{86}$

\footnotetext{
82 HC 300 (1999-2000), § 71-84.

${ }^{83}$ Zie het rapport van de Liaison Committee, The Work of Committees in 2007, HC 427 (2007-08), § 95.

${ }^{84}$ HC 427 (2007-08), § 92.

${ }^{85}$ HC 427 (2007-08), § 93-94 en Appendix 4 (National Audit Office Support for House of Commons Select Committees in 2007).

${ }^{86}$ Maer \& Sandford 2004, p. 25-26. Volgens de jaarafrekening van het Lagerhuis over het jaar 2009-10 werd in totaal $£ 80.933,26$ door de verschillende commissies besteed onder de post "work commissioned, specialist publications, and interpretation". Vergeleken met de uitgaven voor "Specialist Advisers" (£ 322.014,20) en “Overseas Visits" (£ 1.057.820,94) is dit niet erg veel.
} 


\subsection{Overige onderzoekscommissies}

\subsubsection{Thematische onderzoekscommissies ('cross-cutting committees')}

Naast de departementale onderzoekscommissies kent het Lagerhuis verscheidene andere vaste onderzoekscommissies, die niet primair departementaal-geörienteerd zijn. Deze commissies worden veelal aangeduid als 'cross-cutting committees' en verrichten verschillende vormen van onderzoek. Zij beschikken over dezelfde onderzoeksbevoegdheden als de departementale commissies. De belangrijkste zijn de $\mathrm{Pu}-$ blic Administration Select Committee (PASC), de Environmental Audit Committee (EAC) en de European Scrutiny Committee. ${ }^{87}$

De onderzoeksopdracht van PASC is tweeledig. Ten eerste is deze commissie belast met het monitoren van de rapporten van de Britse ombudsman. ${ }^{88}$ Hiernaast heeft PASC de taak onderzoek te doen naar "...matters in connection therewith, and to consider matters relating to the quality and standards of administration provided by civil service departments, and other matters related to the civil service..." 89 De commissie heeft sinds haar oprichting in 1997 veel (fundamenteel) onderzoek verricht naar de positie, rol en organisatie van het openbaar bestuur en de publieke sector in het algemeen. ${ }^{90}$ De individuele rapporten van de ombudsman kunnen daarbij als aanknopingspunt dienen voor breder onderzoek, gericht op lessen voor de toekomst. Soms doet de commissie echter specifiek vervolgonderzoek naar aanleiding van een individueel ombudsmanrapport. ${ }^{91}$

De Environmental Audit Committee is eveneens in 1997 ingesteld. Haar taakopdracht is te bezien in hoeverre het beleid van ministeries en andere publieke orga-

\footnotetext{
${ }^{87}$ De in 2007 opgeheven en later heropgerichte Science \& Technology Committee zou overigens eveneens tot deze categorie commissies kunnen worden gerekend, maar in de Standing Orders (No. 152) wordt deze commissie aangemerkt als een departemental select committee. Zie verder hierboven, par. 3.2.3.

88 Zie House of Commons Standing Order No. 146 van 25 juni 1979 (laatstelijk gewijzigd: 25 november 2008), lid 1. het Verenigd Koninkrijk kent verschillende ombudsfuncties. De belangrijkste is de Parliamentary Commissioner for Administration. Deze ombudsman kan onderzoek doen naar gevallen van 'maladministration', maar alleen op aangeven van een lid van het parlement. De Commissioner rapporteert dan ook terug aan het parlement; namens het parlement verricht PASC nader onderzoek naar deze rapporten.

${ }^{89}$ House of Commons Standing Order No. 146 van 25 juni 1979 (laatstelijk gewijzigd: 25 november 2008), lid 1.

90 Voorbeelden zijn onderzoeken naar de betekenis van ministeriële verantwoordelijkheid, de staatsrechtelijke positie van ambtenaren, de publicatie van politiek memoires, klantgerichtheid bij publieke diensten en openbaarheid van bestuur. De commissie is de opvolger van de Public Service Committee en de Select Committee on the Parliamentary Commissioner for Administration. Formeel is PASC geen departementale commissie, maar in de praktijk heeft veel van het werk van de commissie betrekking op de Cabinet Office, het ministerie waar thans de verantwoordelijkheid voor het ambtelijke apparaat van de centrale overheid ligt. Zie ook Blackburn \& Kennon 2003, p. 573.

91 Een recent voorbeeld van dit laatste is een vervolgonderzoek naar een compensatieregeling voor mensen wiens pensioenaanspraken vervallen waren, naar het oordeel van de ombudsman mede als gevolg van onduidelijke regelgeving en gebrekkige overheidscommunicatie. Zie Public Administration Select Committee, Pensions Bill. Government Undertakings Relating to the Financial Assistance Scheme, HC 523 (2006-07). Zie over deze commissie verder Blackburn \& Kennon 2003, p. 609-610. Zie ook Rodgers \& Walters 2006, p. 350-351.
} 
nen bijdraagt aan "environmental protection and sustainable development" en te controleren of doelstellingen worden gehaald die ministers in dat kader hebben geformuleerd. De commissie bestaat uit zestien leden, waaronder ex officio de minister voor Milieu. ${ }^{92}$ De commissie kiest haar eigen onderzoeksonderwerpen, waarbij veelal gebruik gemaakt wordt van milieu-gerelateerde stukken die van regeringswege worden gepubliceerd..$^{93}$

Een derde commissie die hier genoemd kan worden is de European Scrutiny Committee. Deze commissie, opgericht na de toetreding van het Verenigd Koninkrijk tot de Europese Economische Gemeenschap in 1973, heeft verschillende functies. Ten eerste dient de commissie te beslissen over "the legal and political importance" van de EU-documenten die aan de nationale parlementen worden toegestuurd, zoals voorstellen voor verordeningen, richtlijnen en kaderbesluiten. Zij kan in haar rapporten voorts haar opvattingen weergeven en aanbevelingen doen. Verder kan de commissie naar aanleiding van EU-voorstellen nader rapporteren over "any matters of principle, policy or law which may be affected." Tenslotte heeft de commissie de algemene taak "to consider any issue arising upon any such document or group of documents, or related matters." 94 De commissie bestaat uit zestien leden en kent verschillende vaste subcommissies. Het aantal rapporten van deze commissie is, vergeleken met andere commissies, zeer hoog (de commissie rapporteert wekelijks). Rapporten bevatten doorgaans een korte analyse en toelichting van de belangrijkste EU-documenten. In veel gevallen concludeert de commissie dat een EU-document juridisch of politiek niet van groot belang is. In andere gevallen beveelt de commissie vaak aan het document nader te bespreken in één van de European Standing Committees of in de plenaire vergadering. ${ }^{95}$

In juni 2010, toen voor het eerst in decennia weer een coalitieregering tot stand kwam, werd aan deze groep thematische commissies een nieuwe commissie toegevoegd: de Political and Constitutional Reform Committee. ${ }^{96}$ Deze commissie dient zich het bijzonder te richten op het werk van de Deputy Prime Minister, die politieke en constitutionele hervorming in zijn takenpakket heeft. Inmiddels heeft de commissie gerapporteerd over onder meer de lessen van kabinetsformatie van 2010, het regeringsvoorstel om de parlementaire zittingstermijn voortaan te fixeren op vijf jaar, het kiesstelsel en de financiering van politieke partijen. ${ }^{97}$

\footnotetext{
92 Zie House of Commons Standing Order No. 152A van 10 november 1997 (laatstelijk gewijzigd: 25 november 2008), lid 1.

93 Zo heeft de commissie zich de afgelopen jaren beziggehouden met onderwerpen als klimaatverandering en duurzaam bouwen. Zie verder Blackburn \& Kennon 2003, p. 610-611. Zie ook Rodgers \& Walters 2006, p. 348.

94 Zie House of Commons Standing Order No. 143 van 17 november 1998 (laatstelijk gewijzigd: 25 november 2008), lid 1 .

${ }^{95}$ De behandeling van Europese zaken blijft hier verder buiten beschouwing. Zie hierover o.a. Blackburn \& Kennon 2003, p. 606-607.

96 Zie HC Deb 7 juni 2010, col. 136-148.

${ }_{97}$ Zie respectievelijk HC 528 (2010-12), HC 436 (2010-12), HC 437 (2010-12) en HC 1763 (2010-12).
} 


\subsubsection{Public Accounts Committee}

\subsubsection{De commissie}

Een bijzondere parlementaire onderzoekscommissie is de Committee of Public Accounts, kortweg PAC. De commissie stamt uit 1861 en is groter dan veel andere commissies (maximaal zestien leden). De voorzitter van de PAC is traditioneel altijd een vooraanstaand lid van de grootste oppositiepartij. Volgens conventie is een minister op het departement van Financiën ex officio lid van de commissie; deze ontvangt wel alle commissiestukken, maar is nooit bij commissievergaderingen aanwezig. De commissie beschikt over de gebruikelijke PPR-bevoegdheden. ${ }^{98}$

De taak van de PAC is onderzoek te doen naar "the accounts showing the appropriation of the sums granted by Parliament to meet the public expenditure, and of such other accounts laid before Parliament as the committee may think fit..." 99 Bijzonder is dat de commissie bij haar onderzoek intensief samenwerkt met de National Audit Office (NAO). De samenwerking met de rekenkamer is wettelijk geregeld in de National Audit Act 1983. Aan het hoofd van de NAO staat de Comptroller \& Auditor General (C\&AG). Dit is een functionaris van het Lagerhuis, die wordt aangesteld op voordracht van de Prime Minister en met instemming van de voorzitter van de PAC. 100

\subsubsection{Samenwerking met Comptroller \& Auditor General}

De taak van de C\&AG is tweeledig. Enerzijds doet hij onderzoek naar de rechtmatigheid van overheidsbestedingen. De C\&AG is van oudsher belast met het controleren van de rekeningen van de departementen en overige publieke diensten; dit gebeurt middels periodieke 'certification audits'.101 Ten tweede is de C\&AG belast met doelmatigheidstoetsing. Op grond van art. 6 van de National Audit Act 1983 kan hij onderzoek doen naar "the economy, efficiency and effectiveness with which any department, authority or other body to which this section applies has used its resources in discharging its functions." Deze zogenaamde 'value-for-money' onderzoeken kunnen betrekking hebben op specifieke uitgaven, maar hebben de laatste jaren ook steeds vaker de vorm van brede periodieke analyses van grote bestedingsprogramma's. ${ }^{102}$ De C\&AG is volledig vrij in zijn onderwerpskeuze, al dient hij rekening te houden met eventuele voorstellen van de Public Accounts Committee. ${ }^{103}$ Het is de

\footnotetext{
98 Zie House of Commons Standing Order No. 148 van 3 april 1862, (laatstelijk gewijzigd: 5 juli 2001), lid 1. Anders dan de departementale onderzoekscommissies kan de PAC niet vergaderen buiten parlementaire zittingsdagen. Zie ook Erskine May 2004, p. 784.

${ }^{99}$ House of Commons Standing Order No. 148 van 3 april 1862, (laatstelijk gewijzigd: 12 maart 2012), lid 1.

100 National Audit Act 1983 (c. 44), art. 1, lid 1-2.

101 Zie hiervoor: Exchequer and Audit Departments Act 1921 (c. 52), art. 2.

102 Blackburn \& Kennon 2003, p. 605. Een voorbeeld van deze laatste ontwikkeling is het C\&AGrapport 'Department for Environment, Food and Rural Affairs: Management of Expenditure', HC 309 (2007-08); zie voor het hieraan gerelateerde PAC-rapport (onder dezelfde titel): HC 447 (2007-08).

103 Zie National Audit Act 1983 (c. 44), art. 1, sub 3. Zie ook Erskine May 2004, p. 785.
} 
C\&AG echter uitdrukkelijk niet toegestaan "to question the merits of the policy objectives" die achter de bestedingen liggen. ${ }^{104}$

Het onderzoek van de Public Accounts Committee bouwt voort op de resultaten van 'value for money'-rapporten van de C\&AG. Ongeveer tweederde van deze NAO-rapporten worden door de PAC behandeld. De C\&AG woont alle vergaderingen en hoorzittingen van de PAC bij. De bevindingen, conclusies en aanbevelingen van de commissie worden neergelegd in een commissierapport. Dit rapport wordt niet door de eigen staf, maar door de NAO in concept voorbereid. ${ }^{105}$ Daarnaast kan de PAC gebruik maken van de expertise van de in 2002 opgerichte Scrutiny Unit van het Lagerhuis. Jaarlijks publiceert de PAC zo'n vijftig rapporten, veel meer dan gebruikelijk is bij parlementaire onderzoekscommissies.

In vergelijking met andere onderzoekscommissies wordt aan het werk van de PAC relatief veel aandacht besteed in de plenaire vergadering. Eén dag per jaar wordt hiervoor ingeroosterd. In beginsel worden alle rapporten van de PAC besproken, maar in de praktijk worden de meeste rapporten voor kennisgeving aangenomen en wordt gedebatteerd over een aantal specifieke thema's. ${ }^{106}$

\subsubsection{Bijzondere positie van Accounting Officers}

De commissie houdt op basis van de rapporten van de NAO hoorzittingen met de ambtelijke leiding van de betreffende ministeries, zoals de secretarissen-generaal ('permanent secretaries'). In bijzondere (politiek gevoelige) gevallen verschijnen ministers persoonlijk voor de commissie. Hoewel de ministeriële verantwoordelijkheid in beginsel ook voor de financiële huishouding van departementen geldt, nemen bepaalde (top)ambtenaren een bijzondere positie in ten opzichte van het parlement. Elk departement heeft een Accounting Officer. Bij conventie is dit de secretarisgeneraal. Op basis van de Ministerial Code heeft de Accounting Officer (AO) een "personal duty for the propriety and regularity of the public finances for which he or she is responsible; for keeping proper accounts; for the avoidance of waste and extravagance; and for the efficient and effective use of resources." 107

Deze Accounting Officers "answer personally to the Committee of Public Accounts on these matters, within the framework of Ministerial accountability to Parliament for the policies, actions and conduct of their departments." Wanneer een AO zich vanuit het oogpunt van 'propriety and regularity' niet kan vinden in een bestedingsvoorstel van een minister, dan dient hij zijn bezwaren schriftelijk kenbaar te maken. Sinds 1991 geldt dit ook wanneer de AO van oordeel is dat een bestedingsvoorstel niet efficiënt of effectief is ('value for money'). Mocht de minister zijn plannen desondanks doorzetten, dan is de AO gehouden hieraan medewerking te verlenen. Tegelijkertijd dient hij in een dergelijk geval de C\&AG te informeren en

\footnotetext{
104 National Audit Act 1983 (c. 44), art. 6, lid 1-2. De vraag is echter of onderzoek naar doelmatigheid van de bestedingen los kan worden gezien van het achterliggende beleid. Blackburn en Kennon stellen dan ook: "In practice, any value for money report is bound to touch on the underlying policy." Blackburn \& Kennon 2003, p. 605.

105 Zie verder Erskine May 2004, p. 784-785; Blackburn \& Kennon 2003, p. 604-605; Rodgers \& Walters 2006, p. 283.

106 Blackburn \& Kennon 2003, p. 606.

107 Zie Ministerial Code 2010, art. 5.3.
} 
hem de relevante stukken toe te sturen. Langs die weg wordt ook de Public Accounts Committee ervan op de hoogte gesteld dat de AO geen "personal responsibility" draagt voor de betreffende handelingen. ${ }^{108}$

\subsubsection{De rol van de PAC}

De rol van de PAC op het terrein van de overheidsfinanciën is uitzonderlijk te noemen. In het algemeen kan gezegd worden dat de invloed van het Britse parlement op dit terrein minimaal is. Hoewel de bevoegdheid tot het heffen van belastingen en het vaststellen van de bestedingen ('the power of the purse') in beginsel aan het Lagerhuis toekomen, speelt het parlement feitelijk nauwelijks een rol. De jaarlijkse vaststelling van de begroting is volledig in handen van de regering, in het bijzonder het ministerie van Financiën. Ook bij het heffen van belastingen, sinds de Bill of Rights de exclusieve bevoegdheid van het parlement, is de werkelijke invloed beperkt. In beide gevallen is het politieke prestige groot: het verwerpen van de begroting wordt gezien als een vertrouwenskwestie. Bovendien is de materie complex en voor individuele parlementariërs moeilijk te doorgronden. De regering weet zich daarom doorgaans verzekerd van een parlementaire meerderheid. Wijziging van begrotings- of belastingvoorstellen, zelfs indien geïnitieerd door regeringsgezinde parlementariërs, is niet alleen politiek moeilijk denkbaar maar ook reglementair aan banden gelegd. 109 McEldowney stelt dan ook dat de zeggenschap van het Lagerhuis over de inkomsten en de uitgaven van de centrale overheid in de praktijk is gereduceerd tot "the right to criticize. In reality both political power and economic control over public expenditure actually resides in the Government of the day." 110

Waar de parlementaire invloed vooraf minimaal is, blijkt de parlementaire controle van de overheidsbestedingen achteraf vrij sterk ontwikkeld. Zoals gezegd is er sprake van een intensieve samenwerking tussen de parlementaire onderzoekscommissie PAC en de National Audit Office. Met deze specialistische ondersteuning kan de PAC een groot deel van de totale overheidsuitgaven onderzoeken en middels beknopte rapporten inzichtelijk maken. De Accounting Officers bij de departementen spelen in dit samenspel een bijzondere rol. Zij leggen niet alleen namens de minister rechtstreeks verantwoording af aan de parlementaire commissie, maar zij kunnen eventuele onregelmatigheden in de departementale bestedingen zelfstandig signaleren en kenbaar maken aan de NAO en de PAC. De samenwerking tussen PAC en NAO zorgt ervoor dat de bevindingen van de onafhankelijke rekenkamer min of meer systematisch in parlementair verband worden behandeld. Het rekenkameronderzoek staat hoog in aanzien en krijgt bovendien meer (politieke) gewicht door het parlementaire vervolgonderzoek. De effectiviteit van het werk van de PAC en de rekenkamer is moeilijk meetbaar en moet vooral op de langere termijn bezien worden: "At the least it can be said that inquiries by the C and AG and the PAC spark off activity within the department. At the most, it can often be legitimately claimed that

\footnotetext{
108 Zie Ministerial Code 2010, artt. 5.3-5.5. Zie hierover verder Bradley \& Ewing 2007, p. 373-374. Zie ook McEldowney 2007, p. 361-362. Voor niet-departementale publieke organen (NDPBs) geldt een soortgelijke verhouding tussen het bestuur van het orgaan en de chief executive als AO.

${ }^{109}$ Zie Standing Orders No. 48 e.v.

110 McEldowney 2007, p. 364.
} 
the inquiries have disclosed defects in the working of departments which would otherwise not have been disclosed at that time." 111

In de discussie over de parlementaire controlefunctie krijgt de financiële controle de laatste jaren steeds meer aandacht. De Hansard Society deed in 2006 uitvoerig onderzoek op dit terrein. Geconcludeerd werd onder meer dat een systematische follow-up van de bevindingen van de PAC gewenst is. Daarnaast zouden de departementale onderzoekscommissies meer systematisch financieel onderzoek moeten doen, bijvoorbeeld middels permanente subcommissies. ${ }^{112}$ De Liaison Committee publiceerde begin 2008 een rapport met aanbevelingen. Daarin lijkt te worden geaccepteerd dat de parlementaire rol aan de voorkant van de financiële cyclus beperkt is; wel klinkt de roep om de manier waarop de regering haar begrotingsplannen presenteert inzichtelijker en niet onnodig complex te maken. ${ }^{113}$ Aan de achterkant van het proces ziet de commissie meer ruimte voor verbetering, vooral aan parlementaire zijde. Financiële controle is sinds enige tijd een van de 'core tasks' van de departementale onderzoekscommissies. De PAC, die op dit terrein een algemene taak heeft, zou meer moeten samenwerken met departementale commissies. Deze zouden bovendien zelf meer gebruik moeten maken van de expertise van de NAO.114 Tegelijkertijd wordt gewaarschuwd voor het gevaar van overlap, als de departementale commissies zich meer met financiële controle gaan bezighouden.

\subsubsection{Liaison Committee}

De Liaison Committee vormt de schakel tussen de onderzoekscommissies. Alle commissievoorzitters zijn lid van deze commissie, die voornamelijk een algemene, coördinerende taak heeft. De voorzitter is sinds 1992 echter niet meer afkomstig uit een van de onderzoekscommissies. De Liaison Committee is een forum voor overleg tussen de voorzitters van de verschillende onderzoekscommissies en treedt in de praktijk vaak op als belangenbehartiger van de commissies, bijvoorbeeld door de regering te wijzen op achterstanden in het reageren op rapporten. ${ }^{115}$ De commissie publiceert jaarlijks een verslag van het werk van de onderzoekscommissies. Verder heeft de Liaison Committee de afgelopen jaren verschillende rapporten gepubliceerd over algemene thema's als het functioneren van het commissiestelsel. ${ }^{116}$ De commissie beheert tevens het gezamenlijke budget voor werkbezoeken en extern onderzoeksopdrachten en bepaalt welke commissierapporten zullen worden voorgedragen voor debat in de plenaire vergadering of in Westminster Hall. ${ }^{117}$

111 Blackburn \& Kennon 2003, p. 605.

112 Brazier \& Ram 2006, p. 35-45.

113 Liaison Committee, Parliament and Government Finance. Recreating Financial Scrutiny, HC 426 (2007-08), § 7-14.

114 HC 426 (2007-08), § 68-72.

115 Zie verder Blackburn \& Kennon 2003, p. 618-619 en Rodgers \& Walters 2006, p. 349-350.

116 Zie bijvoorbeeld een reeks rapporten getiteld Shifting the Balance: Select Committees and the Executive, o.a. te vinden onder HC 300 (1999-2000).

117 House of Commons Standing Order No. 145 van 31 januari 1980 (laatstelijke gewijzigd: 20 mei 2009). 
Sinds enkele jaren heeft de Liaison Committee meer dan alleen een coördinerende functie. In 2002 besloot de toenmalige Prime Minister Blair tweemaal per jaar voor de commissie te verschijnen voor een openbare hoorzitting omtrent het gevoerde regeringsbeleid.118 Afgesproken is dat de Prime Minister tevoren te horen krijgt welke beleidsaspecten of thema's aan de orde zullen komen, maar niet welke specifieke vragen zullen worden gesteld. Blairs opvolgers Brown en Cameron hebben deze gewoonte voortgezet. De halfjaarlijkse hoorzitting met de Prime Minister is inmiddels uitgegroeid tot een vertrouwd onderdeel van het Britse parlementaire commissiestelsel, waarbij commissievoorzitters de kans krijgen om vanuit hun onderzoekservaring vragen te stellen aan de regeringsleider. ${ }^{119}$ De Liaison Committee is echter nog niet helemaal tevreden met de wijze waarop deze hoorzittingen tot nu toe verlopen. In een recent jaarverslag wordt gesteld dat de hoorzittingen "have the potential to provide a valuable extra means of holding the Prime Minister to account but that this potential has not yet been fully realised (...) we will therefore keep the detailed arrangements under review." 120

\subsubsection{Onderzoekscommissies in het Hogerhuis}

Niet alleen in het Lagerhuis is parlementair onderzoek sinds de jaren '70 van de twintigste eeuw een steeds belangrijkere rol gaan spelen. Ook in het Hogerhuis is in de loop der tijd een stelsel van permanente onderzoekscommissies ontstaan. ${ }^{121} \mathrm{Ken}$ merkend verschil met het commissiestelsel in het Lagerhuis is dat het commissiestelsel in het Hogerhuis zich niet hoofdzakelijk langs departementale lijnen heeft ontwikkeld, maar vooral thematisch en grensoverstijgend ('cross-cutting'). Lange tijd waren de European Union Committee en de Science \& Technology Committee hiervan de belangrijkste voorbeelden. De hervormingen van het Hogerhuis, die na het aantreden van de Labourregering in 1997 plaatsvonden, waarbij vrijwel alle 'peers' die hun lidmaatschap op erfelijke titel hadden verkregen werden verwijderd uit het Hogerhuis, gaven een verdere impuls aan de activiteit (en assertiviteit) van het Hogerhuis. Dit heeft ook zijn weerslag gehad op het commissiewerk, dat steeds verder groeide. Terwijl na de Lagerhuisverkiezingen van 2001 de geplande verdere hervormingen van het Hogerhuis niet van de grond kwamen, bleek er wel ruimte om twee nieuwe permanente onderzoekscommissies in te stellen, te weten de invloedrijke Constitutional Committee en de Economic Affairs Committee. ${ }^{122}$

Het verschil in commissiestructuur in beide Huizen heeft ertoe geleid dat, zo stellen Rodgers en Walters, "there is now general acceptance that this enables Lords

\footnotetext{
118 In de Standing Orders is vervolgens vastgelegd dat de Liaison Committee bevoegd is de Prime Minister te horen. Zie House of Commons Standing Order No. 145 van 31 januari 1980 (laatstelijke gewijzigd: 20 mei 2009), lid 2.

119 Rodgers \& Walters 2006, p. 350.

${ }^{120}$ Liaison Committee, The Work of Committees in 2008-09, HC 426 (2009-10), § 10.

121 Deze permanente commissies worden 'sessional committees' genoemd, die op grond van de Standing Order No. 64 elk jaar automatisch opnieuw worden ingesteld.

122 Zie voor een overzicht van alle permanente commissies ('sessional committees', dat wil zeggen commissies die elk jaar automatisch opnieuw worden ingesteld tenzij anders wordt besloten): House of Lords Standing Orders No. 64 van 10 november 1975.
} 
committees work to complement rather than compete with or duplicate that of the Commons." 123 Niet alleen de structuur is verschillend, ook het karakter van het onderzoekswerk is anders. Het Hogerhuis staat op enige afstand van de dagelijkse partijpolitiek staat en waar in het Lagerhuis steeds meer carrièrepolitici verschijnen, bezitten veel leden van het Hogerhuis specifieke expertise in beleidsterreinen als techniek, geneeskunde, recht en economie. Deze bijzondere expertise komt mede tot uitdrukking in de onderzoekscommissies. Door het niet-partijpolitieke karakter van veel onderzoekscommissies kunnen partijloze leden (crossbenchers) hierin een belangrijke rol spelen. ${ }^{124}$

Naast permanente commissies wordt de laatste jaren met enige regelmaat gebruik gemaakt van tijdelijke ad hoc onderzoekscommissies, gericht op specifieke beleidskwesties. Te denken valt aan stamcelonderzoek, dierproeven, de regelgeving omtrent godslastering of de hervorming van de publieke omroep. Zo nu en dan worden ook onderzoekscommissies ingesteld ten aanzien van bijzondere wetsvoorstellen. Meestal gaat het daarbij overigens om initiatiefwetsvoorstellen en niet om regeringsvoorstellen. Die laatsten, zo is de gedachte, zouden bij een dergelijk onderzoek in het Hogerhuis teveel vertraging oplopen. ${ }^{125}$

De werkwijze van de onderzoekscommissies in het Hogerhuis komt in hoge mate overeen met die van de commissies in het Lagerhuis. Ook het Hogerhuis kent een Liaison Committee, al heeft deze een ander karakter. De commissie bestaat uit de leiders van de verschillende partijen en van de leider van de partijloze leden (Convenor of the Crossbench Peers) of hun vertegenwoordigers, almede enkele backbenchers. ${ }^{126}$ Naast haar coördinerende activiteiten en het beheren van budgetten, heeft deze commissie een adviserende rol bij het instellen van nieuwe tijdelijke commissies, waartoe individuele leden van het Hogerhuis voorstellen kunnen indienen. De adviezen van de Liaison Committee wordt doorgaans door de plenaire vergadering overgenomen. Opvallende uitzondering hierop betreft de instelling van de Select Committee on the Crash of Chinook Helicopter ZD576. De Liaison Committee had negatief geadviseerd, omdat de taakomschrijving ('order of reference') teveel een quasi-gerechtelijk karakter zou hebben. De plenaire vergadering nam het voorstel toch aan. ${ }^{127}$

Tenslotte moet nog het onderzoekswerk dat samen met het Lagerhuis wordt uitgevoerd, zowel op permanente basis als ad hoc, worden vermeld. Zo wordt intensief samengewerkt in de Joint Committee on Human Rights, een commissie met twaalf leden waarin de regeringspartij geen meerderheid heeft. De commissie heeft onder meer de taak onderzoek te doen naar de 'remedial orders' van regeringswege naar aanleiding van een rechterlijke verklaring van incompatibiliteit onder de Human Rights Act. In 2001 stelde de commissie zichzelf een breder doel: alle wetsvoor-

\footnotetext{
${ }^{123}$ Rodgers \& Walters 2006, p. 378. Zie in vergelijkbare zin ook Blackburn \& Kennon 2003, p. 705. Zie verder Oliver 2003, p. 191 e.v.

124 Blackburn \& Kennon 2003, p. 705.

125 Uitzonderlijk was de onderzoekscommissie ten aanzien van de Constitutional Reform Bill uit 2004, een regeringsvoorstel dat onder meer beoogde de rechterlijke functie van het Hogerhuis onder te brengen in een apart Hooggerechtshof. Zie verder Rodgers \& Walters 2006, p. 378-379.

126 Erskine May 2004, p. 736.

127 Rodgers \& Walters 2006, p. 379-380. Zie over dit bijzondere onderzoek ook hierboven, par. 2.4.3.4.
} 
stellen van regeringswege worden nu getoetst op hun compatibiliteit met mensenrechtenbepalingen. Verder wordt onderzoek gedaan naar bredere mensenrechtelijke vraagstukken. ${ }^{128}$ Naast deze invloedrijke commissie zijn er zo nu en dan gezamenlijke ad hoc onderzoekscommissies met betrekking tot beleidsvoorstellen of wetsontwerpen ('draft bills'). Ook worden gezamenlijke commissies ingesteld voor onderwerpen die het functioneren van beide Huizen aangaan, zoals de Joint Committee on Parliamentary Privilege en de Joint Committee on Lords Reform. ${ }^{129}$ In de zomer van 2012 deed de regering een voorstel voor een gezamenlijke commissie die onderzoek zou moeten verrichten naar een schandaal in de bankenwereld. ${ }^{130}$

\subsection{Wetgevingscommissies}

Kenmerkend voor het Britse wetgevingsproces is dat de voorbereidende behandeling van wetsvoorstellen plaatsvindt in ad hoc samengestelde wetgevingscommissies. De commissiefase in de wetsbehandeling is aan het einde van de negentiende eeuw ontstaan met de bedoeling het parlementaire wetgevingsproces te versnellen. Voordien was het gebruikelijk dat de gedetailleerde, artikelgewijze behandeling plaatsvond in een zogenaamde 'committee of the Whole House', bestaande uit alle leden van het Huis uitgezonderd de Speaker. ${ }^{131}$ De oorspronkelijke bedoeling was om vier vaste commissies in het leven te roepen, wiens leden op een breed beleidsterrein expertise zouden kunnen ontwikkelen, wat de parlementaire behandeling van wetsvoorstellen ten goede zou komen (vandaar de naam 'standing committee'). ${ }^{132}$ Dit is echter nooit van de grond gekomen. In plaats daarvan is het gebruikelijk geworden om voor elk wetsvoorstel dat in behandeling werd genomen, een nieuwe, tijdelijke commissie in het leven te roepen. Bij een volgend wetsvoorstel worden aldus nieuwe leden benoemd.

Eind 2006 werden de 'standing committees' hervormd en omgedoopt tot 'public bill committees'. Het ging bij deze vernieuwing om méér dan alleen een naamsverandering. Achtergrond is een langlopende discussie over de beperkte rol die het parlement in het wetgevingsproces speelt. Dit proces wordt, zoals in veel parlementaire stelsels, in sterke mate gedomineerd door de regering. Hoewel het parlement formeel de wetgevende macht bezit, wordt de meeste wetgeving feitelijk gevormd tijdens de departementale voorbereidingsfase. Beïnvloeding van het wetgevingsproces door

\footnotetext{
${ }^{128}$ House of Commons Standing Order No. 152B van 17 januari 2001 (laatstelijk gewijzigd: 15 oktober 2003) en House of Lords Standing Order No. 64 van 10 november 1975. Zie verder Blackburn \& Kennon 2003, p. 614-615.

129 Rodgers \& Walters 2006, p. 384-385.

${ }^{130}$ De regering kwam met een voorstel voor een Joint Committee na onthullingen in de pers over rentetarieven die zouden zijn gemanipuleerd door de Barclays Bank. Het schandaal leidde bij de oppositie en in de media tot de roep om een uitgebreid openbaar onderzoek ('public inquiry'), maar de regering zag dus meer in een Joint Committee met leden uit beide Huizen die zou moeten worden geleid door de voorzitter van de Treasury Committee in het Lagerhuis. Zie P. Wintour \& J. Treanor, 'David Cameron orders speedy bank inquiry', The Guardian, 3 juli 2012.

131 Committees of the Whole House worden nu alleen nog gebruikt in uitzonderlijke gevallen: zeer oncontroversiële wetsvoorstellen, urgente wetsvoorstellen of wetsvoorstellen die van groot staatsrechtelijk belang zijn. Zie Blackburn \& Kennon 2003, p. 384 en Rodgers \& Walters 2006, p. 221.

132 Rodgers \& Walters 2006, p. 211.
} 
parlementariërs, belangengroepen en anderen vindt, voor zover de politieke omstandigheden dit toelaten, dan ook voornamelijk in die fase plaats. De invloed van het parlement tijdens de parlementaire fase is zeer beperkt; het parlement functioneert veeleer als forum voor partijpolitiek debat dan als kritische beschouwer van voorgelegde wetsontwerpen. Het gehele proces staat onder controle van de whips, die ervoor zorgen dat wetsvoorstellen van regeringszijde doorgaans moeiteloos door het parlement geloodst worden. Amendementen of initiatiefvoorstellen van oppositiezijde en zelfs van regeringsgezinde backbenchers maken weinig kans. ${ }^{133}$

Tegen deze achtergrond zijn de afgelopen jaren verschillende initiatieven ontplooid om het wetgevingsproces te verbeteren. Zo bestaat de mogelijkheid van publieke consultatie in de departementale voorfase en weten ook de departementale select committees zo nu en dan een rol voor zichzelf op te eisen in een vroege fase van de wetsbehandeling ('pre-legislative scrutiny'). ${ }^{134}$ De hervorming van de wetgevingscommissies werd in gang gezet door de Modernisation Committee, de bijzondere onderzoekscommissie ingesteld in 1997 met het doel om voorstellen te doen voor 'modernisering' van de parlementaire werkwijze. De commissie stond onder voorzitterschap van de Leader of the House. In haar rapport The Legislative Process bespreekt de commissie verschillende manieren om het wetgevingsproces transparanter en toegankelijker te maken voor individuen en organisaties die belang hebben bij wetgeving. ${ }^{135}$ Daarbij ging bijzondere aandacht uit naar het functioneren van de wetgevingscommissies. De commissie zegt hierover: "the work of standing committees has been one of the most criticised aspects of the legislative process." 136 Kort gezegd komt deze kritiek erop neer dat de oude wetgevingscommissies weinig nauwkeurig te werk gingen, politiek geen rol van betekenis speelden, in tegenstelling tot de onderzoekscommissies nauwelijks contact hadden met belanghebbenden en de media en bovendien onvoldoende gebruik maakten van deskundigheid buiten het parlement. ${ }^{137}$

Hoewel de moderniseringscommissie deze kritiek niet geheel onderschreef - zo stelt zij dat het partijpolitieke debat dat in de wetgevingscommissies overheerst als "a useful way of testing the provisions of a bill, of identifying its weaknesses and the case for change" - ziet zij wel sterke voordelen in "introducing a more collaborative, evidence-based approach to the legislative process..." De nieuwe wetgevingscommissies zijn daarom uitgerust met dezelfde onderzoeksbevoegdheden als de onderzoekscommissies. Het gebruik van onderzoeksbevoegdheden bij de behandeling van

\footnotetext{
133 Alleen als de regering gehaast en ondoordacht te werk gaat, wil de parlementaire behandeling nog eens leiden tot enige amendering. Zie verder: Turpin \& Tomkins 2012, p. 636 e.v. De mogelijkheden voor backbenchers om de parlementaire agenda te beïnvloeden lijken recentelijk te zijn verbeterd met de invoering van de Backbench Business Committee, die een deel van de parlementaire agenda zonder inmenging van de regering mag gaan invullen met voorstellen van backbenchers. Deze commissie is een uitvloeisel van het rapport van de House of Commons Reform Committee. Zie nader: HC 1117 (2008-09). Zie hierover ook: Russel 2011, p. 620 e.v.

134 Zie hierna, hoofdstuk 4.

135 Modernisation Committee, The Legislative Process, HC 1097 (2005-06).

136 HC 1097 (2005-06), § 50.

137 Zo vatten de vertegenwoordigers van de Hansard Society het samen tijdens een hoorzitting voor de moderniseringscommissie. Zie HC 1097 (2005-06), § 50.
} 
wetgeving is op zichzelf niet nieuw: ook in de oude situatie bestond de mogelijkheid een wetgevingscommissie met onderzoeksbevoegdheden in te stellen. Van deze zogenaamde 'special standing committees' werd echter nauwelijks gebruik gemaakt. ${ }^{138}$ Met deze hervorming is deze commissievorm dus de norm geworden. ${ }^{139}$

De nieuwe wetgevingscommissies beschikken evenals onderzoekscommissies over de bevoegdheid om mondeling en schriftelijk bewijsmateriaal te verzamelen ('to send for persons, papers and records' $).{ }^{140}$ Dit geldt overigens alleen voor de commissies die wetsvoorstellen van regeringswege behandelen. ${ }^{141}$ Het verzamelen van 'evidence' is voorts aan beperkingen gebonden. Alle wetgevingscommissies hebben een subcommissie die een werkprogramma opstelt voor de behandeling van het wetsvoorstel ('programming sub-committee'). Hierin wordt onder andere opgenomen of en zo ja, hoeveel, (hoor)zittingen kunnen worden gehouden. Dit gebeurt overeenkomstig het tijdskader dat de regering heeft vastgesteld in de 'programme order', al kan de subcommissie voorstellen de gestelde einddatum aan te passen. De commissie beslist vervolgens bij meerderheidsstemming of het werkprogramma wordt overgenomen. Het werkprogramma dient vervolgens strikt in acht te worden genomen; zo mag het gestelde tijdskader voor hoorzittingen slechts met vijftien minuten worden overschreven, met toestemming van de commissievoorzitter. ${ }^{142}$

Evenals de oude 'special standing committees' valt het commissiewerk uiteen in twee fases: een onderzoeksfase en een debatfase. Tijdens de onderzoeksfase wordt schriftelijk bewijsmateriaal verzameld en worden enkele hoorzittingen gehouden. In deze fase wordt de commissie bij voorkeur geleid door de voorzitter van een onderzoekscommissie. Na afronding van de onderzoeksfase wordt het wetsvoorstel op de gebruikelijke wijze behandeld in de debatfase, waarbij ook amendering mogelijk is. Overeenkomstig de voorstellen van de moderniseringscommissie bezitten de nieuwe wetgevingscommissies iets meer flexibiliteit dan hun voorgangers, in die zin dat het aantal hoorzittingen door de programma-subcommissie kan worden aangepast. De subcommissie kan aldus rekening houden met het onderwerp en de complexiteit van een wetsvoorstel en op basis daarvan balans brengen tussen de twee fases. Bij sommige wetsvoorstellen kan één hoorzitting met de verantwoordelijke minister en ambtenaren voldoende zijn. Verder wordt verwacht dat een productieve onderzoeksfase

\footnotetext{
138 Sinds de invoering in 1980 is slechts negen maal een 'special standing committee' gebruikt. Zie HC 1097 (2005-06), § 60.

139 Zie voor het plenaire debat over het rapport van de moderniseringscommissie en de aanvaarde wijzigingen in de Standing Orders: HC Deb 1 november 2006, cc 304-408.

140 Zie House of Commons Standing Order No. 84A van 1 november 2006.

141 Zie House of Commons Standing Order No. 63 van 16 april 1907 (laatstelijk gewijzigd: 1 november 2006), lid 2. Het betreft wetsvoorstellen die onderworpen zijn aan een 'programme order'. Commissies die overige voorstellen behandelen, zoals initiatiefwetsvoorstellen ('private member's bills'), kunnen deze bevoegdheden middels een gewone motie tijdens de tweede lezing overigens wel toegekend krijgen.

142 Zie verder House of Commons Standing Order No. 83C van 26 oktober 2004 (laatstelijk gewijzigd: 1 november 2006).
} 
de debatfase kan ontlasten door de mogelijkheid direct vragen te stellen aan ministers en ambtenaren. ${ }^{143}$

Ondanks deze hervormingen is veel bij het oude gebleven. Zo is in de samenstelling van de wetgevingscommissies geen verandering gebracht. Het samenstellen van commissies gebeurt zoals voorheen ad hoc door de Committee of Selection, die wordt gedomineerd door de whips. Er zijn drie soorten leden: de frontbenchers onder wie tenminste één minister, de (loyale) backbenchers die door de whips opgeroepen zijn en de backbenchers die zelf interesse hebben getoond bij de selectiecommissie. ${ }^{144}$ Ook de voorzitter is nog steeds een neutrale arbiter en niet, zoals bij de onderzoekscommissies, de stuwende kracht achter de commissie. Verder beschikken wetgevingscommissies niet over deskundige ondersteuning. De clerk van de commissie houdt zich slechts bezig met procedurele zaken en niet met de inhoud van het wetsvoorstel. Bovendien zijn de commissies gebonden aan een strikt tijdsschema.

Wetgevingscommissies hebben hierdoor nog steeds een wezenlijk ander karakter dan de onderzoekscommissies. De vraag is in hoeverre het verlenen van onderzoeksbevoegdheden aan deze commissies iets zal veranderen aan hun antagonistische karakter. Radicale veranderingen zijn overigens ook niet direct beoogd, afgaande op het rapport van de Modernisation Committee: "Partisan debates can be a useful way of testing the provisions of a bill, of identifying its weaknesses and the case for change." Het verlenen van onderzoeksbevoegdheden zou dat moeten aanvullen, niet vervangen: "We do believe that there is a strong case for introducing a more collaborative, evidence-based approach to the legislative process (...), but it should suppliment, rather than supplant, traditional standing committee debates." 145 Niettemin, zo is de gedachte, zou het introduceren van een onderzoeksfase in de commissiebehandeling kunnen bijdragen aan een zorgvuldiger beoordeling van het voorliggende wetsontwerp en bovendien het wetgevingsproces transparanter maken:

\footnotetext{
"There are several benefits that an evidence-taking stage could provide. It is first and foremost a mechanism for ensuring that Members are informed about the subject of the bill and that there is some evidential basis for the debate on the bill. Evidence-gathering is also, by its nature, a more consensual and collective activity than debate, and there is evidence that those outside Parliament have a more positive view of select committee proceedings than of debate. So there is a reputational benefit to Parliament in being seen to engage in a more open, questioning and consensual style of law-making, before moving on to the necessary partisan debate. $(\ldots)^{\prime 146}$
}

Een onderzoeksfase biedt bovendien de gelegenheid, zo verklaarden verschillende belangenorganisaties tegenover de moderniseringscommissie, om de parlementaire behandeling beter toegankelijk te maken voor het bredere publiek. Belangenorganisaties richtten zich voorheen voornamelijk op andere fases in het wetgevingsproces,

143 Voorheen werden amendementen soms louter ingediend om debat uit te lokken, met alle procedurele vertraging van dien, aldus de moderniseringscommissie. Zie verder HC 1097 (2005-06), § 67-71 en Standing Order No. 83C van 25 oktober 2004 (laatstelijk gewijzigd: 1 november 2006).

144 Rodgers \& Walters 2006, p. 212.

${ }^{145}$ HC 1097 (2005-06), § 51. In dezelfde zin: Rodgers \& Walters 2006, p. 220-221.

${ }^{146}$ HC 1097 (2005-06), § 53. 
zoals de departementale voorbereiding en de consultatieronde. Het nieuwe stelsel biedt meer mogelijkheden voor derden om betrokken te raken bij de totstandkoming van wetgeving. ${ }^{147}$

De hervorming van de wetgevingscommissies in 2006 werd door de meeste betrokkenen verwelkomd, zowel van parlementaire kant als van regeringszijde. "They appear to have improved the involvement of backbench members in the committee, and have provided a good opportunity for ministers to refute the claims of opposition pressure groups in public and in detail," zo concludeerde de Hansard Society in 2008. ${ }^{148}$ Vergeleken met de vrij autonome select committees blijft de invloed van de regering groot; zo beslist de regering uiteindelijk over de te verhoren getuigen. ${ }^{149}$ Met name aan de zijde van het parlement klinkt de roep om verdere hervormingen, bijvoorbeeld door - in navolging van de departementale select committees - over te schakelen op permanente wetgevingscommissies met vaste leden. 150

\subsection{Conclusie}

In dit hoofdstuk is uitvoerig stilgestaan bij het kenmerkende stelsel van permanente, departementaal-geörienteerde onderzoekscommissies ('departmental select committees') in het Lagerhuis, die het leeuwendeel van de onderzoekswerkzaamheden in het Britse parlement voor hun rekening nemen. Het stelsel vindt zijn oorsprong in de jaren '60 van de twintigste eeuw en was het gevolg van de groeiende onvrede over de effectiviteit van de bestaande instrumenten voor parlementaire controle van de uitvoerende macht, zoals het vragen- en debatrecht. Invoering van het departementale commissiestelsel vond uiteindelijk plaats in 1979 en heeft ervoor gezorgd dat het beleid, de bestedingen en de bestuurshandelingen van alle belangrijke onderdelen van de uitvoerende macht, te weten de ministeries en alle bijbehorende publieke organen, voortaan systematisch konden worden onderworpen aan parlementair onderzoek door permanente, gespecialiseerde commissies.

Het stelsel heeft een aantal kenmerkende eigenschappen. Allereerst kunnen de departementale onderzoekscommissies in het Lagerhuis als relatief klein worden omschreven. De meeste commissies bestaan uit niet meer dan 11 leden. Ten tweede worden de leden van de departementale commissies en verschillende andere onderzoekscommissies benoemd voor de gehele parlementaire zittingstermijn. De samenstelling van de commissies weerspiegelt de partijpolitieke verhoudingen in het Lagerhuis. Belangrijk kenmerk is verder dat in beginsel alleen zogenaamde 'backbenchers' lid zijn van deze onderzoekscommissies. Deze parlementsleden vervullen doorgaans geen hoofdrol in de dagelijkse politieke strijd tussen regering en oppositie. De samenhang en kwaliteit van het werk hangt in belangrijke mate tevens af van de commissievoorzitter, die een sleutelrol binnen de commissie speelt. Ook de voorzittersposities worden verdeeld over de partijen; het is dus niet zo dat de grootste

\footnotetext{
${ }^{147}$ HC 1097 (2005-06), § 54.

148 Brazier, Kalitowski \& Rosenblatt 2008, p. 221.

149 Wel is er overleg met de 'opposition whips', maar het gehele proces verloopt vaak in een tamelijk gehaaste sfeer. Liaison Committee, The Work of Committees in 2008-09, HC 426 (2009-10), § 41-42.

150 Zie Levy 2009.
} 
partij alle voorzitters levert. De commissievoorzitter wordt gezien als de drijvende kracht achter de commissie en neemt veelal het voortouw in de besluitvorming binnen de commissie over bijvoorbeeld het onderzoeksprogramma, de hoorzittingen en het eindrapport. De statuur van een commissie wordt dan ook vaak afgemeten aan het optreden van de voorzitter.

Tot voor kort vond de invulling van de commissiezetels plaats op voordracht van een aparte selectiecommissie. In de praktijk werd deze selectiecommissie gedomineerd door de verschillende partijmanagers ('whips'). Hierop bestond al lange tijd kritiek, omdat de invloed van met name de 'whips' van de regeringspartij op de keuze van de commissieleden ertoe zou leiden dat te regeringskritische kandidaten gemakkelijk konden worden geweerd. Na veel mislukte pogingen om de invloed van de partijmanagers op de selectie van commissieleden te verminderen, bleek er uiteindelijk in 2009 voldoende politiek momentum te zijn voor een ingrijpende hervorming - een hervorming die binnen en buiten het parlement wel wordt omschreven als de meest verregaande hervorming in het Lagerhuis sinds de invoering van de departementale commissies in 1979. In de nieuwe procedure, die voor het eerst werd toegepast na de verkiezingen van 2010, worden de voorzitters van de belangrijkste onderzoekscommissies in het Lagerhuis, waaronder alle departementale commissies, rechtstreeks gekozen door de leden van het Huis middels een geheime stemming. Vervolgens worden de overige leden verkozen binnen de eigen partijgeledingen, eveneens via een geheime stemming.

De departementale commissies beschikken over een relatief kleine vaste staf, bestaande uit vijf à zes medewerkers. Naast de griffier ('clerk') en tweede griffier ('second clerk'), die in vaste dienst zijn van het Lagerhuis, beschikken de meeste commissies over één of twee commissiespecialisten met inhoudelijke expertise op het onderzoeksterrein van de commissie. Voorts maken commissies veel gebruik van speciale externe adviseurs, die zij voor specifieke onderzoeken kunnen inhuren. Sinds 2002 beschikken de commissies ook over een gezamenlijke onderzoeksdienst, de Scrutiny Unit, die waar nodig met name op het terrein van financieel onderzoek en wetgeving extra onderzoekscapaciteit kan leveren. Van de mogelijkheid om onderzoek uit te besteden wordt relatief weinig gebruik gemaakt; commissies lijken meer te vertrouwen op hun andere ondersteuningsvormen.

Naast de departementale onderzoekscommissies kent het Lagerhuis een aantal thematische onderzoekscommissies, zoals de Public Administration Select Committee en de Environmental Audit Committee. Een bijzondere commissie is de Public Accounts Committee, die zich bezighoudt met het controleren van de rekeningen en de effectiviteit en doelmatigheid van de bestedingen van de departementen ('value for money'). Deze commissie wordt hierin in belangrijke mate ondersteund door de National Audit Office, de algemene rekenkamer. Het werk van de onderzoekscommissies wordt gecoördineerd en jaarlijks geëvalueerd door de Liaison Committee, welke bestaat uit de verschillende commissievoorzitters. Deze commissie beheert tevens het gezamenlijke onderzoeks- en reisbudget van de commissies. Sinds 2002 houdt de Liaison Committee tweemaal per jaar een hoorzitting met de Prime Minister over het gevoerde regeringsbeleid.

Het succes van de (departementale) onderzoekscommissies heeft recentelijk geleid tot een hervorming van het andere commissiestelsel binnen het Lagerhuis, na- 
melijk dat van de wetgevingscommissies. Deze commissies zijn niet permanent: voor elk wetsvoorstel van regeringswege wordt een nieuwe commissie in het leven geroepen die de voorbereidende behandeling op zich neemt. De commissies functioneren vooral als debatcommissies en worden beheersd door partijpolitieke stellingname. Kritiek op de vaak weinig zorgvuldige behandeling van wetsvoorstellen in het Lagerhuis leidde eind 2006 tot hervormingen. Sindsdien beschikken alle wetgevingscommissies over bevoegdheden om schriftelijke en mondelinge informatie te verzamelen (PPR-bevoegdheden). 


\section{Hoofdstuk 4. Onderzoeksproces}

\subsection{Inleiding}

Hieronder wordt de werkwijze van departementale onderzoekscommissies belicht. Hoewel individuele commissies binnen de formele kaders van de Standing Orders veel vrijheid genieten met betrekking tot de wijze waarop zijn hun onderzoekstaken vervullen, vertoont de werkwijze van commissies in de praktijk herkenbare patronen.

Hieronder wordt daarom uitgegaan van de werkwijze, die als gangbaar kan worden gezien voor de departementale (en aanverwante) onderzoekscommissies. In dit hoofdstuk wordt allereerst ingegaan op de onderzoeksprogrammering van de permanente onderzoekscommissies in het Lagerhuis, waarna het gebruikelijke verloop en de afronding van een onderzoek wordt besproken. Daarbij wordt tevens stilgestaan bij de problematiek van de samenloop van onderzoeken. Verder worden de belangrijkste kenmerken van de Britse onderzoekspraktijk geschetst, waarna tot slot kort wordt stilgestaan bij enkele nieuwe vormen van onderzoek waar de commissies zich de laatste jaren mee zijn gaan bezighouden.

\subsection{Onderzoeksprogrammering}

De permanente (departementale) select committees, die een plaats hebben gekregen in de standing orders van het Lagerhuis, beschikken over een grote mate van vrijheid ten aanzien van de wijze waarop zijn hun onderzoeksopdracht uitvoeren. Dit volgt alleen al uit de eerder besproken onderzoeksopdracht zelf, die zeer ruim is geformuleerd ("to examine the expenditure, administration and policy of the principle government departments..."1) Verder is van belang de "power to report from time to time", waarover alle onderzoekscommissies beschikken. ${ }^{2}$ Een select committee kan hiermee haar eigen agenda bepalen en rapporteren wanneer zij wil. Dit betekent dat een commissie zelf kan bepalen welke (deel)onderwerpen - binnen de grenzen van de onderzoeksopdracht - zullen worden onderzocht, welke accenten daarbij worden gelegd, en op welke wijze daarover gerapporteerd zal worden aan het Huis.

Wanneer een select committee op tijdelijke basis wordt ingesteld, met de bedoeling om een bepaalde nader omschreven kwestie te onderzoeken, dan wordt in de order of reference waarmee de commissie wordt opgericht bepaald welke reikwijdte het onderzoek heeft en daarmee welke ruimte de commissie krijgt om dat onderzoek

\footnotetext{
1 Standing Order No. 152 van 25 juni 1979 (laatstelijk gewijzigd: 30 juni 2010). Zie hierboven, par. 3.2.2. 2 Zie bijvoorbeeld Standing Order No. 152 van 25 juni 1979 (laatstelijk gewijzigd: 30 juni 2010), lid 4 sub a.
} 


\section{VERENIGD KONINKRIJK}

nader uit te werken. Het Huis kan een order of reference overigens altijd nog wijzigen, mocht een meerderheid vinden dat de commissie niet op de gewenste wijze uitvoering geeft aan haar onderzoekstaak. Het instellings- of verwijzingsbesluit kan tevens bepalen binnen welke termijn de commissie dient te rapporteren. ${ }^{3}$

In de meeste instellingsbesluiten van permanente select committees, opgenomen in de standing orders van het Huis, is bepaald dat de commissie bevoegd is "to sit notwithstanding adjournment of the House", zoals in het geval van de departmental select committees. ${ }^{4}$ Op deze manier kunnen select committees bijeenkomen op elk gewenst moment, los van de parlementaire kalender, dus ook gedurende recesperiodes. ${ }^{5}$ Verder zijn de meeste onderzoekscommissies bevoegd om buiten de parlementaire gebouwen te vergaderen en hoorzittingen te houden (de "power to adjourn from place to place" $) .6$

De departementale onderzoekscommissies, die elk een ministerie schaduwen, kunnen onmogelijk alle beleidsvoornemens, rapportages en andere activiteiten van het betreffende ministerie en de daaraan gerelateerde publieke diensten onderzoeken. Commissies maken daarom keuzes op basis van (politieke) prioriteiten, die zij zelf kunnen vaststellen. Het belangrijkste agendapunt bij de eerste vergadering van een departementale onderzoekscommissie is daarom het vaststellen van een (globaal) onderzoeksprogramma. ${ }^{7}$ De onderzoeksprogramma's en de mate van structurering en thematisering verschilt per commissie. Een voorbeeld van gebruikelijk programma is dat van de Education Committee, die zich tussen 2002 en 2004 richtte op het thema voortgezet onderwijs en daarbinnen vier grote onderzoeken uitvoerde naar onderwijsdiversiteit, leerlingenprestaties, toelatingsbeleid en het behoud van leerkrachten; tussendoor hield de commissie korte onderzoeken en eenmalige hoorzittingen op andere onderwijsgerelateerde terreinen. ${ }^{8}$ Deze aanpak, waarbij aan de hand van een of twee brede thema's een aantal meer specifieke onderzoeken worden gehouden, afgewisseld met kleinere onderzoeken en losstaande hoorzittingen op diverse terreinen, blijkt ook door andere commissies te worden nagestreefd. ${ }^{9}$

Naast de vastgestelde onderzoeksprioriteiten worden bepaalde jaarlijks terugkerende onderzoeken ingepland, bijvoorbeeld met betrekking tot het jaarverslag van het gerelateerde departement. Ook wordt getracht ruimte te laten om in te kunnen spelen op actuele gebeurtenissen. ${ }^{10}$

\footnotetext{
${ }^{3}$ Erskine May 2004, p. 743-744. Zie ook Blackburn \& Kennon 2003, p. 579.

${ }^{4}$ Zie Standing Order No. 152 van 25 juni 1979 (laatstelijk gewijzigd: 30 juni 2010), lid 4 sub a.

${ }^{5}$ Zie ook Blackburn \& Kennon 2003, p. 577. Gewoonlijk kunnen onderzoekscommissies namelijk niet zonder toestemming van het Huis bijeen komen op dagen dat het Huis 'adjourned' is. Zie Standing Order No. 123 van 7 maart 1888 (laatstelijk gewijzigd: 1 augustus 1963).

${ }^{6}$ Zie bijvoorbeeld Standing Order No. 152 van 25 juni 1979 (laatstelijk gewijzigd: 30 juni 2010), lid 4 sub a.

${ }^{7}$ Rodgers \& Walters 2006, p. 362.

${ }^{8}$ Zie o.a. Education Committee, The Work of the Committee in 2004, HC 359 (2004-05). Zie verder het case study onderzoek van Maer \& Sandford 2004, p. 20.

${ }_{9}^{9}$ Maer \& Sandford 2004, p. 20.

${ }^{10}$ Maer \& Sandford 2004, p. 20-21.
} 


\subsection{Het verloop van een onderzoek}

\subsubsection{Aanvang, kader en tijdspad}

Het verloop van een onderzoek door een departementale onderzoekscommissie volgt in grote lijnen een vast stramien. ${ }^{11} \mathrm{Op}$ basis van het door haar vastgestelde onderzoeksprogramma besluit een commissie tot het doen van een onderzoek naar een meer bepaald onderwerp. Daartoe stelt de commissie een onderzoekskader vast ('terms of reference'). De commissie is hieraan echter niet gebonden; het is dan ook niet ongebruikelijk dat de focus verandert naarmate het onderzoek vordert. Het vooraf vastgestelde onderzoekskader dient vooral ter informatie van mogelijke getuigen of andere geïnteresseerden. ${ }^{12}$

Bij het vaststellen van het onderzoekskader wordt tevens getracht een tijdspad voor het onderzoek vast te stellen. Soms bepalen externe factoren de duur van een onderzoek, bijvoorbeeld wanneer een commissie onderzoek doet naar een onderwerp waarover wetgeving wordt voorbereid door de regering; wil het onderzoek enige invloed hebben, zo is de gedachte, dan moet het onderzoek afgerond zijn voordat het wetsvoorstel bij het parlement wordt ingediend. ${ }^{13}$

Via een persbericht wordt de start van het onderzoek en het onderzoekskader bekend gemaakt. Vaak wordt daarbij tevens een zogenaamd 'Issues and Questions Paper' uitgegeven, dat wordt gepubliceerd op de website van de commissie. Dit 'paper' bedoeld om discussie over het onderwerp te stimuleren en het publiek uit te nodigen tot het insturen van 'written evidence'. ${ }^{14}$ Naast deze algemene uitnodiging worden ministeries, belangengroepen en andere relevante organisaties en instituten afzonderlijk benaderd met het verzoek om schriftelijk te reageren op vragen van de commissie. ${ }^{15}$

\subsubsection{Schriftelijk bewijsmateriaal}

Het onderzoek begint met het verzamelen en analyseren van het ontvangen gevraagde en ongevraagde 'written evidence'. De term 'evidence' moet in het kader van een departementale onderzoekscommissie overigens ruim worden opgevat: commissies zijn niet alleen op zoek naar feitelijke informatie of statistische gegevens, maar vaak ook naar standpunten, ideeën, bezwaren of andersoortige reacties van individuen en organisaties op het onderzoeksonderwerp in het algemeen en over de knelpunten en vragen die de commissie heeft geformuleerd in het bijzonder.

11 Zie o.a. Blackburn \& Kennon 2003, p. 585; Rodgers \& Walters 2006, p. 383-368; Maer \& Sandford 2004, p. 19-26.

12 Rodgers \& Walters 2006, p. 363.

13 Maer \& Sandford 2004, p. 21.

14 Rodgers \& Walters 2006, p. 363.

${ }^{15}$ Rodgers \& Walters 2006, p. 364. 


\section{VERENIGD KONINKRIJK}

Ten aanzien van de vormgeving en inhoud van schriftelijk bewijsmateriaal beschikt het Huis over algemene richtlijnen. ${ }^{16}$ Schriftelijk bewijsmateriaal dient te worden aangeleverd in de vorm van een 'self-contained memorandum'. ${ }^{17}$ Dit betekent dat de notitie zo opgesteld moet zijn dat deze op zichzelf bruikbaar is als bewijsmateriaal, dus los van andere bronnen of documenten. Het stuk dient zo bondig mogelijk te zijn (commissies kunnen een woordgrens aangeven). Inhoudelijk moet de notitie enerzijds relevante 'factual information' verschaffen die de commissie kan gebruiken in haar rapport of die kan worden voorgelegd aan andere getuigen. Anderzijds kunnen eventuele 'recommendations for action' worden opgenomen die de regering of anderen in de ogen van de betreffende respondent zouden moeten nemen. ${ }^{18}$

Bij de aankondiging van het onderzoek wordt een termijn gesteld, waarbinnen reacties op het verzoek om bewijsmateriaal kunnen worden ingestuurd. De hoeveelheid schriftelijk materiaal dat van verschillende kanten wordt ingestuurd en vervolgens moet worden onderzocht, is soms erg groot. Maer en Sandford beschouwen dit om verschillende redenen als problematisch. Ten eerste lijkt het doen van algemene oproepen via persberichten en het gericht aanschrijven van bepaalde organisaties ertoe te leiden dat commissies geneigd zijn om hoofdzakelijk aandacht te besteden aan de informatie en opvattingen afkomstig van de gebruikelijke respondenten (grote belangengroepen, ministeries). Hierdoor bestaat het risico dat relevante informatie van anderen over het hoofd wordt gezien. Een tweede probleem is dat commissieleden veelal niet in de gelegenheid zullen zijn om de grote hoeveelheid binnengekomen reacties zelf te bestuderen en evalueren. Dit wordt dan veelal aan de ambtelijke staf overgelaten. Soms wordt door de clerks een selectie gemaakt uit het binnengekomen materiaal voordat het wordt doorgestuurd naar de commissieleden. Er zijn ook clerks die alleen een lijst met binnengekomen stukken aan de commissieleden sturen, waarna deze zelf kunnen aangeven welke stukken zij wensen te ontvangen. ${ }^{19}$

\subsubsection{Hoorzittingen}

Bij aanvang van het onderzoek wordt een lijst met mogelijke getuigen opgesteld die zullen worden uitgenodigd om te verschijnen voor een hoorzitting. De definitieve lijst met getuigen wordt opgesteld na afloop van de termijn voor indiening van schriftelijke bewijsmateriaal. Doorgaans bestaat de lijst uit een selectie van de personen die tevens schriftelijke reacties hebben gegeven. De samenstelling van deze lijst

\footnotetext{
${ }^{16}$ House of Commons, Guide for witnesses giving written or oral evidence to a House of Commons select committee, juni 2011, < http://www.parliament.uk/documents/commonscommittees/witnessguide.pdf > (laatst geraadpleegd: 28 november 2012).

${ }^{17}$ Guide for witnesses 2011, p. 5.

18 Eventuele bijlagen (bijv. brochures of artikelen) zijn toegestaan. De notitie moet niettemin zelfdragend zijn, aangezien commissies ingestuurde bijlagen veelal niet publiceren. Zie verder Guide for witnesses 2011, p. 5-6.

19 Zie Maer \& Sandford 2004, p. 22. Commissies zouden volgens hen meer toegespitste (deel)vragen moeten voorleggen aan specifieke groeperingen, of bijvoorbeeld moeten gaan werken met focusgroepen. Verder zouden de clerks altijd een overzicht van de binnengekomen reacties moeten verstrekken aan commissieleden.
} 
en de volgorde waarin getuigen worden gehoord vertoont een zeker patroon. Departementale onderzoekscommissies beginnen vaak met het horen van betrokken ambtenaren. Vervolgens worden vertegenwoordigers van belangengroepen, verschillende experts en eventuele overige getuigen waaronder individuele belanghebbenden gehoord. De mondelinge bewijsgaring wordt doorgaans afgesloten met het horen van de verantwoordelijke minister(s). ${ }^{20}$ Het horen van ambtenaren, zeker wanneer het om hooggeplaatste ambtenaren gaat, gebeurt in plaats van aan het begin ook wel tegen het einde van de reeks hoorzittingen. Soms worden ambtenaren of andere getuigen meerdere keren gehoord, bijvoorbeeld wanneer de commissie nadere vragen heeft naar aanleiding van andere getuigeverklaringen.

Vooral bij de tweede categorie getuigen, de vertegenwoordigers en de experts, is het maken van een selectie vaak onvermijdelijk. Het selecteren gebeurt door de commissieleden, de ambtelijke staf en de eventueel aangestelde specialist advisers gezamenlijk. ${ }^{21}$ Hoewel hierbij veel 'usual suspects' zullen zitten, zoals de grote belangengroepen, wordt toch ook getracht de blik de verruimen en op basis van het binnengekomen schriftelijke materiaal ook minder voor de hand liggende getuigen uit te nodigen, zoals vertegenwoordigers van kleinere, lokale organisaties en individuele burgers. 22

De meeste departementale onderzoekscommissies houden gemiddeld één of twee hoorzittingen per week in het kader van verschillende, gelijklopende onderzoeken. De commissieleden zitten aan een hoefijzervormige tafel, met de voorzitter en de clerk in het midden. De tafelschikking is verder tamelijk willekeurig. Leden van verschillende partijen zitten meestal door elkaar. Getuigen nemen plaats aan een tafel aan de uiteinden van de commissietafel. De meeste hoorzittingen duren ongeveer twee tot tweeëneenhalf uur. Getuigen verschijnen alleen of in panels van maximaal drie of vier personen. Bij grotere onderzoeken (of bij een zekere tijdsdruk) worden soms tijdens een hoorzitting meerdere panels van getuigen na elkaar gehoord. ${ }^{23}$

Voorafgaand aan een hoorzitting ontvangen de commissieleden een 'brief' (notitie) van de clerk met informatie over het doel en de achtergrond van de hoorzitting, de belangrijkste punten uit het schriftelijke bewijsmateriaal dat de getuige heeft ingediend en gerelateerde kwesties die verder zouden kunnen worden onderzocht, maar ook zaken waarvan de staf meent dat deze 'on the record' moeten komen in verband met het te schrijven rapport. Verder is een belangrijk onderdeel van de 'brief' een lijst met mogelijke vragen voor de getuige, die de commissieleden kunnen gebruiken. ${ }^{24}$ Het getuigenverhoor wordt voorbereid tijdens een besloten vergadering van de commissie, die meestal direct voorafgaand aan de hoorzitting plaatsvindt. Om ervoor te zorgen dat alle commissieleden goed voorbereid zijn, wordt tijdens

\footnotetext{
${ }^{20}$ Maer \& Sandford 2004, p. 22-23.

${ }^{21}$ Maer \& Sandford 2004, p. 23.

22 Rodgers \& Walters 2006, p. 364.

${ }^{23}$ Zie ook Rodgers \& Walters 2006, p. 364.

${ }^{24}$ Zie Rodgers \& Walters 2006, p. 364 en Maer \& Sandford 2004, p. 23.
} 
deze vergadering soms door de clerks of de specialist advisers nog een mondelinge toelichting gegeven op de brief. 25

De meeste hoorzittingen van departementale onderzoekscommissies vinden plaats in een vrij ontspannen sfeer. Rodgers en Walters omschrijven de gemiddelde hoorzitting als een proces van "exploration and discussion of a subject about which the witnesses have special knowledge, on which the committee wants to draw." 26 Hoorzittingen kunnen echter gemakkelijk een meer antagonisch karakter krijgen, bijvoorbeeld wanneer een commissie onderzoek doet naar gevoelige misstanden of wanneer een getuige in de ogen van commissieleden onvoldoende coöperatief is. ${ }^{27}$ Commissieleden lijken dit in het algemeen te willen voorkomen, zo blijkt uit onderzoek van Maer en Sandford, mede vanuit de gedachte dat het moeilijk is een constructieve, inhoudelijke discussie te voeren met getuigen die zich geïntimideerd voelen of ministers die voortdurend op hun hoede zijn. Tegelijkertijd wordt erkend dat een scherpe manier van ondervragen soms noodzakelijk is, wil het werk van parlementaire onderzoekscommissies enige aandacht genereren; soms leidt dit ertoe dat commissieleden vooral uit lijken te zijn op het creëren van politiek theater dan op het verkrijgen van inlichtingen van getuigen. ${ }^{28}$

Het doel van hoorzittingen lijkt opmerkelijk genoeg niet in de eerste plaats het vergaren van feitelijke informatie te zijn. Commissies zijn vooral geïnteresseerd in bevestiging van bestaande kennis: "testing arguments and credibility" . ${ }^{29}$ Het idee hierachter is dat feitelijke informatie ook buiten hoorzittingen om kan worden vergaard, bijvoorbeeld door schriftelijke inlichtingen aan ministers, departementen en externe instanties of personen te vragen. In het geval van verzoeken aan ministers en departementen kan tevens gebruik worden gemaakt van het reguliere parlementaire vragenrecht. Hoorzittingen kunnen, zoals gezegd, ook andere doelen dienen, die niet altijd direct met het onderzoek te maken hebben. Zo blijken sommige vragen van commissieleden, vaak voorafgegaan door lange inleidingen, eerder bedoeld om een politiek standpunt over het voetlicht te brengen en in het verslag te doen opnemen. Bovendien bieden hoorzittingen door hun publieke karakter een forum voor commissieleden om zichzelf te profileren. ${ }^{30}$

\subsubsection{Andere onderzoeksmethoden}

Het verzamelen van schriftelijk en mondeling bewijsmateriaal vormt de kern van het onderzoek van de departementale onderzoekscommissies, maar daarnaast maken commissies ook steeds vaker gebruik van andere onderzoeksmethoden. Een daarvan is het houden van besloten seminars, waarvoor de commissie experts op het terrein van het onderzoeksonderwerp uitnodigt. Wanneer een commissie een nieuw onder-

\footnotetext{
${ }^{25}$ Maer \& Sandford 2004, p. 23.

${ }^{26}$ Rodgers \& Walters 2006, p. 365.

27 Rodgers \& Walters 2006, p. 365. Recent, in de pers breed uitgemeten voorbeeld is het verhoor van mediamagnaat Rupert Murdoch en diens zoon door de Culture, Media and Sport Committee omtrent de afluisterpraktijken in de Britse schandaalpers.

28 Maer \& Sandford 2004, p. 23.

${ }^{29}$ Maer \& Sandford 2004, p. 24.

${ }^{30}$ Maer \& Sandford 2004, p. 24.
} 
zoek wil starten, is het houden van een dergelijk seminar een manier om het onderzoekskader af te bakenen en de hoofdlijnen van onderzoek uit te zetten. ${ }^{31}$

Een andere, vrij populaire methode is het afleggen van binnenlandse en buitenlandse werkbezoeken. Onderzoekscommissies beschikken niet over een eigen reisbudget, maar kunnen hiervoor aanvragen indienen bij de Liaison Committee. Rodgers en Walters stellen dat binnenlandse en buitenlandse werkbezoeken een grote bijdrage leveren aan de "effectiveness" van onderzoekscommissies. Werkbezoeken maken de commissie beter toegankelijk en vormen een laagdrempige manier om in contact te komen met het publiek. Bovendien krijgen commissieleden de kans om zelf ervaring op te doen en de opvattingen van direct betrokkenen te horen. Dat geldt ook voor buitenlandse reizen, die vergelijking met buitenlandse ervaringen mogelijk maken. "No amount of background reading and written evidence is a substitute for seeing for oneself, and finding out first-hand about the benefits and the problems", aldus Rodgers en Walters. ${ }^{32}$ De vraag is echter, zo menen Maer en Sandford, welke bijdrage deze informele werkbezoeken werkelijk aan het onderzoek leveren. Aangezien doorgaans geen verslag wordt gemaakt van de bijeenkomsten en de gesprekken tijdens een werkbezoek, is de bruikbaarheid van deze ervaringen voor het eindrapport gering, of in elk geval moeilijk vast te stellen. 33 Om die reden combineren commissies hun werkbezoeken tegenwoordig overigens vaak met het houden van hoorzittingen ter plaatse. ${ }^{34}$

Verder maken commissies steeds vaker gebruik van werkwijzen die de onderzoekscapaciteit van commissies vergroten. Een daarvan is het instellen van subcommissies. Ook wordt (informeel) gewerkt met zogenaamde 'rapporteurs', waarbij een of enkele commissieleden een vooronderzoek van een gecompliceerd onderwerp doen om te bepalen of nader onderzoek door de commissie nodig is. Dit wordt gezien als een manier om efficiënter met de tijd van de commissie om te gaan. ${ }^{35}$ Tenslotte wordt de laatste jaren geëxperimenteerd met de digitale methoden van onderzoek. Sinds 2007 beschikt het Lagerhuis over de mogelijkheid om een 'online forum' op te zetten, waarvan enkele commissies inmiddels gebruik gemaakt hebben. De Liaison Committee is positief over deze ontwikkeling, zowel ten aanzien van het onderzoek als in breder perspectief: "Online forums can be a means of accessing information from people who would be hard to reach through the routes traditionally used by committees, and have the potential to encourage the public to engage more fully with Parliament." 36

\footnotetext{
${ }^{31}$ Maer \& Sandford 2004, p. 21-22. Zie ook Liaison Committee, The Work of Committees in 2007, HC 427 (2007-08), § 86: "The use of seminars, on which we have commented in previous Reports, is now routine for many committees."

32 Rodgers \& Walters 2006, p. 366.

${ }^{33}$ Maer \& Sandford 2004, p. 24-25.

${ }^{34}$ Liaison Committee, The Work of Committees in 2007, HC 427 (2007-08), § 89.

35 Zie bijvoorbeeld de Environment, Food and Rural Affairs Committee, Work of the Committee in 2007, HC 250 (2007-08), § 32-33. Zie ook Liaison Committee, HC 427 (2007-08), § 86.

${ }^{36} \mathrm{Al}$ moet deze techniek volgens de commissie wegens de hoge kosten alleen worden toegepast als dit meerwaarde oplevert voor het onderzoek en zouden commissies ernaar moeten streven een verslag en een aantal bijdragen aan het online debat in het eindrapport op te nemen. HC 427 (2007-08), § 90-91. Zie ook Blackburn \& Kennon 2003, p. 587-588.
} 


\subsubsection{Samenloop van onderzoeken}

\subsubsection{Inleiding}

Incidenteel hebben parlementaire onderzoeken in het Verenigd Koninkrijk betrekking op onderwerpen die tevens voorwerp is van gerechtelijke procedures, bijvoorbeeld een strafrechtelijk onderzoek. Deze samenloop van onderzoeken naar dezelfde feiten kan praktische of logistieke problemen opleveren, bijvoorbeeld als het gaat om het verhoren van getuigen die tevens verdachte zijn of wanneer een commissie stukken wil inzien die tevens onderdeel zijn van een strafdossier. Vanuit constitutioneel oogpunt roept een samenloop van onderzoeken vragen op over de verhouding tussen parlement en rechterlijke macht, in het bijzonder de vraag in hoeverre een parlementaire commissie onderzoek kan doen naar zaken die onder de rechter zijn.

In de Britse staatsrechtelijke doctrine wordt de verhouding tussen parlement en rechter beheerst door een aantal constitutionele regels en conventies, die tezamen invulling geven aan het beginsel van de scheiding der machten. Enerzijds spelen de historische rechten en vrijheden van parlementsleden hier een rol. Deze eeuwenoude verworvenheden, bekend onder de noemer 'parliamentary privileges', worden gezien als essentieel voor beide Huizen en voor hun afzonderlijke leden om hun parlementaire taken te kunnen vervullen. ${ }^{37}$ Het belangrijkste privilege in dit verband is de vrijheid van meningsuiting voor parlementsleden, dat ontstond in de vijftiende eeuw en definitief erkenning vond in 1689, toen het werd gecodificeerd in art. 9 van de Engelse Bill of Rights. ${ }^{38}$ Hierin is bepaald dat "the freedom of speech and debates or proceedings in Parliament ought not to be impeached or questioned in any court or place out of Parliament." Op grond hiervan kunnen parlementariërs niet vervolgd of aansprakelijk gesteld worden voor hetgeen zij zeggen of doen gedurende parlementaire debatten, vergaderingen of andere parlementaire procedures. Het betreft een absolute immuniteit, die een ruime reikwijdte heeft en bijvoorbeeld ook het stellen van schriftelijke vragen aan ministers omvat. Parlementaire ambtenaren die hun functie vervullen en getuigen die verklaringen afleggen voor parlementaire commissies worden eveneens beschermd door dit privilege. ${ }^{39}$ De publicatie (buiten het parlement) van de parlementaire handelingen en van commissierapporten valt er echter niet onder, zo bleek na een rechterlijke uitspraak in 1839; op dit punt vloeit de (absolute) parlementaire immuniteit voort uit de Parliamentary Papers Act van 1840.40

Aan de andere zijde staan beginselen die samenhangen met de rechterlijke onafhankelijkheid en onbevangenheid. Het belang van een onafhankelijke rechterlijke macht komt onder meer tot uitdrukking in de regels rondom 'contempt of court', zoals die in de common law tot ontwikkeling zijn gekomen. Sinds de invoering van de Contempt of Court Act 1981 hebben deze regels (in enigszins gewijzigde vorm) een wettelijke basis. Volgens de wet is het strafbaar om door middel van "publica-

\footnotetext{
37 Parlementaire privileges zijn ontstaan uit parlementaire gewoontes en, wanneer het de positie van derden betreft, rechterlijke uitspraken. Bradley \& Ewing 2007, p. 223.

38 Erskine May 2004, p. 95. Zie ook Joint Committee on Parliamentary Privilege, First Report, HC 43 (1998-99), § 36 e.v.

${ }^{39}$ Bradley \& Ewing 2007, p. 224-226.

${ }^{40}$ Bradley \& Ewing 2007, p. 228-229. Zie ook Joint Committee on Parliamentary Privilege, First Report, HC 43 (1998-99), § 339 e.v.
} 
tions ... addressed to the public at large or any section of the public" lopende gerechtelijke procedures zodanig te beïnvloeden dat gesproken kan worden van "a substantial risk that the course of justice in the proceedings in question will be seriously impeded or prejudiced." 41 Kort gezegd is van een lopende strafrechtelijke procedure sprake, zodra een aanhouding heeft plaatsgevonden of is bevolen. In civiele zaken is sprake van een 'active case' wanneer een zittingsdatum is vastgesteld. ${ }^{42}$ In de praktijk gaat het in veel contempt-zaken om krantenberichten of andere publicaties (waar ook mondelinge uitlatingen onder moeten worden verstaan) voorafgaand aan een strafproces die tot bevooroordeeldheid bij een jury zouden kunnen leiden. ${ }^{43}$

De Contempt of Court Act is niet van toepassing op uitingen die zijn gedaan tijdens parlementaire debatten, beraadslagingen, hoorzittingen of andere procedures in de beide Huizen. ${ }^{44}$ Dit zou een verregaande beperking van de genoemde privileges van parlementsleden betekenen en zover wilde men kennelijk niet gaan. Niettemin bestaat ook in het parlement al geruime tijd het besef dat het beïnvloeden van lopende gerechtelijke procedures vanuit het oogpunt van 'fair trail' en een onafhankelijke, onbevooroordeelde rechtspraak niet wenselijk is. Of, zoals de Joint Committee on Parliamentary Privilege, die in 1999 aan beide Huizen rapport uitbracht over het gebruik van de parlementaire privileges, stelt: "The privilege of freedom of speech in Parliament places a corresponding duty on every member to use the freedom responsibly." Vergeleken met andere actoren, zoals de media, rust op het parlement zelfs een extra verantwoordelijkheid:

\footnotetext{
"Restrictions on media comment are limited to not prejudicing the trial, but Parliament needs to be especially careful: it is important constitutionally, and essential for public confidence, that the judiciary should be seen to be independent of political pressures." 45
}

In beide Huizen geldt daarom sinds jaar en dag de gewoonte dat geschillen die onder de rechter (sub judice) zijn, niet inhoudelijk worden besproken in het parlement. Deze gewoonte, in feite een vorm van vrijwillige parlementaire terughoudendheid, is in het Lagerhuis sinds 1963 als regel vastgelegd in een parlementaire resolutie. In het Hogerhuis is de sub judice-exceptie op de parlementaire uitingsvrijheid af te leiden uit beslissingen van de Procedure Committee in dat Huis. Omdat de regeling in ieder Huis afzonderlijk tot stand is gekomen, bleek de betekenis en toepassing ervan in de loop der tijd op enkele punten te verschillen. De Joint Committee on Parliamentary Privilege achtte dit onwenselijk en formuleerde een uniforme concept-resolutie. ${ }^{46}$

\footnotetext{
41 Contempt of Court Act 1981, artt. 1 en 2. De wet was nodig om de bestaande regels omtrent 'contempt of court' aan te passen naar aanleiding van de Sunday Times uitspraak van het Europese Hof voor de Rechten van de Mens. Zie nader over deze wet, haar achtergrond en toepassing: Bradley \& Ewing 2007, p. 398-399.

42 Contempt of Court Act 1981, art. 2 en Schedule 1. Zie ook Bradley \& Ewing 2007, p. 399-400.

43 Bradley \& Ewing 2007, p. 400.

44 Bradley \& Ewing 2007, p. 391.

45 Joint Committee on Parliamentary Privilege, First Report, HC 43 (1998-99), § 188, 192.

46 Zie HC 43 (1998-99), § 202.
} 
Deze werd in 2000 en 2001 door beide Huizen integraal overgenomen. ${ }^{47}$ Sindsdien geldt in het hele parlement dus dezelfde sub judice-regeling. ${ }^{48}$

\subsubsection{De sub judice-regeling}

In art. 1 van de resolutie wordt het uitgangspunt van de regeling geformuleerd: "Cases in which proceedings are active in United Kingdom courts shall not be referred to in any motion, debate or question." Kern van de regeling is een verbod om in moties, debatten of vragen te refereren aan actieve gerechtelijke procedures. Hieruit volgt dat de sub judice-regeling geen absoluut verbod instelt: als een zaak niet langer als 'active' kan worden beschouwd, vervalt de beperking. De regeling heeft in feite slechts een opschortende werking.

Wat onder actieve gerechtelijke procedures moet worden verstaan, wordt in de resolutie nauwkeurig aangegeven. In het geval van strafrechtelijke procedures kan van een actieve procedure worden gesproken "when a charge has been made or a summons to appear has been issued, or, in Scotland, a warrant to cite has been granted." Strafrechtelijke procedures zijn niet langer actief "when they are concluded by verdict and sentence or discontinuance, or, in cases dealt with by courts martial, after the conclusion of the mandatory post-trial review." In het geval van civiele procedures geldt dat deze actief (in de zin van de resolutie) zijn "when arrangements for the hearing, such as setting down a case for trial, have been made, until the proceedings are ended by judgment or discontinuance." Het verbod 'herleeft' echter weer zodra hoger beroep wordt ingesteld.

Wanneer deze regeling wordt vergeleken met de Contempt of Court Act 1981, dan valt op dat strafzaken in het parlement pas als actief worden beschouwd wanneer er een telastelegging is uitgebracht, terwijl buiten het parlement al sprake is van een actieve strafzaak wanneer een aanhouding heeft plaatsgevonden. ${ }^{49}$ Wat verder

\footnotetext{
47 Zie voor het Hogerhuis: HL Deb 11 mei 2000, vol. 612, col. 1725-1726 en voor het Lagerhuis: HC Deb 15 november 2001, vol. 374, col. 1012-1014. In het Lagerhuis vormt deze resolutie inmiddels een bijlage bij de standing orders; in het Hogerhuis is de resolutie opgenomen in de officiële toelichting op de Standing Orders. Voor de Commons-resolutie van 1963, de aanvullende resolutie uit 1972 en de toelichting op de praktijk in het Hogerhuis, zie HC 43 (1998-99), Annex E.

${ }^{48} \mathrm{Na}$ het rapport van de Joint Committee, dat leidde tot de resoluties van 2000 en 2001, is de regeling nog twee maal geëvalueerd door de Procedure Committee van het Lagerhuis. Het constitutionele belang van de sub judice-regel wordt daarin nog eens uitvoerig bevestigd, enerzijds vanwege het gevaar van beïnvloeding van de rechtsgang ('prejudice') en anderzijds vanwege het belang van machtenscheiding ('comity', 'inter-institutional courtesy') en het voorkomen van de schijn van verstrengeling van politiek en rechtspraak. Zie verder: Procedure Committee, The Sub Judice Rule of the House of Commons, HC 125 (2004-05) en Application of the Sub Judice Rule to Proceedings in Coroner's Courts, HC 714 (2005-06).

${ }^{49}$ De Joint Committee on Parliamentary Privilege overwoog om het toepassingsbereik te verruimen, omdat het risico van parlementaire beïnvloeding van een strafproces reeds bestaat als een zaak nog in een voorbereidende fase is. De commissie besloot desondanks om hiervan af te zien omdat daarmee onduidelijkheid zou ontstaan over het start- en eindpunt van een gerechtelijk onderzoek. Daarmee zou de regeling voor het parlement onwerkbaar worden. Hiermee was echter niet gezegd dat in het voorbereidende stadium geen rekening behoefde te worden gehouden met de mogelijke gevolgen van parlementaire inmenging voor toekomstige stafrechtelijke procedures: "It should be emphasised that drawing the line at this point does not remove the obligation on individual members or select commit-
} 
opvalt, is dat de regeling slechts betrekking heeft op de klassieke rechterlijke macht in het Verenigd Koninkrijk, waaraan de strafrechtelijke en civielrechtelijke rechtspleging is opgedragen. De regeling geldt niet ten aanzien van de verschillende 'tribunals' die het Britse rechtsstelsel kent. Dit zijn gespecialiseerde rechtscolleges die buiten de klassieke rechterlijke macht staan en veelal (maar niet uitsluitend) administratiefrechtelijke geschillen beslechten op terreinen als sociale zekerheid, gezondheidszorg en immigratie. De Procedure Committee overwoog in haar evaluatie naar aanleiding van voorstellen hiertoe van enkele getuigen om ook deze tribunals onder de reikwijdte van de regeling te brengen, maar zag daar uiteindelijk vanaf. Zij onderschreef het standpunt van haar voorganger uit 1963, die de eerste sub judice-resolutie in het Lagerhuis ontwierp, en concludeerde dat dit "too restrictive of the rights of Parliament" zou zijn. Echter, de commissie voegde daaraan toe: "We understand that remarks made in Parliament could prejudice cases before tribunals, and would expect Members to take care to avoid doing so." 50

In de aanhef van de resolutie is bepaald dat de voorzitter ('Chair') een algemene discretionaire bevoegdheid heeft om de regeling in individuele gevallen buiten toepassing te laten. In sommige gevallen, zo is de gedachte, gaat het publieke belang van het parlementaire debat boven dat van een ongestoorde rechtsgang. Een verstandig gebruik van deze bevoegdheid is van groot belang voor de werkbaarheid van de regeling, zo stelt de Joint Committee in haar rapport: "The key to the successful operation of the sub judice rule over the years in the House of Commons has been the sensitive use by the Speaker of discretionary powers." 51 In een tweetal categorieën is het gebruik van de discretionaire bevoegdheid in het bijzonder aangewezen, zo blijkt uit een aanvullende overweging in art. 1:

\footnotetext{
"But where a ministerial decision is in question, or in the opinion of the Chair a case concerns issues of national importance such as the economy, public order or the essential services, reference to the issues or the case may be made in motions, debates or questions." 52
}

De eerste categorie betreft ministeriële beslissingen waartegen bij de rechter beroep is ingesteld ("where a ministerial decision is in question"). Hiermee wordt gedoeld op de rechtsgang tegen administratieve besluiten, bekend als 'judicial review of administrative action'. ${ }^{33}$ De tweede categorie betreft "issues of national importance such as the economy, public order or the essential services". Deze uitzonderingsgrond komt

tees to act responsibly and avoid actions which impede criminal investigations or abort trials." Zie HC 43 (1998-99), § 193-196.

50 Zie HC 125 (2004-05), § 29-31.

51 Joint Committee on Parliamentary Privilege, First Report, HC 43 (1998-99), § 200.

52 Zie art. 1 van de resolutie. Zie over de achtergrond van deze overweging: HC 125 (2004-05), § 5.

${ }^{53}$ Deze bestuursrechtelijke rechtsgang is in het Britse rechtssysteem tot ontwikkeling gekomen binnen de civiele rechtspraak, waardoor de sub judice-regeling hierop in beginsel van toepassing is. In de oude Commons-resolutie werd gesproken over "matters awaiting or under adjudication in all civil courts, including the National Industrial Relations Court, in so far as such matters relate to a Ministerial decision..." Het uitzonderen van kan deels verklaard worden vanuit de relatief late opkomst van het bestuursrecht in het Verenigd Koninkrijk. Toetsing van ministeriële beslissingen vindt traditioneel plaats in het parlement; de rol van de rechter is pas in de laatste decennia tot ontwikkeling gekomen. Zie verder: Blackburn \& Kennon 2003, p. 288. 
voort uit het politieke klimaat van de jaren 70 van de vorige eeuw, een tijd van voortdurende arbeidsconflicten binnen de Britse staatsbedrijven. Deze uitzonderingsgrond is zonder discussie gehandhaafd in de gezamenlijke parlementaire resolutie van 2001.54 Het ontbreken van een definitie of toelichting hierop bij het aanvaarden van de resolutie heeft ertoe geleid dat het begrip in de recente praktijk een veel ruimere betekenis heeft gekregen dan in het oorspronkelijk kader van de jaren 70. De Procedure Committee concludeerde in haar meest recente rapport over de sub judice-resolutie dan ook dat de oorspronkelijke betekenis van de term 'national importance' moet worden losgelaten. In plaats daarvan moet het begrip worden uitgelegd, "as it would reasonably have been understood when the House agreed the resolution in 2001." De commissie concludeerde bovendien dat "[s]uch issues may need to be discussed in Parliament from time to time, despite the existence of an active court case." Hoewel het belang van een parlementair debat ook dan moet worden afgewogen tegen het risico van ongewenste beïnvloeding van een gerechtelijke procedure, gaat de commissie ervan uit dat de Speaker sneller gebruik maakt van zijn discretionaire bevoegdheid "when a discussion in Parliament could result in a positive impact on the matter in question." 55

In de dagelijkse parlementaire praktijk wordt de sub judice-regel in het Lagerhuis zo nu en dan toegepast met betrekking tot moties, vragen en debatten. Dit geeft slechts een enkele keer aanleiding tot conflicten tussen de Speaker, die belast is met de handhaving van de regeling, en individuele leden, zo blijkt uit onderzoek van de Procedure Committee. 56

\subsubsection{Select committees}

Bij de herziening van de sub judice-regels in 2001, werd bevestigd dat ook commissiewerkzaamheden onder de regeling vallen. ${ }^{57}$ Dit blijkt uitdrukkelijk uit de aanhef van de gezamenlijke parlementaire resolutie, waarin is bepaald dat deze betrekking heeft op alle handelingen van het Huis, inclusief "proceedings of committees of the House". Hiermee worden echter alleen die handelingen van commissies bedoeld die in het openbaar plaatsvinden. De regeling is daarom niet van toepassing op de beraadslagingen van commissies, die achter gesloten deuren plaatsvinden. Ook besloten hoorzittingen vallen niet onder de regeling. ${ }^{58}$

Dit betekent voor de leden van select committees dat zij in hun onderzoekswerk in beginsel niet dienen te refereren aan lopende strafrechtelijke of civielrechtelijke

\footnotetext{
54 Zie Joint Committee on Parliamentary Privilege, First Report, HC 43 (1998-99), § 199.

${ }^{55}$ HC 714 (2005-06), § 54.

56 Tussen juli 2004 en november 2004 werd door de griffiers van de Table Office, die deze controle namens de Speaker uitvoeren, in totaal 51 maal gecontroleerd of een vraag of motie betrekking had op een sub judice zaak. Dit bleek in 12 gevallen zo te zijn. Slechts in vier gevallen werd vervolgens door het betreffende lid beroep ingesteld bij de Speaker. Zie HC 125 (2004-05), § 15.

57 Overigens bleken select committees ook voor 2001 de uitgangspunten van de regeling in de praktijk reeds in acht te nemen. Erskine May wijst op een aantal gevallen waarin select committees een onderzoek hebben opgeschort, omdat een getuige tevens verdachte werd in een strafrechtelijke procedure die verband hield met het onderwerp van het onderzoek. Ook zijn bepaalde getuigen niet verhoord, omdat de commissie had vernomen dat de getuigen eveneens getuige zouden zijn in een gerechtelijke procedure. Erskine May 2004, p. 751-752.

58 Zie Erskine May 2004, p. 752.
} 
procedures. Zoals in de plenaire vergadering kan hierop echter een uitzondering worden gemaakt door de 'Chair'. Met de 'Chair' wordt in het kader van select committees gedoeld op de commissievoorzitter, niet op de Speaker. ${ }^{59}$ De commissievoorzitter is daarmee ook verantwoordelijk voor het handhaven van de regel tijdens commissievergaderingen. Wanneer een getuige of een commissielid tijdens een hoorzitting (onverwacht) refereert aan een zaak die sub judice is, dan dient deze in te grijpen. ${ }^{60}$ Wanneer de commissievoorzitter echter meent dat er reden is om de regeling in een concreet geval buiten toepassing te laten, dan dient echter waar mogelijk overleg plaats te vinden met de Speaker. Dit is bijvoorbeeld het geval wanneer een select committee een nieuw onderzoek start, waarvan het onderwerp zou kunnen overlappen met lopende gerechtelijke procedures. Een besluit hieromtrent van een commissievoorzitter kan namelijk gevolgen hebben voor andere parlementaire handelingen, zoals het stellen van vragen of het houden van debatten. ${ }^{61}$ De Procedure Committee concludeert daarom dat "wherever practicable, chairmen should first consult the Speaker, both to ensure that they have correctly understood their responsibilities, and so that consistency between the implementation of the rule in the House and in its committees can be maintained." 62

Een alternatief voor het opzij zetten van de sub judice-regeling in een concreet geval is het gebruik van houden van hoorzittingen in beslotenheid. Select committees "have found this a useful way of conducting inquiries where sub judice issues have arisen", zo constateerde de Procedure Committee. ${ }^{63}$ In haar eerste evaluatierapport zag de Procedure Committee het houden van besloten hoorzittingen als de meest aangewezen manier om onderzoek te doen naar onderwerpen die sub judice zijn, vooral als er geen gelegenheid is voor overleg met de Speaker. ${ }^{64}$ Tijdens de tweede evaluatie van de Procedure Committee bleek het houden van besloten hoorzittingen in bepaalde gevallen op bezwaren te stuiten, getuige de verklaring van de voorzitter van de Home Affairs Committee met betrekking tot een hoorzitting over de Londense bomaanslagen:

\footnotetext{
"I did not feel we could go into private session in the circumstances of this one-off hearing. Given that the committee's intention was to show that Parliament was considering these matters of national importance - we were meeting in September, the House was not sitting - it made no sense to go into private session." 65
}

De Procedure Committee bleek gevoelig voor dit betoog. In haar tweede evaluatierapport stelt zij daarom dat, hoewel "it will not always be appropriate for

\footnotetext{
59 Zie Procedure Committee, HC 125 (2004-05), § 36. 06), Ev 4, Q22.

61 Zie ook HC 714 (2005-06), § 85.

${ }^{62}$ HC 714 (2005-06), § 86; in vergelijkbare zin zie HC 125 (2004-05), § 38.

${ }^{63} \mathrm{HC} 714$ (2005-06), § 87.

${ }^{64}$ HC 125 (2004-05), § 38.

65 HC 714 (2005-06), § 87 en Q24.
}

${ }^{60}$ Zie ook HC 714 (2005-06), § 85. Het risico dat getuigen ten overstaan van select committees de gelegenheid zouden aangrijpen om "gratuitous references to cases before the courts" te maken, wordt overigens niet als een groot probleem gezien. Bovendien worden commissievoorzitters in staat geacht om getuigen die te ver zouden gaan, tot de orde te roepen. Zie HC 125 (2004-05), § 39 en HC 714 (2005- 


\section{VERENIGD KONINKRIJK}

select committees to use private sessions to deal with issues of sub judice, (...) we recommend that any select committee considering taking evidence on a sub judice case should give serious consideration to the option of hearing the evidence in private." 66

\subsubsection{Samenloop in de praktijk}

De samenloop van parlementair en gerechtelijk (met name strafrechtelijk) onderzoek is geen alledaags verschijnsel in het Britse stelsel. Een verklaring hiervoor kan worden gevonden in de aard van het (reguliere) onderzoek van select committees, dat zich veelal richt op bredere beleidsvragen en minder op concrete voorvallen die het werkterrein van openbaar ministerie en rechter benaderen. ${ }^{67}$

Waar samenloop wel op de loer ligt, blijken commissies zich in de meeste gevallen terughoudend op te stellen. Ook vóór de inwerkingtreding van de gezamenlijke sub judice-resolutie in 2001 was dat al het geval. ${ }^{6}$

Soms beginnen commissies aan een onderzoek, om na bezwaren van bijvoorbeeld politie of openbaar ministerie hun onderzoeksplannen bij te stellen. Een voorbeeld is een onderzoek van de Public Administration Select Committee inzake een compensatieregeling voor Britse geïnterneerden in Azië tijdens de Tweede Wereldoorlog. ${ }^{69}$ De regering bleek inconsistent te zijn in de uitvoering van deze regeling, waarbij bovendien veel betrokkenen werden uitgesloten. De select committee besloot een onderzoek in te stellen en plande een hoorzitting, waarbij de verantwoordelijke minister van Defensie zou worden gehoord. In dezelfde periode liep echter een judicial review-procedure van een betrokkene die bezwaar had gemaakt op grond van discriminatie. In verband met deze bestuursrechtelijke procedure werd de select committee door het ministerie van Defensie verzocht haar onderzoek op te schorten. Dit werd door de commissie van de hand gewezen. Wel besloot de commissie, na overleg met de Speaker, om tijdens het verhoor van de minister niet in te gaan op het specifieke geval dat aan de rechter was voorgelegd. ${ }^{70}$ Een ander voorbeeld betreft het reeds genoemde onderzoek van de Home Affairs Committee naar aanleiding van de bomaanslagen in Londen in de zomer van 2005. De commissie concludeerde dat deze zaak, die op het moment van de hoorzitting sub judice was, een zaak van nationaal belang was. De commissievoorzitter overwoog daarom de regeling op die grond buiten toepassing te laten, maar zag daar, na advies te hebben ingewonnen bij de griffie van het Huis, van af. De geplande hoorzitting ging door, voorafgegaan door

\footnotetext{
${ }^{66} \mathrm{HC} 714$ (2005-06), § 88.

67 Zie ook de verklaring van de Clerk of the House tegenover de Procedure Committee, die stelde: "...in the normal sort of inquiry that committees conduct it is a fairly rare thing to arise." HC 125 (2004-05), Ev 6, Q 35. Zie over de aard van de onderzoek van select committees ook hierna, par. 4.5.

68 Zie Erskine May 2004, p. 751-752.

69 Zie de brief van de voorzitter van de Public Administration Select Committee aan de Procedure Committee, HC 714 (2005-06), Ev 52.

${ }^{70}$ De commissie besloot daarnaast om enkele stukken die zij tijdens haar onderzoek had verzameld, niet te publiceren omdat die teveel verwijzingen naar de feiten van de aanhangige bestuursrechtelijke procedure bevatten. Zie HC 714 (2005-06), Ev 52.
} 
de uitdrukkelijke verklaring van de voorzitter dat de feiten van de genoemde gebeurtenissen niet aangehaald mochten worden. ${ }^{71}$

In andere gevallen besluiten commissie om hun onderzoek tijdelijk op te schorten. Deze situatie deed zich voor tijdens een onderzoek van de Public Administration Select Committee in de zogenaamde 'cash for honours'-affaire. In het voorjaar van 2006 verschenen berichten in de Britse kranten over mogelijke onregelmatigheden bij de parlementsverkiezingen van het jaar daarvoor. De Labour Party zou donaties (in de vorm van leningen) hebben aangenomen in ruil voor de belofte dat de betreffende donoren een adellijke titel zouden krijgen die hen een plaats in het Hogerhuis zou verschaffen. De Public Administration Committee besloot in reactie daarop een onderzoek in te stellen naar de werking van het bestaande systeem van het toekennen van adellijke titels (en de daarbij behorende functies). ${ }^{72}$ Hiertoe werden hoorzittingen gepland met onder andere de belangrijkste fundraiser van Labour, Lord Levy. ${ }^{73}$

Kort daarna startte de Londense politie een verkennend onderzoek naar vermeende overtredingen van Honours (Prevention of Abuses) Act 1925, waarin het verlenen van adellijke titels in ruil voor (financiële) gunsten strafbaar is gesteld. Politie en openbaar ministerie verzochten de commissie vervolgens dringend om haar onderzoek op te schorten, omdat het onderzoek van de commissie "could be viewed as an abuse of process in terms of fairness in any future potential criminal trial." 74 In het bijzonder vreesden zij voor nadelige effecten van de activiteiten van de select committee op het strafrechtelijke (voor)onderzoek. Ten eerste zouden getuigen door de commissie in een andere volgorde kunnen worden gehoord dan door de politie, waardoor het verloop van het politie-onderzoek zou worden verstoord. Ten tweede zouden getuigen kunnen worden benadeeld als zij zouden worden ondervraagd zonder de gebruikelijke 'police caution' en toegang tot de nodige documentatie. Voorts kunnen getuigen bewust of onbewust worden beïnvloed door de verklaringen van andere getuigen. En tenslotte geeft een parlementair onderzoek "witnesses an opportunity to rehearse their evidence before appearing in any subsequent trial." 75

\footnotetext{
71 Verhoord werden de Home Secretary, de burgemeester van Londen en de hoofdcommissaris van de Londense politie. Zie voor het verslag: Home Affairs Committee, Counter-Terrorism and Community Relations in the aftermath of the London bombings, HC 462-i (2005-06). Het probleem waarmee de commissievoorzitter geconfronteerd werd, zo verklaarde hij achteraf tegenover de Procedure Committee, was niet zozeer de betekenis van het begrip 'national importance', maar de wijze een select committee zou moeten handelen wanneer besloten was dat de situatie zich zou lenen voor het gebruik van de discretionaire bevoegdheid. De commissie bleek onvoldoende in staat te zijn om te bepalen hoe zij onderzoek zou kunnen doen naar een gebeurtenis die reeds sub judice is, zonder onnodige schade toe te brengen aan een parallel lopende gerechtelijke procedure.

72 Dit onderzoek zou deel uitmaken van een reeds langer lopend onderzoek naar ethische standaarden in de publieke sector. Zie Public Administration Select Committee, Third Special Report, HC 1020 (200506), § 1 .

73 Public Administration Select Committee, 'PASC to investigate propriety and honours', Press Notice 30, Session 2005-06, 22 maart 2006, < http:/ /www.parliament.uk/parliamentary_committees / public_administration_select_committee/pasc0506pn30.cfm> (laatst geraadpleegd: 27 november 2012).

74 Zie de brief van politie-commissaris John Yates aan de voorzitter van de select committee. Yates erkende overigens dat de zaak formeel nog niet sub judice was. Zie HC 1020 (2005-06), Appendix.

${ }^{75}$ HC 1119 (2005-06), § 17.
} 
De commissie erkende dat delen van haar onderzoek, "if conducted in public, could jeopardise the investigation and the integrity of any trial process, not least because of the likely nature of the associated reporting and publicity." Daarom werd besloten het onderzoek gedeeltelijk op te schorten: de commissie ging door met haar onderzoek naar de aanstellingsprocedure van leden van het Hogerhuis en naar het functioneren van de onafhankelijke benoemingscommissie, maar legde haar onderzoek naar "the appropriateness or otherwise of the legal framework in respect of the system of honours and peerages" stil tot duidelijk zou worden wat de uitkomst was van het politie-onderzoek. Dat politie-onderzoek zou veel langer duren dan aanvankelijk gedacht. Toen in de zomer van 2007 duidelijk werd dat het openbaar ministerie tegen geen enkele verdachte vervolging zou instellen, hervatte de select committee haar onderzoek. Het politie-onderzoek, zo verklaarde commissie, "was thorough and exhaustive, and had access to material that would not have been available to us." De bedoeling was dan ook niet om dat onderzoek over te doen, maar "to consider the policy and regulatory issues arising from the matters investigated by the police." De select committee werd gedurende het politie-onderzoek tijdens besloten hoorzittingen door politie en openbaar ministerie op de hoogte gehouden van hun vorderingen. De commissie maakte de verslagen van die zittingen achteraf openbaar. Verder kreeg de commissie inzage in vertrouwelijke stukken die de politie tijdens het onderzoek had verzameld. 76

Wanneer het gaat om de belangen van bepaalde individuele getuigen blijken commissies soms beduidend minder begripvol, met name als het gaat om invloedrijke personen die het middelpunt zijn van een groot schandaal dat veel maatschappelijke verontwaardiging heeft veroorzaakt. Een voorbeeld is het eerder genoemde verhoor van de gebroeders Maxwell, die na de dood van hun omstreden vader de leiding kregen over het Maxwell-imperium, door de Social Security Committee in 1986. ${ }^{77} \mathrm{Zij}$ weigerden aanvankelijk om voor de commissie te verschijnen, onder meer met het argument dat een openbaar verhoor in strijd zou zijn met de parlementaire sub judice-regels. De commissie weigerde hierin mee te gaan - de broers waren toen nog niet formeel aangeklaagd voor hun betrokkenheid bij malversaties rondom het Maxwell-pensioenfonds - en sommeerde de broers te verschijnen. ${ }^{78}$ In 2011 bevonden vader en zoon Murdoch, de sleutelfiguren in het wereldwijde mediabedrijf News Corporation, zich in een vergelijkbare positie. Na aanvankelijk te hebben geweigerd, zegden zij na daartoe formeel te zijn gesommeerd toe om te verschijnen voor de Culture, Media and Sports Committee, die onderzoek deed naar de afluisterschandalen in de Britse tabloidpers. De commissie had aanwijzingen dat eerdere verklaringen van medewerkers van het bedrijf tegenover select committees vals waren en daarmee wellicht konden worden aangemerkt als 'contempt'. Omdat naast het select committee onderzoek ook een openbaar onderzoek ('public inquiry') onder

\footnotetext{
${ }^{76}$ Zie verder HC 153 (2007-08), § 5-7. Hoewel de commissie overwoog om de vertrouwelijk verstrekte stukken ook openbaar te maken, werd hier uiteindelijk van afgezien: niet alleen was de commissie van mening dat informatie die door de politie in vertrouwelijkheid had verkregen zou niet langs andere weg alsnog openbaar moeten worden. HC 153 (2007-08), § 8.

77 Zie ook hierboven, par. 2.3.3.1.

78 Zie Leopold 1992, p. 541-542.
} 
leiding van Lord Leveson en een strafrechtelijk vooronderzoek gaande waren waarin de Murdochs een rol speelden, lieten zij de commissievoorzitter wel weten dat "in the light of the fact that there are to be multiple reviews of the issues, this does carry the risk of prejudicing other judicial proceedings and in particular the ongoing police investigation..." Hun zorgen konden echter op weinig begrip rekenen. "None of them have been arrested and sub judice rules do not apply," zo reageerde een commissielid. ${ }^{79}$ In haar rapport stelde de commissie dat "we have struck the appropriate balance between considering the important matter of a possible contempt of the House and allowing the Metropolitan Police investigation and the inquiry by Lord Justice Leveson to proceed unimpeded." 80

\subsubsection{Slot}

Uit de sub judice-resolutie van 2001 kan worden afgeleid dat samenloop van parlementair en gerechtelijk onderzoek in beginsel als onwenselijk wordt beschouwd. Het belang van een onafhankelijke, onbevooroordeelde rechtspraak staat onder druk wanneer in het parlement over een lopende (straf)zaak wordt gedebatteerd. Tegelijkertijd vallen bestuursrechtelijke geschillen, die veelal niet door de klassieke rechterlijke macht maar door zogenaamde 'tribunals' worden beslecht, niet onder de resolutie; voorstellen daartoe werden door het parlement afgewezen, omdat haar positie daarmee te veel zou worden aangetast.

Ook voor parlementaire onderzoekscommissies is dit het uitgangspunt: het doen van onderzoek naar of anderszins refereren aan zaken die onder de rechter zijn, dient te worden vermeden. Toch geeft de resolutie ook ruimte aan commissievoorzitters om, in overleg met de Speaker, in concrete gevallen hiervan af te wijken. In de incidentele gevallen waarin parlementair onderzoek overlapt met een gerechtelijke procedure, blijken commissies zich veelal terughoudend op te stellen. Soms worden onderzoeksplannen gaandeweg aangepast, wanneer blijkt dat een (voorbereidend) strafrechtelijk onderzoek wordt gestart, of wordt een onderzoek tijdelijk stilgelegd of vindt afstemming plaats met de betrokken (justitiële) instanties. Een enkele keer blijken commissies echter minder toegeeflijk, bijvoorbeeld wanneer bepaalde omstreden getuigen weigerachtig zijn in het verlenen van medewerking uit vrees voor mogelijke nadelige gevolgen in een (later) strafproces.

De wijze waarop commissies in concreto omgaan met de mogelijkheid om de sub judice-regel en de mogelijkheid om deze in bepaalde gevallen buiten toepassing te laten, is moeilijk in algemene termen te beschrijven. Het uitgangspunt dat het parlement, ook in haar onderzoekswerkzaamheden, zich terughoudend opstelt, lijkt nog steeds breed te worden onderschreven, al lijken commissies vooral bij incidenten of schandalen die veel maatschappelijke ophef hebben veroorzaakt soms toch de ruimte te willen nemen om, ondanks lopende strafrechtelijke onderzoeken, het onderwerp op te pakken en te laten zien dat men 'bovenop de zaak zit'. Wanneer dat het geval is, lijkt toch sterk afhankelijk van omstandigheden als de stemming in de commissie,

\footnotetext{
${ }^{79}$ Zie N. Watt, 'Phone hacking: both Murdochs agree to face MPs following jail threat', in: The Guardian, 14 juli 2011.

${ }^{80}$ Zie Culture, Media and Sports Committee, News International and Phone-hacking, HC 903-I (2010-12), $\S 14$.
} 


\title{
VERENIGD KONINKRIJK
}

de vraag of de commissie al eerder onderzoek naar het betreffende thema heeft gedaan en daarop kan voortbouwen, of eventuele politieke gevoeligheden.

Het ontbreekt verder aan nadere richtlijnen over bijvoorbeeld overleg en afstemming met justitiële instanties. Kennelijk bestaat hieraan ook niet echt veel behoefte. Zo benadrukt de voorzitter van de Public Administration Committee tijdens de meest recente evaluatie van de regeling door de Procedure Committee de noodzaak van enige manoevreerruimte en onderstreepte daarbij het belang van parlementair onderzoek, ook in het geval van samenloop:

\begin{abstract}
"Decisions on these matters can obviously only be made in the light of the circumstances of the particular case. But I believe it is important that when those decisions are made proper account is taken not just of the fear that Parliament may improperly interfere in judicial proceedings, but of the danger that too great a deference to the courts may reduce our ability to carry out our own proper functions - to influence policy or hold governments to account in a timely way." 81
\end{abstract}

De voorzitter van de Home Affairs Committee kwam met een voorstel om zaken die op zichzelf sub judice zijn, toch te onderzoeken, maar daarbij getuigen te verzoeken "direct allegations or implications against named individuals" te vermijden. De Procedure Committee is op dit laatste voorstel niet ingegaan. Wel concludeerde zij dat het mogelijk zou moeten zijn om beleidsaspecten gerelateerd aan concrete gebeurtenissen die sub judice zijn te bespreken. Daarbij vertrouwt de commissie in algemene zin op het oordeel van de Speaker, die ervoor moet waken dat discussies over beleidsaspecten niet overgaan in discussies over concrete zaken. ${ }^{82}$

Van directe beïnvloeding van gerechtelijke procedures of verstoring van strafrechtelijke opsporingsonderzoeken als gevolg van parlementaire onderzoeken is tot op heden in elk geval nog niet gebleken. Wellicht is dit, tesamen met de incidentele aard van de samenloopproblematiek, de reden waarom een nadere regeling omtrent afstemming en overleg tussen instanties tot dusver niet nodig is bevonden.

\subsection{Afronding van een onderzoek}

\subsubsection{Het eindrapport}

\subsubsection{Rapportagebevoegdheid}

Hiervoor bleek dat de meeste onderzoekscommissies in het Lagerhuis de bevoegdheid hebben "to report from time to time". ${ }^{83}$ Commissies kunnen op grond van deze rapportagebevoegdheid naar eigen inzicht en op eigen initiatief rapporteren omtrent hun bevindingen aan het Huis. In Standing Order No. 133 is voorts bepaald dat elke select committee in het Lagerhuis "shall have leave to report to the House its opinion and observations upon any matters referred to it for its consideration, together with the minutes of the evidence taken before it, and also to make a special report of any

\footnotetext{
${ }^{81} \mathrm{HC} 714$ (2005-06), Ev 53.

${ }^{82}$ HC 714 (2005-06), § 48, 53.

83 Zie hiervoor, par. 4.2. Ten aanzien van de departmental select committees is deze rapportagebevoegdheid te vinden in Standing Order No 152 van 25 juni 1979 (laatstelijk gewijzigd: 30 juni 2010), lid 4 sub a.
} 
matters which it may think fit to bring to the notice of the House." 84 Select committees ontlenen aan deze bepaling de bevoegdheid om 'reports' op te stellen, zelfs wanneer dat niet uitdrukkelijk van een select committee wordt verwacht op basis van de order of reference. Tevens kan het bewijsmateriaal, zowel het schriftelijke als het woordelijk verslag van het mondelinge bewijs, in de vorm van 'minutes of evidence' openbaar gemaakt worden. ${ }^{85}$ Andere stukken, die de commissie van belang acht, kunnen worden gepubliceerd in de vorm van een 'special report'. Daarbij gaat het onder meer om de reactie van de regering op een eerder gepubliceerd onderzoeksrapport van de betreffende select committee. ${ }^{86}$ In het Hogerhuis wordt de bevoegdheid om te rapporteren geregeld in de orders of appointment van elke afzonderlijke commissie. ${ }^{87}$

\subsubsection{Procedure}

Het vaststellen van een onderzoeksrapport door een select committee gebeurt volgens een vaste procedure. ${ }^{88}$ Nadat de hoorzittingen zijn afgerond, komt de commissie bijeen om te overleggen over het te publiceren rapport, in het bijzonder over de formulering van de conclusies en aanbevelingen op grond van het verzamelde bewijsmateriaal. Het is gebruikelijk dat de clerk(s) van de commissie hiertoe een 'heads of report' paper schrijven, een soort raamwerk met mogelijke thema's, conclusies, aanbevelingen en openstaande vraagpunten op basis waarvan de commissie overlegt. Naar aanleiding hiervan wordt door de clerk in naam van de commissievoorzitter een conceptrapport geschreven, dat vervolgens aan de commissie in overweging wordt gegeven. Het voorleggen van een conceptrapport is echter niet uitsluitend voorbehouden aan de voorzitter; andere commissieleden kunnen een conceptrapport schrijven en voorleggen aan de commissie. ${ }^{89}$

Het voorgelegde conceptrapport wordt vervolgens eerst op informele wijze behandeld door de commissie. In deze fase kunnen commissieleden vrijelijk overleggen over eventuele aanpassingen van de tekst en kan worden bezien in hoeverre eventuele meningsverschillen kunnen worden opgelost. Het daadwerkelijk vaststellen van het rapport gebeurt tijdens een formele behandeling in twee lezingen. Indien slechts één conceptrapport aan de commissie in overweging is gegeven, dan wordt dit concept automatisch geacht te zijn aangenomen in eerste lezing. Als meerdere conceptrapporten zijn voorgelegd, dan moet middels stemming worden beslist over de volgorde waarin deze concepten worden behandeld. Doorgaans wordt het con-

\footnotetext{
${ }^{84}$ Standing Order No. 133 van 25 oktober 1968 (laatstelijk gewijzigd: 28 maart 2007). De regelingen ten aanzien van subcommissies is anders, zoals hiervoor reeds bleek.

${ }^{85}$ Daarnaast kunnen select committees op grond van Standing Order No. 135 de Clerk of the House toestemming geven hun rapporten, na deze te hebben voorgelegd aan het Huis, maar vóór openbaarmaking, onder embargo te verstrekken aan ambtenaren, getuigen, journalisten en anderen. Standing Order No. 135 van 16 juli 1971 (laatstelijk gewijzigd: 30 maart 1983). Zie ook Erskine May 2004, p. 776 en Rodgers \& Walters 2006, p. 368.

${ }^{86}$ Zie verder Erskine May 2004, p. 774-775 en 777-779.

87 Zie Erskine May 2004, p. 723.

88 Zie Erskine May 2004, p. 769-777. Zie ook Rodgers \& Walters 2006, p. 366-368.

${ }^{89}$ Erskine May 2004, p. 770.
} 
ceptrapport dat in opdracht van de commissievoorzitter is geschreven, als eerste in tweede lezing behandeld. ${ }^{90}$

In tweede lezing wordt de tekst alinea voor alinea behandeld. In deze fase kunnen amendementen op de tekst worden voorgesteld. Het behandelen van amendementen gebeurt volgens de gebruikelijke regels van het Huis. Wanneer eenmaal bij meerderheid is beslist over een voorgesteld amendement, kan de betreffende alinea niet meer worden aangepast. De commissievoorzitter beschikt niet over de bevoegdheid om amendementen te selecteren of te groeperen, maar kan wel beslissen over de 'orderliness' van amendementen. Het is in de praktijk gebruikelijk dat inhoudelijke amendementen vooraf worden toegestuurd aan de Clerk, die de ingediende amendementen sorteert op volgorde van de betreffende overwegingen in het conceptrapport (een 'marshalled list'). Noodzakelijk is dit echter niet. Alinea's en amendementen kunnen ook in andere volgorden worden behandeld. Als alle amendementen zijn behandeld, wordt het gehele conceptrapport, zoals geamendeerd, in stemming gebracht. Indien de commissie het concept in meerderheid aanneemt, is het rapport vastgesteld. Mocht dit niet het geval zijn, dan wordt een tweede conceptrapport in tweede lezing behandeld (indien van toepassing).

De vaststelling van rapporten gebeurt in de praktijk meestal op basis van consensus. Eventuele verschillen van mening worden vaak tijdens het informele overleg opgelost, waardoor het niet nodig is om te stemmen en rapporten op basis van consensus kunnen worden vastgesteld. De formele vaststelling van het rapport in twee lezingen is dan niet meer dan een formaliteit; het rapport wordt feitelijk in één beslissing vastgesteld. ${ }^{91}$ Mocht de commissie niet bij meerderheid overeenstemming kunnen bereiken over een conceptrapport, dan kan de commissie ervoor kiezen om een 'special report' 92 uit te brengen waarin dit aan het Huis wordt medegedeeld. Verder kan de commissie het verzamelde bewijsmateriaal publiceren, zonder nadere rapportage. Het is ook voorgekomen dat, in aanvulling op het bewijsmateriaal, de tekst van een afgewezen conceptrapport werd gepubliceerd. ${ }^{93}$

\subsubsection{Minderheidsstandpunten}

Wanneer unanimiteit ten aanzien van het commissierapport niet haalbaar blijkt, zal een minderheid zich uiteindelijk toch moeten neerleggen bij het meerderheidsbesluit. Erskine May stelt hierover: "It is the opinion of the committee, as a committee, not that of the individual Members, which is required by the House, and, failing unanimity, the conclusions agreed to by the majority are the conclusions of the committee." Minderheidsrapporten bestaan daarom formeel niet. Een commissierapport kan in beginsel ook niet worden voorzien van bijlagen of memoranda met afwijkende standpunten van commissieleden die zich niet in de opvattingen of conclusies van de meerderheid kunnen vinden. ${ }^{94}$ In de praktijk blijkt dit toch niet geheel onmogelijk te zijn. Zo besloot de Modernisation Committee in een rapport over het wetgevingspro-

\footnotetext{
${ }^{90}$ Erskine May 2004, p. 770.

91 Zie ook Rodgers \& Walters 2006, p. 368.

92 Zie over 'special reports' hierna, par. 2.5.2.3.

${ }^{93}$ Erskine May 2004, p. 771 en 773.

${ }^{94}$ Erskine May 2004, p. 772.
} 
ces een bijlage op te nemen, waarin twee commissieleden uitdrukkelijk het 'Majority Report' afwezen. ${ }^{95}$

Is de meerderheid niet bereid tot het toevoegen van een dergelijke bijlage, dan kan een minderheid haar standpunten wereldkundig maken via de notulen van de vergadering waarin het rapport wordt vastgesteld. Conceptrapporten en amendementen die door de commissie zijn behandeld en afgewezen, worden namelijk integraal in de notulen van de commissie opgenomen. Deze notulen ('formal minutes') worden altijd toegevoegd aan het rapport en zijn dus openbaar. Wanneer een afgewezen conceptrapport via de notulen wordt gepubliceerd, wordt dus toch bereikt dat een minderheid binnen de commissie een afwijkend standpunt naar buiten brengt. ${ }^{96}$ Deze gang van zaken is, gezien de doorgaans consensuele werkwijze van commissies, uitzonderlijk en speelt met name bij controversiële onderwerpen. Een voorbeeld is het onderzoek van de Science and Technology Committee over wetenschappelijke ontwikkelingen sinds de inwerkingtreding van de Britse abortuswetgeving. Zowel de voorzitter als een minderheid van twee commissieleden had een conceptrapport geschreven. Beide werden in eerste lezing behandeld, waardoor het conceptrapport van de minderheid in de notulen werd afgedrukt. Vervolgens werd besloten om het conceptrapport van de voorzitter in tweede lezing te behandelen. De meerderheid stemde met dit rapport in. ${ }^{97}$

Conceptrapporten die niet door de commissie worden behandeld ('entertained'), zo stelt Erskine May, worden niet opgenomen in de notulen. Dit is het geval wanneer de commissie niet toekomt aan de eerste lezing van een ingediend conceptrapport, omdat een ander conceptrapport reeds door een meerderheid van de commissie in tweede lezing is aangenomen. ${ }^{98}$ De volgorde van behandeling van conceptrapporten is dus bepalend voor de vraag of een conceptrapport uiteindelijk via de notulen van de commissie openbaar zal worden. Deze volgorde, zo bleek hiervoor, wordt bij stemming bepaald. Dit betekent strikt genomen dat de meerderheid bepaalt of een minderheidsstandpunt uiteindelijk in de notulen terechtkomt. ${ }^{99}$ Hoe hiermee in de praktijk wordt omgegaan, is moeilijk vast te stellen, maar het ligt voor de hand dat ook hierover in informeel overleg afspraken worden gemaakt, waardoor alternatieve conceptrapporten alleen aan de commissie zullen worden voorgelegd als die ten minste in eerste lezing zullen worden aanvaard.

Een andere manier waarop een minderheid zich - subtieler - kan manifesteren is door een uitdrukkelijke stemming aan te vragen over het conceptrapport of specifieke overwegingen daarin. Ook bestaat de mogelijkheid om amendementen op on-

\footnotetext{
95 Zie Modernisation Committee, HC 382 (2000-01). Zie ook Erskine May 2004, p. 772. Overigens is de samenstelling van de Modernisation Committee anders dan die van de overige select committees: de commissievoorzitter is de Leader of the House en als zodanig lid van de regering. De commissie heeft daarom een bijzonder karakter, wat de ongebruikelijke beslissing om een minderheidsstandpunt toe te voegen aan het rapport zou kunnen verklaren.

${ }^{96}$ Rodgers \& Walters 2006, p. 368.

97 Zie Science and Technology Committee, Scientific Developments Relating to the Abortion Act 1967, Formal Minutes, HC 1045-I (2006-07).

98 Zie verder Erskine May 2004, p. 771 en 773-734.

${ }^{99}$ Het opnemen van een bijlage met het minderheidsstandpunt, zoals bij de Modernisation Committee gebeurde, was eveneens een meerderheidsbesluit. Zie de 'formal minutes' bij HC 382 (2000-01).
} 


\section{VERENIGD KONINKRIJK}

derdelen van het conceptrapport voor te stellen. De stemmingen hierover worden in de notulen vastgelegd en geven een indicatie van de mate van steun binnen de commissie voor de bevindingen, conclusies en aanbevelingen die in het rapport zijn opgenomen. ${ }^{100}$

\subsubsection{Special reports}

Op grond van standing order No. 133 kunnen select committees tevens 'special reports' voorleggen aan het Huis. Hiervan wordt gebruik gemaakt wanneer een select committee aan het Huis wil rapporteren over zaken betreffende de bevoegdheden, functies of procedures van de commissie. Te denken valt aan de wijze waarop de commissie een onderzoek wil gaan uitvoeren of voortzetten, een verzoek aan het Huis om nadere instructies omtrent de taken en bevoegdheden van de commissie, of het rapporteren van een weigerachtige getuige aan het Huis. Special reports worden bovenal veel gebruikt om de reactie van de regering op een onderzoeksrapport te publiceren (zie hierna). De procedure voor het vaststellen van een special report is hetzelfde als voor een onderzoeksrapport. 101

\subsubsection{Openbaarheid en vertrouwelijkheid}

\subsubsection{Beraadslagingen en rapportage}

De beraadslagingen van select committees vinden altijd achter gesloten deuren plaats. Dit is noodzakelijk om in commissieverband tot overeenstemming te komen over zaken als onderwerpskeuze en vraagstelling, het uitnodigen van getuigen, en het vaststellen van een gezamenlijk rapport. ${ }^{102}$ Een rapport van een select committee wordt niet eerder gepubliceerd dan nadat de commissie met het conceptrapport heeft ingestemd. ${ }^{103}$ Het zonder toestemming publiceren van rapporten of conceptrapporten van select committees kan zelfs worden aangemerkt als contempt. ${ }^{104}$ Incidenteel blijken rapporten voortijdig uit te lekken, zoals in 1999 toen een lid van de Foreign Affairs Committee een conceptrapport toezond aan enkele ministers. De gebruikelijke procedure is dat dergelijke incidenten worden gemeld aan de Committee on Standards and Privileges. ${ }^{105}$ Commissieleden die de vertrouwelijkheid van het commissieoverleg schenden, lopen het risico te worden geschorst als lid van het parlement. ${ }^{106}$

\footnotetext{
100 Erskine May 2004, p. 773.

101 Zie verder Erskine May 2004, p. 774-775.

102 Zie Blackburn \& Kennon 2003, p. 630.

${ }^{103}$ Dit geldt niet voor het bewijsmateriaal dat tijdens een openbare hoorzitting is verstrekt. Zie Standing Order No. 136 van 30 maart 1983.

104 Erskine May 2004, p. 776.

105 Zie Standing Order No. 149 van 6 november 1995 (laatstelijk gewijzigd: 12 maart 2012).

106 Zoals in het geval van de Foreign Affairs Committee gebeurde. Zie Committee on Standards and Privileges, Eight Report: Premature Disclosure of Reports of the Foreign Affairs Committee, HC 607 (199899). Zie voor enkele andere voorbeelden Blackburn \& Kennon 2003, p. 630 en Erskine May 2004, p. 776-777.
} 
Een rapport van een select committee wordt niet eerder gepubliceerd dan nadat de commissie, volgens de hierboven ${ }^{107}$ beschreven procedure, met het conceptrapport heeft ingestemd. Wanneer een select committee een rapport heeft vastgesteld, wordt dit in de parlementaire handelingen vermeld. Vervolgens wordt het rapport onder verantwoordelijkheid van het Huis gedrukt. ${ }^{108}$ Inmiddels is het gebruikelijk dat het rapport ook via de parlementaire website openbaar wordt gemaakt. Het Huis is echter bevoegd om de publicatie van een rapport te weigeren, in te trekken, of om te besluiten om alleen het bewijsmateriaal te publiceren. Dit is echter zeer uitzonderlijk. 109 Tijdens recesperiodes kunnen select committees die bevoegd zijn om tijdens recesperiodes bijeen te komen, zelfstandig besluiten tot publicatie van een rapport. Dit gebeurt evenwel onder verantwoordelijkheid van het Huis. ${ }^{110}$ Select committees kunnen op grond van Standing Order No. 135 beslissen om hun rapporten vóór openbaarmaking onder embargo en onder strikte geheimhouding te verstrekken aan ambtenaren, getuigen, journalisten en anderen. Dit kan echter alleen nadat het betreffende rapport is voorgelegd aan het Huis. ${ }^{111}$

Onderzoeken die, op het moment dat een commissie wordt ontbonden of opgeheven, nog niet zijn afgerond, kunnen niet worden voortgezet. In dat geval wordt hiervan door de commissie melding gemaakt aan het Huis en het reeds verzamelde bewijsmateriaal wordt aan het Huis overgedragen. Als er reeds een conceptrapport is, kan dit eveneens worden overgedragen. Het Huis beslist vervolgens over het al dan niet openbaar maken van het beschikbare materiaal. ${ }^{112}$ Interne werkdocumenten van de commissie, zoals briefing papers of notities, blijven in beginsel vertrouwelijk. In zeer uitzonderlijke gevallen blijkt een select committee bereid te zijn om dergelijke documenten openbaar te maken. ${ }^{113}$

\subsubsection{Bewijsmateriaal}

Het bewijsmateriaal dat gedurende het onderzoek is verzameld wordt doorgaans tezamen met het onderzoeksrapport gepubliceerd. Select committees zijn op grond van de standing orders bevoegd het bewijsmateriaal te rapporteren aan het Huis. ${ }^{114}$ Het betreft zowel de verslagen van hoorzittingen als de schriftelijke stukken die aan de commissie zijn overlegd.

Het is gebruikelijk dat commissies ook de woordelijke verslagen van hoorzittingen rapporteren aan het Huis. Voordat een verslag wordt gepubliceerd door het Huis, krijgen de betreffende getuigen de gelegenheid om het transcript te corrigeren.

\footnotetext{
107 Zie par. 4.4.1.2.

108 Erskine May 2004, p. 773. Zie ook Blackburn \& Kennon 2003, p. 590. In het Hogerhuis is dit vastgelegd in Standing Order No. 69 van 18 mei 1865. Zie ook Erskine May 2004, p. 730.

109 Zie Erskine May 2004, p. 773.

110 Zie Standing Order No. 137 van 30 maart 1983. Zie ook Erskine May 2004, p. 774.

111 Standing Order No. 135 van 16 juli 1971 (laatstelijk gewijzigd: 30 maart 1983). Zie ook Erskine May 2004, p. 776 en Rodgers \& Walters 2006, p. 368.

112 Zie verder Erskine May 2004, p. 775-776.

${ }^{113}$ Dit gebeurde in verband met een openbaar onderzoek naar de dood van David Kelly, een getuige die was verhoord door de Foreign Affairs Committee. Zie Erskine May 2004, p. 766.

114 Standing Order No. 133 van 25 oktober 1968 (laatstelijk gewijzigd: 28 maart 2007). Zie ook Erskine May 2004, p. 764.
} 
Het gaat hierbij uitsluitend om onjuistheden in de verslaglegging of om aanpassingen van feitelijkheden in een antwoord die de strekking ervan niet veranderen. Substantiële aanvullingen of correcties kunnen uitsluitend middels een voetnoot of een aanvullende schriftelijke verklaring worden aangebracht. Bij verhoren van ministers is het gebruikelijk dat het ongecorrigeerde verslag direct via de parlementaire website openbaar worden gemaakt. Bij andere getuigenverhoren gebeurt dit alleen met toestemming van de betreffende getuige. ${ }^{115}$

De verslagen van hoorzittingen die achter gesloten deuren zijn gehouden, kunnen in beginsel eveneens worden gerapporteerd en gepubliceerd. Een getuige die meent dat het openbaar maken van een verklaring die in beslotenheid is gegeven ongewenst is, bijvoorbeeld op grond van het algemeen belang of in verband met persoonlijke of bedrijfsbelangen, kan de commissie verzoeken om de verklaring geheel of gedeeltelijk niet te rapporteren aan het Huis. Dit wordt 'side-lining' genoemd.116 De commissie besluit of aan het verzoek gehoor wordt gegeven. ${ }^{117}$ In plaats daarvan kan ook besloten worden in verband met de onderbouwing van het rapport slechts een samenvatting van het verhoor te rapporteren. Wanneer de commissie heeft besloten om een getuigenverklaring geheel of gedeeltelijk niet te rapporteren, kan het Huis de commissie achteraf opdragen om de verslagen alsnog te overleggen. In dergelijke gevallen is het gebruikelijk dat het materiaal ook wordt gepubliceerd. ${ }^{118}$

Ook andere schriftelijke stukken die de commissie heeft verzameld worden meestal gerapporteerd en gepubliceerd. Soms wordt een deel van het materiaal vanwege de grote hoeveelheid alleen ter inzage gelegd in het parlement. In dat geval wordt in de rapportage wel een vermelding van de stukken opgenomen. ${ }^{119}$ Het schriftelijke bewijsmateriaal dat aan een select committee wordt toegezonden, wordt eigendom van de commissie. Documenten die eenmaal in het bezit zijn van de clerk van een select committee kunnen niet worden teruggetrokken of gewijzigd zonder toestemming van de betreffende commissie. ${ }^{120}$ Verder blijkt uit de standing orders dat een getuige die schriftelijke stukken heeft ingediend de toestemming van de commissie nodig heeft, wanneer hij zelf het materiaal openbaar wil maken voordat de commissie de stukken heeft gerapporteerd aan het huis en besloten is tot publicatie. ${ }^{121}$ In de praktijk wordt deze toestemming overigens bijna altijd verleend. ${ }^{122}$

\footnotetext{
${ }^{115}$ Erskine May 2004, p. 765.

${ }^{116}$ In het verslag wordt vervolgens gemarkeerd op welke plaatsen gedeelten zijn weggelaten. Erskine May 2004, p. 765-766. Zie ook Blackburn \& Kennon 2003, p. 590.

117 Vgl. ook de wijze waarop met departementale stukken wordt omgegaan. Zie hierboven, par. 2.4.4.

118 Erskine May 2004, p. 766.

119 Erskine May 2004, p. 766.

120 Zie Standing Order No. 127 van 15 juli 1935 (laatstelijk gewijzigd: 28 juli 1948). Zie verder Erskine May 2004, p. 758. Select committees met PPR-bevoegdheden zijn tevens bevoegd zijn het verzamelde bewijs te delen met andere select committees in beide Huizen. Zie Standing Order No. 137A van 5 juli 2001 (laatstelijk gewijzigd: 13 juli 2005), lid 1 sub a.

121 Zie Standing Order No. 135 van 16 juli 1971 (laatstelijk gewijzigd: 25 november 2008). Dit geldt overigens alleen voor select committees met onderzoeksbevoegdheden ('to send for persons, papers and records').

122 Zie Rodgers \& Walters 2006, p. 371.
} 


\subsubsection{Na publicatie}

\subsubsection{Reactie van de regering}

De meeste rapporten van select committees hebben in meer of mindere mate betrekking op aspecten van het beleid van de regering of de uitvoering daarvan. Uit het kwantitatieve onderzoek van Russell en Benton over de periode 1997-2010 blijkt dat $83 \%$ van alle aanbevelingen in commissierapporten gericht is aan de centrale overheid. ${ }^{123}$ Dit is niet verwonderlijk. Met name de departmental select committees hebben immers uitdrukkelijk de taak onderzoek te doen naar de uitgaven, de uitvoering en het beleid van de ministeries. Hoewel select committees formeel slechts aan het Huis rapporteren, wordt met de eindrapporten doorgaans een breder publiek beoogd - in het bijzonder de regering. ${ }^{124}$ Veel van de aanbevelingen die commissies in hun rapporten doen, zijn dan ook gericht op de regering.

Bij de invoering van de departemental select committees is afgesproken dat de regering in beginsel binnen twee maanden na publicatie schriftelijk reageert op de bevindingen en de aanbevelingen in een select committee rapport. Inmiddels wordt gesproken van een parlementaire conventie. ${ }^{125}$ Een 'Government Response' wordt soms afzonderlijk gepubliceerd door de regering, maar meestal door het betrokken departement rechtstreeks toegezonden aan de select committee. De commissie publiceert het document dan in de vorm van een special report. ${ }^{126}$ Wanneer niet binnen de afgesproken termijn van twee maanden kan worden gereageerd, dan dient de regering hiervan gemotiveerd mededeling te doen aan de betreffende commissie. ${ }^{127}$ In de praktijk blijkt dit overigens lang niet altijd te gebeuren en moet de commissie langer op de reactie van de regering wachten. ${ }^{128}$

Het gebeurt zelden dat de regering de conclusies en aanbevelingen in een select committee rapport in haar reactie zonder meer overneemt. Zeker wanneer een commissierapport ingrijpende maatregelen aanbeveelt of kritisch is ten aanzien van het optreden of het beleid van de regering, is de houding van de regering vaak terughoudend of zelfs defensief. 129 De bevindingen van select committees leiden daarom meestal niet tot onmiddellijke veranderingen in het regeringsbeleid. Veelal wordt er echter vanuit gegaan dat de aanbevelingen van select committees vooral op de langere termijn effect kunnen hebben, zoals bijvoorbeeld door Rodgers en Walters wordt betoogd:

"Ambitious recommendations may change the whole public debate on a subject; they may be taken up by public bodies and pressure groups; and months (or sometimes two or three years)

\footnotetext{
${ }^{123}$ De rest heeft betrekking op andere publieke diensten of op de private sfeer, zoals het bedrijfsleven. Zie Russell \& Benton 2011, p. 66.

124 Rodgers \& Walters 2006, p. 368.

125 Rodgers \& Walters 2006, p. 368-369.

${ }^{126}$ Incidenteel wordt op een andere wijze gereageerd, zoals via antwoorden op parlementaire vragen of ministeriële verklaringen in de Chamber. Zie verder Erskine May 2004, p. 777-778.

127 Erskine May 2004, p. 778.

128 Zie Liaison Committee, Shifting the Balance, HC 300 (1999-2000), § 45, waarin commissies werd aangeraden om, bij ministeries die herhaaldelijk te laat reageren, de verantwoordelijke ministers iets meer dan twee maanden na publicatie van een rapport te laten verschijnen voor een hoorzitting.

${ }^{129}$ Rodgers \& Walters 2006, p. 369.
} 


\section{VERENIGD KONINKRIJK}

later they may contribute substantially to a major shift in government policy. Similarly, the effect of justified criticism may not be immediately apparent; but a department may be quietly changing its procedures to avoid making the same mistake again." 130

Op de langere termijn kan een rapport in de praktijk dus alsnog een zekere invloed hebben, al zullen wijzigingen in beleid of de uitvoering dan niet altijd direct meer herleidbaar zijn tot de aanbevelingen van een select committee. ${ }^{131}$

\subsubsection{Follow-up}

"Whatever the contents of the government reply, committees are most influential if they follow up on their reports," zo stellen Rodgers en Walters. ${ }^{132}$ Er zijn verschillende manieren waarop select committees de implementatie van de aanbevelingen naar aanleiding van hun onderzoek trachten te bevorderen. Het doel is daarbij vooral om de conclusies en aanbevelingen die in een onderzoeksrapport zijn gedaan, op de politieke agenda te houden. Onderwerpen die de commissie van groot belang acht, keren vaak met enige regelmaat terug op de onderzoeksagenda van de commissie. Dat biedt de gelegenheid om de resultaten van eerder onderzoek opnieuw tegen het licht te houden en na te gaan in hoeverre de regering de gedane aanbevelingen heeft opgevolgd. Dit kan aanleiding zijn voor een vervolgonderzoek. Individuele commissieleden kunnen parlementaire vragen stellen aan de verantwoordelijke ministers. Ook worden hoorzittingen gehouden, waarop ministers om uitleg wordt gevraagd over de implementatie van de (al dan niet toegezegde) maatregelen. Soms wordt om een voortgangsrapport van het betreffende ministerie gevraagd. ${ }^{133}$ Vasthoudende commissies kunnen er op deze manier voor zorgen dat er, zoals Turpin en Tomkins het omschrijven, een "continuous dialogue" ontstaat tussen commissies en de departementen die zij schaduwen. ${ }^{134}$

Select committees gebruiken daarnaast informele methoden om de resultaten van hun onderzoek op de agenda te houden. Te denken valt aan het aanspreken van ministers via partijlijnen of via de media en het houden van seminars, waarvoor experts en belanghebbenden (zoals ambtenaren en vertegenwoordigers van belangengroepen) worden uitgenodigd om in besloten kring met de commissie van gedachten te wisselen over de resultaten van een onderzoek. ${ }^{135}$

De follow-up van commissierapporten gebeurt in de praktijk, zo constateren Maer en Sandford, niet erg gestructureerd. Het aantal aanbevelingen dat een commissie jaarlijks doet is erg groot - soms enkele honderden - en de beschikbare capaciteit om de resultaten daarvan te blijven volgen is beperkt. ${ }^{136}$

\footnotetext{
130 Rodgers \& Walters 2006, p. 369.

131 Zie over de impact van select committees verder hierna, par. 4.7.

132 Rodgers \& Walters 2006, p. 369.

133 Zie ook Erskine May 2004, p. 778-779.

134 Turpin \& Tomkins 2011, p. 626.

135 Zie verder Maer \& Sandford 2004, p.

136 Maer \& Sandford 2004, p. 39. Mede op basis van de formele 'zestig-dagen' reactie van de regering, zo adviseren zij, zouden commissies hun aanbevelingen moeten categoriseren en hun aandacht vervolgens moeten richten de belangrijkste aanbevelingen.
} 


\subsubsection{Parlementaire behandeling}

Nadat het rapport is aangeboden aan het Huis, kan besloten worden om het rapport plenair te behandelen. Dit gebeurt middels een debat, dat op twee manieren kan worden gehouden. Meestal vindt een debat over een select committee rapport plaats op basis van een 'motion for the adjournment'. Formeel gaat een zogenaamd 'adjournment debate' over de vraag of de vergadering zou moeten worden geschorst tot de volgende dag; in de praktijk is een dergelijke motie een mechanisme om debatten over uiteenlopende onderwerpen te initiëren. ${ }^{137}$ In plaats van een adjournment debate kan ook een debat gehouden worden op basis van een 'substantive motion'. Het verschil is dat een debat over een 'substantive motion' altijd plaatsvindt op basis van een (inhoudelijke) 'question' waarover het Huis aan het eind van het debat een besluit dient te nemen. Dergelijke debatten worden veelal gevoerd wanneer de regering een expliciete uitspraak van het Huis wenst, zoals het geval is bij het besluiten over aanhangige wetsvoorstellen. Wanneer het gaat om een debat over een select committee rapport, dan kan gedacht worden aan het aanvaarden of verwerpen van het rapport of van bepaalde passages daaruit. Bij adjournment debates hoeft geen inhoudelijke vraag ${ }^{138}$ te worden geformuleerd en heeft dus een tamelijk vrijblijvend karakter.

In de praktijk wordt slechts een klein aantal select committee rapporten daadwerkelijk besproken in een plenair debat. Dit heeft onder andere te maken met de parlementaire agenda, die door de regering wordt beheerst en relatief weinig ruimte biedt voor debatten naar aanleiding van select committee rapporten. Tot 1999 werd slechts op enkele momenten tijdens de jaarlijks begrotingsbehandeling tijd gereserveerd voor de behandeling van (gerelateerde) select committee rapporten. Dit betekende dat een select committee gemiddeld slechts eenmaal per drie jaar de gelegenheid kreeg om een van haar rapporten in debat voor het voetlicht te brengen. ${ }^{139}$ Daarbij moest dan bovendien een zekere samenhang met de begrotingsbehandeling worden gezocht.

In 1999 is het aantal mogelijkheden vergroot door de ingebruikname van Westminster Hall, een tweede plenaire vergaderzaal die bedoeld is om de drukke agenda van de Chamber te ontlasten. In Westminster Hall worden uitsluitend adjournment debates gehouden. De wijze van debatteren in Westminster Hall is minder antagonistisch dan in de Chamber, wat mede tot uitdrukking komt in de wijze waarop de zaal is ingericht (hoefijzeropstelling in plaats van de tegenover elkaar opgestelde banken zoals in de Chamber). Aanvankelijk konden maximaal zes donderdagen per jaar in Westminster Hall worden besteed aan rapporten van select committees; later werden dit maximaal twintig donderdagen. De Liaison Committee, de commissie bestaande uit de voorzitters van de select committees, bepaalt welke rapporten op de gereserveerde tijdstippen zullen worden besproken. ${ }^{140}$ Het aantal rapporten dat kan worden behandeld is daarmee echter nog steeds vrij beperkt. Bovendien is het tijdstip waar-

\footnotetext{
137 Zie ook Rodgers \& Walters 2006, p. 294 e.v.

138 Doorgaans wordt volstaan met de formele vraag: “That this House do now adjourn”.

139 Blackburn \& Kennon 2003, p. 595.

140 Zie Standing Order No. 10, sub 13 van 29 oktober 2002 (laatstelijk gewijzigd: 15 juni 2010). Zie verder Blackburn \& Kennon 2003, p. 595-596 en Rodgers \& Walters 2006, p. 296-298.
} 
op de debatten plaatsvinden (donderdagmiddag) niet erg gunstig: veel leden maken zich dan al op voor hun vrijdagse terugreis naar hun kiesdistrict. In 2007 werden van de 345 onderzoeksrapporten die door select committees werden uitgebracht, in totaal 25 rapporten behandeld in Westminster Hall en vijf rapporten tijdens de jaarlijkse begrotingsbehandeling in de Chamber. ${ }^{141}$

Overigens kunnen rapporten van select committees ook tijdens reguliere debatten aan de orde komen. Wanneer een commissierapport relevant wordt geacht voor een gepland debat, wordt dit op de parlementaire dagagenda ('Order Paper') aangegeven middels een cursieve vermelding. Het rapport is dan, zoals dat heet, 'tagged'. Dit gebeurt door de griffiers die de agenda opstellen, met toestemming van de aanvrager van het debat. In het geval van wetgevingsdebatten betekent dit meestal dat de toestemming van de regering nodig is. Terwijl het aantal momenten voor debat over commissierapporten beperkt is, kunnen rapporten ongelimiteerd worden vermeld bij debatten over andere zaken. Gebleken is dat een rapport op deze manier (onverwacht) veel aandacht kan krijgen en zelfs het eigenlijke onderwerp van debat kan overschaduwen. ${ }^{142}$

Debatten over commissierapporten zijn over het algemeen niet bijzonder druk bezocht. Vaak zijn alleen de leden van de betreffende select committee en de verantwoordelijke minister aanwezig. Het gebrek aan animo zou te maken kunnen hebben met de vorm waarin de meeste debatten plaatsvinden (een adjournment debate), waardoor er bijna nooit sprake is van een stemming over het rapport. Dit maakt het debat wellicht politiek minder aantrekkelijk. ${ }^{143}$ Verder zijn debatten over commissierapporten vaak weinig actueel, aangezien in beginsel wordt gewacht met het houden van een debat totdat de formele regeringsreactie op het rapport is verschenen. ${ }^{144}$ Afgezien van de procedurele kwesties en de afwijzende houding van de regering, speelt ook mee dat de interesse voor het houden van plenaire debatten bij de leden van select committees zèlf niet bijster groot is: "there is little evidence that the demand actually exceeds the supply," aldus Blackburn en Kennon. Select committees kiezen kennelijk liever voor andere methoden om hun rapporten onder de aandacht te krijgen en te houden, zoals de follow-up mechanismen die hierboven besproken zijn. ${ }^{145}$ Onlangs deed de House of Commons Reform Committee een poging om het

141 Zie HC 427 (2007-08), § 66-67, 112. In het zittingsjaar 2008-2009 betrof het respectievelijk 20 en 6 rapporten. Zie HC 426 (2008-09), § 78-79.

${ }^{142}$ Een voorbeeld is een rapport van de Foreign Affairs Committee over wapenhandel in Sierra Leone, dat vermeld werd bij een belangrijk debat dat door de oppositie was aangevraagd. Zie verder Blackburn \& Kennon 2003, p. 593. Zie ook Erskine May 2004, p. 791.

143 Hansard Society Commission 2001, p. 40-41. Zie ook Norton Commission 2000, p. 32.

144 Teneinde de actualiteit te vergroten, heeft de Liaison Committee enige tijd geleden voorgesteld om wekelijks een half uur te reserveren voor een korte discussie over een rapport dat in de twee weken daaraan voorafgaand is gepubliceerd. Na een bijdrage van de verantwoordelijke minister en de voorzitter van de select committee, zou de rest van de tijd beschikbaar moeten zijn voor backbenchers van oppositiepartijen en de regeringspartij. Dit wekelijkse halfuurtje zou ruimte moeten scheppen voor "an early exchange of views on reports and subjects of immediate topicality". Zie HC 321 (2000-01), § 34. Zie ook Hansard Society Commission 2001, p. 40-41. Dit voorstel is door de regering afgewezen; de gestelde termijn van twee weken zou niet voldoende zijn om een afgewogen reactie te geven. Zie verder HC 300 (1999-2000), § 39-43 en HC 321 (2000-01), § 31-35.

145 Blackburn \& Kennon 2003, p. 598. 
werk van select committees meer onder de aandacht te brengen: de nieuwe Backbench Business Committee zou wekelijks tien minuten moeten reserveren voor een presentatie van een commissievoorzitter over een recent rapport in de plenaire vergadering, zonder dat de verantwoordelijke minister direct een reactie zou geven. ${ }^{146}$ De nieuwe commissie heeft deze handschoen opgepakt en 'mini-statements' door commissievoorzitters als een van de mogelijke onderdelen op de nieuwe, wekelijkse 'backbenchdag' in de Chamber. Deze presentaties kunnen maximaal twintig minuten duren, inclusief interrupties en - toch - een korte eerste reactie van de minister. ${ }^{147}$

In het Hogerhuis is het gebruikelijk dat alle rapporten van onderzoekscommissies ('investigative select committees') worden behandeld in een debat, tenzij het rapport door de commissie is aangeboden "for information". In de standing orders is zelfs geregeld dat in de parlementaire agenda een datum voor debat moet worden voorgesteld, zodra een rapport wordt aangeboden aan het Huis. ${ }^{148}$ Bij debatten kunnen, zoals in het Lagerhuis, verschillende soorten moties worden aangenomen. Gebruikelijk zijn moties "to take note" of "that the report by agreed to". ${ }^{149}$ Ook in het Hogerhuis blijken parlementaire debatten over commissierapporten overigens weinig aandacht te genereren. ${ }^{150}$

\subsection{Kenmerken van de onderzoekspraktijk}

\subsubsection{Hoeveelheid onderzoek}

De omvang van het onderzoekswerk van de departementale onderzoekscommissies is sinds de invoering van het commissiestelsel in 1979 aanzienlijk gegroeid, wanneer gekeken wordt naar de 'output' van commissies. In de eerste vier parlementaire jaren (1979-83) werden in totaal 193 (inhoudelijke) rapporten gepubliceerd door departementale onderzoekscommissies gezamenlijk; alleen al in het parlementaire jaar 200607 lag het totaal op 145 (inhoudelijke) rapporten. Het aantal commissievergaderingen steeg van gemiddeld 535 (waarvan gemiddeld 308 hoorzittingen) in de jaren 1979-83 naar gemiddeld 697 (waarvan gemiddeld 463 hoorzittingen) in de jaren 2003-07. Dit is exclusief informele bijeenkomsten, die eveneens veel voorkomen; zo hield de Foreign Affairs Committee in 2006-07 in totaal 63 informele bijeenkomsten. De laatste

\footnotetext{
146 HC 1117 (2008-09), § 221. De Liaison Committee, die jaarlijks rapporteert over het werk van de commissies, zag wel wat in dit voorstel, al vreesde zij tevens dat een dergelijke 'tienminutenpresentatie' zou kunnen leiden tot "an undesirable element of Punch and Judy politics to the work of select committees”. Zie HC 426 (2008-08), § 34.

147 Backbench Business Committee, Second Special Report: Work of the Committee 2010-12, HC 1926 (201012), §48-49.

148 Zie House of Lords Standing Order No. 69 van 18 mei 1865.

149 Zie Erskine May 2004, p. 730-731. Zie ook Rodgers \& Walters 2006, p. 381.

${ }^{150}$ Hoewel de meeste onderzoeksrapporten anders dan in het Lagerhuis wel degelijk plenair worden besproken, gebeurt dit meestal op een motie "to take note". Commissieleden klagen verder over de weinige tijd die de regering, vaak op het laatste moment, vrijmaakt voor de debatten. Debatten over select committee rapporten blijken evenals in het Lagerhuis nauwelijks deelnemers te trekken buiten de specialisten van de commissie zelf. Ook hier kiezen select committees dan ook voor andere methoden om ministers te ondervragen en om het rapport onder de aandacht te brengen. Zie Rodgers \& Walters 2006, p. 306-307.
} 
jaren worden, buiten de recesperiodes, wekelijks ongeveer 20 formele commissievergaderingen gehouden en zo'n 4 à 5 rapporten gepubliceerd. Het aantal leden van het Lagerhuis dat lid is van departementale onderzoekscommissies steeg van 148 leden in 1979 naar 224 in 2007.151

\subsubsection{De aard van het onderzoek: verschillende types}

Het onderzoekswerk van departementale onderzoekscommissies is zeer divers van aard. Een aantal typen onderzoek kan worden onderscheiden. De Liaison Committee beschrijft in haar rapport Shifting the Balance: Unfinished Business (2001) vier onderzoekstypen. Ten eerste worden grote onderzoeken ('major inquiries') gehouden. Recente voorbeelden zijn onderzoeken naar wederopbouw na conflicten (International Development Committee), sociale uitsluiting in Wales (Welsh Affairs), of het stelsel van geestelijke gezondheidszorg (Health). Een tweede categorie betreft kortlopende onderzoeken naar actuele zaken, zoals naar de humanitaire crises in Sudan en Kosovo (International Development) en de ontwikkelingen bij autofabrikant Rover (Trade and Industry). Een derde type betreft onderzoeken naar nieuwe ontwikkelingen (ook wel 'blue sky thinking' genoemd), gericht op het bijdragen aan beleidsontwikkeling of stimulering van publiek debat. Voorbeelden zijn onderzoeken naar de klimaatdoelstellingen en de tabaksindustrie. De laatste categorie betreft onderzoeken naar aanleiding van specifieke gebeurtenissen (ook wel 'post-mortem' of 'what-went-wrong inquiries' genoemd), die zijn gericht op het trekken van lessen voor de toekomst. Dit type onderzoek komt thans minder voor dan voorheen, merkt de commissie op. Genoemd worden onderzoeken naar de militaire interventie in Kosovo (Foreign Affairs, Defence) en het verwerken van Georgisch nucleair afval in een Britse centrale (Trade and Industry). ${ }^{152}$ Blackburn en Kennon voegen aan deze categorisering nog een vijfde type toe, te weten onderzoeken specifiek gericht op de bestedingen van ministeries, bijvoorbeeld naar aanleiding van de departementale jaarverslagen. 153

Overigens volgt uit deze onderzoeken niet per definitie een volwaardig onderzoeksrapport. Soms kiezen commissies ervoor alleen een of meerdere hoorzittingen te houden en de schriftelijke weergave van de getuigenverklaringen zonder nader rapport te publiceren. Het gaat dan bijvoorbeeld om actuele ontwikkelingen, die veel media-aandacht genereren. Commissies lijken er dan vooral op uit te zijn hun betrokkenheid te tonen of eerder gedaan onderzoek nog eens onder de aandacht te brengen.

\footnotetext{
151 Zie verder Lock 1989, p. 321, 334-346; Liaison Committee, The Work of Committees in 2007, HC 427 (2007-08), par 111-112; House of Commons Standing Order No. 152 van 25 juni 1979 (laatstelijk gewijzigd: 30 juni 2010).

152 Liaison Committee, Shifting the Balance. Unfinished Business, HC 321 (2000-01), § 64-67. Zie ook Blackburn \& Kennon 2003, p. 586.

153 Blackburn \& Kennon 2003, p. 586.
} 


\subsubsection{Het object van onderzoek}

Departementale onderzoekscommissies hebben, zoals bekend, de taak "to examine the expenditure, administration and policy of the principal government departments ... and associated public bodies" ${ }^{154}$ Binnen deze ruim geformuleerde onderzoeksopdracht zijn commissies vrij om te bepalen waarop zij hun onderzoeken wensen te richten. Een enquête die de Hansard Society in 2001 hield geeft een beeld van de inhoudelijke voorkeuren van commissies. De clerks van de departementale onderzoekscommissies werd gevraagd de onderzoeksrapporten van hun commissie tussen 1997 en 1999 te classificeren, waarbij meer dan één classificatie per rapport mogelijk was. ${ }^{155}$ Hieruit kwam naar voren dat $33.1 \%$ van de rapporten betrekking had op 'expenditure', 59.3\% had betrekking op 'administration' en $77.1 \%$ had betrekking op 'policy'. Wanneer vervolgens onderscheid werd gemaakt tussen grote en kleine onderzoeken, dan bleek dat maar liefst $94.7 \%$ van de grote onderzoeken betrekking had op 'policy'. ${ }^{156}$

Nadere specificatie binnen de drie hoofdthema's leverde het volgende op. Bij de rapporten die (mede) gericht waren 'expenditure', had $45.0 \%$ betrekking op 'value for money' en $20.4 \%$ op verspilling en fraude. Van rapporten die (mede) gericht waren op 'administration' bleek $37.9 \%$ te gaan over de kwaliteit van publieke diensten, $35.9 \%$ over de organisatie van overheidsdiensten en $29.4 \%$ over verzelfstandigde 'executive agencies' en niet-departementale publieke diensten. ${ }^{157}$ De rapporten (mede) gericht op 'policy' waren in meerderheid (57.3\%) gericht op het analyseren van bestaand beleid ('audit of existing policy'), 24.1\% had betrekking op door de regering gepubliceerde 'white papers', $15.1 \%$ op 'green papers', $14.6 \%$ ging over specifieke gebeurtenissen of beslissingen en $13.1 \%$ werd getypeerd als 'blue sky thinking'. Wat verder opviel was dat bij $28.4 \%$ van de rapporten die betrekking hadden op 'expenditure' geen nadere specificatie werd gegeven; een mogelijke verklaring hiervoor is dat de betreffende rapporten hoofdzakelijk betrekking hebben op 'policy' en daarbij slechts zijdelings de bestedingsaspecten van het onderzochte beleid werd behandeld. 158

\subsubsection{Consensus en unanimiteit}

De werkwijze van departementale onderzoekscommissies wordt gekenmerkt door besluitvorming op basis van consensus en unanimiteit. Het houden van stemmingen

\footnotetext{
154 Zie Standing Order No. 152 van 25 juni 1979 (laatstelijk gewijzigd: 30 juni 2010).

155 Zie Hansard Society Commission 2001, p. 156-173. Daarbij werd opgemerkt dat een inventarisatie op basis van onderzoeksrapporten nooit een volledig beeld kan geven, aangezien niet alle onderzoeksactiviteiten van commissies resulteren in een rapport.

156 Zie Hansard Society Commission 2001, p. 159-160.

157 Zie daarover ook hierboven, par. 2.4.5.

158 Zie voor een volledig overzicht en nadere analyse: Hansard Society Commission 2001, p. 160-163. Zie ook Blackburn \& Kennon 2003, p. 586-587.
} 
over te nemen beslissingen is ongebruikelijk. Doorgaans wordt door middel van overleg overeenstemming bereikt tussen de commissieleden. ${ }^{159}$

De werkwijze van onderzoekscommissies wijkt daarmee sterk af van de gebruikelijke, meer antagonistische manier waarop debat en besluitvorming elders in het Lagerhuis verloopt. Dat de departementale onderzoekscommissies een werkwijze hanteren die wordt gekenmerkt door unanimiteit en consensus, wordt in de Britse literatuur op verschillende manieren verklaard. Rodgers en Walters noemen in dit verband drie factoren. Ten eerste beraadslagen commissies in beginsel achter gesloten deuren. Alleen openbare hoorzittingen zijn toegankelijk voor het publiek en de pers. Het besloten karakter van de commissievergaderingen heeft verschillende effecten. Het uitoefenen van partijpolitieke druk op commissieleden wordt bemoeilijkt, aangezien de whips geen direct zicht hebben op hetgeen besproken wordt in commissievergaderingen; hierdoor ontstaat binnen onderzoekscommissies de ruimte om als individueel commissielid standpunten in te nemen die afwijken van de partijlijn. Vooral de bereidheid om van standpunt te veranderen schept mogelijkheden om tot een gezamenlijke conclusie te komen. ${ }^{160}$ Ten tweede speelt mee dat commissieleden elkaar goed leren kennen in de jaren dat zij tijdens een parlementaire zittingstermijn samenwerken, waardoor een zekere mate van vertrouwen ontstaat. Het gaat zelfs zover dat de commissieleden, allen backbenchers, zich soms meer gaan zien als onderdeel van een collectief dan als de vertegenwoordigers van hun partij. ${ }^{161}$ Ook de persoon en leiderschapsstijl van de voorzitter speelt hierbij een rol. ${ }^{162}$ Ten derde is van groot belang dat onderzoekscommissies werken met mondelinge en schriftelijke verklaringen van getuigen en deskundigen. Dit is niet alleen van belang omdat de regering minder gemakkelijk aanbevelingen naast zich neer kan leggen die worden ondersteund door gedegen onderzoek, maar ook omdat commissieleden op basis van de verzamelde informatie wellicht eerder geneigd zijn om hun standpunten bij te stellen en overeenstemming te bereiken. ${ }^{163}$

Het verschil in werkwijze tussen de onderzoekscommissies enerzijds en de traditionele plenaire vergaderingen anderzijds wordt mooi zichtbaar in de inrichting van de zalen waarin wordt vergaderd. Zo zitten de leden van onderzoekscommissies tijdens vergaderingen en hoorzittingen niet recht tegenover elkaar, zoals in de Chamber, maar aan een halfronde, hoefijzervormige tafel. De leden zitten vrij willekeurig rondom de voorzitter en niet gegroepeerd per partij. Ook niet-leden, zoals clerks of specialist advisers, zitten aan (of dichtbij) de tafel en kunnen tijdens vergaderingen deelnemen aan de discussie. Wanneer commissieleden spreken, dan gebeurt dat zittend en veelal zonder formeel toestemming te vragen aan de voorzitter. Zelfs hoorzittingen verlopen vaak op tamelijk gemoedelijke wijze in een sfeer van

\footnotetext{
159 Besluiten over bijvoorbeeld het starten van een nieuw onderzoek, het selecteren van getuigen of zelfs het vaststellen van het rapport worden dan ook vaak op informele wijze door de voorzitter genomen middels een concluderende opmerking als "well I think we all agree that..." Zie Blackburn \& Kennon 2003, p. 583. Deze consensuele werkwijze was overigens reeds gebruikelijk bij de voorgangers van de departementale onderzoekscommissies. Zie Drewry 1989b, p. 362.

160 Rodgers \& Walters 2006, p. 369-370. Zie in dezelfde zin ook Blackburn \& Kennon 2003, p. 584.

161 Rodgers \& Walters 2006, p. 370. Zie over dit laatste ook Giddings 1989, p. 372.

162 Zie Drewry 1989b, p. 364.

163 Rodgers \& Walters 2006, p. 370.
} 
onderling overleg. In de Chamber wordt alleen staand gesproken en gelden de parlementaire debattradities, waarbij de leden zonder gebruikmaking van documentatie een scherp, vaak wat plechtig betoog houden en bovendien uitsluitend kunnen spreken wanneer en voor zover de voorzitter hen het woord heeft verleend. 164

Het ontwikkelen van een consensuscultuur binnen de onderzoekscommissies was aanvankelijk, toen het stelsel van departementale commissies werd ingevoerd, overigens niet vanzelfsprekend - en werd ook niet door iedereen als wenselijk beschouwd. Uit onderzoek van Drewry op dit punt komt een gemengd beeld naar voren. Hoewel consensusvorming in de beginjaren voor de meeste commissies voorop stond, zagen de Scottish Affairs Committee en de Welsh Affairs Committee zichzelf aanvankelijk juist niet als een plaats voor "dispassionate and constructive policy analysis and departemental monitoring" maar veeleer als forum voor regionaal politiek debat. Voor de andere commissies was consensus wel een belangrijk streven, maar daar bleek dat, "[h]aving reached a consensus about the desirability of consensus, most committees proceeded towards that goal by carefully avoiding topics of inquiry that might be expected to foment discord; this often became translated into an emphasis upon the task of monitoring departmental activities and administrative efficiency rather than straying too far into minefields of substantive policy." 165 De Home Affairs Committee nam in deze periode een uitzonderingspositie in en koos ervoor controversiële onderwerpen juist niet te schuwen. Opmerkelijk genoeg bleek dit in de meeste gevallen niet in de weg te staan aan een harmonieuze samenwerking binnen de commissie, volgens Drewry waarschijnlijk het resultaat van "a group of members with knowledge of and an interest in the subjects under investigation being willing to work constructively together." 166

In latere jaren lijkt het beeld niet wezenlijk te zijn veranderd. Terwijl bij sommige commissies (en commissievoorzitters) de controversiëlere thema's worden vermeden, teneinde consensus en compromis mogelijk te maken, hebben andere commissies hier minder moeite mee. ${ }^{167}$ De meeste commissieleden lijken ervan overtuigd dat unanimiteit, consensus en cohesie belangrijk zijn voor de politieke status van commissies en de impact van conclusies en aanbevelingen in commissierapporten. In dat verband wordt ook een goede, 'constructief-kritische' verhouding met de betrokken ministers en departementen door veel commissieleden van groot belang geacht. Dat parlementsleden van verschillende partijen in staat blijken te zijn om op basis van consensus en unanimiteit samen te werken, wordt zowel binnen als buiten het parlement nog steeds gezien als een van de belangrijkste vernieuwingen die het in 1979 ingevoerde commissiestelsel te weeg heeft gebracht in het Britse parlement. ${ }^{168}$ Rodgers en Walters schrijven dan ook stellig:

\footnotetext{
164 Zie ook Blackburn \& Kennon 2003, p. 583.

165 Drewry 1989b, p. 362-363. Waarschijnlijk ligt dit, sinds de devolutie in beide regio's, inmiddels anders.

166 Drewry 1989, p. 364-365.

167 Zie Blackburn \& Kennon 2003, p. 587.

168 Zie bijvoorbeeld $\mathrm{Ph}$. Norton, in: Longley \& Davidson 1998, p. 150; Hansard Society Commission 2001, p. 20; Maer \& Sandford 2004, p. 31; Bradley \& Ewing 2007, p. 220.
} 


\title{
VERENIGD KONINKRIJK
}

\begin{abstract}
"There is no doubt that unanimous committees are more effective. They speak with a single voice, and it is much harder for governments to dismiss cross-party agreement. Some people see consensus as implying flabby compromise, but select committees show time and again that they can reach a tough agreed view on politically hot subjects." 169
\end{abstract}

Het gebruik van het adjectief 'flabby' laat overigens zien dat de door de commissies in het Britse parlement geïntroduceerde consensusgerichtheid - en dan met name de daarbij horende compromissen, die uit de aard der zaak nu eenmaal niet altijd even stellig en soms ook niet eenduidig geformuleerd worden - nog niet door iedereen in de Britse politiek wordt gewaardeerd (of begrepen). ${ }^{170}$

\subsection{Nieuwe ontwikkelingen}

Naast het onderzoek op het terrein van de klassieke hoofdthema's "expenditure, administration and policy", zijn de departementale onderzoekscommissies en de daaraan gerelateerde thematische commissies zich de laatste jaren steeds meer gaan bezighouden met andersoortige onderzoeksactiviteiten. Om enige lijn te brengen in het groeiend aantal activiteiten van select committees, heeft het Lagerhuis in 2002 een aantal 'core tasks' voor de commissies geformuleerd. Hierin zijn de klassieke hoofdtaken nader uitgewerkt en een aantal nieuwe taken toegevoegd. De 'core tasks', zo stelt de Liaison Committee, zijn bedoeld als richtlijnen, niet als bindende instructies. ${ }^{171}$

Hieronder komen de meest in het oog springende nieuwe ontwikkelingen aan de orde. Hierbij gaat het om onderzoeksactiviteiten op wetgevingsgebied, enerzijds met betrekking tot ontwerp-wetsvoorstellen ('pre-legislative scrutiny') en anderzijds op het gebied van wetsevaluatie ('post-legislative scrutiny'), waarmee in de jaren negentig een begin werd gemaakt. Daarnaast heeft de afgelopen jaren een experiment plaatsgevonden met het houden van openbare hoorzittingen bij benoemingen in de publieke sector. ${ }^{172}$

\subsubsection{Pre-legislative scrutiny}

Met 'pre-legislative scrutiny' wordt gedoeld op een procedure voorafgaand aan het formele wetgevingsproces, waarbij ontwerpwetsvoorstellen die door de regering worden gepubliceerd worden onderzocht door parlementaire onderzoekscommissies. De laatste regering-Major maakte een begin met het publiceren van ontwerpvoorstellen in het kader van het streven naar meer externe consultatie. De nieuwe Labourregering kondigde in 1997 aan deze praktijk te willen uitbreiden. De eerder

\footnotetext{
169 Rodgers \& Walters 2006, p. 369.

170 Zie ook het uitvoerige, kwalitatieve onderzoek van Russell \& Benton 2011, p. 43-44, waaruit blijkt dat consensusgerichtheid door veel respondenten als belangrijk wordt ervaren, hoewel sommige geïnterviewden ook wel vraagtekens zetten bij de "deep-rooted culture of consensus" omdat dit zou kunnen leiden tot onduidelijke conclusies en aanbevelingen.

171 Zie voor een overzicht: Liaison Committee, The Work of the Committees in Session 2008-09, HC 426 (2009-10), §12. Zie ook Rodgers \& Walters 2006, p. 372-374.

172 Zie de 'core tasks' 3 ('conduct scrutiny of any published draft bill'), 8 ('scrutinise major appointments') en 9 ('examine the implementation of legislation...').
} 
genoemde Modernisation Committee stelde in een rapport datzelfde jaar dat het parlement in deze voorfase een belangrijke rol zou kunnen vervullen door haar onderzoekscommissies in te zetten. ${ }^{173}$

Het verder ontwikkelen van pre-legislative scrutiny door het parlement werd om diverse redenen aanbevolen. Ten eerste zou het parlement, in het bijzonder individuele backbenchers en leden van de oppositie, hiermee de gelegenheid krijgen om een werkelijke bijdrage te leveren aan de totstandkoming van wetgeving - iets wat tijdens de formele behandeling van wetsvoorstellen nauwelijks mogelijk is, onder meer omdat ministers in die fase nauwelijks nog bereid zijn om amendementen te accepteren. Ten tweede wordt het wetgevingsproces toegankelijk voor buitenstaanders die belang hebben bij of anderszins betrokken zijn bij de voorgestelde wetgeving. Daarnaast heeft ook de regering baat bij deze procedure, omdat een grondige behandeling in de voorfase wellicht de formele behandelingsfase zou kunnen versnellen. Bovenal zou pre-legislative scrutiny moeten leiden tot betere wetgeving. ${ }^{174}$

In procedurele zin stelde de commissie voor om in deze onderzoeksfase de beproefde onderzoeksmethoden te gebruiken, zoals het verzamelen van schriftelijk en mondeling bewijsmateriaal en het publiceren van een rapport met conclusies en aanbevelingen, die de verantwoordelijke minister vervolgens kon gebruiken bij de afronding van het uiteindelijke wetsvoorstel. Het onderzoek zou kunnen worden gedaan door de reeds bestaande departementale onderzoekscommissies, maar ook door ad hoc onderzoekscommissies (bijvoorbeeld wanneer een wetsvoorstel meerdere departementen betreft) of door onderzoekscommissies samengesteld uit leden van beide Huizen. De meest geschikte commissievorm zou per wetsontwerp moeten worden afgewogen. ${ }^{175}$ De reeds genoemde Scrutiny Unit zou hierbij specialistische ondersteuning moeten bieden. ${ }^{176}$

In 1997 is met deze nieuwe procedure een begin gemaakt. Sindsdien worden de meeste 'draft bills' die de regering publiceert door een parlementaire onderzoekscommissie onderzocht. Dit gebeurt soms door departementale onderzoekscommissies, soms door ad hoc commissies en soms door gezamenlijke (ad hoc) commissies van beide Huizen. ${ }^{177}$ Tussen 1997 en 2005 is het aantal 'draft bills' dat de regering

\footnotetext{
173 Over de formele parlementaire behandeling van wetgeving en de kritiek daarop, zie par. 4 over de wetgevingscommissies (public bill committees).

174 Zie Modernisation Committee, The Legislative Process, HC 190 (1997-98), § 20. Zie over de veronderstelde tekortkomingen van het formele wetgevingsproces ook hierna, par. 4.

175 Alle vormen kleefden zowel voor- als nadelen. Zo zouden de bestaande commissies wellicht een te druk regulier onderzoeksprogramma hebben en zouden ad hoc commissies de nodige ervaring en expertise missen en onvoldoende in staat zijn een totaaloverzicht te vormen. Een vierde mogelijkheid die de commissie noemde, het instellen van permanente wetgevingscommissies, leek echter het minst aantrekkelijk. De commissie vreesde vooral dat het moeilijk zou zijn om voldoende commissieleden te vinden (vooral aan oppositiekant) zijn en er veel overlap met de bestaande departementale onderzoekscommissies zou ontstaan. Zie HC 190 (1997-98), § 21-30.

176 Zie hierover o.a. Liaison Committee, Shifting the Balance, HC 300 (1999-2000), § 82.

177 Deze ad hoc onderzoekscommissies worden genoemd naar het ontwerp, bijvoorbeeld de Joint Committee on the Draft Charities Bill. Zie voor een overzicht van de commissies die zich in de periode 1997-2007 met pre-legislative scrutiny bezighielden: Kelly 2010.
} 
jaarlijks publiceert sterk toegenomen. ${ }^{178}$ Het hoogste aantal werd tot nu toe bereikt in het zittingsjaar 2003-04, toen 12 ontwerpwetsvoorstellen werden gepubliceerd. ${ }^{179}$ Opvallend is dat het aantal sinds 2005 weer is afgenomen. 180

De eerste ervaringen met een onderzoeksfase voorafgaand aan het wetgevingsproces werden wisselend beoordeeld. Uit de eerste evaluaties van de nieuwe procedure bleek dat niet geheel duidelijk leek te zijn wat de functie van deze nieuwe voorfase van het wetgevingsproces zou moeten zijn. Zo concludeerde Power in 2000 dat tevoren onvoldoende leek te zijn doordacht wat men met de nieuwe parlementaire onderzoeksfase wilde bereiken: “...although the value of consulting on draft legislation was clear, there was some ambiguity as to what the Government hoped Parliamentary scrutiny would add to the consultation process." 181 Blackburn en Kennon schreven in 2003: "Pre-legislative scrutiny is still experimental and lacks structure." 182 In de praktijk blijken onderzoekscommissies daarom niet altijd goed te weten wat van hen verwacht wordt: "Select committees looking at draft bills seem to have steered a middle way between challenging the whole principle of the bill and minutely scrutinising the text of each clause." 183 Binnen het parlement - en de regering - wordt de introductie van een parlementaire onderzoeksfase vooraan in het wetgevingsproces over het algemeen toegejuicht. ${ }^{184}$ De Modernisation Committee stelt in een rapport uit 2006 over het wetgevingsproces: "The introduction of prelegislative scrutiny is generally acknowledged to be one of the most successful innovations in the legislative process in recent years." 185 Pre-legislative scrutiny, zo schrijft de commissie, blijkt een effectieve manier om buitenstaanders te betrekken bij het anders zo gesloten wetgevingsproces. Het onderzoek blijkt verder een duidelijke impact te hebben op de wetsvoorstellen die uiteindelijk bij het parlement worden ingediend, gezien het grote aantal aanbevelingen dat de regering uit de commissierapporten overneemt. De commissie concludeert dan ook dat " $\mathrm{t}]$ here is little doubt that pre-legislative scrutiny produces better laws." 186

De Modernisation Committee wees in haar rapport nog wel op een aantal knelpunten die voor verbetering vatbaar zijn. Ten eerste is het aantal wetsvoorstellen van

\footnotetext{
178 In de eerste termijn werden 11 van de 17 gepubliceerde voorstellen onderzocht, in de tweede termijn liep dit op naar 28 van de 33 voorstellen. In de tweede termijn betrof het overigens in een aantal gevallen slechts losse ontwerpbepalingen. Zie Kelly 2010, p. 7.

${ }^{179}$ In vergelijking met het totaal aantal ingediende wetsvoorstellen dat jaar (111) is dit overigens nog steeds een minderheid. Zie Smookler 2006, p. 522 en noot 3.

180 Tussen 2005 en 2007 werden in totaal slechts 8 voorstellen gepubliceerd, waarvan er 6 door commissies werden onderzocht. Volgens Prime Minister Brown is het streven nog steeds om zoveel mogelijk wetsvoorstellen in ontwerp te publiceren, maar is dat niet altijd mogelijk, "especially in relation to justice and counter-terrorism”. Zie HC Deb 11 juli 2007, col. 1458. Zie verder Kelly 2010, p. 7.

181 De Modernisation Committee had in haar rapport weliswaar gewezen op de kansen van prelegislative scrutiny (zoals het 'verbreden' van het wetgevingsproces, zie citaat hierboven), maar dit kon volgens Power ook grotendeels bereikt worden via het departementale consultatieproces. De unieke rol van het parlement bleef daarmee onduidelijk. Power 2000, p. 10.

182 Blackburn \& Kennon 2003, p. 727.

183 Blackburn \& Kennon 2003, p. 624.

184 Zie bijvoorbeeld: House of Lords Constitution Committee, Parliament and the Legislative Process, HL 173 (2003-04), § 25 en de regeringsreactie daarop, HL 114 (2004-05), § 10-11.

185 Modernisation Committee, The Legislative Process, HC 1097 (2005-06), § 12.

186 HC 1097 (2005-06), § 16-29.
} 
regeringszijde dat in ontwerpvorm wordt gepubliceerd nog steeds vrij laag; voorstellen die vanuit partijpolitiek oogpunt mogelijk gevoelig liggen werden tot dan toe zelfs bijna nooit in ontwerp gepubliceerd. Ten tweede zouden leden van onderzoekscommissies die in de voorfase betrokken waren bij een wetsvoorstel vaker moeten worden benoemd in de wetgevingscommissies (public bill committees) die de wetsvoorstellen vervolgens formeel behandelen. ${ }^{187}$ Uit de ervaringen van onderzoekscommissies zelf bleek verder dat de regering niet altijd voldoende meewerkte: ontwerpwetsvoorstellen (of belangrijke gedeelten daarvan) werden soms erg laat gepubliceerd, belangrijke aanvullende informatie (zoals ontwerp-secundaire wetgeving of nadere richtlijnen) werd niet of te laat gepubliceerd en zo nu en dan werden te krappe deadlines voor het onderzoek gesteld. Ook bleek het na publicatie in bepaalde gevallen erg lang te duren voordat een (gezamenlijke) ad hoc onderzoekscommissie kon worden benoemd. 188

De gesignaleerde tekortkomingen bleken hardnekkig: enkele jaren later verschenen zij opnieuw in het jaarverslag van de Liaison Committee over het functioneren van de select committes. 189 Opvallend is ook dat, hoewel het aantal gepubliceerde ontwerpwetsvoorstellen in 2007-08 weer licht toenam (in totaal 9 voorstellen), de regering in de jaren daarna weer minder wetsvoorstellen in 'draft' publiceerde. ${ }^{190}$

\subsubsection{Post-legislative scrutiny}

In de brede discussie die de afgelopen jaren is ontstaan over het verbeteren van het wetgevingsproces is eveneens veel aandacht voor de laatste fase in dit proces, dat wil zeggen de evaluatie van in werking getreden wetgeving, in het Britse jargon 'postlegislative scrutiny' genoemd. De Law Commission, een belangrijk adviesorgaan van de regering, publiceerde in 2006 een uitvoerig rapport over dit onderwerp. Hierin werd 'post-legislative scrutiny' gedefinieerd als een brede vorm van onderzoek naar de effectiviteit van wetgeving, waarbij gekeken wordt naar de mate waarin de gestelde beleidsdoelen door de wetgeving worden bereikt, maar waarbij ook juridischtechnische vraagstukken aan de orde kunnen komen. ${ }^{191}$

Het evalueren van wetgeving gebeurt thans op verschillende plaatsen. ${ }^{192}$ Aan regeringszijde voeren departementen interne evaluaties uit; meer in het algemeen houdt de Better Regulation Executive ${ }^{193}$ zich bezig met de effectiviteit van regelgeving. Daarnaast worden onafhankelijke analyses uitgevoerd, bijvoorbeeld door de

\footnotetext{
${ }^{187}$ HC 1097 (2005-06), § 30-35.

188 Zie verder Kelly 2010, p. 12-13. Zie ook Liaison Committee, Shifting the Balance: Unfinished Business, HC 321 (2000-01), § 77-80.

189 Zie het jaarverslag van de Liaison Committee, The Work of Committees in 2008-09, HC 426 (2009-10), $\S 25-36$

190 Zowel in 2008-09 als in 2009-10 werden uiteindelijk vier wetsvoorstellen in 'draft' gepubliceerd, al betreft het in elke gevallen doublures.

191 Zie Law Commission, Post-Legislative Scrutiny, Law Com No. 302, Cm. 6945 (oktober 2006), § 2.4.

192 Law Commission, Post-Legislative Scrutiny, Law Com No. 302, Cm. 6945 (oktober 2006), § 3.18.

193 Deze eenheid was oorspronkelijk onderdeel van de Cabinet Office en sinds juni 2007 ondergebracht bij het Department for Business, Innovation and Skills.
} 
National Audit Office, maar ook door andere instanties die daartoe in de betreffende wetgeving zijn aangewezen. Binnen het parlement verrichten de departementale onderzoekscommissies de laatste jaren zo nu en dan onderzoek naar de implementatie van wetgeving. Dit gebeurt soms in de vorm van een groot onderzoek inclusief rapportage, maar ook middels losstaande hoorzittingen. Op dit terrein zijn de laatste jaren door parlementaire onderzoekscommissies onder meer evaluaties verricht van wetgeving inzake terrorismebestrijding, lokaal bestuur, collegegelden en verkiezingsfraude. 194

Het nut van post-legislative scrutiny wordt breed onderschreven. De Law Commission stelt dat post-legislative scrutiny onder andere meer inzicht kan bieden in de wijze waarop wetgeving in de praktijk uitwerkt en de gelegenheid biedt om lessen te trekken uit al dan niet succesvolle ervaringen. Bovendien ontstaat daarmee meer aandacht voor de implementatiefase in het wetgevingsproces. ${ }^{195}$ De Lords Constitution Committee verwacht verder dat meer evaluatie kan leiden tot een zorgvuldiger wetgevingsproces. ${ }^{196}$ Van verschillende kanten is daarom de afgelopen jaren gepleit voor het verder uitbouwen van 'post-legislative scrutiny'. Het parlement zou daarbij een centrale positie moeten gaan vervullen. Dit laatste is met name van belang, zo wordt gesteld, omdat het parlement vanuit haar wetgevende taak in het Britse constitutionele bestel oog zou moeten hebben voor de praktische uitwerking van wetgeving. Wetsevaluatie kan daarom niet alleen aan de regering worden overgelaten. ${ }^{197}$

Opvattingen over de wijze waarop het parlement zijn rol in wetsevaluatie zou moeten vormgeven lopen uiteen. De Liaison Committee stelde enige jaren geleden, mede op basis van de opgedane ervaringen, dat de departementale onderzoekscommissies in het bijzonder geschikt zouden zijn om deze parlementaire taak op meer systematische manier te gaan vervullen, onder meer omdat commissies openhartiger zouden kunnen zijn in hun evaluaties dan wanneer dit in departementale kringen plaatsvindt en daarnaast meer open zouden staan voor de opvattingen van belanghebbenden. Daarvoor zou wel extra ondersteuning beschikbaar moeten worden gesteld. ${ }^{198}$ Ook de Lords Constitution Committee zag een hoofdrol voor de departementale onderzoekscommissies, maar stelde voor om de werklast te beperken door bij elke wet eerst een departementale evaluatie te laten uitvoeren en vervolgens de commissies de mogelijkheid te geven te beslissen of een nader onderzoek nodig zou zijn. ${ }^{199}$ De Law Commission zag meer in het instellen van een gezamenlijke parlementaire onderzoekscommissie voor post-legislative scrutiny, die de evalua-

\footnotetext{
194 Rogers \& Walters 2006, p. 373-374.

195 Zie nader Law Com No. 302, Cm. 6945 (oktober 2006), § 2.1-2.24.

${ }^{196}$ House of Lords Constitution Committee, Parliament and the Legislative Process, HL 173 (2003-04), § 170-172.

197 Zie Law Com No. 302, Cm. 6945 (oktober 2006), § 1.8 en 3.30; zie ook HL 173 (2003-04), § 170-172, 193.

198 Liaison Committee, Annual Report for 2004, HC 419 (2004-05), § 74.

${ }^{199}$ HL 173 (2003-04), § 182-192.
} 
tie van een wet indien nodig zou kunnen overnemen van departementale commissies. 200

In maart 2008 gaf de regering aan, in reactie op het rapport van de Law Commission, een voorkeur te hebben voor het verder uitbouwen van post-legislative scrutiny op de wijze voorgesteld door de Constitution Committee in het Hogerhuis. Dit betekent dat "the basis for a new process for post-legislative scrutiny should be for the Commons committees themselves, on the basis of a Memorandum on appropriate Acts submitted by the relevant Government department, and published as a Command paper, to decide whether to conduct further post-legislative scrutiny of the Act in question." 201 Publicatie van de departementale evaluatiememoranda als 'Command papers' betekent dat de stukken openbaargemaakt worden en dat ook anderen, zoals Hogerhuiscommissies, kunnen inspringen. Het voorstel van de Law Commission voor een gezamenlijke parlementaire evaluatiecommissie werd afgewezen, omdat dit zou kunnen leiden tot doublures en een aantasting van de centrale rol van de departementale commissies in het onderzoeken van het geheel van departementale activiteiten. ${ }^{202}$

Het nieuwe systeem voor post-legislative scrutiny zou verder worden vormgegeven in samenspraak met de Liaison Committee. ${ }^{203}$ De regering zegde toe om binnen drie tot vijf jaar nadat een wet in werking is getreden met een wetsevaluatie te komen en die in de vorm van memoranda te publiceren, op basis waarvan de commissies een eigen evaluatie kunnen starten. Alle commissies hebben inmiddels nadere afspraken gemaakt met de ministeries die zij monitoren omtrent de evaluatie van voor hen relevante wetgeving. Sinds 2008 verschijnen zo nu en dan dergelijke memoranda, waarop commissies soms actie ondernemen. De Scrutiny Unit biedt daarbij specifieke inhoudelijke ondersteuning. De Liaison Committee heeft deze nieuwe loot aan de stam van de select committees verwelkomd, al maakt zij zich tevens enige zorgen over de toenemende werklast voor met name die commissies die gericht zijn op departementen met een grote wetgevingsoutput. 204

\subsubsection{Publieke benoemingen}

De selectie en benoeming van functionarissen in de talloze verzelfstandigde overheidsdiensten, onafhankelijke inspectie- en controleorganen en adviescolleges (de zogenaamde 'Non-Departmental Public Bodies' of 'quangos') is voorbehouden aan de regering. Het gaat hierbij om uiteenlopende instanties, van lokale zorginstellingen ('national health trusts') en culturele organisaties tot marktautoriteiten ('regulators'). In totaal gaat het in deze categorie om ongeveer 21.000 functionarissen, die door ministers worden benoemd. Ongeveer de helft van deze benoemingen vindt plaats bij

\footnotetext{
${ }^{200}$ Een verplichte departementale evaluatie voorafgaand aan de parlementaire evaluatie wordt daarbij als 'too rigid' beschouwd en zou afhankelijk van het geval minder strict moeten worden opgevat. Law Com No. 302, Cm. 6945 (oktober 2006), §3.47-3.48.

201 Office of the Leader of the House of Commons, Post-Legislative Scrutiny - The Government's Approach, Cm. 7320 (maart 2008), §9.

202 Zie verder Cm. 7320 (maart 2008), § 19-22.

${ }^{203}$ Liaison Committee, The Work of Committees in 2007, HC 427 (2007-08), § 63-64.

${ }^{204}$ Liaison Committee, The Work of Committes in 2008-09, HC 426 (2009-10), § 137-139.
} 
instanties die onderworpen zijn aan de richtlijnen van de Commissioner for Public Appointments. Deze richtlijnen moeten ervoor zorgen dat kandidaten worden gekozen op basis van inhoudelijke kwaliteiten, op een transparante wijze en met voldoende oog voor diversiteit. Deze instanties worden verder regelmatig gecontroleerd ('audited') door de Commissioner. Bij klachten in een specifiek geval kan een onderzoek worden ingesteld. Ook instanties die niet onder de regeling van de Commissioner vallen, blijken de opgestelde uitgangspunten in de praktijk toe te passen. De bedoeling van dit mechanisme is om een belangrijk deel van het selectieproces op enige afstand te plaatsen van de minister, die wel verantwoordelijk blijft voor de uiteindelijke keuze en benoeming van kandidaten: “The appointments system maintains the principle of ministerial responsibility in relation to the public appointments, but puts checks on how the principle is applied in practice." 205

Het parlement heeft in dit benoemingsproces formeel geen bevoegdheden; haar mogelijkheden zijn beperkt tot het aanspreken van ministers op hun politieke verantwoordelijkheid voor benoemingen en het daaraan voorafgaande selectieproces. De parlementaire rol op dit terrein is de laatste jaren echter veranderd. Sinds 1998 houden parlementaire onderzoekscommissies steeds vaker hoorzittingen met functionarissen van NDPBs direct na hun benoeming, vaak nog voor aanvang van hun werkzaamheden. ${ }^{206}$ Zo startte de Treasury Committee in 1998 met het horen van de nieuwe leden van de recent opgerichte Monetary Policy Committee, die verantwoordelijk zou worden voor het vaststellen van de Britse rentetarieven. Ook andere departementale onderzoekscommissies houden inmiddels dergelijke 'confirmation hearings', waarbij zowel personen worden gehoord die onder de ministeriële verantwoordelijkheid werken als personen die benoemd worden op functies die een zekere onafhankelijkheid van de regering vereisen, bijvoorbeeld bij marktautoriteiten of 'watchdogs'. 207

Hoewel de regering zich vanaf het begin welwillend opstelde, werd een verdere formalisering van de parlementaire rol bij openbare benoemingen, zoals in 2000 door de Liaison Committee voorgesteld, lange tijd van de hand gewezen. ${ }^{208}$ Dit veranderde in 2007 na het aantreden van Prime Minister Brown en de presentatie van een serie voorstellen voor staatsrechtelijke vernieuwing, onder meer gericht op het versterken van de parlementaire controlefunctie. De regering wilde parlementaire onderzoekscommissies voortaan de gelegenheid geven om zogenaamde 'pre-

205 Public Administration Select Committee, Pre-Appointment Hearings By Select Committees, HC 152 (2007-08), § 5. De functie van Commissioner for Public Appointments is voortgekomen uit het eerste rapport van de Committee on Standards in Public Life. Deze commissie bestaande uit parlementariërs en niet-parlementariërs werd in 1994 ingesteld naar aanleiding van de 'Cash-for-Questions'-affaire in het Lagerhuis. In haar eerste rapport (bekend als het Nolan-rapport 1995) stelde de commissie onder andere voor een veiligheidsmechanisme te ontwikkelen, teneinde de (persoonlijke) ministeriële beslissingsruimte te verkleinen en het benoemingsproces bij NDPBs "sufficiently robust" te maken. Zie Bradley \& Ewing 2007, p. 306-307 en 319-320.

206 Zie Liaison Committee, Shifting the Balance, HC 300 (1999-2000), § 24 en Shifting the Balance. Unfinished Business, HC 321 (2000-01), § 90-93. Zie hierover ook Blackburn \& Kennon 2003, p. 588.

207 De nadruk, zo stelt de Liaison Committee, zou op de laatste categorie moeten liggen: "appointments of those charged with independence from the Executive should be of special interest to committees." HC 321 (2000-01), § 92.

${ }^{208}$ HC 321 (2000-01), § 91. 
appointment hearings' te houden met kandidaten voor een aantal belangrijke openbare functies. 209

De reacties op dit voorstel waren wisselend. De Public Administration Select Committee, die al langer ijverde voor een grotere parlementaire rol op dit terrein, reageerde evenals veel andere commissies positief op de plannen van de regering. ${ }^{210}$ Wel achtte PASC het nodig om, mede gelet op de bedenkingen die Janet Gaymer, de Commissioner for Public Appointments, had geuit, het voorstel van pre-appointment hearings nader uit te werken. Zo was niet duidelijk wat met deze hoorzittingen precies werd beoogd. Van kandidaten kon enerzijds immers niet worden verwacht dat zij voor aanvang van de werkzaamheden reeds verantwoording zouden afleggen, terwijl anderzijds niet duidelijk was welke rol de hoorzittingen zouden hebben in de selectie en nominatie van kandidaten, aangezien dat het terrein zou blijven van de minister (die in veel gevallen wordt geadviseerd door een Commissioner for Public Appointments). De commissie concludeerde daarom: "The proper role for select committees in the selection of candidates for public appointments is in informing the final ministerial decision, not in influencing the impartial process that precedes that decision. Select committees should only become involved once every part of the interview and selection process has been completed except for this final decision." 211 Hierdoor zou bovendien worden voorkomen dat het benoemingsproces (opnieuw) zou worden gepolitiseerd. ${ }^{212}$

De commissie stelde bovendien dat niet alle (belangrijke) benoemingen geschikt zouden zijn voor een hoorzitting. Parlementaire hoorzittingen, zo stelt de commissie, hebben vooral een toegevoegde waarde wanneer van de nieuwe functionaris publieke of parlementaire verantwoording wordt verwacht: "The value that committees can add over and above that provided by a rigorous selection process is to expose a candidate to parliamentary and public scrutiny. It follows that hearings should normally apply only to posts for which accountability to Parliament and the public are an important part of the role. A positive outcome of holding pre-appointment hearings for such posts is the likelihood that appointees will perform this accountability function more effectively." 213 Verder stelde de commissie dat de komende jaren bij wijze van proef zou moeten worden bezien welke (negatieve) effecten het houden van pre-appointment hearings zou hebben. Ook de Commissioner wees in dit verband op mogelijke risico's. Zo zouden potentiële kandidaten wellicht kunnen worden afgeschrikt door de verplichting te verschijnen voor een parlementaire commissie en zou het selectie- en benoemingsproces kunnen worden vertraagd. Verder zou niet duidelijk zijn wat de juridische (arbeidsrechtelijke) effecten zijn van het introduceren van een parlementaire fase in het selectieproces en hoe ministers zullen

\footnotetext{
${ }^{209}$ Ministry of Justice, The Governance of Britain, Cm. 7170 (juli 2007), § 74-79.

210 Zie Public Administration Select Committee, Pre-Appointment Hearings By Select Committees, HC 152 (2007-08), § 7. De commissie deed enkele jaren daarvoor reeds een vergelijkbaar voorstel in een uitgebreider rapport over publieke benoemingen. Zie Public Administration Select Committee, Government By Appointment. Opening Up the Patronage State, HC 165 (2002-03), § 103-110.

${ }^{211}$ HC 152 (2007-08), § 13.

212 De commissie wees in dit verband op de negatieve ervaringen met vaak sterk gepoliseerde 'confirmation hearings' in de Amerikaanse Senaat. HC 152 (2007-08), § 12.

${ }^{213}$ HC 152 (2007-08), § 14.
} 
omgaan met een mogelijk negatief oordeel van een parlementaire commissie. Bovendien werd gewezen op het risico dat dergelijke hoorzittingen de commissies teveel zouden belasten. 214

Onder meer naar aanleiding van dit rapport besloot de regering in maart 2008 om voorlopig alleen op proef te beginnen met pre-appointment hearings. Doel van de proef is "to ensure that the right balance is struck between strenghtening the role of Parliament in scrutinising public appointments and maintaining an appointments process which is proportionate and continues to attract high quality candidates." 215 Daartoe werd, in overleg met de Liaison Committee, een lijst met functies opgesteld waarbij 'pre-appointment hearings' zouden worden gehouden. De lijst bevat 60 functies, voornamelijk bestaande uit voorzitters van NDPBs die veel in de belangstelling staan. Bij vacatures worden de relevante parlementaire onderzoekscommissie(s) gevraagd een hoorzitting te houden met de kandidaat die uit het selectieproces naar voren is gekomen en de voorkeur van de regering heeft. De hoorzitting zou moeten resulteren in een advies aan de regering. Commissies dienen zich in hun vraagstelling vooral te richten op de professionele competenties en geschiktheid van de kandidaat voor de functie. Uit een externe evaluatie, die de eerste ervaringen met deze procedure besloeg, blijkt dat eind 2009 in totaal 18 hoorzittingen zijn gehouden met betrekking tot 19 benoemingen. In één geval werd een negatief advies uitgebracht. De regering zette de benoeming echter toch door. ${ }^{216}$ Opvallend is dat de personen die op deze manier werden gehoord door select committees neutraal tot positief tegenover de procedure stonden, waarbij door sommigen werd gewezen op de grotere democratische legitimatie die de hoorzitting opleverde. Commissieleden bleken minder enthousiast: men vertrouwde er niet op dat de regering een eventueel negatief oordeel van een commissie voldoende serieus zou nemen. Ook zou men liever zien dat commissies meerdere kandidaten voor een vacature zouden kunnen horen of een daadwerkelijk veto over een kandidaat zouden kunnen uitspreken. ${ }^{217}$

Over het algemeen, zo blijkt uit de evaluatie, lijkt het doel waarmee het expirement is begonnen - het vergroten van de transparantie van publieke benoemingen te zijn bereikt. De openbare hoorzittingen vormen "a clear democratic gain", zo stellen de onderzoekers, al moet het effect ook weer niet worden overdreven. Er wordt maar één kandidaat gehoord, namelijk de voorkeurskandidaat van de regering, en verder blijkt de media-aandacht vrij beperkt te zijn en lijken sommige kandidaten de hoorzitting slechts als niet meer dan een van de hordes in het benoemingsproces te zien. In elk geval lijkt er geen sprake te zijn van een door sommigen gevreesde afname van het aantal geschikte personen dat zich kandidaat stelt voor de functies op de lijst. ${ }^{218}$ De Liaison Committee heeft op basis van de evaluatie voorgesteld door te gaan met 'pre-appointment hearings'. 219

\footnotetext{
${ }^{214}$ De commissie verwacht overigens dat de nadelige effecten wel mee zullen vallen. Zie hierover uitvoeriger: HC 152 (2007-08), § 23-41.

215 Ministry of Justice, The Governance of Britain - Constitutional Renewal (White Paper), Cm. 7342-I (maart 2008), § 251.

216 Zie Waller \& Chalmers 2010, p. 71-81. Zie nader Cm. 7342-I (maart 2008), § 251-253.

217 Waller \& Chalmers 2010, p. 69.

218 Waller \& Chalmers 2010, p. 108-109.

${ }^{219}$ Wel had zij nog enkele aanbevelingen. Zie verder: HC 426 (2009-10), § 68-72.
} 


\subsection{Slotbeschouwing: dertig jaar departmental select committees}

\subsubsection{Ingrijpende hervorming?}

De invoering van het stelsel van permanente, departementaal-geordende onderzoekscommissies in 1979 wordt vaak gezien als de meest ingrijpende hervorming van het Britse Lagerhuis na de Tweede Wereldoorlog. ${ }^{220}$ Dat zegt veel over de relatieve starheid van het Britse parlementaire stelsel. Van begin af aan was namelijk duidelijk dat met het nieuwe commissiestelsel, ondanks de ronkende woorden van de Leader of the House die bij de invoering sprak over 'redressing the balance of power'221, geen fundamentale verandering van het Britse politiek-constitutionele bestel werd beoogd. De staatsrechtelijke verhouding tussen regering en parlement bleef ongewijzigd, evenals het takenpakket van het parlement. Ook de nieuwe commissies zelf kregen geen bijzonder sterke onderzoeksbevoegdheden toebedeeld; ze moesten het doen met de nogal verouderde rechten die altijd al aan onderzoekscommissies werden toebedeeld en als weinig effectief werden beschouwd. Sceptici zowel binnen als buiten het parlement deden de hervorming dan ook af als hoofdzakelijk cosmetisch van aard. Tegenstanders vreesden juist dat de introductie van wat werd gezien als een op Amerikaanse leest geschoeid commissiestelsel, niet zou werken in het Britse parlementaire stelsel. De meerderheidspartij had uiteindelijk immers vooral de taak om de regering in het zadel te houden, wat moeilijk te combineren zou zijn met kritisch onderzoek in commissieverband. 222

Het gebrek aan sterke onderzoeksbevoegdheden en een politiek systeem dat niet uitnodigt tot partijoverstijgende samenwerking stond echter niet in de weg aan de ontwikkeling van een bloeiend commissiestelsel. Voorheen onzichtbare parlementsleden op de backbenches omarmden de commissies en zagen een mogelijkheid voor zinvolle tijdsbesteding en profilering. Binnen de bestaande constitutionele kaders bleken de nieuwe commissies een belangrijke bijdrage te leveren aan de parlementaire controlefunctie. Waar ministers zich voorheen vaak van hun verantwoordingsplicht konden kwijten met het beantwoorden van parlementaire vragen, of het met behulp van (naar Britse traditie vaak goed ontwikkelde) retorische vaardigheden ontwijken daarvan, kan het handelen van ministers en hun departementen sindsdien op elk moment worden onderworpen aan een uitgebreid parlementair onderzoek. ${ }^{223}$ Bovendien heeft de controlefunctie met de vele dagelijkse onderzoeksactiviteiten, zoals het verhoren van getuigen, het verzamelen van bewijsmateriaal en het formuleren van onderbouwde conclusies en aanbevelingen over het geheel genomen een kwalitatieve impuls gekregen. Met hun consensuele werk-

\footnotetext{
220 Zie bijv. Blackburn \& Kennon 2003, p. 744.

${ }^{221}$ HC Deb vol 969, col 36, 25 juni 1979.

222 Baines 1989, p. 15-18.

223 Deze verandering werd overigens al iets eerder ingezet met de introductie van de Expenditure Committees en haar subcommissies in de jaren '60. Vergeleken daarmee is het werk door de departmental select committees het volgens de Procedure Committee, die tien jaar na de commissiehervorming van 1979 een uitgebreide evaluatie hield aan de hand van hoorzittingen met betrokken en deskundigen, wel "significantly more systematic and comprehensive". Zie Procedure Committee, The Working of the Select Committee System, HC 19-I (1989-90), § 355.
} 
wijze 224 voegden zij nu eens een minder antagonistisch element toe aan de traditionele, gepolariseerde modus operandi van het Lagerhuis. De hervorming van 1979 kan inderdaad als ingrijpend worden beschouwd, niet vanwege een constitutionele ommeslag, maar vanwege de subtiele, informele, graduele verdieping van de parlementaire controlefunctie die erdoor teweeg is gebracht. ${ }^{225}$

\subsubsection{Effect en effectiviteit}

Belangrijkste consequentie is dat parlementaire controle en het activeren van de ministeriële verantwoordelijkheid in de loop der tijd, zo is wel duidelijk, primair de taak van de select committees is geworden. ${ }^{226}$ De rol van commissies in het parlement strekt echter verder dan dat. Door hun breed-geformuleerde onderzoekstaak en permanente aanwezigheid konden de commissies zich ontwikkelen tot tamelijk autonome eenheden binnen het parlement, die met de opgebouwde expertise en een groeiende media-aandacht een bijdrage kunnen leveren aan het bredere politieke en maatschappelijke debat. ${ }^{227}$ Andere, vaak genoemde veranderingen die het nieuwe stelsel teweeg heeft gebracht zijn een grotere transparantie en toegankelijkheid van het parlementaire proces. De nieuwe commissies zorgden er met hun onderzoek voor dat er meer departementale informatie in de openbaarheid kwam en op gestructureerde wijze toegankelijk werd gemaakt. Daarnaast kregen experts en belangengroepen toegang tot het parlementaire controleproces en de kans om in het openbaar hun input te leveren (waarmee tegelijkertijd meer zicht ontstond op de rol die met name belangenorganisaties in het beleidsvormingsproces spelen). ${ }^{228}$

Tegen deze achtergrond zijn de select committees in de afgelopen dertig jaar een factor van betekenis geworden. Hun bestaan staat al lang niet meer ter discussie. 229 Uit een grote enquête onder parlementsleden in 2001 bleek dat meer dan $80 \%$ van de respondenten het commissiestelsel beschouwde als een effectief of zeer effectief instrument om ministers ter verantwoording te roepen. Bijna $60 \%$ vond de commissies zelfs "the most effective weapon in Parliament's armory." 230 Wat de werkelijke invloed of de impact van deze commissies op het beleidsvormingsproces is, is echter moeilijk vast te stellen. Het meten van zoiets onbepaalds als 'invloed' is immers lastig. Met het recent gepubliceerde, grootschalige onderzoek van onderzoekers van University College London in samenwerking met stafleden van het Lagerhuis is getracht hierin toch enig inzicht te krijgen. Het onderzoek bestond uit een kwantitatief gedeelte, waarbij werd nagegaan wat er is gebeurd met de aanbevelingen uit alle

\footnotetext{
224 Zie ook hierboven, par. 4.5.3.

225 Zie ook Drewry, '1979 Reforms - New Labels on Old Bottles?', in: Drewry 1989, p. 391-392.

226 Zie o.a. Procedure Committee, The Working of the Select Committee System, HC 19-I (1989-90), § 354-

357; zie in vergelijkbare zin ook Hansard Society Commission 2001, p. 30 en Blackburn \& Kennon 2003, p. 744.

${ }^{227}$ Zie over de bijdrage van commissies aan het bredere politieke debat ook: Russell \& Benton 2011, p. 80-82.

228 Zie o.a. Hansard Society Commission 2001, p. 30. Zie ook Russell \& Benton 2011, p. 87-88.

${ }^{229}$ In 1989 constateerde Drewry dit reeds. Zie Drewry, '1979 Reforms - New Labels on Old Bottles?', in: Drewry 1989, p. 384.

${ }^{230}$ Hansard Society Commission 2001, p. 43.
} 
commissierapporten in de periode 1997-2010, aangevuld met een kwalitatief onderzoek bestaande uit diepteinterviews met commissievoorzitters, -leden, -medewerkers en andere betrokkenen rondom zeven representatieve case studies. 231

Uit het eerste gedeelte van het UCL-onderzoek blijkt dat ongeveer $40 \%$ van de aanbevelingen die de commissies in hun rapporten deden, direct door de regering werden aanvaard. Een nadere analyse van de aanvaarde aanbevelingen liet zien, dat zo'n $60 \%$ van de aanbevelingen die slechts een kleine (beleids)wijziging of geen wijziging inhielden werd aanvaard; bij de middelgrote en grote aanbevolen wijzigingen ging het om ongeveer eenderde. Hoewel dat laatste dus betekent dat tweederde van de substantiële aanbevelingen door de regering werd afgewezen of genegeerd, is het volgens de onderzoekers, wanneer het grotere geheel in ogenschouw wordt genomen, niettemin gerechtvaardigd om op basis van de cijfers te concluderen dat "select committees therefore appear to contribute much to the policy process." 232

Een kwantitieve analyse gebaseerd op de aanvaarding van aanbevelingen in rapporten geeft echter slechts een beperkt beeld van de invloed van select committees, zo bleek ook uit het tweede gedeelte van het onderzoek. Of aanbevelingen uit een commissierapport door de regering worden aanvaard (en geïmplementeerd) hangt af van vele factoren, waaronder de timing van een rapport en de context (worden dezelfde aanbevelingen ook door andere actoren gedaan; hoeveel actoren zijn actief in het betreffende beleidsveld). Ook speelt mee of de commissie haar aanbevelingen kon onderbouwen met "firm evidence" en of zij specifieke expertise en ervaring heeft op het betreffende onderwerp. ${ }^{233}$ Los daarvan bleken andere, nietkwantificeerbare vormen van invloed minstens even belangrijk te zijn - volgens sommige respondenten zelfs belangrijker. Daarbij gaat het met name om de reeds genoemde bijdrage van commissies aan het bredere debat, het ter verantwoording roepen van ministers en het verzamelen van bewijsmateriaal en de opvattingen van deskundigen, maar ook om het identificeren en op de agenda plaatsen (en houden) van problemen, het zichtbaar maken van tekortkomingen binnen de overheid en "perhaps most importantly 'generating fear' in terms of anticipated reactions." Hoewel nauwelijks meetbaar, kunnen deze onmiskenbaar optredende vormen van invloed er bijvoorbeeld voor zorgen dat ministers hun beleid bijstellen nog voordat een hoorzitting heeft plaatsgevonden, of dat op departementaal niveau handelingen worden vermeden die moeilijk verdedigbaar zouden zijn in het geval van een parlementair onderzoek. ${ }^{234}$

\subsubsection{Ruimte voor verbetering}

De hervorming van 1979, zo kan uit bovenstaande evaluaties worden opgemaakt, mag op zichzelf als een succes worden beschouwd. Met hun permanente status, rela-

\footnotetext{
${ }^{231}$ Russell \& Benton 2011, p. 13-17. Dit onderzoek bouwt deels voort op eerder, kleinschaliger onderzoek.

232 Zie voor een nadere uiteenzetting: Russell \& Benton 2011, 67-68.

${ }^{233}$ Russell \& Benton 2011, p. 89-90.

${ }^{234}$ Russell \& Benton 2011, p. 90. Zie ook Rodgers \& Walters 2006, p. 375 en Turpin \& Tomkins 2011, p. 626.
} 
tief beperkte omvang, breed geformuleerde onderzoeksopdracht en kleine, maar deskundige staf kregen de commissies de ruimte om zich te ontwikkelen tot tamelijk autonome eenheden binnen het Britse Lagerhuis. Het gevolg van die autonome ontwikkeling is wel, dat tussen commissies grote verschillen bestaan. Het succes van een commissie is van veel factoren afhankelijk, waaronder de kwaliteit van de ambtelijke ondersteuning en het type beleidsterrein waarop de commissie actief is, maar staat of valt uiteindelijk toch vooral met de deskundigheid, vaardigheden en inzet van haar leden, in het bijzonder van de voorzitter. ${ }^{235}$

De hoge mate van autonomie waarover commissies beschikken kan daarom worden gezien als deel van succes van het stelsel, maar ook als een van haar zwaktes. ${ }^{236}$ Het werk van commissies, zo klinkt het al enige tijd, is van wisselende kwaliteit. 237 Die kwaliteit heeft onder meer te lijden onder het korte-termijndenken van commissieleden, mede veroorzaakt door een te grote gerichtheid op media-aandacht. Hoewel het genereren van media-aandacht tot op zekere hoogte noodzakelijk is, aangezien de Britse commissies in hun werk vaak afhankelijk zijn van informele vormen van beïnvloeding, brengt een teveel hiervan onmiskenbaar risico's met zich mee voor de diepgang en zorgvuldigheid van het onderzoek. ${ }^{238}$ Juist wanneer commissies gedegen onderzoek doen en daarover rapporteren, is hun invloed vaak het grootst. ${ }^{239}$ Een gerelateerd kritiekpunt is dat de onderzoeksactiviteiten van commissies vaak onvoldoende systematisch van aard zijn. Ook hier geldt dat dit tot op zekere hoogte onvermijdelijk is, gezien de brede taakopdracht en de beperkte tijd en middelen waarover commissies beschikken. ${ }^{240}$ Ook speelt mee dat commissieleden, ondanks de vaak goed ontwikkelde onderlinge loyaliteit, natuurlijk ook altijd nog partijleden zijn, die niet altijd even doortastend willen zijn als het om thema's gaat die de zittende regering direct raken. ${ }^{241}$

Tegelijkertijd leeft al jaren de overtuiging dat de effectiviteit van commissieonderzoek aanzienlijk kan verbeteren wanneer commissies structureler nagaan wat er met hun rapporten gebeurt. Ook zouden ze, vaker dan nu het geval is, aandacht moeten blijven vragen voor hun conclusies en aanbevelingen. ${ }^{242}$ Ministers en depar-

235 Zie ook Rodgers \& Walters 2006, p. 376-377.

236 Zie ook Hansard Society Commission 2001, p. 31.

237 Zie Procedure Committee, The Working of the Select Committee System, HC 19-I (1989/90), § 363; Hansard Society Commission 2001, p. 30-31; Turpin \& Tomkins 2011, p. 626-627.

${ }^{238}$ Zo zou de Home Affairs Committee zich de afgelopen jaren volgens een aantal respondenten in het onderzoek van Russell en Benton te vaak hebben opgesteld als 'ambulance chaser' door (te) veel korte onderzoeken en eenmalige hoorzittingen te organiseren, waarop dan ook nog eens (te) veel 'celebrity witnesses' werden verhoord. Zie Russell \& Benton 2011, p. 91.

239 Russell \& Benton 2011, p. 93.

${ }^{240}$ Met de formulering van een aantal 'core tasks' in 2002 heeft de Liaison Committee wel een handvat gekregen om output van de commissies systematisch in beeld te brengen. Zie bijvoorbeeld Liaison Committee, The Work of the Committees in Session 2008-09, HC 426 (2009-10), § 12 e.v. Zie ook Rodgers \& Walters 2006, p. 372-374.

241 Weir \& Beetham 1999, p. 407. Dergelijke terughoudendheid bij een deel van de commissieleden kan ook leiden tot vage conclusies, bedoeld om de unanimiteit binnen de commissie te bewaren, wat de impact van een rapport niet ten goede komt. Zie Russell \& Benton 2011, p. 94. Zie ook hierboven, par. 4.5.3.

242 Zie o.a. Procedure Committee, The Working of the Select Committee System, HC 19-I (1989-90), § 363 en Hansard Commission 2001, p. 39. Sommige commissies hebben de afgelopen jaren wel stappen 
tementen moeten op dat punt nog wel eens worden 'aangespoord', vooral wanneer de formele reactie op een commissierapport vaag of afhoudend is. Bovendien worden gedane toezeggingen van regeringszijde niet altijd nagekomen. Hier geldt overigens dat de bereidwilligheid van ministers en ambtenaren ten aanzien van de commissie die hun werk schaduwt mede bepaald wordt door de houding van commissieleden. 243

Gebrek aan inzet, voorbereiding en betrokkenheid bij een deel van de commissieleden wordt al jaren gezien als een zwak punt in het commissiestelsel. Het commissiewerk is uiteraard een van de vele taken en verantwoordelijkheden die de aandacht van een parlementslid opeisen, maar bij sommige commissieleden, zo luidt de kritiek, staat het commissielidmaatschap te laag in de prioriteitenlijst. Dit uit zich bijvoorbeeld in veelvuldige afwezigheid bij vergaderingen en hoorzittingen, of het enkel even 'binnenvliegen' voor het stellen van een vraag. Dit kan ertoe leiden (een probleem van 'collective action') dat commissies feitelijk worden gedragen door slechts enkele leden, onder wie de voorzitter, al dan niet gepaard gaande met een te grote afhankelijkheid van de ambtelijke staf of 'specialist advisers' ${ }^{244}$ De vergroting van de commissies in de loop der tijd heeft dit gevaar alleen maar doen toenemen; om die reden is de omvang recentelijk weer teruggedraaid. ${ }^{245}$ De hoeveelheid 'commitment' verschilt sterk per commissie; de opstelling en het gezag van de voorzitter, die de leden achter de schermen tot de orde kan roepen en ervoor kan zorgen dat iedereen de ruimte krijgt om een bijdrage te leveren, speelt daarbij uiteraard een rol. 246

Mogelijk gaat de invoering van de directe en geheime verkiezing van de commissieleden in 2010 verbetering brengen op het punt van inzet en betrokkenheid, maar dat zal moeten worden afgewacht. Deze vernieuwing heeft wel de potentie om een ander, als hardnekkig bestempeld probleem in het commissiestelsel te verminderen, namelijk de invloed die de partijmanagers ('whips') op de samenstelling van de commissies uitoefenen. ${ }^{247}$

De Hansard Commission ziet verder veel ruimte voor kwalitatieve verbetering in het aangaan van samenwerkingsverbanden met externe controle- en inspectieorganen, die veel hoogwaardig onderzoekswerk verrichten waarop zou kunnen worden voortgebouwd. De commissies zouden in zekere zin een intermediair kunnen worden tussen deze externe instanties en het parlement. 248 Ook zouden commissies, zo stellen Russell en Benton, meer gebruik moeten maken van het uitbesteden van onderzoekswerk, iets wat in de Britse praktijk ongebruikelijk is. Zij wijzen op een

naar een meer systematische follow-up ondernomen, bijvoorbeeld door de regering te vragen te rapporteren over de implementatie van aanbevelingen over een langere periode, of door het houden van follow-up hoorzittingen met ministers. Voor de meeste commissies is dit echter (nog) geen gewoonte. Zie Russell \& Benton 2011, p. 95.

243 Zie Russell \& Benton 2011, p. 93-95.

244 Russell \& Benton 2011, p. 92.

245 Zie hierboven, par. 3.2.4.1.

${ }^{246}$ Russell \& Benton 2011, p. 92-93.

247 Zie hierboven, par. 3.2.4.2.

248 Dit kan ook voor deze organen zelf interessant zijn, omdat het de nodige politieke aandacht voor hun werkzaamheden kan genereren. Zie Hansard Commission 2001, p. 30-33. 
aantal voorbeelden van invloedrijke commissierapporten, waarbij commissies zelf origineel onderzoek (enquêtes en opiniepeilingen) hadden laten doen. ${ }^{249}$

\subsection{Conclusie}

De start van een onderzoek wordt middels een persbericht bekend gemaakt, vaak voorzien van een uitgebreide probleem- en vraagstelling. De uitvoering van onderzoeken gebeurt veelal volgens een vast stramien. Eerst worden deskundigen en belanghebbenden verzocht schriftelijk bewijsmateriaal toe te sturen in de vorm van memoranda. Deze schriftelijke fase is de belangrijkste bron van informatie voor commissies. Op basis hiervan worden hoorzittingen belegd: eerst met betrokken ambtenaren, daarna met experts en belangengroepen, en tenslotte met de verantwoordelijke ministers. Het doel van de hoorzittingen is niet zozeer het verzamelen van informatie, meer veeleer het testen van de argumenten en de geloofwaardigheid van de getuigen. Naast schriftelijke en mondelinge bewijsvergaring gebruiken commissies andere onderzoeksmethoden, zoals het houden van besloten seminars en het afleggen van werkbezoeken. Het onderzoek wordt doorgaans afgesloten met een eindrapport, dat wordt gepubliceerd samen met het vergaarde bewijsmateriaal.

Commissies werken op basis van een onderzoeksprogramma, waarin de hoofdlijnen van de te verrichten onderzoeken worden vastgesteld. Dit bestaat vaak uit een aantal grotere thematische onderzoeken, die betrekking hebben op het gevoerde beleid van het betreffende departement of op nieuwe maatschappelijke ontwikkelingen gericht op het stimuleren van beleidsontwikkeling of publiek debat. Dit wordt aangevuld met kleine, meer specifieke onderzoeken naar actuele zaken. Incidenteel richten onderzoekscommissies zich op specifiek overheidsfalen ('what-went-wrong' inquiries) met het oog op het trekken van lessen voor de toekomst, maar deze lijken steeds minder voor te komen. Van de drie hoofdtaken die de departementale commissies hebben ('to examine the expenditure, administration and policy of the principle government departments') is beleidsmatig onderzoek het populairst. Naast volledige onderzoeken worden ook losstaande hoorzittingen gehouden om bepaalde actuele ontwikkelingen te belichten, zonder dat hiervan een commissieverslag wordt opgemaakt. De laatste jaren houden commissies zich naast hun traditionele beleidsgerichte onderzoeken ook steeds vaker bezig met nieuwe vormen van onderzoek, gericht op ontwerpwetsvoorstellen ('pre-legislative scrutiny'), de implementatie van wetgeving ('post-legislative scrutiny') en publieke benoemingen.

Kenmerkend voor de werkwijze van de departementale onderzoekscommissies is dat onderzoek wordt verricht op basis van consensus en unanimiteit. Overleg en besluitvorming binnen de commissie vindt plaats achter gesloten deuren. Stemmingen over te initieren onderzoek of te horen personen zijn zeldzaam. Besluitvorming op basis van consensus is vanaf het begin van het departementale commissiestelsel een belangrijk streven geweest. Het streven naar consensus en unanimiteit heeft een

${ }^{249}$ Zo liet een commissie een enquête uitvoeren onder cafébezoekers in een onderzoek naar horecabedrijven. Een andere commissie liet de opvattingen van Lagerhuisleden peilen in het kader van een onderzoek omtrent de hervorming van het Hogerhuis. Zie Russell \& Benton 2011, p. 93, 97. Zie ook hierboven, par. 3.3.4. 
tweeledig effect. Enerzijds kan dit ertoe leiden dat controversiële onderwerpen vermeden worden, teneinde te voorkomen dat de commissie langs partijpolitieke lijnen verdeeld raakt. Anderzijds wordt dit door parlementariërs vaak gezien als een belangrijke factor in het succes van het departementale commissiestelsel: een unaniem rapport op basis van zorgvuldig verricht onderzoek van een parlementaire commissie waarin alle belangrijke politieke partijen vertegenwoordigd zijn kan niet lichtvaardig door de regering terzijde worden geschoven.

De 'output' van de departementale onderzoekscommissies is de afgelopen jaren sterk gegroeid. Jaarlijks worden ruim honderd onderzoeksrapporten gepubliceerd en bijna 700 hoorzittingen gehouden. De toename in de afgelopen jaren heeft geleid tot een beperkte groei van de vaste staf.

Select committees beschikken over het algemeen over een grote mate van vrijheid met betrekking tot de inrichting van hun onderzoek. Dit geldt eveneens voor de rapportage van de resultaten van het onderzoek. De meeste select committees beschikken over de bevoegdheid "to report from time to time" en kunnen op grond hiervan zelf bepalen op welk moment en waarover zij aan het Huis rapporteren. De vaststelling van onderzoeksrapporten en de besluitvorming omtrent de bevindingen, conclusies en aanbevelingen die uit het onderzoek volgen gebeurt volgens een vaste procedure. Besluitvorming gebeurt meestal op basis van consensus. Wanneer unanimiteit niet mogelijk is, wordt bij meerderheid besloten. Het aangenomen rapport geldt niettemin als een rapport van de gehele commissie. Hoewel geen minderheidsrapporten worden uitgebracht, kunnen de standpunten van minderheden binnen een commissie toch openbaar worden via de formele notulen van de vergadering waarin het rapport werd vastgesteld. Alternatieve rapporten of amendementen die door de commissie zijn behandeld, worden hierin integraal opgenomen.

Ook wat betreft de inhoud van het rapport beschikken select committees over veel vrijheid. In eerste instantie is het aan de commissie om te bepalen in hoeverre het bewijsmateriaal dat gedurende het onderzoek is verzameld wordt toegevoegd bij het rapport. Getuigen die bezwaar maken tegen de publicatie van het verslag van een hoorzitting, kunnen dit kenbaar maken aan de commissie. Deze beslist echter zelf in hoeverre hieraan, mede gelet op de onderbouwing van het rapport, tegemoet kan worden gekomen. Aangezien de commissie rapporteert aan het Huis, beslist het Huis vervolgens of het rapport gedrukt (en op de parlementaire website geplaatst) kan worden. Het is gebruikelijk dat het rapport vrijwel onmiddellijk na aanbieding aan het Huis openbaar gemaakt wordt.

$\mathrm{Na}$ de rapportage is het onderzoek formeel afgerond. Wat met de conclusies en aanbevelingen in het rapport wordt gedaan, is in belangrijke mate afhankelijk van de opstelling van derden. De meeste rapporten van (departmental) select committees richten zich op het werk van de regering. Van de regering wordt binnen zestig dagen een inhoudelijke reactie op het rapport verwacht. Het Huis, waaraan het rapport formeel is gericht, behandelt slechts een zeer klein gedeelte van het aantal rapporten dat jaarlijks wordt uitgebracht. De debatten over select committee-rapporten worden slecht bezocht en hebben doorgaans nauwelijks directe (politieke) consequenties. De mate waarin de conclusies en aanbevelingen worden opgevolgd, hangt dan veeleer af van informele inspanningen die de select committee zelf doet om haar bevindingen op de politieke agenda te houden. Wanneer de regering aanbevelingen van een 
parlementaire commissie niet direct overneemt, betekent dit niet dat bepaalde aanbevelingen niet alsnog en doorgaans stilzwijgend latere beleidsontwikkeling kunnen beïnvloeden. Onderzoekscommissies proberen hun rapporten veelal via andere wegen onder de aandacht te brengen, bijvoorbeeld door persconferenties of door het houden van seminars met belanghebbenden en ambtenaren. Ook worden dezelfde onderwerpen soms opnieuw onderzocht in het licht van eerdere bevindingen ('follow up').

Na dertig jaar departmental select committees is, alles overziend, duidelijk dat de permanente onderzoekscommissies niet meer weg te denken zijn uit het Britse parlementaire stelsel. Zij hebben een belangrijke impuls gegeven aan de parlementaire controlefunctie en ervoor gezorgd dat het Britse Lagerhuis niet louter een debatparlement is, dat volledig door de regering wordt beheersd en bestuurd. Een fundamentele herschikking van de verhoudingen heeft het niet teweeggebracht, maar zo was het ook nooit bedoeld. De verbeteringen zijn niettemin substantieel, al zijn de prestaties van commissies, die vaak relatief autonoom opereren, zeker niet altijd van het gewenste niveau. Op een aantal punten is dan ook nog steeds ruimte voor verbetering. 


\section{Deel III.}

Parlementair onderzoek in de Verenigde Staten 



\section{Hoofdstuk 1. Politiek-constitutioneel kader}

\subsection{Inleiding}

Bij de vormgeving van de federale instellingen in de Verenigde Staten hebben de ontwerpers ervan, de zogenaamde 'framers' of 'founders', zich laten leiden door een bijzonder strikte opvatting omtrent de scheiding van machten. Hierbij is, anders dan in Nederland en het Verenigd Koninkrijk, uitgegaan van een verdeling van de wetgevende, uitvoerende en rechtsprekende macht over drie afzonderlijke instituties. In de Amerikaanse Constitutie valt deze institutionele machtenscheiding direct op: artikel I kent de wetgevende macht toe aan het Congres, terwijl de artikelen II en III de uitvoerende en rechtsprekende macht toekennen aan respectievelijk de President en het Supreme Court. In de uitoefening van hun bevoegdheden op wetgevend, uitvoerend en rechtsprekend terrein zijn de drie instituties echter zeker niet geheel autonoom. Uit vrees voor machtsmisbruik hebben de framers allerlei vormen van 'checks and balances' aangebracht, waardoor de instituties voortdurend van elkaar afhankelijk zijn. Door deze checks and balances kan bij veel belangrijke constitutionele processen, zoals het maken van wetgeving, beter worden gesproken van machtsverdeling dan van machtenscheiding, zoals hierna nog zal blijken.

Een ander kenmerkend onderdeel van het Amerikaanse stelsel is de sterk ontwikkelde traditie van constitutionele toetsing door de rechter. Hoewel de Constitutie hierover zwijgt, heeft het Supreme Court zich al vrij snel na de oprichting van de Amerikaanse republiek op het standpunt gesteld dat de rechter vanuit de aard van haar functie bevoegd is om de Constitutie te interpreteren en het handelen van de wetgevende en uitvoerende macht te beoordelen op hun grondwettigheid. ${ }^{1}$ Deze 'implied power', een aanvulling op de grondwettelijke vormen van 'checks and balances', heeft de rechter met beide handen aangegrepen. De rechtspraak van het Supreme Court, als hoogste rechter, is daarom een belangrijke bron van constitutionele interpretatie. De rechterlijke macht drukt daarmee een belangrijk stempel op het constitutionele stelsel, niet alleen op het (voor de hand liggende) terrein van de grondrechten, maar ook als het gaat om het bewaken van de constitutionele scheiding van machten.

\subsection{Het Congres en de wetgevende macht}

\subsubsection{Organisatie}

Het Congres, dat de wetgevende macht uitoefent, bestaat uit twee kamers - het Huis van Afgevaardigden (kortweg: het Huis) en de Senaat - die beiden direct verkozen

${ }^{1}$ Zie de beroemde uitspraak in de zaak Marbury v. Madison, 5 U.S. 137 (1803). 
worden. ${ }^{2}$ In het wetgevingsproces spelen zij in constitutioneel opzicht een gelijkwaardige rol: in beide kamers kunnen wetsvoorstellen worden ingediend en in beiden moeten een meerderheid instemmen, wil een voorstel aangenomen kunnen worden. Bovendien beschikken zowel Huis als Senaat over een amendementsrecht. De wetgevende taak van het Congres strekt zich uit over een aantal, voornamelijk in artikel I van de Constitutie opgesomde terreinen. De instemming van de President is vereist voordat een aangenomen wetsvoorstel in werking kan treden, al kan een presidentieel veto met een versterkte meerderheid in beide kamers worden 'overruled'. ${ }^{3}$ Verder kent de Constitutie het Congres het budgetrecht toe. Zo beschikt het Congres over de bevoegdheid belasting te heffen en kunnen uitgaven uit de federale kas alleen worden gedaan nadat deze daartoe bij afzonderlijke wet zijn aangemerkt ('appropriated'). ${ }^{4}$ Hiermee beschikt het Congres over belangrijke beleidsvormende instrumenten. Belangrijk is voorts dat de Senaat beschikt over een instemmingsrecht bij de benoeming van federale rechters en overige ambtenaren ('officers of the United States'), die door de President worden voorgedragen. ${ }^{5}$

Waar in de meeste Europese parlementen de partij- en coalitieverbanden bepalend zijn voor de wijze waarop parlementaire taken en bevoegdheden worden uitgeoefend, is de invloed van Amerikaanse partijorganisaties op het Congres in vergelijking daarmee veel beperkter. Tijden van sterke partijcohesie komen wel voor $^{6}$, maar worden afgewisseld met periodes waarin partijen juist bijzonder weinig invloed uitoefenen. De relatief zwakke ontwikkeling van het partijenstelsel in de Verenigde Staten hangt onder meer samen met het kiesstelsel, waarin de individuele kandidatuur centraal staat. De meeste congresleden financieren bovendien hun eigen verkiezingscampagnes. Het ontbreken van een vertrouwensband tussen President en Congres maakt een strakke partijorganisatie ook veel minder noodzakelijk dan in veel Europese parlementaire stelsels, waar de voornaamste taak van de leden van de meerderheids- of coalitiepartijen is om de regering in het zadel te houden. Verder zorgen ook regionale verschillen en de invloed van belangenorganisaties ervoor dat partijdiscipline in de Verenigde Staten, vergeleken met veel Europese stelsels, veel minder sterk ontwikkeld is. ${ }^{7}$ De invloed van het partijleiderschap is doorgaans nog het grootst in het Huis. Dit hangt enerzijds samen met de verschillen in omvang: het Huis (435 leden) is vier maal groter dan de Senaat (100 leden), waardoor een een strakkere regie nodig is om tot besluiten te kunnen komen. Bovendien zijn de getalmatige verschillen tussen meerderheid en minderheid in de Senaat vaak kleiner dan

\footnotetext{
2 Zie Const., art. I, secties 1-3 en amend. XVII.

${ }^{3}$ Const., art. I, sectie 7.

${ }^{4}$ Zie Const., art. I, secties 7-9.

${ }^{5}$ Const., art. II, sectie 2. Daarbij geldt bovendien dat het Congres de benoemingswijze van lagere ambtenaren bij wet kan opdragen aan de President alleen, de rechterlijke macht of aan de departementshoofden.

${ }^{6}$ Slechts incidenteel blijkt partijorganisaties een dominante rol te kunnen spelen, zoals tijdens de regeerperiode van President Franklin Roosevelt en na de congresverkiezingen in 1994, toen de Republikeinen na jaren van oppositie ineens in beide Kamers een stevige meerderheid verworven. Zie ook Deering \& Smith 1997, p. 52.

${ }^{7}$ Zie verder Oleszek 2001, p. 17-19. Zie ook Deering \& Smith 1997, p. 52-53.
} 
in het Huis en zijn senatoren door hun lange ambtstermijn minder afhankelijk van het politieke wel en wee van hun partij. ${ }^{8}$

Het traditionele gebrek aan een strakke partijpolitieke structurering binnen het Congres werkt door op organisatorisch vlak. Op dit punt wordt het Congres gekenmerkt door een hoge mate van decentralisatie. In de uitvoering van de taken van het Congres op wetgevend, budgettair en toezichthoudend vlak is een primaire plaats weggelegd voor de vaste commissies en de talloze subcommissies die in beide kamers zijn ingesteld. Deze commissies vervullen niet alleen voorbereidende werkzaamheden, maar ook een belangrijk deel van de besluitvorming vindt hier plaats. Anders dan in de Nederlandse en Britse parlementen kunnen wetsvoorstellen bijvoorbeeld reeds in de commissiefase worden geamendeerd of zelfs afgewezen. De sterke verankering van het commissiestelsel in beide kamers heeft enerzijds een praktische reden - de hoeveelheid werkzaamheden is gewoonweg te groot om in plenaire vorm te kunnen verrichten ${ }^{9}$ - maar sluit tevens aan bij de behoefte van individuele congresleden om daadwerkelijk invloed te kunnen uitoefenen op de besluitvorming. Congressionele besluitvorming is daarom, bij afwezigheid aan hiërarchische, gecentraliseerde partijpolitieke sturing, vaak het resultaat van gelegenheidscoalities tussen Democraten en Republikeinen. Bij de vorming van deze veranderlijke coalities spelen naast beleidsinhoudelijke en (partij)politieke overwegingen ook overwegingen van loyaliteit aan commissies een rol bij de vorming van deze coalities. De vaste commissies blijken in tijden van zwakke partijcohesie vaak opvallend autonoom en onafhankelijk van het partijleiderschap te werk kunnen gaan. ${ }^{10}$ Vooral commissievoorzitters kunnen hierdoor een grote machtspositie opbouwen. ${ }^{11}$

De laatste jaren wordt het Congres gekenmerkt door een sterkere partijpolitiek cohesie. Deze ontwikkeling lijkt al enige tijd gaande en werd goed zichtbaar in het midden van de jaren 90, toen de Republikeinen vanuit het Congres een felle persoonlijke campagne tegen de Democratische President Clinton voerden. De verhoudingen tussen Democraten en Republikeinen zijn sindsdien verhard, waardoor samenwerking moeilijker is geworden. Partijleiders in het Congres hebben een belangrijkere functie gekregen en treden in de media veelvuldig op als het gezicht van de partij. De politieke besluitvorming in het Congres is meer gecentraliseerd, wat ten koste is gegaan van de positie van commissievoorzitters. Vergeleken met enkele decennia geleden heeft het Congres een geheel ander karakter gekregen, zo stellen Smith c.s.: "In

\footnotetext{
${ }^{8}$ Dit uit zich onder meer in de reglementen van orde van beide kamers, die in de Senaat minder strak zijn dan in het Huis. Bekend voorbeeld is de figuur van de 'filibuster', waarmee een substantiële minderheid in de Senaat besluitvorming omtrent wetgeving kan blokkeren. De partijorganisaties en hun leiderschap in de Senaat hebben de afgelopen jaren echter wel aan invloed gewonnen. Zie Smith, Roberts \& VanderWielen 2007, p. 143 e.v.

${ }^{9}$ Oleszek 2001, p. 17.

${ }^{10}$ De mate waarin commissies (en dan met name de commissiemeerderheid) in concrete situaties ook daadwerkelijk de politieke ruimte hebben om gebruik te maken van hun procedurele bevoegdheden, hangt af van de positie die het partijleiderschap in de betreffende Kamer op dat moment inneemt. Deering en Smith concluderen dan ook dat "...the history of the modern Congress reflects an ebb and flow of power between parties and committees." Zie Deering \& Smith 1997, p. 53.

11 Zie uitvoerig: Smith, Roberts \& VanderWielen 2007, p. 192 e.v.
} 
the 1970s, extreme individualism was the most common description of Congress; during the last 20 years, unrestrained partisanship has been the dominant theme." 12

\subsubsection{Wetgevende bevoegdheid}

De Constitutie van 1787 kent het federale Congres een aantal uitdrukkelijke bevoegdheden toe. In het Amerikaanse stelsel van gescheiden staatsmachten is het Congres voornamelijk belast met wetgevende taken, zo blijkt uit artikel I, sectie 1, van de Constitutie: "All legislative Powers herein granted shall be vested in a Congress of the United States, which shall consist of a Senate and House of Representatives." 13 Deze wetgevende macht is niet absoluut, noch onbegrensd. De Constitutie voorziet in beperkingen, waarin de ideeën van machtsverdeling en federalisme doorklinken. Als gezegd krijgt een wetsvoorstel, waarover Huis en Senaat overeenstemming hebben bereikt, in beginsel geen kracht van wet zonder de handtekening van de President. Alleen met een versterkte meerderheid in beide Kamers kan een presidentieel veto worden doorbroken. ${ }^{14}$ Ten tweede vloeit uit de geciteerde bepaling voort dat het federale Amerikaanse Congres niet beschikt over een algemene wetgevende macht, zoals het Britse parlement. Het Congres is slechts bevoegd wetgeving tot stand brengen op een limitatief aantal terreinen, zo kan uit de opsomming in sectie 8 van artikel I worden afgeleid. Het Congres is onder andere bevoegd belastingen te heffen, staatsleningen aan te gaan, interstatelijke handel te reguleren, federale rechtbanken in te stellen, de oorlog te verklaren en te voorzien in een federaal leger. ${ }^{15}$ Dat de bevoegdheden van het Congres in beginsel van beperkte omvang zijn, blijkt eens te meer uit het Tiende Amendement van de Constitutie, waarin staat dat bevoegdheden die niet zijn toegekend ('delegated') aan het federale niveau aan de deelstaten of aan het volk toevallen. ${ }^{16}$

Niettemin werd al snel na de inwerkingtreding van de federale Constitutie duidelijk dat de wetgevende taak van het Congres niet te restrictief moet worden opgevat. In 1819 oordeelde het Hooggerechtshof in McCulloch v. Maryland, een uitspraak over de grondwettigheid van de bij federale wet opgerichte centrale bank, dat "there is no phrase in the instrument which, like the articles of confederation, excludes incidental or implied powers; and which requires that everything granted shall be expressly and minutely described." 17 Dit kan volgens het Hof allereerst worden afgeleid uit de tekst en de geest van het Tiende Amendement: hadden de Framers bedoeld om impliciete bevoegdheden uit te sluiten, zoals dat wel het geval was in de Articles of Confederation, dan zouden zij dit uitdrukkelijk hebben vastgelegd. ${ }^{18}$ Voorts speelt de zogenaamde 'necessary and proper clause' aan het slot van artikel I,

\footnotetext{
12 Smith, Roberts \& VanderWielen 2007, p. 153.

${ }^{13}$ Const., art. I, sec. 1.

14 Const., art. I, sec. 7.

${ }^{15}$ Zie verder: Const., art. I, sec. 8, lid 1-17.

16 "The powers not delegated to the United States by the Constitution, nor prohibited by it to the States, are reserved to the States respectively, or to the people." Const., amend. X. Dit geldt overigens niet alleen voor het Congres, maar voor alle federale instellingen.

17 McCulloch v. Maryland, 17 U.S. 316, 406 (1819).

${ }_{18}$ Bijvoorbeeld door te spreken van "expressly delegated powers". Zie 17 U.S. 316, 406-407 (1819).
} 
sectie 8 , een belangrijke rol in de opvattingen van het Hof. Deze bepaling kent aan het Congres de bevoegdheid toe "To make all Laws which shall be necessary and proper for carrying into Execution the foregoing Powers, and all other Powers vested by this Constitution in the Government of the United States, or in any Department or Officer thereof" ${ }^{19}$ Het Hof concludeerde dat het begrip 'necessary' niet bedoeld is in de zin van 'essentieel' of 'absoluut noodzakelijk'. ${ }^{20}$ Integendeel, het Congres is bevoegd om alle regelingen te treffen die redelijkerwijs nodig zijn om de opgesomde bevoegdheden daadwerkelijk uit te oefenen. ${ }^{21}$ Het oprichten van een centrale bank, zo oordeelde het Hof in deze zaak, pastte in de uitoefening van de fiscale bevoegdheden van het Congres. 22

Naast de expliciet opgesomde constitutionele bevoegdheden ("enumerated powers") bestaat er dus ruimte voor 'implied powers': impliciete, aanvullende bevoegdheden. De wetgevende taak van het Congres is weliswaar limitatief, maar niet strict enumeratief: zij omvat meer dan uitsluitend de bevoegdheden die uitdrukkelijk zijn beschreven in de Constitutie. ${ }^{23}$ De weinig specifieke beschrijving van wetgevingsterreinen, zoals het begrip 'interstatelijke handel', maakt de federale wetgevende bevoegdheid potentieel erg omvangrijk. De omvang van deze (impliciete) bevoegdheden kunnen niet in algemene zin worden vastgesteld, maar hangt af van de betekenis die daaraan op grond van constitutionele interpretatie moet worden gegeven. Het Supreme Court speelt hierin een belangrijke rol.

\subsection{De President en de uitvoerende macht}

\subsubsection{Constitutioneel kader}

Artikel II draagt de uitvoerende macht direct aan de President op. ${ }^{24}$ Op grond hiervan wordt de President vaak aangeduid als de 'Chief Executive'. De Constitutie kent de President voorts een aantal specifieke taken en bevoegdheden toe. De belangrijkste bevoegdheden liggen op het gebied van buitenlands beleid en defensie, waarvan het opperbevel over de strijdkrachten de meest in het oog springende is. De Presi-

\footnotetext{
${ }^{19}$ Const., Art. I, sec. 8, lid 18.

${ }^{20}$ McCulloch v. Maryland, p. 411-421.

${ }^{21}$ Het Hof concludeert als volgt: "We admit, as all must admit, that the powers of the government are limited, and that its limits are not to be transcended. But we think the sound construction of the constitution must allow to the national legislature that discretion, with respect to the means by which the powers it confers are to be carried into execution, which will enable that body to perform the high duties assigned to it, in the manner most beneficial to the people. Let the end be legitimate, let it be within the scope of the constitution, and all means which are appropriate, which are plainly adapted to that end, which are not prohibited, but consist with the letter and spirit of the constitution, are constitutional." 17 U.S. 316, 421 (1819).

2217 U.S. 316, 424 (1819). Zie verder Nowak \& Rotunda 2000, p. p. 136-140.

${ }^{23}$ Ook de andere staatsmachten beschikken overigens over impliciete constitutionele bevoegdheden, zoals het 'executive privilege' van de President (waarover meer in par. 6) en het constitutionele toetsingsrecht van de rechterlijke macht. Zie over de discussie omtrent 'implied powers' verder: Nowak \& Rotunda 2000, p. p. 134 e.v.; Fisher 2005, p. p. 163-165.

${ }^{24}$ Const., art. II, sec. 1, lid 1.
} 
dent heeft verder de algemene taak erop toe te zien dat wetgeving op de juiste wijze wordt uitgevoerd: "...he shall take Care that the Laws be faithfully executed..." 25

De wijze waarop de uitvoerende macht zou moeten worden ingericht, speelde nauwelijks een rol tijdens de constitutionele conventie in Philadelphia. Hoewel de conventie in het teken stond van het ontwerpen van een sterkere federaal staatsbestel ter vervanging van het bestaande, weinig effectieve confederale verband, bestond bij veel deelnemers een diep wantrouwen tegen overheidsmacht en dan vooral tegen machtsconcentratie. In het eerste ontwerp dat tijdens de constitutionele conventie besproken werd, voorgelegd door de staat Virginia, zou de President en de rechterlijke macht door het Congres gekozen en benoemd worden. De President zou vervolgens zelfstandig alle overige federale functionarissen kunnen benoemen, met uitzondering van de gevallen waarin de Constitutie zelf zou voorzien. Naarmate de conventie vorderde, raakte dit plan uit beeld en ontstond het idee van drie gescheiden staatsinstellingen die elkaar via 'checks and balances' in evenwicht zouden houden. Het bestuurlijk-ambtelijke apparaat van de nieuwe federale republiek werd kennelijk geen rol van betekenis toegedicht. ${ }^{26}$

Bij de inrichting van de uitvoerende macht is uiteindelijk een hoofdrol toegekend aan het Congres. Dit kan worden afgeleid uit de zogenaamde Appointment Clause in artikel II, lid 2. Hierin is de benoeming geregeld van "all other Officers of the United States, whose appointments are not herein otherwise provided for, and which shall be established by Law". ${ }^{27}$ De Constitutie vereist dus een wettelijke grondslag voor de benoeming van federale ambtenaren. ${ }^{28}$ Hieruit kan worden afgeleid dat de federale ambtelijke organisaties die tot de uitvoerende macht worden gerekend, te allen tijde een wettelijke grondslag nodig hebben. Verder is bepaald dat de Senaat beschikt over een instemmingsrecht ten aanzien van de kandidaten die de President voordraagt voor ambtelijke posities. Ten aanzien van lagere ambtenaren, de zogenaamde 'inferior Officers', geldt dat een afwijkende benoemingswijze bij wet kan worden geregeld. Daarbij bestaat de mogelijkheid om de President een zelfstandig benoemingsrecht toe te kennen, maar ook om de benoeming op te dragen aan rechtbanken of aan de 'heads of departments'. ${ }^{29}$ Verder bepaalt artikel II slechts dat

\footnotetext{
${ }^{25}$ Const., art. II, sec. 3.

${ }^{26}$ Zie verder Aberbach 1990, p. 2-3.

27 Zie ook Fisher 2007, p. 21-22.

28 Onder de term 'officers of the United States' verstaat het Hooggerechtshof "all appointed officials exercising responsibility under the public laws of the Nation." Buckley v. Valeo, 424 U.S. 1, 131 (1976).

${ }^{29}$ Const., art. II, lid 2. Het Congres kan het benoemingsrecht van 'officers of the United States' bij wet overdragen, maar niet naar zich toetrekken, zoals in de Buckley-zaak het geval was. De leden van de Federal Elections Commission, benoemd door het Congres, beschikten op grond van de wet over de bevoegdheid federale kieswetgeving uit te voeren en via de burgerlijke rechter te handhaven. Dit, zo oordeelde het Hooggerechtshof, was in strijd met de Appointments Clause. Het Hof stelde: "Congress may undoubtedly under the Necessary and Proper Clause create "offices" in the generic sense and provide such method of appointment to those "offices" as it chooses. But Congress' power under that Clause is inevitably bounded by the express language of Art. II, s 2, lid 2, and unless the method it provides comports with the latter, the holders of those offices will not be "Officers of the United States." They may, therefore, properly perform duties only in aid of those functions that Congress may carry out by itself, or in an area sufficiently removed from the administration and enforcement of
} 
de President "...may require the Opinion, in writing, of the principle Officer in each of the Executive Departments, upon any Subject relating to the Duties of their respective Offices..." 30 Over de bevoegdheid tot ontslag van federale ambtenaren, de zogenaamde 'removal power', zwijgt de Constitutie, maar het Supreme Court heeft bepaald dat deze wel volledig in handen van de President is. ${ }^{31}$

De Constitutie verschaft de Senaat dus de mogelijkheid om invloed uit te oefenen op de te benoemen (hogere) ambtenaren binnen de uitvoerende macht. Senatoren maken actief gebruik van dit instemmingsrecht om invloed uit te oefenen op de benoeming van belangrijke federale ambtenaren, mede vanuit de gedachte dat deze functionarissen uitvoering moeten geven aan wettelijke en budgettaire maatregelen die het Congres heeft vastgesteld. Het is gebruikelijk dat de vaste senaatscommissie die inhoudelijk het meest betrokken is hoorzittingen houdt met de kandidaten die de President heeft voorgedragen. Deze hoorzittingen bieden de mogelijkheid om kandidaten in het openbaar te vragen naar hun opvattingen of doelstellingen met betrekking tot de organisaties en beleidsprogramma's waarbij zij betrokken zullen zijn. Ook kunnen zo specifieke toezeggingen van kandidaten worden verkregen. Is een kandidaat eenmaal benoemd, dan kan later tijdens follow-up hoorzittingen worden nagegaan in hoeverre eerder uitgesproken voorkeuren en toezeggingen daadwerkelijk zijn opgevolgd. Het daadwerkelijk afwijzen van kandidaten voor posities binnen de uitvoerende macht komt in de praktijk overigens weinig voor. De President, zo is de gedachte, moet als hoofd van de uitvoerende macht enige ruimte worden geboden, met name wanneer het gaat om kabinetsposten. Dat neemt niet weg dat kritische ondervragingen heel gebruikelijk zijn; stevig verzet vanuit de betrokken senaatscommissies is, zeker wanneer de President van een andere politieke kleur is dan de meerderheid in de Senaat, evenmin uitgesloten. Incidenteel voelt een President zich daarom gedwongen een kandidaat terug te trekken. ${ }^{32}$

\subsubsection{Departementen en agentschappen}

De contouren van de bestuurlijke organisatie van de federale uitvoerende macht zijn in belangrijke mate bepaald door het eerste Congres, dat in 1789 werd geïnstalleerd. ${ }^{33}$ Onder de oude confederale staatsregeling bestond reeds een klein aantal departementen, die werden geleid door een bestuurscommissie. Dit collegiale bestuursmodel werd door veel congresleden echter als weinig effectief ervaren en daarom besloot het eerste Congres om de nieuwe departementen onder het eenhoof-

the public law as to permit their being performed by persons not "Officers of the United States." Buckley v. Valeo, 424 U.S. 1, 138-139.

30 Const., art. II, sec. 2 , lid 1.

${ }^{31}$ Myers v. United States, 272 U.S. 52 (1926).

32 Bovendien zullen sommige kandidaten uit vrees voor beschadiging of afwijzing soms niet eens worden voorgedragen. Zie over de rol van de Senaat verder Fisher 2007, p. 35-36. Zie ook Kernell \& Jacobson 2000, p. 269 en Smith, Roberts \& Vander Wielen 2007, p. 298. Overigens is het gebruikelijk dat wanneer het gaat om een functie die een regionaal karakter heeft, bijvoorbeeld een ambtelijke buitenpost in een bepaalde staat, dat de senatoren van die staat worden betrokken in het nominatieproces. Zie Fisher 2007, p. 32-33.

${ }^{33}$ Fisher 2005, p. 172. 
dig gezag van een Secretary te plaatsen. ${ }^{34}$ In eerste instantie richtte het Congres departementen op die ook al onder de confederale staatsregeling bestonden: financiën, buitenlandse zaken en oorlog. Daarnaast werd de functie van Attorney General ingesteld, die (part-time) juridisch advies gaf aan de President en de hoofden van de departementen. ${ }^{35}$ Dit bleef zo tot het midden van de negentiende eeuw, toen het departement voor binnenlandse zaken werd opgericht dat zich met name zou bezighouden met de westwaardse expansie van de Verenigde Staten. Na de Amerikaanse burgeroorlog werd het departement van Justitie opgericht als gevolg van groeiende taak van de federale overheid op het gebied van rechtshandhaving.

Het wetgevingsproces ten aanzien van de instelling en herinstelling van departementen en agentschappen wordt 'authorization' genoemd en is nader uitgewerkt in de reglementen van orde van beide Kamers. Hierbij is een sleutelrol weggelegd voor de vaste commissies. Hoewel een aantal uitvoerende diensten beschikt over een permanente wettelijke autorisatie, geldt voor veel instellingen dat zij slechts voor bepaalde tijd zijn ingesteld. De autorisatie is verder van belang omdat hierin wordt bepaald welke taken en beleidsprogramma's deze instellingen uitvoeren. Ook wordt middels autorisatie vastgesteld welk budget aan de uitvoering van deze taken en programma's wordt toegekend. ${ }^{36}$ Wanneer een authorisatietermijn afloopt, dient herauthorisatie plaats te vinden om de betreffende instelling, dan wel een organisatorische eenheid daarbinnen of een beleidsprogramma dat zij uitvoert, te kunnen voortzetten. Deze herautorisatie gebeurt wederom bij wet.

Vooral in de twintigste eeuw, met name vanaf de jaren 30 onder invloed van de New Deal van President Roosevelt, is de federale overheidsbemoeienis sterk toegenomen, als gevolg waarvan ook het federale bestuursapparaat explosief gegroeid is. Naast de klassieke departementen, zoals die van buitenlandse zaken en financiën, werden binnen de uitvoerende macht steeds meer zelfstandige agentschappen opgericht, 'independent executive agencies' genoemd, die zich met allerhande nieuwe beleidsprogramma's gingen bezighouden. Voorbeelden zijn de Environmental Protection Agency en de Social Security Administration, die voor wat betreft hun budget en aantal medewerkers overigens zeker niet onderdoen voor veel departementen. In de loop der tijd is aan bepaalde agencies, of samenvoegingen van agencies, de status van departement verleend. Het hoofd van het departement, de secretary of state, verkreeg hiermee een plaats aan de tafel van het presidentiële kabinet. Dat laatste heeft geen constitutionele betekenis, maar wordt vooral gezien als een politieke erkenning van het belang van het beleidsgebied. ${ }^{37}$ Een independent executive agency heeft staatsrechtelijk dezelfde status als een departement. De autorisatie verloopt eveneens bij wet en de benoeming van officers binnen het agency, waaronder het hoofd van het agency (vaak director genoemd), gebeurt volgens de constitutionele

\footnotetext{
34 Fisher 2005, p. p. 172.

${ }^{35}$ Kernell \& Jacobson 2000, p. p. 249.

${ }^{36}$ Dit betekent niet dat de betreffende instelling het vastgestelde budget ook daadwerkelijk toegekend krijgt. Hiervoor kennen beide Kamers een afzonderlijke procedures ('appropriations'), die worden geleid door de Appropriations Committees. De authorisatie, die in belangrijke mate in handen is van de vaste commissie tot wiens werkterrein de betreffende instellingen of beleidsprogramma's valt, bepaalt slechts het maximale budget dat kan worden toegekend. Zie hierna.

${ }^{37}$ Kernell \& Jacobson 2000, p. 256.
} 
Appointment Clause. Het adjectief 'independent' duidt dan ook vooral op het feit dat de dienst organisatorisch geen onderdeel is van een departement. Er zijn allerlei redenen denkbaar waarom het Congres nog steeds een voorkeur heeft voor zelfstandige organisaties. Hiermee kan bijvoorbeeld een beleidsterrein worden geaccentueerd of de als bureaucratisch ervaren gelaagdheid van een departement worden omzeild. 38

Het Congres heeft echter ook verschillende agencies opgericht die wel degelijk een andere positie innemen dan de departementen. Hierbij gaat het om een relatief kleine, maar invloedrijke groep organisaties die zich bezighouden met taken op het gebied van marktregulering, zowel ten aanzien van regelstelling als van handhaving en geschilbeslechting. Voorbeelden zijn de Federal Trade Commission, het Federal Reserve System en de National Labor Relations Board. Bij deze organisaties, ook wel 'independent regulatory agencies' of 'regulatory commissions' genoemd, wordt gelet op hun takenpakket een zekere institutionele onafhankelijkheid van politieke invloeden wenselijk geacht. Zij kennen veelal een collegiaal bestuur bestaande uit vijf commissieleden, waarvan er nooit meer dan drie van dezelfde partij mogen zijn. Benoeming gebeurt zoals voorgeschreven in de Appointment Clause, dus door de President met instemming van de Senaat, maar commissieleden worden op getrapte wijze aangesteld voor een vaste periode van bijvoorbeeld vijf of zeven jaar, vaak zonder mogelijkheid van herbenoeming. Tussentijds ontslag door de President is, anders dan bij ambtenaren binnen departementen en executive agencies, slechts mogelijk op bij de wet omschreven gronden. Het Supreme Court heeft het stellen van wettelijke beperkingen van de presidentiële benoemings- en ontslagbevoegdheden van federale officers aanvaard, omdat het hier gaat om instellingen met een quasigerechtelijk karakter die daarmee niet geheel binnen de uitvoerende macht vallen. ${ }^{39}$

\subsubsection{Begroting en bekostiging}

De constitutionele invloed van het Congres op de uitvoerende macht wordt verder versterkt door de budgettaire bevoegdheden die het Congres toekomen. Het Congres speelt een voorname rol bij het vaststellen van de federale begroting, zowel wat betreft de (belasting)inkomsten als de uitgaven. ${ }^{40}$ Alle bestedingen uit de schatkist dienen bij wet te worden vastgesteld. Lid 9 van artikel I bepaalt hieromtrent: "No money shall be drawn from the treasury, but in consequence of appropriations made by law." Het Congres, waaraan de wetgevende macht is toegekend, beschikt aldus over het budgetrecht.

De vaststelling van de budgetten voor de diverse departementen en agentschappen is een jaarlijks terugkerend proces, dat in grote lijnen op het volgende

\footnotetext{
38 Soms is het vooral de President die aandringt op een aparte organisatie om meer directe invloed te kunnen uitoefenen. Zie Kernell \& Jacobson 2000, p. 260.

${ }^{39}$ Humphrey's Executor v. United States, 295 U.S. 602 (1935). Zie nader Fisher 2007, p. 62-64. Zie ook Kernell \& Jacobson 2000, p. 260-264.

40 Zie art. I, sect. 8, lid 1 ("The Congress shall have Power to lay and collect Taxes, Duties, Imposts and Excises, to pay the Debts and provide for the common Defence and general Welfare of the United States..."). Bevestigd in United States v. Butler, 297 U.S. 1, 56 S.Ct. 312, 80 L.Ed. 477 (1936). Zie over deze uitspraak verder Nowak \& Rotunda 2000, p. 223 e.v.
} 
neerkomt. ${ }^{41}$ Het begint bij het reeds genoemde presidentiële begrotingsvoorstel voor de gehele uitvoerende macht. Het Congres stelt naar aanleiding van het presidentiële voorstel een eigen Budget Resolution op. Deze resolutie wordt voorbereid door een Budget Committees in beide Kamers op basis van onder meer de 'views and estimates' die de vaste (wetgevings)commissies in beide Kamers ten aanzien van hun werkterreinen verschaffen. In deze fase wordt door de vaste wetgevingscommissies onder meer bekeken in hoeverre bestaande bestuursorganen en beleidsprogramma's hun doelstellingen hebben behaald of anderzins voldoende prestaties hebben geleverd.

De congressionele budgetresolutie vormt het algemene kader voor de nadere uitwerking in afzonderlijke toekenningswetgeving, de zogenaamde 'appropriations'. ${ }^{42}$ Deze wetsvoorstellen worden voorbereid door de Appropriations Committees in beide Huizen. Besluitvorming binnen deze commissies is sterk gedecentraliseerd via een groot aantal subcommissies. De mate waarin de President zijn budgettaire voorkeuren terugziet in de appropriations die uiteindelijk worden vastgesteld, hangt af van de politieke verhoudingen tussen President, de Budget Committees en de Appropriations Committees. ${ }^{43}$ Ook de positie van de vaste (wetgevings)commissies in beide kamers is van belang, aangezien toegekende budgetten in beginsel niet de kaders kunnen overstijgen die eerder via autorisatiewetgeving zijn vastgesteld. En juist in het autorisatieproces spelen de vaste commissies een belangrijke rol.

\subsubsection{Sturing en coördinatie}

De constitutionele bevoegdheden op het gebied van inrichting en organisatie, alsmede op het gebied van de toebedeling van taken en het vaststellen van budgetten, geven het Congres in verschillende hoedanigheden en op verschillende momenten verregaande beleidsmatige invloed op de uitvoerende macht. De tamelijk bescheiden positie die de President in bestuurlijk opzicht is toegekend door de 'framers' - naast een beperkt aantal omschreven taken, voornamelijk op de terreinen van buitenlands beleid en defensie, ziet hij immers 'slechts' toe op een behoorlijke uitvoering van de wet - heeft echter niet kunnen verhinderen dat de President in de praktijk een belangrijke coördinerende rol is gaan spelen ten aanzien van de uitvoerende macht. In vergelijking met het Congres, waarin partijdiscipline zwak ontwikkeld is en besluitvorming dientengevolge vaak ondoorzichtig en inconsequent is, heeft het eenhoofdige presidentschap met de groei van het uitvoerend apparaat in de loop der tijd een

\footnotetext{
${ }^{41}$ Het betreft een vrij gecompliceerd proces, dat grotendeels voortvloeit uit de Congressional Budget and Impoundment Control Act van 1974. Doel van deze wet was onder meer de destijds grote invloed van (sub)commissies binnen het Congres te verminderen door de coördinatie van de congressionele procedures in handen van centrale budgetcommissies in beide Huizen te leggen. Zie verder Smith, Roberts \& Vander Wielen 2007, p. 364 e.v.

${ }^{42}$ De noodzaak van 'appropriation' bij wet volgt uit de Constitutie, artikel 1, sectie 9, lid 7 ("No money shall be drawn from the Treasury, but in Consequence of Appropriation made by Law..."). Overigens wordt slechts een deel van de totale federale bestedingen jaarlijks via afzonderlijke wetten toegekend; een belangrijk deel ligt reeds bij wet vast, zoals sociale-zekerheidsvoorzieningen.

${ }^{43}$ Aangezien bestedingen bij gewone wet worden vastgesteld gelden hiervoor de gebruikelijke institutionele verhoudingen, waarbij het Congres wetgeving aanneemt, maar de President een vetorecht heeft dat het Congres slechts met tweederde meerderheid kan overtreffen. Zie over de politieke processen rondom de begroting verder Smith, Roberts \& Vander Wielen 2007, p. 361-385.
} 
richtinggevende functie gekregen. Vooral sinds de New Deal van President Roosevelt in de jaren 30 van de twintigste eeuw, toen de federale overheidsbemoeienis groeide en dientengevolge complexer werd, verwachten kiezers dat de President de grotere politieke lijnen uitzet, de koers bepaalt en de nodige initiatieven neemt.

Om die verwachtingen waar te maken hebben Presidenten in de loop van de twintigste eeuw een steeds omvangrijker ondersteunend ambtelijk apparaat om zich heen gebouwd: het zogenaamde Executive Office of the President. Binnen deze presidentiële ambtelijke organisatie, met name binnen het zogenaamde Office of Management and Budget, wordt getracht de werkzaamheden van de verschillende federale diensten te coördineren en te sturen, bijvoorbeeld door departementsoverstijgende beleids- en begrotingsplannen te maken. ${ }^{44}$ De gegroeide coördinerende functie van de President komt heel uitdrukkelijk tot uiting in het jaarlijkse presidentieel begrotingsplan voor de gehele federale uitvoerende macht, dat wordt gepresenteerd voorafgaand aan het begrotingsproces in het Congres. Hoewel het Congres op basis van haar constitutionele budgetrecht uiteraard vrij is hierin wijzigingen aan te brengen, gaat van 'the President's Budget' een belangrijke sturende en coördinerende werking uit. De politieke statuur van de President kan veel gewicht in de schaal leggen. Departementen weten dat een presidentieel 'stempel' op departementale beleidsvoorstellen een belangrijk politiek effect kan hebben; tegelijkertijd realiseren congresleden zich dat obstructie van populaire presidentiële plannen publicitaire en electorale risico's met zich mee kan brengen. Dit stimuleert de verschillende zijden tot samenwerking en afstemming. Wanneer de partij van de President een meerderheid in het Huis en de Senaat heeft, dan zal dit uiteraard gemakkelijker gaan dan wanneer dat niet het geval is.

\subsection{Toezicht op de uitvoerende macht}

Hierboven kwam naar voren dat het Congres zich middels de wetgevende en budgettaire bevoegdheden die de Constitutie hem toekent grote invloed uitoefent op het takenpakket, de beleidsvoering en de inrichting van de uitvoerende macht. Met deze constitutionele bevoegdheden komen echter ook verantwoordelijkheden. Wanneer het in eerste instantie aan het Congres is om de uitvoerende macht vorm en inhoud te geven, zo is de gedachte, dan vloeit daaruit tevens de taak voort om toezicht te houden op het functioneren ervan. Die toezichthoudende taak, in het Amerikaanse spraakgebruik 'oversight' genoemd, heeft in de loop der tijd aan belang gewonnen en is steeds verder geïnstitutionaliseerd.

\subsubsection{Oversight: toezicht door het Congres}

Al vanaf de oprichting van de federale republiek houdt het Congres zich bezig met verschillende vormen van toezicht op de uitvoerende macht. Aanvankelijk stelde dit nog weinig voor. Het federale bestuursapparaat was klein en het Congres nam, althans buiten oorlogstijd, een dominante positie in ten opzichte van de President. De

\footnotetext{
${ }^{44}$ Ook wel aangeduid als 'the White House', aangezien de meeste diensten die onder het Executive Office vallen in of nabij de presidentiële ambtswoning zijn gevestigd.
} 
beperkte overheidstaak en de dominante positie leidden ertoe dat het Congres middels veelal zeer gedetailleerde wetgeving een hoge mate van sturing en controle ten aanzien van de uitvoerende macht kon uitoefenen. ${ }^{45}$

In deze periode schreef Woodrow Wilson, destijds hoogleraar en later president, zijn invloedrijke werk Congressional Government (1885). Zoals de titel reeds suggereert, oefende het Congres volgens Wilson in die tijd door middel van zijn wetgevende bevoegdheden feitelijk de uitvoerende macht uit. Tot zijn ongenoegen, want volgens Wilson was een parlement niet geschikt voor die taak. Het Congres zou minder aandacht moeten besteden aan (gedetailleerde) wetgeving en zich meer moeten bezighouden met toezicht:

\begin{abstract}
"Legislation unquestionably generates legislation. (...) It is not surprising, therefore, that the enacting, revising, tinkering, repealing of laws should engross the attention and engage the entire energy of such a body as Congress. It is, however, easy to see how it might be better employed; or, at least, how it might add others to this overshadowing function, to the infinite advantage of the government. Quite as important as legislation is viligant oversight of administration; and even more important than legislation is the instruction and guidance in political affairs which the people might receive from a body which kept all national concerns suffused in a broad daylight of discussion. There is no legislature in existence which is so shut up to the one business of law-making as is our Congress." 46
\end{abstract}

Naast de wetgevende functie heeft het Congres, zo betoogt Wilson, dus ook een controlerende in de zin van toezichthoudende functie (niet controle over, maar controle van de uitvoerende macht). Vanuit democratisch oogpunt is deze 'oversight' functie, zo vervolgt Wilson, zelfs van groter gewicht dan de wetgevende. Naar het voorbeeld van het Britse parlement, waar inmiddels de beginselen van ministeriële verantwoordelijkheid tot ontwikkeling waren gekomen, zou het Congres zich vanuit zijn democratische positie als volksvertegenwoordiging juist daarop moeten concentreren:

\footnotetext{
"It is the proper duty of a representative body to look diligently into every affair of government and to talk much about what it sees. It is meant to be the eyes and the voice, and to embody the wisdom and will of its constituents. Unless Congress have and use every means of acquainting itself with the acts and the disposition of the administrative agents of the government, the country must be helpless to learn how it is being served... (...) The informative function of Congress should be preferred even to its legislative function. The argument is not only that discussed and interrogated administration is the only pure and efficient administration, but, more than that, that the only really self-governed people is that people which discusses and interrogates its administration." 47
}

Met zijn roep om meer aandacht voor 'vigilant oversight of administration' bleek Wilson zijn tijd vooruit te zijn. Tegen het einde van de negentiende eeuw begon de verhouding tussen Congres, President en de uitvoerende diensten te veranderen. De omvang van het federale bestuur groeide snel en de politieke positie van de President werd sterker. In eerste instantie (de jaren '20 van de twintigste eeuw) leidde dit

\footnotetext{
${ }^{45}$ Aberbach 1990, p. 19-20.

${ }^{46}$ Wilson 1885, p. 194-195.

47 Wilson 1885, p. 198.
} 
tot een grotere samenwerking tussen Congres en President ten aanzien van de controle van en over het uitvoerende apparaat. ${ }^{48}$ Het Congres richtte in deze periode, ter ondersteuning van zijn toezichthoudende functie, een eigen budgettair onderzoeksbureau op: de General Accounting Office (GAO) geheten. ${ }^{49}$

De regeerperiode van President Franklin D. Roosevelt (1933-1945), die gepaard ging met een explosieve groei van het bestuursapparaat als gevolg van de New Deal en de Tweede Wereldoorlog, vormde echter een keerpunt. De invloed van de President op de departementen en agentschappen nam, mede dankzij zijn sterk gegroeide stafdiensten in het Witte Huis, in deze periode sterk toe. De positie van het Congres kwam onder druk te staan, enerzijds vanwege de toegenomen invloed van de President, anderzijds vanwege de grotere beleidsvrijheid die het Congres noodgedwongen aan het bestuursapparaat verleende bij de uitvoering van de nieuwe, grootschalige overheidstaken. ${ }^{50}$

\subsubsection{Versterking congressioneel toezicht}

De vanzelfsprekendheid waarmee het Congres invloed en controle uitoefende over de uitvoerende macht verdween dus in de loop van de twintigste eeuw als gevolg van de ontwikkeling van presidentieel leiderschap gecombineerd met een sterke groei van het uitvoerende apparaat. In reactie op het verlies aan politieke invloed en zeggenschap over de uitvoerende macht nam het Congres maatregelen om het tij te keren. Dit gebeurde in de vorm van de Legislative Reorganization Act, die in 1946 werd aangenomen. ${ }^{51}$

Kenmerkend element in deze wet is de uitdrukkelijke institutionalisering van de congressionele toezichtstaak: de wet gaf de vaste commissies in het Huis en de Senaat de taak om "continuous watchfulness" uit te oefenen ten aanzien van de uitvoering van wetgeving en beleid dat tot hun werkterrein behoorde. ${ }^{52}$ Alle commissies kregen bovendien permanente ambtelijke en professionele ondersteuning. Daarnaast

\footnotetext{
48 Aberbach 1990, p. 21.

${ }^{49}$ Het General Accounting Office (GAO) werd opgericht in 1921 door middel van de Budget and Accounting Act 1921 en kreeg de opdracht "to investigate ... all matters relating to the receipt, disbursement, and application of public funds." 42 Stat. 25-26 (1921). Sinds 2004 staat GAO voor Government Accountability Office. Zie uitvoerig hierna, par. 3.4.3.

50 Aberbach 1990, p. 22.

${ }^{51}$ De Legislative Reorganization Act 1946 kan worden gezien als een poging de politieke verhoudingen tussen President en Congres ten aanzien van de uitvoerende macht te herstellen. In hetzelfde jaar werd de Administrative Procedure Act (APA) aangenomen, waarin bestuursrechtelijke voorschriften werden geformuleerd die betrekking hebben op de vele administratieve diensten die inmiddels waren ontstaan. Ook dit kan worden gezien als een reactie op de groei van het federale bestuursapparaat, al heeft deze wet met name betrekking op de relatie tussen de uitvoerende macht en de burger. Zie ook Tiefer 1998a, p. 203 e.v.

52 De betreffende bepaling (sec. 136) luidt: "To assist the Congress in appraising the administration of the laws and in developing such amendments or related legislation as it may deem necessary, each standing committee of the Senate and the House of Representatives shall exercise continuous watchfulness of the execution by the administrative agencies concerned of any laws, the subject matter of which is within the jurisdiction of such committee ; and, for that purpose, shall study all pertinent reports and data submitted to the Congress by the agencies in the executive branch of the Government." 60 Stat. 832 (1946).
} 
werd de Legislative Reference Service opgericht, sinds 1970 de Congressional Research Service (CRS) genaamd, die als onderdeel van de Library of Congress de taak kreeg "to advise and assist any committee of either House or joint committee in the analysis, appraisal, and evaluation of any legislative proposal ... and otherwise assist in furnishing a basis for the proper determination of measures before the committee." 53

In de periode van 1946 tot aan de jaren '60 leek de nieuwe, toezichtgerichte koers van het Congres nog van beperkte betekenis. In de weinige literatuur die in deze periode verscheen over dit onderwerp komt een gemengd beeld naar voren. Sommigen benadrukken de toename van het aantal toezichtsactiviteiten na 1946, anderen wijzen erop dat congressioneel toezicht in vergelijking met andere activiteiten nog steeds van beperkte betekenis was. ${ }^{54}$ Bovendien bleek het versterken van de congressionele toezichtsfunctie niet onomstreden te zijn. Zo werd de toename van het aantal congressionele toezichts- en onderzoeksactiviteiten wel gezien als een teken van een te bemoeizuchtig Congres, dat via gedetailleerde wetgeving en intensief toezicht zowel vooraf als achteraf de effectiviteit van de uitvoerende macht negatief zou beïnvloeden. Deze klacht sloot aan bij de gedachte die destijds in de (bestuurskundige) literatuur overheerste, namelijk dat het federale bestuursapparaat het meest gebaat zou zijn bij een heldere, eenduidige aansturing door de President. Die zou, voorzien van goede ondersteuning en in samenspraak met de departementale leiding, het publieke belang veel beter kunnen dienen dan het verstokte, gedecentraliseerde Congres. Deze scepsis ten aanzien van congressioneel toezicht werd verder gevoed door de ervaringen met congressionele onderzoeksactiviteiten in de jaren ' 50 , toen de beruchte communistenjacht van de House Unamerican Activities Committee en de commissie van Senator McCarthy op zijn hevigst was. ${ }^{55}$

In de jaren '70 nam het Congres opnieuw maatregelen om haar rol als toezichthouder te versterken. Dit gebeurde tegen de achtergrond van de nieuwe groeiimpuls van het federale bestuursapparaat in het kader van President Johnsons 'Great Society'. In eerste instantie waren het vooral de Republikeinen die bezorgd waren over de groeiende overheidsbemoeienis, maar naarmate de buitenlandse en binnenlandse politiek van Johnson aan populariteit verloor, raakten ook steeds meer Democraten in het Congres overtuigd van de noodzaak van goed toezicht op de uitvoerende macht. De aggressieve pogingen van Johnsons opvolger, President Nixon, om de presidentiële invloed op de uitvoerende macht te vergroten, leidden uiteindelijk tot nieuwe maatregelen om de rol van het Congres als toezichthouder te versterken en te stimuleren. ${ }^{56}$

In 1970 werd als uitvloeisel daarvan de Legislative Reorganization Act gewijzigd. Sindsdien bepaalt de wet dat iedere vaste commissie in het Huis of de Senaat "shall review and study, on a continuing basis, the application, administration, and execution of those laws or parts of laws, the subject of which is within the jurisdiction

\footnotetext{
${ }^{53}$ Legislative Reorganization Act, sec. 203, 60 Stat. 836 (1946).

54 Aberbach 1990, p. 24.

55 Aberbach 1990, p. 24-25.

56 Aberbach 1990, p. 27.
} 
of that committee." 57 Bovendien kregen de meeste commissies de opdracht om tweejaarlijks 'oversight reports' te publiceren: commissies dienen sindsdien dus periodiek inzicht te geven in hun toezichtsactiviteiten. Ook werd de ambtelijke en professionele ondersteuning van de commissies verder uitgebouwd en werden de taken van de Government Accounting Office en de Congressional Research Service uitgebreid. ${ }^{58}$ In 1974 werd het toezicht op de uitvoerende macht opnieuw versterkt. Met de inwerkingtreding van de Congressional Budget Act 1974 kunnen commissies in de Senaat en het Huis de controle en evaluatie van beleidsprogramma's contractueel uitbesteden of de uitvoerende overheidsinstellingen opdracht geven zelf evaluaties te verrichten en daarover te rapporteren aan het Congres. Verder werden bij deze gelegenheid de bevoegdheden van de GAO verder versterkt. Ook werden in beide Huizen budgetcommissies ingesteld en ter ondersteuning het Congressional Budget Office (CBO) opgericht, die de bevoegdheid kreeg "to secure information, data, estimates, and statistics directly from the various departments, agencies, and establishments". 59

\subsubsection{Toezichtsorganisatie: vaste commissies}

Sinds de herziening van Legislative Reorganization Act in 1970, zo bleek hierboven, bepaalt de wet dat de vaste commissies voortdurend ("on a continuing basis") de uitvoering ("application, administration, and execution") van wetgeving binnen hun werkterrein dienen te onderzoeken en bestuderen ("review and study").

Het houden van toezicht op de uitvoerende macht is daarmee het terrein van de vaste commissies ('standing committees') in beide kamers. De taken van de vaste commissies zijn uitgewerkt in de interne kamerregels: de House Rules en de Senate Rules. De Rules regelen de instelling, bevoegdheden en werkterrein van de verschillende commissies. De commissies zijn belast met wetgevende taken, autoriserende (wetgevende) taken en toezichthoudende taken binnen hun respectievelijke werkterreinen. ${ }^{60}$ Veel commissies maken gezien de omvang van de werkzaamheden gebruik van verschillende subcommissies. Het aantal subcommissies is groot: zo kende het Huis in de periode 2007-2009 (het 110e Congres) 20 vaste commissies met in totaal 99 subcommissies; in de Senaat bestonden 16 vaste commissies met in totaal 72 subcommissies. Bij sommige commissies, met name in het Huis, wordt het toezichthoudende werk gecentreerd in één subcommissie voor 'oversight'; de wetgevende taken worden dan verdeeld over de andere subcommissies. Beide kamers kennen voorts één vaste commissie die toezicht houdt op de doelmatigheid en efficiency van alle federale departementen en agentschappen gezamenlijk. 61

\footnotetext{
${ }^{57}$ Legislative Reorganization Act 1970, Sec. 136 (a), 84 Stat. 1156 (1970).

${ }^{58}$ Legislative Reorganization Act 1970, Sec. 204 e.v., 301-304, 84 Stat. 1168-1180 (1970).

${ }^{59}$ Congressional Budget Act 1974, Sec. 201(d), 202 (a), 88 Stat. 302-329 (1974).

${ }^{60}$ De vaste commissies in het Huis zijn ingesteld op grond van House Rule X, lid 1, sub a-t (111th Congr.); in de Senaat is dit geregeld in Senate Rule XXV, lid 1, sub a-p. In elk Huis is één vaste commissie uitsluitend belast met 'appropriations', een (bijzondere) wetgevende taak.

${ }^{61}$ Het betreft de Senate Committee on Homeland Security and Governmental Affairs, zie Senate Rule XXV (k) (111 th Congr.) en de House Committee on Oversight and Government Reform, zie House Rule X (111 th Congr.).
} 


\subsubsection{Toezichtsinstrumentarium: het onderzoeksrecht}

Parlementaire controleinstrumenten die in Europese parlementaire stelsels bijna als vanzelfsprekend worden gezien, het vragenrecht en het debatrecht, zijn in het Amerikaanse stelsel van gescheiden machten nooit tot ontwikkeling gekomen. ${ }^{62}$ Heel verwonderlijk is dit niet: deze instrumenten zijn er vooral op gericht de ministeriële verantwoordelijkheid te activeren en zoals bekend ontbreekt een dergelijk beginsel in het constitutionele recht van de Verenigde Staten. Het belangrijkste formele instrument waarover het Congres beschikt in de uitoefening van zijn toezichthoudende taak is het congressionele onderzoeksrecht. Onderzoeksactiviteiten, zoals het houden van hoorzittingen, behoren dan ook tot de dagelijkse praktijk van het congressionele toezicht op de uitvoerende macht.

Het congressionele onderzoeksrecht heeft oude papieren. Al in 1792 stelde het Huis een speciale commissie in die onderzoek moest doen naar de oorzaken van een desastreus verlopen veldtocht van generaal St. Clair. Het Supreme Court noemde de congressionele "power of inquiry - with process to enforce it" in een standaardarrest uit 1927 een impliciete bevoegdheid die zelfs al voor de inwerkingtreding van de Constitutie door deelstaatparlementen werd toegepast en hoort bij de wetgevende functie van het Congres. ${ }^{63}$ Dit onderzoeksrecht, zo voegde het Hof hier later aan toe, is erg breed en kan zowel betrekking hebben "the administration of existing laws as well as proposed or possibly needed statutes." 64 Het onderzoeksrecht is daarmee sterk verbonden met de toezichtsfunctie van het Congres, maar kan dus eveneens worden ingezet om de wenselijkheid of noodzakelijkheid van nieuwe wetgeving te onderzoeken.

In zowel het Huis als de Senaat is de bevoegdheid om 'investigations' uit te voeren uitdrukkelijk gedelegeerd aan de vaste commissies. ${ }^{65}$ Voorafgaande toestemming van de plenaire vergadering voor het houden van een onderzoek is dus niet nodig. Daarnaast maken beide Kamers zo nu en dan gebruik van bijzondere commissies ('select committees') voor dit soort onderzoeken. Enkele van bekendste congressionele onderzoeken uit de Amerikaanse geschiedenis zijn uitgevoerd door tijdelijke, bijzondere commissies. Bekende voorbeelden hiervan zijn de Senate Watergate Select Committee (1973) en de House Select Bipartisan Committee naar aanleiding van de orkaan Katrina (2005). Tijdelijke onderzoekscommissies zijn echter uitzonderlijk; het leeuwendeel van het onderzoek in het Congres wordt verricht door de vaste commissies.

\footnotetext{
62 In beide kamers van het Congres wordt weliswaar veelvuldig plenair gedebatteerd, maar daarbij zijn nooit ministers of andere functionarissen behorende tot de uitvoerende macht aanwezig. Enige uitzondering vormt de vice-president, die als voorzitter van de Senaat soms een vergadering bijwoont.

${ }^{63}$ McGrain v. Daugherty, 273 U.S. 135, 174 (1927).

${ }^{64}$ Watkins v. United States, 354 U.S. 178, 187.

65 Zie House Rule XI, lid 1, sub (b)(1) ("Each committee may conduct at any time such investigations and studies as it considers necessary or appropriate in the exercise of its responsibilities under rule X.") en Senate Rule XXVI, lid 1 ("Each standing committee ... may make investigations into any matter within its jurisdiction...").
} 
De wijze waarop de vaste commissies hun onderzoeksbevoegdheden inzetten in het kader van de opgedragen toezichtstaak is zeer verschillend en hangt af van het onderwerp en het kader waarbinnen het onderzoek plaatsvindt. Een congressioneel onderzoek kent, anders dan parlementaire onderzoeken in het Verenigd Koninkrijk en Nederland, dan ook geen geijkte vorm of doelstelling. ${ }^{66}$ Soms blijft het toezicht beperkt tot een bescheiden hoorzitting met een secretary of state, agency director of andere ambtenaren binnen de uitvoerende macht in het kader van een herautorisatie of budgettoekenningsprocedure. In andere gevallen, vooral wanneer er vermoedens zijn van falend overheidsbeleid of concrete misstappen, maken commissies of subcommissies er meer werk van en worden bijvoorbeeld grote hoeveelheid documenten opgevraagd, hoorzittingen belegd met betrokkenen en experts en rapporten uitgebracht.

In de literatuur wordt daarom wel onderscheid gemaakt tussen twee typen toezicht: 'legislative oversight' en 'investigative oversight'. ${ }^{67}$ Van 'legislative oversight', dat een vrij regelmatig karakter heeft, wordt gesproken wanneer een congrescommissie bijvoorbeeld nagaat of wetgeving op de beoogde wijze door de betrokken uitvoerende instellingen is geïmplementeerd, beleidsdoelen zijn gehaald of de toegekende budgetten zijn aangewend zoals bedoeld. Het zogenaamde 'investigative oversight' is daarentegen veel incidenteler van aard en "typically involves examining allegations of corruption or malfeasance within an individual department or by a specific official." 68 Het karakter van het onderzoekend toezicht verschilt dan ook aanzienlijk van het reguliere toezicht, zo stelt Rosenberg:

\footnotetext{
"The adversarial, often confrontational, and sometimes high profile nature of congressional investigations sets it apart from the more routine, accommodative facets of the oversight process experienced in authorization, appropriations or confirmation exercises." 69
}

Dit soort onderzoeken naar corruptie of andere misstappen binnen de uitvoerende macht staat volgens Pray niet direct in verband met de reguliere taken van congrescommissies op het gebied van wetgeving en begroting. Het gaat in eerste instantie om het vaststellen van feiten, zonder dat tevoren vaststaat dat of (en zo ja, welke) maatregelen op wetgevingsterrein nodig zijn.70

In de Amerikaanse doctrine wordt de term 'congressional investigation' vaak gereserveerd voor de meer omvangrijke, op zichzelf staande onderzoeken van het tweede type. Onderzoek speelt echter, als gezegd, ook in het meer reguliere toezicht een belangrijke rol. Deze reguliere onderzoeksactiviteiten zijn niet persé minder uitvoerig, kritisch of indringend van aard. Verder kunnen ook losstaande onderzoeken van het tweede type worden gebruikt als aanleiding voor nieuwe wetgeving of con-

\footnotetext{
${ }^{66}$ Zie ook Kaiser, Oleszek \& Tatelman 2011, p. 27.

67 Zie Pray 2005, p. 306. Eberling maakt een vergelijkbaar onderscheid tussen 'judicial investigations', gebaseerd op "the enumerated privileges of Congress" enerzijds en 'legislative investigations', gericht op "the administration of the law" dan wel "securing information to aid in the making of legislation" anderzijds. Eberling 1928, p. 229. Zie ook Auchincloss 2006, p. 165-166.

68 Pray 2005, p. 307.

${ }^{69}$ Rosenberg 2007, p. 1.

70 Pray 2005, p. 307.
} 
sequenties hebben voor de inrichting en budgetten van de betrokken uitvoerende diensten. ${ }^{71}$ De grens tussen regulier toezicht en een volwaardig onderzoek is daarom moeilijk te trekken. Zowel in de literatuur als in de praktijk worden de begrippen 'oversight' en 'investigation' dan ook vaak in een adem genoemd en door elkaar gebruikt. ${ }^{72}$

\subsubsection{Andere vormen van toezicht}

Naast het verrichten van onderzoeksactiviteiten hebben de vaste commissies in de loop der tijd ook allerlei andere instrumenten en werkwijzen ontwikkeld om uitvoering te geven aan hun toezichtsfunctie. Uit onderzoek van Aberbach blijkt dat commissies bijvoorbeeld veel gebruik maken van informele middelen, waaronder het onderhouden van contacten tussen de staf van de commissie en functionarissen binnen de betreffende uitvoerende diensten. ${ }^{73}$ Daarnaast beschikt het Congres als gezegd over een aantal eigen onderzoeksinstellingen, die al dan niet op verzoek van de commissies onderzoek doen en evaluaties uitvoeren op allerlei terreinen. Een bijzonder - en constitutioneel omstreden - instrument dat een toezichtsfunctie kan hebben is het zogenaamde 'legislative veto': het Congres behoudt zich het recht voor een veto uit te kunnen spreken over uitvoeringsmaatregelen die federale diensten nemen in het kader van de discretionaire ruimte die de wet hen toekent. ${ }^{74}$

Met de groei van het federale overheidsapparaat heeft het Congres steeds meer interne toezichtsmechanismen bij departementen en zelfstandige diensten ingebouwd. Dit heeft onder meer geresulteerd in allerlei periodieke rapportageverplichtingen aan de toezichthoudende congrescommissies in beide kamers. ${ }^{75}$ Belangrijk is ook de functie van Inspector General (IG), die vanaf de jaren 70 in veel federale instellingen is geïntroduceerd. IG's hebben een grote mate van zelfstandigheid, beschikken over eigen personeel en zijn bevoegd audits en andere onderzoeken uit te

\footnotetext{
71 Zie bijvoorbeeld het 'investigative report' inclusief talloze bijlagen getiteld 'TSA Ignores More CostEffective Screening Model' (2011) van de House Committee on Transportation and Infrastructure, naar eigen zeggen verantwoordelijk voor 'general oversight' van de Transportation Security Administration (TSA), waarin de commissie zeer kritisch is over het wettelijke ingekaderde beleid van de TSA op het gebied van de screening van vliegtuigpassagiers.

72 Voor een volledig beeld van de Amerikaanse onderzoekspraktijk wordt in het navolgende het begrip congressioneel onderzoek in brede zin gebruikt, in die zin dat daaronder ook onderzoeksactiviteiten die als regulier kunnen worden bestempeld worden begrepen. Vgl. Boon 1982, p. 11, noot 1, die onder het begrip parlementaire enquête in de Amerikaanse context alleen 'full-dress investigations' schaart.

${ }^{73}$ Aberbach 1990, p. 132.

${ }^{74}$ Hoewel het Supreme Court het legislative veto in de zaak INS $v$. Chadha (1983) ongrondwettig verklaarde, is het in de praktijk allerminst verdwenen. Zie hierover uitvoerig: Fisher 2007, p. 137-154.

75 Dit heeft ertoe geleid dat thans jaarlijks ongeveer 4.000 rapporten naar het Congres worden gestuurd omtrent het gevoerde en te voeren beleid, overzichten van verrichte werkzaamheden of de voortgang van specifieke projecten of hervormingen. Pogingen om de onvermijdelijke doublures en als onnodig ervaren rapportages te verminderen, hebben door de komst van steeds weer nieuwe rapportageverplichtingen tot op heden weinig effect gehad. Zie Kaiser, Oleszek \& Tatelman 2011, p. 95100 , waar ook een overzicht van andere, uit wetgeving voortvloeiende informatiebronnen te vinden is.
} 
voeren, zowel inzake effectiviteit en efficiency als mogelijke vormen van fraude of misbruik. ${ }^{76}$

Tot slot moet nog worden gewezen op de zogenaamde 'blue ribbon commissions'. Dit zijn bijzondere, ad hoc commissies die zo nu en dan worden ingesteld. Daarbij gaat het soms om commissies met een adviserende functie, maar het kan ook gaan om een commissie die is ingesteld om een diepgravend feitenonderzoek te verrichten naar aanleiding van een gebeurtenis die voor veel maatschappelijke onrust heeft geleid. Voorbeelden van die laatste categorie zijn de Warren Commission naar aanleiding van de moord op President Kennedy en de zogenaamde 9/11 Commission, die de terroristische aanslagen op 11 september 2011 onderzocht. Soms gaat het daarbij om commissies die zijn ingesteld bij presidentieel besluit, soms gaat het om commissies ingesteld bij wet, waarbij dus ook het Congres betrokken is; dat laatste is overigens noodzakelijk wanneer de commissie over de nodige dwangmiddelen moet kunnen beschikken bij de uitvoering van haar onderzoek. ${ }^{77}$

Er zijn verschillende redenen denkbaar voor het instellen van een dergelijke commissie. Het is vaak de President die het initiatief neemt tot een extern onderzoek, bijvoorbeeld om een eventueel congressioneel onderzoek voor te zijn, zeker wanneer congrescommissies worden gedomineerd door de andere partij. Het Congres is wat minder snel geneigd het initiatief te nemen tot dergelijke commissies; het beschikt immers over een eigen onderzoeksbevoegdheid en de betrokken commissies zijn niet snel geneigd daarvan af te zien. Soms kan een onderzoek door partijpolitiek gekleurde congrescommissies toch als onwenselijk worden gezien gelet op de ernst en aard van het onderwerp, of wordt reeds gevoerd congresonderzoek als onbevredigend ervaren. In dergelijke gevallen kan ook meespelen dat het Congres samen met de President wil optrekken, om in de nasleep van bepaalde traumatische gebeurtenissen een zekere mate van eenheid en onpartijdigheid uit te stralen; niet voor niets krijgen dergelijke commissies vaak de titel 'National Commission'. ${ }^{78}$

\subsection{Conclusie}

In dit hoofdstuk zijn enkele fundamenten in het Amerikaanse politieke stelsel aan de orde gekomen. In de Amerikaanse Constitutie is een stelsel van gescheiden, elkaar controlerende machten neergelegd, waarbij het Congres de wetgevende macht toekomt en in de President de uitvoerende macht is gevestigd.

\footnotetext{
76 Dit gebeurt op basis van de Inspector General Act 1978, herzien in 2008. Zie nader: Kaiser, Oleszek \& Tatelman 2011, p. 84 e.v.

77 Het blijkt ook mogelijk om een commissie, die bij presidentieel besluit is ingesteld, nadien dwangmiddelen (te weten subpoena- en immuniteitsbevoegdheden) toe te kennen middels een gezamenlijke resolutie van Huis en Senaat, zoals het geval was bij de genoemde Warren Commission. Zie Cole \& Brand 2011, p. 458.

78 Een gezamenlijk initiatief van President en Congres, waarbij het onderzoek wordt opgedragen aan een externe commissie van wederzijds vertrouwde personen, kan er ook voor zorgen dat de betrokken uitvoerende diensten beter medewerking verlenen dan wanneer een onderzoek door een (de President vijandige) congrescommissie wordt verricht. Zie verder Cole \& Brand 2011, p. 455-456 en 479 480 .
} 
Het hierboven geschetste constitutionele bestel en de politieke werkelijkheid daaromheen plaatst het ambtelijke apparaat van de uitvoerende macht in een gecompliceerde positie. De benoeming van (hogere) ambtenaren binnen de uitvoerende macht, inclusief de hoofden van de departementen en zelfstandige diensten, is in handen van zowel de President als de Senaat. De President gaat over hun ontslag, maar voor de inrichting, taken en bekostiging zijn de federale diensten uiteindelijk afhankelijk van het Congres. Dit maakt de verhouding tussen regering en parlement wezenlijk anders dan die in Nederland en het Verenigd Koninkrijk. Ministeriële verantwoordelijkheid als organisatieprincipe en scharnierpunt ontbreekt in de Verenigde Staten. Van een eenduidige, hiërarchische gezagsstructuur binnen de uitvoerende macht is dan ook geen sprake. Door het ontbreken van een politieke vertrouwensrelatie in combinatie met een zwak ontwikkeld partijenstelsel is samenwerking en coördinatie tussen President en Congres, zelfs al is een meerderheid in beide kamers van dezelfde partij, allerminst verzekerd. In de praktijk betekent dit dat federale diensten voortdurend moeten laveren tussen de wensen van de President en die van het Congres, in het bijzonder van de vaste commissies in Huis en Senaat.

De Constitutie kent het Congres nergens expliciet de bevoegdheid toe om toezicht te houden op de uitvoerende macht. Niet ter discussie staat echter dat het Congres over deze bevoegdheid beschikt: het kunnen houden van toezicht op de uitvoerende macht wordt gezien als een vanzelfsprekende component van de constitutionele taken die het Congres ten aanzien van de inrichting en bekostiging van de uitvoerende diensten verricht. Vergeleken met veel Europese parlementaire stelsels beschikt het Congres niet over veel formele instrumenten om zijn toezichtstaak uit te oefenen. Het belangrijkste is het congressionele onderzoeksrecht, dat al sinds het prille begin van de Amerikaanse republiek wordt toegepast en aan de vaste commissies in beide kamers is gedelegeerd. Van dit onderzoeksrecht wordt op verschillende momenten en met wisselende intensiteit gebruik gemaakt. Daarnaast heeft het Congres verschillende andere toezichtsmechanismen ontwikkeld, variërend van het onderhouden van informele contacten tussen ambtenaren van congrescommissies en uitvoerende diensten en het inzetten van de vaste onderzoeksinstellingen van het Congres tot het creëren van toezichtsorganen binnen de uitvoerende macht en incidenteel het instellen van onafhankelijke commissies van wijzen. 


\section{Hoofdstuk 2. Onderzoeksrecht en onderzoeksbevoegdheden}

\subsection{Inleiding}

In de vorige paragraaf zijn de voornaamste constitutionele en politieke functies van het Congres aan de orde gekomen. Het Congres blijkt intensief betrokken te zijn bij de vaststelling van wetgeving en beleid, de inrichting en budgettering van de uitvoerende macht, en het toezicht op de uitvoerende macht. Ter uitoefening van deze functies beschikt het Congres over het recht om onderzoek te doen. Dit recht staat als zodanig nauwelijks nog ter discussie. Zo overwoog het Hooggerechtshof in 1957 ten aanzien van het congressionele onderzoeksrecht: "That power is broad. It encompasses inquiries concerning the administration of existing laws as well as proposed or possibly needed statutes. It includes surveys of defects in our social, economic or political system for the purpose of enabling the Congress to remedy them. It comprehends probes into departments of the Federal Government to expose corruption, inefficiency or waste." 1

Toch was deze ruim geformuleerde opvatting van het congressionele onderzoeksrecht niet altijd zo vanzelfsprekend. Bovendien heeft de wijze waarop het onderzoeksrecht in het midden van de twintigste eeuw is toegepast door bijvoorbeeld de House Un-American Activities Committee en de commissie onder leiding van Senator Joseph McCarthy, geleid tot veel kritiek. De positie van getuigen stond daarbij nadrukkelijk ter discussie. Dit heeft geleid tot een nadere, rechterlijke afbakening van het onderzoeksrecht. In deze paragraaf staat de juridische betekenis van het recht van onderzoek centraal. Allereerst wordt het onderzoeksrecht in historische perspectief geplaatst. Nagegaan wordt wat de (constitutionele) grondslag van het onderzoeksrecht is en hoe het denken over congressioneel onderzoek zich heeft ontwikkeld. Vervolgens wordt bezien hoe dit onderzoeksrecht is vertaald in onderzoeksbevoegdheden. Tenslotte wordt nagegaan welke juridische grenzen het onderzoeksrecht kent, met name bezien vanuit de positie van getuigen. De positie van de uitvoerende macht, in het bijzonder de President, komt daarbij afzonderlijk aan de orde.

\subsection{Grondslag van het onderzoeksrecht}

\subsubsection{Vroege ontwikkeling}

In het vorige hoofdstuk bleek reeds dat niet ter discussie staat dat het Congres een recht van onderzoek bezit, al bevat de Constitutie hieromtrent geen uitdrukkelijke

${ }^{1}$ Watkins v. United States, 354 U.S. 178, 187 (1957). Zie ook Grabow 1988, p. 79. 
bepalingen. Aangenomen wordt dat de opstellers van de Constitutie tijdens de conventie in Philadelphia het niet nodig achtten om het onderzoeksrecht van het Congres uitdrukkelijk te regelen, omdat dit een vanzelfsprekende bevoegdheid van een parlement zou zijn. ${ }^{2}$ Ook de parlementaire praktijk laat vanaf het prille begin van de Amerikaanse republiek zien dat beide Kamers er niet aan twijfelen dat zij een onderzoeksrecht bezitten. Het Congres nam hiermee een houding aan die al veel langer gangbaar was in de parlementen van de verschillende deelstaten. Die verrichtten reeds in de koloniale tijd verschillende parlementaire onderzoeken. De bevoegdheid hiertoe werd afgeleid uit het Britse parlementsrecht, waarin het parlementaire onderzoeksrecht inmiddels tot ontwikkeling was gekomen. ${ }^{3}$ De onafhankelijkheid veranderde hieraan niets. In sommige deelstaatconstituties werd het onderzoeksrecht uitdrukkelijk vermeld, terwijl in andere deelstaten algemeen werd aangenomen dat het deelstaatparlement dit recht bezat. ${ }^{4}$

Het eerste congressionele onderzoek op federaal niveau dateert van 1792, toen het Huis van Afgevaardigden een onderzoekscommissie instelde naar aanleiding van een zware nederlaag van generaal St. Clair in een slag met indianen in het Ohiogebied. Een bijzondere ('select') commissie werd ingesteld "to inquire into the causes of the failure of the late expedition under Major General St. Clair; and that the said committee be empowered to call for such persons, papers, and records, as may be necessary to assist their inquiries." Een eerder voorstel om dit onderzoek te laten uitvoeren door de President, haalde het niet; een dergelijke opdracht aan de President werd geacht in strijd te zijn met de constitutionele verdeling van machten. ${ }^{5}$

Verschillende andere onderzoeken, steeds betrekking hebbende op het functioneren van de uitvoerende macht, volgden spoedig daarna in zowel Huis als Senaat. ${ }^{6}$ Na de Amerikaanse burgeroorlog (1860-1865) ontstaat een piek in het aantal congressionele onderzoeken. In minder dan tien jaar verrichtte het Congres 37 onderzoeken naar gevallen van wanbestuur. ${ }^{7}$ De onderzoekspraktijk kwam werkelijk tot bloei in de twintigste eeuw met de opkomst van de massamedia. ${ }^{8}$ Pas toen begon het onderzoeksrecht ook in de rechtspraak een rol te spelen.

\subsubsection{Rechterlijke bevestiging}

\subsubsection{Restrictief begin: Kilbourn $v$. Thompson (1881)}

De eerste uitspraak van het Supreme Court in het kader van een congressioneel onderzoek kwam in 1881. Getuige Kilbourn weigerde medewerking te verlenen aan een onderzoekscommissie in het Huis van Afgevaardigden, die de opdracht had om onderzoek te doen naar het faillissement van een onderneming die grote sommen geld schuldig was aan de federale overheid. Daarvoor had het Huis de commissie de be-

\footnotetext{
2 Zie Taylor 1955, p. 12-13. Enkele deelstaten legden het onderzoeksrecht van hun parlementen wel uitdrukkelijk vast. Boon 1982, p. 11-12.

${ }^{3}$ Grabow 1988, p. 16-17.

${ }^{4}$ Zie ook Eberling 1928, p. 27.

${ }^{5}$ Grabow 1988, p. 18-19. Zie ook Boon 1982, p. 12.

${ }^{6}$ Boon 1982, p. 12-13.

7 Boon 1982, p. 13-14.

${ }^{8}$ Cole \& Brand 2011, p. 3-4.
} 
voegdheid verleend "to send for persons and papers and report to this House". Kilbourn werd door het Huis schuldig bevonden aan 'contempt'. ${ }^{9}$ De zaak belandde uiteindelijk bij het Supreme Court, dat concludeerde dat het onderzoek "in its nature clearly judicial" was. ${ }^{10}$ Het onderzoek kon volgens het Hof op geen enkele manier in verband worden gebracht met een expliciete constitutionele bevoegdheid van het Huis, zoals het vaststellen van de uitslag van verkiezingen of het vervolgen van federale functionarissen op grond van 'impeachment'. Uit de resolutie waarmee het onderzoek en de commissie werden ingesteld werd bovendien niet duidelijk welk ander legitiem doel het onderzoek zou moeten dienen. Hoe dan ook, zo merkte het Hof terloops op, zou een "fruitless" onderzoek louter gericht op het onderzoeken van private aangelegenheden (in casu een faillissementskwestie) de bevoegdheden van het Huis te buiten gaan. ${ }^{11}$ Met "fruitless" bedoelde het Hof: "...that it could result in no valid legislation on the subject to which the inquiry referred." 12 Het Hof oordeelde dat het Huis in deze zaak zijn legitieme bevoegdheden overschreden had en dat de veroordeling en detentie van Kilbourn wegens 'contempt' daarmee onrechtmatig waren. ${ }^{13}$

Met het Kilbourn-arrest werden de eerste contouren van het congressionele onderzoeksrecht zichtbaar. Het Hof ging duidelijk uit van een zeer beperkt onderzoeksrecht. ${ }^{14}$ In de enige andere relevante uitspraak in deze periode werd slechts bevestigd dat het Congres in elk geval bevoegd is onderzoek te doen naar mogelijke corruptie of onregelmatigheden binnen de eigen gelederen. ${ }^{15}$

In de jaren '20 van de twintigste eeuw veranderde de houding van het Hof. Aanleiding was het zogenaamde Teapot Dome-schandaal, één van de grootste corruptieschandalen uit de Amerikaanse geschiedenis. ${ }^{16}$ Een hieraan gerelateerd onderzoek vormde de achtergrond van de eerste principiële uitspraak van het Hooggerechtshof omtrent het congressionele onderzoeksrecht. Het ging om een onderzoek van een bijzondere Senaatscommissie naar de gebrekkige wijze waarop het ministerie van Justitie optrad in de Teapot Dome-zaak. ${ }^{17}$ Daugherty, een broer van

\footnotetext{
9 Beide Huizen beschikken in beginsel over de bevoegdheid om personen te straffen wegens 'contempt'. Zie hierna, par 2.3.2. Zie ook Boon 1982, p. 19 e.v.

${ }^{10}$ Kilbourn v. Thompson, 103 U.S. 168, 192 (1881)

11103 U.S. 168, 194 (1881).

12103 U.S. 168,194 (1881).

13103 U.S. 168, 195 (1881). In hoeverre het Huis of de Senaat hun 'contempt power' kunnen inzetten in het kader van hun wetgevende functie, laat het Hof overigens uitdrukkelijk in het midden. 103 U.S. 168,189 (1881).

${ }^{14}$ Ook bevestigde deze uitspraak dat het Hof zich bevoegd achtte de uitoefening van deze congressionele bevoegdheid te toetsen aan de Constitutie. Zie Hamilton 1976, p. 109.

${ }^{15}$ In re Chapman, 166 U.S. 661 (1897). Het ging om een onderzoek naar de handel en wandel van een aantal Senatoren, die betrokken waren bij mogelijke speculatie rondom de suikerprijs, terwijl juist een nieuwe heffingswet in het Congres werd behandeld. Dit onderzoek vond plaats in het kader van het constitutionele recht (Artikel I, lid 5, sub 2) de eigen leden te straffen of uit te sluiten wegens "disorderly behavior."

${ }^{16}$ De minister van Binnenlandse Zaken Albert Fall zou geld hebben aangenomen van oliehandelaren in ruil voor het recht om onder andere Teapot Dome, een olieveld in Wyoming, te exploiteren. Boon 1982, p. 15. Zie ook Eberling 1928, p. 366 en Grabow 1988, p. 23-24.

17 De Senaatsresolutie bepaalde onder meer: "Resolved, that a committee of five Senators, consisting of three members of the majority and two of the minority, be authorized and directed to investigate
} 
de minister van Justitie, werd door de Senaatscommissie als getuige opgeroepen. Hij weigerde te verschijnen, waarop de Senaat de medebrenging en gijzeling van de getuige gelastte.

In de daarop volgende gerechtelijke procedure concludeerde de lagere rechtbank dat "the Senate's action is invalid and absolutely void, in that, in ordering and conducting the investigation, it is exercising the judicial function, and power to exercise that function, in such a case as we have here, has not been conferred upon it expressly or by fair implication." De kennelijke bedoeling, zo oordeelde de rechtbank, was "to determine the guilt of the Attorney General of the shortcomings and wrongdoings set forth in the resolutions." 18 De rechtbank ging, in lijn met de Kilbourn-jurisprudentie, uit van een restrictieve opvatting van het onderzoeksrecht. Daaraan werd toegevoegd dat de ruime interpretatie die in verschillende deelstaten werd gegeven aan het onderzoeksrecht, niet kon worden doorgetrokken naar het federale Congres. Een essentieel constitutioneel verschil tussen deelstaatsparlementen en het federale Congres is immers, zo stelde de rechtbank, dat de deelstaten op grond van de betreffende constituties beschikken over een in beginsel algemene wetgevende bevoegdheid, terwijl het federale Congres op grond van artikel I en het Tiende Amendement van de Constitutie juist een beperkte taak heeft. 19

Gevolg van dit vonnis was dat het in de praktijk ontwikkelde congressionele onderzoeksrecht, in ieder geval dat van de Senaat, sterk werd beperkt: het was nu immers aan de rechter om op grond van de feitelijke omstandigheden te bepalen of een onderzoek teveel een gerechtelijk karakter zou hebben. Een onderzoek naar het functioneren van het ministerie van Justitie, onderdeel van de uitvoerende macht, was kennelijk een stap te ver. De vraag was wat dit zou betekenen. Wanneer is dan wel sprake van een legitiem doel? Is de wetgevende functie van het Congres een legitiem doel? En zijn Huis en Senaat bevoegd medewerking af te dwingen en indien nodig hun 'contempt'-bevoegdheden in te zetten bij weigerachtigheid van getuigen? De rechtbank vond het niet nodig, in navolging van het Hooggerechtshof in de Kilbourn-uitspraak, ${ }^{20}$ om hierover in algemene zin te oordelen. ${ }^{21}$

circumstances and facts, and report the same to the Senate, concerning the alleged failure of Harry M. Daugherty, Attorney General of the United States, to prosecute properly violators of the Sherman Anti-Trust Act and the Clayton Act against monopolies and unlawful restraint of trade (...) and his alleged failure to prosecute properly, efficiently, and promptly, and defend all manner of civil and criminal actions wherein the government of the United States is interested as a party plaintiff or defendant. And said committee is further directed to inquire into, investigate, and report to the Senate the activities of the said Harry M. Daugherty, Attorney General, and any of his assistants in the Department of Justice, which would in any manner tend to impair their efficiency or influence as representatives of the government of the United States..." Zie Ex parte Daugherty, 299 Fed. 620, 622 (1924).

18299 Fed. 620, 639 (1924).

19299 Fed. 620, 635-640 (1924). Zie ook Eberling 1928, p. 367-369.

20103 U.S. 168, 189 (1881). Het Hof betwijfelt in Kilbourn of de congressionele 'contempt'bevoegdheden kunnen worden toegepast in legislatieve onderzoeken, maar laat een definitief oordeel achterwegen.

${ }^{21}$ De rechter merkte slechts op: "I do no more than say that I have very serious doubt as to the existence of such power.” 299 Fed. 620, 638 (1924). Zie ook Eberling 1928, p. 372-373. 


\title{
2.2.2.2. Principiële erkenning: McGrain v. Daugherty (1927)
}

Ook feitelijk had het vonnis consequenties. Steeds meer getuigen weigerden medewerking aan lopende Senaatsonderzoeken. ${ }^{22}$ Het beroep in deze zaak werd door het Hooggerechtshof daarom met spoed behandeld. ${ }^{23}$ De voornaamste rechtsvraag die het Hof te beantwoorden had, was:

\begin{abstract}
"(a) whether the Senate - or the House of Representatives, both being on the same plane in this regard - has power, through its own process, to compel a private individual to appear before it or one of its committees and give testimony needed to enable it efficiently to exercise a legislative function belonging to it under the Constitution; and (b) whether it sufficiently appears that the process was being employed in this instance to obtain testimony for that purpose." 24
\end{abstract}

Het Hof maakt in haar vraagstelling direct duidelijk dat beide kamers op deze kwestie dezelfde positie innemen. Het door de rechtbank gemaakte onderscheid werd hiermee afgewezen, overigens zonder nadere toelichting.

Ten aanzien van de eerste deelvraag overwoog het Hof als volgt. De Constitutie bevat geen bepalingen die het Congres een recht van onderzoek of de daarbij behorende noodzakelijke dwangmiddelen verlenen teneinde de wetgevende taak op een geinformeerde en effectieve wijze uit te oefenen. Daarom moet nagegaan worden "whether this power is so far incidental to the legislative function as to be implied." 25 Deze vraag beantwoordde het Hof bevestigend in een uitvoerige bespreking van de parlementaire praktijk, geldende wetgeving en relevante jurisprudentie. Het Hof merkt op dat in de parlementaire praktijk het onderzoeksrecht al lange tijd wordt gezien een onderdeel van de wetgevende functie; dit was reeds zo in het Britse parlement en ten tijde van de koloniale parlementen en is na de Amerikaanse onafhankelijkheid overgenomen door het federale Congres en de deelstaatparlementen. Dit zonder veel tegenstand binnen het Congres. ${ }^{26}$ Jurisprudentie op deelstaatniveau laat zien dat het onderzoeksrecht veelal wordt gezien als onderdeel van de parlementaire wetgevingsfunctie. ${ }^{27}$ Voorts wijst het Hof op verschillende wettelijke maatregelen die in de loop der tijd zijn vastgesteld ter ondersteuning van het congressionele onderzoeksrecht: de bevoegdheid om getuigen onder ede te horen (1798 en 1817), de wettelijke dwangmiddelen bij weigerachtigheid van getuigen en de bewijs- en strafuitsluitingsgronden (1857 en 1862). Hieruit blijkt volgens het Hof, kort gezegd, dat het Congres het onderzoeksrecht van beide Kamers heeft erkend en dat daarbij de nodige bevoegdheden horen. ${ }^{28}$ Tenslotte haalt het Hof verschillende eerdere uitspraken aan. Hoewel geen van deze uitspraken volgens het Hof ingaat op de vraag in hoeverre het Congres beschikt over een onderzoeksrecht en -bevoegdheden in het kader van zijn wetgevende taak, kan hieruit wel worden afgeleid dat beide kamers

\footnotetext{
22 Eberling 1928, p. 373.

24273 U.S. 135, 154 (1927).

25273 U.S. 135, 161 (1927).

${ }^{26} 273$ U.S. 135, 161 (1927).

27273 U.S. 135, 165-167 (1927).

28273 U.S. 135, 167-168 (1927).
}

${ }^{23}$ McGrain v. Daugherty, 273 U.S. 135, 154 (1927) ("We have given the case earnest and prolonged consideration because the principal questions involved are of unusual importance and delicacy.") Zie over deze uitspraak ook: Eberling 1928, p. 373-378; Hamilton 1976, p. 57-58; Boon 1982, p. 15-16. 
niet alleen beschikken over expliciet in de Constitutie vastgelegde bevoegdheden, maar ook over "such auxiliary powers as are necessary and appropriate to make the express powers effective"; en voorts dat de Kamers geen algemeen recht bezitten om onderzoek te doen naar private aangelegenheden, maar slechts beschikken over "such limited power of inquiry as is shown to exist when the rule of constitutional interpretation just stated is rightly applied." 29 Op grond van deze analyse concludeert het Hof:

\begin{abstract}
"We are of opinion that the power of inquiry - with process to enforce it - is an essential and appropriate auxiliary to the legislative function. It was so regarded and employed in American Legislatures before the Constitution was framed and ratified. Both houses of Congress took this view of it early in their history (...) So, when their practice in the matter is appraised according to the circumstances in which it was begun and to those in which it has been continued, it falls nothing short of a practical construction, long continued, of the constitutional provisions respecting their powers, and therefore should be taken as fixing the meaning of those provisions, if otherwise doubtful." 30
\end{abstract}

Het recht onderzoek te doen, inclusief de bevoegdheden om dit recht te kunnen toepassen, werd hiermee expliciet door het Hooggerechtshof erkend als een onmisbare component van de wetgevende bevoegdheden van Huis en Senaat. Het onderzoeksrecht zoals zich dat heeft ontwikkeld kan in de visie van het Hof worden gezien als een bestendige praktische uitwerking van de constitutionele bepalingen inzake de (wetgevende) bevoegdheden van beide kamers. Deze praktijk moet worden beschouwd als leidend, tenzij er anderszins redenen zijn om aan deze congressionele toepassing van de bepalingen van de Constitutie te twijfelen. Dat laatste is niet het geval, zo vervolgt het Hof.

Om zijn wetgevende taken op grond van de Constitutie te kunnen uitvoeren, kan het Congres beschikken over "such auxiliary powers as are necessary and appropriate to that end." 31 Het Hof beschouwt dat in haar motivering als niet meer dan logisch:

\footnotetext{
"A legislative body cannot legislate wisely or effectively in the absence of information respecting the conditions which the legislation is intended to affect or change; and where the legislative body does not itself possess the requisite information - which not infrequently is true - recourse must be had to others who do possess it. Experience has taught that mere requests for such information often are unavailing, and also that information which is volunteered is not always accurate or complete; so some means of compulsion are essential to obtain what is needed. All this was true before and when the Constitution was framed and adopted. In that period the power of inquiry, with enforcing process, was regarded and employed as a necessary and appropriate attribute of the power to legislate - indeed, was treated as inhering in it. Thus there is ample warrant for thinking, as we do, that the constitutional provisions which commit the legislative function to the two houses are intended to include this attribute to the end that the function may be effectively exercised." 32
}

\footnotetext{
29273 U.S. 135, 168-174 (1927). Op het punt van de beperkte reikwijdte van het onderzoeksrecht (private aangelegenheden) bevestigt het Hof hier hetgeen werd overwogen in de Kilbourn-uitspraak.

30273 U.S. 135, 174 (1927).

31273 U.S. 135, 175 (1927).

32273 U.S. 135, 175 (1927).
} 
De wetgevende taken van het Congres kunnen volgens het Hof dus niet effectief en 'wisely' worden uitgevoerd zonder een bijkomend recht om de informatie te verkrijgen die nodig is om te kunnen bepalen waartoe die wetgeving moet dienen of zal leiden. Tevens concludeert het Hof dat een effectief onderzoeksrecht niet zonder de nodige handhavingsbevoegdheden kan, aangezien de praktijk heeft laten zien dat het louter verzoeken om (vrijwillige) medewerking aan een onderzoek niet altijd leidt tot een juiste en volledige informatievoorziening. Deze bevoegdheden zijn in de visie van het Hof daarom onlosmakelijk verbonden met het recht van onderzoek.

Ten aanzien van de tweede deelvraag - stond het onderzoek in casu daadwerkelijk ten dienste van de wetgevende taak van de Senaat? - oordeelde het Hof bevestigend. Het onderwerp van het onderzoek, zo stelde het Hof simpelweg, was het functioneren van het ministerie van Justitie. Dit was onmiskenbaar een onderwerp "on which legislation could be had and would be materially aided by the information which the investigation was calculated to elicit", zeker wanneer wordt bedacht dat de taken en bevoegdheden van het ministerie, die van de minister en die van zijn assistenten bepaald worden door wetgeving en dat het departement functioneert op basis van wettelijke budgettoekenningen ('appropriations'). ${ }^{33}$ Het Hof concludeerde:

"The only legitimate object the Senate could have in ordering the investigation was to aid it in legislating, and we think the subject-matter was such that the presumption should be indulged that this was the real object. An express avowal of the object would have been better; but in view of the particular subject-matter was not indispensable." 34

Het Hof verwierp met deze conclusie de stelling van de rechtbank dat het betreffende onderzoek in feite een gerechtelijk onderzoek was, gericht op het veroordelen van de minister van Justitie. Ook wanneer het doel niet uitdrukkelijk blijkt uit de resolutie waarmee het onderzoek werd ingesteld, kan een congressioneel onderzoek als legitiem worden beschouwd. ${ }^{35}$ Dat legitieme doel kon in casu niet anders dan een legislatief doel zijn en gelet op het onderwerp van het Senaatsonderzoek ging het Hof uit van de veronderstelling dat het onderzoek inderdaad een legislatief doel diende.

Het onderzoeksrecht van het Congres is met deze uitspraak zowel verhelderd als versterkt. De vraag of het Congres zijn onderzoeksrecht en -bevoegdheden kan inzetten ten behoeve van zijn wetgevende functie is door het Hof bevestigend beantwoord. Bovendien is duidelijk dat het Hof een relatief terughoudende rol verkiest in de beoordeling van de legitimiteit van een congressioneel onderzoek. Eberling, schrijvend een jaar na de uitspraak in McGrain v. Daugherty, stelt vast dat "it is obvious from this decision that the Supreme Court will construe an investigation of either House to be a legislative one if possible, which means that most Congressional investigations will be presumptively legislative, and hence constitutional, unless there is a

${ }^{33} 273$ U.S. 135, 177-178 (1927). Zie ook Eberling 1928, p. 378.

34273 U.S. 135, 178 (1927).

${ }^{35} \mathrm{Op}$ dit punt sloot het Hof aan bij een uitspraak inzake een congressioneel onderzoek naar een aantal van corruptie verdachte Senatoren, waarin reeds werd gesteld dat "it was certainly not necessary that the resolutions should declare in advance what the Senate meditated doing when the investigation was concluded."166 U.S. 661, 670 (1897). Zie ook Grabow 1988, p. 116. 
clear statement and avowal to the contrary." 36 Het is voldoende als wetgeving "could be had" naar aanleiding van een onderzoek, niet dat wetgeving ook persé zou volgen: een potentieel voor wetgeving is voldoende om van een legitiem doel te spreken. Puur toezichthoudend onderzoek zonder concreet wetgevend doel is dus ook legitiem. ${ }^{37}$

Deze terughoudende opstelling ten aanzien van de legitimiteit van congressioneel onderzoek heeft het Hof sindsdien vastgehouden. ${ }^{38}$ Zo weigert het Hof om de (vermeende) motieven achter een congressioneel onderzoek mee te wegen bij het beoordelen van de legitimiteit. ${ }^{39}$ Het doen van onderzoek brengt ook onvermijdelijk met zich mee, zo voegde het Hof in een uitspraak decennia later nog toe, dat congressioneel onderzoek zo nu en dan in 'blind alleys' terecht kan komen. Dat maakt het onderzoek echter niet minder legitiem; een voorspelbaar eindresultaat is dus niet vereist. ${ }^{40}$

In de jaren '50 keert de betekenis van het onderzoeksrecht weer terug in de rechtspraak, maar nu vooral in verband met de positie van getuigen. Alvorens deze jurisprudentie te bespreken, volgt eerst een overzicht van de belangrijkste onderzoeksbevoegdheden waarover het Congres beschikt ten behoeve van de uitoefening van het onderzoeksrecht.

\subsection{Onderzoeksbevoegdheden}

\subsubsection{Getuigen verhoren en documenten opvragen ('subpoena power')}

De bevoegdheid tot het oproepen van personen voor verhoor en het opvragen van documenten, kortweg 'subpoena power' genoemd, wordt beschouwd als essentieel voor een effectieve uitoefening van het congressionele onderzoeksrecht. ${ }^{41}$ Aangezien het onderzoeksrecht als zodanig en de dagvaardingsbevoegdheid in het bijzonder in beginsel slechts toekomen aan de kamers als zodanig, kunnen commissies of subcommissies alleen subpoenas uitvaardigen indien hen deze bevoegdheid middels (sub)delegatie is toegekend. Beide kamers hebben dit met betrekking tot hun vaste commissies in hun Rules geregeld. ${ }^{42}$ In het geval van bijzondere commissies wordt dit in de instellingsresolutie geregeld, indien de betreffende kamer deze bevoegdheid

\footnotetext{
${ }^{36}$ Eberling 1928, p. 379.

${ }^{37}$ Fisher 2004, p. 19.

${ }^{38}$ In dezelfde Teapot Dome-affaire werd een ander getuige, Sinclair, opgeroepen om te getuigen omtrent oliewinningscontracten die hij (vermeend frauduleus) had afgesloten met de federale overheid. Zijn stelling dat het congressionele onderzoek naar deze affaire, althans met betrekking tot zijn rol daarin, louter betrekking had op zijn "private or personal affairs", omdat het om privaatrechtelijke contracten ging, werd door het Hof resoluut verworpen. De overheid was als eigenaar van het Teapotgebied bij die contracten betrokken en dat alleen al gaf de Senaat het recht onderzoek te doen. Bovendien deed ook een lopende strafzaak tegen Sinclair niets af aan het recht van de senaatscommissie om bewijsstukken op te vragen. Sinclair v. United States, 279 U.S. 263, 294-297 (1929).

${ }^{39}$ Watkins v. United States, 354 U.S. 178, 200 (1957).

${ }^{40}$ Eastland v. United States Servicemen's Fund, 421 U.S. 491, 509 (1975). Zie ook Fisher 2004, p. 19.

${ }^{41}$ Eastland v. United States Servicemen's Fund, 421 U.S. 491, 505 (1975).

42 Zie House Rule XI, lid 2, sub m en Senate Rule XXVI, lid 1.
} 
wenst toe te kennen. ${ }^{43}$ Commissies blijken deze bevoegdheid vervolgens te kunnen delegeren aan hun voorzitter, die deze bevoegdheid vervolgens al dan niet met de instemming van of in overleg met de 'ranking member' van de minderheidspartij kan uitoefenen. Veel commissies hebben een dergelijke voorziening opgenomen in hun commissiereglement. ${ }^{44}$

De bevoegdheid is tweeledig. Ten eerste kunnen commissies personen middels 'subpoena' (dagvaarding) oproepen om een getuigenis af te leggen. Ten tweede kunnen commissies documenten of andere materialen opvragen; deze dagvaarding wordt een 'subpoena duces tecum' genoemd. In beginsel is een ieder die zich in de Verenigde Staten bevindt, verplicht om gehoor te geven aan congressionele dagvaardingen. 45

Het verhoren van getuigen kan onder ede plaatsvinden. De bevoegdheid tot het afnemen van de eed bij getuigen werd al in 1798 bij wet toegekend aan alle commissievoorzitters, later werd dit recht ook verleend aan andere commissieleden. ${ }^{46}$ Het afleggen van een valse verklaring in het kader van een congressioneel onderzoek is strafbaar op grond van de wet. ${ }^{47}$ Overigens kan uit de betreffende bepaling worden opgemaakt dat het afleggen van een valse verklaring te allen tijde strafbaar is, dus ook zonder dat sprake is van eedaflegging. De eed heeft in de praktijk dan ook vooral een symbolische waarde: het verleent een zekere (gerechtelijke) status aan het verhoorproces. ${ }^{48}$ Ook andere handelingen kunnen leiden tot strafvervolging, zoals het

\footnotetext{
${ }^{43}$ Boon 1982, p. 17. Zie ook Grabow 1988, p. 80.

44 Wanneer dit niet nadrukkelijk is geregeld, kan een commissievoorzitter geen subpoenas uitvaardigen zonder instemming van de commissie. De rechter toetst dit nadrukkelijk en kijkt bijvoorbeeld of de bevoegdheid als zodanig is gedelegeerd of alleen de administratieve uitvoering ervan. Zie bijvoorbeeld Shelton v. United States, 327 F.2d 601 (D.C. Cir. 1963). Zie ook Grabow 1988, p. 81-82. Soms wordt de subpoenabevoegdheid uitdrukkelijk voorbehouden aan de voltallige commissie, waardoor subcommissies deze niet zelfstandig kunnen uitoefenen. Zie verder Kaiser, Oleszek \& Tatelman 2011, p. 28 en Hamilton, Muze \& Amer 2007, p. 1127.

${ }^{45}$ De positie van getuigen die zich in het buitenland bevinden is zowel in juridische als praktische zin minder helder. Zie hierover Grabow 1988, p. 82-83.

462 U.S.C.A. § 191. In het geval een getuige in plenair verband wordt verhoord, beschikt zelfs elk lid van de betreffende kamer over het recht om de eed af te nemen, zo kan uit deze bepaling worden afgeleid. Zie ook Boon 1982, p. 17-18.

47 Zie 18 U.S.C.A. § 1001. Deze strafbepaling heeft betrekking op "whoever, in any matter within the jurisdiction of the executive, legislative, or judicial branch of the Government of the United States, knowingly and willfully ... makes any materially false, fictitious, or fraudulent statement or representation". Ten aanzien van de wetgevende macht wordt hieronder (mede) verstaan "any investigation or review, conducted pursuant to the authority of any committee, subcommittee, commission or office of the Congress, consistent with applicable rules of the House or Senate." Zie over de betekenis van het begrip 'false statement' verder Hamilton, Muse \& Amer 2007, p. 1128.

${ }^{48}$ Het afnemen van de eed kan soms tot conflicten leiden. Zo weigerde de Republikeinse commissievoorzitter Stevens (Alaska) in 2005, ondanks verzoeken daartoe van de Democratische minderheid, om de eed af te nemen bij een aantal directeuren van oliebedrijven die waren verschenen in het kader van een onderzoek naar de sterke stijging van olieprijzen. Hij zei daarop: "This hearing is about issues, not just getting a picture of all the CEOs taking the oath. I know the political value of that sort of picture, but I am going to do all I can to make this a hearing about substance and not about pictures." Zie Hamilton, Muse \& Amer 2007, p. 1157.
} 
vernietigen van documenten met het doel een congressioneel onderzoek te frustreren. ${ }^{49}$

Verhoren vinden in beginsel in het openbaar plaats. In beide kamers bestaat de mogelijkheid om verhoren in beslotenheid af te nemen, maar alleen als een meerderheid besluit dat een openbaar verhoor een gevaar zou vormen voor de nationale veiligheid, schadelijk zou kunnen zijn voor gevoelige opsporingsinformatie, of "would tend to defame, degrade, or incriminate any person." 50 Een getuigenverklaring afgelegd tijdens een besloten verhoor blijft vertrouwelijk, tenzij de commissie in meerderheid besluit om die vertrouwelijkheid op te heffen. ${ }^{51}$ Die laatste mogelijkheid biedt commissies de ruimte om creatieve tussenvormen toe te passen. Zo hield een subcommissie van de Senate Judiciary Committee in 2009 een hoorzitting met een voormalig CIA-agent inzake het 'martelbeleid' van de regering-Bush, waarbij pers en publiek welkom waren, maar waarbij de getuige om veiligheidsredenen werd verhoord achter een groot scherm. ${ }^{52}$

Dat hoorzittingen in beginsel toegankelijk zijn voor het publiek betekent ook dat persfotografie en (rechtstreekse) radio- en televisieuitzending zijn toegestaan, zo is uitdrukkelijk in de reglementen van beide kamers vastgelegd. ${ }^{33}$ Dit is niet altijd zo geweest. Tussen 1970 en 1997 had een getuige die op basis van een subpoena voor een Huiscommissie moest verschijnen het recht om zich te verzetten tegen het maken van foto's en radio- en televisieopnamen. In dat geval gold dat foto- en televisiecamera's moesten worden bedekt en microfoons worden uitgezet. ${ }^{54}$ Tussen 1957 en 1970 waren hoorzittingen in alle gevallen verboden terrein voor radio en televisie. Directe aanleiding voor dit verbod was de tragische dood van een getuige die was opgeroepen door de inmiddels beruchte House Unamerican Activities Committee; uit angst voor de televisiecamera's, zo was te lezen in zijn afscheidsbrief, sprong hij van het dak van zijn hotel. ${ }^{5}$ Met de Legislative Reorganization Act van 1970, waarin maatregelen werden genomen om de openbaarheid en toegankelijkheid van het

\footnotetext{
${ }^{49}$ Dit kan worden opgevat als 'obstruction of justice'. Hamilton, Muse \& Amer 2007, p. 1129.

${ }^{50}$ Het besluit tot het houden van een besloten verhoor dient tijdens een openbare zitting te worden genomen. Zie House Rule XI, lid 2(g)(1). De Senaat kent vergelijkbare bepalingen. Zie Senate Rule XXVI, lid 5(b).

51 Zie House Rule XI, lid 2(k)(7). In de Senaat is dit geregeld in de afzonderlijke commissiereglementen. Zie ook Kaiser, Oleszek \& Tatelman 2011, p. 30.

52 Senate Judiciary Committee, Subcommittee on Administrative Oversight and the Courts, 'What Went Wrong. Torture and the Office of Legal Counsel in the Bush Administration', S. Hrg. 111-324, 13 mei 2009.

${ }^{53}$ House Rule XI, lid 2(g)(1) en Senate Rule XXVI, lid 5(c). In lid 4 van de genoemde House Rule zijn specifieke instructies opgenomen omtrent het (rechtstreeks) op radio of televisie uitzenden van hoorzittingen. Zo dient de verslaglegging op een waardige en evenwichtige manier plaats te vinden, zonder commerciële onderbrekingen. Verder mag het gebruik van audiovisuele apparatuur het verloop van de hoorzitting niet storen. In de Senaat dient elke commissie zelf regels hieromtrent vast te stellen. ${ }^{54}$ House Rule XI, lid 3(f)(2) (oud) bepaalde dat "No witness served with a subpoena by the committee shall be required against his or her will to be photographed at any hearing or to give evidence or estimony while the broadcasting of that hearing, by radio or television, is being conducted. At the request of any such witness who does not wish to be subjected to radio, television or still photography coverage, all lenses shall be covered and all microphones used for coverage turned off." Zie H. Rep. 105-382 (1997), p. 3.
}

${ }^{55}$ H. Rep. 105-382 (1997), p. 15. 
Congres te verbeteren, kregen radio en televisie weer toegang. In het Huis werd daarbij wel het genoemde recht van verzet in de kamerregels opgenomen. In 1997 werd dit weer afgeschaft. Het weren van moderne, audiovisuele middelen (terwijl de schrijvende pers wel werd toegelaten), zo werd gesteld, was niet meer van de tijd en het afschaffen van deze "antiquated House rule" paste in het grotere streven van de toenmalige Republikeinse meerderheid om het Congres opener en toegankelijker te maken voor het publiek. ${ }^{56}$ De afschaffing was zeer tegen de zin van de Democratische minderheid binnen de Rules Committee, die dit recht zag als de enige gegarandeerde vorm van bescherming voor getuigen, waarmee gezien het verleden niet te lichtzinnig moest worden omgesprongen. ${ }^{57}$ In de 27 jaar dat getuigen in het Huis het recht hadden om radio en televisie te weren tijdens hun verhoor, werd er overigens relatief weinig gebruik van gemaakt: slechts veertien keer deed een getuige er een beroep op. ${ }^{58}$

Bijzonder is verder dat ook stafleden van commissies getuigenverklaringen kunnen afnemen. Naast de mogelijkheid van het houden van informele interviews of voorgesprekken, kunnen zij deelnemen aan een hoorzitting en in bepaalde gevallen zelfs ook buiten hoorzittingen, eventueel zonder aanwezigheid van commissieleden, formele verhoren afnemen. Van deze laatste mogelijkheid, 'staff depositions' genoemd, lijkt steeds vaker gebruik gemaakt te worden. De figuur van de deposition is afkomstig uit het burgerlijk procesrecht, waar het fungeert als een middel om bewijsmateriaal te verzamelen. Het voordeel van dit instrument voor congrescommissies is dat zij hiermee in korte tijd grote aantallen getuigen kunnen verhoren en inlichtingen kunnen verzamelen. ${ }^{59} \mathrm{Bij}$ de meeste grote congressionele onderzoeken van de afgelopen jaren werden staff depositions toegepast. Zo verrichtten commissiestafleden bij het onderzoek inzake het Iran-Contra-schandaal honderden depositions. Ook de vaste commissies kunnen de bevoegdheid toegekend krijgen om ten behoeve van een specifiek onderzoek staff depositions te kunnen houden. ${ }^{60}$ Deze stafverhoren vinden plaats achter gesloten deuren, waardoor getuigen, zo is de gedachte, bereidwilliger zullen zijn om inlichtingen te verschaffen dan in een openbaar verhoor. ${ }^{61}$ Getuigen kunnen zich tijdens een stafverhoor laten bijstaan. Van het verhoor, dat onder ede plaatsvindt, wordt een verslag opgemaakt door een rechtbankgriffier en daarna aan de commissie gerapporteerd. ${ }^{62}$ Onduidelijk is echter wat de

\footnotetext{
${ }^{56}$ H. Rep. 105-382 (1997), p. 9.

${ }^{57}$ H. Rep. 105-382 (1997), p. 14 e.v.

58 Zie voor een overzicht van enkele gevallen: H. Rep. 105-382 (1997), p. 6.

59 Zie hierover uitgebreid: Shampansky 1999.

${ }^{60}$ De House Oversight and Government Reform is in de House Rules uitdrukkelijk bevoegd verklaard in haar commissiereglement een voorziening te treffen voor staff depositions. Zie House Rule X, lid 4, sub c. In andere gevallen is het gebruikelijk dat de betreffende kamer dit middels een resolutie regelt voor specifieke onderzoeken. Zie ook, al lijkt men er soms ook vanuit te gaan dat commissies deze bevoegdheid ook zonder uitdrukkelijke delegatie hebben. Zie Shampansky 1999, p. 3-8. In de Senaat gaat de Committee on Homeland Security and Governmental Affairs er bijvoorbeeld vanuit over een dergelijke bevoegdheid te beschikken, zonder dat dit in de Senate Rules is gedelegeerd. Zie Committee Rule 5, sub j (2011). Vgl. ook Hamilton, Muse \& Amer 2007, p. 1127.

61 Shampansky 1999, p. 2.

${ }^{62}$ Grabow 1988, p. 85-86.
} 
juridische status van dergelijke stafverhoren is en of getuigen verplicht zijn om hieraan medewerking te verlenen. De rechter heeft zich hierover nog niet uitgelaten. ${ }^{63}$

De mogelijkheden voor getuigen om zich te verzetten tegen het uitvaardigen van een subpoena, anders dan via onderhandelingen met de commissie, zijn uiterst beperkt. De rechter weigert zich vooraf uit te spreken over de rechtmatigheid van een dagvaarding, onder verwijzing naar de Speech and Debate Clause (artikel I, lid 6, sub 1) in de Constitutie. ${ }^{64}$ Dit betekent dat een getuige die meent dat zijn (constitutionele) rechten geschonden zijn weinig anders kan dan geheel of gedeeltelijk te weigeren om gehoor te geven aan de dagvaarding. Wanneer daarop een 'contempt'procedure tegen de getuige volgt (zie hierna), dan kunnen bezwaren ter verdediging van de weigering in die procedure naar voren worden gebracht. 65

\subsubsection{Dwangmiddelen en sancties ('Contempt of Congress')}

Het Congres beschikt over verschillende instrumenten om weigerachtige getuigen tot inkeer te brengen of te straffen. Het niet voldoen aan een rechtmatig uitgevaardigd subpoena, zowel het niet verschijnen als het niet afleggen van een verklaring, kan namelijk worden opgevat als 'contempt of Congress'. In de loop der tijd zijn drie verschillende contemptprocedures ontstaan, elk met eigen functies en procedures.

De rechtsfiguur van 'contempt' wordt gezien als een bevoegdheid van het Congres die, evenals het onderzoeksrecht en de subpoenabevoegdheid, inherent is aan zijn functie als wetgever. De figuur is afkomstig uit de Britse rechtstraditie, waardoor Amerikaanse deelstaatsparlementen er al voor de inwerkingtreding van de federale Constitutie gebruik van maakten. Vergelijkbaar met 'contempt of Parliament' in het Verenigd Koninkrijk is in de Amerikaanse context sprake van 'contempt of Congress' wanneer iemand handelt met het doel of met het effect om het Congres te storen in de uitoefening van zijn functies. Wanneer een van de kamers van het Congres iemand verdenkt van 'contempt', dan kan de Sergeant-at-Arms van het Huis of de Senaat worden ingeschakeld om de persoon te arresteren en in de kamer voor de 'bar' te berechten. Indien iemand vervolgens wordt veroordeeld, dan kan de persoon worden vastgehouden in een gevangenis of binnen de muren van het Capitool. ${ }^{66}$ Een contemptveroordeling kan als dwangmiddel dienen, bijvoorbeeld om een getuige te

\footnotetext{
63 Shampansky gaat er vanuit dat een weigering om medewerking te verlenen aan stafverhoren zou kunnen worden opgevat als contempt, omdat congressionele stafmedewerkers in de rechtspraak wel worden gezien als verlengstuk van het Congres. Zie Shampansky 1999, p. 10 e.v. Vgl. ook Hamilton, Muse \& Amer 2007, p. 1153-1154.

64 Eastland v. United States Servicemen's Fund, 421 U.S. 491, 507 (1975). Zie ook Kaiser, Oleszek \& Tatelman 2011, p. 29.

65 Zie nader Grabow 1988, p. 84-85.

${ }^{66}$ De veroordeelde heeft het constitutionele recht van habeas corpus om zijn gevangenneming voor te leggen aan de rechter en kan een civiele schadevergoedingsactie starten. De rechter toetst echter niet feiten waarop de veroordeling is gebaseerd, maar alleen of het Congres rechtsmacht had - in het geval van een onderzoek is bijvoorbeeld de vraag of hiermee een legitiem doel werd gediend - en of aan de elementaire eisen van due process werd voldaan. Zie Hamilton, Muze \& Amer 2007, p. 1132.
} 
bewegen om alsnog medewerking te verlenen, maar ook als strafsanctie worden toegepast. ${ }^{67}$

Nadeel van de inherente contemptbevoegdheid is dat deze alleen een gijzeling mogelijk maakt, die bovendien nooit langer kan duren dan de zittingstermijn van de kamer die de veroordeling uitsprak. In 1857 kwam daarom een wet tot stand, die de mogelijkheden van het Congres verruimde om specifiek tegen weigerachtige getuigen op te treden. ${ }^{68} \mathrm{Op}$ basis van deze wet kan iemand die gesommeerd is een getuigenis af te leggen of documenten te overleggen door een van de kamers, of door een commissie daaruit, en hieraan opzettelijk niet voldoet ('willfully makes default') dan wel na verschijning weigert een toepasselijke vraag ('question pertinent to the inquiry') te beantwoorden, worden gestraft met een boete of gijzeling in een reguliere gevangenis. ${ }^{69}$ Wanneer een getuige niet verschijnt, niet de gevraagde documenten overlegt, of weigert een toepasselijke vraag te beantwoorden, dan kan de commissie dit rapporteren aan de kamer. Vervolgens is de kamervoorzitter - de President of the Senate respectievelijk de Speaker of the House - verplicht om het feitenverslag dat de commissie heeft opgemaakt door te sturen naar de openbaar aanklager, die vervolgens een strafrechtelijke procedure moet starten. De bepaling is dwingend geformuleerd: de kamervoorzitters en aanklagers kunnen geen eigen afweging maken. ${ }^{70}$ Uit de rechtspraak blijkt echter dat uit deze bepaling moet worden afgeleid dat een meerderheidsstemming in de kamer nodig is om het oordeel van de rapporterende commissie te bevestigen, voordat de kamervoorzitter het dossier kan overdragen. ${ }^{71}$

Door het bestaan van de wettelijke contemptprocedure is de inherente contemptprocedure na verloop in onbruik geraakt. Sinds 1934 is deze niet meer toegepast. ${ }^{72}$ De strafrechtelijke contemptprocedure is een sanctieregeling, bedoeld om onwillige getuigen te straffen en eventuele toekomstige weigeraars af te schrikken. In de meeste gevallen zal een veroordeling niet worden opgeheven wanneer een getuige alsnog de gevorderde medewerking verleent. ${ }^{73}$ Sinds 1978 bestaat daarnaast nog een andere wettelijke regeling. Deze voorziening geldt opmerkelijk genoeg alleen

\footnotetext{
${ }^{67}$ Een voorbeeld is het geval van een getuige die brieven had vernietigd, die op grond van een 'subpoena duces tecum' hadden moeten worden overhandigd aan een Senaatscommissie. De schade was onherstelbaar, dus een dwangmiddel inzetten zou geen zin meer hebben, maar dat betekende niet dat de getuige niet door de Senaat kon worden gestraft wegens contempt. Zie Boon 1982, p. 19-20.

${ }^{68}$ Zie Boon 1982, p. 20-21 en Hamilton, Muse \& Amer 2007, p. 1133-1134.

692 U.S.C. $\S 192$.

702 U.S.C. $§ 194$.

71 Verder wordt in de literatuur op basis van jurisprudentie betwijfeld of de openbaar aanklager wel verplicht kan worden om te vervolgen - als dat al zo is, dan zijn er nog allerlei manieren waarop de aanklager een vervolging kan doen mislukken. Dit speelt met name wanneer het gaat om vervolging van ambtenaren van uitvoerende diensten wegens contempt. Zie Rosenberg \& Tatelman 2008, p. 25-27 en Hamilton, Muse \& Amer 2007, p. 1135-1136. Zie ook hierna, par. 2.6.3.

72 Hamilton, Muse \& Amer 2007, p. 1133. Aanvankelijk bleven de kamers overigens nog de voorkeur hebben voor de oude procedure, onder meer omdat deze eenvoudiger en sneller is. Zie Boon 1982, p. 21-23. De wettelijke procedure was overigens niet bedoeld als vervanging, maar als alternatief voor de inherente procedure. Zie over de totstandkoming van de wet uitvoerig: Rosenberg \& Tatelman 2008, p. 20 e.v.

73 Indien de procedure voor de rechter nog niet is afgerond, kan een melding van de kamer dat de getuige alsnog heeft meegewerkt er wel toe leiden dat de vervolging wordt gestaakt. Rosenberg \& Tatelman 2008, p. 24.
} 
voor de Senaat ${ }^{74}$ en maakt het mogelijk om de juridische dienst van de Senaat door middel van een resolutie in de plenaire vergadering opdracht te geven een civiele procedure te starten om een subpoena (of ander bevel) te handhaven, te laten toetsen op rechtmatigheid middels een verklaring voor recht, of om "the threatened failure or refusal to comply" te voorkomen. ${ }^{75}$ Deze civiele rechtsgang is bedoeld als een minder ingrijpend instrument naast de inherente en strafrechtelijke contemptprocedures. Zo kan, door eerst een verklaring voor recht te vragen, de getuige de kans worden geboden om alsnog aan de subpoena te voldoen zonder meteen met sancties geconfronteerd te worden. Verder biedt de wet meer flexibiliteit wat betreft de handhaving. Sancties, zowel gijzeling als boetes, worden opgelegd voor zolang een getuige niet meewerkt. Zodra de getuige medewerking verleent, worden deze weer opgeheven. ${ }^{76}$ Deze civiele procedure dient daarmee vooral als dwangmiddel. ${ }^{77}$ Belangrijkste beperking van deze civiele contemptprocedure is dat deze meestal niet toepasbaar is wanneer het gaat om subpoenas gericht aan ambtenaren binnen de uitvoerende macht die uit hoofde van hun functie medewerking weigeren. Deze uitzondering - die de wet van 1857 overigens niet kent - is in de wet beland op aandringen van de toenmalige Attorney General, die van mening was dat informatieconflicten tussen de wetgevende en uitvoerende macht langs politieke weg dienden te worden opgelost. ${ }^{78}$

\subsubsection{Immuniteitsverlening}

Getuigen die voor congrescommissies verschijnen hebben, zo zal hierna nog uitvoeriger zal worden belicht, op grond van het Vijfde Amendement het recht te zwijgen wanneer zij vrezen zichzelf anders bloot te stellen aan strafrechtelijke vervolging. Wanneer een getuige ten overstaan van een congrescommissie op dit zwijgrecht een beroep doet, dan kan de commissie dit doorbreken door de getuige immuniteit te verlenen. Een immuniteitsbevel van een congrescommissie houdt in, dat de verklaring die de getuige op basis van dit bevel aflegt of inlichtingen die in dat kader worden verstrekt niet tegen de getuige mogen worden gebruikt in een strafzaak, tenzij het gaat om vervolging wegens omkoping, meineed of het op andere wijze niet voldoen aan het bevel. Deze vorm van immuniteit geldt ook voor "any information di-

\footnotetext{
${ }^{74}$ De procedure was onderdeel van een breder wetsvoorstel en tijdens de behandeling daarvan in een conference committee bleken de afgevaardigden uit het Huis dit onderdeel nog niet te hebben 'overwogen', waardoor de procedure alleen voor de Senaat is gaan gelden. Sindsdien heeft het Huis enkele malen in specifieke resoluties de indruk gewekt een civiele rechtsgang te scheppen waarmee commissies hun subpoenas zouden kunnen afdwingen, maar die werden in de praktijk nooit gebruikt. Het is ook de vraag de Constitutie het toelaat dat het Huis middels een resolutie een rechtsgang bij een federale rechter creëert. Zie Rosenberg \& Tatelman 2008, p. 34, noot 205 en p. 37 e.v.

752 U.S.C. $\$ 288$ d.

${ }^{76}$ Zo kan worden afgeleid uit 28 U.S.C. 1365 (b). Zie ook Hamilton, Muze \& Amer 2007, p. 1137.

77 Sinds 1979 is deze procedure zes maal toegepast door de Senaat. Zie verder Rosenberg \& Tatelman 2008, p. 34-36.

7828 U.S.C. $\S 1365$. De uitzondering zou overigens alleen gelden voor gevallen waarin ambtenaren door de President zijn verzocht om hun medewerking aan een Senaatsonderzoek te weigeren. Zie Rosenberg \& Tatelman 2008, p. 36-37.
} 
rectly or indirectly derived from such testimony or other information". ${ }^{79}$ Het gaat dus nadrukkelijk niet om een volledige immuniteit voor strafrechtelijke vervolging wegens aan de verstrekte inlichtingen gerelateerde strafbare feiten ('transactional immunity'), maar om een vorm van bewijsuitsluiting ('use immunity'). 80

De procedure is als volgt. Een congrescommissie of subcommissie die een getuige strafrechtelijke immuniteit wil verlenen, legt een verzoek hiertoe voor aan een federale rechtbank. Deze rechtbank vaardigt het gevraagde bevel alleen uit, indien het verzoek wordt ondersteund door tenminste tweederde van de leden van de (voltallige) commissie. Daarnaast dient de Attorney General, die zowel het hoofd van het Department of Justice als de hoogste federale openbaar aanklager is, tenminste tien dagen tevoren op de hoogte te zijn gesteld van het voorgenomen immuniteitsverzoek. Op verzoek van de AG schort de rechtbank de uitvaardiging van het immuniteitsbevel op tot maximaal twintig dagen nadat het verzoek is gedaan. ${ }^{81}$

Uit de genoemde bepalingen blijkt dat de rechter, die het immuniteitsbevel uitvaardigt, vooral een administratieve rol vervult: nagegaan wordt of het verzoek van een commissie aan het vereiste quorum voldoet en of de AG tijdig is geïnformeerd. Congrescommissies beschikken daarom over een vrijwel autonome bevoegdheid tot het verlenen van immuniteit. ${ }^{82}$ De AG blijkt enige invloed te hebben op de uitvaardiging van een immuniteitsbevel, zij het slechts in vertragende zin; veel meer dan dat zou volgens de opstellers van de wet ertoe kunnen leiden dat de uitvoerende macht de mogelijkheid zou hebben om legitieme congressionele onderzoeken te verhinderen. ${ }^{83}$ De vertraging die de AG kan afdwingen - in totaal maximaal dertig dagen geeft het openbaar ministerie de ruimte om het reeds verzamelde bewijsmateriaal te ordenen en te bezien op welke wijze een strafrechtelijke vervolging zou kunnen plaatsvinden nadat een geïmmuniseerde getuige een verklaring heeft afgelegd of anderszins inlichtingen heeft verschaft aan een congrescommissie en vooral op welke wijze reeds verzameld bewijsmateriaal kan worden veiliggesteld. De rechter blijkt namelijk zeer strict de hand te houden aan de eis dat het aangevoerde bewijsmateriaal niet direct of indirect voortvloeit uit de inlichtingen verstrekt aan het Congres. De aanklager, zo bepaalde het Supreme Court, heeft "the affirmative duty to prove that the evidence it proposes to use is derived from a legitimate source wholly independent of the compelled testimony." 84

\footnotetext{
7918 U.S.C. § 6002. Deze bepaling verschaft de bevoegdheid een dergelijk bevel uit te vaardigen overigens ook aan de kamers als geheel en aan alle federale rechtbanken, 'grand juries' en uitvoerende diensten ('agencies').

80 Tot 1970 voorzag de wet wel in volledige ('transactional') immuniteit. Een wetswijziging in dat jaar maakte daar een einde aan. Het Supreme Court achtte deze beperking niet in strijd met het Vijfde Amendement, omdat het niet alleen het directe gebruik van getuigenverklaringen uitsluit maar ook bewijsmateriaal dat daaruit direct of indirect is afgeleid. Zie nader: Cole \& Brand 2011, p. 233-235.

81 18 U.S.C. $\S 6005$. Zie ook Boon 1982, p. 24.

$82 \mathrm{Bij}$ de behandeling van een immuniteitsverzoek van de Watergatecommissie leek de rechter wel enige beoordelingsruimte voor zichzelf te bewaren wanneer sprake zou zijn van een overschrijding van de grenzen van het congressionele onderzoeksrecht. Zie Hamilton, Muse \& Amer 2007, p. 1131, noot 84 .

${ }^{83}$ Hamilton, Muse \& Amer 2007, p. 1131.

${ }^{84}$ Kastigar v. United States, 406 U.S. 441, 460 (1972). Zie ook Hamilton, Muse \& Amer 2007, p. 1130.
} 
De bevoegdheid tot immuniteitsverlening werd lange tijd met enige regelmaat toegepast, maar dat veranderde sterk na de geruchtmakende strafzaken rondom twee hoofdrolspelers in het Iran-Contraschandaal, Oliver North en John Poindexter. Deze twee stafmedewerkers van de National Security Council waren nauw betrokken bij de affaire, waarbij door hoge functionarissen in de regering-Reagan heimelijk financiële steun werd verleend aan de Contrabeweging in Nicaragua met middelen afkomstig uit wapenverkopen aan Iran, terwijl beide uitdrukkelijk door het Congres verboden waren. North en Pointdexter hadden op basis van een immuniteitsverlening getuigenissen afgelegd ten overstaan van de bijzondere Senaat- en Huiscommissies die gezamenlijk onderzoek deden naar de affaire. De immuniteitsverlening verliep moeizaam. De AG wilde meer tijd om bewijsmateriaal veilig te stellen en vroeg om uitstel van het verzoek aan de rechter. De raadslieden van North stelden allerlei eisen omtrent de duur en de vraagstelling van het voorgenomen verhoor en dreigden, indien de commissies deze eisen niet zouden inwilligen, hun client te adviseren geen medewerking te verlenen en daarmee een (langdurige) strafrechtelijke contemptprocedure uit te lokken, waarmee het congressionele onderzoek sterk vertraagd zou worden. Dit leidde tot uitvoerige onderhandelingen tussen commissies, openbaar ministerie en getuigen. ${ }^{85}$ Het verhoor van North duurde uiteindelijk zes dagen en bleek een waar mediaspektakel, door Cole en Brand omschreven als "the most dramatic congressional testimony in our national experience to date". Miljoenen televisiekijkers zagen hoe de getuige erin slaagde zichzelf met een uitgekiende presentatie in morele zin zo goed als vrij te pleiten. ${ }^{86}$

Twee jaar na de congresverhoren werden zowel North als Pointdexter in eerste instantie veroordeeld voor verschillende vergrijpen, maar in hoger beroep werden hun veroordelingen op alle punten vernietigd. Het beroepshof in Washington, D.C. achtte de kans aanwezig dat de getuigen die in de strafrechtelijke procedure werden gehoord waren beïnvloed door de verklaringen die de verdachten in het congressionele onderzoek hadden afgelegd. De uitvoerig in beeld gebrachte en besproken verklaringen waren gebruikt door getuigen in het strafproces om hun herinneringen aan specifieke gebeurtenissen op te frissen en dat, zo oordeelde het hof, komt neer op het gebruiken van de geïmmuniseerde verklaring. Een ander probleem was dat de aanklager tijdens het proces voor de rechtbank onvoldoende had aangetoond dat zijn bewijsvoering niet door de congressionele verklaringen was beïnvloed. De rechtbank, zo stelde het hof, had tijdens het proces een zitting moeten wijden aan het onderzoeken van de inhoud en herkomst van de getuigenverklaringen waarop de aanklager ofwel had moeten aantonen dat zijn getuigen nooit blootgesteld waren aan de geïmmuniseerde getuigenis van de verdachte, ofwel dat hun verklaringen niet waren 'besmet' omdat ze in lijn zijn met eerder geïsoleerd ('canned') bewijsmateriaal. ${ }^{87}$ De lat ligt hierdoor bijzonder hoog, vooral wanneer het gaat om geïmmuniseerde congresverhoren van high-profile verdachten die breed in de media zijn uitgemeten. Zo zal het vaak moeilijk zijn om bewijsmateriaal te isoleren, bijvoorbeeld

\footnotetext{
${ }^{85}$ Cole \& Brand 2011, p. 238-239.

${ }^{86}$ Zie hierover uitvoerig: Cole \& Brand 2011, p. 239-241.

87 United States v. North, 910 F.2d 843, 856 en 872-783 (1990). Zie nader Wright 1995, p. 426; zie ook Hamelton, Muze \& Amer 2007, p. 1130-1131 en uitvoerig: Cole \& Brand 2011, p. 235-323.
} 
door getuigenverklaringen op band op te nemen voordat de congresverhoren plaatsvinden, omdat getuigen niet altijd willen meewerken of zich beroepen op het Vijfde Amendement. Bovendien zullen aanklagers niet altijd in een vroeg stadium een goed beeld van de zaak hebben en kunnen voorzien welke getuigen van belang zijn voor het strafrechtelijk onderzoek. ${ }^{88}$ Ook de rechtbank wacht een moeilijke taak. De openbaar aanklager in de Iran-Contrazaken, Independent Counsel Walsh, concludeerde in zijn eindrapport dat de uitspraak van het beroepshof "will require a complex psychological inquiry into the thought processes and memory of every witness" en zal leiden tot een aanzienlijke verlenging van het gerechtelijk onderzoek. ${ }^{89}$

Het vervolgen van getuigen nadat zij van congrescommissies immuniteit hebben verkregen, is door deze uitspraak bemoeilijkt; in de ogen van veel congresleden en openbaar aanklagers is het zelfs praktisch onmogelijk geworden. ${ }^{90}$ Het verlenen van immuniteit, hoewel formeel slechts een vorm van bewijsuitsluiting, komt daarmee in de praktijk toch vrijwel gelijk te staan aan een volledige immuniteit voor strafvervolging. Het lijkt er dan ook sterk op dat de gang van zaken in de IranContrakwestie, waarin een behendige getuige zichzelf tot ongenoegen van veel congresleden door middel van zijn congresverhoor niet alleen bij het grote publiek wist vrij te pleiten maar vervolgens ook nog zijn straf ontliep, een ontmoedigende werking heeft gehad op congresleden. Sinds de vrijspraak van North en Pointdexter in 1990 hebben congrescommissies nauwelijks nog immuniteitsverzoeken gedaan. ${ }^{91}$ Uit angst voor het stuklopen van strafzaken blijkt het instrument voor de congressionele onderzoekspraktijk, vooral in gevallen waarbij veel media-aandacht bestaat, sterk aan belang te hebben ingeboet. In dergelijke gevallen, waarin een getuige met een beroep op het Vijfde Amendement weigert om medewerking te verlenen aan een

\footnotetext{
${ }^{88}$ Wright 1995, p. 426.

${ }^{89}$ In praktische zin, zo verwachtte hij, werd het in dergelijke zaken bovendien onmogelijk om bijvoorbeeld medeplichtingen die geen belang hebben bij een veroordeling van de verdachte als getuigen op te roepen; zij kunnen zich immers gemakkelijk diskwalificeren. Geciteerd in Cole \& Brand 2011, p. 322. De zaken van North en Pointdexter werden door het beroepshof teruggewezen naar de rechtbank, waarna de Independent Counsel besloot de vervolging te staken na te hebben geconcludeerd dat de gestelde bewijsrechtelijke eisen niet haalbaar waren. Zie ook Congressional Oversight Manual 2011, p. 31-32.

90 Zie Cole \& Brand 2011, p. 323.

${ }^{91}$ Zie voor een overzicht van gevallen waarin commissies immuniteitsverlening uitdrukkelijk werd vermeden: Cole \& Brand 2011, p. 323-324. Sinds de inwerkingtreding van de immuniteitswet in 1970 werden zo'n 300 immuniteitsverzoeken gedaan. Het overgrote gedeelte daarvan kwam voor rekening van een aantal grote congressionele onderzoeken, zoals de Watergate-affaire en de moord op President Kennedy, waarbij tientallen getuigen in clusters immuniteit werd verleend. Tussen 1990 en 2007 werden in totaal nog slechts zes immuniteitsverzoeken door Senaats- of Huiscommissies gedaan en in geen van die gevallen ging het om prominente getuigen. Zo werd in het congressionele Whitewateronderzoek naar mogelijke vastgoedmalversaties van President Clinton in 1994 uitdrukkelijk verwezen naar de North- en Pointdexterzaken in de beslissing om niemand immuniteit te verlenen. Zie verder Wright 1995, p. 429-433 en Hamilton, Muze \& Amer 2007, p. 1165. In 2007 werd nog een lagere ambtenaar in het Department of Justice immuniteit verleend in een onderzoek van de House Judiciary Committee naar het vermeend politieke ontslag van een aantal openbaar aanklagers op aanwijzing van het Witte Huis. Hoewel zij tijdens haar congresverhoor toegaf de wet te hebben overtreden, werd zij hiervoor niet vervolgd -vermoedelijk mede vanwege de hoge eisen die gelden sinds de North- en Pointdexterzaken. Cole \& Brand 2011, p. 324.
} 
congressioneel onderzoek, staat de commissie praktisch alleen nog de mogelijkheid van een contemptprocedure ter beschikking om de weigering door de rechter te laten toetsen en daarmee te proberen medewerking alsnog af te dwingen. ${ }^{92}$

\subsection{De positie van getuigen}

\subsubsection{Inleiding: de 'Red Scare', HUAC en McCarthy}

Een congressioneel onderzoek, zo bleek uit de McGrain-uitspraak van het Supreme Court in 1927, is constitutioneel aanvaardbaar indien een legitiem (constitutioneel) doel wordt beoogd. Dit betekent dat het onderzoek verband moet houden met een congressionele bevoegdheid. Te denken valt aan de bevoegdheden van de Senaat inzake publieke benoemingen, of de bevoegdheden van beide Huizen inzake impeachment. In de meeste gevallen zal het echter gaan om een wetgevingsdoel ('legislative purpose'). Het Hof is snel bereid aan te nemen dat een onderzoek een legislatieve functie heeft. Een directe verbinding met een concreet wetgevingsproces is niet noodzakelijk en ook onderzoeken die geheel in het teken van de toezichthoudende functie van het Congres staan zijn aanvaardbaar. Het Hof gaf het Congres aldus ruim baan om van zijn onderzoeksrecht gebruik te maken.

Met de zegen van het Supreme Court kreeg de congressionele onderzoeksfunctie in de decennia daarna steeds verder vorm. Met de opbouw van het federale overheidsapparaat groeide de behoefte aan controle en het onderzoeksrecht bleek daarvoor zeer geschikt. Veel lof oogstten de onderzoeken naar verspilling en corruptie binnen het defensieapparaat van de in 1941 ingestelde senaatscommissie onder leiding van Harry Truman. ${ }^{93}$

Het breed gedragen enthousiasme over congressioneel onderzoek verdween in de jaren na de oorlog. De oplopende spanningen tussen de Verenigde Staten en de Sovjetunie leidden tot een ongekende angst voor het communisme. Deze 'Red Scare' beheerste lange tijd de Amerikaanse politiek. In het Congres stortten onderzoekscommissies zich op de gevaren van het communisme. De belangrijkste was de House Un-American Activities Committee (HUAC). Deze commissie was al in 1938 op tijdelijke basis ingesteld om zich met allerlei 'on-Amerikaanse' activiteiten bezig te houden. De commissie verrichtte aanvankelijk enkele onderzoeken naar met name fascistische organisaties in de Verenigde Staten, maar raakte vervolgens in vergetelheid. Na de oorlog kreeg de commissie echter een permanente status en onder een nieuwe, Republikeinse voorzitter - en met de enthousiaste medewerking van een nieuw lid, Richard Nixon - richtte zij zich vanaf dat moment uitsluitend op (vermoedelijke) communistische invloeden. In de Senaat was het Joseph McCarthy, die zich als voorzitter van de Permanent Subcommittee on Investigations - ironisch genoeg de vaste commissie die voortkwam uit de Truman Committee - op het onderwerp stortte en het gezicht werd van de excessieve wijze waarop de commissies

\footnotetext{
92 Hierna, in par. 2.4.3, wordt hierop nog nader ingegaan.

${ }^{93}$ Het gezag en de bekendheid die Truman als commissievoorzitter opbouwde zou hem in 1944 zelfs het presidentschap hebben opgeleverd. Zie over de Truman Committee uitvoerig: Cole \& Brand 2011, p. 41-49.
} 
zochten naar (vermeende) communistische netwerken binnen de federale overheid. $\mathrm{Al}$ snel breidden de onderzoeken zich uit tot allerlei andere maatschappelijke sectoren, zoals de vakbeweging, het onderwijs en de filmindustrie. De talloze verhoren, waarin congresleden er vooral op uit waren om getuigen in een kwaad daglicht te stellen, gaven de onderzoeken het karakter van wat wel wordt genoemd 'legislative trials' ${ }^{94}$

Het duurde even voordat het Supreme Court bereid bleek het onderzoeksrecht opnieuw tegen het licht te houden; de 'Red Scare' werd tijdens de hoogtijdagen van HUAC en McCarthy zodanig overheersend dat de rechterlijke macht lang aarzelde om congrescommissies tot de orde te roepen. In eerste instantie werden beroepszaken van getuigen die weigerden hun medewerking te verlenen aan de subversiviteits- en loyaliteitsonderzoeken in Huis en Senaat en op basis van de eerder genoemde wettelijke contemptprocedure ${ }^{95}$ werden veroordeeld, dan ook afgewezen. Dit veranderde pas echt toen McCarthy al door de Senaat uit zijn functie als commissievoorzitter was ontheven. ${ }^{96}$ Tegen die achtergrond koos het Hof er nu voor de nadruk te leggen op de grondrechten van getuigen. Belangrijk zijn de uitspraken van het Hof in het kader van de Due Process Clause en de betekenis van het nonincriminatierecht, beide vervat in het Vijfde Amendement. Deze worden hieronder besproken. ${ }^{97}$

\subsubsection{Due Process en de toepasselijkheidstoets}

De eerste stappen zette het Hof in de zaak United States $v$. Rumely (1953), die ging om een onderzoek van de House Select Committee on Lobbying Activities. Getuige Rumely, een handelaar in boeken "of a particular political tendentiousness", werd gevraagd de namen te geven van personen die grote partijen van deze boeken hadden ingekocht. Rumely weigerde en werd hiervoor veroordeeld. ${ }^{98}$ Het Hooggerechtshof toetste in haar uitspraak "the scope of authority" die het Huis aan de commissie had verleend. De instellingssresolutie, benadrukte het Hof, is "the controlling charter of the committee." Deze resolutie gaf de commissie de opdracht "to conduct a study and investigation of (...) all lobbying activities intended to influence, encourage, promote, or retard legislation" ${ }^{99}$ Het begrip 'lobbying' werd echter nergens uitdrukkelijk gedefinieerd. Het Hof concludeerde op basis van een taalkundige interpretatie dat het begrip 'lobbying' betrekking heeft op "representations made directly to the

\footnotetext{
${ }^{94}$ Zie over deze periode uitvoerig o.a. Boon 1982, p. 34-42 en Cole \& Brand 2011, p. 51-80.

95 Zie hierboven, par. 2.3.2. Het ging om een ware stortvloed van contemptprocedures. Waar in de periode van 1796 tot 1945 in totaal 108 procedures, ging het in de twaalf jaar daarna om 226 personen. Zie Guide to Congress 2008, p. 295.

${ }^{96}$ Dit gebeurde in 1954, toen McCarthy de politieke inschattingsfout maakte om de loyaliteit van hoge militairen ter discussie te stellen en President Eisenhower zich genoodzaakt zag politiek tegengas te gaan geven.

97 Andere grondrechten, waaronder de uitings- en verenigingsvrijheid (Eerste Amendement), het verbod van onredelijke huiszoeking en inbeslagname (Vierde Amendement) zijn in de praktijk van minder belang gebleken en blijven hier verder buiten beschouwing. Zie daarover uitvoerig: Grabow 1988, p. 133 e.v.

98 United States v. Rumely, 345 U.S. 41, 42 (1953).

99345 U.S. 41, 44 (1953).
} 
Congress, its members, or its committees" en niet tevens, zoals de commissievoorzitter had betoogd, alle pogingen "to saturate the thinking of the community". Indien het Huis een onderzoek had willen laten doen naar beïnvloeding van de publieke opinie in het algemeen, dan was dat volgens het Hof wel duidelijker uit de resolutie gebleken. Omdat de commissie buiten haar boekje was gegaan en van de getuige daarom niet mocht worden verlangd wat hem was gevraagd, was de veroordeling wegens contempt onrechtmatig. ${ }^{100}$

Met Rumely liet het Hof zien dat congrescommissies de grenzen van hun onderzoeksopdracht niet mogen overschrijden; doen zij dat wel, dan verspelen zij daarmee het recht om getuigen tot medewerking te dwingen. De rechter acht zich bevoegd om indien nodig de onderzoeksopdracht nader te interpreteren. Deze benadering bood echter weinig soelaas in de contemptzaken die voortvloeiden uit vele subversiviteitsonderzoeken van de House Un-American Activities Committee. Het optreden van deze commissie ${ }^{101} \mathrm{kwam}$ aan de orde in de zaak Watkins v. United States (1957), het belangrijkste arrest in deze periode. Watkins werd als getuige opgeroepen in een onderzoek dat leek te gaan over communistische infiltratie in de Amerikaanse vakbeweging. Tijdens zijn verhoor weigerde hij in te gaan op een lijst met 'verdachten' die hem werd voorgehouden. Daarop volgde een veroordeling wegens contempt. Het Hof nam de beroepszaak aan. Chief Justice Earl Warren, die de bijna unanieme uitspraak schrijft, begon met de constatering dat het inherente onderzoeksrecht van het Congres weliswaar ruim is, maar dat tevens vaststaat dat " $\mathrm{t}]$ here is no general authority to expose the private affairs of individuals without justification in terms of the functions of the Congress. (...) No inquiry is an end in itself; it must be related to, and in furtherance of, a legitimate task of the Congress."102 Daaraan werd toegevoegd dat "[i]nvestigations conducted solely for the personal aggrandizement of the investigators or to 'punish' those investigated are indefensible" en "there is no congressional power to expose for the sake of exposure."103 Burgers zijn verplicht zijn om hun medewerking te verlenen aan een congressioneel onderzoek, maar dat brengt tevens met zich mee, zo benadrukte het Hof, "that the constitutional rights of witnesses will be respected by the Congress as they are in a court of justice. The Bill of Rights is applicable to investigations as to all forms of governmental action." 104

\footnotetext{
100345 U.S. 41, 47 (1953).

${ }^{101}$ De instellingresolutie van HUAC luidt als volgt: 'The Committee on Un-American Activities, as a whole or by subcommittee, is authorized to make from time to time investigations of (1) the extent, character, and objects of un-American propaganda activities in the United States, (2) the diffusion within the United States of subversive and un-American propaganda that is instigated from foreign countries or of a domestic origin and attacks the principle of the form of government as guaranteed by our Constitution, and (3) all other questions in relation thereto that would aid Congress in any necessary remedial legislation.' H.Res. 5, 83d Cong., 1st Sess., 99 Cong.Rec. 15, 18, 24.

102 Watkins v. United States, 354 U.S. 178, 187 (1957).

103354 U.S. 178, 187, 200 (1957). Dat laatste, zo suggereert het Hof in een voetnoot, geldt alleen voor gevallen waarin de rechten van individuele getuigen op het spel staan en niet voor onderzoeken die betrekking hebben op het aan het licht brengen van misstanden binnen de uitvoerende macht. Daar is 'exposure for the sake of exposure' dus wel degelijk toegestaan, omdat het onthullen van dergelijke misstanden nu juist hoort bij de wetgevende taak van het Congres. Zie ook Cole \& Brand 2011, p. 87. 104354 U.S. 178, 188 (1957).
} 
Na deze algemene, waarschuwende opmerkingen nam het Hof wat gas terug. Het is in eerste instantie aan het Congres en niet de rechter om ervoor te waken dat het onderzoeksrecht op een legitieme wijze wordt uitgeoefend, zo vervolgde Warren zijn betoog. Wel is het daarbij van groot belang dat "the instructions to an investigating committee spell out that group's jurisdiction and purpose with sufficient particularity." Het Hof merkte op hierover op: "The more vague the committee's charter is, the greater becomes the possibility that the committee's specific actions are not in conformity with the will of the parent House of Congress." 105 In het geval van de HUAC liet het Hof geen twijfel bestaan over de vaagheid van de onderzoeksopdracht: "It would be difficult to imagine a less explicit authorizing resolution. Who can define the meaning of 'un-American'?"106 Een nauwkeurige toetsing zoals in de Rumely, zo concludeerde het Hof, was hierdoor onmogelijk, maar veel kon of wilde de rechter daar niet aan doen: "[i]t is, of course, not the function of this Court to prescribe rigid rules for the Congress to follow in drafting resolutions establishing investigating committees." 107 Met een beroep op de machtenscheiding ontweek het Hof hier moeilijke vragen over de legitimiteit van de onderzoeksopdracht en daarmee van de commissie als zodanig.

Het Hof koos in Watkins dan ook een andere benadering. Hoe vaag de onderzoeksopdracht van de commissie ook moge zijn, volgens het Hof heeft een getuige te allen tijde het recht om te weten op welke wijze de vragen die hem gesteld worden verband houden met het onderzoek dat de commissie uitvoert. ${ }^{108}$ Die vragen, zo stelde het Hof, moeten 'pertinent' (toepasselijk) zijn:

\footnotetext{
"Plainly these committees are restricted to the missions delegated to them, i.e., to acquire certain data to be used by the House or the Senate in coping with a problem that falls within its legislative sphere. No witness can be compelled to make disclosures on matters outside that area. This is a jurisdictional concept of pertinency drawn from the nature of a congressional committee's source of authority. It is not wholly different from nor unrelated to the element of pertinency embodied in the criminal statute under which petitioner was prosecuted." 109
}

Het 'pertinency'-criterium, zoals dat ook in de contemptwet voortkomt, staat dus in verband met de eerder besproken contemptwet op basis waarvan de getuige werd vervolgd. ${ }^{110}$ Deze wet bepaalt dat getuigen die weigeren "to answer any question pertinent to the question under inquiry", strafbaar zijn. Een weigering om vragen die niet 'pertinent' zijn te beantwoorden is daarmee dus niet strafbaar. De wijze waarop deze strafbepaling is geformuleerd, brengt echter met zich mee dat getuigen, op het gevaar af van mogelijke latere vervolging, op het moment van ondervraging zelf zullen moeten beoordelen of een vraag toepasselijk is en dus wel of niet beantwoord hoeft te worden. De getuige "acts at his peril", benadrukt het Hof. ${ }^{111}$ Het is daarom

105354 U.S. 178, 201 (1957).

106354 U.S. 178, 202 (1957).

107354 U.S. 178, 204-205 (1957).

108 Zie hierover ook Grabow 1988, p. 120-123; Hamilton 1976, p. 240-243; Boon 1982, p. 68-69.

109354 U.S. 178, 206 (1957).

110 Zie 2 U.S.C.A. 192. Zie ook hierboven, par. 3.3.2.

111354 U.S. 178, 208 (1957). Dit geldt overigens niet alleen voor het beantwoorden van vragen; ook het verschaffen van documenten valt onder de eisen van 'pertinency'. Zie Grabow 1988, p. 120-121. 
volgens het Hof niet meer dan 'fair' dat getuigen op dat moment voldoende informatie ter beschikking hebben omtrent het onderwerp van het onderzoek (de 'question of inquiry'). De eisen van 'clarity' en 'explicitness' die voortvloeien uit de Due Process Clause in het Vijfde Amendement zijn hier van toepassing zoals in elk ander strafproces. ${ }^{112}$

Bij congressionele onderzoeken kan de 'question under inquiry' op verschillende manieren worden bepaald. Het Hof beperkte zich niet tot de instellingsresolutie; ook opmerkingen van de commissievoorzitter of de 'nature of the proceedings' kunnen aanwijzingen bevatten. De reactie van de voorzitter op het moment dat de getuige bezwaar maakte tegen een vraag, kan eveneens aanknopingspunten geven. ${ }^{113}$ In deze zaak leidde geen van deze aanknopingspunten echter tot meer helderheid. Hoewel de commissie de indruk wekte dat het onderzoek betrekking had op communistische inflitratie in de vakbeweging, was bijna een kwart van de namen van vermeende communisten die aan de getuige werd voorgelegd in het geheel niet betrokken bij de vakbeweging. ${ }^{114}$ In reactie op zijn bezwaar antwoordde de commissievoorzitter slechts dat het onderzoek betrekking had op "subversion and subversive propaganda", volgens het Hof "woefully inadequate to convey sufficient information as to the pertinency of the questions to the subject of the inquiry." 115 Tenzij het onderwerp onomstotelijk vaststaat, zo bepaalde het Hof, "it is the duty of the investigative body, upon objection of the witness on grounds of pertinency, to state for the record the subject under inquiry at that time and the manner in which the propounded questions are pertinent thereto. To be meaningful, the explanation must describe what the topic under inquiry is and the connective reasoning whereby the precise questions asked relate to it." 116 Een onderzoekscommissie heeft dus de plicht om, wanneer een getuige bezwaar maakt tegen bepaalde vragen op grond van 'pertinen$\mathrm{cy}^{\prime}$, voldoende duidelijkheid te verschaffen over het onderwerp van het onderzoek en de wijze waarop ('the connective reasoning whereby') de gestelde vragen in dat kader relevant zijn. ${ }^{117}$ Dat was in dit geval niet gebeurd en daarom mocht de getuige volgens het Hof terecht twijfelen aan het onderwerp van het onderzoek en de toepasselijkheid van de betwiste vragen. Zijn veroordeling wegens 'contempt' werd vernietigd wegens strijd met de Due Process Clause van het Vijfde Amendement.

Het Hof heeft met de toepasselijkheidstoets die in Watkins werd geïntroduceerd gekozen voor een middenweg: enerzijds worden geen consequenties verbonden aan de vaagheid van de onderzoeksopdracht van de HUAC-commissie, anderzijds worden wel eisen gesteld aan de wijze waarop de commissie haar bevoegdheden toepast. Hiermee trachtte het Hof naar eigen zeggen een balans te vinden tussen de noodza-

\footnotetext{
112354 U.S. 178, 209 (1957). ("That knowledge must be available with the same degree of explicitness and clarity that the Due Process Clause requires in the expression of any element of a criminal offense.")

113354 U.S. 178, 214 (1957).

114354 U.S. 178, 214 (1957).

115354 U.S. 178, 215 (1957).

116354 U.S. 178, 215 (1957).

${ }^{117}$ Niet helemaal duidelijk is overigens of een getuige die tegen bepaalde vragen geen bezwaar maakt tijdens zijn verhoor daarmee de mogelijkheid verliest om de toepasselijkheid van vragen bij de rechter ter discussie te stellen. Zie Grabow 1988, p. 123.
} 
kelijke vrijheid en flexibiliteit van congressionele onderzoekscommissies en het fundamentele belang van 'fairness' en zorgvuldigheid wanneer het gaat om de constitutionele rechten van individuele burgers. "That is a small price to pay if it serves to uphold the principles of limited, constitutional government without constricting the power of the Congress to inform itself." 118

Tot veel vrijspraken heeft de introductie van de toepasselijkheidstoets overigens niet geleid. In de zaak Barenblatt v. United States (1959), waarin getuige Barenblatt weigerde te antwoorden op vragen omtrent communistische elementen in het Amerikaanse hoger onderwijs, oordeelde het Hof met een krappe meerderheid dat het doel van de hoorzitting voldoende duidelijk was gemaakt aan de getuige. ${ }^{119}$ Ook in verschillende latere uitspraken werd een beroep op het toepasselijkheidsvereiste verworpen omdat de commissie hieromtrent - vermoedelijk met Watkins in het achterhoofd - voldoende duidelijkheid had geboden. ${ }^{120}$ Hoewel daarom wel wordt betoogd dat het Hof in feite enigszins is teruggekomen van haar felle stellingname in Watkins, ${ }^{121}$ lijkt het erop dat de uitspraak in elk geval een preventief effect heeft gehad en commissies nauwkeuriger zijn gaan beargumenteren waarom een bepaalde vraagstelling tijdens hoorzittingen van belang is voor het onderzoek. ${ }^{122}$

\subsubsection{Het non-incriminatierecht}

Het Vijfde Amendement bij de Amerikaanse Constitutie bevat, naast de hierboven besproken Due Process Clause, ook het zogenaamde non-incriminatierecht. Het Vijfde Amendement bepaalt hieromtrent: "No person (...) shall be compelled in any criminal case to be a witness against himself". Dat deze bescherming tegen gedwongen zelf-incriminatie van toepassing wordt geacht op congressionele onderzoeken, ligt vanuit tekstueel oogpunt wellicht niet direct voor de hand. De bepaling verwijst immers duidelijk naar strafrechtelijke procedures ('any criminal case'). Al vroeg in de geschiedenis van de congressionele onderzoekspraktijk wordt het Vijfde Amendement echter zonder veel discussie van toepassing geacht. ${ }^{123}$ Zo weigerde de directeur van de centrale bank in 1834 om documenten aan een congrescommissie te verstrekken wegens mogelijke zelfincriminatie. De eerder besproken wettelijke immuniteitsregeling, die tijdens de Burgeroorlog tot stand kwam, regelde met zoveel woorden dat getuigen voor congressionele commissies een spreekplicht hebben; niettemin werd tevens geregeld dat getuigen die zichzelf hierdoor zouden belasten strafrechtelijke immuniteit kon worden verleend. Hierin kan een erkenning worden gezien van de toepasselijkheid van het Vijfde Amendement; immers, een immuniteitsregeling

\footnotetext{
118354 U.S. 178, 216 (1957).

119 Barenblatt v. United States, 360 U.S. 109, 124-125 (1959).

120 Zie Cole \& Brand 2011, p. 88-89.

${ }^{121}$ Fisher 2007, p. 165. Vgl. Cole \& Brand 2011, p. 89, die stellen dat andere uitspraken "the more widely held view" onderschrijven dat het Hof sinds Watkins niettemin indringender is gaan toetsen.

122 Zie ook Boon 1982, p. 41-42.

${ }^{123}$ Hamilton, Muse \& Amer 2007, p. 1138 Zie ook Grabow 1988, p. 124.
} 
zou niet nodig zijn geweest als de Constitutie geen grenzen aan deze spreekplicht zou stellen. ${ }^{124}$

Het Hooggerechtshof bevestigde de toepasselijkheid van het Vijfde Amendement op congressionele onderzoeken voor het eerst in 1955, wederom in een serie uitspraken gerelateerd aan de HUAC-onderzoeken. ${ }^{125}$ De vraag was niet òf het Vijfde Amendement van toepassing was, maar op welke wijze getuigen een beroep kunnen doen op de constitutionele bescherming tegen gedwongen zelfincriminatie. Er blijken weinig formaliteiten verbonden te zijn aan een beroep op het amendement: een "special combination of words" 126 is niet nodig, de commissie moet in redelijkheid uit de bewoordingen van de getuigen kunnen opmaken dat het om een beroep op het Vijfde Amendement gaat. Er bestaat geen recht om in het geheel niet te getuigen of om te weigeren de eed af te leggen. Er is dus geen sprake van een algemeen zwijgrecht vergelijkbaar met dat van een verdachte in het strafprocesrecht. ${ }^{127}$ De bescherming van het Vijfde Amendement is bovendien persoonlijk en kan niet worden ingeroepen ter bescherming van de belangen of de goede naam van derden of van bedrijfsbelangen. De bescherming geldt in beginsel alleen voor getuigenissen ('testimony') en ten aanzien van 'persoonlijke' schriftelijke stukken. ${ }^{128}$ Het geldt niet ten aanzien van documenten die iemand "as representative" onder zich heeft. Dit laatste betekent dat iemand die bijvoorbeeld schriftelijke bedrijfsinformatie in bezit heeft, deze stukken op verzoek moet overhandigen aan een congrescommissie op straffe van 'contempt', zelfs wanneer deze documenten kunnen wijzen op strafbare feiten door de beheerder van de documenten gepleegd. ${ }^{129}$

Essentieel is voorts dat het Vijfde Amendement alleen bescherming biedt bij vragen of verzoeken die kunnen worden gezien als "a link in the chain of eviden$\mathrm{ce}^{\prime \prime} .{ }^{130}$ Een getuige hoeft echter niet te bewijzen dat het beantwoorden van een vraag belastend voor hem is. In Hoffman, een zaak die overigens om een gerechtelijke en niet een congressionele procedure ging, bepaalde het Hof:

"...if the witness, upon interposing his claim, were required to prove the hazard in the sense in which a claim is usually required to be established in court, he would be compelled to surrender the very protection which the privilege is designed to guarantee. To sustain the privilege, it need only be evident from the implications of the question, in the setting in which it is asked, that a responsive answer to the question or an explanation of why it cannot be answered might be dangerous because injurious disclosure could result." 131

Niet alleen de vraag op zich, maar ook de context waarin de vraag is gesteld, kan dus worden betrokken in de beoordeling van een beroep op het Vijfde Amendement. Het

\footnotetext{
124 Zie Hamilton, Muse \& Amer 2007, p. 1138 Zie ook Hamilton 1976, p. 211-212. Zie verder Grabow 1988, p. 124-125 en hierboven, par. 2.3.3.

125 Zie Quinn v. United States, 349 U.S. 155 (1955); Emspak v. United States, 349 U.S. 190 (1955); Bart v. United States, 349 U.S. 219 (1955).

126349 U.S. 155, 162 (1955).

127 Zie ook Grabow 1988, p. 126.

128 Zie Grabow 1988, p. 130.

${ }^{129}$ Hamilton 1976, p. 215.

${ }^{130}$ Hoffman v. United States, 341 U.S. 479, 486 (1951). Zie ook Grabow 1988, p. 126.

131341 U.S. 479, 486-487 (1951).
} 
blijft echter de vraag wanneer het 'evident' is dat de beantwoording van een vraag belastend is. Het Hof geeft hieromtrent weinig nadere uitleg, maar in een uitspraak van een lagere rechter inzake een getuige die weigerde bepaalde vragen van een subcommissie uit de Senaat te beantwoorden, is dit wel wat verder uitgewerkt. De rechtbank stelde dat "in certain circumstances, a witness should explain why an answer to an apparently innocent question might tend to incriminate him in order to avoid the conclusion that he was resorting to subterfuge to prevent giving information which he is required to give", maar dat "there can certainly be no such burden upon a witness when the circumstances are such that reasonable apprehension on his part is evident." Bovendien, zo vervolgde de rechtbank, "it is well recognized that, once it has become apparent that the answer to a question would expose a witness to the danger of conviction or prosecution, wider latitude is permitted the witness in refusing to answer other questions upon the ground that such answers would tend to incriminate him." 132 Een nadere motivering kan in bepaalde omstandigheden, als een vraag ogenschijnlijk geen belastend effect heeft, dus van een getuige worden verlangd. De getuige verkeert hierdoor nog steeds in een onzekere positie. In de rechtspraak lijkt echter te zijn aanvaard dat dit dilemma niet op te lossen is. Illustratief is een uitspraak van de appelrechter Learned Hand, in een zaak rondom een weigerachtige getuige in een gerechtelijke procedure:

\footnotetext{
"Obviously a witness may not be compelled to do more than show that the answer is likely to be dangerous to him, else he will be forced to disclose those very facts which the privilege protects. Logically, indeed, he is boxed in a paradox, for he must prove the criminatory character of what it is his privilege to suppress just because it is criminatory. The only practicable solution is to be content with the door's being set a little ajar, and while at times this no doubt partially destroys the privilege, and at times it permits the suppression of competent evidence, nothing better is available." 133
}

Een beroep op het Vijfde Amendement is dus niet zonder risico. Een andere complicatie is dat de mogelijkheid is aanvaard dat een verlaat beroep op het Vijfde Amendement ertoe kan ertoe leiden dat de getuige zijn bescherming heeft verspeeld. Een getuige kan namelijk zowel expliciet als impliciet afstand doen van zijn rechten op grond van het Vijfde Amendement. Dat laatste, impliciete afstand, was aan de orde in de zaak Rogers v. United States. De getuige had toegegeven gedurende enige tijd kaderlid te zijn geweest van de Communistische Partij. Aangezien zij deze, mogelijk belastende, informatie vrijwillig had verstrekt, kon zij zich vervolgens niet langer beroepen op het Vijfde Amendement toen haar gevraagd werd nadere details te verstrekken. Het Hof stelde: "When incriminating facts have been voluntarily revealed, the privilege cannot be invoked to avoid disclosure of the details." 134

\footnotetext{
132 United States v. Jaffe, 98 F.Supp. 191, 194 (D.D.C.1951). Zie ook Rosenberg 2008, p. 63-64.

133 United States v. Weisman, 111 F.2d 260, 252 (2d Cir. 1940). Zie ook Grabow 1988, p. 128.

134 Rogers v. United States, 340 U.S. 367, 373 (1951). Zie ook Grabow 1988, p. 131-132 en Hamilton, Muse \& Amer 2007, p. 1139-1140.
} 


\subsection{Tussenconclusie, mede in vergelijkend perspectief}

Het congressionele onderzoeksrecht. Hierboven is duidelijk geworden dat het congressionele onderzoeksrecht ruim moet worden opgevat. Het onderzoeksrecht van het Congres is breed en strekt zich uit over het gehele takenpakket van het Congres. De geschiedenis van congressioneel onderzoek gaat terug tot de beginjaren van de Amerikaanse republiek. Definitieve rechterlijke erkenning volgt relatief laat, aan het begin van de twintigste eeuw. Het Congres beschikt over een aantal verstrekkende onderzoeksbevoegdheden, zoals het oproepen van getuigen middels een bevel (subpoena), het vervolgen van weigerachtige getuigen wegens contempt en het verlenen van strafrechtelijke immuniteit. Deze bevoegdheden zijn in beide kamers gedelegeerd aan de vaste commissies.

In hoeverre legt de jurisprudentie van het Hof beperkingen op aan congressionele onderzoekscommissies? Vereist wordt dat een congressioneel onderzoek een legitiem doel heeft, maar dat dit zo is, wordt door de rechter bijna nooit betwijfeld. Voorts blijkt het Hof van het Congres te verlangen dat onderzoeksopdrachten helder geformuleerd en duidelijk afgebakend zijn, maar ook daarbij komt het niet snel tot daadwerkelijke sanctionering. Zelfs de onderzoeksopdracht aan de HUACcommissie, die bijzonder vaag geformuleerd was, werd aanvaardbaar geacht. Het Hof lijkt het, gelet op de machtenscheiding, niet als zijn constitutionele taak te beschouwen om het Congres op dit punt daadwerkelijk terug te fluiten.

In plaats daarvan legt het Hof de nadruk op de bescherming van de individuele getuige, die ook ten overstaan van een congrescommissie een beroep kan doen op diens constitutionele grondrechten. Zo moet een getuige vanuit het oogpunt van 'fairness', zoals dat voortvloeit uit de Due Process Clause van het Vijfde Amendement, tijdens het verhoor in voldoende mate kunnen beoordelen of de gestelde vragen toepasselijk zijn op het lopende onderzoek. ${ }^{135}$ Getuigen die menen om redenen van 'ongepastheid' te mogen weigeren om medewerking te verlenen, handelen immers met het risico dat zij zullen worden vervolgd wegens contempt. Onderzoekscommissies hebben volgens het Hof daarom de plicht om duidelijkheid te verschaffen over het precieze onderwerp van het onderzoek en de relevantie of toepasselijkheid van de gestelde vragen.

Het non-incriminatierecht. Het Vijfde Amendement biedt getuigen daarnaast het recht om vragen onbeantwoord te laten, althans wanneer beantwoording zou leiden tot zelfincriminatie. Aan het doen van een beroep op dit beperkte zwijgrecht worden niet veel procedurele eisen gesteld, al kan onder omstandigheden worden verlangd dat de getuige toelicht waarom de gevraagde feiten belastend zouden zijn. Dat daarmee alsnog een bepaalde mate van inzicht moet worden gegeven en enigszins afgedaan wordt aan de waarde van het zwijgrecht, wordt in de rechtspraak als onvermijdelijk gezien. Dat is begrijpelijk, want wanneer een beroep op het zwijgrecht wegens mogelijke zelfincriminatie voor de commissie en in tweede instantie de rechter niet evident gerechtvaardigd is, dan zal een vorm van verificatie noodzakelijk zijn. Daarmee wordt de deur naar eventueel nader strafrechtelijk onderzoek op een

135 Aangenomen wordt overigens dat ook andere vormen van medewerking, zoals het verstrekken van documenten aan de onderzoekscommissie, onder de eisen van 'pertinency' vallen. 
kier gezet. Voor getuigen is een beroep op het zwijgrecht aldus niet zonder risico. Daarnaast kan een getuige bij een beroep op het Vijfde Amendement gemakkelijk de verdenking op zich laden dat hij iets te verbergen heeft. Zelfs zonder een commissie die van dat effect uitvoerig misbruik maakt, zoals de HUAC en de senaatscommissie van McCarthy, is dat voor getuigen niet bepaald een aantrekkelijk perspectief.

In Nederland wordt ter bescherming van getuigen door verschillende auteurs gepleit voor invoering van een dergelijk (familiaal) zwijgrecht wegens nonincriminatie. ${ }^{136}$ Gezien het bovenstaande is het echter de vraag of de positie van een getuige, die vreest voor strafrechtelijke (of andersoortige juridische) consequenties, daarmee werkelijk verbetert. Een beroep op een zwijgrecht wegens mogelijke zelfincriminatie en een eventuele rechterlijke toetsing daarvan kan justitie immers eveneens op een spoor zetten - of in elk geval wakkerschudden. ${ }^{137}$ Verder kunnen ook de publicitaire gevolgen voor de betreffende getuige groot zijn. Wanneer de verklaring van een getuige die vreest voor vervolging noodzakelijk is voor het onderzoek, dan lijken zowel de getuige als de commissie mij het meest gebaat bij een oplossing in de sfeer van onderling overleg en afstemming, waarbij alle belangen zorgvuldig worden meegewogen. Ook de commissie kan hier veel baat bij hebben, want het is maar de vraag of getuigen die ernstig vrezen voor vervolging zo behulpzaam zullen zijn en betrouwbare verklaringen zullen afleggen. ${ }^{138}$ Desnoods kan, zoals ook de initiatiefnemers van de Wpe 2008 aangaven, gebruik gemaakt worden van een besloten verhoor. Ook daarvoor geldt echter, dat een besluit daarover aan de commissie zou moeten blijven. Een besloten verhoor brengt immers aanzienlijke beperkingen voor het onderzoek met zich mee, bijvoorbeeld ten aanzien van de rapportage. Wel zou moeten worden overwogen om de besluitvorming rondom een besloten verhoor nader uit te werken. Zo zou kunnen worden geregeld dat over een verzoek van een getuige in elk geval in de commissie gestemd dient te worden. Verder zou kunnen worden bepaald dat een afwijzing gemotiveerd dient te worden en wellicht zelfs een versterkte meerderheid zou vereisen. ${ }^{139}$

De immuniteitsregeling. Het zwijgrecht, zoals dat voortvloeit uit het Vijfde Amendement, kan worden doorbroken door de betreffende getuige strafrechtelijke immuniteit te verlenen. De wettelijke regeling hieromtrent verleent echter geen absolute immuniteit, maar bepaalt slechts dat getuigenverklaringen niet in rechte als bewijs kunnen dienen. De Amerikaanse immuniteitsregeling kan daarmee worden gezien als een ad hoc variant van de Nederlandse bewijsuitsluitingsregel van art. 30 Wpe. In de Amerikaanse rechtspraak zijn strenge normen aangelegd voor het gebruik van ander bewijsmateriaal, dat op geen enkele wijze terug te voeren mag zijn op de congressionele verklaringen van de verdachte. Vooral bij getuigen wiens congressionele optreden veel media-aandacht heeft gekregen, lijkt het sinds een enkele 'mislukte' strafzaken praktisch niet meer mogelijk om nadien tot strafrechtelijke ver-

136 Zie hierboven, Deel I, par. 2.3.4.2.

137 Zie ook Dölle 1985, p. 161.

138 Zo ook Drexhage 2009, p. 16.

${ }^{139}$ Dit zou bijvoorbeeld in de RPE kunnen worden geregeld. Wanneer ook een versterkte meerderheid vereist zou worden om een verzoek af te wijzen, dan is een wetswijziging noodzakelijk. Uit art. 12 Wpe 2008 volgt thans dat de commissie bij gewone meerderheid besluit over een besloten verhoor. 
oordeling te komen. De beperkte immuniteit, die de regeling beoogt, is in de rechtspraak tot een bijna absolute immuniteit verworden. De bewaarheid geworden vrees dat prominente getuigen hun straf daardoor ontlopen, heeft ervoor gezorgd dat de immuniteitsregeling in de praktijk nauwelijks nog wordt toegepast.

Het invoeren van een dergelijke regeling in Nederland, zoals soms wordt gesuggereerd, is niet verstandig. Wanneer de regeling letterlijk wordt overgenomen, voegt deze niets toe (en doet zelf af) aan de bestaande bewijsuitsluitingsregel. Een ruimere, bijna absolute immuniteitsregeling, zoals die in de praktijk werkt, is evenmin aan te raden. Zoals het roemruchte voorbeeld van de getuigen North en Pointdexter in de Iran-Contrazaak laat zien, kan het 'belonen' van het verlenen van medewerking aan een parlementaire enquête met strafrechtelijke immuniteit tot ongewenste en onrechtvaardige uitkomsten leiden. Terecht zagen de initiatiefnemers van de Wpe 2008 daarom af van een dergelijke regeling. ${ }^{140}$

Organisatorische en procedurele waarborgen. Niet alleen in de rechtspraak heeft de bescherming van getuigen naar aanleiding van de McCarthy-periode nader vorm gekregen, ook het Congres zelf heeft op dit punt maatregelen genomen om nieuwe excessen te voorkomen. Het onderzoeksrecht wordt sinds 1945 voornamelijk uitgeoefend door de vaste commissies in beide kamers. Hun werkterreinen zijn in de kamerregels steeds verder gespecificeerd. De formuleringen die zijn gekozen, die inmiddels ook bij de instelling van bijzondere commissies ('select committees') wordt gevolgd, zijn dermate gedetailleerd dat de reikwijdte van de bevoegdheid van commissies thans nauwelijks nog tot onduidelijkheid leidt. Waar de vaag geformuleerde HUACresolutie in de jaren 50 nog tot kritische rechtspraak leidde, speelt deze bron van onzekerheid en willekeur in de moderne praktijk daarom feitelijk geen rol van betekenis meer.

Ook in procedurele zin zijn sindsdien in beide kamers waarborgen ter bescherming van getuigen aangebracht, waarvan een groot gedeelte nog steeds van kracht is. ${ }^{141}$ In het Huis bepaalt Rule XI dat de voorzitter bij aanvang van een hoorzitting het onderwerp ervan aankondigt en dat getuigen een recht op bijstand hebben "for the purpose of advising them concerning their constitutional rights". Verder kunnen getuigen, wanneer zij vrezen dat hun verklaringen of bewijsmateriaal "may tend to defame, degrade, of incriminate the witness", de commissie verzoeken het verhoor in een besloten zitting af te nemen. Ook kan een getuige verzoeken om andere getuigen op te roepen. Alleen een meerderheid van de aanwezige commissieleden kan een dergelijk verzoek afwijzen. ${ }^{142}$ De Senaat kent geen kamerbrede regels omtrent de bescherming van getuigen, maar laat dit over aan de afzonderlijke commissies. Met name de Permanent Subcommittee on Investigations, waar McCarthy tot 1954 het scepter zwaaide, kent uitvoerige bepalingen op dit punt. Zo kan een verhoor alleen worden afgenomen wanneer minimaal twee leden aanwezig zijn en kan iedereen die meent beschadigd te zijn door getuigenverklaringen van anderen, verzoeken om zelf te worden gehoord of een schriftelijke verklaring te kunnen indienen. ${ }^{143}$ Deze her-

\footnotetext{
140 Kamerstukken II 2005/06, 30 415, nr. 6, p. 56. Zie verder hierboven, Deel I, par. 2.6.

141 Cole \& Brand 2011, p. 90-92.

142 Zie House Rule XI, lid 2.

143 Guide to Congress 2008, p. 296.
} 
vormingen hebben er overigens wel toe geleid, dat de rol van rechtsbijstandsverleners tijdens congressionele onderzoeken sterk is gegroeid. ${ }^{144}$

Beeld- en geluidsregistratie tijdens hoorzittingen. In het Huis konden getuigen zich tussen 1970 en 1997 verzetten tegen de aanwezigheid van televisie of radio. Met een beroep op het belang van openheid werd dit recht in 1997 door de toenmalige Republikeinse meerderheid afgeschaft. Een dergelijk recht voor getuigen om radio- en televisieregistratie te weren heeft in Nederland, zoals hiervoor ${ }^{145}$ besproken, nooit bestaan. In de literatuur is hiervoor wel gepleit. Vooral voor 'gewone burgers', die niet gewend zijn aan indringende media-aandacht, kan met name de uitzending van een verhoor op televisie immers bijzonder ingrijpend zijn en aanzienlijke risico's voor reputatieschade met zich meebrengen. Bij de herziening van de enquêtewetgeving in 2008 is dit pleidooi door de initiatiefnemers afgewezen. Zij achtten verslaggeving, ook via radio en televisie, van groot belang bij parlementaire enquêtes. Daarom zou het voldoende zijn om de commissie de bevoegdheid te geven om een verhoor zonder beeld- en geluidsregistratie te laten plaatsvinden, wanneer daarvoor gewichtige redenen zijn. Verder wordt erkend, op aandringen van de Raad van State, dat een ieder uiteraard het recht heeft om de voorzieningenrechter te benaderen wanneer gevreesd wordt voor inbreuken op de persoonlijke levenssfeer. ${ }^{146}$

Hoewel de initiatiefnemers terecht wijzen op het belang van verslaglegging, wordt hier toch te gemakkelijk voorbijgegaan aan de genoemde impact die met name televisie kan hebben op getuigen en de aanvullende (publicitaire) risico's die een beroep op de rechter met zich meebrengt. De wet dient in de eerste plaats om parlementair onderzoek mogelijk te maken en dat is hier niet in het geding, aangezien het verhoor ook zonder televisieregistratie nog steeds openbaar en dus bruikbaar is. Het 'secundaire' belang van televisieregistratie weegt niet per definitie op tegen het belang van de bescherming van getuigen. Een en ander rechtvaardigt mijns inziens het versterken van de rechten van getuigen, die in dit verband niet afhankelijk van de commissie of de rechter zouden moeten zijn. ${ }^{147}$ Overigens is een al te lichtvaardig beroep op een dergelijk recht niet te verwachten. Dölle wees er al op dat zulks immers 'bevreemding' kan wekken. ${ }^{148}$ De ervaringen in de Verenigde Staten, waar getuigen slechts in enkele gevallen een beroep op dit recht deden, wijzen hier ook op. De regel, zoals die tussen 1970 en 1997 gold in het Huis, kan daarom als voorbeeld dienen. Wel zou een uitzondering kunnen worden gemaakt voor (gewezen) bewindspersonen of bestuurders van zbo's, aangezien zij doorgaans voldoende mediaervaring bezitten en bovendien ook om redenen van (ministeriële) verantwoordelijkheid een andere positie innemen.

\footnotetext{
144 Cole \& Brand 2011, p. 92.

145 Zie Deel I, par. 2.3.2.2.

146 Kamerstukken II 2005/06, 30 415, nr. 6, p. 20-22.

147 Of de (televisie)media sterk gehinderd zullen worden wanneer getuigen van een dergelijk recht gebruik kunnen zouden maken, mag worden betwijfeld: met een shot van de getuige die de zaal binnenkomt, verlaat, of de eed dan wel belofte aflegt, is er immers vaak al meer dan genoeg materiaal om de verslaglegging in de avondjournaals van achtergrondbeelden te voorzien.

148 Dölle 1985, p. 112.
} 


\subsection{De uitvoerende macht}

\subsubsection{Medewerkingsplicht}

Het congressionele onderzoeksrecht wordt zowel in de rechtspraak als in de praktijk, zo bleek hierboven, een ruime betekenis toegekend. Een congressioneel onderzoek dient, aldus het Supreme Court, gericht te zijn op een legitiem doel - een vereiste waarvan weinig kaderstellende werking uitgaat. Er is doorgaans weinig voor nodig om aannemelijk te maken dat een onderzoek op enigerlei wijze in verband kan worden gebracht met de legitieme functies van het Congres. Aangezien het houden van toezicht op de uitvoerende macht, als pendant van de wetgevende en budgettaire bevoegdheden van het Congres, zo een legitieme taak is, ligt het voor de hand dat de functionarissen binnen de uitvoerende macht geacht worden medewerking te verlenen aan een congressioneel onderzoek. Het Congres kan zijn onderzoeksbevoegdheden in beginsel ook jegens federale ambtenaren inzetten teneinde medewerking van de uitvoerende macht af te dwingen. Concreet betekent dit, dat congrescommissies die over de reguliere onderzoeksbevoegdheden beschikken zowel mondelinge als schriftelijke inlichtingen van federale ambtenaren kunnen verlangen en inzage in departementale stukken kunnen vorderen.

De verplichting om medewerking te verlenen aan een congressioneel onderzoek geldt voor elke federale ambtenaar; het is dus niet noodzakelijk om een verzoek aan het hoofd van een departement of agency te richten. Wanneer het gaat om het verstrekken van ambtelijke stukken, dan wordt het verzoek meestal gericht aan de secretary van het departement respectievelijk het hoofd van het agency waarvan de stukken afkomstig zijn. Ambtenaren kunnen bovendien, net als ieder ander, onder ede worden verhoord. Een congrescommissie beslist zelf welke ambtenaar zij zou willen horen. Een verzoek om te verschijnen voor verhoor of om departementale stukken te verstrekken kan kracht bijgezet worden met behulp van subpoenas. Bij weigerachtigheid bestaat zelfs de mogelijkheid van een contemptprocedure. De strafrechtelijke contemptregeling maakt geen uitzondering voor executieve ambtenaren, ook niet voor de hoogsten. Een strafrechtelijke veroordeling wegens contempt is daarom wettelijk niet uitgesloten. 149

Met de constatering dat de medewerkingsplicht in beginsel ook voor functionarissen binnen de uitvoerende macht geldt en dat het reguliere arsenaal aan dwangmiddelen van het Congres daarbij inzetbaar is, is echter niet alles gezegd. Het vorderen van medewerking van federale ambtenaren raakt namelijk aan de constitutionele scheiding van machten. Het Amerikaanse constitutionele stelsel gaat uit van een zekere institutionele gelijkwaardigheid van de staatsmachten, waardoor de legitieme doelen die met het congressionele onderzoeksrecht worden nagestreefd moeten worden afgezet tegen de legitieme taken van de andere staatsmachten. Dan blijkt dat er ruimte is voor de uitvoerende macht, wanneer het publieke belang daarmee gediend is, om onder omstandigheden te weigeren om informatie aan het Congres te verstrekken. In de doctrine die hieromtrent tot ontwikkeling is gekomen, 'executive privilege', speelt de President een sleutelrol.

${ }^{149}$ Fisher 2004, p. 111. 


\subsubsection{De ontwikkeling van het 'executive privilege'}

De Constitutie zwijgt over het bestaan van een geheimhoudingsrecht voor de uitvoerende macht ten opzichte van de andere staatsmachten. Op de vraag of de 'Framers' een dergelijk voorrecht in gedachten hadden toen zij de Constitutie opstelden, kan geen eenduidig antwoord worden gegeven. ${ }^{150} \mathrm{Al}$ bij het eerste congressionele onderzoek na de inwerkingtreding van de Constitutie speelde de vraag in hoeverre de uitvoerende macht in constitutionele zin verplicht zou zijn om de congrescommissie de gevraagde inlichtingen te verschaffen. De bijzondere Huiscommissie die in 1792 onderzoek deed naar de militaire nederlaag van St. Clair verzocht de minister van Oorlog om alle schriftelijke stukken omtrent de militaire expeditie ter beschikking te stellen. President Washington belegde vervolgens een kabinetsvergadering, waarin het verzoek van de commissie werd besproken. ${ }^{151}$ Uit de aantekeningen van Jefferson blijkt dat Washington niet twijfelde aan de rechtmatigheid van het congressionele onderzoek, maar dat hij zich tegelijkertijd kon voorstellen dat er stukken zouden zijn "so secret a nature, as that they ought not to be given up." 152 Het kabinet kwam vervolgens, mede op basis van een vergelijking met het parlementaire onderzoeksrecht in het Britse Lagerhuis, met een unaniem standpunt:

"First, that the House was an inquest and therefore might institute inquiries. Second, that they might call for papers generally. Third, that the Executive ought to communicate such papers as the public good would permit, and ought to refuse those, the disclosure of which would endanger the public. Fourth, that neither the committee nor House had a right to call on the Head of a department, who and whose papers were under the President alone, but that the committee should instruct their chairman to move the House to address the President." 153

In reactie op dit kabinetsbesluit nam het Huis een resolutie aan, waarin de President werd verzocht om "such papers of a public nature" die van belang waren voor het onderzoek te doen toekomen. Aan dit verzoek kwam de President tegemoet, zij het dat hij alleen kopieën liet verstrekken. Belangrijker nog, zo blijkt uit de notities van Jefferson, is dat de President zich expliciet het recht voorbehield om stukken achter te houden, "the disclosure of which would injure the public." 154 Dit voorbehoud

150 In de literatuur bestaat hieromtrent onenigheid. Volgens Berger, die in de Nixonjaren een invloedrijk boek over 'executive privilege' schreef, biedt de constitutionele geschiedenis "not a scintilla of evidence ... of a design to curtail the historical scopy of legislative inquiry or to authorize executive withholding of any information." Berger 1974, p. 59. Rozell ziet onder verwijzing naar enkele passages in de Federalist Papers wel degelijk aanwijzingen dat de 'Framers' een presidentieel geheimhoudingsrecht als vanzelfsprekend zagen in een stelsel van gescheiden machten. Rozell 2002, p. 24-27.

${ }^{151}$ Een van de kabinetsleden, de latere president Jefferson, merkte in zijn aantekeningen op dat Washington "had called us to consult, merely because it was the first example, and he wished that so far as it should become a precedent, it should be rightly conducted." Zie Grabow 1988, p. 19-20.

152 Randolph 1829, p. 464.

153 Zie Grabow 1988, p. 20. Zie ook Boon 1982, p. 44.

154 Grabow 1988, p. 20-21. Zie ook Rozell 2002, p. 29 en Fisher 2004, p. 10-11. Washington beperkte zijn voorbehoud dus tot het publieke belang; het beschermen van de eigen politieke belangen of het verhullen van onrechtmatige handelingen van de President of diens directe medewerkers, zoals Nixon later zou betogen, behoorde daar in de visie van Washington nadrukkelijk niet toe. Zie Rozell 2002, p. 30. Zie ook Fisher 2004, p. 11. 
werd uiteindelijk overigens met betrekking tot dit onderzoek niet ingezet: alle stukken waarom de Huiscommissie had gevraagd werden verstrekt. De minister van Oorlog verscheen zelfs nog persoonlijk als getuige voor de commissie. ${ }^{155} \mathrm{Na}$ dit onderzoek maakte Washington nog wel verschillende keren gebruik van het door hem geformuleerde presidentiële geheimhoudingsrecht, eenmaal jegens de Senaat ten aanzien van diplomatieke stukken en eenmaal jegens het Huis ten aanzien van verdragsonderhandelingen.

Het precedent van President Washington zette kennelijk de toon. De gevallen waarin presidenten zich in de negentiende eeuw beriepen op hun geheimhoudingsrecht in verband met het publieke belang zijn volgens Rozell zo talrijk dat een individuele analyse nauwelijks mogelijk is. In de meeste gevallen, zo kan uit zijn historisch overzicht van deze periode worden afgeleid, ging het om congressionele verzoeken die betrekking hadden op de buitenlandse betrekkingen, zoals verzoeken om inzage in diplomatieke correspondentie of verdragsonderhandelingen. Met name President Lincoln, wiens presidentschap in een uitzonderlijke tijdsperiode plaatsvond, weigerde daarnaast verschillende malen inlichtingen te verschaffen omtrent lopende strafzaken. ${ }^{156}$

In de twintigste eeuw zette deze praktijk zich voort. Na de Tweede Wereldoorlog kreeg President Truman verschillende keren te maken met congressionele verzoeken om informatie over gesprekken tussen hem en zijn persoonlijke adviseurs. Truman beschouwde deze gesprekken als vertrouwelijk en verbood zijn adviseurs om gehoor te geven aan subpoenas van congrescommissies.157 Zijn opvolger, Eisenhower, dacht hier hetzelfde over en introduceerde voor de eerste keer de term 'executive privilege'. Opmerkelijk was een brief van Eisenhower aan de minister van Defensie, waarin hij de minister opdroeg om zijn ambtenaren te instrueren om niet onvoorwaardelijk mee te werken aan het onderzoek naar communistische elementen binnen het leger van de senaatscommissie onder leiding van Joseph McCarthy. Eisenhower, die voluit de aanval op McCarthy inzette nu hij had gewaagd om ook het leger onder de loep te nemen, schreef dat "essential to efficient and effective administration that employees of the Executive Branch be in a position to be completely candid in advising with each other on official matters, and because it is not in the public interest that any of their conversations or communications, or any documents or reproductions, concerning such advice be disclosed." De minister diende daarom zijn ambtenaren op te dragen de commissie op geen enkele wijze inzicht te verschaffen in de intra-departementale communicatie. ${ }^{158}$

De suggestie die Eisenhower met zijn brief wekte was dat het executive privilege niet alleen voor presidentiële communicatie geldt, maar ook voor communicatie tussen andere functionarissen binnen de uitvoerende macht. Deze mogelijke verbre-

155 Grabow 1988, p. 20-21.

156 Zie nader: Rozell 2002, p. 32-37.

157 Rozell 2002, p. 38-39.

158 Geciteerd in Rozell 2002, p. 39-40. Later motiveerde Eisenhower zijn standpunt ten aanzien van zijn persoonlijke adviseurs nog door te stellen dat "I would be astonished if any of my personal advisors would undertake to give testimony on intimate staff counsel and advice. The result would be to eliminate all such offices from the presidential staff. In turn, this would mean paralysis." Zie Rozell 2002, p. 40 . 
ding van het presidentiële voorrecht wekte argwaan binnen het Congres. Eisenhowers opvolger, President Kennedy, werd spoedig na zijn aantreden door John Moss, voorzitter van de House Subcommittee on Government Information, verzocht zijn standpunt ten aanzien van executive privilege te bepalen. Kennedy antwoordde dat dit privilege alleen door de President persoonlijk kan worden ingeroepen en dus niet door anderen kan worden toegepast zonder uitdrukkelijke presidentiële instemming. Bovendien bevestigde Kennedy het belang van een zo groot mogelijke openheid ten opzichte van het Congres. ${ }^{159}$ Ook Kennedy's opvolger, Johnson, werd gevraagd om zijn beleid te verduidelijkheid; hij onderschreef Kennedy's uitgangspunten. Opvallend is echter, zo blijkt uit de analyse van Rozell, dat dit beleid in de praktijk niet altijd werd gevolgd: ook lagere functionarissen beriepen zich in deze periode op executive privilege, zonder specifieke presidentiële toestemming, om medewerking aan congressionele onderzoeken te omzeilen. ${ }^{160}$

\subsubsection{Het privilege in de rechtspraak}

\subsubsection{Nixon en het Watergateschandaal}

De discussie over de vraag of ook lagere functionarissen een beroep konden doen op 'executive privilege', laat zien dat de reikwijdte van dit executieve voorrecht niet helemaal duidelijk was, maar tegelijkertijd ook dat het bestaan van het privilege als zodanig voor het Congres niet (meer) ter discussie stond. Met het presidentschap van Richard Nixon veranderde dit volledig. Nixons vermeende betrokkenheid bij de inbraak in het hoofdkwartier van de Democratische partij tijdens de verkiezingscampagne van 1972 en zijn pogingen nadien om dit met behulp van een beroep op 'executive privilege' te verhullen, leidden tot een politieke vertrouwenscrisis die zijn weerga niet kende in de Amerikaanse geschiedenis. De affaire 'Watergate' was zo ingrijpend, schrijft Rozell, dat Nixons opvolgers "have been reluctant to assert executive privilege, and many members of Congress have characterized all exercises of executive branch secrecy as Nixonian attempts to conceal and deceive."161

Nixon begon zijn presidentschap, in antwoord op het gebruikelijk geworden verzoek van het congreslid Moss, nog met veel goede voornemens. In zijn memorandum stelde hij dat "[w]hile the Executive branch has the responsibility of withholding certain information the disclosure of which would be incompatible with the public interest, this administration will invoke [executive privilege] only in the most compelling circumstances and after a rigorous inquiry into the actual need for its exercise." Bovendien zou executive privilege, zoals ook zijn voorgangers hadden bepaald, niet kunnen worden uitgeoefend "without special Presidential approval." 162 Aan het begin van zijn tweede ambtstermijn voegde hij daar nog stellig aan toe: "Executive privilege will not be used as a shield to prevent embarrassing information from being made available but will be exercised only in those particular instances in

\footnotetext{
159 Rozell 2002, p. 41.

160 Rozell 2002, p. 41-42.

161 Rozell 2002, p. 54.

162 Geciteerd in Rozell 2002, p. 56.
} 
which the disclosure would harm the public interest."163 In werkelijkheid beriep Nixon zich overigens al voor de Watergate-affaire verschillende keren op executive privilege ${ }^{164}$ en stond hij toe, evenals zijn voorgangers, dat lagere functionarissen binnen de uitvoerende macht zelfstandig weigerden om medewerking te verlenen aan congressionele onderzoeken. Opvallend was verder dat Nixon sommige leden van zijn kabinet tevens als persoonlijk adviseur had benoemd, om daarmee congressionele onderzoeken gemakkelijk te kunnen ontwijken - ook wanneer het ging om louter departementale aangelegenheden. ${ }^{165}$

Begin 1973 onthulde de Washington Post een inbraak bij het Democratische hoofdkwartier in het Watergate-gebouw, waarbij de naam van Nixon al snel werd genoemd. De Senaat stelde een bijzondere commissie in die onderzoek moest gaan doen naar de vermeende betrokkenheid van de president en zijn medewerkers (de commissie-Ervin) bij deze affaire. ${ }^{166}$ De President, die alle betrokkenheid ontkende, benoemde tegelijkertijd zelf een speciale openbaar aanklager, die een strafrechtelijk vooronderzoek naar de inbraak moest doen. ${ }^{167}$ Het onderzoek nam een onverwachte wending toen een voormalig medewerker van het Witte Huis tijdens een van de hoorzittingen van de Senaatscommissie verklaarde dat Nixon de gewoonte had om gesprekken in de Oval Office op band te laten opnemen. De commissie verzocht de President vervolgens om de geluidsbanden te overleggen. Toen de President weigerde hieraan tegemoet te komen, vaardigde de commissie subpoenas uit. Nixon beriep zich vervolgens op zijn executive privilege. Tegelijkertijd eiste ook de speciale openbaar aanklager de geluidsbanden op. De President gaf de minister van Justitie daarop opdracht om de speciale aanklager te ontslaan. Diens weigering daartoe leidde vervolgens tot een bizarre reeks ontslagen, die bekend staat als het 'Saturday Night Massacre' en waarin de President uiteindelijk onder grote politieke druk besloot om toch weer een speciale aanklager te benoemen. De gang van zaken vormde voor het Huis van Afgevaardigden aanleiding om haar Judiciary Committee opdracht te geven te onderzoeken of er grond is voor impeachment van de President. ${ }^{168}$

Inmiddels had 'Watergate' dus al geleid tot een congressioneel onderzoek, een strafrechtelijk onderzoek en een impeachmentprocedure. De bijzondere Senaatscommissie, die nog steeds niet de beschikking had gekregen over de geluidsbanden, besloot vervolgens ook nog een civiele procedure te starten, waarin zij een verklaring voor recht vorderde dat de President verplicht was haar subpoenas op te volgen en dat Nixons weigering dus onrechtmatig was. De rechtbank verklaarde zich in eerste

163 Geciteerd in Rozell 2002, p. 56-57.

164 Onder andere ten aanzien van de spraakmakende 'Pentagon Papers' over de besluitvorming rondom de oorlog in Vietnam. Het Congres kan pas in 1971 kennisnemen van deze stukken, als zij worden gepubliceerd door de New York Times. Zie Boon 1982, p. 46.

165 Rozell 2002, p. 58.

166 Zie S.Res. 60 (1973), getiteld: "A resolution to establish a select committee of the Senate to conduct an investigation and study of the extent, if any, to which illegal, improper, or unethical activities were engaged in by any persons, acting individually or in combination with others, in the presidential election of 1972, or any campaign, canvass, or other activity related to it." De commissie, bestaande uit een Democratische voorzitter, drie andere Democraten en twee Republikeinen, werd met unanieme stemmen op 7 februari 1973 ingesteld. Zie verder Schlesinger \& Bruns 1975, p. 3926 e.v.

167 Boon 1982, p. 47.

168 Boon 1982, p. 47. 
instantie onbevoegd om te oordelen in deze zaak. In reactie daarop nam de Senaat een verklarende resolutie aan ${ }^{169}$ en werd bij wet geregeld dat de federale rechtbank in het District of Columbia uitdrukkelijk bevoegd was om civiele vorderingen te behandelen van de commissie-Ervin gericht op handhaving van haar subpoenas tegen de President of andere 'officers of the United States'. ${ }^{170}$

De civiele procedure belandde uiteindelijk bij het federale beroepshof in Washington, dat in haar uitspraak, Senate Select Committee v. Nixon, de benadering volgde die het eveneens gevolgd had in een andere uitspraak, kort daarvoor, in de strafrechtelijke procedure rondom Watergate. Ook in die procedure werd namelijk verzocht om de geluidsbanden, al ging het daar om vertrouwelijke inzage. ${ }^{171}$ Het hof maakte in die zaak een belangenafweging en stelde dat "application of Executive privilege depends on a weighing of the public interest protected by the privilege against the public interests that would be served by disclosure in a particular case." Hoewel 'presidential conversations' in beginsel dus beschermd worden door executive privilege, kan deze bescherming worden doorbroken wanneer de wederpartij een zwaarder wegend publiek belang kan aantonen. In de zaak van de senaatscommissie bevestigde het hof deze benadering: "the presumption that the public interest favors confidentiality" kan worden doorbroken, maar alleen "by a strong showing of need by another institution of government - a showing that the responsibilities of that institution cannot responsibly be fulfilled without access to records of the President's deliberations..."172

In de strafzaak had het hof de belangenafweging in het voordeel van de rechtbank laten uitvallen: de geluidsbanden moesten worden overhandigd zodat de 'grand jury' deze in camera (achter gesloten deuren) kon beluisteren. In het geval van de senaatscommissie, die inzage verzocht omwille van haar toezichthoudende en wetgevende taken, viel de belangenafweging anders uit. De House Judiciary Committee was inmiddels begonnen met een impeachment-onderzoek tegen de President en had na onderhandelingen met het Witte Huis zowaar de beschikking gekregen over kopieën van de gevorderde geluidsbanden. ${ }^{173}$ Dat was voor het hof van belang. Niet gebleken was, zo werd geconcludeerd, dat het Congres bedoeld heeft om deze kwestie door twee commissies tegelijkertijd te laten onderzoeken, waardoor de noodzaak van de Senaatscommissie op dit punt onvoldoende aannemelijk was geworden. Voor het doen van aanbevelingen voor toekomstige wetgeving, zo oordeelde het hof verder, is de noodzaak voor het verzamelen van feiten en het reconstrueren van gebeurtenissen doorgaans veel kleiner dan in bijvoorbeeld rechterlijke procedures. Bovendien is de vordering van de commissie ook op dit punt ach-

\footnotetext{
${ }^{169}$ Hierin werd bevestigd dat de commissie de bevoegdheid had de subpoenas uit te vaardigen en te procederen tegen de President. Bovendien werd in de resolutie benadrukt dat de commissie haar onderzoek uitvoerde in het kader van een legitiem legislatief doel. Zie S.Res. 194 (1973).

170 Pub.L. No. 93-190 (1973), getiteld: "An Act to Confer Jurisdiction upon the District Court of the United States of Certain Civil Actions Brought by the Senate Select Committee on Presidential Campaign Activities, and for Other Purposes." Nixon liet het voorstel zonder zijn handtekening in werking treden.

171 Zie ook Bush 1993, p. 727.

172 Senate Select Committee on Presidential Campaign Activities v. Nixon, 498 F.2d 725, 730 (1974).

173 Boon 1982, p. 47.
} 
terhaald door politieke ontwikkelingen. Zo had de President inmiddels de transcripten van de gevraagde geluidsbanden gedeeltelijk openbaar gemaakt. Niet aannemelijk was dat inzicht in de weggelaten gedeelten en de 'toon' van de gesprekken noodzakelijk was in het wetgevingsproces. Van een doorslaggevend, zwaarwegend belang was daarom geen sprake, zo concludeerde het hof. ${ }^{174}$

Niet lang hierna zorgde de Watergate-affaire ervoor dat het Supreme Court zich over de betekenis van 'executive privilege' zou uitlaten. In de zaak United States $v$. Nixon betwistte de President wederom de bevoegdheid van de rechter om zich over de toepassing van het 'executive privilege' te buigen. Dit verweer werd, weinig verrassend, door het Hof verworpen met de opmerking dat “...it is the province and duty of this Court 'to say what the law is' with respect to the claim of privilege presented in this case." 175 Het Hof erkende vervolgens de constitutionaliteit van het executive privilege ten aanzien van vertrouwelijk overleg van de President met zijn adviseurs. Dit geheimhoudingsrecht is een vanzelfsprekend element in de relatie tussen overheidsfunctionarissen en hun adviseurs, zo oordeelde het Hof. Het kan daarom worden gezien als een impliciete presidentiële bevoegdheid (implied power) voortvloeiend uit Art. II van de Constitutie en uit het stelsel van gescheiden machten ("the supremacy of each branch within its own assigned area of constitutional duties"). ${ }^{176}$ Een absoluut geheimhoudingsrecht is het echter niet: "To read the Art. II powers of the President as providing an absolute privilege as against a subpoena essential to enforcement of criminal statutes on no more than a generalized claim of the public interest in confidentiality of nonmilitary and nondiplomatic discussions would upset the constitutional balance of 'a workable government' and gravely impair the role of the courts under Art. III." 177 Het Hof gaat daarom uit van een "presumptive privilege', een vermoedelijk voorrecht, dat in concrete gevallen moet worden afgewogen tegen andere zwaarwegende belangen zoals "the integrity of the judicial system and public confidence in the system [which] depend on full disclosure of all the facts." 178 Deze afweging viel, zo concludeerde het Hof, in dit geval uit ten nadele van de President. Nadat het Supreme Court uitspraak had gedaan, kon Nixon de resterende geluidsbanden niet langer voor zich houden en was zijn politieke lot bezegeld. ${ }^{179}$

De (unanieme) uitspraak van het Supreme Court in Nixon is in constitutioneel opzicht van belang omdat sindsdien vaststaat dat de hoogste federale rechter de constitutionele basis van executive privilege erkent en tegelijkertijd relativeert: de President kan er geen absoluut geheimhoudingsrecht aan ontlenen. De rechter acht zich bevoegd om de toepassing van het voorrecht te toetsen en af te wegen tegen andere zwaarwegende belangen. Veel verder dan dat reikt de uitspraak echter niet. Het ging in deze zaak om slechts één verschijningsvorm van executive privilege, namelijk het

\footnotetext{
174498 F.2d 725, 733 (1974).

175 United States v. Nixon, 418 U.S. 683, 705 (1974).

176418 U.S. 683,705 (1974). In een voetnoot wijst het hof nog maar eens op de constitutionele conventie van 1787, die volledig in het geheim plaatsvond.

177418 U.S. 683, 707 (1974).

178418 U.S. 683, 709 (1974). Het hof bevestigde hiermee de redenering die door het beroepshof werd gevolgd in Senate Select Committee.

179 Rozell 2002, p. 62.
} 
(niet-absolute) recht van de President om vertrouwelijk overleg met zijn persoonlijke adviseurs te beschermen. Het Hof brengt ook militaire of diplomatieke inlichtingen, alsmede informatie die de nationale veiligheid betreft 180 , in verband met 'executive privilege', maar gaat daar niet verder op in omdat dit in de Watergate-affaire niet aan de orde was. De vraag of het presidentiële voorrecht op die terreinen wellicht zwaarder weegt, zoals het Hof lijkt te suggereren, is daarmee nog onbeantwoord. Verder ging het in deze zaak om een strafrechtelijk vooronderzoek. De relatie tussen President en rechterlijke macht in andere gerechtelijke procedures, maar belangrijker nog, de verhouding tussen President en Congres, bleef hier buiten beschouwing. In een voetnoot benadrukte het Hof dit zelf ook, 181 al bevestigde het Hof hiermee tenminste wel dat 'executive privilege' ook in andere verhoudingen aan de orde kan zijn. ${ }^{182}$ In hoeverre en op welke wijze, ook dat blijft de vraag. In Senate Select Committee, de zaak die wel betrekking had op de relatie tussen President en Congres, achtte de rechter zich wel bevoegd om een uitspraak te doen en werd eveneens uitgegaan van een belangenafweging, maar een principiële uitspraak over de reikwijdte van het 'executive privilege' werd vermeden. Nu ging het hier natuurlijk om een zeer uitzonderlijke, politiek licht ontvlambare situatie waar het persoonlijke (wan)gedrag van de President aan de orde was. Hoe de rechter zich in toekomstige informatieconflicten tussen de wetgevende en de uitvoerende macht zou opstellen, was daarom moeilijk te voorspellen. Duidelijk was in elk geval wel, dat de doctrine van 'executive privilege' een flinke deuk had opgelopen. ${ }^{183}$

\subsubsection{Reagan en het Environmental Protection Agency}

$\mathrm{Na}$ Watergate raakte het 'executive privilege' wat op de achtergrond. Nixons opvolgers Ford en Carter sloegen een coöperatieve toon aan en probeerden een beroep op executive privilege zoveel mogelijk te vermijden. Ford verscheen zelfs persoonlijk voor een congrescommissie om zijn besluit on Nixon gratie te verlenen toe te lichten. ${ }^{184}$ Het Congres werd assertiever ten opzichte van de uitvoerende macht: executieve functionarissen, zelfs leden van het cabinet, die weigerden om departementale stukken aan congrescommissies te verstrekken konden rekenen op contemptprocedures. De dreiging daarvan leidde er telkens toe, dat de betreffende functionarissen alsnog de gevraagde medewerking verleenden. ${ }^{185}$ Met het aantreden van President

\footnotetext{
180418 U.S. $683,684,707$ (1974).

181418 U.S. 683, 712 (1974) ("We are not here concerned with the balance between the President's generalized interest in confidentiality and the need for relevant evidence in civil litigation, nor with that between the confidentiality interest and congressional demands for information, nor with the President's interest in preserving state secrets. We address only the conflict between the President's assertion of a generalized privilege of confidentiality and the constitutioneel need for relevant evidence in criminal trials." (noot 19)).

182 Zie ook Boon 1982, p. 49.

183 Boon vermoedde in 1982 nog dat de rechter, wanneer een principiële uitspraak in een toekomstige zaak onvermijdelijk zou zijn, mogelijk naar de doctrine van de 'political question' zou grijpen en de zaak daarmee onberechtbaar zou kunnen verklaren. Zie Boon 1982, p. 59-60.

184 Tijdens deze hoorzitting bevestigde Ford zijn beleid om zeer terughoudend om te gaan met executive privilege, al erkende hij eveneens de constitutionele basis van het recht om de vertrouwelijkheid van presidentieel overleg te beschermen. Rozell 2002, p. 78.

185 Zie over een aantal spraakmakende gevallen uitvoerig: Fisher 2004, p. 111-126.
} 
Reagan leek het tij weer wat te keren. Rozell signaleert een zekere omslag in het denken over het presidentiële geheimhoudingsrecht: “...his presidency differed substantially on issues of governmental secrecy from the 'open' presidencies of Gerald Ford and Jimmy Carter, who mistakenly assumed that, after the Watergate scandal, a policy of openness best suited the demands of presidential leadership. Reagan perhaps better understood that information control, not openness, enhances presidential power." 186 Hoewel Reagan een restrictief beleid voerde op terreinen als openbaarheid van bestuur, was ook hij erg terughoudend in het toepassen van executive privilege ten opzichte van het Congres; evenals zijn voorgangers gaf hij er de voorkeur aan om andere uitwegen te zoeken of om via onderhandelingen tot overeenstemming te komen met het Congres.

Reagan probeerde ondanks zijn geheimhoudingspolitiek het inroepen van executive privilege tegenover congrescommissies dus zoveel mogelijk te voorkomen. In de weinige gevallen waarin hij dit wel deed, bleek hij weinig succesvol. ${ }^{187}$ In één geval leidde een beroep op executive privilege tot een gerechtelijke procedure, waarmee de federale rechter in Washington voor het eerst sinds Watergate weer de vraag kreeg om zich uit te spreken over een conflict over het verstrekken van inlichtingen door de executieve aan een congrescommissie. Het ging om een onderzoek in 1982 van de Subcommittee on Oversight and Investigation van de House Commitee on Public Works and Transportation naar de (gebrekkige) uitvoering en handhaving van milieuverontreinigingsregelgeving (de zogenaamde 'Superfund regulations') door het Environmental Protection Agency (EPA). Tijdens het onderzoek bleek het EPA, een 'executive agency', bij het verstrekken van gegevens aan de subcommissie in bepaalde gevallen te worden teruggefloten door het ministerie van Justitie, dat het als haar taak zag om het vrijgeven van gevoelige gegevens over lopende handhavingszaken door andere uitvoerende instellingen waar nodig te voorkomen. ${ }^{188}$ Toen de subcommissie Anne Gorsuch, de EPA-bestuurder ('Administrator'), verzocht om alle documenten te verstrekken omtrent bij de wet als prioriteiten aangeduide gebieden, verklaarde zij in een hoorzitting van de commissie, daartoe op initiatief van het ministerie van Justitie geinstrueerd door President Reagan, dat het EPA begonnen was met het verzamelen van de gevraagde documenten, maar met uitzondering van bepaalde "sensitive documents found in open law enforcement files". 189

De weigerachtigheid van Gorsuch leidde tot een stemming in de voltallige commissie en vervolgens in de plenaire vergadering van het Huis, waarbij de EPAbestuurder 'in contempt' werd verklaard. De daarop volgende gebeurtenissen zijn bijzonder te noemen. Volgens de strafrechtelijke contempt-regeling betekent een stemming in de plenaire vergadering van het Huis dat de Speaker de verklaring overdraagt aan de betreffende federale aanklager, die vervolgens verplicht is strafvervolging in te stellen. ${ }^{190}$ Het ministerie van Justitie weigerde dit echter en koos

\footnotetext{
186 Rozell 2002, p. 93.

187 Zie voor een uitvoerige bespreking op dit punt van de belangrijkste kwesties in het Reagantijdperk: Rozell 2002, p. 98-106.

188 Rozell 2002, p. 100-101.

189 Zie het memorandum van Reagan, weergegeven in: Cole \& Brand 2011, p. 167.

190 Zie 2 U.S.C. § 192.
} 
voor een andere route door in een civiele actie tegen het Huis van Afgevaardigden een verklaring voor recht te eisen "that Administrator Gorsuch acted lawfully in refusing to release certain documents to a congressional committee." 191

De rechtbank deed de zaak vrij eenvoudig af. Overwogen werd dat de rechter altijd zeer terughoudend is geweest "to interfere with the statutory scheme by considering cases brought by recalcitrant witnesses seeking declaratory or injunctive relief." 192 Uit vaste rechtspraak blijkt, zo vervolgt de rechtbank, dat de rechter de plicht heeft om het geven van een oordeel in constitutionele kwesties zoveel mogelijk te vermijden. In het geval van een conflict tussen de twee politieke staatsmachten is bovendien duidelijk dat "judicial intervention should be delayed until all possibilities for settlement have been exhausted." Een rechterlijk oordeel in deze zaak is om die redenen niet noodzakelijk. Dat is pas het geval wanneer Gorsuch zou worden vervolgd wegens contempt. ${ }^{193}$ En daarvan zegt de rechtbank:

\footnotetext{
"The difficulties apparent in prosecuting Administrator Gorsuch for contempt of Congress should encourage the two branches to settle their differences without further judicial involvement. Compromise and cooperation, rather than confrontation, should be the aim of the parties. The Court, therefore, finds that to entertain this declaratory judgment action would be an improper exercise of the discretion granted by the Declaratory Judgment Act..." 194
}

Twee weken na de uitspraak van de rechtbank bereikten partijen een compromis over de te verstrekken stukken. Een andere subcommissie die zich eveneens met deze affaire bezighield, de Subcommittee on Oversight and Investigation van de House Energy and Commerce Committee, vond het compromis echter onaanvaardbaar en verzocht het EPA alsnog om volledige inzage in de relevante stukken. De regeringReagan leek inmiddels van de kwestie af te willen en gaf toe aan de steeds verder toenemende congressionele druk. Partijen kwamen een regeling overeen, op basis waarvan de commissie uiteindelijk met slechts enkele beperkingen alle gewenste documenten kon inzien. ${ }^{195}$

\subsubsection{George W. Bush en het ontslag van federale aanklagers}

De rechter voelde er dus nog steeds weinig voor om een conflict tussen de President en het Congres over het verstrekken van inlichtingen inhoudelijk te beslechten; volstaan wordt met een poging de partijen weer om de onderhandelingstafel te krijgen. Het duurde, wellicht daarom, lang voordat de rechter opnieuw werd benaderd in een dergelijk conflict. Dat gebeurde uiteindelijk tegen het einde van het presidentschap van George W. Bush. De aanleiding was het (gedwongen) opstappen van een aantal federale openbaar aanklagers in 2006. Het Department of Justice verklaarde in de pers dat het ging om reguliere functioneringsproblemen, maar de geruchten wa-

191 United States v. House of Representatives, 556 F.Supp. 150, 151 (1983).

192556 F.Supp. 150, 152 (1983), met verwijzing naar het eerder aangehaalde Eastland.

193556 F.Supp. 150, 152 (1983).

194556 F.Supp. 150, 153 (1983).

195 Onderdeel van de afspraken was verder, dat de commissie een resolutie aan het Huis zou voorleggen waarin verklaard werd dat de constatering dat de EPA-bestuurder niet langer in contempt was. Het Huis nam de resolutie aan, waarop Gorsuch door de 'grand jury' werd vrijgesproken. Zie Cole \& Brand 2011, p. 182. Zie ook Rozell 2002, p. 102. 
ren dat hun vertrek zou zijn verzocht onder druk van het Witte Huis - in het bijzonder van Karl Rove, topadviseur van President Bush. Hij zou van mening zijn dat de betreffende aanklagers te voortvarend waren in het onderzoeken van corruptie bij Republikeinse kopstukken en juist te weinig assertief waren in Democratische gevallen. Ook zouden zij onvoldoende inzet tonen in het bestrijden van verkiezingsfraude, een Republikeins speerpunt. ${ }^{196}$

De vermoedens van politieke bemoeienis met de functievervulling van federale aanklagers - die in het Amerikaanse stelsel een tamelijk autonome positie innemen als het gaat om het vervolgingsbeleid - werden hoog opgenomen in het Congres, waar op dat moment zowel het Huis als de Senaat in Democratische handen waren. De House Judiciary Committee startte een onderzoek, waarin onder meer de ontslagen aanklagers en verschillende functionarissen binnen het Department of Justice, onder wie Attorney General Alberto Gonzales, werden verhoord. Vervolgens richtte de commissie haar aandacht op het Witte Huis om erachter te komen wat de rol van topadviseur Rove in de affaire was. Onderhandelingen over de wijze waarop medewerking zou worden verleend leidden niet tot overeenstemming, waarna de commissie besloot de hoogste juridisch adviseur van het Witte Huis, Harriet Miers, en het hoofd van de ambtelijke staf, Joshua Bolten, middels subpoenas op te roepen om te verschijnen voor verhoor respectievelijk interne stukken te verstrekken. President Bush beriep zich vervolgens op 'executive privilege' en beval zowel Miers als Bolten om geen gehoor te geven aan de subpoenas. Wat er daarna gebeurde, leek sterk op de gang van zaken in de EPA-affaire. Het Huis verklaarde Miers en Bolten op verzoek van de commissie 'in contempt', waarna de kamervoorzitter de zaak overdroeg aan de federaal aanklager in Washington. Die weigerde een strafrechtelijke contemptprocedure te starten en beriep zich op de rechtsopvatting die de juridische adviesdienst van het Department of Justice, het invloedrijke Office of Legal Counsel (OLC), in 1984 had uitgebracht naar aanleiding van de EPA-zaak. Hierin stelt het OLC dat "the contempt of Congress status was not intended to apply and could not constitutionally be applied to an Executive Branch official who asserts the President's claim of executive privilege." 197

Deze keer was het de commissie die de civiele rechter verzocht om een verklaring voor recht dat beide functionarissen in het Witte Huis verplicht waren om gehoor te geven aan de subpoenas. Het verweer van Miers en Bolton, namelijk dat zij als adviseurs van de President nooit gedwongen zouden kunnen worden om medewerking te verlenen aan een congresonderzoek, werd gemakkelijk door de rechter verworpen. Van een absolute immuniteit kan geen sprake zijn, althans niet in dit geval; gesuggereerd wordt dat het anders zou kunnen zijn wanneer een beroep op executive privilege betrekking heeft op "the President's personal exposure to suits for money damages based on his official conduct or concerning matters of national security or foreign affairs". ${ }^{198}$ Zowel Miers als Bolton waren daarom in beginsel ver-

\footnotetext{
196 Cole \& Brand 2011, p. 199.

197 Prosecution for Contempt of Congress of an Executive Branch Official Who Has Asserted a Claim of Executive Privilege, 8 Op. O.L.C. 101, 102 (1984). Zie ook Cole \& Brand 2011, p. 201.

198 Committee on the Judiciary, United States House of Representatives v. Harriet Miers et. al., 558 F.Supp.2d 53,56 (2008).
} 
plicht om gehoor te geven aan subpoenas, maar hadden daarbij wel het recht om zich in specifieke gevallen te beroepen op 'executive privilege'. Een beoordeling van de gevallen waarin dat gerechtvaardigd zou zijn is aan de rechterlijke macht, zo blijkt uit de rechtspraak van het Supreme Court, en niet aan de Executieve zelf. Daaraan kwam de rechter echter niet toe, want Miers en Bolton hadden slechts een algemeen beroep op een (absoluut) executive privilege gedaan. De uitspraak in deze zaak, zo benadrukte de rechter andermaal, heeft daarom een "narrow scope". 199

$\mathrm{Na}$ deze uitspraak bereikten beide partijen overeenstemming over de gewenste medewerking, waarbij de commissie vrijwel alle informatie kreeg die zij via de subpoenas had opgeëist. 200

\subsubsection{Slot: informatieconflicten in de praktijk}

De rechter, zo bleek uit de hierboven besproken gevallen, lijkt weinig genegen om conflicten tussen het Congres en de President over het verlenen van medewerking aan een congresonderzoek op te lossen. In de incidentele gevallen waarin de rechter in een dergelijk conflict door een van de partijen werd benaderd, werd een principiële uitspraak over de toepassing van 'executive privilege' in de concrete casus ontweken. In plaats daarvan wordt voortdurend het belang van onderling overleg en compromisbereidheid benadrukt.

Het begrip 'executive privilege' behoudt daarmee een tamelijk onbepaald karakter. Achter dit begrip en de conflicten die ermee gepaard gaan schuilt een voortdurende spanning in de verhouding tussen de belangen van de uitvoerende macht en die van de wetgevende macht, waarbij beide partijen zich er bovendien op beroepen het publieke belang te dienen. De uitvoerende macht verlangt geheimhouding, bijvoorbeeld ter bescherming van de nationale veiligheid of het waarborgen van de vertrouwelijkheid en openhartigheid in politiek-ambtelijke communicatie, terwijl de wetgevende macht juist openheid verlangt in het belang van bestuurlijke transparantie en effectieve democratische controle op de uitvoerende macht. ${ }^{201}$ De President en het Congres houden daarbij, ongeacht de wisselende politieke verhoudingen, al jaren vast aan hun eigen constitutionele interpretaties en staan, als het erop aankomt, daarmee lijnrecht tegenover elkaar. ${ }^{202}$

Hoewel een exacte definitie van 'executive privilege' daarom dus niet te geven is, kunnen ten aanzien van informatieconflicten tussen President en Congres op basis van de politieke praktijk en de hierboven besproken rechtspraak wel enkele contouren worden geschetst. ${ }^{203} \mathrm{Om}$ te beginnen heeft het Supreme Court in de zaak Nixon in elk geval aanvaard dat er omstandigheden kunnen zijn waarin de President met een beroep op 'executive privilege' de verstrekking van informatie aan de rechterlijke en de wetgevende macht mag weigeren. Veel meer zekerheid biedt die uitspraak

\footnotetext{
199558 F.Supp.2d 53, 105 (2008).

200 Een en ander werd vastgelegd in een 'Agreement Concerning Accommodation'. Zie voor een weergave daarvan: Cole \& Brand 2011, p. 214-216.

201 Zie o.a. Rozell 2002, p. 1; Fisher 2007, p. 177; Enthoven 2011, p. 537-540.

202 Cole \& Brand 2011, p. 182-183.

203 Zie ook Fisher 2007, p. 155.
} 
echter niet; het ging immers over een geschil tussen de President en de rechterlijke macht en over de verhouding tussen President en Congres werd uitdrukkelijk geen uitspraak gedaan. In de twee latere conflicten die hierboven werden besproken, ontweek de rechter als gezegd een inhoudelijk oordeel. Toch wordt wel steeds benadrukt dat rechter uiteindelijk het laatste woord heeft als het gaat om de vraag of een beroep op 'executive privilege' in een concreet geval gerechtvaardigd is; geen van de beide politieke machten beschikt dus over een absoluut of autonoom geheimhoudings- c.q. toegangsrecht ten aanzien van executieve inlichtingen en documenten.

De rechter gaat altijd uit van een afweging van belangen, waarbij aanvaard wordt dat de President in bepaalde gevallen een gerechtvaardigd belang heeft bij geheimhouding, dat slechts kan worden doorbroken wanneer er sprake is van een zwaarwegend ander belang. Uit de rechtspraak en de politieke praktijk komt een aantal terreinen naar voren waarop een beroep op executive privilege aanvaardbaar wordt geacht. Het minst omstreden is het idee dat de President, in zijn rol als 'Chief Executive', de ruimte moet hebben om in vertrouwen te kunnen overleggen met zijn naaste adviseurs. In mindere mate lijkt dat ook te gelden voor overleg met andere functionarissen binnen de uitvoerende macht. Verder wordt in de rechtspraak gesuggereerd dat de President een sterk geheimhoudingsrecht heeft wanneer het gaat om inlichtingen die betrekking hebben op de nationale veiligheid en defensie, terreinen waarop de President een belangrijke constitutionele rol speelt. Onomstreden is dit zeker niet: ook het Congres heeft immers taken op die terreinen. ${ }^{204}$ Tenslotte is het de vraag of, zoals in de EPA-zaak, het verstrekken van inlichtingen met betrekking tot lopende strafzaken met een beroep op het privilege mag worden geweigerd wanneer dit in het belang van het gerechtelijk onderzoek is. ${ }^{205}$ Duidelijk is in elk geval wel dat alleen de President zelfstandig een beroep op 'executive privilege' toekomt. Dat betekent dat andere executieve functionarissen, zoals de hoofden van departementen en andere federale uitvoerende diensten, alleen op aanwijzing van de President hun medewerking aan een congresonderzoek kunnen weigeren wegens 'executive privilege'.

Wanneer een beroep op 'executive privilege' nu wel of niet gerechtvaardigd is, of wanneer het recht van het Congres om haar onderzoeksrecht te kunnen uitoefenen zwaarder moet wegen, kan niet in abstracto worden bepaald. Wanneer een departement of andere uitvoerende dienst, al dan niet op initiatief van de President, meent dat medewerking aan een congresonderzoek moet worden geweigerd in verband met publieke belangen die onder het 'executive privilege' vallen, dan kan dit twee dingen tot gevolg hebben: de congrescommissie berust hierin - dit is zeker niet onvoorstelbaar, aangezien een presidentieel beroep op 'executive privilege' veel politieke druk op de zaak kan zetten - of de commissie volhardt in haar verzoek om mondelinge of schriftelijke inlichtingen. In dat laatste geval betekent dit meestal verdere onderhandelingen tussen beide partijen, waarbij gekeken wordt of gedeeltelijke

\footnotetext{
${ }^{204}$ Fel tegenstander van executive privilege op deze terreinen is Fisher, die de opmerkingen die het Supreme Court hieromtrent in Nixon maakte als "unfortunate dicta" kwalificeert. Zie Fisher 2004, p. 258.

205 Op de verstrekking van inlichtingen omtrent lopende strafzaken wordt in het kader van de samenloopproblematiek nog nader ingegaan in par. 4.3.2.
} 
medewerking voldoende zou zijn of dat nadere afspraken kunnen worden gemaakt over bijvoorbeeld een speciale, vertrouwelijke inzageprocedure. Dergelijke afspraken worden altijd ad hoc gemaakt: er bestaan geen standaardprotocollen tussen departementen en commissies, zoals in Nederland ${ }^{206}$ gebruikelijk is, want dat, zo is de gedachte aan beide zijden, zou de onderhandelingsposities van partijen en hun constitutionele aanspraken in de toekomst alleen maar kunnen verzwakken. Mochten deze onderhandelingen niet tot een bevredigend resultaat leiden, dan kan de commissie besluiten om de druk op te voeren en formele subpoenas uit te vaardigen tegen de executieve functionarissen van wie medewerking wordt verlangd. Dit blijkt zeker geen theoretische mogelijkheid: de praktijk laat zien dan commissies zelfs bereid zijn om ook hoge functionarissen als kabinetsleden een subpoena te bezorgen. Ook een contemptprocedure is niet ondenkbaar, zoals het kwestie rondom EPAbestuurder Gorsuch liet zien. Tot een daadwerkelijke strafprocedure is het echter nog nooit gekomen, omdat de Attorney General eenvoudigweg weigert een dergelijk proces in gang te zetten en de zaak via de civiele rechter probeert op te lossen.

In de gevallen waarin het Congres naar subpoenas grijpt en dreigt met contemptprocedures, blijkt de uitvoerende macht uiteindelijk in veel gevallen haar verzet te staken en bereid te zijn tot om tot een compromis te komen. Daar kan echter een lang proces van onderhandelingen vooraf gaan. Wanneer het daadwerkelijk zover komt dat partijen met een beroep op rechten en privileges 'op hun constitutionele strepen gaan staan', dan is de kwestie veelal geëscaleerd. Om nu te concluderen dat het Congres in de praktijk meestal aan het langste eind trekt, is daarom te gemakkelijk. Het tijdsverlies en de vaak bedorven verhoudingen doen het onderzoeksproces op zijn zachtst gezegd geen goed. ${ }^{207}$ Het tamelijk ongrijpbare 'executive privilege' kan daarom het beste worden gezien als het presidentiële tegenwicht tegen het sterke onderzoeksrecht van het Congres: het ontbreken van constitutionele helderheid dwingt President en Congres om in onderling overleg een balans te vinden tussen enerzijds het belang van geheimhouding en vertrouwelijkheid en anderzijds het belang van toezicht en controle. In die zin is het een typisch voorbeeld van 'checks and balances' in het Amerikaanse stelsel van gescheiden machten.

\footnotetext{
206 Zie ook hierboven, Deel I, par. 4.5.1.1.

${ }^{207} \mathrm{Al}$ is natuurlijk ook denkbaar dat een congrescommissie, zeker als de meerderheid van een andere kleur is dan de President, haar bevoegdheden vooral gebruikt om publiciteit te genereren en de President probeert af te schilderen als iemand die bedenkelijke zaken probeert te verhullen, terwijl de President de commissie wellicht het politiseren van het publieke belang in de schoenen wil schuiven. In dat geval gaat het dus meer om beeldvorming dan om daadwerkelijk onderzoek en is het inroepen van rechten en privileges meer bedoeld voor de bühne.
} 
VERENIGDE Staten 


\section{Hoofdstuk 3. Onderzoeksorganisatie}

\subsection{Inleiding}

Hiervoor is aandacht besteed aan het constitutionele kader waarbinnen het congressionele onderzoeksrecht moet worden geplaatst. In deze paragraaf wordt nader bezien op welke wijze het Congres in de praktijk gebruik maakt van dit onderzoeksrecht.

Beide Kamers kennen verschillende commissies die onderzoekstaken verrichten. Het overgrote deel van het onderzoekswerk in het Congres vindt plaats in de vaste commissies. Daarnaast maken beide Kamers zo nu en dan gebruik van bijzondere commissies, die 'select committees' of 'special committees' worden genoemd. Vaak worden deze bijzondere commissies ingesteld met een specifiek omschreven onderzoeksopdracht. Zij hebben doorgaans een tijdelijk karakter. Tenslotte kunnen ook gezamenlijke commissies ('joint committees') onderzoekstaken hebben. ${ }^{1}$

\subsection{Vaste commissies}

Beide kamers worden al geruime tijd gekenmerkt door een sterk gedecentraliseerde werkwijze. Woodrow Wilson schreef hierover in 1885: "Congress in session is Congress on public exhibition, whilst Congress in its committee-rooms is Congress at work." 2 De vaste commissies ('standing committees') in het Huis ${ }^{3}$ en in de Senaat ${ }^{4}$ vormen de ruggegraat van het Amerikaanse Congres. De kamers zijn in beginsel vrij om naar eigen inzicht commissies in te stellen. In de loop der tijd ontstond daarom

\footnotetext{
${ }^{1}$ In uitzonderlijke gevallen, zoals na een gebeurtenis die grote maatschappelijke onrust teweeg heeft gebracht, kiest het Congres voor het instellen van een externe commissie, een zogenaamde 'blue ribbon commission', voor het doen van een specifiek onderzoek. Deze commissies kunnen allerlei vormen hebben en worden soms ook in samenwerking met de President ingesteld. Een recent voorbeeld is de 9/11 Commission, die onderzoek deed naar de aanslagen op 11 september. Zie ook hierboven, par. 1.4.5.

${ }^{2}$ Wilson 1885, p. 69.

${ }^{3}$ In het Huis van Afgevaardigden betreft het de vaste commissies voor Agriculture; Appropriations; Armed Services; Budget; Education and Labor; Energy and Commerce; Financial Services; Foreign Affairs; Homeland Security; Judiciary; Natural Resources; Oversight and Government Reform; Science and Technology; Rules; Small Business; Transportation and Infrastructure; Veterans' Affairs; Ways and Means; en de zogeheten Permanent Select Committee on Intelligence.

${ }^{4}$ De Senaat kent vaste commissies voor Agriculture, Nutrition, and Forestry; Appropriations; Armed Services; Banking, Housing, and Urban Affairs; Budget; Commerce, Science, and Transportation; Energy and National Resources; Environment and Public Works; Finance; Foreign Relations; Health, Education, Labor, and Pensions; Homeland Security and Governmental Affairs; Judiciary; Rules and Administration; Small Business and Entrepreneurship; Veterans' Affairs; en de Select Committee on Intelligence.
} 
een wildgroei aan vaste en tijdelijke commissies. Met name de Legislative Reorganization Act van 1946 heeft gezorgd voor een zekere stroomlijning, waardoor de stelsels van vaste commissies in beide kamers steeds meer op elkaar zijn gaan lijken. ${ }^{5}$

\subsubsection{Taken en bevoegdheden}

De taken en bevoegdheden van de vaste commissies zijn neergelegd in de Kamerregels (Chamber Rules). ${ }^{6}$ Elke Kamer stelt op de eerste dag van een tweejarige Congrestermijn haar eigen Rules vast. Doorgaans worden de Rules van de voorgaande termijn voor een belangrijk deel overgenomen; afhankelijk van de politieke wensen van de meerderheid worden hierin wijzigingen aangebracht. Wat betreft de vaste commissies kan bijvoorbeeld gedacht worden aan veranderingen ten aanzien van de naamgeving of taakverdeling. ${ }^{7}$

\subsubsection{Wetgevende taken}

De meeste vaste commissies houden zich in de eerste plaats bezig met het behandelen van wetsvoorstellen. In beide Kamers bezitten vaste commissies op grond van de kamerregels het exclusieve recht om wetsvoorstellen en andere zaken die binnen hun werkterrein vallen te behandelen en al dan niet voor te leggen ('to report') aan de plenaire vergadering. ${ }^{8}$ Dit maakt hun positie in het wetgevingsproces cruciaal: "Committees decide with respect to legislation what will be buried, what will barely come out of committee, and what will come out with a favored likelihood of enactment." 9 Daarnaast spelen zij, zoals eerder besproken ${ }^{10}$, een belangrijke rol in totstandkoming van federale overheidsdiensten en beleidsprogramma's, kortweg het proces van 'authorization'. De vaste commissies worden, gelet op hun hoofdtaken, ook wel 'authorizing committees' of 'committees of jurisdiction' genoemd. ${ }^{11}$ Belangrijk in het autorisatieproces is dat hierin onder meer een budgettair plafond wordt vastgesteld. Langs deze weg oefenen commissies dus invloed uit op de beleidsuitvoering door de betrokken uitvoerende diensten. De autorisatiecommissies zijn eveneens betrokken bij de jaarlijkse toekenning van budgetten aan individuele diensten, een apart proces dat wordt beheersd door de Appropriation Committees. ${ }^{12}$

\footnotetext{
${ }^{5}$ Zie Deering \& Smith 1997, p. 18-19. Zie ook Guide to Congress 2008, p. 631-632.

${ }^{6}$ Zie House Rule X en Senate Rules XXIV-XXVII.

${ }^{7}$ Ook later nog kunnen wijzigingen worden aangebracht bij meerderheidsbesluit (resolution).

${ }^{8}$ Zie House Rule X, lid 1 ("All bills, resolutions, and other matters relating to subjects within the jurisdiction of the standing committees listed in this clause shall be referred to those committees..."). Vergelijkbare bepalingen voor de Senaatcommissies zijn te vinden in Senate Rule XXV.

${ }_{9}$ Tiefer 1989 , p. 57-58.

10 Zie hierboven, par. 1.3.2.

${ }^{11}$ De budgetcommissies, zoals de Budget Committees en de Appropriations Committees, vallen hier buiten.

12 Dit zogenaamde appropriatieproces wordt beheersd door de Appropriation Committees in beide kamers. De autorisatiecommissies spelen hierbij een adviserende rol.
} 


\subsubsection{Toezichtstaken}

Naast wetgevende taken hebben de vaste commissies in beide kamers de algemene taak om toezicht ('oversight') uit te oefenen op de uitvoering van wetgeving en beleid door de departementen en diensten binnen hun werkterrein ('jurisdiction'). ${ }^{13}$ Enkele commissies hebben een specifieke subcommissie belast met toezichts- en onderzoekswerk op alle beleidsterreinen waarop de commissie bevoegd is. In sommige gevallen wordt een commissie in de Rules een toezichtsbevoegdheid toegekend ten aanzien van een onderwerp dat tot het wetgevingsgebied van een andere commissie behoort. ${ }^{14}$

Beide kamers kennen bovendien een speciale vaste commissie met de taak om toezicht te houden op de gehele federale overheid. Dit zijn de House Committee on Oversight and Government Reform en de Senate Homeland Security and Governmental Affairs Committee. Deze commissies hebben wegens hun beperkte wetgevende taken een ander karakter dan de reguliere, 'authorizing' vaste commissies. ${ }^{15}$

\subsubsection{Onderzoeksrecht}

Het doen van onderzoek is nadrukkelijk onderdeel van het instrumentarium van de vaste commissies. In House Rule XI, lid 1, is bepaald dat elke commissie "may conduct at any time such investigations and studies as it considers necessary or appropriate in the exercise of its responsibilities under rule X." 16 In dezelfde Rule wordt vervolgens de bevoegdheid tot het houden van hoorzittingen en het verzamelen van mondeling en schriftelijk material gedelegeerd aan commissies en subcommissies. Een (sub)commissie kan, ook tijdens recessen, op elke gewenste dag en plaats vergaderen en hoorzittingen houden "as it considers necessary". Zij zijn voorts bevoegd "to require, by subpoena or otherwise, the attendance and testimony of such witnesses and the production of such books, records, correspondence, memoranda, papers, and documents as it considers necessary." Getuigenissen kunnen onder ede worden afgenomen. Het uitvaardigen van een subpoena (dagvaarding) gebeurt in beginsel bij meerderheidsbesluit in de commissie, maar deze bevoegdheid kan in het commissiereglement worden gedelegeerd aan de commissievoorzitter. Het handhaven van een subpoena is echter uitdrukkelijk voorbehouden aan de plenaire vergadering. ${ }^{17}$

De onderzoeksbevoegdheden van de vaste Senaatscommissies, zoals toegekend in de Senate Rules, zijn vrij summier omschreven, maar lijken in inhoudelijke zin

\footnotetext{
${ }^{13}$ Zie House Rule X, lid 2 ("The various standing committees shall have general oversight responsibilities ... each standing committee (other than the Committee on Appropriations) shall review and study on a continuing basis...") en Senate Rule XXVI, lid 8, sub a ("each standing committee (except the Committees on Appropriations and the Budget), shall review and study, on a continuing basis the application, administration, and execution of those laws, or parts of laws, the subject matter of which is within the legislative jurisdiction of that committee.").

${ }^{14}$ Zie bijvoorbeeld House Rule X, lid 3 ("Special Oversight Functions”). Zie ook Tiefer 1989, p. 83-84.

${ }^{15} \mathrm{Al}$ heeft de genoemde senaatscommissie, naast haar algemene toezichtstaak, sinds de instelling van het Department of Homeland Security specifieke wetgevende taken gekregen op het terrein van het nationale veiligheidsbeleid. In het Huis is dit beleidsterrein ondergebracht bij een afzonderlijke vaste commissie.

${ }^{16}$ House Rule XI, lid 1, sub b (1).

${ }^{17}$ House Rule XI, lid 2, sub m (1-3).
} 
sterk op die in het Huis. Elke vaste Senaatscommissie "may make investigations into any matter within its jurisdiction..." 18 De commissies en hun subcommissies zijn bevoegd te vergaderen en hoorzittingen te houden op ieder gewenst moment. Commissies kunnen getuigen oproepen en schriftelijke stukken opvragen, zo nodig met behulp van een subpoena. Ook is uitdrukkelijk bepaald dat commissies onderzoek kunnen doen naar iedere aangelegenheid die binnen hun werkterrein valt. Daartoe is een budget beschikbaar, waarvan de hoogte door de Committee on Rules and Administration wordt vastgesteld. ${ }^{19}$ Verder vermelden de Senaatsregels dat commissies toezichtsactiviteiten contractueel kunnen uitbesteden of de hulp kunnen inroepen van (uitvoerende) federale diensten. Ook zijn bepaalde bijzondere onderzoekstechnieken, zoals 'pilot testing' en kosten-baten analyses, uitdrukkelijk toegestaan. ${ }^{20}$

\subsubsection{House Oversight and Government Reform Committee}

De House Oversight and Government Reform Committee ${ }^{21}$ (kortweg: House Oversight Committee) behoort tot de vaste commissies in het Huis, maar heeft een bijzonder karakter. De commissie beschikt over een beperkte wetgevende taak en is vooral gericht op toezicht en onderzoek. De commissie heeft de omvangrijke taak "[to] review and study on a continuing basis the operation of Government activities at all levels with a view to determining their economy and efficiency". ${ }^{22}$ Bovendien bepalen de Rules dat de commissie "may at any time conduct investigations of any matter", ook al betreft het een onderwerp dat in beginsel tot het werkterrein van een andere vaste commissie behoort. ${ }^{23}$ De commissie kent thans vijf subcommissies.

De commissie, oorspronkelijk genaamd Government Operations Committee, bestaat sinds 1946 en was in eerste instantie een weinig populaire commissie. Sinds de jaren '70 nam de interesse voor het lidmaatschap onder Huisleden toe, onder meer door opeenvolgende begrotingscrises en schandalen rondom aanbestedingen binnen de federale overheid. ${ }^{24}$ Bovendien is het omvangrijke toezichts- en onderzoeksterrein van deze commissie een aantrekkelijk alternatief voor de meer beleidsgerichte vaste commissies wanneer er gedurende een Congrestermijn weinig autorisatiewetgeving op het programma staat. ${ }^{25}$

De commissie ontwikkelde zich tot een van de meest zichtbare en actieve vaste commissies gedurende het 110e Congres (2007-2009), toen de Democraten voor het eerst in twaalf jaar de meerderheid in het Huis haalden. De commissie, onder het voorzitterschap van het ervaren congreslid Henry Waxman, werd het speerpunt van het Democratische toezichts- en onderzoeksprogramma inzake het beleid van de

\footnotetext{
18 Senate Rule XXVI, lid 1.

${ }^{19}$ Senate Rule XXVI, lid 1.

${ }^{20}$ Senate Rule XXVI, lid 8, sub (a) ("Such committees may carry out the required analysis, appraisal, and evaluation themselves, or by contract, or may require a government agency to do so and furnish a report thereon to the Senate. Such committees may rely on such techniques as pilot testing, analysis of costs in comparison with benefits, or provision for evaluation after a defined period of time.")

${ }^{21}$ House Rule X, lid 1, sub n.

${ }^{22}$ House Rule $X$, lid 3, sub i.

${ }^{23}$ House Rule X, lid 4, sub (c)(2).

${ }^{24}$ Deering \& Smith 1997, p. 74.

${ }^{25}$ Deering \& Smith 1997, p. 74.
} 
regering-Bush in de voorgaande zes jaren. Onder leiding van Waxman en met een aanzienlijk gegroeide staf, voerde de commissie tientallen onderzoeken uit naar uiteenlopende onderwerpen, zoals de oorlog in Irak, het functioneren van de federale crisisdiensten na de orkaan Katrina, corruptie bij de aanbesteding van overheidscontracten en het gebruik van prive-emailadressen in het Witte Huis. ${ }^{26}$

\subsubsection{Senate Permanent Subcommittee on Investigations}

In de Senaat is een bijzondere rol weggelegd voor de Permanent Subcommittee on Investigations (PSI), onderdeel van de Homeland Security and Governmental Affairs Committee. Hoewel de naam suggereert dat deze subcommissie een permanente status heeft, verschilt de subcommissie wat dit betreft niet van andere subcommissies. Wel is het inmiddels de oudste subcommissie die de Senaat kent.

De subcommissie kwam tot stand in 1948 en heeft een roemrucht verleden. De oorsprong van de subcommissie ligt bij de Senate Special Committee to Investigate the National Defense Program, beter bekend als de Truman Committee. Deze bijzondere commissie werd ingesteld naar aanleiding van de enorme defensie-uitgaven die op iniatitief van President Roosevelt werden vrijgemaakt voor de Amerikaanse mobilisatie tijdens de Tweede Wereldoorlog. Wanneer van het Congres werd verwacht dat zij hieraan zou meewerken, zo meende Senator Truman, dan was een onderzoekscommissie nodig om ervoor te zorgen dat het geld verstandig en efficient zou worden besteed. ${ }^{27}$ De commissie onderzocht in de periode 1941-1948 talloze gevallen van verspilling en corruptie bij militaire toeleveringsbedrijven en werd gezien als zeer succesvol. ${ }^{28}$ Haar relatief onbekende voorzitter genereerde met het diepgravende en gedetailleerde onderzoek van de commissie bovendien veel publiciteit en aanzien. Zoveel zelfs, dat President Roosevelt hem bij de verkiezingen van 1944 als zijn 'running mate' koos. ${ }^{29}$

Nadat de Senaat in 1948 besloot al haar bijzondere commissies op te heffen, werd de opgebouwde expertise op het gebied van 'waste, fraud and abuse' ondergebracht in een gespecialiseerde, 'permanente' subcommissie, eerst bij de Committee on Expendures in the Executive Branch en sinds 1952 bij wat inmiddels de Homeland Security and Governmental Affairs Committee heet. Het werkterrein van de subcommissie werd echter uitgebreid. De subcommissie kan sindsdien onderzoek doen naar "the efficiency and economy of operations of all branches of the Government including the possible existence of fraud, misfeasance, malfeasance, collusion, mismanagement, incompetence, corruption, or unethical practices, waste, extravagance, conflicts of interest, and the improper expenditure of Government funds...", maar ook naar vormen van (georganiseerd) crimineel gedrag in de private sector. ${ }^{30}$ Ook

\footnotetext{
${ }^{26}$ Zie 'White House Feels Waxman's Oversight Gaze', Washington Post, 25 oktober 2007, p. A01.

27 Nunn 1986, p. 19-20.

28 Zie Nunn 1986, p. 20

${ }^{29}$ Nunn 1986, p. 21.

${ }^{30}$ Dit kan worden afgeleid uit de resolutie waarin het budget van de voltallige commissie wordt toegekend. Zie voor de meest recente taakomschrijving: S. Res. 81-112 (2011), art. 12, lid e ("Investigations"). Zie ook Rule 7, Rules of Procedure of the Committee on Homeland Security and Governmental Affairs, S. Prt. 112-11 (2011), waarin de subcommissies worden ingesteld, overigens zonder nadere specificering van de werkterreinen van de afzonderlijke subcommissies.
} 
van belang is dat de voorzitter van de subcommissie zelfstandig subpoenas kan uitvaardigen. ${ }^{31}$

Toen de Republikeinen in 1952 de meerderheid in de Senaat bemachtigden, kreeg Senator Joseph McCarthy de leiding over de PSI. Onder zijn voorzitterschap verrichtte PSI tussen 1953 en 1955 een groot aantal onderzoeken naar vermeende communistische infiltratie in federale overheidsorganisaties. Het werkterrein werd spoedig uitgebreid naar allerlei maatschappelijke sectoren, zoals de vakbeweging en de filmindustrie. De subcommissie hield in twee jaar maar liefst 169 hoorzittingen en werd berucht om de wijze waarop in het bijzonder haar voorzitter gebruik maakte van de ruime onderzoeksbevoegdheden waarover de subcommissie beschikte. De onderzoeken van McCarthy leken er vooral op gericht om getuigen zoveel mogelijk te beschadigen. Zijn carrière als communistenjager eindigde in december 1954 met tegen hem gerichte 'resolution of censure' in de plenaire vergadering.

Sindsdien stelt de subcommissie zich beduidend bescheidener op. De lopende onderzoeken naar subversieve elementen in de federale overheid werden snel afgerond - overigens zonder aanmerkelijk resultaat. Daarna verlegde de PSI haar focus. De belangrijkste aandachtsgebieden werden de georganiseerde misdaad, verspilling van overheidsgelden, nationale veiligheid en defensie. ${ }^{32}$ De laatste jaren verricht de PSI vooral onderzoek op financieel-economisch gebied, onder andere met betrekking tot belastingontduiking, creditcardfraude en witwaspraktijken. Zo deed de subcommissie een grootschalig onderzoek naar de ondergang van het energiebedrijf Enron. ${ }^{33}$

Het onderzoek van de PSI kenmerkt zich vandaag de dag door haar lengte, diepgang en 'bipartisanship'. De stafleden van de meerderheidspartij en de minderheidspartij werken vaak vanaf het begin van een onderzoek intensief samen. Onderzoeken kunnen meer dan een jaar duren en betreffen vaak omvangrijke analyses van grote hoeveelheden opgevraagde documenten en intensieve interviews en hoorzittingen met getuigen. Rapporten kunnen honderden, soms duizenden pagina's bevatten met uitvoerig gedocumenteerde bevindingen en bijlagen met bewijsmateriaal. De subcommissie volgt bepaalde onderzoekslijnen vaak gedurende meerdere jaren en is heeft een sterk naam opgebouwd door het regelmatige vervolgonderzoek dat zij uitvoert.

\subsubsection{Samenstelling, omvang, verhoudingen}

Bij aanvang van een nieuwe Congrestermijn worden in beide kamers nieuwe leden van de vaste commissies benoemd. ${ }^{34}$ De Senaatscommissies zijn permanente lichamen, aangezien de Senaat een 'continuous body' is. Aan het begin van een nieuwe tweejarige termijn worden daarom alleen de vrijkomende posities opnieuw gevuld. ${ }^{35}$ De Senaat kent geen formele procedureregels hieromtrent; besluiten omtrent de be-

31 Zie Rule 2, Rules of Procedure for the Permanent Subcommittee on Investigations, S. Prt. 112-5 (2011).

32 Zie voor een nader overzicht: Nunn 1986, p. 29-56.

33 U.S. Senate, Homeland Security and Governmental Affairs Committee, Permanent Subcommittee on Investigations, The Role of the Board of Directors in Enron's Collapse, S. Prt. 107-70 (2002).

${ }^{34}$ House Rule X, lid 5 en Senate Rule XXV, lid 1.

${ }^{35}$ Guide to Congress 2008, p. 658. 
noeming van commissieleden zijn daarom onderworpen aan reguliere meerderheidsbesluitvorming. In het Huis, waar alle commissies elke twee jaar opnieuw moeten worden ingesteld, is in de Rules vastgelegd dat de Democratische en RepuRepublikeinse kandidaten door hun respectievelijke fracties worden voorgedragen en vervolgens door de plenaire vergadering worden benoemd. Middels een resolutie kan de samenstelling van commissies tussentijds worden gewijzigd. ${ }^{36}$ Wanneer een commissielid niet langer lid is van de voordragende fractie, dan vervalt het commissielidmaatschap automatisch. ${ }^{37}$ De betreffende fractie kan vervolgens een nieuw lid voordragen. ${ }^{38}$ Het grootste deel van de benoemingen in de Huiscommissies betreft echter herbenoemingen: het is gebruikelijk dat commissieleden na verkiezingen hun oude posities weer innemen, voor zover de nieuwe verhouding tussen de partijen dat toelaat.

Congresleden zijn meestal lid van meerdere vaste commissies van hun Kamer. In beginsel kunnen leden van het Huis behoren tot maximaal twee vaste commissies. Bovendien kan een Huislid slechts deel uitmaken van maximaal vier subcommissies. Het Huis kan echter, op voorstel van de betrokken fractie, van deze regel afwijken. ${ }^{39}$ Ook Senatoren zijn doorgaans lid van meerdere commissies, maar evenals in het Huis wordt dit in de Rules in de meeste gevallen beperkt tot maximaal twee belangrijke commissies en een minder belangrijke commissie. Bij sommige belangrijke commissies, zoals de Budget Committee, is geen tweede lidmaatschap toegestaan. ${ }^{40}$ In de praktijk worden overigens, net als in het Huis, wel uitzonderingen gemaakt op deze limieten. ${ }^{41}$

De stemming in de plenaire vergadering in beide Kamers en de voordracht van kandidaat-commissieleden door de fractie zijn in de praktijk formaliteiten. De feitelijke selectie van commissieleden is zowel in de Senaat als het Huis in handen van de selectiecommissies in beide fracties: de 'steering committees', ook wel 'committees on committees' genoemd. ${ }^{42}$ Deze selectiecommissies bestaan uit de partijleiders binnen de fracties en overige, voornamelijk door de partijleiders aangewezen leden. Al te directe politieke sturing van de partijleiding in individuele gevallen blijkt in de praktijk vrij uitzonderlijk te zijn. Deering en Smith stellen: “Currently, the dominant emphasis is on party harmony and accommodation of requests rather than on manipulation of assignments for political advantage." 43 Deze terughoudendheid past in het beeld van de relatief zwakke partijhiërarchie in het Amerikaanse Congres. Beide partijen hanteren bovendien een verdelingssysteem, dat erop gericht is zoveel mogelijk aan de voorkeuren van leden tegemoet te komen en de 'vrijkomende' posi-

\footnotetext{
${ }^{36}$ House Rule X, lid 5, sub a (1). Voor de Budget Committee en de Committee on Standards of Official Conduct gelden bijzondere regels. Zie Rule X, lid 5, sub a (2-4).

${ }^{37}$ House Rule X, lid 5, sub b (1).

${ }^{38}$ House Rule X, lid 5, sub e.

${ }^{39}$ Zie House Rule X, lid 5, sub b (2). Dergelijke uitzonderingen zijn zeker niet ongebruikelijk met het oog op "the need to retain effective numerical control of committees and satisfy members' political needs." Guide to Congress 2008, p. 659. Zie ook Brown \& Johnson 2003, p. 240-241.

40 Senate Rule XXV, lid 4, sub a.

41 Deering \& Smith 1997, p. 100.

42 Guide to Congress 2008, p. 659.

${ }^{43}$ Deering \& Smith 1997, p. 103.
} 
ties bij de meest gewilde commissies min of meer gespreid over de leden van de fractie te verdelen. Vooral in de Senaat wordt daarbij veel waarde gehecht aan senioriteit: de Senaatsleden krijgen bij de verdeling van commissieposities voorrang op basis van het aantal jaren dat zij lid zijn van de Senaat. Ook deze gewoonte voorkomt conflicten bij de zetelverdeling. ${ }^{4}$

De grootte van de Senaatscommissies is in de Rules vastgelegd. Deze varieert, maar de belangrijkste senaatscommissies hebben veelal tussen de 18 en 20 leden. ${ }^{45}$ Gelet op het grote aantal 'zittenblijvers', is in de Rules bepaald dat het aantal leden van een commissie tijdelijk kan worden vergroot, om ervoor te zorgen dat de meerderheidspartij een meerderheid in de commissie krijgt of behoudt. Dit gebeurt middels een overeenkomst tussen de Majority Leader en de Minority Leader. ${ }^{46}$

De House Rules bevatten geen voorschriften omtrent de grootte van de vaste commissies. ${ }^{47}$ In beginsel betekent dit dat het Huis hierover (bij meerderheid) besluit, maar in de praktijk wordt ook dit bepaald aan de hand van informele afspraken tussen de Democratische en Republikeinse partijleiders, die op hun beurt rekening moeten houden van de wensen en belangen van de fractieleden. De vaste commissies zijn in de afgelopen decennia sterk gegroeid: terwijl het aantal commissies in de periode 1947-1997 ongeveer gelijk bleef, nam het totaal aantal beschikbare commissieposities toe van 482 tot 803 . Deze groei kan worden verklaard vanuit de gedachte dat de partijleiding tegemoet komt aan de toenemende behoefte van (nieuwe) leden in het Huis om meer dan een commissielidmaatschap te vervullen. ${ }^{48}$ Het aantal leden per commissie varieert aanzienlijk. Zo hebben de commissies in het 112e Congres (2011-2013) met veel wetgevende en budgettaire taken soms wel 50 of 60 leden, zoals Financial Services (61) en Transportation (58), terwijl minder belangrijke commissies soms slechts 26 leden tellen (Veterans' Affairs). Het gemiddelde in deze periode is 44 leden. ${ }^{4} 9$

In geen van beide Kamers bevatten de Rules een regeling omtrent de getalsmatige verhouding tussen de meerderheid en de minderheid. Ook dit wordt bepaald op basis van informele afspraken tussen de partijleiders. ${ }^{50}$ Zowel in het Huis als de Senaat sluit de verhouding tussen de twee partijen ('party ratio') in het algemeen min of meer aan bij de verhoudingen in de plenaire vergadering. ${ }^{51}$ In het Huis lijkt echter sinds de jaren 70 een trend te zijn ontstaan waarbij de meerderheidspartij zich met name in de belangrijke commissies meer commissiezetels toe-eigent dan op basis de

\footnotetext{
${ }^{44}$ Zie verder Deering \& Smith 1997, p. 96-108.

${ }^{45}$ Senate Rule XXV, lid 2-3. De kleinste commissie heeft 6 leden (Ethics), de grootste 28 leden (Appropriations).

${ }^{46}$ Senate Rule XXV, lid 4, sub a, c.

47 De Legislative Reorganization Act 1946 bevatte stricte voorschriften omtrent de commissiegrootte, maar vanaf 1975 heeft het Huis nagenoeg alle regelingen hieromtrent geschrapt.

48 Deering \& Smith 1997, p. 98-99. Zie ook Tiefer 1989, p. 87.

${ }^{49}$ Dit gemiddelde is gebaseerd op commissieoverzicht per 12 september 2012 en is exclusief de interne/huishoudelijke commissies (Rules, House Administration en Standards of Official Conduct). Zie http://clerk.house.gov/committee_info/scsoal.pdf.

50 Brown \& Johnson 2003, p. 242.

${ }^{51}$ Deering \& Smith 1997, p. 97.
} 
verhouding in de plenaire vergadering te verwachten zou zijn. ${ }^{52}$ In de meest recente congrestermijnen is de 'overbedeling' in het Huis beperkt. In het 110e Congres hadden de Democraten 59\% van de zetels en $61 \%$ van de commissieplaatsen. In het $111 \mathrm{e}$ Congres bezetten de Republikeinen $56 \%$ van de zetels in het Huis, wat vertaald is in $59 \%$ van de commissieplaatsen. ${ }^{53}$

\subsubsection{Subcommissies}

Alle belangrijke vaste commissies verdelen hun werkzaamheden over subcommissies. Het is aan de commissies zelf om middels subdelegatie te bepalen of en hoe zij hun taken en bevoegdheden willen opdragen aan subcommissies. Doorgaans behandelt een subcommissie een deel van het werkterrein van de voltallige commissie. De wijze waarop commissies hun bevoegdheden subdelegeren verschilt per commissie en wordt vastgelegd in de Committee Rules. De benoeming van de leden en de voorzitters van de subcommissies is formeel een bevoegdheid van de voltallige commissie, maar in de praktijk ligt het voor de hand dat dit soort beslissingen, vooral bij subcommissies die een belangrijk beleidsterrein behandelen, worden betrokken in de bredere politieke besluitvorming omtrent de invulling van commissies.

Het aantal subcommissies in met name het Huis groeide sterk vanaf de jaren 70 . Een belangrijke reden hiervoor was een politieke. De groeiende progressieve vleugel van de Democratische partij probeerde in deze periode onder meer middels het instellen van subcommissies de ijzeren greep van de seniore, veelal conservatieve Democratische voorzitters van de voltallige commissies over met name het wetgevingsproces te breken. ${ }^{54}$ Deze groei van subcommissies leidde echter tot een aantal organisatorische problemen. Zo ontstonden er conflicten tussen subcommissies over de taakverdeling en over overlappende vergaderschema's. Daarnaast werd de belasting van ambtenaren van departementen en andere uitvoerende diensten, die voor meerdere subcommissies moesten verschijnen, steeds groter. ${ }^{55}$ Bovendien zorgde deze ontwikkeling voor een nieuwe machtsbalans: waar de controle van de commissievoorzitters over het wetgevingsproces afnam, onstonden nieuwe, gefragmenteerde machtscentra die de eenheid van beleid en de politieke sturing ervan in gevaar brachten.

\footnotetext{
52 Deze ontwikkeling werd ingezet door de Democratische partij, die gedurende lange tijd een meerderheid in zowel Huis als Senaat bezat. In de Democratische partijregels van 1975 was zelfs bepaald dat de commissies 'firm working majorities' moesten hebben. Het doel van deze koerswijziging was de conservatieve coalitie van zuidelijke Democraten en Republikeinen te breken door meer (noordelijke) Democraten in de commissies te benoemen. Een beroep hiertegen van de Republikeinse minderheid bij de federale rechter in 1981 werd verworpen, omdat het een interne aangelegenheid van het Congres betrof. Zie Tiefer 1989, p. 90. De Republikeinen hebben deze trend na de machtswisseling in 1995 voorgezet. Zie verder Guide to Congress 2008, p. 656-657.

53 De enige commissie waarin traditioneel een significante meerderheid wordt afgedwongen is de House Rules Committee, aangezien deze besluit over de wetsgevingsagenda in het Huis (thans 9 tegen 4 zetels). Deze commissie en die voor House Administration en Standards zijn in de percentages niet meegerekend. Zie over de ontwikkelingen rondom de 'party ratio' verder Deering \& Smith 1997, p. 96-97; 2008, p. 565-566; Brown \& Johnson 2003, p. 242; Tiefer 1989, p. 87-93.

54 Deering \& Smith 1997, p. 30-39.

55 Deering \& Smith 1997, p. 151.
} 
Dit fenomeen, ook wel 'subcommittee government' genoemd, leidde in de jaren 80 en 90 tot een tegenreactie waarbij met name de leiding van de meerderheidspartij in het Huis meer sturende invloed probeerde te bewerkstelligen. ${ }^{56}$ In procedureel opzicht leidde deze tegenreactie ertoe dat in het Huis een concreet maximum aan het aantal subcommissies werd ingevoerd. Thans kunnen commissies in beginsel niet meer dan vijf subcommissies instellen. Het is alleen toegestaan een zesde subcommissies in te stellen, wanneer dit een 'Oversight and Investigations Subcommittee' is. ${ }^{57} \mathrm{Op}$ dit moment maken 10 van de 16 voornaamste vaste commissies gebruik van een dergelijke subcommissie. ${ }^{8}$ Voor de House Committee on Oversight and Government Reform geldt overigens een bijzondere regeling. Deze commissie kan maximaal zeven subcommissies instellen. ${ }^{59}$

In de Senaat was de politieke druk om het commissiestelsel te hervormen minder sterk dan in het Huis. Niettemin groeide ook in deze (kleinere) kamer het aantal subcommissies, waardoor vergelijkbare organisatorische problemen ontstonden. ${ }^{60}$ Dit heeft niet geleid tot een maximum aantal subcommissies, zoals in het Huis. In beginsel kan elke commissie zelf bepalen welke subcommissies zij instelt en welke procedure daarbij gevolgd moet worden. ${ }^{61}$ Wel kennen de Senate Rules beperkingen ten aanzien van het aantal subcommissies waarvan individuele senatoren lid kunnen zijn. ${ }^{62}$ Dit kan de facto worden gezien als een beperking van het aantal subcommissies. ${ }^{63}$ Voorts bepalen de Rules dat commissies geen 'subunits' mogen instellen die niet de status van subcommissie hebben, zonder uitdrukkelijke toestemming van de plenaire vergadering. ${ }^{64} \mathrm{Op}$ deze manier wordt voorkomen dat de bepalingen in de Rules worden omzeild.

Evenals in het Huis maken Senaatscommissies op verschillende wijze gebruik van subcommissies. Sommige commissies kennen een speciale subcommissie voor 'oversight', al is dit minder gebruikelijk dan in het Huis. De Homeland Security and Governmental Affairs Committee heeft haar toezichtstaak verdeeld over verschillende subcommissies, waaronder de reeds besproken 'Permanent Subcommittee on Investigations'.

De grootte van subcommissies varieert sterk, waarbij de subcommissies in het Huis in het algemeen groter zijn dan die in de Senaat. Indien een Huiscommissie gebruik maakt van een Oversight and Investigations Subcommittee, dan is dit meestal een van de kleinere subcommissies. Doorgaans hebben dergelijke subcommissies

\footnotetext{
56 Zie over deze ontwikkeling uitvoeriger: Deering \& Smith 1997, p. 168-175.

${ }^{57}$ House Rule X, lid 5, sub d(1-2) (2011).

${ }^{58}$ In sommige gevallen hebben deze subcommissies aanvullende (wetgevende) taken. Zie verder het commissieoverzicht, http://clerk.house.gov/committee_info/scsoal.pdf.

${ }^{59}$ Zie House Rule X, lid 5, sub d(2) (2011). In het 112e Congres kent deze commissie ook zeven subcommissies, terwijl in het 111e Congres gekozen werd voor slechts vijf (bredere) subcommissies. Ook voor de Appropriations Committee geldt overigens een bijzondere regeling.

${ }^{60}$ Deering \& Smith 1997, p. 40-42.

61 Tiefer 1989, p. 109.

62 Senate Rule XXV, lid 4, sub b (2011).

63 Deering \& Smith 1997, p. 152.

64 Senate Rule XXV, lid 4, sub b (4) (2011).
} 
tussen 10 en 15 leden. ${ }^{65}$ Hoewel het bestaan van een dergelijke subcommissie niet betekent dat de overige subcommissies of de voltallige commissie geen toezichthoudende activiteiten meer mogen of zullen verrichten, zorgt dit in de praktijk natuurlijk wel voor een zekere concentratie van de werkzaamheden (en van deskundigheid) op het gebied van toezicht en onderzoek binnen de commissie.

\subsubsection{Voorzitterschap}

De voorzitters van de vaste commissies in het Huis worden, op voordracht van de meerderheidsfractie, door het Huis gekozen uit de leden van de betreffende commissies. ${ }^{66}$ In de Senaat bestaan hieromtrent geen Kamerregels. De wijze waarop de kandidaten voor de voorzittersfuncties worden geselecteerd, worden in beide Kamers vooral bepaald door de interne fractieregels van de meerderheidspartij. Tot 1911 werden de commissievoorzitters in het Huis nog rechtstreeks door de Speaker benoemd. Daarna gold lange tijd de ongeschreven regel, de zogenaamde 'seniority rule', dat het langst zittende commissielid aan de kant van de meerderheidspartij aanspraak kon maken op het voorzitterschap van die commissie. De hervormingen in de jaren 60 en 70 aan met name Democratische zijde maakten aan dit automatisme in het Huis een einde. ${ }^{67}$ Hoewel het commissievoorzitterschap thans nog steeds vaak door het meest ervaren commissielid wordt vervuld, is dit inmiddels door een aantal hervormingen van zowel de Democratische als de Republikeinse fractieregels geen vanzelfsprekendheid meer. ${ }^{68}$ In de Senaat, waar hervormingen minder ingrijpend waren, is de 'seniority rule' nog steeds dominant. ${ }^{69}$

De voorzitters zijn bijna altijd lid van de meerderheidspartij. Gezien de cruciale rol die de vaste commissies spelen in onder meer het wetgevingsproces, is dit niet verwonderlijk. Hoewel commissievoorzitters, evenals de partijleiders, voortdurend rekening moeten houden met de wensen en belangen van de overige leden, kunnen zij in hoge mate een sturende rol binnen de commissies innemen. De voorzitters van de commissies beschikken over verschillende bevoegdheden. De voorzitter verricht

${ }^{65}$ De partijverhouding binnen de subcommissie komt grofweg overeen met die binnen de voltallige commissie, zo kan worden afgeleid uit het commissieoverzicht. Zie http://clerk.house.gov/committee_info/scsoal.pdf.

${ }^{66} \mathrm{Bij}$ afwezigheid van de voorzitter worden de taken waargenomen door een ander commissielid, te bepalen op basis van de ledenrangschikking in de betreffende Huisresolutie. House Rule X, lid 5, sub c.

${ }^{67}$ Ook de Republikeinen namen initiatieven. Zo werd in 1995, toen zij de controle over het Huis verwierven, in de House Rules vastgelegd dat een commissielid maximaal drie opeenvolgende Congrestermijnen het voorzitterschap mocht bekleden. Deering \& Wahlbeck 2006, p. 224.

68 Guide to Congress 2008, p. 657-657. Zie ook Tiefer 1989, p. 102-105. Uit onderzoek met betrekking tot het 107e Congres, waarin het Huis onder Republikeinse controle stond en waarin veel voorzitters werden vervangen, blijkt dat naast senioriteit ook op de positie van kandidaten binnen de partij en het vermogen om fondsen te werven een belangrijke rol speelden. Zie Deering \& Wahlbeck 2006, p. 237238.

${ }^{69}$ Senate Rule XXV, lid 4, sub e, stelt een maximum op het aantal voorzitterschappen van commissies en subcommissies dan een senator kan bekleden. In 1997 stelden de Republikeinen in de Senaat in hun fractieregels dat een senator maximum drie opeenvolgende congrestermijnen voorzitter van dezelfde commissie kan zijn. De Democraten kennen geen formele 'term limits'. Zie Guide to Congress 2008, p. 657. 
allereerst verschillende vertegenwoordigende, procedurele en coordinerende taken. De commissievoorzitter is doorgaans ex officio lid van alle subcommissies. Belangrijk is voorts dat de voorzitter het commissiebudget beheert en de grootste deel van de commissiestaf aanstuurt. ${ }^{70}$ In politiek opzicht zijn commissievoorzitters vaak bijzonder invloedrijke spelers op hun beleidsterrein en binnen hun partij. Ten aanzien van de toezichthoudende taken van de vaste commissies wordt de positie van de commissievoorzitter verder versterkt, wanneer de commissie bevoegdheden zoals het recht om getuigen te sommeren (de 'subpoena power') delegeert aan de voorzitter. ${ }^{71}$

Naast de voorzitter is een bijzondere rol weggelegd voor het hoogst gerangschikte commissielid van de minderheidspartij, 'ranking minority member' genoemd. De selectie en benoeming van de ranking minority members is afhankelijk van de interne fractieregels van de minderheidspartij. De formele rol van de leider van het minderheidssmaldeel is beperkt. Veelal beschikt de ranking member op basis van Committee Rules over het recht om door de voorzitter geconsulteerd of geïnformeerd te worden omtrent voorgenomen besluiten. ${ }^{72}$ Ook kan hij een deel van de commissiestaf ('minority staff') aansturen. De invloed die de minderheid binnen een commissie uitoefent, hangt uiteindelijk voor een belangrijk deel af van de politieke en de persoonlijke verhoudingen tussen de voorzitter en de ranking member. ${ }^{73}$

\subsubsection{Coördinatie en planning}

Sinds de jaren 70 bevatten de House Rules bepalingen omtrent de coördinatie van het toezicht dat de afzonderlijke commissies zelfstandig uitoefenen. Alle vaste commissies dienen binnen enkele weken na het aantreden van een nieuw Congres een toezichtsplan ('oversight plan') vast te stellen. Dit toezichtsplan dient te worden voorgelegd aan de Committee on Oversight and Government Reform en aan de Committee on House Administration. Bij het opstellen ervan dienen commissies een aantal richtlijnen in ogenschouw te nemen. Zo dienen toezichtsactiviteiten zoveel mogelijk te worden afgestemd met andere commissies en zou in het bijzonder aandacht moeten worden besteed aan regelgeving en beleid "that are ambiguous, arbitrary, or nonsensical, or that impose severe financial burdens on individuals." Verder wordt van elke commissie verwacht in overweging te nemen dat "all significant laws, programs, or agencies within its jurisdiction are subject to review every 10 years."74 De plannen van de afzonderlijke commissies worden vervolgens door de Committee on Oversight and Government Reform gerapporteerd aan het Huis na overleg met de Speaker, Majority Leader en Minority Leader. De Oversight Committee en de overige betrokkenen kunnen aan deze rapportage aanbevelingen toevoegen van coördinerende aard. ${ }^{75}$ In het Huis bezit de Speaker sinds 1995 de bevoegdheid

\footnotetext{
70 Zie House Rule X, lid 9, sub a. De Senate Rules geven geen nadere bepalingen omtrent de aansturing van de staf. Meer over de positie van de commissiestaf, hierna.

${ }^{71}$ Zie House Rule XI, lid 2, sub (m)(3). Zie ook Brown \& Johnson 2003, p. 243.

72 In de Senaat is dit op grond van gewoonte per definitie het geval. Guide to Congress 2000, p. 566.

73 Guide to Congress 2008, p. 658.

74 Zie verder House Rule X, lid 2, sub d (2011).

${ }^{75}$ House Rule X, lid 2, sub d (2011).
} 
om, na instemming van het Huis, "special ad hoc oversight committees" in te stellen ten aanzien van onderwerpen die meer dan één vaste commissie aangaan. ${ }^{76}$

Zowel in het Huis als in de Senaat dienen commissies na afloop van de tweejarige Congrestermijn verslag uit te brengen over de toezichtsactiviteiten tijdens de voorbije periode. 77 Bovendien geldt in het Huis sinds 2009 dat alle vaste commissies tenminste één hoorzitting per 120 dagen dienen te houden "on the topic of waste, fraude, abuse, or mismanagement in Government programs which that committee may authorize." 78 Ook dient elke vaste Huiscommissie tenminste één hoorzitting te houden over verspilling en misbreuk bij federale instanties of programma's op de zogenaamde 'high-risk list' die de Comptroller General opstelt. ${ }^{79}$ Of van deze plannings- en rapportageverplichten en de coördinatie vanuit de Oversight Committee in de praktijk veel sturende werking uitgaat, valt overigens te betwijfelen. Al vanaf de invoering van deze verplichtingen lijkt de Oversight Committee ervoor terug te schrikken om ook daadwerkelijk enige coördinatie tot stand te brengen, nadat eerdere voorstellen voor een meer centrale toezichtsplanning, gecoördineerd door de leiding van de meerderheidspartij, in het Huis op weerstand stuitten. ${ }^{80}$ De aanbevelingen van de Oversight Committee naar aanleiding van de ingediende toezichtsplannen zijn dan ook vaak nogal algemeen geformuleerd. ${ }^{81}$ De wijze waarop de commissies hun toezichtstaken uitvoeren, is afhankelijk van vele factoren, zoals de interesses van de leden en actuele (politieke) ontwikkelingen. De ingediende plannen en rapporten lijken daarom vooral een inventariserende functie te hebben.

\subsection{Bijzondere commissies}

\subsubsection{Inleiding}

Niet alleen de vaste commissies verrichten onderzoeksactiviteiten. Beide kamers maken incidenteel gebruik van bijzondere onderzoekscommissies. Deze worden 'select committee' of 'special committee' genoemd.82 De redenen voor het instellen van bijzondere commissies lopen uiteen. Een bijzondere commissie kan bedoeld zijn om een beleidsterrein te accentueren, om de behandeling van overlappende beleidsterreinen te coördineren, of om onderzoek te doen naar een specifiek probleem. Kenmerkend

\footnotetext{
${ }^{76}$ House Rule X, lid 2, sub e (2011).

77 House Rule XI, lid 1, sub d (1); Senate Rule XXVI, lid 9, sub b (2011).

${ }^{78}$ Een dergelijke hoorzitting dient betrekking te hebben op "the most egregious instances of waste, fraude, abuse, or mismanagement" die zijn gerapporteerd door Inspectors General bij de departementen en agentschappen of door de Comptroller General. Zie House Rule XI, lid 2, sub n (2011).

${ }^{79}$ House Rule XI, lid 2, sub p (2011).

${ }^{80}$ Veel behoefte aan coördinatie is er bij de afzonderlijke commissies dus kennelijk niet. Zie Aberbach 1990, p. 207-208.

81 Zie bijvoorbeeld House Oversight and Government Reform Committee, Oversight Plans for All House Committees, H.Rep. 111-69 (maart 2009), waarin de commissies wordt aanbevolen om gebruik te maken van de "wide variety of available oversight resources", zoals de diensten van GAO en de IGs, en verder om vooral veel met elkaar samen te werken.

82 Het verschil tussen 'select committees' en 'special committees' lijkt voornamelijk semantisch van aard. Niet alle 'select' en 'special committees' kunnen overigens worden aangemerkt als onderzoekscommissies. Deering \& Smith 1997, p. 16. Zie ook Tiefer 1989, p. 79.
} 
voor bijzondere commissies is dat zij doorgaans geen wetgevende taken hebben en voor een beperkte tijd worden ingesteld. Deze commissies houden zich voornamelijk bezig met onderzoek en advisering. ${ }^{83}$ Onderzoek kan overigens ook worden uitgevoerd door een gezamenlijke commissie ('joint committee'), bestaande uit leden uit zowel Huis als Senaat, al wordt van die mogelijkheid slechts sporadisch gebruik gemaakt; de twee kamers staan niet bekend om hun harmonieuze samenwerking.

\subsubsection{Soorten bijzondere commissies}

Tegen deze achtergrond kunnen twee soorten bijzondere onderzoekscommissies worden onderscheiden. ${ }^{84}$ Het betreft allereerst thematisch georiënteerde commissies, die de geijkte beleidsterreinen overstijgen. Een voorbeeld is de in 2007 ingestelde House Select Committee on Energy Independence and Global Warming. ${ }^{85}$ Deze commissies houden zich vooral bezig met het verrichten (of uitbesteden) van studies en het formuleren van aanbevelingen voor beleid of wetgeving. Soms groeien dit soort commissies de facto uit tot vaste commissies, omdat zij na afloop van de instellingstermijn steeds opnieuw worden ingesteld. Een voorbeeld is de Senate Select Committee on Aging, die sinds 1977 bestaat. Deze commissies kunnen worden omschreven als themacommissies.

De tweede categorie betreft de bijzondere commissies met een specifieke onderzoeksopdracht, die veelal worden ingesteld naar aanleiding van bijzondere gebeurtenissen, incidenten of schandalen. Dergelijke commissies zijn niet in de eerste plaats gericht op het doen van aanbevelingen voor wetgeving of beleid, maar op het verzamelen van feiten rondom een gebeurtenis waarover onduidelijkheid of maastschappelijke onrust bestaat. Hun levensduur is doorgaans korter dan die van themacommissies. Verschillende van de meest spraakmakende congressionele onderzoeken werden door dit type bijzondere commissie uitgevoerd. Het eerste congressionele onderzoek, dat plaatsvond in 1792, werd uitgevoerd door een bijzondere commissie. ${ }^{86}$ De House Un-American Activities Committee begon in 1938 als een tijdelijke commissie. ${ }^{87}$ Voorbeelden uit de naoorlogse periode zijn de Watergatecommissie in de Senaat (1972), de samenwerkende bijzondere commissies in Huis en Senaat inzake het Iran-Contra schandaal (1986), de Senate Special Whitewater Com-

\footnotetext{
${ }^{83}$ Deering \& Smith 1997, p. 16 en Davidson \& Oleszek 2002, p. 207.

${ }^{84} \mathrm{Zie}$ ook Brown \& Johnson 2003, p. 253-254. Een derde categorie bijzondere commissie, gericht op interne zaken zoals de organisatie van het Congres, wordt hier buiten beschouwing gelaten.

85 De taakomschrijving van deze commissie luidt: "The select committee shall not have legislative jurisdiction and shall have no authority to take legislative action on any bill or resolution. Its sole authority shall be to investigate, study, make findings, and develop recommendations on policies, strategies, technologies and other innovations, intended to reduce the dependence of the United States on foreign sources of energy and achieve substantial and permanent reductions in emissions and other activities that contribute to climate change and global warming." Zie H. Res. 202, lid 4(c) (2007). Deze commissie werd bij aanvang van het 111e Congres in 2009 opnieuw ingesteld, maar bij aanvang van het 112e Congres, waarin de Republikeinen een meerderheid hadden verworven, opgeheven.

${ }^{86}$ Het ging om de onderzoekscommissie in het Huis naar aanleiding van de militaire nederlaag van generaal St. Clair. Zie hiervoor, par. 2.2.1.

${ }^{87}$ In 1945 werd de commissie opgenomen in de House Rules, waarmee het een vaste commissie werd. Pas in 1975 werd de commissie opgeheven.
} 
mittee (1995) en de House Select Bipartisan Committee inzake de hulpverlening na de orkaan Katrina (2005). ${ }^{88}$ Deze commissies kunnen worden omschreven als bijzondere onderzoekscommissies.

Het onderscheid tussen deze twee typeringen is overigens niet altijd even duidelijk. Sommige commissies kunnen daarom, gelet op hun taakstelling, in beide categorieen worden ingedeeld. ${ }^{89}$ Het aantal bijzondere commissies laat overigens al jaren een dalende trend zien. ${ }^{90}$ Deze afname betekent overigens niet automatisch dat de kamers minder geinteresseerd zijn in het type onderzoek dat bijzondere commissies verrichtten. Vergelijkbaar onderzoek kan immers ook door de vaste commissies worden verricht.

\subsubsection{Instelling, taakopdracht, leden}

In welke gevallen en met welke redenen een kamer kan besluiten tot het instellen van een bijzondere commissie, is niet in regels gevat. Bijzondere commissies worden ingesteld middels een daartoe strekkende resolutie: een gewoon meerderheidsbesluit in de betreffende kamer. De omvang, taken en bevoegdheden van de commissie wordt in deze resolutie geregeld. Zoals gezegd bezitten bijzondere commissies doorgaans geen wetgevende taken. Wanneer het gaat om een onderzoekscommissie, dan wordt de onderzoeksopdracht bepaald in de instellingsresolutie. Deze opdracht is vaak specifiek gericht op een (vermeende) gebeurtenis, een incident of een politiek schandaal. Naarmate het onderwerp gevoeliger ligt, zal meer aandacht worden besteed aan de formulering van de onderzoeksopdracht. Dit kan uiteraard tot politieke onenigheid leiden, zowel tussen de twee partijen als binnen partijen. Zo wilde de Republikeinse minderheid in de Senaat dat de Watergate-commissie niet alleen de gebeurtenissen rondom verkiezingen van 1972 zou onderzoeken, maar ook die van 1968. Dit voorstel haalde het niet. ${ }^{91}$

Bijzondere onderzoekscommissies krijgen meestal dezelfde onderzoeksbevoegdheden als de vaste commissies, zoals de bevoegdheid om getuigen op te roepen middels subpoenas. Soms worden aanvullende bevoegdheden toegekend. Zo kregen de commissies die onderzoek deden naar de Iran-Contrakwestie (1987) de bevoegdheid om federale diensten in te schakelen die in het buitenland gegevens konden verzamelen en kreeg de Huiscommissie die de geruchten omtrent de betrokkenheid van het campagneteam van Reagan in de bevrijding van het gegijzelde

\footnotetext{
88 Zie onder andere Schlesinger \& Bruns 1975, p. 3923 e.v. Zie verder Deering \& Smith 1997, p. 16 en Tiefer 1989, p. 82-85.

${ }^{89}$ Een globale categorisering aan de hand van de taakstelling van bijzondere commissies in het Huis en Senaat tussen 1947 en 1993 laat zien dat de genoemde soorten commissies grofweg in vergelijkbare mate voorkomen. Gegevens over de taakstelling van bijzondere commissies ontleend aan: Nelson 1993.

${ }^{90}$ Werden er in het Huis in de jaren ' 80 van de twintigste eeuw nog gemiddeld 5 a 6 bijzondere commissies ingesteld per Congrestermijn, vanaf de jaren '90 neemt dit sterk af. Tijdens het 110e Congres (2007-2008) was er slechts een bijzondere commissie actief. In de Senaat is de afname minder dramatisch: van 4 tot 5 bijzondere commissies in de jaren ' 80 naar 3 à 4 commissies sinds 2000. Ter vergelijking: het aantal vaste commissies schommelt in het Huis al sinds 1955 rond 20, in de Senaat rond 16. Zie voor statistieken: Ornstein, Mann \& Malbin 2008, p. 103.

${ }^{91}$ Schlesinger \& Bruns 1975, p. 3926.
} 
Amerikaans ambassadepersoneel in Iran onderzocht (1991) de bevoegdheid zich te voegen in gerechtelijke procedures. ${ }^{92}$

Er bestaat geen vaste procedure voor het selecteren van de leden en de voorzitters van bijzondere commissies. Wanneer een bijzondere commissie wordt ingesteld om onderzoek te doen naar een gebeurtenis of schandaal dat tot veel politieke of maatschappelijke onrust heeft geleid, kunnen factoren als deskundigheid, aanzien en onpartijdigheid een belangrijke rol spelen bij de selectie van de leden, in het bijzonder van de voorzitter. De Watergate-commissie in de Senaat is hiervan een voorbeeld. Door de gebeurtenissen rondom Watergate was het vertrouwen in en het aanzien van de politiek tot een dieptepunt gedaald. De Senaat stemde begin 1973 unaniem voor het instellen van een bijzondere commissie "to conduct an investigation and study of the extent, if any, to which illegal, improper, or unethical activities were engaged in by any persons, acting individually or in combination with others, in the presidential election of 1972, or any campaign, canvass, or other activity related to it." 93 De voorzitter, Sam Ervin, genoot veel gezag en was ervaren in het doen van onderzoek als lid van de Senate Government Operations Committee. De commissie bestond uit vier Democraten en drie Republikeinen. Alleen de voorzitter behoorde tot hoogste rangen in de Senaat. Beide partijen droegen kandidaten voor met zeer verschillende achtergronden. Voorzitters van de vaste commissies en partijleiders aan beide zijden kwamen niet in aanmerking; senatoren die presidentskandidaat waren geweest of zouden kunnen worden bleven eveneens buiten beschouwing. ${ }^{94}$

Zo'n twintig jaar later was het gedrag van de president wederom voorwerp van onderzoek. Deze keer was de politieke context echter beduidend anders. De Senate Whitewater Select Committee ingesteld in 1995, kort nadat de Republikeinen de controle over het Congres hadden gekregen, onderzocht een aantal dubieuze grondaankopen van de toenmalige president Clinton. ${ }^{95}$ Anders dan bij het Watergateonderzoek was deze commissie "tinged with partisanship from the beginning." 96 Beide partijen in de commissie kwamen dan ook met aparte eindrapporten, waarin tegenovergestelde conclusies werden getrokken. De Republikeinse meerderheid leek met deze en andere onderzoeken er vooral op uit te zijn de Democraat Clinton zoveel mogelijk te beschadigen ("attack politics"). ${ }^{97}$

\subsection{Ondersteuning}

Ter ondersteuning beschikken commissies in eerste instantie over een eigen, vaste staf. In aanvulling daarop kunnen commissies gebruik maken van verschillende ondersteunende diensten, die ter beschikking staan van het Congres of de betreffende Kamer als geheel.

\footnotetext{
92 Zie voor een overzicht: Kaiser, Oleszek \& Tatelman 2011, p. 74-75.

93 S. Res. 60 (1973).

94 Schlesinger \& Bruns 1975, p. 3927.

95 S. Res. 104-229 (1995).

96 Guide to Congress 2008, p. 318.

97 Zie uitvoerig: Guide to Congress 2008, p. 317-321.
} 


\subsubsection{Vaste staf}

Kenmerkend voor congrescommissies is de omvangrijke ambtelijke ondersteuning waarover zij beschikken. Stafleden worden door congresleden gezien als een onmisbare factor bij de uitoefening van hun wetgevende en toezichthoudende taken. Stafleden genieten evenals congresleden bescherming onder de constitutionele 'speech and debate clause', zo bevestigde het Hooggerechtshof in 1972. Het Hof onderschreef daarbij de stelling dat "the day-to-day work of such aides is so critical to Members' performance that they must be treated as the latter's alter egos" ${ }^{98}$

\subsubsection{Ontstaan en groei}

De rol van stafleden is niet altijd zo evident geweest. In de beginjaren van het Congres werkten leden en commissies zonder eigen staf. In de loop van de negentiende eeuw, toen het aantal vaste en bijzondere commissies sterk groeide, veranderde dit en kregen sommige commissies de beschikking over beperkte administratieve ondersteuning. Professionele (vakinhoudelijke) ondersteuning, zowel voor individuele leden als commissies, werd lange tijd geschuwd. Congresleden wilden niet worden gezien als onvoldoende deskundig en vreesden bovendien dat professionele stafleden op enig moment wellicht zelf politieke aspiraties zouden krijgen. Deze houding veranderde in de loop van de twintigste eeuw. De federale overheid groeide sterk in omvang en complexiteit, wat gepaard ging met een steeds groter wordende werklast van congresleden. Daarnaast ontstond onvrede over de mate waarin congresleden in de uitoefening van hun (wetgevende) taken afhankelijk waren van informatie afkomstig van de uitvoerende macht, waardoor de gelijkwaardige positie van het Congres ten opzichte van de uitvoerende macht onder druk kwam te staan. ${ }^{99}$

Enkele experimenten vanaf de jaren 20 met professionele, niet-partijpolitieke ondersteuning van commissies leidden uiteindelijk in 1946 tot structurele maatregelen. Met de Legislative Reorganization Act van dat jaar werd het commissiestelsel in beide kamers hervormd en werden alle commissies voorzien van een permanent aantal stafleden. Voortaan konden de meeste vaste commissies maximaal tien stafleden aanstellen: vier professionele stafleden, met inhoudelijke expertise op het werkterrein van de betreffende commissie, en zes administratieve krachten. Stafleden dienden te worden geselecteerd "solely on the basis of fitness to perform the duties of office." 100 Het vaste professionele stafleden werd bij herziening van Legislative Reorganization Act in 1970 verhoogd naar zes per commissie. Twee vernieuwingen waren in het bijzonder van belang. Voor de eerste keer werd een formeel onderscheid gemaakt tussen meerderheids- en minderheidsstaf: bepaald werd dat twee professionele stafleden en een administratieve medewerker uitsluitend voor de commissieleden van de minderheidspartij zouden werken. Bovendien kregen commissies de mogelijkheid om middelen aan te vragen voor aanvullende onderzoeksstaf; hierdoor zou het aantal commissiemedewerkers snel gaan toenemen. ${ }^{101}$

\footnotetext{
98 Gravel v. United States, 408 U.S. 606, 616-617 (1972).

${ }^{99}$ Guide to Congress 2008, p. 678.

100 Guide to Congress 2008, p. 678.

101 Guide to Congress 2008, p. 679-680.
} 
Vanaf de jaren 70 nam de professionele (commissie)ondersteuning een grote vlucht. Dit gebeurde tegen een achtergrond van een steeds groter aantal activistische congresleden, het verval van het senioriteitsprincipe (met name in het Huis) en de daarmee samenhangende opkomst van subcommissies, en de explosieve groei van lobbyactiviteiten door belangengroepen ('special interests') waardoor meer behoefte ontstond aan deskundige ondersteuning in eigen huis. Verder speelde de voortgaande groei van presidentiële ondersteunende diensten in het Witte Huis en van de uitvoerende macht in het algemeen een rol. Dit werd gezien als een bedreiging, vooral na de ervaringen met de Vietnamoorlog en het Watergate-schandaal; het verder optuigen van het congressionele ambtelijke apparaat, zowel voor commissies als voor individuele leden, moest als tegenwicht dienen. ${ }^{102}$

In 1974 resulteerde dit in een verhoging van het aantal vaste commissiestafleden in het Huis naar dertig medewerkers per commissie: 18 professionele en 12 administratieve stafleden. Spoedig konden ook subcommissies in het Huis eigen medewerkers gaan aanstellen, waardoor het totaal aantal stafleden verder groeide. In de Senaat groeide de vaste commissieondersteuning, mede door het kleinere aantal subcommissies, minder hard. ${ }^{103}$ In beide Kamers werden aanvullende stafmedewerkers, vaak 'temporary' of 'investigative staff' (omdat ze in eerste instantie voornamelijk ten behoeve van een specifiek onderzoek werden aangesteld ${ }^{104}$ ) genoemd, echter steeds belangrijker. Hiermee kan de commissiestaf aanzienlijk worden uitgebreid. Tijdelijke onderzoeksmedewerkers werden aanvankelijk slechts op jaarbasis aangesteld; inmiddels is het gebruikelijk dat commissies de gelden hiervoor elke congrestermijn opnieuw toegekend krijgen. Dergelijke stafleden kunnen daarom feitelijk als vaste medewerkers worden beschouwd. ${ }^{105}$ Niet onbelangrijk is tenslotte de sterke groei van het aantal persoonlijke medewerkers van congresleden, die eveneens een bijdrage kunnen leveren aan commissiewerkzaamheden. In de Senaat kan elke senator zelfs maximaal drie persoonlijke medewerkers aanstellen die uitsluitend assisteren bij commissietaken. ${ }^{106}$

Na een piek rond 1990, toen het Huis zo'n 2.000 commissiemedewerkers kende en de Senaat ongeveer 1.000, is het aantal stafleden van commissies weer afgenomen. Dit is voornamelijk het gevolg van verlaging van de aanvullende budgetten. Een ingrijpende vermindering vond plaats in 1995, toen de Republikeinen de controle over beide Kamers verwierven en in het kader van hun 'Contract with America' omvangrijke bezuinigingen in het congressionele ambtenarenapparaat doorvoerden. Met name de commissieondersteuning werd aangepakt. Het aantal stafleden in het

\footnotetext{
102 Guide to Congress 2008, p. 674.

${ }^{103}$ Meer over de ontwikkeling en positie van de staf van subcommissies: Deering \& Smith 1997, p. 163 e.v.

104 Zie ook: Joint Committee on the Organization of Congress 1993.

105 Guide to Congress 2008, p. 679-682.

106 In het Huis bestaat de persoonlijke staf van een lid uit ongeveer 14 medewerkers, terwijl senatoren gemiddeld 34 persoonlijke medewerkers hebben. Het totaal aantal persoonlijke medewerkers in beide Huizen groeide sterk in de jaren 70 en 80 en is vervolgens gestabiliseerd in de Senaat en wat afgenomen in het Huis. In 2005 werkten in totaal 6.804 stafleden voor individuele Huisleden, tegen 3.934 persoonlijke medewerkers in de Senaat. Zie Guide to Congress 2008, p. 682-684, 692 en Ornstein, Mann \& Malbin 2008, p. 111.
} 
Huis daalde direct met dertig procent; ook in de Senaat werd bezuinigd, zij het in mindere mate. ${ }^{107}$ De laatste jaren is aantal medewerkers relatief stabiel: in het jaar 2005 werkten in totaal 1.272 stafleden voor de 20 vaste commissies in het Huis, terwijl de 17 vaste Senaatscommissies gezamenlijk over 887 stafleden beschikten. ${ }^{108}$ Het aantal stafleden per commissie verschilt sterk en hangt af van factoren als de omvang van het werkterrein van commissies, maar ook van de mate van politiek activisme binnen de commissie - en in het bijzonder van de voorzitter. ${ }^{109}$ Gemiddeld beschikken vaste commissies in het Huis over ongeveer 60 tot 70 medewerkers, terwijl Senaatscommissies gemiddeld zo'n 40 tot 50 medewerkers hebben. ${ }^{110}$

\subsubsection{Samenstelling, taken en middelen}

Commissies beschikken over een eigen budget voor stafsalarissen en andere kosten, dat jaarlijks of tweejaarlijks wordt vastgesteld. Daarnaast kunnen aanvullende middelen worden toegekend. ${ }^{111}$ De beschikbare middelen zijn aanzienlijk en verschillen per commissies. Zo konden veel vaste commissies in het Huis voor de periode 20092011 rekenen op 10 tot 20 miljoen dollar per commissie voor de uitvoering van hun taken. 112

Wat betreft de functionele samenstelling van de commissiestaf kan onderscheid gemaakt worden tussen professionele stafleden en administratieve medewerkers. De professionele stafleden, veelal juristen en academici met vakinhoudelijke of beleidsmatige expertise, bieden inhoudelijke ondersteuning bij de uitoefening van commissietaken. Zij vervullen functies met titels als 'chief counsel', 'counsel', 'investigator' en 'economist'. De administratieve medewerkers - met titels als 'clerical assistant', 'secretary' en 'documents clerk' - houden zich vooral bezig met secretariële en coördinerende taken. De staf staat veelal onder leiding van een 'staff director' of 'chief of staff'. ${ }^{113}$

Bij de algemene toezichtscommissies in Huis en Senaat zijn de meeste professionele stafleden, niet verwonderlijk, specialisten op het gebied van onderzoek en controle. Bij de beleidsgerichte vaste commissies houden stafleden zich op wetgevingsgebied onder meer bezig met beleidsstudies en het schrijven van briefings, wetteksten en commissieverslagen; wat betreft de toezichtsfunctie verrichten

${ }^{107}$ De bezuinigingen troffen overigens met name het grote aantal Democratische commissiemedewerkers, die overbodig waren geworden als gevolg van de machtswissel in het Huis. In hun plaats werden minder nieuwe medewerkers aangesteld. In de persoonlijke ondersteuning van congresleden werd niet gesneden. Guide to Congress 2008, p. 683-684.

108 Ornstein, Mann \& Malbin 2008, p. 103, 112.

109 Deering \& Smith 1997, p. 167-168.

${ }_{110}$ De House Government Reform and Oversight Committee beschikt in verband met haar algemene toezichtsfunctie over meer dan 100 medewerkers; de Appropriations Committee heeft zelfs 164 medewerkers. In de Senaat heeft de Judiciary Committee, wegens haar rol in de benoeming van federale functionarissen, bijzonder veel medewerkers. Zie voor de cijfers per commissie: Ornstein, Mann \& Malbin 2008, p. 113-114.

111 Deze budgetaanvragen worden behandeld door de Committee on House Administration respectievelijk de Senate Committee on Rules and Administration, alvorens de plenaire vergadering de definitieve middelen vaststelt. Zie House Rule X, lid 6 en Senate Rule XXVI, lid 9.

112 H. Res. 111-279 (2009). In de Senaat liggen de bedragen iets lager. Zie S. Res. 111-73 (2009).

113 Zie Pontius \& Bullock 2003, p. 2. 
zij onder meer studies naar de implementatie van wetgeving en de uitvoering van beleidsprogramma's en controleren zij periodieke rapportages van uitvoerende departementen en diensten. Verder assisteren zij commissieleden tijdens vergaderingen en hoorzittingen en onderhouden zij contacten met andere commissies, ambtenaren binnen de uitvoerende macht en belangengroepen. ${ }^{114}$

De mate waarin de beleidsgerichte commissies zich bezighouden met toezicht en onderzoek wordt in belangrijke mate bepaald door de politieke interesses van de commissieleden - in het bijzonder van de voorzitter. Toezichtswerk hangt daarbij vaak in hoge mate samen met de wetgevende (en budgettaire) taken van commissies, waardoor veel stafleden deze taken combineren in hun werkzaamheden.

\subsubsection{Partijpolitieke achtergrond en aansturing}

De Legislative Reorganization Act 1946 ging, zoals eerder aangegeven, uit van het beginsel dat stafleden van commissies zouden worden geselecteerd en benoemd "solely on the basis of fitness to perform the duties of office." 115 Benoeming en ontslag van deze niet-partijpolitieke stafleden werd op grond hiervan overgelaten aan de commissie(meerderheid). Dit systeem bleek al gauw moeilijk werkbaar te zijn, omdat onvoldoende rekening werd gehouden met de partijpolitieke omgeving waarin commissies functioneren. ${ }^{116}$ De regels lieten toe dat de meerderheid binnen veel commissies, in de naoorlogse jaren veelal Democratisch van signatuur, de selectie van stafleden grotendeels naar zich toe kon trekken. In de Legislative Reorganization Act van 1970 werd daarom bepaald dat de minderheid de controle kreeg over drie van de twaalf reguliere stafleden. Belangrijker nog was dat de minderheid de beschikking kreeg over tenminste eenderde van de aanvullende budgetten voor onderzoeksmedewerkers. In het Huis wist de Democratische meerderheid de uitvoering van deze laatste bepaling lange tijd te verhinderen. ${ }^{117}$ Pas na de Republikeinse machtsovername in 1995, toen de Democratische commissiestaf zwaar getroffen werd, veranderde dit. Inmiddels wordt de minderheidspartij bij ruim de helft van de commissies ongeveer eenderde van alle beschikbare staffuncties gegund. In de Senaat, waar het getalsmatige verschil tussen meerderheid en minderheid in zowel de plenaire vergadering als commissies doorgaans kleiner is dan in het Huis, is het al langer gebruikelijk dat de minderheid tenminste eenderde van de professionele staffuncties krijgt. 118

De politieke strijd om de controle over stafleden illustreert de positie die commissiemedewerkers innemen. Slechts enkele commissies kennen nog een centrale staf

\footnotetext{
114 Zie verder Guide to Congress 2008, p. 684-687 en Pontius \& Bullock 2003.

115 Zie ook par. 3.4.1.1.

116 Joint Committee on the Organization of Congress 1993. Over de toegenomen invloed van partijen en partijleiders in het Congres sinds de jaren 70, zie Smith, Roberts \& Vander Wielen 2007, p. 152 e.v.

117 Zo werden de wettelijke bepalingen omtrent de minderheidsstaf op initiatief van de Democraten in het Huis spoedig weer geschrapt. Guide to Congress 2008, p. 688. Hierdoor zijn belangrijke bepalingen over de commissiestaf met betrekking tot het Huis neergelegd in de House Rules.

118 Zie ook Senate Rule XXVII, lid 3, waarin gesteld wordt dat de stafverdeling "should reflect the relative numbers of majority and minority members of committees". In de praktijk ligt de verdeling in het Huis op 2:1, in de Senaat op 6:4. Zie verder het hoofdstuk over 'Committee Staffs' in: Joint Committee on the Organization of Congress 1993; zie ook Guide to Congress 2008, p. 686-688.
} 
met medewerkers die niet primair op grond van partijpolitieke of ideologische voorkeuren zijn aangetrokken. ${ }^{119}$ In de meeste commissies wordt gewerkt met een meerderheidsstaf en een minderheidsstaf. Benoeming en ontslag van commissiestafleden - hoewel formeel een aangelegenheid van de voltallige commissie - zijn feitelijk in handen van de commissievoorzitter of, ten aanzien van de minderheidsstaf, de 'ranking minority member'. ${ }^{120}$ Eenmaal benoemd worden stafleden geplaatst onder het gezag van de commissievoorzitter respectievelijk 'ranking member'. ${ }^{121}$ Hierdoor zijn stafleden veelal politiek-ideologisch verbonden met het commissiesmaldeel waarvoor zij werken en in het bijzonder de leider daarvan.

De mate waarin meerderheids- en minderheidsstafleden samenwerken verschilt sterk per commissie. De minderheidsleden en hun staf bezitten op grond van commissieregels doorgaans enige reglementaire rechten ${ }^{122}$, maar zijn in de praktijk toch veelal afhankelijk van de bereidwilligheid van de (staf van de) meerderheid. Persoonlijke verhoudingen, niet alleen tussen commissieleden maar ook tussen hun stafleden, bepalen tot op grote hoogte in hoeverre de minderheid werkelijk wordt betrokken bij de besluitvorming over bijvoorbeeld nieuw onderzoek.

\subsubsection{Rol en invloed}

Stafleden vormen onmiskenbaar een belangrijke factor in het Congres. Hun werkzaamheden zijn veel meer dan louter voorbereidend en uitvoerend van aard. Het is zeer gebruikelijk dat stafleden intensief betrokken zijn bij onderhandelingen tussen congresleden, vertegenwoordigers van de uitvoerende macht en belangengroepen over beleidsmatige of wetstechnische zaken. Ook op toezichts- en onderzoeksgebied is de staf invloedrijk. Door hun dossierkennis, contacten met 'het veld' en nauwe band met de commissievoorzitter kunnen met name de meerderheidsstafleden grote invloed uitoefenen op de onderzoeksagenda van de commissie. De vertrouwensband tussen commissieleden en stafmedewerkers leidt ertoe dat de laatsten veel (onderzoeks)werkzaamheden op relatief autonome wijze uitvoeren. Zo wordt gedurende het onderzoeksproces vaak slechts incidenteel overleg met de commissie(voorzitter) wordt gevoerd omtrent de voortgang. ${ }^{123}$

Sommige congresleden vertrouwen volledig op hun stafleden en wijzen op de sterke groei van de federale overheidstaken en daarmee de werklast van congresleden. Kennis is macht, zo luidt het bekende adagium: zonder adequate ambtelijke ondersteuning kunnen congresleden hun veelheid aan taken niet naar behoren uitoefenen, zo is de gedachte. Commissiemedewerkers, samen met persoonlijke stafleden

\footnotetext{
119 Voorbeelden zijn de Appropriations Committees, de Ethics Committee en de Joint Committee on Taxation. Ook hier staat de niet-partijpolitieke traditie echter onder druk. Zie hierover verder: Guide to Congress 2008, p. 688-689.

${ }^{120}$ Guide to Congress 2008, p. 686.

121 Zie House Rule X, lid 9, sub (a)(1) (2011) ("Each professional staff member appointed under this subparagraph shall be assigned the chair and the ranking minority member of the committee, as the committee considers advisable."). In de Senaat spreken de Rules slechts van "[s]taff members appointed to assist minority members of committees". Zie Senate Rule XXVII, lid 1 (2011), maar aangenomen mag worden dat de 'ranking minority member' deze stafleden feitelijk aanstuurt.

122 Zie bijvoorbeeld hierna, par. 4.3.2.

123 Zie Deering \& Smith 1997, p. 162-163.
} 
en de eigen ondersteunende diensten, zorgen ervoor dat het Congres in staat wordt gesteld de grote hoeveelheid informatie en expertise afkomstig van de uitvoerende macht en van externe partijen, zoals lobbyisten en belangengroepen, effectief te kunnen analyseren en beoordelen. ${ }^{124}$ Een deskundige staf wordt in dat opzicht gezien als een essentieel element, wil het Congres haar constitutionele gelijkwaardigheid aan de President en de immer groeiende uitvoerende macht ook in de praktijk kunnen handhaven.

Critici zien echter ook nadelige effecten van de gegroeide stafformaties van commissies. Zo zouden stafleden hun commissies overladen met onnodig werk en eindeloze hoorzittingen, die bovendien de betrokken ambtenaren van uitvoerende diensten veel extra werk bezorgen. Ook zou de staf ervoor zorgen dat commissieleden van elkaar vervreemden. ${ }^{125}$ Stafleden zouden vooral te veel invloed hebben bij onderhandelingen en besluitvormingsprocessen binnen de commissies, wat heeft geresulteerd in bijnamen als 'the new Senate barons' en 'governors on the Hill'. ${ }^{126}$ De laatste jaren bestaat met name veel bezorgdheid over de contacten die congresleden en hun stafmedewerkers onderhouden met lobbyisten. De regels omtrent hieromtrent zijn recentelijk dan ook aangescherpt. ${ }^{127}$

Wat de werkelijke invloed van stafmedewerkers op de wetgevings- en toezichtsagenda's van commissies is, is moeilijk vast te stellen. Stafmedewerkers zijn over het algemeen hooggekwalificeerde professionals, maar vaak ook relatief jong en onervaren. ${ }^{128}$ Ongetwijfeld zal de verhouding tussen staf en commissie mede worden bepaald door de managementkwaliteiten van de betrokken congresleden en de mate waarin zij hun staf kunnen en willen aansturen. Volgens sommigen wordt de invloed van stafmedewerkers overschat. Zo uitte Howard Baker, die na zijn termijn als 'majority leader' in de Senaat in dienst trad bij een Washingtons advocatenkantoor, zijn verbazing over de aandacht die lobbyisten aan stafleden besteedden:

"I was struck by the fact that [lobbyists] had list after list of people on the staff they'd gone to
see... I think part of it is an illusion... [W] hen I met with most committee chairmen every Tues-
day morning around the conference table in my office, I saw how it worked. They would really
go at it hammer and tongs on particular items within their jurisdiction. So I think the impact of

124 Guide to Congress 2008, p. 687.

125 Senator William Cohen zei hierover: "There is so much competition among staffs, fighting over issues, that sometimes you'll call a senator and ask, 'Why are you opposing me on this?' and he'll say, 'I didn't know I was.' And you'll say, 'Well, check with your staff and see.'” Guide to Congress 2008, p. 687.

${ }^{126}$ Deering \& Smith 1997, p. 163.

127 Directe aanleiding was het schandaal rondom lobbyist Jack Abramoff, die geprobeerd heeft congresleden en stafmedewerkers om te kopen. Tom DeLay, 'majority leader' in het Huis, kwam in opspraak en trad uiteindelijk af. Zie over de nieuwe lobbyregels verder Guide to Congress 2008, p. 700701.

${ }^{128}$ Een enquête uit 2004 wees uit dan meer dan 60 procent van de stafleden in het Huis minder dan drie jaar ervaring had, waaronder 39 procent van de 'chiefs of staff'. In de Senaat lag de gemiddelde aanstellingsduur op ruim vijf jaar. Guide to Congress 2008, p. 693. Wat hierbij wel moet worden bedacht, is dat congressionele stafmedewerkers relatief weinig baanzekerheid hebben. Ook kunnen zij na enkele jaren op 'the Hill' met de opgedane ervaring en contacten veel meer verdienen in de private lobbysector. Een en ander leidt ertoe dat de commissiestaf voortdurend in beweging is (het verschijnsel van de 'revolving door'). 
staff is overrated. But God knows, there's enough of them, they generate enough memos, and I know they attract lobbyists and lawyers like flies." 129

\subsubsection{Congressional Research Service}

De Congressional Research Service (CRS) wordt wel omschreven als de denktank, beleidsadviseur en informatiefabriek van het Congres. ${ }^{130}$ De organisatie biedt allerlei informatie- en onderzoeksdiensten aan congresleden, commissies en stafmedewerkers. CRS werd als 'Legislative Reference Bureau' binnen de Library of Congress opgericht in 1912 en hield zich aanvankelijk slechts bezig met het compileren en beschikbaar maken van wetsteksten. Met de congressionele hervormingen van 1946 en 1970 kreeg de organisatie meer taken op het gebied van beleidsonderzoek en evaluatie, in het bijzonder ten behoeve van het wetgevingsproces. De CRS dient in dit verband "continuous liaison" met de vaste commissies te onderhouden. ${ }^{131}$ De CRS verricht onder meer beleidsanalyses en biedt juridisch advies op wetgevings- en toezichtsgebied, verstrekt informatie en houdt briefings en workshops over beleidsmatige, wetgevingstechnische en andere onderwerpen. ${ }^{132}$ Meer in het bijzonder heeft CRS de wettelijke taak om commissies aan het begin van een congrestermijn een overzicht te verschaffen van beleidsprogramma's en overheidsactiviteiten die gedurende die termijn in aanmerking komen voor herautorisatie, alsmede "a list of subjects and policy areas which the committee might profitably analyze in depth". ${ }^{133}$ Onderzoek en advisering aan commissies en congresleden vindt, afhankelijk van het onderwerp en de wensen van de aanvrager, veelal plaats op basis van mondeling overleg met de aangewezen specialist of via (vertrouwelijke) memoranda. Meer omvattende analyses voor breder gebruik worden binnen het Congres beschikbaar gesteld in de vorm van 'Reports for Congress'. ${ }^{134}$

129 Guide to Congress 2008, p. 687.

130 Guide to Congress 2008, p. 882.

131 Zie voor de wettelijke taakopdracht van CRS: 2 U.S.C.A. § 166 (d). Zie verder Guide to Congress 2008 , p. 883.

132 Kaiser, Oleszek \& Tatelman 2011, p. 108-111. In het kader van haar taakopdracht kan CRS, op verzoek en onder verantwoordelijkheid van een congrescommissie, inzage verlangen in alle stukken waarover een federaal departement of agentschap beschikt. Zie 2 U.S.C.A. § 166 (d) (1) ("the Service shall have authority, when so authorized by a committee and acting as the agent of that committee, to request of any department or agency of the United States the production of such books, records, correspondence, memoranda, papers, and documents as the Service considers necessary, and such department or agency of the United States shall comply with such request"). De toegang tot overheidsinformatie lijkt voor CRS in de praktijk overigens weinig problematisch te zijn.

1332 U.S.C.A. $§ 166(\mathrm{~d})$.

134 Vaak anticiperen specialisten op vragen over actuele beleidskwesties vanuit het Congres en wordt 'alvast' een rapport geschreven of een eerder rapport bijgewerkt. Vanuit de gedachte dat CRS voor het Congres werkt en niet voor het brede publiek, worden rapporten in beginsel niet openbaar gemaakt. Wel staat het elk congreslid vrij om een CRS-rapport zelf openbaar te maken. Veel van deze rapporten, vaak van hoge kwaliteit, zijn daarom toch via internet beschikbaar. De website opencrs.com biedt een ruime verzameling. Verder was de publicatie van zo'n 6.800 CRS-rapporten in 2009 de eerste grote collectie documenten op het inmiddels roemruchte wikileaks.org. 
De CRS kent een vaste staf van ongeveer 700 medewerkers. ${ }^{135}$ De onderzoeksstaf is ondergebracht in vijf divisies en bestaat onder meer uit juristen, economen, bestuurskundigen, informatiespecialisten, sociale wetenschappers, defensiespecialisten, natuurkundigen en biologen. ${ }^{136}$ Commissies, hun leden en medewerkers maken veelvuldig gebruik van de diensten van CRS, dat als laagdrempelig wordt ervaren. ${ }^{137}$ Rapporten staan hoog in aanzien en worden algemeen beschouwd als objectief en politiek neutraal. ${ }^{138}$ De directeur van CRS wordt benoemd door de Librarian of Congress, na overleg met de Joint Committee on the Library. ${ }^{139}$ De directeur en de onderzoeksspecialisten worden uitsluitend geselecteerd op basis van hun expertise ('merit-based selection'). ${ }^{140} \mathrm{Om}$ haar neutraliteit ook in de praktijk te waarborgen, hanteert CRS het beleid dat opdrachten die te partijpolitiek van aard zijn en de neutrale positie van de organisatie of haar medewerkers kunnen schaden, worden geweigerd. ${ }^{141}$

\subsubsection{Government Accountability Office}

De Government Accountability Office (GAO) wordt wel gezien als "the watchdog of Congress"142 en vervult een belangrijke ondersteunende rol in het kader van de congressionele toezichtsfunctie. GAO werd opgericht in 1921 onder de naam 'General Accounting Office' en wordt in de wet omschreven als een "instrumentality of the United States Government independent of the executive departments." 143 De organisatie was aanvankelijk belast met het uitvoeren van reguliere audits van federale departementen en agentschappen. ${ }^{144}$ De belangrijkste taken zijn thans "[to] investigate all matters related to the receipt, disbursement and expenditure of public

\footnotetext{
135 In 2008 had de CRS een budget van ruim \$102 mln. Zie Library of Congress, Fiscal Year 2009 Congressional Budget Justification, < http://www.loc.gov/about/reports/budget/index.html>, p. 179.

136 Het betreft de divisies American Law; Government and Finance; Domestic Social Policy; Foreign Affairs, Defense, and Trade; en Resources, Science, and Industry. Zie verder Kaiser, Oleszek \& Tatelman 2011, p. 111-113.

137 Enthoven 2011, p. 516.

138 Opvallend is dat CRS-rapporten, in tegenstelling tot de rapporten van de hierna nog te bespreken GAO en CBO, altijd de naam van de auteur(s) vermelden.

139 Zie 2 U.S.C.A. § 166 (c) (1). De Librarian is het hoofd van de Library of Congress en wordt zelf, op grond van de wet, benoemd door de President na goedkeuring door de Senaat. Zie 2 U.S.C.A. § 136. Hoewel de wet niets bepaalt over de aanstellingsduur, lijken Librarians in de praktijk voor het leven benoemd te worden. De huidige Librarian werd aangesteld in 1987. Zie verder Beermann 2006, p. 129130 (nt. 326-327).

1402 U.S.C.A. $\$ 166$ (c) (3) ("without regard to political affiliation, and solely on the basis of fitness to perform the duties of the position"). Zie ook Guide to Congress 2008, p. 883.

141 Zie voor een overzicht van alle beperkingen: Kaiser, Oleszek \& Tatelman 2011, p. 114-116.

142 Guide to Congress 2008, p. 877. Zie over GAO ook: Beermann 2006, p. 127-130.

14331 U.S.C.A. § 702.

${ }^{144}$ De Budget and Accounting Act 1921 voorzag in een sterkere rol voor de President in de jaalijkse begrotingscyclus, onder meer door de oprichting van het Bureau of the Budget binnen de uitvoerende macht (het huidige Office of Management and Budget, inmiddels onderdeel van het Witte Huis). De oprichting van GAO als onderdeel van de wetgevende macht moest als tegenwicht dienen. Zie Kaiser 2008, p. 4 .
} 
funds" 145 en "to evaluate the results of a program or activity the Government carries out under existing law." 146 GAO stelt zich ten doel "to support the Congress in meeting its constitutional responsibilities and to help improve the performance and ensure the accountability of the federal government for the benefit of the American people." 147 Het accent is in de loop der jaren verschoven van accountantscontrole naar algemene beleidscontrole en -evaluatie van federale agentschappen en programma's; de naamsverandering in 2004 moest hieraan uiting geven. ${ }^{148}$ De aandacht gaat daarbij vooral uit naar de effectiviteit van federale beleidsprogramma's, de noodzaak van beleidsmatige of organisatorische aanpassingen, mogelijke alternatieve en goedkopere manieren om de gestelde beleidsdoelen te bereiken, gevallen van verspilling en inefficiëntie, de rechtmatigheid van overheidsoptreden en de juistheid van (financiële) rapportages aan het Congres. ${ }^{149}$ GAO heeft verder een kleine afdeling voor bijzondere onderzoeken, ${ }^{150}$ verstrekt adviezen aan andere controlerende instanties en leent medewerkers op tijdelijke basis uit aan congrescommissies. ${ }^{151} \mathrm{De}$ organisatie is met ruim 3.000 medewerkers en een budget van $\$ 540 \mathrm{mln}$ de grootste ondersteunende dienst van het Congres. ${ }^{152}$

Het hoofd van de organisatie, de Comptroller General (CG), wordt voor een niet-verlengbare periode van 15 jaar benoemd door de President, na goedkeuring van de Senaat. ${ }^{153}$ Bijzonder aan de benoemingswijze is dat sinds 1981 een tienkoppige commissie van congresleden, onder wie de Speaker in het Huis en de partijleiders in beide Kamers, een aantal kandidaten voor de functie voordraagt bij de President. Deze voordracht wordt, gelet op de constitutionele Appointments Clause, als nietbindend beschouwd en de President kan de commissie vragen om 'aanvullende' kandidaten voor te dragen. ${ }^{154}$ Ontslag van de CG is uitsluitend mogelijk via impeachment of, in bepaalde gevallen, op basis van een gezamenlijke congresresolutie. ${ }^{155}$ Met deze bijzonder procedures wordt benadrukt dat de CG zich in de loop der tijd

\footnotetext{
14531 U.S.C.A. $\S 712(1)$.

14631 U.S.C.A. § 717 (b). Deze wijziging was onderdeel van de Legislative Reorganization Act van 1970.
}

147 Aldus het 'mission statement'. Zie Government Accountability Office, About GAO, <www.gao.gov/about/index.html> (laatst geraadpleegd: 28 november 2012).

148 Zie ook Guide to Congress 2008, p. 878.

${ }^{149}$ Kaiser, Oleszek \& Tatelman 2011, p. 127.

${ }^{150}$ Het Office of Special Investigations (OSI) is "responsible for conducting congressional oversight investigations of alleged violations of federal criminal law and serious abuse and for integrating such work within GAO's audit and evaluation work." Zie <http://www.gao.gov/fraudnet/osi.htm> (laatst geraadpleegd: 6 augustus 2009). Zie ook GAO's Congressional Protocols 2004, p. 21-22. Zo deed OSI recent bijvoorbeeld (undercover) onderzoek naar de illegale verkoop van gevoelige militaire materialen via internet. Zie "Undercover Purchases on eBay and Craigslist Reveal a Market for Sensitive and Stolen U.S. Military Items" (GAO-08-644T).

151 Zie verder Kaiser, Oleszek \& Tatelman 2011, p. 129.

152 Zie Government Accountability Office, GAO's Fiscal Year 2010 Performance Plan (GAO-09-304SP) en Brudnick 2009, p. 14.

15331 U.S.C.A. § 703 (a).

${ }^{154}$ De twee vacatures die zijn ontstaan sinds de invoering van deze voordrachtprocedure in 1981 werden door de presidenten Reagan en Clinton opgevuld met een van de voorgedragen kandidaten. Zie ook Kaiser 2008, p. 18 en Guide to Congress 2008, p. 878-879.

15531 U.S.C.A. $\$ 703$ (e). Deze procedures zijn tot op heden nog niet toegepast. 
heeft ontwikkeld tot "an individual whose primary function is to provide assistance to Congress." 156 De lange aanstellingsduur zonder mogelijkheid van verlenging dient de onafhankelijkheid en integriteit van de CG te bevorderen. ${ }^{157}$

GAO verricht onderzoek en publiceert rapporten op grond van wettelijke verplichtingen, op verzoek van het Congres of op eigen initiatief. In de praktijk werkt de organisatie bijna uitsluitend op grond van de wet of in opdracht van congrescommissies. De hoeveelheid verzoeken is zo hoog, dat sinds enige jaren wordt gewerkt met protocollen ${ }^{158}$ omtrent de aanvraagprocedures, prioritering van aanvragen en het onderzoeksverloop. Om haar neutrale positie ten opzichte van het Congres te waarborgen, worden verzoeken van commissievoorzitters op dezelfde voet behandeld als verzoeken van de 'ranking minority members' binnen commissies. 159 De dienst hanteert strikte zorgvuldigheidseisen en methodologische standaarden. Onderzochte federale instellingen worden voor publicatie van het rapport in de gelegenheid gesteld te reageren op de bevindingen. De resultaten van een onderzoek of evaluatie worden altijd gepubliceerd - dus ook als het rapport de aanvrager onwelgevallig is. ${ }^{160}$ Medewerkers van GAO verschijnen verder veelvuldig als getuigedeskundigen voor congrescommissies. ${ }^{161}$

Met de koerswijziging van strikte accountantscontroles van federale agentschappen naar meer ambitieuze beleidsanalyses en -evaluaties op allerlei terreinen, nam ook de kritiek op de organisatie toe. Hoewel het werk van de organisatie in het algemeen hoog in aanzien staat, hebben de benoemingsprocedures van de CG en de zorgvuldigheidsnormen die GAO hanteert niet kunnen voorkomen dat in de jaren 90 met name aan Republikeinse zijde, onder aanvoering van Speaker Newt Gingrich, het gevoelen ontstond dat GAO in haar onderzoeksbeleid en -aanpak niet onpartijdig te werk ging. ${ }^{162}$ In het kader van de Republikeinse bezuinigingen bij de wetgevende macht van midden jaren 90 werd ook GAO budgettair scherp gekort. Sindsdien nemen de beschikbare middelen overigens weer toe. ${ }^{163}$

GAO beschikt over verregaande bevoegdheden ter uitoefening van haar taken. Op grond van de wet dienen alle federale agentschappen informatie omtrent de "duties, powers, activities, organization, and financial transactions of the agency" aan de

\footnotetext{
156 Zie Kaiser 2008, p. 19.

157 Kaiser 2008, p. 20.

158 Zie voor de meest recente editie: GAO's Congressional Protocols 2004 (GAO-04-310G).

159 Zie verder GAO's Congressional Protocols 2004, p. 8-9.

160 De aanvrager wordt daarom voortdurend op de hoogte gehouden van de voortgang van een onderzoek en tijdig geinformeerd over de uitkomsten. Indien gewenst kan de naam van de aanvrager uit het te publiceren rapport verwijderd worden. Zie GAO's Congressional Protocols 2004, p. 13-18.

161 In 2008 werden 304 getuigenverklaringen afgelegd. GAO's Fiscal Year 2010 Performance Plan (GAO09-304SP), p. 7. Zie ook GAO's Congressional Protocols 2004, p. 19.

162 Guide to Congress 2008, p. 879. De kritiek richtte zich met name op de wijze waarop GAO het beleid van de Republikeinse presidenten Reagan en Bush sr. benaderde. Zie ook Kaiser 2008, p. 23. Tijdens het presidentschap van Bush jr., die gedurende een groot deel van zijn ambtsperiode een Republikeins Congres naast zich had, bestond juist de indruk dat GAO minder kritisch was en weinig genegen leek het optreden van het Witte Huis te onderzoeken. Zie Enthoven 2011, p. 513.

163 In 1995 werd het budget met ongeveer 25\% verminderd. Het aantal medewerkers nam tussen 1992 en 1998 met 39\% af. Tussen 1998 en 2008 nam het budget weer met 30\% toe. De neerwaartse trend in het aantal medewerkers lijkt echter pas in 2009 te worden gekeerd. Kaiser 2008, p. 12-13.
} 
CG te verschaffen wanneer deze daarom verzoekt. De CG kan ook zelf de boeken inspecteren om de gewenste informatie te verkrijgen. 164 Wanneer een agentschap niet de gewenste informatie verstrekt, kan de CG hierover rapport uitbrengen aan onder meer de President en het Congres. Mocht dat niet baten, dan kan de CG in een civielrechtelijke procedure bij de federale rechtbank om inzage verzoeken. ${ }^{165} \mathrm{Er}$ zijn ook beperkingen op het inzagerecht van de CG, zo blijkt uit hetzelfde artikel. Zo heeft de CG geen toegang tot documenten die bij (bijzondere) wet expliciet zijn uitgezonderd. Ook stukken die volgens de President betrekking hebben op 'foreign intelligence' 166 kunnen worden achtergehouden. Dit geldt ook voor "inter-agency or intra-agency memorandums" waarvan de President bepaalt dat "disclosure reasonably could be expected to impair substantially the operations of the Government". ${ }^{167}$

In de praktijk blijkt GAO in bepaalde sectoren van het federale bestuursapparaat al jaren grote moeite te hebben om inzage te krijgen in de gewenste stukken. ${ }^{168}$ Met name de departementen van Defensie en Buitenlandse Zaken, verschillende inlichtingendiensten en de FBI blijken in verschillende gevallen onvoldoende medewerking te verlenen bij accountantscontroles en andere onderzoeken. Soms wordt na melding hiervan bij de toepasselijke congrescommissie(s) een (politieke) oplossing gevonden, in andere gevallen lukt dit niet. Bij de CIA voert GAO sinds 1962 in het geheel geen accountantscontroles meer uit, omdat dit agentschap weigert medewerking te verlenen. 169

De wettelijke mogelijkheid om inzage in overheidsdocumenten af te dwingen via de burgerlijke rechter werd voor de eerste keer toegepast in 2001. Op verzoek van de Democratische congresleden Dingel en Waxman, de 'ranking minority members' van twee Huiscommissies met energiebeleid in hun portefeuille, deed GAO een onderzoek naar de beleidsvorming binnen de National Energy Policy Development Group, een zogenaamde 'executive commission' onder leiding van vice-president Cheney. Nadat de CG verzocht om inzage in de relevante stukken, ontstond een hoog opgelopen conflict tussen GAO en het Witte Huis, waarbij Comptroller General David Walker en passant vooral van Republikeinse zijde werd verweten partijpolitiek te bedrijven. ${ }^{170}$ De burgerlijke rechter ontweek de principiële vragen die partijen op-

16431 U.S.C.A. § 716 (a) ("Each agency shall give the Comptroller General information the Comptroller General requires about the duties, powers, activities, organization, and financial transactions of the agency. The Comptroller General may inspect an agency record to get the information.") De CG kan zijn bevoegdheden delegeren aan functionarissen en medewerkers van de GAO. Zie 31 U.S.C.A. § 711 (b).

16531 U.S.C.A. § 716 (b). Verder kunnen documenten die in het bezit zijn van derden (personen die niet werkzaam zijn bij de federale overheid) middels subpoenas worden opgevraagd. 31 U.S.C.A. § 716 (c).

16631 U.S.C.A. $\$ 716$ (d) jo. $\$ 714$ (b). Zie ook Kaiser 2008, p. 4.

16731 U.S.C.A. $§ 716$ (d) jo. 5 U.S.C.A. § 552 (b) (5) en (7). Overigens wordt daaraan toegevoegd: “This section does not authorize information to be withheld from Congress." 31 U.S.C.A. § 716 (e)(3).

168 Fisher 2002, p. 374-377.

169 Fisher 2002, p. 375. De CIA beroept zich op haar instellingswet (Central Intelligence Agency Act 1949), waaruit zou blijken dat GAO niet bevoegd is controles en onderzoeken bij dit agentschap uit te voeren. Zie hierover Kaiser 2008, p. 10-11.

${ }^{170}$ In plaats van een verklaring af te geven dat de betreffende documenten onder een van de wettelijke uitzonderingen zouden vallen, stelde de vice-president onder meer dat het verzoek van GAO strijdig 
wierpen omtrent de constitutionele verhouding tussen GAO, als onderdeel van de wetgevende macht, enerzijds en de President, de vice-president en de staf in het Witte Huis anderzijds. De vordering van de CG werd op procedurele gronden afgewezen. ${ }^{171}$ Hoewel de CG de uitspraak van de rechtbank betreurde, werd om pragmatische redenen besloten niet in beroep te gaan. ${ }^{172}$

Ondanks de hoge kwaliteitsnormen die GAO hanteert en de sterke reputatie die haar rapporten over het algemeen genieten, blijft de dienst dus niet geheel gevrijwaard van kritiek vanuit partijpolitieke hoek. Bovendien blijkt zij tegen een onwillige (Vice) President, als het erop aankomt, in het partijpolitieke en juridische strijdgewoel geen vuist te kunnen maken. ${ }^{173}$ Het gehanteerde beleid, waarbij verzoeken van zowel meerderheden als minderheden in het Congres in beginsel worden gehonoreerd, maakt de dienst op dit punt natuurlijk kwetsbaar. In die zin biedt het beleid dat CRS voert, namelijk dat al te partijpolitiek getinte verzoeken worden afgewezen, meer bescherming.

\subsubsection{Congressional Budget Office}

De Congressional Budget Office werd opgericht in 1974, als onderdeel van een bredere herziening van de begrotingsbehandeling in het Congres. ${ }^{174}$ De meeste werkzaamheden van $\mathrm{CBO}$ vinden plaats in het voorjaar, als de begrotingscommissies in beide Kamers het congressionele begrotingsplan vaststellen met de inkomsten- en uitgavenniveau's en de globale verdeling van gelden over de verschillende beleidsterreinen. CBO publiceert in deze periode een invloedrijk rapport met de economische en budgettaire vooruitzichten voor de komende tien jaar. Dit rapport bevat vaak ook analyses van actuele economische vraagstukken. Ook het jaarlijkse begrotingsvoorstel van de President wordt doorgerekend en afgezet tegen de eigen cijfers. Verder berekent $\mathrm{CBO}$ periodiek verschillende economische en fiscale vooruitzichten, onder meer over werkloosheidcijfers en inflatie. ${ }^{175}$ In het kader van het reguliere wetgevingsproces verricht $\mathrm{CBO}$ onderzoek naar de economische en budgettaire 'kos-

was met de constitutionele machtenscheiding. Hij liet het aankomen op een rechterlijke uitspraak. Fisher 2002, p. 386-390. Zie over deze affaire ook: Fisher 2004, p. 183-198.

${ }^{171}$ Wegens de machtenscheidingsaspecten van deze zaak werden de criteria voor 'standing' in deze zaak zeer strict uitgelegd door de rechtbank. Zie Walker v. Cheney, 230 F.Supp.2d 51, 74 (2002). Zie verder over de politieke context van deze zaak en mogelijke gevolgen voor de juridische en feitelijke bewegingsruimte van GAO en van het Congres ten opzichte van de uitvoerende macht: Fisher 2002, p. 377-394 en Halstead 2004, p. 7 e.v.

172 Halstead 2004, p. 7-8.

173 De Cheney-kwestie heeft in het Huis overigens tot pogingen geleid om - vooralsnog zonder resultaat -de inzagebevoegdheden van GAO op verschillende punten te versterken. Een wetsvoorstel (H.R. 6338,110 e Congres) dat in 2008 in het Huis werd aangenomen, bleef liggen in de Senaat. Zie ook Kaiser 2008, p. 5-6. In juni 2009 werd opnieuw een voorstel ingediend in het Huis (H.R. 2646, 111e Congres), maar dat was eenzelfde lot beschoren.

174 De oprichting van CBO was onderdeel van de Congressional Budget and Impoundment Act 1974, die voorzag in een centralisering van het congressionele begrotingsproces via de nieuwe House en Senate Budget Committees. De instelling, taken en bevoegdheden van CBO zijn thans te vinden in 2 U.S.C.A. § 601 e.v.

175 Zie verder: Kaiser, Oleszek \& Tatelmann 2011, p. 118-119 en Guide to Congress 2008, p. 880. 
ten' van wetsvoorstellen. Op toezichtsgebied biedt CBO specifieke ondersteuning aan (voornamelijk) commissievoorzitters en 'ranking minority members'. Op verzoek worden lopende federale beleidsprogramma's geanalyseerd en worden de effecten ervan op de economie en de federale begroting in kaart gebracht. CBO-studies variëren in omvang en duur: sommige onderzoeken kunnen in korte tijd worden uitgevoerd, terwijl andere onderzoeken meer dan een jaar kunnen duren. ${ }^{176}$

De directeur van CBO wordt voor vier jaar benoemd door de House Speaker en de President Pro Tempore van de Senaat, op aanbeveling van de beide begrotingscommissies en "without regard to political affiliation and solely on the basis of his fitness to perform his duties." 177 De directeur heeft toegang tot alle noodzakelijke gegevens en faciliteiten van federale agentschappen. ${ }^{178} \mathrm{CBO}$ is sinds haar oprichting weinig gegroeid en beschikt thans over een budget van zo'n $\$ 35$ mln en ongeveer 230 arbeidsplaatsen. De meeste specialisten die bij CBO werkzaam zijn, hebben een economische of beleidskundige achtergrond. ${ }^{179}$

De organisatie werkt, zoals de andere ondersteunende diensten, op partijneutrale basis. Om die reden bevatten CBO-rapporten geen beleidsmatige aanbevelingen. Om de professionaliteit en geloofwaardigheid van haar rapporten te bevorderen, worden de gebruikte methoden en aannames uitvoerig onderbouwd en verklaard. ${ }^{180}$ Toch ontkomt ook CBO niet altijd aan verwijten van partijdigheid. Dit is wellicht onvermijdelijk gezien de politieke gevoeligheid van de onderzoeksthema's. De organisatie opereert tussen twee politieke groeperingen "that want budget figures to help make a point, not a decision." 181 Bij de oprichting van de organisatie in 1974 bestond overigens al onenigheid over de koers: in het Huis werd vooral gedacht aan een neutrale, sterk analytische onderzoeksinstelling, te vergelijken met de GAO, terwijl de Senaat een voorkeur had voor een instelling die ook beleidsalternatieven zou aandragen voor de plannen van het Witte Huis. ${ }^{182}$ De positie van directeur van CBO blijkt in de praktijk niet altijd gemakkelijk te worden opgevuld, omdat Huis en Senaat het niet eens kunnen worden over de kandidaat. Opvallend is tenslotte dat opeenvolgende $\mathrm{CBO}$-directeuren een specifiek partijpolitieke achtergrond hebben. ${ }^{183}$

\subsubsection{Juridische diensten}

De drie hiervoor besproken instellingen functioneren als zelfstandige organisaties binnen de wetgevende macht en werken voor het gehele Congres. Bij de uitoefening

\footnotetext{
176 Kaiser, Oleszek \& Tatelmann 2011, p. 119-120.

1772 U.S.C.A. $\S 601$ (a)(2).

1782 U.S.C.A. $\S 601$ (d). Toegang tot informatie lijkt bij CBO in de praktijk weinig problemen op te leveren.

179 Guide to Congress 2008, p. 881.

180 Kaiser, Oleszek \& Tatelmann 2011, p. 120.

181 Guide to Congress 2008, p. 881.

182 Guide to Congress 2008, p. 881.

183 Dan Crippen, CBO-directeur van 1999 tot 2003, was eerder chief counsel voor de Republikeinse Senaatsleider Howard Baker. Zijn opvolger, Douglas Holtz-Eakin, was eerder lid van de economische adviesraad van President George W. Bush. Peter Orszag, die de functie in 2007 en 2008 vervulde, was economisch adviseur van President Clinton. Zie Guide to Congress 2008, p. 882. Orszag werd daarna de directeur van het Office of Management and Budget in de regering-Obama.
} 
van hun toezichts- en onderzoekstaken kunnen commissies ook een beroep doen op de juridische dienst van de eigen Kamer: de Senate Legal Counsel en de House General Counsel. Beide diensten ontstonden eind jaren 70 tegen de achtergrond van het toenemende juridische conflicten met de uitvoerende macht, bijvoorbeeld over de constitutionaliteit van wetten en de toegang tot documenten. In beide Kamers ontstond de gedachte dat eigen juridische ondersteuning noodzakelijk was om de institutionele belangen van de kamers, hun commissies en hun leden te behartigen. ${ }^{184}$

De Office of Senate Legal Counsel werd bij wet opgericht in 1978. De Senate Legal Counsel staat aan het hoofd van de dienst en wordt aangesteld "without regard to political affiliation and solely on the basis of fitness to perform the duties of the position" door de President Pro Tempore, op advies van de meerderheids- en minderheidsleiders in de Senaat. ${ }^{185}$ In het Huis ontwikkelde de House Office of General Counsel, die oorspronkelijk slechts juridisch advies aan de griffie verschafte, zich vanaf jaren '70 in dezelfde richting. Sinds 1993 bedient de Counsel Office het gehele Huis van "legal assistance and representation ... without regard to political affiliation." 186

In het kader van de toezichts- en onderzoeksactiviteiten bieden de Counsel Offices grotendeels vergelijkbare diensten aan commissies. Ten eerste kunnen zij commissies in rechte vertegenwoordigen en adviseren bij juridische kwesties, bijvoorbeeld rondom het verlenen van strafrechtelijke immuniteit aan getuigen en bij procedures naar aanleiding van subpoenas. Daarnaast verstrekken hun juridische specialisten, zowel formeel als informeel, algemene adviezen aan commissies, zoals de betekenis en reikwijdte van onderzoeksbevoegdheden en de wijze waarop subpoenas moeten worden uitgevaardigd. ${ }^{187}$

\subsubsection{Slot}

Uit het voorgaande is gebleken dat congrescommissies bij hun toezichts- en onderzoeksactiviteiten gebruik kunnen maken van een waaier aan ondersteunende diensten. In de loop van de twintigste eeuw, met name vlak na de Tweede Wereldoorlog en in de jaren 70, is de diversiteit en de capaciteit van de beschikbare ondersteuning in algemene zin sterk gegroeid. De motor achter deze groei was steeds de gedachte dat het Congres haar wetgevende en toezichthoudende taken, tegen de achtergrond van de groter wordende rol van de President en de gestage groei van het uitvoerende bestuursapparaat, onvoldoende zou kunnen vervullen zonder adequate professionele ondersteuning.

De ondersteuning die commissies in beide Kamers ter beschikking hebben valt in twee soorten uiteen. Enerzijds hebben commissies hun eigen stafleden, anderzijds kunnen zij een beroep doen op verschillende ondersteunende diensten. Deze twee vormen van ondersteuning worden gezien als fundamenteel verschillend van karak-

\footnotetext{
184 Voorheen werd juridische ondersteuning geleverd door private kantoren of het ministerie van Justitie. Zie verder Tiefer 1998b, p. 48-49.

185 Zie 2 U.S.C.A. $§ 288$ (a)(2).

186 Zie House Rule II, lid 8 jo. 2 U.S.C.A. § 130f. Zie ook Kaiser, Oleszek \& Tatelmann 2011, p. 125.

187 Zie verder Kaiser, Oleszek \& Tatelmann 2011, p. 122-127.
} 
ter. Commissiestafleden bieden uitsluitend ondersteuning aan het commissiesmaldeel waarvoor zij werken; hun werkzaamheden en achtergrond zijn daarom veelal partijpolitiek gekleurd. De ondersteunende diensten daarentegen werken in beginsel voor beide politieke kanten en hechten sterk aan hun politieke neutraliteit. Dit komt onder meer tot uiting in de zelfstandigheid die de diensten bij de uitvoering van opdrachten betrachten en de professionele protocollen en wetenschappelijke methoden die worden gehanteerd. GAO, CRS en CBO hebben relatief veel invloed: congresleden blijken de analyses en beleidsopties afkomstig van deze 'nabijgelegen' organisaties eerder serieus te nemen dan die van andere informatiebronnen, zoals departementen, maatschappelijke organisaties of kennisinstellingen. ${ }^{188}$

Toch is ook duidelijk geworden dat een professionele en zelfstandige opstelling niet kan voorkomen dat congressionele ondersteunende diensten te maken krijgen met beschuldigingen van partijdigheid en vooringenomenheid. Dergelijke kritiek lijkt welhaast onvermijdelijk gezien de intens politieke omgeving waarin deze instellingen werkzaam zijn. Het veranderende gezicht van het Congres, waarin partijpolitiek de afgelopen decennia een steeds belangrijkere rol is gaan spelen, veelal ten koste van wat de 'institutionele' houding van congresleden kan worden genoemd, draagt hier aan bij. 189

De positie van de congressionele diensten, hoewel over het algemeen hoog in aanzien, is dan ook niet onomstreden in Washington - en zeker ook niet onaantastbaar. Toen de Republikeinen de controle over het Congres verwierven, werd direct besloten tot de opheffing van het Office of Technology Assessment (OTA). Dit in 1972 opgerichte onderzoeksbureau - naast GAO, CRS en CBO de vierde ondersteunende dienst - hield zich bezig met (vaak langlopende) studies op het gebied van wetenschappelijke en technologische ontwikkelingen, bedoeld om de doorgaans weinig technologisch onderlegde Congresleden te helpen bij het beoordelen van de voor- en nadelen van die ontwikkelingen. Volgens critici verrichtte OTA echter overbodig en traag werk, dat aan andere overheids- of private instellingen kon worden overgelaten. De opheffing, onderdeel van de bredere Republikeinse bezuinigingsoperatie binnen de wetgevende macht, was zeer omstreden. 190

\footnotetext{
188 Zie Enthoven 2011, p. 526.

189 Zie ook Tiefer 1998 b, p. 56 e.v.

190 Guide to Congress 2008, p. 882. De afgelopen jaren gaan er stemmen op om de OTA weer nieuw leven in te blazen. Zie o.a. 'Clinton Says She Would Shield Science From Politics', New York Times, 5 oktober 2007.
} 
VERENIGDE STATEN 


\section{Hoofdstuk 4. Onderzoeksproces}

\subsection{Inleiding}

De onderzoeksactiviteiten van congrescommissies, zo is in het voorgaande al wel duidelijk geworden, verlopen zelden volgens een vast stramien. In wat het klassieke (of ideale) onderzoeksproces kan worden genoemd, wordt een onderzoek uitgevoerd op grond van een vooraf bepaalde onderzoeksvraag, waarna schriftelijk en mondeling bewijsmateriaal wordt verzameld, op basis waarvan een onderzoeksrapport met daarin bevindingen, conclusies en aanbevelingen wordt opgesteld en aangeboden aan de kamer. In het geval van bijzondere onderzoekscommissies, ingesteld ten behoeve van een specifiek gedefinieerd onderzoek, is dit de meest voor de hand liggende procedure.

Bij de vaste commissies, die zich vanaf 1946 hebben ontwikkeld tot de voornaamste onderzoeksinstituten binnen het Congres, hebben onderzoeksactiviteiten echter een veel grilliger patroon. Aangezien de vaste commissies een vaste (onderzoeks)staf hebben, beschikken zij over een permanente, flexibele onderzoeksvoorziening. Veel onderzoeken hebben daarom een vloeiend karakter. Vaak is een onderzoek van vaste commissies gericht op of onderdeel van achterliggende wetgevings-, toezichts- of begrotingsprocessen; een concreet eindresultaat in de vorm van een onderzoeksrapport is dan niet altijd nodig of gewenst. ${ }^{1}$ Soms is een onderzoek bijvoorbeeld een min of meer slapend agendapunt, dat bij tijd en wijle opleeft door actuele ontwikkelingen zoals een krantenbericht, een klokkeluider die zich spontaan meldt, of een aankomende periodieke herautorisatie van een beleidsprogramma. Dit kan aanleiding geven tot het houden van een hoorzitting, het uitbrengen van een kort (vervolg)rapport, een brief van de voorzitter aan de leidinggevende van een agentschap, of soms niet meer dan een persbericht op de commissiewebsite.

Hieronder worden verschillende aspecten van het onderzoeksproces nader belicht. Met name ten aanzien van de vaste commissies moet echter steeds worden bedacht dat van een geordend 'proces' niet altijd sprake is.

\subsection{Aanvang van een onderzoek}

Bij bijzondere commissies wordt de onderzoeksopdracht, commissiesamenstelling en het tijdskader door de instellingsresolutie bepaald. Bij de vaste commissies kan het initiatief voor een onderzoek van verschillende kanten komen. In veel gevallen begint een onderzoek bij de commissievoorzitter, die al dan niet in overleg met andere commissieleden besluit dat een onderzoek gewenst is. Aangezien de commissievoor-

1 Zie ook Enthoven 2011, p. 499-500. 
zitter de meerderheidsstaf van de commissie aanstuurt, kan deze zelfstandig opdracht geven tot initiële onderzoeksactiviteiten als het verzamelen en analyseren van schriftelijk materiaal en het houden van (informele) interviews met betrokkenen. Een formeel commissiebesluit is, wanneer gebruik gemaakt wordt van openbare of via informele weg toegankelijke bronnen, niet nodig. Het onderzoek wordt in dat geval veelal direct in opdracht van de voorzitter uitgevoerd. Het onderzoeksrapport wordt door de staf aan de voorzitter aangeboden en gepubliceerd op de commissiewebsite, die door de voorzitter wordt beheerd, of met (stilzwijgende) toestemming van de commissie als bijlage aan het verslag van een hoorzitting toegevoegd. ${ }^{2}$ In andere gevallen wordt wel expliciete steun van de commissie gezocht voor het starten van een onderzoek. Hiermee kan het onderzoek meer politiek gewicht krijgen, vooral wanneer beide partijen achter het onderzoek staan. Soms bepaalt het commissiereglement dat een formeel commissiebesluit inzake het starten van een onderzoek vereist is. ${ }^{3}$ Deze weg is bovendien noodzakelijk wanneer formele onderzoeksbevoegdheden moeten worden ingezet, bijvoorbeeld om bewijsstukken te kunnen vorderen, tenzij die bevoegdheden zijn gedelegeerd aan de voorzitter. ${ }^{4}$ Soms wordt een (tijdelijke) subcommissie ingesteld ten behoeve van een specifiek onderzoek. Het onderzoeksproces lijkt in dat geval meer op dat van een bijzondere commissie.

In de praktijk in het niet ongebruikelijk dat het initiatief voor een onderzoek feitelijk van stafmedewerkers zelf komt. Door hun dagelijkse werkzaamheden en frequente contacten met 'het veld' 5 hebben zij vaak een goed beeld van mogelijke onderzoekslijnen. De vertrouwensband tussen de staf(leiding) en de commissievoorzitter en de belangrijkste overige leden zorgt ervoor dat soms zelfs zonder expliciete opdracht met een onderzoek wordt begonnen. Overigens kan de minderheidsleider ('ranking member') binnen de commissie, die de leiding heeft over de minderheids-

\footnotetext{
2 Een voorbeeld is een analyse die de meerderheidsstaf in opdracht van subcommissievoorzitter McCaskill uitvoerde naar de werking van een federaal beleidsprogramma ter bevordering van indiaans ondernemerschap in Alaska. Het rapport van de staf diende ter voorbereiding op een hoorzitting van de subcommissie, waar de verantwoordelijke federale dienst (U.S. Small Business Administration) en vertegenwoordigers van indiaanse organisaties werden gehoord. In haar openingsverklaring stelde de subcommissievoorzitter voor dat het rapport, "without objection", aan het verslag van de hoorzitting zou worden toegevoegd. Zie Senate Homeland Security and Governmental Affairs Committee, Subcommittee on Contracting Oversight, 'New Information About Contracting Preferences for Alaska Native Corporations', S. Hrg. 111-250 (2009), p. 1 en 138-160. Overigens worden ook andere stukken, zoals brieven en externe rapporten, gewoonlijk aan het officiële verslag worden toegevoegd indien commissieleden dat wensen. Zie bijvoorbeeld S. Hrg. 111-250 (2009), p. 131-135 en 160-180.

${ }^{3}$ Zie bijvoorbeeld de Senate Energy and Natural Resources Committee, Rule 10, S. Prt. 111-11 (2009), waar is bepaald: "Neither the Committee nor any of its Subcommittees may undertake an investigation or preliminary inquiry unless specifically authorized by a majority of all the Members of the Committee." Dit staat dan weer niet in de weg aan "an initial review of any allegation of wrongdoing intended to determine whether there is substantial credible evidence that would warrant a preliminary inquiry or an investigation."

${ }^{4}$ Zoals het geval is bij de Permanent Subcommittee on Investigations van de Senate Homeland Security and Governmental Affairs Committee. Zie S. Prt. 111-13 (2009).

${ }^{5}$ Uit onderzoek blijkt dat stafleden veelvuldig informeel contact hebben met diverse ambtenaren in de departementen en agentschappen die tot het werkterrein van de commissie behoren. Zie hierover: Aberbach 1990, p. 79 e.v.
} 
staf, opdracht geven tot een eigen onderzoek. Door de kleinere staf en de beperkte onderzoeksbevoegdheden die de minderheid kan inzetten, komen minderheidsonderzoeken weinig voor. ${ }^{6}$

Het onderzoeksproces in deze beginfase kent een hoge mate van flexibiliteit en speelt zich grotendeels af achter de schermen van de commissieburelen af. Veel onderzoeken hebben daarom geen formeel begin- en eindpunt. Een onderzoek naar aanleiding van geruchten in de pers kan bijvoorbeeld gemakkelijk weer worden afgelast, bijvoorbeeld wanneer de aantijgingen na enig onderzoek ongegrond of anderszins niet (politiek) relevant blijken te zijn. Mochten tegelijkertijd wel andere onderzoekswaardige kwesties naar boven zijn gekomen, dan kan de focus van het onderzoek worden bijgesteld. Een onderzoek kan om verschillende redenen, bijvoorbeeld wegens veranderde prioriteiten, ook tijdelijk worden stopgezet om op een later moment weer te worden voortgezet.

\subsection{Uitvoering}

Wanneer eenmaal vaststaat dat een bepaald onderwerp zal worden onderzocht, kan de commissie twee kanten op. Besloten kan worden dat de eigen commissiestaf het onderzoek verder zal uitvoeren, bijvoorbeeld door het verzamelen en bestuderen van de schriftelijke stukken, het afleggen van werkbezoeken, het houden van interviews met betrokkenen en het schrijven van een rapport. Met deze aanpak behoudt de commissie de volledige controle over de koers van het onderzoek. Nadeel is echter dat een onderzoek, afhankelijk van het onderwerp en de hoeveelheid materiaal dat moet worden verwerkt, veel stafcapaciteit kan vragen - capaciteit die nodig kan zijn voor wetgevende werkzaamheden of andere onderzoeken.

Het alternatief is om het onderzoek geheel of gedeeltelijk uit te besteden. Zo kan de Government Accountability Office of de Congressional Research Service worden ingeschakeld om een (deel)studie te verrichten. Wel verliest de commissie daarmee een bepaalde mate van zeggenschap over de formulering van de onderzoeksvraag (die zal moeten voldoen aan de neutraliteits- en kwaliteitseisen van de betreffende onderzoeksdienst), het onderzoeksproces en dus ook de uitkomst ervan. Dit is eveneens het geval bij het inhuren van externe onderzoeksinstellingen of adviesbureaus; daarvan wordt, mede om financiële redenen, weinig gebruik gemaakt.

\subsubsection{Informatievergaring}

Commissiemedewerkers hanteren verschillende methoden om onderzoeksmateriaal te verzamelen. In eerste instantie bestaat een onderzoek in belangrijke mate uit het verzamelen en analyseren van schriftelijke stukken. Dit kan betrekking hebben op

\footnotetext{
${ }^{6}$ Een voorbeeld is het rapport uit 2002 van de Democratische minderheidsstaf bij de House Oversight and Government Reform over wachtlijsten bij een veteranenziekenhuis in Oklahoma. Deze minderheidsstaf had een eigen 'Special Investigations Division'. Het rapport is alleen op online gepubliceerd. Zie < http://oversight.house.gov/documents/20040607131923-83374.pdf>. Een meer gebruikelijke werkwijze is dat de minderheid in een kort rapport haar eigen conclusies en aanbevelingen formuleert naar aanleiding van een onderzoeksrapport van de meerderheidsstaf of dat van een ondersteunende dienst.
} 
reeds gepubliceerde stukken, zoals rapportages en jaarverslagen van federale overheidsinstellingen. Het kan ook gaan om ongepubliceerde, niet-openbare stukken. Soms kunnen deze op informele en vrijwillige basis worden verkregen bij overheidsinstellingen, bedrijven of individuen. Het is echter gebruikelijk om schriftelijke stukken middels een brief van de commissievoorzitter op te vragen. ${ }^{7} \mathrm{Bij}$ weigerachtigheid kan, indien de commissie daartoe besluit, daarna worden overgegaan tot het uitvaardigen van een subpoena duces tecum, waarmee schriftelijke stukken kunnen worden gevorderd. ${ }^{8}$ Vaak is de (impliciete) dreiging met het inzetten van deze subpoena-bevoegdheid voldoende om weigerachtige overheidsinstellingen, bedrijven of individuen te bewegen om de commissie(staf) tegemoet te komen.

Naast het opvragen en analyseren van schriftelijk materiaal voeren stafleden doorgaans gesprekken met verschillende contactspersonen binnen en buiten de federale overheid, zoals ambtenaren, vertegenwoordigers van maatschappelijke organisaties en belangengroepen (lobbyisten), en experts uit de wetenschap. Soms worden ook individuele burgers benaderd om een beter beeld te krijgen van de dienstverlening van een overheidsorganisatie. Deze informele gesprekken kunnen allerlei vormen aannemen: van een kort telefoongesprek met een deskundige tot een meer diepgravend interview met een getuige of een klokkenluider, waarbij meerdere stafleden betrokken zijn.

Wanneer de commissieregels daarin voorzien, kunnen stafleden naast informele interviews ook formele getuigenverhoren houden. In dat geval wordt de commissievoorzitter de bevoegdheid toegekend om getuigen uit te nodigen of middels subpoena op te roepen voor een stafverhoor. ${ }^{9}$ Deze 'staff depositions' worden onder ede en achter gesloten deuren afgenomen. Van het verhoor wordt een verslag gemaakt. Deze mogelijkheid is met name geschikt voor het verhoren van grote aantallen getuigen en wordt daarom gezien als een praktisch alternatief voor commissiehoorzittingen: de aanwezigheid van commissieleden is niet noodzakelijk, sommige getuigen zullen in beslotenheid openlijker spreken en de staf kan aan de hand van deze verhoren beter bepalen welke getuigen geschikt zijn voor een latere openbare hoorzitting. 10

\subsubsection{Beperkingen: samenloop van onderzoeken}

Voor het verzamelen van inlichtingen beschikken congrescommissies over verregaande informatierechten, zo is hiervoor reeds uitvoerig aan de orde geweest. Ook is

\footnotetext{
${ }^{7}$ Dergelijke 'request letters' worden vaak begeleid door een persbericht op de commissiewebsite gepubliceerd. Zie bijvoorbeeld de brief van de voorzitter van de House Oversight and Government Reform Committee aan Kenneth Lewis, voorzitter van de raad van bestuur van Bank of America, om (electronische) kopieën toe te sturen van alle stukken gerelateerd aan de overname van de noodlijdende bank Merrill Lynch op < http:/ / oversight.house.gov/documents/20090806165928.pdf>.

${ }^{8}$ Zie over de subpoena-bevoegdheid hierboven, par. 2.3.1.

${ }^{9}$ Zie bijv. de Permanent Subcommittee on Investigations van de Senate Homeland Security and Governmental Affairs Committee, Subcommittee Rule 9, S. Prt. 111-13 (2009) de House Oversight and Government Reform Committee, Committee Rule 15 (2011).

${ }^{10}$ Zie over de (juridische) achtergrond van de figuur van de staff deposition verder hierboven, par. 2.3.1.
} 
al duidelijk geworden, dat commissies bij het vorderen van inlichtingen van de uitvoerende macht kunnen worden gehinderd, wanneer de President - al dan niet op verzoek van een departement of ander uitvoerend orgaan - een beroep doet op het zogenaamde 'executive privilege'. De voornaamste redenen hiervoor zijn het beschermen van de nationale veiligheid of de vertrouwelijkheid van politiek-ambtelijk overleg. Dit kan gemakkelijk leiden tot een informatieconflict, waarbij de staatsmachten vaak conflicterende constitutionele standpunten betrekken. Aangezien de derde staatsmacht, de rechter, zich vooralsnog weigert uit te spreken in dergelijke conflicten, zijn commissies genoodzaakt om in onderhandeling te treden met de uitvoerende macht. ${ }^{11}$

Complicaties kunnen zich eveneens voordoen wanneer congrescommissies onderzoek doen naar zaken die tevens voorwerp zijn van strafrechtelijk onderzoek. Dit is in de praktijk niet ongebruikelijk. ${ }^{12}$ Dat het Congres bevoegd is onderzoek te doen in dergelijke situaties, staat al lang niet meer ter discussie. In vaste jurisprudentie van het Supreme Court naar aanleiding van de affaire rondom de Teapot Dome in de jaren 20 van de twintigste eeuw, werd dit reeds bevestigd. Sinclair, een van de verdachten in het grootschalige fraudeschandaal rondom federale oliemijnvergunningen, weigerde te getuigen voor een senaatscommissie, omdat hij inmiddels verdachte was in een strafzaak die betrekking had op dezelfde feiten. Het Hof stelde dat het Congres weliswaar niet bevoegd was "to compel disclosures for the purpose of aiding the prosecution of pending suits", maar dat haar constitutionele onderzoeksrecht op zichzelf niet beperkt wordt omdat "the information sought to be elicited may also be of use in such suits." 13 Zolang een congressioneel onderzoek voldoet aan de reguliere voorwaarden, zoals de eis van een legislatief doel14, zijn er dus geen constitutionele bezwaren tegen samenlopende onderzoeken. ${ }^{15}$ Duidelijk is echter ook, dat congressioneel onderzoek ertoe kan leiden dat de strafrechtelijke bewijsvoering wordt bemoeilijkt. In de rechtspraak worden stricte bewijsrechtelijke normen gehanteerd als verdachten tevens als getuige voor het Congres zijn verschenen, waarbij het risico van rechterlijke bevooroordeeldheid zwaar weegt. Strafzaken blijken daardoor gemakkelijk te kunnen stuklopen, vooral wanneer getuigen wettelijke immuniteit wordt verleend. Het is uiteindelijk aan de commissie om te bepalen of zij haar onderzoek al dan niet wil doorzetten, dan wel om te besluiten maatregelen te nemen om onnodige schade aan het strafrechtelijk onderzoek te voorkomen, bijvoorbeeld in de sfeer van vertrouwelijke behandeling of besloten verhoren. ${ }^{16}$ De samenloopproblematiek levert dus niet zozeer constitutionele vragen op als wel vragen rondom de opportuniteit van congressioneel onderzoek.

Ingewikkelder wordt het, wanneer een congrescommissie niet alleen onderzoek doet naar zaken die tevens voorwerp van strafrechtelijk onderzoek zijn, maar daarbij tevens inzage vordert in lopende strafdossiers. Al decennia lang stelt het openbaar

\footnotetext{
11 Zie uitvoerig hierboven, par. 2.6.

12 Kaiser, Oleszek \& Tatelman 2011, p. 60.

13 Sinclair v. United States, 279 U.S. 263, 295 (1929).

14 Zie over deze en andere voorwaarden hierboven, hoofdstuk 2.

${ }^{15}$ Zie ook Boon 1982, p. 33 en Grabow 1988, p. 117.

${ }^{16}$ Kaiser, Oleszek \& Tatelman 2011, p. 61. Zie ook Rosenberg 1995, p. 26-27. Zie nader hierboven, par. 2.3.3.
} 
ministerie zich namelijk op het standpunt dat informatie uit lopende strafdossiers niet aan het Congres behoeft te worden verstrekt. De constitutionele machtenscheiding ligt in belangrijke mate aan dat standpunt ten grondslag. Zo wordt er in verschillende notities en memoranda van de Attorney General op gewezen dat het verstrekken van inlichtingen uit lopende strafdossiers opsporingsstrategieën kan hinderen en de identiteit van informanten blootleggen. Belangrijkste bezwaar in dit verband is echter, dat het overleggen van lopende strafdossiers het vervolgingsbeleid van openbaar aanklagers, die op dat punt een volledig discretionaire bevoegdheid hebben, negatief kan beïnvloeden ('chilling effect'). Daarmee zou de constitutionele zelfstandigheid van het openbaar ministerie, als onderdeel van de uitvoerende macht, worden bedreigd. Verder wordt gewezen op de bescherming van de rechten van derden, die al dan niet terecht worden genoemd in een lopend opsporingsonderzoek, en de mogelijke aantasting van de onbevangenheid van de rechter. ${ }^{17}$

Binnen het Congres wordt hierover anders gedacht. In verschillende rapporten die de Congressional Research Service aan dit onderwerp heeft gewijd, wordt de vermeende bijzondere status van lopende strafdossiers krachtig bestreden. Zo zou het idee dat vervolging van strafbare feiten een exclusieve bevoegdheid van de uitvoerende macht is, geen steun vinden in de rechtspraak. ${ }^{18}$ Het beroep op de machtenscheiding wordt daarmee in feite verworpen. Voor het overige geldt, aldus de CRS, dat de vaste jurisprudentie van het Supreme Court omtrent het congressionele onderzoeksrecht met zich meebrengt dat alle federale departementen en agencies verplicht zijn om congrescommissies de gewenste inlichtingen te verschaffen ten aanzien van de uitvoering van federale wetgeving. Dat geldt evenzeer voor de "law enforcement activities of the Department of Justice."19 Dit principiële standpunt, zo wordt nog wel erkend, betekent niet dat congrescommissies al te lichtvaardig zouden moeten omspringen met het zwaarwegende belang van effectieve opsporing en vervolging van strafbare feiten. De praktijk laat volgens CRS echter zien, dat commissies hier doorgaans zorgvuldig mee omgaan. ${ }^{20}$

Hoewel praktische oplossingen en vormen van afstemming in de praktijk dus mogelijk blijken, blijft het steeds de vraag hoe de diametraal tegengestelde opvattingen over het congressionele recht om inzage te krijgen in lopende strafdossiers in concreto moeten worden verenigd. Gezien de fundamentele verschillen van inzicht tussen de uitvoerende en de wetgevende macht, is het nauwelijks verbazend dat vaste afspraken of protocollen hieromtrent ontbreken. Afspraken worden op ad hoc basis gemaakt en kunnen bijvoorbeeld betrekking hebben op vertrouwelijke behandeling van stukken, de wijze van inzage, afstemming over de vraagstelling aan getuigen en eventuele verdere medewerking of zelfs verhoren van officieren van justitie. ${ }^{21}$ Ook blijken commissies soms bereid een onderzoek op te schorten totdat een strafrechte-

\footnotetext{
17 Aan de basis hiervan lag een notitie van Attorney General Robert Jackson, 40 Op. Atty. Gen. 45 (1941). Zie ook Kaiser, Oleszek \& Tatelman 2011, p. 60 en uitvoerig: Peterson 2002, p. 1379-1385.

18 Rosenberg 2007, p. 22 e.v. Zie ook Rosenberg 1995, p. 23-29. Voor een bespreking van de verschillende CRS-rapporten: Peterson 2002, p. 1385-1388.

${ }_{19}$ Rosenberg 2007, p. 33.

${ }^{20}$ Rosenberg 2007, p. 34.

${ }^{21}$ Zie voor voorbeelden: Grabow 1988, p. 181-182 en Peterson 2002, p. 1391 e.v.
} 
lijke procedure is afgerond.22 Wanneer partijen echter niet tot overeenstemming kunnen komen, dan ligt een moeilijk oplosbaar conflict op de loer. Pogingen om een rechterlijk oordeel te verkrijgen zijn tot op heden gestrand. In de eerder besproken zaak rondom EPA-bestuurder Anne Gorsuch, deed President Reagan een beroep op 'executive privilege' teneinde het verstrekken van informatie uit lopende strafdossiers aan het Congres te verhinderen. De rechter weigerde een principiële uitspraak te doen en beschouwde de zaak als een constitutioneel conflict tussen de wetgevende en uitvoerende macht, dat via onderhandelingen diende te worden opgelost. ${ }^{23} \mathrm{De}$ rechter wijst het presidentiële standpunt dat het beschermen van lopende strafdossiers onder de paraplu van het executive privilege valt, dus niet uitdrukkelijk af, maar hoe de verschillende belangen in concreto dan moeten worden afgewogen, is niet duidelijk geworden. Veel houvast voor toekomstige conflicten verschaft de uitspraak daarom niet.

\subsubsection{Openbare verhoren}

Het houden van openbare hoorzittingen is een belangrijk onderdeel van congressionele onderzoeken. Hoorzittingen dienen in beide Kamers tenminste een week van tevoren te worden aangekondigd, al kan hiervan worden afgeweken indien de meerderheid meent dat hiervoor goede redenen zijn. ${ }^{24}$ Voor het kunnen afnemen van getuigenverklaringen tijdens een hoorzitting is de aanwezigheid van slechts een klein aantal commissieleden voldoende. In het Huis geldt een algemeen quorum van twee leden, terwijl in de Senaat bij de meeste commissies een hoorzitting reeds doorgang kan vinden bij aanwezigheid van één commissielid. ${ }^{25}$ In beide Kamers dienen de vaste commissies in hun commissiereglement nadere procedureregels op te nemen ten aanzien van hoorzittingen. ${ }^{26}$ De wijze waarop hoorzittingen verlopen, verschilt daarom per commissie. ${ }^{27}$ De meeste hoorzittingen vinden plaats in Washington, maar de vaste commissies kunnen indien gewenst ook naar andere locaties in het land uitwijken ('field hearings'). Ook tijdens recesperiodes kunnen commissiezittingen plaatsvinden. ${ }^{28}$

\footnotetext{
22 Zie Fisher 2007, p. 181.

${ }^{23}$ En zo geschiedde. Zie over deze zaak ook hierboven, par. 2.6.3.2.

${ }^{24}$ Zie House Rule XI, lid 2, sub g (3) en Senate Rule XXVI, lid 4, sub (a). Bij veel commissies is voorts in het commissiereglement vastgelegd dat documenten of rapporten die de aanleiding vormen voor de hoorzitting of anderszins daarbij van belang zijn, tijdig aan de commissieleden worden verstrekt. Dit is uiteraard vooral van belang voor de minderheidsleden, die niet noodzakelijkerwijs betrokken zijn geweest bij de voorbereiding van de hoorzitting.

${ }^{25}$ In het commissiereglement kunnen aanvullende regels worden gesteld. Zo geldt bij sommige commissies een hoger quorum wanneer getuigen onder ede worden verhoord, of vervolging van getuigen wegens meineed mogelijk moet zijn. Zie verder .

${ }^{26}$ Zie House Rule XI, lid 2 en Senate Rule XXVI, lid 2.

${ }^{27}$ Het is dan ook gebruikelijk dat getuigen voorafgaand aan een hoorzitting een exemplaar van het toepasselijke commissiereglement wordt toegestuurd. .

${ }^{28}$ Zie House Rule XI, lid 2, sub m (1)(A) (“...a committee or subcommittee is authorized ... to sit and act at such times and places within the United States, whether the House is in session, has recessed, or has adjourned, and to hold such hearings as it considers necessary..."). Zie in vergelijkbare zin ook Senate Rule XXVI, lid 1.
} 
Hoorzittingen beginnen met een openingsverklaring van de voorzitter, waarin het onderwerp van de hoorzitting wordt aangeduid. Deze openingsverklaring kan een belangrijke sturende functie vervullen. De voorzitter kan hiermee het onderwerp en doel van het onderzoek en van de hoorzitting nader definiëren en afbakenen. Dit kan in juridische zin van belang zijn, aangezien deze openingsverklaring een rol kan spelen bij het bepalen van de 'pertinency' (toepasselijkheid) van de vragen die daarop aan getuigen gesteld worden. ${ }^{29} \mathrm{Na}$ de voorzitter worden de minderheidsleider en de andere aanwezige leden in de gelegenheid gesteld een openingsverklaring af te leggen. Commissieleden gebruiken deze ronde veelal om opvattingen, ervaringen en verwachtingen kenbaar te maken, maar ook om onderlinge politieke tegenstellingen te articuleren. De openingsverklaringen kunnen daarom een belangrijke indicatie zijn voor de toon van de verhoren.

Het houden van hoorzittingen en het selecteren van getuigen is een commissiebevoegdheid ${ }^{30}$ en is daarmee in handen van de meerderheidspartij. Niettemin zijn de minderheidsleden in beide Kamers bij hoorzittingen gerechtigd om een aantal getuigen te selecteren. ${ }^{31}$ Van getuigen wordt verwacht dat zij voorafgaand aan de hoorzitting een schriftelijke weergave van hun voorgenomen getuigenverklaring aan de commissie verstrekken. Hoewel getuigen in beginsel niet het recht hebben om een openingsverklaring af te leggen, wordt die mogelijkheid doorgaans wel geboden. ${ }^{32}$

De verhoren worden vervolgens op in de kamerregels en in het commissiereglement bepaalde wijze en duur afgenomen. In het Huis geldt in beginsel een vijfminutenregel: beurtelings krijgt ieder commissielid de gelegenheid om (tenminste) gedurende vijf minuten vragen te stellen aan de aanwezige getuigen. Hiervan kan door commissies worden afgeweken, mits de meerderheids- en minderheidsleden op gelijke voet behandeld worden. ${ }^{33}$ Gebruikelijk is dat de voorzitter en de minderheidsleider beginnen, waarna wordt afgewisseld tussen de overige meerderheids- en minderheidsleden. Daarna volgen aanvullende vragenrondes, totdat alle vragen gesteld zijn. ${ }^{34}$ Vaak kiezen commissies er om redenen van efficiency voor om getuigen gegroepeerd in 'panels' te horen. ${ }^{35}$

\footnotetext{
${ }^{29}$ Zie ook Grabow 1988, p. 161. Zie over het vereiste van 'pertinency' verder hierboven, par. 3.4.3.

${ }^{30}$ Zie House Rule XI, lid 2, sub m en Senate Rule XXVI, lid 1.

${ }^{31}$ Zie House Rule XI, lid 2, sub (j)(1) en Senate Rule XXVI, lid 4, sub d (“...the minority members of the committee shall be entitled, upon request to the chair by a majority of them before the completion of the hearing, to call witnesses selected by the minority to testify with respect to that measure or matter during at least one day of hearing thereon.")

32 Kaiser, Oleszek \& Tatelman 2011, p. 31. Getuigen dienen zich tijdens hun openingspresentatie zoveel mogelijk te beperken tot een korte samenvatting van hun vooraf ingediende schriftelijke verklaring. In het Huis geldt voor getuigen van buiten de federale overheid dat zij ontvangen federale subsidies of contracten dienen te vermelden in hun schriftelijke verklaring. Zie House Rule XI, lid 2, sub (g)(4) en Senate Rule XXVI, lid 4, sub b.

${ }^{33}$ House Rule XI, lid 2, sub (j)(2).

${ }^{34}$ Grabow 1988, p. 162-163. Hoewel doorgaans om-en-om gewerkt wordt, is het ook mogelijk dat de voorzitter met het oog op de partijpolitieke verhoudingen in de commissie na twee meerderheidsleden één minderheidslid aan het woord laat. Zie bijvoorbeeld House Transportation and Infrastructure Committee, Rule VI, lid e (111 e Congres).

${ }^{35}$ Het gebruik van panels kan, afhankelijk van wijze waarop de andere getuigen zich gedragen of commissieleden zich opstellen, voordelig of nadelig uitpakken voor de betrokken getuigen. Hamilton, Muse \& Amer 2007, p. 1157-1158.
} 
Bij alle commissies bestaat de mogelijkheid om getuigen onder ede te horen. ${ }^{36}$ Soms worden aanvullende afspraken over het gebruik van deze bevoegdheid in het commissiereglement vastgelegd. ${ }^{37} \mathrm{Bij}$ sommige commissies worden alle getuigen onder ede verhoord. ${ }^{38} \mathrm{Bij}$ andere commissies gebeurt dat minder frequent. Juridisch is het niet erg relevant: ook zonder de eed is het afleggen van een valse verklaring strafbaar. Het gaat daarom vooral om een symbolische handeling, die vooral vanuit publicitair oogpunt aantrekkelijk kan zijn. Meestal laten commissies de beslissing over het afnemen van de eed in individuele gevallen over aan de beoordeling van de voorzitter. ${ }^{39}$

Getuigen mogen zich tijdens het verhoor laten bijstaan door rechtshulpverleners ('counsel'). Hun rol dient beperkt te blijven, zo is in de House Rules bepaald, tot het adviseren van getuigen omtrent hun constitutionele rechten. In de Senaat hebben sommige commissies aanvullende regels gesteld die het 'coachen' van getuigen tijdens het verhoor moeten tegengaan. ${ }^{40}$

Bijzonder aan de congressionele onderzoekspraktijk is dat, indien de commissie daartoe besluit, ook stafleden tijdens hoorzittingen vragen kunnen stellen aan getuigen. ${ }^{41}$ Hoewel de meeste verhoren door commissieleden zelfs worden afgenomen, is het inzetten van stafleden vooral in de meer omvangrijke congressionele onderzoeken niet ongebruikelijk. Stafmedewerkers kunnen daarmee een belangrijk stempel drukken op het verloop van de hoorzittingen, zeker wanneer het kundige verhoorders betreft. ${ }^{42}$ De deelname van stafleden aan openbare verhoren is niet onomstreden. Zo wordt wel gesteld dat een verhoor door stafmedewerkers, veelal geoefende juristen, zeker wanneer het bijvoorbeeld gaat om vragen rondom het gedrag van individuele ambtenaren teveel kan gaan lijken op een verkapt strafproces. ${ }^{43} \mathrm{Op}$

\footnotetext{
${ }^{36}$ Zie hiervoor, par. 2.3.1.

37 Zie bijvoorbeeld de Senate Energy and Natural Resources Committee, Rule 11 (111e Congres) ("Witnesses in Committee or Subcommittee hearings may be required to give testimony under oath whenever the Chairman or Ranking Minority Member of the Committee or Subcommittee deems such to be necessary. If one or more witnesses at a hearing are required to testify under oath, all witnesses at such hearing shall be required to testify under oath.").

${ }^{38}$ Met name bij commissies waar veel indringend onderzoek wordt gedaan, dat tot conflicten met getuigen kan leiden, is dit gebruikelijk. De Permanent Subcommittee on Investigations in de Senaat is hiervan een voorbeeld. Zie Grabow 1988, p. 161.

${ }^{39}$ Kaiser, Oleszek \& Tatelman 2011, p. 30-31. Zie ook Hamelton, Muse \& Amer 2007, p. 1156-1157.

40 Zie House Rule XI, lid 2(k)(3). In de Senaat is dit in de afzonderlijke commissiereglementen geregeld. Zie ook Rosenberg 1995, p. 35.

${ }^{41}$ Ook hierbij geldt dat de meerderheid en minderheid een gelijke hoeveelheid tijd moeten krijgen. Zie House Rule XI, lid 2, sub j. In de Senaat bestaan hieromtrent geen algemene regels. Zie ook Grabow 1988 , p. 163. Zie verder hierboven, par. 2.3.1.

42 Tijdens de gezamenlijke verhoren van de bijzondere Huis- en Senaatscommissies inzake het IranContraschandaal speelden de indringende verhoren van stafleden een belangrijke rol. Zie hierover: Grabow 1988, p. 56 e.v.

${ }^{43}$ Dit leidde er bijvoorbeeld bij het onderzoek inzake het Iran-Contraschandaal toe dat bepaalde getuigen zichzelf wisten neer te zetten als slachtoffers van 'roekeloze' stafjuristen; hun advocaten slaagden er daardoor in het onderzoek aanzienlijk te bemoeilijken. Tijdens het Watergate-onderzoek leek de rol van stafleden beter geregeld. Zij beperkten zich tot de eerste fase van de verhoren, waarin vooral zeer feitelijke vragen werden gesteld. De commissieleden namen het verhoor vervolgens over. Zie verder Grabow 1988, p. 74-75.
} 
grond van het geldende quorum voor het houden van hoorzittingen in beide Kamers is het overigens niet mogelijk dat hoorzittingen zonder aanwezigheid van commissieleden plaatsvinden.

Openbare hoorzittingen zijn een wezenlijk onderdeel van een congressioneel onderzoek, maar vaak niet in de eerste plaats als middel om informatie of bewijsmateriaal te vergaren. Veeleer dienen verhoren om hetgeen de staf en de commissie reeds in een eerder stadium te weten zijn gekomen, in het openbaar ('for the record') te (doen) bevestigen. Hoorzittingen vervullen verder ook een belangrijke politieke functie. $\mathrm{Zij}$ vormen het enige openbare gedeelte van een onderzoek en kunnen, afhankelijk van het onderwerp, veel publiciteit genereren. De openingsverklaringen vormen dan ook een belangrijk onderdeel van congressionele hoorzittingen. Ook voor bepaalde getuigen kunnen de openbare verhoren een belangrijke functie vervullen, bijvoorbeeld wanneer het gaat om vertegenwoordigers van federale diensten die voorwerp zijn van onderzoek. Zeker wanneer zij de gelegenheid krijgen om een openingsverklaring af te leggen, vormt een hoorzitting een publiek forum waar zij hun kennis en zienswijze, maar ook hun geleverde prestaties, zorgen of wensen voor het voetlicht kunnen brengen.

Tegen deze achtergrond ligt het voor de hand dat de toon van de verhoren zeer verschillend kan zijn. Sommige hoorzittingen hebben een ontspannen en bijna collegiaal karakter, bijvoorbeeld wanneer het onderwerp politiek weinig controversieel is, de betrokken federale diensten goed meewerken en Democratische en Republikeinse commissieleden het eens zijn over de te volgen koers. Andere verhoren zijn meer antagonistisch van toon, bijvoorbeeld wanneer vertegenwoordigers van federale agentschappen de indruk wekken informatie achter te houden. Bij meer controversiële onderwerpen kunnen de verhoren een sterk partijpolitiek karakter krijgen; deze hoorzittingen dienen vaak de politieke agenda van de meerderheidspartij (en in het bijzonder de commissievoorzitter) en zijn dan ook vooral bedoeld om de politieke verschillen tussen commissieleden te articuleren. ${ }^{44}$ Een dergelijke hoorzitting lijkt dan nog het meest op een parlementair debat. De combinatie van sterk partijpolitiek gekleurde openingsverklaringen en felle verhoren van 'elkaars' getuigen zorgen voor veel drama en theater, versterkt door de vaak overvloedige media-aandacht. De aanwezige getuigen lijken in dat geval vooral te zijn uitgenodigd om de (reeds ingenomen) standpunten van commissieleden te bevestigen of te onderbouwen. 45

Opmerkelijk is tenslotte de praktijk van informele hoorzittingen, die buiten de formele commissieprocedures plaatsvinden. Dit blijkt een manier te zijn waarop de minderheidspartij haar politieke (onderzoeks-)agenda kan nastreven, wanneer de

\footnotetext{
44 Zie ook Enthoven 2011, p. 503-504.

${ }^{45} \mathrm{Er}$ wordt in dit verband wel gesproken over 'friendly witnesses'. Hoewel de uitnodigende partijleden deze getuigen doorgaans zeer welwillend tegemoet treedt, worden zij door de andere partij vaak zeer fel ondervraagd. De getuigen worden in feite onderdeel van het debat tussen de commissieleden. Dit maakt dat getuigen in hun voorbereiding niet alleen veel tijd besteden aan hun juridische positie, maar ook aan de politieke context die medebepalend is voor het verloop van het verhoren. Wie het zich kan veroorloven, laat zich dan ook bijstaand door ervaren Washingtonse advocaten die zich in de congrespraktijk hebben gespecialiseerd. Zie voor gratis advies omtrent "the partisan factors involved, the agendas of different members, the motives of staff, the interests and biases of the media" en "how much lawyers can do at public hearings": Hamilton, Muse \& Amer 2007, p. 1150 e.v.
} 
meerderheidspartij hiervoor binnen de betreffende commissies geen ruimte wil bieden. Tijdens een groot deel van het presidentschap van George W. Bush, toen de Republikeinen over een meerderheid in het Congres beschikten, maakten de Democratische minderheidsleden (en hun stafleden) bij een aantal commissies veel gebruik van het zogenaamde 'Democratic Policy Forum' waar personen werden gehoord omtrent onderwerpen die in hun ogen door de Republikeinen werden vermeden. Verder organiseren ook individuele congresleden wel informele hoorzittingen, doorgaans ten aanzien van onderwerpen die vooral van belang zijn voor hun eigen kiesdistrict. Uiteraard beschikken congresleden bij deze informele fora niet over dwingende onderzoeksbevoegdheden. Medewerking van getuigen vindt dan ook plaats op basis van vrijwilligheid.

\subsection{Rapportage en afsluiting}

\subsubsection{Eindrapport en afsluitende hoorzitting}

Congressioneel onderzoek volgt, zoals gezegd, zelden een geijkte koers. Alleen bij bijzondere onderzoekscommissies, die een expliciete onderzoeksopdracht hebben meegekregen en doorgaans na rapportage ophouden te bestaan, wordt een onderzoek steeds afgesloten met de publicatie van een eindrapport. Bij de vaste commissies, waar onderzoek een veel flexibeler karakter heeft, kan een eindrapport worden opgemaakt, maar een onderzoek kan ook eenvoudig zonder tastbaar resultaat blijven wanneer de staf, die het onderzoek heeft uitgevoerd, of de voorzitter van oordeel is dat publicatie van de bevindingen niet nodig of onwenselijk is. Soms wordt aan de hand van stafonderzoek volstaan met een of meerdere hoorzittingen, waarvan verslag wordt opgemaakt. Wanneer een stafonderzoek wel wordt gepubliceerd, dan kan dat in naam van de voorzitter of, wanneer de meerderheid daarmee instemt, in naam van de commissie. Het kan gaan om een korte analyse van enkele pagina's, maar bij grootschaliger onderzoek betreft het soms vele honderden pagina's met bewijsstukken, bevindingen, conclusies en aanbevelingen.

Publicatie van een commissierapport kan op verschillende manieren. In de eerste plaats kan dit in de vorm een officieel kamerrapport ("House Report" of "Senate Report"). Hiertoe volstaat een gewoon commissiebesluit; verder geldt in beide Kamers dat eventuele aanvullende of afwijkende standpunten van commissieleden aan het rapport moeten worden toegevoegd, onder vermelding hiervan op het titelblad. 46 Deze methode wordt echter weinig gebruikt voor onderzoeksrapporten. ${ }^{47}$ Een debat in de plenaire vergadering naar aanleiding van een officieel onderzoeksrapport is ongebruikelijk.

\footnotetext{
${ }^{46}$ Zie House Rule XIII, lid 3, sub (a)(1) en Senate Rule XXVI, lid 10, sub c. Zie bijvoorbeeld U.S. House of Representatives, Misleading Information from the Battlefield: The Tillman and Lynch Episodes, First Report by the Committee on Oversight and Government Reform, Together with Additional Views, H. Rep. 110-858 (2008).

${ }^{47}$ De figuur van het kamerrapport wordt voornamelijk gebruikt voor het rapporteren van voorbereide en geamendeerde wetsvoorstellen aan de plenaire vergadering.
} 
Commissies kunnen hun rapporten ook zelf publiceren in de vorm van een commissiestuk ("Committee Print"). ${ }^{48}$ Een veel gebruikte methode is om een staf- of commissierapport toe te voegen aan het officiële verslag van de hoorzitting die naar aanleiding van het rapport wordt gehouden. Verder is het gebruikelijk dat rapporten op informele wijze via de commissiewebsite - die meestal onder beheer van de voorzitter staat - toegankelijk worden gemaakt; hierdoor hoeft de officiële publicatiewijze niet te worden afgewacht en komt de inhoud ervan snel beschikbaar voor pers en publiek.

Het is gebruikelijk om een onderzoek af te ronden met een afsluitende hoorzitting. Dit is ook de wijze waarop onderzoeken uitgevoerd door ondersteunende diensten, zoals GAO, door de commissie worden behandeld. ${ }^{49}$ Deze afsluitende hoorzitting heeft verschillende functies. Ten eerste worden de bevindingen uit het onderzoek, zo nodig met gebruik van visuele middelen, in het openbaar gepresenteerd. Doorgaans doet de voorzitter dit. De overige commissieleden maken tijdens hun openingsverklaring gebruik van de mogelijkheid om hun (politieke) reactie te geven op de bevindingen. Wanneer het onderzoek (deels) is uitgevoerd door een ondersteunende dienst, zoals GAO, dan worden de betrokken onderzoekers vaak in de gelegenheid gesteld om als getuige-deskundigen hun werk mondeling toe te lichten.

Vaak is deze afsluitende hoorzitting ook het moment waarop ministers, bestuurders of andere ambtenaren van de federale instellingen worden verhoord waarvan het functioneren voorwerp was van onderzoek. Deze verhoren kunnen dan worden gezien als het forum waar federale functionarissen aan het toezichthoudende Congres verantwoording afleggen voor het optreden van zichzelf of dat van hun dienst, maar ook om lessen voor de toekomst te formuleren en, bij geconstateerde gebreken, mogelijke oplossingsrichtingen door te nemen. Daarnaast kunnen ook andere getuigen worden gehoord die op enigerlei wijze betrokken zijn bij het (onderwerp van) onderzoek, zoals vertegenwoordigers van bedrijven en maatschappelijke organisaties.

Hoewel een onderzoek na publicatie van het rapport en de afsluitende hoorzitting in de meeste gevallen ten einde is, wil dit niet zeggen dat hiermee het onderwerp van de onderzoeksagenda is. Aangezien de vaste commissies beschikken over een algemeen onderzoeksrecht en een permanente onderzoeksstaf (die steeds meer expertise opbouwt), kan een onderzoek gemakkelijk op een later moment weer worden opgepakt. Soms gaat het daarbij om een enkele 'follow-up' hoorzitting, maar ook om een meer omvangrijk vervolgonderzoek, bijvoorbeeld naar aanleiding van nieuwe ontwikkelingen. Verder kunnen ook het jaarlijkse begrotingsproces en het reauthorisatieproces aanleiding geven tot hernieuwde interesse in een eerder verricht onderzoek. Wanneer het een onderwerp betreft dat de bijzondere interesse heeft van

\footnotetext{
${ }^{48}$ Zie bijvoorbeeld Fishtail, Bacchus, Sundance, and Slapshot: Four Enron Transactions Funded and Facilitated by U.S. Financial Institutions, Report Prepared by the Permanent Subcommittee on Investigations of the Committee on Governmental Affairs, United States Senate, S. Prt. 107-82 (2003).

${ }^{49}$ Overigens zijn zowel GAO als CBO wettelijk verplicht om hun rapporten ook zelf te publiceren. Openbaarmaking van deze rapporten is dus niet afhankelijk van de commissie die het onderzoek heeft aangevraagd. Rapporten van CRS worden daarentegen in beginsel niet openbaargemaakt, al staat het een commissie vrij om dat uit eiger beweging te doen.
} 
de commissie - en dan met name de voorzitter - dan is het doen van vervolgonderzoek niet ongebruikelijk. 50

\subsubsection{Openbaarheid en vertrouwelijkheid}

De bevoegdheden om getuigen op te roepen en documenten te vorderen geven commissies in beginsel de bevoegdheid om hun bevindingen in een onderzoeksrapport neer te leggen en het verzamelde bewijsmateriaal te publiceren. Is informatie op rechtmatige wijze gevorderd, dan is de commissie in beginsel dus vrij om te bepalen wat zij met die informatie wil doen. De mogelijkheden van publicatie kunnen evenwel bij wet beperkt zijn. Zo zijn er regelingen die verregaande beperkingen stellen aan de openbaarmaking van privacygevoelige gegevens, zoals belastingaanslagen of medische dossiers. De meeste wetgeving waarin beperkingen worden gesteld aan de publieke toegankelijkheid van overheidsinformatie, zoals de Freedom of Information Act, is echter niet van toepassing op de verstrekking van informatie aan het Congres. In bepaalde gevallen, zoals ten aanzien van geheime ('classified') informatie, geldt daarom dat congrescommissies in beginsel wel inzage kunnen krijgen, maar niet bevoegd zijn om de informatie openbaar te maken. Ook kan het zo zijn dat gegevens alleen toegankelijk zijn voor de kamers als zodanig en voor de commissies die op een bepaald werkterrein bevoegd zijn wetgeving te maken, toezicht te houden en onderzoek te doen. ${ }^{51}$

Beide kamers hebben nadere regels gesteld omtrent de openbaarmaking en archivering van commissiestukken. In het Huis geldt dat alle door commissies verzamelde stukken, inclusief verslagen van hoorzittingen en notulen van commissievergaderingen, aan het einde van een congrestermijn overgaan op de Clerk van het Huis. De stukken worden vervolgens bewaard in de National Archives, maar blijven eigendom van het Huis. Tenzij er wettelijke beperkingen zijn, kan een ieder vanaf dat moment een ieder inzage krijgen in de stukken. ${ }^{52}$ Voor stukken die reeds eerder openbaar zijn gemaakt, bijvoorbeeld omdat een commissie ze heeft gepubliceerd, geldt dat ze direct in het nationaal archief beschikbaar worden gesteld. Stukken die persoonlijke gegevens van nog levende personen bevatten en waarvan de openbaarmaking een inbreuk in de persoonlijke levenssfeer zou betekenen, worden pas na 50 jaar openbaar. Dat geldt ook voor stukken die betrekking hebben op personele aangelegenheden binnen de overheid en voor de verslagen van besloten verhoren. Wanneer een commissie ten aanzien bepaalde stukken nadere voorwaarden heeft gesteld omtrent het moment en de wijze van openbaarmaking, dan blijven

\footnotetext{
50 Zo verrichtte de Permanent Subcommittee on Investigations reeds enige jaren onderzoek naar belastingparadijzen, een van de politieke speerpunten van de Democratische subcommissievoorzitter Carl Levin. Zie bijvoorbeeld het rapport opgenomen in: Permanent Subcommittee on Investigations, Committee on Homeland Security and Governmental Affairs, United States Senate, Dividend Tax Abuse. How Offshore Entities Dodge Taxes on U.S. Dividends, S. Hrg. 110-778 (2008). Deze onderzoeken leidden, onder leiding van Levin, tot verschillende wetswijzingen waarmee werd beoogd belastingvlucht tegen te gaan.

51 Zie nader: Kaiser, Oleszek \& Tatelman 2011, p. 54 e.v.

${ }^{52}$ House Rule VII, lid 1-3(b)(2) jo. lid 5(a).
} 
die voorwaarden in beginsel van kracht. Alle overige documenten worden na 30 jaar openbaar. ${ }^{53}$

Het stellen van voorwaarden kan voortvloeien uit de genoemde wettelijke beperkingen of uit afspraken die zijn gemaakt met de leverancier van de stukken, bijvoorbeeld over de vertrouwelijke behandeling van bepaalde gevoelige informatie. Zo kunnen ad hoc afspraken worden gemaakt omtrent de behandeling van stukken die bedrijfsgeheimen bevatten of van documenten afkomstig van de uitvoerende macht waarover het executive privilege is ingeroepen. Hoewel het in veel gevallen formeel niet noodzakelijk is om met getuigen te onderhandelen, zoals ten aanzien van bedrijfsgevoelige informatie, is het maken van afspraken over de wijze waarop inzage wordt verleend in de praktijk niet ongebruikelijk, niet in de laatste plaats omdat de commissie met het oog op de voortgang van het onderzoek nu eenmaal niet gebaat is bij een voortslepend conflict en de eventuele contemptprocedures die daaruit kunnen voortkomen. ${ }^{54}$

Belangrijk is echter, zo kan uit de kamerregels worden afgeleid, dat het Huis aan het einde van de congrestermijn, bij de overdracht aan het archief, de door een commissie gestelde voorwaarden kan opheffen of aanpassen. ${ }^{55}$ Een verklaring hiervoor kan waarschijnlijk worden gevonden in het uitgangspunt dat de commissies werken in opdracht van het Huis. Een absolute garantie dat aan het Congres verstrekte gegevens (die niet door wettelijke beperkingen worden beschermd) nooit openbaar zullen worden, kan dus niet worden afgegeven. Tenslotte kan de Clerk besluiten bepaalde stukken niet openbaar te maken indien zulks niet in het openbaar belang zou zijn of de rechten en privileges van het Huis zou schaden. ${ }^{56}$ De Senaat kent vergelijkbare publicatieregels, al zijn die minder gedetailleerd. ${ }^{57}$ Over het openbaarmaken van vertrouwelijke stukken wordt in de senaatsregels niets uitdrukkelijk geregeld, maar aannemelijk is dat de Senaat bij de archivering van stukken de afspraken op commissieniveau kan overrulen.

\subsection{Karakterisering onderzoek}

\subsubsection{Aard, object en effect}

Parlementair onderzoek vormt een dagelijks onderdeel van de congressionele praktijk. Jaarlijks worden vele onderzoeken, groot en klein, uitgevoerd door vaste commissies in beide kamers, waarbij honderden hoorzittingen worden gehouden. Onderzoeksactiviteiten hebben in de meeste gevallen betrekking op het functioneren van de federale departementen en andere agencies behorende tot de uitvoerende macht. Een groot deel daarvan vindt plaats in relatieve politieke luwte, maar onder-

\footnotetext{
${ }^{53}$ House Rule VII, lid 3(b)(3).

54 Zie ook Hamilton, Muse \& Amer 2007, p. 1158-1159.

${ }^{55}$ House Rule VII, lid 3(b)(3) ('Except as otherwise provided by order of the House...').

${ }^{56}$ Een dergelijke beslissing kan echter worden overruled door het Huis of de commissie die het aangaat. Zie House Rule VII, lid 4(a)-(b).

${ }^{57}$ De betreffende Rule bepaalt dat stukken aan het einde van een Congrestermijn worden overgedragen aan de General Services Administration "for preservation, subject to the orders of the Senate." Zie Senate Rule XI, lid 2.
} 
zoek kan ook betrekking hebben op incidenten, schandalen en andere politiek gevoelige zaken. McCubbins en Schwartz onderscheiden in hun klassieke analyse twee soorten van congressioneel toezicht: enerzijds 'police-patrol oversight', anderzijds 'fire-alarm oversight'. Onder 'police patrol oversight' verstaan zij een actieve surveillance van de uitvoerende macht door de betrokken congrescommissies zelf, waardoor tekortkomingen kunnen worden gesignaleerd, verholpen en voorkomen. Bij 'fire alarm oversight' is sprake van een veel passievere houding van congrescommissies. $\mathrm{Zij}$ reageren dan vooral op signalen vanuit de samenleving omtrent tekortkomingen. Deze laatste vorm van toezicht, zo stellen McCubbins en Schwartz, is verreverreweg de populairste, omdat deze maximale politiek resultaat opleveren voor congresleden met relatief weinig inspanning. ${ }^{58}$

Dat congressioneel toezicht effect heeft, wordt in de Amerikaanse literatuur nauwelijks betwijfeld. McCubbins en Schwartz wijzen op de preventieve werking van toezicht, met name wanneer sprake is van 'fire-alarm oversight': wanneer federale diensten zich realiseren dat congrescommissies op ieder moment kunnen worden gealarmeerd door meldingen over tekortkomingen in de uitvoering en vervolgens een onderzoek kunnen starten. ${ }^{59}$ Ook Aberbach stelt dat congressioneel toezicht een wezenlijke invloed heeft op het gedrag van uitvoerende diensten: "Congress plays an active role both in writing the laws that establish the skeleton and muscle and in setting the budgets that give the lifeblood to administrative agencies. When Congress shows an interest, agencies ignore it at their peril." 60 Ook op een ander vlak, namelijk dat van de publieke opinie, kan congressioneel toezicht en onderzoek een belangrijk effect hebben. Kriner deed empirisch onderzoek naar de relatie tussen de publieke opinie en de toename van het congressionele onderzoek na de Democratische machtsovername eind 2006 ten aanzien van de oorlog in Irak. Zijn analyse "strongly suggests that critical congressional oversight can cause political problems for the President by eroding popular support for his military policies." 61

Congressioneel onderzoek kan dus op de langere termijn invloed hebben op het opereren van federale diensten en op de vorming van beleid. Een onderzoek kan ook direct grote politieke en maatschappelijke gevolgen hebben en soms zelfs een concrete bijdrage leveren aan de ontwikkeling van het congressionele onderzoeksrecht - en van het Amerikaanse staatsrecht in zijn algemeenheid. ${ }^{62}$ Veel van die onderzoeken werden verricht door bijzondere commissies. Zo vormde het St. Clair-onderzoek in het Huis het beginpunt van de congressionele onderzoekspraktijk. Belangrijke constitutionele implicaties hadden de Senaatsonderzoeken inzake het Teapot Domeschandaal in de jaren '20 van de twintigste eeuw, toen het congressionele onderzoeksrecht ook in de jurisprudentie van het Hooggerechtshof erkenning vond. De loyaliteitsonderzoeken in de jaren ' 40 en '50 van de House Un-American Activities Committee en de Senaatscommissie onder leiding van Senator McCarthy leidden tot

\footnotetext{
${ }^{58}$ McCubbins \& Schwartz 1984, p. 166-169.

${ }_{59}$ McCubbins \& Schwartz 1984, p. 174-176. Zie ook Kriner 2009, p. 774.

${ }^{60}$ Aberbach 1990, p. 195. Zie verder: Enthoven 2011, p. 498-499.

${ }^{61}$ Kriner 2009, p. 790.

62 Zie voor een uitvoerig historisch overzicht van de belangrijkste congressionele onderzoeken tussen 1792 en 1974 het meerdelige werk van Schlesinger \& Bruns 1975. Zie ook Grabow 1988, p. 13-75.
} 
hernieuwde aandacht voor het onderzoeksrecht, met name vanuit het oogpunt van individuele rechtsbescherming. Het Watergate-onderzoek door de SenaatcommissieErvin in de jaren 70 heeft grote betekenis gehad voor de positie van de President ten opzichte van het Congres en zijn onderzoekscommissies.

Genoemde onderzoeken laten tevens zien, dat congressioneel onderzoek in het algemeen vooral effectief is wanneer commissieleden van beide partijen met elkaar samenwerken en op basis van het onderzoek met gedeelde conclusies en aanbevelingen komen. Met name een goede verstandhouding tussen de commissievoorzitter en de leider van de minderheidspartij binnen de commissie ('ranking member') draagt daaraan bij. ${ }^{63}$ Dit is in de praktijk echter lang niet altijd het geval. Met name in het Huis, waar de leden elke twee jaar herkozen moeten worden, is samenwerking tussen Republikeinen en Democraten allerminst vanzelfsprekend. In de minder hectische Senaat lijkt hier meer ruimte voor te bestaan, vooral op thema's waar beide partijen elkaar kunnen vinden. De werkwijze van de Permanent Subcommittee on Investigations is hiervan een voorbeeld. 64

Een gebrekkige samenwerking tussen meerderheid en minderheid betekent overigens niet, dat congressioneel toezicht en onderzoek in dat geval per definitie niet effectief is. Een scherpe partijpolitieke verdeeldheid binnen de commissie kan immers ook politieke functies hebben. Hierboven bleek bijvoorbeeld al dat hoorzittingen niet alleen een onderzoeksfunctie hebben, maar tevens kunnen fungeren als forum voor politiek debat tussen de twee partijen. ${ }^{65}$ In een situatie van 'divided government', waarbij de congressionele meerderheid een andere kleur heeft dan de President, kan een onderzoek ook vooral bedoeld zijn om politiek en publicitair tegenwicht te bieden aan het beleid van de President. In zekere zin past dit bij het Amerikaanse politiek-constitutionele stelsel, dat immers uitgaat van gescheiden, elkaar in evenwicht houdende machten. Dergelijke vormen van onderzoek kunnen echter ook een venijniger karakter krijgen, wanneer het er vooral om gaat om de President (persoonlijk) te beschadigen. Met de toenemende partijpolitieke polisatie, die zich de afgelopen jaren aftekent in het Congres, wordt deze functie van congressioneel onderzoek steeds zichtbaarder. Hierover meer in de volgende paragraaf.

\subsubsection{Kwantiteit en kwaliteit}

De congressionele toezichts- en onderzoeksfunctie heeft, zo bleek eerder al, in 1946 een belangrijke impuls gekregen met de invoering van de Legislative Reorganization Act. Verdere versterking van de toezichtsstructuur volgde in de jaren 70 , tegen de achtergrond van een groeiende federale overheidstaak en de behoefte aan versterking van de positie van het Congres ten opzichte van de President. Omvangrijk kwantitatief onderzoek van Aberbach laat zien dat het Congres sinds de jaren 70 in algemene zin meer tijd is gaan besteden aan toezicht. Er is een stijgende trend waarneembaar wat betreft het aantal hoorzittingen dat hoofdzakelijk op toezicht gericht is: waar het dit aantal in de periode 1961-1969 min of meer stabiel is, neemt het aantal

\footnotetext{
${ }^{63}$ Enthoven 2011, p. 504.

${ }^{64}$ Zie hierboven, par. 3.2.1.5.

65 Zie par. 4.3.3.
} 
in de jaren daarna aanzienlijk toe. Niet alleen in absolute zin is een toename waarneembaar, maar ook in verhouding tot andere congressionele activiteiten. ${ }^{66}$ Dit komt ook naar voren in enquêtes die in het kader van dit onderzoek werden gehouden onder de belangrijkste commissiestafleden in het Congres. Bijna 90 procent van de respondenten onderschreef de stelling dat de congressionele toezichtsfunctie sterk is gegroeid sinds de jaren 70.67

Aberbach geeft een aantal verklaringen voor deze groei. Om te beginnen biedt het Amerikaanse politieke systeem de randvoorwaarden voor een zelfstandig en onafhankelijk opererend Congres. Er is sprake van gescheiden instellingen, machtenscheiding en overlappende bevoegdheden, en een eigen kiezersmandaat inclusief vaste ambtsperiodes voor zowel President als Congres. Dit wordt versterkt door een politieke context waarin een relatief zwak partijenstelsel er onder meer toe leidt dat President, Senaat en Huis niet noodzakelijkerwijs worden gedomineerd door één partij. Tegen deze achtergrond, zo vervolgt Aberbach, werd het vervolgens in de jaren 70 steeds aantrekkelijker voor congresleden om zich met toezicht bezig te houden. Hiervoor wijst hij vier factoren aan. Ten eerste ontstond bij burgers, tegen de achtergrond van een sterk gegroeid overheidsapparaat, steeds minder interesse in nieuw beleid en meer in toezicht op bestaande overheidsprogramma's. Ten tweede raakte het land in deze periode een economische recessie, waardoor er minder ruimte was voor nieuwe initiatieven; het controleren en verbeteren van bestaande overheidstaken werd daardoor politiek relevanter. Ten derde leidden de poging van President Nixon om effectieve zeggenschap te krijgen over de uitvoerende macht tot een tegenreactie binnen het Congres, gericht op het herstellen van de constitutionele machtsbalans. Tenslotte zorgden interne hervormingen binnen het Congres voor verdere decentralisatie; subcommissies werden autonomer en kregen meer ondersteuning, waardoor het houden van toezicht verder werd gestimuleerd. 68

Aberbachs onderzoek laat zien dat "...congressional oversight most often is done in a context of program advocacy. Objective evidence may well be used, but it is likely to be used selectively to meet the political needs of committee overseers and their constituencies." 69 Dit verschijnsel lijkt zich vooral voor te doen bij de beleidsgerichte vakcommissies, zo stelt Enthoven. Veel commissieleden in de beleidscommissies dragen hun werkterrein een warm hart toe en richten zich daarom in hun toezichtsactiviteiten vooral op bijsturing op detailniveau. De gespecialiseerde toezichtscommissies in beide kamers, zoals de House Oversight and Government Re-

\footnotetext{
66 Tussen 1961 en 1967 ligt het aantal toezichtshoorzittingen en -vergaderingen gedurende de eerste helft van het jaar op ongeveer 1.800, zo'n 10\% van het totaal aantal activiteiten; in de periode 19691983 stijgt dit naar zo'n 2.500, ongeveer 20\% van de activiteiten. Overigens moet hieruit niet worden afgeleid dat toezicht alleen middels (formele) hoorzittingen verloopt, noch dat hoorzittingen de belangrijkste vormen van toezichten zijn; hoorzittingen zijn wel de meest zichtbare en te kwantificeren vorm van toezicht. Zie Aberbach 1990, p. 35.

${ }^{67}$ Belangrijkste redenen hiervoor, zo kwam uit de enquetes naar voren, zijn de gegroeide omvang en complexiteit van het overheidsoptreden (55\%); de groei en het misbreuk van macht door de executieve, waarmee gedoeld werd op de President (22\%); meer en betere ondersteuning (17\%); en de impact van congressionele hervormingen (17\%). Zie Aberbach 1990, p. 40-43.

68 Aberbach 1990, p. 190-193.

${ }^{69}$ Aberbach 1990, p. 47.
} 
form Committee, zijn niet verbonden met een specifiek beleidsterrein en lijken daarom onafhankelijk te werk te gaan. ${ }^{70}$

Uit het onderzoek van Aberbach tot 1990 blijkt verder dat systematische toezichtsmethoden ('comprehensive review techniques'), niet significant minder worden toegepast dan de meer op incidenten gerichte technieken ('piecemeal techniques'). ${ }^{71}$ In de jaren daarna lijkt hierin enige verandering te zijn gekomen. Hoewel de groei van de hoeveelheid toezichts- en onderzoeksactiviteiten zich sinds 1990 heeft voortgezet, lijkt er sindsdien wel een verschuiving te hebben plaatsgevonden in het karakter van de toezichts- en onderzoekspraktijk. ${ }^{72}$ In een follow-up studie constateerde Aberbach een toename van sterk partijpolitiek gemotiveerde vormen van toezicht. Dit was bijzonder zichtbaar in 1995, het jaar waarin de Republikeinen de macht in beide kamers van het Congres overnamen. ${ }^{73}$ Deze toename ging ten koste van het meer systematische, niet partijgebonden, maar misschien politiek minder zichtbare toezicht.

Van de ontwikkeling van een uniforme, stabiele toezichts- en onderzoekspraktijk is daarom geen sprake. De mate waarin en wijze waarop het Congres gebruikmaakt van haar toezichts- en onderzoeksinstrumenten lijkt eerder onderhevig aan een soort slingerbeweging. In de woorden van Kriner:

"...when we examine the intensity with which Congress has dedicated itself to its oversight responsibilities, we see a pattern much like that of a swinging pendulum; at times, Congress appears to use its investigative powers aggressively to police the executive while at others it takes a decidedly passive role and fails to meet normative standards of a responsible independent legislature." 74

Deze slingerbeweging hangt volgens Kriner sterk samen met de partijpolitieke verhoudingen tussen President en Congres. Een van de meest opvallende voorbeelden is het gebrekkige congressionele toezicht na de Amerikaanse inval in Irak in 2003, toen het Witte Huis en het Congres in Republikeinse handen waren ('unified government'). Volgens Ornstein en Mann ontbrak het veel congresleden in deze periode aan een institutionele houding:

\begin{abstract}
"Members of the majority party, including congressional leaders, act as field lieutenants in the president's army rather than as members of an independent branch of government. Serious oversight almost inevitably means criticism of performance, and this Republican Congress has shied away from criticizing its own White House." 75
\end{abstract}

Nadat de Democraten in 2006 in beide kamers de meerderheid verwierven en er weer sprake was van 'divided government', volgde, weinig verwonderlijk, een enorme hausse aan kritische onderzoeken. Ook uit breder empirisch onderzoek blijkt volgens Kriner dat "congressional willingness to use its investigative and oversight

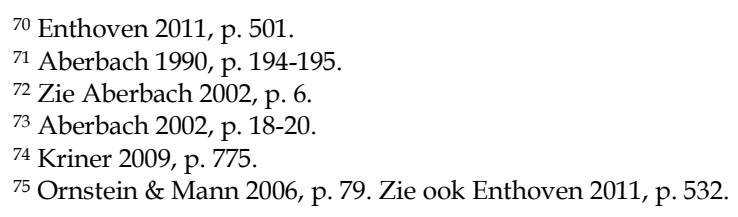


powers to superintend the executive branch varies considerably according to the contours of the political environment." 76 Deze ontwikkeling past in de bredere trend van meer partijpolitieke centralisatie en polarisatie binnen het Congres, die zich sinds de jaren 90 aftekent. ${ }^{77}$ De hoeveelheid, kwaliteit en intensiteit van congressioneel toezicht en onderzoek vormt, met andere woorden, net zoals andere congressionele processen, onmiskenbaar - en de laatste jaren in toenemende mate - onderdeel van een sterker gearticuleerde partijpolitieke context.

\subsection{Conclusie}

Het initiatief tot een onderzoek kan binnen de vaste commissies van verschillende kanten komen. In veel gevallen begint een onderzoek bij de commissievoorzitter, die al dan niet in overleg met andere commissieleden besluit dat een onderzoek gewenst is. In de uitvoering van congressioneel onderzoek speelt de vaste staf van commissies, die in grote mate door de meerderheidspartij wordt aangestuurd, een sleutelrol. Daarnaast kan de hulp worden ingeroepen van gespecialiseerde ondersteunende diensten. Hierdoor zijn congrescommissies in staat grote aantal onderzoeken te verrichten. Congressioneel onderzoek is veelal onderdeel van bredere processen op het gebied van wetgeving, budgettering en toezicht. Voortvloeiend uit de congressionele taken staat het functioneren van de uitvoerende macht vaak centraal. Het brede, algemene onderzoeksrecht en de aanwezigheid van permanente ondersteuning biedt commissies de ruimte om flexibel met de onderzoeksfunctie om te gaan. Van een zekere uniformiteit in de onderzoekspraktijk is dan ook, anders dan in Nederland en het Verenigd Koninkrijk, geen sprake.

De hoeveelheid toezichts- en onderzoeksactiviteiten in het Congres vertoont al jaren een stijgende lijn. Het karakter van het onderzoek kan zeer verschillend zijn: wanneer commissieleden - en dan met name de voorzitter en de leider van de minderheidspartij - elkaar op thema's kunnen vinden, dan kan een productieve samenwerking ontstaan. Staan de partijen binnen een commissie echter lijnrecht tegenover elkaar en neemt de meerderheidspartij het heft in eigen hand, dan kan vooral in een situatie van 'divided government' een sterk partijpolitiek gemotiveerde onderzoeksagenda ontstaan die er vooral op gericht lijkt de President en diens beleid te bekritiseren. Deze laatste vorm van onderzoek lijkt de afgelopen decennia een steeds belangrijkere plaats te hebben ingenomen. De toenemende invloed van partijpolitiek in het Congres is dus ook op dit terrein merkbaar.

Commissieleden en -medewerkers hanteren verschillende methoden om onderzoeksmateriaal te verzamelen. In eerste instantie bestaat een onderzoek in belangrijke mate uit het verzamelen en analyseren van schriftelijke stukken. Naast het opvragen en analyseren van schriftelijk materiaal voeren stafleden doorgaans ge-

\footnotetext{
${ }^{76}$ Kriner 2009, p. 791. Zie ook Enthoven 2011, p. 507-508. Een voorbeeld is het gebruik van de subpoenabevoegdheid. Zo maakten Republikeinse commissievoorzitters in de jaren 90 veelvuldig gebruik van dit instrument bij hoorzittingen die vooral tot doel hadden om de Democratische president Clinton politiek te beschadigen, terwijl tussen 2000 en 2006, toen de Republikeinen eveneens een meerderheid hadden, nauwelijks subpoenas werden toegepast. Zie Enthoven 2011, p. 534-535.

77 Zie ook hierboven, par. 1.2.1.
} 
sprekken of interviews en soms zelfs formele stafverhoren met verschillende contactspersonen binnen en buiten de federale overheid, zoals ambtenaren, vertegenwoordigers van maatschappelijke organisaties en belangengroepen (lobbyisten), experts uit de wetenschap en individuele burgers. Bij het vergaren van inlichtingen kunnen commissies op weerstand stuiten vanuit de uitvoerende macht. In het vorige hoofdstuk werd al duidelijk werd dat de President daarbij een beroep kan doen op het executive privilege. Daarnaast kan het openbaar ministerie bezwaren aanvoeren tegen congresssioneel onderzoek dat samenloopt met strafrechtelijk onderzoek. Dat het Congres bevoegd is onderzoek te doen naar feiten die tevens voorwerp van strafrechtelijk onderzoek zijn, staat op zichzelf niet ter discussie. Of een congrescommissie ook inzage moet kunnen krijgen in lopende strafdossiers, levert echter al jarenlang een constitutioneel verschil van inzicht op tussen de Attorney General en het Congres. Beide partijen stellen zich principieel op; standaardafspraken zijn er daarom niet. In concrete gevallen moet, evenals in het geval van een beroep op executive privilege, middels onderhandelingen een oplossing worden gezocht.

Openbare verhoren beginnen met een openingsverklaring van de voorzitter, waarin het onderwerp van de hoorzitting wordt aangeduid. Deze openingsverklaring kan een belangrijke sturende functie vervullen en is in verband met de afbakening van het onderzoeksonderwerp voor getuigen ook juridisch van belang. $\mathrm{Na}$ de voorzitter worden de minderheidsleider en de andere aanwezige leden in de gelegenheid gesteld een openingsverklaring af te leggen. Commissieleden gebruiken deze ronde veelal om opvattingen, ervaringen en verwachtingen kenbaar te maken, maar ook om onderlinge politieke tegenstellingen te articuleren. De openingsverklaringen kunnen daarom een belangrijke indicatie zijn voor de toon van de verhoren. Wanneer de commissie politiek sterk verdeeld is, kan een hoorzitting via de openingsverklaringen, maar ook in de keuze en ondervraging van getuigen, de functie van een politiek debat krijgen.

Een onderzoek kan worden afgesloten met een formeel onderzoeksrapport, maar noodzakelijk is dit niet. Soms is er alleen een rapport opgesteld door de meerderheidsstaf, dat tijdens een afsluitende hoorzitting wordt gepresenteerd en voorgelegd aan de betrokken ministers en ambtenaren. Vaak hebben onderzoeken van vaste commissies een vloeiende vorm: bij nieuwe incidenten wordt een eerder onderzoek of een oude serie hoorzittingen weer opgepakt. Na afloop van een congrestermijn worden alle stukken die commissies hebben verzameld overgebracht naar het nationaal archief. Beide kamers hanteren regels omtrent openbaarheid en vertrouwelijkheid, waarbij het uitgangspunt is dat afspraken die commissies met informatieverstrekkers hebben gemaakt over vertrouwelijke behandeling van stukken worden gerespecteerd. In elk geval in het Huis bestaat echter de mogelijkheid dat deze vertrouwelijkheid door de kamer wordt opgeheven. 


\section{Slotbeschouwing}

\section{Onderzoek in opkomst}

Onderzoek hoort bij het parlement, zo kan uit de voorgaande delen van dit boek worden afgeleid. Al zolang zij bestaan maken de parlementen in Nederland, het Verenigd Koninkrijk en de Verenigde Staten gebruik van de mogelijkheid om onderzoek te doen. Dit parlementaire onderzoek had in de bestudeerde stelsels lange tijd een incidenteel karakter. Parlementen gebruikten het onderzoeksinstrument voor verschillende constitutionele taken: het voorbereiden van wetgeving en het controleren van de regering, maar ook het handhaven van interne parlementaire voorschriften. In de Verenigde Staten vond onderzoek in eerste instantie vooral plaats bij grote incidenten of schandalen waarbij overheidsfunctionarissen betrokken waren. Het Huis of de Senaat stelde vervolgens een onderzoekscommissie in, die de zaak tot op de bodem moest uitzoeken. Zo had het eerste congressionele onderzoek, kort na de inwerkingtreding van de Amerikaanse Constitutie, betrekking op een destastreus verlopen veldtocht onder leiding van generaal St. Clair. Het Britse parlement maakte al sinds de late middeleeuwen zo nu en dan gebruik van tijdelijke onderzoekscommissies ('select committees'). Dergelijke commissies werden ingesteld voor allerlei kwesties, bijvoorbeeld om onderzoek te doen naar vermeende malversaties van parlementsleden, of om de militaire mislukkingen tijdens de Krimoorlog in kaart te brengen. In Nederland, waar het onderzoeksrecht in 1848 in de Grondwet werd vastgelegd, domineerde in de negentiende eeuw de zogenaamde wetgevingsenquête: de Tweede Kamer stelde een enquêtecommissie in met het doel inzicht te verkrijgen in de behoefte aan of noodzaak van nieuwe wetgeving.

In de loop van de twintigste eeuw onderging de parlementaire onderzoeksfunctie in deze drie stelsels een gedaantewisseling. De achtergrond hiervan is het ontstaan van de moderne westerse verzorgingsstaat. Het toenemend aantal publieke taken ging gepaard met een sterke groei van het openbaar bestuur. Parlementen zochten naar manieren om deze ontwikkeling te kunnen bijbenen. In alle drie de stelsels hebben parlementen immers de constitutionele taak om het bestuur te controleren, dat wil zeggen om zowel zicht als grip te houden op het bestuurlijk apparaat. ${ }^{1}$ Een noodzakelijke voorwaarde om overheidsorganisaties effectief te kunnen controleren, zo was de gedachte, is het kunnen beschikken over voldoende kennis en exper-

\footnotetext{
${ }^{1}$ Waar in Nederland gesproken wordt over parlementaire controle, waarmee zowel op controle in enge zin (controleren in de zin van nagaan, 'zicht hebben') als in ruime zin (controleren in de zin van 'grip hebben'), spreekt men in het Verenigd Koninkrijk van 'parliamentary scrutiny' (enge zin) en 'parliamentary control' (ruime zin). In de Verenigde Staten wordt de term 'congressional oversight' gebruikt, dat hier wordt vertaald met het houden van toezicht door het Congres. De term 'oversight' wordt in de Amerikaanse literatuur gebruikt voor controlende activiteiten in zowel enge als ruime zin.
} 
tise ten aanzien van het functioneren van deze organisaties. Voor steeds meer parlementsleden werd duidelijk dat zij op dit punt op achterstand stonden: het traditionele parlement werd onvoldoende in staat geacht om zicht en grip te houden op de alsmaar uitdijende departementen, agentschappen en andere publieke diensten.

Tegen deze achtergrond werden in de besproken stelsels initiatieven genomen om de parlementaire onderzoeksfunctie te versterken en de benodigde kennis en kunde op te bouwen waarmee zicht en grip op het bestuursapparaat kon worden verkregen. In de Verenigde Staten gebeurde dit in de vorm van een grootschalige reorganisatie van het Congres direct na de Tweede Wereldoorlog. Sinds de Legislative Reorganization Act van 1946 zijn de 'standing committees' in beide kamers in aanvulling op hun wetgevende en budgettaire taken uitdrukkelijk belast met het houden van toezicht op de instellingen van de uitvoerende macht binnen hun werkterrein. Het onderzoeksrecht is een belangrijk formeel instrument dat commissies hebben om hun toezichthoudende opdracht te vervullen; het begrip onderzoek ('investigation') wordt in de Amerikaanse praktijk dan ook vaak in een adem genoemd met toezicht ('oversight'), zonder een strict onderscheid te maken. In de jaren zestig en zeventig volgde het Britse Lagerhuis met een afzonderlijk stelsel van permanente onderzoekscommissies. ${ }^{2}$ In de jaren zeventig en tachtig werd uiteindelijk ook in Nederland het onderzoeksrecht door de Tweede Kamer nieuw leven ingeblazen. Het enquêterecht, dat inmiddels decennia lang in onbruik was, wordt sinds 1983 weer met enige regelmaat toegepast. Het gebruik van andere tijdelijke parlementaire onderzoekscommissies nam nog grotere vlucht. Parlementaire onderzoeken richten zich soms op het naar boven halen van de feiten naar aanleiding van een schandaal of incident, terwijl in andere gevallen een bredere, meer beleidsevaluerende insteek wordt gekozen. Sindsdien fungeert het onderzoeksinstrument in Nederland in de eerste plaats als instrument van parlementaire controle.

\section{Constitutionele ruimte}

De intensivering van de onderzoeksfunctie met het oog op de controlerende taak van het parlement, vond in alle stelsels plaats binnen een politiek en staatsrechtelijke kader dat daartoe in toenemende mate ruimte bood. De meeste ruimte bood het Britse staatsrecht, vooral omdat het parlementaire onderzoeksrecht daar nergens uitdrukkelijk wordt gedefinieerd. Het Verenigd Koninkrijk kent geen geschreven grondwet en kent ook geen andere bron waarin het onderzoeksrecht en de andere taken en bevoegdheden van het parlement zijn samengebracht. In zowel de Britse literatuur als in de parlementaire praktijk wordt het bestaan van een onderzoeksrecht echter niet betwijfeld. Beide kamers beschikken van oudsher over onderzoeksbevoegdheden als het recht om getuigen op te roepen voor verhoor, zo leert de parlementaire geschiedenis. Het doen van onderzoek wordt thans vooral beschouwd als een van de instrumenten die het parlement ter beschikking staan ter uitoefening van zijn taak om de regering te controleren. De controlerende taak van het parlement, die voortvloeit uit het beginsel van 'responsible and accountable government' is in de Britse doctrine sterk ontwikkeld. Met de groeiende dominantie van de regering in het Britse

2 Zie Deel II, par. 4.2.2. 
parlementaire stelsel groeide in de loop van de twintigste eeuw ook de aandacht voor effectieve vormen van parlementaire controle, waarmee de ministeriële verantwoordelijkheid kon worden geactiveerd.

In Nederland is het onderzoeksrecht sinds 1848 wel grondwettelijk erkend. De Britse traditie vormde daarbij een belangrijke inspiratiebron. Het huidige artikel 70 bepaalt dat beide kamers, alsmede de verenigde vergadering, beschikken over het 'recht van onderzoek (enquête)'. Nadere regeling van het enquête-instrument is dus aan de wetgever overgelaten. Met het oog op de machtenscheiding werd de toepassing van wettelijke dwangmiddelen, anders dan in het Britse stelsel, bij de totstandkoming van de eerste enquêtewet in 1850 aan de rechter opgedragen. Een nadere omschrijving van de reikwijdte van het enquêterecht ontbrak echter. De regering ging er in de negentiende eeuw, als gezegd, nog vanuit dat enquêtes slechts dienden als middel om inlichtingen te verzamelen in het kader van het wetgevingsproces. In de loop der tijd groeide zowel in de literatuur als in de parlementaire praktijk de overtuiging dat het onderzoeksrecht een bredere betekenis moest worden toegekend. Dit leidde ertoe dat het onderzoeksrecht, na een groot gedeelte van de twintigste eeuw in onbruik te zijn geraakt, in de jaren 70 en 80 opleefde en sindsdien vooral een instrument ten behoeve van de parlementaire controletaak is. Een belangrijke uitdrukking daarvan is de wijziging van de enquêtewet in 1977, die het mogelijk maakte om bewindslieden in een enquête te verhoren, iets wat tot dan toe vrijwel was uitgesloten. Sindsdien is een bestendige onderzoekspraktijk tot ontwikkeling gekomen. In 2008 werd de oude Wet op de Parlementaire Enquête, die nog grotendeels uit 1850 stamde, integraal herzien.

In de Verenigde Staten is het recht van onderzoek niet uitdrukkelijk in de Constitutie opgenomen, maar al in het prille begin van de Amerikaanse republiek werd dit recht erkend als een van de 'implied powers' waarover het Congres beschikt bij de uitoefening van haar taken. Ook hier werd teruggegrepen op het oude Britse parlementsrecht, al vormde dit in het Amerikaanse stelsel van 'common law' niet slechts een inspiratiebron maar ook een rechtsbasis. De taken van het Congres zijn voornamelijk te vinden in artikel I van de Constitutie, waarin het Congres de wetgevende macht wordt toegekend. Hieruit vloeien echter niet slechts bevoegdheden van regelgevende aard voort. Hoewel de President ingevolge artikel II aan het hoofd van de uitvoerende macht staat, bepaalt het Congres middels wetgeving in hoge mate de inrichting, taakverlening en bekostiging van het uitvoerende apparaat. Bovendien heeft de Senaat een instemmingsrecht bij de benoeming van ambtenaren binnen de uitvoerende macht. Uit het samenstel van deze bevoegdheden wordt afgeleid dat het Congres een (impliciete) toezichthoudende taak heeft ten aanzien van de uitvoerende macht. Ook het houden van toezicht is daarmee een legitiem doel waarvoor het onderzoeksrecht kan worden ingezet. In de vaste rechtspraak van het Hof worden het onderzoeksrecht en de bevoegdheden om dat recht af te dwingen erkend als essentiële hulpmiddelen voor het Congres bij de uitoefening van zijn constitutionele taken. Het doen van onderzoek is bovendien een van de weinige parlementaire controlemiddelen die het Congres ter beschikking staan, aangezien Huis en Senaat, anders dan hun parlementaire tegenhangers in het Verenigd Koninkrijk en Nederland, de President of uitvoerende functionarissen niet via het vragenrecht of debatrecht ter verantwoording kunnen roepen. Het Hof heeft het onderzoeksrecht in zijn recht- 
spraak steeds meer ruimte geboden. Met name sinds de uitspraak in de zaak McGrain (1923) beschikt het Congres over veel vrijheid. De rechter toetst in concrete gevallen slechts marginaal of een onderzoeksopdracht binnen de constitutionele grenzen valt en richt zich sinds de jaren 50 vooral op de positie van de individuele getuige.

\section{Onderzoek geïnstitutionaliseerd}

In de loop van de twintigste eeuw kwam het onderzoeksrecht in alle besproken stelsels dus in opkomst. In staatsrechtelijke zin was dit mogelijk omdat daarvoor de nodige constitutionele ruimte bestond of werd gecreëerd. Voor de groei van de onderzoeksfunctie zijn echter ook andere factoren van belang geweest. Hierbij moet gedacht worden aan de wijze waarop de onderzoeksfunctie institutioneel vormgegeven werd en de politieke context waarbinnen dat gebeurde.

Het onderzoeksrecht is in alle besproken stelsels een meerderheidsrecht. Dat betekent dat voor het instellen van een parlementair onderzoek in deze stelsels een meerderheidsbesluit in de kamer vereist is. De meerderheid beslist daarmee ook over de wijze waarop het onderzoek wordt uitgevoerd: welk type commissie aangewezen is, welke leden deze commissie telt, hoe de onderzoeksopdracht luidt en welke onderzoeksbevoegdheden aan de commissie moeten worden toegekend. Alleen in Nederland werden, toen de onderzoeksfunctie in de jaren 70 nieuw leven werd ingeblazen, pogingen ondernomen om het onderzoeksrecht - meer specifiek het enquêterecht - ook aan een parlementaire minderheid toe te kennen. De voorstanders daarvan hoopten daarmee het doen van (controlerend) onderzoek te stimuleren. Deze pogingen, die een grondwetswijziging vereisten, zijn echter tot tweemaal toe gestrand in de Eerste Kamer. Het idee van een minderheidsenquête is sindsdien van de politieke agenda verdwenen.

Het meerderheidsrecht is in alle stelsels dus gehandhaafd, maar in de toepassing van het onderzoeksrecht is in de loop van de twintigste eeuw een aanmerkelijk verschil ontstaan tussen het Amerikaanse Congres en het Britse parlement enerzijds en de Nederlandse Tweede Kamer anderzijds. In Nederland is de besluitvorming rondom het inzetten van het onderzoeksrecht steeds in handen van de plenaire vergadering gebleven, die incidenteel besluit tot het instellen van een tijdelijke onderzoekscommissie, terwijl in de andere stelsels gekozen is voor verregaande delegatie en decentralisatie aan vaste commissies.

Het begon in de Verenigde Staten, waar de vaste commissies in het Huis en in de Senaat sinds 1946, naast hun wetgevende en budgettaire werkzaamheden, uitdrukkelijk ook een toezichthoudende taak te vervullen hebben. In de reglementen van beide kamers is te dien aanzien bepaald dat de commissies de opdracht hebben "to review and study, on a continuing basis, the application, administration, and execution of those laws, or parts of laws, the subject matter of which is within the jurisdiction of that committee." 3 Aan de commissies is het onderzoeksrecht uitdruk-

\footnotetext{
${ }^{3}$ Zie House Rule X, lid 2 en Senate Rule XXVI, lid 8, sub a. Deze formulering wordt sinds 1970 gehanteerd. Zie nader: Deel III, par. 3.2.1.
} 
kelijk gedelegeerd. ${ }^{4}$ Daarbij beschikken zij over een aantal onderzoeksbevoegdheden. Zo kunnen commissies subpoenas uitvaardigen: formele oproepen voor verhoor of het verschaffen van documenten, waarmee in beginsel een ieder tot medewerking kan worden verplicht. Deze subpoenas konden van oudsher via 'contempt of Congress', afgeleid van de Britse parlementaire contempt, worden afgedwongen, maar deze inherente rechtsfiguur raakte in onbruik toen werd voorzien in een wettelijke contemptprocedure waarmee weigerachtige getuigen kunnen worden gestraft. Voor een veroordeling op basis van de contemptwet is wel de instemming van de plenaire vergadering vereist, alsmede - anders dan bij de inherente contemptprocedure - een rechterlijk oordeel. Commissies kunnen getuigen wel zonder tussenkomst van het plenum immuniteit laten verlenen door de rechter, waarmee hun grondwettelijke zwijgrecht wegens non-incriminatie wordt doorbroken, maar van die bevoegdheid wordt nog maar weinig gebruikgemaakt. ${ }^{5}$ Dat de intensivering van de parlementaire toezichts- en onderzoeksfunctie van de besproken stelsels het eerst in het Amerikaanse Congres op gang kwam, is op zichzelf niet verwonderlijk. In het Amerikaanse constitutionele stelsel van gescheiden machten, waar een vertrouwensrelatie tussen President en Congres ontbreekt en het gezag over de uitvoerende macht niet via ministeriële verantwoordelijkheid volledig bij de regering ligt, kan het Congres een veel zelfstandiger houding ten opzichte van de President aannemen dan in de meeste Europese parlementaire stelsels. Voorts past de keuze voor decentralisatie van de toezichts- en onderzoeksfunctie in het bredere politieke kader waarbinnen het Congres opereert. Door het van oudsher relatief zwakke partijenstelsel is de besluitvorming omtrent wetgeving en begroting altijd al tamelijk diffuus geweest en is de rol van de partijtop in beide kamers veel minder sterk dan in veel Europese stelsels. Het zwaartepunt van politieke besluitvorming bevindt zich zowel politiek als procedureel dan ook vaak in de commissies.

De Britse onderzoekscommissies, die zich in beginsel uitsluitend met controle bezighouden, zijn in 1979 ingesteld en sindsdien belast met de opdracht "to examine the expenditure, administration and policy of the principle government departments ... and associated public bodies." 6 Hier kwam de decentralisatie van de controle- en onderzoeksfunctie dus later op gang en was het gevolg van een steeds sterker wordend besef onder parlementsleden dat parlementaire controle op het bestuurlijk apparaat van belang was. Het inrichten van een stelsel van vaste onderzoekscommissies was hier echter veel minder vanzelfsprekend. Experimenten in de jaren 60 waren geen onverdeeld succes. Sceptici hadden weinig vertrouwen in het vermogen van deze op Amerikaanse leest geschoeide commissies om het regeringsoptreden kritisch te onderzoeken. Daarvoor zou de dominantie van de regering in het Britse parlementaire stelsel met een sterk ontwikkeld partijensysteem simpelweg te groot zijn: te indringend onderzoek zou immers een bedreiging voor de posi-

${ }^{4}$ Zie House Rule X, lid 1 en Senate Rule XXVI, lid 1. Zie nader Deel III, par. 2.6.1 en Deel III, par. 4.2.1.

5 Zie over de subpoena-, contempt- en immuniteitsregelingen en de betrokkenheid van de plenaire vergadering en rechter daarbij uitvoerig: Deel III, par. 2.3.

${ }^{6}$ Deze algemene onderzoeksopdracht is vastgelegd in het Kamerreglement. Zie House of Commons Standing Order No. 152 van 25 juni 1979 (laatstelijk gewijzigd: 30 juni 2010). Zie nader: Deel II, par. 3.2 . 
tie van ministers kunnen worden. Ook de regering zelf, die het stelsel in 1979 invoerde, wilde de verhoudingen niet fundamenteel veranderen en kende de commissies wel de parlementaire onderzoeksbevoegdheden toe om getuigen te verhoren en documenten op te vragen ('PPR powers'), maar liet na om een adequaat handhavingsmechanisme te creëren; dit betekent dat bij weigerachtigheid slechts kon worden teruggevallen op de figuur van 'contempt of Parliament', een verouderde procedure die geen praktische betekenis meer heeft. Dat het stelsel er hoe dan ook kwam, was voor een belangrijk deel te danken aan de inzet van een verantwoordelijk minister die overtuigd was van het nut van effectieve parlementaire controle en in de maanden na het aantreden van de regering-Thatcher kans zag zijn hervormingen door te voeren. Hij kreeg hierbij steun van de vele backbenchers die het Lagerhuis telt en die, vooral wanneer zij van de regeringspartij waren, weinig meer om handen hadden dan het trouw uitbrengen van hun stem op regeringsvoorstellen. In het Britse parlementaire stelsel is de vaststelling van overheidsbeleid (wetgeving en begroting) zowel in politieke als procedurele zin in de loop van de twintigste eeuw vrijwel volledig in handen van de regering gekomen. Van de regeringspartij, die doorgaans over een absolute meerderheid beschikt, wordt immers verwacht dat zij haar verkiezingsbeloften waarmaakt. De parlementaire processen op dit terrein zijn, in vergelijking met de Verenigde Staten (maar ook wel met Nederland), daarom sterk gecentraliseerd en verder vrij zwak ontwikkeld. Alles is erop gericht om het regeringsprogram zou efficiënt mogelijk door het parlement te loodsen. Voor veel backbenchers vormde het nieuwe commissiestelsel daarom een kans om hun parlementslidmaatschap meer inhoud te geven.

Amerikaanse en Britse commissies gebruiken hun onderzoeksrecht voor toezicht op de uitvoerende macht respectievelijk controle op de regering en het ambtelijk apparaat, maar ook in andere parlementaire taken blijkt het onderzoeksrecht van pas te komen. De meeste Amerikaanse vaste commissies hebben als gezegd niet alleen toezichthoudende taken ('oversight'), maar ook wetgevende en budgettaire. Het onderzoeksrecht, dat aan de vaste commissies is toegekend, kan dan ook voor verschillende taken worden ingezet. Een aantal commissies heeft het zuivere toezichtsonderzoek, dat los van wetgevings- of begrotingsprocedures plaatsvindt, ondergebracht in een speciale subcommissie. Dat wil echter niet zeggen dat de andere (beleids)subcommissies, zich in het geheel niet bezighouden met onderzoeksactiviteiten: ook bij het formuleren van nieuwe wetgeving en beleid is vaak sprake van evaluatie en worden hoorzittingen gebruikt om uitvoerende diensten aan de tand te voelen over hun geleverde prestaties. De Britse departementale onderzoekscommissies beschikken niet over wetgevende taken - die zijn opgedragen aan de wetgevingscommissies - en zijn in eerste instantie ingesteld ter versterking van de parlementaire controlefunctie ('scrutiny of administration'). Hoewel dit nog steeds hun hoofdtaak is, wordt van deze commissies sinds de jaren 90 wel zo nu en dan gevraagd hun licht te laten schijnen over wetsontwerpen die nog niet formeel zijn ingediend ('pre-legislative scrutiny') - al is deze ontwikkeling tot op heden van bescheiden omvang gebleven. Daarnaast beschikken de eigenlijke wetgevingscommissies, die in het Britse parlement een tijdelijk karakter hebben, sinds 2006 ook over onderzoeksbevoegdheden. Het parlementaire onderzoeksrecht in het Verenigd Ko- 
ninkrijk krijgt, naarmate het verder 'ingeburgerd' raakt, dus voorzichtig een bredere functie.

Parlementair onderzoek in de Verenigde Staten en het Verenigd Koninkrijk, zo kan worden geconcludeerd, wordt gekenmerkt door sterke institutionalisering, is in hoge mate gedecentraliseerd en vervult een functie ten aanzien van zowel controle als wetgeving. De Amerikaanse en Britse commissies worden ingesteld voor de duur van een gehele parlementaire zittingstermijn. Kenmerkend voor beide stelsels is de breed geformuleerde onderzoeksopdracht die commissies hebben meegekregen. Commissies kunnen onderzoeken verrichten ten aanzien van elk onderwerp en elke overheidsorganisatie die binnen hun werkterrein valt. In beide landen volgt het commissiestelsel in grote lijnen de organisatorische structuur van de uitvoerende macht. Het sterkst komt dit naar voren in het Verenigd Koninkrijk, waar de departementale indeling leidend is. Departementale herindelingen worden daar doorgaans gevolgd door een herziening van het commissiestelsel. Daarnaast bestaat een beperkt aantal thematische onderzoekscommissies, die niet direct aan een departement zijn gekoppeld. Ook het Hogerhuis kent sinds enige tijd een aantal onderzoekscommissies, die, om doublures te voorkomen, ook een thematische insteek hebben. Ook in de Verenigde Staten wordt gewerkt met brede beleidscommissies. Hier is de precieze afbakening van werkterreinen tussen commissies echter een meer autonoom, vanuit het Congres zelf gestuurd proces en wordt niet per definitie aangesloten bij de structuur van de uitvoerende macht. ${ }^{7}$ Overigens maakt het Amerikaanse Congres zo nu en dan nog steeds gebruik van tijdelijke onderzoekscommissies. Met name bij gebeurtenissen met een grote maatschappelijke impact, zoals het Watergateschandaal of de falende hulpverlening na de orkaan Katrina, wordt soms de behoefte gevoeld om een aparte commissie in het leven te roepen met een specifieke onderzoekstaak. In het Verenigd Koninkrijk is dit ongebruikelijk. Wel kent de Britse praktijk de figuur van het openbaar onderzoek ('public inquiry'), dat door de regering kan worden ingesteld om onderzoek te doen naar zaken die grote maatschappelijke onrust teweeg hebben gebracht. Dergelijke commissies worden vaak geleid door een oudrechter of een ander gezaghebbend persoon en beschikken over verregaande onderzoeksbevoegdheden en een groot budget. Zorgvuldig feitenonderzoek bij grote incidenten, is daarbij de gedachte, kan niet aan het parlement worden overgelaten.

Het delegeren van het onderzoeksrecht aan commissies met een breed werkterrein, zo kan uit het voorgaande worden afgeleid, zorgt in zowel de Britse als de Amerikaanse stelsels voor een grote mate van onderzoeksvrijheid. Binnen de grenzen van hun werkterrein kunnen commissies zelf bepalen hoe zij hun onderzoekstaak concreet invullen. In Nederland heeft de onderzoeksfunctie, als gezegd, op een andere wijze vorm gekregen. De intensivering (of eigenlijk: herintroductie) van parlementair onderzoek in Nederland is later op gang gekomen dan in de Verenigde Staten en het Verenigd Koninkrijk. Een structurele inbedding in de parlementaire commissiestructuur heeft hier nooit plaatsgevonden. In plaats daarvan werd de oude praktijk nieuw leven ingeblazen. In eerste instantie ging de aandacht vooral uit naar

\footnotetext{
7 Wegens de grote wetgevende en budgettaire invloed van commissies vinden voortdurend en tot in het kleinste detail onderhandelingen plaats over territoriale afbakening tussen commissies (zogenaamde 'turf wars').
} 
het enquêterecht, dat sinds 1848 in de Grondwet was verankerd en in de Wet op de Parlementaire Enquête was uitgewerkt. De besluitvormingsprocedure die hierin sinds jaar en dag was neergelegd, werd niet aangepast. De noodzakelijk wetswijzigingen werden al in 1977 doorgevoerd, maar duurde het nog tot 1983 totdat de eerste moderne enquête plaatsvond. Dit onderzoek, de RSV-enquête, werd echter gezien als een groot succes. Bij latere enquêtes werd het beproefde model voortgezet. Ook reguliere parlementaire onderzoeken zijn altijd ad hoc ingesteld, doorgaans op basis van een besluit van de kamer. In de Nederlandse traditie wordt parlementair onderzoek opgedragen aan tijdelijke commissies, eventueel toegerust met enquêtebevoegdheden, die werken op basis van een specifieke, gedetailleerde onderzoeksopdracht vastgesteld door de kamer. ${ }^{8}$ De kamer bepaalt tevens de termijn waarbinnen de commissie verslag dient uit te brengen. Nadat de commissieleden verantwoording hebben afgelegd over hun werkzaamheden wordt de commissie opgeheven. Het onderzoeksrecht fungeert in Nederland sinds 1983 hoofdzakelijk als controlemiddel, al is het niet ongebruikelijk dat onderzoekscommissies in hun eindrapport ook aanbevelingen op wetgevingsgebied doen. De vaste commissies in de Tweede Kamer, die belast zijn met de voorbereidende behandeling van wetsvoorstellen, zijn uitgerust met dezelfde onderzoeksbevoegdheden als tijdelijke (reguliere) onderzoekscommissies, zoals het houden van hoorzittingen, maar hiervan wordt slechts incidenteel gebruik gemaakt.

Tegelijkertijd is ook in Nederland de laatste jaren een voorzichtige beweging in de richting van een meer structurele inzet van het onderzoeksinstrument in gang gezet. Op advies van de parlementaire werkgroep zelfreflectie is in 2009 besloten te gaan experimenteren met een Toekomst- en onderzoeksagenda, op basis waarvan jaarlijks maximaal drie onderzoeken zullen worden uitgevoerd. ${ }^{9}$ Het kan daarbij gaan om zogenaamde uitvoeringsonderzoeken 'ex post' of toekomstverkenningen. De vaste commissies kunnen voorstellen indienen, waarna de kamer besluit welke voorstellen zullen worden gehonoreerd. Inmiddels hebben verschillende onderzoeken op deze manier plaatsgevonden. Afgewacht zal moeten worden hoe deze nieuwe vorm van onderzoeksprogrammering zich verder zal ontwikkelen.

\section{Uiteenlopende onderzoekstradities}

De Britse en Amerikaanse commissiestelsels vertonen, zoals hierboven bleek, op elementair niveau een aantal belangrijke overeenkomsten. In beide stelsels is gekozen voor een structurele inbedding van de onderzoeksfunctie middels delegatie aan vaste commissies. In Nederland is onderzoek vooral een incidentele aangelegenheid en is de besluitvorming in handen gebleven van de plenaire vergadering. Wel is het aantal onderzoeken in de afgelopen decennia sterk gestegen en is de laatste tijd een voorzichtige vorm van structurering zichtbaar (onderzoek is met de invoering van de onderzoeksagenda als het ware 'structureel-incidenteel' geworden). Wanneer nader

\footnotetext{
${ }^{8}$ Dit model is ook reglementair verankerd. Zie art. 141 jo. art. 142 RvOTK. Zie ook art. 2 RPE. In de praktijk laat de Kamer wel enige ruimte aan commissies om de onderzoeksvragen nader uit te werken of zelfs bij te stellen. Zie ook Deel I, par. 4.2.2.

${ }^{9}$ Zie Deel I, par. 3.2.3.
} 
naar de inrichting van deze drie stelsels gekeken wordt, dan komen vooral meer verschillen aan het licht. In elk stelsel is, binnen de politieke context waarin de onderzoeksfunctie wordt uitgeoefend, een geheel eigen onderzoekstraditie tot ontwikkeling gekomen.

De Britse onderzoekscommissies in het Lagerhuis tellen doorgaans 11 tot 14 leden en kunnen als relatief klein worden bestempeld. Slechts een deel van de Lagerhuisleden is lid van een onderzoekscommissie. De Amerikaanse vaste commissies tellen gemiddeld veel meer leden; Congresleden zijn doorgaans lid van meerdere commissies, aangezien daar via het wetgevings- en begrotingsproces veel invloed kan worden uitgeoefend op het federale beleid. Opvallend is echter dat het onderzoeksrecht voor een belangrijk deel in kleinere, maar vaak invloedrijke subcommissies wordt uitgeoefend. Een deel van de vaste commissies, met name in het Huis, beschikt hiertoe over een speciale toezichts- en onderzoekssubcommissie. Daarnaast kennen zowel Huis als Senaat een algemene toezichtscommissie, waar subcommissies eveneens een belangrijke rol spelen. Ook bijzondere commissies zijn van relatief klein van omvang. Zo kende de Watergatecommissie in de Senaat zeven leden. Daarom kan worden gesteld, dat veel toezichts- en onderzoekswerkzaamheden plaatsvinden in commissieverbanden van relatief kleine omvang. In dat opzicht benadert het Amerikaanse stelsel op onderzoeksgebied in de praktijk vaak het Britse.

Grote verschillen komen aan het licht wanneer de interne vormgeving van commissies in beide stelsels wordt vergeleken. In het Verenigd Koninkrijk, waar regering en parlement zowel constitutioneel als politiek sterk met elkaar verweven zijn, werd bij de inrichting van het stelsel van permanente onderzoekscommissies in het Lagerhuis veel nadruk gelegd op onafhankelijkheid, cohesie en expertisevorming. De nieuwe commissies, die zich uitsluitend met controlerend onderzoek zouden gaan bezighouden, moesten op die manier tegenwicht bieden aan de plenaire vergadering, waar de beleidsvoorstellen van de regering de agenda domineren, het partijpolitieke debat gevoerd wordt en tegenstellingen worden gearticuleerd. De bedoeling van het nieuwe commissiestelsel komt naar voren in verschillende procedurele regels en gewoonten. De verdeling van commissiezetels is evenredig aan de partijpolitieke verhoudingen in het Lagerhuis. Ook de voorzitterschappen worden op deze manier verdeeld. Procedurevergaderingen vinden plaats achter gesloten deuren. Belangrijk is verder dat partijen hebben afgesproken in beginsel alleen backbenchers, die op zekere afstand staan van de dagelijkse partijpolitiek, in aanmerking te laten komen voor benoeming in een onderzoekscommissie. In de praktijk bleken overigens de partijmanagers ('whips') een steeds grotere invloed uit te oefenen op het selectieproces. Een recente wijziging van de procedure, waarbij de voorzitters en leden van onderzoekscommissies via een geheime stemming worden verkozen door de kamer, moet hierin verandering brengen.

In het Amerikaanse stelsel van gescheiden machten, waar een vertrouwensrelatie tussen President en Congres ontbreekt, zien de interne verhoudingen en de relatie tussen commissies en de President er vaak heel anders uit. Middels de wetgevende macht en het budgetrecht drukt het Congres een zwaar stempel op het federale overheidsbeleid. Binnen het Congres zijn de vaste commissies de belangrijkste fora voor (partij)politieke besluitvorming. De wijze waarop commissies zijn ingericht en samengesteld is daarom van veel groter politiek belang dan in het Verenigd Konink- 
rijk, waar de onderzoekscommissies middels hun rapportages hooguit indirect invloed kunnen uitoefenen op beleidsvorming. In de toepasselijke regelingen en gewoonten komt dit tot uiting. De benoeming van commissieleden gebeurt formeel bij kamerbesluit, maar in de praktijk wordt de voordracht van kandidaten overgelaten aan selectiecommissies binnen de twee partijen. Bij de keuze van kandidaten spelen allerlei overwegingen een rol, waarbij ook rekening wordt gehouden met individuele wensen en belangen van congresleden. De voorzitterschappen komen toe aan de meerderheidspartij en zijn veelal in handen van invloedrijke (en ervaren) congresleden. De voorzitter vervult in politieke zin een leidende rol binnen de commissie en wordt in het commissiereglement vaak een aantal belangrijke onderzoeksbevoegdheden toegekend, zoals het dagvaarden van getuigen. Bovendien geeft de voorzitter leiding aan het grootste deel van de commissiestaf. De getalsmatige verhouding tussen meerderheids- en minderheidspartij binnen de commissies is niet reglementair vastgelegd, maar sluit in de praktijk in grote lijnen aan bij de partijpolitieke verhouding in het plenum. Bij een aantal belangrijke beleidscommissies in het Huis bestaat sinds de jaren 70 echter een trend waarbij de meerderheidspartij zich een groter aantal zetels toe-eigent.

De onderwerpskeuze en de intensiteit waarmee de Amerikaanse vaste commissies gebruik maken van hun toezichts- en onderzoeksbevoegdheden verschilt van commissie tot commissie en hangt sterk af van de ambities van de commissieleden van de meerderheidspartij, in het bijzonder die van de voorzitter. Erg belangrijk voor de samenwerking tussen commissieleden op onderzoeksgebied is ook de politieke verhouding tussen President en Congres. In het geval van 'divided government', waarbij een meerderheid in Huis of Senaat niet dezelfde politieke kleur heeft als de President, is de meerderheidspartij eerder geneigd veel en indringend onderzoek te doen naar zaken die tot de beleidsmatige prioriteiten van de President behoren. Een en ander heeft ertoe geleid dat een harmonieuze samenwerking tussen de meerderheids- en minderheidsleden binnen de commissie alles behalve vanzelfsprekend is: vaak lijkt er sprake van twee commissies in één lichaam, met eigen websites en een schaduwvoorzitter ('ranking member'), waarbij de meerderheid de koers bepaalt. Om een volledige buitensluiting van het minderheidssmaldeel te voorkomen, is in de kamerregels in zowel het Huis als in de Senaat gewaarborgd dat de minderheid over bepaalde minimale onderzoeksrechten kan beschikken, bijvoorbeeld ten aanzien van het selecteren van getuigen. De indringende onderzoeken die in het geval van 'divided government' worden gehouden, zoals in de twee jaar waarin de Democraten een meerderheid hadden in het Huis in de tweede ambtsperiode van George W. Bush de Democratische commissievoorzitters stelden het gebrek aan 'oversight' uit de voorgaande, door de Republikeinen gedomineerde congresperiodes ten aanzien van belangrijke beslissingen van de president te moeten herstellen ${ }^{10}-$, genereren veel media-aandacht en creëren een beeld van congressioneel onderzoek dat vooral functioneert als politiek strijdmiddel. Hoewel dit type congressioneel onderzoek de laatste jaren aan belang lijkt te hebben gewonnen, kent de Amerikaanse praktijk ook een traditie als het gaat om onderzoeken die in een meer collegiale, constructieve sfeer plaatsvinden. Zo blijken (sub)commissies die verder van het partijpolitieke strijdto-

${ }^{10}$ Zie nader: Deel III, par. 4.5 . 
neel staan en minder met incidenten bezig zijn, of waarvan de belangrijkste leden (voorzitter en 'ranking member') elkaar op persoonlijk of politiek vlak goed kunnen vinden, wel degelijk eensgezind te kunnen optreden bij het doen van onderzoek. Welk type onderzoek op enig moment domineert, is in hoge mate afhankelijk van de politieke context.

De samenstelling van de tijdelijke onderzoeks- en enquêtecommissies in de Nederlandse Tweede Kamer wijkt op een aantal punten af van de Britse en Amerikaanse praktijk. Met zo'n 5 tot 9 leden zijn de Nederlandse commissies in vergelijking beperkt van omvang. Het bepalen van de grootte alsmede de samenstelling van enquêtecommissies is de bevoegdheid van de Kamer. Ten aanzien van gewone onderzoekscommissies bepaalt het Reglement van Orde dat de Kamervoorzitter de omvang van de commissie bepaalt en de leden benoemt. Na instelling kiezen commissies zelf een voorzitter uit hun midden door middel van geheime stemming. In de praktijk is de selectie van commissieleden en in het bijzonder van de voorzitter, die het gezicht van de commissie is, echter voorwerp van politieke onderhandelingen tussen de Kamerfracties.

In het Nederlandse meerpartijenstelsel is het gebruikelijk dat fracties maximaal één commissielid leveren; van een afspiegeling van de partijpolitieke verhoudingen in de Kamer is dan ook geen sprake. Commissieleden worden geselecteerd in het onderhandelingsproces tussen fracties. Het is ook niet vanzelfsprekend dat de coalitiepartijen gezamenlijk een getalsmatige meerderheid binnen een onderzoekscommissie vormen. Bovendien blijkt het voorzitterschap zowel door coalitie- als oppositieleden te kunnen worden bekleed. Een en ander weerspiegelt de Nederlandse parlementaire onderzoekscultuur, die wordt gekenmerkt door een hoge mate van collegiale samenwerking en consensusgerichtheid. In die zin wijkt de onderzoekspraktijk af van de dominante modus operandi in de Tweede Kamer, waarin fractieverbanden en coalitieverhoudingen veelal leidend zijn. Het waarborgen van een coalitiegezinde meerderheid blijkt bij de samenstelling van onderzoekscommissies niet noodzakelijk te worden geacht. Ook staat het lidmaatschap van een onderzoekscommissie niet, zoals in het Verenigd Koninkrijk, uitsluitend open voor backbenchers - voor zover je al van 'backbenchers' kan spreken in het kleinere Nederlandse parlement met een meerpartijenstelsel. Bij de samenstelling wordt vooral gekeken naar persoonlijke kwaliteiten en ambities van kandidaten, waarbij op individueel niveau wel partijpolitieke gevoeligheden kunnen meespelen. Zeker bij grotere onderzoeken, waarbij commissieleden voor langere tijd worden vrijgemaakt en nog maar weinig fractietaken vervullen, ontstaat binnen commissies vaak een zekere groepsmentaliteit. Onwrikbaar is die overigens zeker niet: met name wanneer het aankomt op het formuleren van conclusies en aanbevelingen - en dan vooral wanneer het optreden van individuele bewindspersonen aan de orde is - kunnen partijaffiliaties weer de boventoon gaan voeren.

\section{Nederland: meer onderzoek gewenst?}

In de voorgaande paragrafen zijn de voornaamste kenmerken van de parlementaire onderzoeksfunctie in Nederland, het Verenigd Koninkrijk en de Verenigde Staten geschetst en tegen elkaar afgezet. De wijze waarop het Britse parlement en het Ame- 
rikaanse Congres hun onderzoeksrecht in institutionele zin hebben vormgegeven, zo kan daaruit worden afgeleid, heeft de onderzoeksfunctie van beide parlementen in kwantitatieve zin een stevige impuls gegeven. In Nederland vertoont het aantal parlementaire onderzoeken dat sinds de heropleving van het onderzoeksrecht in de jaren 80 heeft plaatsgevonden weliswaar een stijgende lijn, maar de onderzoeksfunctie van de Nederlandse Tweede Kamer is in vergelijking met de andere stelsels nog altijd van bescheiden omvang. De vraag is daarom of er, gelet op de ervaringen in het Verenigd Koninkrijk en de Verenigde Staten, redenen zijn om de onderzoeksfunctie van het Nederlandse parlement te versterken en zo ja, of die stelsels daarvoor aanknopingspunten kunnen bieden.

\subsection{Parlement als tegenwicht}

De opkomst van parlementair onderzoek in Nederland, het Verenigd Koninkrijk en de Verenigde Staten in de loop van de twintigste eeuw, zo werd aan het begin van deze beschouwing al gememoreerd, kwam voor een belangrijk deel voort uit een verlangen naar versterking van het parlement ten opzichte van het bestuurlijkuitvoerend apparaat. Dat apparaat had in alle drie de stelsels een sterke groei doorgemaakt. Als gevolg van de opbouw van de verzorgingsstaat nam het aantal overheidstaken op terreinen als sociale zekerheid, volkshuisvesting, ruimtelijke ordening, werkgelegenheid, onderwijs en gezondheidszorg toe. De maatschappelijke problematiek, waarmee de overheid zich geconfronteerd zag, werd bovendien steeds complexer van aard. Dat groeiende takenpakket ten aanzien van steeds complexer wordende maatschappelijke vraagstukken leidde ertoe dat binnen het bestuurlijk apparaat, dat belast was met de voorbereiding en uitvoering van het overheidsbeleid, steeds specialistischer wordende kennis en expertise werd opgebouwd. Hiermee kwam het bestuur op een informatievoorsprong. Wilde het parlement, zo was de gedachte, hieraan effectief tegenwicht kunnen bieden, dan moest het werken aan een versterking van de eigen informatiepositie. Deze gedachte kwam als gezegd het eerst tot ontwikkeling in de Verenigde Staten, waar de verlichte ideeën rondom machtsverdeling en 'checks and balances' altijd al grote invloed hebben gehad op de constitutionele ontwikkeling. Later volgden het Verenigd Koninkrijk en Nederland.

Wanneer de ontwikkelingen in de drie stelsels worden vergeleken, dan kan worden geconstateerd dat het Amerikaanse Congres en het Britse parlement veel verder zijn gegaan in het versterken van de eigen informatiepositie dan het Nederlandse parlement. In het voorgaande is reeds gewezen op de structurele wijze waarop het onderzoeksrecht in de parlementen van de Verenigde Staten en het Verenigd Koninkrijk is ingebed door vaste (onderzoeks)commissies in te stellen en deze een vrije, doorlopende onderzoeksopdracht te verlenen. Daar kwam bij dat deze permanente commissies de beschikking kregen over een vaste commissiestaf, waarin vakdeskundigen een belangrijke plaats innemen. Bovendien werd het parlement als geheel voorzien van eigen, professionele onderzoeksdiensten die de commissies in hun toezichts- en onderzoekswerkzaamheden ondersteunen. Het Amerikaanse Congres loopt hierin al jaren voorop, maar ook in het Britse Lagerhuis is met de oprichting van de Scrutiny Unit het belang van een flexibel inzetbare, centrale onderzoeksvoorziening erkend. 
Het Nederlandse parlement loopt in vergelijking dus achter. Het belang van een sterke parlementaire informatiepositie is echter ook hier nog steeds onverminderd groot. Onder invloed van technologische ontwikkelingen, maar ook processen als europeanisering en globalisering is het overheidsbestuur de afgelopen decennia immers alleen maar gecompliceerder geworden. Wat wellicht wel is veranderd, is de aard van de informatieproblematiek waarmee het parlement kampt. Door de digitale revolutie is de daadwerkelijke beschikbaarheid van informatie voor het parlement immers vaak niet meer het probleem. Wanneer informatie niet vanzelf het parlement bereikt, dan beschikt het parlement over relatief sterke informatierechten, zeker in vergelijking met het Britse parlement. Hoewel de toegang tot informatie daarmee niet altijd af te dwingen is - met name het belang van de staat blijkt, als het erop aankomt, een effectief verweermiddel voor de regering - verlenen ministers en ambtenaren doorgaans medewerking aan parlementaire onderzoeken. Veeleer is het daarom de vraag hoe de stroom aan informatie die het parlement gevraagd en ongevraagd bereikt effectief en efficiënt kan worden verwerkt en ingezet. ${ }^{11}$ Niet het verkrijgen van informatie als zodanig, maar effectieve vormen van kennis- en expertiseopbouw binnen het parlement zijn daarom van belang.

Die kennis en expertise zijn wel aanwezig maar bevinden zich veelal buiten het parlement, bijvoorbeeld binnen de Algemene Rekenkamer en andere onafhankelijke adviescolleges en planbureaus die bij wet zijn ingesteld. Naast de rapporten die deze instellingen op eigen initiatief vervaardigen, wordt hen vanuit de Kamer soms gericht om advies gevraagd. Ook maakt de Kamer met enige regelmaat gebruik van de mogelijkheid om onderzoeksopdrachten uit te besteden aan externe onderzoeksinstituten of universiteiten. Erg systematisch gebeurt dit niet, maar nog problematischer is dat de bestaande parlementaire infrastructuur thans onvoldoende mogelijkheden biedt om deze bronnen van kennis zo in te zetten, dat zij een werkelijke bijdrage kunnen leveren aan het versterken van de parlementaire informatiepositie. De Kamer beschikt over een stelsel van vaste commissies, maar die zijn van relatief grote omvang en vertonen weinig interne samenhang: commissieleden stellen zich meestal op als vertegenwoordigers van hun fracties. Hoewel de commissies over een aantal reguliere onderzoeksbevoegdheden beschikken, zoals het houden van hoorzittingen, wordt hiervan slechts bij uitzondering gebruikgemaakt. In plaats daarvan domineert het partijpolitieke debat tussen commissieleden en de aanwezige bewindspersonen. Aangezien de commissies in eerste instantie bedoeld zijn voor de voorbereidende behandeling van wetsvoorstellen, wordt de commissieagenda grotendeels bepaald door de stroom wetsontwerpen en beleidsnota's van regeringswege. Ook in die zin verschilt het karakter van de vaste commissies niet veel van dat van de plenaire vergadering. Voor zover er sprake is van expertiseopbouw, is die vooral gelegen in de persoonlijke kennis en interesse van individuele commissieleden en hun persoonlijke medewerkers. De onderzoekscommissies die de Kamer zo nu en dan instelt, blijken hiervoor veel beter ingericht, maar door hun tijdelijke karakter gaat veel kennis na afloop van het onderzoek weer verloren. Het eigen onderzoeksbureau, dat de Kamer sinds 2002 kent, is van beperkte omvang en houdt zich vooral bezig met onderzoeksbegeleiding. Het ontbreekt de Kamer daarom niet alleen aan de noodzakelijke voor-

11 Zie ook Rapport parlementaire zelfreflectie 2009, p. 45. 
zieningen om kennis en expertise op te bouwen, maar ook om deze behouden: van een institutioneel geheugen is nauwelijks sprake. Met de steeds korter wordende 'omlooptijd' van Kamerleden neemt dit probleem bovendien alleen maar toe.

\subsection{Parlement als verantwoordingsforum}

Naast de functie van het parlement als tegenwicht, kan het parlement in alle besproken stelsels ook gezien worden als een forum voor publieke verantwoording. Vanuit dat perspectief dient het parlement als een democratisch gelegitimeerd forum waar publieke actoren verantwoording af te leggen over de wijze waarop zij met hun verantwoordelijkheden zijn omgegaan. Zo beschouwd kan - zoals in het model van Bovens - gesproken worden van een verantwoordingsrelatie tussen een actor en een forum, waarbij de actor verplicht is niet slechts inlichtingen over het gevoerde beleid of de verrichtte handelingen te verschaffen, maar deze ook te motiveren en zo te nodig verdedigen. Daar staat tegenover dat het forum beschikt over mogelijkheden om vragen te stellen en een oordeel uit te spreken. Bovendien loopt de actor in een dergelijke relatie de kans te worden geconfronteerd met enige vorm van sanctionering. ${ }^{12}$

Wanneer dit kader op de relatie tussen regering en parlement wordt toegepast, dan vertonen met name de Britse en Nederlandse stelsels, waar de ministeriële verantwoordelijkheid als constitutioneel beginsel leidend is, op dit punt veel overeenkomsten. In de politiek dominante kamers, het Britse Lagerhuis en de Nederlandse Tweede Kamer, is de plenaire vergadering van oudsher de plaats waar ministers verantwoording afleggen over het handelen van henzelf en van de aan hen ondergeschikte ambtelijke dienst. Het vragenrecht en het debatrecht (of interpellatierecht) fungeren daarin als de belangrijkste instrumenten om de ministeriële verantwoordelijkheid te activeren, terwijl het opzeggen van vertrouwen als de meest verregaande vorm van sanctionering geldt. Wanneer gekeken wordt naar andere verbanden die binnen deze parlementen een zekere forumfunctie vervullen, dan vertonen de stelsels belangrijke verschillen. In het Nederlandse stelsel van vaste commissies, dat bedoeld is om de behandeling van wetsvoorstellen voor te bereiden en met ministers te overleggen over beleidsvoornemens, is ook gelegenheid voor het afleggen van verantwoording, maar de wijze waarop dat gebeurt verschilt niet wezenlijk van de wijze waarop dat in de plenaire vergadering gebeurt. Hoewel departementsambtenaren wel kunnen deelnemen aan commissievergaderingen, doen zij dit alleen op instructie van de verantwoordelijke bewindspersoon. In de praktijk betekent dit, dat ambtenaren alleen in het bijzijn van ministers of staatssecretarissen een bijdrage leveren. De vaste commissies werken, zoals al eerder gezegd, weinig onderzoeksgericht, worden gedomineerd door partijpolitiek debat, laten zich veelal sturen door de informatie die van regeringszijde wordt verstrekt en vertonen bovendien weinig interne samenhang.

In het Britse Lagerhuis daarentegen hebben de permanente, langs departementale lijnen gestructureerde onderzoekscommissies de functie van verantwoordingsforum in de loop der tijd voor een belangrijk deel overgenomen van de plenaire vergadering. Daarmee heeft het verantwoordingsproces in het Britse parlement een

12 Zie Bovens 2007, p. 450. Zie ook Verhey \& Claes 2008, p. 11. 
ander karakter gekregen. Omdat deze commissies niet werken op basis van debat maar in de vorm van onderzoek, is er ruimte voor meerdere publieke actoren: naast ministers nemen ook departementsambtenaren en bestuurders van zelfstandige bestuursorganen deel. Zij treden veelvuldig op tijdens hoorzittingen. Hoewel departementsambtenaren dat ook in het Britse parlement alleen doen op aanwijzing van hun minister, weerhoudt hen dan in de praktijk niet om ruimhartig en tamelijk zelfstandig medewerking te verlenen aan parlementaire onderzoeken. Belangrijk is ook dat het verantwoordingsproces in commissies ten opzichte van plenaire debatten vaak veel minder partijpolitiek gekleurd is - commissieleden werken over partijgrenzen heen samen en vertonen vaak een zekere saamhorigheid - en daarom minder antagonistisch van aard is. Alleen het gebrek aan sanctiemogelijkheden maakt dat de plenaire vergadering vanuit verantwoordingsperspectief uiteindelijk onmisbaar blijft, al kunnen commissies allerlei andere middelen, bijvoorbeeld via 'naming en shaming', inzetten om gebrekkig functioneren van ministers en departementen informeel te sanctioneren. De opkomst van onderzoekscommissies in het Lagerhuis heeft er in elk geval voor gezorgd dat het parlement vanuit verantwoordingsperspectief twee gezichten heeft gekregen: enerzijds er is het traditionele, overwegend partijpolitieke (vaak antagonistische) debat tussen ministers en (oppositie)leden in de plenaire vergadering, anderzijds een overwegend collegiale, breder toegankelijke, op onderzoek gerichte werkwijze in de commissies.

Met de opkomst van onderzoekscommissies is het verantwoordingsproces in het Britse Lagerhuis dus pluriformer geworden. Uit de Britse literatuur blijkt verder dat de commissies ervoor hebben gezorgd dat het parlementaire verantwoordingsproces inhoudelijker en zorgvuldiger is geworden. In de commissies verloopt het proces 'evidence-based': mondelinge en schriftelijke bewijsgaring is leidend. Hierdoor wordt een zekere mate van objectiviteit ingebouwd en krijgt het proces meer diepte. Ook de onderwerpkeuze draagt daaraan bij: onderwerpen met veel partijpolitieke gevoeligheden worden doorgaans vermeden in het belang van de interne samenhang. In de Tweede Kamer verloopt het verantwoordingsproces, afgezien van de incidentele onderzoeken, nog steeds hoofdzakelijk in de vorm van debatten en overleggen waaraan in beginsel alleen Kamerleden en ministers deelnemen. Meer onderzoek kan het verantwoordingsproces ook in Nederland verbreden en verdiepen. Hoewel het plenaire debat nooit kan worden vervangen als het ultieme verantwoordingsforum, kunnen onderzoekscommissies op dit punt een waardevolle aanvullende functie vervullen. Veel parlementaire onderzoeken die de Kamer sinds 1983 heeft gehouden, laten dit ook zien. Bij de verbreding van het verantwoordingsproces via de parlementaire onderzoeksfunctie kan, zoals in het Verenigd Koninkrijk13, ook de controle op zelfstandige bestuursorganen worden versterkt. In het reguliere parlementaire verantwoordingsproces is sprake van een staatsrechtelijke leemte, omdat deze organen op afstand van de minister zijn geplaatst. Via parlementair onderzoek, waarin bestuurders van zelfstandige bestuursorganen zelf tekst en uitleg geven omtrent het optreden van hun organisaties, kan deze leemte tot op zekere hoogte wor-

${ }^{13}$ Zie Deel II, par. 2.4.5. 
den opgevuld. ${ }^{14}$ Parlementair onderzoek kan daarmee ook een bijdrage leveren aan de legitimiteit van het overheidsoptreden in algemene zin en dat van zbo's in het bijzonder.

\subsection{Parlement als 's lands vergaderzaal}

De Tweede Kamer is het enige direct democratisch gelegitimeerde orgaan op landelijk niveau. Het is daarom in eerste instantie in de Kamer, 's lands vergaderzaal, waar de democratie gestalte krijgt. In de hedendaagse gedachtevorming over democratie gaat het al lang niet meer alleen om het tellen van stemmen en het vormen van meerderheden. Minstens zo belangrijk is het proces dat daaraan vooraf gaat. Dat proces vindt plaats in een 'public sphere', waarin de participatie van burgers centraal staat en discussie en overleg worden gefaciliteerd. Effectieve participatie en zorgvuldige deliberatie, zo is de gedachte, kunnen een bijdrage leveren aan de kwaliteit van het debat en het bijeenbrengen van verschillende opvattingen en voorkeuren, waardoor het bereiken van consensus wordt bevorderd. ${ }^{15}$ In het hedendaagse constitutionalisme, zo stelt Morison, staan daarom niet langer de traditionele instituties centraal, maar draait het om "guaranteeing fair procedures, including free and equal access to the relevant deliberative arenas for the purposes of establishing procedures, setting the agenda, and making the final decision." 16 In de meest verregaande gedachtenvorming over democratische vernieuwing op het gebied van participatie en deliberatie worden de gevestigde instituties van de representatieve democratie dan ook eerder als obstakel dan als oplossing gezien. De ervaringen met parlementair onderzoek in de hier besproken stelsels laten echter zien, dat ook binnen de traditionele parlementaire democratie ruimte voor verbetering bestaat.

Het Britse parlement lijkt op dit punt vergelijkenderwijs de meeste ontwikkeling te hebben doorgemaakt. De onderzoeksprocedure die binnen de departementale onderzoekscommissies gebruikelijk is geworden, is overzichtelijk en toegankelijk vormgegeven. Aangezien de commissies niet beschikken over effectieve dwangmiddelen, zijn zij voor hun informatievoorziening sterk afhankelijk van de vrijwillige medewerking van informatiebezitters. Daarbij gaat het niet alleen om de regering, maar ook om derden zoals belanghebbenden en deskundigen. De onderzoeksaanpak lijkt daarop te zijn ingericht. Kort na hun installatie aan het begin van een parlementaire zittingsperiode stellen de commissies een globale onderzoeksagenda vast, waarin de belangrijkste thema's die de commissies op hun eigen werkterrein willen gaan belichten worden aangeduid. Deze agenda's geven een indruk van de inhoudelijke voorkeuren van de commissieleden, in het bijzonder van de voorzitters. Dit geeft belanghebbenden, deskundigen en andere geinteresseerden de mogelijkheid om daarop te anticiperen. De uitvoering van een concreet onderzoek start met de vaststelling van een voorlopig onderzoekskader ('terms of reference'), dat tevens een globaal tijdpad bevat. Via persberichten en de commissiewebsite wordt het onder-

\footnotetext{
${ }^{14}$ De bestaande wettelijke en reglementaire kaders bieden daartoe voldoende ruimte. Zie Deel I, par. 2.5.2.2.

15 Zie ook Enthoven 2011, p. 628-630, die spreekt over 'Democratie 2.0'.

${ }^{16}$ Morison 2007, p. 149.
} 
zoek bekendgemaakt en wordt een 'call for evidence' uitgevaardigd. In aanvulling daarop wordt vaak een gedetailleerde vraagpuntennota ('issues and questions paper') gepubliceerd, waarop potentiële respondenten in het bijzonder zouden moeten ingaan. Daarnaast worden specifieke belangengroepen en deskundigen ook direct benaderd door de commissie met het verzoek om feitelijke informatie te verstrekken of hun opvattingen kenbaar te maken.

Deze methode van informatievergaring is veel minder gebruikelijk in de Amerikaanse en Nederlandse onderzoekspraktijk. Nederlandse parlementaire onderzoekscommissies gaan in de beginfase van het onderzoek hoofdzakelijk zelf op zoek naar informatie, waarbij vaak een deel van het veldwerk ook nog wordt uitbesteed aan externe onderzoeksinstanties. Het onderzoeksproces voltrekt zich in deze fase bovendien veelal in een zekere afzondering en teruggetrokkenheid. Na de inlichtingenfase bepalen commissies, mede aan de hand van besloten interviews en voorgesprekken, welke personen in het openbaar worden gehoord. Het gehele proces maakt een veel minder toegankelijke indruk dan het Britse voorbeeld. Dat geldt in zekere zin ook voor de Amerikaanse praktijk. De onderzoeksaanpak verschilt daar van commissie tot commissie en kent geen geijkte vorm, waardoor het proces voor buitenstaanders over het algemeen tamelijk ondoorzichtig is. Alleen goed ingevoerde partijen, zoals professionele lobbyisten, kennen de weg in de commissievertrekken rondom het Capitool goed. Wel vormen de commissies door hun permanente aanwezigheid een duidelijk aanspreekpunt en zijn individuele commissieleden door Amerikaanse traditie van 'constituency service' en de uitgebreide stafondersteuning relatief goed zichtbaar en bereikbaar.

Het Britse voorbeeld toont aan dat het onderzoeksinstrument mogelijkheden biedt om een van oudsher nogal gesloten en naar binnengekeerd parlement op transparante wijze toegankelijk te maken voor belanghebbende, deskundige of anderszins geïnteresseerde buitenstaanders. ${ }^{17}$ De Britse ervaringen hebben laten zien dat het actief betrekken en verwerken van kennis, expertise en opvattingen vanuit verschillende maatschappelijke bronnen een belangrijke meerwaarde is die parlementair onderzoek te bieden heeft. Britse commissies richten zich vaak op het inventariseren, analyseren en beoordelen van reeds bestaande kennis en ideeën die in de samenleving aanwezig zijn. De nadruk ligt daarbij niet zozeer op het (laten) doen van gedetailleerd feitenonderzoek, zoals bij veel Nederlandse parlementaire onderzoeken het geval is. In Nederland krijgt het feitenonderzoek nog een extra zware lading, wanneer de Kamer 'waarheidsvinding' ten doel heeft gesteld. Met name bij enquêtes is dat het geval. Dergelijke hooggespannen doelstellingen worden in het Verenigd Koninkrijk doorgaans vermeden, al betekent dat niet dat parlementaire onderzoeksrapporten daarmee niet invloedrijk kunnen zijn. ${ }^{18}$ Vanuit democratisch

\footnotetext{
17 Natuurlijk is de praktijk weerbarstig: net als in de Verenigde Staten spelen in de Britse onderzoekspraktijk gevestigde belangen met hun goede contacten en ervaring vaak een hoofdrol. Wel proberen commissies hun bereik op allerlei manieren te verbreden, bijvoorbeeld door gebruik te maken van moderne communicatietechnieken.

18 De effectiviteit van parlementaire onderzoeken, in de zin van de invloed op de beleidsvorming, hangt niet alleen af van de kwaliteit van de onderbouwing van conclusies en aanbevelingen, maar ook van factoren als context en timing, zo blijkt bijvoorbeeld uit het onderzoek van Russell en Benton. Zie Russell \& Benton 2011, p. 73 e.v. Zie ook hierboven, Deel II, par. 4.7.2.
} 
perspectief kan de Britse onderzoekspraktijk vooral worden gezien als een manier waarop het parlement kan gaan fungeren als de centrale plaats waar verschillende ideeën, opvattingen en belangen vanuit de samenleving samenkomen, worden afgewogen, geanalyseerd en van een politieke beoordeling worden voorzien. Dit type parlementair onderzoek komt ook in Nederland wel voor, zowel in de tijdelijke onderzoekscommissies als in beperkte mate in de vaste commissies, maar zou in het belang van de participatie- en deliberatietaak van het parlement verder moeten worden uitbouwd. ${ }^{19}$ Waar het dan vooral op aankomt, is het creëren van een toegankelijk, inzichtelijk en gestructureerd onderzoeksproces.

\section{Beperkingen}

Parlementair onderzoek kan een belangrijke bijdrage leveren aan het verbeteren van de parlementaire informatiepositie, zo is hierboven uiteengezet, waardoor het parlement beter in staat is zijn tegenwichtfunctie waar te maken. Onderzoek kan daarnaast bijdragen aan een pluriformere publieke verantwoording in het parlement, alsmede de mate van participatie en deliberatie binnen het parlement verbeteren.

De vraag die aan het slot van deze beschouwing centraal staat, is of de parlementaire onderzoeksfunctie in Nederland verder zou kunnen worden ontwikkeld aan de hand van ervaringen uit het Verenigd Koninkrijk en de Verenigde Staten. Om die vraag te kunnen beantwoorden, is het van belang om eerst te bezien in hoeverre het Nederlandse parlementaire stelsel voor een dergelijke intensivering ruimte zou bieden. Het staatsrecht vormt hier geen belemmering, zo bleek hiervoor al. ${ }^{20}$ Het onderzoeksrecht is in Nederland breed van aard. Wanneer de Kamer enquêtebevoegdheden aan een onderzoekscommissie wil toekennen, dan gelden daarbij uiteraard de bepalingen in de Wet op de parlementaire enquête. De wet geeft de Kamer echter veel vrijheid, bijvoorbeeld als het gaat om het bepalen van het onderzoeksonderwerp. Belangrijk is verder dat de regering, of het nu gaat om een enquête of een regulier onderzoek, in beginsel verplicht is om parlementaire commissies medewerking te verlenen waar het gaat om het verstrekken van mondelinge en schriftelijke inlichtingen. Helemaal absoluut is die medewerkingsplicht echter niet. Het 'belang van de staat', zoals bedoeld in artikel 68 Grondwet en artikel 19 Wpe, vormt bij zowel enquêtes als reguliere onderzoeken een belangrijke beperkingsgrond. Ministers en ambtenaren kunnen op grond daarvan bepaalde inlichtingen slechts op vertrouwelijke basis verstrekken, alleen ter inzage geven of, in het uiterste geval, in het geheel geen kennisname toestaan. Het recht biedt, indien de commissie zich niet kan vinden in het standpunt van de regering, geen mogelijkheden om medewerking

\footnotetext{
19 Tegelijkertijd wordt in de Britse discussie, waarin dit type onderzoek dus reeds sterk ontwikkeld is, door sommigen juist gepleit voor meer origineel, uitbesteed onderzoek, bijvoorbeeld het laten uitvoeren van publieksenquêtes. Ook met een dergelijke intensivering zal de betekenis van uitbesteed onderzoek vermoedelijk van bescheiden omvang blijven vergeleken met de Nederlandse praktijk. Zie ook hierboven, Deel II, par. 4.7.3.

${ }^{20}$ Zie paragraaf 2 van deze beschouwing.
} 
alsnog af te dwingen. ${ }^{21}$ Die beperking kan daarom een zwaar beslag leggen op een parlementair onderzoek. ${ }^{22}$

Vanuit organisatorisch oogpunt moet om te beginnen worden gewezen op de omvang van de Nederlandse Tweede Kamer, die in de vergelijking met zijn Britse en Amerikaanse zusterinstituten beperkt is. Er zijn alleen al in absolute aantallen simpelweg minder parlementariërs beschikbaar die zich met onderzoek kunnen bezighouden. Verder zorgt het Nederlands meerpartijenstelsel voor praktische beperkingen. De fracties zijn veel kleiner dan die in het Verenigd Koninkrijk en de Verenigde Staten. Fractieleden moeten verschillende parlementaire functies vervullen, waarbij woordvoerderstaken veel tijd en aandacht vergen. Het aantal Kamerleden dat beschikbaar kan (of wil) worden gemaakt voor onderzoekstaken is daarom niet groot - anders dan bijvoorbeeld in het Verenigd Koninkrijk, waar een groot aantal backbenchers weinig omhanden had voordat de huidige onderzoekscommissies werden ingesteld. De langzame afkalving van de drie traditionele middenpartijen heeft voor een politieke versplintering in de Kamer gezorgd, die het aantal voor onderzoek beschikbaar Kamerleden alleen maar verder heeft doen verminderen. ${ }^{23}$

Naast praktische beperkingen zijn er ook politieke. Parlementaire onderzoekscommissies in Nederland bestaan van oudsher uit vertegenwoordigers van een veelheid aan partijen. De meerwaarde ligt vooral in de inhoudelijke aanpak, waarin het verzamelen en analyseren van (bewijs)materiaal centraal staat en waarmee partijpolitieke verschillen kunnen worden overbrugd. Ook in de Amerikaanse en Britse tweepartijenstelsels hebben de grote fracties, ieder op hun eigen manier, te maken met interne verdeeldheid en factievorming, waardoor samenwerking tussen parlementsleden ingewikkeld kan zijn. Toch gaat het daar uiteindelijk om vertegenwoordigers van twee (à drie) brede stromingen; in Nederland moet in de praktijk consensus worden bereikt door leden van zes of zeven gedisciplineerde fracties met een relatief sterk ideologisch profiel.

Of dit in de praktijk zal lukken, hangt weer af van verschillende factoren die van invloed zijn op de vraag of de noodzakelijke politieke wil om samen te werken kan worden gevonden. Bij onderwerpen die voor veel maatschappelijke beroering hebben gezorgd - grote misstanden, rampen, schandalen - blijken commissieleden vanuit een gedeeld gevoel van urgentie vaak goed te kunnen samenwerken. Dat wil zeggen, zolang het (nog) niet gaat om het beoordelen van het handelen van politieke ambtsdragers. De grootste kans op consensus ligt echter bij onderzoeksonderwerpen

\footnotetext{
21 Zie Deel I, par. 2.5.3.

22 De recente parlementaire enquête naar het financieel stelsel (enquêtecommissie-De Wit) liet zien welke gevolgen een beroep op het belang van de staat met zich meebrengen. Bij dat onderzoek werd een groot deel van het benodigde materiaal, afkomstig van het ministerie van Financiën en de financiële toezichthouders, wegens toezichtsgevoeligheid onder voorwaarde van strikte vertrouwelijkheid verstrekt of alleen ter inzage gegeven. De verstrekking verliep moeizaam, waardoor de commissie veel vertraging opliep. Ook kon de commissie in haar eindrapport niet naar die informatie verwijzen. Zie verder Deel I, par. 2.5.3.2 en Deel I, par. 4.7.2.2.

${ }^{23} \mathrm{Al}$ heeft de meest recente verkiezingsuitslag (september 2012), waarbij PvdA en VVD een onverwacht sterke groei doormaakten, weer even voor een zekere concentratie gezorgd. Aangezien bij deze fracties niet iedereen een belangrijk woordvoerdersschap zal kunnen worden toegewezen, zal een aantal leden waarschijnlijk de facto de rol van 'backbencher' vervullen.
} 
met een lage partijpolitieke gevoeligheid, waar het lot van individuele ministers of de kern van het regeringsbeleid niet direct in het geding zijn. Daarbij kan gedacht worden aan het systematisch evalueren van beleidsprogramma's die meerdere kabinetsperiodes bestrijken of het in kaart brengen van mogelijke toekomstige beleidsthema's. De nieuwe Toekomst- en onderzoeksagenda die de Tweede Kamer sinds 2009 hanteert, kan worden gezien als een poging om te voorzien in een behoefte aan dergelijke vormen van onderzoek. Welke onderwerpen concreet in aanmerking komen voor parlementair onderzoek, hangt, naast de hiervoor genoemde constitutioneel-wettelijke beperkingen, uiteindelijk vooral af van de politieke interesse van Kamerleden. Wat parlementair onderzoek onderscheidt van andere vormen van onderzoek, is de politieke duiding (of: lading) die parlementaire commissies aan onderzoeksresultaten kunnen geven. Die meerwaarde ontstaat alleen als Kamerleden gemotiveerd zijn om het onderzoek te verrichten. Zonder politiek draagvlak komt er van de geschetste kansen op het gebied van tegenwicht, verantwoording, participatie en deliberatie weinig terecht. ${ }^{24}$

\section{Denkrichtingen}

Op welke wijze zou, met inachtneming van de hierboven geschetste praktische en politieke beperkingen, de onderzoeksfunctie van het Nederlandse parlement verder kunnen worden uitgebouwd? Het gaat hierbij om een vraag van organisatorische aard, die ook politiek-juridische kanten heeft. Hieronder worden twee mogelijke denkrichtingen uitgewerkt.

\subsection{Eerste denkrichting: verbetering coördinatie}

De eerste richting die zou kunnen worden verkend betreft het zoeken naar manieren om het parlementaire onderzoeksrecht op meer systematische, structurele en gecoördineerde wijze in te zetten dan nu het geval is. In het verleden zijn hiertoe, in breder verband, reeds enkele voorstellen gedaan. Zo pleitte Van Schagen in 1994 al voor de invoering van een algemene controlecommissie, naast een wetgevings- en een begrotingscommissie, die zich toelegt op het coördineren van controleactiviteiten door de vaste commissies. Deze algemene commissie zou als een soort permanente onderzoekscommissie moeten gaan fungeren. ${ }^{25}$ Verhey deed een voorstel in dezelfde richting. Naar het voorbeeld van de Liaison Committee in het Britse Lagerhuis zou de Kamer een commissie kunnen instellen die een coördinerende rol zou kunnen spelen bij het selecteren van beleidsthema's waarop de Kamer zich gedurende een bepaalde periode zal concentreren. De uitvoering zou volgens Verhey zoveel mogelijk binnen het bestaande stelsel moeten plaatsvinden. Dit kan deels door toepassing van bestaande instrumenten en procedures, uitbesteding van onderzoek, maar ook door meer parlementair onderzoek. Daarbij moet dan niet direct aan grootschalige enquê-

\footnotetext{
${ }^{24}$ Het risico is zelfs dat onderzoek vooral ambtelijk gestuurd wordt, commissieleden de regie verliezen. In de Verenigde Staten is dit een belangrijk kritiekpunt in de bestaande onderzoekspraktijk. Zie Deel III, par. 3.4.1.4.

${ }^{25}$ Van Schagen 1994, p. 295-299.
} 
tes of onderzoeken worden gedacht, maar aan lichtere vormen met verschillende intensiteit. Dit kan het beste aan de bestaande (vaste) commissies worden overgelaten, waarbij de werkwijze van de Britse select committees aanknopingspunten zou kunnen bieden. ${ }^{26}$

Met de invoering van de eerder genoemde Toekomst- en onderzoeksagenda heeft de Tweede Kamer een eerste stap in deze richting gezet. De Commissie voor de Rijksuitgaven maakt jaarlijks een selectie uit de voorstellen die de fracties via de vaste commissies indienen, waarbij onder meer gekeken wordt naar de toegevoegde waarde ervan. De onderzoeksagenda komt overigens niet in de plaats van de bestaande praktijk om ad hoc grotere (enquête)onderzoeken in te stellen. Zij is bedoeld als een inhoudelijke aanvulling op de bestaande onderzoekspraktijk, die meestal reactief van aard is en zich vaak richt op actuele kwesties of specifieke gebeurtenissen. ${ }^{27}$ Uitgangspunt blijft echter, dat parlementair onderzoek wordt uitgevoerd door tijdelijke commissies met een redelijk vastomlijnde, door de Kamer bepaalde onderzoeksopdracht.

Met de nieuwe onderzoeksagenda is het onderzoeksinstrument op een meer structurele manier onderdeel geworden van de dagelijkse parlementaire werkzaamheden. Ook draagt de ingestelde procedure bij aan de gewenste coördinatie en systematisering van het onderzoekswerk dat in de Kamer wordt verricht. Hoewel deze innovatie daarom op zichzelf kan worden toegejuicht, kent zij tegelijkertijd een aantal inherente beperkingen. Zo betreft het allereerst een tamelijk bescheiden vernieuwing. Er is vanuit praktisch oogpunt uiteraard een grens aan het aantal onderzoekscommissies dat de Kamer op enig moment draaiende kan houden. De huidige onderzoeksagenda gaat uit van maximaal drie onderzoeken, naast de eventuele incidentele enquêtes of onderzoeken die de Kamer kan instellen. Gezien de omvang van de Kamer en van haar vaste ondersteuning lijkt daarmee het maximum wel bereikt. Verder heeft het onderzoeksinstrument, ondanks de meer gesystematiseerde besluitvorming en structurele inzet, nog steeds een incidenteel karakter. De geplande onderzoeken worden immers nog steeds bij voorkeur uitgevoerd door tijdelijke commissies. Ook blijft de toepassing van het onderzoeksinstrument, anders dan in het Verenigd Koninkrijk en de Verenigde Staten, uiteindelijk steeds afhankelijk van centrale, Kamerbrede besluitvorming. ${ }^{28}$ Dergelijk centralisme, zowel ten aanzien van de onderzoeksthema's als ten aanzien van de instelling van commissies, moge aantrekkelijk zijn vanuit het oogpunt van coördinatie, tegelijkertijd schuilt hierin een belangrijke hindernis voor de hiervoor bepleite groei van de parlementaire onderzoeksfunctie.

\footnotetext{
${ }^{26}$ Verhey 2001a, p. 34. Zie ook Verhey 2001b, p. 320-321. Ook Enthoven lijkt in deze richting te wijzen. Zie Enthoven 2011, p. 620.

27 Zie Deel I, par. 3.2.3.

${ }^{28}$ Ook in de eerder genoemde hervormingsvoorstellen van Van Schagen en Verhey blijft dit het uitgangspunt.
} 


\subsection{Tweede denkrichting: decentralisatie}

Op basis van de Britse en Amerikaanse ervaringen kan een tweede denkrichting worden gevolgd, waarbij gekeken wordt naar de mogelijkheid van de vorming van vaste onderzoekscommissies over verschillende werkterreinen. De Kamer zou haar onderzoeksrecht aan die commissies kunnen delegeren en de opdracht kunnen geven om zelfstandig onderzoekstaken uit te voeren. Een dergelijke 'decentraliserende' ontwikkeling zou passen in een al langer zichtbare trend binnen parlementaire stelsels, waarbij veelal langs departementale lijnen ingerichte commissiestructuren worden ingesteld of versterkt teneinde beter tegenwicht te kunnen bieden aan de uitvoerende macht. ${ }^{29}$

De Britse onderzoekscommissies en in mindere mate de Amerikaanse (sub)commissies hebben laten zien, dat een permanente onderzoeksinfrastructuur een aantal belangrijke kansen biedt. Belangrijk is allereerst dat de permanente onderzoekscommissies in deze stelsels een hoge mate van agendavrijheid bezitten. Binnen de gestelde kaders van hun werkterrein zijn commissies vrij om te bepalen welke onderwerpen zij wensen te onderzoeken en op welke wijze zij dit doen. Commissies kunnen hun onderzoeksbevoegdheden dan ook flexibel inzetten: er kan planmatig worden gewerkt aan een aantal onderzoeksprioriteiten, maar tegelijkertijd kan ook snel worden ingesprongen op actuele ontwikkelingen. Er kan intensief feitenonderzoek worden gedaan, of juist worden volstaan met een of meerdere hoorzittingen en een kort verslag met conclusies en aanbevelingen. Informatiestromen die nu ongestructureerd op het parlement afkomen, zoals jaarverslagen van overheidsorganen of rapporten van adviescolleges, kunnen binnen deze vaste onderzoekscommissies worden gekanaliseerd, geanalyseerd en van een politiek oordeel worden voorzien.

Met het creëren van permanente onderzoekscommissies voorzien van een brede taakopdracht, zo laat met name het Britse voorbeeld zien, kan het Nederlandse parlement een toegankelijker instituut worden. In de bestaande vaste commissies staat het politieke debat tussen Kamerleden en bewindspersonen centraal. Dit is ook niet verwonderlijk, gezien de grote omvang van deze commissies. Voor belanghebbenden en deskundigen is vaak slechts een rol als toehoorder weggelegd. Het instellen van kleinere, permanente onderzoekscommissies bevordert de onderlinge samenwerking tussen de leden, waarmee deze commissies zich kunnen onderscheiden van reeds bestaande verbanden in de Kamer. Deze commissies bezitten de potentie om uit te groeien tot herkenbare fora waar politici, bestuurders, ambtenaren, experts, belangengroepen en andere betrokken burgers elkaar kunnen vinden rondom maatschappelijk en politiek relevante onderzoeksthema's. De onderzoeksgerichte ('evidence based') werkwijze nodigt uit tot participatie van derden. De ruime onderzoeksopdracht stelt hen in staat een onderzoeksbeleid te voeren en aan de hand van de interesses van commissieleden eigen accenten leggen. Ook voor individuele leden biedt deze benadering kansen, aangezien zij zich via een herkenbare onderzoekscommissie binnen de Kamer nadrukkelijk kunnen profileren.

Langs deze weg kan de parlementaire informatiepositie worden versterkt en kan het parlement méér worden dan het nu is: de Kamer krijgt een permanent insti-

${ }^{29}$ Zie Hazan 2001, p. 77-81. Vgl. ook Heringa 2001, p. 164. 
tutioneel kader waar kennis en expertise wordt vergaard, opgebouwd en van politieke duiding wordt voorzien. Deze denkrichting biedt daarom het meeste perspectief. Hieronder wordt deze denkrichting verder uitgewerkt en wordt bezien op welke wijze deze gestalte zou kunnen krijgen.

\section{Voorstel}

\subsection{Organisatorische inbedding}

Hoe een onderzoeksomgeving, zoals hierboven voorgesteld, vorm te geven? Een geheel nieuw commissiestelsel invoeren, zoals het Britse Lagerhuis in 1979 deed, zou een mogelijkheid kunnen zijn, maar dit lijkt mij niet de meest voor de hand liggende oplossing. De Nederlandse Tweede Kamer is simpelweg te klein voor het instellen van een afzonderlijk stelsel van permanente, langs departementale lijnen ingerichte onderzoekscommissies. In het Britse stelsel was hiervoor ruimte, niet alleen wat betreft het aantal beschikbare parlementsleden, maar ook omdat daar nog geen vaste commissiestructuur bestond. In Nederland zou een dergelijk stelsel bovenop het bestaande stelsel van grotendeels departementaal georganiseerde vaste commissies in de Tweede Kamer komen, en dat lijkt me met het oog op de beperkte tijd die Kamerleden ter beschikking hebben teveel van het goede.

Kansrijker is daarom een benadering, waarbij gekeken wordt of de onderzoeksfunctie van het parlement kan worden versterkt binnen de kaders van het bestaande commissiestelsel. ${ }^{30}$ Welke rol zouden de vaste commissies hier kunnen spelen? Op dit punt kan inspiratie worden opgedaan bij de Amerikaanse vaste commissies. Binnen veel van deze commissies, die zowel wetgevende als controlerende taken hebben, bestaat intern een zekere werkverdeling. Veel van het onderzoekswerk wordt overgelaten aan een subcommissie voor controle en onderzoek ('oversight and investigations'), terwijl de voltallige commissie - al dan niet onderverdeeld in thematische subcommissies - zich toelegt op de wetgevende, budgettaire en beleidsmatige taken. Een dergelijke invulling behoort mijns inziens ook in Nederland tot de mogelijkheden. De voornaamste vaste commissies ${ }^{31}$ in de Tweede Kamer bestaan thans uit drieentwintig leden; denkbaar zou zijn, dat vijf à zeven van deze leden zich in de vorm van een subcommissie voornamelijk zouden toeleggen op onderzoekswerkzaamheden. Zo zou elke vaste commissie haar eigen onderzoekssubcommissie kunnen krijgen. ${ }^{32}$ Inbedding binnen het bestaande stelsel van vaste commissies is procedureel betrekkelijk eenvoudig. Het zou betekenen dat de figuur van de subcommissie, die bij eerdere reglementswijzigingen is verdwenen, zou moeten worden geherintrodu-

\footnotetext{
${ }^{30}$ Vgl. ook Verhey 2001a, p. 34 en Verhey 2001b, p. 321 over het inzetten van de bestaande commissies of subcommissies daaruit ten behoeve van onderzoek.

${ }^{31}$ Hiertoe behoren in elk geval tien commissies: Binnenlandse Zaken, Veiligheid en Justitie, Financiën, Economische Zaken en Landbouw, Onderwijs, Infrastructuur en Milieu, Sociale Zaken, Volksgezondheid, Buitenlandse Zaken, en Defensie.

32 Ook is denkbaar, wanneer het aantal voorgestelde subcommissies op praktische bezwaren zou stuiten, dat verwante vaste commissies een gezamenlijke subcommissie instellen. Zo zou bijvoorbeeld kunnen worden aan gezamenlijke onderzoekssubcommissies voor binnenlandse zaken en justitie, voor financieel-economische zaken en voor ruimtelijke ordening en infrastructuur.
} 
ceerd in het Reglement van Orde van de Tweede Kamer. De vraag of een onderzoekssubcommissie wordt ingesteld, al dan niet samen met andere commissies, zou formeel kunnen worden overgelaten aan de vaste commissies, maar realistischer lijkt het mij wanneer de Kamer de vorming van deze subcommissies opneemt in haar Reglement van Orde. Op die manier behoudt de Kamer de regie over de afbakening van de verschillende onderzoeksterreinen en kan de selectie van de leden van subcommissies worden meegenomen bij de samenstelling van de voltallige commissies aan het begin van een parlementaire zittingstermijn. ${ }^{33}$

Het werken met relatief kleine subcommissies is om twee redenen aantrekkelijk. Ten eerste blijft het aantal benodigde Kamerleden hierdoor beperkt. Met de bestaande omvang van de Kamer is hiervoor ruimte. ${ }^{34}$ Bij de samenstelling kan het gebruik om zoveel mogelijk fracties vertegenwoordigd te zien, samenhangend met het meerpartijenstelsel, worden gehandhaafd. De grotere fracties zullen waarschijnlijk in vrijwel alle subcommissies vertegenwoordigd kunnen zijn, terwijl de kleinere fracties, zoals dat overigens nu ook al het geval is bij de samenstelling van tijdelijke onderzoekscommissies, moeten afwegen in welke commissies zijn vertegenwoordigd kunnen en willen zijn. Ook ten aanzien van de verdeling van voorzitterschappen kan voldoende spreiding worden aangebracht. Ten tweede is het werken met kleine onderzoekscommissies in het algemeen, zo laat de praktijk zien, bevorderlijk voor het bereiken van een zekere interne samenhang ('team spirit') alsmede voor het vinden van consensus inzake het te voeren onderzoeksbeleid. Beide aspecten worden in de Nederlandse discussie vaak beschouwd als cruciaal in het succes van parlementair onderzoek.

Bijkomend voordeel van het werken met subcommissies is, dat het onderzoekswerk direct een rol kan krijgen binnen de reguliere activiteiten van de vaste commissie(s) waarvan zij deel uitmaken. Het ligt dan wel voor de hand, dat de leden geen hoofdrol spelen in de voltallige commissie, waaruit de subcommissie voortkomt. Zo zou er bijvoorbeeld naar moeten worden gestreefd om geen leden te benoemen die binnen hun fracties tevens belangrijke woordvoerderschappen vervullen op het terrein waarop de subcommissie werkzaam is. Naar Brits voorbeeld kan op die manier een zekere afstand worden bewaard tot de dagelijkse partijpolitiek, wat van belang kan zijn voor de samenhang binnen de subcommissie. Dit zou feitelijk betekenen dat Kamerleden die lid willen worden van een onderzoekssubcommissie op hetzelfde terrein niet tevens op wetgevend en beleidsmatig vlak actief zouden

\footnotetext{
${ }^{33}$ Omdat de Kamer gaat over de instelling en samenstelling van de commissies, is er geen sprake van de invoering van een minderheidsrecht, zoals in het verleden een aantal malen is voorgesteld ten aanzien van het enqueterecht. Dat zou ook niet wenselijk zijn, omdat het onderzoeksrecht daarmee een oppositie-instrument zou worden, terwijl de kracht vooral zit in de samenwerking tussen leden van verschillende (coalitie- en oppositie)fracties. Bij het samenstellen van de subcommissies dient hiermee rekening te worden gehouden, zoals dat overigens ook altijd gebruikelijk is geweest bij tijdelijke onderzoekscommissies.

34 Een verkleining van het aantal Kamerleden, zoals door het kabinet Rutte I voorgesteld, zou een en ander lastiger maken. Zie Kamerstukken II 2011/12, 33 345, nr. 2. Alleen al vanwege het belang van een versterking van de parlementaire onderzoeksfunctie zou een dergelijke grondwetswijziging zeer onverstandig zijn. Inmiddels is het betreffende wetsvoorstel weer ingetrokken.
} 
moeten zijn. ${ }^{35}$ Dit laatste is waarschijnlijk niet voor elke fractie praktisch haalbaar, in welk geval het aan de betrokken leden is om hun werkzaamheden niet te zeer te laten overlappen. Wanneer op dit punt een zekere scheiding kan worden aangebracht, kan voorkomen worden dat het verrichten van onderzoek binnen de vaste commissies er toe zou leiden dat Kamerleden in feite hun eigen optreden in een zaak zouden gaan beoordelen. ${ }^{36}$

\subsection{Taken en bevoegdheden}

De voorgestelde subcommissies dienen, als gezegd, een brede taakopdracht mee te krijgen. De commissies moeten de ruimte krijgen om zelf hun onderzoeksprioriteiten vast te stellen en te bepalen op welke wijze en met welke intensiteit zij te werk willen gaan. Daarbij zouden commissies zich vooral moeten richten op brede, beleidsgerichte onderzoeken. In lijn met de intenties van de bestaande Toekomst- en onderzoeksagenda zou het accent moeten liggen op enerzijds restrospectieve onderzoeken naar de uitvoering van wetgeving en beleid en anderzijds naar meer prospectieve onderzoeken naar beleidsvraagstukken die in de toekomst kunnen gaan spelen. De nadruk zou moeten liggen op de hoofdlijnen van beleid; het doen van gedetailleerd, diepgravend feitenonderzoek, zoals in Nederland vooral bij enquêtes voorkomt, ligt hierbij minder voor de hand. Er moet echter ook ruimte zijn om in te spelen op actuele gebeurtenissen, bijvoorbeeld door hoorzittingen met bewindslieden, ambtenaren of andere betrokkenen te organiseren. ${ }^{37}$

Hiertoe is het van belang om de subcommissies in elk geval de onderzoeksbevoegdheden toe te kennen die thans op grond van artikel 27 RvOTK alleen gelden voor reguliere commissies. Zonder die toekenning zouden de subcommissies strikt genomen immers steeds de voltallige commissie moeten inschakelen om bijvoorbeeld een hoorzitting te houden of ministers schriftelijk om inlichtingen te vragen. Naar Brits en Amerikaans voorbeeld is het verder verstandig om een taakomschrijving voor de in te stellen subcommissies op te nemen in het Reglement van Orde. Op die manier kan worden aangegeven waarop het onderzoek gericht zou moeten zijn en kunnen de werkterreinen van de verschillende subcommissies worden afgebakend. Een heel specifieke omschrijving is niet nodig en ook niet wenselijk; daarmee zou de onderzoeksvrijheid teveel beknot kunnen worden. Het is voldoende om een bepaling op te nemen waarin wordt vastgesteld dat een onderzoekssubcommissie de

\footnotetext{
${ }^{35}$ In plaats daarvan kan het juist een stimulans zijn voor meer inhoudelijk debat tussen Kamerleden. Wellicht zou op deze manier ook binnen de Kamer ook een striktere scheiding kunnen ontstaan tussen de wetgevende en controlerende functie. Leden van deze subcommissies kunnen zich op deze manier nadrukkelijk profileren als 'controleurs van de macht', terwijl andere Kamerleden zich binnen de voltallige vaste commissies meer met beleidsvorming kunnen bezighouden. Zo ontstaan - dwars door fracties en coalitie- en oppositieverhoudingen heen - verschillende typen Kamerleden, zoals dat ook in de Britse en Amerikaanse parlementen te zien is.

${ }^{36}$ Die vrees was een van de redenen waarom het Presidium besloot om onderzoek voortaan alleen nog aan tijdelijke (enquête)commissies op te dragen en niet langer (ook) door de vaste commissies te laten uitvoeren. Zie hierboven, NL-hoofdstuk, par. 2.4.2 en 3.2.2.

${ }^{37}$ Dit lijkt vooral zinvol wanneer zich een actualiteit voordoet op een terrein waarop de subcommissie expertise heeft opgebouwd middels eerder verricht onderzoek. Op die manier kunnen eerdere bevindingen als het ware direct worden 'toegepast' op een actuele casus.
} 
taak heeft om op het werkterrein van de vaste commissie waaruit zij voortkomt, onderzoeksactiviteiten te verrichten van retrospectieve of prospectieve aard ten aanzien van naar eigen inzicht te bepalen beleidsthema's. Om wel enig zicht te krijgen op de gekozen thema's en mogelijke doublures te voorkomen, zouden commissies kunnen worden verplicht om voor een of meerdere jaren een globale onderzoeksplanning te maken. ${ }^{38}$

Gezien de aard van de te verrichten onderzoeken, ligt het toekennen van zwaardere onderzoeksbevoegdheden dan welke reeds uit artikel 27 RvOTK voortvloeien niet voor de hand. Vergelijkbare reguliere parlementaire onderzoeken, zoals die in de afgelopen decennia door tijdelijke commissies zijn uitgevoerd, maar ook de Britse ervaringen, laten zien dat medewerking van zowel regeringszijde als van derden in de meeste gevallen op vrijwillige basis wordt verleend en dat dus ook zonder aanvullende bevoegdheden voldoende informatie kan worden vergaard. ${ }^{39}$ Mocht een subcommissie op dit punt toch problemen ervaren, dan kan worden overwogen om alsnog enquêtebevoegdheden toe te kennen. Aangezien het enquêterecht op basis van de Grondwet en de Wet op de parlementaire enquête is toegekend aan de Kamer(s) als geheel, zal hieraan steeds een Kamerbesluit vooraf moeten gaan. Het ligt voor de hand dat de subcommissie daartoe zelf een verzoek indient bij de Kamer. Als de Kamer daarmee instemt, dan zal de subcommissie tijdelijk moeten worden worden omgedoopt tot enquêtecommissie. ${ }^{40}$ Bovendien zal de Kamer ingevolge artikel 2, derde lid, Wpe het onderwerp van het onderzoek moeten vaststellen. Daarbij kan worden aangesloten met het onderwerp dat de subcommissie eerder heeft vastgesteld, maar natuurlijk kan ook worden besloten, indien de Kamer dat wenst, om de commissie op dat punt bij te sturen. ${ }^{41}$ De commissie is volgens de wet verplicht een

\footnotetext{
38 Zo'n voorlopige planning moet overigens niet verworden tot een keurslijf. Uitgangspunt blijft dat commissies de nodige vrijheid en flexibiliteit moeten hebben. Waar het vooral om gaat is - en zo functioneert de planningsverplichting ook in de Verenigde Staten - om enige inventarisatie en afstemming mogelijk te maken.

${ }^{39}$ Het komt vooral aan op effectief (of effectiever) gebruik van bestaande bevoegdheden. Een voorbeeld is het instrument van de hoorzitting. Het houden van 'losse' hoorzittingen door vaste commissies werd in het verleden niet altijd als zinvol ervaren, zo bleek tijdens de parlementaire zelfreflectie. Naar aanleiding daarvan is een aantal vaste commissies gaan experimenteren met de 'hoorzitting nieuwe stijl'. Hierbij wordt een goede (ambtelijke) voorbereiding gecombineerd met scherper (door)vragen en onderlinge afstemming tussen commissieleden. Zie Rapport parlementaire zelfreflectie 2009, p. 49. Zo werd begin 2010 door de vaste commissie voor Onderwijs, Cultuur en Wetenschap besloten een 'uitgebreide hoorzitting', verspreid over meerdere dagen, te houden inzake het beleid rondom het passend onderwijs. Uit de commissie werden zes leden gekozen, die de hoorzittingen zouden voeren. Zie Kamerstukken II 2009/10, 31 497, nr. 20. Deze innovatieve werkwijze kan worden gezien als een eerste stap in de richting van de hier voorgestelde subcommissies.

${ }^{40}$ Volgens het systeem van de wet zal een tijdelijke enquêtecommissie moeten worden ingesteld. De Kamer benoemt de leden. Voor de hand ligt dat dit de leden van de subcommissie zijn, maar desgewenst kan de commissie worden aangevuld met andere leden. De Kamer is daarin uiteraard vrij.

${ }^{41}$ In elk geval is een zorgvuldige en duidelijk geformuleerde onderzoeksopdracht, ook wanneer commissies zich voornamelijk richten op brede beleidsvraagstukken, met name bij enquêtes van groot belang in verband met de positie van getuigen. Enquêtebevoegdheden mogen ingevolge art. 4, tweede lid, Wpe 2008 alleen worden uitgeoefend voor zover dat naar het redelijk oordeel van de commissie voor de vervulling van haar taak noodzakelijk is. Het subjectieve evenredigheidsbeginsel dat hieruit voortvloeit, beperkt de mogelijkheden voor rechterlijke toetsing achteraf en legt een grote verantwoordelijkheid bij de commissie. Een duidelijke openingsverklaring van de commissievoorzitter aan
} 
eindrapport aan de Kamer aan te bieden en verantwoording af te leggen over haar werkzaamheden. Daarna houdt de enquêtecommissie als zodanig op te bestaan. De Kamer kan echter ook besluiten (voortijdig) de enquêtebevoegdheden af te nemen door de enquête te beëindigen. ${ }^{42}$

De wetenschap dat een subcommissie volgens het bestaande wettelijke systeem, indien de Kamer dat wil, op ieder moment kan worden omgedoopt tot enquêtecommissie en daarmee de beschikking krijgt over verregaande dwangmiddelen, kan worden gezien als een goede 'stok achter de deur'. Met de mogelijkheid van het toekennen van enquêtebevoegdheden op basis van de Wpe bevinden de voorgestelde subcommissies zich in vergelijking in een veel sterkere positie dan de Britse commissies. In het Britse stelsel is überhaupt geen effectief systeem van dwangmiddelen voorhanden; de contemptprocedure is sterk verouderd en sinds lange tijd in onbruik geraakt. Zelfs het Amerikaanse stelsel, waar wel een effectieve wettelijke contemptregeling bestaat, gaat minder ver. Daar moeten commissies, indien getuigen weigeren om medewerking te verlenen, immers in elk afzonderlijk geval een beroep doen op de kamer om de getuige 'in contempt' te doen verklaren, waarna bestraffing door de rechter mogelijk wordt. In Nederland hebben commissies, wanneer zij de status van enquêtecommissie hebben of krijgen, in feite 'carte blanche' om in voorkomende gevallen zelf de inzet van dwangmiddelen en sancties te verzoeken bij de rechter. De rechter toetst dergelijke verzoeken bovendien, anders dan de Amerikaanse rechter, slechts marginaal. Nadeel van het Amerikaanse stelsel is verder, dat de handhaving van de medewerkingsplicht en de vraag of sprake is van een legitiem beroep op verschoningsrechten in individuele gevallen noodgedwongen in de partijpolitieke arena van het plenum terechtkomen.

Aanpassing of verdere decentralisatie van het enquêterecht lijkt mij daarom niet nodig; de bestaande wettelijke regeling voldoet op dit punt. ${ }^{43}$ Wel kan worden afgevraagd of bij elk onderzoek dat de status van enquête krijgt, of het nu gaat om een voortzetting van een subcommissieonderzoek of niet, het in alle gevallen nodig is het gehele arsenaal aan enquêtebevoegdheden dat de wet te bieden heeft onverkort toe te kennen. ${ }^{44}$ De wet biedt wat dat betreft geen ruimte voor maatwerk, terwijl niet valt in te zien waarom een subcommissie die gedurende een onderzoek bijvoorbeeld moeite blijkt te hebben om van bepaalde informatiebezitters documenten te verkrijgen, ook meteen de bevoegdheid moet hebben om plaatsen te betreden. Verder is in het voorgaande een aantal andere knelpunten in de huidige wettelijke regeling aan de orde geweest die nadere overweging verdienen, waarbij het in het bijzonder gaat om het verlenen van het recht aan getuigen om radio- en televisieopnamen te weren

\footnotetext{
het begin van een hoorzitting, naar Amerikaans voorbeeld, zou op dat punt voor getuigen meer houvast kunnen bieden. Zie verder Deel I, par. 2.3.1 en Deel III, par. 4.3.3.

42 Art. 33-34 Wpe 2008.

${ }^{43}$ Een doorlopende toekenning van enquetebevoegdheden aan vaste (sub)commissies zou een wetswijziging vereisen, aangezien de Wpe thans uitgaat van incidenteel in te stellen, dus tijdelijke enquetecommissies.

44 Zie ook de vragen van de PvdA-fractie tijdens de behandeling van het wetsvoorstel-Wpe in de Eerste Kamer, Kamerstukken I 2006/07, 30 415, E, p. 5.
} 
tijdens openbare verhoren, ${ }^{45}$ een nadere procedure rondom besloten verhoren, ${ }^{46}$ het verhelderen en versterken van positie en taak van de commissievoorzitter ${ }^{47}$ en een verbeterde regeling rondom het enquêtearchief. ${ }^{48}$ Ten dele kunnen deze knelpunten overigens worden opgelost met aanpassingen op het niveau van het Reglement van Orde of de Regeling parlementair en extern onderzoek.

\subsection{Ondersteuning en samenwerking}

Willen de voorgestelde vaste onderzoekssubcommissies hun brede taakopdracht kunnen uitvoeren, dan zullen zij, net zoals in de Verenigde Staten en het Verenigd Koninkrijk, moeten beschikken over adequate ambtelijke ondersteuning. Elke commissie zal moeten worden ondersteund door een griffier, die de algehele leiding op ambtelijk niveau heeft, alsmede een of meerdere administratieve ondersteuners. Belangrijk is verder dat elke subcommissie beschikt over een aantal vakdeskundigen die de commissie inhoudelijk kunnen adviseren en assisteren bij de uitvoering van het onderzoek. Het instellen van een professionele subcommissiestaf is niet alleen van praktisch belang, maar kan ook bijdragen aan het verminderen van het eerder gememoreerde gebrek aan institutioneel geheugen en onderzoekservaring binnen de Kamer. Aangezien de subcommissies, zoals in Nederland gebruikelijk is bij parlementair onderzoek, niet langs coalitie- en oppositielijnen worden samengesteld maar vooral een afspiegeling moeten zijn van de Kamer als geheel, ligt het voor de hand dat de staf die de commissie ondersteunt op politiek-neutrale wijze te werk gaat. Om dat te waarborgen, treden zij in dienst van de Kamer voor een periode die niet gekoppeld is aan de zittingstermijn van de commissie en vallen zij onder het gezag van de Griffier.

Verder zou moeten worden overwogen om ook de centrale onderzoeksvoorziening binnen de Kamer te versterken, zodat de subcommissiestaf op specifieke terreinen zoals onderzoeksplanning, coördinatie, maar ook specialistische kennis op bijvoorbeeld financieel of technisch terrein kan worden gebundeld en flexibel ter beschikking kan worden gesteld. Een en ander betekent dat de bestaande ambtelijke dienst van de Tweede Kamer moet worden uitgebreid. ${ }^{49}$ Hoewel daaromtrent in de recente Nederlandse discussie vaak wordt geaarzeld, is de hier bepleite uitbouw van de parlementaire onderzoeksfunctie zonder die uitbreiding niet of nauwelijks denkbaar. De uitbreiding is bedoeld om commissieleden te ondersteunen in hun onderzoekstaak, niet om die taak van hen over te nemen. Het is dan ook niet de bedoeling om een omvangrijke parlementaire bureaucratie in het leven te roepen, die - zoals in

\footnotetext{
${ }^{45}$ Hier kunnen Amerikaanse ervaringen als voorbeeld dienen. Zie Deel III, par. 2.5. Zie op dit punt verder Deel I, par. 2.3.2.2 en Deel I, par. 2.6.

46 Zie Deel III, par. 2.5.

47 Zie Deel I, par. 4.6.1.

48 Zie Deel I, par. 4.7.2.1.

49 Verschillende parlementaire onderzoekscommissies hebben in hun eindrapport ook al gepleit voor een dergelijke versterking van de centrale kennisinfrastructuur binnen de Kamer. Zie bijvoorbeeld het eindrapport van de Tijdelijke commissie Infrastructuurprojecten, Kamerstukken II 2004/05, 28 283, nr. 6, p. 77-78, waar de vergelijking wordt gemaakt met het Amerikaanse CBO. Zie ook Enthoven 2011, p. 355.
} 
de Verenigde Staten wel eens het geval is - een eigen leven zou kunnen gaan leiden. Bedacht moet worden, dat met de voorgestelde uitbreiding de totale ambtelijke staf van de Kamer nog steeds van bescheiden omvang zal zijn, zeker wanneer de vergelijking met het Britse parlement en vooral het Amerikaanse Congres wordt gemaakt. Ook ten opzichte van de omvangrijke ambtelijke dienst die de regering bijstaat blijft de parlementaire ondersteuning natuurlijk van geringe omvang. Een kleine maar deskundige ambtelijke staf, zo laat het Britse voorbeeld zien, kan echter een groot verschil maken als het gaat om het versterken van het parlementaire tegenwicht.

Tenslotte verdient het aanbeveling om samenwerking te zoeken met externe kennis- en expertisecentra. Daarbij kan gedacht worden aan universiteiten, denktanks en andere onderzoekinstituten, maar ook aan de diverse adviescolleges en planbureaus op rijksniveau. Vooral van die laatste categorie is nog een wereld te winnen, zo laten ook de ervaringen in de andere stelsels zien. Met het uitzetten van specifieke onderzoeksvragen bij onafhankelijke onderzoeksinstituten kunnen de onderzoekssubcommissies veel hoogwaardige analytische informatie vergaren, die zij kunnen gebruiken als basis voor hun eigen onderzoek. Naar het voorbeeld van de Britse Public Accounts Committee zouden bijvoorbeeld doelmatigheidsrapporten van de Algemene Rekenkamer kunnen worden ingezet als basis voor een breder onderzoek naar de uitvoering van beleid, aan de hand waarvan de betrokken ministers of bestuurders in een hoorzitting om verantwoording kunnen worden gevraagd of belanghebbenden kunnen worden gehoord. De subcommissies zouden, afhankelijk van hun werkterrein, structureel gebruik moeten maken van deze onafhankelijke politiek-neutrale expertisecentra. In veel gevallen beschikt het parlement reeds over de bevoegdheid om instellingen zoals de Algemene Rekenkamer met onderzoeksverzoeken te benaderen. ${ }^{50}$ De betrokken onderzoekers of hun leidinggevenden zouden na publicatie kunnen verschijnen op een hoorzitting om hun conclusies en eventuele aanbevelingen toe te lichten. Niet alleen de commissies, ook de betrokken

\footnotetext{
50 Voor adviescolleges die vallen onder de Kaderwet adviescolleges geldt dat de Kamer reeds toegang heeft. Voor planbureaus was dit tot voor kort nog niet mogelijk. In de motie-Koopmans werd de regering gevraagd de Kamer "de facto rechtstreekse toegang te geven tot alle planbureaus en dat de jure zo snel mogelijk te regelen". Kamerstukken II 2008/09, 31 490, nr. 9. Zie ook Deel I, par 3.4; Rapport parlementaire zelfreflectie 2009, p. 13, 45 en Enthoven 2011, p. 356. In reactie stelde de minister van Binnenlandse Zaken en Koninkrijksrelaties dat de planbureaus, anders dan de adviescolleges, onderdeel zijn van de ministeries en daarmee staatsrechtelijk ook onder de ministeriële verantwoordelijkheid vallen. Niettemin was het kabinet bereid om ruimte te bieden om het parlement toegang te geven tot de "rijke kennisbron die een planbureau is." Een verzoek van de Kamer zou wel aan de minister moeten worden gericht, gelet op de formele positie van de planbureaus, maar het kabinet was bereid "de afspraak vast te leggen dat een verzoek van de Kamer gelijktijdig en ongeclausuleerd met de formele toezending aan de minister wordt toegezonden aan het planbureau." Wel zou moeten worden beoordeeld of een parlementair verzoek inpasbaar is in de werkzaamheden van het planbureau; dit zou conform de bestaande praktijk in eerste instantie aan het planbureau zelf kunnen worden overgelaten, al ligt de uiteindelijke verantwoordelijkheid, zo wordt daarbij aangetekend, bij de minister. Zie Kamerstukken II 2008/09, 31 490, nr. 20, p. 2-3. In de gevallen waarin het parlement onderzoeksverzoeken bij adviescolleges of planbureaus kan indienen, ligt de bevoegdheid hiertoe bij de Kamer(s) als zodanig. Overwogen zou moeten worden om dit verzoekrecht te delegeren aan de voorgestelde subcommissies. Van belang is wel, dat parlementaire verzoeken de politieke neutraliteit van deze instellingen niet in gevaar brengt. Ook moet kunnen worden beoordeeld of er voldoende capaciteit is om een verzoek te kunnen voldoen.
} 
instellingen kunnen daarvan profiteren. Immers, door de uitvoerige parlementaire behandeling en politieke duiding via het onderzoek van de subcommissie wordt de kans dat hun 'producten' daadwerkelijk impact hebben vergroot.

\section{Conclusie}

Met de hierboven bepleite inrichting van onderzoekssubcommissies binnen de bestaande vaste commissies in de Tweede Kamer wordt de parlementaire onderzoeksfunctie onderdeel van de dagelijkse parlementaire werkelijkheid. Samengevat komt het voorstel erop neer, dat 'het nieuwe onderzoek' kleinschalig van opzet is en gericht is op beleidsevaluatie of toekomstige beleidsvraagstukken. Het vindt plaats in subcommissies: kleine verbanden die worden ingebed in de reeds bestaande vaste commissies. Hierin dienen onderzoeksgerichte Kamerleden te worden benoemd, die over fractiegrenzen heen samenwerken. De onderzoekstaak wordt gedecentraliseerd: de subcommissies voeren hun onderzoekstaak uit op basis van een brede taakopdracht die zij zelf nader invullen met concrete onderzoekslijnen. De subcommissies worden de reguliere onderzoeksbevoegdheden toegekend die de vaste commissies nu reeds bezitten, maar de Kamer kan deze ten behoeve van specifieke onderzoeken tijdelijk aanvullen met wettelijke enquêtebevoegdheden. Ondersteuning komt van een eveneens compacte, maar vakkundige ambtelijke staf. Verder wordt zoveel mogelijk samenwerking gezocht met bestaande kennis- en expertisecentra, waaronder adviescolleges en planbureaus. Zo kan de Kamer structureel werk maken van een versterking van haar tegenwichtfunctie, een verdieping van het verantwoordingsproces en een verbreding van haar toegankelijkheid. Het creëren van een permanente parlementaire onderzoeksinfrastructuur kan bijdragen aan een kwalitatieve verbetering van de parlementaire controle, waarmee ook de legitimiteit van het openbaar bestuur en de participatie van burgers en maatschappelijke groeperingen kan worden versterkt. Het parlement wordt daarmee, veel meer dan nu het geval is, een werkplaats waar overheidsbeleid dagelijks aan de hand van bewijsmateriaal en met de bijdragen van belanghebbenden en experts wordt onderzocht, inzichtelijk wordt gemaakt, wordt bediscussieerd en en uiteindelijk beoordeeld. Ervaringen in het buitenland laten bovendien zien, dat het parlement op deze manier een wezenlijke invloed kan uitoefenen op de ontwikkeling van toekomstig beleid.

Implementatie van dit voorstel vergt weinig juridische arbeid: volstaan kan worden met enkele aanpassingen van het Reglement van Orde. Bovenal is het zaak de politieke wil te tonen om tot een daadwerkelijke versterking van de onderzoeksfunctie - en daarmee van de parlementaire informatiepositie - te komen. De bestaande onderzoekspraktijk, uitgaande van tijdelijke onderzoekscommissies met of zonder enquêtebevoegdheden, kan daarnaast worden voorgezet. Wanneer de Kamer behoefte heeft aan diepgravend feitenonderzoek of commissieoverstijgend onderzoek wil faciliteren, dan blijft het instellen van een tijdelijke commissie aangewezen. ${ }^{51}$ Wel zouden de subcommissies die inhoudelijk de meeste affiniteit met het

\footnotetext{
51 Verder moet er rekening mee worden gehouden dat ook de Eerste Kamer zich vaker met onderzoek zal gaan bezighouden, nu deze Kamer onlangs haar onderzoeksrecht leven heeft ingeblazen met een regulier onderzoek naar het privatiserings- en verzelfstandigingsbeleid in de afgelopen decennia.
} 
onderzoek hebben kunnen worden betrokken bij de opzet ervan en, na afloop, de follow-up voor hun rekening kunnen nemen. Ook de bestaande Toekomst- en onderzoeksagenda kan gehandhaafd worden, maar zou met de invoering van het bepleite stelsel waarschijnlijk beter dienst kunnen doen als procedure voor het toekennen van aanvullend budget aan subcommissies die bijvoorbeeld deelonderzoeken willen uitbesteden of voor een bepaald onderzoek aanvullende stafmedewerkers of adviseurs willen aantrekken.

Deze ontwikkeling is toe te juichen, maar gezien haar omvang zal de bijdrage van die Kamer aan de parlementaire onderzoeksfunctie naar verwachting beperkt blijven. 
PARLEMENTAIR ONDERZOEK 


\section{Summary}

This dissertation offers a study of the parliamentary power of investigation in a comparative perspective. A parliamentary investigation, as defined here, is an inquiry carried out by a parliamentary committee provided with investigative jurisdiction and accompanying powers by its parent chamber, to which the committee is also expected to report.

The Dutch parliament's power of investigation (or inquiry) was first recognized in the Constitution of 1848. A Parliamentary Inquiries Act was adopted in 1850. The PIA, as amended, provides both chambers with the power to create a temporary investigatory committee with special statutory powers such as the right to summon witnesses to provide oral or written evidence. After a promising start in the nineteenth century, in which it was applied mainly as an instrument for large legislative projects, the instrument was largely abandoned for most of the twentieth century. In the late 1970s, however, increasing parliamentary activism led the Dutch House of Representatives - the politically dominant chamber - to revive its investigative power. Since then, the House has adopted more than thirty motions to launch a parliamentary investigation. These investigations are carried out by specially created temporary committees of the House and mainly serves as a tool for in-depth parliamentary scrutiny of the government. Only nine of these modern investigations were carried out by statutory committees established under the PIA ('enquêtecommissies'). The others were 'regular' investigations carried out by temporary committees without special statutory powers. In 2012, the Dutch Senate used its investigatory power for the first time in history by establishing a temporary (nonstatutory) committee of investigation.

Since its revival, the power of investigation is generally considered a successful innovation in parliamentary practice. In the light of the ongoing debate about parliament's ability to perform its constitutional functions, especially its duty to scrutinize the policies and actions of the government, members as well as observers of parliament have called for the further development of the investigative function. Through investigations, it is argued, parliament can improve its institutional knowledge base, which is essential to maintaining an independent position vis-à-vis the government. Against this background, this dissertation focuses on the law and practice of parliamentary investigations in three systems: the Netherlands, the United Kingdom and the United States. Through a comparative analysis, it aims to provide insights, ideas and recommendations for the Dutch parliament's investigative function. To acquire a good understanding of the way in which the investigative power is applied in each system, the subject is studied from a broad perspective. Thus, it includes all forms of investigations carried out by parliamentary committees, statutory and non-statutory, and focuses not only on constitutional or legal aspects but also on organizational and practical matters. 
In each country report, the discussion is divided in four chapters. The first chapter provides an analysis of the constitutional background of the parliament's power to investigate, including the political context in which it functions. Key constitutional concepts, such as ministerial accountability, parliament's controlling or scrutinizing role, existing parliamentary instruments, as well as important elements in the political context, such as the party system, are discussed. In the second chapter, the specific powers associated with parliamentary investigations, such as the right to summon witnesses and to gather written evidence, are discussed. This chapter also focuses on the special constitutional position of ministers and civil servants - or, in the American context: the President and the executive branch - in the context of parliamentary investigations. The third chapter discusses the committee structure, support organizations and other organizational aspects. The fourth chapter focuses on the investigative process, including issues such as confidentiality of evidence and the concurrence of parliamentary and criminal investigations.

In the final part of this dissertation, the key findings in the country reports for the Netherlands, the United Kingdom and the United States are compared and contrasted. What has become clear is that the history of power of investigation in all three systems goes back to the early beginnings of each parliament. For a long time, these parliaments applied their investigative power incidentally and for various purposes. In the twentieth century, however, the face of parliamentary investigations began to change. With the development of the welfare state came a growing government bureaucracy. In their efforts to keep pace, members of parliament realized that in order to exercise parliamentary control (congressional oversight in American terminology) effectively, acquiring adequate knowledge and expertise were of the essence. In each system, parliamentary (or congressional) reforms included strengthening the investigative function. In the United States Congress, the Legislative Reform Act of 1946 restructured the system of standing committees in both chambers, requiring them to exercise continuous watchfulness over executive departments and agencies within their jurisdiction. In the British House of Commons, a system of departmental select committees was created in 1979 in order to examine the expenditure, administration and policy of the principle government departments and associated public bodies. In both systems, the power of investigation was delegated to these permanent committees to be used at their discretion in the exercise of their functions. The House and Senate standing committees in the United States were provided with the right to subpoena witnesses for oral or written testimony, while the British select committees were granted the traditional parliamentary powers to send for persons, papers and records. These committees, established for a full parliamentary or congressional term, cover a broad policy area - roughly mirroring the structure of the executive branch - and can initiate investigations at their own accord, allowing them to set their own research agenda. In the Netherlands, by contrast, the investigative power, rediscovered in the 1970s primarily as an instrument for parliamentary scrutiny, has always remained a power to be incidentally delegated by the House of Representatives to temporary statutory or non-statutory committees. Dutch investigative committees are created for a specific inquiry, work within a detailed research framework as determined by the House and are dissolved after the report 
has been published and debated. Such temporary committees have become exceptional in the United States and the United Kingdom.

While the British and American committee systems share some basic characteristics, a closer look at the way in which these committees operate also reveals a number of key differences. The British select committee system was introduced as a new institutional framework to complement the traditional instruments for parliamentary scrutiny of government, mainly exercised in the politically strongly divided and antagonistic chamber. In order to stimulate independence, coherence and cooperation within committees, the new committees are relatively small and membership is restricted to backbenchers, i.e. members who do not fulfill prominent party-political functions within parliament such as (shadow) ministers and (opposition) whips. House and Senate committees in the United States are generally much larger and have significant legislative and budgetary powers next to their oversight responsibilities, making committees important forums for political decision making within Congress. Allocation of seats within committees generally reflects the broader party balance within the chamber, but unlike the more consensual British select committees, the majority party often determines the committee's investigative agenda, even though the minority is procedurally entitled to a minimum of investigative rights. Especially in times of divided government, committee oversight and investigations can be highly partisan, although congressional committee practice also harbors a tradition of cross-party cooperation. Such cooperation is mainly to be seen at the level of oversight subcommittees working in low-politics areas, where majority and minority leaders find common interests and maintain good personal relationships. The Dutch temporary committees do not reflect the political power balance in the multiparty chamber. Instead, it has become customary for each party group within the House to detach one of their members to serve on the committee. Unlike standing committees, in which political differences and coalition or opposition positions are articulated, investigative committees in the Dutch parliament are usually characterized by interparty cooperation and consensus building across the political spectrum.

The analysis of the three systems has shown that power of investigation has been significantly more institutionalized in the British House of Commons and the American Congress, albeit in different ways, than in the Dutch House of Representatives. Even though the number of parliamentary investigations in the Netherlands has grown over the past decades, their appearance in everyday parliamentary practice has remained incidental. On the basis of experiences in the British and American systems, it is argued in the final chapter of this book that the investigative function of the Dutch parliament should be further developed. There are several reasons for doing so. First, delegating the investigative power to permanent committees can contribute to parliament's efforts to reduce the current imbalance of power between government and parliament. Permanent investigative committees, supported by a small but professional committee staff and possibly a central research facility within the House, can improve parliament's institutional ability to process and analyze the ever growing amount of information that is made available by government departments and other sources. Such committees, unlike the existing standing committees in the House, would be well-suited to improve parliament's institutional memory. Second, as the British example shows, permanent investigative committees could 
play a useful role in parliament's function as forum for ministerial accountability. The accountability process can become more substantial than in the chamber or the standing committees, because investigative committees proceed on the basis of evidence rather than political debate. Moreover, in a less politically divisive environment the accountability process can more easily accommodate other actors such as departmental civil servants and officials from independent government agencies. Even though in the constitutional context of ministerial accountability in both the United Kingdom and the Netherlands departmental civil servants are normally expected to act upon the instructions of their ministers, the British case has demonstrated that this does not have to prevent ministers from allowing their civil servants to provide evidence to investigative committees. Third, the investigative process can serve as a way to make parliament more accessible, as it allows for outside participants such as interest groups and community organizations to share their opinions, experiences and expertise and actively participate in the evaluation of government policies. The investigative process is most useful in this respect when it is organized in a more or less standardized, predictable and transparent way. In addition, committees should actively seek the participation of outsiders, especially from groups or individuals who might not otherwise find their way to parliament. The British committees have been more successful in this respect than their Dutch and American counterparts.

When elaborating initiatives to further develop the investigative function of the Dutch parliament on the basis of experiences in other systems, one obviously needs to take into account the specific characteristics of the Dutch system. From a constitutional perspective, the power of investigation is sufficiently broad to allow for new initiatives. The government is required to cooperate with investigative committees in parliament, for example by providing documents and other forms of evidence upon request, although the 'interest of the state', a fairly undefined concept, prevents the (unconditional) provision of certain information. In organizational terms, the Dutch House of Representatives is much smaller than the British and American parliaments, while the multi-party system has resulted in an ideologically much more fragmented political landscape. This makes the overall number of members available for investigative committees much smaller in the Dutch parliament than in the other systems. Therefore, if the predominant and often celebrated culture of building crossparty consensus is to be preserved within Dutch investigative committees and the constructive cooperation of the government is considered essential, then further developing the investigative function is most likely to succeed if one primarily stimulates investigations regarding topics which are not at the heart of party-political debate and in which the position of individual ministers is not directly at stake.

Taking into account the specific conditions as noted above, the book argues that strengthening parliament's investigative function can take several directions. One direction is to further stimulate coordinating initiatives already taking place, such as the new research agenda procedure. This initiative provides, in addition to the tradition of ad hoc inquiries into specific policy shortcomings or incidents which have caused public concern, for a decision making process to establish a limited number of small-scale parliamentary investigations annually focusing broadly on the implementation of policy and future challenges. Topics are selected on the basis of pro- 
posals brought forward by members in the standing committees. The agenda initiative, however, remains a centralized form of parliamentary decision making and the investigations included in the annual agenda are again carried out by temporary investigative committees. In both political and practical terms, further developing the investigative function along this path has its limits. In the spirit of the American and especially the British system, a more promising direction would be, it is argued, to decentralize the investigative function and to examine possibilities to create permanent committees with a continuous and flexible investigative mandate. In that light, the book concludes with a detailed proposal for the introduction of a system of permanent investigative subcommittees within the current standing committees. Such a reform requires no constitutional or statutory action and can be easily implemented by amending the House Rules. These subcommittees should be instructed to carry out investigations on topics of their own choosing with the jurisdiction of their parent committee, preferably focusing on broad forms of policy evaluation that stimulate a constructive (but not uncritical) dialogue with ministers and civil servants and allow for the participation of others. To stimulate internal coherence, subcommittee members should preferably not fulfill party-political positions within the committee's jurisdiction. Providing these subcommittees with statutory investigative powers under the Parliamentary Inquiries Act seems unnecessary, but if circumstances so require, the Act does not prevent the House to temporarily delegate such powers. Rather than providing formal powers, however, what is essential is for these subcommittees to be provided with a small but professional support staff and to actively seek cooperation with independent expert bodies such as auditing, planning and advising institutions.

The proposed institutional reform would be an addition to, rather than a replacement of, the existing practice of establishing temporary statutory or nonstatutory committees for specific inquiries, even though for practical reasons such investigations will likely become more exceptional. The existing legislative and procedural framework for ad hoc parliamentary investigations, which underwent a comprehensive modernization in 2008, should therefore be maintained, although on the basis of recent practice as well as comparative insights, some recommendations for improvement are formulated, for example with respect to the protection of witnesses, the position of the committee chair, and the rules regarding the archiving of evidence and other committee documents. 
PARLEMENTAIR ONDERZOEK 


\section{Literatuuropgave}

Aberbach 1990

J.D. Aberbach, Keeping a Watchful Eye. The Politics of Congressional Oversight, Washington, DC: Brookings Institution 1990.

Aberbach 2002

J.D. Aberbach, 'What's Happened to the Watchful Eye?', in: Congress \& the Presidency 2002, p. 323.

Andeweg \& Thomassen 2007

R. Andeweg \& J. Thomassen, Binnenhof van binnenuit. Tweede Kamerleden over het functioneren van de Nederlandse democratie, Den Haag: Raad voor het openbaar bestuur 2007.

Van Angeren 1996

J.A.M. van Angeren, 'Mag de ministeriële verantwoordelijkheid voor het bestuur worden beperkt?', in: RM Themis 1996, p. 367-375.

Auchincloss 2006

K. Auchincloss, 'Congressional Investigations and the Role of Privilege', in: American Criminal Law Review 2006, p. 165-198.

Bagehot 1867

W. Bagehot, The English Constitution (1867), herdrukt, Oxford: Oxford University Press 2001.

Baines 1989

P. Baines, 'History and Rationale of the 1979 Reforms', in: G. Drewry (red.), The New Select Committees. A Study of the 1979 Reforms, Oxford: Clarendon Press 1989, p. 13-36.

Barron \& Dienes 2003

J.A. Barron \& C.Th. Dienes, Constitutional Law in a Nutshell, St. Paul: Thomson/West 2003.

Beermann 2006

J.M. Beermann, 'Congressional Administration', in: San Diego Law Review 2006, p. 61-158.

Beetham e.a. 2002

D. Beetham e.a., Democracy under Blair. A Democratic Audit of the United Kingdom, London: Politico's 2002.

Van den Berg 1995

J.Th.J. van den Berg (red.), Inleiding staatkunde, Deventer: Kluwer 1995. 


\section{PARLEMENTAIR ONDERZOEK}

Van den Berg 2007

J.Th.J. van den Berg, 'Het parlement. Eén instelling, drie instituties', in: J.Th.J. van den Berg, J.L.W. Broeksteeg \& L.F.M. Verhey (red.), Het Parlement. Staatsrechtconferentie 2006, Nijmegen: Wolf Legal Publishers 2007, 15-37.

Van den Berg 2009

J.Th.J. van den Berg, 'De parlementaire orde is een politieke orde', in: Vertrouwen en zelfvertrouwen. Analyse en aanbevelingen parlementaire zelfreflectie, Kamerstukken II 2008/09, 31 845, nr. 3, p. 130-140.

Van den Berg, Broeksteeg \& Verhey 2007

J.Th.J. van den Berg, J.L.W. Broeksteeg \& L.F.M. Verhey (red.), Het Parlement. Staatsrechtconferentie 2006, Nijmegen: Wolf Legal Publishers 2007.

\section{Berger 1974}

R. Berger, Executive Privilege. A Constitutional Myth, Cambridge, Mass.: Harvard University Press 1974.

Blackburn \& Kennon 2003

R. Blackburn \& A. Kennon, Griffith \& Ryle on Parliament. Functions, Practice and Procedures, London: Sweet \& Maxwell 2003.

\section{Bogdanor 2004}

V. Bogdanor (red.), The British Constitution in the Twentieth Century, Oxford: Oxford University Press 2004.

\section{Boon 1982}

P.J. Boon, De parlementaire enquête. Een rechtsvergelijkende studie (diss. Amsterdam VU), Zwolle: W.E.J. Tjeenk Willink 1982.

BOR-evaluatie 2009

Bureau Onderzoek en Rijksuitgaven, Eindrapport tussentijdse evaluatie, 09-BOR-N-080, <http:// parlis.nl/pdf/bijlagen/BLG20880.pdf>, Den Haag: Tweede Kamer der Staten-Generaal 2009.

Bovend'Eert 2002

P.P.T. Bovend'Eert, Ministeriële verantwoordelijkheid, Nijmegen: Ars Aequi 2002.

\section{Bovend'Eert 2007}

P.P.T. Bovend'Eert, 'De wetgevende macht van het parlement', in: J.Th.J. van den Berg, J.L.W. Broeksteeg \& L.F.M. Verhey (red.), Het Parlement. Staatsrechtconferentie 2006, Nijmegen: Wolf Legal Publishers 2007, p. 91-116.

Bovend'Eert \& Kummeling 2010

P.P.T. Bovend'Eert \& H.R.B.M. Kummeling, Het Nederlandse parlement, Deventer: Kluwer 2010.

\section{Bovens 2007}

M. Bovens, 'Analysing and Assessing Accountability. A Conceptual Framework', in: European Law Journal 2007, p. 447-468. 


\section{LITERATUUROPGAVE}

Bradley \& Ewing 2007

A.W. Bradley \& K.D. Ewing, Constitutional and Administrative Law, Harlow: Pearson/Longman 2007.

Brazier \& Ram 2006

A. Brazier \& V. Ram, The Fiscal Maze. Parliament, Government and the Public Money, London: Hansard Society 2006.

Brazier, Kalitowski \& Rosenblatt 2008

A. Brazier, S. Kalitowski \& G. Rosenblatt, Law in the Making. Influence and Change in the Legislative Process, London: Hansard Society 2008.

Broeksteeg 2004

J.L.W. Broeksteeg, Verantwoordelijkheid en aansprakelijkheid in het staatsrecht (diss. Groningen), Deventer: Kluwer 2004.

Broeksteeg, Van den Berg \& Verhey 2006

J.L.W. Broeksteeg, J.Th.J. van den Berg \& L.F.M. Verhey (red.), Ministeriële verantwoordelijkheid opnieuw gewogen, Deventer: Kluwer 2006.

Brown \& Johnson 2003

W.H. Brown \& Ch.W. Johnson, House Practice. A Guide to the Rules, Precedents, and Procedures of the House, Washington, D.C.: U.S. Goverment Printing Office 2003.

Brudnick 2009

I.A. Brudnick, Legislative Branch. FY2010 Appropriations, CRS Report R40617, Washington, D.C.: Congressional Research Service 2009.

\section{Buruma 2002}

Y. Buruma, 'Inzake de beladen bouwnijverheid. Voorbeschouwing op een parlementaire enquête', in: Nederland Juristenblad 2002, p. 701-708.

Bush 1993

J.D. Bush, 'Congressional-Executive Access Disputes. Legal Standards and Political Settlements', in: Journal of Law and Politics 1993, p. 719-747.

Cole \& Brand 2011

L. Cole \& S.M. Brand, Congressional Investigations and Oversight. Case Studies and Analysis, Durham: Carolina Academic Press 2011.

Cowley 2005

Ph. Cowley, The Rebels. How Blair Mislaid his Majority, London: Politico's 2005.

Daalder 2008

E.J. Daalder, 'Parlementaire enquêtecommissies en bestuursrechtelijke normen', in: Nederlands Tijdschrift voor Bestuursrecht 2008, p. 325-332.

Van Damme \& Meersschaut 2003

M. Van Damme \& F. Meersschaut, Parlementair en gerechtelijk onderzoek in België, preadvies voor de Vereniging voor de vergelijkende studie van het recht van België en Nederland, Deventer: Kluwer 2003. 


\section{PARLEMENTAIR ONDERZOEK}

Dannemann 2006

G. Dannemann, 'Comparative Law. Study of Similarities or Differences?', in: M. Reimann \& R. Zimmermann, The Oxford Handbook of Comparative Law, Oxford: Oxford University Press 2006, p. 383-419.

Davidson \& Oleszek 2002

R.H. Davidson \& W.J. Oleszek, Congress and Its Members, Washington, D.C.: CQ Press 2002.

Deering \& Wahlbeck 2006

Ch.J. Deering \& P.J. Wahlbeck, 'Determinants of House Committee Chair Selection', in: American Politics Research 2006, p. 223-242.

Deering \& Smith 1997

Ch.J. Deering \& S.S. Smith, Committees in Congress, Washington, DC: CQ Press 1997.

Dölle 1985

A.H.M. Dölle, Het recht van parlementaire enquête, Groningen: Wolters-Noordhoff 1985.

Drewry 1989a

G. Drewry (red.), The New Select Committees. A Study of the 1979 Reforms, Oxford: Clarendon Press 1989.

\section{Drewry 1989 b}

G. Drewry, 'Scenes from Committee Life - The New Committees in Action', in: G. Drewry (red.), The New Select Committees. A Study of the 1979 Reforms, Oxford: Clarendon Press 1989, p. 348-366.

Drexhage 2009

E.C. Drexhage, 'Nieuwe regels voor de parlementaire enquête', in: RM Themis 2009-1, p. 3-19.

Van den Driessche 2005

I.A. Van den Driessche, Politieke ministeriële verantwoordelijkheid. Het Nederlandse begrip in rechtsvergelijkend perspectief (diss. Groningen), Deventer: Kluwer 2005.

Van Dijk 1999

C.P. van Dijk, 'De Bijlmer-enquête. Een terugblik', in: Openbaar bestuur 1999, nr. 11, p. 12-15.

Eberling 1928

E.J. Eberling, Congressional Investigations. A Study of the Origin and Development of the Power of Congress to Investigate and Punish for Contempt (herdruk 1973), New York: Columbia University Press 1928.

Elzinga 1994a

D.J. Elzinga (red.), Ministeriële verantwoordelijkheid in Nederland, Zwolle: W.E.J. Tjeenk Willink 1994.

\section{Elzinga 1994b}

D.J. Elzinga, ‘De politieke ministeriële verantwoordelijkheid', in: D.J. Elzinga (red.), Ministeriële verantwoordelijkheid in Nederland, Zwolle: W.E.J. Tjeenk Willink 1994, p. 31-63. 
Elzinga 1994c

D.J. Elzinga, 'De strafrechtelijke ministeriële verantwoordelijkheid', in: D.J. Elzinga (red.), Ministeriële verantwoordelijkheid in Nederland, Zwolle: W.E.J. Tjeenk Willink 1994, p. 65-78.

Elzinga \& Warmelink 1993

D.J. Elzinga \& H.G. Warmelink, Het Nederlandse parlementaire stelsel, Nijmegen: Ars Aequi Libri 1993.

Engels 1987

J.W.M. Engels, Het parlementaire enquêterecht, Leiden: Stichting Burgerschapskunde/Nederlands Centrum voor Politieke Vorming 1987.

Enthoven 2011

G. Enthoven, Hoe vertellen we het de Kamer? Een empirisch onderzoek naar de informatierelatie tussen regering en parlement (diss. Tilburg), Delft: Eburon 2011.

Erskine May 2004

Th. Erskine May, W.R. MacKay \& F. Cranmer, Erskine May's Treatise on the Law, Priviliges, Proceedings and Usage of Parliament, London: LexisNexis 2004.

Fernhout 2004

F.J. Fernhout, Het verschoningsrecht van getuigen in civiele zaken, Deventer: Kluwer 2004.

Fisher 2002

L. Fisher, 'Congressional Access to Information. Using Legislative Will and Leverage', in: Duke Law Journal 2002, p. 323-402.

Fisher 2004

L. Fisher, The Politics of Executive Privilege, Durham, NC: Carolina Academic Press 2004.

Fisher 2005

L. Fisher, American Constitutional Law. Constitutional Structures, Separated Powers and Federalism, Durham, NC: Carolina Academic Press 2005.

Fisher 2007

L. Fisher, Constitutional Conflicts between Congress and the President, Lawrence, KS: University Press of Kansas 2007.

Fleuren, Bovend'Eert \& Kummeling 2001

J.W.A. Fleuren, P.P.T. Bovend'Eert \& H.R.B.M. Kummeling (red.), Grensverleggend staatsrecht (Kortmann-bundel), Deventer: Kluwer 2001.

Gay 2005

O. Gay, The Osmotherly Rules, House of Commons Library Standard Note SN/PC/2671, 4 augustus 2005.

Gay 2012

O. Gay, Parliamentary Commissions of Inquiry, House of Commons Library Standard Note SN/PC/06392, 24 juli 2012. 


\section{PARLEMENTAIR ONDERZOEK}

\section{Giddings 1989}

Ph. Giddings, 'What Has Been Achieved?', in: G. Drewry (red.), The New Select Committees. A Study of the 1979 Reforms, Oxford: Clarendon Press 1989, p. 367-381.

Glazener 2002

P. Glazener, 'Een klopjacht met teveel jagers. Over de parlementaire enquête en de $\mathrm{NMa}^{\prime}$, in: Nederlands Juristenblad 2002, p. 709-710.

Grabow 1988

J.C. Grabow, Congressional Investigations. Law and Practice, Clifton, NJ: Prentice Hall 1988.

Guide to Congress 2000

Guide to Congress, Washington, D.C.: CQ Press 2000.

Guide to Congress 2008

Guide to Congress, Washington, D.C.: CQ Press 2008.

Hagelstein 1991

G.H. Hagelstein, De parlementaire commissies (diss. Groningen), Groningen: Wolters-Noordhoff 1991.

Halstead 2004

T.J. Halstead, Walker v. Cheney: District Court Decision and Related Statutory and Constitutional Issues, CRS Report RL31713, Washington, DC: Congressional Research Service 2004.

Hamilton 1976

J. Hamilton, The Power to Probe. A Study of Congressional Investigations, New York: Vintage Books 1976.

Hamilton, Muse \& Amer 2007

J. Hamilton, R.F. Muse \& K.R. Amer, 'Congressional Investigations. Politics and Process', in: American Criminal Law Review 2007, p. 1115-1176.

Hansard Society Commission 2001

The Challenge for Parliament. Making Government Accountable. Report of the Hansard Society Commission on Parliamentary Scrutiny, London: Hansard Society/Vacher Dodd Publishing 2001.

't Hart \& Wille 2002

P. 't Hart \& A.C. Wille e.a., Politiek-ambtelijke verhoudingen in beweging, Amsterdam: Boom 2002.

\section{Hazan 2001}

R.Y. Hazan, Reforming Parliamentary Committees. Israel in Comparative Perspective, Columbus: Ohio State University Press 2001.

\section{Heringa 2001}

A.W. Heringa, 'Ministeriële verantwoordelijkheid en parlementaire controle', in: J.W.A. Fleuren, P.P.T. Bovend'Eert \& H.R.B.M. Kummeling (red.), Grensverleggend staatsrecht (Kortmannbundel), Deventer: Kluwer 2001, p. 155-173.

Heringa e.a. 2012

A.W. Heringa e.a., Staatsrecht, Deventer: Kluwer 2012. 
Een herkenbare staat 2004

Een herkenbare staat. Rapport van de werkgroep Verzelfstandigde Organisaties op Rijksniveau (commissie-Kohnstamm), Interdepartementaal Beleidsonderzoek 2003-2004, nr. 1, Den Haag 2004.

Hood Philips, Jackson \& Leopold 2001

O. Hood Philips, P. Jackson \& P. Leopold, Constitutional and Administrative Law, London: Sweet \& Maxwell 2001.

Hirschl 2005

R. Hirschl, 'The Question of Case Selection in Comparative Constitutional Law', in: American Journal of Comparative Law 2005, p. 125-155.

Inzake Opsporing 1996

Inzake Opsporing. Eindrapport van de Parlementaire Enquêtecommissie Opsporingsmethoden, Kamerstukken II 1995/96, 24 072, nr. 11, Den Haag: Tweede Kamer der Staten-Generaal.

Jaarverslag Raad van State 2005

Jaarverslag Raad van State, Den Haag: Raad van State 2006.

Janse de Jonge 1993

E.J. Janse de Jonge, Het budgetrecht. Rechtsvergelijkende studie naar de begrotingsbehandeling door het parlement in de Verenigde Staten, Engeland en Nederland (diss. Tilburg), Zwolle: W.E.J. Tjeenk Willink 1993.

Janse de Jonge 2012

E. Janse de Jonge, Amerikaans Staatsrecht. Beschouwingen over de rule of Law, staatsinstellingen en politiek in de Verenigde Staten van Noord-Amerika, Nijmegen: Wolf Legal Publishers 2012.

\section{Johnson 1988}

N. Johnson, 'Departmental Select Committees', in: M. Ryle \& P.G. Richards (red.), The Commons under Scrutiny, London: Routledge 1988, p. 157-185.

Joint Committee on the Organization of Congress 1993

Joint Committee on the Organization of Congress, Organization of the Congress, Final Report, Washington, D.C. 1993, <http://democrats.rules.house.gov/archives/jcoc2.htm>.

Jowell \& Oliver 2007

J. Jowell \& D. Oliver (red.), The Changing Constitution, Oxford: Oxford University Press 2007.

Jurgens 1975

E.C.M. Jurgens, 'De Parlementaire Enquête', in: Politiek, parlement, democratie. Opstellen voor Prof. Mr. F.J.F.M. Duynstee, Deventer: Kluwer 1975, p. 99-108.

Jurgens 2004

E.C.M. Jurgens, 'Koningsdrama of waarheidsvinding? Over kennisvergaring door gericht parlementair onderzoek', in: Nederlands Juristenblad 2004, p. 218-224.

Kaiser 2006

F.M. Kaiser, Congressional Oversight, CRS Report 97-936 GOV, Washington, D.C.: Congressional Research Service 2006. 


\section{PARLEMENTAIR ONDERZOEK}

\section{Kaiser 2008}

F.M. Kaiser, GAO. Government Accountability Office and General Accounting Office, CRS Report RL 30349, Washington, D.C.: Congressional Research Service 2008.

Kaiser, Oleszek \& Tatelman 2011

F.M. Kaiser, W.J. Oleszek \& T.B. Tatelman, Congressional Oversight Manual, CRS Report RL30240, Washington, D.C.: Congressional Research Service 2011.

Kappeyne van de Coppello 1978

A. Kappeyne van de Coppello, De parlementaire enquête, preadvies voor de Vereniging voor de vergelijkende studie van het recht van Belgie en Nederland, Zwolle: W.E.J. Tjeenk Willink 1978.

Kappeyne van de Coppello 1986

A. Kappeyne van de Coppello, 'Het recht van enquête', in: H.M. Franssen (red.), Het parlement in Aktie. Bevoegdheden van de Staten-Generaal, Assen/Maastricht: Van Gorcum 1986, p. 63-90.

Karsten 1860

E.H. Karsten, De parlementaire enquête in de constitutionele staten (diss. Utrecht), Utrecht: Kemink en Zoon 1860.

Kelly 2010

R. Kelly, Pre-legislative scrutiny, House of Commons Library Standard Note SN/PC/2822, 9 april 2010.

Kernell \& Jacobson 2000

S. Kernell \& G.C. Jacobson, The Logic of American Politics, Washington, D.C.: CQ Press 2000.

Kiiver 2012

$\mathrm{Ph}$. Kiiver, The Early Warning System for the Principle of Subsidiarity. Constitutional Theory and Empirical Reality, London: Routledge 2012.

Koekkoek 2000

A.K. Koekkoek (red.), De Grondwet. Een systematisch en artikelsgewijs commentaar, Deventer: W.E.J. Tjeenk Willink 2000.

Koekkoek 2001

A.K. Koekkoek, 'De methode van staatsrechtelijke rechtsvergelijking', in: P.P.T. Bovend'Eert, J.W.A. Fleuren \& H.R.B.M. Kummeling (red.), Grensverleggend staatsrecht, Deventer: Kluwer 2001, p. 175-196.

Koopmans 2003

T. Koopmans, Courts and Political Institutions: A Comparative View, Cambridge: Cambridge University Press 2003.

Kortmann 1987

C.A.J.M. Kortmann, De grondwetsherzieningen 1983 en 1987, Deventer: Kluwer 1987.

Kortmann 1996

C.A.J.M. Kortmann, 'Ministeriële verantwoordelijkheid', in: RM Themis 1996, p. 243-244.

Kortmann 2008

C.A.J.M. Kortmann, Constitutioneel recht, Deventer: Kluwer 2008. 


\section{LITERATUUROPGAVE}

Kriner 2009

D. Kriner, 'Can Enhanced Oversight Repair “The Broken Branch"?', in: Boston University Law Review 2009, p. 765-793.

Kummeling 2005

H.R.B.M. Kummeling, 'Beperkte immuniteit bij parlementaire enquêtes', in: Getuigend staatsrecht. Liber amicorum A.K. Koekkoek, Nijmegen: Wolf Legal Publishers 2005, p. 55-67.

Kummeling, Kortmann \& Verhey 2006

H.R.B.M. Kummeling, C.A.J.M. Kortmann \& L.F.M. Verhey, De parlementaire enquête in Duitsland, Frankrijk en het Verenigd Koninkrijk, Den Haag: Tweede Kamer der Staten-Generaal 2006.

Kummeling \& Mijnen 2006

H.R.B.M. Kummeling \& C.A. Mijnen, 'Parlementair enquêterecht in de Bondsrepubliek Duitsland', in: H.R.B.M. Kummeling, C.A.J.M. Kortmann \& L.F.M. Verhey, De parlementaire enquête in Duitsland, Frankrijk en het Verenigd Koninkrijk, Den Haag: Tweede Kamer der Staten-Generaal 2006, p. 7-42.

Kummeling 2007

H.R.B.M. Kummeling, 'Parlementair onderzoek. Op zoek naar de waarheid, met een politiek tintje...', in: J.Th.J. van den Berg, J.L.W. Broeksteeg \& L.F.M. Verhey (red.), Het Parlement. Staatsrechtconferentie 2006, Nijmegen: Wolf Legal Publishers 2007, p.69-81.

Leopold 1992

P. Leopold, 'The Power of the House of Commons to Question Private Individuals', in: Public Law 1992, p. 541-551.

Leren van parlementair onderzoek 2007

Algemene Rekenkamer, Leren van parlementair onderzoek, Rapport, Kamerstukken II 2007/08, 31 235, nrs. 1-2.

Levy 2009

J. Levy, 'Public Bill Committees. An Assessment, Scrutiny Sought; Scrutiny Gained', in: Parliamentary Affairs 2009, p. 534-544.

Liaison Committee Note 2004

Liaison Committee, Scrutiny of Government: Select Committees after Hutton. Note by the Clerks, zie http://www.publications.parliament.uk/pa/cm200304/cmselect/cmliaisn/memo/memo.pdf (laatst geraadpleegd: 26 november 2012).

Lock 1989

G. Lock, 'Resources and Operations of Select Committees: A Survey of the Statistics', in: G. Drewry, The New Select Committees. A Study of the 1979 Reforms, Oxford: Clarendon Press 1989, p. 319-347.

Loeffen 2007

S.C. Loeffen, 'Parlementair onderzoek heroverwogen', in: J.Th.J. van den Berg, J.L.W. Broeksteeg \& L.F.M. Verhey (red.), Het Parlement. Staatsrechtconferentie 2006, Nijmegen: Wolf Legal Publishers 2007, p. 83-90. 


\section{PARLEMENTAIR ONDERZOEK}

Longley \& Davidson 1998

L.D. Longley \& R.H. Davidson (red.), The New Roles of Parliamentary Committees, London: Cass 1998.

Lubberdink 2003

H.G. Lubberdink, Enkele opmerkingen over de parlementaire enquête in Nederland in de afgelopen vijfentwintig jaar, preadvies voor de Vereniging voor de vergelijkende studie van het recht van België en Nederland, Deventer: Kluwer 2003.

Maer \& Sandford 2004

L. Maer \& M. Sandford, Select Committees under Scrutiny, London: The Constitution Unit 2004.

Marshall 1989

Geoffrey Marshall (red.), Ministerial Responsibility, Oxford: Oxford University Press 1989.

McEldowney 2007

J. McEldowney, 'The Control of Public Expenditure', in: J. Jowell \& D. Oliver (red.), The Changing Constitution, Oxford: Oxford University Press 2007, p. 359-386.

Mill 1859

J.S. Mill, Considerations on Representative Government (1861), herdruk, Oxford: Oxford University Press 1998.

Morison 2007

J. Morison, 'Models of Democracy. From Representation to Participation?', in: J. Jowell \& D. Oliver (red.), The Changing Constitution, Oxford: Oxford University Press 2007, p. 134-156.

Muller 2002

E.R. Muller, 'Waarheidsvinding en parlementair onderzoek', in: Justitiële Verkenningen 2002, nr. 2, p. 37-49.

Muller \& Coenen 2002

E.R. Muller \& N.J.P. Coenen, Parlementair onderzoek in Nederland, Den Haag: Sdu Uitgevers 2002.

Munneke 2006

S.A.J. Munneke, Inlichtingenplichten en verschoningsgronden in het staatsrecht (diss. Groningen), Deventer: Kluwer 2006.

Naeyé \& Schalken 1996

J. Naeyé \& T.M. Schalken, 'Commissie-Van Traa en de crisis in de opsporing', in: Nederlands Juristenblad 1996, p. 197-205.

Nelson 1993

G. Nelson, Committees in the U.S. Congress, 1947-1992. Committee Jurisdiction and Member Rosters, Washington, D.C.: Congressional Quarterly 1993.

Norton 1998

Ph. Norton, 'Nascent Institutionalisation. Committees in the British Parliament', in: L.D. Longley \& R.H. Davidson (red.), The New Roles of Parliamentary Committees, London: Cass 1998, p. $143-162$. 


\section{LITERATUUROPGAVE}

Norton 2005

Ph. Norton, Parliament in British Politics, Basingstoke: Palgrave Macmillan 2005.

Norton Commission 2000

Strengthening Parliament, Report of the Commission to Strengthen Parliament, London: Conservative Party 2000, <www.conservatives.com/pdf/norton.pdf>.

Nowak \& Rotunda 2000

J.E. Nowak \& R.D. Rotunda, Constitutional Law, St. Paul, Minn.: West Group 2000.

Nunn 1986

S. Nunn, 'The Impact of the Senate Permanent Subcommittee on Investigations on Federal Policy', in: Georgia Law Review 1986, p. 17-56.

\section{Oderkerk 1999}

A.E. Oderkerk, De preliminaire fase van het rechtsvergelijkend onderzoek, Nijmegen: Ars Aequi Libri 1999.

Oleszek 2001

W.J. Oleszek, Congressional Procedures and the Policy Process, Washington, D.C.: CQ Press 2001.

Oliver 2003

D. Oliver, Constitutional Reform in the United Kingdom, Oxford: Oxford University Press 2003.

Ornstein \& Mann 2006

N.J. Ornstein \& Th.E. Mann, 'When Congress Checks Out', in: Foreign Affairs 2006, p. 67-82.

Ornstein, Mann \& Malbin 2008

N.J. Ornstein, Th.E. Mann \& M.J. Malbin, Vital Statistics on Congress 2008, Washington, D.C.: Brookings Institution 2008.

Osmotherly Rules 2005

Departmental Evidence and Response to Select Committees (Osmotherly Rules), London: Cabinet Office 2005.

\section{Oud 1967}

P.J. Oud, Het constitutioneel recht van het Koninkrijk der Nederlanden, deel I, Zwolle: W.E.J. Tjeenk Willink 1967.

\section{Pedroli 2002}

W.J. Pedroli, 'A call to arms. De parlementaire enquête evenwichtig geregeld', in: Wetten, woorden en wensen. Opstellen over constitutie, wetgeving en beleid (Peters-bundel), Den Haag: Ministerie van Binnenlandse Zaken en Koninkrijksrelaties 2002.

\section{Peterson 2002}

T.D. Peterson, 'Congressional Oversight of Open Criminal Investigations', in: Notre Dame Law Review 2002, p. 1373-1148.

Pontius \& Bullock 2003

J.S. Pontius \& F.M. Bullock, Congressional Staff. Duties and Functions, CRS Report 98-340 GOV, Washington, D.C.: Congressional Research Service 2003. 


\section{PARLEMENTAIR ONDERZOEK}

Power 2000

G. Power, Parliamentary Scrutiny of Draft Legislation 1997-1999, London: Constitution Unit/Hansard Society 2000.

Van der Pot/Elzinga \& De Lange 2006

D.J. Elzinga \& R. de Lange, Van der Pot. Handboek van het Nederlandse staatsrecht, Deventer: Kluwer 2006.

Pontius \& Bullock 2003

J.S. Pontius \& F.M. Bullock, Congressional Staff. Duties and Functions, CRS Report 98-340 GOV, Washington, D.C.: Congressional Research Service 2003.

Pray 2005

J.G. Pray, 'Congressional Reporting Requirements. Testing the Limits of the Oversight Power', in: University of Colorado Law Review 2005, p. 297-325.

Randolph 1829

Th.J. Randolph, Memoir, Correspondence, and Miscellanies, from the Papers of Thomas Jefferson, Charlottesville: Carr 1829.

Rapport parlementaire zelfreflectie 2009

Vertrouwen en zelfoertrouwen. Analyse en aanbevelingen parlementaire zelfreflectie, Kamerstukken II 2008/09, 31845 , nr. 3 .

Reimann \& Zimmermann 2006

M. Reimann \& R. Zimmermann, The Oxford Handbook of Comparative Law, Oxford: Oxford University Press 2006, p. 383-419.

\section{Reitz 1998}

J.C. Reitz, 'How To Do Comparative Law', in: American Journal of Comparative Law 1998, p. 617636.

Riddell 2000

P. Riddell, Parliament under Blair, London: Politico's 2000.

Rodgers \& Walters 2006

R. Rodgers \& R. Walters, How Parliament Works, Harlow: Pearson/Longman 2006.

\section{Rouvoet 1999}

A. Rouvoet, 'Werkwijze enquêtecommissie kritisch bezien', in: Openbaar bestuur 1999, nr. 11, p. 20-23.

Rosenberg 1995

M. Rosenberg, Investigative Oversight. An Introduction to the Law, Practice and Procedure of Congressional Inquiry, CRS Report 95-464A, Washington, D.C.: Congressional Research Service 1995.

Rosenberg 2007

M. Rosenberg, Congressional Investigations of the Department of Justice, 1920-2007. History, Law, and Practice, CRS Report RL34197, Washington, D.C.: Congressional Research Service 2007. 


\section{LITERATUUROPGAVE}

Rosenberg \& Tatelman 2008

M. Rosenberg \& T.B. Tatelman, Congress's Contempt Power. Law, History, Practice, and Procedure, CRS Report RL34097, Washington, D.C.: Congressional Research Service 2008.

Rozell 2002

M.J. Rozell, Executive Privilege. Presidential Power, Secrecy, and Accountability, Lawrence, KS: University Press of Kansas 2002.

Russell 2011

M. Russell, "Never Allow a Crisis Go To Waste": The Wright Committee Reforms to Strenghten the House of Commons', in: Parliamentary Affairs 2011, p. 612-633.

Russell \& Benton 2011

M. Russell \& M. Benton, Selective Influence. The Policy Impact of House of Commons Select Committees, London: The Constitution Unit 2011.

Ryle \& Richards 1988

M. Ryle \& P.G. Richards (red.), The Commons under Scrutiny, London: Routledge 1988.

Van Schagen 1994

J.A. van Schagen, De Tweede Kamer der Staten-Generaal. Een staatsrechtelijke studie over haar organisatie en werkwijze (diss. Utrecht), Zwolle: W.E.J. Tjeenk Willink 1994.

Scheltema 1974

M. Scheltema, Zelfstandige bestuursorganen (oratie Groningen), Groningen: H.D. Tjeenk Willink 1974.

Scheltema 2000

M. Scheltema, 'Voldoet de ministeriële verantwoordelijkheid nog bij een professionele overheidsorganisatie?', in: Nederlands Juristenblad 2000, p. 1861-1867.

Schlesinger \& Bruns 1975

A.M. Schlesinger \& R. Bruns (red.), Congress Investigates. A Documented History, 1792-1974, New York: Chelsea House 1975.

Schneider 2007

J. Schneider, The Committee System in the U.S. Congress, CRS Report RS20794, Washington, D.C.: Congressional Research Service 2007.

Shampansky 1999

J.R. Shampansky, Staff Depositions in Congressional Investigations, CRS Report 95-949A, Washington, D.C.: Congressional Research Service 1999.

Smith, Roberts \& Vander Wielen 2007

S.S. Smith, J.M. Roberts \& R.J. Vander Wielen, The American Congress, Cambridge: Cambridge University Press 2007.

Smookler 2006

J. Smookler, 'Making a Difference? The Effectiveness of Pre-Legislative Scrutiny', in: Parliamentary Affairs 2006, p. 522-535. 


\section{PARLEMENTAIR ONDERZOEK}

Steekhoudend ministerschap 1993

Steekhoudend ministerschap. Rapport van de Eerste externe commissie van de Bijzondere Commissie Vraagpunten (Commissie-Scheltema), Kamerstukken II 1992/93, 21 427, nr. 41.

Taylor 1955

T. Taylor, The Grand Inquest. The Story of Congressional Investigations, New York: Simon \& Schuster 1955.

\section{Tiefer 1989}

Ch. Tiefer, Congressional Practice and Procedure. A Reference, Research and Legislative Guide, Westport, Conn.: Greenwood Press 1989.

\section{Tiefer 1998a}

Ch. Tiefer, 'Congressional Oversight of the Clinton Administration and Congressional Procedure', in: Administrative Law Review 1998, p. 199-216.

Tiefer 1998b

Ch. Tiefer, 'The Senate and House Counsel Offices. Dilemmas of Representing in Court the Institutional Congressional Client', in: Law and Contemporary Problems 1998, p. 47-63.

Tomkins 2003

A. Tomkins, Public Law, Oxford: Oxford University Press 2003.

\section{Tomkins 2008}

A. Tomkins, 'Political Accountability in the United Kingdom', in: L. Verhey, H. Broeksteeg \& I. Van den Driessche, Political Accountability in Europe: Which Way Forward?, Groningen: Europa Law Publishing 2008, p. 245-269.

Turpin \& Tomkins 2007

C. Turpin \& A. Tomkins, British Government and the Constitution. Text and Materials, Cambridge: Cambridge University Press 2007.

Turpin \& Tomkins 2011

C. Turpin \& A. Tomkins, British Government and the Constitution. Text and Materials, Cambridge: Cambridge University Press 2011.

Tushnet 2008

M. Tushnet, Weak Courts, Strong Rights. Judicial Review and Social Welfare Rights in Comparative Constitutional Law, Princeton: Princeton University Press 2008.

Tuurenhout 1992

M.E. Tuurenhout, Parlementaire controle en ambtelijke verantwoordelijkheid (diss. Leiden), Arnhem: Gouda Quint 1992.

Verhey 2001a

L.F.M. Verhey, De zwoegers in het vooronder. Over ambtelijke taakuitoefening, ministeriële verantwoordelijkheid en parlementaire controle (oratie Maastricht), Zwolle: W.E.J. Tjeenk Willink 2001.

Verhey $2001 b$

L.F.M. Verhey, 'Parlementaire controle en scrunity of administration. De betekenis van de Britse select committees', in: J.W.A. Fleuren P.P.T. Bovend'Eert, H.R.B.M. Kummeling, Grensverleggend staatsrecht (Kortmann-bundel), Deventer: Kluwer 2001, p. 299-322. 
Verhey 2006

L.F.M. Verhey, 'Parlementair onderzoek in het Verenigd Koninkrijk. De Select Committees van de House of Commons', in: H.R.B.M. Kummeling, C.A.J.M. Kortmann \& L.F.M. Verhey, De parlementaire enquête in Duitsland, Frankrijk en het Verenigd Koninkrijk, Den Haag: Tweede Kamer der Staten-Generaal 2006, p. 63-102.

Verhey \& Verheij 2005

L.F.M. Verhey \& N. Verheij, De macht van de markmeesters. Markttoezicht in constitutioneel perspectief, Handelingen Nederlandse Juristen-Vereniging 2005-1, Deventer: Kluwer 2005, p. 135-332.

Verhey, Broeksteeg \& Van den Driessche 2008

L. Verhey, H. Broeksteeg \& I. Van den Driessche (red.), Political Accountability in Europe. Which Way Forward?, Groningen: Europa Law Publishing 2008.

Verhey \& Claes 2008

L. Verhey \& M. Claes, 'Introduction: Political Accountability in a European Perspective', in: L. Verhey, H. Broeksteeg \& I. Van den Driessche (red.), Political Accountability in Europe: Which Way Forward?, Groningen: Europa Law Publishing 2008, p. 3-23.

Vermeule 2007

Adrian Vermeule, Mechanisms of Democracy. Institutional Design Writ Small, Oxford: Oxford University Press 2007.

Visscher 1978

G. Visscher, 'De parlementaire enquête in vergelijkend perspectief', in: Acta Politica 1978, p. 212260.

Visscher 1994

G. Visscher, 'Ministeriële verantwoordelijkheid en parlementair inlichtingenrecht', in: D.J. Elzinga (red.), Ministeriële verantwoordelijkheid in Nederland, Zwolle: W.E.J. Tjeenk Willink 1994, p. 237-256.

Visser 2008

R.K. Visser, In dienst van het algemeen belang. Ministeriële verantwoordelijkheid en parlementair vertrouwen (diss. Leiden), Amsterdam: Boom 2008.

Waller \& Chalmers 2010

P. Waller \& M. Chalmers, 'An Evalution of Pre-Appointment Scrutiny Hearings', in: Liaison Committee, The Work of Committees in Session 2008-09, HC 425 (2009-10), Annex 3.

Warmelink 1994

H.G. Warmelink, 'Ministeriële verantwoordelijkheid voor ambtelijk handelen', in: D.J. Elzinga (red.), Ministeriële verantwoordelijkheid in Nederland, Zwolle: W.E.J. Tjeenk Willink 1994, p. 103115 .

Webb 2000

P. Webb, The Modern British Party System, London: Sage Publications 2000.

Weir \& Beetham 1999

S. Weir \& D. Beetham, Political Power and Democratic Control in Britain. The Democratic Audit of the United Kingdom, London/New York: Routledge 1999. 


\section{PARLEMENTAIR ONDERZOEK}

De WPE onder de loep 2004

De Wet op de Parlementaire Enquête onder de loep. Verslag van het symposium over de Wet op de Parlementaire Enquête op 26 januari 2004, Den Haag: Tweede Kamer der Staten-Generaal 2004.

Wilson 1885

W. Wilson, Congressional Government. A Study in American Politics, New York: Riverside Press 1885 (herdruk Mineola: Dover 2006).

Woodhouse 1994

D. Woodhouse, Ministers and Parliament. Accountability in Theory and Practice, Oxford: Clarendon Press 1994.

Woodhouse 2004

D. Woodhouse, 'Ministerial Responsibility', in: V. Bogdanor (red.), The British Constitution in the Twentieth Century, Oxford: Oxford University Press 2004.

Wright 1995

R.F. Wright, 'Congressional Use of Immunity Grants after Iran-Contra', in: Minnesota Law Review 1995, p. 407-468.

Zijlstra \& Wilkeshuis 2006

S.E. Zijlstra \& K. Wilkeshuis, 'Verantwoordelijkheid: bevoegdheid en publieke taak', in: J.L.W. Broeksteeg, J.Th.J. van den Berg \& L.F.M. Verhey (red.), Ministeriële verantwoordelijkheid opnieuw gewogen, Deventer: Kluwer 2006, p. 9-18.

Zijlstra 2009

S.E. Zijlstra, Bestuurlijk organisatierecht, Deventer: Kluwer 2009.

Zweigert \& Kötz 1998

K. Zweigert \& H. Kötz, Introduction to Comparative Law, Oxford: Clarendon Press 1998. 


\section{Curriculum vitae}

Sandor Loeffen (1979) studeerde Nederlands recht en Amerikanistiek aan de Radboud Universiteit Nijmegen. Ook studeerde hij, als uitwisselingsstudent, een jaar aan de University of North Carolina at Chapel Hill (VS). Na zijn studie werkte hij aan de Universiteit Maastricht, eerst als promovendus en later als universitair docent, bij de capaciteitsgroep Publiekrecht en het Montesquieu Instituut. In zijn Maastrichtse periode nam hij verder deel aan een postdoctoraal programma over Britse politiek aan de London School of Economics, liep hij stage bij het Britse parlement en verbleef hij enige tijd als gastonderzoeker aan Georgetown University Law Center (Washington DC, VS). Sinds januari 2013 is hij als universitair docent staatsrecht verbonden aan de Faculteit der Rechtsgeleerdheid van de Vrije Universiteit Amsterdam, waar hij zowel onderzoek doet als onderwijs verzorgt. 